\author{
UNIVERSIDADE DE SÃO PAULO \\ FaCUldade DE Filosofia, Letras E CiÊnCias Humanas \\ DEPARTAMENTO DE HISTÓRIA \\ PROGRAMA DE PÓS-GRAdUAÇÃO EM HiSTÓRIA SOCIAL
}

FLAMARION MAUÉS PELÚCIO SILVA

\title{
Livros que tomam partido: a edição política em Portugal, 1968-80
}

\author{
VOL. 1
}

São Paulo

2013 


\section{FLAMARION MAUÉS PELÚCIO SILVA}

\section{Livros que tomam partido: a edição política em Portugal, 1968-80}

VOL. 1

Tese do Doutorado apresentada ao Programa de História Social do Departamento de História da Faculdade de Filosofia, Letras e

Ciências Humanas da Universidade de São Paulo, para a obtenção do título de doutor em História.

Orientador: Prof. Dr. Lincoln Ferreira Secco.

São Paulo

2013 
Autorizo a reprodução e divulgação total ou parcial deste trabalho, por qualquer meio convencional ou eletrônico, para fins de estudo e pesquisa, desde que citada a fonte.

Catalogação na Publicação

Serviço de Biblioteca e Documentação

Faculdade de Filosofia, Letras e Ciências Humanas da Universidade de São Paulo

S5861 Silva, Flamarion Maués Pelúcio

Livros que tomam partido: a edição política em

Portugal, 1968-80 / Flamarion Maués Pelúcio Silva ; orientador Lincoln Ferreira Secco. - São Paulo, 2013.

$617 \mathrm{f}$.

Tese (Doutorado)- Faculdade de Filosofia, Letras e Ciências Humanas da Universidade de São Paulo. Departamento de História. Área de concentração: História Social.

1. Edição política - Portugal. 2. História Editorial Portugal. 3. Portugal - Revolução dos Cravos. 4. História Ibérica. I. Secco, Lincoln Ferreira, orient. II. Título. 
Nome: SILVA, Flamarion Maués Pelúcio.

Título: Livros que tomam partido: a edição política em Portugal, 1968-80.

Tese do Doutorado apresentada ao Programa de História Social do Departamento de História da Faculdade de Filosofia, Letras e Ciências Humanas da Universidade de São Paulo, para a obtenção do título de doutor em História.

Aprovado em:

\section{Banca Examinadora}

Prof. Dr. Instituição:

Julgamento: Assinatura:

Prof. Dr. Instituição:

Julgamento: Assinatura:

Prof. Dr. Instituição:

Julgamento: Assinatura:

Prof. Dr. Instituição:

Julgamento: Assinatura: 
Para Leisa,

que me fez reencontrar o amor. 


\section{AGRADECIMENTOS}

Foram muitas as pessoas que de alguma forma colaboraram para que este trabalho pudesse ser levado a cabo. Certamente esquecerei de mencionar algumas delas, às quas peço desde já desculpas pelo lapso.

Desde o início e até o final do trabalho, contei sempre com o apoio de meu orientador, Lincoln Secco (meu antigo colega na graduação). Sem isso talvez o projeto não tivesse ido adiante.

Nos primeiros momentos, quando ainda tateava o terreno a ser investigado, tive a colaboração importante de Valério Arcary, historiador, também colega da graduação, que com sua vivência luso-brasileira ajudou-me a entender um pouco mais a Revolução dos Cravos. E além disso me apresentou a Raquel Varela e a António Simões do Paço, historiadores portugueses que de certa forma me introduziram no mundo acadêmico português. Ambos me ajudaram mais do que talvez saibam.

Em Portugal, além deles, são muitas as pessoas que desde o primeiro momento foram colaboradoras ativas e desinteressadas. José Manuel Lopes Cordeiro, da Universidade do Minho, foi meu orientador no período em que desfrutei de uma bolsa da Fundação Calouste Gulbenkian. E, além disso, como grande conhecedor da história da extrema esquerda portuguesa, deu muitas informações e orientações fundamentais.

Eduardo de Sousa, da Livraria Ler, de Lisboa, foi um manancial de informações. Cada vez que eu ia à livraria tinha uma pequena aula da história da edição em Portugal.

Fernando Moreira, da Biblioteca-Museu República e Resistência (BMRR), de Lisboa, abriu-me as portas do riquíssimo acervo dessa instituição, e sempre foi extremamente prestativo. Com a sua colaboração, pude organizar o Ciclo de Debates “Livros que Tomam Partido: Editoras de Caráter Político na Transição da Ditadura em Portugal (1968-1982)", realizado em março de 2012 na BMRR-Grandella.

Maria Inácia Rezola, Paula Borges Santos e Miguel Cardina, do Instituto de História Contemporânea da Universidade Nova de Lisboa, foram sempre gentis e amigos, além de proporcionarem bons momentos de debates e discussões sobre a história recente de Portugal.

Nuno Medeiros, da Universidade Nova de Lisboa, tornou-se um grande colaborador e um grande amigo, assim como seus pais, Manuel Medeiros e Fátima Medeiros (da Livraria Culsete de Setúbal). Por seu intermédio conheci Daniel Melo, 
também da Nova, e Nuno Seabra Lopes, também colaboradores importantes.

José Antunes Ribeiro e Lúcia Ribeiro, da livraria Ulmeiro, de Lisboa, tornaramse também amigos e colaboradores, assim como João Barrote e Amélia, das editoras Escorpião/Textos Exemplares, que me receberam em sua casa em Arnoia, em Braga.

João Bernardo foi também muito atencioso e uma longa conversa em seu apartamento em Alfornelos foi muito útil ao meu trabalho. O mesmo posso dizer de António Monteiro Cardoso, João Soares e Pedro Alves.

Todos os que aceitaram me receber para serem entrevistados sobre a sua experiência e trajetória no mundo editorial foram fundamentais para a pesquisa, além de terem me proporcionado momentos agradáveis nestas conversas. São eles: Ana Barradas, António Daniel Abreu, Carlos da Veiga Ferreira, Fernando Abreu, Brandão Guedes, Francisco Melo, Jacinta Ferreira, João Camacho, João Carlos Alvim, João Freire, José Sousa Ribeiro, Miguel Freitas da Costa, Rita Delgado, Sérgio Ribeiro e Silvério Amaro.

Também houve aqueles que não pude entrevistar pessoalmente, mas nas conversas por telefone ou na troca de emails, foram sempre muito atenciosos: António José Fonseca, Luís Manuel Vaz Alves, Carlos Loures, Manuel Simões, Manuel António Ribeiro Resende e Maria Teresa Horta.

$\mathrm{Na}$ banca de qualificação, pude contar com a observações e comentários das professoras e amigas Sandra Reimão e Marisa Midori, que muito ajudaram na fase final do trabalho.

Alguns amigos devem ser lembrados: Janaina Teles, Maria Viana, Paulo Fontes, Augusto Gomes.

Devo agradecer também à Capes (Coordenação de Aperfeiçoamento de Pessoal de Nível Superior) pela bolsa que recebi durante boa parte do doutorado, e à Fundação Calouste Gulbenkian, de Portugal, pela bolsa de sete meses para o início da pesquisa em terras lusitanas. Estes dois apoios foram fundamentais para que eu pudesse me dedicar com exclusividade ao trabalho acadêmico.

Por fim, a família. A presença de meu pai, José Flamarion, e da Lígia em Lisboa foi não apenas um apoio logístico e material importantíssimo, mas também representou um apoio afetivo imprescindível.

Minha mãe, Olgaíses, minhas irmãs, Larissa e Verônica, minhas sobrinhas, Tainá, Giulia, Milla e Helena, e o Mário, marido da Larissa, foram sempre apoios firmes e decisivos. 
No meio do caminho, perdemos a Julieta, mãe de quase todos nós. Mas sem dúvida ela está bem - e contente pela conclusão deste trabalho.

Também devo muito à amizade e à alegria da Lenina, Liliana, Leise, Rubens, D. Anésia, Oliver, Osvaldinho e Ricardo, que representaram um apoio para que tudo pudesse correr melhor.

E finalmente aquilo que não há como medir ou avaliar, o amor. O reencontro com a Leisa, já na metade final do doutorado, fez tudo ficar mais claro e definido. Devo a ela a energia para concluir o trabalho e o ânimo para projetar nosso futuro.

São Paulo, abril de 2013 
Viemos com o peso do passado e da semente

Esperar tantos anos torna tudo mais urgente e a sede de uma espera só se estanca na torrente ("Liberdade", de Sérgio Godinho) 


\section{Resumo}

SILVA, Flamarion Maués Pelúcio. Livros que tomam partido: a edição política em Portugal, 1968-80. 2013. 617 f. Tese (Doutorado em História Social) - Faculdade de Filosofia, Letras e Ciências Humanas, Universidade de São Paulo, São Paulo, 2013.

O objetivo deste trabalho é analisar a atuação das editoras de livros de caráter político em Portugal entre 1968 e 1980, a fim de verificar o papel político, cultural e ideológico que desempenharam no processo de transformações pelo qual passou o país nesse período. Para isso, busquei: a) identificar as editoras que realizaram essas publicações e examinar as vinculações políticas que tinham; b) realizar o recenseamento das obras de caráter político publicadas no período em estudo; c) identificar as pessoas e organizações responsáveis por essas editoras e publicações.

A partir dos dados levantados procuro entender como atuavam estes editores, quais suas motivações políticas, ideológicas e empresariais, como organizavam as editoras do ponto de vista intelectual e comercial, e qual o peso das vinculações políticas na vida das editoras.

Em termos cronológicos, o período em foco começa em 1968, com o afastamento por motivos de saúde de Salazar do poder e sua substituição por Marcelo Caetano, e vai até 1980, com a formação do primeiro governo de direita após o fim da ditadura em 25 de abril de 1974.

Uma síntese do trabalho mostra que existiram pelo menos 137 editoras que publicaram livros de caráter político em Portugal entre 1968 e 1980, tendo editado cerca de 4.600 títulos políticos no período. Este trabalho apresenta estudos sintéticos sobre 106 destas editoras.

Minha tese é que estas editoras conformaram o que podemos chamar de edição política no país. Ao realizar um trabalho editorial que vinculava de modo direto engajamento político e ação editorial, estas editoras - e seus editores - atuaram com clara intenção política de intervenção social, tornando-se sujeitos ativos no processo político português no período final da ditadura e nos primeiros anos de liberdade política.

Palavras-chave: Edição política - Portugal; História Editorial - Portugal; Revolução dos Cravos. 
SILVA, Flamarion Maués Pelúcio. Books and political parties: the political publishing houses in Portugal, 1968 - 1980. 2013. 617 f. Thesis (Doctorate in Social History) Faculdade de Filosofia, Letras e Ciências Humanas, Universidade de São Paulo, São Paulo, 2013.

\begin{abstract}
The aim of this thesis is to analyze the political publishing houses actions in Portugal between 1968 and 1980. Our particular focus is the political, cultural and ideological role of these publishing houses in the process of profound changes that Portugal went through that period. In order to achieve these goals, I have sought: a) to identify the main publishing houses and their political connections; b) to make a census of the political oeuvres published in that period; c) to identify people and organization that were in charge of the publishing houses.

Taking in consideration the sources and data collected, I examine how these publishers acted, and which were their political, ideological and business motivations. I also analyze how they organize the publishing houses from a intellectual and commercial perspective, as well as how was the weight of the political connections in the everyday life of the publishing houses. Chronologically, my investigation starts in 1968, when the Dictator Salazar, due health reasons, was replaced by Marcelo Caetano. The final date of my research is 1980, when a first rightwing government is formed after the end of the dictatorship in April 25, 1974.

In short, my thesis demonstrates that at least 137 publishing houses edited books with clear political features in Portugal between 1968 and 1980. In this period 4,600 different political titles were published. This thesis presents synthetic studies about 106 publishing of these.

My argument is that those publishing houses conformed what we can call "political publishing era" in Portugal. By realizing an editorial work that directly combined political activism and editorial action, theses publishing houses and their publishers acted with a clear political intention of social intervention. In this sense they become important and active social actors in the Portuguese political process in the final period of the dictatorship and beginning of the democratization years.
\end{abstract}

Key-words: Political publishing houses - Portugal; History of books - Portugal; The Carnation Revolution 


\section{SUMÁRIO}

Introdução....................................................................................................................... 18

O universo da pesquisa: editoras que publicaram livros de caráter político em

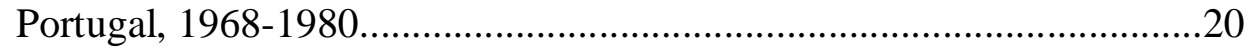

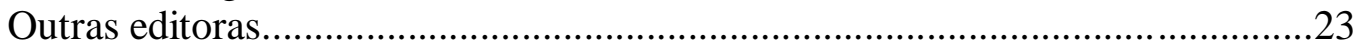

Exposição da investigação e dos seus resultados................................................24

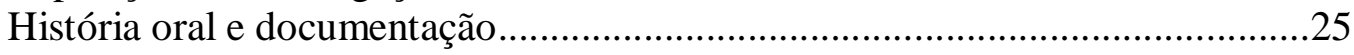

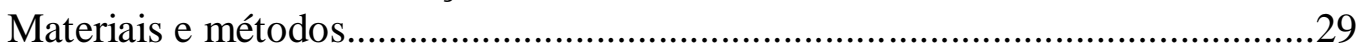

Um estrangeiro estudando a história contemporânea de Portugal.......................33

\section{$\underline{\text { Parte I - A edicão política em Portugal nos anos 1960-70 }}$}

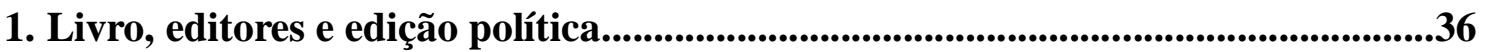

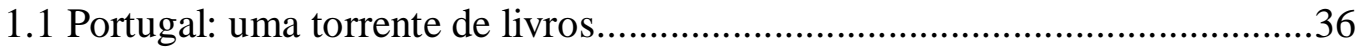

1.2 Portugal no final dos anos 1960 e o mercado editorial..................................42

1.3 Editoras de oposição e Editoras da revolução...............................................45

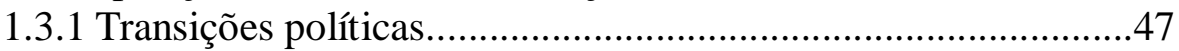

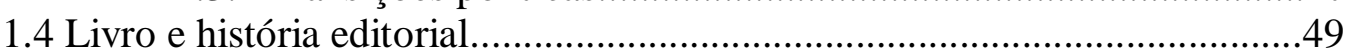

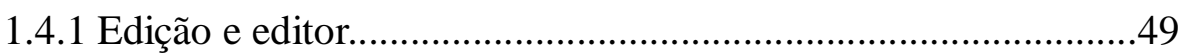

1.4.2 História do livro em Portugal...................................................54

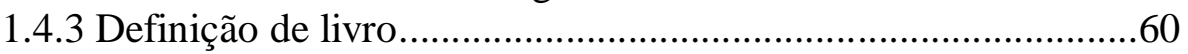

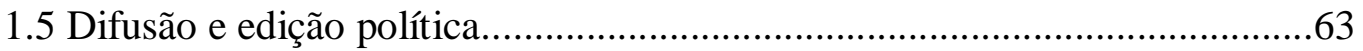

1.5.1 Difusão e disseminação ampla.................................................63

1.5.2 A edição política e o livro político.............................................66

2. A edição política em Portugal antes e depois do 25 de Abril...................................74

2.1 Os livros de caráter político antes do 25 de Abril.........................................74

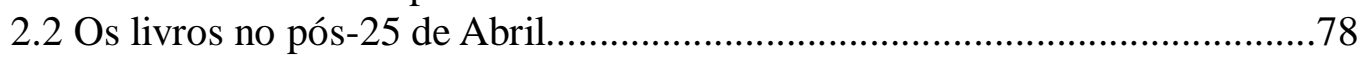

2.3 As editoras no pré e no pós-25 de Abril....................................................... 81

3. As editoras que publicaram livros de caráter político em Portugal, 1968-80......91

3.1 Quadro Sinóptico das editoras que publicaram livros de caráter político em

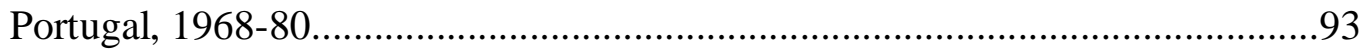

3.2 Síntese analítica do "Quadro Sinóptico".....................................................98

3.2.1 Lisboa e Porto concentraram a produção editorial.....................98

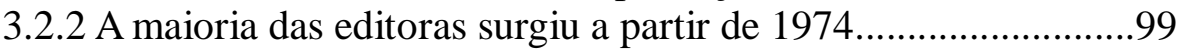

3.2.3 Quase três quartos das editoras tinham perfil político..............101

3.2.4 Mais da metade das editoras eram ligadas à esquerda..............101

3.2.5 Editoras ligadas a grupos maoistas formavam o maior conjunto;

PCP era o partido com maior número de editoras........................103

3.2.6 Editoras ligadas a grupos de esquerda....................................104

3.2.7 Mais de metade das editoras era de pequeno porte..................105

$\underline{\text { Parte II - As editoras de caráter político em Portugal: história e atuacão }}$

4. Editoras políticas de esquerda - ligadas ao Partido Comunista Português

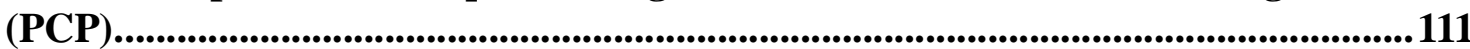

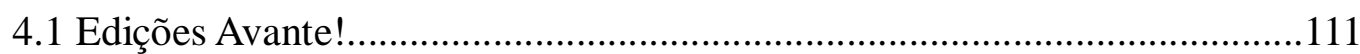

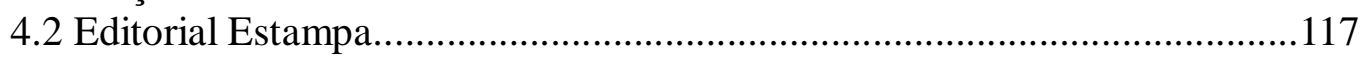




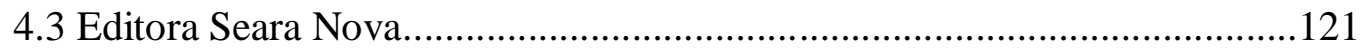

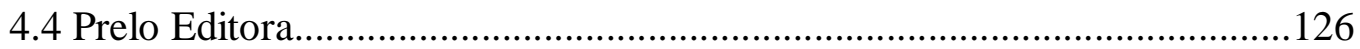

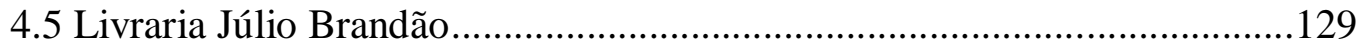

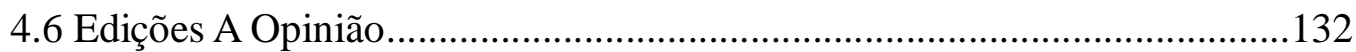

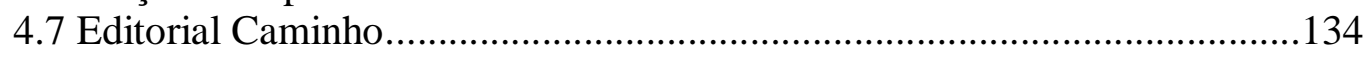

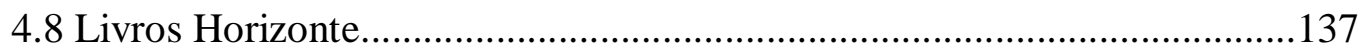

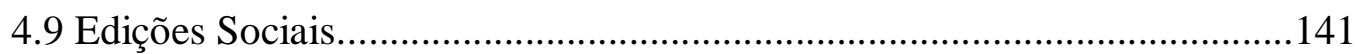

4.10 Manuel Rodrigues Xavier.....................................................................144

4.11 Novo Curso Editores.................................................................................... 145

5. Editoras políticas de esquerda - ligadas a grupos de extrema esquerda maoistas...............................................................................................................................147

5.1 Partido Comunista de Portugal (marxista-leninista) - PCP(m-l)-Vilar / Comitê Marxista-Leninista Português (CMLP)...................................................148

5.1.1 Edições do Partido.......................................................................148

5.1.2 Edições Seara Vermelha...............................................................150

5.2. Partido Comunista de Portugal (marxista-leninista) - PCP(m-l)-Mendes/

Comité Marxista-Leninista Português (CMLP) ..................................................152

5.2.1 Edições Unidade Popular.........................................................152

5.2.2 Ediçõos Militão Ribeiro..............................................................153

5.2.3 Edições A Verdade....................................................................155

5.3 Organização Comunista Marxista-Leninista Portuguesa (OCMLP)............157

5.3.1 Edições O Grito do Povo.........................................................157

5.3.2 Edições Spartacus/OCMLP..........................................................159

5.4 Comité Marxista-Leninista de Portugal (CMLdeP)......................................161

5.4.1 Publicações O Proletário Vermelho/Editora Outubro................161

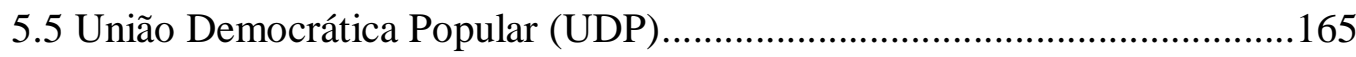

5.5.1 Edições Maria da Fonte...........................................................165

5.5.2 Edições Voz do Povo..................................................................169

5.5.3 Edições Povo e Cultura...............................................................171

5.6 Organização para a Reconstrução do Partido Comunista (marxista-leninista)

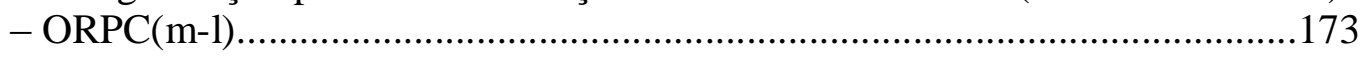

5.6.1 Edições A Causa Operária...........................................................173

5.6.2 Revolução Proletária...............................................................175

5.7 Partido Comunista Português (Reconstruído)-PCP(R) / Partido Comunista

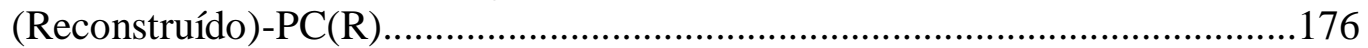

5.7.1 Edições Bandeira Vermelha.........................................................176

5.8 Movimento Reorganizativo do Partido do Proletariado (MRPP)/ Partido Comunista dos Trabalhadores Portugueses (PCTP).........................................178

5.8.1 Vento de Leste.......................................................................... 178

5.8.2 Publicações Nova Aurora.........................................................185

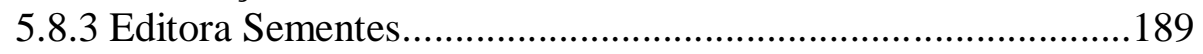

5.8.4 Edições Estrela Vermelha.........................................................194 
5.8.5 Germinal Editora e Distribuidora............................................195

5.8.6 Edições Bandeira Vermelha - PCTP/MRPP.............................198

5.8.7 Edições AAPA (Associação de Amizade Portugal-Albânia)...199

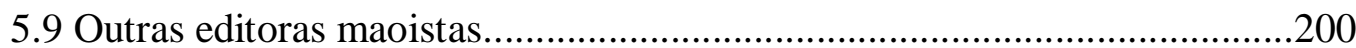

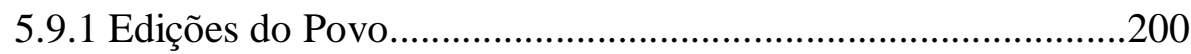

5.9.2 Edições Movimento Operário..................................................202

5.9.3 Pensamento e Acção............................................................203

5.9.4 Textos da Revolução.............................................................204

6. Editoras políticas de esquerda - ligadas a outros grupos (esquerda radical, trotskistas, anarquistas, Partido Socialista, outros)..................................................206

6.1 Editoras ligadas a grupos de esquerda radical e trotskistas.......................206

6.1.1 Edições Contra a Corrente (jornal Combate)...........................206

6.1.2 Edições Revolução (PRP/BR).................................................213

6.1.3 Editora 17 de Outubro (PRP/BR) ...........................................215

6.1.4 SLEMES - Serviço de Livros e Edições do MES (Movimento de

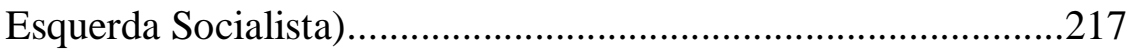

6.1.5 Edições Antídoto (LCI/PSR).................................................219

6.1.6 Editorial Divul (PRT) ......................................................221

6.2 Editoras ligadas ao pensamento anarquista..............................................223

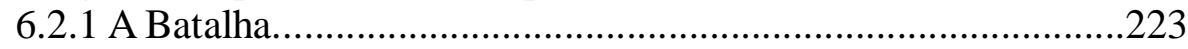

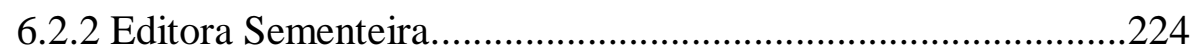

6.2.3 Cooperativa Cultural Editora Fomento Acrata........................22

6.2.4 Livraria Editora Sotavento..................................................228

6.3 Editoras ligadas ao Partido Socialista.......................................................229

6.3.1 Edições Portugal Socialista..................................................229

6.3.2 Perspectivas \& Realidades - p\&r..........................................230

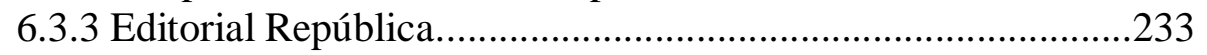

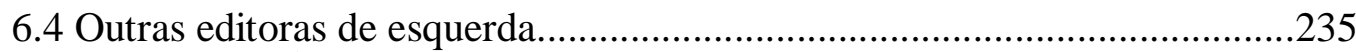

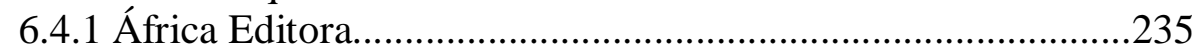

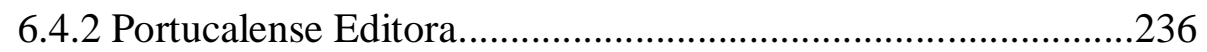

6.4.3 AEPPA (Associação de Ex-Presos Políticos Antifascistas)......239

7. Editoras políticas de esquerda sem vinculação partidária.................................242

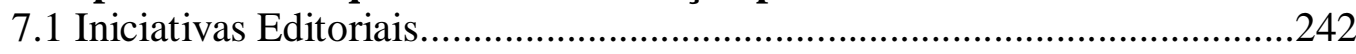

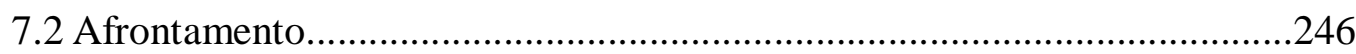

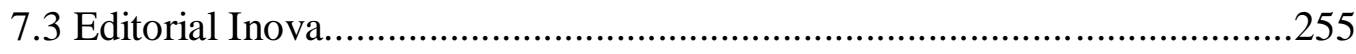

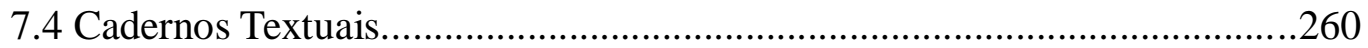

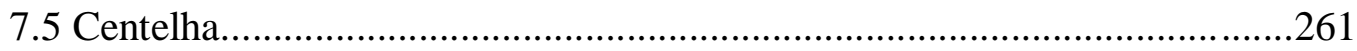

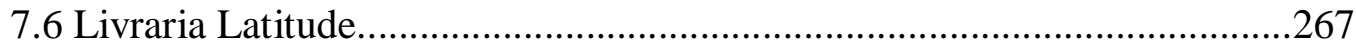

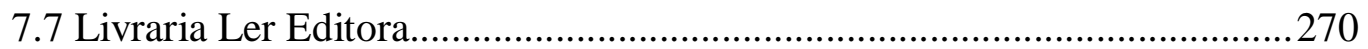

7.8 Cadernos Para o Diálogo.........................................................................2276

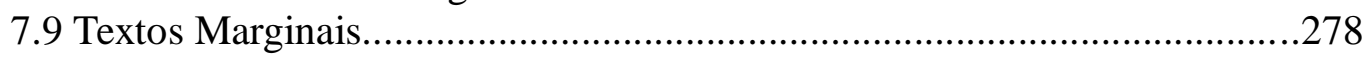

7.10 Publicações Escorpião/Textos Exemplares............................................282

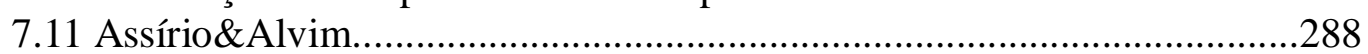

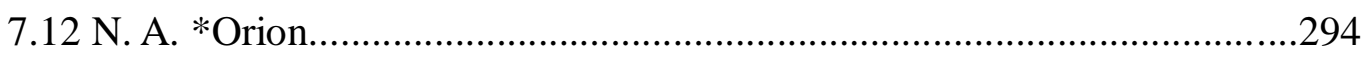




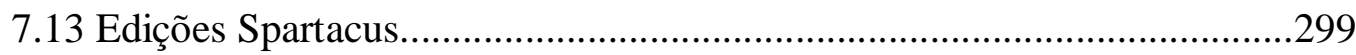

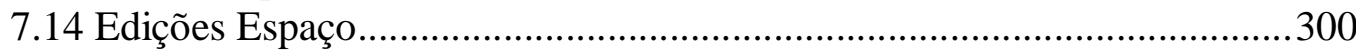

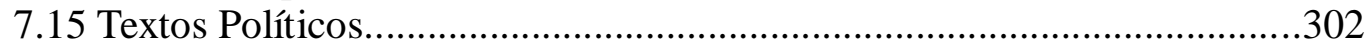

7.16 Serviços Sociais dos Trabalhadores CGD (Caixa Geral de Depósitos).....304

7.17 DiAbril Cooperativa Editorial....................................................................307

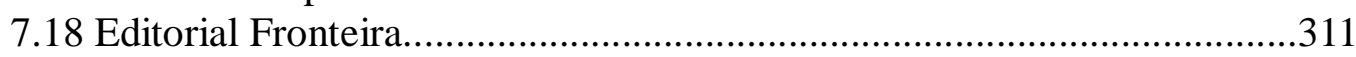

8. Editoras políticas ligadas à oposição católica/católicos progressistas..................316

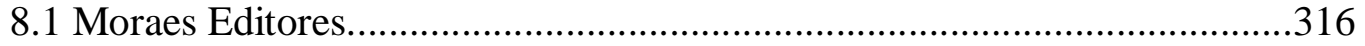

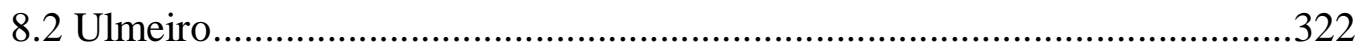

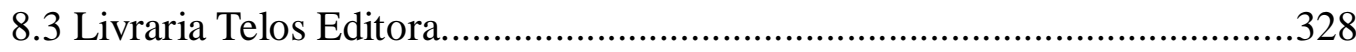

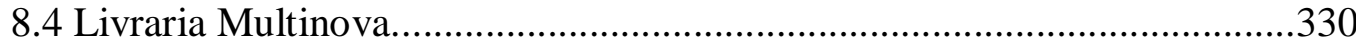

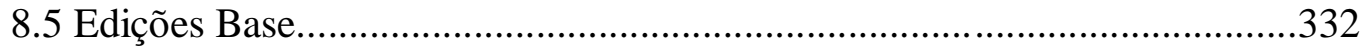

8.6 Edições CIDAC (Centro de Informação e Documentação Amílcar

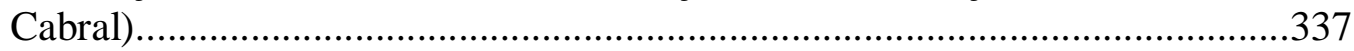

9. Editoras políticas sem vinculação a grupos políticos.............................................340

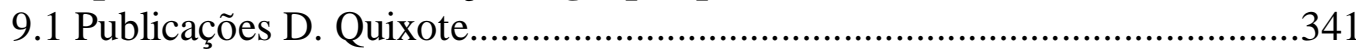

9.2 Edições Afrodite/ Edições Fernando Ribeiro de Mello................................347

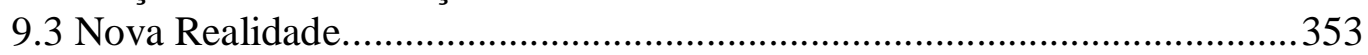

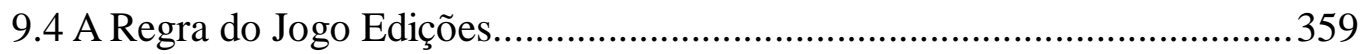

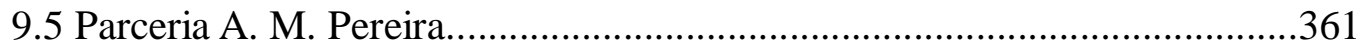

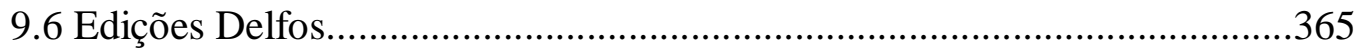

10. Editoras políticas de direita...................................................................................367

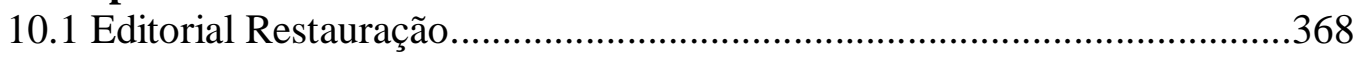

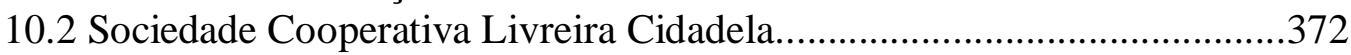

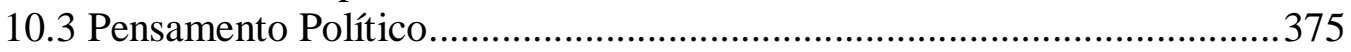

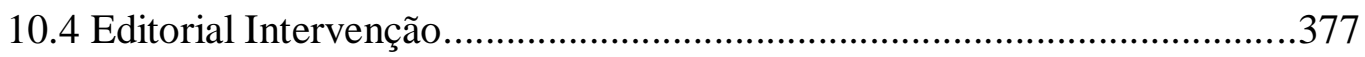

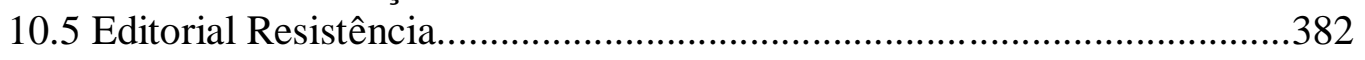

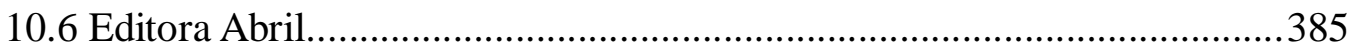

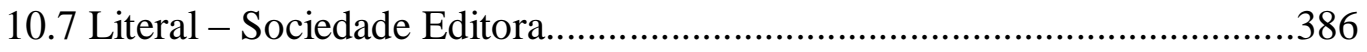

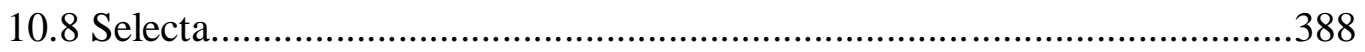

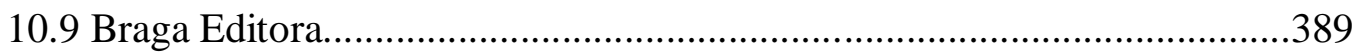

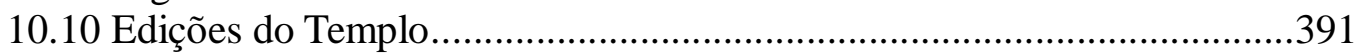

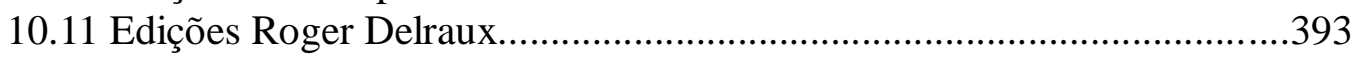

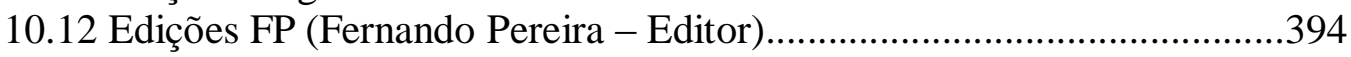

10.13 Livraria Popular de Francisco Franco .......................................................396

11. Algumas editoras que publicaram livros políticos, mas que não se caracterizavam como editoras políticas...........................................................398

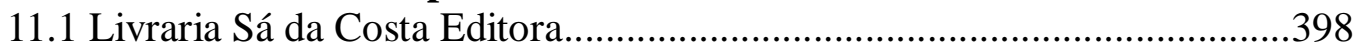

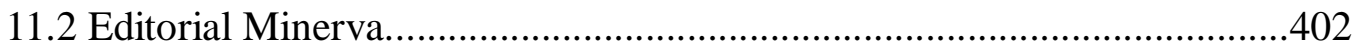

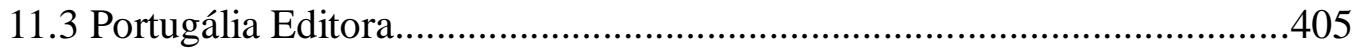

11.4 Editorial Estúdios Cor............................................................................409

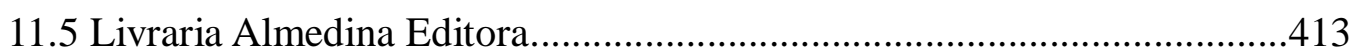

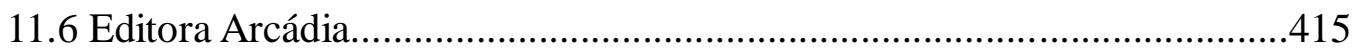

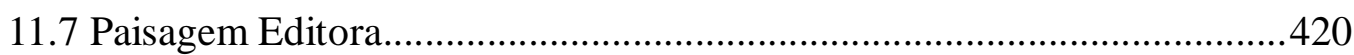

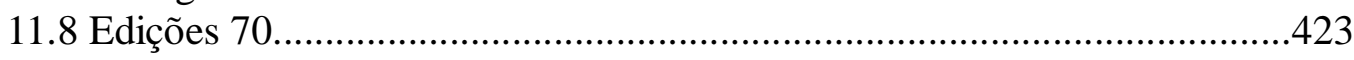

11.9 Liber - Editorial e Publicidade Portugal Brasil.......................................426 
11.10 Edições Rés

11.11 Editora Nova Crítica.

Parte III - A edicão política e seu papel nas lutas contra a ditadura 435-464

12. O papel da edição política em Portugal. .432

12.1 A edição política e a denúncia dos crimes da ditadura em Portugal (1968-80)

12.1.1 Livros de oposição antes do 25 de Abril

12.1.2 O pós-25 de Abril.

12.1.3 Um breve balanço

12.1.4 Algumas considerações preliminares.

12.2 A edição política no olhar do editor 448

Conclusões. .461

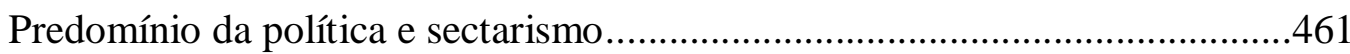

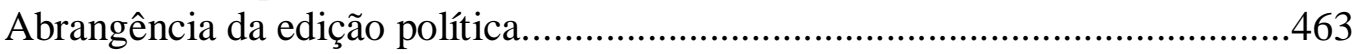

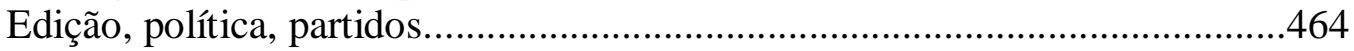

Agitação política, engajamento e estratégias editoriais....................................466

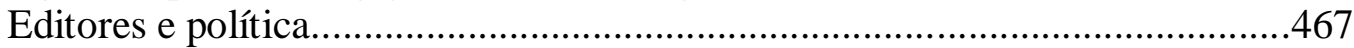

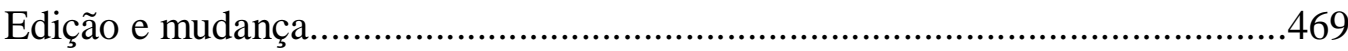

Bibliografia e fontes..................................................................................................471

Apêndice 1 - Lista das Editoras Políticas (100 editoras). .494

Apêndice 2 - Lista das Editoras Não Políticas (37 editoras) que publicaram livros políticos...... 496

Apêndice 3 - Lista de livros políticos publicados em Portugal entre 1968 e 1980 pelas 137 editoras incluídas neste trabalho.

Apêndice 4 - Lista de livros políticos publicados em Portugal entre 1968 e 1980 por outras 107 editoras não incluídas neste trabalho (publicaram menos de cinco títulos políticos no período) 
Nota:

O leitor perceberá a presença da grafia brasileira e portuguesa neste trabalho. Isso porque preferi manter, nas citações de textos portugueses, a grafia utilizada naquele país na época em que os textos citados foram editados.

Já as citações de textos brasileiros tiveram sua grafia atualizada conforme o mais recente acordo ortográfico. 


\section{INTRODUÇÃO}

Inicialmente, gostaria de expor brevemente como cheguei ao tema e ao desenvolvimento desta tese, uma vez que em suas origens este trabalho tinha um objeto de pesquisa mais amplo e propunha como um de seus objetivos a realização de um estudo comparativo.

Esta tese é uma decorrência e uma continuidade de minha dissertação de mestrado intitulada Editoras de oposição no período da abertura (1974-1985): Negócio e política, que defendi em 2006 na Universidade de São Paulo ${ }^{1}$. Na dissertação, estudei a atuação de algumas editoras de oposição no Brasil e seu papel na luta contra a ditadura. Foi a partir dos seus resultados que surgiu a ideia de realizar um estudo comparativo entre as editoras de oposição no Brasil e experiências relacionadas à edição política em outros países. A ideia básica era tentar verificar o que havia de particular na experiência brasileira e o que poderia ser considerado como traço comum com outras experiências comparáveis.

A partir dessa ideia, o passo seguinte foi fazer uma opção entre qual país, ou países, eleger como objeto de estudo comparativo com o Brasil. Argentina, Chile e Uruguai apareciam inicialmente como opções interessantes, pelo fato de terem passado por ditaduras militares no mesmo período histórico em que o Brasil também vivia sob ditadura, e pelo fato de estas experiências políticas guardarem importantes similaridades, como a doutrina de segurança nacional e a concepção de "inimigo interno", por exemplo.

Outras possibilidades eram Espanha e Portugal, países europeus que tiveram decisiva participação na história latino-americana e que tinham passado por longas ditaduras no século XX, e em meados dos anos 1970 viveram processos de democratização.

A escolha de Portugal se deu pelo fato de neste país ter acontecido um processo único de revolução política e social após a queda da ditadura, processo esse que teve seu ápice no período entre o final de abril de 1974 e novembro de 1975, o que deu a esta etapa da história portuguesa um dinamismo e uma radicalidade singulares em comparação com os outros países mencionados.

\footnotetext{
${ }^{1}$ SILVA, Flamarion Maués Pelúcio. Editoras de oposição no período da abertura (1974-1985): Negócio e política. 2006. Dissertação (Mestrado em História) - Programa de Pós-graduação em História Econômica, Faculdade de Filosofia, Letras e Ciências Humanas, Universidade de São Paulo, 2006.
} 
Além disso, outro fator de ordem pessoal teve alguma influência na definição de Portugal como objeto de estudo: meu pai foi morar em Lisboa em 2007, de modo que isso me garantia uma base de apoio excelente para a meu trabalho.

Ao mesmo tempo, esse projeto acadêmico relacionava-se com minha experiência profissional de cerca de 15 anos na edição de livros em São Paulo, sendo a parte mais substancial desse trabalho vinculado à Fundação Perseu Abramo, do Partido dos Trabalhadores.

Ao iniciar a pesquisa sobre as editoras políticas em Portugal, minha primeira surpresa foi verificar que este tema ainda não havia sido objeto de investigação. $\mathrm{Na}$ verdade, comecei a perceber que, sob certos aspectos, o estudo do período da história portuguesa que se abre com a Revolução dos Cravos e vai até o final dos anos 1970 estava ainda começando a ser feito, principalmente no que diz respeito a questões sociais e culturais.

Com o desenvolvimento da investigação, foi ficando claro que o período imediatamente anterior ao golpe dos capitães que derrubou a ditadura de 48 anos em Portugal, e os anos que se seguiram, foram de intensa atividade editorial de caráter político no país. Principalmente após o 25 de abril havia ocorrido um verdadeiro surto de edição de livros políticos, de dimensões consideráveis se comparado a qualquer outro país, mas especialmente significativo para Portugal, que em 1974 tinha cerca de 8 milhões de habitantes, dos quais pelo menos um terço eram pessoas sem alfabetização.

Conforme conhecia mais sobre a ação das editoras portuguesas - e dos seus editores - naqueles anos, e sobre seu papel nas lutas políticas do país, começou a surgir a percepção de que valeria a pena um estudo aprofundado que fosse dedicado somente à edição política em Portugal naqueles anos, o que incluía buscar perceber a atuação dos editores em um período revolucionário. Tal opção acabou por ser também sugerida em minha qualificação, tanto por meu orientador como pelas professoras Sandra Reimão e Marisa Midori, que compuseram a banca.

Foi esta a opção que adotei a partir de então. Apesar de lamentar ter de deixar de lado o estudo comparativo com o Brasil, esta escolha me pareceu extremamente interessante e proveitosa, pois de fato a experiência portuguesa de edição política nesses anos foi excepcional, como espero que este trabalho demonstre. 


\section{O universo da pesquisa: editoras que publicaram livros de caráter político} em Portugal, 1968-1980

A partir desse novo enquadramento do objeto de estudo, meu objetivo passou a ser a investigação e a análise das editoras que publicaram livros de caráter político em Portugal no período entre 1968 e 1980. Para atingir este objetivo, era necessário: a) realizar o recenseamento das obras de caráter político publicadas no período em estudo, buscando verificar os títulos lançados, sua abrangência, seus autores e os temas abordados; b) identificar as editoras que realizaram essas publicações e examinar as vinculações políticas que tinham; e c) identificar as pessoas e organizações responsáveis por essas editoras e publicações, e entrevistar algumas delas.

Ao final, espero ter conseguido traçar um amplo retrato da edição política em Portugal naquele período, que permita compreender e avaliar a relevância política destas editoras, além de indicar alguns elementos relativos ao papel político-ideológico que buscaram desempenhar e à possível repercussão social de sua atuação.

O levantamento que realizei gerou uma lista de 137 editoras que publicaram livros de caráter político. Incluí nesta lista as editoras das quais localizei pelo menos cinco títulos políticos publicados no período entre 1968 e 1980. Esse foi o critério básico que utilizei para a seleção. Tal critério somente deixou de ser utilizado em alguns poucos casos de pequenas editoras, geralmente ligadas a grupos de esquerda radical, em que a sua produção total não passou de três ou quatro títulos, ou seja, em que a lista total de suas edições não atingiu os cinco títulos.

Ao analisar o conjunto de 137 editoras, verifiquei que elas deveriam ser divididas em dois subgrupos: as editoras políticas e as editoras não políticas. Isso porque nem todas as editoras que publicaram livros de caráter político eram, necessariamente, editoras políticas. Entre elas havia também algumas editoras que, apesar de terem publicado tais obras, não tinham na política o centro de sua atuação, e caracterizavam-se como editoras em que os fins comerciais sobrepunham-se aos demais objetivos. Algumas dessas editoras passaram a publicar tais livros em função da boa aceitação que eles começaram a ter na nova conjuntura portuguesa.

Nos Apêndices 1 e 2 apresento as listas das 100 editoras políticas e das 37 editoras não políticas que compõem o universo analisado neste trabalho. E no Apêndice 3 estão listados todos os livros políticos editados por estas 137 editoras. Eles somam um 
total de cerca de 4.600 títulos.

Assim, adotei como critério para a classificação de uma editora como editora política o fato de nela prevalecer o vínculo entre engajamento político e ação editorial, conforme definição de François Valloton e Julien Hage ${ }^{2}$. Já as editoras não políticas, neste trabalho, são aquelas que publicavam livros políticos, mas cujo foco central de atuação não era a política. Estas categorias serão detalhadas no Capítulo 1.

O meu foco concentrou-se nas editoras políticas, pois foi nestas editoras que a edição política teve mais relevo, além de terem sido estas editoras as que desempenharam um papel político de maior destaque no período estudado. Mas as editoras não políticas também são objeto de análise no decorrer do trabalho.

Para tornar mais produtiva a análise das editoras políticas, adotei quatro subcategorias, a partir da posição de cada editora no espectro político português: a) editoras políticas de esquerda; b) editoras políticas de direita; c) editoras políticas vinculadas a grupos católicos progressistas/oposição católica; d) editoras políticas sem vinculação a grupos ou partidos.

Entre as editoras políticas, privilegiei o estudo das editoras de esquerda. Três fatores, basicamente, levaram a esta escolha. Em primeiro lugar, o fato de meu levantamento ter indicado que as editoras de esquerda representavam a metade das editoras que compõem o meu universo de investigação. Em segundo, por estas editoras se caracterizarem pela forte militância política, fazendo com que a edição política fosse parte de sua própria natureza. Em terceiro lugar, porque em todas as etapas da pesquisa foi sempre bem mais fácil encontrar informações sobre estas editoras, o que se juntava ao fato de as pessoas ligadas às editoras de esquerda terem sido também, na grande maioria dos casos, muito receptivas às abordagens para tratar do tema, o que proporcionava condições mais produtivas de trabalho. Além disso - e não há porque não deixar claro este ponto -, minhas simpatias políticas e ideológicas sempre estiveram deste lado, na esquerda.

Mas é importante ressaltar que o destaque para as editoras de esquerda não representou a exclusão das demais editoras do âmbito do estudo, inclusive as editoras

\footnotetext{
${ }^{2}$ VALLOTON, François. "Edition et militantisme: le catalogue de 'La Cité: Editeur' (1958-1967)". In: BURNAND, Léonard; CARRON, Damien; JEANNERET, Pierre. Livre et militantisme. La Cité Editeur, 1958-1967. Lausanne, Editions d'en bas, 2007; HAGE, Julien. "Collections politiques et effets de sens: Littérature et politique dans les nouvelles maisons d'édition politique d'extrême gauche au cours des années 1960 et 1970". Cahiers du CRHQ (Centre de Recherche d'Histoire Quantitative), n 2, 2010. Disponível em: <http://www.crhq.cnrs.fr/cahiers/page-article.php?num=313\&ch=7>. Acesso em $17 / 10 / 2012$
} 
ligadas à direita e à extrema direita, e as editoras não políticas.

Ao aprofundar a análise das editoras de esquerda, surgiu a necessidade de estabelecer novas subdivisões, que tornavam mais claro o entendimento do seu conjunto, a saber: I) editoras de esquerda ligadas ao Partido Comunista Português (PCP); II) editoras de esquerda ligadas a grupos de extrema esquerda maoistas; III) editoras de esquerda ligadas a outros grupos (esquerda radical, trotskistas, anarquistas, Partido Socialista, outros); IV) editoras de esquerda sem vinculação partidária.

Finalmente, em relação ao grupo formado pelas editoras políticas de esquerda, estabeleci ainda uma última tipificação, que vem a ser o subgrupo das editoras políticas militantes, que reúne aquelas editoras nas quais a militância política foi um fator determinante na sua ação, sobrepondo-se a todos os demais fatores.

O organograma abaixo nos permite uma visualização do conjunto das editoras estudadas e dos subgrupos que estabeleci para facilitar a sua análise.

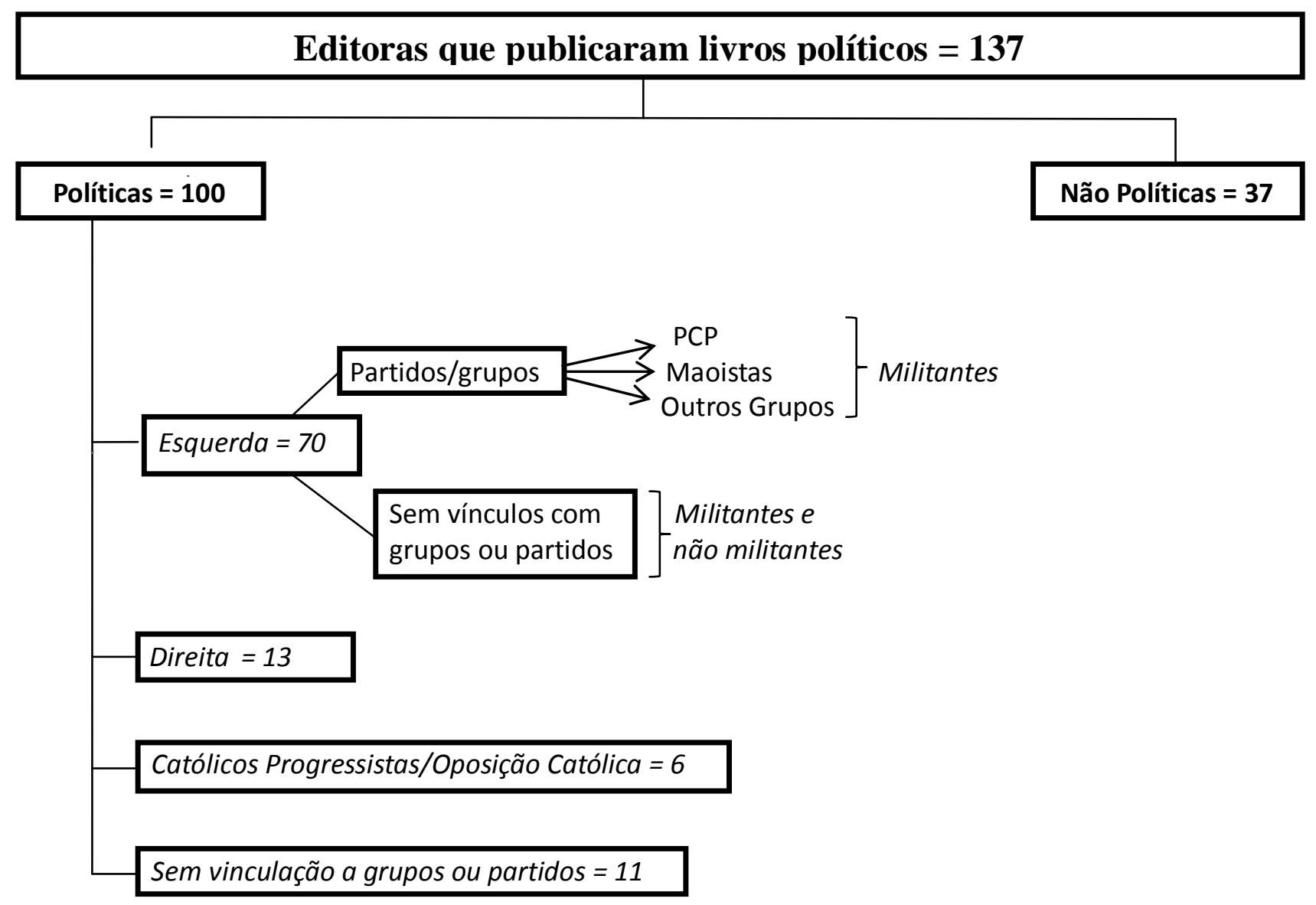




\section{Outras editoras}

Além dos livros políticos publicados pelas editoras abrangidas neste estudo, deve-se lembrar que havia uma série de editoras que não foram aqui incluídas por terem editado menos de cinco títulos desse tipo no período entre 1968 e 1980. Pelo que apurei, elas formam um grupo de pelo menos 107 editoras. Entre elas há editoras de variados tipos: micro, pequenas, médias e grandes editoras; cooperativas; ligadas a associações ou a grupos; antigas ou fundadas após o 25 de Abril; livrarias ou outros tipos de organizações que realizavam esporadicamente edições. Em $60 \%$ dos casos (64 editoras), publicaram apenas um livro político no período 1968-1980, o que mostra que tal edição representou quase sempre uma excepcionalidade na linha editorial seguida por aquela casa.

No Apêndice 4, estas editoras são apresentadas no item "Lista de livros políticos publicados em Portugal entre 1968 e 1980 por outras 107 editoras não incluídas neste trabalho (publicaram menos de cinco títulos políticos no período)", juntamente com os títulos editados por elas.

Por último, é necessário ainda falar de mais uma forma de edição sob a qual apareceram muitos livros políticos. Trata-se da edição de autor, ou seja, aquela que é financiada e realizada pelo próprio autor. Esta modalidade sofreu algumas variações em Portugal, durante o período da ditadura, como a edição do tradutor ou a edição do coordenador da obra. Esta era uma forma de prescindir da licença para edição de livros exigida de uma casa editora - licença esta que deveria ser aprovada pela PIDE (Polícia Internacional de Defesa do Estado), portanto estava sujeita ao crivo político-ideológico do Estado.

Na edição de autor, este assumia a responsabilidade total pela publicação da obra. Com a ampliação desse recurso por meio das edições do tradutor ou do coordenador, como veremos em alguns casos descritos no decorrer deste estudo, muitas vezes aparecia como responsável pela edição alguém que de fato não havia realizado este trabalho, mas que emprestava o seu nome para este fim. Dessa forma, protegia-se o verdadeiro responsável pela edição de possíveis problemas com a polícia política. Em certos casos, personalidades públicas de renome assumiam este papel, com o intuito de criar uma certa barreira de proteção para o livro e para o seu efetivo editor. 
Finalmente, ressalto que não foram incluídas neste levantamento as edições em língua portuguesa realizadas em outros países e distribuídas em Portugal, como era o caso de obras publicadas nas ex-colônias africanas ou no Brasil, além de outras editadas pela Editorial Progresso, da URSS; pelas Edições em Língua Estrangeira, da China; e pela Sofia Press, da Bulgária, entre outras.

\section{Exposição da investigação e dos seus resultados}

Meu trabalho está organizado em três partes: Parte I - A edição política em Portugal nos anos 1960-70; Parte II - As editoras de caráter político em Portugal: história e atuação; e Parte III - A edição política e seu papel nas lutas contra a ditadura.

A Parte I é composta por três capítulos. O primeiro ("Livro, editores e edição política"), apresenta um quadro introdutório da edição política em Portugal, além da exposição de alguns pressupostos teóricos relativos ao papel do editor, à história do livro em Portugal, à definição de livro e à edição política.

O segundo capítulo ("A edição política em Portugal antes e depois do 25 de Abril") traz um relato mais detalhado sobre os livros e as editoras de caráter político antes e depois do fim da ditadura, apresentando sumariamente as editoras que publicaram livros políticos em Portugal entre 1968 e 1980.

O terceiro capítulo ("As editoras que publicaram livros de caráter político em Portugal 1968-80") apresenta o "Quadro Sinóptico" dessas editoras, em que são apresentadas algumas de suas características principais. Em seguida há uma síntese analítica deste Quadro.

A segunda parte é aquela que considero a mais substancial deste trabalho, e apresenta estudos sintéticos sobre 95 editoras políticas e 11 editoras não políticas, totalizando 106 editoras analisadas de modo sintético. São oito capítulos que desenham um quadro abrangente da história e da atuação das editoras políticas de esquerda (capítulos 4 a 7), das editoras políticas ligadas aos católicos progressistas e à oposição católica (Capítulo 8), das editoras políticas sem vinculação a grupos políticos (Capítulo 9), e das editoras políticas de direita (Capítulo 10). O Capítulo 11 apresenta algumas editoras que publicaram livros políticos, mas que não se caracterizavam como editoras 
políticas.

Por fim, na Parte III procuro demonstrar como foi de modo mais concreto a atuação das editoras políticas nas lutas contra a ditadura, por meio de um estudo sobre a publicação de obras de denúncia dos crimes da ditadura em Portugal antes e depois do 25 de Abril, buscando ainda desenvolver algumas ideias sobre o papel da edição política. E também apresento algumas avaliações dos editores sobre a atuação de suas casas editoras e o sobre o seu próprio papel na oposição ao salazarismo e nos primeiros tempos de democracia em Portugal.

Como já mencionado, após as Conclusões há ainda quatro Apêndices que trazem as listas das 137 editoras que publicaram livros políticos em Portugal entre 1968-1980 (Apêndices 1 e 2), e dos livros de caráter político editados em Portugal nesse período que apurei em minha investigação (Apêndices 3 e 4). Este dois últimos Apêndices permitem uma análise mais detalhada da produção de cada editora, assim como dos títulos publicados e das possíveis formas de organizá-los em categorias ou tipologias.

\section{História oral e documentação}

Uma das importantes fontes que utilizei para a reconstituição da trajetória das editoras de caráter político em Portugal foi a história oral, por meio de entrevistas realizadas com editores e colaboradores. Já havia constatado no mestrado que as entrevistas são fundamentais para a reconstituição das origens e para o entendimento do funcionamento dessas editoras, uma vez que, em geral, a documentação administrativa, contábil, empresarial ou mesmo política dessas empresas praticamente inexiste sob a forma de arquivos ou material escrito ou iconográfico.

Assim, estes depoimentos ganham grande importância. São "vozes [que] não se tornam apêndices ou anexos. Elas são parte integrante e fundamental" do trabalho de investigação ${ }^{3}$. Procurei tirar dessas entrevistas o melhor proveito possível, sabendo de suas imperfeições e do seu subjetivismo - que, de resto, estão presentes em todas as fontes históricas. E valorizar o que há nelas de memória afetiva, subjetiva e objetiva, tomando-as como verdadeiras no sentido de que representam a verdade de cada um dos entrevistados, ainda que sempre seja necessário ter clareza de que trazem embutidas

${ }^{3}$ FREITAS, Sônia Maria de. História oral: Possibilidades e procedimentos. São Paulo: Humanitas/Imesp, 2002, p. 117. 
omissões, distorções ou supervalorizações. Considero que o importante, nestes casos, "é saber por que o entrevistado foi seletivo ou omisso, pois esta seletividade tem o seu significado" 4 .

Com base nas narrativas construídas pelos depoimentos - e também nos documentos escritos ou iconográficos -, procurei contrapor versões, levantar problemas, explicitar conflitos e tensões, tomando tais depoimentos como basicamente verídicos, como fonte confiável e segura. E tendo sempre em conta que "o discurso do depoente transmite um ponto de vista do presente nos conteúdos rememorados" 5.

A partir destes procedimentos, o passo seguinte foi proceder ao questionamento das versões que daí surgiram. É sempre necessário precaver-se ante o risco de tomar a fonte, ou a memória, como verdade e não questioná-la ou problematizá-la. Para isso é importante, na realização e no tratamento das entrevistas, utilizar alguns instrumentos e métodos da história oral, entendendo-a como "método de pesquisa que utiliza a técnica da entrevista e outros procedimentos articulados entre si, no registro de narrativas da experiência humana" ${ }^{6}$. Empregando a conceituação de Sônia Maria de Freitas, utilizei métodos da história oral temática, em que

a entrevista tem caráter temático e é realizada com um grupo de pessoas, sobre um assunto específico. Essa entrevista - que tem característica de depoimento - não abrange necessariamente a totalidade da existência do informante. Dessa maneira, os depoimentos podem ser mais numerosos, resultando em maiores quantidades de informações, o que permite uma comparação entre eles, apontando divergências, convergências e evidências de uma memória coletiva. ${ }^{7}$

No que diz respeito ao texto resultante dos depoimentos, a postura que adotei foi a que considera que "a entrevista é uma criação textual, fazendo parte de sua metodologia tornar a leitura mais compreensiva por meio da reestruturação do depoimento"8. Ao mesmo tempo, procurei "garantir [que] a visão de mundo, as ideias, os sonhos e as crenças dos depoentes"9 fossem preservados na passagem da gravação para o texto a que ela deu origem e que está parcialmente reproduzido no trabalho final.

Vale a pena destacar que no campo da história editorial há alguns interessantes

\footnotetext{
${ }^{4}$ Ibidem, p. 69.

${ }^{5}$ Ibidem, p. 119.

${ }^{6}$ Ibidem, p. 18.

${ }^{7}$ Ibidem, p. 21-22. Ver também MEIHY, José Carlos Sebe. Manual de história oral. $4^{\text {a }}$ ed. São Paulo: Loyola, 2002, p. 145-48.

${ }^{8}$ FREITAS, op. cit., p. 75-76.

${ }^{9}$ Ibidem, p. 94.
} 
trabalhos que fizeram uso da história oral para registrar a experiência de editores. No Brasil temos a coleção Editando o Editor, coordenada por Jerusa Pires Ferreira, que teve sete volumes publicados até o momento ${ }^{10}$, e representa uma significativa contribuição para o estudo das empresas editoras e dos editores na segunda metade do século XX no país. Há também publicações importantes na Itália ${ }^{11}$, Espanha ${ }^{12}$ e Argentina $^{13}$, entre outros países.

Em dezembro de 2012 a Booktailors lançou em Portugal a coleção Protagonistas da Edição, composta por entrevistas, conduzidas pela jornalista Sara Figueiredo Costa, com editores, tradutores, revisores e designers. O primeiro volume lançado foi Fernando Guedes: $O$ decano dos editores portugueses ${ }^{14}$, que trata da trajetória do fundador da Editorial Verbo. Os dois próximos volumes, já anunciados, deverão trazer entrevistas com Carlos da Veiga Ferreira (Teorema) e Guilhermina Gomes (Círculo de Leitores).

\section{Documentação}

Cabe destacar que em minha pesquisa foram fundamentais três tipos de fontes, além das orais: a) os livros editados pelas editoras aqui estudadas; b) os catálogos e acervos de bibliotecas; c) os acervos de sebos (alfarrabistas). Tais fontes não foram utilizadas apenas como instrumentos intermediários para poder ter acesso a certas informações, como muitas vezes elas são usadas, ou seja, utiliza-se o catálogo e o acervo de uma biblioteca ou alfarrabista para ter acesso a um livro, e, uma vez obtida a possibilidade de leitura daquele livro, poder chegar ao seu conteúdo, às análises e ideias do seu autor.

${ }^{10}$ AMORIM, Sônia Maria de. J. Guinsburg. São Paulo: Com-Arte, v. 1, 1989; CABRINI, Conceição A. Flávio Aderaldo. São Paulo: Com-Arte/Edusp, v. 2, 1991; ALMEIDA, Marta de Assis et alii. Enio Silveira. São Paulo: Com-Arte/Edusp, v. 3, 1992; FERREIRA, Jerusa Pires (org.). Arlindo Pinto de Souza. São Paulo: Com-Arte/Edusp, v. 4, 1995; FERREIRA, Jerusa Pires (org.). Jorge Zahar. São Paulo: Com-Arte/Edusp, v. 5, 2001; FERNANDES, Magali Oliveira et alii. Cláudio Giordano. São Paulo: ComArte/Edusp, v. 6, 2003; VICENTINI, Raquel Maygton. Samuel Leon. São Paulo: Com-Arte/Edusp, v. 7, 2010.

${ }^{11}$ CESARI, Severino. Colloquio con Giulio Einaudi. Turim: Giulio Einaudi Editore, 2007; GAMBARO, Fábio. Dalla Parte degli Editori. Interviste sul lavoro editoriale. Milano: Unicopli, 2001.

12 AAVV, Conversaciones con editores en primera persona. Madrid: Fundación Germán Sánchez Ruipérez, 2006.

${ }^{13}$ MAUNÁS, Delia. Boris Spivacow: memoria de un sueño argentino. Entrevistas de Delia Maunás. Buenos Aires: Colihue, 1995.

${ }^{14}$ COSTA, Sara Figueiredo. Fernando Guedes: O decano dos editores portugueses. Lisboa: Booktailors, 2012. 
No caso de minha investigação, em boa parte dos casos os livros, os acervos das bibliotecas e dos alfarrabistas foram eles mesmos as fontes; não apenas fontes intermediárias para alcançar certa informação, mas eram eles em si mesmos $a$ informação. Tentando ser mais claro: em muitos casos a consulta aos catálogos e aos acervos das bibliotecas e alfarrabistas foi o ponto inicial da pesquisa sobre diversas editoras, a respeito das quais eu desconhecia muitas vezes até mesmo a sua existência, e que foram descobertas por mim nos catálogos ou nas estantes de uma biblioteca, ou em uma banca de alfarrabista, ao deparar-me com livros por elas editados. E, a partir daí, muitas vezes foram os livros a principal fonte de informação sobre tais editoras, havendo mesmo casos em que somente foi possível reconstituir a trajetória da editora a partir de algumas obras que ela editou e às quais pude ter acesso.

Assim, o livro enquanto materialidade, suporte físico e objeto final em que se materializa o trabalho editorial, foi utilizado, para além de fonte pelo seu conteúdo escrito e visual, também como fonte em sua dimensão material (documento físico), e a análise das informações materiais, editoriais e paratextuais que ele carrega fundamentaram parte substantiva de minha investigação. $\mathrm{Na}$ verdade, trata-se de analisar como conteúdo e como informação esta materialidade, verificando o que ela pode revelar de informações sobre o trabalho criativo envolvido no processo editorial que levou ao surgimento daquele volume, acrescentando, dessa forma, novos elementos ao livro, que vão além do conteúdo autoral e textual normalmente analisados.

Desse modo, seguimos as ideias de D. F. McKenzie ${ }^{15}$ sobre "a dimensão material do livro como variável necessária à restituição dos sentidos investidos num texto" "16. O que significa que "a encadernação e o aspecto gráfico do livro, o formato da página impressa e as suas divisões internas, ou a articulação entre texto e paratexto índices, ilustrações, notas, tabelas -, são instâncias atuantes nos significados interpretáveis, interferindo na leitura do objeto impresso" "17. Para McKenzie "Novos leitores criam textos novos e extraem sentidos novos que dependem diretamente da sua forma nova"18.

Chartier ressalta, neste sentido, que "Uma realidade textual não deve ser

\footnotetext{
${ }^{15}$ MCKENZIE, D. F. Bibliography and the Sociology of Texts. London: The British Library, 1986.

${ }^{16}$ MEDEIROS, Nuno. "Objecto dúctil: a emergência de uma sociologia histórica da edição". Tempo Social. Revista de Sociologia da USP. São Paulo, Departamento de Sociologia, Faculdade de Filosofia, Letras e Ciências Humanas, Universidade de São Paulo, vol. 22, nº 2, nov. 2010, p. 248.

${ }^{17}$ Ibidem, p. 248.

${ }^{18}$ MCKENZIE, op. cit., p. 20.
} 
entendida unicamente em sua dimensão literária, pois também arraiga-se profundamente em sua realidade material, que é a forma do livro em que se abarcava o texto"19. Tal ocorre porque "O processo de publicação, qualquer que seja sua modalidade, sempre é um processo coletivo, que implica numerosos atores e que não separa a materialidade do texto da textualidade do livro" 20 .

No caso deste trabalho, a dimensão material foi fundamental para a reconstituição de parte da história da edição política em Portugal.

Este olhar para o livro como fonte rica em informações, em sua múltiplas dimensões, inclusive a material, deve ser, acredito, uma etapa necessária de qualquer história da edição, ou de qualquer história editorial ${ }^{21}$.

Outra fonte importante de documentação que utilizei foi a imprensa do período estudado, tanto os jornais e revistas de maior circulação como os editados por pequenos grupos e organizações políticas. Estas publicações forneceram muitas informações sobre os livros lançados no período, trazendo comentários sobre alguns deles que permitiram obter alguma notícia sobre como eram recebidas tais obras. Alem disso, traziam também reportagens e artigos sobre o mercado editorial, a criação e a crítica literária e a atuação pública de escritores, editores e intelectuais.

\section{Materiais e métodos}

A base desta tese funda-se nas origens e nas trajetórias das editoras de caráter político atuantes em Portugal no período analisado.

Para construir um amplo quadro histórico e informativo sobre esse universo editorial e político, realizei pesquisas em instituições acadêmicas, editoriais, políticas e empresariais; em bibliotecas (públicas e particulares), livrarias e sebos (alfarrabistas); entrevistei editores, livreiros e colaboradores das editoras; levantei, da forma mais ampla possível informações que me possibilitaram estabelecer o quadro das editoras de

\footnotetext{
${ }^{19}$ CHARTIER, Roger. Cultura escrita, literatura e história. Porto Alegre: Artmed, 2001, p. 43.

${ }^{20}$ CHARTIER, Roger. "Materialidad del texto, textualidad del libro". Orbis Tertius-Revista de teoría y crítica literaria, Centro de Estudios de Teoría y Crítica Literaria, Facultad de Humanidades y Ciencias de la Educación, Universidad Nacional de La Plata, Argentina, vol. 11, $\mathrm{n}^{\mathrm{o}}$ 12, 2006. Disponível em: <http://www.orbistertius.unlp.edu.ar/numeros/numero-12/1-chartier.pdf>. Acesso em 28/12/2012.

${ }^{21}$ Sobre isso, ver o estimulante artigo: MOLLIER, Jean-Yves. Sources et methodes en histoire du livre, de l'edition et de la lecture. Texto apresentado na Escola São Paulo de Estudos Avançados Sobre a Globalização da Cultura no Século XIX. Campinas, Unicamp, 20-24/8/2012. Mimeogr.
} 
caráter político em Portugal e de sua produção editorial.

Os procedimentos metodológicos que possibilitaram a construção desse painel histórico foram basicamente os seguintes:

1) Pesquisas em instituições acadêmicas e em bibliotecas (públicas e particulares) que contêm material relevante relacionado ao tema da investigação. E também em instituições editoriais, políticas e empresariais, e em livrarias e sebos (alfarrabistas), onde havia possibilidade de serem encontrados livros de caráter político produzidos pelas editoras em foco. As instituições e estabelecimentos pesquisados foram as seguintes:

- Biblioteca-Museu República e Resistência (Departamento de Bibliotecas e Arquivos de Lisboa)

- Biblioteca Nacional de Portugal

- Biblioteca do Instituto de História Contemporânea da Universidade Nova de Lisboa

- Biblioteca da Faculdade de Ciências Sociais e Humanas da Universidade Nova de Lisboa

- Biblioteca da Faculdade de Letras da Universidade de Lisboa

- Rede de Bibliotecas Municipais da cidade de Lisboa, em particular a Biblioteca Galveias (Central)

- Biblioteca João Paulo II da Universidade Católica de Lisboa

- Biblioteca do Instituto Universitário de Lisboa (ISCTE-IUL)

- Biblioteca da Universidade Autônoma de Lisboa Luís de Camões

- Centro de Documentação 25 de Abril da Universidade de Coimbra

- Arquivo da Fundação Mario Soares, em Lisboa

- Hemeroteca Municipal de Lisboa

- Arquivo da Associação Portuguesa de Editores e Livreiros (APEL), em Lisboa

- Acervo da Livraria Letra Livre, em Lisboa

- Acervo da Livraria Ulmeiro, em Lisboa

- Acervo da Livraria Culsete, em Setúbal

- Arquivo das Edições Afrontamento, no Porto

- Arquivo das Edições Base, em Lisboa

- Arquivo de João Freire (Editora Sementeira, sob guarda da Biblioteca 
Nacional de Portugal, em Lisboa)

- Arquivo de João Barrote (editoras Paisagem, Textos

Exemplares/Escorpião)

- Arquivo de Rita Delgado (Edições Contra a Corrente)

2) Pesquisas em publicações da imprensa do período revolucionário, inclusive a imprensa militante, para verificar como a produção editorial de livros de caráter político era tratada por estes veículos de comunicação.

Os principais veículos de imprensa pesquisados foram os seguintes:

- Flama (revista)

- Vida Mundial (revista)

- Seara Nova (revista)

- Opção (revista)

- Vértice (revista)

- Revista dos Livros (revista)

- Livros de Portugal (revista)

- O Tempo e o Modo (revista)

- O Comunista (revista)

- O Militante (revista)

- Patuleia (revista)

- Que Fazer? (revista)

- Resistência (revista)

- Prelo (revista)

- O Bolchevista (revista)

- Expresso (jornal)

- República (jornal)

- Público (jornal)

- A Capital (jornal)

- Página Um (jornal)

- Em Marcha (jornal)

- Luta Popular (jornal)

- O Grito do Povo (jornal)

- A Causa Operária (jornal) 
- A Verdade (jornal)

- Bandeira Vermelha (jornal)

- Foice e Martelo (jornal)

- Folha Comunista (jornal)

- Voz do Povo (jornal)

- Ponto (jornal)

3) Entrevistas com editores, livreiros e colaboradores das editoras e outras pessoas envolvidas, direta ou indiretamente, na atuação das editoras em estudo.

Realizei as seguintes entrevistas para a realização deste trabalho:

- António Daniel Abreu (editoras Cadernos Para o Diálogo, Textos Marginais, Rés e Nova Crítica)

- António José Fonseca (editoras Sementes e Estrela Vermelha)

- Carlos Loures e Manuel Simões (Editora Nova Realidade)

- Carlos da Veiga Ferreira (Editora Teorema)

- Eduardo Sousa (Editora Centelha e Livraria Letra Livre)

- Fernando Abreu e Brandão Guedes (Edições Base)

- Francisco Melo (Editorial Avante!)

- Jacinta Ferreira (Editora Centelha)

- João Barrote (editoras Paisagem e Textos Exemplares/Escorpião)

- João Camacho (editoras Nova Aurora e Vento de Leste)

- João Carlos Alvim (Editora Assírio\&Alvim)

- João Freire (Editora Sementeira)

- José Antunes Ribeiro (editoras Ulmeiro e Assírio\&Alvim)

- José Sousa Ribeiro (Edições Afrontamento)

- Manuel António Ribeiro Resende (tradutor)

- Maria Teresa Horta (escritora e jornalista)

- Miguel Freitas da Costa (APEL)

- Rita Delgado (Editora Contra a Corrente)

- Sérgio Ribeiro (Editora Prelo)

- Silvério Amaro (Distribuidora Dinalivro)

Quinze destas entrevistas foram gravadas em vídeo e áudio (amador). Três foram 
realizadas por meio de correio eletrônico. A entrevista com João Freire foi realizada pessoalmente mas em condições que não permitiram a gravação.

\section{Um estrangeiro estudando a história contemporânea de Portugal}

O último ponto sobre o qual gostaria de fazer alguns comentários tem caráter pessoal, mas ao mesmo tempo vai muito além disso. Trata-se do fato de eu ser um estrangeiro que se aventurou a tratar da história contemporânea de Portugal, o que nem sempre pode ser visto com bons olhos ou bem compreendido por certas pessoas.

$\mathrm{Na}$ verdade já existe há tempos uma prática perfeitamente normal de pesquisadores estrangeiros que não só estão presentes no exterior, como aí realizam estudos sobre outro país que não o seu - como é o caso dos brasilianistas entre nós. Além disso, há um fluxo antigo e permanente de intercâmbios entre Brasil e Portugal no que diz respeito ao estudo da história comum aos dois países, principalmente sobre os acontecimentos que se passaram até o século XIX.

Este intercâmbio permanece muito ativo e dinâmico em relação à chamada história colonial brasileira, mas há um enorme desconhecimento, entre nós, da história portuguesa do século XX. Poucos, muito poucos mesmo, são os pesquisadores brasileiros que se dedicam a este tema.

Devo destacar que em nenhum momento, durante minha investigação em Portugal, percebi qualquer tipo de preconceito ou má vontade pelo fato de eu ser brasileiro. Ao contrário, em geral houve grande receptividade ao meu trabalho e as pessoas com as quais tive contato foram prestativas e atenciosas - havendo mesmo casos em que se tornaram colaboradoras ativas e entusiastas do meu estudo. Além disso, a Fundação Calouste Gulbenkian, uma instituição portuguesa de primeiro plano naquele país e na Europa, proporcionou-me condições para que uma parte da pesquisa pudesse ser realizada em Portugal.

Mas o que me fez pensar na relevância desta questão foi algo mais pessoal, que foi ficando claro para mim no decorrer do trabalho, durante as minhas várias estadas em Portugal durante a sua realização. Fui percebendo de modo cristalino que eu, como brasileiro, nascido e criado no Brasil, jamais terei a familiaridade e a intimidade com a história portuguesa que tem um português - qualquer português - nascido e criado em 
Portugal. Por mais que estude, leia, viva no país, tente me entranhar na sua cultura e nos seus costumes, isso não proporcionará a vivência e os sentimentos de um português em relação à história do seu país, o que significa dizer que meu olhar sobre a história de Portugal será sempre o de um estrangeiro, ainda que um estrangeiro com certa proximidade com o país, devido ao idioma, à história comum que temos, às proximidades culturais etc.

Como muitos já disseram, essas limitações são em parte compensadas por um olhar diferente que o "ser estrangeiro" proporciona, pontos de vista que muitas vezes passariam despercebidos aos nativos pela própria familiaridade com aquela realidade. Mas de toda forma esta característica, este certo estranhamento, esteve sempre presente em cada frase e em cada ideia deste trabalho. Espero que isto o tenha enriquecido. 


\section{PARTE I}

\section{A EDIĈ̃̃ O POLÍTICA EM PORTUGAL NOS ANOS 1960-70}




\section{LIVRO, EDITORES E EDIÇÃO POLÍTICA}

\subsection{Portugal: uma torrente de livros}

Portugal assistiu desde 1968, mas principalmente após a derrubada da ditadura salazarista em 25 de abril de 1974, a um forte incremento do que podemos chamar de edição política, que se manifestava por meio da publicação de livros de caráter político, com destaque para obras vinculadas ao pensamento de esquerda. Parte de um movimento cultural e político mais amplo, este boom editorial tinha, num primeiro momento (de 1968 até 25 de abril de 1974), um caráter oposicionista, e, a partir da queda ditadura e até o final da década de 1970, expressou a liberação política e cultural decorrente do fim da opressão. Surgiram, nesse processo, inúmeras editoras de cunho claramente político-ideológico, muitas delas com vinculações com partidos ou grupos políticos.

Desde 1968, com a substituição, em setembro daquele ano, de Oliveira Salazar por Marcelo Caetano à frente do governo português, iniciou-se um movimento editorial que acompanhou a rearticulação de setores oposicionistas, em especial os ligados ao campo estudantil, aos grupos de católicos progressistas que se opunham à guerra colonial e a grupos à esquerda do Partido Comunista Português (PCP). Além disso, as promessas de liberalização do regime que então surgiram deram certo alento, inicialmente, a este movimento, pois resultaram no relaxamento de alguns instrumentos de controle da ditadura ${ }^{1}$. Mas esta "primavera marcelista" pouco durou, e no começo dos anos 1970 voltou a prevalecer um regime político mais duro ${ }^{2}$.

Mas foi sobretudo a onda de liberdade advinda do fim da ditadura em Portugal, em abril de 1974, que fez crescer como nunca o número de editoras e de livros publicados, dos quais parte significativa era de cunho político e com perfil de esquerda, ou de denúncia do antigo regime. Um jornalista brasileiro em visita a Lisboa pouco depois do 25 de Abril registrava:

\footnotetext{
${ }^{1}$ LEITE, Pedro Jorge de Oliveira Pereira. Mercadores de letras : rumos e estratégias dos editores e livreiros na divulgação cultural durante o Estado Novo : 1933-1974. 1998. 192 f. Dissetração (Mestrado em História Contemporânea) - Faculdade de Letras, Universidade de Lisboa, 1998. Disponível em: $<$ http://barrigadefreira.blogspot.com/>.

2 OLIVEIRA, César. Anos decisivos: Portugal 1962-1985. Um testemunho. Lisboa: Presença, 1993, p. 114.
} 
A Revolução de Abril provocou um boom no terreno da informação. Os livros proibidos caíram de súbito em meio à curiosidade de quase meio século. Espalham-se pelas calçadas os clássicos marxistas e as obras de divulgação, que compreendem desde os enciclopedistas até os modernos divulgadores da genética. As livrarias também fervem. Em suas vitrinas predominam os fascículos sobre os eventos e livros nunca difundidos. Percebe-se, de fato, o voraz manuseio dos volumes de capa vermelha, destacando-se os títulos das memórias de [Álvaro] Cunhal e [Mário] Soares, líderes respectivos dos partidos comunista e socialista. $^{3}$

O mesmo autor ressalta entre os livros então em destaque trabalhos de divulgação das estruturas de repressão do salazarismo, que traziam um inventário do sistema policial, listas com a relação dos torturadores, além de informações sobre processos de espionagem interna durante a ditadura. E também outros livros mais antigos, proibidos até aquele momento, alguns deles relativos aos primeiros anos do fascismo ${ }^{4}$.

Menos de seis meses após o fim da ditadura já se falava em uma "inflação editorial do pós-25 de Abril"

Se há um sector do comércio que passa a conhecer uma situação diferente com as novas condições criadas pelo 25 de Abril, esse sector é o livreiro. [...] A que se deve esta súbita intensificação no comércio do livro? Naturalmente, à situação política que o país actualmente está a viver. Houve um véu que se rasgou e as pessoas sentiram-se, de repente, necessitadas: dum esclarecimento, duma explicação, duma palavra; ou dum suporte, dum argumento, duma referência que lhes permita definirem-se, situarem-se, num contexto subitamente subvertido e alterado. [...] São agora "de política" os livros que mais se consomem. Suspeita-o a experiência diária da rua e do convívio, confirmam-no os livreiros [...]. Desnecessário dizer que o ideário socialista domina esmagadoramente os livros "de política" que actualmente mais correm. A predominância é o resultado de inúmeras condições já há muito começadas a criar, a resultante de um processo semiclandestino de formação ideológica. [...] No entanto, é preciso anotar que o maior número destes livros vende-se na rua, nas bancas dos ambulantes (geralmente ardinas [jornaleiros]). ${ }^{6}$

\footnotetext{
${ }^{3}$ MERCADANTE, Paulo. Portugal ano zero. Rio de Janeiro: Artenova, 1975, p. 26.

${ }^{4}$ Ibidem, p. 27. Mercadante menciona ainda a difusão em Portugal de obras que tratam das lutas de libertação nas colônias: "Mais impressiona a divulgação da literatura dos movimentos africanos. Os textos de Amílcar Cabral, líder do Partido da Independência da Guiné e de Cabo Verde (PAIGC), morto na luta em janeiro de 1973, aparecem em brochura, enquanto que o Movimento Popular de Angola edita páginas sobre o neocolonialismo. A Frente de Libertação de Moçambique é porém a mais ativa em seu programa editorial, pois além de relatos, distribui um número sem conta de prospectos mimeografados a respeito dos vários problemas africanos" (p. 27).

5 Resenha do livro Indústria, ideologia e quotidiano (ensaio sobre o capitalismo em Portugal), de João Martins Pereira. Vida Mundial, Lisboa, nº 1.829, 3 /10/1974, p. 6.

${ }^{6}$ M. R. "Prioridade ao tema político". Vida Mundial, Lisboa, no 1.834, 7 /11/1974, p. 49-50.
} 
Assim, ocorreu uma explosão editorial de cunho político:

As editoras começaram a lançar os livros proibidos ou que haviam sido recolhidos, as traduções prontas mas censuradas e uma vaga de títulos esquerdistas, de Mao a Guevara e Marx, ensaios de sociologia, política, guerra do ultramar, fazendo o movimento de vendas subir, repentinamente, $60 \% .^{7}$

Algumas das editoras que se destacam nesse momento já existiam antes de 1974. Eis algumas delas: Afrontamento, Nova Realidade, Arcádia, Bertrand, Delfos, Dom Quixote, Estampa, Europa-América, Horizonte, Iniciativas Editoriais, Moraes, Prelo, Seara Nova (todas estas criadas antes de 1968); Assírio \& Alvim, Base, Centelha, Edições 70, Textos Marginais, Escorpião/Textos Exemplares, Latitude, Livraria Júlio Brandão, Maria da Fonte, Povo e Cultura, e Ulmeiro (estas criadas a partir de 1968 e antes de 1974).

Além disso, surgem dezenas de editoras após o 25 de Abril, que terão uma atuação marcadamente política, entre as quais se destacam: Antídoto, Avante!, Caminho, Contra a Corrente, DiAbril, Edições Sociais, Fronteira, Nova Aurora, O Proletário Vermelho, Perspectivas \& Realidades, Revolução, Revolução Proletária, Seara Vermelha, Sementeira, Sementes, Serviços Sociais dos Trabalhadores da Caixa Geral de Depósitos, Spartacus, Textos da Revolução e Vento de Leste.

Os livros de caráter político publicados por estas editoras podem ser classificados em alguns tipos. De 1968 até o fim da ditadura têm destaque:

- obras de ficção em prosa e poesia de caráter crítico ou questionador, seja de questões sociopolíticas ou de costumes e moral;

- livros de contestação política, por exemplo, com textos da oposição democrática, com a reprodução de processos contra opositores, sobre movimentos estudantis ou com qualquer tipo de crítica a Salazar ou ao regime do Estado Novo;

- livros de, ou sobre, presos políticos;

- obras questionando a política colonial, questões econômicas e agrárias;

- livros que abordavam sob uma perspectiva crítica a visão oficial da história imposta pelo regime salazarista;

- obras sobre o pensamento socialista e comunista ("comunizantes" ou "subversivas", segundo a censura salazarista);

- livros que tratassem da pobreza, das condições de vida e das desigualdades

\footnotetext{
${ }^{7}$ SECCO, Lincoln. A Revolução dos Cravos e a crise do império colonial português. São Paulo: Alameda, 2004, p. 167.
} 
sociais em Portugal $^{8}$.

Depois de abril de 1974 ganham destaque:

- as obras que descrevem a resistência e a repressão durante o salazarismo;

- a edição de títulos que haviam sido proibidos até então;

- os textos programáticos de organizações de esquerda e os documentos dos movimentos de libertação africanos;

- os livros sobre os países socialistas;

- e uma profusão de obras de divulgação das doutrinas socialista e comunista.

Há também, de forma minoritária, toda uma linha de livros de direita, anticomunistas e contra a independência dos países africanos que até então eram colônias portuguesas. As editoras de direita que publicam boa parte desses livros surgem principalmente a partir de 1976.

Neste trabalho o foco estará nas editoras de caráter político que atuaram e surgiram em Portugal no período entre 1968 e 1980, tomando como marcos cronológicos dois eventos políticos que marcaram certa inflexão política no país e que tiveram algum reflexo na edição política. Em 1968, como já dito, Salazar deixou a chefia do governo por motivos de saúde. Sem que isso representasse qualquer perspectiva de ruptura ou mudança mais acentuada nos rumos da nação, não deixava de possibilitar, ao mesmo tempo, alguma expectativa de renovação, mesmo que limitada, até mesmo pelo fato de ser a primeira vez em que este cargo deixava de ser exercido por Salazar desde 1932. As movimentações políticas para definir o novo chefe de governo, que envolviam algum grau de incerteza, já que não havia regras claras para a escolha do substituto, e tampouco Salazar havia indicado um sucessor, criavam um clima na sociedade que convidava ao debate sobre o futuro do país, ainda que tal debate tivesse que se sujeitar a limites muito estreitos.

E o marco cronológico final deste trabalho é a vitória, com maioria absoluta, nas eleições de fins de 1979, da Aliança Democrática, coligação de centro-direita que reunia o Partido Social Democrata (PPD/PSD), o Centro Democrático Social (CDS) e o Partido Popular Monárquico (PPM), e a formação, em janeiro de 1980, do primeiro

8 LIVROS proibidos no Estado Novo. Catálogo da exposição realizada na Livraria Parlamentar, Assembleia da República, em abril de 2004. Lisboa: Divisão de Edições da Assembléia da República, 2005, p. 22; AZEVEDO, Cândido de. Mutiladas e proibidas: para a história da censura literária em Portugal nos tempos do Estado Novo. Lisboa: Caminho, 1997, p. 10. 
governo de direita (social-democrata) após o 25 de Abril, chefiado por Francisco de Sá Carneiro. Esta vitória da direita simbolizava o fim definitivo do processo de transformações mais profundas que se ensaiara a partir do fim da ditadura e do período de radicalização política que se seguiu. Na verdade, tal fim já havia começado em novembro de 1975, mas a vitória eleitoral majoritária da Aliança Democrática dava ao encerramento desse processo uma legitimidade que lhe garantia a força para enterrar de vez todos os resquícios revolucionários que porventura ainda existissem em Portugal.

Uma primeira aproximação a uma parte das editoras que surgiram nesse período em Portugal indica, segundo testemunho do historiador José Manuel Lopes Cordeiro, do Departamento de História do Instituto de Ciências Sociais da Universidade do Minho, que

A maior parte destas editoras foram autenticamente improvisadas, nem sequer eram verdadeiras empresas, não estavam legalizadas, a maior parte era inteiramente amadora (outras estavam ligadas a organizações e partidos políticos recém-constituídos); as traduções não eram muito cuidadas, o grafismo era algo que se desconhecia, mas como havia uma enorme procura, vendia-se tudo. ${ }^{9}$

Tal diagnóstico se aplica plenamente às editoras partidárias e mais engajadas politicamente. Todavia, havia uma parte das editoras que publicaram livros de caráter político que possuía uma organização empresarial, ainda que de pequeno ou médio porte.

Ao mesmo tempo, a atividade editorial de caráter político também se ligava a uma "elite dos intelectuais da oposição, [que] na esteira da tradição liberal, cultivava o gosto pelo livro como ferramenta de construção de um "novo mundo". Para estes intelectuais, o livro "Era simultaneamente um objecto pedagógico e uma arma de combate político"10.

Parece claro que estas editoras de caráter político - e as obras por elas editadas desempenharam um papel político-ideológico e social de alguma relevância, seja nos anos que antecederam ao 25 de Abril, seja no processo desencadeado a partir daquele momento. Forneceram subsídios aos debates, trouxeram ideias novas e reavivaram outras, refletiram o pensamento e as propostas de cada um dos agrupamentos políticos existentes, proporcionando canais de expressão a esses agrupamentos, oxigenaram a sociedade que até então tinha o acesso limitado ao pensamento inovador, contestador ou

\footnotetext{
${ }^{9}$ Mensagem eletrônica enviada por José Manuel Lopes Cordeiro em 5 de março de 2008.

${ }^{10}$ LEITE, op. cit, p. 14.
} 
simplesmente reformista, enfim, colaboraram para tornar Portugal um país mais aberto, livre e moderno.

Aliás, um livro, Portugal e o futuro, do general António Spínola, teve papel importante no processo político que levou ao golpe de 25 de abril. Publicado pela editora Arcádia, de Lisboa, em 20 de fevereiro de 1974, a obra representou uma contestação aberta, ainda que moderada, à política colonial do regime português, feita por um dos mais importantes generais do exército, que havia sido até pouco tempo antes governador e comandante-chefe das Forças Armadas da Guiné, e ocupava na ocasião do lançamento do livro o cargo de vice-chefe do Estado Maior General das Forças Armadas. De acordo com José Alberto Loureiro dos Santos: "Este facto [a publicação do livro] funcionou como um autêntico anúncio de uma revolta militar" ${ }^{11}$.

Todavia, pelo que pude apurar, não existem pesquisas ou trabalhos aprofundados, acadêmicos ou de outra natureza, sobre as editoras de livros de caráter político em Portugal no período abarcado por minha pesquisa. Tratarei dessa questão mais adiante no tópico "História do livro em Portugal". Dessa forma, constatamos que não se procedeu ainda a um levantamento amplo das editoras que publicaram obras de caráter político em Portugal no período final da ditadura e, principalmente, após a sua queda; não se apuraram quais eram suas vinculações políticas; não foram recenseadas de modo exaustivo as obras de caráter político publicadas no período que vai de 1968 até o fim dos anos 1970, de modo a verificar a sua quantidade, a abrangência dos títulos, a origem dos autores, os temas abordados, assim como não se tem notícia segura dos resultados de vendas e da repercussão política e social que estes livros alcançaram. Da mesma forma, não foram investigados de modo sistemático quais pessoas e organizações realizaram a façanha de criar estas editoras e dar-lhes vida.

Um dos objetivos deste trabalho é colaborar para começar a preencher algumas dessas lacunas. Outro objetivo é propiciar elementos para uma análise de como se deu a atuação dessas editoras nos processos que levaram ao fim da ditadura e no período imediatamente seguinte, ou seja, nas etapas iniciais de vida democrática que se abria em Portugal.

\footnotetext{
${ }^{11}$ SANTOS, José Alberto Loureiro dos. "Os militares na democratização de Portugal". In: TEIXEIRA, Nuno Severiano. Os militares e a democracia. Lisboa: Edições Colibri, 2007, p. 14. Sobre o impacto do livro de Spínola, ver os textos introdutórios da reedição de Portugal e o futuro de 2003 (Lisboa: Prefácio), de autoria de Nuno de Carvalho, José Veiga Simão e José Loureiro dos Santos.
} 


\subsection{Portugal no final dos anos 1960 e o mercado editorial}

Em fins dos anos 1960 Portugal era um dos países mais pobres da Europa ocidental. António Barreto sintetiza de modo claro alguns indicadores do país em relação ao continente:

O mais antigo e durável império colonial ultramarino, o único, aliás, ainda existente. A mais longa ditadura pessoal moderna. $\mathrm{O}$ país onde eram mais elevadas as taxas de analfabetismo e de mortalidade infantil. A mais jovem população, com a mais elevada natalidade e a mais baixa esperança de vida à nascença. $\mathrm{O}$ menor número de médicos e de enfermeiros por habitante. $O$ mais baixo rendimento por habitante. A menor produtividade por trabalhador. A maior população agrícola e a menor taxa de industrialização. O menor número de alunos no ensino básico e de estudantes no ensino superior. $\mathrm{O}$ menor número de pessoas abrangidas pelos sistemas de segurança social. ${ }^{12}$

A manutenção da guerra colonial iniciada em 1961 era um dos fatores centrais que definia as opções políticas, econômicas e sociais que o governo ditatorial português adotava naquela etapa. A guerra, travada em três frentes na África (Angola, Moçambique, e Guiné e Cabo Verde), consumia os recursos econômicos e sociais do país, além de levar ao isolamento internacional, com sucessivas condenações das Nações Unidas e aumento da pressão dos tradicionais aliados ${ }^{13}$.

A guerra colonial chegou a "representar perto de $50 \%$ da despesa pública e mobilizar, em média, 200 mil soldados em armas por ano", o que representava mais de 2\% da população total do país ${ }^{14}$. Em 1974, após 13 anos de conflito armado, o saldo era de 8 mil mortos e 28 mil feridos. Com o aumento dos gastos com a guerra, os impostos quadruplicaram de 1960 para $1973^{15}$.

"Rara era a família que não tinha alguém a combater em África", lembra António Reis, que completa:

[...] o serviço militar durava quatro anos, a expressão de opiniões contra o regime e contra a guerra era severamente reprimida pelos aparelhos censório e policial, os partidos e os movimentos políticos se encontravam proibidos, as prisões políticas cheias, os líderes políticos exilados, os sindicatos fortemente controlados, a greve interdita, o

\footnotetext{
12 BARRETO, António. “Mudança social em Portugal, 1960-2000”. In: PINTO, António Costa (coord.). Portugal contemporâneo. Lisboa: D. Quixote, 2005, p.161.

13 “Introdução". In: REIS, António (coord.). Portugal 20 anos de democracia. Lisboa: Temas e Debates, 1996.

${ }^{14}$ BARRETO, op. cit., p.139.

${ }^{15}$ MINISTÉRIO DA COMUNICAÇÃO SOCIAL. Portugal: Liberdade é também vontade. Lisboa: Ministério da Comunicação Social, 1975, p. 8.
} 
despedimento facilitado, a vida cultural apertadamente vigiada. ${ }^{16}$

Por questões econômicas e por causa da guerra, 1,4 milhão de portugueses deixaram o país entre 1960 a 1972, fazendo com que a população diminuísse $3 \%{ }^{17}$.

Nos entanto, a década de 1960 foi também de industrialização e crescimento econômico. Com a entrada do país na EFTA (Associação Europeia do Comércio Livre/European Free Trade Agreement), da qual Portugal foi um dos fundadores, em 1959, o capital estrangeiro investido no país decuplicou entre 1960 e 1967. O governo garantia alguns "incentivos” ao investidores: “[...] os mais baixos salários da Europa, a classe operária sem direito a greve e desorganizada pela repressão policial, possibilidade de remessa ilimitada dos lucros para o estrangeiro [...]"18 .O salário mínimo nacional para a indústria e o comércio somente foi criado em 1974, após o fim da ditadura ${ }^{19}$.

Apesar dessas condições de extrema exploração, "Entre 1960 e 1973, o rendimento nacional por habitante cresceu a uma média superior a 6,5\% ao ano [...]. Foi este o período de maior crescimento económico da história do país" ${ }^{20}$.

Este processo de industrialização foi marcado por uma crescente integração de Portugal na economia mundial, "ocupando uma posição semiperiférica na divisão internacional do trabalho"21. Houve um reforço na concentração demográfica e econômica em alguns poucos distritos e um significativo deslocamento de mão de obra da agricultura para os setores secundário e terciário ${ }^{22}$.

Mas isso não garantiu grandes avanços sociais: dos 8 milhões de habitantes que Portugal tinha no começo dos anos 1970, 25\% ainda eram analfabetos; $31 \%$ da população ativa trabalhava na agricultura; crescia, nas cidades, a população que tinha de viver em "bairros de lata" e barracas (favelas); as condições de saúde eram precárias, o número de médicos e de leitos por habitante era o mais baixo da Europa ${ }^{23}$.

Era nessas condições concretas que atuava a indústria editorial portuguesa naquele período.

Os pontos de venda listados pelo Grêmio Nacional dos Editores e Livreiros não

\footnotetext{
16 "Introdução", op. cit.

${ }^{17}$ MINISTÉRIO DA COMUNICAÇÃO SOCIAL, op. cit., p. 10.

18 Ibidem, p. 19.

${ }^{19}$ BARRETO, op. cit., p.154.

${ }^{20}$ Ibidem, p. 138.

${ }^{21}$ NORONHA, Ricardo. “A revolução portuguesa”. In: VARELA, Raquel (org.). Revolução ou transição? História e memória da Revolução dos Cravos. Lisboa: Bertrand, 2012, p. 97.

${ }^{22}$ NORONHA, op. cit., p. 97.

${ }^{23}$ MINISTÉRIO DA COMUNICAÇÃO SOCIAL, op. cit.
} 
chegava a 600, no começo da década de $1970^{24}$.

Em 1978, estavam filiadas à APEL, 208 editoras de Lisboa e arredores, e 77 de outras localidades, como Porto, Coimbra e Braga, totalizando 285 editoras $^{25}$.

O número de títulos editados no país foi o seguinte, entre 1968 e 1980:

\section{Número de obras editadas em Portugal que deram entrada na Biblioteca Nacional de Portugal - 1968-1980}

\begin{tabular}{|l|l|}
\hline Ano & $\mathbf{N}^{\mathbf{0}}$ de títulos \\
\hline 1968 & 5.087 \\
\hline 1969 & 5.213 \\
\hline 1970 & 5.897 \\
\hline 1971 & 5.963 \\
\hline 1972 & 6.370 \\
\hline 1973 & 6.874 \\
\hline 1974 & 6.716 \\
\hline 1975 & 6.963 \\
\hline 1976 & 6.454 \\
\hline 1977 & 6.712 \\
\hline 1978 & 6.869 \\
\hline 1979 & 6.728 \\
\hline 1980 & 6.933 \\
\hline
\end{tabular}

Fonte: Mensagem eletrônica de Maria Luísa Santos, diretora de Serviços Bibliográficos Gerais da Biblioteca Nacional de Portugal, enviada em 9/1/2013.

Vemos que há um aumento significativo de títulos editados entre 1968 e 1972 (+25\%). Em 1973 há um crescimento de 7\% em relação ao ano anterior, com uma pequena variação negativa em 1974 e novo crescimento em 1975 - ano que tem o maior número de títulos lançados da série.

Entre 1968 e 1980, o crescimento do número de títulos foi de $36 \%$.

\footnotetext{
${ }^{24}$ FARIA, Margarida Lima; CAMPOS, Ana Margarida. "Contextos sociais de edição e de leitura da Colecção Livros RTP-Verbo - Uma abordagem preliminar”. In: SERUYA, Teresa (org.). Estudos de tradução em Portugal: a colecção de livros RTP-Biblioteca Básica Verbo 1971-1972. Lisboa: Universidade Católica, 2005, p. 23.

${ }^{25}$ LARSSON, Flora Manuela. "Alguns aspectos da actividade editorial portuguesa desde 1973 a 1976". In: COELHO, Jacinto do Prado et alii. Problemática da Leitura. Aspectos sociológicos e pedagógicos. Lisboa: Instituto Nacional de Investigação Científica, 1980, p. 62.
} 
Eduarda Dionísio destaca o aumento do consumo de produtos culturais em 1975. Diz ela que nesse ano publicaram-se mais 7 milhões de livros do que em 1974 - e os de ciências sociais e política quase duplicaram de um ano para o outro. As tiragens médias também eram maiores, e havia mais editores e mais publicações periódicas, de acordo com a autora ${ }^{26}$.

Mas a partir de 1976 e 1977, diz ela, o consumo de bens culturais decresce: "Em 1976 publicam-se menos livros novos (pouco mais do que em 1971). Serão mais em 1977, mais não atingem o número de 1975. Pelo contrário, as tiragens crescem em 1976 (33 milhões) e decrescem em 1977 (24 milhões)"27.

\subsection{Editoras de oposição e Editoras da revolução}

Em Portugal, é necessário diferenciar os momentos de atuação para caracterizar de modo mais preciso as editoras de caráter político, uma vez que parte delas surgiu como editoras de oposição no período salazarista, mas outra parte surgiu após o 25 de Abril. Neste último caso, já não podem ser caracterizadas como de oposição, uma vez que a ditadura já havia acabado. Talvez possam ser chamadas de editoras da revolução, pois têm como fator principal de seu surgimento e de sua atuação o próprio processo revolucionário iniciado em 1974.

Trabalhei com a categoria editoras de oposição em minha dissertação de mestrado $^{28}$, que tratou do surgimento e da atuação destas editoras no Brasil, no período da abertura política (1974-1984). No Brasil houve, a partir de meados dos anos 1970, um movimento editorial e cultural que guarda semelhanças com o que ocorreu em Portugal. Houve uma revitalização de editoras com perfil marcadamente político e de oposição ao governo militar iniciado em 1964. Editoras já estabelecidas, como a Civilização Brasileira, a Brasiliense, a Vozes e a Paz e Terra, voltaram a atuar de forma bem mais ousada politicamente, editando livros que tratavam de temas que punham em questão a ideologia, os objetivos e os procedimentos do regime de 1964. Ao mesmo tempo, novas editoras surgiram com o projeto de publicar livros com claro caráter político. Alguns exemplos são as editoras Alfa-Ômega, Global, Edições Populares, Brasil Debates, Ciências Humanas, Kairós, Hucitec, L\&PM, Graal, Codecri, Vega e

\footnotetext{
${ }^{26}$ DIONÍSIO, Eduarda. “As práticas culturais". In: REIS, António (coord.). Portugal 20 anos de democracia. Lisboa: Temas e Debates, 1996, p. 457.

${ }^{27}$ DIONÍSIO, op. cit., p. 467-68.

${ }^{28}$ SILVA, op. cit., 2006.
} 
Livramento, entre outras.

Os livros de oposição no Brasil, que se enquadram no que se pode chamar de literatura $^{29}$ política, podem ser classificados nas seguintes categorias: clássicos do pensamento socialista, obras de parlamentares de oposição, depoimentos de exilados e ex-presos políticos, livros-reportagem, memórias, romances políticos, romancesreportagem, livros de denúncias contra o governo. Este segmento ganha impulso mais significativo a partir de 1977-78, com o retorno à cena pública do movimento estudantil e do movimento sindical, em particular com as greves no ABC paulista, e o avanço da campanha da anistia.

No caso do Brasil, estas editoras podem ser caracterizadas como editoras de oposição, pois tinham como ponto comum a oposição à ditadura civil-militar pós-1964.

Em minha dissertação de mestrado, defini as editoras de oposição como aquelas editoras que tinham perfil nitidamente político e ideológico de oposição ao governo militar, com reflexos diretos em sua linha editorial, ou seja, haviam publicado certo número de livros de oposição.

Um número suficiente, na produção daquela editora, para que fique claro que tais livros representavam parcela importante da produção da empresa. Disso resulta que os referenciais básicos para se saber se uma editora pode ser chamada de editora de oposição são o perfil político e ideológico da editora, determinado pelas simpatias e filiações políticas de seus proprietários e/ou editores, e o seu catálogo de livros publicados. ${ }^{30}$

Em função dos diferentes graus de engajamento político de seus proprietários, editores e colaboradores - que podia ir desde a militância orgânica em partidos ou grupos políticos até uma postura de oposição mais geral diante dos propósitos do regime, sem que isso implicasse vinculação ou militância em alguma organização -, criei uma subcategoria entre as editoras de oposição, as editoras de oposição engajadas, que eram aquelas que:

a) publicavam predominantemente livros de oposição $e$ b) tinham envolvimento político claro, isto é, tinham vínculos com organizações políticas oposicionistas, caracterizando-se algum tipo de vinculação entre empresa e organização política. Geralmente, seus proprietários e/ou editores militavam em partidos ou organizações de oposição ao regime militar. ${ }^{31}$

\footnotetext{
${ }^{29}$ Literatura aqui tem o sentido de "conjunto das obras científicas, filosóficas etc., sobre um determinado assunto, matéria ou questão; bibliografia", conforme o Dicionário Houaiss.

${ }^{30}$ SILVA, op. cit., p. 54.

${ }^{31}$ SILVA, op. cit., p. 55.
} 
A maioria das editoras de oposição no Brasil se enquadrava nesta subcategoria.

Em Portugal, os livros de oposição foram também importantes na luta contra a ditadura, questão que abordaremos mais de perto no capítulo 12. Pedro Leite, por exemplo, destaca que "O valor do livro, quer como mercadoria quer como símbolo surge-nos como um elemento crucial para a compreensão dos processos de resistência da oposição democrática durante este período", pois tornou-se para esta oposição "uma forma de resistência e uma possível actividade política"32.

Precisamos, portanto, de mais uma categoria - além das editoras de oposição para estudar a edição política após o fim da ditadura em Portugal. Uma ideia interessante para tal, uma vez que ilumina a cronologia e a origem das editoras de caráter político em Portugal, foi apresentada por José Manuel Lopes Cordeiro, ao sugerir que teria havido uma "primeira geração" de editoras, surgidas a partir de 1969 com a abertura iniciada por Marcelo Caetano, e uma "segunda geração", filha do golpe de 25 de abril e do processo revolucionário que ele desencadeia ${ }^{33}$.

Esta segunda geração seria composta por aquelas às quais chamo de editoras da revolução. Suas características principais são: terem surgido após o 25 de Abril; terem como principal eixo de sua atuação a intervenção política por meio da edição; terem um forte engajamento político, não necessariamente partidário; editarem obras em geral voltadas para a conjuntura política mais imediata; serem de pequeno porte e com pouca capacidade econômica.

Boa parte das editoras de caráter político - tanto as de oposição como as da revolução - estava ligada ao campo das ideias de esquerda, mas há também uma parte delas que tem uma visão política de outro matiz, esposando ideias liberais, reformistas, nacionalistas, além de haver também editoras ligadas à direita.

\subsubsection{Transições políticas}

Uma das características da edição política em Portugal no período aqui abordado é que as editoras que a realizam atuam em um momento de crise do governo ditatorial, que acaba por levar ao fim desse mesmo governo e ao início de um processo de transição política do regime ditatorial para outro diferente. Estas editoras atuam também durante a própria transição - e muitas delas surgem nesses períodos. É o que ocorre em

\footnotetext{
${ }^{32}$ LEITE, op. cit, p. 21 e 214.

${ }^{33}$ Mensagem eletrônica enviada por José Manuel Lopes Cordeiro em 8 de março de 2008.
} 
Portugal a partir de 1968 - quando se delineia o início de uma crise do regime -, mas principalmente após o 25 de Abril.

Portugal conheceu uma curta abertura política a partir de fins de 1968, com Marcelo Caetano, logo frustrada, e uma ruptura abrupta em 1974, que tomou um rumo verdadeiramente revolucionário, com um processo de 19 meses (abril de 1974 a novembro de 1975) de efervescência e conflitos radicais na sociedade. Foi um processo marcado por um ritmo e uma intensidade que o diferenciam de outros processos de transição contemporâneos, justamente por sua componente revolucionária.

Após 48 anos sem democracia, parece ter havido uma aceleração do tempo histórico a partir do 25 de Abril, com a liberalização imediata de toda uma série de atividades, iniciativas, manifestações, opiniões, que havia muito estavam sufocadas e que ganharam as ruas com força e intensidade, gerando um período de euforia democrática - e mesmo revolucionária. A explosão editorial em Portugal é parte desse processo.

Este trabalho não terá como foco o estudo da transição política em Portugal nos anos 1960-70, mas a compreensão desse contexto será fundamental para os objetivos buscados, relacionados à atuação das editoras de caráter político no país. Assim, minha preocupação será a de buscar em alguns estudos sobre os processos de transição em Portugal e em outros países - inclusive no Brasil - certos elementos, informações e análises que joguem luz sobre meu objeto de estudo, mas sem a pretensão de apresentar uma colaboração original no que se refere aos processos de transição em si, que já vêm sendo estudados de forma aprofundada há pelo menos 25 anos.

Parece-me mais correto definir estes processos de transição como "transições políticas”, e não como transições democráticas. Como salienta Osvaldo Coggiola, referindo-se aos casos de Espanha e Portugal - e criticando a visão de Philippe Schmitter $^{34}-$, apresentar esses processos

como "transições democráticas" ou "para a democracia", implica um parti-pris ideológico, com base no pressuposto da democracia (sem uma definição de classe da mesma) como o regime político ideal e como decorrência lógica da integração desses países [europeus] à "democrática" Comunidade Econômica Européia (CEE). ${ }^{35}$

\footnotetext{
34 SCHMITTER, Philippe C. "Introdução às transições sul-européias do regime autoritário: Itália, Grécia, Portugal e Espanha”. In: O’DONNEL, Guillermo; SCHMITTER, Philippe C.; WHITEHEAD, Laurence (eds.). Transições do regime autoritário: Sul da Europa. São Paulo: Vértice, 1988, p. 19-20.

35 COGGIOLA, Osvaldo. "A origem das crises portuguesa e espanhola da década de 70". In: COGGIOLA, Osvaldo (org.). Espanha e Portugal: O fim das ditaduras. São Paulo: Xamã, 1995, p. 35.
} 
Particularmente no caso de Portugal, que viveu um período de fato revolucionário em 1974-75, não estava dado que a transição tivesse que "chegar" à democracia de tipo ocidental, nem que outras possibilidades não fossem plenamente viáveis. Por isso, é pertinente a observação do mesmo autor de que aquele pressuposto "obsta, de um lado, a pesquisa histórica [mas] também inviabiliza a análise política" ${ }^{36}$. Afinal, desse modo lança-se um olhar determinista para um processo que deve ser visto pelo historiador como aberto a inúmeras direções e caminhos, e não a partir de seus resultados posteriores.

Assim, o conceito de "transições do regime autoritário", desenvolvido principalmente por estudiosos da ciência política $^{37}$, pode ser útil à análise do caso português ao fornecer algumas categorias e conceitos, mas não deve ser uma camisa-deforça para o pesquisador, que deve sempre estar aberto a analisar seu objeto sem conceitos predeterminados, de modo a que todas as variáveis sejam devidamente consideradas. Por isso, utilizo o conceito de transição política, sem adjetivações.

\subsection{Livro e história editorial}

\subsubsection{Edição e editor}

Para fazer uma história da edição política em Portugal entre o final dos anos 1960 e o final da década de 1970, optei por elaborar uma história das editoras responsáveis pela edição de livros políticos, uma vez que lidamos com um período histórico em que o centro do processo editorial localiza-se na casa editora, em geral desligada da oficina gráfica, e o seu personagem central e centralizador é o editor, que coordena todas as etapas da edição.

Com o livro transformado em um produto industrial em grande medida padronizado, num processo em que a interferência pessoal do gráfico tem cada vez menor importância no que diz respeito à sua concepção e criação, ganha relevância a compreensão do processo editorial em si mesmo, em particular as etapas anteriores e posteriores à impressão do livro ${ }^{38}$.

\footnotetext{
${ }^{36}$ Ibidem.

37 Ver, por exemplo, a série de livros Transições do regime autoritário, organizada por Guillermo O’Donnel, Philippe C. Schmitter e Laurence Whitehead (São Paulo: Vértice, 1988).

38 Sobre algumas destas questões, ver: DARNTON, Robert. "A importância de ser bibliográfico". In: A questão dos livros. São Paulo: Cia. das Letras, 2010, p. 146-163.
} 
Assim, este trabalho se debruçará sobre as editoras responsáveis pela publicação dos livros de caráter político, pois entendo que elas representam a reunião das atividades intelectuais, políticas, editoriais, artísticas, empresariais, industriais e comerciais que transformam um texto em livro, permitindo que ideias atinjam, por meio desse suporte material concreto, um certo público e tornem-se, assim, elementos ativos em um processo de atuação e participação social e política. Desde essa perspectiva, os sujeitos desse processo não são primordialmente o autor e o leitor, mas, de forma determinante, a empresa editorial e o editor, que coordenam as etapas do processo editorial.

$\mathrm{Na}$ verdade, a trajetória da obra desde o autor até o leitor conforma o que se chama de atividade editorial, um "circuito de comunicação que vai do autor ao editor, [daí] ao impressor, ao distribuidor, ao vendedor, e chega ao leitor. [...]" ${ }^{39}$. Nessa trajetória, "a edição é o momento em que um texto se torna mercadoria e encontra leitores" ${ }^{40}$, em um processo em que o editor tem papel central, pois atua como "coordenador de todas as possíveis seleções que levam um texto a se transformar em livro, e tal livro em mercadoria intelectual, e esta mercadoria intelectual em um objeto difundido, recebido e lido" 41 .

Nesse sentido, compartilho a seguinte definição de editor:

Pessoa que exerce a indústria da produção e divulgação de obras literárias, artísticas, científicas, musicais, etc., por meio da imprensa, embora nem sempre se ocupe da arte tipográfica e do comércio de livros. Nesse papel concebe e planeja o livro ou uma série deles, procura e escolhe originais, determina o tamanho, a forma da edição e todos os seus pormenores, dirige sua execução material e divulga as publicações pelos mercados que podem estar interessados nelas. ${ }^{42}$

Assim, para que ocorra a produção e a circulação do livro é necessária uma cadeia que envolve aspectos dos campos industrial, intelectual e comercial, cadeia esta que é

\footnotetext{
${ }^{39}$ DARNTON, Robert. "O que é a história dos livros". In: O beijo de Lamourette. São Paulo: Cia. das Letras, 1990, p. 112.

${ }^{40}$ CHARTIER, Roger. Cultura escrita, literatura e história. Porto Alegre: Artmed, 2001, p. 44-45.

${ }^{41}$ Ibidem, p. 48.

${ }^{42}$ FARIA, Maria Isabel e PERICÃO, Maria da Graça. Dicionário do livro: da escrita ao livro eletrônico. São Paulo: Edusp, 2008, p. 271. Outra definição de editor, anterior a esta e que guarda proximidade com ela, é seguinte: "[...] pessoa física ou jurídica que, por conta própria e devidamente autorizada, transforma em livros os originais que escolhe ou manda elaborar, coordenando a atividade criadora dos autores com revisores, ilustradores e produtores, e com os processos industriais necessários para a multiplicação desses originais, promovendo em seguida sua venda". Uma política integrada do livro para um país em processo de desenvolvimento: preliminares para a definição de uma política nacional do livro. São Paulo/Rio de Janeiro: Câmara Brasileira do Livro/Sindicato Nacional dos Editores de Livros, 1976, vol. 1, p. 223.
} 
vinculada à atividade dos seguintes elementos: empresários (editor, gráfico, livreiro); trabalhadores vinculados à empresa editora, gráfica e livreira; os trabalhadores intelectuais (escritores, tradutores de textos); os consumidores do produto livro (compradores e/ou leitores). ${ }^{43}$

Em virtude dessas definições, trabalho aqui com a ideia de "edição como espaço social complexo". Tal espaço, de acordo com Nuno Medeiros, é:

[...] constituído por um conjunto de agentes que actuam como construtores activos na esfera das ideias e da cultura escrita através de uma matriz prescritiva e selectiva da sua intervenção no livro, infundindo-lhe uma identidade própria que extravasa o texto na sua estrita acepção autoral. ${ }^{44}$

Esta concepção assume a edição como "uma intervenção no texto que é também co-criação". De modo que "O editor participa, assim, na esfera de elaboração das ideias, colaborando nesse empreendimento coletivo que atribui a um conjunto de agentes a propriedade do conhecimento e dos modos de o prescrever" ${ }^{\wedge 5}$. Como destaca o mesmo autor, "A edição define o livro, enunciando-o enquanto objeto concebido e materializado de determinada maneira" 46 .

Logo, o trabalho de edição é visto aqui como o

[...] processo que transpõe no livro o lugar da própria produção da escrita como mosaico de reflexões, fragmentações, operações. $\mathrm{O}$ mosaico espelha a intervenção no texto, externa e simultaneamente internalizada, corresponsabilizando pela sua autoria enquanto livro um cortejo de atores, diluindo a autoria e a entronização essencialista de que é amiúde objeto. O editor é, então, um prescritor que propõe um livro, isto é, uma leitura ou um conjunto de leituras para um determinado texto, conferindo-lhe uma identidade representacional e material. $^{47}$

Desse modo é possível almejar a "restituição de um papel fundamental à edição e ao editor na hermenêutica da produção do livro e da cultura escrita em geral, colocando no eixo da análise quer os mecanismos de intervenção prescritiva e

\footnotetext{
${ }^{43}$ KOSHIYAMA, Alice Mitika. Monteiro Lobato: intelectual, empresário, editor. São Paulo: T. A. Queiroz, 1982, p. 8. Certamente outros personagens devem ser incluídos na lista de partícipes desta cadeia: editores de texto, revisores, ilustradores, diagramadores e divulgadores, bibliotecários, entre outros.

${ }^{44}$ MEDEIROS, Nuno. "Acções prescritivas estratégicas: a edição como espaço social”. Revista Crítica de Ciências Sociais, Coimbra, Centro de Estudos Sociais, nº 85, jun. 2009, p. 131.

${ }^{45}$ Ibidem, p. 132.

${ }^{46}$ MEDEIROS, Nuno. "Problematizar o objecto consagrado: definindo o livro como ideia e materialidade através da edição". Revista Portuguesa de História do Livro, n. ${ }^{\circ}$ 25, 2010, p. 556.

${ }^{47}$ Ibidem, p. 558.
} 
mediadora, quer os de mercado industrial da cultura" ${ }^{\text {"48 }}$.

Em consequência,

A edição surgirá, assim, ao olhar como espaço contingente e plural, aberto e situado historicamente, apreensível como processo sempre permeável à emergência de rupturas e recorrências, irisado por colorações e subtilezas, e onde se constrói a desnaturalização do livro e do ordenamento que por este se faz do mundo moderno. ${ }^{49}$

Assim, a edição projeta para o presente e para o futuro bem mais do que o discurso do autor, pois contempla um conjunto de práticas culturais, industriais, comerciais e econômicas do momento em que foi realizada. Desse modo, a "disponibilidade [do livro], no mercado livreiro ou na biblioteca, amplia a influência desse livro muito para além dos consumidores contemporâneos dessa edição, tornando o livro um processo de comunicação, teoricamente intemporal" ${ }^{\prime 50}$.

Em relação ao perfil de editor com que deparamos neste estudo, ele pode ser basicamente definido em três tipos: o publisher: "editores implicados na propriedade e condução dos destinos de uma casa editora, cujo trabalho [resulta em] um catálogo a partir do qual se desenha uma proposta clara de intervenção cultural e, e muitos casos, política"51; o editor anglo-saxónico, que podemos chamar também de editor profissional: "profissional a quem se acomete, não a propriedade, mas a coordenação editorial de uma coleção ou mesmo de toda a casa editora"52; e o editor militante.

Gostaria de me estender um pouco mais sobre este terceiro tipo, uma vez que ele tem especial destaque no universo de editoras abarcadas em meu trabalho. Podemos subdividi-lo em três subtipos. O primeiro equivale ao militante político que assume a tarefa da edição como incumbência determinada pela organização política a que pertence, muitas vezes sem ter experiência profissional anterior no ramo editorial. É um editor por delegação, que pode ou não ser remunerado e que exerce a função em decorrência do compromisso político com o grupo ao qual a editora está ligada.

Já o segundo subtipo é o militante que assume a edição como opção política e profissional (ou semiprofissional), e cria a sua própria editora como instrumento de ação política, cuja atuação está claramente vinculada, ou em certos casos subordinada, ao grupo político ao qual pertence, de modo que a sua linha editorial está intimamente

\footnotetext{
${ }^{48}$ MEDEIROS, “Ações prescritivas...”, op. cit., p. 144.

${ }^{49}$ Ibidem, p. 144.

${ }^{50}$ LEITE, op. cit, p. 3-4.

${ }^{51}$ MEDEIROS, Nuno. Edição e editores: o mundo do livro em Portugal, 1940-1970. Lisboa: ICS, 2010, p. $127-28$

${ }_{52}$ Ibidem, p. 128.
} 
ligada às prioridades estabelecidas pelo grupo. Mas isso não lhe retira o caráter de empresa privada, em que o proprietário assume os riscos empresariais envolvidos. Assim, é um tipo de editora política, militante, vinculada a um grupo político, mas, do ponto de vista econômico, é privada. Este tipo de editor militante não se confunde com o publisher, pois, como vimos, o publisher é o responsável pleno pela condução de sua casa editora, enquanto este segundo tipo de editor militante compartilha, ainda que informalmente, a orientação política da editora com a organização a que pertence.

Podemos ainda falar de um terceiro subtipo, que guarda proximidade com este último apresentado, e que vem a ser o editor que é militante ou simpatizante de alguma organização política, e que na sua editora adota uma linha editorial que reflete suas simpatias políticas, mas sem que a organização à qual está ligado tenha efetivamente qualquer poder de interferência na editora.

Quanto às características da indústria editorial em termos gerais, destaque-se que ela "se singulariza por ser de giro lento, com imobilização de capitais, complexa e de rentabilidade incerta. Os investimentos são recuperados depois de longo tempo". Por isso, ela depende, idealmente, de planejamento metódico e de uma estratégia que tenha como base esse planejamento ${ }^{53}$. Ao mesmo tempo, "a editora se caracteriza pela necessidade de ser financiadora durante o ciclo operacional do livro" ${ }^{54}$. No caso das editoras políticas em Portugal, no período analisado, algumas dessas características sofreram variações significativas, em função da grande demanda que houve durante certo tempo das obras que elas editavam.

Os estudiosos ressaltam ainda que o setor editorial é sempre muito influenciado pelos fatores do entorno ${ }^{55}$. O papel cultural do produto livro, ao combinar fatores comerciais com exigências culturais ${ }^{56}$, é outro ponto que confere a este setor características próprias.

\footnotetext{
${ }^{53}$ AUGSBURGER, Alberto E. El mercado del libro en América Latina. Unesco, 1981, p. 36.

${ }^{54}$ SAAB, William George Lopes, GIMENEZ, Luiz Carlos Perez e RIBEIRO, Rodrigo Martins. "Cadeia de comercialização de livros: situação atual e propostas para desenvolvimento". Estudos Setoriais, BNDES, Rio de Janeiro, dez. 1999, p. 7. Disponível em: $\langle$ http://www.bndes.gov.br/conhecimento/relato/rel-livr.pdf>. Acesso em 15/01/2004.

55 GARCÍA, Clara Eugenia. El sector editorial; DELKÁDER, Jorge. La actividad editorial como actividad empresarial. Textos apresentados no I Curso de Formación para Editores de América y de España. Sociedad Iberoamericana de Amigos del Libro y de la Edición/ Universidad Carlos III de Madrid, março de 2001, mimeogr.

${ }^{56}$ SAAB, W. G. L., GIMENEZ, L. C. P. e RIBEIRO, R. M., op. cit., p. 1.
} 


\subsubsection{História do livro em Portugal}

Como já afirmou João Luís Lisboa, "Em Portugal, a investigação do livro tem raízes antigas" ${ }^{, 57}$. Além da tradição em trabalhos sobre o tema ${ }^{58}$, este campo de estudos se caracteriza por privilegiar os períodos anteriores ao século XX como foco de pesquisa.

Essa é a conclusão que podemos tirar a partir de algumas importantes fontes de referência sobre essa área de estudos em Portugal. Assim, o projeto "Memória do Livro", da Biblioteca Nacional Digital, de Portugal, coordenado por Manuela D. Domingos, com a colaboração de Paula Gonçalves e Dulce Figueiredo, representa um importantíssimo esforço, e "Apresenta textos fundadores da história do livro em Portugal (séc. XV- XVIII)”. Seu objetivo é “disponibilizar os materiais de trabalho, por vezes de difícil acesso, que abarcam diversos aspectos do fabrico, distribuição e usos do livro, através dos séculos" 59 .

Da mesma forma, a obra História da edição em Portugal: das origens até 1530, de Artur Anselmo, também circunscreve o seu foco cronológico aos tempos antigos ${ }^{60}$. As importantes colaborações de Diogo Ramada Curto ${ }^{61}$ também, em sua maior parte, estão voltadas para épocas anteriores ao século XX, mas cabe destacar a abrangente coletânea por ele dirigida, Estudos de Sociologia da Leitura em Portugal no século XX

\footnotetext{
${ }^{57}$ LISBOA, João Luís. “Ao leytor”. Cultura - Revista de História e Teoria das Ideias, Centro de História da Cultura-FCSH, Universidade Nova de Lisboa, II ${ }^{a}$ série, vol. IX, 1997, p. 12. Volume temático sobre "O livro e a leitura", coordenado por João Luís Lisboa.

58 Podemos mencionar os trabalhos de Barbosa Machado (1741) e de Inocêncio da Silva (1858). Cf. MACHADO, Diogo Barbosa, 1741-1759, Bibliotheca Lusitana, 4 vols., Lisboa, Cf. António Isidoro da Fonseca [et al.] (edição diplomática, 1965-67, Coimbra, Atlântida); SILVA, Inocêncio F. da, e BRITO ARANHA, 1858-1923, Diccionario Bibliographico Portuguez. 23 vols. Lisboa: Imprensa Nacional. Citados em 350 TÍTULOS PARA A HISTÓRIA DO LIVRO E DA LEITURA EM PORTUGAL. Grupo Interdisciplinar do Livro e da Leitura. Universidade Nova de Lisboa. Cultura - Revista de História e Teoria das Ideias, Centro de História da Cultura-FCSH, Universidade Nova de Lisboa, II ${ }^{\mathrm{a}}$ série, vol. IX, 1997, p. 314-35. Volume temático sobre "O livro e a leitura", coordenado por João Luís Lisboa. Disponível em <http://www.fcsh.unl.pt/chc/pdfs/350TIT.pdf>. Acesso em 17/3/2008.

59 Memória do Livro. Coordenação científica: Manuela D. Domingos (Biblioteca Nacional); Paula Gonçalves e Dulce Figueiredo (colaboradoras). Lisboa: Biblioteca Nacional Digital de Portugal. Disponível em: <http://purl.pt/401/1/livro/index.html>. Acesso em 16/3/2008. Ver também: DOMINGOS, Manuela D. Estudos de Sociologia da Cultura: livros e leitores do século XIX. Lisboa: Instituto Português do Ensino a Distância, 1985.

${ }^{60}$ ANSELMO, Artur. História da edição em Portugal. Das origens até 1530. Porto: Lello \& Irmão, 1991.

${ }^{61}$ Entre outras: CURTO, Diogo Ramada. "A história do livro em Portugal: uma agenda em aberto". Leituras: Revista da Biblioteca Nacional, no 9-10, Outono-Primavera (2001--2002): 13-61; CURTO, Diogo Ramada. "Notas para uma história do livro em Portugal". In: Cultura Escrita: Séculos XV a XVIII. Lisboa: Imprensa de Ciências Sociais, 2007, p. 317-359; CURTO, Diogo Ramada. "As gentes do livro". In: CURTO, Diogo Ramada; DOMINGOS, Manuela; FIGUEIREDO, Dulce; GONÇALVES, Paula (orgs.). As gentes do livro: Lisboa: Século XVIII. Lisboa: Biblioteca Nacional, 2007, 15-47; CURTO, Diogo Ramada. Cultura Escrita: Séculos XV a XVIII. Lisboa: Imprensa de Ciências Sociais, 2007.
} 
62.

Essa limitação quanto ao recorte temporal desse campo de estudos é confirmada por Manuel Portela, ao afirmar que "Trata-se de um campo em crescimento, embora ainda incipiente no que diz respeito a certos períodos e temáticas" 63 .

A comprovar, ainda uma vez, essa tendência, o estudo "350 títulos para a história do livro e da leitura em Portugal" apresenta "trabalhos que vão desde o livro anterior à imprensa até ao livro e jornal oitocentistas" 64 .

O grupo de investigação sobre Livro e Leitura do Centro de História da Cultura, coordenado por João Luís Lisboa e vinculado à Faculdade de Ciências Sociais e Humanas da Universidade Nova de Lisboa, tem o mérito de estender o seu campo de investigação até o século XX, principalmente com o projeto Edição e Cultura de Massas, voltado para a investigação dos arquivos da Editora Romano Torres. "Pretendese, a partir do estudo de um caso concreto, contribuir para o conhecimento da edição portuguesa no século XX, os seus agentes, os seus mecanismos, o lugar central das traduções, alguns géneros e os seus públicos”, dizem os responsáveis ${ }^{65}$.

Talvez o primeiro estudo de maior fôlego sobre a indústria editorial portuguesa no século XX seja o Inquérito ao livro em Portugal: editores e livreiros ${ }^{66}$, realizado por Irene Lisboa e editado em 1944 a partir de entrevistas com editores e livreiros, e publicado inicialmente na forma de artigos na revista Seara Nova.

O trabalho surgiu, segundo a autora, a partir do "reconhecimento do crescimento do comércio livreiro e da actividade de edições de livros e da leitura" ${ }^{67}$ no país, e procura traçar um panorama da evolução da organização editorial em Portugal e da história dos editores e livreiros. Analisa também alguns aspectos desse trabalho, como as coleções de divulgação cultural que surgiram com força nos anos 1940 no país como a Biblioteca Cosmos e os Cadernos Agostinho da Silva -, a publicidade e a crítica de livros, a distribuição e a tradução. "É um retrato de um país de pequeno número de

\footnotetext{
${ }^{62}$ CURTO, Diogo Ramada (ed.). Estudos de Sociologia da Leitura em Portugal no século XX. Lisboa: Fundação Calouste Gulbenkian, 2006.

${ }^{63}$ PORTELA, Manuel. "Essa estória da História Livro (1998, 2004)”. Biblos, $2^{\text {a }}$ série, Vol.III, 2005, p. 85112. Disponível em <http://www1.ci.uc.pt/pessoal/mportela/arslonga/MPENSAIOS/essa_estoria_da_historia.htm\#L4>. Acesso em 17/3/2008.

64350 títulos para a história..., op. cit.

65 Página eletrônica do Centro de História da Cultura. Disponível em: <http://www.fcsh.unl.pt/chc/pg_pj_livro.htm\#6>. Acesso em janeiro de 2013.

${ }^{66}$ LISBOA, Irene. Inquérito ao livro em Portugal. Vol. I, Editores e livreiros. Lisboa: Seara Nova, 1944; LISBOA, Irene. Inquérito ao livro em Portugal. Vol. II, A arte do livro. Lisboa: Seara Nova, 1946.

${ }^{67}$ LISBOA, Inquérito..., Vol. I, op. cit., "Explicação".
} 
leitores, com uma elevada taxa de analfabetismo que as estatísticas para essa época apontam para metade da população", mas que passa por um "processo de alargamento de mercado", graças a "um público letrado em crescimento, entusiasmado com a leitura, que procura todo o tipo de gêneros" ${ }^{68}$. Sem dúvida, apesar de suas limitações, o trabalho de Irene Lisboa é um marco na história editorial portuguesa, por seu pioneirismo, por privilegiar os editores como sujeitos da edição e por reunir uma quantidade de informações que ainda hoje são de muita utilidade aos estudiosos do tema.

Em 1987, Ronald Chilcote publicou uma vasta bibliografia anotada de milhares

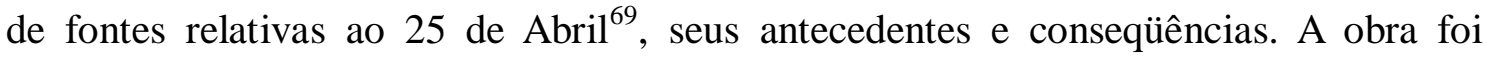
dividida em dois volumes, sendo o primeiro dedicado às monografias (inclusive livros) e folhetos sobre o período; e o segundo aos artigos de periódicos e às organizações e movimentos políticos. Em ambos os casos, as bibliografias incluem as publicações realizadas na clandestinidade e no exterior. Trata-se de importante fonte de referências sobre o período, de grande utilidade para os pesquisadores, mas o trabalho não pretende ser mais do que uma bibliografia anotada, não apresentando uma análise ou interpretação do período.

Em termos de trabalhos que abordem a atuação política de editores durante o Estado Novo português, cabe destacar o mestrado de Pedro Jorge de Oliveira Pereira Leite, Mercadores de letras: rumos e estratégias dos editores e livreiros na divulgação cultural durante o Estado Novo (1933-1974), de $1998^{70}$, que por meio da análise da trajetória de alguns editores mostra como, em alguns casos, as estratégias editoriais estiveram ligadas às questões políticas e à oposição ao regime vigente. Todavia, sua análise se circunscreve ao período anterior ao 25 de Abril, com forte ênfase para as coleções de divulgação cultural dos anos 1940 e 1950, em particular as experiências de Francisco Lyon de Castro na Publicações Europa-América, e de Manuel Rodrigues de Oliveira e Bento de Jesus Caraça com a Biblioteca Cosmos.

Uma nova etapa na investigação sobre a história editorial em Portugal no século XX abre-se com a contribuição do investigador Nuno Medeiros, voltada para a sociologia da edição e centrada na atuação de editores e livreiros e em suas relações

\footnotetext{
${ }^{68}$ LEITE, op. cit., p. 162.

${ }^{69}$ CHILCOTE, Ronald H. A revolução portuguesa de 25 de Abril de 1974: bibliografia anotada sobre os antecedentes e evolução posterior. Vol. I e II. Coimbra, Centro de Documentação 25 de Abril, 1987.

${ }^{70}$ LEITE, op. cit.
} 
com o poder instituído ${ }^{71}$. Em seu livro ${ }^{72}$, Medeiros dedica grande espaço à análise das relações e conflitos políticos entre editores e livreiros, de um lado (representados pelo Grêmio Nacional de Editores e Livreiros), e o Estado Novo, de outro. Além disso, analisa as formas de repressão à atividade editorial, o modo como editores e livreiros enfrentaram esta repressão (ou se adequaram a ela, conforme o caso) e as características particulares da atividade editorial e livreira. Aborda também o início de um movimento de maior politização da edição, a partir do final dos anos 1960, mas não desenvolve muito a questão, em função de seu trabalho ter como limite cronológico o ano de 1974. Trata-se de contribuição seminal e inovadora a este campo de estudo em Portugal.

Recentemente surgiram também as contribuições de Rui Beja, profissional do livro que trabalhou por 30 anos na editora Círculo de Leitores. Sua primeira obra ${ }^{73}$, de caráter memorialista, traz algumas interessantes observações sobre as condições e as restrições à atuação editorial no período do Estado Novo e do marcelismo, assim como aponta certas mudanças ocorridas a partir de 1974. A obra centra-se na história do Círculo de Leitores desde a sua criação em outubro de 1970 e pelos 30 anos seguintes, período em que o autor acompanhou de perto esta história, tendo ocupado vários cargos na editora, inclusive o de presidente da empresa. Em 2012 Beja publicou outro livro, dessa vez resultante de dissertação de mestrado em Estudos Editoriais na Universidade de Aveiro $^{74}$. Esta obra apresenta um breve panorama da edição em Portugal nos últimos 40 anos, ou seja, engloba o período abarcado em meu trabalho. A ênfase, todavia, recai na análise das mudanças e transformações pelas quais vem passando o mercado editorial do país, particularmente a partir dos anos 1990. Apesar de haver uma seção do livro dedicada à trajetória de algumas editoras - inclusive algumas abordadas neste trabalho , não existe a preocupação em analisar de modo mais detalhado o aspecto político da

\footnotetext{
${ }^{71}$ Por exemplo: MEDEIROS, N. "Editores e Estado Novo: o lugar do Grémio Nacional dos Editores e Livreiros". Análise Social, vol. XLIII (4. $\left.{ }^{\circ}\right), 2008$, p. 795-815; MEDEIROS, Nuno. "O universo editorial nos anos trinta e quarenta: a dinâmica do livro, entre persistência e mudança". In: PITA, António Pedro Pita; TRINDADE, Luís Trindade (coords.). Transformações estruturais do campo cultural português: 1900-1950. Coimbra: Centro de Estudos Interdisciplinares do Século XX da Universidade de Coimbra, 2009, p. 107-133; MEDEIROS, Nuno. "Objecto dúctil: a emergência de uma sociologia histórica da edição". Tempo Social. Revista de Sociologia da USP. São Paulo, Departamento de Sociologia, Faculdade de Filosofia, Letras e Ciências Humanas, Universidade de São Paulo, vol. 22, n 2, nov. 2010, p. 241-261; MEDEIROS, Nuno. "Ações prescritivas...", op. cit., p. 131-146; MEDEIROS, Nuno. "Editores e livreiros: que papéis de mediação para o livro?". In: CURTO, Estudos de Sociologia da Leitura..., op. cit., p. 343-385; MEDEIROS, Nuno. Edição e editores portugueses. Prescrições, percursos e dinâmicas (décadas de 1940 a 1960). Dissertação (Mestrado em Sociologia Histórica). 2007. Universidade Nova de Lisboa, Lisboa, 2007.

72 MEDEIROS, Edição e editores, op. cit.

73 BEJA, Rui. À janela dos livros: memória de 30 anos de Círculo de Leitores. Lisboa: Círculo de Leitores, 2011.

${ }^{74}$ BEJA, Rui. A edição em Portugal, 1970-2010: percursos e perspectivas. Lisboa: APEL, 2012.
} 
atuação dessas editoras. De toda forma, é uma importante contribuição ao estudo do setor editorial em tempos recentes em Portugal, produzido por um profissional da área.

Tudo isso faz ressaltar o fato de que há poucos trabalhos acadêmicos, ou de outra natureza, sobre as editoras de livros de caráter político em Portugal no período entre 1968 e o final da década de 1970. As obras que apurei, até o momento, que dedicam alguma atenção ao tema, além das de Nuno Medeiros, Pedro Jorge de Oliveira Pereira Leite e Rui Beja (já citadas), são as de Miguel Cardina ${ }^{75}$, Martinho de Freitas $^{76}$ e António Ventura ${ }^{77}$.

No caso de Cardina ${ }^{78}$ e de Martinho de Freitas, trata-se de levantamentos muito sucintos e preliminares de livros de caráter político editados desde finais dos anos 1960, que basicamente listam certo número de edições em períodos delimitados. No caso de Freitas, deve-se ter em mente que seus artigos - publicados em 1971 e 1972 - eram, de fato, uma denúncia pública desses livros e das editoras que os publicavam, feita ainda durante o regime ditatorial. Freitas, de certa forma, parece estar a bradar: "Como deixam publicar estes livros!”. Apesar disso, seu levantamento configura talvez o primeiro recenseamento organizado dos livros de caráter político, de cunho contestador e de esquerda, publicados nesse período.

Além desses, temos o trabalho de António Ventura sobre o marxismo em Portugal no século $\mathrm{XX}$, que analisa a difusão e divulgação dessa corrente de pensamento a partir do levantamento e análise das obras referentes a ela publicadas no país, destacando as editoras responsáveis pelos livros. No entanto, em virtude até mesmo das limitações de espaço do seu artigo, Ventura não analisa a atuação e as vinculações dessas editoras, apesar de deixar claro que aquele era um movimento editorial de cunho marcadamente político. Mas o autor não se propõe a estudar as

${ }^{75}$ CARDINA, Miguel. A tradição da contestação: resistência estudantil em Coimbra no marcelismo. Coimbra: Angelus Novus, 2008, p. 118. A obra apresenta como apêndice uma lista de "Obras de autores marxistas publicada durante o marcelismo" (p. 252).

${ }^{76}$ Trata-se de uma série de oito artigos, publicada de novembro de 1971 a abril de 1972, no jornal Época, que apresenta um levantamento de livros que conformam, nas palavras do autor, um "movimento editorial de intenção revolucionária”. FREITAS, Martinho de. "Análise dos textos para-revolucionários de autores de língua portuguesa editados em Portugal (1971)". Época, Lisboa, ano 2, no 426, 9 abr. 1972. Os demais artigos estão referidos na bibliografia deste trabalho. Agradeço a José Manuel Lopes Cordeiro, que me indicou estes artigos e gentilmente cedeu-me cópias dos mesmos.

77 VENTURA, António. "O marxismo em Portugal no século XX”. In: CALAFATE, Pedro (dir.). História do pensamento filosófico português. Lisboa: Caminho, vol. V, tomo 2, 2000, p. 195-220.

78 Destaque-se que a citada obra de Miguel Cardina foi editada em 2008 e é um rico e instigante estudo sobre a juventude e o movimento estudantil contestador nos anos 1960 e 1970 em Portugal. 
editoras que estão por trás desse movimento ${ }^{79}$.

Flora Manuela Larsson procurou estudar "Alguns aspectos da actividade editorial portuguesa desde 1973 a 1976", compararando a fase pré-revolucionária (1973), a fase revolucionária (1974-75) e a fase pós-revolucionária (1976) ${ }^{80}$. A autora concluiu que houve no período uma "eclosão do livro político", principalmente nas editoras médias, fruto da "influência exercida pela Revolução Portuguesa" de 1974, em grande medida graças à abolição da censura. Mas a autora aponta também a tendência de declínio do livro político a partir de $1975^{81}$. O trabalho não se aprofunda na análise dessa observação, e volta-se mais a uma comparação entre grandes e médias editoras, além de se basear em uma amostra muito pequena de editoras (dez).

Em relação à historiografia portuguesa, o que pude levantar inicialmente, como obras que se relacionam de forma mais próxima ao tema proposto - além dos trabalhos já citados - são trabalhos que têm como foco a censura à circulação de livros em Portugal e nas colônias, que constituem um objeto de pesquisa já razoavelmente explorado $^{82}$; e, em termos mais amplos, trabalhos sobre a censura ou o cerceamento às atividades culturais de um modo geral ${ }^{83}$.

Sobre esta temática, é valioso também, ainda que sucinto, o depoimento de Francisco Lyon de Castro, fundador da Publicações Europa-América ${ }^{84}$.

Por último, cabe lembrar as obras de Fernando Guedes sobre o mundo editorial e

\footnotetext{
${ }^{79}$ Ventura tem ainda outra obra em que apresenta um abrangente levantamento de livros de memórias e de depoimentos sobre a resistência ao Estado Novo em Portugal, muitos das quais surgidos no período abarcado pelo nosso estudo e publicados por editoras de caráter político. Cf. VENTURA, A. Memórias da Resistência: literatura autobiográfica da resistência ao Estado Novo. Lisboa: Câmara Municipal de Lisboa, 2001.

${ }^{80}$ MELO, Daniel. A leitura pública no Portugal contemporâneo (1926-1987). Lisboa: ICS, 2004, p. 23334.

${ }^{81}$ LARSSON, Flora Manuela. "Alguns aspectos da actividade editorial portuguesa desde 1973 a 1976". In: COELHO, Jacinto do Prado et al. Problemática da leitura. Aspectos sociológicos e pedagógicos. Lisboa: Instituto Nacional de Investigação Científica, 1980, p. 83-84.

${ }^{82}$ Ver, entre outros: LIVROS proibidos no Estado Novo, op. cit.; AZEVEDO, Cândido de. Mutiladas $e$ proibidas, op. cit.; BRANDÃO, José. "Os livros e a censura em Portugal”. Disponível em: <http://www.vidaslusofonas.pt/livros_e_censura.htm>; ALVIM, Maria Luísa. Livros portugueses proibidos no regime fascista: bibliografia. Braga: Faculdade de Letras da Universidade do Porto, 1992. Disponível em: <http://eprints.rclis.org/archive/00009450/01/livros_proibidos.pdf>. Acesso em 8/3/2008; PRÍNCIPE, César. Os segredos da censura. Lisboa: Caminho, 1979.

${ }^{83}$ AZEVEDO, Cândido de. A censura de Salazar e Marcelo Caetano. Imprensa, teatro, cinema, televisão, radiodifusão, livro. Lisboa: Caminho, 1999; CARVALHO, Alberto Arons de. A censura à imprensa na época marcelista. Coimbra, Minerva, 1999; CARVALHO, Alberto Arons de; CARDOSO, A. Monteiro. Da liberdade de imprensa. Lisboa: Meridiano, 1971. Uma boa bibliografia sobre a censura no Estado Novo está disponível no sítio eletrônico "Passado/Presente: a construção da memória no mundo contemporâneo", mais especificamente no endereço: $<$ http://ppresente.wordpress.com/bibliografias/bibliografias-1/>. Acesso em 2/3/2008.

${ }^{84}$ CASTRO, F. Lyon de. "Percurso de um editor". In: AZEVEDO, A censura de Salazar e Marcelo Caetano, op. cit., p. 526-544.
} 
livreiro português ${ }^{85}$.

Há outra linha de investigação relacionada à história do livro que, por seu lado, está totalmente vinculada às inovações contemporâneas relacionadas aos materiais impressos e está voltada para as mudanças que vêm atingindo nos últimos anos o negócio da edição. Estuda o impacto das tecnologias digitais na indústria da edição e o futuro do livro diante das novas tecnologias. Nesse campo, as obras de José Afonso Furtado são referenciais em Portugal ${ }^{86}$. Também Jorge Manuel Martins tem buscado analisar essas mudanças, inserindo-as no desenvolvimento histórico do livro e da indústria editorial ${ }^{87}$.

Destaque ainda para o trabalho de Nuno Seabra Lopes ${ }^{88}$, que realiza uma análise aprofundada da "indústria do livro" em Portugal e os seus principais problemas, buscando uma compreensão detalhada de suas bases econômicas e empresariais, com especial atenção à questão da gestão e de sua modernização para o desenvolvimento do setor.

\subsubsection{Definição de livro}

É importante esclarecer a definição de livro que adoto neste trabalho, já que existem diferentes concepções sobre este objeto - ainda mais nos tempos que correm, quando o suporte material deixou de ser um pressuposto obrigatório para a existência do livro.

José Afonso Furtado lembra que "é com a publicação, a partir de 1751, da Encyclopédie, sob a responsabilidade de Diderot e D'Alembert, que se nos depara uma tentativa consistente e decididamente moderna de caracterizar" o conceito de livro "e de recuperar, a um tempo, as diferentes fontes coevas que a ele se referem" ${ }^{\text {" }}$.

Na Encyclopédie o livro é definido a partir de quatro critérios:

\footnotetext{
${ }^{85}$ GUEDES, Fernando. Livreiros em Portugal e suas associações, desde o século XV até aos nossos dias: subsídios para a sua história. Lisboa: Verbo, 2005; GUEDES, Fernando. O livro como tema. História, cultura, indústria. Lisboa: Verbo, 2001.

${ }^{86}$ FURTADO, José Afonso. Os livros e as leituras: novas ecologias da informação. Lisboa: Livros e Leituras, 2000; FURTADO, José Afonso. O papel e o Pixel. Coimbra: Ariadne, 2007. Há também edição brasileira do Escritório do Livro, de Florianópolis, Santa Catarina, de 2006.

${ }_{87}$ MARTINS, Jorge Manuel. Profissões do livro: editores e gráficos, críticos e livreiros. Lisboa: Verbo, 2005.

${ }^{88}$ LOPES, Nuno André Proença Vaz Seabra. Panorama editorial: a indústria do livro em Portugal e os seus principais problemas. Dissertação (Mestrado em Linguística). 2006. Faculdade de Letras, Universidade de Lisboa, Lisboa, 2006.

${ }^{89}$ FURTADO, José Afonso. O que é o livro. Lisboa: Difusão Cultural, 1995, p. 14.
} 
ele é caracterizado pelo seu lado mental (trata-se de um escrito...), pelo autor e suas capacidades (homem inteligente ou de letras...), pela sua função (instruir, comunicar, dar prazer...) e pela sua materialidade e extensão (o livro distingue-se do tomo ou do volume como o todo se diferencia das partes...). ${ }^{90}$

Tal definição compila "temas, critérios e distinções que, de um modo geral, vão aparecer doravante em todas as definições de livro". E, salienta Furtado, "fica estabelecido o princípio de que [o livro] possui duas acepções distintas embora inseparáveis, uma material e outra espiritual"91. Assim, é no Século das Luzes que surge a "concepção do livro como uma realidade dupla" 92 .

Após apresentar uma síntese do debate sobre o tema até os dias atuais, Furtado conclui que "Parece claro que o livro continua, passados dois séculos, a ser entendido como a mesma realidade dupla, como bem material e bem espiritual"93, apesar de manifestarem-se opiniões sobre a impossibilidade de se adotar, nos dias de hoje, uma definição clara de livro, em virtude de sua complexidade. Robert Escarpit chega mesmo a considerá-lo indefinível ${ }^{94}$.

Talvez por isso, Nuno Medeiros diga que "o livro como objecto-representação existe também pelo desafio que coloca à capacidade de delimitação conceptual"95. Baseado em Chartier, este autor pensa o livro como uma tríplice realidade: "Lugar de congregação de texto e linguagem, de matéria tipográfica e mercadoria e de objecto legível e interpretável, o livro impresso apresenta-se como princípio que ordena o texto, o objecto e a leitura" 96 .

Para Fabrice Piault, nos encontramos num momento em que “já se não compreende o que constitui a natureza profunda" do livro e em que "a polivalência de conteúdos e a multidimensionalidade do objeto contribuem para a sua banalização e tendem a diluir a sua identidade" $" 97$.

Apesar disso, cabe-me aqui estabelecer, da forma mais clara possível, o conceito de livro que utilizo neste trabalho, inclusive para distinguir o livro do impresso em

\footnotetext{
90 Ibidem., p. 16.

${ }^{91}$ Ibidem, p. 19.

92 Ibidem, p. 24.

${ }^{93}$ Ibidem, p. 27.

94 "Ou pelo menos nunca ninguém conseguiu dar-lhe uma definição, ao mesmo tempo, completa e permanente", completa o autor. Cf. ESCARPIT, Robert. A revolução do livro. Rio de Janeiro: Ed. Fundação Getúlio Vargas/Instituto Nacional do Livro, 1976, p. 3.

95 MEDEIROS, “Problematizar o objecto...”, op. cit., p. 553-54.

${ }^{96}$ Ibidem, p. 554.

${ }^{97}$ PIAULT, Fabrice. Le livre: La fin d'un règne. Paris, Stock, 1995, p. 54, citado em FURTADO, O que é o livro, op. cit., p. 27.
} 
geral, e delimitar o meu campo de investigação. Assim, apresento a seguir alguns parâmetros para a definição que adoto e que será explicitada a seguir.

O Dicionário do livro, de Maria Isabel Faria e Maria da Graça Pericão, define livro da seguinte maneira:

Livro - Conjunto de cadernos, manuscritos ou impressos, cosidos ordenadamente e formando um bloco - Obra, científica ou literária que forma ou pode formar um volume - Cada uma das partes principais em que se dividem os textos dos livros - Documento impresso ou não impresso - Transcrição do pensamento por meio de uma técnica de escrita em qualquer suporte com quaisquer processos de inscrição. O livro supõe um suporte, signos, um processo de inscrição, um significado. Integra-se num processo de criação, de reprodução, de distribuição, de conservação e de comunicação. Dirige-se a um leitor, possui uma finalidade: a reflexão, o ensino, o conhecimento, a evasão, a difusão do pensamento e a cultura [...]. ${ }^{98}$

Há outra definição muito utilizada, da Unesco, criada para estabelecer padrões internacionais para as estatísticas sobre a produção e circulação de livros. Esta definição, de 1964, considera livro todo "impresso não-periódico de pelo menos 49 páginas, excluídas as capas, [...] disponibilizado ao público"99. Em termos gerais é a mesma definição adotada pela International Standards Organization (ISO) ${ }^{100}$, pela Associação Brasileira de Normas Técnicas $(A B N T)^{101}$ e pelo Instituto Nacional de Estatística de Portugal ${ }^{102}$.

Já a agência portuguesa para o ISBN (International Standard Book Numbering) define como 45 o número de páginas mínimo para que um impresso não-periódico seja considerado livro, além de estar sujeito ao depósito legal ${ }^{103}$. E a Association of American Publishers considera livro “os volumes cartonados não periódicos independentemente do número de páginas, os volumes infanto-juvenis cartonados ou brochados, independentemente do número de páginas, com excepção dos livros para

\footnotetext{
${ }^{98}$ FARIA, Maria Isabel; PERICÃO, Maria da Graça. Dicionário do livro: da escrita ao livro eletrônico. Coimbra: Almedina, 2008, p. 763.

${ }^{99}$ UNESCO. Records of the General Conference. Thirteenth Session. Resolutions. United Nations Educational, Scientific and Cultural Organization. Paris: Unesco, 1964, p. 144. Disponível em: <http://unesdoc.unesco.org/images/0011/001145/114581e.pdf>. Acesso em 9/10/2012.

${ }^{100}$ FARIA; PERICÃO, op. cit. , p. 763.

101 ABNT NBR 6029. Informação e documentação - Livros e folhetos - Apresentação. Associação Brasileira de Normas Técnicas, 2006, p. 3. Disponível em: <http://www.ufpi.br/subsiteFiles/ppgaarq/arquivos/files/6029-LivroseFolhetos.pdf>. Acesso em $8 / 10 / 2012$.

102 INSTITUTO NACIONAL DE ESTATÍSTICA (de Portugal). Estatísticas da cultura, desporto $e$ recreio. Lisboa: INE, 2003.

${ }^{103}$ FARIA; PERICÃO, op. cit. , p. 763.
} 
colorir, os volumes brochados não periódicos com mais de 48 páginas" ${ }^{104}$.

Neste trabalho, considero livro a publicação impressa não-periódica, encadernada por qualquer técnica, com capa, que seja identificável como volume - ou seja, não são folhas soltas ou simples folhetos, nem são concebidos com o caráter descartável destes -, que contenha uma ou mais obras intelectuais ou artísticas, independentemente do número de páginas. Podem ou não trazer identificado o editor ou o responsável pela edição - e o autor. Variáveis como distribuição e tiragem não são fundamentais aqui, ou seja, o impresso que obedeça a estes critérios, mesmo que dele tenha sido feito um único exemplar e que fique guardado no gabinete de seu autor, é um livro de acordo com esta definição.

Saliento que tal definição é resultante da minha observação e pesquisa da produção editorial e livreira portuguesa nos anos 1960 e 1970, particularmente do período 1974-1975, quando houve uma intensa publicação de impressos no país. Considero que esta definição permite diferenciar claramente os livros dos panfletos e folhetos editados, de modo a permitir uma análise adequada de cada um desses tipos de impressos.

\subsection{Difusão e edição política}

\subsubsection{Difusão e disseminação ampla}

A discussão sobre o papel que desempenharam as editoras de caráter político em Portugal no período imediatamente anterior e posterior à transição política - e durante esta transição - passa, certamente, pela compreensão de como estavam organizados os setores que configuravam a oposição à ditadura e de quem formava essa oposição, ou seja, os setores políticos, sociais, econômicos e culturais que a compunham. Foi principalmente neste campo que os livros políticos surgiram, atuaram e prosperaram. Várias das editoras que publicavam estes livros foram criadas nessa época e dentro desse setor. A pesquisa que realizei mostra que estas editoras ganham importância e projeção a partir de relações que os seus responsáveis estabelecem nesse campo. Indica também que, num momento posterior, elas passam a colaborar com certa importância para a difusão mais ampla na sociedade de ideias reformistas ou revolucionárias.

${ }^{104}$ MEDEIROS, “Problematizar o objecto...”, op. cit., p. 552. 
É nesse caldo de cultura, em que a atuação política de forma um pouco mais pública torna-se possível - ainda que sujeita a toda gama de medidas repressivas da ditadura - que as editoras de caráter político ganham corpo, se desenvolvem e passam a ter algum destaque na vida nacional, difundindo ideias, denúncias, novos comportamentos e atitudes culturais, dando voz a exilados, presos políticos, personalidades proscritas da vida pública, líderes da oposição, dissidentes do regime que findava, fazendo circular farta literatura socialista e marxista, trazendo a público uma literatura nacional feita por novos e velhos escritores e que tinha a marca do questionamento da realidade do seu país.

Se é certo que tais livros "transmitiam uma mensagem política e uma visão geral da política" ${ }^{105}$, seria possível pensar, como Robert Darnton pensou em relação a outro contexto, que eles de certa forma "moldaram a própria realidade e ajudaram a determinar o curso dos acontecimentos"? ${ }^{106}$

É claro que devemos levar em conta as diferenças entre o impacto da circulação de livros no quarto final do século XX, época do nosso estudo, e em fins do século XVIII, época estudada por Darnton. Mas a hipótese sugerida por Darnton da construção social e simbólica da realidade política através da cultura impressa é algo que me parece pertinente analisar no período aqui abordado.

Nesta análise é preciso não cair no erro de "supor uma noção linear de causalidade, como se pudéssemos discutir desde a venda de um livro até sua leitura, as convicções dos leitores, a mobilização da opinião pública e o envolvimento popular" na ação política. Ainda de acordo com Darnton, "o modelo de difusão que estabelece uma relação direta entre causa e efeito não leva em conta fatores independentes, como as fontes não literárias da opinião pública e a própria leitura como apropriação ativa e não recepção passiva dos textos" 107.

Para nos aproximar de tais questões será de grande valia o modelo desenvolvido por Darnton a respeito da difusão de livros em uma sociedade e das redes de

\footnotetext{
${ }^{105}$ DARNTON, Robert. Os best-sellers proibidos da França revolucionária. São Paulo: Cia. das Letras, 1998, p. 14.

${ }^{106}$ Ibidem, p. 15.

107 Ibidem, p. 197. A propósito do conceito de apropriação do livro e do dado textual, vejam-se os trabalhos de Roger Chartier (de que destaco CHARTIER, Roger (coord.). As utilizações do objecto impresso (séculos XV-XIX). Miraflores: Difel, 1998), Michel de Certeau (sobretudo o texto "Ler: uma operação de caça", do livro A invenção do cotidano, vol. I, Artes de fazer. Petrópolis: Vozes, 2001, p. 259-273) e de Janice Radway (Reading the Romance: women, patriarchy and popular literature. Chapel Hill: University of North Carolina Press, 1984).
} 
comunicação em que isso ocorre ${ }^{108}$. De forma sucinta, podemos dizer que este modelo busca "representar o processo de comunicação de forma que faça justiça à sua natureza sistêmica e à inter-relação de suas partes", de modo a admitir "influências externas em cada estágio" 109.

Outro conceito que nos ajudou na pesquisa foi o de "disseminação ampla", desenvolvido por Elizabeth Eisenstein em seu livro A revolução da cultura impressa ${ }^{110}$, que estuda as consequiências da invenção da imprensa no desenvolvimento das ideias na Europa, analisando os efeitos do aumento da produção de materiais impressos e as mudanças na recepção e na produção intelectual decorrentes desse processo.

Segundo a autora, a disseminação mais ampla de livros, proporcionada pelo aumento da produção decorrente da invenção da imprensa no século XV, gerava alterações na recepção dos livros e na produção intelectual da época, e se caracterizava por alguns pontos:

- a reunião de textos já publicados, que passam a ser "aproximados entre si e reunidos para uso de leitores individuais";

- o aumento da oferta de livros, com preços mais baixos e tiragens maiores;

- consequentemente, maior acesso a livros;

- possibilidade de escolha "mais rica e variada" de textos, que refletiam maior "conflito e diversidade";

- entre os estudiosos, diminuição da atividade meramente de glosador ou comentarista e

- início de uma "era de intensas referências cruzadas entre um livro e outro" $" 111$.

Para a autora, houve uma "efervescência [intelectual] provocada pelo acesso a um maior número de livros" 112 .

Eisenstein destaca também o papel proeminente que tiveram nesse processo os "profissionais engajados em operações editoriais", a começar pelo mestre impressor, o que fez com que as oficinas impressoras passassem a exercer forte atração sobre “estudiosos e homens de letras". A isso se relaciona também o fato de que nesse período "uma quantidade notável de trabalho inovador, tanto no campo da erudição como no da

\footnotetext{
${ }^{108}$ Ibidem, p. 185-213.

${ }^{109}$ Ibidem, p. 198.

${ }^{110}$ EISENSTEIN, Elizabeth L. A revolução da cultura impressa: os primórdios da Europa Moderna. São Paulo: Ática, 1998.

${ }^{111}$ Ibidem, p. 57 a 59.

${ }^{112}$ Ibidem, p. 59.
} 
ciência, foi realizada fora dos centros universitários" 113 .

Aqui também devemos ressaltar que não podemos simplesmente transpor esse conceito, pensado para a análise dos efeitos na Europa, nos séculos XV e XVI, da edição de livros impressos, para os processos vividos em Portugal nos anos 1960 e 1970. Nem é preciso ressaltar as diferenças.

Todavia, vale salientar que este conceito de disseminação ampla nos empresta alguns elementos que podem ser muito úteis para a definição e a análise das editoras de caráter político e do papel que tiveram no período em foco. Tomadas as devidas precauções, parece que as características da disseminação ampla apontadas por Elizabeth Eisenstein são em grande medida válidas para a edição política no período aqui analisado.

Suas sugestões sobre as possibilidades que se abrem a partir da ampliação da circulação de materiais impressos, e em particular dos livros, em uma determinada sociedade e em um determinado período histórico e de suas conseqüências intelectuais, políticas, econômicas e culturais nos dão um importante suporte para avançar na compreensão de como se estruturavam e atuavam as editoras de caráter político.

\subsubsection{A edição política e o livro político}

Jean-Yves Mollier, ao analisar o papel do impresso como arma no combate político na França, em um amplo período que vai do século $\mathrm{XV}$ ao século $\mathrm{XX}^{114}$, aponta para algumas questões que nos podem ser úteis para o estudo da edição e do livro políticos.

O autor sugere que o impresso é uma das bases para a formação de uma opinião pública $^{115}$, com especial força nos períodos de agitação política. E indica que é quando as lutas políticas se acentuam - e o impresso político ocupa um lugar estratégico nestas lutas, contribuindo fortemente "para fazer a política descer às ruas" - que aumenta o

\footnotetext{
113 Ibidem, p. 60.

114 MOLLIER, Jean-Yves. "Quando o impresso se torna uma arma no combate político: a França do século XV ao século XX”. In: DUTRA, Eliana Freitas; MOLLIER, J.Y. (Org.). Política, nação e edição. O lugar dos impressos na construção da vida política. Brasil, Europa e Américas nos séculos XVIII-XX. São Paulo: Annablume, v. 1, 2006, p. 259-274.

${ }^{115}$ No que converge com Jürgen Habermas na ideia geral de que o impresso desempenhou um papel determinante na constituição de um espaço público a partir das discussões e tertúlias que, essencialmente no século XIX, começaram a surgir em espaços como os cafés, nos quais se foi engendrando a noção que mais tarde se veio a designar de opinião pública. Ver HABERMAS, Jürgen. Mudança estrutural da esfera pública. Rio de Janeiro: Tempo Brasileiro, 1984.
} 
vigor do sistema editorial, "peça essencial na produção e difusão da literatura política". E "a multiplicação desses escritos sediciosos são o signo que pressagia uma mudança importante". No caso da França pré-revolucionária, afirma ele, o impresso "teve um papel excepcional para solapar as bases do regime"116.

Evidentemente, ao tratar do impresso, Mollier abarca um universo bem mais amplo do que o do livro, pois inclui também a imprensa, o panfleto, o folheto, os cartazes etc. Mas podemos transpor e adaptar algumas de suas sugestões para o período do nosso estudo e para o campo mais restrito da edição de livros políticos. Particularmente interessante me parece a ideia de que os momentos de maior agitação e lutas políticas propiciam condições para o fortalecimento do sistema editorial e, podemos inferir, dentro dele dos setores que buscam dar à edição um sentido de intervenção política. Desse modo, a edição política liga-se estreitamente às lutas políticas que se travam na sociedade em que ela se insere.

No caso de Portugal, no período que tratamos neste trabalho, esta ligação entre os momentos de agitação e lutas políticas, e a edição política é muito clara. Mas é interessante assinalar que processos análogos ocorreram em alguns outros casos concretos da história recente, além de Portugal. No Brasil temos algo semelhante, no período da abertura política, entre meados das décadas de 1970 e $1980^{117}$, e o mesmo parece ter ocorrido na Espanha, nos últimos anos da década de 1960 e nos primeiros da de 1970. "Naqueles anos convulsos o livro se converteu [...] 'em uma arma de luta política que muitos não duvidaram em utilizar" ${ }^{118}$. Tal movimento acentuou-se com o fim do franquismo, gerando "a euforia dos anos 1970, quando proliferaram as editoras de tema político que eram muito mais do que editoras" ${ }^{" 119}$. De acordo com o jornal $E l$ País, de fevereiro de 1977, o país vivia naquele momento de transição, após a morte de Franco, um "boom do livro político" e suas livrarias estavam "repletas de leituras políticas" $" 120$.

\footnotetext{
${ }^{116}$ MOLLIER, "Quando o impresso...”, op. cit., p. 260-269.

${ }^{117}$ Cf. MAUÉS, Flamarion. "Livros contra a ditadura: A Editora Brasil Debates e a Dissidência do PCdoB". Revista Perseu: História, Memória e Política, $\mathrm{n}^{\circ}$ 2, São Paulo, Editora Fundação Perseu Abramo, set./dez. 2008, ISSN 1982-4289, p. 261-291. Disponível em: <http://www.fpabramo.org.br/uploads/P2A-FlamarionMaues.pdf>.

${ }^{118}$ Palavras de Pedro Altares, um dos responsáveis pela editora Cuadernos para el Diálogo, citadas em: MORET, Xavier. Tiempo de editores: historia de la edición en España, 1939-1975. Barcelona: Destino, 2002, p. 295.

${ }^{119}$ Ibidem, p. 7.

120 PEREDA, Rosa Maria. "La fiebre del libro político". El País, 3/2/1977. Disponível em: <http://elpais.com/diario/1977/02/03/cultura/223772401_850215.html>. Acesso em 23/10/2012. Um detalhado painel do mundo editorial espanhol a partir dos anos 1970 e do fim do franquismo encontra-se
} 
Outra referência importante para meu estudo, no que diz respeito à conceituação do que é a edição política e das características de uma editora política, é a investigação de Julien Hage sobre três editoras políticas que ele classifica como de extrema esquerda, surgidas entre 1955 e 1964: a Feltrinelli, na Itália; a Maspero, na França; e a Wagenbach, na Alemanha ${ }^{121}$. Tais editoras são de certa forma continuadoras de um tipo de editora política cujo "modelo e paradigma"" 22 seria a francesa Éditions de Minuit, criada clandestinamente na França ocupada em $1942^{123}$.

Para Hage, as editoras sobre as quais se debruçou constituíram uma "tribuna das vanguardas intelectuais e estéticas de seu tempo". E mesmo sujeitas a uma forte censura, "repercutiram a emergência de uma nova esquerda nutrida pelo antiimperialismo e à margem dos partidos comunistas e sociais-democratas", e foram "as precursoras do desenvolvimento do livro político" na Europa ocidental ${ }^{124}$.

Elas utilizaram o livro para "difundir uma mensagem política à luz do terceiromundismo e do renovado movimento operário, e para promover o casamento entre edição e política de uma maneira criativa e militante" ${ }^{125}$.

Seus editores (que eram também os proprietários) apresentavam três perfis de editor muito diferentes: o empresário (Giangiacomo Feltrinelli), o intelectual (François Maspero) e o editor literário (Klaus Wagenbach) ${ }^{126}$. E representavam também três modelos específicos de edição política: a grande casa de edição profissional (Feltrinelli), o livreiro-editor (Maspero) e a pequena casa de edição literária (Wagenbach) ${ }^{127}$.

São editoras "engajadas politicamente, e nas quais esta orientação constitui a sua razão de ser e estrutura o seu catálogo", 128 . Assim, "Se a literatura permaneceu no centro das preocupações desses atores, ela por vezes ficou em segundo plano em benefício de

em: VILA-SANJUÁN, Sergio. Pasando página: autores y editores en la España democrática. Barcelona, Destino, 2003.

${ }^{121}$ HAGE, Julien. Feltrinelli, Maspero, Wagenbach: une nouvelle génération d'éditeurs politiques d'extrême gauche en Europe Occidentale 1955-1982. Thèse de Histoire Contemporaine, Université de Versailles Saint-Quentin-En-Yvelines Batiment D’Alembert, Decembre, 2010.

${ }^{122}$ HAGE, Julien. "Collections politiques et effets de sens: Littérature et politique dans les nouvelles maisons d'édition politique d'extrême gauche au cours des années 1960 et 1970". Cahiers du CRHQ (Centre de Recherche d'Histoire Quantitative), $\mathrm{n}^{\mathrm{o}}$ 2, 2010. Disponível em: <http://www.crhq.cnrs.fr/cahiers/page-article.php?num=313\&ch=7>. Acesso em 17/10/2012.

${ }^{123}$ SIMONIN, Anne. Les éditions de Minuit, 1942-1955. Le devoir d'insoumission. Paris, IMEC Éditions, 1994.

${ }^{124}$ HAGE, Feltrinelli, Maspero, Wagenbach, op. cit.

${ }^{125}$ HAGE, Julien. "François Maspero, éditeur partisan". Contretemps, Paris: Les Éditions Textuel, no 15, fev. 2006, p. $104 . \quad 10$ Disponível em: <http://www.contretemps.eu/sites/default/files/Contretemps\%2015.pdf>. Acesso em 24/10/2012.

${ }^{126}$ HAGE, "Collections politiques...", op. cit.

${ }^{127}$ HAGE, Feltrinelli, Maspero, Wagenbach, op. cit.

${ }^{128}$ HAGE, "François Maspero, éditeur partisan", op. cit., p. 104. 
uma produção mais diretamente política e pragmática, imediatamente relacionada com a atualidade" $" 129$.

Hage conclui que estas editoras “contribuíram para a renovação da oferta editorial, para a promoção do documento político e dos textos teóricos, para novas formas de paraliteratura, e de ciências sociais e militantes", em um contexto "de um compromisso resoluto na promoção do livro a custo acessível"130.

E é pela interação entre esta oferta editorial renovada e "uma demanda social pontual ou duradouramente politizada que se pode sem dúvida definir melhor o livro político, assim como por uma série de características que fundamentam uma natureza ou um 'tipo' muito bem definido e determinado" ${ }^{\text {131 }}$.

Ao analisar de forma mais ampla a edição política, Hage destaca a forte determinação simbólica e política das obras publicadas pelas editoras políticas como uma das bases de identidade destas editoras, "forjadas tanto por suas estratégias editoriais como por seus engajamentos militantes"132. E afirma que a valorização dos elementos paratextuais é uma das suas características principais, particularmente por meio de recursos como os prefácios e o aparelho crítico (notas explicativas, por exemplo). "A multiplicação e enriquecimento destes paratextos [...] sublinham uma politização crescente da oferta editorial, assim como um alargamento dos públicos visados, que resultam em uma complexificação das estratégias editoriais" ${ }^{133}$.

Uma experiência editorial importante em meu quadro de referências, por suas características particulares, é a da Éditions La Cité, editora militante suíça criada por Nils Andersson em 1958.

François Valloton relaciona o surgimento da La Cité à emergência de "uma nova geração de editores europeus que, no contexto da descolonização e das transformações na extrema esquerda internacional, vão associar de modo estreito engajamento político e editorial ${ }^{\prime 134}$. Entre estes editores estariam, além de Andersson, François Maspero e Jérôme Lindon (Éditions du Minuit) na França, Giangiacomo Feltrinelli na Itália, e, alguns anos depois, Klaus Wagenbach na Alemanha. Eles levaram adiante "o mesmo combate pela liberdade de expressão contra a razão de Estado, um interesse pelo

\footnotetext{
${ }^{129}$ HAGE, “Collections politiques...", op. cit.

${ }^{130}$ Ibidem.

${ }^{131}$ Ibidem.

${ }^{132}$ Ibidem.

${ }^{133}$ Ibidem.

${ }^{134}$ VALLOTON, François. "Edition et militantisme: le catalogue de 'La Cité: Editeur' (1958-1967)". In: BURNAND, Léonard; CARRON, Damien; JEANNERET, Pierre. Livre et militantisme. La Cité Editeur, 1958-1967. Lausanne: Editions d'en bas, 2007, p. 20. Grifos meus.
} 
terceiro-mundismo e pelos debates que agitavam a 'nova esquerda' nestes anos"135.

No entanto, Valloton destaca três pontos que diferenciam a atuação de Andersson como editor político dos três editores analisados por Hage. Em primeiro lugar, seu engajamento editorial não deriva diretamente da experiência da Segunda Guerra Mundial e da luta antifascista, pois sua formação política é feita mais tarde, "através da leitura de semanários franceses e do encontro com intelectuais e estudantes daquele país, engajados à esquerda e frequentemente fascinados tanto pelo existencialismo como por algumas novas correntes artísticas e literárias"136.

Em segundo lugar, a ideia de Andersson com a La Cité não era construir uma editora de grande porte, em função de suas limitações financeiras. Tal limitação somente poderia ser superada por meio de financiamentos bancários ou privados aos quais Andersson não quis recorrer, pois eles representariam uma dependência econômica, mas, inevitavelmente, também editorial de terceiros. "Não depender de empréstimos bancários ou privados lhe proporcionou criar uma das principais marcas da La Cité: a indocilidade" ${ }^{137}$.

O terceiro elemento distintivo era o fato de Andersson não ter verdadeiramente um projeto editorial de longo prazo: "La Cité era um instrumento mais do que uma empresa para sustentar", dizia o próprio Andersson ${ }^{138}$. Tal percurso, conclui Valloton, representou "Uma escolha que sem dúvida limitou a envergadura" da editora, mas foi fundamental para "a grande coerência de um catálogo ao serviço de ideias e não do lucro" $" 139$.

Todos estes pontos relacionados a algumas das mais destacadas editoras políticas europeias dos anos 1960, e à edição política em termos mais amplos, trazem alguns elementos importantes para que possamos refletir sobre a edição política em Portugal no período entre 1968 e o final da década seguinte. O contexto da guerra colonial e das transformações na esquerda em âmbito internacional, que vêm desde o começo dos anos 1960, são dois destes elementos. Nesse quadro, a possibilidade de associar engajamento político e atuação editorial aparece como uma das opções de ação política para setores ligados aos meios universitários, aos grupos de extrema esquerda que proliferam a partir de meados de 1964, aos emergentes grupos de "católicos progressistas" que passam a

\footnotetext{
135 VALLOTON, op. cit., p. 20.

${ }^{136}$ Ibidem., p. 21.

${ }^{137}$ Ibidem., p. 21.

138 Ibidem., p. 21.

${ }^{139}$ Ibidem., p. 21-22.
} 
questionar de modo cada vez mais direto o projeto colonial português, e a outros setores ligados à chamada oposição democrática. Num país em que a ditadura ainda proibia a existência de partidos políticos, sindicatos e associações civis independentes, a edição de livros que promovessem a denúncia da ditadura e o debate sobre temas políticos apesar da censura e das diversas formas de coerção e repressão utilizadas pelo governo - ganhava relevância como forma de intervenção pública na sociedade, intervenção esta que era vedada por quase todos os demais canais pelos quais esta participação poderia se dar $^{140}$. Em muitas dessas iniciativas, a edição era concebida primordialmente como instrumento político. Assim, para boa parte dessas editoras, o lucro era algo secundário, o que aumentava mais ainda os riscos envolvidos nessas empreitadas - pois haviam, é claro, os riscos da repressão em virtude do desafio político que essas editoras lançavam à ditadura.

Com o fim da ditadura, a lógica de associar engajamento político e atuação editorial permanece para muitos grupos políticos com o mesmo sentido de intervenção na realidade, mas sem os constrangimentos repressivos do pré-25 de Abril.

A partir dessa amálgama de sugestões, como podemos definir a edição política? O que caracteriza as editoras e os livros políticos em Portugal no período aqui enfocado?

A edição política pode ser definida como aquela que vincula de modo direto engajamento político e ação editorial, o que significa dizer que é a edição feita com intenção política de intervenção social, ou seja, que parte de um projeto editorial e/ou empresarial de fundo político, cujo objetivo é divulgar, debater ou defender determinadas ideias políticas publicamente na sociedade. Assim, a editora política caracteriza-se pelo engajamento político, que estrutura o seu catálogo.

A casa editorial que realiza a edição política poderá, em certos casos, manter vínculos orgânicos com instituições políticas, como por exemplo partidos e associações cívicas. Mas poderá também ser iniciativa de um indivíduo, ou grupo de indivíduos, que a título pessoal (ou do grupo) empenha-se no ramo editorial e busca que esta atividade reflita, em alguma medida, a sua forma de ver e interpretar o mundo. Em ambos os casos o engajamento se dá pela defesa de certos princípios, ideias e causas, e se materializa nos livros editados, como resultado da íntima ligação entre engajamento e edição.

Principalmente nas editoras políticas que tinham vínculos com grupos ou partidos, 140 Além das editoras, também as cooperativas culturais e livreiras que surgem nos anos 1960
representaram uma forma de pôr em prática essa participação. 
era marcante a militância de editores, autores e colaboradores em torno das ideias que as animavam. Por isso, estas editoras podem também ser caracterizadas como editoras políticas militantes.

Havia também um conjunto significativo de editoras que publicavam livros políticos, mas que não se caracterizavam como editoras políticas. Estas editoras não tinham como foco central de sua atuação a política, mas por razões circunstanciais ou comerciais abriram em seus catálogos espaço para este tipo de livro, sem que necessariamente houvesse algum tipo de engajamento político por parte da casa editorial. Mas, ainda assim, a edição de obras políticas acabou por representar, para estas editoras, um segmento importante em seu catálogo, mesmo que apenas por um período limitado de sua vida.

Assim, é preciso diferenciar as editoras políticas das editoras que publicavam obras de caráter político. No primeiro grupo estão as editoras cujas publicações refletem o predomínio do engajamento político na definição de sua linha editorial e cujo catálogo reflete, de modo consistente, uma certa posição política (esquerda, direita, católica progressista, liberal, anarquista). O segundo grupo é composto pelas editoras que circunstancialmente ou por razões predominantemente comerciais publicaram títulos de caráter político, sem que a edição de tais obras implicasse em engajamento ideológico ou político com as ideias e princípios defendidos nestas obras.

Por último, é preciso lembrar que houve também muitos livros políticos que foram publicados por editoras que não se enquadram nem na definição de editoras políticas, nem na de editoras que publicavam livros políticos (não políticas). Conforme explicado anteriormente, estas editoras não foram incluídas em meu levantamento, pelo fato de terem editado menos de cinco livros políticos no período em foco. Nestes casos, a edição desses livros não representou, no catálogo dessas editoras, um conjunto de títulos que caracterizasse, em qualquer momento, a política como um fator importante para a sua atuação - seja pelo número de títulos publicados, seja pela importância desses títulos.

O livro político, por sua vez, tem um escopo mais fluido, pois, na definição de Pierre Jeanneret, "Toda obra literária que se propõe a exercer uma ação sobre a sociedade, a fortiori que lança sobre ela um olhar crítico e pretende concorrer à sua transformação, pode com efeito ser considerada como política" ${ }^{141}$. Tentando sair de um

${ }^{141}$ JEANNERET, Pierre. "Les engagements politiques des années 60 et l'expulsion de Nils Andersson". In: BURNAND; CARRON; JEANNERET, op. cit., p. 124. 
um quadro tão abrangente, podemos dizer que é certo que existe aquele tipo de livro que é claramente de intenção política, seja pelo tema tratado, seja por sua abordagem, seja por seu autor, assim como há também livros que, sem serem diretamente políticos, tornam-se políticos em virtude de certas circunstâncias. Por exemplo, livros que tratassem de temas relacionados à antiga União das Repúblicas Socialistas Soviéticas eram muitas vezes censurados por razões políticas tão-somente por referirem-se ou originarem-se naquele país, ainda que tratassem de temas como física, química ou medicina.

Outra das características marcantes de grande parte dos livros políticos é a valorização dos elementos paratextuais, utilizados para marcar a intenção política e prescritiva da obra - e até, mais do que da obra, do editor.

Eis alguns outros pontos que podem distinguir os livros políticos: 1) o papel político que a obra desempenhou no período estudado; 2) o conteúdo do livro; 3) as condições em que a obra foi criada; 4) o percurso do original ao livro publicado; 5) o perfil do autor e da editora; 6) as ligações políticas do autor e da editora; 7) a difusão da obra; 8) a repercussão nos meios políticos e na imprensa; 9) a análise da obra como produto editorial e comercial ${ }^{142}$.

\footnotetext{
${ }^{142}$ Estabeleci estes pontos a partir do estudo sobre "livros de oposição" no Brasil. Um livro de oposição é, necessariamente, um livro político (apesar de o inverso não ser sempre verdadeiro), de modo que considero que estes pontos servem para definir tanto um livro de oposição como os livros políticos em geral. No artigo “"Ter simplesmente este livro nas mãos é já um desafio”: Livros de oposição no regime militar, um estudo de caso", de minha autoria, apresento o estudo de um livro de oposição (Poemas do povo da noite, de Pedro Tierra) feito com base neste modelo de análise. O artigo foi publicado na revista Em Questão, Revista da Faculdade de Biblioteconomia e Comunicação, ISSN 1807-8893 UFRGS, v. 11, n. 2, julho a dezembro 2005, p. 259-279. Disponível em: <http://www6.ufrgs.br/emquestao/pdf_2005_v11_n2/3_tersimplesmente.pdf>. Também em meu artigo "A tortura denunciada sem meias palavras: um livro expõe o aparelho repressivo da ditadura" utilizo este modelo de análise para estudar o livro Tortura: A história da repressão política no Brasil, do jornalista Antonio Calos Fon. In: SANTOS, Cecília MacDowell, TELES, Edson Luís de Almeida e TELES, Janaina de Almeida (Orgs.). Desarquivando a Ditadura: Memória e Justiça no Brasil. São Paulo: Hucitec, 2009, p. 110-134.
} 


\section{A EDIÇÃo POLÍtica EM PORTUGAL ANTES E DEPOIS DO 25 DE ABRIL}

\subsection{Os livros de caráter político antes do 25 de Abril}

Como já destacado, o incremento da edição política em Portugal tem como marco o ano de 1968, e ganha uma nova dimensão a partir de 25 de abril de 1974.

Boa parte da literatura marxista e socialista, principalmente dos seus principais teóricos e pensadores, foi publicada em Portugal ainda durante o governo de Marcelo Caetano, e, com maiores ou menores dificuldades e perseguições, estava disponível ao público de estudantes, militantes e simpatizantes que tinha um interesse mais imediato por tais obras - e que conhecia os caminhos para ter acesso a elas.

O livreiro e editor Luís Alves Dias, da Livraria Ler, desde 1970 instalado no bairro de Campo de Ourique, em Lisboa, explica como fazia, naquela época, para vender livros que poderiam sofrer perseguições da DGS (Direção Geral de Segurança), novo nome que a famigerada PIDE (Polícia Internacional e de Defesa do Estado) havia recebido no período do marcelismo:

Fazíamos, por exemplo, 5.000 exemplares e a tipografia passáva-nos uma factura de 1.500. Sobre esses 1.500 é que nós faturávamos a todas as livrarias. Ficavam 3.500 para vender pela porta do cavalo, como se costumava dizer. Era isso que nos salvava. Dos 1.500 eram apreendidos, se calhar, uns 700 ou 800. Isto porque as apreensões vinham três ou quatro dias depois de estarem os livros nas livrarias. ${ }^{1}$

Havia, dessa forma, uma forte aliança entre editores, tipógrafos e livreiros para que fosse possível a circulação desses livros. "À sorrelfa, arranjavam-se os livros dos quais o regime não queria que se ouvisse sequer falar. Escondiam-se em vãos de estantes, paredes falsas, ou até baldes de tinta, e só se vendiam a clientes de confiança 'por debaixo do balcão', embrulhados em papel pardo" ${ }^{2}$.

Como recorda José Reis, gerente da Livraria Portugal, em Lisboa, “Os livros

\footnotetext{
1 DAURO, Covas. "Ler com o Sr. Luís". Entrevista com Luís Alves Dias. Blogue Todos os Livros, jan./fev. 2008. Disponível em: <http://todos-os-livros.blogspot.com/2008/01/ler-com-o-sr-lus-1.html>. Acesso em maio de 2010.

2 BARATA, Clara; QUEIRÓS, Luís Miguel. "Os livros da resistência: livrarias no regime fascista". Público, Lisboa, 11 Jun. 1994, sup. Leituras, p. 1-4. Disponível em: <http://quexting.di.fc.ul.pt/teste/publico94/ED940606.txt>. Acesso em maio de 2010.
} 
proibidos eram verdadeiros best-sellers, tanto pelo que eram, como por serem proibidos. Muitas vezes nem eram nada de especial. Mas a proibição aguçava o apetite" ${ }^{3}$.

António Abreu, da Editora Textos Marginais, aponta na mesma direção:

Antes do 25 de Abril o livro saía com o rótulo de proibido, então havia todo um mercado paralelo, que se formou em função disso [...]. Os livros já saíam vendidos, as livrarias recebiam e nem expunham, ficavam debaixo do balcão e havia os clientes certos que iam lá e compravam. Eram tiragens de 3 mil, 4 mil exemplares e vendia tudo. Normalmente uns $30 \%$ ou $40 \%$ da tiragem eram já destinados para a apreensão, a gente já contava com aquilo. ${ }^{4}$

Todos estes mecanismos de burla da repressão existiam justamente porque havia grande cerceamento à atuação das editoras e dos livreiros. Em um texto publicado na tradicional revista Seara Nova em dezembro de 1974, os responsáveis pela Editora Seara Nova lembravam o clima em que tinham que trabalhar durante a ditadura:

Era permanente a presença da PIDE nas nossas instalações, sob qualquer pretexto ou sem pretexto nenhum, com seu habitual cortejo de ameaças e violência e depredações; as monstruosas apreensões de livros que nos criaram uma situação financeira angustiante e se revelavam processo eficaz de nos impedir de continuar com as nossas edições; as constantes intimidações para depor em processos que se acumulavam e aos quais sabíamos mal como poderíamos resistir. ${ }^{5}$

A intimidação e a repressão tinham por fim atingir também economicamente as editoras e os livreiros:

Nos dois anos que antecedem ao 25 de Abril de 1974, as prateleiras da [Editora] Seara Nova ficaram com menos 1.500 contos de livros que a PIDE/DGS se encarregou de levar para os armazéns da Rua António Maria Cardoso [sede da PIDE]. Além de ter alguns dirigentes e colaboradores detidos na prisão de Caxias (situação que era já quase normal), a Seara Nova podia contar, nessa altura, com pelo menos cinco processos por edições de livros considerados subversivos e que a DGS tinha já enviado para o Tribunal Plenário. ${ }^{6}$

O caráter de perseguição econômica da repressão fica bem claro no caso ocorrido com a Publicações Europa-América em junho de 1965, quando teve, de uma vez só, 73 mil livros apreendidos e 23 títulos proibidos ${ }^{7}$, o que causou grande prejuízo

\footnotetext{
${ }^{3}$ Ibidem.

${ }^{4}$ Entrevista com António Daniel Abreu em São Paulo, 23/8/2012.

5 "Seara Nova: ontem e hoje ao serviço da democracia". Seara Nova, no 1.550, dez. 1974, p. 2-3.

6 BRANDÃO, José. "Os livros e a censura em Portugal". Disponível em: <http://www.vidaslusofonas.pt/livros_e_censura.htm>. Acesso em outubro de 2009.

${ }^{7}$ Ibidem.
} 
financeiro à editora, que quase foi à falência.

O clima de temor que havia entre muitos daqueles que de alguma forma estavam ligados à edição política e à oposição é magistralmente exposto num poema de Ana Hatherly:

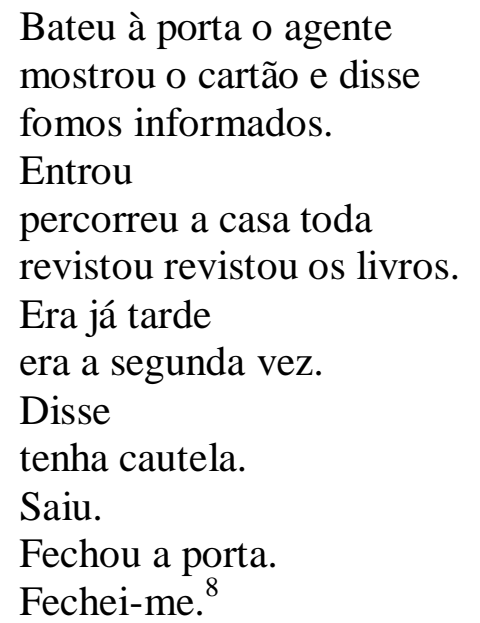

Ainda poucos meses antes de 25 de abril de 1974, o ministro do Interior, Gonçalves Rapazote, deu ordem à polícia política para que fosse intensificada a vigilância sobre a edição e a venda de livros "subversivos". Tais ordens eram as seguintes:

1 - Relacionar as tipografias que se dedicam à impressão de livros suspeitos - pornográficos ou subversivos;

2 - Organizar um plano de visitas regulares a essas tipografias para impedir, efetivamente, a impressão de textos suscetíveis de proibição; $[\ldots]$

5 - Organizar a visita regular às livrarias de todo o País para sequestro de livros, revistas e cartazes suspeitos e para apreensão dos que já estão proibidos pela Direção dos Serviços de Censura. ${ }^{9}$

Além disso, continuava em vigor a exigência de licença governamental para quem desejasse abrir uma editora, ou seja, os nomes daqueles que se propunham a criar uma casa editorial eram submetidos à análise da PIDE/DGS, e a autorização somente era concedida se não houvesse veto por parte da polícia política. Não era incomum que a autorização não fosse concedida em função de os sócios, ou algum deles, serem considerados "adversários do Estado Novo", caso em que a PIDE carimbava em suas

\footnotetext{
${ }^{8}$ HATHERLY, Ana. Poesia: 1958-1978. Lisboa: Moraes Editores, 1980. Reproduzido também em: HATHERLY, Ana. "Prefácio". In: SACHER-MASOCH. A Vénus de Kazabaïka. Lisboa: Relógio d'Água Editores, 2. "a edição, 1994.

${ }^{9}$ Ibidem.
} 
fichas: "Elemento de tendências comunistas, não dando garantias de cooperar na realização dos fins superiores do Estado".

Tal controle se estendia a toda a atuação do editor, representando uma restrição constante à sua liberdade. João Barrote, editor da Escorpião/Textos Exemplares, diz: "Se eu me matriculasse como editor no SNI [Secretariado Nacional da Informação, Cultura Popular e Turismo] eu estava automaticamente a ser controlado de uma forma mais apertada" ${ }^{\prime 10}$. Por isso ele optou por criar a sua editora sem autorização oficial, como outros também fizeram, usando o subterfúgio das edições de autor, ou seja, os livros eram publicados como se fossem editados pelo autor, ou pelo tradutor, mas de fato havia uma editora que os publicava, mas que não tinha existência legal como editora. De acordo com Barrote, não ser um editor registrado dava-lhe maior liberdade de ação.

Mas, mesmo com estas perseguições e restrições, podemos afirmar que ainda durante a ditadura salazarista a produção e circulação de livros de esquerda, marxistas e socialistas, foi razoavelmente ampla, principalmente no final dos anos 1960 e início da década de 1970. Como nos disse o professor António Monteiro Cardoso, na altura militante do Movimento Reorganizativo do Partido do Proletariado (MRPP): "Li tudo o que precisava para a minha formação marxista antes de 1974. Estava tudo disponível e editado em Portugal, desde que se tomassem certos cuidados e se conhecessem os canais certos" 11 .

Tão ampla era a circulação desta literatura que chegou a ser tratada em uma série de oito artigos - já mencionada no Capítulo 1 -, publicados de novembro de 1971 a abril de 1972 no jornal Época, um periódico claramente identificado com o regime ${ }^{12}$. Este levantamento, feito pelo jornalista Martinho de Freitas, apresentava, nas palavras do autor, os livros que conformavam um "movimento editorial de intenção revolucionária" ${ }^{13}$. Freitas listou dezenas de títulos de Marx, Engels, Lenin, Stalin, Trotsky, Mao Tsé-tung, Fidel Castro, Che Guevara, entre outros, editados apenas no ano

\footnotetext{
${ }^{10}$ Entrevista com João Barrote na freguesia de Arnoia, concelho de Celorico de Bastos, distrito de Braga, Portugal, 22/6/2011.

${ }^{11}$ Entrevista com António Monteiro Cardoso, Lisboa, 2/3/2011.

${ }^{12} \mathrm{O}$ jornal Época era de tal modo identificado com o regime que sua sede foi cercada por uma multidão e tomada por manifestantes em 26 de abril de 1974. Cf. ANDRADE, John. Dicionário do 25 de Abril. Lisboa: Nova Arrancada, 2002, p. 133-134.

13 FREITAS, Martinho de. "Análise dos textos para-revolucionários de autores de língua portuguesa editados em Portugal (1971)". Época, Lisboa, ano 2, no 426, 9 abr. 1972. Os demais artigos deste autor estão citados na bibliografia.
} 
de 1971 em Portugal.

Tratando da difusão de obras sobre marxismo em Portugal, António Ventura detecta um "surto editorial nunca antes experimentado" dessas edições a partir de 1970, afirmando que: "Se antes era difícil encontrar, no mercado luso, obras de Marx e Engels, elas começaram a surgir com uma profusão surpreendente" desde então ${ }^{14}$. O mesmo fenômeno é também destacado por Miguel Cardina:

$\mathrm{Na}$ aurora dos anos 70, ocorre em Portugal uma verdadeira explosão ao nível da tradução de textos das mais variadas correntes do marxismo [...]. Marx, Engels, Lenine, Mao Tsé Tung, Rosa Luxemburgo, Trotsky e Gramsci são profusamente vertidos para o português. ${ }^{15}$

De acordo com este autor, algumas das editoras que relacionamos ao grande movimento editorial de caráter político pós-25 de Abril destacaram-se, mesmo antes do fim da ditadura, por publicar parte substancial das traduções por ele mencionadas, nomeadamente as editoras D. Quixote, Prelo, Portucalense, Estampa, Presença e Centelha. Ainda segundo Cardina:

Uma fatia não despicienda era também traduzida e divulgada no limitado circuito estudantil, através de estruturas de imprensa clandestina. Importante era ainda o papel das cooperativas livreiras, bastante ativas durante o marcelismo e animadas por variados setores de oposição [...]. ${ }^{16}$

No Capítulo 12 voltaremos a enfocar a produção de livros políticos no período entre 1968 e 25 de abril de 1974.

\subsection{Os livros no pós-25 de Abril}

No entanto, esses fatos não querem dizer que com o fim da ditadura a situação referente à edição de livros de caráter político não tenha se modificado. Modificou-se significativamente, pois passou a ser possível publicar tudo sem restrições legais, sem perseguição policial e, principalmente, houve um grande aumento do interesse por este tipo de livro. Se antes eram os estudantes, militantes e simpatizantes de grupos de esquerda os principais compradores, em 1974 e 1975 esse público aumentou

\footnotetext{
${ }^{14}$ VENTURA, op. cit., p. 217.

${ }_{15}^{15}$ CARDINA, A tradição da contestação, op. cit, p. 118.

${ }^{16}$ Ibidem, p. 119.
} 
enormemente.

José Antunes Ribeiro, da Editora Ulmeiro, diz que, após o 25 de Abril, “A política está nas ruas, na TV, nas rádios, os acontecimentos estão por todo lado e as pessoas querem alguma informação, porque a maior parte delas estava completamente desinformada". Para ele, "O grosso da população acorda para a política com a revolução"17. E os livros políticos supriram parte dessa demanda, dessa sede de informação.

"Aquilo foi um rio que se soltou, rompeu-se o dique, era um entusiasmo enorme, grandes tiragens", destaca Francisco Melo, diretor das Edições Avante!, a editora do $\mathrm{PCP}^{18}$. Não era incomum ler-se na imprensa referências a uma "inflação editorial do pós-25 de Abril"19.

Mirian Halpern destacava, em 1975, que o maior interesse pelos livros políticos após o fim da ditadura relacionava-se com "a própria necessidade de intervenção das pessoas, de novas categorias sociais na vida política do país [que] as levou a sentir a necessidade de se documentarem melhor sobre as questões econômicas, sociais, políticas" ${ }^{20}$.

O caráter pedagógico e/ou doutrinário de muitos títulos lançados era também destacado:

Proliferam nas livrarias de todas as cores do arco-íris, nas estantes, nas mãos, eventualmente nas leituras das pessoas, os chamados livros políticos. Como proliferaram os partidos a seguir ao 25 de Abril [...]. Estes livros de um modo geral têm todos a mesma função objectivamente detectável. Fornecer as ideias, o sistema, a resposta, as diversas soluções autorizadas, para os problemas da vida nacional, da construção da democracia, do rumo ao socialismo, outras coisas mais. $^{21}$

Não há como negar, assim, que onda de liberdade advinda da revolução que se iniciou com o fim da ditadura em Portugal fez crescer como nunca o número de editoras e de livros publicados, dos quais parte significativa era de cunho político e com perfil de

\footnotetext{
${ }^{17}$ Entrevista com José Antunes Ribeiro, Lisboa, 2/2/2011.

${ }^{18}$ Entrevista com Francisco Melo, Lisboa, 1/2/2011.

${ }^{19}$ Resenha do livro Indústria, ideologia e quotidiano (ensaio sobre o capitalismo em Portugal), de João Martins Pereira. Vida Mundial, Lisboa, nº 1.829, 3 /10/1974, p. 6.

${ }^{20}$ HALPERN, Miriam. “Enorme interesse pelo marxismo". Vida Mundial, Lisboa, no 1.860, 8/05/1975, p. 29.

21 "Dossiers de luta: uma explicação necessária". In: Trabalhadores dos transportes Estefânia em luta contra o patrão. Lisboa, Contra a Corrente, 1976, p. 1.
} 
esquerda, ou de denúncia do antigo regime, dentro de um movimento cultural mais amplo, que abrangia variadas áreas. Somente em 1974 e 1975 foram criadas 54 novas editoras que publicavam obras de caráter político no país (ver o Capítulo 3).

Em 1979, Maria da Piedade e Pina Mendes, responsáveis pelo Departamento Editorial da Bertrand, uma das maiores editoras de Portugal, analisavam as mudanças no setor editorial após o 25 de Abril:

[...] nunca em Portugal se editou tanto livro como depois do "25 de Abril". Mesmo hoje, decorridos quase cinco anos, editam-se e vendem-se mais livros do que "antigamente", embora, talvez não tantos como em 1975 e 1976. O "25 de Abril" trouxe ao nosso país profundas alterações políticas, sociais e econômicas: a censura foi abolida, houve, por parte do público um interesse por temas até aí proibidos ou escamoteados, fome de cultura, e houve, por outro lado, uma melhoria substancial das condições de vida. ${ }^{22}$

Halpern, um anos após o fim da ditadura, detectava sinais muito positivos decorrentes dos novos interesses estimulados pela liberdade pós-25 de Abril, que eram em parte supridos pelo surto editorial que então se vivia:

As pessoas sabem mais sobre o mundo que as rodeia do que sabiam há um ano: o nível médio da cultura em Portugal aumentou extraordinariamente na medida em que identifico "cultura" com conhecimento do mundo. Na maior parte das pessoas, a capacidade crítica aumentou, o que é importante tendo em conta que houve pessoas que partiram do ponto zero. [...] Atualmente, o que se verifica é que depois do 25 de Abril um povo inteiro começou a pensar e a agir. [...] $\mathrm{O}$ que houve aqui foi uma grande difusão da cultura e a criação de um grande público para todas as formas de cultura. Se isto se vai traduzir ou não por um progresso da cultura portuguesa depende da evolução do país e dessas condições serem apoiadas por uma reestruturação das instituições ligadas à cultura, o que até agora só aconteceu muito parcialmente. ${ }^{23}$

Desse modo, no período que se inicia com a derrubada da ditadura, e que teve uma intensidade extraordinária até o final de 1975, veremos uma enorme efervescência editorial, com amplo destaque para as edições de esquerda. Apenas nestes dois anos (1974 e 1975) apareceram 42 novas editoras de esquerda (ver a seguir as editoras da revolução).

Se considerarmos o período entre 1968 e 1980, constatamos que houve pelo

\footnotetext{
22 Entrevista com Maria da Piedade e Pina Mendes, responsáveis pelo Departamento Editorial da Bertrand. Notícias do Livro, Lisboa, n 5, mar. 1979, p. 8.

${ }^{23}$ HALPERN, op. cit.
} 
menos 137 editoras que publicaram livros políticos em Portugal, das quais quase três quartos eram editoras políticas. Veremos mais detalhes sobre este levantamento no capítulo seguinte.

Estas editoras publicaram cerca de 4.600 títulos de caráter político no período indicado. No Apêndice deste trabalho pode-se consultar a lista dessas obras, catalogadas por editora $^{24}$.

\subsection{As editoras no pré e no pós-25 de Abril}

Apresento a seguir uma lista de editoras que publicaram obras de caráter político, para que possamos visualizar mais claramente esse movimento editorial. A caracterização mais detalhada de cada uma destas editoras pode ser vista no Quadro Sinóptico que faz parte do Capítulo 3.

Comecemos pelas editoras mais antigas, que surgiram antes de 1968 e que também editaram obras de caráter político no período 1968-1980. Elas totalizam 37 editoras, e são as seguintes:

Editoras criadas antes de 1968

Acrópole

Afrodite

Afrontamento

Agência Portuguesa de Revistas

Almedina

Arcádia

Aster

Ática

\footnotetext{
${ }^{24}$ Todavia, é preciso dizer que, inevitavelmente, um certo número de títulos terá escapado a esse levantamento, havendo a necessidade de mantê-lo em permanente atualização. Isso ocorre em virtude das dificuldades em realizar um levantamento desse tipo, decorrentes das deficiências das fontes de pesquisa (pois não é possível localizar catálogos completos das editoras em nenhum lugar). A isso deve-se agregar o fato de que parte dessas obras não foi guardada por bibliotecas públicas ou universitárias, o que dificulta a pesquisa. Mesmo na Biblioteca Nacional de Portugal, em geral o sítio onde há o melhor acervo destas editoras, sempre há lacunas. Deve-se lembrar, ainda, que algumas obras foram editadas clandestinamente antes de 1974, o que dificulta a pesquisa. Além disso, um levantamento desse tipo, ainda que muito abrangente e amplo, dificilmente será definitivo e completo, pois o universo das obras publicadas naqueles anos é vastíssimo.
} 
Atlântida

Bertrand

Brasília

Centro do Livro Brasileiro

Delfos

Dom Quixote

Editorial Notícias

Estampa

Estúdios Cor

Europa-América

Horizonte

Iniciativas Editoriais

Jornal do Fundão

Livraria AI (Apostolado da Imprensa)

Livraria Popular de Francisco Franco

Meridiano

Minerva

Moraes

Nova Realidade

O Século (editora)

Parceria A. M. Pereira

Portucalense

Portugália

Prelo

Presença

Sá da Costa

Seara Nova

Ulisséia

Verbo

Até em função da ditadura vigente em Portugal, predominam entre as editoras criadas até 1967 as casas não políticas (mas que publicaram entre 1968 e 1980 obras de caráter político). Elas são 22 das 37 editoras deste grupo. 
É a partir de 1968 que a edição política ganha fôlego e surgem novas editoras voltadas para este tipo de livro. A partir de 1968 e antes de 1974 foram criadas 33 editoras que publicaram, com maior ou menor ênfase em sua linha editorial, títulos de viés político:

Editoras criadas entre 1968 e 1973

A Regra do Jogo

Assírio \& Alvim

Base

Cadernos Para o Diálogo

Cadernos Textuais

Centelha

Cidadela

Círculo de Leitores

Edições 70

Edições do Partido

Edições do Povo

Escorpião/Textos Exemplares

Futura

Inova

Latitude

Livraria Júlio Brandão

Livraria Ler Editora

Manuel Xavier

Maria da Fonte

Multinova

N. A. * Orion

O Grito do Povo (editora)

Paisagem

Pensamento Político

Plátano

Portugal Socialista

Povo e Cultura 


\author{
República (editora) \\ Restauração \\ Socicultur \\ Telos \\ Textos Marginais \\ Ulmeiro
}

Entre as editoras criadas neste período, predominam de forma absoluta aquelas voltadas para a edição política, que somam 26 entre as 33 do grupo, mostrando que a partir de 1968 inicia-se um período em que as publicações políticas estarão cada vez mais presentes em Portugal, apesar da censura e da repressão.

Após o 25 de abril e até o final dos anos 1970 foram criadas 67 editoras que publicaram livros políticos, 48 das quais podemos caracterizar como editoras da revolução, por terem como fator principal de seu surgimento e de sua atuação o processo revolucionário iniciado em 1974. Destas, apenas três não eram de esquerda: Expresso, Teorema e Terra Livre.

As outras 45 editoras da revolução eram de esquerda, sendo que 42 delas foram criadas nos anos de 1974 e 1975 (as exceções foram a AAPA (Associação de Amizade Portugal-Albânia) e a Bandeira Vermelha/PCP(R) (Partido Comunista Português [Reconstruído]), ambas criadas em 1976, e a Editora Sotavento (1979).

\title{
Editoras criadas após 1974 (editoras da revolução)
}

17 de Outubro

A Batalha ${ }^{25}$

A Causa Operária (editora)

A Opinião (editora)

A Verdade (editora)

AAPA (Associação de Amizade Portugal-Albânia)

Acrata

AEPPA (Associação de Ex-Presos Políticos Antifascistas)

África Editora

\footnotetext{
25 A editora A Batalha já existia desde o começo do século XX, mas voltou a ter atuação legal e mais ampla a partir de 1974 . Ver detalhes no Capítulo 6.
} 
Antídoto

Avante! $!^{26}$ (editora)

Bandeira Vermelha/MRPP (Mov. Reorganizativo do Partido do Proletariado)

Bandeira Vermelha/PCP(R) (Partido Comunista Português [Reconstruído])

Caminho

CIDAC (Centro de Informação e Documentação Amílcar Cabral)

Contra a Corrente

DiAbril

Edições Sociais

Edições Divul

Edições Militão Ribeiro

Espaço

Estrela Vermelha (editora)

Expresso

Fronteira

Germinal

Movimento Operário

Nova Aurora

Novo Curso

O Proletário Vermelho (editora)

Pensamento e Acção

Perspectivas \& Realidades

Revolução

Revolução Proletária

Seara Vermelha (editora)

Sementeira

Sementes

Serviços Sociais dos Trabalhadores da Caixa Geral de Depósitos

SLEMES (Serviço de Livros e Edições do Movimento de Esquerda Socialista)

Sotavento

Spartacus

\footnotetext{
${ }^{26}$ A Edições Avante!, do PCP, já existia e atuava desde 1931, mas sempre de forma clandestina. Foi só a partir de maio de 1974 que passou a atuar na legalidade. Ver detalhes no Capítulo 4.
} 
Spartacus/OCMLP (Organização Comunista Marxista-Leninista Portuguesa)

Teorema

Terra Livre

Textos Políticos

Textos da Revolução

Unidade Popular (editora)

Vento de Leste

Voz do Povo (editora)

Ainda no campo das editoras que surgiram em decorrência das mudanças políticas geradas com o 25 de Abril, há nove editoras ligadas às ideias de direita (talvez possam ser chamadas de editoras da contrarrevolução):

\section{Editoras criadas após 1974 (editoras da contrarrevolução)}

Abril

Braga Editora

Edições do Templo

Edições FP (Fernando Pereira - Editor)

Edições Roger Delraux

Intervenção

Literal

Resistência

Selecta

E surgiram também após o 25 de Abril dez editoras que, sem se caracterizarem como editoras propriamente políticas, publicaram obras políticas:

Editoras criadas após 1974 que publicaram obras políticas mas que não se caracterizavam como editoras políticas
Alfaómega
António Ramos
Armazém das Letras
Forja 


\section{Heptágono \\ Líber \\ Limiar \\ Nova Crítica \\ Rés \\ Via Editora}

No capítulo seguinte e na Parte II ficarão mais claros e detalhados os vínculos entre engajamento político e edição, que caracterizam a edição política, tal como a definimos no Capítulo 1. Mas, pelo já exposto até aqui, fica claro que estes vínculos se desenvolveram, inicialmente, em função principalmente da oposição ao salazarismo, que a partir de meados dos anos 1960 se ampliou e passou a incorporar alguns setores sociais que até então não tinham papel importante nesses embates, como é o caso dos setores católicos que passam a militar na oposição.

Um dos fatores de mobilização de muitos setores políticos e sociais contra o governo foi a questão colonial, o que levou ao questionamento da opção por uma solução pela força para o conflito na África, e do sacrifício de jovens e de grandes recursos nessa guerra.

A edição de livros mostrou-se um caminho viável para os que queriam apresentar estes temas - e outros tantos mais - para debate nos setores mais politizados do país, apesar dos cerceamentos que a ditadura impunha. Mostrou-se também um instrumento importante para os grupos e partidos, principalmente de esquerda, que buscavam informar seus militantes e simpatizantes, divulgar suas ideias e angariar novos apoios para as causas que defendiam.

Com o fim da ditadura, a edição política teve um boom nos anos 1974 e 1975, quando o número de editoras e de livros políticos cresceu de modo nunca antes visto no país. As editoras e os livros políticos respondiam a uma parte do anseio por informação - e formação - de grande parte da população, e alcançaram nestes anos um público muito mais amplo do que o normalmente atingido pelas obras políticas. Tal surto durou até 1976. Nesse ano, a edição política começou a retroceder, o interesse pelas obras políticas diminuiu, juntamente com o refluxo do próprio processo revolucionário que se iniciara em 1974.

Assim, a edição política, em Portugal, desenvolveu-se num período de grande 
agitação política, tal como sugerido por Jean-Yves Mollier na França ${ }^{27}$, pressagiando momentos de importantes mudanças políticas e sociais e tornando-se parte das lutas políticas que eram então travadas.

Mas, como vimos, nem todas as editoras que publicaram livros de caráter político eram, necessariamente, editoras políticas. Entre elas havia também algumas em que os aspectos comerciais prevaleciam, que não tinham ligações com grupos políticos, e que até então não se voltavam para a edição desse tipo. Estas editoras passaram a publicar tais livros em função da boa aceitação que eles começaram a ter na nova conjuntura portuguesa. "Editoras que não tinham nenhuma ligação com qualquer espécie de atividade política militante também passam a publicar política”, lembra José Antunes Ribeiro. "Até a Agência Portuguesa de Revistas publica um livro sobre a PIDE"28.

Este "oportunismo" foi denunciado em alguns jornais de grupos de esquerda, como podemos ver nesta matéria do Revolução, jornal do Partido Revolucionário do Proletariado-Brigadas Revolucionárias (PRP-BR):

Temos vindo a assistir, depois do 25 de Abril, ao grande oportunismo com que se editam livros nesta terra. Os senhores do capital desenvolvem mais um negócio, metem mais algum no bolso e passam a ter a suprema qualidade de "democratas" pois até já editam Marx, Lenine etc. etc. ${ }^{29}$

A editora Bertrand, uma das maiores do país, também foi alvo de críticas nessa linha, por ter publicado, em 1976, tanto um livro de autoria do general António Spínola, como um livro que denunciava a participação do mesmo general em um golpe de direita:

A Bertrand continua a saber "fazer dinheiro". Na forja dois livros para "best-sellers": Ao serviço de Portugal de António Spínola e Descoberta de uma conspiração - a ação de Spínola de Gunter Wallraff. De grão em grão ou de pluralismo em pluralismo... enche a Bertrand o "papo". 30

Sobre o conteúdo e a qualidade de parte do boom editorial ocorrido em 19741975, é interessante a avaliação de Josué da Silva:

\footnotetext{
${ }^{27}$ MOLLIER, “Quando o impresso...”, op. cit., p. 260-269.

${ }^{28}$ Entrevista com José Antunes Ribeiro, Lisboa, 2/2/2011.

29 "Parceria A. M. Pereira: ocupação de uma editora". Jornal Revolução, Lisboa, no 35, 10/4/1975, p. 10.

30 “Bertrand (Plurali\$ta) edita Spínola e Wallraff”. Página Um, 21/10/1976, p. 12.
} 
Nada do que se escreveu após o "25 de Abril" em torno do regime implantado pelo "28 de Maio" de 1926 e das organizações com que o Estado Novo fascista pretendeu eternizar a sua vigência, pode ser considerado como obra verdadeiramente histórica. Apontamentos, achegas, reflexões que hão-de permitir aos autênticos historiadores debruçar-se com alguma lógica sobre o negro período da ditadura iniciada por Salazar, o seu fim, foi tudo quanto se deu à luz neste primeiro ano de democracia. $O$ que não deixa de ser importante. Mesmo descontando as lacunas, os exageros naturais de um clima revolucionário, a contribuição está dada, e isto sem que se possa dizer que tenha sido escassa. A par das primeiras descrições, várias delas muito sobre o joelho, do golpe dos Capitães, logo surgiram os "dossier PIDE-DGS" em profusão de muitos militantes antifascistas, a cronologia dos vários acontecimentos revolucionários com que, ao longo de quarenta e oito anos, se tentou derrubar o regime odiado, as narrativas da resistência etc. Na realidade, nem sempre bem escrito (o que talvez não importe, atendendo ao fim em vista), raramente bem escolhido, repetitivo, falhado neste ou naquele pormenor, o material apresentado foi de tal modo profuso que nos espanta. ${ }^{31}$

Mas talvez um dos aspectos mais importantes de toda essa ampla difusão de livros políticos ocorrida desde o final dos anos 1960, independentemente do que pensemos da sua qualidade, é que a história e a realidade mais recentes de Portugal começaram a vir a público e a ser conhecidas por amplas camadas da sociedade, de uma maneira totalmente diferente do que ocorria até 1974. E isso certamente foi importante para ajudar a transformar o país.

Assim, parece-me que as editoras de caráter político - e as obras por elas editadas - foram um destacado sujeito do processo político português, seja nos anos que antecederam ao 25 de Abril, seja no processo desencadeado a partir daquele momento.

Como veremos na Parte II, os livros políticos tiveram grande aceitação no período 1968-1980, principalmente em 1974-1975, quando também passou a ser possível apurar de forma mais detalhada os resultados de vendas desses livros. As listas de livros mais vendidos publicadas em 1974 e 1975 pelo semanário Expresso, um dos jornais mais importantes naquele período, mostra sempre os livros de caráter político dominando as vendas, sobrando pouco espaço para livros de outros tipos. Da mesma forma, alguns depoimentos que apuramos de editores atuantes naqueles anos referendam esse fato, confirmando que a venda da edição política atingiu níveis nunca mais alcançados no país. Esse é um dos indicadores da repercussão, da circulação e da

\footnotetext{
31 SILVA, Josué. "Nota introdutória". In: Legião Portuguesa: força repressiva do fascismo. Lisboa:
} DiAbril, 1975, p. 7-8. 
possível influência social que estas publicações tiveram naquele período.

O levantamento de editoras que publicaram obras políticas no período aqui abordado não é definitiva. Mas acredito que representa uma primeira tentativa para permitir conhecer melhor a dimensão e o papel da edição política em Portugal no período final da ditadura e nos anos iniciais do regime democrático. Por meio do aprofundamento desse estudo talvez seja possível abrir mais um caminho que colabore para o conhecimento e a análise dos embates políticos e sociais daquele período. 


\section{AS EDITORAS QUE PUBLICARAM LIVROS DE CARÁTER POLÍTICO EM PORTUGAL, 1968-80}

O resultado de minha investigação sobre as editoras que publicaram títulos de caráter político em Portugal no período 1968-1980 mostra um quadro de 137 editoras que se encaixam neste perfil, e inclui as editoras das quais localizei pelo menos cinco títulos ${ }^{1}$ de caráter político editados naquele período.

Como já exposto no Capítulo 1, este conjunto de 137 editoras inclui dois grupos: 1) as editoras de caráter político, que somam 100 editoras, e 2) as editoras que publicaram obras de caráter político, mas que não se caracterizavam como editoras políticas (que somam 37 editoras).

No primeiro grupo estão apenas as editoras cujas publicações são predominantemente políticas e cuja linha editorial reflete, de modo consistente, uma forma de engajamento na defesa de certos princípios, ideias e causas, que se materializa nos livros editados, ou seja, em que há uma forte ligação entre engajamento e edição.

No segundo grupo estão as editoras não incluídas no conjunto anterior e que publicaram pelo menos cinco títulos políticos entre 1968 e 1980, incluindo editoras de linha editorial eclética, religiosas, acadêmicas e aquelas em que o aspecto comercial predominava.

O Quadro Sinóptico a seguir visa especificar a linha de atuação de cada uma das editoras e apontar as vinculações políticas de algumas delas (quando houver), além dos responsáveis pelas publicações ${ }^{2}$. As informações que constam do quadro são as seguintes:

- Nome e cidade sede da editora;

- Ano de início das edições;

\footnotetext{
${ }^{1}$ Há quatro casos de editoras que publicaram menos de cinco títulos e que foram incluídas no levantamento. São as editoras Movimento Operário, Revolução Proletária, Sotavento e Unidade Popular, que foram mantidas na lista por serem editoras claramente políticas e porque sua produção total não atingiu cinco títulos.

${ }^{2}$ Agradeço as informações fornecidas por José Manuel Lopes Cordeiro, que ajudaram a complementar o quadro em relação a algumas editoras, em particular as do campo da esquerda. Informações importantes também me foram transmitidas pelos editores José Antunes Ribeiro, João Barrote, João Carlos Alvim, Francisco Melo, João Camacho, José Sousa Ribeiro, António Daniel Abreu, Manuel António Ribeiro Resende, Carlos Loures e Manuel Simões, pelo livreiro Eduardo Sousa e pelos professores Nuno Medeiros, João Bernardo e António Monteiro Cardoso. Fernando Moreira, da Biblioteca-Museu República e Resistência de Lisboa, também forneceu-me muitas informações úteis à minha investigação. A todos eles deixo o meu agradecimento.
} 
- Posição política da editora (quando houver): esquerda, direita, liberal, oposição católica/católicos progressistas;

- Grupo/partido aos qual estava ligada (quando for o caso);

- Caracterização da linha editorial: política ou não política;

- Editor/responsável;

- Número de títulos publicados.

Após o quadro, há uma síntese analítica dos principais indicadores ali presentes.

Uma ressalva importante que se deve sempre ter em conta na leitura deste trabalho é que este quadro de 137 editoras não é, de forma alguma, o quadro completo das editoras atuantes em Portugal no período 1968-1980. Trata-se tão-somente do quadro das editoras que realizaram a edição de pelo menos cinco títulos de caráter político naquele período. Isso significa que há todo um outro universo de editoras, também atuantes no período, que não fazem parte do nosso quadro, por não terem esta característica. Como já apontado, localizei também outras 107 editoras que, no período em foco, publicaram menos de cinco livros políticos, e por isso não foram incluídas no meu levantamento.

Em suma, os dados e as análises que apresento aqui são sempre restritos ao universo das 137 editoras que, de acordo com os critérios adotados neste trabalho, publicaram livros políticos em Portugal entre 1968 e 1980, e não ao setor editorial português como um todo. 


\subsection{Quadro Sinóptico das editoras que publicaram livros de caráter político em Portugal, 1968-80³.}

(1) Refere-se ao início da atividade de edição de livros.

(2) Refere-se somente ao período de nossa investigação (1968-80), e não a todo o período de existência da editora.

(3) $\mathrm{N}^{\mathrm{o}}$ aproximado de títulos políticos editados no período 1968-1980.

\begin{tabular}{|c|c|c|c|c|c|c|c|}
\hline Editora & Início(1) & Sede & Posição política (2) & Grupo/partido & \begin{tabular}{|l|} 
Caracterização \\
(2)
\end{tabular} & Editor/responsável & Títulos(3) \\
\hline 17 de Outubro & 1975 & Barreiro & Esquerda & $\mathrm{PRB} / \mathrm{BR}$ & Política & João Lobo & 6 \\
\hline A Batalha (4) & 1975 & Lisboa & Esquerda & Anarquista & Política & Emídio Santana & 6 \\
\hline A Causa Operária & 1975 & Lisboa & Esquerda & $\operatorname{ORPC}(m-1)$ & Política & Sem informação & 11 \\
\hline A Opinião & 1975 & Porto & Esquerda & PCP & Política & João Huet Viana Jorge e Macedo Varela & 15 \\
\hline A Regra do Jogo & 1973 & Porto/Lisboa & Não definida & & Política & José Leal Loureiro & 30 \\
\hline A Verdade & $1974 / 75$ & Lisboa & Esquerda & PCP(ml)-Mendes & Política & Sem informação & 5 \\
\hline AAPA Ass. Amiz. Portugal-Albânia & 1976 & Lisboa & Esquerda & MRPP & Política & Luís Borges, João Camacho & 5 \\
\hline Abril & 1976 & Sem inf. & Direita & & Política & Martinho Simões & 8 \\
\hline Acrata & 1975 & Lisboa & Esquerda & Anarquista & Política & José de Brito & 10 \\
\hline Acrópole & 1954 & Alfragide & & & Não política & Neves Ramos & 14 \\
\hline AEPPA & 1974 & Lisboa & Esquerda & AEPPA & Política & Sem informação & 7 \\
\hline África Editora & 1974 & Lisboa & Esquerda & MPLA & Política & Albertino Almeida e Alfredo Bobela-Mota & 15 \\
\hline Afrodite & 1965 & Lisboa & Contestadora & & Política & Fernando Ribeiro de Mello & 40 \\
\hline Afrontamento & 1963 & Porto & Esquerda & & Política & Pedro Francisco, José Sousa Ribeiro & 150 \\
\hline Agência Portuguesa de Revistas & 1948 & Lisboa & & & Não política & Sem informação & 15 \\
\hline Alfaómega & 1975 & Lisboa & & & Não política & Sem informação & 6 \\
\hline Almedina & 1955 & Coimbra & & & Não política & Joaquim Machado & 15 \\
\hline Antídoto & 1975 & Lisboa & Esquerda & LCI/PSR & Política & Cabral Fernandes & 50 \\
\hline António Ramos & 1976 & Lisboa & & & Não política & António Ramos & 17 \\
\hline Arcádia & 1957 & Lisboa & & & Não política & Paradela de Abreu, Natália Correia, Nelson de Matos & 65 \\
\hline Armazém das Letras & 1977 & Lisboa & & & Não política & Sem informação & 7 \\
\hline Assírio \& Alvim & 1973 & Lisboa & Esquerda & & Política & $\begin{array}{l}\text { José Ribeiro, João Alvim, Assírio Bacelar, Mário Reis, } \\
\text { Calos Caeiro }\end{array}$ & 75 \\
\hline Aster & Anos 1950 & Lisboa & & Opus Dei & Não política & Rui Belo, Henrique J. Barrilaro F. Ruas & 10 \\
\hline
\end{tabular}

${ }^{3}$ Agradeço especialmente as informações fornecidas por José Manuel Lopes Cordeiro e por João Barrote. 


\begin{tabular}{|c|c|c|c|c|c|c|c|}
\hline Ática & 1933 & Lisboa & & & Não política & Sem informação & 14 \\
\hline Atlântida & 1926 & Coimbra & & & Não política & Sem informação & 30 \\
\hline Avante! (5) & 1974 & Lisboa & Esquerda & $\begin{array}{l}\text { PCP (Editora } \\
\text { oficial) }\end{array}$ & Política & Francisco Melo & 210 \\
\hline Bandeira Vermelha /MRPP & 1975 & Lisboa & Esquerda & MRPP/ & Política & Sem informação & 8 \\
\hline Bandeira Vermelha / $\mathrm{PCP}(\mathrm{R})$ & 1976 & Lisboa & Esquerda & $\mathrm{PCP}(\mathrm{R})$ & Política & Sem informação & 50 \\
\hline Base & 1973 & Lisboa & Católicos progressistas & Base/FUT & Política & Fernando Moreira de Abreu & 35 \\
\hline Bertrand & 1732 & Lisboa & & & Não política & Sem informação & 102 \\
\hline Braga Editora & 1977 & Braga & Direita & & Política & Sem informação & 11 \\
\hline Brasília & Anos 1950 & Porto & & & Não política & J. Carvalho Branco & 30 \\
\hline Cadernos para o Diálogo & 1971 & Porto & Esquerda & & Política & António Daniel Abreu & 6 \\
\hline Cadernos Textuais & 1969 & Porto & Esquerda & & Política & Sem informação & 6 \\
\hline Caminho & 1975 & Lisboa & Esquerda & PCP & Política & Zeferino Coelho & 60 \\
\hline Centelha & 1971 & Coimbra & Esquerda & & Política & Soveral Martins e outros & 150 \\
\hline Centro do Livro Brasileiro & 1963 & Lisboa & & & Não política & Álvaro Gonçalves Pereira & 10 \\
\hline CIDAC & 1974 & Lisboa & Católicos progressistas & CIDAC & Política & Luis Moita & 15 \\
\hline Cidadela & 1970 & Coimbra & Direita & & Política & José Miguel Júdice & 10 \\
\hline Círculo de Leitores & 1971 & Lisboa & & & Não política & Manuel Dias de Carvalho & 6 \\
\hline Contra a Corrente & 1975 & Lisboa/Porto & Esquerda & Jornal Combate & Política & João Bernardo, Rita Delgado, João Crisóstomo & 55 \\
\hline Delfos & Anos 1960 & Lisboa & Esquerda & & Política & Humberto de Madureira & 70 \\
\hline DiAbril & 1975 & Lisboa & Esquerda & & Política & Serafim Ferreira e Orlando Neves & 60 \\
\hline Dom Quixote & 1965 & Lisboa & Liberal & & Política & Snu Abecassis, Carlos Araújo & 200 \\
\hline Edições 70 & 1970 & Lisboa & & & Não política & Joaquim Soares da Costa & 51 \\
\hline Edições FP (Fernando Pereira) & 1978 & Lisboa & Direita & & Política & Fernando Pereira & 7 \\
\hline Edições do Partido & 1970 & Sintra & Esquerda & PCP(ml)-Vilar & Política & Sem informação & 45 \\
\hline Edições do Povo & 1971 & Porto & Esquerda & & Política & Sem informação & 7 \\
\hline Edições do Templo & 1977 & Lisboa & Direita & & Política & José Vale de Figueiredo & 10 \\
\hline Edições Militão Ribeiro & 1975 & Sem inf. & Esquerda & $\mathrm{PCP}(\mathrm{m}-\mathrm{I})$-Mendes & Política & Sem informação & 6 \\
\hline Edições Roger Delraux & 1977 & Lisboa & Direita & & Política & Gerard Leroux & 7 \\
\hline Edições Sociais & 1974 & Lisboa & Esquerda & PCP & Política & Rui Moura & 27 \\
\hline Editorial Divul & 1974 & Sem inf. & Esquerda & PRT & Política & Jaime Gonçalves & 10 \\
\hline Editorial Notícias & 1929 & Lisboa & & & Não política & Maximino Gonçalves & 11 \\
\hline Escorpião/ Textos Exemplares & 1973 & Porto & Esquerda & & Política & João Barrote & 60 \\
\hline Espaço & 1974 & Braga & Esquerda & & Política & António Correia & 7 \\
\hline Estampa & 1960 & Lisboa & Esquerda & PCP & Política & António Carlos Manso Pinheiro (a partir de 1969) & 300 \\
\hline Estrela Vermelha & 1974 & Porto & Esquerda & MRPP & Política & António José Fonseca & 8 \\
\hline
\end{tabular}




\begin{tabular}{|c|c|c|c|c|c|c|c|}
\hline Estúdios Cor & 1949 & Lisboa & & & Não política & José Saramago, Natália Correia, Nataniel Costa & 30 \\
\hline Europa-América & 1945 & Mem Martins & & & Não política & Francisco Lyon de Castro & 75 \\
\hline Expresso & 1974 & Lisboa & Liberal & & Política & Sem informação & 8 \\
\hline Forja & 1975 & Lisboa & & & Não política & Sem informação & 15 \\
\hline Fronteira & 1975 & Amadora & Esquerda & & Política & Serafim Ferreira & 34 \\
\hline Futura & 1971 & Lisboa & & & Não política & Carlos Silva & 20 \\
\hline Germinal & 1974 & Lisboa & Esquerda & MRPP & Política & José Manuel & 20 \\
\hline Heptágono & 1975 & Lisboa & & & Não política & Albertino Antunes & 8 \\
\hline Horizonte & 1953 & Lisboa & Esquerda & PCP & Política & Rogério Mendes de Moura & 70 \\
\hline Iniciativas Editoriais & 1956 & Lisboa & Esquerda & & Política & José F. Fafe, Isabel Ferreira, Maria José Tição & 200 \\
\hline Inova & 1968 & Porto & Esquerda & & Política & José da Cruz Santos & 35 \\
\hline Intervenção & 1974 & Braga/Lisboa & Direita & & Política & Paradela de Abreu & 41 \\
\hline Jornal do Fundão & 1959 & Fundão & & & Não política & António Paulouro & 9 \\
\hline Latitude & $1970 / 1971$ & Porto & Esquerda & & Política & $\begin{array}{l}\text { António Abreu, J.F. Viegas, F. Sardo, M.A. Ribeiro } \\
\text { Resende }\end{array}$ & 16 \\
\hline Líber & 1975 & Lisboa & & & Não política & Sem informação & 32 \\
\hline Limiar & 1975 & Porto & & & Não política & Egito Gonçalves e Eugénio de Andrade & 15 \\
\hline Literal & 1976 & Queluz & Direita & & Política & Sem informação & 27 \\
\hline Liv. Al (Apostolado da Imprensa) & Anos 1920 & Porto & & & Não política & Sem informação & 6 \\
\hline Livraria Júlio Brandão & 1971 & V.N.Famalicão & Esquerda & PCP & Política & Manuel Cunha e Macedo Varela & 15 \\
\hline Livraria Ler Editora & 1971 & Lisboa & Esquerda & & Política & João Camacho, Luís Alves Dias, J. Bragança & 41 \\
\hline Liv. Popular de Francisco Franco & Anos 1930 & Lisboa & Direita & & Política & Sem informação & 8 \\
\hline Manuel Xavier & 1971 & Amadora & Esquerda & PCP & Política & Manuel Rodrigues Xavier & 20 \\
\hline Maria da Fonte & 1973 & Lisboa & Esquerda & UDP & Política & Manuel Quirós e M. Isabel Ventura & 80 \\
\hline Meridiano & 1964 & Lisboa & & & Não política & Sem informação & 10 \\
\hline Minerva & 1927 & Lisboa & & & Não política & Manoel Rodrigues & 22 \\
\hline Moraes & 1956 & Lisboa & Oposição católica & & Política & António Alçada Baptista, Nelson de Matos & 95 \\
\hline Movimento Operário & 1974 & Lisboa & Esquerda & & Política & Sem informação & 4 \\
\hline Multinova & 1973 & Lisboa & Católicos progressistas & & Política & Manuel Bidarra & 18 \\
\hline N. A. * Orion & 1973 & Amadora & Esquerda & & Política & Orlando Gonçalves & 13 \\
\hline Nova Aurora & 1974 & Lisboa & Esquerda & MRPP & Política & João Camacho e Silvio Conde & 35 \\
\hline Nova Crítica & 1975 & Porto & & & Não política & António Daniel Abreu & 18 \\
\hline Nova Realidade & 1966 & Tomar & Não definida & & Política & Carlos Loures, Manuel Simões, Júlio Estudante & 8 \\
\hline Novo Curso & 1975 & Amadora & Esquerda & PCP & Política & Manuel Rodrigues Xavier & 14 \\
\hline O Grito do Povo & 1973 & Lisboa/ Porto & Esquerda & OCMLP & Política & Sem informação & 36 \\
\hline O Proletário Vermelho & 1974 & Lisboa & Esquerda & CMLdeP & Política & Bento Vintém & 20 \\
\hline
\end{tabular}




\begin{tabular}{|c|c|c|c|c|c|c|c|}
\hline O Século & 1900 & Lisboa & & & Não política & Afonso Cautela & 15 \\
\hline Paisagem & 1969 & Porto & & & Não política & João Barrote, Viale Moutinho & 30 \\
\hline Parceria A. M. Pereira (6) & 1848 & Lisboa & Não definida & & Política & Sem informação & 11 \\
\hline Pensamento e Acção & 1975 & Lisboa & Esquerda & & Política & Sem informação & 5 \\
\hline Pensamento Político & 1971 & Lisboa & Direita & & Política & Sem informação & 21 \\
\hline Perspectivas \& Realidades (p\&r) & 1975 & Lisboa & Esquerda & PS & Política & João Soares e Vítor Cunha Rêgo & 25 \\
\hline Plátano & 1972 & Lisboa & & & Não política & Sem informação & 6 \\
\hline Portucalense & 1928 & Porto & Esquerda & & Política & Sem informação & 20 \\
\hline Portugal Socialista & 1973 & Lisboa & Esquerda & PS (editora oficial) & Política & Sem informação & 15 \\
\hline Portugália & 1942 & Lisboa & & & Não política & Serafim Ferreira, Orlando Neves (até 1975) & 20 \\
\hline Povo e Cultura & 1971 & $\begin{array}{l}\text { Baixa } \\
\text { Banheira }\end{array}$ & Esquerda & UDP & Política & Manuel Miranda & 20 \\
\hline Prelo & 1960 & Lisboa & Esquerda & PCP & Política & $\begin{array}{l}\text { Viriato Camilo, Sérgio Ribeiro, Rui Moura, Carlos } \\
\text { Carvalhas }\end{array}$ & 140 \\
\hline Presença & 1962 & Lisboa & Não definida & & Política & Francisco Espadinha & 75 \\
\hline República & 1973 & Lisboa & Esquerda & PS & Política & Sem informação & 12 \\
\hline Rés & 1975 & Porto & & & Não política & Reinaldo de Carvalho, António Abreu & 20 \\
\hline Resistência & 1975 & Lisboa & Direita & & Política & António da Cruz Rodrigues & 15 \\
\hline Restauração & 1969 & Lisboa & Direita & & Política & António da Cruz Rodrigues & 7 \\
\hline Revolução & 1974 & Lisboa & Esquerda & PRP-BR & Política & Sem informação & 10 \\
\hline Revolução Proletária & 1975 & Lisboa & Esquerda & $\mathrm{ORPC}(\mathrm{m}-\mathrm{I})$ & Política & Sem informação & 3 \\
\hline Sá da Costa & 1913 & Lisboa & & & Não política & Augusto Sá da Costa, João Sá da Costa & 40 \\
\hline Seara Nova & 1921 & Lisboa & Esquerda & $\mathrm{PCP}$ & Política & José Garibaldi & 200 \\
\hline Seara Vermelha & 1974 & Lisboa & Esquerda & PCP(ML)-Vilar & Política & Sem informação & 45 \\
\hline Selecta & 1976 & Lisboa & Direita & & Política & Sem informação & 26 \\
\hline Sementeira & 1974 & Lisboa & Esquerda & Anarquista & Política & João Freire & 10 \\
\hline Sementes & 1974 & Porto & Esquerda & MRPP & Política & António José Fonseca & 20 \\
\hline Serv.Sociais Trabalhadores CGD & 1974 & Lisboa & Esquerda & & Política & Sem informação & 14 \\
\hline Slemes & 1975 & Lisboa & Esquerda & MES & Política & Sem informação & 20 \\
\hline Socicultur & 1971 & Lisboa & & & Não política & Sem informação & 15 \\
\hline Sotavento & 1979 & Faro & Esquerda & Anarquista & Política & Julio Carrapato & 4 \\
\hline Spartacus & 1974 & Lisboa & Esquerda & & Política & Sem informação & 6 \\
\hline Spartacus OCMLP & 1974 & Lisboa & Esquerda & OCMLP & Política & Sem informação & 5 \\
\hline Telos & 1972 & Porto & Católicos progressistas & & Política & Sem informação & 25 \\
\hline Teorema & 1974 & Lisboa & Não definida & & Política & Carlos Araujo e Carlos da Veiga Ferreira & 15 \\
\hline Terra Livre & 1975 & Lisboa & Governamental & & Política & Sem informação & 9 \\
\hline
\end{tabular}




\begin{tabular}{|c|c|c|c|c|c|c|c|}
\hline Textos Marginais & 1972 & Porto & Esquerda & & Política & António Daniel Abreu, João Barrote & 27 \\
\hline Textos Políticos & 1974 & Porto & Esquerda & & Política & Henrique A. Carneiro & 15 \\
\hline Textos da Revolução & 1974 & Porto & Esquerda & & Política & Fernando Osório & 12 \\
\hline Ulisséia & 1946 & Lisboa & & & Não política & Sem informação & 15 \\
\hline Ulmeiro & 1970 & Lisboa & Católicos progressistas & & Política & José Antunes Ribeiro & 60 \\
\hline Unidade Popular & 1974 & Lisboa & Esquerda & & Política & Beatriz Oliveira M. & 4 \\
\hline Vento de Leste & 1974 & Lisboa & Esquerda & MRPP & Política & $\begin{array}{l}\text { A. Telo, J. Camacho, A. Barros Baptista, J. Pinto e } \\
\text { Castro }\end{array}$ & 70 \\
\hline Verbo & 1959 & Lisboa & & & Não política & Fernando Guedes & 15 \\
\hline Via Editora & 1976 & Lisboa & Não definida & & Política & Sem informação & 20 \\
\hline Voz do Povo & 1974 & Lisboa & Esquerda & UDP & Política & Sem informação & 5 \\
\hline Tota de Títulos & & & & & & & 4561 \\
\hline
\end{tabular}

(4) Refundação do jornal A Batalha em 1974; fundação original em 1919.

(5) Início da atuação legal da editora.

(6) Consideramos apenas o período em que a editora esteve em autogestão e sua linha editorial modificou-

se significativamente.

\section{Siglas:}

CARP (m-l) - Comité de Apoio à Reconstrução do Partido (marxistaleninista)

CDL - Central Distribuidora Livreira

CGTP-IN - Confederação Geral dos Trabalhadores PortuguesesIntersindical Nacional

CIDAC - Centro de Informacção e Documentação Amílcar Cabra

CMLP - Comité Marxista-Leninista de Portugal

CMLdeP - Comité Marxista-Leninista de Portugal

EDP - Empresa Distribuidora de Publicações

FUT - Frente Unitária de Trabalhadores

LCl - Liga Comunista Internacionalista

MDP/CDE - Movimento Democrático Português/Comissão

Democrática Eleitoral

MFA - Movimento das Forças Armadas

MES - Movimento de Esquerda Socialista
MRPP - Movimento Reorganizativo do Partido do Proletariado

OCMLP - Organização Comunista Marxista-Leninista Portuguesa

ORPC (m-I) - Organização para a Reconstrução do Partido Comunista (Marxista-Leninista)

PCP - Partido Comunista Português

$\mathrm{PCP}(\mathrm{m}-\mathrm{I})$ - Partido Comunista de Portugal (marxista-leninista)

PCP(R) - Partido Comunista Português (Reconstruído)

PRP-BR - Partido Revolucionário do Proletariado-Brigadas

Revolucionárias

PS - Partido Socialista

PSD - Partido Social-Democrata

PSR - Partido Socialista Revolucionário

PUP - Partido de Unidade Popular

UDP - União Democrática Popular 


\subsection{Síntese analítica do "Quadro Sinóptico"}

\subsubsection{Lisboa e Porto concentraram a produção editorial}

Como era de esperar, a grande maioria das editoras de livros de caráter político que atuou em Portugal entre 1968 e 1980 se concentrava nas duas maiores cidades do país. Lisboa sozinha reúne quase dois terços das editoras (89 editoras ou 65\%), e no Porto estão $15,3 \%$ delas (21 editoras). Somadas, as duas cidades sediavam 80,3\% das editoras em foco. Este percentual chega a $82,5 \%$ se acrescentarmos as três editoras que tinham a sua sede dividida entre as duas cidades.

As demais cidades, onde estão as 17,5\% restantes editoras, têm, na maior parte dos casos, apenas uma editora atuante, exceto Amadora (quatro editoras; vale destacar que esta cidade é parte da Grande Lisboa), Coimbra (também com quatro editoras) e Braga (três editoras, sendo que uma delas com sua sede dividida entre Braga e Lisboa).

Outras 11 cidades sediavam apenas uma editora cada uma. E havia ainda duas editoras sobre as quais não foi possível determinar onde era a sua sede.

Tal concentração nas duas principais cidades do país reflete o fato de que praticamente todos os grupos editoriais e políticos atuantes em Portugal tinham sua sede em Lisboa e no Porto, que concentravam também a maior parte da população e dos seus setores mais politizados - e ainda a maior parcela do público leitor. Dessa forma, apesar de os livros editados circularem por todo o país, é inegável o fato de que há uma concentração enorme de sua produção e venda nestas duas cidades. 


\section{Quadro 1 - Editoras que publicaram livros de caráter político em Portugal,}

1968-1980 - Cidades sede

\begin{tabular}{|c|c|c|}
\hline Cidade & Editoras & \% \\
\hline Lisboa & 89 & 65,0 \\
\hline Porto & 21 & 15,3 \\
\hline Lisboa/Porto & 3 & 2,2 \\
\hline Alfragide & 1 & 0,7 \\
\hline Amadora & 4 & 2,9 \\
\hline Baixa da Banheira & 1 & 0,7 \\
\hline Barreiro & 1 & 0,7 \\
\hline Braga & 2 & 1,5 \\
\hline Braga/Lisboa & 1 & 0,7 \\
\hline Coimbra & 4 & 2,9 \\
\hline Faro & 1 & 0,7 \\
\hline Fundão & 1 & 0,7 \\
\hline Mem Martins & 1 & 0,7 \\
\hline Sintra & 1 & 0,7 \\
\hline Queluz & 1 & 0,7 \\
\hline Tomar & 1 & 0,7 \\
\hline Sem inf. & 3 & 2,2 \\
\hline Total & $\mathbf{1 3 7}$ & $\mathbf{1 0 0}$ \\
\hline
\end{tabular}

\subsubsection{A maioria das editoras surgiu a partir de 1974}

Quase metade (67 editoras ou 48,9\%) das editoras do nosso levantamento surgiu a partir de 1974, ou seja, sua história está diretamente relacionada com o fim da ditadura em Portugal. É impressionante a efervescência editorial proporcionada pelo clima de liberdade gerado com o 25 de Abril, já que apenas nos anos de 1974 e 1975 nasceram 54 destas editoras $(39,4 \%)$. Trata-se do período em que a agitação e a participação políticas atingiram níveis nunca antes vistos no país.

Mas é importante salientar também que o período do chamado marcelismo, que se iniciou em setembro de 1968 e se encerrou com a queda do regime em abril de 1974, assistiu a um intenso movimento editorial. Nesses anos surgiram 33 editoras de caráter político $(24,1 \%)$, inclusive algumas das mais atuantes delas, como Centelha, Maria da Fonte, Assírio \& Alvim, Ulmeiro e Escorpião, por exemplo.

A ressaltar, finalmente, que algumas das editoras mais prolíficas no campo da 
edição política surgiram antes de 1968, e ampliaram a sua atuação a partir do marcelismo e após o 25 de Abril, com destaque para Seara Nova (1921), Iniciativas Editoriais (1956), Estampa (1960), Prelo (1960), Afrontamento (1963) e Dom Quixote (1965).

Se somarmos as editoras que surgiram entre 1968 e o final dos anos 1970, veremos que chegam a 100 editoras (73\%), ou seja, quase três quartos das editoras analisadas, o que reforça e confirma a constatação de que o período de lutas políticas do final da ditadura e o 25 de Abril foram os fatores determinantes para a explosão editorial de caráter político ocorrida em Portugal nesse período.

Tais números indicam que foram estas novas editoras surgidas a partir do período do marcelismo as responsáveis por parte fundamental da produção editorial política do período 1968-1980. Mas, apesar disso, não deixa de ser significativo que somente aquelas seis editoras acima citadas, que surgiram antes de 1968, tenham sido responsáveis por cerca de $26 \%$ dos títulos políticos lançados no período estudado.

Isso parece indicar, por um lado, que se é inegável que grande parte das novas editoras esteve ligada a jovens que a partir de 1968 utilizaram a edição de livros como canal de participação política, por outro, havia também uma geração já mais velha e com experiência na área editorial que aproveitou as mudanças políticas no país para fazer da edição um campo em que o debate político pudesse ter maior proeminência.

\section{Quadro 2 - Editoras que publicaram livros de caráter político em Portugal,}

\section{8-1980 - Data de início das edições por período}

\begin{tabular}{|c|c|c|}
\hline Início das edições & Editoras & \% \\
\hline Até a década de 1940 & 17 & 12,4 \\
\hline Década de 1950 & 11 & 8,0 \\
\hline 1960 a 1967 & 9 & 6,6 \\
\hline 1968 a 1973 & 33 & 24,1 \\
\hline 1974 e 1975 & 54 & 39,4 \\
\hline 1976 a 1980 & 13 & 9,5 \\
\hline Total & $\mathbf{1 3 7}$ & 100 \\
\hline
\end{tabular}




\subsubsection{Quase três quartos das editoras tinham perfil político}

Analisando os títulos publicados pelas 137 editoras que compõem o nosso quadro, verificamos que 100 delas (73\%) podem ser caracterizadas como editoras políticas, ou seja, editoras cujas publicações são predominantemente políticas e nas quais há uma forte ligação entre engajamento e edição.

Outras 37 editoras $(27 \%)$ se encaixam no perfil das editoras que publicaram obras políticas mas não podem ser consideradas editoras políticas.

Esta análise nos permite pensar que, no período em tela, houve efetivamente uma grande politização da edição em Portugal, com o surgimento de um grande número de editoras de perfil predominantemente político, na maioria dos casos com vinculações a organizações políticas, transformando a edição de livros em um dos campos de disputas de projetos e ideias políticas, num momento em que a politização da sociedade foi intensa em Portugal. Como veremos no item a seguir, a maioria destas editoras vinculou-se ao campo das ideias políticas de esquerda.

\section{Quadro 3 - Editoras que publicaram livros de caráter político em Portugal, 1968-1980 - Caracterização da linha editorial}

\begin{tabular}{|c|c|c|}
\hline Linha editorial & Editoras & $\mathbf{\%}$ \\
\hline Política & 100 & 73,0 \\
\hline Não Política & 37 & 27,0 \\
\hline Total & $\mathbf{1 3 7}$ & $\mathbf{1 0 0}$ \\
\hline
\end{tabular}

\subsubsection{Mais da metade das editoras eram ligadas à esquerda}

Mais da metade das editoras analisadas eram ligadas ou simpáticas às ideias de esquerda. Eram 52 editoras que mantinham vínculos com organizações políticas de esquerda e outras 18 que tinham uma linha editorial que refletia ideias ligadas a este campo de idéias, totalizando 50 editoras $(51,1 \%$ do total). Isso sem dúvida reflete o clima político dos anos 1974-1975, quando os grupos de esquerda passaram a ter um protagonismo político inédito em Portugal, ocupando posições importantes no governo 
e nas instituições sociais, e liderando os muitos movimentos sociais que então surgiram. Somente nestes dois anos foram criadas 42 editoras ligadas à esquerda.

A destacar, em relação a isso, que a existência de muitos pequenos grupos de esquerda e de extrema esquerda foi um fator decisivo para que surgisse este grande número de editoras de esquerda neste período. César Oliveira já havia ressaltado, referindo-se ao pré-25 de Abril, que "Cada grupo, por mais pequeno e insignificante que fosse, publicava o seu órgão de imprensa" ${ }^{4}$, e o mesmo pode ser dito em relação à edição de livros, principalmente a partir de 1974. Entre as editoras de esquerda estão incluídas quatro vinculadas ao pensamento anarquista (3\% do total).

Já as editoras ligadas à direita representavam apenas 9,5\% do nosso universo (13 editoras), das quais apenas duas surgiram nos anos 1974-1975. A maior parte delas (sete editoras) surgiu após 1976. Aliás, um militante da direita salientava, em texto de dezembro de 1976, a necessidade de setores deste campo ideológico assumirem-se publicamente em Portugal após o 25 de Abril. Depois de afirmar que "A literatura política tem proliferado nestes últimos tempos entre nós", recomenda ele: "Parece também ter chegado a hora de aparecerem aqueles que estavam convencidos de que tinham emudecido; as direitas, as autênticas. E é preciso que assim seja, pois as novas gerações poderiam até supor que nunca tínhamos existido"

Comparando o número de editoras criadas por setores ligados à direita e à esquerda - a relação é de um para cinco -, constatamos o claro predomínio destas últimas, o que parece ser decorrência da intensa atuação da esquerda nesse período. É também um indicador da relevância que a área cultural, a divulgação e o debate de ideias têm para este setor político, em contraposição aos setores de direita. Os dados parecem indicar também uma maior capacidade da esquerda de responder ao novo quadro político surgido com o 25 de Abril, ao mesmo tempo em que espelham as dificuldades dos setores de direita de se articularem após a queda do fascismo.

Além desses dois grandes campos políticos, há um terceiro grupo composto pelas editoras não políticas, que representam $27 \%$ do total (37 editoras). São editoras que publicaram obras políticas com maior intensidade no período de nosso estudo, mas cujas linhas editorias não tinham como característica principal a política. Neste bloco se destacam algumas editoras com perfil mais tradicional e criadas antes de 1968:

\footnotetext{
${ }^{4}$ OLIVEIRA, op. cit., p. 116.

${ }^{5}$ MESQUITELA, Gonçalo. “Apresentação”. In: ZORRO, António Maria. Cuidado, Carl... Queluz: Literal, 1978, p. 7.
} 
Almedina, Arcádia, Ática, Atlântida, Bertrand, Estúdios Cor, Europa-América, Minerva, Portugália, Sá da Costa e Ulisseia, entre outras.

As editoras ligadas aos grupos de católicos progressistas ou à oposição católica eram seis $(4,4 \%)$. Chama a atenção o fato de que apenas duas editoras $(1,5 \%)$ podem ser classificadas como relacionadas ao pensamento liberal - uma dessas editoras, a D. Quixote, foi uma das mais atuantes e importantes editoras políticas do período; a outra era a Edições Expresso, ligada ao jornal homônimo.

\section{Quadro 4 - Editoras que publicaram livros de caráter político em Portugal,} 1968-1980 - Posição política da editora

\begin{tabular}{|c|c|c|}
\hline Posição política & Editoras & \% \\
\hline Esquerda & 70 & 51,1 \\
\hline Direita & 13 & 9,5 \\
\hline $\begin{array}{c}\text { Católicos Progressistas/ } \\
\text { Oposição Católica }\end{array}$ & 6 & 4,4 \\
\hline Liberal & 2 & 1,5 \\
\hline Contestadora & 1 & 0,7 \\
\hline Governo & 1 & 0,7 \\
\hline Não definida & 7 & 5,1 \\
\hline Não Política & 37 & 27,0 \\
\hline Total & $\mathbf{1 3 7}$ & $\mathbf{1 0 0}$ \\
\hline
\end{tabular}

3.2.5 Editoras ligadas a grupos maoistas formavam o maior conjunto; PCP era o partido com maior número de editoras

Se considerarmos apenas as editoras políticas que fazem parte do nosso levantamento (100 editoras), verificamos que aquelas ligadas aos grupos maoistas formam o maior grupo (25 editoras). No entanto, devemos lembrar que muitas das editoras deste grupo eram de pequeno porte e publicaram poucos títulos. Muitas delas tiveram vida efêmera, o que significa que apesar das editoras ligadas aos grupos maoistas representarem o maior conjunto entre as editoras políticas, elas não foram as que mais publicaram livros.

Se considerarmos o vínculo a um único grupo, o PCP é o partido que se destaca, pois são 11 as editoras que estavam relacionadas a ele. Como já vimos, algumas das 
editoras políticas mais ativas eram ligadas ao partido.

Entre as editoras ligadas a outros grupos de esquerda, destacam-se as anarquistas (4) e as ligadas ao Partido Socialista (3).

Um grupo significativo de editoras de esquerda não se vinculava a nenhum grupo específico (18). E outro grupo de 11 editoras políticas também não tinha ligações partidárias.

As editoras de direita (13) representavam 13\% das editoras políticas.

\section{Quadro 5 - Editoras de caráter político em Portugal, 1968-1980 -}

\section{Vinculação a grupos políticos}

\begin{tabular}{|c|c|c|}
\hline Posição política & Editoras & \% \\
\hline $\begin{array}{c}\text { Editoras políticas de esquerda - } \\
\text { ligadas ao Partido Comunista } \\
\text { Português (PCP) }\end{array}$ & 11 & 11,1 \\
\hline $\begin{array}{c}\text { Editoras políticas de esquerda - } \\
\text { ligadas a grupos de extrema } \\
\text { esquerda maoistas }\end{array}$ & 25 & 25,0 \\
\hline $\begin{array}{c}\text { Editoras políticas de esquerda - } \\
\text { esquerda radical, trotskistas, } \\
\text { anarquistas, PS, outros) }\end{array}$ & 16 & 16,0 \\
\hline $\begin{array}{c}\text { Editoras políticas de esquerda sem } \\
\text { vinculação a grupos }\end{array}$ & 18 & 18,0 \\
\hline $\begin{array}{c}\text { Editoras políticas ligadas à oposição } \\
\text { católica/católicos progressistas }\end{array}$ & 6 & 6,0 \\
\hline $\begin{array}{c}\text { Editoras políticas sem vinculação a } \\
\text { grupos políticos }\end{array}$ & 11 & 11,0 \\
\hline Editoras políticas de direita & 13 & 13,0 \\
\hline Total & $\mathbf{1 0 0}$ & $\mathbf{1 0 0}$ \\
\hline \multicolumn{2}{|c|}{} \\
\hline
\end{tabular}

\subsubsection{Editoras ligadas a grupos de esquerda}

Quando consideramos as editoras vinculadas a grupos de esquerda (52 editoras), constatamos que cinco grupos eram responsáveis por 27 destas editoras, ou seja, 52\% delas: PCP (11), MRPP (7), PS (3), UDP (3) e PCP(m-l)-Mendes (3).

Consultando o Quadro 6, vemos que as restantes 25 editoras (48\% do total) estavam pulverizadas entre 11 grupos e quatro associações anarquistas - havendo ainda seis editoras que não foi possível identificar a quais grupos estavam vinculadas. 
Quadro 6 - Editoras ligadas a grupos de esquerda, 1968-1980

\begin{tabular}{|c|c|c|}
\hline Partido/Grupo & Editoras & \% \\
\hline PCP & 11 & 21,2 \\
\hline PCP(m-l)-Vilar/CMLP & 2 & 3,8 \\
\hline PCP(m-l)-Mendes & 3 & 5,8 \\
\hline OCMLP & 2 & 3,8 \\
\hline CMLdeP & 1 & 1,9 \\
\hline UDP & 3 & 5,8 \\
\hline ORPC(m-l) & 2 & 3,8 \\
\hline PCP(R)/PC(R) & 1 & 1,9 \\
\hline MRPP & 7 & 13,5 \\
\hline Outras editoras maoistas & 4 & 7,7 \\
\hline Combate & 1 & 1,9 \\
\hline PRP/BR & 2 & 3,8 \\
\hline MES & 1 & 1,9 \\
\hline LCI/PSR & 1 & 1,9 \\
\hline PRT & 1 & 1,9 \\
\hline PS & 3 & 5,8 \\
\hline Anarquistas & 4 & 7,7 \\
\hline Outras & 3 & 5,8 \\
\hline Total & $\mathbf{5 2}$ & $\mathbf{1 0 0}$ \\
\hline
\end{tabular}

\subsubsection{Mais de metade das editoras era de pequeno porte}

Quando analisamos o conjunto das editoras que publicaram livros políticos (137), vemos que uma das características da edição política é que ela foi realizada, na maior parte dos casos, por editoras de caráter efêmero, seja pelo seu tempo de vida, seja pelo número de títulos publicados. Em relação a este último aspecto, destaca-se o fato de que 85 editoras $(62,1 \%)$ do nosso quadro publicaram até 20 títulos políticos durante a sua existência, sendo que 43 editoras $(31,4 \%)$ publicaram dez títulos políticos ou menos. Trata-se de uma ampla maioria de pequenas editoras (publicaram até 20 títulos políticos no período), o que certamente dava-lhes algumas características próprias, como menor profissionalização, maior grau de improvisação na edição e na distribuição, maior agilidade para certos tipos de edição e uma situação econômica quase sempre periclitante (apesar de a venda de livros políticos no período estudado, e principalmente em 1974-1975, ter atingido patamares absolutamente acima da média). 
Entre estas 85 pequenas editoras, 39 (ou seja, 45,9\% desse subgrupo) eram de esquerda, muitas delas ligadas a pequenos grupos de extrema esquerda. Mas a maior parte das editoras de direita também pertencia a este subgrupo: 9 das 13 editoras de direita, ou seja, $10,6 \%$ das pequenas editoras.

É importante lembrar que nosso levantamento aponta apenas o número de títulos de caráter político publicados pela editora, e não o total de livros editados por cada uma delas. Assim, há alguns casos, minoritários, em que o número de títulos políticos é pequeno, mas o total de títulos daquela editora é bem maior. É o caso, por exemplo, de editoras como Círculo de Leitores, Livraria Popular de Francisco Franco, Plátano, Ulisseia e Verbo.

Havia também um segundo bloco constituído por editoras médias, que publicaram entre 21 e 100 títulos políticos no período. Elas somam 43 editoras (31,3\%), das quais $28(20,4 \%)$ publicaram até 50 títulos, e $15(10,9 \%)$ publicaram entre 51 e 100 títulos. Deste grupo de editoras médias, 44,2\% (19 editoras) são de esquerda, e 9,3\% (quatro editoras) são de direita, mesma proporção das editoras ligadas aos católicos progressistas/oposição católica (quatro editoras).

Por último, há um grupo de nove grandes editoras $(6,6 \%)$ que publicaram mais de 100 títulos políticos no período. São elas: Afrontamento, Avante!, Bertrand, Centelha, Dom Quixote, Estampa, Iniciativas Editoriais, Prelo e Seara Nova. Sete destas editoras foram criadas antes de 1968 (apenas Centelha e Avante! surgiram depois, em 1971 e 1974, respectivamente). Outro ponto a destacar é que estas nove editoras foram responsáveis por mais de um terço dos títulos políticos editados no período: cerca de 1.650 títulos, que representaram por volta de $36 \%$ do total.

A salientar ainda que quatro destas editoras estavam sob marcante influência do Partido Comunista Português (PCP): Avante! (a sua editora oficial), Estampa, Prelo e Seara Nova (principalmente a partir de 1974). Outras três editoras deste grupo (Afrontamento, Centelha e Iniciativas Editorias) ligavam-se a setores de esquerda não vinculados ao PCP. Já a Editora Dom Quixote ligava-se a setores da oposição ao salazarismo que não eram necessariamente de esquerda. E a Bertrand era (e é) uma editora de cunho marcadamente comercial e generalista. 
Quadro 7 - Editoras que publicaram livros de caráter político em Portugal,

1968-1980 - $\mathbf{N}^{0}$ de títulos políticos editados por cada editora no período

\begin{tabular}{|c|c|c|}
\hline $\mathbf{N}^{\mathbf{a}}$ de títulos & Editoras & \% \\
\hline Até 10 títulos & 43 & 31,4 \\
\hline De 11 a 20 títulos & 42 & 30,7 \\
\hline De 21 a 50 títulos & 28 & 20,4 \\
\hline De 51 a 100 títulos & 15 & 10,9 \\
\hline Acima de 100 títulos & 9 & 6,6 \\
\hline Total & $\mathbf{1 3 7}$ & $\mathbf{1 0 0}$ \\
\hline
\end{tabular}

Quadro 8 - Editoras que publicaram livros de caráter político em Portugal, 19681980 - Editoras pequenas (até 20 títulos), médias (até 100 títulos) e grandes (mais de 100 títulos)

\begin{tabular}{|c|c|c|}
\hline Tipo de Editora & Número & $\mathbf{\%}$ \\
\hline Pequenas & 85 & 62,1 \\
\hline Médias & 43 & 31,3 \\
\hline Grandes & 9 & 6,6 \\
\hline Total & $\mathbf{1 3 7}$ & $\mathbf{1 0 0}$ \\
\hline
\end{tabular}


PARTE II

AS EDITORAS DE CARÁTER POLÍTICO EM PORTUGAL: HISTÓRIA E ATUAÇÃO 
Nos capítulos 4 a 11 apresentarei estudos sintéticos sobre 95 das 99 editoras de caráter político listadas no Quadro Sinóptico do Capítulo 3 - e também sobre 11 editoras não políticas mas que publicaram livros políticos, ou seja, que não se caracterizavam como editoras políticas. Portanto, são no total estudos sintéticos sobre 106 editoras.

Estes estudos buscam, em seu conjunto, construir um quadro abrangente da edição política em Portugal nos anos 1960 e 1970, mostrando quais eram as ligações políticas destas editoras, quem eram os editores responsáveis, as obras que publicaram, como se organizavam e como sua atuação vinculava-se com as lutas políticas no país desde o final dos anos 1960 até o final dos anos 1970.

Acredito que a visão panorâmica proporcionada por estes estudos poderá permitir um entendimento mais aprofundado da abrangência e do significado da atuação das editoras de caráter político em Portugal, assim como poderá contribuir para uma compreensão mais ampla da história editorial portuguesa como um todo nesse período.

Os estudos não ambicionam dar uma visão completa de cada um das editoras abordadas, o que seria impossível a um único pesquisador realizar, mas buscam traçar um quadro com as informações básicas sobre cada uma delas, enfatizando sempre o período em que cada editora teve uma atuação política mais destacada. Desse modo, alguns estudos são mais completos do que outros, em função do tempo de existência das editoras e da importância que a edição política teve para cada uma delas. Nos casos de editoras mais antigas ou em que a atuação política se limitou a uma pequena etapa da vida da empresa, os estudos concentraram-se no período enfocado neste trabalho e no envolvimento político da casa, deixando em segundo plano outros momentos de atuação destas editoras.

Da mesma forma, deparei-me com diferentes possibilidades de acesso a informações e fontes sobre cada editora, e é claro que os estudos puderam ser mais detalhados em relação àquelas sobre quais foi possível obter mais informações e fontes documentais.

Em muitos casos, esses estudos representam o primeiro levantamento sistemático de informações sobre a história e a produção de algumas editoras, o que, acredito, poderá servir de subsídio para a continuidade de pesquisas sobre o tema.

Optei por organizar estes estudos a partir das vinculações políticas das editoras, 
uma vez que este é o elemento principal que procuro analisar em meu trabalho, mas também porque acredito que dessa forma tornam-se mais claras as motivações, articulações e continuidades que dão sentido às suas trajetórias. Há casos em que estas vinculações são muito evidentes, e outros em que elas são tênues, mas sempre o fator político estava presente.

Começarei, no capítulo seguinte, apresentando os estudos de 11 editoras vinculadas ao PCP. 


\section{EDITORAS POLÍTICAS DE ESQUERDA - LIGADAS AO PARTIDO COMUNISTA PORTUGUÊS (PCP)}

Formam o maior conjunto entre as editoras políticas: eram pelo menos 11 editoras que mantinham vinculações com o PCP, desde a sua editora oficial até aquelas que simplesmente foram criadas por militantes do partido e espelhavam na sua linha editorial os pontos de vista do partido.

Isso mostra a importância que o PCP sempre deu à edição de livros. Mesmo quando estava na clandestinidade, o partido manteve em atuação as Edições Avante! A cultura política comunista, em que a formação política dos militantes e dirigentes é uma tarefa importante, favorece a existência de editoras que produzam os livros necessários para estas atividades. Além disso, os materiais impressos, entre os quais os livros, são importantes instrumentos de propaganda e doutrinação.

\subsection{Edições Avante!}

Lisboa

Editor: Francisco Melo

Fundação: 1974 (atividade legal)

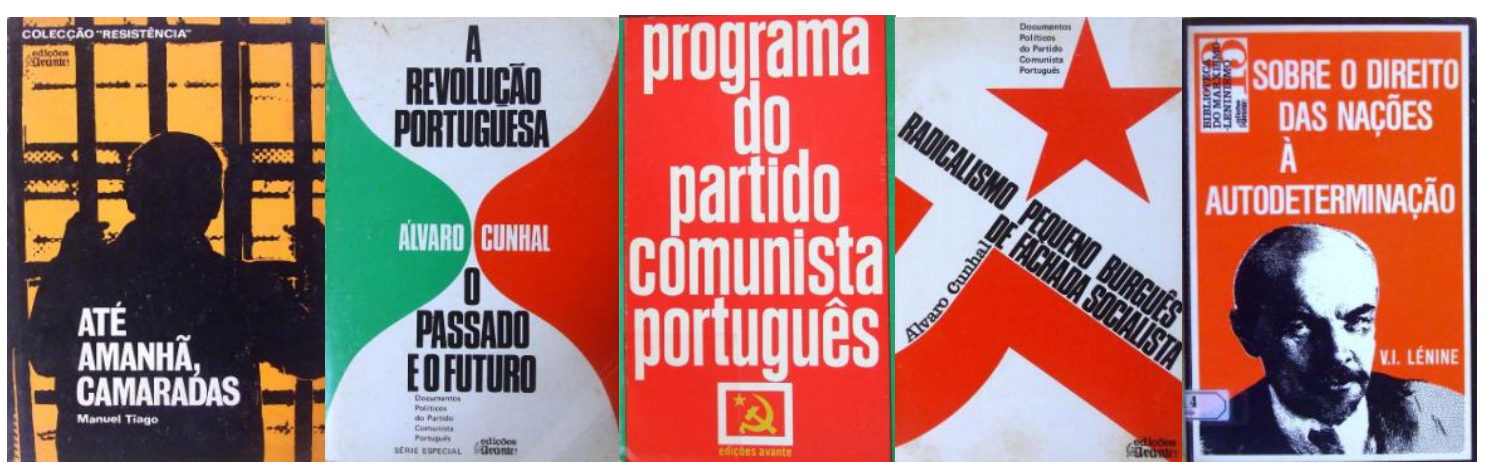

Editora oficial do Partido Comunista Português (PCP), atuante na legalidade desde maio de 1974. Aqui tratarei apenas da atividade das Edições Avante! no que toca à edição de livros, excluindo, assim, a parte referente à edição do jornal Avante! - órgão oficial do PCP desde $1931^{1}$ - e de outras publicações periódicas da editora, pois, apesar

\footnotetext{
1 NUNES, João Arsénio. “Avante!”. Verbete. BARRETO, António e MÓNICA, Maria Filomena. Dicionário de História de Portugal. Porto: Figueirinhas, Vol. VII, Suplemento A/E, 1999, p. 151-53.
} 
de fazerem parte de uma única empresa e terem uma atuação muito próxima, estes setores têm direções e características diferentes de organização e produção.

Desde 1974 as Edições Avante! são dirigidas por Francisco Melo, que é também membro do Comitê Central do partido. No período entre 1968 e o início dos anos 1980, publicou mais de duas centenas de títulos, sendo uma das mais atuantes editoras do país na época. Podemos classificar a sua produção nas seguintes categorias:

- Documentos oficiais do PCP e textos de dirigentes, em especial de Álvaro Cunhal, secretário-geral do PCP até 1992.

- Obras sobre a realidade política, econômica e social portuguesa contemporânea.

- Clássicos do socialismo.

- Obras de divulgação do socialismo.

- Obras ensaísticas de caráter político.

- Obras literárias e memorialísticas.

Francisco Melo havia sido, antes do 25 de Abril, dirigente Unicep (Cooperativa Livreira de Estudantes do Porto). Na altura, surgiram em várias cidades cooperativas livreiras, em muitos casos como forma de tentar escapar às proibições e limitações impostas à atuação das associações estudantis. Estas cooperativas tinham como objetivo facilitar a aquisição de livros pelos estudantes, e acabavam também por difundir obras proibidas, literatura marxista e livros que questionavam o regime salazarista.

No Porto, Melo trabalhou também na Editorial Inova, como tradutor. No começo dos anos 1970, já militante do PCP, veio para Lisboa para fazer o serviço militar e começou a trabalhar na Editorial Estampa, que tinha ligações com o partido, e trabalhou ainda no Bloco Editorial Expresso, empresa que fazia a divulgação e comercialização das obras de várias editoras progressistas, como Livros Horizonte, Estampa, Seara Nova, Prelo, Presença e Delfos, além de Arcádia e Estúdios Cor. Era, portanto, uma pessoa ligada ao meio livreiro e editorial. Com o 25 de Abril, foi chamado para colaborar na área editorial do PCP, assim como outros membros ou simpatizantes do partido que trabalhavam no setor livreiro ${ }^{2}$.

De acordo com Melo, após o 25 de Abril “A primeira preocupação [da Avante!] foi editar documentos fundamentais do partido, o programa, os estatutos, e também

\footnotetext{
${ }^{2}$ Entrevista com Francisco Melo, Lisboa, 1/2/2011. Todas as demais declarações de Melo provêm desta entrevista.
} 
algumas obras do camarada Álvaro Cunhal, a começar pelos discursos pós-25 de Abril”"

Assim, as primeiras obras editadas foram o Programa do PCP e os Estatutos do $P C P$, em maio/junho de $1974^{3}$. O êxito foi imediato, pois o Programa do PCP já aparece na lista "Os best-seller da quinzena" do jornal Expresso de 13 de julho de 1974, em $5^{\circ}$ lugar, e voltará a aparecer na lista de 10 de agosto, dessa vez em $4^{\circ}$ lugar ${ }^{4}$.

"Exprimir a consciência do processo revolucionário, transmitir os conhecimentos fundamentais para uma ação verdadeiramente revolucionária”. Esta era a missão da editora de acordo com um catálogo publicado em maio de $1976^{5}$. Para atingir tal objetivo, o instrumento da editora era, é claro, o livro: "Veículo da experiência adquirida e programa de acção [...] o LIVRO é uma ferramenta indispensável para a

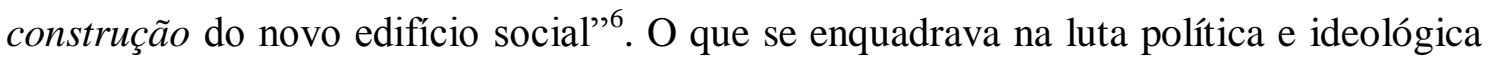
mais ampla do partido, em que o livro era um dos instrumentos: "O combate ideológico também se trava com livros", assinalava um catálogo da Avante! de $1976^{7}$.

As primeiras edições tiveram grande êxito. Como lembra Melo:

Havia, depois de quase meio século de fascismo, muito interesse no conhecimento desse material, quer dos materiais do partido, quer dos clássicos do marxismo, embora um ou outro já se conseguisse editar nos últimos tempos do fascismo, mas aquilo foi um rio que se soltou, rompeu-se o dique, era um entusiasmo enorme, grandes tiragens.

Esse interesse continuou a se refletir na lista de best-sellers do jornal Expresso, em que estiveram presentes os livros $O$ radicalismo pequeno-burguês de fachada socialista, de Álvaro Cunhal (19 de outubro de 1974, em $8^{\circ}$ lugar); Discursos políticos, também de Cunhal ( $1^{\circ}$ de novembro de 1974 , em $6^{\circ}$ ); e a história em quadrinhos (banda desenhada) 25 de Abril, de Ernesto Neves ( $7^{\circ}$ lugar em 3 de maio de 1975) ${ }^{8}$.

Isso se relacionava com o contexto político que se vivia em Portugal, um período de grande mobilização popular e em que o PCP tornou-se um dos principais partidos do país, fazendo parte de todos os governos provisórios de 1974-75. Um ano

\footnotetext{
${ }^{3}$ MELO, Francisco. "As Edições Avante! e a história do PCP. Breve roteiro bibliográfico". O Militante, $n^{\circ}$ 253/254/255, 2001. Disponível em:<http://www.pcp.pt/publica/militant/253/p47.html>. Acesso em 9/3/2009.

4 "Os best-seller da quinzena". Expresso, 1974 e 1975. Hemeroteca Municipal de Lisboa.

${ }^{5}$ Catálogo das Edições Avante!, maio de 1976, por acosião das Feiras do Livro de Lisboa e do Porto. Acervo das Edições Avante!, Lisboa.

${ }^{6}$ Boletim Edições Avante!. Suplemento do no 91 do jornal Avante!, Lisboa, 1975. Grifos do original.

7 "Saudando a Conferência do PCP". Catálogo das Ediçõe Avante!, 1976. Acervo das Edições Avante!, Lisboa.

8 "Os best-seller da quinzena", op. cit.
} 
após o fim da ditadura, o PCP atingia o número de cem mil filiados ${ }^{9}$.

De fato, uma das características que marca a primeira etapa de atuação legal das Edições Avante! são as grandes tiragens. Alguns títulos tiveram tiragem de 50 mil exemplares, como o Manifesto do Partido Comunista, de Marx e Engels, e O que é o comunismo? Perguntas e respostas, da coleção Cadernos de Iniciação ao Marxismo Leninismo, além do livro ilustrado 25 de Abril, de Ernesto Neves, todos editados em 1975. Outros ficaram no patamar de 30 mil (A revolução portuguesa: o passado e o futuro, de 1976, e Avante com Abril, de 1979, ambos documentos oficiais do partido assinados por Álvaro Cunhal). Muitos tiveram tiragem de 20 mil exemplares, outros tantos de 10 mil.

Além do grande interesse que havia em Portugal pelos livros políticos, a realização de grandes tiragens se relacionava também com o fato de que os livros produzidos pela Avante! destinavam-se não só a Portugal, mas também aos países de língua portuguesa. Francisco Melo afirma que:

Por intermédio e em colaboração com os soviéticos, com a Editorial Progresso, nós fazíamos cá os livros, que depois eram comercializados pela [distribuidora] CDL, mas também eram enviados para a União Soviética para irem para Angola, para Moçambique e para outros países de língua portuguesa.

Esse fator também ajuda a compreender as grandes tiragens alcançadas pelos livros da Avante!

Nos primeiros anos de atuação da Avante! a edição de livros foi plenamente autossustentável. Para isso colaborava também toda a estrutura partidária, que potencializava a difusão dos livros. "A abertura dos Centros de Trabalho do partido em todo o país ajudou muito, todos eles tinham uma banca de venda de livros", lembra Melo. Ele continua: "Nos primeiros anos nossos livros circulavam mais através dos Centros de Trabalho do que do circuito comercial, tradicional. Essa grande rede de distribuição dava vazão a toda essa produção editorial”.

Já em 1975 foi criado também o Serviço de Novidades Avante!, que era um sistema de assinatura de coleções. Dessa forma, os leitores podiam tornar-se assinantes de uma ou mais coleções da editora, o que lhes garantia receber os livros antes de sua distribuição às livrarias, além de garantir à editora uma receita antecipada. E a

\footnotetext{
9 “Mais de 100 mil!”. Avante!, Lisboa, n 68, 17/7/1975. Reproduzido em $O$ Militante, Lisboa, nº 2, série IV, jul. 1975.
} 
assinatura acabava por ser também uma forma de apoio militante, num momento em que o PCP estava tendo um grande crescimento.

Por isso, diz Melo, "nesses primeiros anos a militância foi um fator determinante" para o êxito da editora. "Havia também uma rede de agentes de distribuição, de camaradas que tinham por função vender livros e o jornal, como ainda acontece hoje", afirma.

Essa situação manteve-se durante os dois primeiros anos de atuação legal. Com as dificuldades políticas que se acentuaram após as mudanças políticas ocorridas a partir de 25 de novembro de 1975, com o arrefecimento da situação política em Portugal, passou a prevalecer a distribuição comercial, para o que colaborou muito, também, a criação da distribuidora CDL (Central Distribuidora Livreira). A CDL foi uma empresa criada pelo PCP para fazer a distribuição do jornal Avante! e dos livros. A empresa não pertencia oficialmente ao partido, mas de fato estava vinculada a ele. Distribuía os materiais do partido, mas também de outras editoras progressistas, e a partir de certa altura livros e revistas oriundos da União Soviética.

É interessante ver como um documento oficial do partido se refere a essa iniciativa. Trata-se do Relatório aprovado pelo Comitê Central no VIII Congresso do PCP, em novembro de 1976, de autoria de Álvaro Cunhal (depois publicado sob o título A Revolução Portuguesa: o passado e o futuro). Cunhal não deixa dúvidas de que o PCP não só foi responsável pela criação e administração da empresa, mas também pela sua sustentação financeira:

A criação pelo partido de um aparelho próprio de distribuição e vendas (armazenagem, embalagem, distribuição) permite resolver muitas dificuldades. Trata-se de um empreendimento audacioso nos planos organizativo e financeiro, pois, além do mais, envolve volumosos recursos técnicos e humanos. Entretanto, esta iniciativa justa e necessária está dando os seus frutos, mesmo no plano financeiro. ${ }^{10}$

A CDL criou uma estrutura de distribuição nacional, que contava ainda com uma rede de livrarias próprias, as "livrarias populares" CDL. No começo de 1979 eram 16 livrarias, das quais quatro em Lisboa e 12 em outras cidades. Entre estas, algumas eram diretamente ligadas à Edições Avante! e levavam o nome da editora ${ }^{11}$.

Mas havia também críticas à atuação da editora. Na avaliação sobre a atividade

${ }^{10}$ CUNHAL, Álvaro. A Revolução Portuguesa: o passado e o futuro. Lisboa: Avante, 1994, p. 450-51.

11 “Quatro livrarias CDL”. Notícias do Livro, no 4, fevereiro, 1979, p. 34-38. 
editorial aprovada no VIII Congresso do PCP, afirmava-se:

Há entretanto que alargar o leque editorial, com maior variedade de assuntos e edições de atualidade, que respondam aos grandes problemas que se põem ao povo português e contribuam para a elevação da sua formação política e cultural. [...] Em toda a atividade de informação e propaganda verifica-se, a par da correção e rigor da informação sobre os acontecimentos essenciais, uma informação atrasada e insuficiente e um tratamento pouco vivo e incisivo de fatos e situações concretas da vida quotidiana e o uso de uma linguagem pouco acessível. $^{12}$

De acordo com Melo, a direção da editora tinha grande autonomia na definição dos títulos que editava, "mas havia orientações genéricas [do Comitê Central do partido], sobretudo a definição das grandes áreas que se considerava prioritárias".

Em termos da organização do trabalho editorial, houve, inicialmente, colaboradores não remunerados, principalmente tradutores, mas logo foi organizado um corpo fixo de colaboradores especializados, funcionários, para a revisão, a preparação dos livros para a tipografia, capistas etc. ${ }^{13}$

Houve sempre a preocupação de atuar de modo a que a empresa não tivesse prejuízos econômicos: "A preocupação não era o lucro, mas tornar possível que essa atividade fosse viável. Portanto, tínhamos a precaução de que aquilo que editássemos tivesse saída, tivesse procura, que se vendesse, que se pagasse", lembra Melo. A questão da autossustentação, nos primeiros anos, não era um problema no que diz respeito aos livros, mas sim ao jornal ${ }^{14}$.

De acordo com o citado relatório de Álvaro Cunhal, este foi o balanço dos primeiros 28 meses de atuação legal da Edições Avante! (maio/1974 a agosto/1976):

As Edições Avante! editaram 139 títulos com tiragem total de 2.174.430 exemplares, o que dá uma média por livro de 15.643 exemplares. No mercado livreiro português é uma média muito elevada. No total, as edições de divulgação do marxismo-leninismo, incluindo 12 títulos dos clássicos, ocuparam o primeiro lugar com 72 títulos (43\%) e 1.081 .300 exemplares, seguindo-se materiais do Partido com 43 títulos (26\%) e 737.300 exemplares (29\%). ${ }^{15}$

O Relatório destaca os problemas surgidos durante o "Verão Quente" de 1975, quando muitas sedes do PCP foram atacadas e destruídas no país:

\footnotetext{
12 “Sobre agitação e propaganda", O Militante, n 18, série IV, dez. 1976.

${ }^{13}$ Entrevista com Francisco Melo em Lisboa, 1/2/2011.

14 Idem.

${ }^{15}$ CUNHAL, A Revolução Portuguesa..., op. cit., 1994, p. 450-51.
} 
As actividades editoriais sofreram, tal como a imprensa, um sério golpe com a vaga de terrorismo que levou a cabo a destruição de milhares de livros nos Centros de Trabalho, e paralisou praticamente durante muito tempo a distribuição e a venda em vastas regiões.

Em resultado dessas circunstâncias e da situação posteriormente criada verificaram-se grandes prejuízos financeiros, dificuldades de distribuição e a necessidade de adaptar a atividade editorial à situação existente. ${ }^{16}$

Entre 1974 e 1980 a Avante! editou mais de 210 títulos, sem contar as edições da Revista Internacional Problemas da Paz e do Socialismo e da revista Economia.

A produção editorial da Avante! neste período destaca-se por duas características: a edição de clássicos e obras de divulgação do socialismo e do marxismo-leninismo, basicamente por meio de títulos de autores estrangeiros; e a grande ênfase dada à edição de obras sobre a situação política portuguesa contemporânea, principalmente por meio da edição de documentos oficiais do partido e de obras do seu secretário-geral, Álvaro Cunhal.

Uma terceira linha, menos expressiva numericamente, é a de recuperação da participação do PCP na história da luta de resistência ao fascismo em Portugal, por meio de obras literárias e memorialísticas.

As Edições Avante! continuam em plena atividade atualmente, e Francisco Melo mantém-se à frente da direção da editora.

\subsection{Editorial Estampa}

Rua Escola do Exército, 9, r/c, Dto. - Lisboa

Editores: António Manso Pinheiro e Ana Maria Alves.

Fundação: 1960.

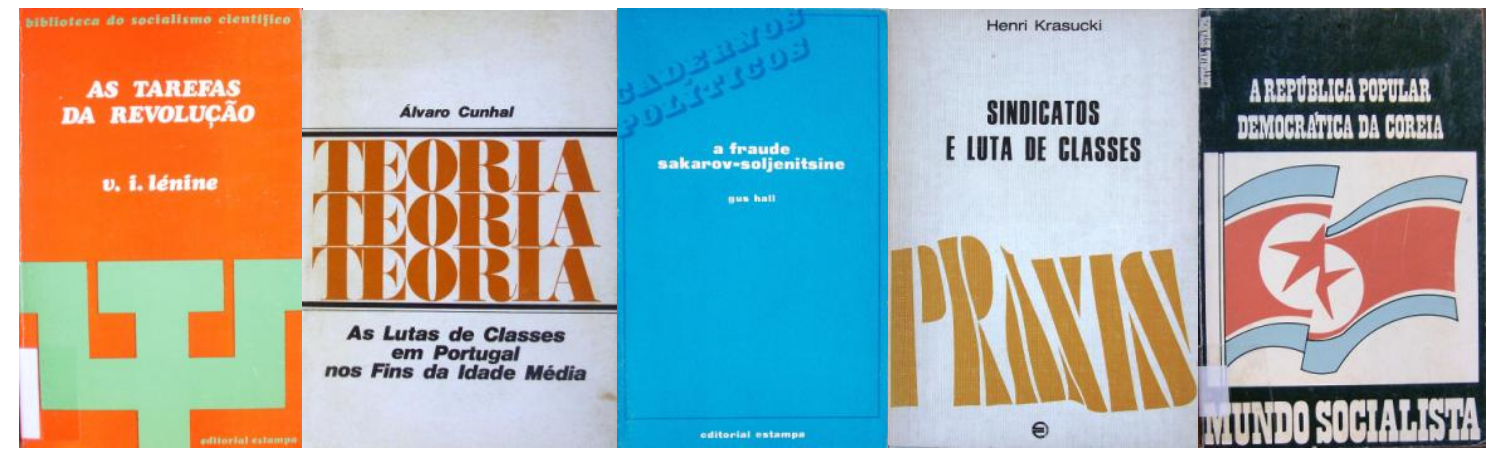

${ }^{16}$ Ibidem. 
Editora fundamental para a divulgação da literatura marxista em Portugal - antes e depois do 25 de Abril -, foi das mais atuantes casas de edição nos anos 1970.

A Editorial Estampa foi criada em dezembro de 1960 por Paradela de Abreu, mas a sua transformação em editora de referência do pensamento de esquerda ocorreu a partir de 1969, quando António Manso Pinheiro tornou-se sócio da empresa e assumiu o seu controle, juntamente com outras pessoas ligadas ao PCP.

Manso Pinheiro era na altura militante do PCP - responsável pelo setor intelectual do partido em Lisboa antes do 25 de Abril - e seu posicionamento ideológico se refletiu claramente na linha editorial que implementou na Estampa. Para Fernando Rosas, a editora "era uma causa antes de um negócio. [...] Começou por ser uma causa do PCP, a causa da divulgação dos autores e das obras de referência da visão do marxismo-leninismo que o partido e a URSS partilhavam"17. Manso Pinheiro deixou o PCP em 1975, como veremos adiante.

A editora, sem ter vínculos formais com o partido, certamente atuou durante alguns anos em consonância com a sua linha política, e forneceu vasto material de estudo e formação para os militantes e simpatizantes comunistas portugueses - e também de outros países de língua portuguesa.

Ana Maria Alves, com quem Manso Pinheiro se casou em 1971, constituiu, ao lado do marido, o núcleo diretor da Estampa, até a sua morte, em $1989^{18}$. Alves era também militante do PCP, e em outubro de 1974 integrou-se no MDP-CDE (Movimento Democrático Português-Comissão Democrática Eleitoral), partido que veio a abandonar em junho de 1975. Em 1977 deixou também o $\mathrm{PCP}^{19}$.

Nuno Medeiros destaca o papel da Estampa na edição de ensaios políticos no terço final dos anos 1960, “com séries como 'Clave' e 'Polémica",20. De fato, a editora foi uma das principais responsáveis, ainda durante a ditadura, pela edição em Portugal de muita literatura marxista e socialista, principalmente dos seus principais teóricos.

Várias coleções com livros de caráter marxista, oposicionista ou contestador

\footnotetext{
${ }^{17}$ ROSAS, Fernando. "Biografia”. In: PINHEIRO, Maria Odete Manso (coord.). Antonio Carlos Manso Pinheiro: a homenagem. Lisboa: Estampa/APEL, 2007, p. 4-7.

${ }^{18}$ PINHEIRO, op. cit.

${ }^{19}$ MATOS E LEMOS, Mário. Candidatos da Oposição à Assembleia Nacional do Estado Novo (19451973). Um Dicionário. Lisboa: Divisão de Edições da Assembleia da República/Texto Editores, 2009, p. 99-100. Disponível em: <http://www.parlamento.pt/ArquivoDocumentacao/Documents/Candidatos_Oposicao.pdf>. Acesso em agosto de 2009.

${ }^{20}$ MEDEIROS, Edição e editores, op. cit., p. 250.
} 
foram lançadas pela Estampa durante o marcelismo: em 1970, a coleção Praxis e a coleção Teoria; em 1971, as coleções Cadernos de Política Internacional e Polémica (Nova Série); em 1972, a Biblioteca Estampa; e em 1973 a Biblioteca de Economia Contemporânea.

A editora aparece com destaque na lista de livros "de intenção revolucionária" editados em Portugal em 1971, elaborada por Martinho de Freitas no jornal Época ${ }^{21}$.

Deve-se destacar, portanto, a ousadia do editor de publicar, ainda na ditadura, muitos títulos de clara conotação marxista, enfrentando, é certo, a perseguição política daí decorrente. No levantamento de "Livros proibidos nos últimos tempos da ditadura", José Brandão aponta 21 títulos da Estampa proibidos até a queda de Marcelo Caetano, o que a torna uma das editoras mais atingidas pela censura ${ }^{22}$.

Não por acaso, o editor havia sido detido pela DGS/PIDE uma semana antes do 25 de Abril, sendo um dos muitos presos políticos libertados com a Revolução dos Cravos $^{23}$.

Após o fim da ditadura, surgiram, entre outras, as coleções Biblioteca do Socialismo Científico e Cadernos Políticos, em 1974, e Mundo Socialista, em 1975, de claro teor político e de divulgação do marxismo e das experiências dos países socialistas.

O caráter partidário de alguns títulos publicados não deixava de causar críticas à editora. É o caso de uma resenha sobre três obras da coleção Cadernos Políticos. Para o autor da crítica, a editora utilizava "critérios partidários", e a coleção publicava "pequenos textos de propaganda mais ou menos directa da política soviética [que] reflectem um propósito propagandístico de tal forma óbvio e grosseiro que se torna, ao fim e ao cabo, ineficaz e até contraproducente" 24 .

Mas a Estampa, nesse mesmo período, também publicava muitas obras de literatura, tendo editado autores como Herberto Hélder, Júlio Cortázar, Luiz Pacheco, Henry Miller, André Breton, entre muitos outros, obras de teatro e as obras completas de Almada Negreiros.

${ }^{21}$ FREITAS, Martinho de. Série de artigos publicados no jornal Época de novembro de 1971 a abril de 1972 (dias 30/11 e 19/12/1971 e 4/1, 7/1, 19/3, 31/3, 7/4, 9/4, 16/4, 21/4 e 23/4/1972). Os artigos estão citados na bibliografia final.

${ }^{22}$ BRANDÃO, José. "Livros proibidos nos últimos tempos da ditadura (Nova relação revista e aumentada em abril de 2007). In: BRANDÃO, José. "Os livros e a censura em Portugal". Disponível em: 〈http://www.vidaslusofonas.pt/livros_e_censura.htm>. Acesso em dezembro de 2008.

${ }^{23}$ PINHEIRO, op. cit.

${ }^{24}$ SILVA, Vicente Jorge. "Selecção - Livros políticos”. Expresso, Lisboa, n’ 113, 1/3/1975. 
Alguns livros da Estampa foram mencionados na lista "Os best-seller da quinzena", do jornal Expresso, em 1974 e 1975, todos eles de autores clássicos do pensamento marxista: Contribuição para a crítica da economia política, de Karl Marx (14 de setembro de 1974 , em $10^{\circ}$ lugar); O socialismo científico, reunião de textos de Marx, Engels, Lenin (25 de janeiro de 1975, em $8^{\circ}$ lugar); Textos filosóficos, de Karl Marx ( $1^{\circ}$ de março de 1975 , em $\left.4^{\circ}\right) ;$ A sociedade comunista, coletânea de Marx, Engels e Lenin ( $9^{\circ}$ lugar em 7 de junho de 1975) ${ }^{25}$.

A Estampa fez parte do Bloco Editorial Expresso (ver item sobre Edições Avante!). A editora tinha estrutura profissional e nos anos 1970 teve sempre um bom volume de lançamentos. A distribuição era feita pelas distribuidoras CDL e O Século.

Após ser um dos coordenadores da campanha eleitoral do PCP para a Assembleia Constituinte em 1975, naquele mesmo ano Manso Pinheiro se afastou do PCP, passando a apoiar ideias mais ao centro do espectro político.

Na década de 1980 tiveram destaque os lançamentos da coleção Imprensa Universitária (criada em 1978) e a publicação das obras completas de José Rodrigues Miguéis. Foi publicada também a coleção Nova História da Expansão Portuguesa, dirigida por Joel Serrão e A. H. de Oliveira Marques.

Manso Pinheiro faleceu em 2007. A Editorial Estampa continua em atuação atualmente, mantendo-se como editora independente. Ainda quando Manso Pinheiro estava à frente da Estampa a sua linha editorial havia se diversificado muito, passando a abranger as áreas de livros práticos, livros espiritualistas e holísticos, thriller esotérico, ensaios sobre os traços fundamentais do pensamento hermético, obras dedicadas à saúde natural e medicinas alternativas, guias turístico e guias linguísticos de conversação ${ }^{26}$.

No período entre 1968 e 1980 a Editorial Estampa editou cerca de 300 títulos de caráter político (o total geral de títulos editados neste período deverá ter chegado a cerca de 500). A maior parte era de obras traduzidas, com significativa participação de autores socialistas, desde os fundadores e principais pensadores - com destaque para Marx, Engels, Lenin e Rosa Luxemburgo - até diversos autores soviéticos. Mas editou também muitas obras políticas de autores portugueses, entre os quais Álvaro Cunhal, Urbano Tavares Rodrigues, Sergio Ribeiro, Maria Belmira Martins, Mário Vieira de Carvalho, Júlio da Silva Martins, Carlos da Fonseca e Pedro Ramos de Almeida.

\footnotetext{
25 “Os best-seller da quinzena”. Expresso, 1974 e 1975. Hemeroteca Municipal de Lisboa.

26 "Historial e Missão". Página eletrônica da Editorial Estampa. Disponível em: $<\mathrm{http}: / /$ www.estampa.pt/novosite/>. Acesso em maio de 2010.
} 


\subsection{Editora Seara Nova}

Rua Bernardo Lima, 23, 1º, Esq. - Lisboa

Editor: José Garibaldi.

Fundação: 1921.

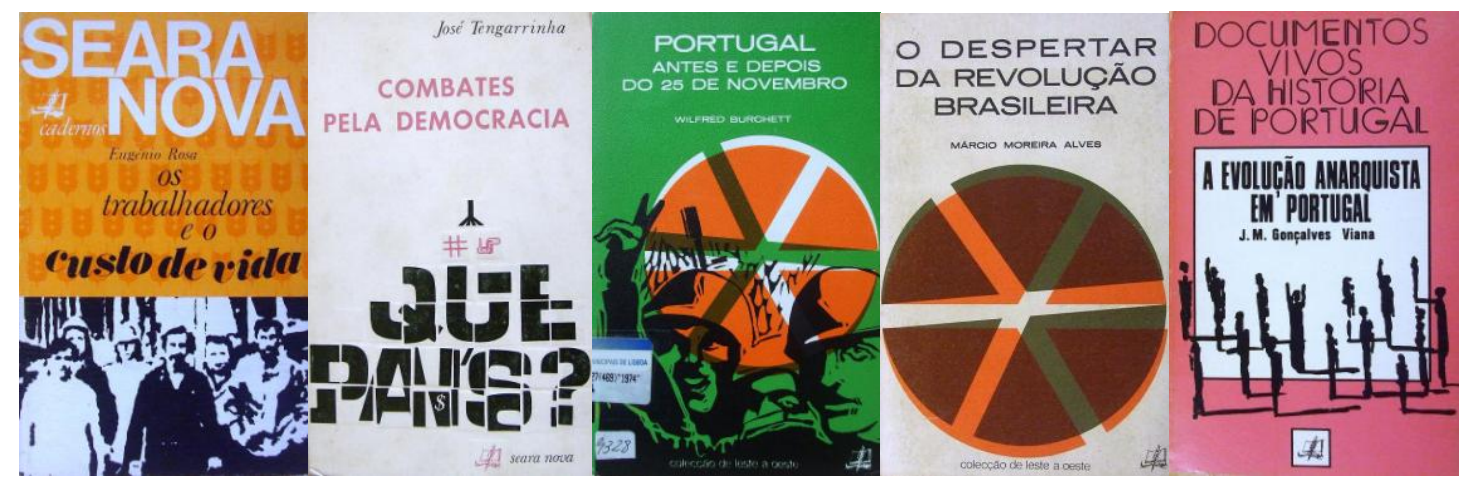

A editora Seara Nova surgiu como decorrência das atividades da revista de mesmo nome, criada em 1921 por um grupo de intelectuais que se tornaria célebre em Portugal: Aquilino Ribeiro, Augusto Casimiro, Câmara Reis, Faria de Vasconcelos, Jaime Cortesão, Raul Brandão, Raul Proença, aos quais logo se juntaram Azeredo Perdigão e António Sérgio ${ }^{27}$. Segundo António Reis, a revista constituiu

o principal órgão de intervenção na vida política e cultural de sucessivos grupos de intelectuais republicanos de esquerda ao longo de seis décadas, a par de outros meios, nomeadamente a atividade editorial e a organização de ciclos de conferências e colóquios, bem como a participação de atos políticos em circunstâncias determinadas. $^{28}$

Assim, acabou por ser "um dos instrumentos escritos mais contumazes no campo da oposição democrática ao regime de Salazar", conforme Nuno Medeiros ${ }^{29}$.

A edição de livros pela Seara Nova começou quase ao mesmo tempo que a edição da revista, pois já em 1921 apareceram livros com este selo. Esta primeira fase, de acordo com Irene Lisboa, caracterizou-se pela edição de "um conjunto de textos dispersos, sem linha editorial definida, na maioria dos casos de autores colaboradores da revista"30. A partir de 1934, sob a direção editorial de Câmara Reis, surgiu a coleção Cadernos Seara Nova, que tinha objetivos de divulgação científica e cultural e teve

\footnotetext{
${ }^{27}$ NASCIMENTO, Ulpiano do. "Seara Nova". Verbete. In: BARRETO, António e MÓNICA, Maria Filomena. Dicionário de História de Portugal. Porto: Figueirinhas, Vol. IX, Suplemento P/Z, 1999, p. 407-10.

${ }^{28}$ REIS, António. "Seara Nova”. Verbete. In: ROSAS, Fernando e BRITO, J. M. Brandão de (coord.). Dicionário de História do Estado Novo. Vol. II. Lisboa: Bertrand, 1996, p. 890-93.

${ }^{29}$ MEDEIROS, Nuno. Edição e editores..., op. cit., p. 159-60 e 275.

${ }^{30}$ LISBOA, Inquérito ao livro..., vol. I, op. cit., p. 214-218. Apud LEITE, op. cit.
} 
grande atividade até 1943, período em que foram publicados 86 volumes. A coleção se manteve ativa até o final da editora, em 1978-79. Além disso, havia também, nesta primeira fase, a coleção Textos Literários, dirigida por Rodrigues Lapa.

Depois de um período relativamente longo em que as atividades da revista e da editora decaíram significativamente, em 1959, ainda sob a direção de Câmara Reis, abriu-se uma nova etapa, com o revigoramento da revista e a participação de novos colaboradores que lhe injetaram novo ânimo, como Manuel Sertório, Rui Cabeçadas, Nikias Skapinakis, Augusto Abelaira e Lopes Cardoso. É o início do que António Reis chamou de o quarto ciclo da vida da Seara Nova (1959-1974): "período de renovação doutrinária mercê de forte influência das correntes marxistas, com abertura às novas gerações, e de significativa expansão da revista e demais publicações, com crescente intervenção cívico-cultural" ${ }^{\prime 31}$.

É dentro do período compreendido por este ciclo que ocorre a substituição de Salazar por Marcelo Caetano, em 1968, marcando, inicialmente, novas possibilidades de atuação política e intelectual para os grupos de oposição. Este será um período de grande expansão da Seara Nova. Nas vésperas do 25 de Abril a revista chegou a ter uma tiragem de 30 mil exemplares e cerca de 18 mil assinantes, a editora publicava uma média de dois novos títulos por mês ${ }^{32}$.

O que não significava que não houvesse censura, perseguições e cerceamento à atuação da editora, como vimos no Capítulo 2. Mas mesmo com essas limitações a Seara Nova vivia uma fase de crescimento.

Sete dias antes do 25 de Abril, José Garibaldi, então o responsável pelas edições da Seara Nova, havia passado à clandestinidade para escapar à prisão, pois a DGS/PIDE detivera elementos da revista Seara Nova. "Foi a última vaga de prisões da polícia política antes da revolução, no dia 18 de abril" ${ }^{\text {33 }}$.

No levantamento de "Livros proibidos nos últimos tempos da ditadura", José Brandão aponta 21 títulos da Seara Nova proibidos até a queda de Marcelo Caetano, marcando-a como uma das editoras mais atingidas pela censura ${ }^{34}$.

Haverá uma viragem importante a partir do 25 de Abril, pois o fim da ditadura de acordo com a cronologia proposta por António Reis - dá início ao quinto ciclo da

${ }^{31}$ REIS, op. cit..

${ }^{32}$ REIS, op. cit.

33 "Clandestinos". Público, Lisboa, 25 de abril de 1994. Disponível em: 〈quexting.di.fc.ul.pt/teste/publico94/ED940425.txt〉. Acesso em maio de 2010.

${ }^{34}$ BRANDÃO, op. cit. 
vida da revista/editora, marcado pela conquista da maioria do capital social da empresa por acionistas ligados ao PCP, o que resulta, segundo Reis, na "hegemonia doutrinária comunista, que leva à imediata desagregação do grupo e à drástica redução do universo dos assinantes e leitores da revista com a sua consequente morte" 35 .

Assim, no que diz respeito ao período entre 1968 e o final dos anos 1970, haverá duas fases distintas na orientação da edição de livros pela Seara Nova: de 1968 até o 25 de Abril, e daí até o fim da editora, em 1978-79. A direção da editora já estava a cargo de José Garibaldi antes do 25 de Abril, mas a partir de janeiro de 1975 ele passou a acumular também a direção da revista, substituindo Rodrigues Lapa.

O período a partir de 1968 representa um certo incremento na edição de livros de caráter político pela Seara Nova, com uma média de 6,6 títulos anuais entre 1968 e 1972. Mas é o ano de 1973 que marca um salto na atuação da editora, com o total de títulos chegando a 21, graças ao incremento da coleção Cadernos Seara Nova e ao início da coleção Que País?.

Os quatro anos seguintes (1974 a 1977) assinalam o período áureo da editora, quando são editados mais de 130 títulos de caráter político, com uma média anual de 34 títulos (sem contar outros títulos de caráter literário, publicados nas coleções Textos Literários, Teatro e Ficcionistas Portugueses). Nesses anos surgem algumas novas coleções: Biblioteca Socialista Portuguesa, Educação e Ensino, Temas Atuais e Ecologia e Sociedade.

Além do aumento da atividade editorial, o período que começa em 1974 apresenta uma maior inclinação à esquerda da linha editorial. Autores como Sottomayor Cardia - que até 1971 havia sido militante do PCP, mas que em 1973 participou da fundação do Partido Socialista - afastam-se da editora. Ao mesmo tempo, nomes claramente vinculados com a linha política (nacional e internacional) do PCP ganham destaque: António Borges Coelho, Eugénio Rosa, José Saramago, Bento Gonçalves, Palmiro Togliatti e Georges Marchais, entre outros. E passam a ser publicados alguns textos de Marx, Engels e Lenin, além de algumas obras sobre a União Soviética. Mas não ocorre uma sectarização do catálogo, que mantém algum arejamento.

Na edição de janeiro de 1974 da revista Seara Nova, um comunicado da editora anunciava a existência de um projeto para incrementar as edições. Este comunicado reafirmava o projeto da Seara Nova de ser uma empresa "com características especiais:

${ }^{35}$ REIS, op. cit. 
o lucro que visamos só interessa na medida em que pode ser reinvestido para a satisfação progressiva dos interesses intelectuais dos nossos leitores e amigos" ${ }^{\text {36 }}$. Essa definição era reforçada em outro texto, publicado menos de dois meses após o fim da ditadura salazarista, em que a Editora Seara Nova definia-se "como uma editora não comercial - não distribui lucros pelos seus acionistas, utilizando-os em investimentos de caráter cultural - atenta e virada para a realidade social do nosso tempo, para a história portuguesa e para os grandes clássicos da nossa literatura" ${ }^{\text {37 }}$.

Entre 1968 e 1978 a Seara Nova editou cerca de 200 títulos de caráter político, sendo uma das mais atuantes editoras do país na época. O ano de 1978 foi o último em que encontrei edições deste tipo realizadas pela editora.

A Seara Nova também fez parte do Bloco Editorial Expresso (ver o item sobre as Edições Avante!).

A editora tinha estrutura profissional, com coleções bem definidas do ponto de vista editorial e gráfico. A distribuição era feita, depois do fim do Bloco Expresso, pelas distribuidoras O Século e CDL. Além da distribuição via livrarias, a própria revista Seara Nova foi muito utilizada para a divulgação dos livros da editora, por meio de anúncios publicitários, sempre presentes nas edições da revista. Mas era a utilização de seu cadastro de assinantes como canal de venda de livros que proporcionava-lhe um diferencial em relação à maior parte das demais editoras. Os livros recém-lançados eram enviados aos assinantes por correio com uma oferta de compra. Se o assinante quisesse comprar o livro era só não o devolver. Neste caso lhe seria enviada uma cobrança por correio. Caso não quisesse o livro, devolvia-o ao carteiro e o exemplar retornava à editora. Tal método foi avaliado pela direção da editora em dezembro de 1974 como:

mais ruinoso do que economicamente vantajoso, pois obrigava a aumento de custos de edição, de custos de correio, a uma complexa máquina administrativa... e os livros não chegavam ao destino, ou, quando chegavam e eram aceites pelos nossos assinantes, só muito lentamente nos iam sendo pagos. E nem sempre o eram... ${ }^{38}$

Em relação às tiragens e às vendas, a Seara Nova parece ter tido um perfil mediano, ou seja, não editava grandes best-sellers, mas seus livros tinham boa aceitação e boas vendas.

\footnotetext{
${ }^{36}$ Comunicado da editora Seara Nova. Seara Nova, Lisboa, ${ }^{\circ}$ 1539, jan. 1974, p. 26.

${ }^{37}$ AA.VV. Editores portugueses na III Bienal Internacional do Livro São Paulo: 15 a 23/junho/1974. Lisboa: Império, 1974.

38 "Seara Nova: ontem e hoje ao serviço da democracia". Seara Nova, Lisboa, nº 1550, dez. 1974, p. 2-3.
} 
Dos livros que pude consultar, cabe destacar alguns que trazem a informação de tiragens acima da média:

- Portugal depois da Revolução dos Capitães, de Wilfred Burchett, lançado em julho de 1975 - Tiragem: 20.200.

- Cantos da revolução, de José Jorge Letria, maio, 1975 - Tiragem: 10.200.

- Herdeiros e continuadores do anarquismo, de Pedro Soares, março, 1975 Tiragem: 10.200 .

- Sobre a nacionalização da banca, de Lenin, abril, 1975 - Tiragem: 7.200.

Além desses, vários títulos foram lançados com tiragens entre 4 mil e 5 mil exemplares, e houve muitas reedições.

Nos anos de 1974 e 1975, três títulos da Seara Nova apareceram na lista dos livros mais vendidos do jornal Expresso: em 8 de junho de 1974 o livro Para onde vai a economia portuguesa?, de Francisco Pereira de Moura ( $9^{\circ}$ lugar); e em 2 de agosto de 1975 os livros Portugal depois da Revolução dos Capitães, de Wilfred Burchett, em $1^{\circ}$ lugar, e No reino de Caliban: antologia panorâmica da poesia africana de expressão portuguesa, em $9^{\text {o }}{ }^{39}$.

Não resta dúvida de que pela sua qualidade, abrangência temática e atualidade, as edições da Seara Nova tiveram um papel importante no período estudado - mesmo que a sua atividade se restringisse apenas à edição de livros, o que não era o caso, visto que o carro-chefe da editora era a revista. Publicou obras de muitos autores portugueses ligados à oposição ao salazarismo e ao pensamento de esquerda. Mesmo após a virada à esquerda pós-1974, quando a editora passou a estar sob o comando da linha política do PCP, a editora manteve um caráter pluralista, ainda que menos aberto do que anteriormente.

Como vimos, António Reis aponta a "hegemonia doutrinária comunista" pós1974 como o fator determinante para o fim da revista e da editora, em 1978-79. Parece certo que uma vinculação tão marcada ao PCP colaborou para isolar a editora e afastar leitores, contribuindo para o fim de uma verdadeira instituição cultural portuguesa, com mais de 50 anos de vida. Mais ainda porque o período que se inicia em 1976 marca uma certa estigmatização do PCP por largos setores da sociedade portuguesa. Mas deve-se levar em conta, também, que no fim dos anos 1970 e início dos anos 1980 assistiu-se ao refluxo de muitas outras iniciativas editoriais ligadas a grupos de esquerda, vinculadas a

39 “Os best-seller da quinzena”. Expresso, 1974 e 1975. Hemeroteca Municipal de Lisboa. 
outros partidos e grupos políticos, tanto à esquerda como à direita do $\mathrm{PCP}$, ou seja, o fim da Seara Nova não foi um fenômeno isolado, ao contrário, fez parte de um certo movimento político de "normalizaçao" política pelo qual Portugal passou.

A revista Seara Nova foi refundada em 1985 por Ulpiano do Nascimento, mantendo-se ainda hoje em circulação trimestral. Não foi reativada a edição de livros.

\subsection{Prelo Editora}

Rua da Misericórdia, 67-2º Esq. - Lisboa (1974)

Alameda de Santo António dos Capuchos, 6B - Lisboa (1975)

Editores: Viriato Camilo, Sérgio Ribeiro, Rui Moura, Fráguas Lucas, Carlos Carvalhas.

Fundação. 1960.

Distribuição: Bloco Editorial Expresso.

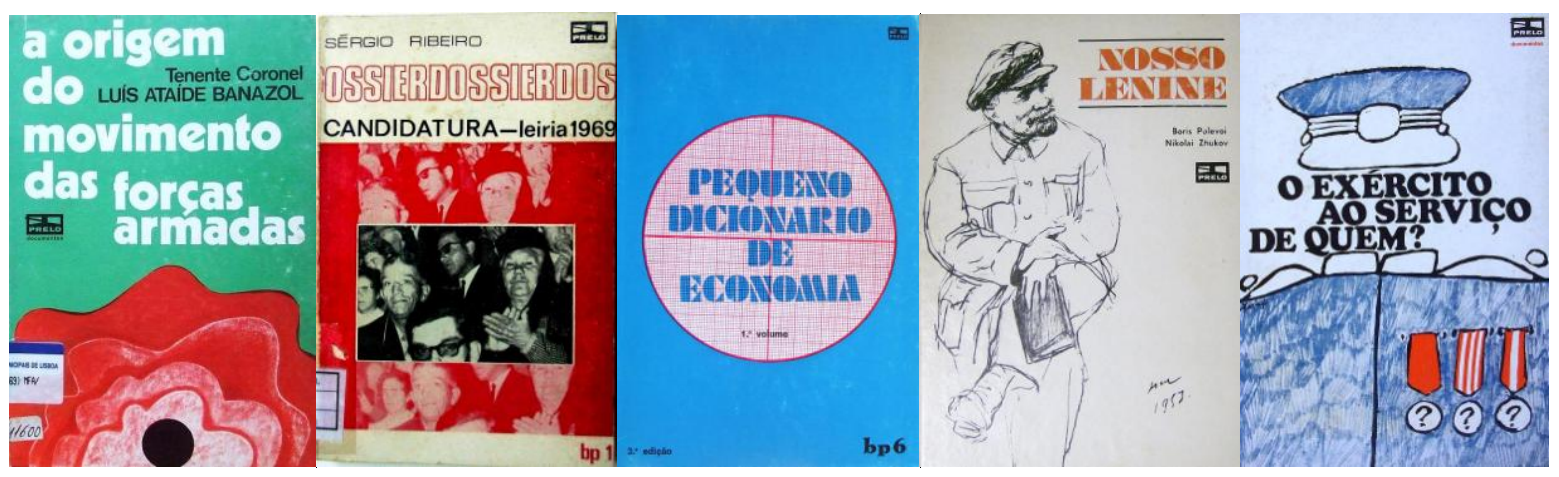

Conta-nos Sérgio Ribeiro sobre as origens da Prelo:

A Prelo Editora foi uma sociedade por quotas criada no começo dos anos 60, em princípio com dois sócios, Rui de Moura e Viriato Camilo. Mas, como Rui de Moura foi preso pela PIDE, começou a existir com Viriato Camilo e Rogério de Moura (da Livros Horizonte), irmão do Rui.

Depois... saiu Rui de Moura, mas foi preso Viriato Camilo! Na prisão, ainda no Aljube, conheci o Viriato Camilo e fizemos uma boa temporada em Caxias na sala $2 \mathrm{r} / \mathrm{c} \mathrm{d}^{\circ}$. Todos cá fora (na liberdade condicionada que o fascismo condescendia para sua sobrevivência), retomamos conversas, e a sociedade por quotas começou por ser alargada a Fráguas Lucas e a mim, e, mais tarde, transformada em sociedade anónima.

Até à segunda metade da década de 80, a Prelo foi editando, depois de ter passado por uma fase de relativo apogeu, em que se chegou a dispor de umas instalações interessantes aos Capuchos, com livraria... mas tudo feneceu em voragens de várias espécies. [...]

Julgo (mas não juro...) que a primeira edição da Prelo foi $O$ menino entre gigantes, de Mário Domingues (com capa do angolano António 
Domingues), saída da tipografia em dezembro de $1960 .^{40}$

Durante os anos 1960 tiveram destaque quatro coleções: Repertório Para um Teatro Actual, Repertório da Sociedade de Escritores e Compositores Teatrais Portugueses - ambas sob a direção de Luiz Francisco Rebello -, Diafragma (voltada para a fotografia) e $\mathrm{O}$ Homem no Mundo, que inicialmente publicava crônicas de viagens ${ }^{41}$.

Em 1965-66 Sérgio Ribeiro e Fráguas Lucas passam a ser sócios da editora.

A partir do final dos anos 1960, a Prelo intensificou as edições de cunho político, com coleções como Biblioteca de Economia - dirigida por Sérgio Ribeiro -, Documentos, Biblioteca Popular, Cadernos de Hoje, Política Económica/Economia Política $^{42}$.

Entre seus principais autores estavam Huglo Blasco Fernandes, Luís Ataíde Banazol, António Borges Coelho, Flausino Torres, Modesto Navarro, Aderito Lopes e Alexandre Cabral, entre outros.

Rui Moura recorda que, devido ao elenco de autores - todos figuras da oposição - e aos temas tratados nos livros da Prelo, a editora teve muitos problemas com a censura. "Só conseguíamos vender esses livros nos primeiros dias, antes de serem apreendidos pela PIDE" $"$.

Eis algumas das obras lançadas antes do 25 de Abril: Dossier Candidatura Leiria 1969, de Sérgio Ribeiro (1970); Estes massacres que nos vêm do Vietnam (My Lay), de Alice Nicolau (1970); A história me absolverá, de Fidel Castro (1970); O dilema da política portuguesa, de Sottomayor Cardia (1971); Chile: povo, governo, poder, coletânea de documentos (1971); Na pátria do socialismo, de Alexandre Babo (1973); O problema feminino e a questão social, coordenado por Helena Neves; Ocupação sem limites: História breve da reacção popular contra os abusos da autoridade praticados na serra de Talhada do Vouga, de Armando Pereira da Silva (1973).

Além das edições voltadas para a política, publicou ainda as coleções Ar Livre e Biblioteca de Medicina e Laboratório.

\footnotetext{
${ }^{40}$ RIBEIRO, Sérgio. “A Prelo Editora 1". Blogue Som da Tinta. Disponível em: <http://som-datinta.blogspot.com.br/2008/07/prelo-editora-1.html>. Acesso em fevereiro de 2012. Grifos do original.

${ }^{41}$ Ibidem.

${ }^{42}$ RIBEIRO, Sergio. 50 anos de economia e militância. Lisboa: Avante!, 2008, p. 171-74.

${ }^{43}$ NUNES, de Maria Leonor. "Os três mosqueteiros - Irmãos Moura". Jornal de Letras, Lisboa, 12 jun. 2002. Disponível em: <http://blogtailors.com/3258982.html>. Acesso em fevereiro de 2012.
} 
Com o 25 de Abril o ritmo das edições acelerou, em particular dos livros políticos. Foram dezenas de obras, publicadas nas diversas coleções, que tratavam da realidade e da história recente portuguesa, de questões internacionais, das lutas de libertação no mundo, dos debates sobre o socialismo e o mundo comunista. Uma das áreas privilegiadas pela editora era a economia, sempre sob um viés de esquerda.

$\mathrm{Na}$ apresentação do quarto volume do Pequeno Dicionário de Economia (março, 1976, coordenado por Sérgio Ribeiro), há uma breve mas direta definição das intenções que parecem ter norteado a atuação da Prelo na edição política: que seus livros fossem "como um instrumento de trabalho, como arma para uma luta" na "procura de intervir, de ser instrumento útil e arma oportuna" 44 para a transformação social e política.

A coleção MAS... AFINAL?!..., surgida no segundo semestre de 1974, foi uma das tentativas de cumprir esses objetivos. Constituída de pequenos cadernos de 16 páginas, visava "não dar respostas redutoras às dúvidas que assaltavam um povo em verdadeiro estado de busca, mas uma informação nova e de que até então tinha estado amputado"45. Em cada um dos 20 volumes publicados em 1974 e 1975 vinha estampado o programa da coleção:

\section{O que se pretende com esta colecção?}

Contribuir para o esclarecimento do povo português de assuntos importantes de todas as épocas de modo a apoiá-lo na elevação do seu nível cultural.

\section{Como?}

Editando a baixo preço cadernos de 16 páginas divididos em séries, abordando temas sociais, políticos, econômicos, desportivos, literários, artísticos, técnicos e biografias, entrevistas, etc.

No entanto, os resultados obtidos com a edição da coleção não foram satisfatórios. Na avaliação de Sérgio Ribeiro, a sua continuidade "só se justificaria se uma tal colecção tivesse uma clara participação vinda do 'ambiente' e dos futuros leitores na definição dos temas a tratar e uma receptividade e distribuição ligada a discussão e debate relativamente ao que fosse publicado". Mas, segundo ele, isso não ocorreu e "não se encontrou a receptividade de quem poderia aproveitar tais 'instrumentos' na sua (e de todos!) luta por um outro amanhã,"46.

\footnotetext{
${ }^{44}$ RIBEIRO, Sergio (coord.). Pequeno Dicionário de Economia . Vol. IV. Lisboa: Prelo, 1976, p. 7.

45 RIBEIRO, Sérgio. "A Prelo Editora 18”. Blogue Som da Tinta. Disponível em: < http://som-datinta.blogspot.com.br/2008/08/prelo-editora-17_09.html>. Acesso em fevereiro de 2012.

${ }^{46}$ RIBEIRO, "A Prelo Editora 18”, op. cit.
} 
Sem ser uma editora de partido, a Prelo caracterizou-se por sua proximidade ao PCP, uma vez que alguns de seus sócios, como Sérgio Ribeiro, Rui Moura, Carlos Carvalhas e Fráguas Lucas, eram membros do partido. E isso se refletiu em sua linha editorial e nos títulos editados. Foi uma das mais atuantes editoras de caráter político do país antes e depois do 25 de Abril, tendo editado, até o final da década de 1970, cerca de 140 títulos políticos. A Prelo deixou de editar no começo dos anos 1980.

\subsection{Livraria Júlio Brandão}

Vila Nova de Famalicão.

Editores: Manuel Cunha e Macedo Varela.

Fundação: 1971.

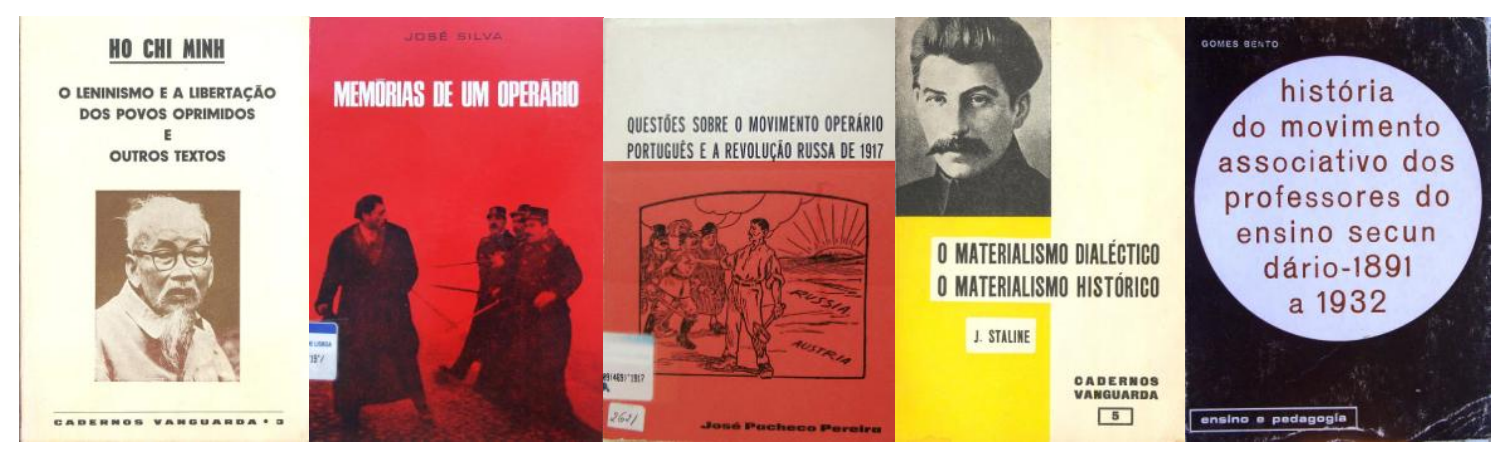

Classificada por José Manuel Lopes Cordeiro como "uma das mais curiosas editoras portuguesas" do início dos anos 1970 (pré-25 de Abril) ${ }^{47}$, tinha sua sede na cidade de Vila Nova de Famalicão, no distrito de Braga. José Pacheco Pereira, que foi colaborador da editora, afirma que foi criada por iniciativa de dois membros do PCP, Manuel Cunha e António Macedo Varela, que na época estavam na clandestinidade e eram militantes ativos na oposição à ditadura ${ }^{48}$.

Manuel Cunha, sindicalista, militou na Oposição Democrática ao Estado Novo e em 1969 foi candidato à Assembleia Nacional pela Comissão Democrática Eleitoral de Braga. António Macedo Varela, advogado, atuou na Oposição Democrática no distrito

${ }^{47}$ CORDEIRO, José Manuel Lopes. “As Origens do PCP no Porto” . Público, 11/3/2001. Disponível em: $<$ http://estudossobrecomunismo2.wordpress.com/2003/05/25/jose-manuel-lopes-cordeiro-origens-do-pcpno-porto/>. Acesso em dezembro de 2009.

${ }^{48}$ PEREIRA, José Pacheco. "Censura - Relatório no 9274 (26 de janeiro De 1972) Relativo a 'Memórias de um Operário', de José Silva”. Blogue Estudos sobre o Comunismo, Biblioteca e arquivo de José Pa Pereira: < http://estudossobrecomunismo.wordpress.com/2012/03/19/censura-relatorio-no-9274-26-dejaneiro-de-1972-relativo-a-memorias-de-um-operario-de-jose-silva/> . Acesso em dez. 2009. 
de Braga. Em 1973 foi candidato à Assembleia Nacional pelo Porto. Nesse mesmo ano foi membro do núcleo dirigente do Movimento Democrático Português no Porto ${ }^{49}$.

A editora publicou seus primeiros livros em 1971. Pacheco Pereira descreveu como funcionava a coleção Cadernos Vanguarda, o que nos permite entender um pouco como eram organizadas as edições da Livraria Júlio Brandão:

Os Cadernos Vanguarda foram publicados com o apoio e a distribuição da Livraria Júlio Brandão [...] de Famalicão por volta de 1971-2. A maioria dos textos foram escolhidos e traduzidos por José Pacheco Pereira e Maria Helena Cunha, nalguns casos com o nome próprio, noutros usando o nome de Álvaro Machado. O arranjo gráfico do primeiro volume foi também de José Pacheco Pereira. Os volumes 4 e 6 não foram de iniciativa dos tradutores, mas usavam os seus nomes para proteger a Livraria de represálias da PIDE. Todos os volumes foram apreendidos pela Censura e proibidos de circular. ${ }^{50}$

Apesar dos responsáveis pela editora serem ligados ao PCP, a coleção Cadernos Vanguarda editou algumas obras que fugiam ao quadro político-ideológico defendido pelo partido, aproximando-se do maoismo. Os títulos publicados na coleção foram: $D a$ prática: de onde vêm as ideias justas, de Mao Tsé-tung (junho, 1971); Cartas (Sobre o materialismo histórico), de F. Engels (agosto, 1971); O leninismo e a libertação dos povos oprimidos e outros textos, de Ho Chi Minh (s/d); O revisionismo contemporâneo: significado e funções, de Alfred Kosing (dezembro, 1971); Materialismo dialéctico, materialismo histórico, de J. Stalin (1972); e O sionismo e o imperialismo, de David Burstein (abril, 1972).

Pacheco Pereira colaborou também na edição pela Livraria Júlio Brandão da obra em dois volumes Memórias de um operário, de José Silva ${ }^{51}$. Ele conta como ocorreu a edição dessa obra:

O livro de José Silva, um dos fundadores do PCP no Porto, contém uma memória da história do movimento operário vivida pelo autor com muita proximidade. O original, datilografado com correções manuscritas, deste [volume] e do II volume sobre a luta democrática nos anos quarenta e cinquenta, foi-me entregue por Maximiniano Silva, amigo próximo de José Silva, então já falecido. Por meu intermédio, foi publicado pela dupla de editores da Livraria Júlio

\footnotetext{
${ }^{49}$ MATOS E LEMOS, op. cit.

${ }^{50}$ PEREIRA, José Pacheco. "Cadernos Vanguarda". Blogue Ephemera, Biblioteca e arquivo de José Pacheco Pereira: <http://ephemerajpp.wordpress.com/2010/07/18/cadernos-vanguarda/>. Acesso em dez. 2009.

${ }_{51}$ CUNHA, Manuel. "A moderação de Pacheco Pereira”. Disponível em: <http://manuelcunha.blogspot.com/2009_06_01_archive.html>. Acesso em janeiro de 2010.
} 
Brandão [...]. Escolhi a fotografia, fiz o arranjo gráfico da capa e todo o trabalho de revisão. $O$ livro foi proibido e os seus editores perseguidos pela PIDE. ${ }^{52}$

Pereira foi o autor de um dos livros publicados pela editora: Questões sobre o movimento operário português e a Revolução Russa de 1917 (1975). E atuou ainda como editor de livros (sempre relacionados à temática marxista e de esquerda) em outras editoras, como a Portucalense e as Edições Rés. Nesta última, dirigiu a coleção Revolução Social.

A Livraria Júlio Brandão aparece nos livros editados sempre como "Distribuidora", mas de fato era a editora dos livros, pelo que se pode concluir das fontes consultadas. Ao que parece, atuou como editora entre os anos de 1971 e 1973, tendo publicado cerca de 15 títulos nesse período.

Muitos dos livros editados pela Livraria Júlio Brandão, em particular as obras de autores marxistas e de estudiosos do marxismo, foram proibidos e apreendidos pela PIDE. Isso aconteceu com todos os títulos dos Cadernos Vanguarda. E também com as Memórias de um operário, de José Silva. Dois foram os motivos para a proibição deste livro, de acordo com o relatório da DGS:

2. [...] O primeiro diz respeito à matéria tratada: sendo a discrição das lutas travadas em Portugal pela "emancipação da classe operária" e "pela conquista das liberdades democráticas", entra claramente nos domínios do socialismo e sindicalismo, considerando-se, por esta razão, inconveniente. O segundo aspecto que destacamos diz respeito à "forma" como o autor aborda os problemas. No contexto geral dos dois volumes pareceu-nos que não existe só a preocupação de fazer 'história' salientando-se a intenção de propaganda e 'aliciamento'. 3. Nesta conformidade, somos de parecer haver inconveniente na sua autorização. $^{53}$

A Livraria Júlio Brandão publicou obras ligadas ao campo do pensamento de esquerda, com autores como Engels, Mao Tsé-tung, Stalin e Ho Chi Minh, mas editou também livros de autores portugueses, como José Silva, José Pacheco Pereira, José Gomes e Manuel Ribeiro (estes dois na coleção Economia), Agostinho Lopes, Bento Gomes, Costa Carvalho (estes três na coleção Ensino e Pedagogia).

Os livros eram produzidos com padrão editorial e gráfico profissional. A

\footnotetext{
${ }^{52}$ PEREIRA, José Pacheco. “Censura - Relatório no 9274...”, op. cit.

53 Relatório 9274 da DGS, de 19/10/1971 sobre o livro Memórias de um operário, de José Silva. Blogue Estudos sobre $\quad$ o $\quad$ Comunismo. $\quad$ Disponível em: <http://estudossobrecomunismo.wordpress.com/2012/03/19/censura-relatorio-no-9274-26-de-janeiro-de1972-relativo-a-memorias-de-um-operario-de-jose-silva/>. Acesso em jul. 2012.
} 
distribuição era feita pela própria Livraria Júlio Brandão (em alguns casos com a colaboração da Distribuidora Expresso, de Lisboa).

\subsection{Edições A Opinião}

Av. da Boavista, 601 - Porto

Fundação: 1973 (jornal); 1975 (edições)

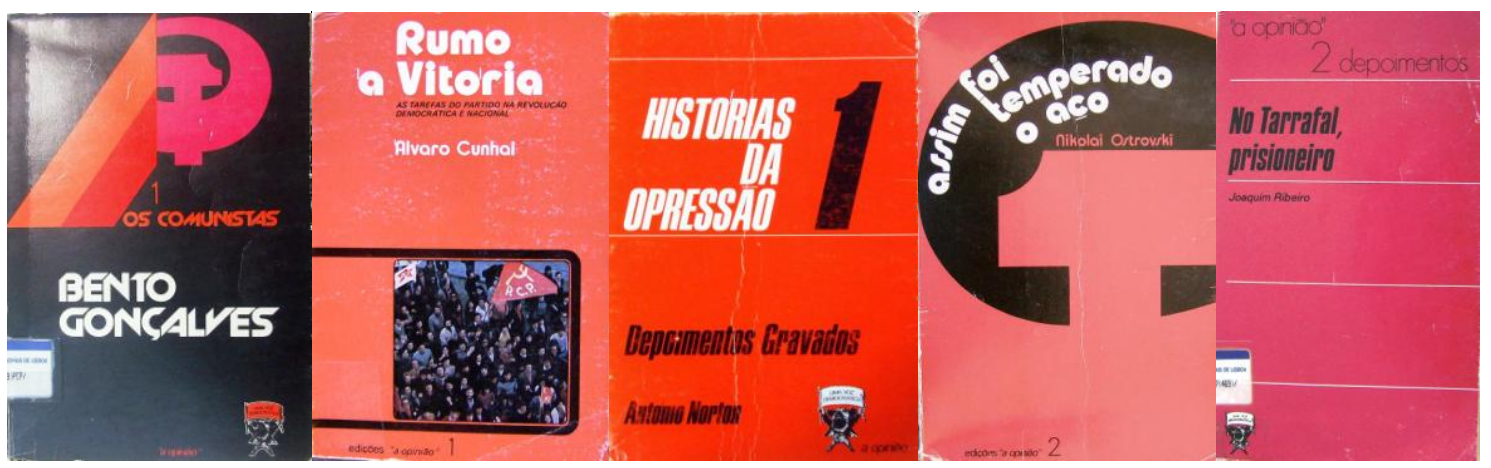

Editora ligada ao jornal homônimo, ambos vinculados ao Partido Comunista Português, seção do Porto. O semanário A Opinião foi editado no Porto de junho de 1973 a junho de 1976, e teve como director João Huet Viana Jorge ${ }^{54}$, e como diretoradjunto António Macedo Varela ${ }^{55}$. Este último, como vimos, havia sido um dos responsáveis pelas edições da Livraria Júlio Brandão, de Vila Nova de Famalicão.

De acordo com Cid Simões, o jornal foi "Concebido no Congresso de Aveiro em abril de 1973" como "Voz da Oposição Democrática" do Norte do país. No primeiro número trazia artigos de Óscar Lopes, Armando de Castro e Nozes Pires ${ }^{56}$.

O primeiro livro publicado pelas Edições A Opinião, em maio de 1975, foi Rumo à vitória, relatório apresentado por Álvaro Cunhal em 1964 ao Comitê Central do PCP, e que se tornou um texto de referência do partido. A editora o apresentava como "um dos mais importantes trabalhos publicados durante a luta revolucionária contra o fascismo" $" 57$.

\footnotetext{
${ }^{54}$ Catálogo da exposição "Ambientes de Abril”. 20 de abril a 28 de junho, 2001. Disponível em: $\langle$ http://www.csarmento.uminho.pt/docs/sms/exposicoes/Cat\%C3\%A1logo25Abril.pdf $>$. Acesso em jul. 2010.

55 "A Opinião". Blogue Almocreve das Petas, 24 de Abril de 2004. Disponível em: <http://almocrevedaspetas.blogspot.com/2004_04_04_almocrevedaspetas_archive.htm〉. Acesso em jul. 2010.

${ }^{56}$ SIMÕES, Cid. “A OPINIÃO - Uma voz democrática”. Blogue As Palavras são Armas, 11/2/2009. Disponível em: < http://aspalavrassaoarmas.blogspot.com/2009_02_01_archive.html>. Acesso em jul. 2010.

57 "Nota prévia”. In: CUNHAL, Álvaro. Rumo à vitória. Porto: A Opinião, 1975, p. 7.
} 
Na coleção intitulada Os Comunistas, que teve início em 1976, o primeiro volume foi o livro Bento Gonçalves, em cuja "Apresentação" havia um texto que resumia o ponto de vista que a editora buscava refletir em seus livros:

A história do movimento operário português durante meio século de fascismo é também a história do Partido Comunista Português. A história dos militantes e dirigentes que conseguiram moldar um Partido forte e coeso, assim assegurando a sua sobrevivência e atuação constante durante os cinquenta anos de ditadura fascista, como única força política organizada. Porque Partido da classe operária, porque fundido nas massas trabalhadoras de que era, ao mesmo tempo, a organização de vanguarda, o PCP conduziu uma permanente luta pela unidade de todos quantos se opunham ao fascismo. Os títulos desta coleção [...] serão antologias, divididas em duas partes: uma primeira, em que se arquivarão textos sobre militantes destacados do PCP, uma segunda, em que se divulgarão escritos (relatórios, obras teóricas ou literárias) desses mesmos militantes. ${ }^{58}$

Em maio de 1975, uma nota de abertura do livro Nacionalizações e controlo da produção, que inaugurava a coleção Economia, mais uma vez assinalava o papel político que a editora pretendia cumprir:

O processo revolucionário iniciado em 25 de Abril de 1974 vem conhecendo sucessivos impulsos que abrem fundadas perspectivas à construção do socialismo. A crescente intervenção organizada das massas trabalhadoras será o garante da marcha irreversível do processo, numa permanente aliança com o MFA [Movimento das Forças Armadas] e com todas as forças progressistas realmente interessadas no avanço da revolução. Edições “A OPINIÃO” pretende alargar a sua contribuição nesta caminhada do povo trabalhador e seus aliados rumo ao socialismo, dando início à publicação de textos sobre as mais diversas frentes de batalha da revolução portuguesa: economia, dinamização cultural e pedagógica, saúde, iniciativa popular etc. $^{59}$

Outro dos primeiros livros editados também trazia uma "Nota prévia" que falava do papel dos livros na resistência à ditadura:

Assim foi temperado o aço, de Nikolai Ostrovski, é uma obra estreitamente ligada a uma fase importante da luta do nosso povo contra o fascismo. Integrada na coleção brasileira "Romances do Povo" [da Editorial Vitória, ligada ao Partido Comunista Brasileiro], conseguiu atravessar muitas vezes a fronteira, entrando clandestinamente em Portugal como o mais precioso contrabando. Clandestinamente, andou de mão em mão, cumprindo a tarefa

\footnotetext{
58 “Apresentação". In: Bento Gonçalves. Porto: A Opinião, 1975, p. 7-8.

59 "Nota". In: Nacionalizações e controlo da produção. Porto: A Opinião, 1975, p. 7.
} 
revolucionária de contribuir junto de muitos combatentes antifascistas para o melhor conhecimento da grandeza da luta travada pelo povo soviético para fazer triunfar a Revolução. [...] era um daqueles livros que os agentes da PIDE-DGS não poupavam quando, ao vasculharem as casas dos prisioneiros, o encontravam [...]. É, pois, um livro ligado à resistência do nosso país. ${ }^{60}$

Todos os livros editados têm claro caráter político e vinculação ideológica com a linha de atuação do PCP. Destacam-se as obras de recuperação da memória da resistência ao fascismo e do papel do PCP nesta luta.

Os livros têm tratamento editorial e gráfico profissional. Não consta informação sobre como era feita a distribuição comercial, mas tudo leva a crer que deve ter sido feita pela DCL, empresa de distribuição ligada ao PCP (ver o item sobre as Edições Avante!).

As Edições A Opinião atuaram entre 1975 e 1978, período em que publicaram cerca de 15 títulos.

\subsection{Editorial Caminho}

Lisboa

Editor: Zeferino Coelho

Fundação: 1975.

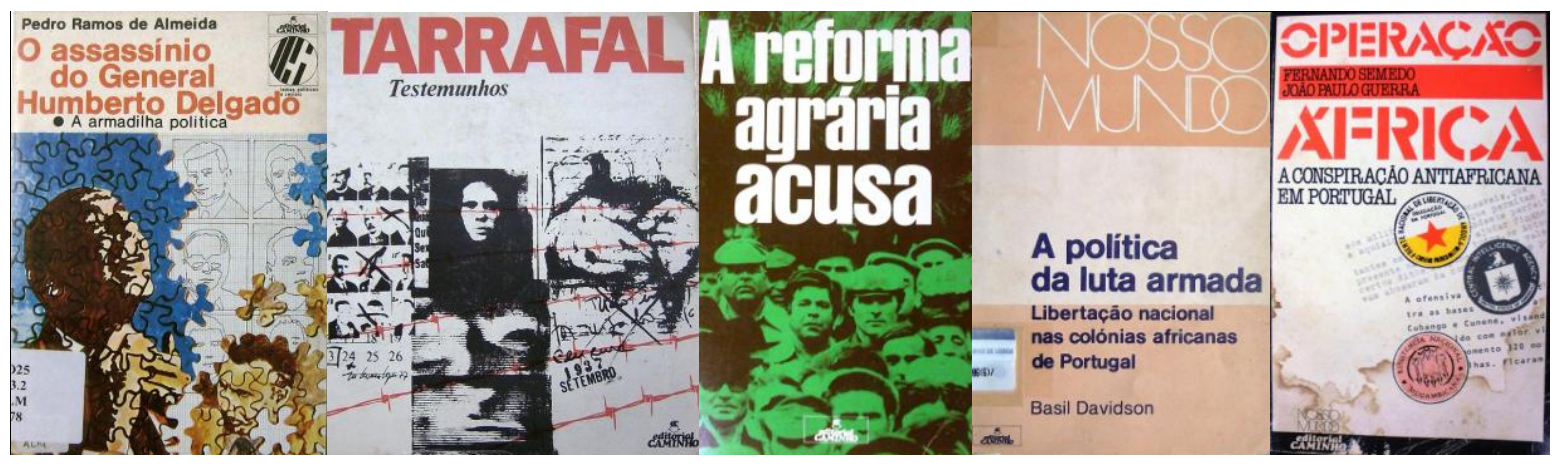

Criada em 1975, sob a direção de Zeferino Coelho e com os auspícios do Partido Comunista Português (PCP). Teve como participantes do seu núcleo original Francisco Melo, diretor das Edições Avante!, José Oliveira, Vitor Branco e outras pessoas ligadas ao PCP, ao qual a editora estava intimamente ligada. Francisco Melo a define com

\footnotetext{
60 “Nota prévia”. In: OSTROVSKI, Nikolai. Assim foi temperado o aço. Porto: A Opinião, 1975, p. 9.
} 
“editora irmã” da Avante! ${ }^{61}$.

De acordo com Melo, a Editorial Caminho "surge como resposta à situação que se criou com o 25 de Novembro", ou seja, com as dificuldades políticas que surgiram para a atuação do partido após as mudanças políticas ocorridas a partir de 25 de novembro de 1975, com o arrefecimento da situação política em Portugal, que criou uma conjuntura pouco favorável ao PCP. Nos primeiros tempos, a Caminho editava apenas o jornal $O$ Diário, que durou até 1990. A partir de abril de 1977 iniciou a edição de $\operatorname{livros}^{62}$.

"A Caminho tinha outras possibilidades de expansão" comparativamente à Avante!, assinala Melo, "porque uma editora de partido tem sempre limitações sobre o conteúdo dos livros, sobre sua orientação política, é a editora oficial, ao passo que uma editora progressista pode editar outras coisas" ${ }^{\prime 63}$.

A editora tinha uma estrutura autônoma, mas durante algum tempo teve uma produção “muito próxima, até coordenada com as Edições Avante!”, diz Melo.

A ligação com o PCP era aberta, o que não deixava de criar algumas limitações à editora. Zeferino Coelho faz menção à "forte conotação política" da editora como um "problema": "[...] era um rótulo a que não se conseguia fugir [...]. Nós tivemos esse problema, mas a ideia era construir uma editora onde se publicava toda a gente e não era preciso mostrar o cartão do Partido, mas onde também se podia trazê-lo e não o editarmos",64.

Zeferino Coelho definiu da seguinte maneira os objetivos da Editorial Caminho:

Quando iniciamos a publicação de livros, tínhamos como objetivo fomentar a difusão de obras com verdadeiro valor artístico e cultural, que exprimissem a nova realidade portuguesa criada após o 25 de Abril, que satisfizessem as novas necessidades criadas pelo processo revolucionário português. ${ }^{65}$

Essa ação foi marcada pela atuação da editora principalmente na área da literatura de ficção, portuguesa e estrangeira. A revista Notícias do Livro, de abril de 1979, destacava que a Caminho tinha "uma orientação literária de marcada preferência por autores que fazem da literatura o seu campo de luta ideológica" ${ }^{\text {. }}$.

\footnotetext{
${ }^{61}$ Entrevista com Francisco Melo, Lisboa, 1/2/2011.

62 Idem.

${ }^{63}$ Idem.

${ }^{64}$ CÉU E SILVA, João. Uma longa viagem com José Saramago. Porto: Porto Editora, 2009, p. 48-52.

${ }^{65}$ Ibidem.

${ }^{66}$ FERREIRA, Serafim. "Editor do mês. Entrevista com Zeferino Coelho (Editorial Caminho)". Notícias
} 
De fato, no período entre 1977 e o início da década de 1980, prevaleceram as coleções de caráter literário, como O Campo da Palavra, Uma Terra sem Amos e Letras, que publicavam basicamente ficção (romances, contos, poesia e teatro).

A coleção O Campo da Palavra publicou autores como António Ramos Rosa, Faure da Rosa, Orlando da Costa, Urbano Tavares Rodrigues, António Borges Coelho, Filipe Leandro Martins e Augusto Sobral. E na coleção Uma Terra sem Amos foram editadas obras de ficção com forte teor político, como, por exemplo: Primavera em Budapeste, de Ferenc Karinthy (1979); Assim foi temperado a aço, de Nikolai Ostrovski (1979); A luz que rompe das trevas, de Alex la Guma (1979); Os plátanos de Barcelona, de Victor Mora (1979); Insurreição, de Liam O’Flaherty (1980); Sob o jugo, de Ivan Vazov (1980); e A paixão de Sacco e Vanzetti, de Howard Fast (1982).

Tiveram importância também as coleções Nosso Mundo e Temas Políticos e Sociais, voltadas para obras sobre questões políticas da atualidade, seja portuguesa, seja internacional. Eis alguns dos títulos da coleção Temas Políticos e Sociais: Revolução e vida, de Miguel Urbano Rodrigues (1977); A reforma agrária em perigo, de Eugénio Rosa (1977); Portugueses na URSS. Entrevistas de Gina de Freitas (1977); O assassínio do general Humberto Delgado, de Pedro Ramos de Almeida (1978); O sistema colonial português em África, de Armando Castro (1978); e O julgamento da rede bombista, de Josué da Silva (1978).

E na coleção Nosso Mundo tivemos, entre outras obras: A política da luta armada: libertação nacional nas colónias africanas de Portugal, de Basil Davidson (1979); Catapulta para a liberdade: como sobrevivem os vietnamitas, de Wilfred Burchett (1979); Os segredos da censura, de César Príncipe (1979); e Constituição e revisão constitucional, de Vital Moreira (1980).

A editora foi organizada em moldes profissionais. Os livros eram editados com muito esmero gráfico e editorial. A distribuição era feita pela distribuidora CDL.

Um dos autores e colaboradores da editora desde seus primeiros tempos foi José Saramago, que veio a receber em 1998 o Prêmio Nobel de Literatura ${ }^{67}$. A parte mais significativa da obra de Saramago foi publicada pela Editorial Caminho, percurso que se iniciou em 1979 com a peça teatral A noite, à qual seguiram-se os romances Levantado do chão (1980) e Memorial do convento (1982), tendo continuado até os últimos anos

${ }^{67}$ ALMEIDA, Sérgio. "Zeferino Coelho, editor de sempre, destaca legado". Diário de Notícias, Lisboa, 19 jun. 2010. 
de vida do escritor. Mas Saramago não era apenas autor da casa, era também colaborador, tendo sido responsável por várias traduções editadas pela Caminho.

Entre 1977 e 1982, a Editorial Caminho editou mais de 80 títulos que podem ser considerados obras de caráter político, seja na área de ficção, seja na de não-ficção.

Em 2008 a Editorial Caminho foi adquirida pelo Grupo Leya, o maior grupo editorial português que congrega quase uma vintena de editoras e atua em Portugal, Brasil, Angola e Moçambique ${ }^{68}$.

\subsection{Livros Horizonte}

Rua das Chagas, $17,1^{\circ}$ dto. - Lisboa.

Editor: Rogério de Moura.

Fundação: 1953.

Distribuição: Expresso, Diglivros.

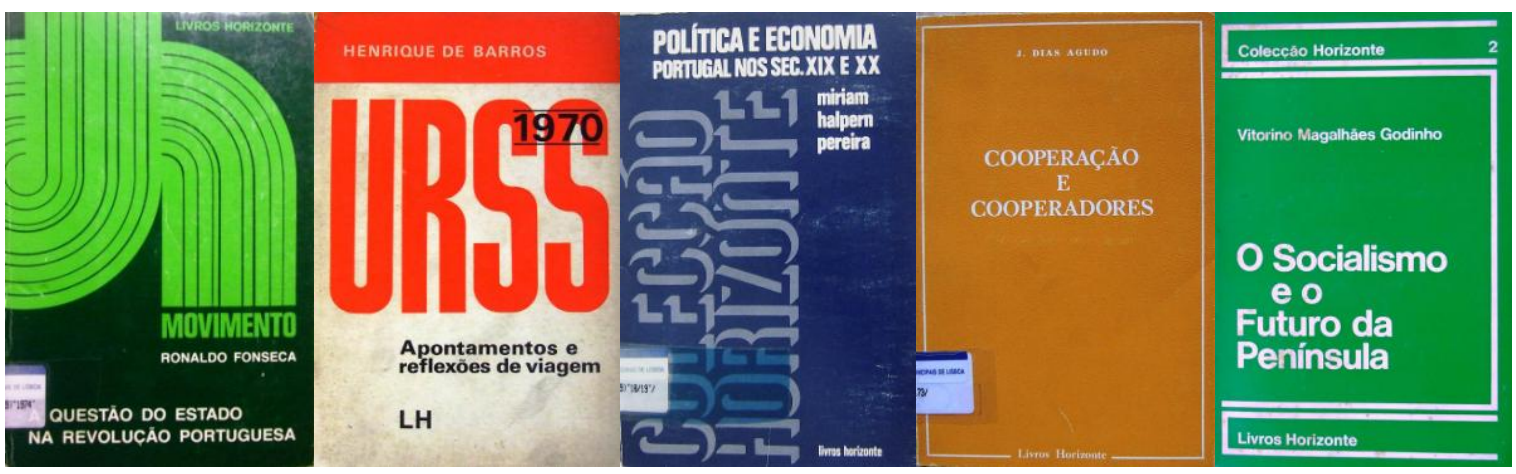

Editora criada a 11 de maio de 1953 em Lisboa por Rogério Mendes de Moura ${ }^{69}$, que viria a ser um dos mais importantes editores de Portugal no século XX. Interessado em criar uma editora, aos 28 anos de idade Rogério de Moura resolveu conhecer melhor o seu país e as livrarias que existiam.

Pegou na sua "carripana" da Peugeot e decidiu correr o País para visitar futuros colegas a quem ia fornecer livros. "Apresentava-me e dizia que queria saber como era a livraria deles, mas eles perguntavam 'então o que tem para vender?' e a minha resposta era sempre a mesma: 'agora nada, mas hei-de ter um dia'. Ficavam todos admirados,". 70

${ }^{68}$ DORIGATTI, Bruno. “Império português”. Página eletrônica Portal Literal, 24/3/2008. Disponível em: < http://portalliteral.terra.com.br/artigos/imperio-portugues >. Acesso em fev. 2011.

${ }^{69}$ MEDEIROS, Edição e editores, op. cit., p. 167.

${ }^{70}$ MARQUES, Vanda. "Vida dedicada aos livros". Diário de Notícias, Lisboa, 9 jun 2007. Disponível em: 〈http://dn.sapo.pt/inicio/interior.aspx?content_id=659043〉. Acesso em abr. 2011. 
Rogério Moura era irmão de Rui Moura, da Editora Prelo e das Edições Sociais, e de Mário Moura, que foi editor no Brasil e em Portugal.

Inicialmente, além da edição, a Livros Horizonte dedicou-se também à importação e distribuição de livros brasileiros, representando as editoras Fundação Getúlio Vargas, Casa dos Estudantes do Brasil e Fundo de Cultura ${ }^{71}$.

Desde o começo de suas atividades, seja como editor ou importador, Moura teve problemas com a polícia política, que apreendeu muitos dos livros que ele pôs à venda.

Membro do Partido Comunista Português, em 1956 Moura foi cofundador da Federação Portuguesa dos Cineclubes, e em 1958 participou da campanha de Humberto Delgado $^{72}$.

A editora dedicou-se às obras de estudos históricos, pedagogia, educação, história da arte e economia, entre outras áreas, com destaque para a cultura portuguesa. Sua marca registrada são as obras dedicadas ao público universitário. Posteriormente enveredou também pela literatura para a infância ${ }^{73}$.

Até os anos 1960, editou algumas obras de grande porte em fascículos, em função de questões econômicas e comerciais. Utilizava, nestes casos, um cadastro com cerca de 30 mil nomes aos quais eram enviados os primeiros fascículos da série. "Eram engenheiros, médicos, professores, arquitetos, etc. Quem queria ficar a receber, pagava a sua assinatura, quem não queria devolvia-nos o fascículo”, conta Rogério Moura ${ }^{74}$.

Duas das coleções mais importantes da Livros Horizonte sugiram na segunda metade dos anos 1960. Em 1967, a Biblioteca do Educador Profissional, inicialmente dirigida por Rogério de Moura e em seguida por Rui Grácio. Esta coleção “foi durante longos anos referência incontestada em termos da sua relevância, extensão e actualidade no domínio particular a que respeitava"75. E em 1969 teve início a Coleção Horizontes, dirigida por Joel Serrão, cujo programa de certa forma sintetizava os objetivos da própria editora, a saber:

O alargamento do público ledor de obras mais ou menos especializadas; a tomada de consciência, pelos seus leitores, dos mais

\footnotetext{
71 "Rogério Mendes de Moura - uma vida". Disponível em: <http://blogtailors.com/3937690.html>. Mário Moura, irmão de Rogério, era o editor no Brasil da Casa dos Estudantes do Brasil e da Fundo de Cultura. LEITE, op. cit..

72 SANTOS, Rogério. "A morte de Rogério de Moura". Disponível em: <http://industriasculturais.blogspot.com/2008/11/morte-de-rogrio-de-moura.html>. Acesso em abr. 2011.

${ }^{73}$ MEDEIROS, Nuno. Edição e editores..., op. cit., p. 167.

${ }^{74}$ Citado em LEITE, op. cit., p. 188. Ver também MEDEIROS, Edição e editores..., op. cit., p. 170-71.

${ }^{75}$ MEDEIROS, Edição e editores..., op. cit., p. 171.
} 
instantes problemas que se põem ao desenvolvimento de Portugal, considerado em todos os seus aspectos [e] contribuir para o desenvolvimento do país mediante o seu apetrechamento cultural e mental [que] só se logrará por uma sistemática prospecção, quer da sua história, quer do seu presente, norteada pela preocupação com o futuro de todos nós. ${ }^{76}$

A questão material e econômica, articulada à qualidade das obras, não é deixada de lado no programa da coleção:

Procurar-se-á alcançar o primeiro objectivo em vista mediante livros de preço acessível, de aspecto agradável e cuidado, mas sobretudo pela qualidade do texto. Aspira-se a que os livros da Coleção Horizonte figurem na Bibliotecas dos estudantes, dos autodidactas, mas também dos próprios especialistas - que sirvam os cultos e os que buscam sê-lo. ${ }^{77}$

Sobre este último ponto, Nuno Medeiros faz uma interessante observação:

A atuação assim demonstrada estilhaça a ideia de lirismo editorial inconsequente, fazendo depender a eficácia cultural da expansão de um mercado que a possa reflectir. O trabalho do 'editor-artífice', que Rogério Moura sempre foi, carece da imprescindível cobertura venal para a prossecução dos títulos seguintes. ${ }^{78}$

Editava também as coleções Movimento, Formação Cooperativa, Horizonte Universitário, Horizonte de Poesia, Horizonte Jurídico, Dialéctica, Obras Completas de Jaime Cortesão, Obras de Victor de Sá e Obras de Alexandre Cabral, entre outras.

A distribuição era feita primeiro pela Expresso, distribuidora da qual Rogério de Moura foi um dos fundadores ${ }^{79}$, e a partir de meados dos anos 1970 pela Diglivros.

Rogério de Moura procurou sempre trazer para a editora a colaboração de intelectuais e acadêmicos, de modo a garantir a qualidade das obras editadas e também a sua credibilidade. Nomes como os de Joel Serrão, Victor Sá, Oliveira Marques, Orlando Ribeiro e José-Augusto França, entre tantos outros, estão entre os colaboradores da editora $^{80}$.

Moura dava especial ênfase, em seu trabalho de editor, à sua atuação como instigador e motivador do surgimento de novos títulos, mediante a encomenda de obras aos autores: "O mais aliciante para mim é ter uma ideia, imaginar um projecto e

\footnotetext{
76 COLEÇÃO Horizontes. In: DRAIN, Michel. Geografia da Península Ibérica. Lisboa: Livros Horizonte, 1969. Citado em LEITE, op. cit., p. 189.

${ }^{77}$ Idem, ibidem. Grifo do original.

${ }^{78}$ MEDEIROS, op. cit., p. 172.

79 "Rogério Mendes de Moura - uma vida", op. cit.

${ }^{80}$ NUNES, Maria Leonor. "Os três mosqueteiros...", op. cit.
} 
convidar uma série de autores para o concretizarem. [...] $\mathrm{O}$ editor tem que procurar o autor e não apenas recebê-lo e ler os textos" $" 81$.

Além disso, ele lia "todos os originais, mesmo que sejam sobre assuntos que não domina". O que mais apreciava em seu trabalho era falar com os autores sobre as alterações que queria sugerir, além de "fazer a marcação do original para a tipografia, escolher o tipo de letra, as entradas e a capa" 82 . "É esse o quê de editor, acompanhar todo o processo de produção, e não apenas assinar papéis e fazer uma boa gestão", conclui Moura ${ }^{83}$.

Rogério de Moura foi também proprietário, por compra, das editoras Confluência e Gleba.

Foi eleito presidente da Direção do Grêmio Nacional dos Editores e Livreiros em 1972 e em maio de 1974 foi reconduzido ao cargo máximo da entidade, já então transformada em Associação Portuguesa de Editores e Livreiros (APEL) ${ }^{84}$.

Em 1980 deixou a Direção do Sector Intelectual do PCP e afastou-se do partido $^{85}$.

Desde sua fundação, a Livros Horizonte caracterizou-se por ter uma linha editorial definida, marcada pela qualidade e coerência dos títulos que editava e pela direção incontrastável de Rogério de Moura. Militante do PCP até 1980, Moura soube manter uma linha de publicações progressista, de esquerda e próxima ao programa comunista, mas sem "carimbar" a editora como uma casa do PCP e sem fechá-la a outros setores políticos e sociais. Mas, ao mesmo tempo, não se pode dissociar a Livros Horizonte e a figura de Rogério de Moura de sua vinculação ao PCP, pois era essa identidade que norteava o trabalho do editor e de sua editora.

Entre 1968 e 1980 a Livros Horizonte publicou centenas de livros, dos quais cerca de 70 podem ser considerados obras de caráter político. Em toda a sua trajetória, a editora publicou mais de mil títulos ${ }^{86}$. Rogério de Moura morreu em 23 de novembro de 2008 aos $83 \operatorname{anos}^{87}$. A editora continua em funcionamento.

\footnotetext{
${ }^{81}$ Citado em NUNES, Maria Leonor. "Os três mosqueteiros...”, op. cit.

${ }^{82}$ NUNES, Maria Leonor. "Os três mosqueteiros...", op. cit.

${ }^{83}$ Citado em NUNES, Maria Leonor. "Os três mosqueteiros...", op. cit.

84 "Rogério Mendes de Moura - uma vida". Disponível em: <http://blogtailors.com/3937690.html>.

${ }^{85}$ Idem.

86 “Historial". Disponível em: <http://www.livroshorizonte.pt/editora.php>. Acesso em jul. 2011.

${ }^{87}$ SILVA, José Mário. "Fundador da Livros Horizonte, publicou mais de 2000 livros em 55 anos de actividade". Expresso, Lisboa, 24/11/2008. Disponível em: <http://aeiou.expresso.pt/rogerio-mendes-demoura-1925-2008=f461530>. Acesso em jul. 2011.
} 


\subsection{Edições Sociais}

Alameda Santo António dos Capuchos, 6-B - Lisboa

Editor: Rui Moura.

Fundação: 1974.

Distribuição: CDL.

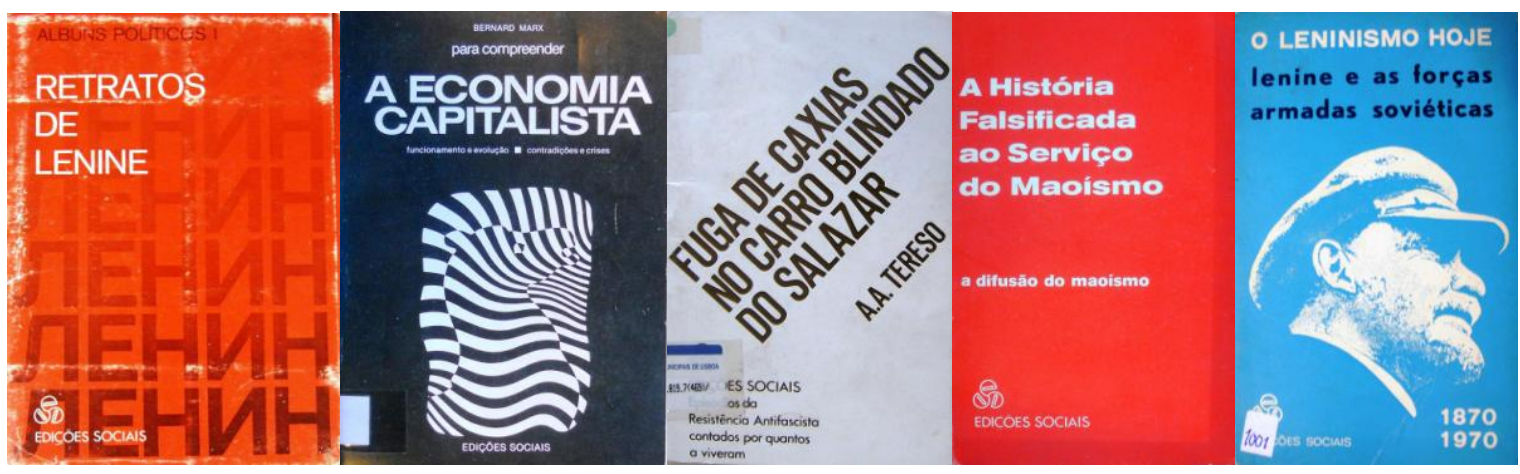

Editora criada em 1974 por Rui Moura, militante do PCP e um dos fundadores da Editora Prelo. Sua primeira edição parece ter sido o livro A farsa dos pseudoradicais em Portugal: estudo político e teórico sobre os grupos maoistas e trotskistas perante a revolução, de José Manuel Jara, lançado já em maio de 1974, ou seja, no mês seguinte ao 25 de Abril.

Rui Moura era irmão de Rogério de Moura, da Editora Livros Horizonte, e de Mário Moura, que foi editor no Brasil e em Portugal. De acordo com Rogério, Rui tinha "profunda formação histórica e política" e foi um autodidata que "aprendeu sozinho a ler e escrever francês e inglês [...]. Dedicou-se, ainda muito novo, à tradução, sobretudo de obras sociais e históricas" $" 88$.

Teve também forte militância política antifascista. "Esteve preso três vezes, a última das quais integrado no chamado caso da prisão dos economistas, com Guilherme Nascimento, Sá da Costa, Costa Leal e outros" ${ }^{\text {"89 }}$. Tal militância refletiu-se plenamente no trabalho das Edições Sociais, que teve "participação ativa no surto editorial militante pós-25 de Abril" 90.

Aliás, o próprio nome da editora já reflete a sua filiação política, pois traduz para o português o nome da francesa Éditions Sociales, tradicional editora de esquerda daquele país ligada ao Partido Comunista Francês ${ }^{91}$.

\footnotetext{
${ }^{88}$ NUNES, “Os três mosqueteiros...”, op. cit.

${ }^{89}$ Ibidem.

${ }^{90}$ MEDEIROS, Edição e editores, op. cit., p. 250.

${ }^{91}$ BOUJU, Marie-Cécile. "Les maisons d'édition du PCF, 1920-1956". Nouvelles FondationS, 3/2007 (n
} 
Os objetivos de combate político da editora aparecem claramente já no primeiro título publicado, voltado diretamente para o enfrentamento político com a extrema esquerda que anatematizava o PCP. Eis um trecho do prefácio desta obra:

A mistificação que estes grupos [maoistas e trotskistas] fazem em relação ao marxismo leva muito boa gente a, por vezes, com eles simpatizar. Pareceu-nos, pois, indispensável uma demarcação rigorosa entre o marxismo e as variantes pseudo-marxistas destes grupos.

Este texto teórico pretende ser um contributo para que todos possamos separar o trigo do joio com clareza, já que a utilização emblemática das "frases marxistas" lança o descrédito no socialismo científico e nos seus verdadeiros defensores. ${ }^{92}$

Este livro foi o primeiro volume da coleção Textos de Intervenção, que em seus dez volumes publicados tinha mais três dedicados ao enfrentamento com o maoismo: Maoísmo em Portugal: ideologia anarquista contra-revolucionária e paródia burguesa do marxismo, de José Manuel Jara (julho, 1975); A história falsificada ao serviço do maoísmo: a difusão do maoísmo, de F. Burlatski e outros (1975); e O maoísmo contra a cultura, de B. Bulatov (1975).

Nesta mesma coleção foram publicados também: Sobre a participação dos trabalhadores na empresa: estudo para reflexão sobre um tema que toma espaço na vida social portuguesa, de Sérgio Ribeiro (1974); A luta económica dos trabalhadores: estudo das formas da luta económica e da força política que é preciso para vencer, também de Sérgio Ribeiro (1974); Anarquistas de ontem e de hoje, de Jacques Duclos (1974); O marxismo e os caminhos do futuro, de Waldeck Rochet (1975); A opção socialista e a democracia nacional: perspectivas que oferece a opção socialista, de Nodari Simonia (1975); O sindicalismo mundial: o Estado de orientação socialista e a democracia, de Sérgio Ribeiro (1975).

Outra coleção importante foi Episódios da Resistência Antifascista Contados por Quantos a Viveram, dirigida por Franco de Sousa, cujo título é autoexplicativo. De acordo com o seu diretor, a coleção teria como autores "camponeses e operários, soldados e marinheiros, empregados de escritório e funcionários públicos, intelectuais e artistas [que] se bateram ao longo destes 48 anos para tornarem possível o 25 de

7-8), p. 260-265. Disponível em: <www.cairn.info/revue-nouvelles-fondations-2007-3-page-260.htm>. Acesso em mai. 2011.

92 "Prefácio". In: JARA. José Manuel. A farsa dos pseudo-radicais em Portugal: estudo político e teórico sobre os grupos maoistas e trotskistas perante a revolução. Lisboa: Edições Sociais, maio, 1974. 
Abril"93.

Esse objetivo de fato foi cumprido nos sete volumes editados, todos trazendo memórias/depoimentos de militantes do PCP, como por exemplo: A revolta dos marinheiros, de João Borda (1974); Fuga de Caxias no carro blindado do Salazar, de Antonio Alexandre Tereso (1974); Com a certeza de quem quer vencer, de Aida Paula (c1974); e A raiva de Salazar e da P.I.D.E. contra a unidade democrática representada por Humberto Delgado e outros episódios por mim vividos em 32 anos de luta antifascista, de António Horácio Simões de Abreu (1975).

Outras cinco coleções tiveram apenas um livro editado cada uma. São elas: O Leninismo Hoje, Combatentes do Povo, Dossier Revolução, Álbuns Políticos e a coleção Para Compreender. Houve também quatro títulos editados fora de coleções.

A edição de Retratos de Lenine, único volume lançado da coleção Álbuns Políticos, é interessante para entender um pouco o clima político vivido em 1974 e 1975 em Portugal. Não se trata de um livro, mas sim de um envelope cartonado no formato de um livro que contém um conjunto de nove cartões postais com fotos de Lenin. A edição não tem data, mas tudo leva a crer que deve ter sido lançada em 1974 ou 1975, anos em que a figura do revolucionário russo tornou-se popular no país, esgrimida por praticamente todos os grupos de esquerda comunistas.

Houve três títulos que tratavam de questões da conjuntura política portuguesa: Elementos para a compreensão do 25 de novembro, do capitão Duran Clemente (1976); e dois livros do capitão Diniz de Almeida: Origens e evolução do movimento de capitães: subsídios para uma melhor compreensão (1977) e Ascensão, apogeu e queda do M.F.A. , Vol. I (1979).

A distribuição dos livros das Edições Sociais era feita pela CDL.

A editora publicou 27 títulos entre 1974 e 1977. Pela análise dos títulos editados, podemos considerá-la uma das editoras políticas mais claramente voltadas para o combate político imediato no pós-25 de Abril, claramente alinhada às posições do PCP.

Após a experiência das Edições Sociais, Rui Moura lançou ainda a editora Politécnica, voltada para livros escolares ${ }^{94}$.

\footnotetext{
${ }^{93}$ SOUSA, Franco de. "Dedicatória ao povo português". In: BORDA, João. A revolta dos marinheiros. Lisboa: Edições Sociais, 1974.

${ }^{94}$ NUNES, "Os três mosqueteiros...", op. cit.
} 


\subsection{Manuel Rodrigues Xavier}

Rua Hélio Rego, 4-A - Venda Nova - Amadora

Editor: Manuel Rodrigues Xavier.

Fundação: 1971.
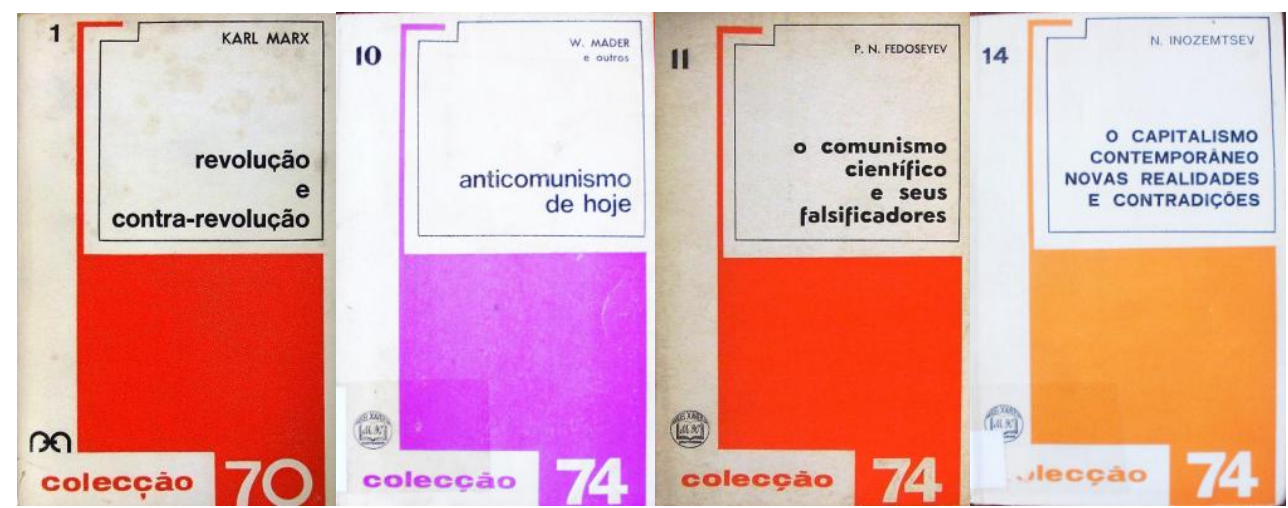

Editora criada, ao que tudo indica, em 1971, por Manuel Rodrigues Xavier, com sede na cidade de Amadora, na Grande Lisboa. Iniciou suas atividades editando alguns volumes selecionados da Colecção 70, originalmente publicada pela Editorial Grijalbo, do México.

Após o 25 de Abril reeditou a mesma coleção com o nome Colecção 74, à qual foram acrescentados alguns títulos.

A Colección 70 da Editorial Grijalbo teve início por volta de 1968 e era composta de livros de "ciências sociais, filosofia, ciências naturais, questões da atualidade e marxismo", entre as quais clássicos do chamado socialismo científico e obras de autores soviéticos e da Editorial Ciência (Hayka) da União Soviética ${ }^{95}$.

Entre os títulos publicados na coleção estavam: Revolução e contra-revolução, de Karl Marx (1971); Literatura, filosofia e realismo, de Máximo Gorki e A. Zdanov (1971); O papel do indivíduo na história, de Jorge Plakanov (1971); Escritos filosóficos e políticos, do Marquês de Sade (1971); A formação dos intelectuais, de António Gramsci (1972); Questões de política, de Stalin (1972) e Teoria da moral, de A. F. Shiskhin (1972). Todos estes volumes foram lançados primeiro na Colecção 70 e relançados na Colecção 74, após o 25 de Abril.

Esta coleção publicou ainda, entre outros títulos: $O$ anticomunismo de hoje, de W. Mader e outros (1974); O método na economia política, de Karl Marx (1974); O

95 "La 'Colección 70' de Editorial Grijalbo". Blogue Disidente del capitalismo. Disponível em: <http://disidentedelcapital.blogspot.com.br/2010/02/la-coleccion-70-de-editorial-grijalbo.html>. Acesso em jul. 2012. 
capitalismo contemporáneo: novas realidades e contradições, de N. Inozemtsev (1975).

As edições portuguesas da Colecção 70 e da Colecção 74 seguiam o mesmo desenho gráfico da capa da edição original da Grijalbo.

O texto da contracapa do livro O Comunismo científico e seus falsificadores, de P. N. Fedoseyev, mostra um pouco das intenções políticas que norteavam a editora. Inicialmente afirma que a obra "Expõe os esforços dos revisionistas para desdenharem do papel da classe operária no processo revolucionário mundial e mostra a natureza anticientífica dos seus "modelos de sociedade socialista"". E conclui: "Os ataques revisionistas ao papel dos Partidos Comunistas como guias na luta pela transformação socialista da sociedade são convincentemente refutados [na obra]"96.

Entre 1971 e 1975 Manuel Rodrigues Xavier editou cerca de 20 obras, todas de autores estrangeiros. Nenhuma obra sobre Portugal foi editada.

O trabalho editorial de Xavier teve continuidade ainda em 1975 com a criação da Novo Curso Editores, também de sua propriedade e sediada no mesmo endereço na cidade de Amadora (ver a seguir).

\subsection{Novo Curso Editores}

Rua Hélio do Rêgo, 4-A, Venda Nova - Amadora

Editor: Manuel Rodrigues Xavier.

Fundação: 1975.

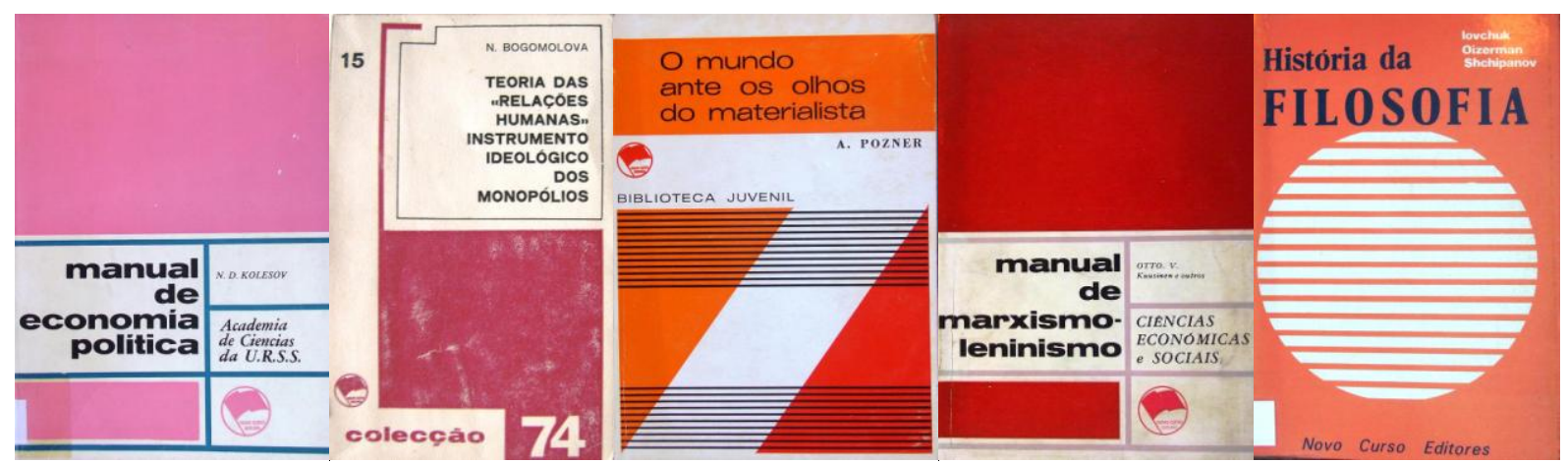

Fundada em 1975 por Manuel Rodrigues Xavier, esta editora deu continuidade ao trabalho desenvolvido por este editor desde 1971, como já visto. A linha editorial era a mesma, inclusive com a continuação da publicação da Colecção 74, iniciada por

${ }^{96}$ FEDOSEYEV, P. N. O comunismo científico e seus falsificadores. Colecção 74, vol 11. Amadora, Manuel Rodrigues Xavier, novembro, 1974. 
Xavier anteriormente. A coleção foi publicada até o volume 14 pela Editora Manuel Rodrigues Xavier, e os volumes 15 e 16 saíram pela Novo Curso.

Nesta nova fase da atuação de Manuel Rodrigues Xavier como editor ganham mais ênfase os livros de autores soviéticos ou originários dos países do socialismo real. Várias obras eram originais produzidos pela Academia de Ciências da União Soviética e/ou tinham o copyright da Agência Soviética para os Direitos de Autor.

Eis alguns dos livros publicados: Os fundamentos da filosofia marxista-leninista, sob a direção de F. V. Konstantinov (1975); Manual de marxismo-leninismo, de Otto V. Kuusinen e outros (1975); Ciências sociais na U. R. S. S. (1976); Manual de economia política, da Academia de Ciências da URSS (1977); Teoria geral marxista-leninista do Estado e do Direito, de N. G. Alexandrov e outros (1978); Economia política do subdesenvolvimento, de Tamás Szentes (1979); Introdução à psicologia social marxista, de Hans Hiebsch e Manfred Vorwerg (1980); Manual de materialismo dialéctico e histórico, de S. M. Kovalhov e outros (1980); A ciência do desenvolvimento: introdução à dialéctica, de $\mathrm{S}$. Stoliarov (1981).

Todos os livros editados eram de autores estrangeiros, sempre de países do bloco socialista. Nenhuma obra sobre Portugal foi editada, mas o livro Dialéctica do processo revolucionário, de I. Krassine, trazia um "Prefácio à edição portuguesa", que abordava algumas questões ligadas à realidade do país.

Entre 1975 e 1981 - ano em que as atividades da editora parecem ter cessado foram editados cerca de 15 títulos. 


\section{EDITORAS POLÍTICAS DE ESQUERDA - LIGADAS A GRUPOS DE EXTREMA ESQUERDA MAOISTAS}

Desde 1964, com o surgimento do Comitê Marxista-Leninista Português (CMLP) e da Frente de Acção Popular (FAP) como dissidências do PCP vinculadas ao maoismo, iniciou-se no país uma proliferação de grupos de extrema esquerda, boa parte deles maoistas. Com forte inserção nos meios estudantis, mas também com atuação em setores da emigração portuguesa e em determinados meios operários, estes grupos, de forte caráter sectário, sempre deram grande importância à imprensa e à edição de livros, sendo responsáveis pela criação de dezenas de editoras ${ }^{1}$.

Os títulos publicados por essas editoras se enquadram na linha política e ideológica dos grupos marxistas-leninistas (m-1)/maoistas, de defesa do que chamam de democracia popular, da ditadura do proletariado, de crítica à União Soviética ("revisionista", "social-fascista", "social-imperialista") e ao seu principal representante português, o PCP. A atuação dessas editoras era sempre estreitamente vinculada aos grupos aos quais elas estavam ligadas, e os livros editados visavam ser instrumentos de combate político direto e de formação de sua militância. Assim, são editoras em que o fator político é primordial e se sobrepõe aos demais, enquadrando-se na definiçãa de editoras políticas militantes que apresentei no Capítulo 1.

O grande número de editoras ligadas ao grupos maoistas - são 25 no total reforça a ideia de que a esquerda privilegia os livros e a imprensa como instrumentos fundamentais da sua atuação política, como já destacado quando da apresentação das editoras ligadas ao PCP.

\footnotetext{
${ }^{1}$ Os trabalhos referenciais sobre o maoismo em Portugal, e que serviram de base para muitas informações relacionadas às editoras mencionadas neste tópico, são: PEREIRA, José Pacheco. O um dividiu-se em dois: origens e enquadramento internacional dos movimentos pró-chineses e albaneses nos países ocidentais e em Portugal (1960-65). Lisboa: Aletheia, 2008; CORDEIRO, José Manuel Lopes. Verbetes "Extrema-Esquerda", "Maoísmo", "Movimento Reorganizativo do Partido do Proletariado (MRPP)", "Organização Comunista Marxista-Leninista Portuguesa (OCMLP)" e "Partido Comunista de Portugal (marxista-leninista) (PCP M-L)”. In: BARRETO, António; MÓNICA, Maria Filomena (coords.). Dicionário de História de Portugal (Suplementos). Porto: Livraria Figueirinhas, vol.7, 8 e 9, 1999-2000; CARDINA, Miguel. Margem de certa maneira: o maoísmo em Portugal (1964-1974). Tese de Doutorado em História, Faculdade de Letras da Universidade de Coimbra, 2010 (Editado em livro em 2011 com o mesmo título pela editora Tinta da China, de Lisboa.); e CARDINA, Miguel. A esquerda radical. Coimbra, Angelus Novus, 2010. Ver também: CORREIA, Helder Manuel Bento. Comité MarxistaLeninista Português: Breve história de uma organização política (1964-1975). Mimeogr., Portimão, 2000; Página eletrônica Ephemera, Biblioteca e arquivo de José Pacheco Pereira: <http://ephemerajpp.wordpress.com/indice-geral/editoras-revolucionarias/>.
} 
Apresento a seguir um histórico da atuação dessas editoras, a partir de sua vinculação aos grupos de extrema esquerda maoistas.

5.1 Partido Comunista de Portugal (marxista-leninista) - PCP(m-1)-Vilar/ Comitê Marxista-Leninista Português (CMLP)

\subsubsection{Edições do Partido}

Rua Casal dos Ossos, $n^{\circ} 2,1^{\circ}$ - Perô-Pinheiro - Sintra

"Proprietário e director: M. R. Luís"

Fundação: 1970.

Distribuição: proLibris.
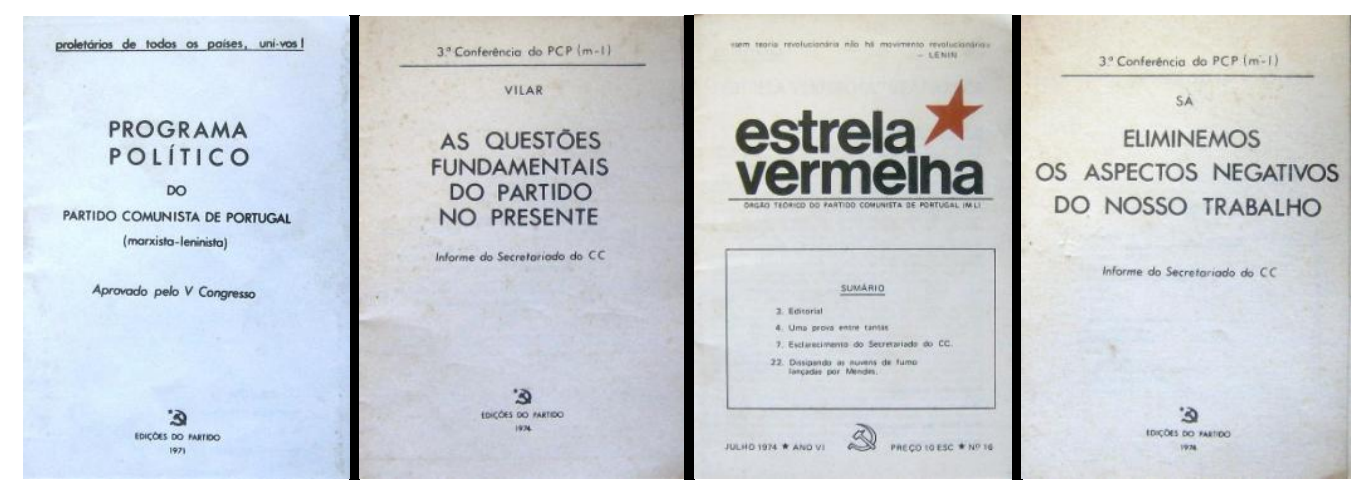

Editora vinculada ao Partido Comunista de Portugal (marxista-leninista)/PCP(m1), criado clandestinamente em 1970 a partir do Comitê Marxista-Leninista Português (CMLP). A editora também surgiu nesse $a^{2}{ }^{2}$, ou seja, atuava inicialmente de forma clandestina.

De 1971 até o primeiro semestre de 1974 foram editados 47 livros, a maior parte deles documentos do Comitê Central do partido, além de documentos do Partido Comunista da China, obras de Lenin e Mao Tsé-tung. Todos os títulos são diretamente ligados à luta política na qual o $\mathrm{PCP}(\mathrm{m}-\mathrm{l})$ pretendia atuar.

Eis, a título de exemplo, alguns dos títulos editados: A expulsão dum membro do $C C$ do P“C” $P$; $O$ abandono da aliança operário-camponesa - Expressão do abandono da revolução; A propósito do socialismo burocrático e autoritário; Tracemos uma linha de demarcação extremamente clara entre marxistas-leninistas e revisionistas Documento de crítica ao castrismo; Sobre o partido revolucionário do proletariado de

\footnotetext{
${ }^{2}$ CORDEIRO, José Manuel Lopes. "Partido Comunista de Portugal (marxista-leninista) [PCP(m-l)]". Verbete. In: BARRETO; MÓNICA, op. cit., Vol. 9, p. 22-24.
} 
tipo novo, de V. I. Lenin; Revisionismo em nova embalagem - A burguesia radical do jornal "O Comunista” faz concorrência ao revisionismo de Cunhal; e Stalin, o amigo do povo chinês, seguido de A amizade mais profunda, de Mao Tsé-tung.

De acordo com informação de José Manuel Lopes Cordeiro, alguns destes 47 volumes não chegaram a ser efetivamente publicados, tendo sido apenas anunciados ${ }^{3}$. Mas a grande maioria foi publicada. Os livros eram pequenas brochuras, grampeadas, com acabamento gráfico semiprofissional. A distribuição era feita pela distribuidora proLibris (ver abaixo).

Editava também a revista Estrela Vermelha - orgão teórico do CMLP até o número 8 (março de 1971), e do PCP(m-l) a partir do número 9 (outubro de 1971) -, que teve 15 edições clandestinas de janeiro de 1969 até o 25 de Abril ${ }^{4}$, e continuou a ser publicada a partir de julho de 1974.

O PCP(m-l) teve ainda outra editora. A partir do segundo semestre de 1974 (setembro/outubro), foi criada a Edições Seara Vermelha (ver adiante). E desde junho de 1973 surgiu a revista Seara Vermelha, editada inicialmente em Paris.

Em março/abril de 1974 houve uma cisão no $\mathrm{PCP}(\mathrm{m}-1)$, em virtude de divergências políticas que vinham desde $1972^{5}$. Passam, então, a existir dois PCP(m-1), um liderado por "Vilar" (Heduíno Gomes), e outro por "Mendes" (Carlos Janeiro). Durante cerca de um ano manteve-se essa singular situação, com os dois grupos usando a mesma denominação de $\mathrm{PCP}(\mathrm{m}-\mathrm{l})$ e editando jornais e boletins também homônimos.

Tal situação atingiu durante algum tempo também as Edições do Partido, pois chegou a haver títulos (não mais que três) editados com este selo mas sob a responsabilidade do $\mathrm{PCP}(\mathrm{m}-\mathrm{l}) / \mathrm{Mendes}^{6}$.

Apesar disso, a Edições do Partido original permaneceu sob o controle do grupo do PCP(m-1) liderado por "Vilar", assim como a Seara Vermelha.

No âmbito do PCP(m-l)/Vilar, as Edições do Partido eram a editora voltada basicamente para a publicação de documentos partidários e para debates político/teóricos mais restritos aos militantes, tendo atuado a maior parte do tempo na cladestinidade. Pouco depois do 25 de Abril, com a atuação pública do $\mathrm{PCP}(\mathrm{m}-1)$ e sua posterior legalização, ao que tudo indica as Edições do Partido deixaram de publicar,

\footnotetext{
${ }^{3}$ Mensagem eletrônica de José Manuel Lopes Cordeiro, 11/6/2011.

${ }^{4}$ CARDINA, Margem de certa maneira, op. cit., p. 83; CORREIA, op. cit., p. 23.

${ }^{5}$ CORDEIRO, José Manuel Lopes. "Glossário dos anos do PREC... e de alguns mais". In: FREITAS, José Gualberto de Almeida. A guerra dos cartazes. Lisboa: Lembrabril, 2009, p. 121-122.

${ }^{6}$ Mensagem eletrônica de José Manuel Lopes Cordeiro, 11/6/2011.
} 
encerrando suas atividades editoriais no final do primeiro semestre de 1974 . O PCP(m1)/Vilar criou então a Edições Seara Vermelha (que veremos a seguir), que procurava ter uma linha de publicações de caráter um pouco mais amplo, apesar de predominarem ainda os títulos de caratér político-ideológico.

Em alguns livros consta a seguinte informação: "Proprietário e diretor: M. R. Luís”. Não foi possível identificar esta pessoa, ou mesmo saber se era um nome verdadeiro ou um pseudônimo.

$\mathrm{O}$ PCP(m-l)/Vilar vinculava-se também à distribuidora de livros proLibris, da qual aparecem anúncios em várias edições do jornal do partido, o Unidade Popular. A proLibris distribuía as seguintes publicações e editoras: Unidade Popular, órgão central do PCP (m-1); Estrela Vermelha, órgão teórico do PCP (m-1); Seara Vermelha, revista marxista de política e cultura; Edições Seara Vermelha; Juventude Vermelha, órgão da Federação das Juventudes Comunistas de Portugal (m-1); Catarina, órgão da União das Mulheres Trabalhadoras de Portugal; Edições Pequim; Edições Tirana.

Os anúncios informavam ainda que a proLibris distribuía "revistas e outras publicações chinesas e albanesas" ${ }^{7}$.

O PCP(m-l)/Vilar é o partido com esta denominação que permaneceu ainda por algum tempo no panorama político do país, tendo o $\mathrm{PCP}(\mathrm{m}-1) / \mathrm{Mendes}$ se dissolvido em abril de $1975^{8}$. O PCP(m-l) foi a única organização marxista-leninista portuguesa "a ser reconhecida pelo Partido Comunista da China como 'partido irmão', desde 1975"9.

\subsubsection{Edições Seara Vermelha}

Av. De Berna, 20, $4^{\circ}, \mathrm{dt}^{\circ}$ - Lisboa.

Fundação: 1974.

Distribuição: proLibris.

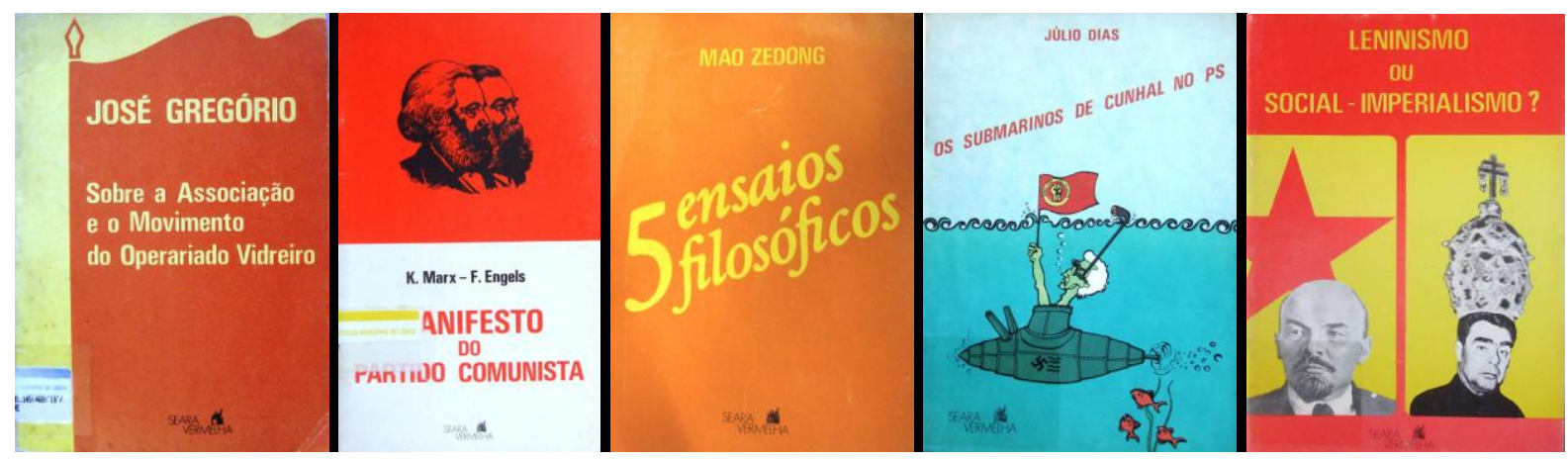

\footnotetext{
${ }^{7}$ Coleção dos jornais Unidade Popular. Biblioteca-Museu República e Resistência, Lisboa.

${ }^{8}$ CORDEIRO, "Partido Comunista de Portugal (marxista-leninista) [PCP(m-l)]", op. cit.

9 CORDEIRO, "Glossário dos anos do PREC...", op. cit., p. 121-122.
} 
Também ligada ao PCP(m-1)/Vilar, as Edições Seara Vermelha foram criadas no segundo semestre de 1974 (setembro/outubro) para substituir a extinta Edições do Partido. O primeiro livro publicado foi Proclamação-Programa dos comunistas (Bolcheviques) revolucionários soviéticos. Em matéria no jornal do $\mathrm{PCP}(\mathrm{m}-\mathrm{l}) / \mathrm{Vilar}$ Unidade Popular, a obra foi assim recomendada: "Este livro deve ser lido por todos os comunistas e divulgado no seio da classe operária pois ele é [...] uma arma acerada contra os revisionistas de [Álvaro] Cunhal [...]" ${ }^{\prime 10}$. Aliás, o título dessa matéria revela qual é o programa das Edições Seara Vermelha: "Biblioteca marxista".

A editora ambicionava, portanto, que suas obras fossem úteis para os embates políticos do momento, como sugere o comentário ao livro Sobre a edificação do Partido, de José Gregório - operário vidreiro dirigente do PCP e um dos líderes da greve inssurreccional de 18 de Janeiro de 1934 -, publicado no jornal do PCP(m1)/Vilar. Tratava-se, de acordo com o jornal, de “[...] obra de grande importância para os comunistas e para a classe operária portuguesa, no momento particular de luta que atravessamos"11.

Os autores com maior número de obras editadas foram Mao Tsé-tung e Stalin (sete títulos cada um), havendo ainda obras de Marx, Engels e Ho Chi Minh, e dos portugueses José Gregório, Heduíno Gomes/Vilar (dois títulos cada) e Júlio Dias.

Eis alguns títulos publicados: Princípios do comunismo, de F. Engels (1975); Manifesto do Partido Comunista, de Marx e Engels (1975); Sobre a propaganda e Sobre a organização, de Mao Tsé-tung (1977); Os submarinos de Cunhal no PS; seguido de Os cabeças de gis do social imperalismo russo, de Júlio Dias (1977); Dois anos a contracorrente: informe apresentado ao VII Congresso do Partido Comunista de Portugal (M-L), de Heduíno Gomes/Vilar (1977); Como escolhi o leninismo, de Ho Chi Minh; Trotskismo ou leninismo?, de Stalin; Stalin, o homem do socialismo, da vitória e da paz, de V. Molotov (1977).

Como vimos, pouco depois do 25 de Abril o $\mathrm{PCP}(\mathrm{m}-\mathrm{l}) /$ Vilar parece ter cessado as publicações da sua editora dos tempos de clandestinidade, as Edições do Partido, tendo então criado as Edições Seara Vermelha, que buscavam ter uma linha de publicações de caráter um pouco mais amplo, apesar de todos os títulos terem marcado

\footnotetext{
10 "Biblioteca marxista". Unidade Popular, Lisboa, no 30, outubro, 1974, p. 5.

11 "Biblioteca Marxista: José Gregório - Sobre a edificação do Partido". Unidade Popular, Lisboa, no 33, 31/10/1974, p. 2.
} 
teor ideológico.

A Seara Vermelha publicou, por exemplo, dois títulos de literatura, mas, de acordo com a visão política da editora, tratava-se de literatura engajada chinesa: $A$ estrela vermelha, de Li Sitian (1975) e Numa comuna popular, de Zhu Li e Tian Shieyun (1975).

Os livros das Edições Seara Vermelha tinham um tratamento editorial e gráfico profissional, sendo que parte deles eram brochuras grampeadas, mas com bom acabamento e boa apresentação gráfica. A distribuição era feita pela distribuidra proLibris (ver o item sobre as Edições do Partido).

O PCP(m-l) publicava, desde junho de 1973, a revista Seara Vermelha, cujos dois primeiros números foram editados em Paris.

A editora atuou provavelmente de 1974 a 1978, período em que publicou cerca de 45 títulos.

5.2 Partido Comunista de Portugal (marxista-leninista) - PCP(m-1)-Mendes / Comitê Marxista-Leninista Português (CMLP)

\subsubsection{Edições Unidade Popular}

Lisboa

Editora: Beatriz Oliveira M.

Fundação: 1974.
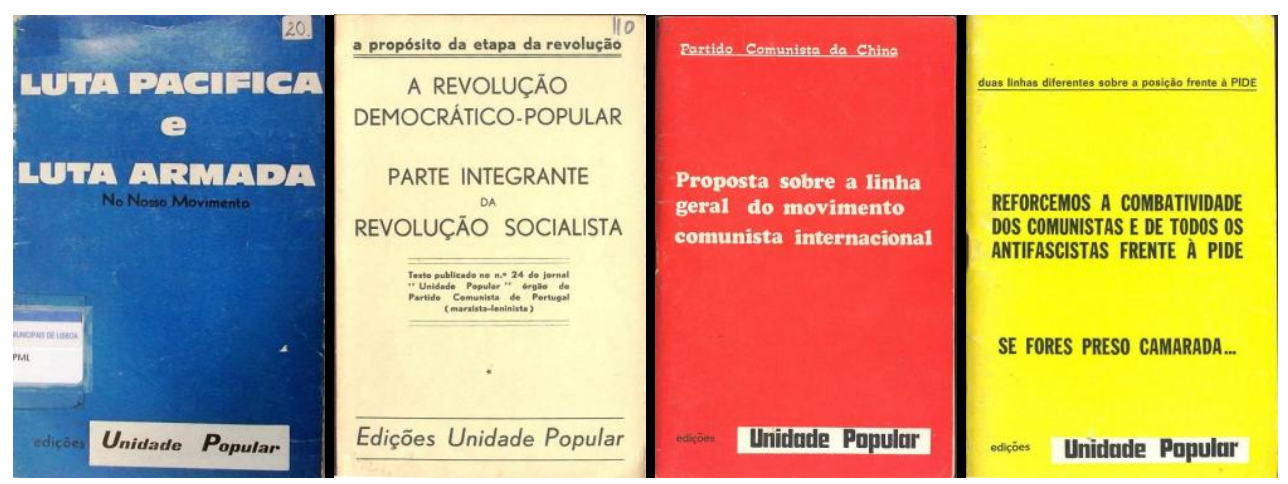

Editora ligada ao Partido Comunista de Portugal (marxista-leninista)/PCP(m1)/Mendes, depois da cisão do $\operatorname{PCP}(\mathrm{m}-\mathrm{l})$ em duas facções, uma liderada por "Vilar" (Heduíno Gomes), e outra por "Mendes" (Carlos Janeiro), em março/abril de 1974 (ver item sobre as Edições do Partido). Unidade Popular era também o nome do jornal, 
criado em março de 1969, do Comitê Marxista-Leninista Português (CMLP), o qual em agosto de 1970 transformou-se no $\mathrm{PCP}(\mathrm{m}-\mathrm{l})^{12}$.

A editora teve uma atuação efêmera, provavelmente somente em 1974 e começos de 1975, tendo editado, ao que tudo indica, apenas quatro títulos: Proposta sobre a linha geral do movimento comunista internacional, documento do Partido Comunista da China (1974); Luta pacífica e luta armada no nosso movimento, de Francisco Martins Rodrigues (outubro, 1974); Reforcemos a combatividade dos comunistas e de todos os antifascistas frente à PIDE / Se fores preso camarada... Duas linhas diferentes sobre a posição frente à PIDE (novembro, 1974); e A revolução democrático-popular, parte integrante da revolução socialista. A propósito da etapa da revolução $(\mathrm{s} / \mathrm{d})$.

No livro Luta pacífica e luta armada no nosso movimento aparece o nome de "Beatriz Oliveira M.” como diretora da Edições Unidade Popular. Infelizmente, não foi possível identificar esta pessoa ou saber se era um nome verdadeiro ou um pseudônimo.

Os livros da editora eram pequenos cadernos grampeados, mas apresentavam cuidado gráfico e editorial profissional. Não há indicação de como era feita a distribuição comercial dos livros.

O PCP(m-1)/Mendes abandonou esta denominação em abril de 1975 e retomou o nome de Comitê Marxista-Leninista Português (CMLP) ${ }^{13}$ (ver o próximo item). Com isso, parece também ter cessado a atividade das Edições Unidade Popular.

\subsubsection{Edições Militão Ribeiro}

Início das edições: 1975.

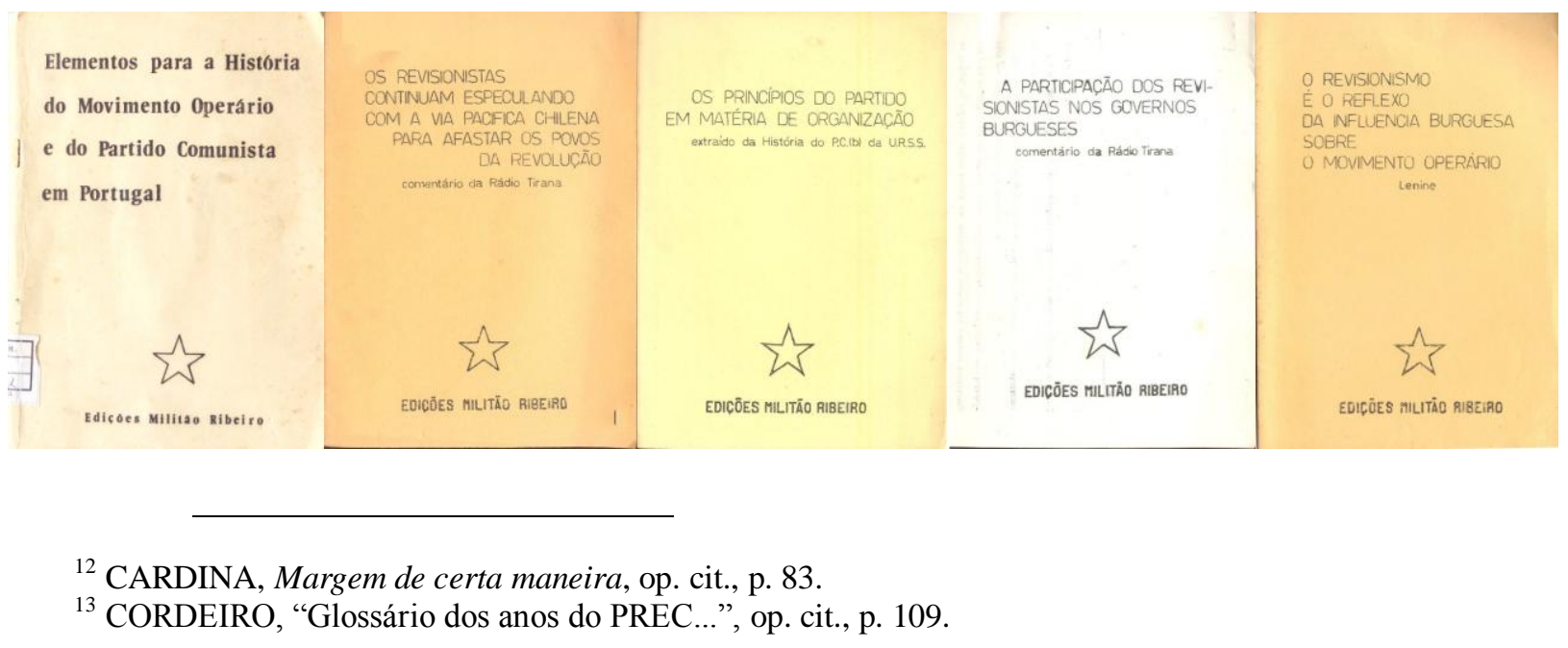


Editora também ligada ao Partido Comunista de Portugal (marxistaleninista)/PCP(m-1)/Mendes. José Manuel Lopes Cordeiro diz que “As Edições Militão Ribeiro não tinham existência legal como editora, e existiram desde janeiro a abril de 1975, ou seja, até ao fim do PCP (m-l)/Mendes, quando voltou a denominar-se CMLP"14.

O nome da editora é uma homenagem ao histórico dirigente do $\mathrm{PCP}$, preso pela PIDE em 1949, juntamente com Álvaro Cunhal e Sofia Ferreira, e assassinado na Penitenciária de Lisboa em 2 de Janeiro de $1950^{15}$.

De acordo com Cordeiro: "Na altura os livros dessa editora tiveram uma difusão reduzida, e o número de exemplares de cada título também deve ter sido pequeno (talvez com excepção do livro de Francisco Martins Rodrigues)"16, intitulado Elementos para a história do movimento operário e do Partido Comunista em Portugal.

Este livro trazia uma "Introdução", datada de janeiro de 1975 e assinada por "Os Editores", que expunha os objetivos da editora:

Com a presente edição [...] pretende-se contribuir para o debate político actualmente em curso no nosso país sobre a via para colocar à cabeça da classe operária portuguesa um sólido Partido Comunista (marxista-leninista) [...], abrindo-lhe caminho para a tomada do poder, para a instauração da ditadura do proletariado e a construção do Socialismo e do Comunismo. ${ }^{17}$

Além deste título, foram editados três livros que reproduziam comentários emitidos pela Rádio Tirana, da Albânia, ou seja, eram documentos produzidos pelo Partido do Trabalho da Albânia. Estes livros são: Os revisionistas continuam especulando com a via pacífica chilena para afastar os povos da revolução; $A$ participação dos revisionistas nos governos burgueses; e A fachada democrática e a realidade portuguesa.

Os outros dois títulos publicados que localizei ${ }^{18}$ foram: $O$ revisionismo é o

\footnotetext{
${ }^{14}$ Mensagem eletrônica de José Manuel Lopes Cordeiro enviada em 2/2/2013.

15 “Militão Ribeiro". Página eletrônica da União de Resistentes Antifascistas Portugueses (URAP).

Disponível em: < http://www.urap.pt/index.php?option=com_content\&task=view\&id=294\&Itemid=37> . Acesso em 2/2/2013.

${ }^{16}$ Mensagem eletrônica de José Manuel Lopes Cordeiro enviada em 2/2/2013.

17 "Introdução". In: Elementos para a história do movimento operário e do Partido Comunista em Portugal. Edições Militão Ribeiro, 1975.

${ }^{18}$ No blogue Ephemera estão reproduzidas as capas dos seis livros aqui citados. Cf. em: $<$ http://ephemerajpp.com/2009/05/26/editoras-revolucionarias-5-edicoes-militao-ribeiro/>. Acesso em $1 / 2 / 2013$.
} 
reflexo da influência burguesa sobre o movimento operário, de Lenine; e Os princípios do partido em matéria de organização, texto extraído da História do PC(b) da URSS.

Os livros apresentavam padrão gráfico amador, sendo os textos datilografados e os livros grampeados. "Nenhum dos volumes foi editado em tipografia, sendo impressos com base em stencil e policopiados" $" 19$.

A editora deixou de atuar em abril de 1975.

\subsubsection{Edições A Verdade}

Lisboa

Fundação: 1975.
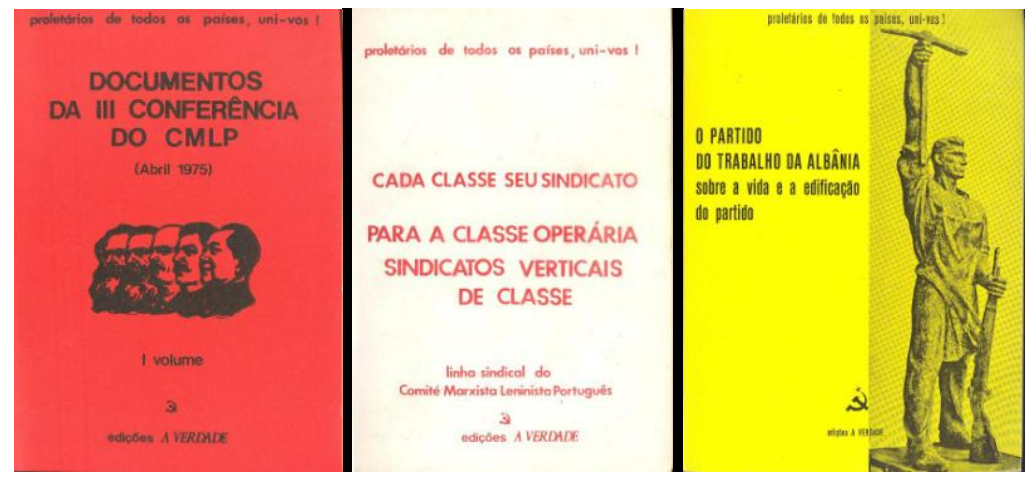

Editora vinculada ao Comitê Marxista-Leninista Português (CMLP), grupo originalmente criado em 1964 e refundado em abril de 1975, quando o setor do Partido Comunista de Portugal (Marxista-Leninista)/PCP(m-l) liderado por Carlos Janeiro ("Mendes") retomou a denominação de $\mathrm{CMLP}^{20}$. Tinha como organização frentista o Partido de Unidade Popular (PUP), cujo jornal intitulava-se A Verdade ${ }^{21}$.

As Edições A Verdade parecem ter sido a substituta das Edições Unidade Popular e das Edições Militão Ribeiro, que eram editoras do PCP(m-1)/Mendes, e que deixaram de atuar quando o partido reassumiu o nome de CMLP.

Em anúncio publicado no jornal $A$ Verdade, de julho 1975, definia-se o programa da editora:

Dado o estado de desorganização das fileiras marxistas-leninistas portuguesas, as edições A VERDADE vão-se preocupar sobretudo na divulgação de propaganda comunista. Por um lado, será através delas

\footnotetext{
${ }^{19}$ Mensagem eletrônica de José Manuel Lopes Cordeiro enviada em 2/2/2013.

${ }^{20}$ CORDEIRO, “Glossário dos anos do PREC...", op. cit., p. 109.

${ }^{21}$ CORREIA, op. cit., p. 28; ALMEIDA, Nuno Ramos de. "Reuni muitas vezes com um capuz enfiado na cabeça. Entrevista com José Pacheco Pereira”. Jornal i, Lisboa, nº 673, 2/7/2011, p. 18-20. Disponível em: <http://www.ionline.pt/conteudo/134127-pacheco-pereira-reuni-muitas-vezes-com-um-capuzenfiado-na-cabeca>. Acesso em julho de 2011.
} 
que os comunistas do CMLP exporão duma forma detalhada os seus pontos de vista e as suas tarefas; por outro lado, serão também devidamente demarcadas, nestas edições, quais as principais divergências entre nós e as outras organizações marxistas-leninistas; finalmente, serão divulgados alguns textos dos grandes dirigentes marxistas-leninistas que pela sua atualidade mereçam prioridade. ${ }^{22}$

Os cinco títulos publicados pela editora, todos em 1975, foram os seguintes: Documentos da III Conferência do Comité Marxista-Leninista Português, volumes I e II; O Partido do Trabalho da Albânia: sobre a vida e a edificação do partido; Cada classe seu sindicato. Para a classe operária sindicatos verticais de classe (linha sindical do CMLP); Lutemos contra os espiões e provocadores. Breve históra de alguns casos de provocação no PCP segundo o original de edições Avante!, Dezembro de 1952.

Um comentário sobre o livro O Partido do Trabalho da Albânia: sobre a vida e a edificação do partido deixa claro como o CMLP se espelhava naquele partido para orientar a sua linha de atuação política:

Através destes textos [publicados no livro] se compreende a luta dos comunistas albaneses pela construção do Partido, as dificuldades com que se depararam na unificação dos grupos comunistas [...] a luta pela revolução e contra o espírito de grupo, contra o fraccionismo e o liquidacionismo e pela edificação de um partido leninista regendo-se pelas normas do centralismo democrático. $\mathrm{Na}$ altura em que os comunistas portugueses se preparam para reconstruir o seu partido, a experiência dos camaradas albaneses neste campo, assim como no campo das formas de organização, dos métodos e estilo de trabalho e da vida interna do partido, é uma experiência preciosa. ${ }^{23}$

Os livros publicados tinham qualidade gráfica e editorial profissional, apesar de serem simples. A editora possuía uma livraria na sede da organização. Não foi possível apurar se havia distribuição comercial dos livros.

Em fins de 1975 o CMLP participou da criação do Partido Comunista Português (Reconstruído)-PCP(R), que fundou as Edições Bandeira Vermelha. Assim, as Edições A Verdade parecem ter estado em atividade apenas no ano de 1975, pois suas funções foram assumidas pela nova editora criada pelo $\mathrm{PCP}(\mathrm{R})$.

\footnotetext{
${ }^{22}$ Anúncio das Edições A Verdade. A Verdade, Lisboa, no 11, série II, $3^{\mathrm{a}}$ semana, jul. 1975.

23 "Edições A Verdade". A Verdade, Lisboa, nº 21, série II, out./nov. 1975.
} 


\subsection{Organização Comunista Marxista-Leninista Portuguesa (OCMLP)}

\subsubsection{Edições O Grito do Povo}

Rua Senhora da Luz - Foz do Douro - Porto

Fundação: 1973.

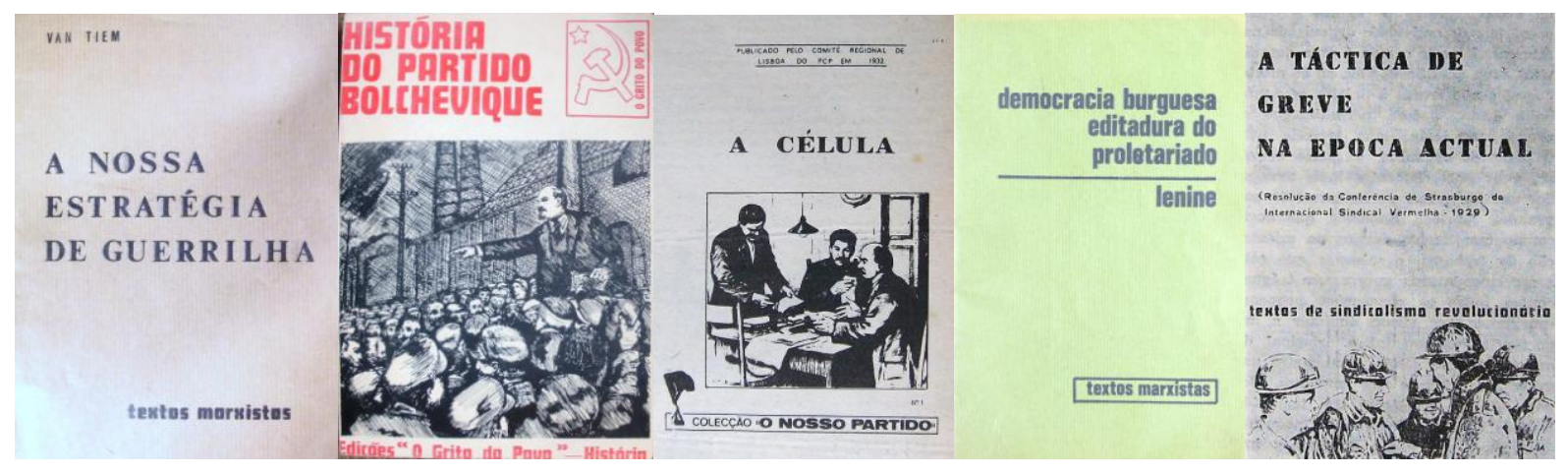

Ligada ao jornal homônimo, fundado no Porto em dezembro de 1971, que a partir de março de 1973 tornou-se porta-voz da Organização Comunista MarxistaLeninista Portuguesa (OCMLP) ${ }^{24}$. Até a primeira dissolução da OCMLP, em abril de 1976, quando grande parte dos seus militantes se integrou no Partido Comunista Português (Reconstruído) $[\mathrm{PCP}(\mathrm{R})]^{25}$, as Edições O Grito do Povo publicaram a coleção Textos Marxistas, com 20 volumes, alguns livros avulsos e a revista MCI (quatro edições até 1976).

A edição da coleção Textos Marxistas, a principal coleção da editora, começou ainda antes do 25 de Abril $^{26}$, ou seja, eram inicialmente edições clandestinas.

Em um anúncio desta coleção no ano de 1974, e já após o fim da ditadura, há como que uma declaração de princípios e de intenções dos editores em relação aos livros que publicam:

A classe operária tem hoje uma arma poderosa para combater a burguesia: as experiências de luta de milhões de trabalhadores teorizadas pelos mais destacados dirigentes do proletariado - Marx, Engels, Lenine, Estaline e Mao-Tsetung. O marxismo-leninismo é uma ciência que explica as leis de funcionamento da sociedade, e pela qual nos devemos guiar para lutar vitoriosamente contra o capitalismo. TEXTOS MARXISTAS são pequenas brochuras que abordam os problemas que neste momento são mais importantes para a luta dos trabalhadores. UM TRABALHADOR ARMADO DO

\footnotetext{
${ }^{24}$ CARDINA, Margem de certa maneira, op. cit., p. 125 e 138.

${ }^{25}$ CORDEIRO, “Glossário dos anos do PREC...", op. cit., p. 115.

26 “Textos Marxistas”. O Grito do Povo, Porto, no 15, jul. 1973, p. 13.
} 


\section{CONHECIMENTO DO MARXISMO-LENINISMO É MAIS SÁBIO QUE UMA CARRADA DE DOUTORES. ${ }^{27}$}

A "Introdução" de uma obra editada em maio de 1975, da coleção Textos de Sindicalismo Revolucionário, reforça a ideia de que os livros eram vistos como instrumentos diretamente voltados para a luta concreta a ser travada: "Esta pequena brochura é primeiro que tudo um manual de combate para os trabalhadores que nos seus locais de trabalho se lançam na luta contra a burguesia"28.

Na coleção Textos Marxistas predominavam alguns dos principais pensadores marxistas: Lenin (o mais editado, com oito títulos), Stalin, Marx, Engels e Mao Tsétung. Eis alguns títulos: O papel do trabalho na transformação do macaco em homem, de Engels; A nossa estratégia da guerrilha, de N. Van Tiem; Socialismo e religião, de Lenin; Sobre o partido, Lenin e Stalin; O X Congresso do Partido Comunista Chinês; As massas constroem o socialismo, o partido torna-as conscientes, de Enver Hoxha; e Lenine e a construção do Partido Bolchevique, de W. S. Mitskévitch Kapsoukas.

Após a dissolução da OCMLP em abril de 1976, em outubro daquele mesmo ano o grupo foi reconstituído, iniciando-se em novembro uma nova série do jornal $O$ Grito do Povo, com continuidade também das Edições O Grito do Povo. Nessa etapa, as edições não foram muitas, talvez pouco mais de dez títulos, predominando as obras com a linha política defendida pelo PC da China e documentos da OCMLP. Aguns exemplos: $O$ pensamento Mao Tsé-Tung orienta sempre a nossa marcha em frente; $O$ esmagamento do "Bando dos Quatro"; A ditadura fascista na URSS; Os neorevisionistas da UCRP (m-l) preparam um novo partido ao serviço do socialimperialismo soviético, com uma Declaração da Comissão Política do CC da OCMLP; O social-imperialismo soviético: inimigo mais perigoso dos povos de todo o mundo.

Em abril de 1987 ocorreu a dissolução definitiva da OCMLP.

As publicações das Edições O Grito do Povo eram, quase todas, pequenas brochuras grampeadas, com padrão gráfico e editorial semiprofissional. Tal padrão parece manter-se em ambas as fases da editora. A distribuição deveria se dar de forma amadora. Também como em outras pequenas organizações políticas de extrema esquerda, a prioridade era dada à edição do jornal do grupo.

\footnotetext{
${ }^{27}$ Texto de anúncio da coleção Textos Marxistas publicado na revista Spartacus - Revista dos Trabalhadores Portugueses, Lisboa, nº 1, $2^{\text {a }}$ edição, set. 1974, p. 29. Grifos do original. O mesmo texto foi publicado em anúncios da coleção em outros números da mesma revista.

28 "Introdução". In: A táctica de greve na época actual (Resolução da Conferência de Strasburgo da Internacional Sindical Vermelha- 1929). Porto: O Grito do Povo, 1975, p. 2.
} 


\title{
5.3.2 Edições Spartacus/OCMLP
}

\author{
Lisboa
}

Início das edições: 1974

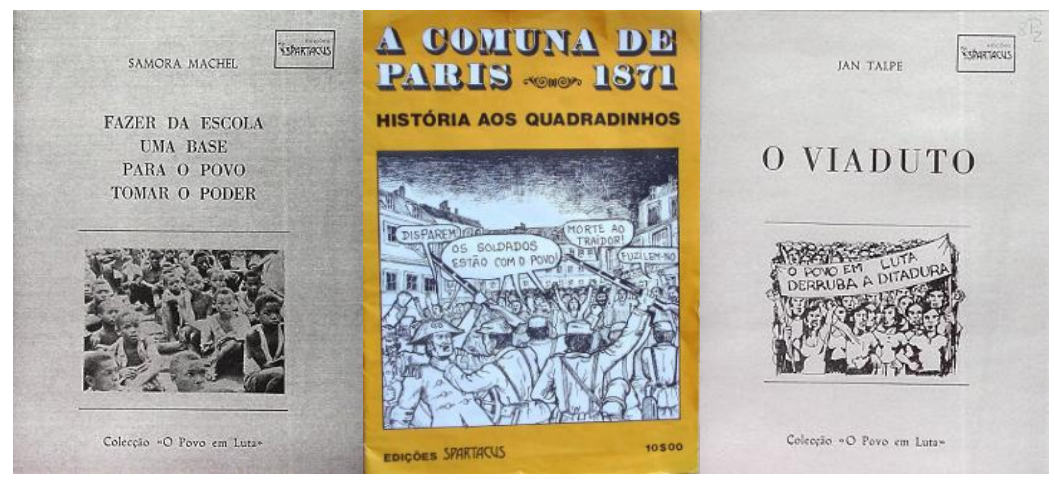

Editora ligada à revista Spartacus, criada por iniciativa de militantes da OCMLP, agrupamento fundado em finais de $1972^{29}$. O primeiro número da revista, editado "ainda antes do 25 de Abril, e na emigração" ${ }^{30}$, teve uma $2^{\text {a }}$ edição, lançada em setembro de 1974, já de forma legal e em Portugal.

De acordo com José Manuel Lopes Cordeiro, "O coordenador da revista Spartacus era Filipe Faria, então membro suplente do CC da OCMLP. Grande parte da redação da Spartacus era constituída por antigos membros do jornal O Comunista", que se integraram na organização que editava $O$ Grito do Povo, dando origem à OCMLP. ${ }^{31}$ A revista foi editada com regularidade até o $\mathrm{n}^{\circ} 11$, de julho de 1976, e as duas últimas edições saíram já após a integração de grande parte da $\operatorname{OCMLP}$ no $\operatorname{PCP}(\mathrm{R})^{32}$.

Os títulos editados pelas Edições Spartacus/OCMLP se enquadram na linha política e ideológica dos grupos marxistas-leninistas (m-l), o que fica claro no texto de contracapa do livro de história em quadrinhos (banda desenhada) A Comuna de Paris, 1871, editado em outubro de 1975. De acordo com o texto, que procura combater as "ideias erradas" que estariam em voga em muitos setores da esquerda portuguesa, o marxismo-leninismo era "a ideologia do proletariado, única capaz de o guiar até à vitória”. E continua:

Hoje, depois de outras revoluções vitoriosas, na União Soviética (até os anos 50), na China e na Albânia, sabemos que a nossa luta só será vitoriosa se for guiada por um verdadeiro partido comunista marxistaleninista, e não um partido traidor como o do Cunhal.

\footnotetext{
${ }^{29}$ CORDEIRO, “OCMLP...”, op. cit, p. 666-69.

30 “Nota à 2a edição". Spartacus, Lisboa, nº 1, $2^{\mathrm{a}}$ ed., set. 1974, p. 2.

${ }^{31}$ Mensagem eletrônica de José Manuel Lopes Cordeiro, 11/06/2011.

${ }^{32}$ CORDEIRO, “Glossário dos anos do PREC...", op. cit., p. 129.
} 
A "Introdução" ao livro O viaduto, de Jan Talpe, publicado em dezembro de 1974, expõe as ambições da coleção O Povo em Luta:

Propomo-nos nestes cadernos "O povo em luta" apresentar experiências do combate que opõem os explorados aos exploradores, em Portugal e noutros países. Textos, reportagens que relatem as lutas do povo, a sua aspiração à democracia popular e a sua luta para acabar com o inimigo de classe, a burguesia e o seu sistema econômico baseado na exploração do homem pelo homem. ${ }^{33}$

Os autores do texto concluem:

Esperamos que a publicação deste texto [O viaduto $]$ seja útil, e constitua um contributo para a execução da tarefa central que se coloca diante dos marxistas-leninistas portugueses e de todo o proletariado revolucionário que é a construção do partido, um partido comunista que siga a linha de Marx, Engels, Lenine, Estaline e Mao Tsé-Tung, e que conduza todo o povo trabalhador à Revolução Popular, ao Socialismo e ao Comunismo. ${ }^{34}$

Os livros da Edições Spartacus/OCMLP tinham padrão gráfico e editorial profissional. Não foi possível verificar se havia distribuição comercial de seus livros.

A editora parece ter atuado apenas em 1974 e 1975, tendo editado cinco livros: O viaduto, de Jan Talpe (1974); Fazer da escola uma base para o povo tomar o poder, de Samora Machel (1975); Contos vietnamitas (s/d); A comuna de Paris, 1871, história em quadrinhos (1975); e Unir a maioria, para derrotar a minoria: a linha revolucionária da política externa chinesa, de Jack A. Smith (s/d).

Houve, a partir de fins de 1974, outra editora com o mesmo nome, talvez com origens também no grupo que inicialmente organizou a revista Spartacus no exterior, e mais ligada a ideias de esquerda vinculadas aos grupos situacionistas e libertários (ver o item sobre a editora Spartacus/Independente) ${ }^{35}$.

E anteriormente, nos anos 1920, houve em Portugal uma Editora Spartacus, fundada em 1924 por João Campos Lima (1877-1956), advogado e jornalista divulgador de ideias libertárias ${ }^{36}$.

\footnotetext{
${ }^{33}$ TALPE, Jan. "Introdução". In: O viaduto. Lisboa, Spartacus, 1974.

${ }^{34}$ Sobre os objetivos da editora ver também a resenha do livro $O$ viaduto na seção Livros a Ler da revista Spartacus, $\mathrm{n}^{\circ}$ 5, mar../abr., 1975, p. 21.

${ }^{35}$ FREIRE, João. Pessoa comum no seu tempo: memórias de um médio burguês de Lisboa na segunda metade do século XX. Porto: Afrontamento, 2010, p. 450-51.

36 "Campos Lima". Verbete. Site Almanaque Republicano. Disponível em:

<http://arepublicano.blogspot.com/search/label/Campos\%20Lima)>. Acesso em nov. 2010.
} 


\section{$\underline{5.4 \text { Comitê Marxista-Leninista de Portugal (CMLdeP) }}$}

\subsubsection{Publicações O Proletário Vermelho/Editora Outubro}

Av. Rainha D. Leonor, 27 - Lisboa

Rua da Boavista, 102, $3^{\text {a }}$ Frente - Lisboa (janeiro 1977)

Editor: Bento Vintém.

Fundação: 1974.

Distribuidora: Livraria Outubro.

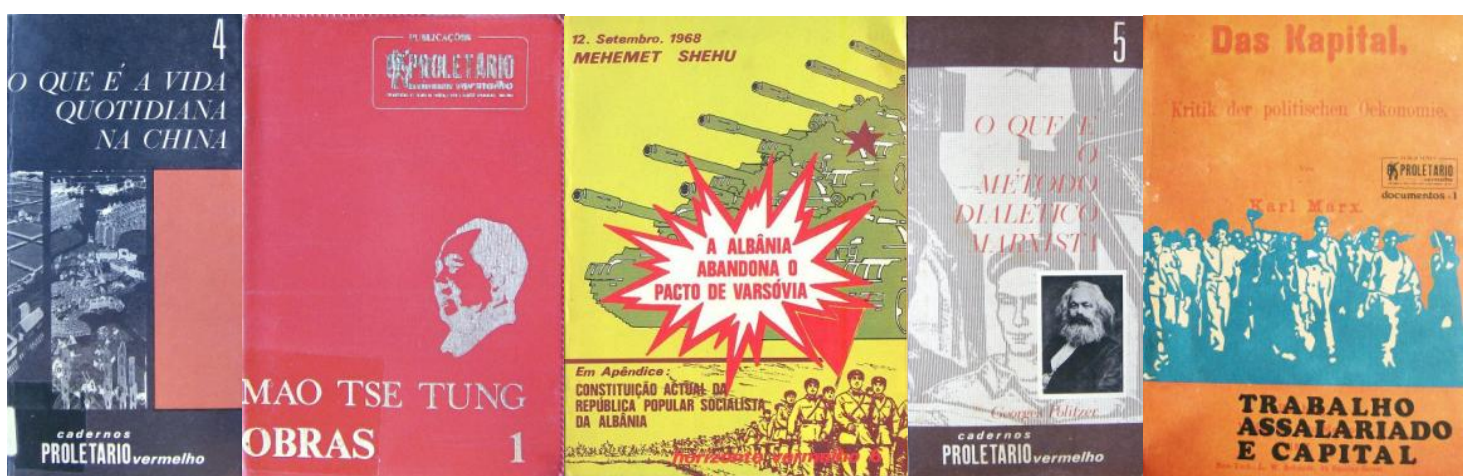

Editora ligada ao grupo maoista Comitê Marxista-Leninista de Portugal (CMLdeP), que editava o jornal $O$ Bolchevista, nome pelo qual a organização ficou conhecida. Teve sua origem em uma dissidência do CMLP (Comitê Marxista-Leninista Português), que se dá "na sequência dos contactos entre António Bento Vintém e Rui d'Espiney em Caxias [prisão política], onde ambos estiveram presos" ${ }^{37}$. Após a libertação de Vintém, em janeiro de 1969, este "começou a trabalhar na criação do coletivo em articulação com a 'família d'Espiney' - o pai, Cláudio d'Espiney, os filhos, José Luís d'Espiney e Sérgio d'Espiney, e Rita Gonçalves" ${ }^{38}$.

Em março de 1970 este grupo começou a editar o jornal O Bolchevista, e alguns de seus membros, também naquele ano, criaram em Lisboa, no bairro Lumiar, a Livraria Outubro $^{39}$, cujo projeto era divulgar a literatura de esquerda, marxista e antifascista, o que significava vender e distribuir muitos livros então proibidos ${ }^{40}$.

Antes do 25 de Abril, o CMLdeP havia editado uma série de livretos clandestinos intitulada Folhetos Vermelhos, do qual localizei referências a cinco títulos. Eram pequenos livretos datilografados, de confecção artesanal, entre os quais destacamse: Um grande centenário! (A Comuna de Paris); Os oportunistas e os marxistas

\footnotetext{
${ }^{37}$ CARDINA, M. Margem de certa maneira, op. cit., p. 163.

${ }^{38}$ Ibidem, p. 163.

${ }^{39}$ Ibidem, p. 163 e 165.

${ }^{40}$ Entrevista com Ana Barradas, Lisboa, 14/4/2011.
} 
perante o grande Staline; e Como pensam e trabalham os bolchevistas e como eles combatem o oportunismo (Acerca das provocações da linha anti-marxista da direcção oportunista do Cmlp).

Em 1971, devido à repressão, parte significativa do grupo mudou-se para a cidade de Inzago, na Itália. Havia ainda outro grupo de pessoas ligado ao jornal $O$ Bolchevista que estava na França, e outros que pemaneceram em Portugal. Em 1973, parte do grupo que estava em Portugal rompeu com os que estavam no exílio, aderindo ao $\mathrm{MRPP}^{41}$.

De acordo com Miguel Cardina, "Com o 25 de Abril, os militantes de $O$ Bolchevista exilados em Itália regressaram ao país e dinamizaram o Partido Comunista de Portugal (em construção) e o jornal O Proletário Vermelho" ${ }^{42}$. É quando se iniciam as edições de livros com o selo O Proletário Vermelho.

O primeiro título da editora parece ter sido editado em finais de 1974. De junho de 1975, quando foi lançado o primeiro volume dos Cadernos O Proletário Vermelho, a maio de 1976, quando saíram os seguintes quatro volumes da série, houve uma "pausa" nas atividades editoriais de O Proletário Vermelho, "que foi sobretudo necessária para a reorganização da Editora" ${ }^{\text {"43 }}$. Em 1976 a editora viveu seu período de maior atuação. Entre fins de 1974 e 1977 as Publicações O Proletário Vermelho editaram cerca de 20 títulos.

Um texto introdutório publicado no livro Trabalho assalariado e capital, de Karl Marx (1976), ajuda a entender os problemas, tanto internos como os relacionados à repressão, que afetaram a atuação da editora durante certo tempo:

Esta edição [...] deveria ter sido lançada em 1971, pouco tempo após a abertura da Outubro como livraria progressista e antifascista. As contingências da vida e da luta política, o apertado controle da Pide e as divergências surgidas entre os próprios fundadores da Outubro sobre onde findava o antifascismo para se transformar em socialfascismo forçaram o seu adiamento. ${ }^{44}$

Os objetivos da editora são expostos no prefácio do segundo volume da coleção Cadernos O Proletário Vermelho:

\footnotetext{
${ }^{41}$ CARDINA, Margem de certa maneira, op. cit., p. 165-68.

42 Ibidem, p. 168.

43 “Prefácio". In: VÁRIOS. O que é o social-fascismo. Coleção Cadernos O Proletário Vermelho, n 2. Lisboa: O Proletário Vermelho, 1976, p. 9.

${ }_{44}$ Texto do editor publicado na p. 3 de: MARX, Karl. Trabalho assalariado e capital. Lisboa: O

Proletário Vermelho, 1976.
} 
Através do preço acessível, queremos ir trazendo à série Cadernos OPV [O Proletário Vermelho] o maior número possível de leitores, que vivam do seu magro salário em época de cada vez maior austeridade, em que tudo sem excepção aumenta. O outro aspecto é o dos textos que iremos procurar reunir nesta série. Esforça-nos-emos por que sejam simples e curtos, acessíveis à compreensão da maioria das pessoas, esclarecendo e, portanto, passando-lhes instrumentos para a mão. É nosso dever empenharmo-nos na luta contra não só a miséria e a pobreza mas também, o atraso cultural que constitui sempre uma arma dos inimigos do povo, por mais ou menos disfarçados que apareçam. $^{45}$

Um dos meios para atingir tais objetivos era, como dito, editar livros que pudessem ser vendidos a preços baixos. Assim, a edição da obra $O$ que é o método dialéctico marxista, de Georges Politzer, foi feita em quatro volumes (e não em um só, como ocorre normalmente), vendidos separadamente, como forma de a "embaratecer" e tornar o acesso à mesma "ainda mais facilitado". Concluem os editores:

A inclusão desta obra na série dos Cadernos O Proletário Vermelho os quais queremos colocar inteiramente e sob todos os ângulos, ao serviço do Homem Novo, que não do intelectual mais exibicionista, para um Portugal também novo -, enriquece pela sua natureza, os objetivos que nos propomos alcançar. ${ }^{46}$

Parte dos títulos das Publicações O Proletário Vermelho eram oriundos de documentos dos partidos comunistas da China e da Albânia. Havia também obras de divulgação do marxismo. Quase todos os títulos editados eram de autores estrangeiros. Eis algumas das obras publicadas: Obras, volumes 1 e 2, de Mao Tsé-Tung (1974), editado com a encadernação clássica em formato de bolso do "Livro vermelho das citações do presidente Mao"; A estrela vermelha, de Li Sin-tien (1976); Resistir ao ocupante, de Wanda Wassilewska (livro vencedor do Prêmio Staline em 1943); O que é a ditadura do proletariado (1976); O que é o método dialéctico marxista, de Georges Politzer (1976); O que é a vida quotidiana na China (1976); O que são as comunas populares; Trabalho assalariado e capital, de Karl Marx.

Ao iniciar uma coleção de obras sobre "cultura popular", a Série Lu Sun, a editora expôs sua visão da cultura e de seu papel na luta política e ideológica. A coleção era definida como voltada para "romance, conto, novela ou outra qualquer forma de obra literária ao serviço de uma cultura ideologicamente científica, de uma autêntica

\footnotetext{
45 "Prefácio". VÁRIOS. O que é o social-fascismo. Lisboa: O Proletário Vermelho, 1976. Grifo do original.

46 "Prefácio". In: POLITZER, Georges. O que é o método dialéctico marxista. Coleção Cadernos O Proletário Vermelho, no 5. Lisboa: O Proletário Vermelho, 1976, p. 8.
} 
cultura popular, não idealista e voltada à formação do Homem Novo". Seu objetivo era também combater "a demagogia literata e caduca do pseudo-realismo socialista"

Outra coleção publicada chamava-se Cadernos Horizonte Vermelho, e nela predominavam as obras de autores chineses e albaneses, como por exemplo: Aliança contra-revolucionária (dos revisionistas e "socialistas" contra os povos), de Omer Hashorva; Linhas gerais da economia chinesa, de Tchem Chi; e A luta entre as duas linhas é a característica principal do movimento democrático internacional da juventude e dos estudantes!, de Asim Bedalli; e A Albânia abandona o Pacto de Varsóvia, de Mehemet Shehu.

Os livros tinham um bom tratamento editorial e gráfico, de nível profissional, em particular a coleção Cadernos O Proletário Vermelho. A distribuição comercial era feita pela Livraria Outubro. A editora tinha oficina gráfica própria.

Em setembro de 1974 o jornal O Proletário Vermelho teve sua circulação suspensa por 60 dias, por determinação da Comissão Ad-hoc para a Imprensa, devido à "publicação de matéria atentatória dos princípios enunciados no programa do Movimento das Forças Armadas e por ofensas ao presidente da República". Teria sido também emitido um mandato de captura contra o diretor do jornal, Bento Vintém. Poucos dias depois, a Livraria Outubro, responsável pela edição do jornal, foi "visitada" por agentes da Polícia de Segurança Pública que pretendiam prender Vintém, num episódio confuso e cheio de mal-entendidos ${ }^{48}$.

Este episódio mostra, de toda forma, que o jornal O Proletário Vermelho sofreu algum cerceamento na sua atuação também após o 25 de Abril, o que pode ter acontecido também com a sua editora homônima - e talvez tenha tido alguma influência sobre sua atuação. Como veremos mais à frente, o MRPP também foi vítima de atos de repressão após o fim da ditadura.

\footnotetext{
${ }^{47}$ Texto do editor publicado na p. 3 de: SIN-TIEN, Li. A estrela vermelha. Séri Lu Sun, vol. 1. Lisboa: O Proletário Vermelho, 1976, p. 5.

48 "O estranho caso da livraria Outubro". Expresso, no 91, 28/9/1974, p. 2; "Solidariedade com $O$ Proletário Vermelho". Voz do Povo, n 9, 1/10/1974, p. 7; "O estranho caso do Proletário Vermelho". Expresso, n 92, 5/10/1974; "Ainda o estranho caso do Proletário Vermelho". Expresso, nº 93, 12/10/1974, p. 2.
} 


\subsection{União Democrática Popular (UDP)}

\subsubsection{Edições Maria da Fonte}

Rua da Fé, 26 - $2^{\circ}$ - Lisboa

Fundação: setembro de 1973

Editores: Manuel Quirós e Maria Isabel Pinto Ventura

Distribuição: O Século

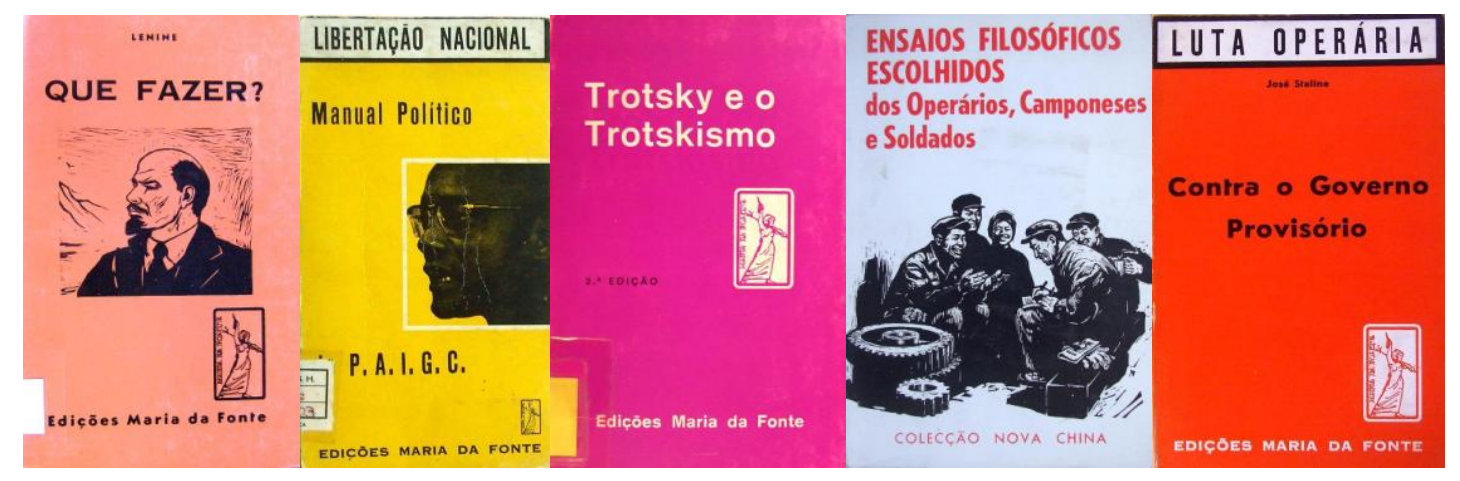

Fundada em setembro de 1973 por João Camacho, Sílvio Conde e Manuel Quirós $^{49}$, foi uma das mais atuantes e importantes editoras do campo da esquerda em Portugal nos anos 1970. Camacho e Conde eram militantes do Movimento Reorganizativo do Partido do Proletariado (MRPP). Quirós era um antigo militante do Partido Comunista Português (PCP) que havia rompido com o partido em 1964, quando participou da fundação do Comitê Marxista-Leninista Português (CMLP) e da Frente de Acção Popular (FAP). Preso em 1965, apenas em 1969 recupera a liberdade ${ }^{50}$. Entre 1971 e o começo de 1974 atuou no Comitê Comunista de Portugal e na União Comunista (Marxista-Leninista) ${ }^{51}$.

Segundo João Camacho, a Maria da Fonte não surgiu como editora de partido, mas sim como uma iniciativa dos três fundadores. "É uma iniciativa de militantes, nossa, não de partidos", diz ele. Manuel Quirós havia sido funcionário da Livraria Guernica, de Camacho, criada nos primeiros anos da década de 1970 na rua da Emenda, em Lisboa ${ }^{52}$.

João Camacho já atuava como editor no começo dos anos 1970, tendo criado os Cadernos Maria da Fonte, que publicava desde 1971, quando ainda era funcionário da Livraria Ler (ver item sobre esta editora), de Campo de Ourique. Ele editou três títulos

\footnotetext{
${ }^{49}$ Entrevista com João Camacho, Lisboa, 3/3/2011.

${ }^{50}$ ALVES, Jofre. "Manuel Quirós: uma vida temperada na luta”. Blogue Abril de Novo, 25/10/2009.

Disponível em: 〈http://abril-de-novo.blogspot.com/search/label/CMLP〉. Acesso em jun. 2011.

${ }^{51}$ CARDINA, Margem de certa maneira, op. cit., p. 176.

${ }^{52}$ Entrevista com João Camacho, Lisboa, 3/3/2011.
} 
com o selo Cadernos Maria da Fonte, que foram distribuídos pela Livraria Ler. A partir dessa experiência, resolveu criar, junto com Conde e Quirós, uma editora formalmente organizada. É quando surge, no segundo semestre de 1973, as Edições Maria da Fonte (os Cadernos Maria da Fonte continuaram a existir, mas apenas sob a responsabilidade e a direção da Livraria Ler).

As Edições Maria da Fonte são desde a sua origem uma editora marxistaleninista-maoista. Pouco tempo depois de criada, porém, começaram a se acentuar as divergências políticas entre os sócios, o que levou à saída de Camacho e Conde, provavelmente um pouco antes do 25 de Abril. Ambos irão criar, então, as Publicações Nova Aurora (ver item sobre esta editora), vinculada ao MRPP.

A Maria da Fonte ficou sob a direção de Manuel Quirós e Maria Isabel Pinto Ventura, sua companheira. Ambos conseguiram imprimir um forte ritmo à editora, tendo lançado cerca de 40 títulos em 1974 e 1975. Quirós foi o tradutor de várias destas obras. Foram lançadas ainda três edições da revista Que Fazer?, da qual Quirós era o diretor e Maria Isabel a editora.

Com o surgimento da UDP (União Democrática Popular), em dezembro de 1974, as Edições Maria da Fonte vincularam-se estreitamente a esta organização. A UDP era uma partido político criado para participar das eleições constituintes de abril de 1975, fruto da união de três grupos marxistas-leninistas: CARP(m-l)-Comitê de Apoio à Reconstrução do Partido (marxista-leninista), CCR(m-l)-Comitês Comunistas Revolucionários (marxistas-leninistas) e URML (Unidade Revolucionária MarxistaLeninista). Em maio de 1975 estes três grupos se fundiram e deram origem à Organização para a Reconstrução do Partido Comunista (marxista-leninista)/ORPC(m1). A partir de fins de 1975, com a criação do Partido Comunista Português (Reconstruído)/PCP(R), a UDP torna-se a organização frentista desse partido ${ }^{53}$.

A partir de fins de 1974, portanto, a atuação da editora passou a ligar-se à UDP, seja na definição dos títulos, seja mesmo na distribuição e venda dos livros. Na prática, isso não significou uma mudança na linha editorial, pois a atuação da Maria da Fonte já era claramente ligada ao marxismo-leninismo-maoismo. De acordo com Ana Barradas, que passou a manter contato com a Maria da Fonte a partir da vinculação da editora com a UDP, a linha editorial e os títulos eram discutidos com a UDP, e o partido também recebia uma certa quantidade de exemplares de cada obra editada. Estes livros

${ }^{53}$ CORDEIRO, “Glossário dos anos do PREC...”, op. cit, p. 131 e 121. 
eram enviados para as sedes da UDP para serem então vendidos ${ }^{54}$.

Em 1974 e 1975, alguns dos títulos de destaque foram: Trotsky e o trotskismo, de vários autores; Um mundo melhor, de Jean Baby; A metade do céu: movimento de emancipação da mulher, na China, de Claudia Broyelle; Marx e os sindicatos: antologia de Marx e Engels sobre o sindicalismo, de A. Lesovski; A transformação socialista da economia nacional na China, de S. M. Kiao, S. Sing e L. Tsé-li; Combater o revisionismo: uma tarefa revolucionária, de Enver Hoxha; Os sindicatos da classe operária, de Lenin; Guerra popular: caminho da luta armada no Brasil, documento do Partido Comunista do Brasil; História do Partido dos Trabalhadores do Vietname; Quem é o inimigo? Qual o nosso objectivo?, de Agostinho Neto; Textos e documentos do MPLA sobre a revolução angolana; Contra o Governo Provisório, de Stalin; Para a reconstrução do Partido Comunista Marxista Leninista, de Manuel Quirós.

Em 25 de outubro de 1975, Manuel Quirós faleceu, vítima de câncer e das sequelas das torturas que sofreu na cadeia ${ }^{55}$. Isso certamente causou um forte abalo à editora, já que era ele o seu principal dirigente, além de ter uma grande capacidade de trabalho. Diante dessa nova situação, Ana Barradas recorda que foi feito um balanço da empresa e constatou-se que a situação econômica era grave. Fez-se então um ajuste entre a UDP e Maria Isabel Pinto Ventura - que ficou à frente da Maria da Fonte - que permitiu à editora continuar suas atividades ${ }^{56}$, aliás ainda com bastante vigor em 1976 e 1977. Nestes dois anos foram lançados cerca de 30 títulos, entre os quais: Os tambores $d a$ chuva, de Ismael Kadaré; A torrente de ferro, de Alexandre Serafimovitch; A Revolução Cultural e a organização industrial na China, de Charles Bettelheim; O método e o estilo de trabalho leninistas, de Enver Hoxha; Teoria da construção económica do socialismo, de Kim Il Sung; Primeiro Congresso do Partido Comunista de Espanha (ML); Os quatro primeiros congressos da Internacional Comunista; Três anos de luta contra o fascismo em Espanha (1935-1938), obra em três volumes de José Diaz.

Entre 1973 e 1978, período em que as Edições Maria da Fonte atuaram de acordo com a linha política traçada em suas origens, foram lançados cerca de 80 títulos.

\footnotetext{
${ }^{54}$ Entrevista com Ana Barradas, Lisboa, 16/4/2011.

55 "Faleceu o secretário-geral da Associação (Unificada) de Amizade Portugal-China". O Grito do Povo, Ano IV, no 54, 31/10/1975; "Morreu o camarada Manuel Quirós". A Verdade, nº 21, série II, 30/10 a 6/11/1975; "Dados biográficos de Manuel Quirós”. In: QUIRÓS, Manuel. Para a reconstrução do Partido Comunista Marxista Leninista. Lisboa: Maria da Fonte, 1975.

${ }^{56}$ Entrevista com Ana Barradas, Lisboa, 16/4/2011.
} 
As Edições Maria da Fonte tiveram como característica ser uma editora eminentemente política, com uma linha ideológica muito definida. Ao mesmo tempo, seus livros tinham um padrão gráfico simples e bem demarcado, o que criava uma identidade visual muito forte em suas edições, todas realizadas com nível profissional.

Como já mencionado, a partir de certo momento uma parte da distribuição dos livros era feita de maneira vinculada à UDP, o que gerou alguns problemas de ordem financeira, em função de falta de pagamento ${ }^{57}$. Todavia, também houve sempre distribuição comercial dos livros, ou seja, eles eram vendidos na rede livreira portuguesa por meio da Distribuidora O Século. Esta distribuidora fazia anúncios publicitários em algumas revistas, como Flama e Vida Mundial, e em alguns destes anúncios apareciam livros das Edições Maria da Fonte ${ }^{58}$.

Como assinalou Jofre Alves, as Edições Maria da Fonte publicaram "dezenas de obras de doutrinação marxista-leninista, análise política e literatura revolucionária" ${ }^{, 59}$. A editora alinhava-se com as políticas emanadas dos partidos comunistas da China e da Albânia, o que se reflete em muitos dos títulos editados, oriundos desses países: 16 títulos são de autores chineses ou tratam do socialismo chinês; 12 são de autores albaneses (sete de Enver Hoxha, secretário-geral do Partido do Trabalho da Albânia).

Além disso, têm destaque as obras de Lenin (sete) e Stalin (três), e mais 11 títulos ligados à política da União Soviética até a realização XX Congresso do PCUS em 1956.

Há também quatro títulos relacionados à vitória comunista no Vietnã (dois de Ho Chi Minh) e quatro sobre a luta de libertação na África (dois sobre Angola, um sobre Moçambique e um sobre Guiné e Cabo Verde).

Destacam-se ainda os títulos relacionados a alguns partidos marxistas-leninistas com os quais havia uma relação mais próxima: o Partido Comunista do Brasil/PCdoB (quatro títulos), o Partido Comunista da Espanha M-L (dois títulos), o Partido Comunista (ML) da Bélgica, o partido comunista da Coreia do Norte e o Comitê Central da Organização dos Marxistas-Leninistas da Grécia (um título cada).

A existência de mais títulos ligados ao PCdoB deve-se a uma relação mais próxima com este partido e com o Brasil, seja pelas razões históricas que ligam os dois países, seja pelo fato de que o dirigente do PCdoB Diógenes Arruda, que estava exilado

\footnotetext{
${ }_{58}^{57}$ Entrevista com Ana Barradas, Lisboa, 16/4/2011.

${ }^{58}$ Ver coleções das revistas Flama e Vida Mundial, 1974-1976. Hemeroteca Municipal de Lisboa.

${ }^{59}$ ALVES, J. "Manuel Quirós...”, op. cit.
} 
em Portugal, ter tido grande participação na $\operatorname{UDP}^{60}$. Chama a atenção o fato de apenas um título editado pela Maria da Fonte ser de autor português (Manuel Quirós), bem como a ausência de obras sobre a realidade portuguesa.

As Edições Maria da Fonte foram uma das mais características editoras da revolução de Portugal, ou seja, foi uma editora política militante, tendo uma atuação marcante na edição política no país. Apesar de ter surgido um pouco antes de 1974, sua atuação ganhou ímpeto e fôlego após o 25 de Abril. Sua vinculação estreita com a UDP tornou-a uma editora de partido, no que diz respeito à definição de sua linha editorial e da distribuição dos livros. Mas manteve também características profissionais, com tratamento gráfico e visual uniformizado, coleções bem definidas, ritmo constante de edições e distribuição profisssional (além da militante).

\subsubsection{Edições Voz do Povo}

Rua da Verónica, 50 A - Lisboa

Início das edições: 1974.

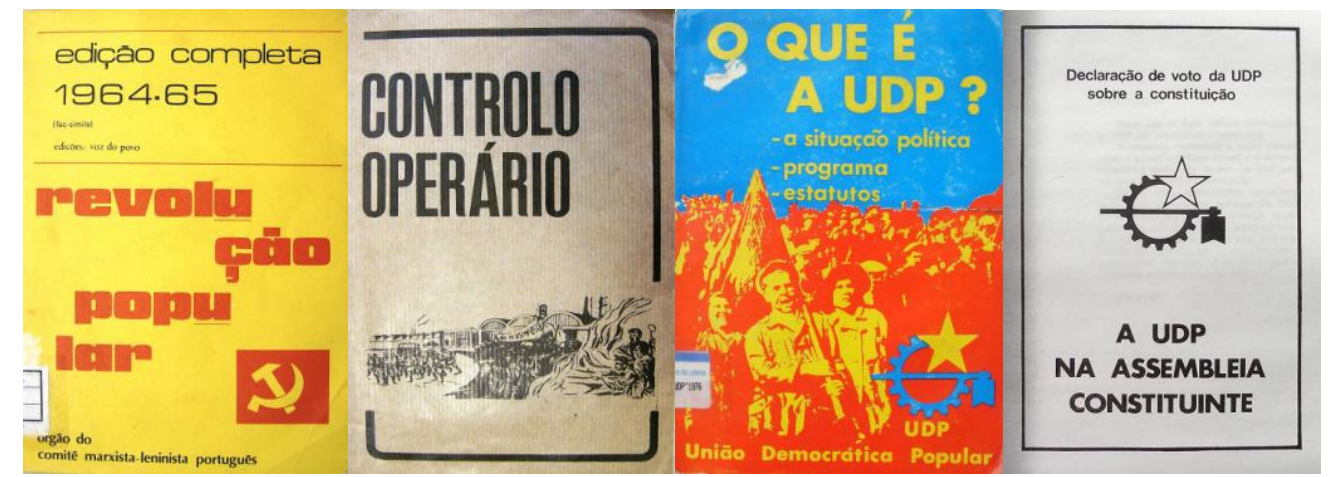

Pequena editora vinculada ao jornal Voz do Povo, cujo número zero saiu em 13 de julho de 1974. O diretor do jornal era João Pulido Valente. O jornal tornou-se um dos porta-vozes da $\operatorname{UDP}^{61}$.

O jornal Voz do Povo parece, inicialmente, ser ligado ao CARP(m-l) - um dos grupos fundadores da UDP -, visto que Pulido Valente integrava este grupo depois de ter sido libertado da prisão após o 25 de Abril ${ }^{62}$. A partir de dezembro de 1974 o jornal

${ }^{60}$ CARVALHO, Frederico. "Diógenes Arruda, construtor e homem de Partido". Bandeira Vermelha, $\mathrm{n}^{\circ}$ 307, 4/12/1981, p. 2.

${ }^{61}$ SOUSA, Pedro Diniz de. A dramatização na imprensa do "PREC". Coimbra, MinervaCoimbra, 2003, p. $22-24$.

${ }^{62}$ CARDINA, Margem de certa maneira, op. cit, 2010, p. 179. 
torna-se um órgão vinculado à UDP ${ }^{63}$.

As Edições Voz do Povo começaram em setembro de 1974, com a publicação do livro Revolução Popular. Edição completa, 1964-65, que reunia os seis números do boletim Revolução Popular, publicados em 1964 e 1965 pelo Comitê Marxista-Lenista Português (CMLP), e desde então esgotados.

Em resenha ao livro A missão histórica mundial da classe operária, do albanês Foto Çami (1975), a revista Que Fazer?, publicada pela Edições Maria da Fonte também ligada à UDP - deixava claro o caráter prescritivo que se esperava que a obra tivesse junto aos militantes do grupo:

Numa altura em que em Portugal tanto se fala em socialismo [...] a leitura deste livro torna-se necessária a todos aqueles que aspiram ao verdadeiro socialismo e não àquele que pregam os sociais-democratas e os revisionistas [e] mostra-nos qual é a classe capaz de construir o socialismo derrubando o regime capitalista. ${ }^{64}$

A editora lançou poucos livros. Localizei referências a apenas cinco títulos. Além dos dois já citados, os outros três títulos publicados foram: $O$ que é a UDP? A situação política, programa, estatutos (1975); Controlo operário (c. 1975); e A União Democrática Popular na Assembleia Constituinte: declaração de voto da UDP sobre a Constituição (1976). Este parece ter sido o último livro publicado pelas Edições Voz do Povo, em meados de 1976.

Os livros tinham tratamento editorial e gráfico desigual, variando desde um livreto datilografado e grampeado até outros com acabamento gráfico profissional. Não localizei referências à distribuição comercial dos livros, e tudo leva a crer que a distribuição era somente militante.

Pelos poucos títulos publicados, podemos conlcuir que a edição de livros parece ter sido pouco importante para o grupo vinculado ao Voz do Povo, que priorizou a edição do seu jornal. Todavia, o mesmo não pode ser dito em relação à UDP, uma vez que outras editoras, em especial as Edições Maria da Fonte, encarregaram-se de forma mais consistente desse campo de atuação no âmbito das organizações que compunham esta agremiação.

\footnotetext{
${ }^{63}$ Ver a coleção dos jornais Voz do Povo. Biblioteca-Museu República e Resistência, Lisboa.

${ }^{64}$ Resenha em Que Fazer? Cadernos Marxistas-Leninistas. Lisboa: Maria da Fonte, no 3, ago. 1975, p. 141.
} 


\subsubsection{Edições Povo e Cultura}

Estrada Nacional, 165-B - Baixa da Banheira

Editor: Manuel Miranda.

Fundação: 1971.

Distribuidora: Dinalivro.

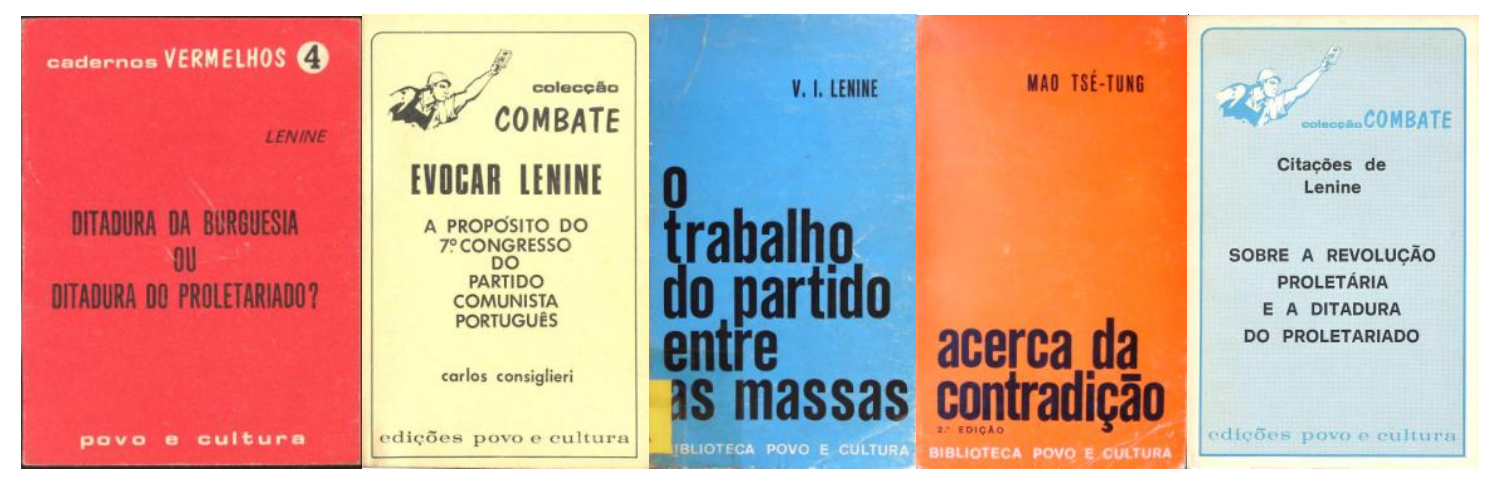

Editora de linha maoista, iniciou suas atividades em 1971, na Baixa da Banheira (concelho de Moita, distrito de Setúbal). O responsável pelas edições era Manuel Miranda.

Entre os livros editados destacam-se: Sobre a democracia nova, de Mao Tsétung (1972); A educação ideológica dos quadros e das massas, de Enver Hoxha (1974); Conquista ou abandono dos sindicatos?, de A. Losovski (1974); Ditadura da burguesia ou ditadura do proletariado?, de Lenin (1974); Estaline, o bolchevique, de Bruce Franklin (s/d); Evocar Lenine. A propósito do $7^{\circ}$ Congresso do Partido Comunista Português, de Carlos Consiglieri (1974); Palestina um povo em armas (1977).

Há um caso interessante sobre a edição de uma obra de Lenin. $\mathrm{Na} 1^{\text {a }}$ edição, em março de 1972, os nomes do livro e do autor foram modificados para evitar problemas com a censura e a polícia política. Assim, o título escolhido foi $O$ trabalho político de massas, e o autor foi identificado como V. I. Ulianov. Já na $2^{\mathrm{a}}$ edição, em 1974, o título era $O$ trabalho do partido entre as massas, e o nome do autor aparecia como V. I. Lenine.

Um anúncio das Edições Povo e Cultura na revista Que fazer ${ }^{65}$, periódico publicado pela Edições Maria da Fonte, e uma resenha de um livro da editora na mesma revista indicam uma provável ligação política entre ambas as editoras. Manuel Quirós, editor da Maria da Fonte, fez a tradução de um livro para as Edições Povo e Cultura. Como vimos, as Edições Maria da Fonte tinham vinculação com a UDP, o que pode

\footnotetext{
${ }^{65}$ Que Fazer? Cadernos Marxistas-Leninistas. Lisboa: Maria da Fonte, no 1, nov. 1974, p. 30 e 127-29.
} 
indicar que as Edições Povo e Cultura, a partir de certo momento, estaria também próximas à UDP.

Os títulos publicados eram quase todos de autores estrangeiros e voltados principalmente para a luta política e ideológica com outros grupos de esquerda, em particular contra o Partido Comunista Português (PCP), alvo de vigorosas acusações de revisionismo feitas nos textos introdutórios dos livros das Edições Povo e Cultura. Por exemplo, a "Nota prévia" ao livro Ditadura da burguesia ou ditadura do proletariado?, de Lenin, iniciava-se da seguinte forma: "No seu último Congresso, o partido de A. Cunhal, ao 'suprimir ou modificar certas expressões correntemente utilizadas na terminologia marxista', desembaraçou-se do pouco que ainda possuía de marxista: precisamente a terminologia" 66 .

Tais textos, aliás, eram uma das características da editora. Não eram assinados e buscavam indicar as razões e a importância da edição da obra e qual deveria ser a sua correta interpretação.

A atuação editorial das Edições Povo e Cultura concentrou-se entre 1972 e o início de 1975. Mas localizei referência a uma publicação ainda em 1977. No total, editou cerca de 20 títulos.

Os livros tinham tratamento editorial e gráfico profissional, inclusive com coleções bem definidas graficamente. A distribuição era feita pela Dinalivro, ou seja, era profissional.

Alguns títulos das Edições Povo e Cultura apareceram, em 1974 e 1975, na secção "Os best-seller da quinzena", publicada pelo jornal Expresso. É o caso dos livros Acerca da contradição, de Mao Tsé-tung (2 lugar em 10/08/1974); O trabalho do partido entre as massas, de Lenin (em $6^{\circ}$ lugar em 19/10/1974 e em $10^{\circ}$ em 30/11/1974); e O pátio da cobrança das rendas: a arte revolucionária na China, esculturas em barro (4 lugar em 25/01/1975) ${ }^{67}$.

\footnotetext{
66 "Nota prévia". In: LENIN. Ditadura da burguesia ou ditadura do proletariado?. Baixa da Banheira: Edições Povo e Cultura, julho, 1974, p. 5.

67 "Os best-seller da quinzena". Expresso, 1974 e 1975. Hemeroteca Municipal de Lisboa.
} 
5.6 Organização para a Reconstrução do Partido Comunista (marxista-leninista) ORPC $(m-1)$

\subsubsection{Edições A Causa Operária}

Lisboa

Início das edições: 1975.

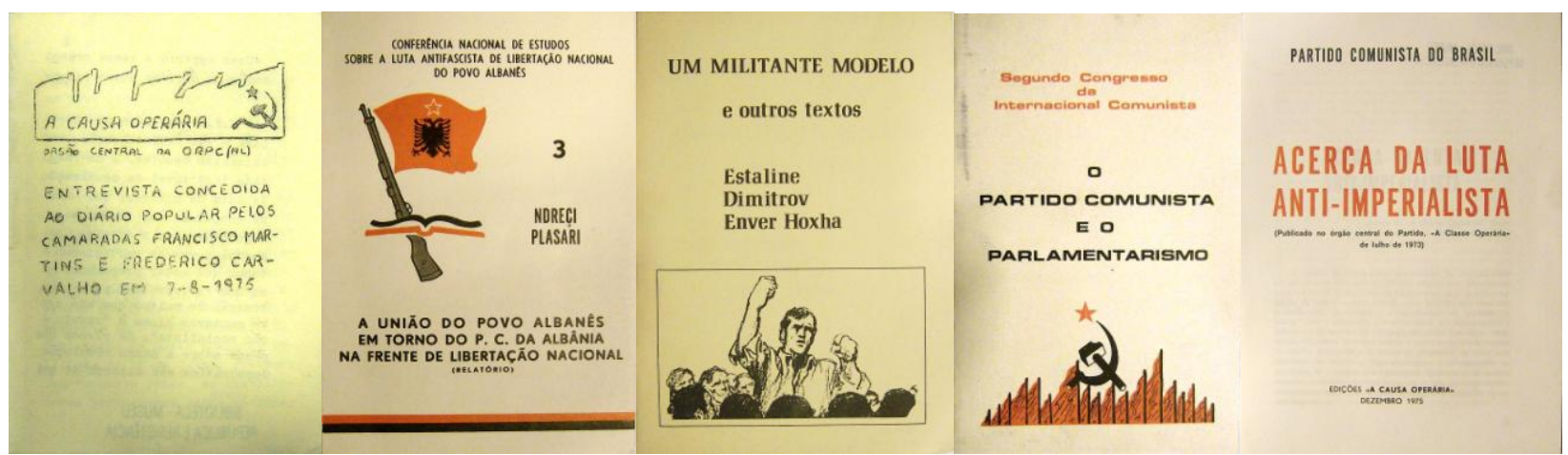

Editora vinculada à Organização para a Reconstrução do Partido Comunista (marxista-leninista) - ORPC(m-1). O grupo possuía um jornal que também se chamava A Causa Operária e um órgão teórico intitulado Revolução Proletária ${ }^{68}$.

A ORPC(m-l) foi fundada em maio de 1975 como resultado da unificação do CARP(m-l)-Comitê de Apoio à Reconstrução do Partido (marxista-leninista), da URML (Unidade Revolucionária Marxista-Leninista) e dos CCR(m-l)-Comitês Comunistas Revolucionários Marxistas-Leninistas, e extinguiu-se em dezembro de 1975, depois da fusão com o CMLP (Comitê Marxista-Leninista Português), no congresso que criou o Partido Comunista Português (Reconstruído)-PCP(R) ${ }^{69}$.

Assim, os livros editados foram todos publicados após o 25 de Abril. Eram basicamente documentos da ORPC(m-l) e do Partido do Trabalho da Albânia. Tratavase de brochuras grampeadas, em geral com tratamento gráfico e editorial de bom nivel técnico, embora houvesse também alguns extremamente precários. Pelo teor dos livros, é de se supor que sua circulação fosse restrita aos militantes do partido, não havendo, provavelmente, distribuição comercial dos mesmos (não há informação sobre isso nos livros).

${ }^{68}$ CORDEIRO, "Glossário dos anos do PREC...", op. cit., p. 121.

${ }^{69}$ CARDINA, Margem de certa maneira, op. cit., p. 162; MARTINS, J. M. "In Memoriam de Francisco Martins Rodrigues - VI Parte". Almanaque Republicano. Disponível em:

<http://arepublicano.blogspot.com.br/search/label/Francisco\%20Martins\%20Rodrigues〉. 
Eis alguns dos títulos publicados, todos em 1975: Informe apresentado na primeira conferência consultiva dos quadros do Partido Comunista da Albânia, de Enver Hoxha; Por uma ampla frente anti-fascista e patriótica caminho para a república popular!, que reproduzia um documento do Comitê Central da ORPC[m-1]); Acerca da luta anti-imperialista, texto do Partido Comunista do Brasil; Um militante modelo e outros textos, de Stalin, Dimitrov e Enver Hoxha.

O texto de apresentação do livro A questão do poder na luta antifascista de libertação nacional do povo albanês (1975), expõe a função que os editores esperam que o livro cumpra:

Estes documentos têm a maior actualidade pois ligam-se com a situação portuguesa e permitem tirar importantes ensinamentos para a nossa luta. [...] os marxistas-leninistas, os operários e demais trabalhadores de vanguarda, todos os simpatizantes do comunismo, devem estudar os textos que agora começamos a editar, discutindo-os com os seus camaradas e extraindo deles as lições que permitam fortalecer as nossas fileiras e avançar de forma firme e decidida na luta contra o Fascismo, pela Revolução Democrática e Popular e pelo Socialismo. $^{70}$

Este livro fazia parte da coleção Conferência Nacional de Estudos sobre a Luta Antifascista de Libertação Nacional do Povo Albanês, e se propunha a publicar os cinco relatórios resultantes desta conferência, mas parece que somente três foram efetivamente editados. Além do livro citado, saíram também: A luta antifascista de libertação nacional. Grande revolução popular conduzida pelo PC da Albânia, de Nexhmije Hoxha (1975) e A união do povo albanês em torno do PC da Albânia na frente de libertação nacional, de Ndreçi Plasari (1975).

As Edições Causa Operária voltavam-se exclusivamente para a publicação de textos partidários e direcionados para os seus militantes, ou seja, parecia produzir livros cujo público leitor era composto principalmente pelos próprios membros do grupo. A editora fez publicações apenas em 1975 (11 títulos), o que indica o encerramento de suas atividades após a fusão da ORPC(m-l) e do CMLP, em dezembro de 1975, que deu origem ao PCP(R). Em 1976 o PCP(R) criou as Edições Bandeira Vermelha (ver item mais à frente), que passou a se encarregar da publicação de livros do partido.

\footnotetext{
${ }^{70}$ Texto do editor publicado nas p. 7-8 de: OMARI, Luan. A questão do poder na luta antifascista de libertação nacional do povo albanês (Relatório). Lisboa: A Causa Operária, 1975.
} 


\subsubsection{Revolução Proletária}

\section{Lisboa}

Editor: "A. J. M. A.”

Início das edições: 1975.

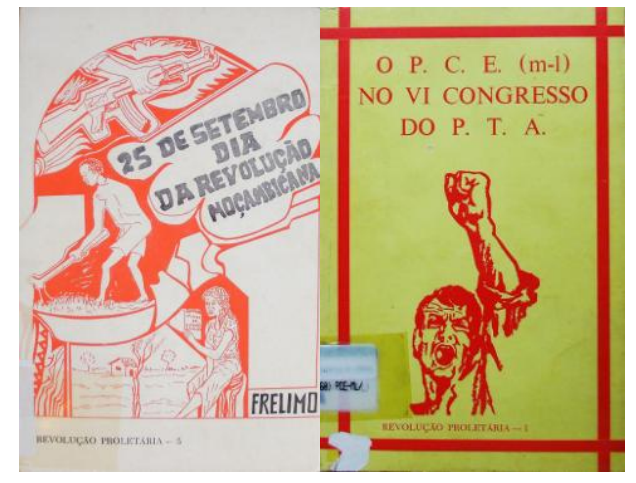

Editora também vinculada $\mathrm{ORPC}(\mathrm{m}-\mathrm{l})$. O órgão teórico do grupo também intitulava-se Revolução Proletária, e o seu jornal era A Causa Operária ${ }^{71}$.

Os três títulos que localizei da editora Revolução Proletária foram publicados em 1975. Dois tratam do processo de libertação de Moçambique: O processo da revolução democrática popular em Moçambique, de Samora Machel; e 25 de Setembro dia da revolução moçambicana, documento da Frente de Libertação de Moçambique. O outro livro editado apresenta um documento do Partido Comunista de Espanha (marxistaleninista): O PCE (ml) no VI Congresso do PTA: discurso pronunciado pelo responsável da delegação do CC do PCE (ml) no VI Congresso do PTA.

Nas três obras aparece a referência a “A. J. M. A.”, em um caso como resposável pela edição e nos outros dois como tradutor(a). Não foi possível identificar esta pessoa. Os livros tinham bom nível de execução editorial e gráfico. Não há indicação do local da edição nem sobre a distribuição comercial dos livros.

A atuação da editora Revolução Proletária foi efêmera, tendo editado talvez apenas os três títulos que localizei. Como vimos, outra editora ligada à $\mathrm{ORPC}(\mathrm{m}-1)$, as Edições A Causa Operária, parece ter ocupado o lugar de editora principal do grupo durante a sua breve existência (maio a dezembro de 1975). Com o rápido fim da $\mathrm{ORPC}(\mathrm{m}-\mathrm{l})$ e a sua participação na fundação do $\mathrm{PCP}(\mathrm{R})$, as Edições Bandeira Vermelha/PCP(R) ocuparam o lugar de editora oficial desse partido a partir de 1976.

O nome Revolução Proletária foi utilizado por outros grupos antes da ORPC(m-

\footnotetext{
${ }^{71}$ CORDEIRO, “Glossário dos anos do PREC...”, op. cit., p. 121; MARTINS, op. cit.
} 
1), o que pode causar certa confusão. Em dezembro de 1972, a URML, um dos grupos que daria origem à $\operatorname{ORPC}(\mathrm{m}-1)$, criou a revista Revolução Proletária como seu órgão teórico $^{72}$. Houve também uma publicação trotskista em maio de 1973 intitulada Revolução Proletária: para a construção do Partido Operário Revolucionário. Tribuna livre dos militantes luta de classe portugueses, editada na França pelo Comitê de Ligação dos Militantes Revolucionários Portugueses ${ }^{73}$. E existiram ainda os Cadernos Revolução Proletária, editados pela Liga Comunista Internacionalista ${ }^{74}$.

5.7 Partido Comunista Português (Reconstruído)-PCP(R) / Partido Comunista (Reconstruído)-PC(R)

\subsubsection{Edições Bandeira Vermelha}

Av. 5 de Outubro, $174,4^{\circ} \mathrm{D}$ - Lisboa

Fundação: 1976.

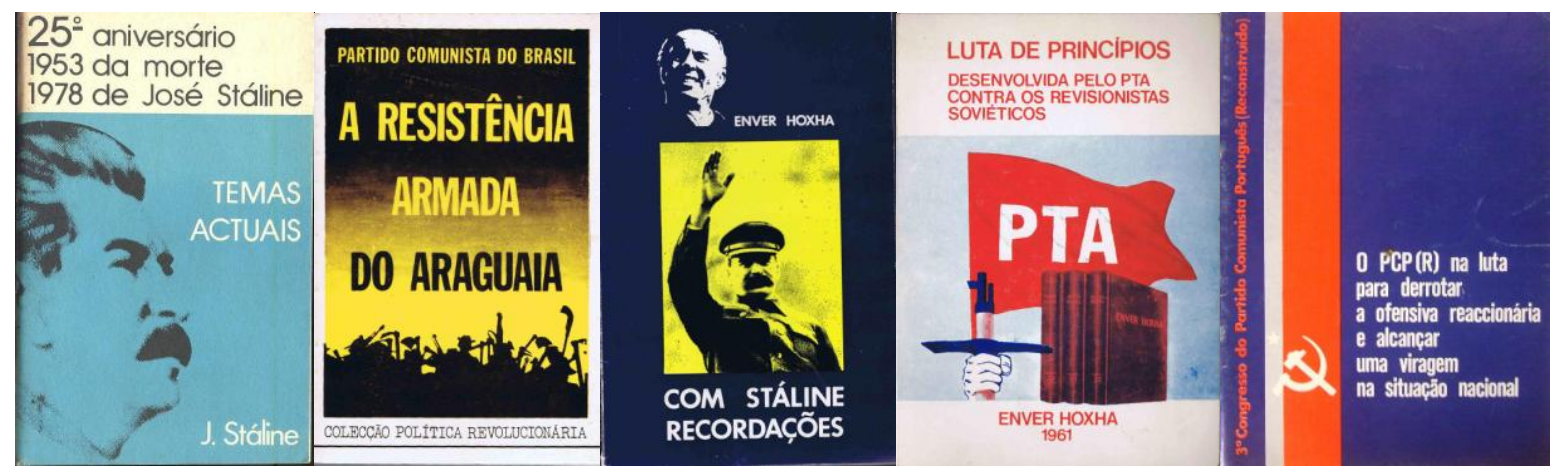

O Partido Comunista Português (Reconstruído)-PCP(R)/Partido Comunista (Reconstruído)-PC(R) foi fundado em dezembro de 1975, a partir da fusão da Organização para a Reconstrução do Partido Comunista (Marxista-Leninista)/ORPC(m1) e do Comitê Marxista-Leninista Português (CMLP). "Em abril do ano seguinte integraram-se nas suas fileiras grande parte dos militantes da OCMLP (Organização

\footnotetext{
${ }^{72}$ CARDINA, Margem de certa maneira, op. cit., p. 145.

${ }^{73}$ PEREIRA, José Pacheco. As armas de papel: publicações periódicas clandestinas e do exílio ligadas a movimentos radicais de esquerda cultural e política (1963-1974). Lisboa: Temas e Debates, 2013, p. 497.

${ }^{74}$ Consulta no catálogo eletrónico da Biblioteca Nacional de Portugal. Disponível em:

$<$ http://catalogo.bn.pt >. Acesso em jun. 2011; Página eletrônica Ephemera, Biblioteca e arquivo de José Pacheco Pereira. Disponível em: <http://ephemerajpp.wordpress.com/2011/05/24/cadernos-revolucaoproletaria/>. Acesso em jun. 2011
} 
Comunista Marxista-Leninista Portuguesa)״75. A UDP (União Democrática Popular) tornou-se, então, a organização frentista desse partido.

O dirigente do Partido Comunista do Brasil (PCdoB) Diógenes Arruda teve grande participação na organização do $\mathrm{PCP}(\mathrm{R})^{76}$.

As Edições Bandeira Vermelha publicavam basicamente documentos do PCP(R)/PC(R) e do Partido do Trabalho da Albânia. Há também, entre os livros editados, dois diretamente relacionados com o $\mathrm{PCdoB}$ e um sobre Diógenes Arruda. Não deve ser confundida com a editora homônima do PCTP/MRPP (Partido Comunista dos Trabalhadores Portugueses/Movimento Reorganizativo do Partido do Proletariado), que veremos mais adiante.

O texto de abertura do livro Resoluções do Comitê Central do Partido Comunista Português (Reconstruído) do I ao II Congresso (1977), assinado por "As Edições Bandeira Vermelha", explicita o que se pretendia com a atuação da editora:

Este volume constitui uma preciosa arma para a acção do Partido nas batalhas de classe em defesa dos interesses das massas trabalhadoras e populares do nosso país, para a sua edificação como Partido proletário de vanguarda, oposto em tudo quer ao grupo renegado revisionista quer aos grupos pequenos-burgueses, e sempre fiel aos interesses de classe do proletariado e aos princípios sempre vitoriosos do marxismo-leninismo e do internacionalismo proletário. ${ }^{77}$

Os livros editados - alguns na forma de brochuras grampeadas - têm tratamento editorial e gráfico profissional. Pelo teor dos livros, é de se supor que sua circulação fosse restrita aos militantes do partido, não havendo, provavelmente, distribuição comercial da maior parte destas obras (não há informação sobre isso nos livros).

Eis alguns dos títulos publicados: O partido, de Lenin e Stalin (1976); A luta do Partido do Trabalho da Albânia contra o revisionismo kruchoviano, de Enver Hoxha (1976); I Congresso do Partido Comunista Português (Reconstruído) (1976); Cinquenta e cinco anos de luta dos comunistas portugueses (1976); A imprensa comunista: princípios e experência (1977); A luta contra o fascismo. Relatório e discursos ao VII Congresso da Internacional Comunista, de Dimitrov (1977); No caminho do 25 de Abril do povo, da democracia popular e do socialismo (1977); A resistência armada do

\footnotetext{
${ }^{75}$ CORDEIRO, “Glossário dos anos do PREC...”, op. cit., p. 124.

${ }^{76}$ Ibidem; CARVALHO, Frederico. "Diógenes Arruda, construtor e homem de Partido". Bandeira Vermelha, $\mathrm{n}^{\mathrm{a}} 307,4 / 12 / 1981$, p. 2.

${ }^{77}$ Texto do editor publicado na p. 7 de: Resoluções do Comitê Central do Partido Comunista Português (Reconstruído) do I ao II Congresso. Lisboa: Bandeira Vermelha, 1977, p. 7.
} 
Araguaia, documento do Partido Comunista do Brasil (1978); O imperialismo e a revolução, de Enver Hoxha (1979); Com Stáline: recordações, de Enver Hoxha (1980); O proletariado e a revolução em Portugal, com informes e resoluções do $4^{\circ}$ Congresso do PC(R) (1983).

A editora manteve-se atuante desde 1976 até a primeira metade dos anos 1980, tendo editado mais de 50 títulos.

5.8 Movimento Reorganizativo do Partido do Proletariado (MRPP)/ Partido Comunista dos Trabalhadores Portugueses (PCTP)

\subsubsection{Vento de Leste}

R. Barão Sabrosa, 159A - Lisboa

Editores: Antonio Telo, João Camacho, Emanuel dos Santos, A. Barros Baptista, J. Pinto e Castro

Início das edições: 1974.
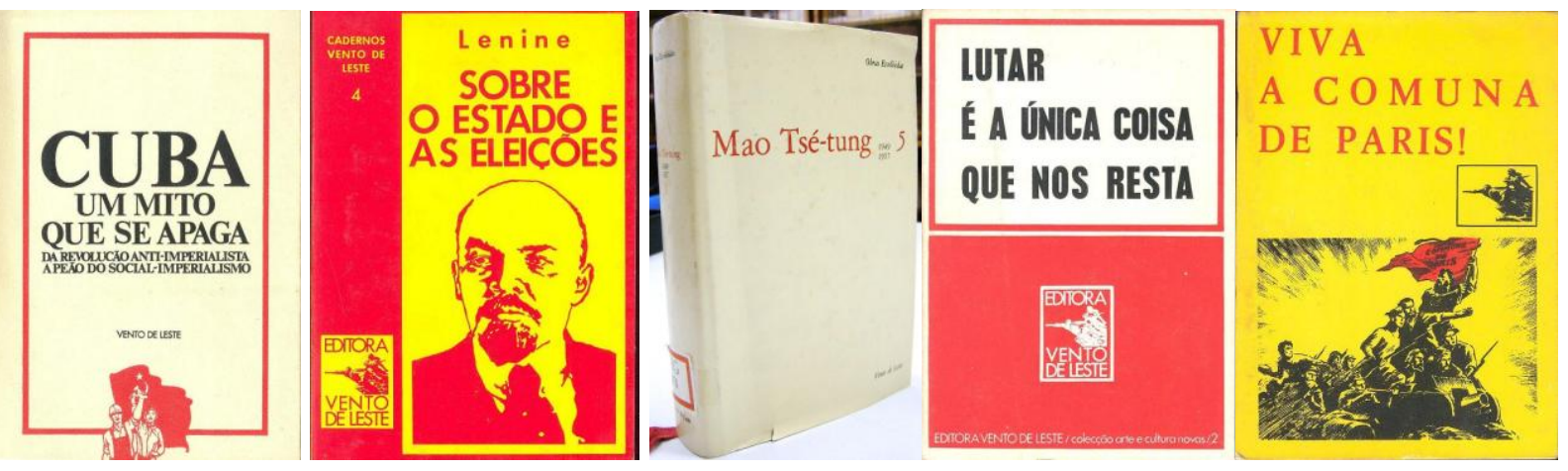

Editora semioficial da organização maoista MRPP (Movimento Reorganizativo do Partido do Proletariado), criada por instâncias do seu comitê central (Comitê Lenine). O MRPP, grupo criado em setembro de 1970, se caracterizava por um forte ativismo político de extrema-esquerda e por uma militância muito jovem. Em muitos momentos de sua atuação parecia que o grupo considerava que o principal inimigo a ser vencido era o Partido Comunista Português, que representava o "revisionismo", o "social-fascismo" e o "social-imperialismo". Daí surgirem, após o 25 de Abril, convergências políticas do grupo com o Partido Socialista e até com o Partido Popular Democrático, de centro-direita ${ }^{78}$.

\footnotetext{
78 Sobre o MRPP ver: CORDEIRO, "Glossário dos anos do PREC...”, op. cit., p. 105-133; CORDEIRO, “MRPP”. Verbete. In: BARRETO; MÓNICA, op. cit., Vol. VIII, Suplemento F/O, 1999, p. 559-60;
} 
A Vento de Leste foi fundada no segundo semestre de 1974 e teve como primeiro diretor António Telo. João Camacho, editor de livros, militante do MRPP e proprietário das Publicações Nova Aurora, asumiu a direção da editora, juntamente com Emanuel dos Santos, após a saída de António Telo. Posteriormente, foram também responsáveis pela editora Abel Barros Baptista e João Pinto e Castro, entre outros ${ }^{79}$.

De acordo com João Camacho, "A Vento de Leste era mesmo a editora do MRPP, embora o partido tivesse outra editora mais ligada ao Comitê Central, a Bandeira Vermelha" 80 .

A Vento de Leste tinha como objetivo auxiliar a atuação do MRPP e publicar textos tanto para a sua militância - com caráter formativo - como para simpatizantes e setores próximos ao partido. O "programa” da editora está clarificado em um anúncio publicado na revista $O$ Tempo e o Modo, nessa altura dirigida pelo MRPP. O anúncio trata da abertura da Livraria Vento de Leste, mas os objetivos propostos para a livraria eram os mesmos que norteavam a atuação da editora:

A Livraria Vento de Leste não é uma livraria como outra qualquer! A Livraria Vento de Leste propõe-se defender a causa do povo, propagando e defendendo intransigentemente os objetivos da revolução democrática e popular, o pão, a paz, a terra, a liberdade, a democracia e a independência nacional. Propõe-se divulgar e difundir a ideologia marxista-leninista-maoista [...] que guiará inevitavelmente o caminho do povo português. A Livraria Vento de Leste pretende ser um centro de propaganda e agitação, um centro cultural e organizador, e de modo algum um mero local de venda de livros. ${ }^{81}$

Muitos dos livros editados traziam textos introdutórios, escritos pelos responsáveis pela editora, em que se explicava a importância do lançamento daquela obra em Portugal e o papel político que se desejava que ela cumprisse. É o caso do livro Dez questões sobre a China, em cuja "Introdução", escrita em março de 1975 e não assinada, afirma-se:

CARDINA, Margem de certa maneira, op. cit.; CARDINA, A esquerda radical, op. cit.; Página eletrônica Ephemera, Biblioteca e arquivo de José Pacheco Pereira: <http://ephemerajpp.wordpress.com/indice-geral/editoras-revolucionarias/>.

${ }^{79}$ Entrevista com Fernando Rosas, Lisboa, 15/2/2011; Entrevista com João Camacho, Lisboa, 3/3/2011.

${ }^{80}$ Entrevista com João Camacho, Lisboa, 3/3/2011. Neste caso, é preciso atenção, pois havia duas editoras com o nome de Bandeira Vermelha. Uma era ligada ao MRPP e outra ao PCP(R)/PC(R). Ver os itens sobre estas editoras.

${ }^{81}$ Anúncio "Abriu a Livraria Vento de Leste". O Tempo e o Modo, Lisboa, no 110, abr. 1975, p. 5.

Disponível on line no site da Fundaçao Mário Soares:

$<$ http://www.fmsoares.pt/aeb_online/visualizador.php?bd=IMPRENSA\&nome_da_pasta=08033.110\&nu mero_da_pagina=7>. Grifos do original. 
Esperamos, pois, que este livro seja uma arma nas mãos de todos os camaradas, que seja utilizado de forma criadora na situação que vivemos em Portugal e que sirva igualmente para dar uma ideia do que poderá ser a sociedade portuguesa livre da exploração e opressão capitalista, livre do domínio imperialista e social-imperialista. ${ }^{82}$

A atuação da editora era totalmente vinculada aos objetivos e táticas políticas do MRPP, o que fica explicitado em uma resenha do volume 1 das Obras Completas de Stalin, editado em 1975 pela Vento de Leste. A resenha, da revista O Tempo e o Modo, informa:

O conjunto da obra, que é constituído por um total de 17 volumes, será publicado, não de acordo com a ordem cronológica, mas tendo em atenção as particularidades e o evoluir da situação política portuguesa e o contributo que as obras de Estaline poderão dar aos marxistas-leninistas, à classe operária e ao povo. [...] Para introdução da edição portuguesa foi escolhida a directiva do Movimento Reorganizativo do Partido do Proletariado 'Que viva Estaline' do Outono de 1972 [...]. ${ }^{83}$

O jornal oficial do MRPP também publicava textos sobre a importância dos

livros editados pela Vento de Leste e indicava como eles deviam ser usados:

A aquisição deste volume [História do Partido Comunista (bolchevique) da URSS. Vol. I] pela Editora Vento de Leste e a organização de todo o trabalho de estudo na base de tal obra é uma tarefa urgente a empreender por todos os camaradas, simpatizantes e ativistas a todos os escalões e em todas as zonas e setores do nosso Movimento. [...] Que se organize a leitura e a discussão coletiva de tal obra na perspectiva da sua aplicação criadora à prática concreta da luta de classes em Portugal! ${ }^{84}$

O nome da editora provém de uma citação de Mao Tsé-tung, de novembro de 1957: "Considero que a atual situação internacional se caracteriza pelo fato do vento leste prevalecer sobre o vento oeste”. Esta citação aparece como epígrafe em muitos livros da editora. A editora teve forte atuação a partir do segundo semestre de 1974 até 1977. No total, editou cerca de 70 títulos nesse período. Os livros tinham padrão editorial e gráfico profissional.

Com excessão de dois títulos (Nós povo: poesia, de Leonel Santos, 1976; e Quadros heróicos do povo em luta, obra teatral de Júlio Vilarinho, 1977), todos os

\footnotetext{
82 "Introdução". In: Dez questões sobre a China. Lisboa: Vento de Leste, 1975.

${ }^{83}$ Resenha do volume 1 das Obras Completas de José Estaline, 1976. O Tempo e o Modo, Lisboa, no 115 , janeiro 1976, p. 37. Disponível on line no site da Fundaçao Mário Soares:

$<$ http://www.fmsoares.pt/aeb_online/visualizador.php?bd=IMPRENSA\&nome_da_pasta=08033.115\&nu mero_da_pagina $=39>$.

84 "Rectifiquemos o nosso estudo". Luta Popular, Lisboa, 9/1/1975, nº 41, p. 2.
} 
demais livros editados pela Vento de Leste eram de autores estrangeiros, incluindo alguns clássicos do pensamento socialista e muitas obras oriundas dos partidos "irmãos" da China e da Albânia. Lenin e Stalin são os dois autores mais editados, mas também há obras de Mao Tsé-tung, Marx e Engels, bem como muitas obras sobre a realidade da China (havia uma coleção chamada Amizade Portugal-China) e da Albânia (coleção Amizade Portugal-Albânia), além de livros que reproduziam documentos que expressavam as linhas oficias dos partidos no poder nesses países.

Eis alguns títulos publicados: Cartas de longe/Teses de Abril, de Lenin (1974); Anarquismo ou socialismo?, de Stalin (1974); Histórias de Ye Sinan, de Ho Yi (1974); História do Partido do Trabalho da Albânia, quatro volumes, do Instituto de Estudos Marxistas-Leninistas (1974-75); Sobre o Estado e as eleições, de K. Marx e F. Engels (1975); A Revolução Cultural nos campos chineses (1975); 25 anos de lutas e de vitórias na construção do socialismo, de Enver Hoxha (1975); Cuba, um mito que se apaga: da revolução anti-imperialista a peão do social.imperialismo (1976); Sobre os quadros, de Georgi Dimitrov (1976); Documentos do XI Congresso do Partido Comunista da China (1977); 4 O que é o marxismo?, de Lenin (1977); Eu próprio: poesia 1912-1916, de Maiakovski (1979); Sobre a linha geral para o movimento comunista internacional (1979).

Apesar de haver apenas dois livros de autores portugueses, devemos ressaltar que a maior parte das obras publicadas trazia sempre um texto introdutório feito em Portugal, de responsabilidade da editora, ou seja, do MRPP, que contextualizava a obra editada e procurava situá-la no quadro político e nas disputas que se davam na sociedade portuguesa.

A Vento de Leste possuía uma livraria que funcionava na rua Barão de Sabrosa, em Lisboa. Posteriormente, foi aberta outra livraria na sede central do MRPP. Teve também uma livraria na cidade do Porto, na avenida da Boavista.

Em março de 1975 o MRPP teve sua atividade política suspensa e foi impedido de participar das eleições para a Assembleia Constituinte, no mês seguinte. Durante esse período foi "proibido de desenvolver propaganda pública, incluindo a realização de comícios", sob a falsa acusação de ter participado ou influenciado o falhado golpe de 11 de março daquele ano ${ }^{85}$. Na noite de 28 de maio de 1975 desencadeou-se uma forte

\footnotetext{
${ }^{85}$ Dois outros partidos sofreram as mesmas sanções nesta data: o Partido da Democracia Cristã (PDC), de extrema direita, que tinha de fato ligações com o golpe, e a Aliança Operário-Camponesa (AOC), partido
} 
repressão sobre o MRPP, executada pelo Comando Operacional do Continente (Copcon), e realizada sob o pretexto de apreender armas que o partido teria em suas sedes. Esta ação levou à invasão das sedes do partido na região de Lisboa e à prisão de mais de 400 militantes. A livraria do MRPP foi um dos locais "assaltados" pelo Copcon nesse dia ${ }^{86}$. Uma das ações do MRPP para responder às acusações de que foi vítima foi promover uma conferência de imprensa das editoras Vento de Leste, Nova Aurora, Germinal e Sementes, todas ligadas ao grupo, para que esclarecessem quais eram os objetivos da sua atuação ${ }^{87}$.

No final de dezembro de 1976 o MRPP adotou o nome de Partido Comunista dos Trabalhadores Portugueses (PCTP).

João Camacho diz que "a editora era dirigida pelo Comitê Lenine [o comitê central do MRPP], por meio do comitê que estava à frente da editora", mas que apesar disso "as decisões sobre os títulos editados eram coletivas, não vinham diretamente do CC, mas dos militantes, do setor estudantil. Só o tomo 5 das Obras Escolhidas de Mao Tsé-tung foi decisão do Comitê Lenine" ${ }^{\text {88 }}$.

A edição, em 1977, desta obra foi um dos principais momentos de atuação da editora, pois tal edição tornou-se o principal objetivo político do MRPP (já então rebatizado como PCTP/MRPP) naquele ano, mobilizando todo o partido para tal empreitada e envolvendo os militantes na venda do livro de um modo muito mais intenso do que era a prática comum.

O objetivo era lançar o livro no começo de novembro, para marcar as comemorações dos 60 anos da Revolução Russa de Outubro, e antes da edição oficial (chinesa) do livro em português. A tradução da obra de 630 páginas foi feita em um prazo muito curto, cerca de um mês, mediante o trabalho de uma equipe de cerca de 20 tradutores $^{89}$. O conjunto total de pessoas envolvidas no trabalho, incluindo datilógrafos e revisores, chegou a 30 elementos ${ }^{90}$. Como explicam os editores, não foi "possível basear a nossa tradução no original chinês, mas sim na versão inglesa autorizada

criado para disputar as eleições de abril de 1975, sob influência do PCP-ML/Vilar, e que, assim como o MRPP, não tinha ligações com o referido golpe. Cf. CORDEIRO, J. M. L. "Glossário dos anos do PREC...", op. cit., p. 106 e 124.

${ }^{86}$ Ibidem, p. 119-120.

87 HORTA, Maria Teresa. “Ecos literários”. Expresso, Lisboa, no 127, 7/6/1975.

${ }^{88}$ Entrevista com João Camacho, Lisboa, 3/3/2011.

${ }^{89}$ Entrevista com João Camacho, Lisboa, 3/3/2011; Entrevista com António Monteiro Cardoso, Lisboa, 2/3/2011.

90 "Prefácio da primeira edição". In: TSÉ-TUNG, Mao. Obras Escolhidas. Vol. V. Lisboa: Vento de Leste, 1977, p. VII. 
proveniente das Edições em Línguas Estrangeiras de Pequim"91, o que certamente tornou um pouco fácil a empreitada.

Os editores, sempre no estilo triunfalista que era marca registrada do MRPP, afirmam que o lançamento do livro "constituiu um acontecimento verdadeiramente único na história da actividade editorial do nosso país: 48 horas antes do seu lançamento a edição se encontrava esgotada; sete mil exemplares da obra foram vendidos num só dia"92. E completavam: "A edição desta obra é, sem dúvida, um acontecimento de grande alcance na vida ideológica e cultural do povo português e um novo e profícuo passo em frente na difusão do Marxismo-Leninismo-Maoismo no nosso país"93.

O livro teve uma grande tiragem, provavelmente de 15 mil exemplares na soma das duas edições feitas, ambas com encadernação em capa dura. Em função de todo o esforço feito, e da mobilização partidária para este fim, as vendas foram muito boas e importantes para as finanças do partido.

Esta edição foi dirigida pessoalmente por Arnaldo de Matos, secretário-geral da organização, que durante algum tempo foi nomeado no jornal Luta Popular, órgão central do MRPP, como "grande dirigente e educador do proletariado português"

Mary Ann, ex-militante do setor bancário do MRPP, confirma esta participação direta de Matos no processo de produção do livro:

[...] estando já o livro no prelo, a empresa que estava a imprimi-lo exigiu que o MRPP (nessa altura já PCTP/MRPP) apresentasse uma garantia bancária de 1200 contos para que a edição fosse liberada e os livros distribuídos. E quem melhor que os camaradas bancários poderiam resolver o problema? Fui então convocada, às 2 da manhã de um Domingo, para estar às 10 da manhã desse mesmo Domingo na Sede Central do Partido [...] fomos conduzidos a uma sala onde estava o Arnaldo Matos e outro membro do Comitê Central. Feita uma breve exposição da situação foi-nos dito que a nós como bancários caberia a resolução do problema, e a mim foi-me especificamente dada a tarefa de, no dia seguinte, junto da Secção de Garantias do BPA, obter a dita garantia bancária de 1200 contos. Tarefa fácil... ${ }^{95}$

A editora encerrou suas atividades no fim dos anos 1970, quando o MRPP também viu sua atuação política diminuída.

\footnotetext{
91 "Prefácio da segunda edição". In: TSÉ-TUNG, Mao. Obras Escolhidas. Vol. V. Lisboa: Vento de Leste, 1977, p. V-VI.

${ }^{92}$ Ibidem, p. V.

93 "Prefácio da primeira edição", op.cit., p. VII.

${ }^{94}$ Por exemplo, na capa da edição n ${ }^{\circ}$ 63, de 14/6/1975, momento em que Matos estava preso.

${ }^{95}$ ANN, Mary. “O desamor”. Blogue MikeRomeoPapaPapa, 21/3/2009. Disponível em: $<$ http://mikeromeopapapapa.blogspot.com/2009_03_01_archive.html>. Acesso em nov. 2010.
} 
É interessante destacar que o MRPP estava vinculado a várias editoras. A mais importante e semioficial era a Vento de Leste, mas havia também a Bandeira Vermelha (a editora oficial do grupo), a Nova Aurora (de João Camacho e Silvio Conde), a Sementes e a Estrela Vermelha (de António José Fonseca, do Porto), a Germinal (de José Manuel), além da editora da Associação de Amizade Portugal-Albânia (AAPA), que estavam sob sua influência. De acordo com João Camacho, a partir de certo momento chegou a haver reuniões conjuntas das editoras Vento de Leste e Nova Aurora para definição dos títulos que seriam lançados. E havia, desde antes do 25 de Abril, uma "plataforma de editoras democráticas e populares" (na verdade, apenas as editoras citadas acima, ligadas ao MRPP), da qual fazia parte também a revista $O$ Tempo e o Modo (que havia lançado a ideia da plataforma), para discussão coletiva ao nível político dos lançamentos e da sua atuação ${ }^{96}$.

António José Fonseca confirmou a existência da "plataforma" de editoras: "É um fato. Havia reuniões na Vento de Leste em Lisboa", mas diz que não havia efetivamente "uma política consistente de colaboração entre as editoras referidas",97.

No Centro de Documentação 25 de Abril, da Universidade de Coimbra, localizei um catálogo conjunto das editoras Vento de Leste e Germinal, produzido para as feiras do livro de 1975, que mostra uma das formas de atuação conjunta destas editoras ${ }^{98}$. Camacho também mencionou o fato de em muitas feiras do livro as editoras Vento de Leste e Nova Aurora terem participado conjuntamente, dividindo um mesmo estande.

A existência de várias editoras ligadas ao MRPP, e o fato de o grupo possuir também livrarias, mostram a importância que este partido dava aos livros e ao seu papel como formador de militantes e divulgador de suas propostas entre os seus simpatizantes. Parece não haver dúvida de que, apesar de a prioridade do MRPP ser o jornal diário Luta Popular ${ }^{99}$, o partido dedicou esforços importantes para a criação e manutenção de editoras a ele vinculadas, seja diretamente, como parecem ser os casos das editoras Vento de Leste e Bandeira Vermelha, seja por meio de iniciativas de militantes do grupo, como as editoras Nova Aurora, Sementes, Estrela Vermelha, Germinal e a editora da Associação de Amizade Portugal-Albânia (AAPA).

Camacho diz, a partir de sua experiência, que o livro "tem uma força política

\footnotetext{
${ }^{96}$ Entrevista com João Camacho, Lisboa, 3/3/2011.

${ }^{97}$ Mensagem eletrônica de António José Fonseca em 9/9/2012.

98 Catálogo das editoras Vento de Leste e Germinal, 1975. Pasta "Cultura”. Dossiers Temáticos, Centro de Documentação 25 de Abril, Universidade de Coimbra.

${ }^{99}$ Entrevista com Fernando Rosas, Lisboa, 15/2/2011.
} 
enorme. E teve um enorme papel político antes e depois do 25 de Abril. Houve um movimento cultural muito grande da esquerda em Portugal, que começou nas livrarias e nos cineclubes, e depois com o nascimento das pequenas editoras". Mas, ao mesmo tempo, Camacho considera que esse papel político do livro "não cresceu, em termos de importância, após o 25 de Abril" ${ }^{100}$.

António José Fonseca avalia que a atuação desse conjunto de editoras teve uma importância relevante para o MRPP: "Contribuíram de forma significativa para reunir a intelectualidade progressista e para a divulgação dos ideais revolucionários e do marxismo-leninismo-maoismo que o MRPP defendia. Para o país creio que tiveram um contributo modesto" $" 101$.

A Vento de Leste foi claramente uma editora de partido, cujo objetivo era expressar a linha política do MRPP, ser seu porta-voz e seu veículo no debate político e de ideias em um nível mais aprofundado do que aquele permitido pela imprensa diária ou semanal. Era, portanto, uma editora política militante, cuja razão de ser era a luta política empreendida pelo seu partido.

\subsubsection{Publicações Nova Aurora}

Trav. Do Giestal, 59-B (à R. Aliança Operária) - Lisboa

Editores: João Camacho e Silvio Conde.

Início das edições: 1974.

Distribuição: Dinalivro.

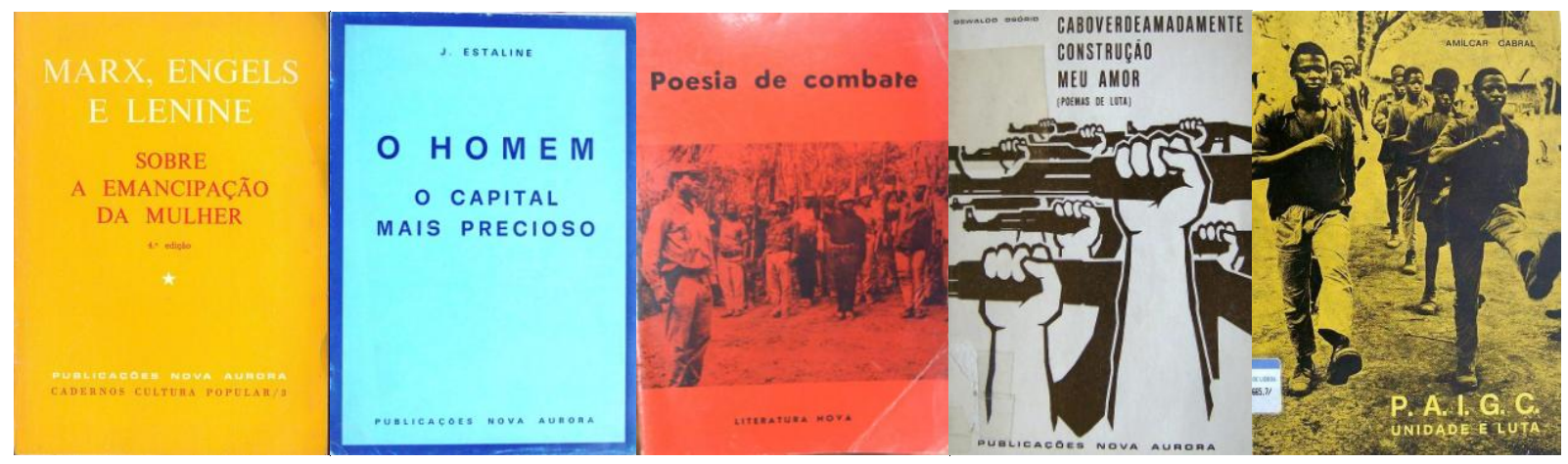

Editora fundada no primeiro semestre de 1974, ainda antes do 25 de Abril, por João Camacho, juntamente com Silvio Conde, ambos militantes do MRPP, após os dois terem deixado, por divergências políticas, as Edições Maria da Fonte (ver item), que

${ }^{100}$ Entrevista com João Camacho, Lisboa, 3/3/2011.
${ }^{101}$ Mensagem eletrônica de António José Fonseca em 9/9/2012. 
haviam iniciado junto com Manuel Quirós ${ }^{102}$.

Começaram editando a coleção Cadernos Cultura Popular, cujo primeiro volume foi lançado em junho de 1974. A editora, apesar de fortemente vinculada ao MRPP, manteve-se sempre sob a direção de João Camacho e Silvio Conde. A decisão sobre o que seria editado era basicamente feita de forma consensual com o MRPP. "Podia haver pequenas divergências em relação a alguns títulos. Nós íamos publicar, por exemplo, um livro do Agostinho Neto e não publicamos porque havia divergências com o MPLA [Movimento Popular de Libertação de Angola], e acabei por dar o livro a outra editora para não criar problemas com o MRPP”, lembra Camacho.

A linha editorial privilegiava, inicialmente, a questão da luta anticolonial e dos movimentos de libertação africanos. Havia duas coleções dedicadas exclusivamente a este tema: Textos de Amílcar Cabral e O Povo Moçambicano em Armas. Em uma "Nota do Editor" publicada no livro Guiné-Bissau: nação africana forjada na luta, de Amílcar Cabral, pode-se ler:

Ao divulgar nesta colecção [...] textos referentes à justa luta de libertação dos povos das colônias portuguesas, queremos exprimir a estes povos, irmãos do nosso povo, a nossa solidariedade militante com a sua luta heróica e vitoriosa, que tão profundamente abalou e abala a ditadura da burguesia colonial-fascista portuguesa que desde há tantos e tantos anos nos (e os) oprime e explora [...]. ${ }^{103}$

De acordo com Camacho, esta "solidariedade militante" não ficava apenas nas palavras, pois muitos livros foram oferecidos gratuitamente ao PAIGC (Partido Africano para a Independência de Guiné e Cabo Verde) e à Frelimo (Frente de Libertação de Moçambique), através das casas de estudantes de Cabo Verde e de Moçambique em Portugal.

O autor mais editado pelas Publicações Nova Aurora foi Samora Machel - líder da Frelimo e primeiro presidente de Moçambique após a independência -, com nove obras publicadas, algumas com títulos singulares, como: No trabalho sanitário materializemos o princípio de que a revolução liberta o povo (junho, 1974) e Impermeabilizemo-nos contra as manobras subversivas do inimigo, intensificando a ofensiva ideológica e organizacional no seio dos combatentes e massas (junho, 1975).

Outros autores recorrentes eram Mao Tsé-tung, Lenin, Stalin, Karl Marx,

\footnotetext{
${ }^{102}$ Entrevista com João Camacho, Lisboa, 3/3/2011. Todas as declarações de Camacho reproduzidas neste item são oriundas desta entrevista.

103 “Nota do Editor”. In: CABRAL, Amílcar. Guiné- Bissau: nação africana forjada na luta. Lisboa: Nova Aurora, agosto, 1974.
} 
Friedrich Engels e Amílcar Cabral. Foram editados também textos do Partido Comunista da China e do Partido do Trabalho da Albânia.

Na coleção Literatura Nova a editora publicou dois livros de poesia (Poesia de combate. Patriotas moçambicanos, combatentes da Frelimo, agosto, 1974; e Caboverdeamadamente - Construção - Meu amor: poemas de luta, de Osvaldo Osório, outubro, 1975) e um romance (Famintos: romance do povo caboverdiano sob o domínio colonialista, de Luís Romano, março, 1975).

A Nova Aurora não editou nenhum livro de autor português.

O trabalho da editora era quase todo realizado por Camacho e Conde. "Fazíamos tudo, tradução, revisão, capas, menos a parte gráfica", diz Camacho. Isso não prejudicou a qualidade das edições, pois os livros da Nova Aurora apresentavam um tratamento editorial e gráfico de nível profissional. A distribuição era feita pela distribuidora Dinalivro, de Lisboa.

"Fazíamos grandes edições e vendíamos muito barato. As tiragens eram de 10 mil, 15 mil, e se esgotavam rapidamente", recorda Camacho. Na sua avaliação,

A Nova Aurora tinha um público mais alargado que a Vento de Leste [a editora semioficial do MRPP], mais voltada para fora do MRPP. A Nova Aurora tinha um público que abrangia praticamente toda a esquerda portuguesa, enquanto a Vento de Leste não conseguiu isso, ficou mais restrita aos militantes e simpatizantes do MRPP.

Talvez por isso Camacho destaque que "A Nova Aurora vendia-se muito bem”. Isso pode ser também constatado pelo fato de seis livros da editora terem aparecido na secção "Os best-seller da quinzena" do jornal Expresso entre os meses de outubro de 1974 e junho de 1975.

O livro Contra a escravidão, pela liberdade, do MPLA, apareceu em $2^{\circ}$ lugar na lista por duas vezes; Estabelecer o poder popular para servir as massas, de Samora M. Machel, ocupou o $4^{\circ}$ e o $5^{\circ}$ lugar em duas ocasiões; Sobre a Emancipação da Mulher, reunião de textos de Marx, Engels e Lenin, esteve duas vezes na lista, em $7^{\circ}$ e $8^{\circ}$ lugares; P.A.I.G.C., unidade e luta, de Amílcar Cabral, apareceu duas vezes na lista, em $2^{\circ}$ e $7^{\circ}$ lugares; Fazer da escola uma base para o povo tomar o poder, de Samora Machel, esteve uma vez em $6^{\circ}$ lugar; e Famintos, de Luís Romano, ocupou uma vez o $1^{\circ}$ $\operatorname{lugar}^{104}$.

\footnotetext{
104 “Os best-seller da quinzena”. Secção do jornal Expresso, junho de 1974 a junho de 1975. Hemeroteca
} Municipal de Lisboa. 
Como vimos, na noite de 28 de maio de 1975 desencadeou-se uma forte repressão sobre o MRPP, executada pelo Copcon, e realizada sob o pretexto de apreender armas que o partido teria em suas sedes. Esta ação levou à invasão das sedes do partido na região de Lisboa e à prisão de mais de 400 militantes. Em decorência dessas prisões, foram organizadas manifestações pela libertação dos presos. Numa manifestação no dia 2 de junho, nas cercanias da prisão de Caxias, onde estavam presos vários militantes do MRPP, João Camacho foi atingido por um tiro na cabeça, e teve de ser submetido a uma cirurgia e ficar internado por algum tempo ${ }^{105}$.

Isso acabou por afetar a editora Nova Aurora, pois no período em que esteve hospitalizado começaram a surgir questões comerciais com a distribuidora Dinalivro, o que levou a que houvesse problemas neste setor.

Esse parece ter sido um dos fatores que levaram ao fim das atividades da editora em 1976, ano em que houve apenas a edição de dois títulos novos. Além disso, o arrefecimento do quadro político nacional após o golpe de 25 de novembro de 1975 e das eleições presidenciais de 1976, em que foi vencedor o general Ramalho Eanes (apoiado pelo MRPP), fizeram com que as organições de extrema esquerda vissem diminuídas as suas possibilidades de atuação.

A Nova Aurora participou da "plataforma de editoras democráticas e populares", que reunia as editoras sob influência do MRPP (ver item sobre a Editora Vento de Leste).

As Publicações Nova Aurora foram ativas somente por três anos, de 1974 a 1976, período em que lançaram cerca de 35 títulos. Tratou-se de uma editora claramente vinculada a um grupo político, o MRPP, e cuja atuação estava intimamente ligada às prioridades estabelecidas pelo grupo.

Como lembra Camacho, a partir de certo momento chegou a haver reuniões conjuntas entre a Nova Aurora e a Vento de Leste para definição dos títulos que seriam lançados. Mas, ao mesmo tempo, a Nova Aurora era uma editora privada, pertencente a João Camacho e Sílvio Conde, e ambos assumiam os riscos empresariais envolvidos. (Esta é a mesma situação das editoras Sementes, Estrela Vermelha e Germinal, também ligadas ao MRPP, que veremos a seguir.)

Em Portugal, no período analisado neste trabalho, muitas editoras de caráter

\footnotetext{
105 "As massas exigem a libertação do camarada Arnaldo de Matos e os militaristas respondem a tiro". Luta Popular, Lisboa, nº 63, 14/6/1975, p. 6-7; Entrevista com João Camacho, Lisboa, 3/3/2011.
} 
político funcionavam de acordo com este modelo híbrido - eram editoras partidarizadas mas ao mesmo tempo eram privadas.

\subsubsection{Editora Sementes}

Rua de Fez, 137 - Porto (1974)

R. Cidade de Luanda, 52, $4^{\circ}$ - Porto (dezembro, 1975)

Editor: António José Fonseca.

Fundação: 1974.

Distribuição: Dinalivro.
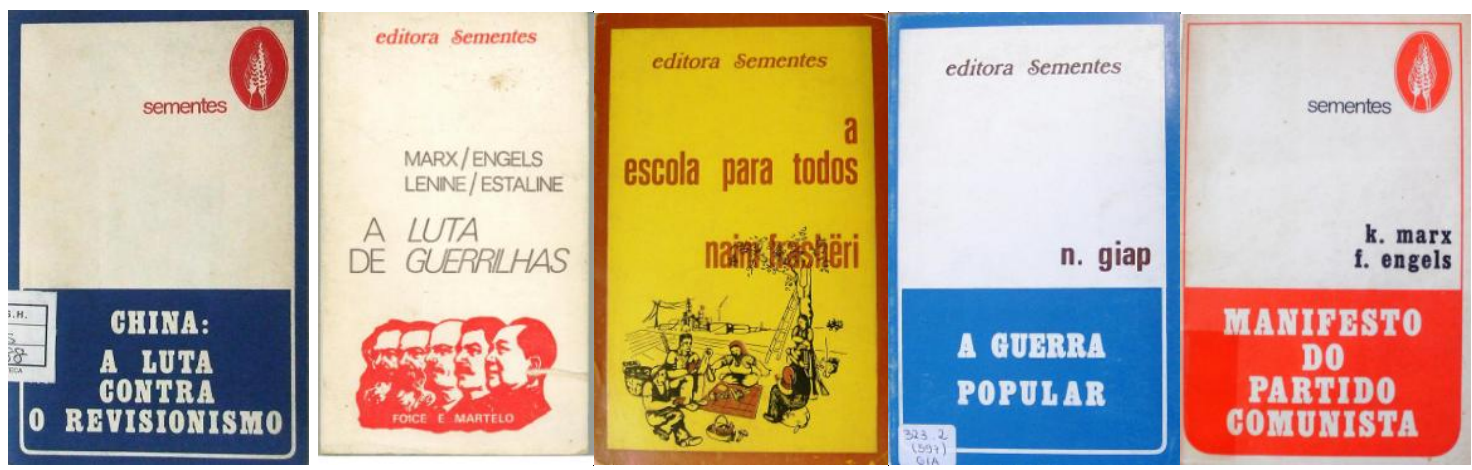

Editora criada em janeiro de 1974, no Porto, por José Martins Soares, advogado e dirigente do MRPP, e por António José Fonseca, estudante de economia e militante do $\mathrm{MRPP}^{106}$.

Soares era diretor da revista $O$ Tempo e o Modo, foi um dos fundadores da Associação de Amizade Portugal-China, atuava nos grupos de intelectuais e artistas simpatizantes do MRPP e era colaborador do jornal Luta Popular, também do MRPP. Ele morreu num acidente de automóvel na região de Águeda em junho de 1974, ou seja, seis meses após a criação da Editora Sementes. De acordo com o MRPP, "O camarada José Maria Martins Soares era o exemplo de como um intelectual disposto a servir inteiramente o povo pode prestar grandes serviços à revolução"107.

João Camacho (dono das Publicações Nova Aurora e colaborador das editoras Vento de Leste e Germinal, editoras também ligadas ao MRPP), lembra que ele e Martins Soares, pouco antes da morte deste último, planejavam lançar uma rede de livrarias ambulantes, que funcionariam em caminhonetes (carrinhas) e circulariam pelo

\footnotetext{
${ }^{106}$ Mensagem eletrônica de António José Fonseca em 31/8/2012.

107 “Honra a Martins Soares". Luta Popular, Lisboa, 14/6/1975, n 63, p. 3
} 
país ${ }^{108}$.

Fonseca já colaborava como tradutor e revisor com o António Daniel Abreu, das editoras Cadernos Para o Diálogo e Textos Marginais, e com João Barrote, da editora Escorpião/Textos Exemplares. Inicialmente, desde 1970 - e antes de aderir ao MRPP -, colaborara com a imprensa antifascista, "em especial com o Comércio do Funchal, então dirigido pelo Vicente Jorge Silva, e com o Jornal do Centro" ${ }^{\text {"109 }}$. Fonseca fundou também as Edições Estrela Vermelha, "claramente vocacionada para publicar livros ideologicamente ligados à linha política do MRPP"110 (ver a seguir). Ele chegou a ser dirigente do MRPP no Porto e candidato a presidente da Câmara Municipal (Prefeitura) dessa cidade ${ }^{111}$.

A Sementes atuou entre 1974 e 1976, período em que editou cerca de 20 títulos. De acordo com Fonseca, as duas editoras que ele ajudou a criar tinham uma intenção totalmente política: "Na época só havia um objetivo: combater a ditadura fascista (antes do 25 Abril de 1974) e, posteriormente, divulgar a ideologia comunista. Não se pode dissociar a atuação das editoras desse aspecto" ${ }^{112}$.

Num dos primeiros títulos editados pela Sementes, o livro China: a luta contra o revisionismo (agosto, 1974), foi publicado um texto que afirmava os objetivos políticos da editora e a forma como ela pretendia sustentar-se economicamente:

\section{ASSINATURAS}

O grupo de camaradas que, em janeiro de 1974, decidiu construir a editora Sementes, pensa que o objetivo maior a ser alcançado é o de difundir o mais amplamente possível a literatura comunista.

Este objetivo só poderá ser conseguido através da adopção de um correcto estilo de trabalho e da organização de uma ampla rede de assinantes capaz de, por todo o país, desenvolver um eficaz trabalho de propaganda.

Pretendendo-se que o preço de capa seja sempre o mais baixo possível, torna-se indispensável a constituição de um grande movimento de assinaturas que possibilitem, a priori, o cálculo de um número mínimo de exemplares vendidos, factor fundamental para a sobrevivência de uma editora sem capital e, por conseguinte, sem potencialidades para efectuar tiragens elevadas.

Neste sentido, a assinatura constitui um contributo muito importante,

${ }^{108}$ Entrevista com João Camacho, 3/3/2011.

${ }^{109}$ Mensagem eletrônica de António José Fonseca em 9/9/2012.

${ }^{110}$ Idem.

111 Idem.

112 Idem. 
não só pelas garantias que oferece mas ainda porque, possibilitando o aumento das tiragens, reduz o custo por exemplar.

$\mathrm{O}$ esquema que propomos beneficia o assinante (assinatura normal) de um desconto de $25 \%$ em cada livro publicado.

A iniciativa de, desde o começo das atividades da editora, buscar a via das assinaturas para a sua sustentação econômica, pode indicar que imaginava-se que a circulação dos livros atingiria, em primeiro lugar, um público próximo à editora e aos seus colaboradores. No entanto, Fonseca lembra que o sistema de assinaturas "Teve pouca relevância. As vendas foram essencialmente asseguradas pela distribuidora"113

Os livros da Sementes recebiam um tratamento editorial e gráfico de nível profissional. A seleção dos títulos era fundamentalmente realizada por Fonseca. Ele recorda que:

Organizei um grupo de colaboradores relativamente amplo que incluía essencialmente estudantes universitários de diversas faculdades do Porto, mas que também teve colaboradores em Lisboa. Este grupo promovia o trabalho de tradução, por vezes pago, e fazia uma pequena distribuição dos livros. ${ }^{114}$

A distribuição comercial era feita pela distribuidora Dinalivro, de Lisboa. A relação com a Dinalivro era consequência da estreita ligação que Fonseca mantinha com a Gráfica Firmeza, no Porto, de Henrique A. Carneiro e do Sr. Agostinho. "O Carneiro tinha uma ligação comercial muito forte com a Dinalivro", lembra Fonseca ${ }^{115}$.

Os livros editados mostram a predominância absoluta de títulos oriundos dos partidos comunistas da China e da Albânia, além de alguns títulos dos clássicos socialistas, como Marx, Engels, Lenin e Stalin. Há ainda uma obra literária, que abordarei mais adiante. Entre os títulos lançados estavam: A nossa política económica, de Mao Tsé-tung; Sobre a literatura, a filosofia e a música, de A. Jdanov (1975); Marxismo e questões de linguística, de Stalin (1975); A democracia popular, de Dimitrov (1975); A revolução em Espanha, de Karl Marx e Friedrich Engels (1976); $O$ controlo operário, de Enver Hoxha (1976); A guerra popular, de N. Giap (1976).

A editora não publicou nenhum título de autor português. Todavia, existia a preocupação de incorporar autores nacionais ao catálogo da editora. Isso é explicitado em um texto publicado no livro A guerra popular (janeiro de 1976) e também distribuído em circular impressa avulsa, que apresentava o programa editorial da

\footnotetext{
113 Idem.

114 Idem.

115 Idem.
} 
Sementes e os seus objectivos, e solicitava o envio de originais de autores portugueses que se alinhassem com este projeto, para possível publicação.

Esta circular, da qual reproduzimos um trecho a seguir, é muito interessante por explicitar o papel político e ideológico que a editora Sementes queria protagonizar e, principalmente, a sua visão - marcadamente instrumentalizadora e propagandística dos intelectuais, da cultura, da arte e da literatura:

\section{Circular}

\section{Sem um amplo trabalho cultural a revolução não é possível}

Originais de autores portugueses

A Editora Sementes, editora democrática e popular, tomou a iniciativa de conclamar os intelectuais revolucionários no sentido de participarem activamente na edificação de uma literatura nacional, patriótica, científica e de massas, tendo como objectivo a propaganda da teoria científica do proletariado, o marxismo-leninismo-maoismo.

Todas as grandes revoluções foram precedidas de um movimento cultural amplo que preparou o terreno, que possibilitou a valorização das massas e a preparação para as novas tarefas e que depois se integrou como parte componente da revolução e veio a adquirir desenvolvimento maior quando ela triunfou. A revolução não é possível sem que o trabalho no campo da cultura tenha alcançado um grande desenvolvimento.

Os trabalhadores da cultura devem "descer do cavalo" e "estabelecerse", ligar-se intimamente ao povo, viver no seu seio, integrar-se na luta de classes e colocar as suas canetas ao serviço da revolução.

Os camaradas devem enviar os originais para possível publicação na Coleção Sementes, podendo desde já contactar-nos para mais informações. [...]. ${ }^{116}$

É dentro deste espírito que devemos entender a edição pela Sementes do romance do albanês Ismail Kadaré ( $O$ general do exército morto), escritor hoje reconhecido internacionalmente e que acabou por abandonar a Albânia em 1990. Sobre este livro, a revista O Tempo e o Modo (abril 1976), dirigida nessa altura pelo MRPP, publicou uma resenha (não assinada) que advogava "[...] a actualidade e a utilidade da sua publicação como instrumento importante de educação do nosso povo na actual fase da revolução". E esclarecia as motivações de tal edição:

[...] a sua utilidade e importância, para o caso concreto da revolução portuguesa, centra-se principalmente naquele campo diretamente

\footnotetext{
116 “Circular: Sem um amplo trabalho cultural a revolução não é possível”, 1976. Pasta "Cultura".
} Dossiers Temáticos, Centro de Documentação 25 de Abril, Universidade de Coimbra. 
relacionado com o atraso relativo da nossa literatura revolucionária, com a inexistência de romances revolucionários portugueses de imediata utilidade para o nosso povo em luta, e com a necessidade imperiosa de que nossos escritores revolucionários produzam tais obras. O general do exército morto é, sob este ponto de vista, uma lição importantíssima que constitui ao nível do rigor político, literário e artístico, uma vitória do romance socialista, que aprendida pelos nossos intelectuais revolucionários, vai certamente contribuir para a mais rápida superação das deficiências que a nossa literatura e a nossa arte novas ainda possuem. ${ }^{117}$

Também constava da programação da editora a publicação de dois livros de Lu Sun (A verdadeira história de $A Q$. e A erva daninha), escritor chinês considerado por alguns como o "fundador da moderna literatura chinesa" e "precursor da revolução cultural proletária" naquele país ${ }^{118}$. No entanto, a edição dessas obras não ocorreu.

Em 1976 a Editora Sementes cessou sua atuação, em função, ao que tudo indica, do esfriamento e da normalização da situação política após o golpe de 25 de novembro de 1975 e das eleições presidenciais de 1976. "Após o período revolucionário a procura de livros marxistas caiu e a editora não tinha planos para prosseguir, tendo terminado", afirma Fonseca $^{119}$.

Fonseca abandonou a militância na década de 1980. "Estava, como muitos outros, cansado e certamente desiludido com a visão muito sectária que o MRPP seguia. Em minha opinião o esforço desmesurado em manter o jornal Luta Popular diário foi um erro enorme que afastou muitos militantes e simpatizantes", avalia ele ${ }^{120}$.

Fonseca tornou-se empresário na cidade de Maia, Portugal.

A Sementes participou da "plataforma de editoras democráticas e populares" do MRPP (ver item sobre a Editora Vento de Leste). Claramente vinculada a este grupo, a atuação da Sementes seguia as suas orientações. Mas tratava-se de uma editora privada, como também eram outras vinculadas ao MRPP (Nova Aurora, Estrela Vermelha e Germinal), ou seja, seus proprietários assumiam os riscos empresariais envolvidos em cada caso.

A editora Sementes, por meio de sua atuação e dos textos programáticos que

\footnotetext{
117 "Nota de leitura do romance $O$ general do exército morto (romance albanês de Ismail Kadaré)". $O$ Tempo e o Modo, Lisboa, n 117, abril 1976, p. 23-25. Disponível on line no site da Fundação Mário Soares: <http://www.fmsoares.pt/aeb_online/visualizador.php?bd=IMPRENSA\&nome_da_pasta=08033.117\&nu mero_da_pagina=25>.

118 “Lu Sun: precursor da revolução cultural proletária”. Spartacus, Lisboa, no 9, março 1979.

${ }^{119}$ Mensagem eletrônica de António José Fonseca em 9/9/2012.

${ }^{120}$ Idem.
} 
inseria em alguns dos livros que editava, é um dos bons exemplos, em Portugal, de editoras políticas militantes, cuja criação e atuação vinculavam-se diretamente a projetos políticos e ideológicos partidários.

\subsubsection{Edições Estrela Vermelha}

Porto

Editor: António José Fonseca.

Início das edições: 1974.

Distribuição: Dinalivro.

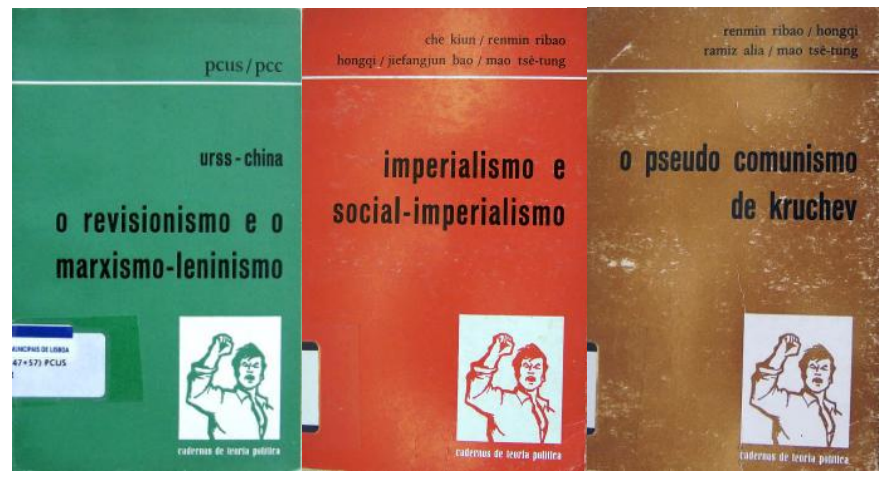

Editora criada após o 25 de Abril por António José Fonseca, estudante de economia e militante do MRPP, que foi também um dos fundadores da Editora Sementes. A Estrela Vermelha atuou em 1974 e 1975, tendo publicado oito títulos.

A Estrela Vermelha foi, nas palavras de Fonseca, "claramente vocacionada para publicar livros ideologicamente ligados à linha política do MRPP"121. Como vimos, Fonseca era claro ao explicitar que as duas editoras que ajudou a criar tinham uma intenção totalmente política.

A Estrela Vermelha publicou obras de Mao Tsé-tung, Deng Xiaoping e Enver Hoxha, além de obras que se inseriam nas disputas políticas e ideológicas travadas pelos grupos maoistas, como O pseudo comunismo de Kruchev, de Renmin Ribao, Hongqi, Ramiz Alia, Mao Tsé-tung (1975); URSS-China: o revisionismo e o marxismo-leninismo (1974); e Imperialismo e social-imperialismo, de Renmin Ribao, Hongqi, Mao TseTung, Che Kiun, Jiefangjun Bao (1975). Todos os títulos editados seguem essa linha.

Os livros publicados mostram um tratamento editorial e gráfico profissional,

${ }^{121}$ Mensagem eletrônica de António José Fonseca em 9/9/2012. 
assim como a distribuição, feita pela Dinalivro, de Lisboa.

A editora deixou de publicar em 1975. De acordo com Fonseca, "O mercado para os livros de propaganda m-1 [marxista-leninista] foi inundado nessa época por numerosas editoras essencialmente ligadas aos partidos políticos que reclamavam essa ideologia". Isso fez com que concentrasse seus esforços na Editora Sementes "que tinha um público mais vasto" $" 122$.

A atuação das Edições Estrela Vermelha, breve e pouco intensa, foi sempre marcada pela total subordinação ao objetivos políticos do MRPP.

\subsubsection{Germinal Editora e Distribuidora}

Rua Duarte Galvão, 14-A - Lisboa

Editor: José Manuel.

Fundação: 1974.

Distribuição: própria.
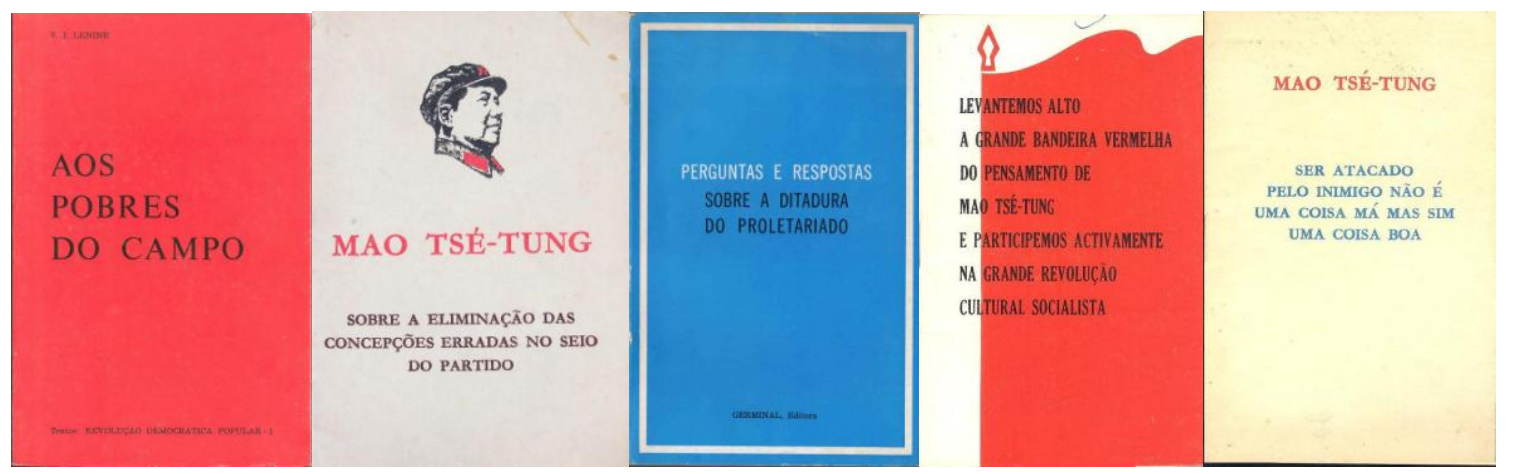

Pequena editora ligada ao MRPP. Foi fundada por José Manuel, com a colaboração de João Camacho (dono das Publicações Nova Aurora e colaborador da Editora Vento de Leste). José Manuel havia sido funcionário da Livraria Guernica, de Lisboa, que pertencera a Camacho ${ }^{123}$. Infelizmente, não foi possível saber qual o sobrenome de José Manuel.

A Germinal surgiu pouco depois do 25 de Abril e atuou até 1976. Nesse período editou cerca de 20 títulos.

Os livros da Germinal tinham tratamento editorial e gráfico de bom nível,

${ }^{122}$ Idem.

${ }^{123}$ Entrevista com João Camacho, Lisboa, 3/3/2011. 
profissional, com coleções bem definidas graficamente, apesar de simples. Em geral as capas eram sóbrias, quase sempre apenas com os títulos dos livros sobre um fundo neutro, sem imagens.

A Germinal possuía uma livraria e fazia ela mesma a distribuição comercial de seus livros, pois era também distribuidora.

Pelos títulos editados, verifica-se que a maior parte deles é oriunda do Partido Comunista da China, e alguns do Partido do Trabalho da Albânia. Quase metade das obras publicadas eram de Mao Tsé-tung (oito). Eis alguns livros editados: Sobre a eliminação das concepções erradas no seio do partido, de Mao Tsé-Tung (1974); Aos pobres do campo, de Lenin (1974); Ser atacado pelo inimigo não é uma coisa má, mas sim uma coisa boa, de Mao Tsé-Tung (1975); A libertação da mulher albanesa, de Enver Hoxha (1975); Colonialismo e neo-colonialismo, de Milo Paskal (1975); A China sem inflação, de Ki Ti, Shia Wei e Wang Sing (1975); A frente única contra o fascismo e a guerra, de Georgi Dimitrov (1976); A tomada da montanha do tigre, de Chaquiapam (1976).

Não há nenhum título de autor português. Talvez por isso, alguns dos livros publicados tivessem a preocupação de trazer textos introdutórios que procuravam contextualizar a posição da editora na situação política portuguesa e o papel que os editores esperavam que aquela obra cumprisse na conjuntura que se vivia, particularmente na questão que aparecia como a principal nestes textos: a construção de um "verdadeiro" partido do proletariado no país.

É o caso, por exemplo, deste texto introdutório, de responsabilidade da editora, datado de julho de 1975:

Nesta fase de grande ascenso da luta de classes em Portugal, em que as condições objetivas que determinam o avanço da Revolução estão preenchidas, determinadas condições subjetivas encontram-se ainda em atraso. Uma destas, sem dúvida essencial, é a não existência em Portugal de um Partido da classe operária e haver um partido que, dizendo-se comunista, é um destacamento da burguesia infiltrado no seio do movimento operário português e uma agência na nossa pátria dos interesses social-imperialistas revisionistas soviéticos. ${ }^{124}$

Textos como este, que reproduziam as posições políticas do MRPP, estavam fortemente influenciados pelos fatos ocorridos entre março e maio de 1975. Em março o MRPP teve sua atividade política suspensa e foi impedido de participar das eleições

124 “Introdução". In: PLÉKHANOV. A concepção materialista da história. Lisboa: Germinal, 1975, p. 6. 
para a Assembleia Constituinte, como já vimos. E em 28 de maio o Copcon invadiu sedes do partido na região de Lisboa e prendeu mais de 400 militantes do grupo ${ }^{125}$. A posição do MRPP sobre estes acontecimentos pode ser vista no texto introdutório, datado de junho de 1975, a uma obra de Mao Tsé-tung:

Após o 25 de Abril, data em que a camarilha no poder foi substituída por outra de máscara democrática, mas que nada mudou no essencial, só mudando nas palavras, novas ilusões se criaram no espírito do povo português. Mas, mal passado um ano, a classe operária e o povo começam a compreender qual a verdadeira natureza de classe dos senhores do 25 de Abril, com a íntima colaboração de todos os partidos traidores e conciliadores com principal destaque para $\mathrm{o}$ partido social-fascista do ministro sem pasta Barreirinhas Cunhal, quando veem impedida a participação nas eleições da vanguarda da classe operária, as prisões e torturas dos seus melhores filhos, e mais recentemente o ataque selvático e terrorista às suas sedes e o roubo descarado do que lá se encontrava [...]. ${ }^{126}$

A Germinal participou da "plataforma de editoras democráticas e populares" (ver item sobre a Editora Vento de Leste). Localizei um catálogo conjunto das editoras Vento de Leste e Germinal, provavelmente produzido para as feiras do livro de 1975, que mostra uma das formas de atuação conjunta destas editoras ${ }^{127}$.

A Germinal era claramente vinculada ao MRPP e seguia as orientações do grupo. Mas, de modo semelhante às editoras Nova Aurora, Sementes e Estrela Vermelha, era uma editora privada, em que o proprietário assumia os riscos empresariais envolvidos.

Em virtude dos textos sobre a conjuntura política que inseria em alguns dos seus livros, a Germinal é mais um claro exemplo de editora política militante, cuja criação e atuação vinculavam-se diretamente a um projeto político e ideológico partidário.

${ }^{125}$ CORDEIRO, "Glossário dos anos do PREC...", op. cit., p. 119-120.

126 "Introdução". In: TSE-TUNG, Mao. Sobre o problema da cooperação agrícola. Lisboa: Germinal, 1975 , p. 5-6.

${ }^{127}$ Catálogo das editoras Vento de Leste e Germinal, 1975. Pasta "Cultura". Dossiers Temáticos, Centro de Documentação 25 de Abril, Universidade de Coimbra. 


\subsubsection{Edições Bandeira Vermelha - PCTP/MRPP}

Sede Nacional do PCTP/MRPP. Av. Álvares Cabral - Lisboa.

Fundação: 1975.

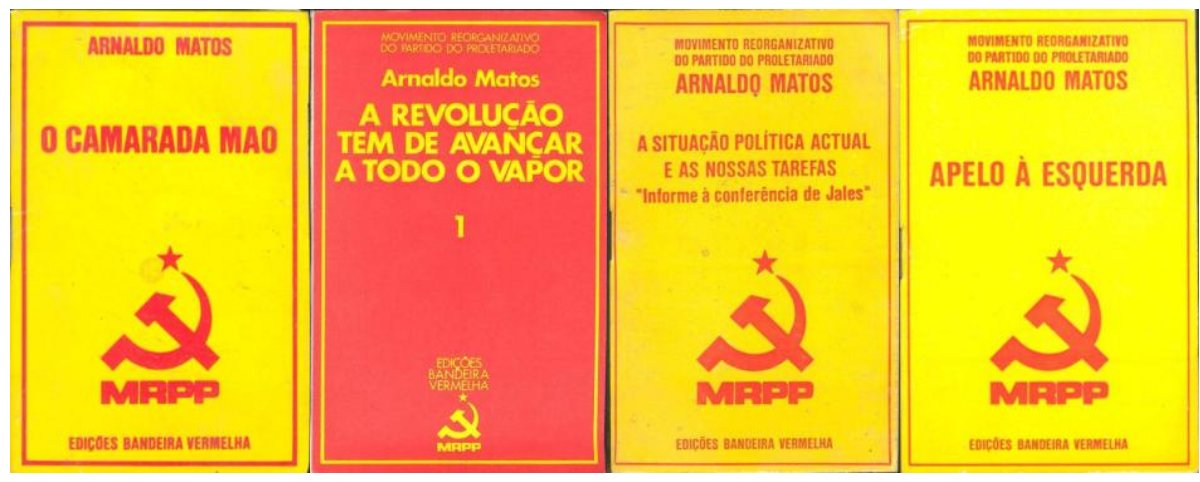

Trata-se da editora oficial do MRPP/PCTP, responsável pela edição de documentos da direção do partido, principalmente de textos do seu secretário-geral, Arnaldo de $\operatorname{Matos}^{128}$. Era subordinada ao Comitê Lenine, o comitê central do MRPP.

O MRPP foi criado em setembro de 1970, e a partir de dezembro de 1976 adotou o nome de PCTP/MRPP (Partido Comunista dos Trabalhadores Portugueses/Movimento Reorganizativo do Partido do Proletariado).

A editora não deve ser confundida com a sua homônima do $\mathrm{PCR}(\mathrm{R}) / \mathrm{PC}(\mathrm{R})$, fundado em janeiro de 1976.

Anúncio publicado na revista $O$ Tempo e o Modo expunha da seguinte forma os objetivos da editora:

As edições Bandeira Vermelha, editora do Partido Comunista dos Trabalhadores Portugueses, destinam-se ao proletariado revolucionário e às amplas massas populares. Erguer uma editora comunista é, nas actuais condições de cerco do capital, uma batalha de classe extremamente aguda. Lutar pela difusão das edições Bandeira Vermelha entre o proletariado e o povo é uma tarefa que cabe a todos os comunistas e amigos da Revolução. ${ }^{129}$

Os livros das Edições Bandeira Vermelha-PCTP/MRPP tinham qualidade editorial e gráfica de nível profissional. Não obtive informação se havia distribuição comercial, mas por sua natureza é mais provável que a distribuição fosse apenas interna,

\footnotetext{
${ }^{128}$ Entrevista com João Camacho, Lisboa, 3/3/2011; Mensagem eletrônica de António José Fonseca em 9/9/2012.

${ }^{129}$ Anúncio das Edições Bandeira Vermelha em O Tempo e o Modo, n 123, mai. 1977, p. 10. Disponível on line no site da Fundaçao Mário Soares:

$<$ http://www.fmsoares.pt/aeb_online/visualizador.php?bd=IMPRENSA\&nome_da_pasta=08033.123\&nu mero_da_pagina $=12>$.
} 
voltada para os militantes e simpatizantes do MRPP e de outras organizações a ele ligadas. De acordo com, António Fonseca, dono das editoras Sementes e Estrela Vermelha (também ligadas ao MRPP), “A distribuição era ao que sei assegurada pelas livrarias Vento de Leste e pelas sedes do MRPP"130.

A editora atuou entre 1975 e 1977, período em que publicou cerca de dez títulos, entre os quais: A revolução tem de avançar a todo o vapor (1975); A situação política actual e as nossas tarefas: informe à conferência de Jales (1975); O camarada Mao (1976), todos estes de Arnaldo Matos; As nossas tarefas. Documentos do I Plenum do I Comité Central do PCTP/MRPP (1977); e Estatutos do PCTP/MRPP - Programa geral do Partido.

O MRPP realizava ainda edições avulsas, sem o selo das Edições Bandeira Vermelha. Tratava-se de textos programáticos ou de discursos de Arnaldo de Matos, algumas vezes editados sob a responsabilidade de grupos de simpatizantes de uma freguesia ou cidade, ou sob a responsabilidade da Federação de Estudantes MarxistasLeninistas (FEM-L).

\subsubsection{Edições da AAPA (Associação de Amizade Portugal-Albânia)}

Campo dos Mártires da Pátria, 19 - Lisboa

Responsável: Luís Borges (abril, 1976)

Início das edições: 1976.

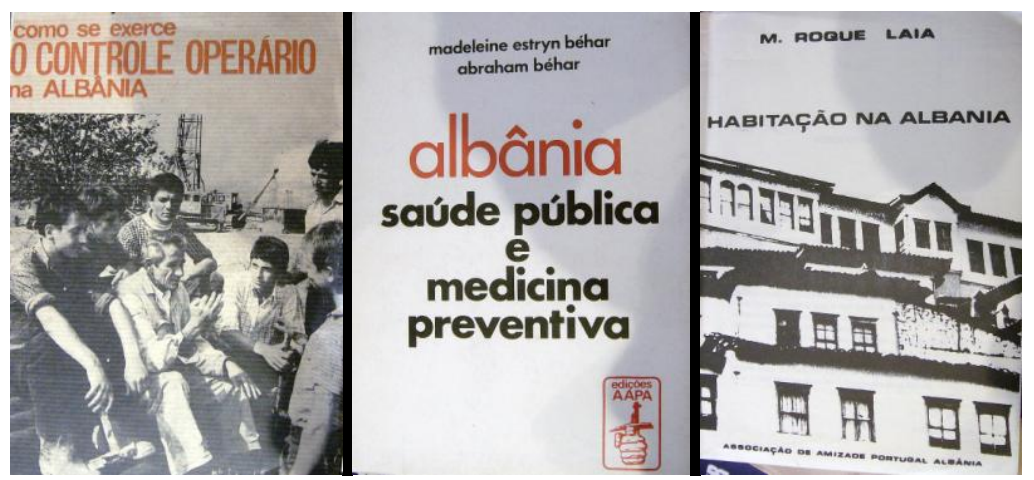

A Associação de Amizade Portugal-Albânia (AAPA) era uma das muitas organizações setoriais ou temáticas vinculadas ao MRPP, como, por exemplo, a Federação dos Estudantes Marxistas-Leninistas (FEM-L), a Associação de Amizade Portugal-China (AAPC), o Movimento Popular Anticolonial (MPAC) e a Resistência

${ }^{130}$ Mensagem eletrônica de António José Fonseca, 20/9/2012. 
Popular Anticolonial (RPAC).

A Secção de Edições da AAPA editou poucos livros - localizei referências a seis títulos - entre 1976 e 1978, sempre dedicados aos objetivos a que a Associação se propunha, ou seja, “[...] a divulgação da realidade concreta do povo albanês [e] o modo como a Albânia Socialista tem vindo a resolver os seus problemas, nos mais diversos campos, desde a libertação de 1944"131.

Desse modo, foram editadas as seguintes obras: O ensino na Albânia (1976); Como se exerce o controle operário na Albânia, de Gilbert Mury e outros (1976); Constituição da República Popular Socialista da Albânia: Projecto (1976); A luta do povo albanês pela emancipação da mulher (1976); Albânia, saúde pública e medicina preventiva, dos médicos franceses Madeleine Stryn Béhar e Abraham Béhar (1977); e Habitação na Albânia, de Mariano Roque Laia (1978).

Em um dos livros aparece o nome de Luís Borges como o responsável pela edição. Os livros tinham padrão editorial e gráfico profissional. Não consta informação sobre a existência de distribuição comercial.

\subsection{Outras editoras maoistas}

\subsubsection{Edições do Povo}

Porto

Editores: F. Dinis e A. Pereira.

Início das edições: 1971.

Distribuição: Dinalivro e Expresso.

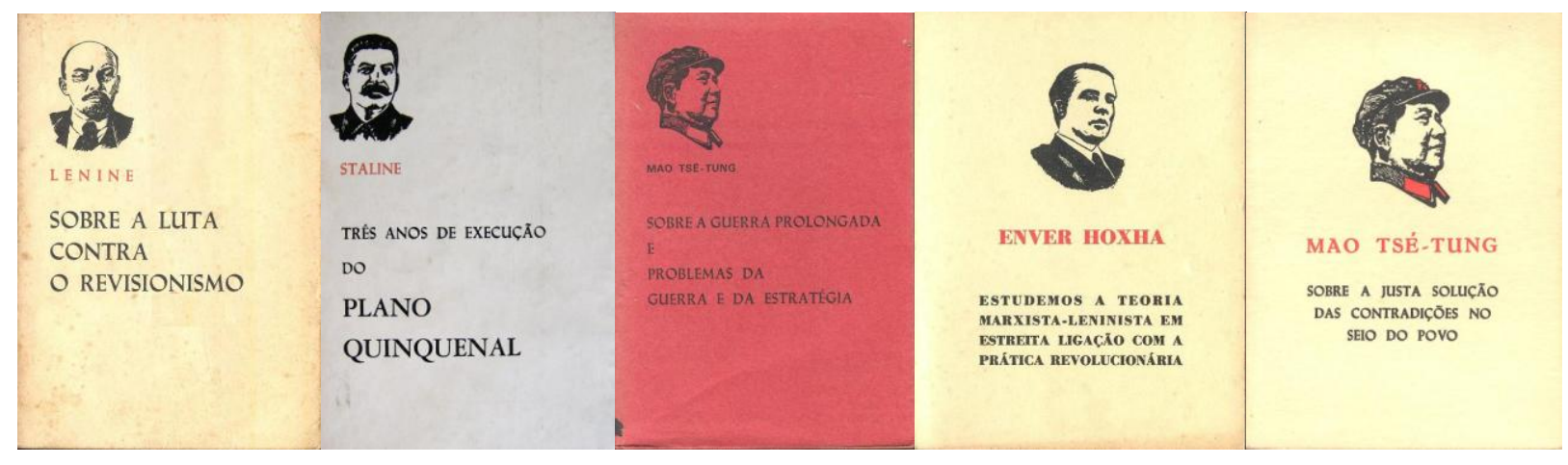

${ }^{131}$ Texto do Grupo de Ensino e Cultura da AAPA. In: O ensino na Albânia. Lisboa: Edições AAPA, 1976, p. 5 . 
Editora maoista de linha albanesa cujas primeiras publicações são anteriores ao 25 de Abril. Não foi possível confirmar se estava vinculada a algum grupo específico. Todavia, os seis títulos que localizei não deixam dúvida quanto à filiação ideológica da editora.

Os livros não mostram o local da edição, mas todas as obras às quais tive acesso (quatro) trazem a informação de que foram impressas no Porto, o que indica que esta deve ter sido a cidade sede da editora.

Da mesma forma, a menção em alguns títulos a Henrique A. Carneiro como responsável pela edição reforça a ideia de que a editora atuava naquela cidade, já que este tipógrafo, dono da Gráfica Firmeza, do Porto, aparece sempre associado a outras editoras desta cidade (Escorpião, Textos Exemplares, Textos Marginais, Textos Políticos, Editora Nova Crítica; ver item sobre a editora Textos Marginais). Aparecem ainda como responsáveis pela edição, em outros títulos, os nomes de F. Dinis e A. Pereira, que talvez sejam nomes intermédios ou pseudônimos.

Três livros têm data de edição de 1971 ou 1972 , ou seja, a editora iniciou suas atividades ainda no período marcelista. São eles: Sobre a luta contra o revisionismo, de Lenin (1971); Sobre a guerra prolongada/Problemas da guerra e da estratégia, de Mao Tsé-tung (1971); e Problemas estratégicos da guerra revolucionária na China e da guerra de guerrilhas contra o Japão, também de Mao Tsé-tung (1972).

Os outros três títulos foram publicados após o fim da ditadura: Três anos de execução do plano quinquenal: a situação económica da Rússia e a crise mundial do capitalismo: 1930, Stalin (agosto, 1974); Sobre a justa solução das contradições no seio do povo, de Mao Tsé-tung (setembro, 1974); e Estudemos a teoria marxista-leninista em estreita ligação com a prática revolucionária, de Enver Hoxha (setembro, 1974).

Os livros tinham bom tratamento editorial e excelente aspecto gráfico, constituindo uma coleção de pequenos livros com características uniformes e bem executadas, que garantiam um padrão visual bem marcado para os volumes.

Não há indicação nos livros sobre como era feita a sua distribuição comercial.

O livro Três anos de execução do plano quinquenal, de Stalin, apareceu em $8^{\circ}$ lugar na lista "Os best-seller da quinzena" do jornal Expresso, em 21 de setembro de 1974, com a indicação de era um livro editato pela "Divalivro"132. Parece haver aí dois erros. Existia na altura - e existe ainda - uma importante distribuidora de livros em

132 “Os best-seller da quinzena”. Secção do jornal Expresso, 1974 e 1975. 
Portugal chamada Dinalivro, e não "Divalivro". O erro deve ser consequência de uma gralha tipográfica. Como a única edição que localizei desta obra em Portugal nos anos 1970 foi a da Edições do Povo, acredito que é a esta edição que a lista do Expresso se refere, sendo a Dinalivro, possivelmente, a distribuidora do livro, e não a editora.

Mas, para complicar a questão, o exemplar desta obra a que tive acesso traz colada uma etiqueta da Distribuidora Expresso, indicando que esta empresa também fazia a distribuição do livro. Pode ser, então, que os livros das Edições do Povo fossem distribuídos por estas duas distribuidoras.

As Edições do Povo parecem ter deixado de atuar no final de 1974, tendo publicado no total seis títulos desde 1971.

\subsubsection{Edições Movimento Operário}

Lisboa

Início das edições: 1974.

Distribuidor: Livraria Ler
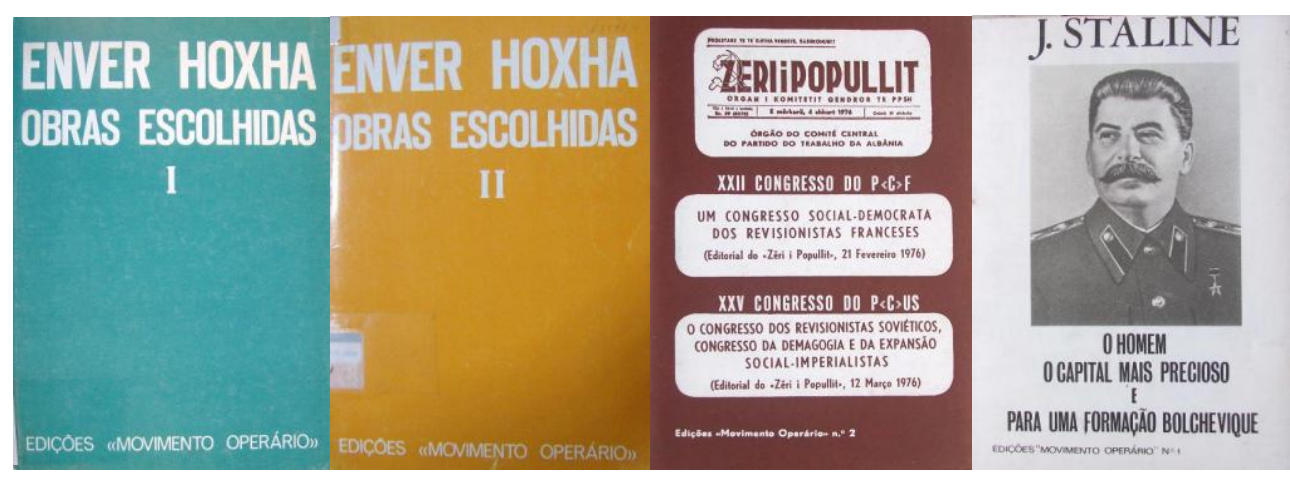

Editora de linha marxista-leninista pró-albanesa. Não foi possível indicar a qual grupo era ligada a editora, pois os livros não trazem nenhuma indicação sobre isso.

A linha política seguida pelos editores fica clara pelos títulos editados: as Obras escolhidas, de Enver Hoxha, líder máximo da Albânia, publicadas em dois volumes (em 1976 e 1977); o livro O homem, o capital mais precioso (que contém também o texto Para uma formação bolchevique) de J. Stalin (1975); e a obra XXII Congresso do $P$ “ C $” F$ (Um congresso social-democrata dos revisionistas franceses) / XXV Congresso do P"C”US: O congresso dos revisionistas soviéticos, congresso da demagogia e da expansão social-imperialistas (1976).

Um trecho do prefácio ao primeiro volume das Obras escolhidas de Hoxha mostra o tipo relação política que havia com o partido albanês: “As obras de Enver 
Hoxha tornam pública a maneira magistral e criadora com que o PCA [Partido Comunista da Albânia ${ }^{133}$ ] aplicou o marxismo-leninismo nas condições concretas da situação interna do país e da situação internacional"134.

Localizei e tive acesso a quatro títulos editados. Os livros têm um tratamento editorial e gráfico profissional, e a distribuição era feita pela Livraria Ler (que editava os Cadernos Maria da Fonte; ver o item sobre a Livraria Ler). Em todas as obras aparece o nome de C. Dionel como tradutor. De acordo com as referências dos livros que localizei, iniciou suas atividades após o 25 de Abril. O último livro encontrado tem data de abril de 1977.

\subsubsection{Edições Pensamento e Acção}

\section{Lisboa}

Início das edições: 1975.

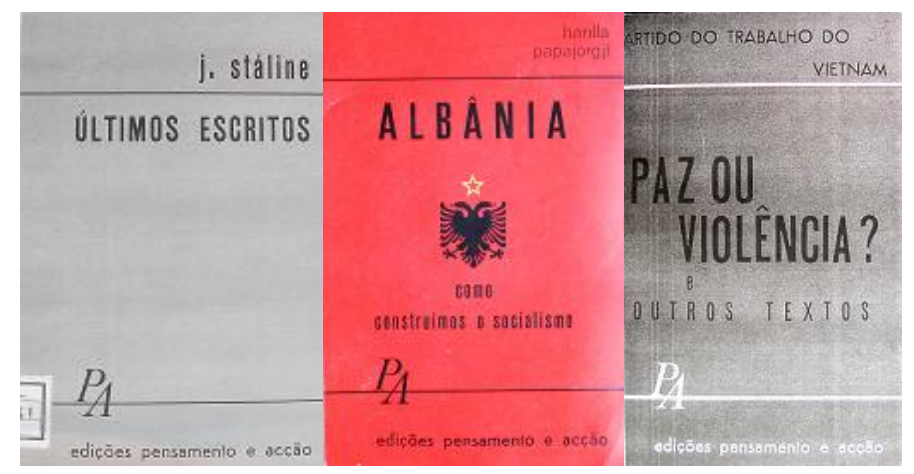

Editora de linha marxista-leninista pró-albanesa cujos primeiros livros foram lançados no começo de 1975. Não foi possível indicar a qual grupo era ligada a editora, pois os livros não trazem nenhuma indicação sobre isso.

Localizei cinco títulos da Pensamento e Acção, todos claramente vinculados a esta linha política. Dois livros são de autoria de Stalin: Últimos escritos, 1950-1953 (que contém os textos "O marxismo e os problemas da linguística"; "Problemas económicos do socialismo na URSS"; “Cartas a Mao Tsétung”; e "Intervenção no XIX Congresso do PCUS"); e Trotskismo ou leninismo?, ambos publicados em 1975.

Os demais livros lançados foram: Paz ou violência?, com textos do Partido do Trabalho do Vietnam (1975); Albânia: como construímos o socialismo (perguntas e

\footnotetext{
${ }^{133} \mathrm{Na}$ verdade, o partido no poder na Albânia naquela data chamava-se Partido do Trabalho da Albânia.

134 "Prefácio". In: HOXHA, Enver. Obras escolhidas. V. I. Lisboa: Ed. Movimento Operário, 1976, p. 10.
} 
respostas), de Harilla Papajorgji (1976); e O trabalho dos bolcheviques no exército antes da Revolução de Outubro, de E. Yarolavsky (1977).

Os editores buscavam ligar este último título a fatos da história recente de Portugal:

O nosso país teve nos últimos dois anos uma rica experiência de trabalho político nas Forças Armadas. Com efeito, a história destes últimos anos desde o 25 de Abril está indubitavelmente ligada às Forças Armadas, aos seus soldados e marinheiros, aos seus oficiais. Mais do que nunca a linha política tocou profundamente o exército português; a luta de classes penetrou nos quartéis acompanhando os avanços e recuos do movimento popular, os recuos e avanços das forças reacionárias. Abordar o tema da luta política no exército, da sua conquista para o lado da revolução, da formação do exército popular é o tema desta brochura da Pensamento e Acção que agora apresentamos. ${ }^{135}$

Os livros editados tinham padrão editorial e gráfico de nível profissional. Não consta informação sobre a sua distribuição comercial. O último livro da editora parece ter sido lançado em 1977.

\subsubsection{Textos da Revolução}

Porto

Editor: Fernando Osório.

Início das edições: 1974.

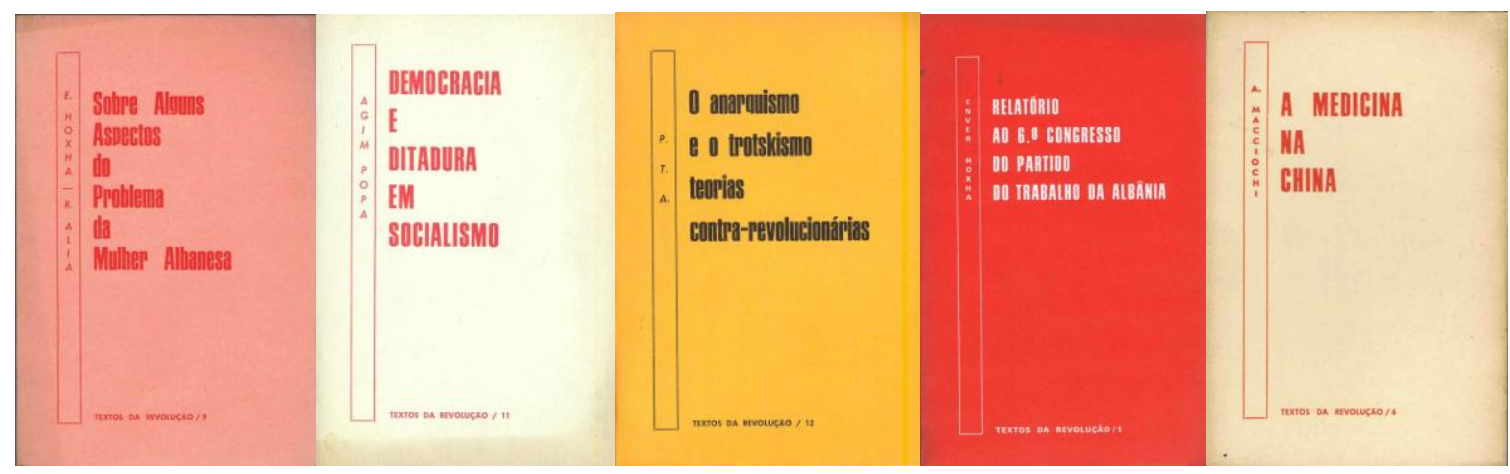

Editora de linha marxista-leninista pró-albanesa que atuou em 1974 e 1975 . Não foi possível indicar a qual grupo era ligada a editora, pois não existe nos livros indicação sobre isso.

\footnotetext{
135 "Prefácio". In: YAROLAVSKY, E. O trabalho dos bolcheviques no exército antes da Revolução de
} Outubro. Lisboa: Pensamento e Acção, 1977, p. 6. 
A Textos da Revolução pertencia à Livraria Saber, do Porto ${ }^{136}$. A edição dos livros era responsabilidade de Fernando Osório (nos livros ele aparecia identificado com F. Osório). Osório havia trabalhado na Editora Inova, do Porto, e depois teria se ligado à UDP (União Democrática Popular). Alguns militantes da UDP o teriam ajudado no trabalho de edição ${ }^{137}$. Posteriormente, Osório trabalhou na Livraria Europa-América, no Porto $^{138}$.

A vinculação da editora às ideias defendidas pelo Partido do Trabalho da Albânia (PTA) fica evidenciada pela edição das seguintes obras, de autoria de líderes daquele partido: Relatório ao $6^{\circ}$ Congresso do Partido do Trabalho da Albânia, de Enver Hoxha (1974); Sobre alguns aspectos do problema da mulher albanesa, de Enver Hoxha e R. Alia (1975); Democracia e ditadura em socialismo, de Agim Popa (1975); e $O$ anarquismo e o trotskismo, teorias contra-revolucionárias, documentos do Partido do Trabalho da Albânia (1975). Além disso, o livro As ideias e a obra de Lenine são imortais (1975) trazia textos de Lenin, Stalin e do jornal Zeri i Popullit, órgão do PTA.

Outros autores editados foram: Friedrich Engels (Princípios do comunismo, 1974), V. I. Lenin (Aos pobres do campo), Samora Machel (A libertação da mulher é uma necesidade da revolução, garantia da sua continuidade, condição do seu triunfo, 1974), A. Macciochi (A medicina na China, 1974), Stalin (A Revolução de Outubro e a táctica dos comunistas russos, 1974; e Perguntas e respostas, 1975) e John Reed (Como funcionam os sovietes, 1975).

A análise destes títulos e autores não deixa dúvidas sobre a filiação ideológica da editora.

Entre 1974 e 1975 a Textos da Revolução editou 12 títulos, todos políticos. As obras tinham padrão editorial e gráfico profissional. Não consta informação sobre como era feita a sua distribuição comercial.

\footnotetext{
${ }^{136}$ Mensagem eletrônica de José Manuel Lopes Cordeiro em dezembro de 2010. Também no sexto volume da Coleção Textos da Revolução consta a seguinte informação: "Este livro acabou de se imprimir em dezembro de 1974 na Douro Manufacturas para a Livraria Saber - Porto".

${ }^{137}$ Entrevista com António Daniel Abreu, São Paulo, 23/8/2012.

${ }^{138}$ Mensagem eletrônica de João Barrote em 8/7/2011.
} 


\section{EDITORAS POLÍTICAS DE ESQUERDA - LIGADAS A OUTROS GRUPOS (ESQUERDA RADICAL, TROTSKISTAS, ANARQUISTAS, PARTIDO SOCIALISTA, OUTROS)}

Neste capítulo estão as editoras com vinculações a outros grupos de esquerda e a a grupos anarquistas. São grupos de esquerda tortskistas ou cuja ideologia vinculava-se a um tipo de marxismo não ortodoxo ou libertário, em certos casos de difícil classificação.

Estão inlcluídas aqui também três editoras ligadas ao Partido Socialista e outras duas em relação às quais não foi possível identificar os vínculos políticos.

No caso das quatro editoras ligadas aos anarquistas, há desde o grupo ligado ao jornal A Batalha, cujas origens remontam ao início do século $\mathrm{XX}$, até aqueles criados nos anos 1970, já no novo quadro político pós-25 de Abril.

\subsection{Editoras ligadas a grupos de esquerda radical e trotskistas}

\subsubsection{Edições Contra a Corrente (jornal Combate)}

Rua do Breiner, 50 - Porto

Rua Atalaia, 204/206 - Lisboa

Editor: Coletivo do Combate (Rita Delgado, João Bernardo, João Crisóstomo e outros) Início das edições: 1975.

Distribuição: própria.

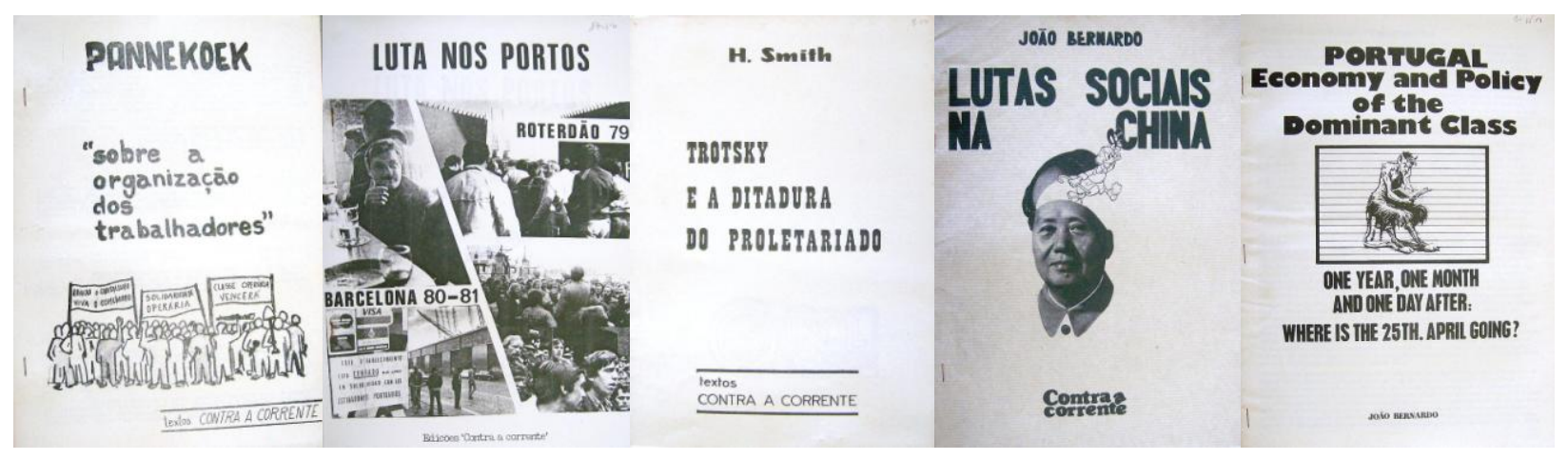

Editora (e livraria) de caráter político e semiamador criada pelos apoiadores do jornal Combate, periódico fundado por João Bernardo, Rita Delgado e João Crisóstomo (este último já falecido) ${ }^{1}$.

De acordo com José Pacheco Pereira: “O jornal Combate foi publicado em

\footnotetext{
${ }^{1}$ Entrevista com Rita Delgado, Lisboa, 12/2/2011.
} 
Portugal, no âmbito das inúmeras iniciativas políticas e populares que se seguiram ao derrube do fascismo em 25 de Abril de 1974",2. O primeiro número, que trazia o Manifesto de lançamento do jornal, saiu em 21 de junho de 1974, e o último número, a edição 51 , é de fevereiro de $1978^{3}$.

João Bernardo e Rita Delgado tinham sido militantes dos Comitês Comunistas Revolucionários (Marxistas-Leninistas)-CCR(m-l), organização clandestina fruto de uma cisão em 1969 do Comité Marxista-Leninista Português (CMLP). Os CCR(m-l) surgiram

no contexto de discussões realizadas na emigração parisiense. Alcançaram uma significativa radicação no Instituto Superior Técnico, tendo vindo a definhar na sequência de prisões ocorridas em 1972 e 1973, às quais se seguiram importantes divergências de cariz ideológico na direcção do organismo. ${ }^{4}$

Com o aprofundamento dessas divergências, o grupo ligado a João Bernardo e José Mariano Gago passou "a defender, a partir de Paris, práticas políticas mais próximas do conselhismo", fazendo uma leitura crítica do leninismo. Estas ideias foram expressas em janeiro de 1974 no documento “Que Fazer? - Hoje". "Este texto serviu de base à constituição, nos meses seguintes, do colectivo reunido em torno do jornal Combate $^{, 5}$.

Rita Delgado lembra que quando ela e João Bernardo retornaram do exílio em Paris, em 1974, já haviam feito a crítica ao maoismo e à China:

Estávamos no caminho de apoio a movimentos de trabalhadores não organizados exteriormente. Achamos que era extremamente importante um movimento não organizado, não partidário, que ouvisse o que os trabalhadores tinham pra dizer, como é que se organizavam, como é que se expressavam. ${ }^{6}$

\footnotetext{
2 PEREIRA, José Pacheco. "O jornal Combate". Disponível em: $<$ (http://estudossobrecomunismo2.wordpress.com/2008/06/28/joao-bernardo-o-jornal-combate/>. Acesso em dez. 2010.

3 A coleção completa do jornal Combate está disponível em: <http://www.marxists.org/portugues/tematica/combate/index.htm>. Acesso em dez. 2010.

${ }^{4}$ CARDINA, Margem de certa maneira, op. cit., p. 154. Para uma síntese da história dos CCR(m-l), da atuação de João Bernardo e das posições políticas da organização, consultar a obra de Cardina, p. 154162. Ver também: PEREIRA, "O jornal Combate", op. cit.

${ }^{5}$ CARDINA, Margem de certa maneira, op. cit., p. 161. Pacheco Pereira dá a seguinte versão sobre essas divergências: "A derrota da Revolução Cultural chinesa e a aproximação efectuada entre os governos da China e dos Estados Unidos haviam dado lugar a acesas polémicas no interior dos CCR e à formação de uma tendência, que passara rapidamente da crítica ao maoísmo à crítica ao próprio leninismo e que começara a defender uma orientação de carácter marxista libertário. [...]”. PEREIRA, J. P. "O jornal Combate", op. cit.

${ }^{6}$ Entrevista com Rita Delgado, Lisboa, 12/2/2011.
} 
É a partir dessa proposta de autoemancipação da classe trabalhadora que surge o jornal Combate, com atuação basicamente em Lisboa e no Porto ${ }^{7}$. No entanto, a maior parte dos militantes dos CCR(m-1) aderiu à União Democrática Popular (UDP), que manteve-se alinhada ao marxismo-leninismo e ao maoismo ${ }^{8}$.

Os objetivos do grupo ligado ao jornal Combate eram

ser um agente activo na ligação entre si das várias lutas particulares, divulgando essas lutas e nomeadamente as experiências organizativas delas resultantes e acelerando por este modo o desenvolvimento da luta dos trabalhadores enquanto luta geral. [E] fomentar a organização de reuniões de massas entre trabalhadores, soldados e marinheiros, ou trabalhadores com soldados e marinheiros inseridos em lutas particulares diferentes. $^{9}$

Tais objetivos eram vistos como tendo uma "função revolucionária", e somente dessa forma, acreditavam os militantes do Combate, se poderia caminhar para colocar em prática o lema do grupo: “A libertação dos trabalhadores só pode dever-se à luta dos trabalhadores".

No começo de 1975, surgiu no Porto a livraria Contra a Corrente, criada pelos apoiadores do jornal Combate naquela cidade, com destaque para José Elísio Melo e Silva $^{10}$. E em outubro surgiu a livraria de Lisboa, também chamada Contra a Corrente. Rita Delgado relembra que "a livraria surge muito em função da necessidade de ter uma sede, um local de reunião, que pudesse também ser usado por grupos que procuravam o Combate e que necessitavam de um lugar em que pudessem se reunir e dinamizar o trabalho que estavam fazendo" 11 .

Como informava uma matéria do jornal Expresso, a livraria seria "Um local de encontro e uma base de apoio material para trabalhadores em luta", ligada a "todo

\footnotetext{
${ }^{7}$ HENRIQUES, Julio. "Um jornal diferente". In: RODRIGUES, Francisco Martins (coord.). O futuro era agora: o movimento popular do 25 de Abril. Lisboa: Dinossauro, p. 52-54.

${ }_{8}^{8}$ Entrevista com Rita Delgado, Lisboa, 12/2/2011.

9 "Manifesto do Combate". Combate, Lisboa, $\mathrm{n}^{\mathrm{o}}$ 1, 21/6/1974. Disponível em: <http://www.marxists.org/portugues/tematica/combate/01/manifesto.htm>. Acesso em dez. 2010.

10 "Graças a ele o Combate conheceu uma grande expansão no Norte", afirma João Bernardo, que recorda uma história que demonstra a importância da atuação de José Elísio na região: "Quando o Sartre e a Simone de Beauvoir estiveram em Portugal, durante o processo revolucionário, foram ao Porto e quiseram visitar fábricas ocupadas. O MES (Movimento da Esquerda Socialista), de quem eles eram próximos e que os guiava no terreno, não tinha contactos nenhuns nesse meio e foi à livraria Contra a Corrente do Porto para pedir contactos. Foi o José Elísio quem lhos deu. E assim o Sartre e a Simone de Beauvoir foram visitar as fábricas ocupadas, levados pelo MES, mas graças ao Combate. E o pobre do José Elísio, que estava de plantão na livraria, ficou sem conhecer o Sartre e a Simone. É a diferença entre o verniz exterior e os mecanismos internos". Mensagem eletrônica de João Bernardo enviada em $15 / 8 / 2012$.

${ }^{11}$ Entrevista com Rita Delgado, Lisboa, 12/2/2011.
} 
comunismo não-leninista"12.

Um folheto de divulgação da Livraria Contra a Corrente assim anunciava as áreas de interesse da livraria:

Jornais e revistas sobre movimento operário, lutas revolucionárias. Experiências práticas e textos teóricos. Luta contra o capitalismo privado e os capitalismos de Estado. Para um debate sobre as experiências históricas do movimento operário e as perspectivas actuais de luta pelo comunismo. ${ }^{13}$

A livraria também caracterizou-se por importar e colocar à venda livros e revistas franceses, ingleses, norte-americanos, espanhois e italianos, numa época em que o acesso a essas publicações era difícil.

Ao lado dessas atividades, havia a ideia de realizar edições de textos que, apesar de intimamente ligados às ideias defendidas no Combate, não cabiam no projeto editorial do jornal, como recorda Rita Delgado:

Era um outro meio de divulgação, que não cabia ao jornal, porque o jornal tinha um formato que nós queríamos manter, com um editorial nosso e o resto era relato de lutas, de entrevistas diretamente, ou por transcrição dos próprios comunicados dos trabalhadores, vindos das empresas, de balanço de lutas. Portanto tudo que não cabia aqui tinha que sair pelas edições. ${ }^{14}$

Começam então as edições de brochuras "roneotipadas" (mimeografadas), datilografadas em estêncil. Diz Rita Delgado:

Nós tínhamos uma maquineta dessas e começamos a tentar fazer edições. Vimos que havia um grande desconhecimento de textos importantes, as traduções não existiam. E nós desde o início começamos a ver que era importantíssimo fazer edições. E também vimos que as editoras comerciais não estavam interessadas nesse tipo de edições, e que se nós não as fizéssemos não se iriam fazer. ${ }^{15}$

A relação entre o jornal e a editora foi explicada da seguinte maneira por um dos seus membros:

Isso parece mais ou menos como duas pernas, digamos: uma perna era o Combate, para andar para a frente; e, a outra perna, que era a Contra a Corrente - aliás os nomes foram escolhidos com este sentido. Combate numa altura mais de avanço, e Contra a Corrente, pensando

12 SILVA, Helena Vaz da. "Um grupo 'contra a corrente' abre uma livraria". Expresso, Lisboa, 19/11/1975, p. 13.

${ }^{13}$ Folheto de divulgação da Livraria Contra a Corrente, s/d. Acervo de Rita Delgado.

${ }^{14}$ Entrevista com Rita Delgado, Lisboa, 12/2/2011.

15 Idem. 
num sentido mais de refluxo, de debate. ${ }^{16}$

Este "refluxo", na altura em que é aberta a livraria em Lisboa, era assim definido por um membro não identificado do coletivo do Combate/Contra a Corrente: "Estabilizamos [a tiragem do jornal] há tempos nos 3.000, depois de, em 1974, termos chegado a 15.000. Creio que isso se deve precisamente ao modo como actuamos. Se quiséssemos, seria fácil atrair grandes grupos e fazer um jornal de maior expansão". Isso se dava, segundo o mesmo membro, também porque a linha política proposta pelo grupo "não é agora a que tem mais sucesso"17.

As primeiras edições da Contra a Corrente foram preparadas pelo grupo do Porto, que publicou alguns títulos, mas depois o principal trabalho de edição passou para Lisboa, onde havia uma melhor infraestrutura e mais colaboradores ${ }^{18}$.

Rita Delagado explica como funcionava a editora:

A definição do que seria editado se dava em reuniões. Dividia-se o trabalho entre os colaboradores presentes. [...] Neste grupo nenhuma pessoa tinha trabalho [profissional] ligado a edições, todos tinham o seu emprego, e faziam o trabalho de edição como continuação da militância, como uma necessidade de ver aqueles textos difundidos. E as livrarias do Porto e de Lisboa nos davam a possibilidade de ter lá estes textos.

Nos primeiros meses muita gente comprava [os livros]. E nós mandávamos para muitas outras pequenas livrarias, existia uma rede de livrarias, tínhamos assinantes do jornal para quem mandávamos a publicidade das edições. Havia um circuito de pontos de venda de publicações, mesmo de quiosques [bancas de jornal], que tinham nossas publicações, não só em Lisboa mas em muitas cidades do país.

A tiragem das edições variava muito. Como éramos nós que fazíamos a impressão, sempre que havia necessidade imprimíamos uma nova tiragem. Em geral fazíamos 250 exemplares de cada vez, pois o estêncil estraga com muita facilidade. [...]

O trabalho era todo militante, nunca houve trabalho pago. Desde a tradução, datilografia, impressão, inclusive a distribuição. [...] Mandávamos para várias outras livrarias e para pessoas que sabíamos que distribuíam e vendiam, que nos mandavam o dinheiro. ${ }^{19}$

A Contra a Corrente não tinha como objetivo ser a fonte de renda ou de

\footnotetext{
${ }^{16}$ BRUNO, Lúcia. Portugal: O “COMBATE” pela autonomia operária. Dissertação de Mestrado em Ciências Sociais, PUC-SP, 1983, p. XII. Citado em ABADIA, Danúbia Mendes. O jornal Combate $e$ as lutas sociais autonomistas em Portugal durante a revolução dos cravos (1974-1978). Dissertação de Mestrado em História, Universidade Federal de Goiás, Faculdade de História, Goiânia, 2010, p. 64.

${ }^{17}$ SILVA, Helena Vaz da, op. cit.

${ }_{18}$ Mensagem eletrônica de Rita Delgado enviada em 15/8/2012.

${ }^{19}$ Entrevista com Rita Delgado, Lisboa, 12/2/2011.
} 
sobrevivência das pessoas envolvidas. Ela pretendia apenas gerar os recursos suficientes para a sua manutenção e a possibilidade de realizar a edição do jornal e dos livros que o grupo achava importante difundir.

As brochuras editadas tinham como tema as lutas operárias de tendência libertária ou autonomista em Portugal e em outros países, textos de autores libertários, obras de análise da situação política e econômica portuguesa, ou de crítica teórica do capitalismo e do capitalismo de Estado.

Destacam-se obras de autores portugueses, como João Bernardo, Manuel Joaquim de Sousa, Charles Reeve (pseudônimo de Jorge Valadas), J. Carvalho-Ferreira, António Bito, Artur J. Castro Neves, Luís Leitão, Francisco Silva e José Luís Farinha. Mas foram vários também os autores estrangeiros editados: H. Smith, Anton Pannekoek, Henri Simon, Helmut Wagner, Maurice Brinton, além de textos dos grupos Solidarity/Londres, Verdade Operária, da Rússia, e Trabajadores por la Autonomia Proletaria y la Revolución Social, da Espanha.

Eis alguns dos títulos publicados: A crise económica actual na esfera do capitalismo americano, de João Bernardo (1975); Um ano, um mês e um dia depois: para onde vai o 25 de Abril? (Economia e política da classe dominante), de João Bernardo (1975); Crise da sociedade portuguesa: "descolonização” e "independência nacional", de Charles Reeve e J. Carvalho-Ferreira (1975); Novo movimento: questões sobre a prática revolucionária, de Henri Simon (1975); O que somos e o que queremos, do Solidarity/Londres (1976); Contribuição para a percepção da cultura (política) em Portugal, de Artur J. Castro Neves (1976); Reforma agrária no Couço (1978); Tortura e repressão na social-democracia: Irlanda e Alemanha (1978); Movimento urbanos e comissões de moradores: Portugal 1974-76, de L. Leitão, A. Dias, J. Manuel, L. Dianoux (1980); Por uma acção revolucionária em situação de refluxo, do Colectivo do Combate e da Contra a Corrente (1980); Sobre a organização dos trabalhadores, de A. Pannekoek; Trabalhadores dos transportes Estefânia em luta contra o patrão (1976); Dossiers de Luta 1977: Balanço de um ano de lutas (1978).

Do ponto de vista gráfico, as brochuras eram muito precárias, pois eram mimeografadas, o que comprometia a sua qualidade. Os textos eram datilografados. $\mathrm{O}$ acabamento também era amador, as brochuras eram grampeadas e não encadernadas. Quase todas as capas eram em preto e branco. A distribuição, como já visto, era feita pela própria Contra a Corrente, de modo militante. Já do ponto de vista editorial, os 
textos eram bem editados e bem traduzidos, seguindo uma linha política totalmente identificada com o jornal Combate, com a preocupação de apresentar ao leitor português textos aos quais não se tinha acesso até então no país.

Além das edições em português, foram feitas algumas edições em inglês de obras que expressavam o pensamento do grupo. O jornal Combate recebia visitas de muitos grupos simpatizantes de outros países interessados em conhecer a experiência portuguesa, principalmente da França, da Inglaterra e dos Estados Unidos (Nova York e Boston). Com a ajuda de três colaboradores estrangeiros - o irlandês Phil Mailer, o australiano Gerry Vignola (que vivia em Londres) e a brasileira Maria Luíza -, eram feitas as traduções para o inglês. No total, foram pelo menos cinco edições em inglês: Manifesto of Combate (1975); Portugal, economy and policy of the dominant class. One year, one month and one day after: where is the 25th April going?, de João Bernardo (1976); After the 25th. November (1976); Crisis historical forms of their appearance and recuperation, de João Bernardo (1976); Portugal: 5 years on (1980).

Chegou também a haver planos de ampliar as edições, lembra Rita Delgado: "Queríamos editar coisas maiores, mas nunca tivemos possibilidade. Até encaramos a hipótese de nós traduzirmos e propormos a uma tipografia coisas que víamos que eram absolutamente essenciais, mas nunca conseguimos" ${ }^{20}$. Em parte, admite Rita, isso ocorreu porque o grupo ligado ao jornal Combate não cresceu, continuou muito pequeno e com uma atuação muito limitada:

A nossa atuação foi muito prematura, no sentido em que as pessoas não percebiam o que nós queríamos. Hoje penso que se percebe melhor onde é que queríamos chegar. [...] $\mathrm{Na}$ altura havia muitas limitações nos movimentos em que nós atuávamos, e havia a força dos movimentos contra, ou seja, os partidos, os sindicatos, os patrões [...] As próprias lutas entre os trabalhadores. Tudo isso faz morrer os movimentos e a força com que as pessoas começaram. ${ }^{21}$

As Edições Contra a Corrente atuaram até o começo dos anos 1980, tendo editado cerca de 50 títulos. A livraria de Lisboa existiu até o final de 1985. Esse ciclo de vida da Contra a Corrente e do jornal Combate está intimamente ligado à história portuguesa do período, e ao ritmo das lutas populares e operárias que então se desenvolveram. De acordo com Rita Delgado:

As primeiras edições tiveram maior circulação, as pessoas queriam

\footnotetext{
${ }^{20}$ Entrevista com Rita Delgado, Lisboa, 12/2/2011.

${ }^{21}$ Idem.
} 
perceber tudo, estavam abertas à novidade. Depois houve um certo cansaço da população, cansaço da atuação dos partidos, e começaram a assustar-se, a achar que era tudo igual, que nada dava saída, e que a atuação dos partidos era perniciosa, e de fato as coisas foram morrendo muito depressa em Portugal. ${ }^{22}$

As Edições Contra a Corrente representaram uma experiência diferenciada no campo das editoras de esquerda nos anos 1970 em Portugal, seja por sua proposta política autonomista/conselhista e marxista libertária, seja por funcionar em todas as suas etapas de modo plenamente independente, militante, amador e não-comercial, inclusive na questão da apresentação gráfica das edições.

Para além das dificuldades técnicas e financeiras para a realização das publicações, esta última característica parece refletir, também, uma certa recusa à prática e à estética editorial vigente, ao diferenciar de imediato suas edições daquelas de caráter comercial, mesmo das publicadas por outras editoras do campo da esquerda.

Esta opção estava também ligada ao desejo de autogestão e independência total do grupo, que, ao ter o controle sobre todas as etapas da edição - desde a definição dos textos a serem publicados, passando por sua produção editorial e gráfica, até a distribuição e venda dos livros - autonomizava-se para publicar o que desejasse, sem interferências externas de qualquer tipo, e sem depender em nenhuma etapa do processo editorial de terceiros. Dessa forma, a editora punha em prática um dos princípios do grupo que lhe deu origem.

\subsubsection{Edições Revolução (PRP/BR)}

Rua Castilho, 70 - Lisboa

Início das edições: 1974.

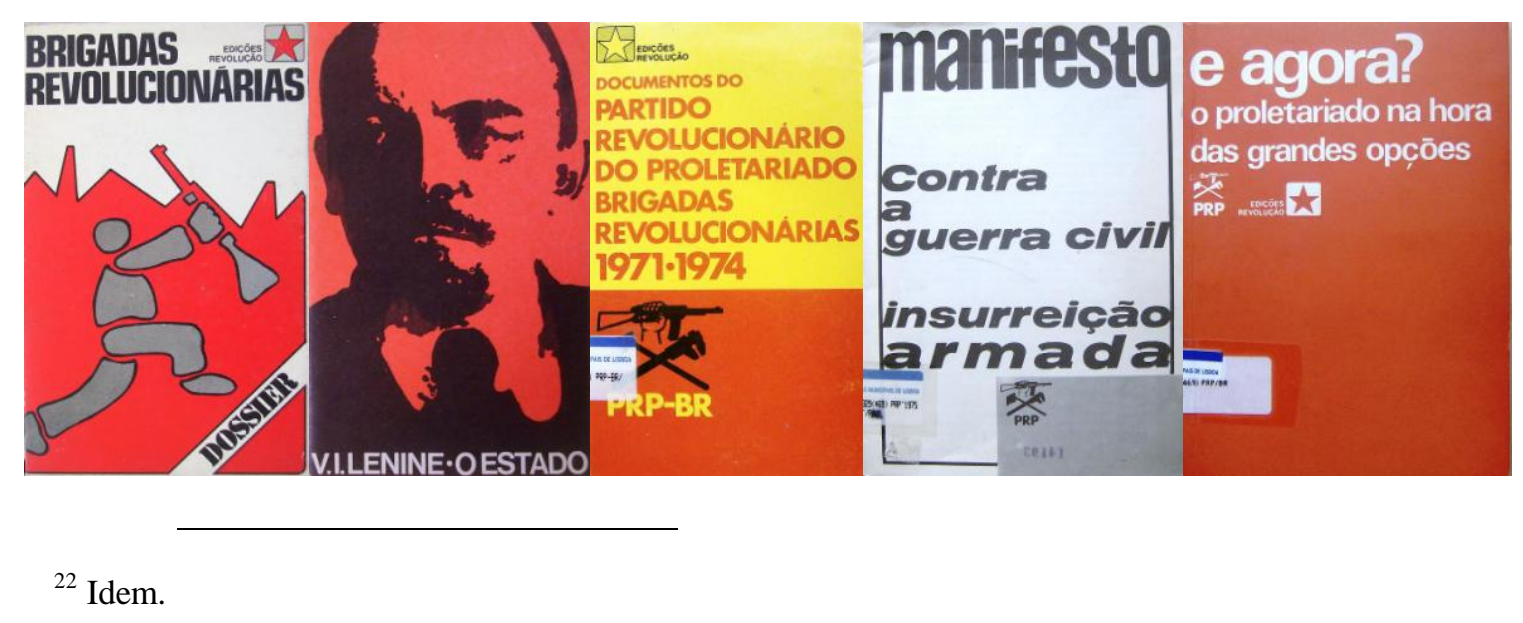


Editora do Partido Revolucionário do Proletariado-Brigadas Revolucionárias (PRP-BR). As Brigadas Revolucionárias foram criadas em 1970, "na sequência de uma cisão registada na Frente Patriótica de Libertação Nacional (FPLN), sediada em Argel)"23. Antes do 25 de Abril as BR praticaram ações armadas contra a ditadura, das quais a primeira foi também a mais célebre: a destruição da base secreta da OTAN/NATO em Setúbal, em novembro de $1971^{24}$.

O Partido Revolucionário do Proletariado surgiu em setembro de 1973 num congresso convocado pelas BR. Os principais dirigentes de ambas as organizações eram Carlos Antunes e Isabel do Carmo ${ }^{25}$. As BR tinham ligações com setores católicos progressistas, e o PRP, em termos doutrinários, "baseava-se num compósito de influências que ia de Rosa Luxemburgo a Che Guevara", e pretendia "conjugar a acção armada com a ideia do primado do proletariado sobre o partido, numa perspectiva crítica ao estalinismo"26.

As BR suspenderam as ações armadas após o 25 de Abril, mas em outubro de 1975 passaram novamente à clandestinidade, em função da lei de desarmamento então decretada, mas o PRP continuou na legalidade ${ }^{27}$. Em meados de 1978, Carlos Antunes e Isabel do Carmo, juntamente com outros militantes do partido, foram presos sob a acusação de "autoria moral" de ações armadas e envolvimento com movimentos e ações revolucionárias, tendo sido condenados e ficado presos até julho de 1982, quando foram libertados ${ }^{28}$.

As Edições Revolução começaram a publicar em 1974 e parecem ter atuado até 1977, tendo editado 11 títulos. As publicações são quase todas de documentos das BR/PRP. Uma das coleções da editora, aliás, se chama Documentos do Partido. Nela foram editados quatro títulos: Dossier Brigadas Revolucionárias (1974); Documentos do Partido Revolucionário do Proletariado-Brigadas Revolucionárias, 1971-1974 (1975); E agora? O proletariado na hora das grandes opções (1976); e Revolução e

\footnotetext{
${ }^{23}$ CORDEIRO, “Glossário dos anos do PREC...”, op. cit., p. 126.

${ }^{24}$ Ibidem.

25 Ibidem; "Partido Revolucionário do Proletariado. Bases pela revolução". Disponível em: <http://prpbr.no.sapo.pt/index2.htm>. Acesso em mai. 2011.

${ }^{26}$ CARDINA, M. A esquerda radical, op. cit., p. 77.

${ }^{27}$ CORDEIRO, J. M. L. "Glossário dos anos do PREC...", op. cit., p. 126; "Face à lei do desarmamento as Brigadas Revolucionárias passam à clandestinidade”. Revolução, Lisboa, no 51, 30/10/1975, p. 3.

${ }^{28}$ AMARAL, Celestino. “Caso PRP: a manobra político-policial...”. Ponto, no 8, 24/121980, p. 4; Página eletrônica <http://memoriando.net/prp/>; GALIZA, Rui Daniel e PINA, João. Por teu livre pensamento: histórias de 25 ex-presos políticos portugueses. Lisboa: Assírio\&Alvim, 2007, p. 129-32.
} 
contra revolução. $O$ PRP responde por si. Documentos do 25 de Abril ao 25 de Novembro (1977).

Outras obras editadas foram: Do Estado, de Lenin (1974); O partido e a organização autônoma: uma só solução revolução socialista (1974); Do desemprego para a socialização: uma luta política a travar (c.1974); Conselhos Revolucionários. Projecto Povo-MFA (1975); Pela ditadura do proletariado, pela revolução socialista (1975); Manifesto. Contra a guerra civil, a insurreição armada (1975); A insurreição operária do 18 de Janeiro (s/d).

Algumas das publicações são livretos, com poucas páginas e grampeados. Mas há também livros com tratamento editorial e gráfico com padrão profissional. Não há informação nos livros sobre como era feita a sua distribuição comercial.

A editora também publicava o jornal Revolução, órgão oficial do PRP-BR, cuja primeira edição foi em $1^{\circ}$ de junho de $1974^{29}$.

Em uma matéria neste jornal é expressa uma opinião que reflete uma certa visão sobre o papel secundário que a edição de livros parece ter para a organização: "O proletariado não tem acesso aos livros, não só porque tem pouco dinheiro, mas também porque sabe que é muito mais importante estar na fábrica a lutar, porque é lá que se toma consciência de classe, é lá que a luta de classes mais se agudiza"30.

\subsubsection{Editora 17 de Outubro (PRP/BR)}

Rua Câmara Pestana, 13 - Barreiro

Início das edições: 1975.

Responsável: João Lobo.

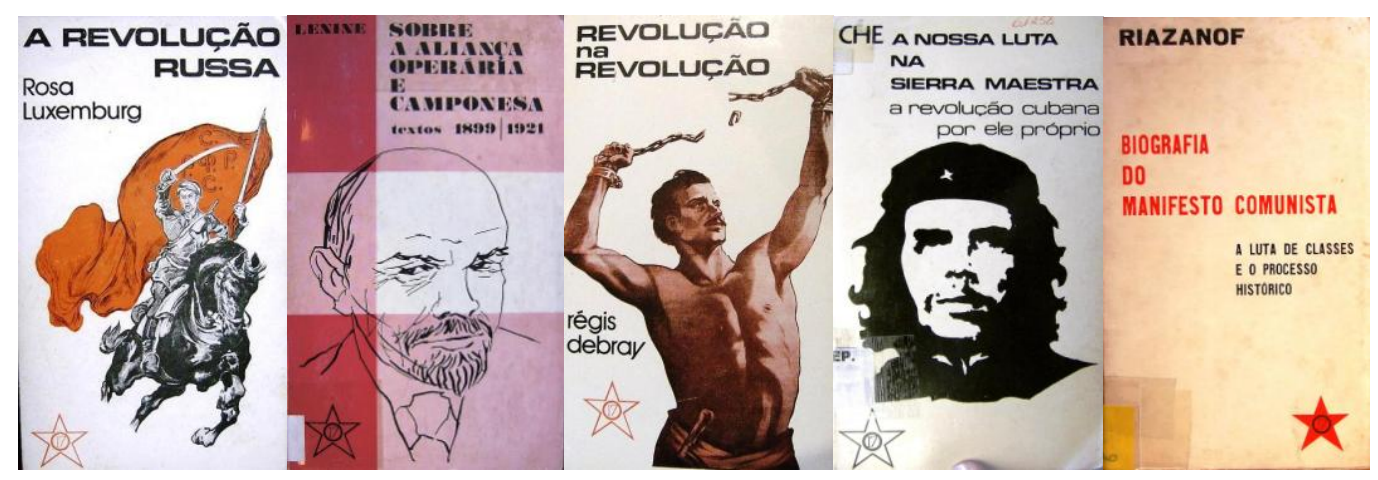

\footnotetext{
29 “Publica-se hoje o primeiro número do jornal do PRP”. República, Lisboa, 1/6/1974.

30 "Parceria A. M. Pereira: ocupação de uma editora". Revolução, Lisboa, no 35, 10/4/1975, p. 10.
} 
Editora criada por João Lobo, militante das Brigadas Revolucionárias (BR) e do Partido Revolucionário do Proletariado (PRP). Era também primo de Isabel Carmo, uma das principais dirigentes dessas organizações (ver o item anterior). João Lobo e Isabel do Carmo haviam publicado, em dezembro de 1968, o livro Dossier Checoslováquia, em edição independente ("edição do coordenador"). O livro trazia textos sobre a invasão daquele país pelas tropas do Pacto de Varsóvia e tinha um canteúdo muito crítico aos partidos comunistas tradicionais, inclusive ao $\mathrm{PCP}^{31}$.

A editora tinha sua sede na cidade do Barreiro (Distrito de Setúbal), localidade de forte característica industrial e operária, onde existe longa tradição de militância política de esquerda, em especial ligada ao Partido Comunista Português.

Localizei referências a seis títulos editados pela 17 de Outubro, quatro deles publicados em 1975 e dois em 1976. Estes livros indicam uma linha política simpática ao castrismo/guevarismo, com dois títulos de autoria de Che Guevara e um de Régis Debray. Os demais títulos são de autoria de Lenin, Rosa Luxemburgo e David Riazanof. Tais publicações se encaixam na linha política das Brigadas Revolucionárias e do PRP, que era marcada por certo ecletismo político-ideológico de esquerda.

Os títulos publicados foram: Sobre a aliança operário e camponesa: textos 1899-1921, de Lenin (1975); A nossa luta na Sierra Maestra: a Revolução Cubana por ele próprio, de Ernesto Che Guevara (1975); A revolução russa, de Rosa Luxemburgo (1975); Revolução na revolução, de Régis Debray (1975); Dimensão internacional da revolução, de Che Guevara (1976); Biografia do Manifesto Comunista: a luta de classes e o processo histórico, de Riazanof (1976).

Os livros tinham edição cuidadosa do ponto de vista gráfico, inclusive com o uso de duas cores nas suas páginas de abertura. O estilo das capas, com ilustrações relacionadas ao tema ou ao autor da obra, também dava aos livros uma identidade marcante. Não há informação nos livros sobre como era feita a distribuição comercial dos mesmos.

De acordo com a secção "Os best-seller da quinzena", do jornal Expresso, uma das obras publicadas pela Editora 17 de Outubro (A nossa luta na Sierra Maestra, de Ernesto Che Guevara) esteve entre as dez mais vendidas no mês de julho de 1975, aparecendo por duas vezes na lista, uma vez em $4^{\circ}$ lugar e outra vez em $6^{\circ}$ lugar ${ }^{32}$.

\footnotetext{
${ }^{31}$ LINDIM, Isabel. Mulheres de armas. Carnaxide: Objectiva, 2012, p. 61-62.

32 "Os best-seller da quinzena”. Secção do jornal Expresso, 19/7/1975 e 2/8/1975. Hemeroteca Municipal
} 
O fato de as Brigadas Revolucionárias terem passado novamente à clandestinidade em outubro de 1975, em função da lei de desarmamento então decretada, pode ter sido um dos fatores que levou ao fim da editora em $1976^{33}$.

\subsubsection{SLEMES - Serviço de Livros e Edições do MES (Movimento de Esquerda Socialista)}

Av. D. Carlos I, 128 - Lisboa

Início das edições: 1975.

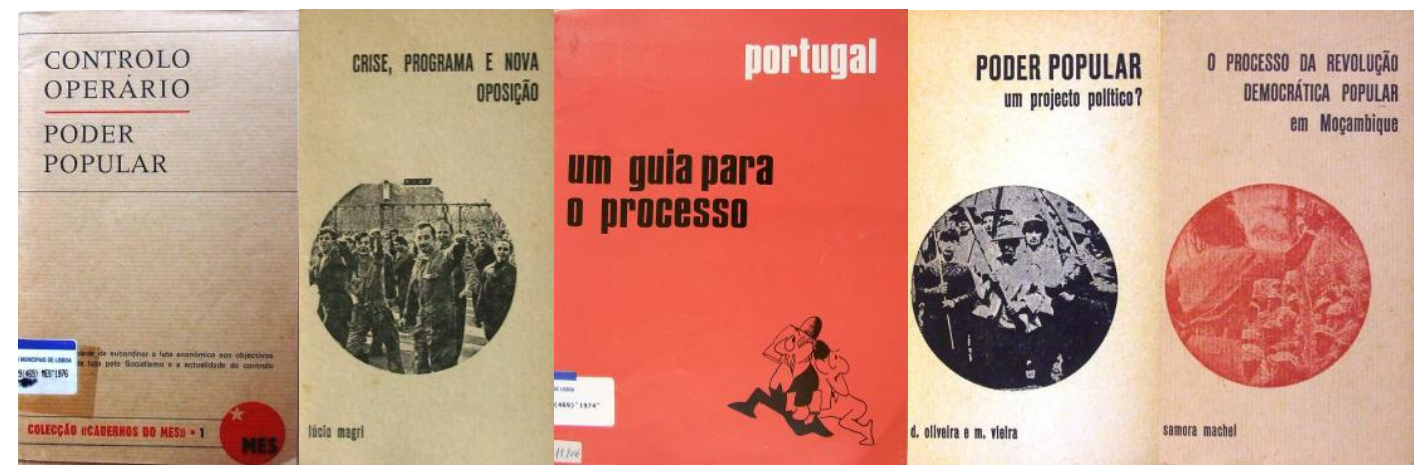

Editora do MES (Movimento de Esquerda Socialista), partido político criado em maio de 1974. Com origens "em um grupo de militantes do catolicismo progressista, intelectuais de diversos sectores e quadros do associativismo estudantil", teve um processo de radicalização que culminou em seu primeiro congresso, em dezembro de $1974{ }^{34}$. No MES "reconheciam-se influências de diferentes correntes radicais não leninistas": o grupo francês PSU (Partido Socialista Unificado), os italianos Lotta Continua e Il Manifesto ou o chileno MIR (Movimento de Esquerda Revolucionária) ${ }^{35}$.

Desde a sua fundação o MES fez edição de livros e livretos com os seus textos políticos e programáticos, totalizando mais de uma dezena de títulos, mas sem que houvesse um selo editorial responsável pelas edições. Estas apareciam apenas como publicações do MES, e se limitavam a textos partidários. A última edição com estas carcterísticas tem a data de outubro de 1975.

Um mês antes, em setembro de 1975, surgiu o primeiro livro com o selo Slemes (Serviço de Livros e Edições do MES): Poder popular: um projeto político?, de D.

\footnotetext{
de Lisboa.

33 "Face à lei do desarmamento...", op. cit., p. 3.

${ }^{34}$ CORDEIRO, "Glossário dos anos do PREC...", op. cit., p. 118.

${ }^{35}$ CARDINA, A esquerda radical, op. cit., p. 67.
} 
Oliveira e M. Vieira. Era o primeiro volume da coleção Cadernos Slemes, que se caracterizava por ter um tratamento gráfico bem mais elaborado e cuidado do que as edições até então feitas. Os livros tinham um formato diferenciado $(10$ x $18 \mathrm{~cm})$, sobrecapa, e tinham distribuição profissional, inicialmente realizada pela Regimprensa e depois pela Livraria Bertrand. Além disso, traziam textos de autores estrangeiros, como Lúcio Magri, Samora Machel, Christian Palloix e Paul Sweezy.

Os textos de caráter partidário passaram a sair com o selo Slemes na coleção Cadernos do MES, mas com o novo padrão gráfico mais elaborado. Houve também edição de textos literários e poesia.

Eis alguns dos livros publicados: O processo da revolução democrática popular em Moçambique, de Samora Machel (1975); Crise, programa e nova oposição, de Lúcio Magri (1976); A questão do imperialismo em V. I. Lénine e Rosa Luxemburgo, de Christian Palloix (1976); Luta de classes em Portugal, de Paul M. Sweezy (Abril); A origem do revisionismo: sobre a questão de Estaline (1976); Controlo operário/Poder popular (1976); Frente de luta nas forças armadas (1976); 25 de Abril 1974/ 25 de Novembro 1975 - 19 meses de luta (1976); Poemas, de António Machado (1976); Antes morrer de pé do que toda a vida de joelhos, de António Albino Machado (s/d).

A Slemes editou cerca de 20 títulos, entre setembro de 1975 e o final de 1976, quando parece ter encerrado suas publicações. O jornal Poder Popular, órgão oficial do MES, teve sua última edição em julho de $1978^{36}$.

Os livros editados mostram uma preocupação com a formação política de militantes e simpatizantes e com a divulgação das ideas políticas do MES. O fato do MES ter se preocupado em criar um selo editorial e passar a tratar de forma mais profissional as suas edições indica uma valorização do partido em relação a esse veículo de comunicação.

\footnotetext{
${ }^{36}$ BÁRCIA, Paulo; SILVA, António. Movimento de Esquerda Socialista: uma improvável aventura. Porto: Afrontamento, 2010, p. 247; Coleção dos jornais Poder Popular. Biblioteca-Museu República e Resistência, Lisboa.
} 


\subsubsection{Edições Antídoto (LCI/PSR)}

Rua da Beneficência, $121,1^{\circ} \mathrm{D}$ - Lisboa

Editor: Cabral Fernandes.

Início das edições: 1975.

Distribuidora: Expresso.

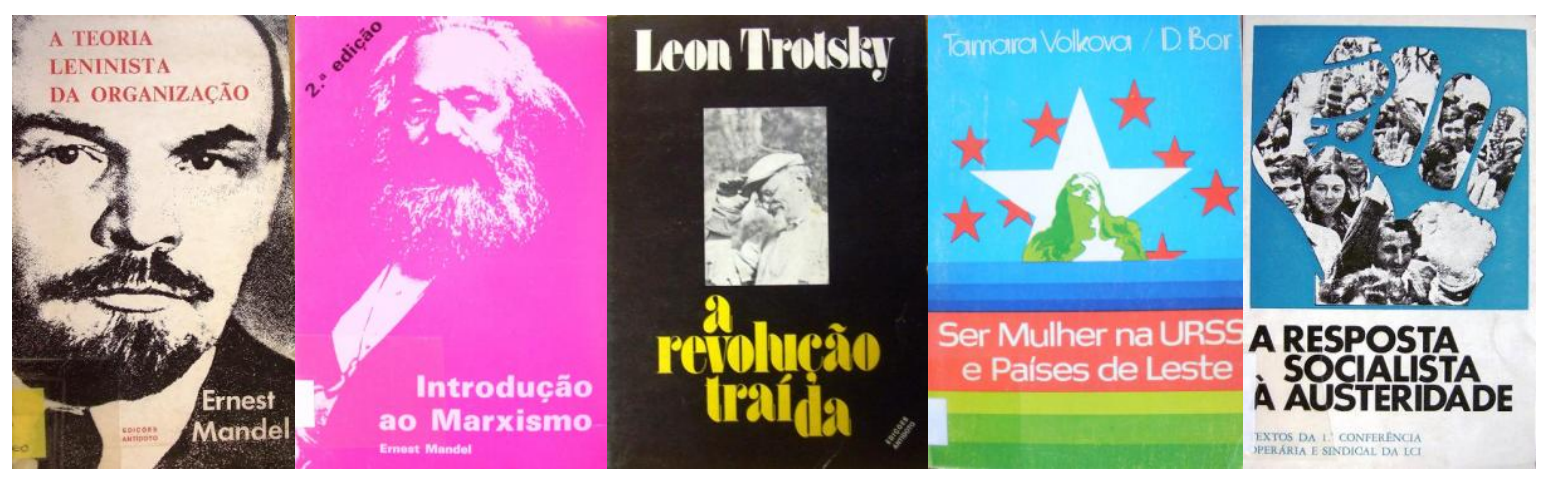

Editora criada por João Cabral Fernandes, dirigente da Liga Comunista Internacionalista (LCI), grupo trotskista fundado em dezembro de 1973 numa conferência em S. Bernardino (Peniche). A LCI tinha origem nos Grupos de Acção Comunista, liderados por Cabral Fernandes, Francisco Sardo, Manuel Resende e Marinho da Silva. A LCI seguia a orientação política do Secretariado Unificado da Quarta Internacional dirigido por Ernest Mandel ${ }^{37}$.

A LCI teria chegado a organizar cerca de 500 ativistas, "alguns com um papel decisivo na iniciativa de formação dos SUV [Soldados Unidos Vencerão], posições em algumas grandes empresas - como a CP [Combois de Portugal] - e liderança entre os trabalhadores da indústria do sapato, próximo do Porto" 38 .

De acordo com Manuel Resende, a Antídoto foi uma iniciativa de Cabral Fernandes "para publicar livros da nossa corrente, e para ver se fazia algum dinheiro para ajudar a Liga. Então ele comprou uma máquina de composição, que ficava na sede da LCI, e começou a editar". Resende ressalta que "a editora não era oficialmente da LCI, mas foi uma emanação do grupo político. E o Cabral Fernandes resolveu, sob sua responsabilidade pessoal, fazer a editora". Mas os resultados econômicos não foram os

\footnotetext{
${ }^{37}$ CORDEIRO, “Glossário dos anos do PREC...", op. cit., p. 118; "Cronologia: 30 anos da LCI/PSR". Disponível em: <http://combate.info/index.php?option=com_content\&task=view\&id=163\&Itemid=41>; HENRIQUES, “A Eduardo. fusão LCI-PRT”. Disponível em: <http://litci.org/especial/index.php/construcao/portugal/portugal-artigos/1806-a-fusao-lci-prt>. Acesso em mai. 2011.

38 ARCARY, Valério. "Quando o futuro era agora". Disponível em: <http://www.socialismo-obarbarie.org/europa/040627_revolucionportuguesa30aniversario.htm\#_ftn32>. Acesso em mai. 2011.
} 
esperados. "Creio que a editora sempre teve problemas financeiros", lembra Resende ${ }^{39}$. Ao que tudo indica, aquilo que Cabral Fernandes julgou que poderia gerar recursos para a LCI acabou por causar problemas financeiros para ele, e a Antídoto acabou por encerrar suas atividades em pouco anos.

A Editora Antídoto iniciou suas publicações em 1975, quando a LCI já estava legalizada. Os primeiros livros foram editados em abril daquele ano. Manuel Resende, que já atuava como tradutor, fez algumas traduções para a Antídoto ${ }^{40}$.

Entre as obras editadas destacam-se aquelas relacionadas à linha política da LCI, representada principalmente por dois autores: Leon Trotsky (12 títulos, e uma obra em coautoria) e Ernest Mandel (11 títulos, além de ser coautor de outras três obras editadas). A soma das obras desses dois autores equivale à metade dos títulos publicados pela Antídoto.

A editora publicou também documentos da Quarta Internacional e da LCI, além de autores como António Gramsci, Rosa Luxemburgo, Plekhanov, W. Reich e Alexandra Kollontai.

Entre os títulos lançados estão: $O 25$ de Abril e a revolução socialista em Portugal e colónias, de Ernest Mandel (1975); A questão parlamentar e a Internacional Comunista, de Zinoviev, Lenin, Trotsky, Bukharine e Bordiga (1975); A revolução portuguesa numa encruzilhada: Teses aprovadas no $3^{\circ}$ Congresso (extraordinário) da Liga Comunista Internacionalista (1976); A revolução desfigurada: a falsificação estalinista da História, de L. Trotsky (1977); Espanha abandonada: como Estaline abriu as portas a Franco, de M. Casanova (1977); Do Compromisso histórico ao eurocomunismo, de Enrico Berlinguer (1977); Sobre o imperialismo, de Jacques Valier (1977); Programa de transição para a revolução socialista, de L. Trotsky (1978); A actualidade de Rosa Luxemburgo, de Norman Geras (1978); O combate sexual da juventude, de W. Reich (1978); Ser mulher na URSS e países de leste, de Tamara Volkova e D. Bor (1978); Reich perante Marx e Freud, de J. M. Brohn, Helmut Dahmer e Paul Frappier (1978); Da comuna a maio de 68: Escritos políticos, de Ernest Mandel (1979); Introdução à filosofia da praxis, de A. Gramsci (1979); Dialéctica e revolução, de Michael Lowy (s/d); Ecologia e luta de classes, de J. P. Dèleage e Enzensberger (s/d); Conferências sobre a libertação das mulheres, de Alexandra Kollontai (s/d).

\footnotetext{
${ }^{39}$ Entrevista com Manuel António Ribeiro Resende por telefone em 30/8/2012.

${ }^{40}$ Idem.
} 
Os livros editados tinham padrão gráfico e editorial profissional e a distribuição era feita pela Distribuidora Expresso.

Em outubro de 1978 a LCI fundiu-se com o Partido Revolucionário dos Trabalhadores (PRT), formando o Partido Socialista Revolucionário (PSR), mas já em novembro de 1979 houve uma cisão com o antigo PRT. A partir de então, o PSR manteve-se como continuidade da $\mathrm{LCI}^{41}$.

Entre 1975 e 1979 as Edições Antídoto publicaram cerca de 50 títulos de caráter político.

\subsubsection{Editorial Divul (PRT)}

Divul, Sociedade de Ensino e Divulgação Científica, Lda.

Rua Marques da Silva, 99, $2^{\circ}$ - Lisboa

Editor: Jaime Gonçalves.

Início das edições: 1974.

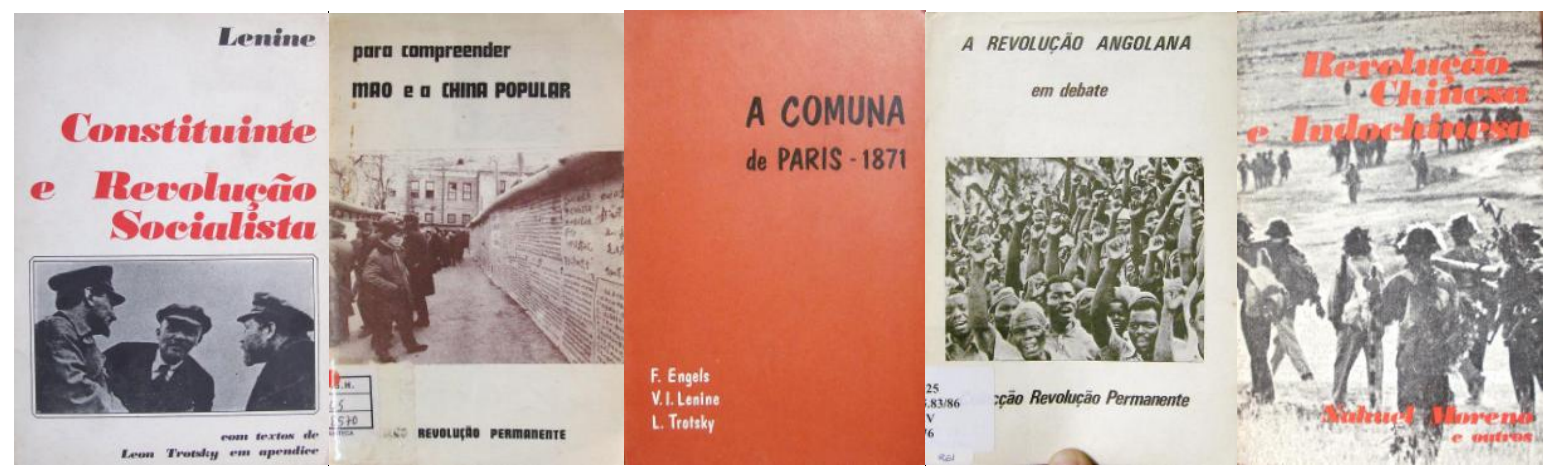

Editora ligada ao Partido Revolucionário dos Trabalhadores (PRT), criado em janeiro de $1975^{42}$ e vinculado à Fração Bolchevique (FB), dirigida por Nahuel Moreno $^{43}$, da seção argentina da IV Internacional. O PRT “organizava uns 200 militantes, dirigindo o movimento secundarista de Lisboa, e tinha influência entre os trabalhadores da limpeza de Lisboa, e posições nos metalúrgicos de Aveiro" e permaneceu como uma organização essencialmente estudantil e politicamente

\footnotetext{
${ }^{41}$ CORDEIRO, "Glossário dos anos do PREC...", op. cit., p. 118; "Cronologia: 30 anos da LCI/PSR", op. cit.

42 "Partido Revolucionário dos Trabalhadores (Portugal)". Verbete da Wikipedia. Disponível em: $\langle$ http://pt.wikipedia.org/wiki/Partido_Revolucion\%C3\%A1rio_dos_Trabalhadores_(Portugal)〉. Acesso em jan. 2012.

${ }^{43}$ HENRIQUES, op. cit.
} 
marginal ${ }^{44}$.

A editora começou a atuar ainda em 1974, antes da fundação formal do PRT. Editou obras de Nahuel Moreno, Lenin, Trotsky, entre outros. A maioria dos livros era parte da Coleção Revolução Permanente.

Eis alguns dos livros editados: A comuna de Paris - 1871, de F. Engels, V. I. Lénine e L. Trotsky (1974); Teses de Abril e Cartas sobre táctica, de Lenin (1974); O marxismo e o desenvolvimento na natureza e na sociedade, de George Novack (1974); A Revolução Chinesa e Indochinesa, de Nahuel Moreno e outros (1975); Constituinte e revolução socialista, de Lenin, com textos de Trotsky em apêndice (1975); O debate entre os marxistas-revolucionários sobre a revolução angolana, documento do Secretariado Unificado da Quarta Internacional (1976); Para compreender Mao e a China popular (1976); O desenvolvimento desigual e combinado na Rússia: três concepções da Revolução, de Leon Trotsky (1976); Lógica marxista e ciências modernas, de Nahuel Moreno (s/d).

O prólogo de Jaime Gonçalves, o responsável pela editora, a um livro lançado em abril de 1975, explicitava os sues objetivos:

Este novo livro da "Colecção Revolução Permanente" contribuirá sem dúvida nenhuma para recordar essas lições [do leninismo] e para apresentá-las com o seu verdadeiro rosto, sem as deformações introduzidas pelo estalinismo. Esse é o seu mérito e o seu objectivo. E, finalmente, é uma das vias para que a experiência histórica do proletariado contribua à resolução dos problemas que os revolucionários enfrentam hoje em dia. ${ }^{45}$

Os livros publicados tinham padrão gráfico e editorial semiprofissionais, e em alguns casos eram brochuras grampeadas, e não encadernadas. Não obtive informações sobre como era feita a distribuição dos livros da editora.

A Editorial Divul publicou cerca de dez títulos entre 1974 e 1976.

Em outubro de 1978 o PRT fundiu-se com a Liga Comunista Internacionalista (LCI), formando o Partido Socialista Revolucionário (PSR), mas já em novembro de 1979 houve uma cisão entre os dois grupos ${ }^{46}$.

\footnotetext{
${ }^{44}$ ARCARY, op. cit.

${ }^{45}$ GONÇALVES, Jaime. "Prólogo". In: LENINE. Constituinte e revolução socialista. Lisboa: Editorial Divul, abril, 1975.

${ }^{46}$ CORDEIRO, "Glossário dos anos do PREC...", op. cit., p. 118; "Cronologia: 30 anos da LCI/PSR", op. cit.; HENRIQUES, op. cit.
} 


\subsection{Editoras ligadas ao pensamento anarquista}

\subsubsection{A Batalha}

R. Angelina Vidal, 17, $2^{\circ}$ Esq. - Lisboa

Editor: Emídio Santana.

Início das edições: 1975.
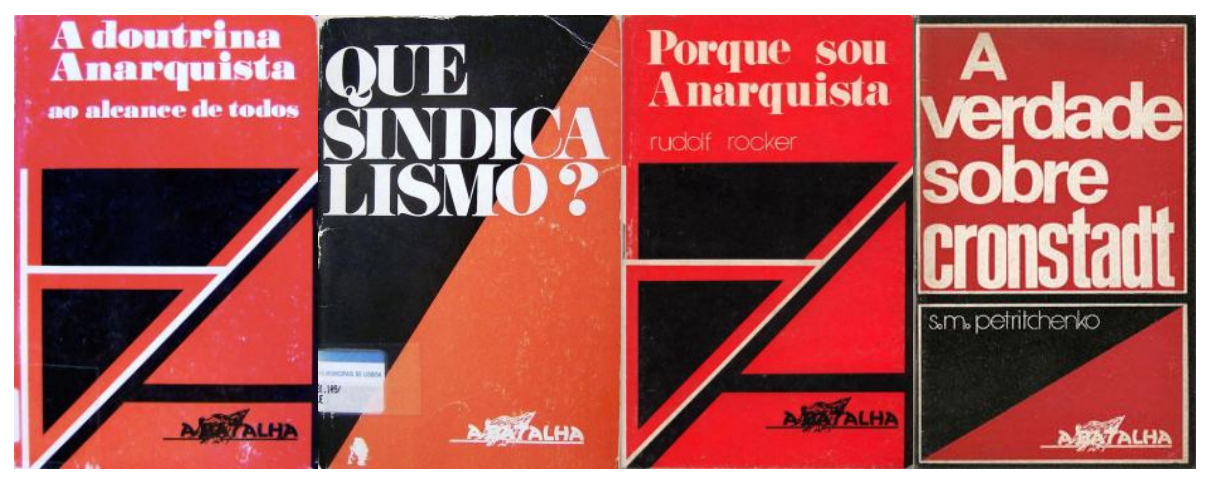

Editora ligada ao jornal homônimo, fundado originalmente em 1919 e que teve publicação diária até 1927, primeiro como "porta-voz da organização operária portuguesa" e depois como "órgão da Confederação Geral do Trabalho". O jornal seguia orientações anarco-sindicalista e nesse período foi um dos mais importantes órgãos da imprensa operária portuguesa ${ }^{47}$. Fechado em maio de 1927 pela ditadura, manteve-se atuante de forma intermitente até o final dos anos 1940.

Reapareceu mais uma vez em setembro de 1974, editado por uma cooperativa. Emídio Santana, histórico militante anarco-sindicalista e libertário assumiu a direção do jornal nesse período ${ }^{48}$, tendo também responsabilidades na editora, ao lado de Moisés Silva Ramos, antigo militante das Juventudes Libertárias dos anos $1930^{49}$. O jornal "agregou em torno de si os restos significativos do antigo movimento anarquista, servindo nesse período de referência essencial do pensamento libertário" ${ }^{50}$. Nesse momento, todavia, o anarquismo era muito débil em Portugal e tinha pouca influência política e social $^{51}$.

Localizei seis livros editados pelas Edições A Batalha nos anos de 1975 e 1976:

\footnotetext{
${ }^{47}$ FREIRE, João. “A Batalha”. Verbete. In: BARRETO; MÓNICA, op. cit., Vol. VII, Suplemento A/E, 1999, p. 176.

${ }^{48}$ CRUZ, Rui Paulo da. "Os jornais progressistas do pós-25 de Abril”. Vida Mundial, Lisboa, n 1.835 , 14/11/1974, p. 47.

${ }^{49}$ Mensagem eletrônica de João Freire enviada em 15/8/2012.

${ }^{50}$ ALVES, Jofre. "Jornais do PREC - 3, A Batalha”. Blogue Abril de Novo em 15/5/2012. Disponível em: $<$ http://abril-de-novo.blogspot.com.br/>. Acesso em jun. 2012.

${ }^{51}$ FREIRE, op. cit.
} 
Anarco-sindicalismo e autogestão, de René Berthier; A verdade sobre Cronstadt, de Stepan Petritchenko; Que sindicalismo?; Porque sou anarquista, de Rudolf Rocker; Autogestão - Gestão operária - Gestão directa, de Maurice Joyeux; A doutrina anarquista ao alcance de todos, de José Oitícica.

Ligada a antigos militantes anarquistas que haviam resistido à ditadura salazarista, a editora não conseguiu dar continuidade por mais tempo às suas edições. Isso certamente está ligado à debilidade do movimento anarquista no país e às divisões que nele surgiram, com novos grupos que apareceram e criaram seus próprios jornais e editoras.

De acordo com João Freire, militante e estudioso do anarquismo em Portugal, "esse esforço editorial se conjugava com a tentativa de estruturação de um Movimento Libertário Português organizado e a sua sede funcionou como 'casa mãe' dos anarquistas, a despeito das suas divisões internas" ${ }^{\prime 52}$.

Os livros editados têm padrão gráfico e editorial profissional, e são todos de doutrinação anarquista, quase sempre de autores estrangeiros. Não obtive informações sobre como era feita a distribuição dos livros, mas provavelmente deveria ser realizada de forma mais militante do que profissional.

\subsubsection{Editora Sementeira}

Apartado 3122 - Lisboa

Editor: João Freire.

Início das edições: 1977.

Distribuição: Própria, Diglivro.

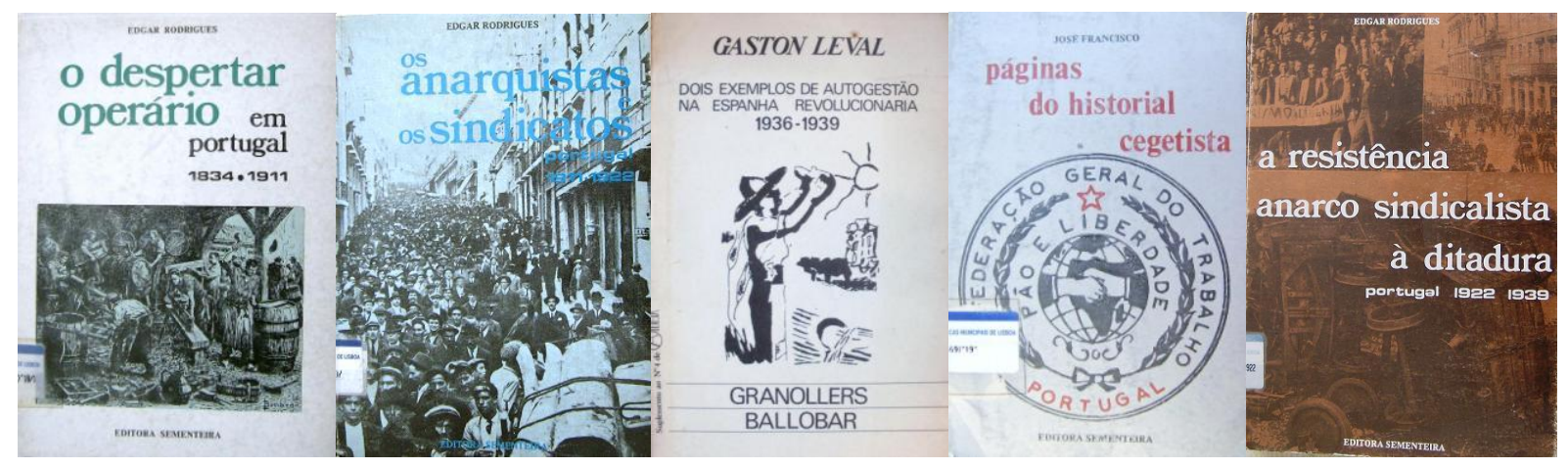

${ }^{52}$ Mensagem eletrônica de João Freire enviada em 15/8/2012. 
Editora criada em julho de 1977 pelo grupo anarquista ligado à revista A Ideia ${ }^{53}$, tendo como editor principal João Freire.

A revista A Ideia tinha lançado seu primeiro número poucos dias depois do 25 de Abril. A edição havia sido feita na França e estava na gráfica quando ocorreu o golpe dos capitães, mas ainda foi possível inserir no número 1 da revista um editorial que já tratava da nova situação política no país. A Ideia tinha:

um conteúdo essencialmente militante e usava [no começo] a linguagem tradicional do doutrinarismo anarquista. [...] assumia o papel de uns "cadernos de formação militante", fornecendo orientações ideológicas em matéria de organizações libertárias, sindicalismo, antimilitarismo, racionalismo anticlerical, educação, ecologia, feminismo, etc. ${ }^{54}$

De acordo com João Freire,

A opção pela edição foi tomada após os insucessos das tentativas de construir uma organização política anarquista em Portugal concretamente, a FARP (Federação Anarquista da Região Portuguesa) - nos anos de 1974-78, devido a desinteligências no campo acrata, e também pela análise racional feita por nós no final dessa década de que a conjuntura revolucionária já tinha acabado em Portugal, e em Espanha a ditadura franquista estava a ceder o passo a um regime democrático. ${ }^{55}$

A Editora Sementeira foi marcada "por uma preocupação dominante de preservar a memória histórica do antigo movimento operário e anarquista em Portugal", tendo editado, por exemplo, obras Edgar Rodrigues, "antigo companheiro que vivia no Brasil, [e] fizera a investigação documental" da história do anarquismo em Portugal. Rodrigues financiou a edição dos quatro livros que escreveu sobre o assunto. Publicou também "diversos livros memoriais de velhos militantes como José Francisco, Elias Matias, Américo Martins Vicente e Francisco Quintal" 56 ao longo de seus 13 anos de atividades.

Os livros publicados entre 1978 e 1982 foram: Páginas do meu caderno: poesia, de Artur Modesto (1978); Solidariedade com os trabalhadores alentejanos! (1978); Maio 68: textos e cronologia (1979); O despertar operário em Portugal, 1834-1911, de Edgar Rodrigues (1980); Os anarquistas e os sindicatos: Portugal, 1911-1922, de Edgar Rodrigues (1981); A resistência anarco-sindicalista à ditadura: Portugal 1922-1939, de

\footnotetext{
${ }^{53}$ FREIRE, op. cit., p. 468.

${ }^{54}$ Ibidem, p. 429 e 466.

${ }_{55}$ Mensagem eletrônica de João Freire enviada em 15/8/2012.

${ }^{56}$ FREIRE, op. cit., p. 473.
} 
Edgar Rodrigues (1981); A oposição libertária em Portugal (1939-1974), de Edgar Rodrigues (1982); Episódios da minha vida familiar e de militante confederal, de José Francisco (1982).

O trabalho na editora era quase todo voluntário, havia apenas uma pessoa remunerada (Isabel Arouca), que fazia a digitação dos textos. Montou-se também uma pequena tipografia para fazer as publicações. A distribuição era precária e militante, mas conseguia-se atingir a rede livreira, por meio de uma distribuição "informal", feita por apoiadores e não por distribuidores profissionais ${ }^{57}$. "Durante alguns anos, antes de passarmos a usar os serviços de uma empresa distribuidora, era eu que ia de comboio a Coimbra e ao Porto e, de saco às costas, percorria o meu circuito livreiro", conta João Freire $^{58}$.

Na Biblioteca Nacional de Portugal, setor de "Reservados", está depositado o fundo do João Freire, referente à revista A Ideia e à Editora Sementeira. Trata-se de material muito rico sobre ambas, com farta documentação sobre a organização interna, planejamento organizacional, planos editoriais, comunicação com os colaboradores e cooperados, prestação de contas e contabilidade. Analisando esse material, fica claro que o centro da atuação do grupo era a revista, sendo a edição de livros relativamente secundária.

No período entre 1978 e 1982 a Sementeira editou oito títulos. Sua atividade com a edição de livros continuou até 1991, tendo publicado no total, entre 1978 e 1991, cerca de 25 títulos.

João Freire acredita que o público leitor dos livros da Sementeira era composto pelos militantes e simpatizantes anarquistas, pessoas de outros grupos de esquerda (que liam “até para poder criticar"), algumas pessoas ligadas ao Partido Socialista e pessoas próximas às ideias libertárias e contestatárias ${ }^{59}$.

O caso da editora Sementeira é especialmente interessante no campo da edição política pois, apesar de tratar-se de uma pequena editora com poucas publicações, os livros e a revista $A$ Ideia eram o principal meio de contato do grupo com a sociedade, uma vez que a atuação pública do grupo se dava quase que exclusivamente por intermédio de suas publicações.

\footnotetext{
${ }^{57}$ Entrevista com João Freire, Lisboa, 21/3/2011; FREIRE, op. cit., p. 469.

${ }^{58}$ FREIRE, op. cit., p. 466.

${ }^{59}$ Entrevista com João Freire, Lisboa, 21/3/2011.
} 


\subsubsection{Cooperativa Cultural Editora Fomento Acrata}

Travessa do Cabral, $35^{\mathrm{a}}, 1^{\mathrm{o}}$ - Lisboa

Editor: José de Brito.

Início das edições: 1975.

Distribuição: Própria.

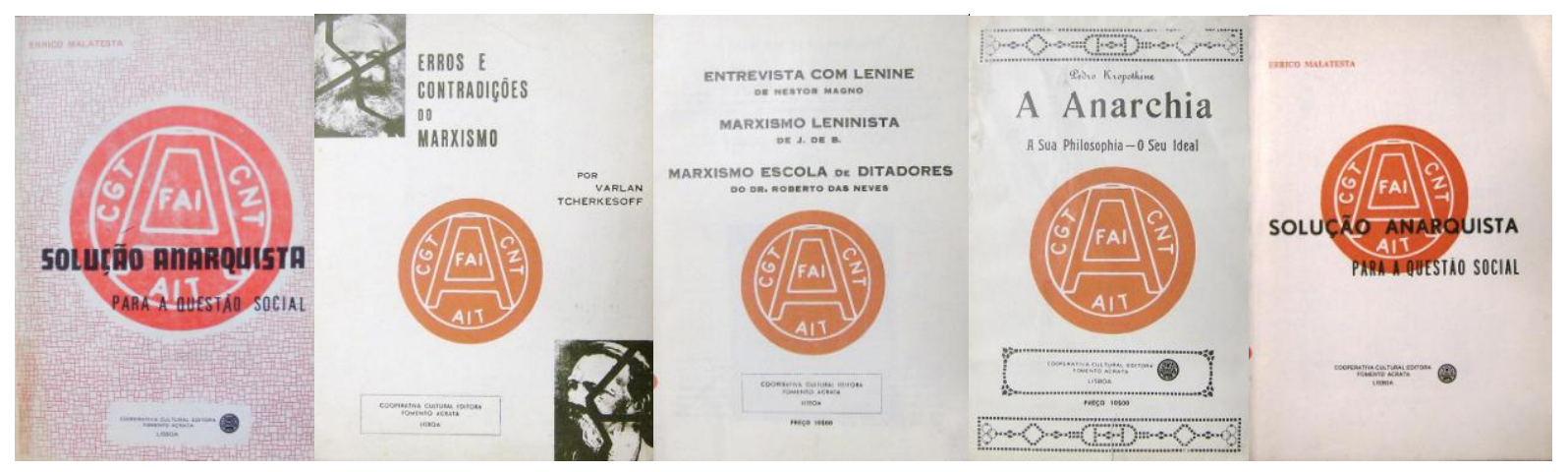

Editora criada por José de Brito, ativo militante anarquista de Lisboa e Almada $^{60}$. Em 1974 colaborou no jornal A Merda, editado em Almada, e do qual foram editados três números ${ }^{61}$.

A Cooperativa Cultural Editora Fomento Acrata publicava pequenas brochuras com textos clássicos do pensamento anarquista, de autores como Malatesta, Kropotkine e Tcherkesoff.

Localizei dez títulos editados pela Acrata. Eis alguns deles: Solução anarquista para a questão social, de Errico Malatesta (1975); A moral anarquista, de Pedro Kropotkine (s/d.); Anarchia, sua philosophia, seu ideal, de Pedro Kropotkine (s/d.); $O$ rei e o anarquista (s/d.); 12 provas da inexistência de deus, de Sebastião Faure (s/d.); Paralelo entre os sistemas económicos "ocidentais" e "soviético", de S. Agourski (s/d.); Erros e contradições do marxismo, de V. Tcherkesoff (s/d.); Marxismo, escola de ditadores, de Roberto das Neves (s/d.); $1^{\circ}$ de Maio de 1866. Greve pelas 8 horas (1979).

As edições provavelmente tiveram início em 1975. O último título parece ter sido publicado em 1979. Os livros tinham padrão gráfico e editorial semiprofissional. Possivelmente a distribuição era amadora e militante.

${ }^{60}$ FREIRE, op. cit., p. 433 e 439.

${ }_{61}$ "Gente de Almada, Gente Que Viveu Almada". Disponível em: <http://almadalmada.blogspot.com.br/2009_10_01_archive.html>. Acesso em fev. 2012. 


\subsubsection{Livraria Editora Sotavento}

Praça Alexandre Herculano, 24 - Faro

Editor: Júlio Carrapato.

Início das edições: 1979.

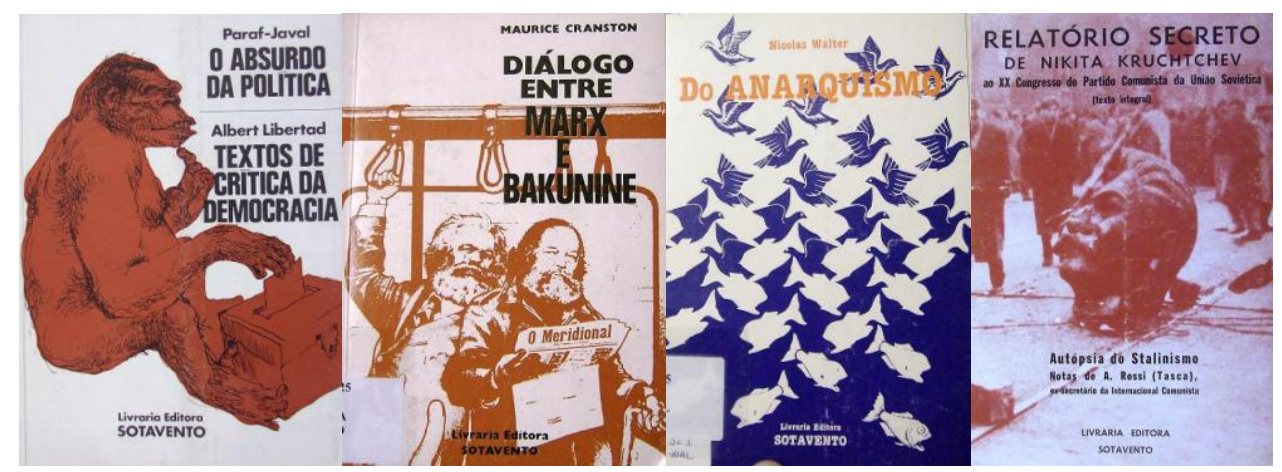

Editora e livraria fundada em 1978 na cidade de Faro (Algarve) por Júlio Carrapato $^{62}$. Publicava também o jornal $O$ Meridional $^{63}$. As obras editadas são todas relacionadas ao pensamento anarquista e à crítica do marxismo e do comunismo.

Trata-se, ao que parece, de uma editora "de um homem só”, já que cinco dos seis livros que localizei, publicados entre 1979 e 1982, foram traduzidos e/ou anotados por Júlio Carrapato. Os títulos editados neste período foram: O ladrão, de G. Darien (1979); Diálogo entre Marx e Bakunine, de Maurice Cranston (1979); O absurdo da política. Textos de crítica da democracia, de Paraf-Javal e A. Libertad (1979); Relatório secreto de Nikita Kruchtchev ao XX Congresso do Partido Comunista da União Soviética (texto integral): autópsia do stalinismo, com notas de A. Rossi (1981); Do anarquismo, de Nicolas Walter (1981); Comunismo e Burocracia, de L. Pellicani (1982).

Os livros tinham padrão gráfico e editorial profissional. Não há referência sobre como era feita a distribuição. A editora permanece em atuação até hoje, sempre com Júlio Carrapato à frente, tendo publicado no total cerca de 20 títulos.

62 "De volta a este meu banco de jardim". Blogue A Fuga do Vagabundo, 4/12/2009. Disponível em: $<$ http://assimfalouzaratrusta.blogspot.com/2009/12/de-volta-este-meu-banco-de-jardim.html $>$. Acesso em fev. 2012.

${ }^{63}$ FREIRE, op. cit., p. 441. 


\section{$\underline{6.3 \text { Editoras ligadas ao Partido Socialista }}$}

\subsubsection{Edições Portugal Socialista}

\section{Lisboa}

Início das edições: 1973.
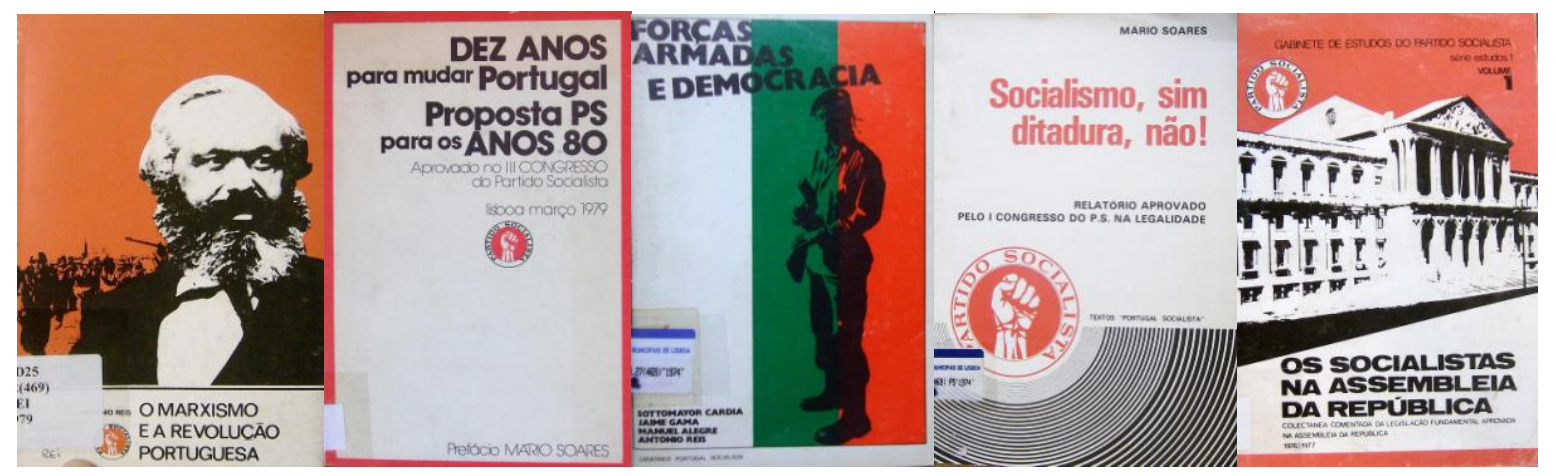

Editora oficial do Partido Socialista (PS). O partido foi fundado em abril de 1973, na Alemanha - já que não podia atuar em Portugal -, a partir da Acção Socialista Portuguesa ${ }^{64}$. Sua figura mais destacada era Mário Soares, que foi ministro dos Negócios Estrangeiros, de maio de 1974 a março de 1975, depois primeiro-ministro (em 1976/78 e 1983/85), e finalmente presidente da República (de 1986 a 1996) ${ }^{65}$.

Até o 25 de Abril o PS tinha uma organização "deficiente e sem implantação fora das maiores cidades. O aparelho do partido não se desenvolveu de um modo significativo até a campanha para as eleições constituintes de $1975^{\circ 66}$, da qual saiu vencedor com $38 \%$ dos votos. Esta debilidade inicial do partido explica a relativa fraqueza de seu setor editorial, que editava o jornal Portugal Socialista e publicava livros com o selo Edições Portugal Socialista.

Entre 1973 e 1981, período em que o PS tornou-se o mais importante partido do país eleitoralmente, localizei apenas cerca de 20 títulos com o selo Edições Portugal Socialista, os primeiros editados ainda no exterior (Roma). Os títulos editados são basicamente resoluções e documentos partidários, além de obras sobre a atuação parlamentar do partido. Os livros e brochuras publicados tinham padrão gráfico e editorial profissional. Provavelmente a distribuição era voltada para militantes e simpatizantes do partido.

${ }^{64}$ CUNHA, Carlos Alberto. "Partido Socialista". Verbete. BARRETO; MÓNICA, op. cit., Vol. IX, Suplemento P/Z, 1999, p. 30.

65 "Mario Soares". Verbete na Wikipedia. Disponível em: <http://pt.wikipedia.org/wiki/M\%C3\%A1rio_Soares>.

${ }^{66}$ CUNHA, op. cit. 
Eis alguns dos títulos publicados: Construir uma nova vida. Destruir o sistema. Por um Partido Socialista forte e combativo (1973, impresso em Roma); Socialismo, sim, ditadura, não! (1975); Vencer a crise, salvar a revolução (1975); O PS na Constituinte: missão cumprida, de Araújo Dantas (1976); Forças armadas e democracia, de Sottomayor Cardia, Jaime Gama, Manuel Alegre e António Reis (1976); Os socialistas na Assembleia da República, em dois volumes (1976-77); O Portugal Socialista na clandestinidade, 1967/1977: 10 anos de luta (1977); PS, fronteira da liberdade: da queda do Gonçalvismo às eleições intercalares 1975-1979, de Mário Soares (1979); O marxismo e a revolução portuguesa, de António Reis (1979); Dez anos para mudar Portugal: proposta PS para os anos 80 (1979).

Destaque para a brochura Socialismo, sim, ditadura, não!, que reproduz o relatório de Mário Soares aprovado pelo I Congresso do PS na legalidade, de 1975, que teve tiragem de 100 mil exemplares, como é informado no livro.

O PS publicou também alguns livros e brochuras com documentos do partido, mas sem o selo Edições Portugal Socialista.

Chama a atenção a discrepância entre a atenção dada ao setor editorial pelo PS e a que era dispensada ao mesmo setor pelos partidos mais à sua esquerda (PCP e esquerda radical), com os quais disputava parte do eleitorado. Comparado a estes grupos e partidos, o PS teve sempre uma atuação pífia no setor editorial, tanto no que diz respeito à imprensa como à edição de livros. No entanto, isso não impediu que se tornasse o mais importante partido do país do ponto de vista eleitoral.

\subsubsection{Perspectivas \& Realidades - p\&r}

Travessa das Chagas, 4-2 ${ }^{\circ}$ Esq. - Lisboa (1976).

Editores: João Soares, Victor Cunha Rego.

Início das edições: 1975.

Distribuição: Diglivro.

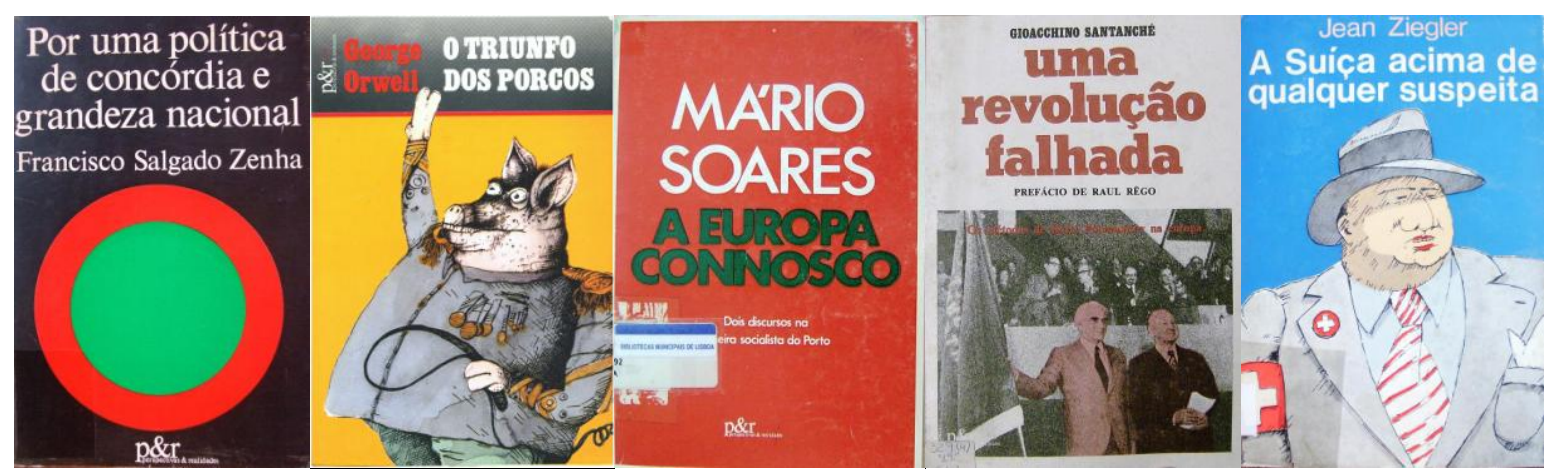


A ideia da criação da editora surgiu em fins de 1974 a partir de conversas entre João Soares e Vítor Cunha Rego ${ }^{67}$. Em setembro de 1975 a editora foi formalmente criada tendo ambos como sócios. Inicialmente foi codirigida por Bernardino Gomes e Ivone Cunha Rego ${ }^{68}$.

Vítor Cunha Rego era jornalista e exilara-se no Brasil em 1958, aos 25 anos de idade, somente tendo retornado a Portugal após o 25 de Abril. No Brasil, trabalhou em alguns dos mais importantes jornais do país e criou a editora Felman-Rego, em São Paulo. Em 1973 foi um dos fundadores do Partido Socialista (PS) ${ }^{69}$. Em 1976 tornou-se secretário de Estado Adjunto (1976-77) e depois embaixador de Portugal na Espanha (1977-80). Em 1980 foi presidente da RTP (Rádio e Televisão Portuguesa) ${ }^{70}$.

João Soares havia atuado no movimento estudantil, era militante do PS e filho de Mario Soares, secretário-geral do partido e ministro dos Negócios Estrangeiros, de maio de 1974 a março de 1975, depois primeiro-ministro (em 1976-78 e 1983-85) e presidente da República (de 1986 a 1996) ${ }^{71}$.

A editora parece ter sido, em suas origens, uma aposta de setores ligados ao Partido Socialista para se contrapor ao predomínio do PCP e da extrema esquerda no campo da edição de livros após o 25 de Abril.

João Soares, todavia, ressalta que "não houve nenhuma ligação orgânica entre a Perspectivas \& Realidades e o PS", ao mesmo tempo em que lembra que "o Cunha Rego era um homem que estava destacadamente empenhado nos combates do PS nessa altura, depois afastou-se, e eu também". E recorda que a editora, já depois da saída de Cunha Rego, realizou, "mais por razões comerciais", algumas edições com uma fundação ligada ao PS que era dirigida por Jorge Campinos ${ }^{72}$.

A proposta da Perspectivas \& Realidades era "ser uma editora que reflicta as realidades do país e que estimule a reflexão sobre essas mesmas realidades”. Pretendia também realizar "a publicação de certos livros de grande divulgação e baixo preço de

\footnotetext{
${ }^{67}$ Depoimento de João Soares no Ciclo de Debates "Livros que tomam partido: Editoras de caráter político na transição da ditadura em Portugal”, realizado em 20/3/2012 na Biblioteca-Museu República e Resistência, em Lisboa.

${ }^{68}$ MATEUS, Rui. Contos proibidos: memórias de um PS desconhecido. Lisboa: Dom Quixote, 1996, p. $85-86$.

69 "Victor Cunha Rego". Verbete na Wikipedia. Disponível em: <http://pt.wikipedia.org/wiki/Victor_Cunha_Rego\#cite_note-11>. Acesso em março de 2012.

70 "Victor Cunha Rego morre aos 66". Folha de São Paulo, 12/1/2000. Disponível em: <http://www1.folha.uol.com.br/fsp/cotidian/ff1201200013.htm>. Acesso em mar. 2012.

71 "Mario Soares", op. cit.

72 Depoimento de João Soares, op. cit.
} 
venda, capazes de darem resposta a alguns problemas quotidianos dos cidadãos portugueses e que necessitem de resoluções concretas" $"$.73.

Vítor Cunha Rego deixou a editora quando se tornou embaixador na Espanha, em 1977, e João Soares ficou à frente da editora. A partir desse ano "As edições de caráter político perderam então peso na Perspectivas \& Realidades, até porque haviam perdido peso do ponto de vista do mundo editorial e livreiro em Portugal nessa altura", diz Soares ${ }^{74}$.

De acordo com João Soares, a Perspectivas \& Realidades “em alguns momentos, foi uma empresa muito bem-sucedida, porque era uma coisa muito pequena. Começamos com um livro que foi logo um sucesso, $O$ triunfo dos porcos, de George Orwell",75. Ressalta ainda que "a editora viveu sempre como uma sociedade de base comercial que se aguentou a si própria" ${ }^{\text {76. }}$.

Até o final de suas atividades, na segunda metade dos anos 1980, lançou cerca de 50 títulos, dos quais metade foram editados em 1975 e 1976.

Publicou autores como Mário Soares (Portugal, que revolução?, 1976; A Europa connosco, 1976; Crise e clarificação, 1977), Salgado Zenha (Por uma política de concórdia e grandeza nacional, 1976), Chico da CUF (A URSS vista pela sua própria imprensa, 1976), Jean Ziegler (A Suíça acima de qualquer suspeita, 1976), Curzio Malaparte (Técnica do golpe de estado, 1976), Mário Cesariny (Textos de afirmação e de combate do movimento surrealista mundial, 1977), Jorge Campinos ( $O$ presidencialismo do Estado Novo, 1978) e Raul Brandão (Memórias, 1980), entre outros.

Entre as coleções editadas, destacam-se: Teoria Política, Construção da Sociedade Socialista, Escritos e Biografias, Tempos Livres e Direito.

\footnotetext{
73 "Perspectivas \& Realidades". In: AA.VV. Editores portugueses na IV Bienal Internacional do Livro São Paulo: 14 a 22/agosto/1976. Lisboa: Associação Portuguesa dos Editores e Livreiros, 1976.

${ }^{74}$ Depoimento de João Soares, op. cit.

75 “Aos 50 anos é um homem contente...". Entrevista de João Soares a Henrique Monteiro e João Garcia. Expresso, Lisboa, 1999. Disponível em: 〈http://www.joaosoares.net/main.asp〉. Acesso em mar. de 2012. No Brasil este livro foi edita com o título de A revolução dos bichos.

${ }^{76}$ Depoimento de João Soares, op. cit.
} 


\subsubsection{Editorial República}

\section{Lisboa}

Início das edições: 1972.

Distribuição: O Século

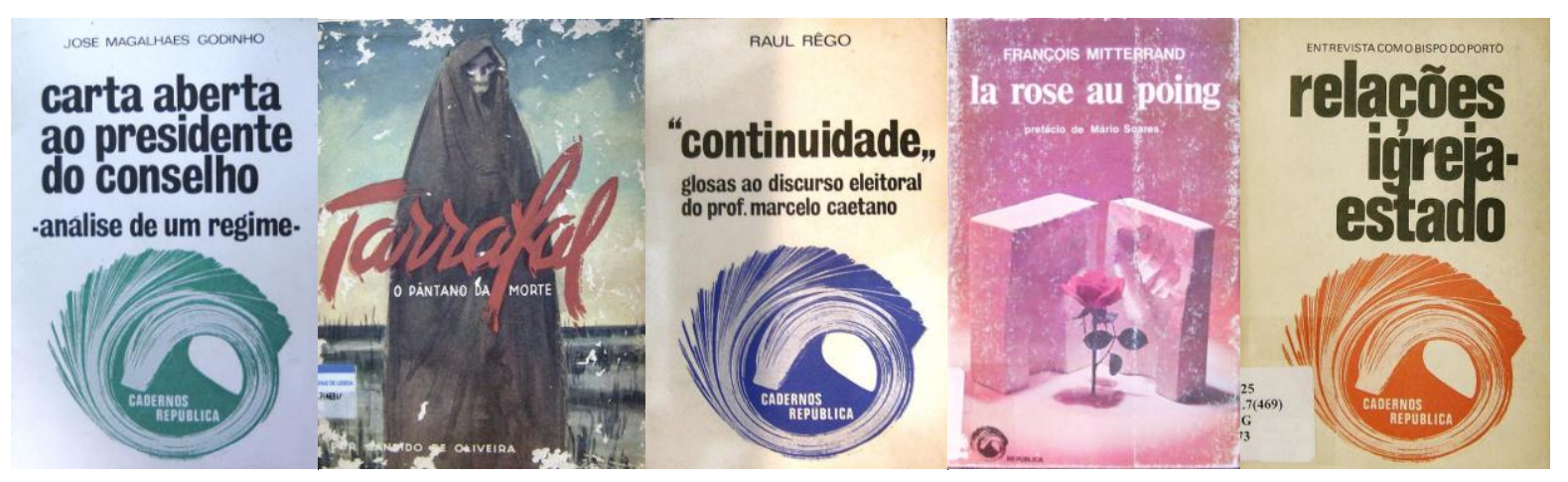

Editora ligada ao jornal República, fundado em janeiro de 1911 por António José de Almeida. Durante o período da ditadura salazarista, manteve-se sempre como um órgão da oposição democrática. Em 1972 passou por profundas reformas e em 1973 Raul Rego, destacado militante socialista assumiu a sua direção ${ }^{77}$. A maioria do capital social do jornal estava também em mãos de socialistas ${ }^{78}$.

Entre os autores editados figuram cinco fundadores do Partido Socialista: Raul Rêgo, José Magalhães Godinho, João Gomes, Francisco de Sales Ramos da Costa e Vasco da Gama Fernandes ${ }^{79}$.

A edição de livros começou em 1972, com a obra A estrutura agrária portuguesa: problema ainda sem solução à vista, de Henrique de Barros. Em 1973 foram lançados cinco títulos, todos de caráter oposicionista: Carta aberta ao presidente do Conselho: análise de um regime, de José Magalhães Godinho; Ano de eleições, de José Magalhães Godinho; "Continuidade”: glosas ao discurso eleitoral do prof. Marcelo Caetano, de Raul Rêgo; Relações Igreja-Estado. Entrevista com o Bispo do Porto, de Raul Rêgo e João Gomes; e Emigração: fatalidade irremediável?, de Francisco Ramos da Costa. Assim, a editora mantinha o mesmo perfil político do jornal.

Após o 25 de Abril, editou os seguintes títulos: Tarrafal, o pântano da morte, de Cândido de Oliveira (1974); Um rumo para a educação, de Vitorino Magalhães

\footnotetext{
${ }^{77}$ RODRIGUES, Avelino; BORGA, Cesário; CARDOSO, Mario. Portugal depois de Abril. Lisboa: Intervoz, 1976, p. 203-207; "República (jornal)". Verbete da Wikipedia. Disponível em: <http://pt.wikipedia.org/wiki/Rep\%C3\%BAblica_\%28jornal\%29>. Acesso em mar. 2012.

${ }^{78}$ CÁDIMA, Francisco Rui. “Os 'media' na revolução (1974-1976). In: ”BRITO, J. M. Brandão de (coord.). O País em Revolução. Lisboa: Editorial Notícias, 2001, p. 333.

79 "República (jornal)", op. cit.
} 
Godinho (1974); Do III Congresso de Aveiro à última campanha eleitoral, de Vasco da Gama Fernandes (1974); Citações, de Américo de Deus Rodrigues Tomás, compiladas por Abílio Belo Marques e Orlando Leonardo (1975); e “Depoimento” ou libelo: reflexões sobre o livro de memórias de Marcelo Caetano, de Raul Rêgo (1975); La rose au poing: para um novo modelo do socialismo, de François Mitterrand, com prefácio de Mário Soares (1975).

Um dos primeiros livros lançados pela editora após o fim da ditadura foi Tarrafal, o pântano da morte, que foi anunciado como um "Impressionante documento que Cândido de Oliveira dedicou à memória dos 30 mortos que repousam no cemitério do Tarrafal [e] Aos heróis e mártires da luta antifascista" ${ }^{\text {" }}$.

No total, entre 1973 e 1975, a Editorial República editou 12 obras. Os livros tinham tratamento gráfico e editorial profissional. A comercialização era feita pela Distribuidora O Século.

A editora sofreu as consequências do chamado "caso República", que levou ao fechamento do jornal no começo de 1976. O "caso República" ocorreu após "uma longa contenda quanto à orientação e linha editorial" ${ }^{\prime 81}$ do jornal, que culminou com a tomada do diário, em 19 de maio de 1975, pela sua Comissão Coordenadora dos Trabalhores (CCT), que acusava a direção de ter "transformado o jornal num órgão oficioso do Partido Socialista, em vez da orientação antifascista apartidária e independente que se comprometera a respeitar" ${ }^{\prime 82}$. Registre-se que a maior parte da redação foi contra esta decisão, tomada com base na preponderância dos tipógrafos na CCT, onde eram maioria os militantes de extrema esquerda. Apesar disso, o PS acusou o PCP pela tomada do jornal e iniciou uma forte luta política contra este partido e o IV Governo provisório liderado por Vasco Gonçalves. Esta crise ganhou corpo e repercussão internacional, e foi o estopim para a saída do PS do IV Governo e de seu rompimento com o PCP $^{83}$.

O jornal não sobreviveu à crise, e a Editorial República tampouco.

\footnotetext{
${ }^{80}$ Anúncio do livro Tarrafal, o pântano da morte no jornal República, Lisboa, 25/07/1974, p. 17.

${ }^{81}$ REZOLA, M. Inácia. 25 de Abril - Mitos de uma Revolução. Lisboa: Esfera dos Livros, 2007, p. 164.

${ }^{82}$ REZOLA, op. cit., RODRIGUES; BORGA; CARDOSO, op. cit.

${ }^{83}$ RODRIGUES; BORGA; CARDOSO, op. cit.
} 
$\underline{6.4 \text { Outras editoras de esquerda }}$

\subsection{1 África Editora}

Lisboa

Fundação: 1974.

Editor: Albertino Almeida e Alfredo Bobela-Mota.
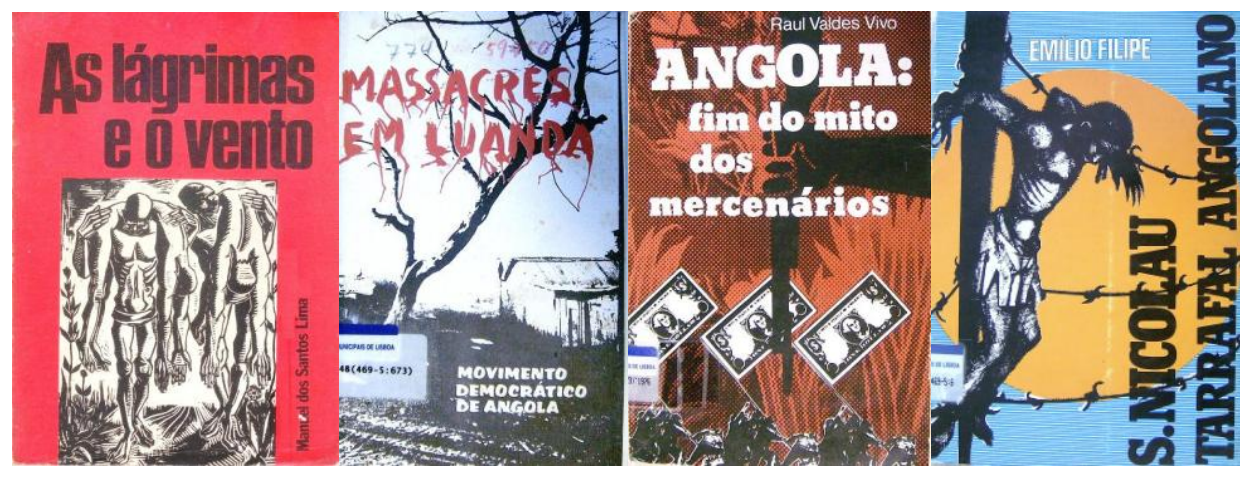

Nito Alves

MEMORIA DA IONGA

RESISTENCIA POPULAR

Editora ligada ao Movimento Democrático de Angola (MDA), organização fundada a 3 de maio de 1974 por Alfredo Bobela-Mota e por Albertino Almeida ${ }^{84}$, e que reunia angolanos e portugueses. O MDA teve origem em movimentos oposicionistas à ditadura colonial "que apoiavam o MFA e batiam-se pela independência de Angola" 85 . Tinha ligações com o Movimento Popular de Libertação de Angola (MPLA).

Nos anos 1960 houve uma editora também chamada África Editora sediada na cidade de Lourenço Marques, em Moçambique, mas que parece não ter qualquer relação com a África Editora criada em Lisboa nos anos 1970.

O primeiro livro editado foi Massacres em Luanda, que reproduzia um relatório do MDA sobre o massacre de 11 de julho de 1974 em Luanda.

Marcando o caráter militante da editora, afirmam os editores na introdução ao livro: "Ao publicarmos os dois importantes documentos que constituem este volume, é nossa intenção prestar homenagem à luta iniciada em 4 de fevereiro de 1961 pelo povo de Angola, pela sua Liberdade e Independência" ${ }^{86}$.

Esta mesma postura aparecia também em outra obra, o livro Angola: fim do mito dos mercenários, de Raul Valdes Vivo, editada em 1976, em que os editores afirmam

84 “Cronologia do ano de 1974 - XXI". Blogue Abril de Novo, 13/5/2010. Disponível em: <http://abrilde-novo.blogspot.com.br/2010/05/cronologia-do-ano-de-1974-xxi.html>. Acesso em set. 2012.

85 CORREIA, P. Pezarat. O processo de descolonização de Angola, do "25 Abril" ao "Alvor". Disponível em: <http://www.25abril.org/a25abril/get_document.php?id=177>. Acesso em set. 2012.

${ }^{86}$ MOVIMENTO Democrático de Angola. Massacres em Luanda. Lisboa: África Editora, 1974, p. $12-$ 13. 
que pretendem "associar-se às comemorações da passagem do primeiro ano de Independência da República Popular de Angola, saudando o seu heróico Povo, a sua vanguarda revolucionária, o MPLA, e os seus militantes revolucionários”87.

A editora publicou livros sobre a atualidade e as lutas políticas em Angola, tanto obras de ficção como de não-ficção. Havia coleções dedicadas à poesia e a romances, sempre com conteúdo político. Nos livros não constam informações sobre como era feita a distribuição comercial da editora.

Alguns dos títulos publicados foram: S. Nicolau, Tarrafal angolano, de Emílio Filipe (1975); Memória da longa resistência popular, de Nito Alves (1976); Não adianta chorar: contos coloniais, de A. Bobela Mota (1977); Terra vermelha: estórias para a história da guerra colonial em Angola, de Carlos Martins Pereira (1978); Voz de prisão, de Manuel Ferreira (1978); Poesia do colonialismo, de Carlos Espírito Santo (1978); A luta é a minha primavera: poemas, de Vasco Cabral (1981).

A África Editora atuou entre 1974 e o começo dos anos 1980, e publicou nesse período cerca de 15 títulos.

\subsubsection{Portucalense Editora}

Rua do Pombal, 95, A, $1^{\circ}$ - Porto

Inicio das edições: 1928.

Editor: José Oliveira (em 1971 e 1972)

Distribuição: Dinalivro.

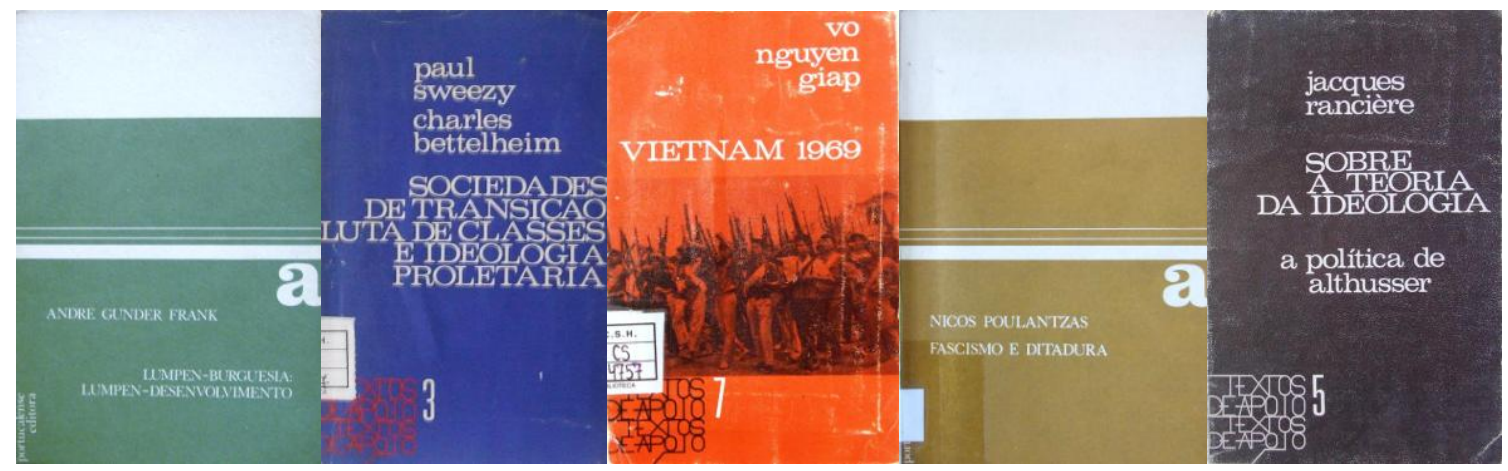

Editora criada na cidade de Barcelos nos anos 1920, e que posteriormente se transferiria para a cidade do Porto. Durante quase toda a sua existência foi uma editora simpática ao Estado Novo.

\footnotetext{
${ }^{87}$ VIVO, Raul Valdes. Angola: fim do mito dos mercenários. Lisboa: África Editora, 1976, p. 10-11.
} 
Somente em 1971 a editora sofreu uma reviravolta, com a morte de seu proprietário, quando a direção passou ao herdeiro José Oliveira. Estudante de arquitetura no Porto, Oliveira era também militante do grupo que a partir de dezembro de 1971 começaria a editar o jornal O Grito do Povo - que posteriormente passou a ser o órgão central da Organização Comunista Marxista-Leninista Portuguesa (OCMLP), quando esta organização foi criada em $1973^{88}$. Oliveira mudaria a linha editorial da Portucalense em seu breve período à frente da empresa.

Em suas origens a editora lançou, em 1928, o primeiro volume da História de Portugal, Edição Comemorativa do $8^{\circ}$ Centenário da Fundação da Nacionalidade, com direção literária de Damião Peres e artística de Eleutério Cerdeira. A coleção teve nove volumes publicados pela Portucalense até 1938 e contou a colaboração de eminentes historiadores e artistas portugueses ${ }^{89}$. A coleção ficou conhecida como História de Portugal "de Barcelos", por ser esta a cidade onde se localizava a editora da obra.

Esta edição marcou, desde as origens, um certo oficialismo da Portucalense, pois a coleção dirigida por Damião Peres pode ser entendida como uma "Obra do regime implantado em Portugal a 28 de Maio de 1926", tendo sido lançada em 24 de junho de 1928, 800 anos após a Batalha de São Mamede, que marcou a independência de fato de Portugal. "A obra foi louvada pelo Ministério da Instrução Pública e premiada com diplomas de honra na Grande Exposição do Norte de Portugal de 1933 e na Exposição Colonial Portuguesa de 1934"90.

Entre outros títulos editados que marcam uma proximidade ideológica com o regime, destaco: Raças do Império, de Mendes Corrêa (1943); O valor universal do corporativismo, de Augusto da Costa (1944); Política internacional, de Adriano Moreira (1970); A contra-revolução africana, de Ivan M. Sicard (1970).

Em 1971, sob a direção do herdeiro José Oliveira, a Portucalense deu uma guinada de 180 graus em sua orientação editorial. Neste ano e no seguinte a editora publicou 20 títulos claramente de esquerda, mas sem que houvesse uma orientação

\footnotetext{
${ }^{88}$ Mensagens eletrônicas de José Manuel Lopes Cordeiro enviadas em 2/9/2012 e em 12/1/2013; PEREIRA, José Pacheco. "Célula Comuna de Paris". Blogue Estudos sobre o Comunismo. Disponível em: <http://estudossobrecomunismo2.wordpress.com/2004/03/28/celula-comuna-de-paris-1971/>. Acesso em jan. 2011; CARDINA, Margem de certa maneira, op. cit., p. 124.

${ }^{89}$ Foi publicado um $10 .^{\circ}$ volume, ou $2 .^{\circ}$ suplemento, em 1981, dirigido por Franco Nogueira e editado pela Livraria Civilização. Cf. Página eletrônica da Livraria 1870 Livros. Disponível em:. <http://1870livros.com/tag/portucalense-editora/>. Acesso em 11 jan. 2013.

90 "História de Portugal de Damião Peres". Disponível em: 〈http://pt.wikipedia.org/wiki/Hist\%C3\%B3ria_de_Portugal_de_Dami\%C3\%A3o_Peres〉. Acesso em 11 jan. 2013.
} 
sectária na seleção das obras editadas.

A coleção Textos de Apoio era coordenada por Francisco Sardo, militante trotskista que seria um dos fundadores da Liga Comunista Internacionalista (LCI $)^{91}$. Estas edições parecem relacionar-se com a realização de sessões de estudo de autores marxistas organizadas por Sardo e Francisco Vale, juntamente com Manuel Resende e João Lafuente, na residência da JUC (Juventude Universitária Católica ${ }^{92}$. Resende, que também foi fundador da LCI, lembra que:

Os jovens católicos naquela época estavam a abrir-se à sociedade em geral e decidiram admitir não crentes nas suas residências. Os "cursos" eram um pretexto para discussão política e formação teórica e baseavam-se numa ideia surgida em Coimbra, durante as lutas estudantis de 1969 , de onde provinha o Sardo. ${ }^{93}$

$\mathrm{Na}$ coleção Textos de Apoio foram publicados os seguintes títulos: China $e$ URSS: dois "modelos" de industrialização, de Charles Bettelheim e Marco Macciò (1971); As lutas operárias contra a carestia de vida em Portugal: a greve geral de novembro de 1918, de José Pacheco Pereira (1971); Sociedades de transição: luta de classes e ideologia proletária, de Paul Sweezy e Charles Bettelheim (1971); Setembro 1970: a quinta tentativa de cerco e de liquidação da resistência palestiniana, documento da Frente Popular Democrática para a Libertação da Palestina (1971); Sobre a teoria da ideologia: a política de Althusser, de Jacques Rancière (1971); Os bakuninistas em acção: o levantamento em Espanha no verão de 1873, de F. Engels (1972); Vietnam 1969, de Vo Nguyen Giap (1972).

Quase todos estes livros foram postos "fora de mercado", ou seja, proibidos ou apreendido pela PIDE.

O fato de José Oliveira ser militante de uma organização maoista e Francisco Sardo, trotskista, ser o coordenador de uma das coleções da editora, é explicado por José Manuel Lopes Cordeiro:

[...] há que sublinhar que nestes anos de 1971-72, apesar do radicalismo, as coisas ainda não estavam bem esclarecidas e demarcadas no que respeitava à orientação ideológica desta juventude pós-Maio de 68, do Porto. Vinham todos do mesmo caldo político - a oposição e, particularmente, a luta antieleitoral de 69 - e coexistiam

\footnotetext{
${ }^{91}$ Sobre a LCI ver o item sobre as Edições Antídoto.

92 PEREIRA, José Pacheco. "Morte de Paul Sweezy". Blog Estudos Sobre o Comunismo, 6 mar. 2004. Disponível em: <http://estudossobrecomunismo2.wordpress.com/category/biografias-vidas/page/14/>. Acesso em: 12 fev. 2011; CARDINA, A esquerda radical, op. cit., p. 79; Mensagem eletrônica de Manuel Resende em 26 nov. 2012.

${ }^{93}$ Mensagem eletrônica de Manuel Resende em 26 nov. 2012.
} 
influências maoistas (maioritárias), mas também trotskistas e, até, anarquistas. Aliás, todos se conheciam (o meio era pequeno) e muitos até eram colegas e amigos, há longa data. É por isso que surgem "ligados" à Portucalense o Sardo e o Francisco Vale, depois (ou já então) dirigentes trotskistas. ${ }^{94}$

Outra coleção editada nessa fase foi a Colecção A, onde foram publicados dez títulos, entre os quais: Poder político e classes sociais do Estado capitalista, de Nicos Poulantzas, obra em dois volumes (1971); Lumpen-burguesia: lumpen-desenvolvimento, de André Gunder Frank (1971); A era do imperialismo: a economia da política externa norte-americana, de Harry Magdoff (1972); A questão agrária, de Karl Kautsky, obra em dois volumes (1972); Fascismo e ditadura: a III internacional face ao fascismo, de Nicos Poulantzas, em dois volumes (1972).

Foi editada também a Terceira Colecção, que teve três volumes: Paris livre 1871, de Jacques Rougerie (1971); O teatro popular porquêe, de Emile Copfermann e Maria Elena Curado e Melo (1971): e Os muros do asilo, de Roger Gentis (1972).

Em 1972 a Portucalense encerrou suas atividades, provavelmente porque José Oliveira teve de passar à clandestinidade após uma tentativa de prisão pela PIDE $^{95}$. Apesar disso, ele continuou sua militância política e chegou a ser membro da Direção da OCMLP às vésperas do 25 de abril ${ }^{96}$.

\subsubsection{AEPPA (Associação de Ex-Presos Políticos Antifascistas)}

Rua António Maria Cardoso, 15 - $3^{\circ} \mathrm{B}$ - Lisboa

Início das edições: 1975.
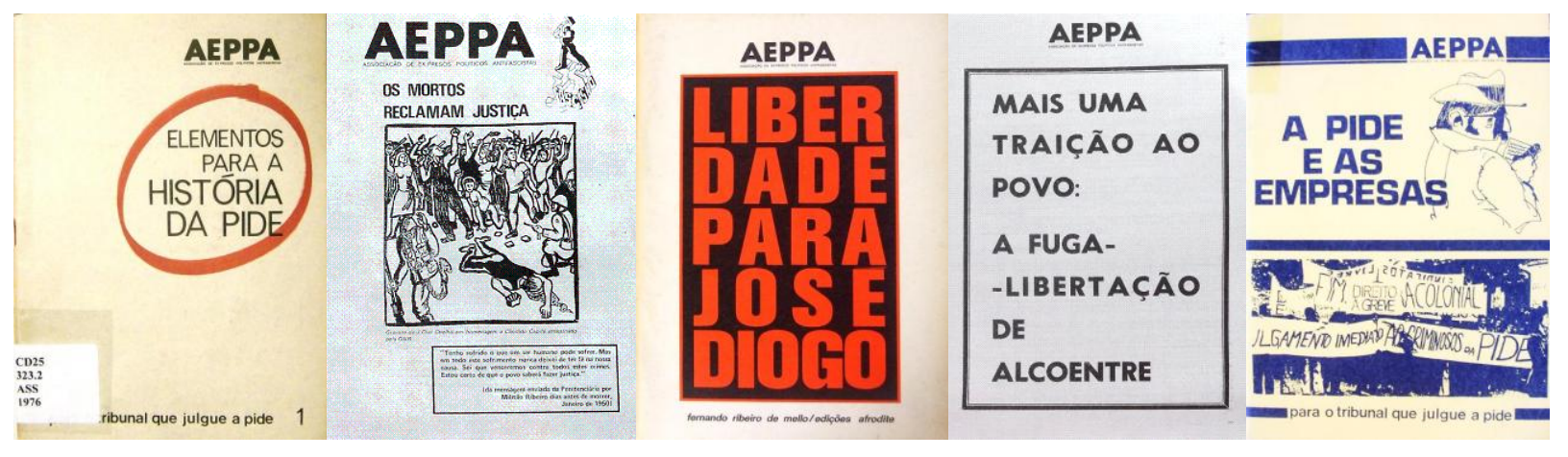

\footnotetext{
${ }^{94}$ Mensagem eletrônica de José Manuel Lopes Cordeiro enviada em 2 set. 2012.

${ }^{95}$ Mensagem eletrônica de José Manuel Lopes Cordeiro enviada em 12 jan. 2012.

${ }^{96}$ Mensagem eletrônica de José Manuel Lopes Cordeiro enviada em 2 set. 2012.
} 
Associação fundada em junho de 1974. Politicamente próxima a setores maoistas que se reuniriam, a partir de dezembro de 1974, na UDP (União Democrática Popular), e que posteriormente formariam o PCP(R) - Partido Comunista Português (Reconstruído), a AEPPA “constituiu-se inicialmente agrupando gente com percursos diferenciados na área da extrema-esquerda" $" 97$.

$\mathrm{Na}$ lista de seus fundadores há pessoas ligadas à FAP (Frente de Acção Popular) e ao CMLP (Comitê Marxista-Leninista Português); ativistas presos por tentativas de deserção com armas ou por apoio a movimentos de libertação africanos; militantes com alguma relação com o MRPP (Movimento Reorganizativo do Partido do Proletariado), com a UCML (União Comunista Marxista-Leninista) e com os Comitês Guerra Popular; e ex-militantes do PCP (Partido Comunista Português) ${ }^{98}$. "A maioria, no entanto", destaca Miguel Cardina, estaria após o 25 de Abril "no CARP (m-1) (Comitê de Apoio à Reconstrução do Partido marxista-leninista) e no percurso de agrupamento que levou à criação da ORPC (m-l) (Organização para a Reconstrução do Partido Comunista marxista-leninista) e depois da UDP e do PCP(R)" ${ }^{\text {"99. }}$.

Manuel Quirós, um dos responsáveis pelas Edições Maria da Fonte, participou da fundação da AEPPA e desempenhou papel de algum destaque na associação até a sua morte, em outubro de $1975^{100}$.

Outro militante de destaque da AEPPA foi Amadeu Lopes Sabino, que havia participado da fundação do MRPP, e que tornou-se nos anos seguintes ao fim da ditadura um advogado atuante na defesa da chamada "justiça popular"101.

A principal publicação da AEPPA era o seu boletim, cuja primeira edição saiu em agosto de 1974 e do qual foram editados sete números ${ }^{102}$.

A publicação de livros começou apenas em 1975. Os nomes das duas principais coleções publicadas pela AEPPA já deixavam claros os objetivos da associação: "Para o

\footnotetext{
${ }^{97}$ CARDINA, Miguel. "Guerra total à fera fascista: a AEPPA e a memória como combate”. Texto apresentado no Colóquio Internacional Legados do Autoritarismo em Portugal em Perspectiva Comparada, realizado na Faculdade de Ciências Sociais e Humanas da Universidade Nova de Lisboa nos dias 23 e 24 de abril de 2012.

${ }^{98}$ Ibidem.

99 Ibidem.

${ }^{100}$ Mensagem eletrônica de José Manuel Lopes Cordeiro enviada em 3/2/2013; ALVES, Jofre. "Manuel Quirós: uma vida temperada na luta". Blogue Abril de Novo, 25/10/2009. Disponível em: <http://abril-denovo.blogspot.com/search/label/CMLP>. Acesso em jun. 2011.

101 “Amadeu Lopes Sabino". Verbete, Wikipédia. Disponível em: < http://pt.wikipedia.org/wiki/Amadeu_Lopes_Sabino\#cite_note-2>. Acesso em 3/3/2013.

${ }^{102}$ CARDINA, "Guerra total à fera fascista", op. cit.
} 
Tribunal que Julgue a PIDE" e "Morte à PIDE".

Na primeira foram editados os livros Elementos para a história da PIDE (1976) e A PIDE e as empresas (fevereiro, 1977). Na segunda, apenas um título: Mais uma traição ao povo: a fuga-libertação de Alcoentre (1977).

Os primeiros títulos publicados pela AEPPA foram Porque não se destroem os ficheiros da PIDE? (1975) e Liberdade para José Diogo, em maio de 1975, este em coedição com a Editora Afrodite (tiragem de 6.200 exemplares). Em 1976 foi lançado $A$ política de genocídio contra os índios do Brasil ("Trabalho elaborado por um grupo de antropólogos patriotas brasileiros que não podem revelar os seus nomes por agora, dado o regime fascista existente no Brasil”); e em 1977 Os mortos reclamam justiça, livro que traz a lista de todos os mortos pela polícia política portuguesa desde 1931 até 25 de abril de 1974.

Os livros editados eram, em sua maior parte, pequenas brochuras grampeadas, com menos de 30 páginas.

A AEPPA editou apenas sete títulos entre 1975 e 1977. Interessante assinalar que três desses títulos foram publicados em 1977. De acordo com Cardina, a AEPPA teria entrado em uma fase "descendente" em finais de $1976^{103}$, o que permite supor que a edição dessas brochuras terá sido, talvez, uma das atividades derradeiras da associação.

103 Ibidem. 


\section{EDITORAS POLÍTICAS DE ESQUERDA SEM VINCULAÇÃO PARTIDÁRIA}

Neste capítulo apresento os estudos sintéticos sobre as 18 editoras políticas sem vinculação partidária. Neste grupo estão algumas das mais interessantes editoras portuguesas desse período, seja por sua marcante atuação no campo cultural, seja porque algumas delas se tornaram nomes inescapáveis do mundo editorial português como Afrontamento, Inova, Centelha, Escorpião e Assírio\&Alvim.

As editoras deste grupo, por não terem vínculos de dependência com nenhuma organização política, reuniam militantes e simpatizantes de várias organizações, conseguindo sempre manter a sua independência política. Ao mesmo tempo, algumas delas foram fortemente engajadas nas lutas políticas, tanto antes como depois do 25 de Abril.

\subsection{Iniciativas Editoriais}

Av. Rio de Janeiro, 6 s/cave - Lisboa.

Editores: José Fernandes Fafe, Carlos de Oliveira, José Gomes Ferreira (fundadores), Faure da Rosa, Nuno Brederode Santos, Isabel Ferreira, Maria José Tição.

Fundação: 1956.

Distribuição: Expresso.
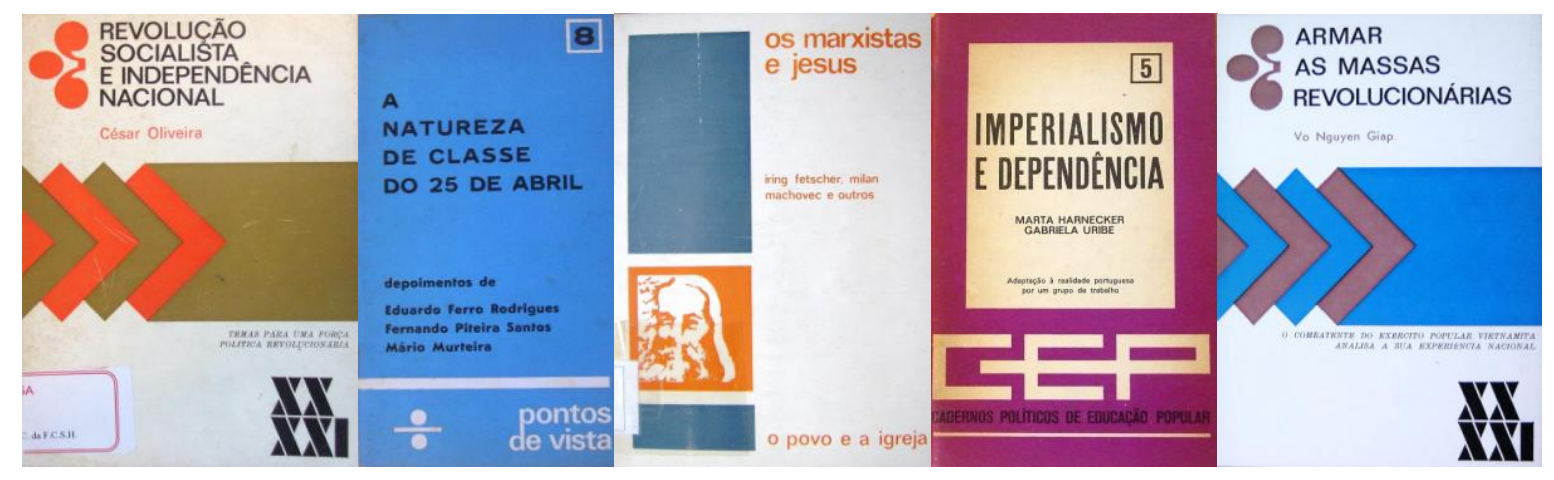

Editora criada em meados dos anos 1950 por José Fernandes Fafe, Carlos de Oliveira e José Gomes Ferreira. Fafe explica que em suas origens a editora tinha objetivos primordialmente comerciais: "Por esses anos 50, a edição de obras em fascículos ilustradas por artistas conhecidos, era, em regra, lucrativa. [...] Houve outras 
motivações [para criar a editora]. Mas esta, se calhar, a mais forte. [...]"1.

Apesar de os três fundadores serem sócios na editora, a empresa foi aberta apenas em nome de Fafe. Ele conta:

Havia que obter um alvará. E a certa altura da tramitação, o requerimento passava pela PIDE, que decidia do nihil obstat. Ora, nesse tempo, as fichas policiais do Carlos Oliveira e do José Gomes Ferreira eram, provavelmente, piores do que a minha. Por isso resolvemos que seria só eu a requerer o alvará. ${ }^{2}$

O alvará foi concedido, mas "Com alguns condicionalismos", continua Fafe. "Só podíamos editar livros de literatura e arte". Mas a editora não cumpriu essa determinação. Fafe tornou-se o diretor literário da editora e, quando saiu de Portugal, foi substituído por Faure da Rosa e Nuno Brederode Santos ${ }^{3}$.

A editora ficou conhecida por editar o Dicionário de História de Portugal, cuja publicação teve início em 1963 e foi coordenado por Joel Serrão - e que tornou-se uma obra de referência na historiografia portuguesa.

Além disso, até os anos 1960, a Iniciativas Editoriais caracterizou-se como editora literária e de poesia, tendo publicado autores como José Rodrigues Miguéis, Manuel da Fonseca, Mario Dionísio e Eugénio de Andrade, entre outros, e obras como Contos tradicionais portugueses, compilados por Carlos de Oliveira e José Gomes Ferreira e ilustrados por Maria Keil; o Grande dicionário da literatura portuguesa e de teoria literária, dirigido por João José Cochofel; e Romanceiro geral do povo português, organizado por Alves Redol.

Assim, tanto pela postura de seus proprietários como pelos autores publicados, a Iniciativas Editoriais era uma editora ligada a setores da oposição democrática à ditadura.

No começo da década de 1970, a editora passou a dar mais espaço em seu catálogo a livros de caráter político, com as coleções Século XX/XXI e Pontos de Vista. Estas coleções tiveram grande crescimento após o 25 de Abril, chegando a primeira a mais de 140 volumes e a segunda a cerca de 30 volumes.

Alguns dos títulos políticos publicados antes do 25 de Abril foram: $O$ presidencialismo português, com textos de Sidónio Pais, Oliveira Salazar e Marcello Caetano, e organização de José-Pedro Gonçalves (1971); O problema do Terceiro

\footnotetext{
${ }^{1}$ SILVA, António. Conversas (durante anos) com José Fernandes Fafe. Lisboa: Almedina, 2002, p. 51.

${ }^{2}$ Ibidem.

${ }^{3}$ Ibidem.
} 
Mundo, de Enrique Ruiz Garcia (1970); Cuba é estalinista?, com textos de Heberto Padilla, Fidel Castro, Vargas Llosa e Charles Bettelheim (1971); Um proletariado explorador?, de Charles Bettelheim, Arghiri Emmanuel, Henry Denis, André Granou, Guy Dhuquoïs e Christian Paloix (1971); Estado de direito e sociedade democrática, de Elias Diaz (1972); A leste, uma sociedade mais justa?, de Maria J. Bandeira (1973); e A experiência chilena, com entrevistas de dirigentes chilenos feitas por José Fernandes Fafe (1973).

Após o 25 de Abril, a linha da editora sofreu uma modificação e os livros políticos passaram a predominar, com grande crescimento das coleções Século XX/XXI e Pontos de Vista, e o surgimento das coleções Cadernos Políticos de Educação Popular (dirigida por Marta Harnecker e Gabriela Uribe) e Real Imaginário. O ritmo das edições políticas também cresceu exponencialmente. Entre 1974 e 1978 foram lançados cerca de 200 títulos políticos, o que faz da editora uma das mais atuantes no período em relação a este tipo de obra, em termos quantitativos.

Esta inflexão para a política parece estar relacionada a ligações dos editores com membros do grupo que em maio de 1974 fundou o Movimento de Esquerda Socialista $(\mathrm{MES})^{4}$. O MES teve origem na campanha eleitoral de 1969, "quando um grupo de militantes do catolicismo progressista, intelectuais de diversos setores e quadros do associativismo estudantil abandonaram a CDE [Comissão Democrática Eleitoral], passando a atuar organizadamente, embora sem qualquer denominação partidária" .

Em seu primeiro congresso, em dezembro de 1974, o MES adotou uma linha radical, o que levou à saída de um grupo de militantes da organização, que criaram o Grupo de Intervenção Socialista (GIS). Foi uma das forças políticas atuantes no "verão quente", com certa influência entre oficiais milicianos que influenciaram algumas posições do MFA ${ }^{6}$.

A linha política adotada pela Iniciativas Editoriais após o 25 de Abril era abrangente e não-sectária. Incluía autores como: Marx, Bakunin, Kropotkin, Lenin, Trotsky, Stalin, Dimitroff, Gramsci, Togliatti, Berlinguer, Ho Chi Minh, Vo Nguyen

\footnotetext{
${ }^{4}$ Mensagem eletrônica de José Manuel Lopes Cordeiro em novembro de 2010.

${ }^{5}$ CORDEIRO, "Glossário dos anos do PREC...", op. cit., p. 118.

${ }^{6}$ Ibidem. Entre os membros do GIS estavam Jorge Sampaio, João Cravinho, Galvão Teles e César Oliveira. Ver: MADAÍL, Fernando. "Comprar 'G-3' a mil escudos no dia da 'maioria silenciosa"”. Diário de Notícias, 28/4/2004. Disponível em: $<$ http://www.dn.pt/especiais/interior.aspx?content_id=1210730\&especial=A\%20revolu\%E7\%E3o\%20de $\% 20$ Abril\&seccao=POL\%CDTICA $>$. Acesso em 8/10/2012.
} 
Giap, José Carlos Mariátegui, Lucien Rioux, Fidel Castro, Che Guevara, Marta Harnecker, Juan Velasco Alvarado, Paul Sweezy, Harry Magdoff, André Gunder Frank, Louis Althusser, Ariel Dorfman, Armand Mattelard, J. K. Gallbraith, entre outros.

Os temas ligados à história recente de Portugal e à situação política do país estavam também contemplados no catálogo com títulos como: Portugal pode viver sem as colónias? Respondem alguns dos melhores economistas portugueses, com textos de António Guterres, Augusto Mateus e Ulpiano F. Nascimento, entre outros (1974); A natureza de classe do 25 de Abril, de Eduardo Ferro Rodrigues, Fernando Piteira Santos e Mário Murteira (1974); 55 dias de uma experiência democrática, de Mário Murteira (1975); A política económica do Governo Provisório, de Eugénio Rosa, Francisco Camões e Maia Cadete (1975); Portugal 75: dependência externa e vias de desenvolvimento, de João Martins Pereira (1975); Histórias da prisão, de Júlio Graça (1975); Presos políticos: documentos 1972-1974, da Comissão Nacional de Socorro aos Presos Políticos (1975); Balanço da colonização portuguesa, vários autores (1975); Revolução socialista e independência nacional, de César Oliveira (1975); Os soldados socialistas de Portugal, de Márcio Moreira Alves (1975); A estrutura agrária portuguesa transformada?, de A. Bandarra e Nelly Jazra (1976); Poder militar e socialismo em Portugal, de Pierre Naville (1976); A crise da revolução: para uma análise do concreto da revolução portuguesa, de Eduardo Lourenço, Eduardo Prado Coelho e César Oliveira (1976); A situação da mulher na sociedade portuguesa actual: os preconceitos e a luta pela emancipação, de Abílio José Salgado (1978).

A partir de 1975, José Fernandes Fafe foi designado embaixador de Portugal em Havana $^{7}$, o que fez com que se afastasse da editora.

A Iniciativas Editorias manteve-se em atuação até o final dos anos 1970. Nesse momento, a atividade da editora, de acordo com Fafe, "deve-se sobretudo a Isabel Ferreira e a Maria José Tição, uma, cunhada do Carlos de Oliveira, a outra, minha cunhada, empregadas na editora, e que foram de uma dedicação a toda a prova, até à de,

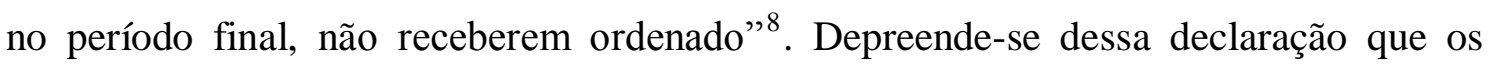
últimos tempos da editora foram de crise e dificuldades econômicas.

Como vimos, a Iniciativas Editorias foi uma das mais prolíficas editoras políticas portuguesas do período pós-ditadura, com um ritmo médio de cerca de 40

\footnotetext{
7 “Quem é José Fernandes Fafe?". Disponível em: <http://area.dgidc.minedu.pt/inovbasic/edicoes/noe/noe50/conversa.htm>. Acesso em 5/9/2011.

${ }^{8}$ SILVA, op. cit., p. 56.
} 
títulos políticos editados por ano entre 1974 e 1978, o que implica uma estrutura de produção e distribuição profissional, e de razoável dimensão. Além, é claro, de significar uma certa capacidade financeira para financiar tal ritmo de produção.

Foi sem dúvida uma das importantes editoras políticas do período, inclusive por sua abrangência temática e ideológica, alinhando-se claramente à esquerda, mas sem ser sectária. Caracterizou-se também por editar autores estrangeiros clássicos do pensamento de esquerda, mas também autores contemporâneos, além de vários títulos sobre a realidade portuguesa do pós-25 de Abril, produzidos por autores que eram também participantes desse processo político.

Provavelmente ligada a setores do "primeiro" MES e do Partido Socialista, não foi todavia editora de um partido ou de um grupo.

\subsection{Afrontamento}

Apartado 532 - Rua Costa Cabral, 859 - Porto

Editor: Pedro Francisco, José M. C. Sousa Ribeiro, Marcela Torres.

Fundação: 1963.

Distribuição: Própria, Ulmeiro, Germinal.

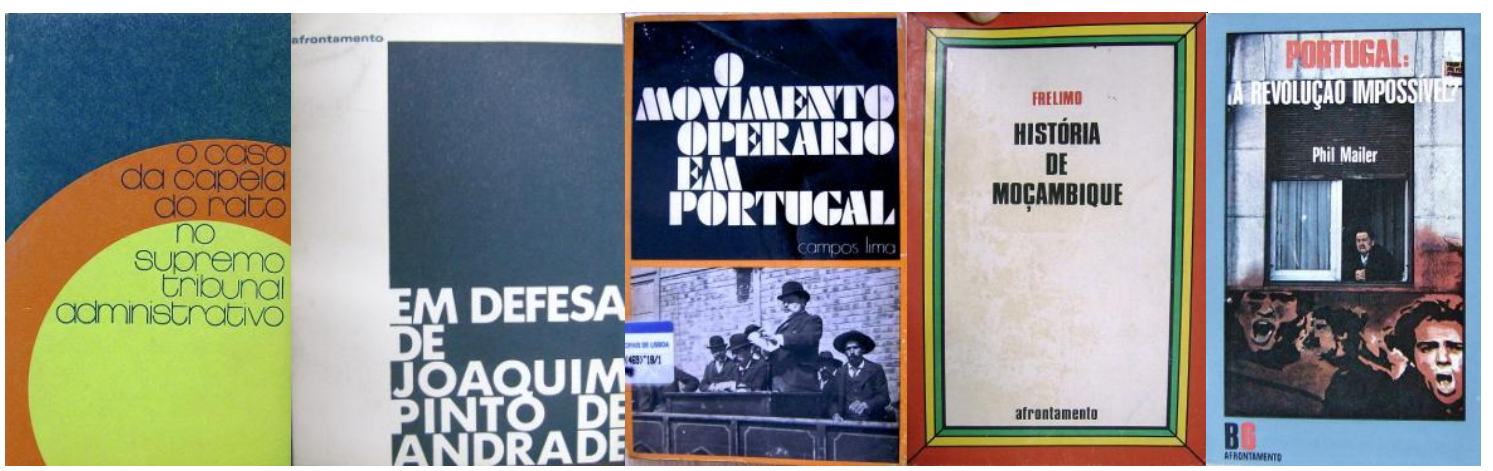

Editora cujas origens remontam a 1963, com o lançamento da coleção de antologias "Afrontamento", publicada no Porto por um grupo composto de "jovens católicos progressistas, que tinham uma perspectiva mais atuante da religião no campo

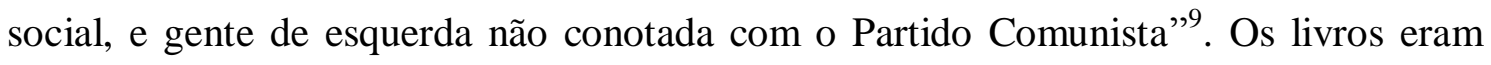
coordenados e editados por Pedro da Conceição Francisco, jovem "provindo da GuinéBissau em maio de 1966 e desde há muito ligado às JUC [Juventude Universitária

\footnotetext{
${ }^{9}$ Grande parte das informações utilizadas neste item são oriundas da entrevista que realizei com José Sousa Ribeiro na cidade do Porto em 24 de março de 2011. Todas as falas de Ribeiro que aqui aparecem provêm dessa entrevista.
} 
Católica] do Porto" ${ }^{\prime 10}$.

Este grupo editou ao ritmo de um livro por ano até 1968, com uma estrutura amadora e semiartesanal. Os títulos publicados nesta série foram: Ao encontro da pessoa, de Emmanuel Mounier e Jean Lacroix (1963); O homem invisível, de Pablo Neruda (1964); Do Integrismo ao Nacional Catolicismo: os católicos e as direitas, de Louis Davallon, P. A. Liège, M Garrigou Lagrange, Louis Guinchard e Yves Congar (1965); O Plano Langevin-Wallon para a reforma do ensino (1966), e Iniciação à teoria económica, de Ernest Mandel (1968).

Os livros desta coleção traziam na contracapa a seguinte frase, de Emmanuel Mounier, que resumia o espírito que motivava seus editores: "Quando a desordem se torna ordem, uma atitude se impõe: afrontamento".

Os editores da coleção assim a definiam:

"Afrontamento", modo de actuação possível de todos os que se reúnem numa mesma contestação das condições históricas de opressão e subordinação dos homens, a uma estabelecida e duradoira desordem pretende fazer face, não a qualquer, mas a uma que especificadamente se define e tantos proximamente e persistentemente constrange. ${ }^{11}$

Mais concretamente, pretendiam "uma profunda reestruturação das relações entre os homens e das bases em que assentam as nossas sociedades contemporâneas" 12 .

Em 1967 o grupo em torno da Afrontamento se amplia e busca dar início a uma nova fase de publicações. Nesse momento, alguns dos membros do grupo são: Pedro Francisco, Mário Brochado Coelho, Raul Moura, Pedro Barros Moura, José Leal Loureiro, Eneias Comiche, Machado Cruz, Artur Castro Neves, Arnaldo Fleming, José Carlos Marques, Eugénio Furtado, Gaspar Barbosa, Bento Domingues, David Miranda $^{13}$, César Oliveira e José Soares Martins (que utilizava o pseudônimo de José Capela). Várias dessas pessoas atuavam na cooperativa cultural Confronto, criada no Porto em 1966.

Desse esforço surge a coleção Textos Afrontamento, também coordenada por Pedro Francisco, cujos dois primeiro títulos são: Mas socialismo porquê?, de Albert Einstein (1968); e Vietnam: a oposição à guerra nos EUA. Programa da Frente

\footnotetext{
${ }^{10}$ COELHO, Mário Brochado. Confronto, memória de uma cooperativa cultural: Porto 1966-1972. Porto: Afrontamento, 2010, p. 24-25.

${ }^{11}$ Texto sem título e não assinado publicado na última página de: DAVALLON, Louis, P. et alli. Do Integrismo ao Nacional Catolicismo: os católicos e as direitas. Porto: Afrontamento, junho, 1965.

${ }^{12}$ Idem, p. 3.

${ }^{13}$ COELHO, op. cit., p. 41.
} 
Nacional de Libertação do Vietname do Sul (1969). Este segundo título talvez indique uma certa radicalização na orientação política do grupo.

Até este momento, a estrutura editorial e comercial existente em torno da Afrontamento era amadora, militante, o que criava algumas limitações para a produção e circulação dos livros editados. É em 1971 que se inicia efetivamente a segunda etapa da atuação do grupo, com o incremento das edições e a sua ampliação. É a partir de então que de fato se pode falar em uma Editora Afrontamento, com coleções diversificadas de livros, constância nos lançamentos e uma melhor estrutura comercial, mais profissional.

José Sousa Ribeiro, que era nessa época um jovem estudante de economia na Faculdade do Porto, aproximou-se do grupo por afinidade, acabando por ser, pouco depois, profissionalizado pela então embrionária Editora Afrontamento, ocupando-se da produção dos livros e da sua venda para as livrarias ${ }^{14}$.

De acordo com Ribeiro, a nova fase da editora começa com a iniciativa do advogado Mário Brochado Coelho, um dos membros do grupo Afrontamento, de editar um livro sobre o processo judicial contra Joaquim Pinto de Andrade, militante da luta anticolonial que estava preso em Angola.

Aproveitando o fato de o processo jurídico ser público, Brochado Coelho decidiu publicar as peças desse processo em livro, dando origem à obra Em defesa de Joaquim Pinto de Andrade, em julho de 1971. "No blecaute de informações que havia na época, essa era uma forma de furar esse bloqueio. Este livro teve uma grande difusão e saiu com a chancela Afrontamento", lembra Ribeiro. Ele afirma que o sucesso de vendas desse livro - que teve tiragem de 20 mil exemplares - e o entusiasmo que ele gerou, levaram a que se começasse a estruturar melhor essas atividades e que se evoluísse para um empreendimento mais organizado.

Os recursos obtidos com o livro foram cedidos por Brochado Coelho e serviram de base para o incremento das edições, que passaram a um ritmo acelerado. Apenas em 1971 foram pelo menos seis títulos, editados entre julho e dezembro. Em 1972 e 1973 foram cerca de dez títulos por ano.

Eis alguns títulos publicados nestes anos: Encontro. Alguns aspectos da religião tradicional discutidos pelo povo de Macieira da Lixa, coordenado por Mario Pais de Oliveira (1971); O socialismo crítico de hoje: Teses de "Il Manifesto" (1971);

\footnotetext{
${ }^{14}$ Entrevista com José de Sousa Ribeiro, Porto, 24/3/2011.
} 
Ocupação do Bairro do Bom Sucesso em Odivelas por 48 famílias de barracas, coordenado por José João Louro (1972); Presos políticos: documentos 1970-1971, editado pela Comissão Nacional de Socorro aos Presos Políticos e por Armando de Castro, Francisco Pereira de Moura e Filipe Lindley Cintra (1972); A dominação inglesa em Portugal, de Armando de Castro (1972); Pedagogia do oprimido, de Paulo Freire (1972); As greves selvagens na Europa ocidental (1973); Luta de classes e instituições burguesas: o debate sobre as eleições legislativas em Itália 1972, do grupo "Il Manifesto", da Itália (1973).

Foram lançados também sete volumes da coleção Movimento Operário Português, entre os quais: O congresso sindicalista de 1911, organizado por César Oliveira (1971); O movimento operário em Portugal, de Campos Lima (1972); O sindicalismo em Portugal, de Manuel Joaquim de Sousa. (1972); O socialismo em Portugal, 1850-1900, de César Oliveira (1973).

E a coleção As Armas e os Varões lançou dois títulos: Moçambique pelo seu povo, organizado por José Capela (1971); e $O$ vinho para o preto: notas e textos sobre a exportação do vinho para África, também de José Capela (1973).

Segundo Ribeiro,

A editora aproveitou-se do fato que, enquanto a imprensa periódica estava sujeita à censura prévia, os livros estavam sujeitos a uma censura a posteriori. Portanto, podia-se publicar fosse o que fosse, embora o destino de muitas das coisas que viemos a publicar fosse a apreensão pela polícia política, mas isso era a posteriori, não havia um controle prévio à publicação. ${ }^{15}$

Os títulos publicados nesses anos têm marcadamente um caráter de oposição ao governo de Marcelo Caetano, com forte ênfase em temas relacionados com a luta anticolonial. Merece destaque a coleção Bezerro D’Ouro, cuja característica era reproduzir em seus volumes peças jurídicas de processos contra oposicionistas: pedidos de habeas corpus, medidas de segurança, reprodução da legislação em vigor, autos de interrogatório, acórdãos de tribunais etc. Tratava-se, portanto, de documentos oficiais, o que tornava embaraçoso para o governo a sua censura. Foi, sem dúvida, um subterfúgio

\footnotetext{
${ }^{15}$ A lei estabelecia a obrigatoriedade de censura prévia aos livros que tratassem de "assuntos de carácter político ou social", mas de fato a grande maioria dos editores de livros não submetia suas obras previamente à censura, sujeitando-se ao risco de vê-las apreendidas após a edição, com as perdas econômicas que isso também implicava, conforme já contaram diversos editores atuantes nessa época. A base legal para a censura prévia aos livros era o Decreto 22.469, de 11 de abril de 1933. Ver: MOURA, Pereira F.; NEVES, Mario; FERNANDES, Rogério; ZENHA, Salgado. O estatuto da imprensa. Lisboa: Prelo, 1968, p. 14-15.
} 
inteligente, apesar de boa parte desses livros ter sido posta "fora de mercado", ou seja, foram censurados ou apreendidos da mesma forma ${ }^{16}$. Todavia, a censura ou a apreensão não significavam, na maior parte dos casos, que os livros efetivamente deixavam de circular, como veremos adiante.

Os livros da coleção Bezerro D’Ouro foram um êxito, venderam milhares de exemplares. Isso colocou a necessidade de uma organização mais profissional para a editora. "Mas no fundo era eu e mais dois ou três colaboradores que tratávamos tudo", afirma Ribeiro.

O sucesso dessa e de outras coleções da Afrontamento tornou a editora rapidamente conhecida em todo o país.

Nessa segunda etapa, diz Ribeiro, alguns dos católicos progressistas “foram se afastando do catolicismo, passando a engrossar as fileiras de uma esquerda não filiada nas organizações políticas clandestinas que existiam. Era um grupo muito marcado pelas questões anticoloniais". De fato, nessa etapa, esse foi o ponto forte do combate político da editora: "Aquilo que afrontava mesmo ao regime de maneira radical eram as questões coloniais. E fomos radicais nisso", afirma Ribeiro.

A definição das coleções e dos títulos publicados era feita de acordo com o projeto mais amplo da editora e com as afinidades dos membros do grupo. A coleção Bezerro D’Ouro foi dirigida por Mário Brochado Coelho; José Soares Martins (José Capela) coordenava a coleção As Armas e os Varões, sobre a história da exploração e da resistência nas colônias; César Oliveira fez uma coleção de história do movimento operário português ${ }^{17}$. Já a coleção Saco de Lacraus foi iniciativa de José Leal Loureiro e José Carlos Marques e "procurava fornecer pistas e novas perspectivas sobre o processo de construção do socialismo e da realidade soviética" ${ }^{18}$. José Carlos Marques criou, já em 1974, a coleção Viver é Preciso, de ecologia ("Uma colecção inteiramente dedicada à análise do modo de vida em regime capitalista e ultra-industrialista", segundo a definição da editora em textos de divulgação da coleção). Além disso, sempre havia propostas de fora que a editora recebia.

César Oliveira destaca que: "Na distribuição das edições da Afrontamento, sobretudo no Centro e Sul do país, é mais do que justo salientar o papel desenvolvido pela Assírio \& Alvim (José [Antunes] Ribeiro e Mário Reis)”. E salienta também o

\footnotetext{
${ }^{16}$ Falarei mais da coleção Bezerro D’Ouro no capítulo 12, “O papel da edição política em Portugal”.

${ }^{17}$ Entrevista com José de Sousa Ribeiro, Porto, 24/3/2011.

${ }^{18}$ OLIVEIRA, Anos decisivos, op. cit., p. 100.
} 
caráter combativo das publicações: "A maioria das edições vibrava golpes no cerne do Estado Novo, a guerra colonial (ou seus efeitos) e o apoio às práticas heterodoxas de certos setores da Igreja portuguesa"19.

Ribeiro diz que é nessa fase que a Afrontamento se torna efetivamente uma editora e vai se estruturando de uma forma mais profissional. Em janeiro de 1973 é criada a primeira sociedade comercial por cotas, uma distribuidora de livros, com nove sócios. Uma sede foi alugada e a editora passou a ter alguns funcionários. "Até então era uma coisa informal, tudo era feito como edição do autor", lembra Ribeiro.

O recurso à "edição do autor" ocorria devido aos riscos existentes na edição de livros de oposição ao regime: "Estávamos conscientes de que a atividade do ponto de vista político era arriscada. A consequência menor, desse ponto de vista, era a apreensão dos livros pela polícia política, $90 \%$ dos livros que publicamos era esse o destino que tinham”, lembra Ribeiro.

A edição do autor era uma maneira de tentar escapar à ação repressiva. Ribeiro lembra que eram apresentados como editores das obras ou o autor ou personalidades públicas, o que tornava mais difícil a atuação policial. "O livro da Comissão Nacional de Socorro aos Presos Políticos, de 1972, é um exemplo disso", recorda. Os editores eram três personalidades de âmbito nacional (Armando de Castro, Francisco Pereira de Moura e Filipe Lindley Cintra), contra quem a polícia dificilmente poderia agir com grande violência.

Apenas em um caso, o livro O julgamento dos padres do Macúti, de João Afonso dos Santos e outros autores, editado em agosto de 1973, a PIDE abriu um processo formal contra a editora. Ribeiro foi chamado a depor na PIDE do Porto em 24 de abril de 1974, tendo sido uma das últimas pessoas a lá ir. "E nós dizíamos que éramos apenas os distribuidores do livro, os editores eram os advogados que apareciam mencionados no livro, todos personalidades da sociedade portuguesa. Esse era o subterfúgio", afirma Ribeiro.

A ação repressiva de apreensão dos livros também tinha resultados apenas parciais, como destaca Ribeiro:

Havia um sistema já completamente montado para obviar isso. Nós podíamos publicar um livro que era apreendido imediatamente mas apesar disso vender milhares de exemplares dessa edição.

${ }^{19}$ Ibidem, p. 100. 
Desenvolvemos a venda mão-a-mão, ou seja, havia uma grande rede de amigos da editora que compravam dez, 20 exemplares e os revendiam fora do mercado livreiro. Os livreiros, fossem quais fossem as suas ideias, eram extremamente solidários, compravam os livros, punham um em exposição e guardavam os outros, vendiam apenas a quem conheciam. A polícia apreendia o exemplar que estava exposto, mas não os escondidos. Muitas vezes isso até aumentava as vendas, porque havia gente que comprava livros porque eles tinham sido apreendidos. Então os livros circulavam sempre, mesmo aqueles que eram apreendidos.

Na verdade, a maior consequência - não sem importância, é claro - de algumas proibições e apreensões de livros era de ordem econômico-financeira, gerando muitas vezes prejuízos consideráveis que afetavam a vida da editora.

Uma terceira fase na vida da Afrontamento se inicia com o 25 de Abril. O fim da censura, das apreensões e a efervescência política que se iniciou a partir de então tiveram reflexos diretos sobre a atuação da editora. Ribeiro lembra que:

Logo em seguida ao 25 de Abril fizemos livros com tiragens nunca pensadas até aí. Uma das nossas primeiras investidas então foi publicar a história das zonas colonizadas, digamos assim, dos movimentos de libertação, a História de Angola que o MPLA divulgava, da Frelimo sobre Moçambique, do PAIGC sobre a Guiné. A História de Angola deve ter tido 80 mil exemplares, exportamos uma parte para Angola, mas a um preço declaradamente mínimo. Nunca aproveitamos disso para capitalizar, nestes casos vendíamos próximos do preço de custo. Prestamos um serviço claramente importante do ponto de vista político, mas nunca perdemos a independência. Sempre quisemos manter a independência, isso pareceu-nos importante após o 25 de Abril.

Podemos entender melhor a importância desses livros a partir do comentário, reproduzido a seguir, de Pedro Tamen a respeito à obra História de Angola, do MPLA:

Para o comum leitor português, intoxicado por uma história viciada de imperialismo pateta, este livro é o abrir da cortina para um mundo totalmente novo, nos melhores casos suspeitado mas não conhecido. É Angola vista do outro lado, do lado oposto àquele em que nos colocaram nos tempos da instrução primária e do liceu. ${ }^{20}$

Após o 25 de Abril foram criadas as coleções Libertação dos Povos das Colônias (1974), Luta de Classes (1974), Crítica e Sociedade (1975) e Afrontamento Bolso (1976), entre outras, que assinalavam a ênfase na edição de obras políticas. Tiveram também continuidade as coleções que já existiam, com exceção da Bezerro D’Ouro.

\footnotetext{
${ }^{20}$ TAMEN, Pedro. Comentário sobre o livro História de Angola. "Selecção crítica da semana". Expresso, Lisboa, ${ }^{\circ}{ }^{112,}$ 22/2/1975.
} 
Nessa etapa, Marcela Torres, então militante do $\mathrm{MES}^{21}$, passou a atuar de forma mais intensa na editora.

Por outro lado, a liberdade para editar era também uma situação que trazia novos desafios do ponto de vista comercial. Foi necessário, até certo ponto, redirecionar a editora, como explica Ribeiro:

Outros editores começaram a editar coisas de conteúdo político e, portanto, vieram fazer-nos concorrência. Isso teve algum impacto. Decidiu-se que a Afrontamento começasse a se abrir a outros campos de edição, e não apenas à edição de conteúdo político. Abrimos essencialmente para dois campos, o campo universitário (ciências sociais e humanas) e a literatura infanto-juvenil. Aí passamos a outra dimensão, começamos a nos estruturar como uma empresa pra valer. Em 1975-76 passamos a editar na ordem de 30 títulos por ano.

Normalmente as tiragens da Afrontamento após o 25 de Abril giravam em torno de 3 a 4 mil exemplares. Depois de 1976 começaram a baixar para 2 a 3 mil, em termos médios.

No que diz respeito à edição política, a editora manteve um caráter de independência em relação a grupos políticos, e editou obras de várias tendências à esquerda do PCP, mas sem se deixar "aparelhar" por nenhum grupo. "Havia uma certa heterogeneidade entre as pessoas que compunham a editora, havia um certo entendimento nessa heterogeneidade, ninguém quis estragar esse ambiente", diz Ribeiro. "Essa heterogeneidade criava uma independência face aos grupos. Mas houve pessoas da Afrontamento que se ligaram a determinados projetos políticos, como o Mário Brochado Coelho, que se ligou à UDP”, afirma.

Eis alguns do títulos editados após o fim da ditadura: Textos políticos, de Amílcar Cabral (1974); A luta continua, de Samora Machel (1974); Escravatura. A empresa a saque. O abolicionismo (1810-1875), de José Capela (1974); Indústria, ideologia e quotidiano (ensaio sobre o capitalismo em Portugal), de João Martins Pereira (1974); Alimentos, saúde e agricultura (crítica da agricultura dominante), de Claude Aubert (1974); Povos de Moçambique: história e cultura, de A. Rita Ferreira (1975); Mobutu, chefe supremo, de Jules Chomé (1975); A emancipação dos trabalhadores é obra dos próprios trabalhadores, de Manuel Rodrigues (1975); A situação da classe trabalhadora em Inglaterra, de F. Engels (1975); Os bolcheviques e 21 "O leitor (im)penitente". Blogue Incursões, 11/1/2007. Disponível $\quad$ em:
<http://incursoes.blogspot.com.br/2007/01/o-leitor-impenitente-10.html>. Acesso em out. 2012. 
o controle operário, de Maurice Brinton (1975); O 25 de Abril e as lutas sociais nas empresas, de Maria de Lourdes Lima dos Santos, Marinús Pires de Lima e Vítor Matias Ferreira (1976); Contribuição para uma alternativa popular à crise da economia em Portugal: textos de apoio da candidatura à Presidência da República de Otelo Saraiva de Carvalho (1976); Tortura na colónia de Moçambique, 1963-1974: depoimentos de presos políticos (1977); A revolução da Maria da Fonte. Subsídios para a sua história e interpretação, de Joaquim Palminha Silva (1978); Portugal: a revolução impossível?, de Phil Mailer (1978); A tradição de resistência em Moçambique: o vale do Zambeze, 1850-1921, de Allen F. Isaacman (1979); Cultura e revolução em Angola, de Leonel Cosme (1979).

Até o final da década de 1970 os livros políticos tiveram grande peso na produção da editora, mas a partir desse momento foram perdendo espaço, apesar de a Afrontamento nunca ter deixado de publicar obras de caráter político - como faz até os dias de hoje.

Ribeiro explica que "A partir do princípio dos anos 1980 a editora foi confrontada com questões de outra natureza, questões de viabilidade econômicofinanceira que têm a ver com opções empresariais”. Para ele isso se deveu a um certo declínio da linha tradicional de publicação da editora. "A editora se descaracteriza um pouco a partir daí, até porque a sociedade mudou muito também nesse período. E fomos confrontando-nos com a vida de uma empresa normal, com os altos e baixos dos ciclos econômicos, com as crises etc.”.

Nos anos 1980 a Afrontamento adquiriu uma gráfica, como alternativa para "defender a editora das dificuldades do mercado editorial", diz Ribeiro. "E temos a gráfica até hoje. E a gráfica desde então foi o principal esteio da permanência da editora".

No período entre 1968 e 1980, a Afrontamento publicou cerca de 150 títulos de caráter político. Atualmente, a Afrontamento publica entre 70 e 80 títulos por ano e mantêm-se como uma editora independente. Ribeiro continua como um dos responsáveis pela editora.

Ribeiro faz uma avaliação ponderada sobre o papel da editora desde a sua criação:

Sobretudo antes do 25 de Abril, numa altura em que a informação estava completamente bloqueada em Portugal, a possibilidade de publicar coisas que não eram controladas era extremamente apelativa 
[atraente], era um desafio. E acho que desse ponto de vista levamos isso ao limite no contexto da situação fechada que havia. $\mathrm{E}$ isso deu o seu contributo para abrir algumas cabeças. A importância do nosso trabalho foi fazer com que certas coisas se tornassem públicas, que abandonassem a clandestinidade a que estariam reservadas. Não quer dizer que isso tivesse uma importância desmesurada, não foi por isso que caiu o fascismo, mas a verdade é que tudo conflui, o rio engrossa se houver muitos fios d'água a ajudar, e a Afrontamento foi um desses fios d'água. Nunca ninguém quis reivindicar mais do que isso.

\subsection{Editorial Inova}

Praça G. Gomes Fernandes, 38-2º - Ap. 466 - Porto

Editor: José da Cruz Santos

Início das edições: 1968.
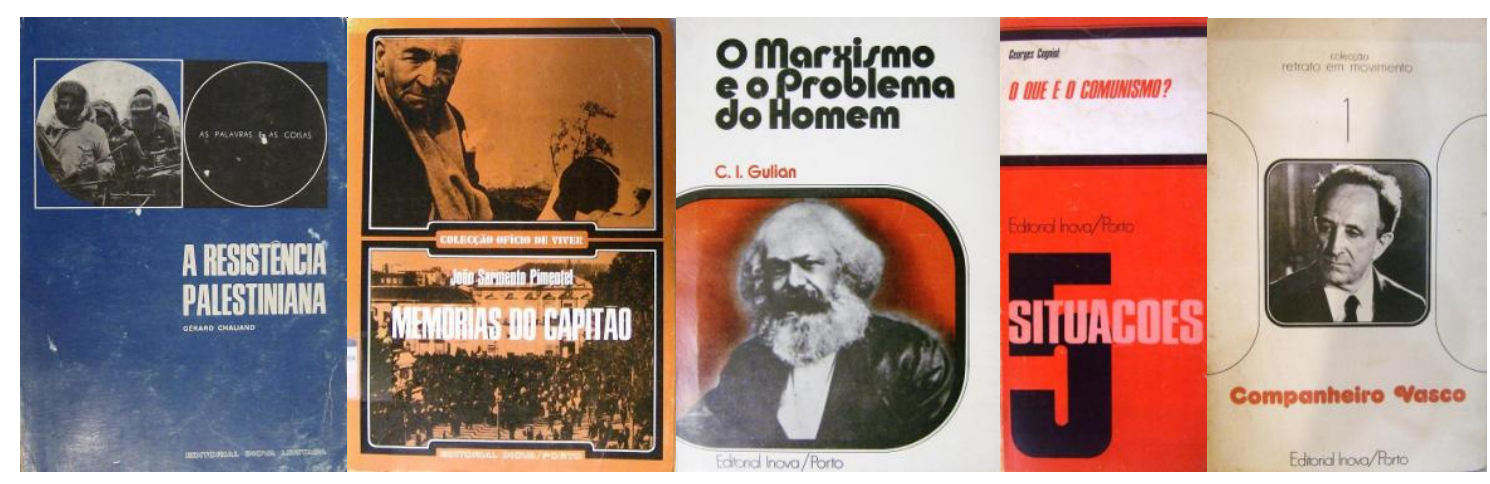

Editora criada em 1968 por José da Cruz Santos, na cidade do Porto. Cruz Santos iniciou sua vida editorial nas Publicações Europa-América, e em 1963, a convite de Agostinho Fernandes, tornou-se coordenador literário da Portugália Editora.

Alguns anos depois decidiu voltar ao Porto e criar a sua editora, a Inova ${ }^{22}$. Em 1967 começou a organizar a nova editora. Cruz Santos recorda que:

As pessoas não imaginam o que era constituir uma editora naquela altura: era necessária uma autorização, que vinha da Presidência do Conselho, e foi preciso meter uma cunha a um homem a quem chamavam "o Lápis de Salazar", um tal Paulo Rodrigues. ${ }^{23}$

${ }^{22}$ MEDEIROS, Edição e editores, op. cit., p. 244-45; ALMEIDA, Sérgio. "Uma vida tecida de livros". Jornal de Notícias, Lisboa, 05/02/2012. Disponível em: <http://www.jn.pt/blogs/babel/archive/2012/02/05/uma-vida-tecida-de-livros.aspx >. Acesso em $15 / 04 / 2012$.

${ }^{23}$ QUEIRÓS, Luís Miguel. “José da Cruz Santos, um inventor de livros”. Público, Lisboa, 1/4/2012. 
Inicialmente, a Portugália era sócia da Inova, o que "facilitou as coisas", lembra Cruz Costa ${ }^{24}$.

Óscar Lopes, escritor e militante do Partido Comunista Português, foi chamado para ser o diretor literário ${ }^{25}$, e o artista plástico Armando Alves assumiu a direção de arte da editora ${ }^{26}$.

A Inova caracterizou-se por suas coleções de poesia - em que foram publicadas obras de Jorge de Sena, Eugénio de Andrade, Ramos Rosa, Carlos de Oliveira, Ruy Belo, Fernando Assis Pacheco, Fiama Hasse Pais Brandão, entre outros - e pelas obras de ficção. Mas também publicava livros de atualidades, jornalísticos e da área de ciências sociais, além de livros técnicos, como na coleção Enciclopédia da Empresa Moderna. As obras políticas representavam, portanto, apenas uma pequena parte de sua produção.

Mas a característica mais marcante da Inova foi sem dúvida a inovação gráfica de seus livros, cuja criação era de Armando Alves. Os volumes da editora usavam quase sempre duas cores nas páginas iniciais e finais do livro, trazendo um diferencial que os destacava em relação às demais editoras, além de em alguns casos utilizar formatos pouco usuais. "A nova editora terá representado um certo ressurgimento tipográfico de base nortenha", afirma Medeiros ${ }^{27}$.

Cruz Santos era simpatizante do PCP, o que significava que era ligado a setores da oposição democrática. Essas ligações se refletirão na escolha de alguns títulos publicados e no rol de autores da editora.

Desde o começo de suas atividades a Inova adotou um ritmo intenso de edições.

\footnotetext{
Disponível em: <http://www.publico.pt/Cultura/jose-da-cruz-santos-um-inventor-de-livros1540311?all=1>. Acesso em 15/04/2012.

${ }^{24}$ QUEIRÓS, op. cit.

${ }^{25}$ Sobre a atuação de Lopes na Inova, Cruz Santos afirmou: "Ele não se importava de fazer as coisas mais simples, lia originais, fazias as badanas [orelhas] dos livros, escrevia folhetos de divulgação". Ver: "Homem da palavra, leitor emocionado". Diário de Notícias, Lisboa, 1/10/2007. Disponível em: <http://www.portugalvivo.com/spip.php?article2517>. Acesso em 16/4/2011.

${ }^{26}$ QUEIRÓS, op. cit. Armando Alves assim recorda a sua ida para a Inova: "Aceitei então o desafio do José da Cruz Santos para integrar a equipa da Editorial Inova, criada em 1968, e de então para cá tenho dividido a minha actividade artística entre as artes-gráficas e a pintura. O Porto era, nesses anos, um verdadeiro deserto no que respeita à actividade gráfica, não havendo praticamente ninguém a trabalhar a tempo inteiro nesta área e a articular a solução prática que a edição requer, com a criatividade que a concepção das capas, da paginação e de colecções completas implicam. O desafio que aquele editor me colocava levaria à alteração deste panorama e aí residia o seu principal aliciante". Ver: "Um olhar na paisagem - Exposição de Pintura de Armando Alves". Disponível em: <http://www.kulone.com/PT/Event/1411037-UM-OLHAR-NA-PAISAGEMExposi\%C3\%A7\%C3\%A3o-de-Pintura-de-Armando-Alves>. Acesso em 16/9/2011.

${ }^{27}$ MEDEIROS, Edição e editores, op. cit., p. 245.
} 
"Editava seis ou sete livros por mês, o que hoje só era possível a uma editora de grande capacidade financeira", mas na época, lembra Cruz Santos, isso foi possível porque "os editores faziam $30 \%$ de desconto aos livreiros, e agora fazem $60 \%$, é só o dobro” ${ }^{\text {}} 28$.

Antes do 25 de Abril, a Inova editou obras de caráter político, tanto sobre temas nacionais quanto sobre questões internacionais. Neste último caso, foi recorrente a edição de obras que, de alguma forma, representassem a valorização de lutas contra a opressão, como era o caso de títulos que tratavam da resistência à dominação nazista na Europa durante a Segunda Guerra Mundial.

Em relação a temas ligados à realidade portuguesa, alguns títulos se destacam. É o caso da obra Eleições de 1969: documentos eleitorais da Comissão Democrática do Porto, que teve seleção e prefácio de Virgínia Moura (1971), em que foram publicados documentos e intervenções da Comissão Democrática do Porto cuja divulgação havia antes sido impedida total ou parcialmente.

Já o livro Uma questão sindical (O processo dos metalúrgicos de Lisboa), de 1970, com seleção e prefácio de Francisco Marcelo Curto e Victor Wengorovius, apresentava os documentos constitutivos do processo de suspensão e destituição de três dirigentes do Sindicatos dos Metalúrgicos de Lisboa em fins de 1970.

Em defesa do pensamento científico (Um incidente / Os condicionamentos do ensino superior), de Armando de Castro (1973), trazia as peças fundamentais do processo a que o autor foi submetido pelo Ministério da Educação Nacional e que levou ao seu afastamento do ensino superior. E a obra Intervenção política: textos integrais, com seleção e edição de Humberto Soeiro, recolhia os principais documentos dos democratas de Braga entre 1949 e 1970.

Alguns outros títulos políticos publicados antes de 1974 foram: Dossier do conflito israelo-árabe, com prefácio de Jean Paul Sartre (1969); Antologia do pensamento político português: liberalismo, socialismo, republicanismo, organizado por Joel Serrão (1970); Memórias de um resistente (Narrativa romanceada), de Alexandre Cabral (1970); Convite para a URSS, de Óscar Lopes (s/d.); Lenine (Seguido de Cartas e Documentos), de Máximo Gorki (1971); A aventura boliviana, de Che Guevara (1972); e Palavras necessárias: a vida proletária em Portugal de 1872 a 1927, de Bento Gonçalves (edição de Virgínia Moura, 1973; Gonçalves havia sido secretáriogeral do PCP de 1929 a 1942).

\footnotetext{
${ }^{28}$ QUEIRÓS, op. cit.
} 
A publicação destes e de outros livros fizeram com que a Inova fosse alvo constante da polícia política. "Entre livros proibidos e apreendidos, foram cerca de 40 títulos", afirma Cruz Sousa ${ }^{29}$. No levantamento de "Livros proibidos nos últimos tempos da ditadura", José Brandão aponta 12 títulos da Inova proibidos até o 25 de Abril $^{30}$.

Após o 25 de Abril a Inova continuou a editar algumas obras políticas, como: Duas teses antifascistas, de Raúl Castro (1974); Agricultura e reforma agrária em Portugal: 1974, de António Bica (1975); Pequeno dicionário do marxismo, de Pierre Masset (1974); e O marxismo e o problema do homem, de C. I. Gulian (1975).

Houve também edição de alguns títulos que denotavam a proximidade entre a editora e o PCP: A resistência em Portugal, de José Dias Coelho (1974), militante comunista assassinado em 1961; O que é o comunismo?, de Georges Cogniot (1974); Agonia e morte de Lenine, de Máximo Gorki e Gerard Walter, traduzido por Egito Gonçalves (1974); e a coletânea Companheiro Vasco (1977).

Esta última obra foi efetivamente uma ação política da Inova de apoio e desagravo ao ex-primeiro-ministro Vasco Gonçalves, que era apoiado pelo PCP. A obra, editada em setembro de 1977, começou a ser elaborada cerca de dois anos antes, em outubro de 1975, quando “a Editorial Inova publicou anúncios pedindo a colaboração para um livro de depoimentos diversos sobre Vasco Gonçalves [...] nome consagrado então por uma grande massa do povo trabalhador que via no ex-primeiro-ministro a figura ímpar da Revolução de Abril” ${ }^{31}$. O anúncio, publicado dois meses após a saída de Vasco Gonçalves do cargo de primeiro-ministro do V Governo Provisório, tinha o seguinte título: "Companheiro Vasco. Homenagem nacional a Vasco Gonçalves, ao revolucionário do MFA, ao governante devotado ao povo, ao português de honra". Nele a editora informava:

Nesta obra serão reunidas declarações individuais e coletivas de apreço por Vasco Gonçalves e pela sua obra de patriota e de revolucionário ao serviço do Povo Português. Pede-se portanto a todas as pessoas que saibam de artigos, cartas, discursos, telegramas e outros testemunhos de apreço publicados que nos indiquem os jornais

\footnotetext{
${ }^{29}$ QUEIRÓS, op. cit.

30 BRANDÃO, José. "Livros proibidos nos últimos tempos da ditadura (Nova relação revista e aumentada em abril de 2007). In: BRANDÃO, José. "Os livros e a censura em Portugal”. Disponível em: <http://www.vidaslusofonas.pt/livros_e_censura.htm>. Brandão indica em sua lista 15 títulos da Inova, mas três dos títulos apontados na verdade não foram editados pela editora.

${ }^{31}$ Texto publicado na orelha [badana] do livro Companheiro Vasco (Porto: Inova, 1977).
} 
ou outras publicações onde o tenham sido [...]. Colabore numa obra que é um ato moral ${ }^{32}$.

De acordo com a editora, a ideia do livro "foi acolhida com enorme interesse, a provar o quanto Vasco Gonçalves deitou raízes no coração do povo que serviu. Dezenas e dezenas de pessoas nos escreveram a enviar cartas de apoio, recortes de jornais, sugestões diversas [...]"33. O êxito da iniciativa demonstra-se pela própria edição do livro, de mais de 500 páginas de depoimentos, fotos e documentos.

Esta iniciativa é um exemplo excelente de como a edição de uma obra pode ser uma ação política de uma editora, desde a sua concepção até o lançamento do produto final, servindo para mobilizar pessoas, engajá-las em um projeto editorial e interferir ou tentar interferir - de modo real na conjuntura política.

No entanto, o fim da ditadura foi mais negativo do que positivo para a editora, pois, de acordo com Cruz Costa, até o 25 de Abril "grande parte dos livros era escoada para África - mais de $60 \%$ da tiragem, em algumas obras -, e no pós-25 de Abril não foi mais nenhum" 34 , o que teria causado graves perdas para a Inova.

A editora ainda se manteve em atividade até 1980, mas o último título político parece ter sido o livro Companheiro Vasco, editado em 1977.

A Editorial Inova publicou entre 1968 e 1977 cerca de 35 livros de caráter político. Isto equivale a algo como $20 \%$ da produção da editora nesse período. Predominavam na sua produção as obras de literatura, principalmente ficção e poesia.

Sem ser um editora vinculada a um grupo ou partido político, parece certo que a proximidade do proprietário da Inova ao PCP foi fator que teve repercussão nas obras políticas por ela editadas, mas sem transformá-la de modo algum em uma editora de partido.

Já no final das atividades da Inova, Cruz Costa criou a editora O Oiro do Dia, que durou até meados dos anos 1980. Em 1999, a convite de Américo Areal, foi trabalhar na editora ASA, onde ficou por dez anos. Depois, criou a editora Modo de Ler, em que atua até hoje ${ }^{35}$.

\footnotetext{
32 "Companheiro Vasco. Homenagem nacional a Vasco Gonçalves". Anúncio publicado no jornal Expresso, Lisboa, 31/10/1975, p. 18.

${ }^{33}$ Texto publicado na orelha [badana] do livro Companheiro Vasco (Porto: Inova, 1977).

${ }^{34}$ QUEIRÓS, op. cit.

${ }^{35}$ QUEIRÓS, op. cit.
} 


\subsection{Cadernos Textuais}

Rua Antero de Quental, 197 - Porto

Início das edições: 1969.

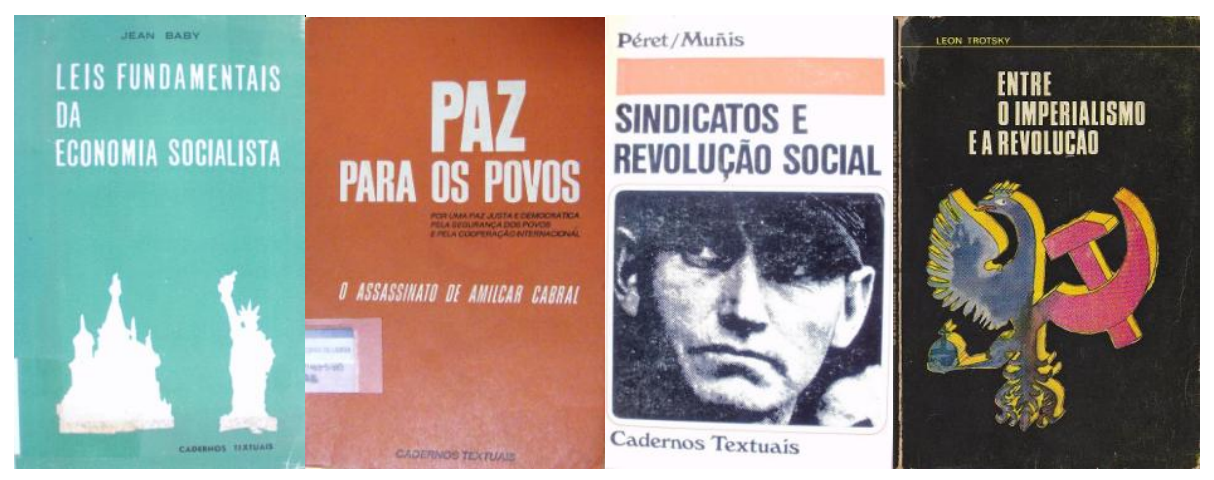

Editora de esquerda marcada por duas fases em sua atuação. A primeira fase, anterior ao 25 de Abril, se caracterizou pelo lançamento de obras de alguns dos autores clássicos do pensamento marxista, como Lenin (O Estado e a revolução, 1969), Mao Tsé-tung (Origens e evolução das divergências, 1970), e Trotsky (Entre o imperialismo e a revolução, 1973), além de um livro que reproduzia um discurso de Leonid Brejnev, na época líder máximo da URSS (Paz para os povos: por uma paz justa e democrática pela segurança dos povos e pela cooperação Internacional/O assassinato de Amílcar Cabral, 1973). Editou ainda, antes de 1974, as obras Leis fundamentais da economia socialista, de Jean Baby (1970), que fora membro do Partido Comunista Francês até 1956 e depois rompera com o PCF; e Teoria do Estado de todo o povo: URSS, de J.-G. Collignon (s/d.).

Aparentemente, a editora não se alinhava a nenhum grupo político, dado o ecletismo dos autores dentro do campo marxista. Foi nesta etapa que a editora lançou a maior parte dos títulos que publicou, seis de um total de nove.

Após o 25 de Abril a editora passou por uma transformação em sua linha política e foi criada a coleção A Memória Subversiva, com uma clara mudança na orientação da editora. Esta coleção era coordenada pelo jornalista Júlio Henriques, ligado a grupos marxistas libertários, conselhistas e autonomistas. Os três títulos publicados então se caracterizavam por conter críticas ao leninismo e ao marxismo ortodoxo. As obras eram: Propriedade e capital: o marxismo dos gagos, de Amadeo Bordiga (1974); Capitalismo e comunismo/Leninismo e ultra-esquerda, de Jean Barrot; e Sindicatos e revolução social, de B. Péret e G. Muñis (s/d.).

Em suas duas etapas a editora Cadernos Textuais publicou, entre 1969 e 1975, 
nove títulos. Os livros tinham padrão editorial e gráfico profissional. Não há informação nos livros sobre a sua distribuição comercial.

\subsection{Centelha}

Apartado 241 - Coimbra

Editores: Alfredo Soveral Martins, Rui Namorado, Orlando de Carvalho.

Início das edições: 1970.

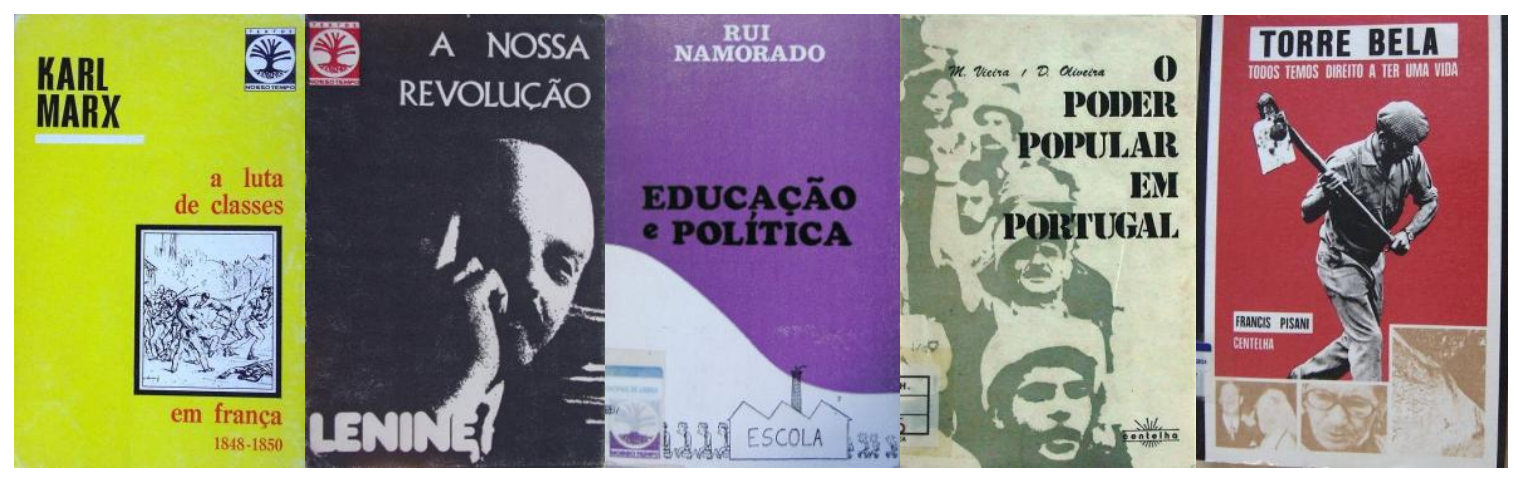

Editora criada em 1970 por intelectuais e estudantes que haviam participado das lutas acadêmicas na Universidade de Coimbra em 1969, durante a chamada "crise estudantil de 69". Era um grupo "que se reunia em repúblicas estudantis e que tentava esforçadamente sair do quadro dos partidos tradicionais (?!), isto é, do PC, das dissidências esquerdistas e, depois, do recentemente refundado PS" ${ }^{36}$. Aliás, a editora esteve sempre ligada ao ambiente acadêmico de Coimbra.

Entre os seus fundadores e animadores mais ativos estiveram Alfredo Soveral Martins, Orlando de Carvalho e Rui Namorado ${ }^{37}$. Martins e Carvalho eram professores na Universidade de Coimbra e Namorado era advogado recém-formado na mesma universidade. Soveral Martins era ligado ao LUAR (Liga de Unidade e Acção Revolucionária), grupo político de oposição surgido em 1967 que realizou ações armadas antes do 25 de Abril, e Carvalho esteve ligado à Comissão Democrática Eleitoral (CDE), em 1969, e ao Movimento Democrático Português (MDP), em 1974 e 1975.

Muitas das pessoas ligadas à Centelha tinham também proximidade com a

\footnotetext{
${ }^{36}$ RIBEIRO, Marcelo Correia. “Au bonheur des Dames n 22”. Blogue Incursões, 5/4/2006. Disponível em: <http://incursoes.blogspot.com/2006/04/au-bonheur-des-dames-n-21.html>. Acesso em jun. 2012.
$37 \quad$ "Centelha
Editora".
Disponível
em:

<http://bibliowiki.com.pt/index.php/Discuss\%C3\%A3o:Centelha_Editora>. Acesso em jun. 2012.
} 
revista Vértice, lembra Rui Namorado ${ }^{38}$, ele mesmo membro do Conselho de Redação da revista entre 1964 e $1975^{39}$. A Vértice era uma "revista de cultura e arte" editada em Coimbra desde 1942 e caracterizada pela intervenção política de oposição durante a ditadura em Portugal, com forte perfil militante e ligada ao movimento neo-realista no país ${ }^{40}$.

Rui Namorado destaca que a Centelha "Tinha um sentido de intervenção radical, mas aberta, pois não era identificada com nenhuma das correntes de esquerda, e estava muito radicada no movimento estudantil anterior, e portanto inserida no panorama cultural". Para ele, a intenção da editora "era trazer diretamente ao conhecimento do público os principais autores marxistas, aqueles marxistas primordiais, até os anos 1920, para exatamente tentar criar condições para um diálogo aberto" no país.

O primeiro livro publicado foi Greve de massas e sindicatos, de Rosa Luxemburgo (coleção Textos Nosso Tempo), ainda em 1970. Outro livro que marcou o lançamento da Centelha foi $O$ canto e as armas, de Manuel Alegre, também editado em $1970^{41}$.

A coleção Textos Nosso Tempo publicou, antes do 25 de Abril, obras de Marx, Lenin, Mao Tsé-Tung e Trotsky. Somente dos dois primeiros autores foram editados cinco títulos de cada um nesta coleção.

Também foram publicados, em 1972 e 1973, na coleção Estudos Nosso Tempo, dois livros de Rui Namorado com críticas à política educacional do governo de Marcelo Caetano, que foram apreendidos e levaram o autor a ser interrogado pela PIDE/DGS ${ }^{42}$. Os livros eram: Movimento Estudantil e política educacional e Educação e política.

Alguns outros títulos publicados antes de 1974 foram: Os Panteras Negras, com textos de Eldridge Cleaver, Huey Newton e organização de Maria João Delgado e Marcelo Correia Ribeiro (1971); Socialismo no Chile?, com textos de Salvador Allende, MIR, Pedro Vuskovic, Rossana Rossanda e outros, com seleção de Rui Namorado (1972); Peru: camponeses e generais, de Ricardo G. Acosta e outros (1972);

\footnotetext{
${ }^{38}$ Intervenção de Rui Namorado no Ciclo de Debates "Livros que tomam partido", realizado na Biblioteca-Museu República e Resistência, em Lisboa, em 13/3/2011. Todas as falas de Rui Namorado que aqui aparecem provêm da intervenção nesse evento.

39 "Biografia". Disponível em: < http://www.ces.uc.pt/investigadores/cv/rui_namorado.php $>$. Acesso em jun. 2012.

${ }^{40}$ C. C. R. "Vértice". Verbete. In: ROSAS, Fernando; BRITO, J. M. Brandão de (coords.). Dicionário de história do Estado Novo. Vol. II. Lisboa: Bertrand, 1996, p. 1004-05.

${ }^{41}$ Intervenção de Rui Namorado..., op. cit.

${ }^{42}$ Intervenção de Rui Namorado..., op. cit.
} 
Cooperativismo e socialismo (1973); Cartas da China, de Anna Louise Strong (1973);

Capitalismo e concorrência, de J. Teixeira Martins (1973).

Além disso, sempre antes do 25 de Abril, a editora publicou também as coleções Poesia Nosso Tempo, Temas Nosso Tempo, Teatro Nosso Tempo e Perspectiva Jurídica - esta última voltada para textos de análise do direito a partir de uma perspectiva marxista.

Publicou um único romance nessa etapa, mas com um viés claramente político, pois era um romance sobre a guerra do Vietnã, intitulado Hon dat, de Anh Duc, um guerrilheiro vietnamita.

A Centelha começou como uma sociedade comercial, "mas de fato funcionava como cooperativa, e depois se transformou mesmo numa cooperativa", lembra Namorado. Logo no início das atividades, "houve problemas com o registo do nome, foi preciso mudá-lo, e legalmente a Centelha passou a chamar-se Fora do Texto, a partir de 1971". Oficialmente, era uma distribuidora de livros. Mas de fato era uma editora, e os livros lançados continuaram a sair também com o selo Centelha.

Somente em 17 de fevereiro de 1973 a Centelha passou a ser formalmente uma editora de livros, mas para isso teve que utilizar uma brecha na lei da ditadura:

[...] tendo os serviços oficiais competentes recebido toda a documentação por eles referida como necessária, em 16 de dezembro de 1972, expirou naquele dia [17 de fevereiro de 1973] o prazo de 60 dias, cujo decurso implica, nos termos da lei de imprensa, que o registo como editora se considere como feito. ${ }^{43}$

Por sua ousadia na edição de obras que desafiavam as proibições impostas pelo regime, a Centelha foi desde o início de suas atividades muito visada pela PIDE/DGS. "A primeira tentativa da repressão contra nós foi uma multa do SNI (Secretariado Nacional da Informação, Cultura Popular e Turismo) por não termos autorização para publicar, pois quando começamos de fato não tínhamos o alvará de editora”, recorda Namorado. Diz ele:

Nós inventamos uma fórmula de edição do autor: era a edição do autor da tradução. Porque as edições de autor podiam ser publicadas sem ser por uma editora, e nós fizemos dessa forma. Mas mesmo assim a multa foi-nos aplicada, mas conseguimos demonstrar que havia uma falha formal na aplicação da multa e eles recuaram. Um dos principais elementos da editora era um jurista excelente, o Soveral Martins, de

\footnotetext{
43 “Centelha - promoção do livro, SARL”. In: NAMORADO, Rui. Educação e política. Coimbra, Centelha, março, 1973.
} 
modo que tínhamos um assessor jurídico de primeira.

A segunda tentativa, sempre de acordo com Namorado, foi um processo por abuso de liberdade de imprensa, por ter editado sem autorização. "Fomos julgados e fomos absolvidos, e a partir daí caíram todos os processos que existiam contra todos os tradutores”, lembra. E houve vários outros casos de coerção e apreensão de livros. Após o 25 de Abril foram devolvidos para a editora milhares de exemplares que haviam sido aprendidos pela PIDE $^{44}$.

Descobriu-se também que a PIDE teve uma informadora que atuava dentro da própria editora, o que mostra a importância que a polícia política dava à Centelha ${ }^{45}$. Esta informadora era Lucinda Pinto Bilhau (ou Balhau), que usava o pseudônimo de “Catarina". Entre 1972 e 1974, ela denunciou "diversas pessoas, incluindo o marido, dizendo que mantinha em sua casa reuniões com colaboradores da editorial Centelha". Entre os denunciados estavam Soveral Martins e Rui Namorado ${ }^{46}$.

Com o 25 de Abril houve aumento no número de edições e alargamento do leque editorial. “Antes era mais Lenine, Marx. Com o 25 de Abril começou-se a editar mais poesia, criamos novas coleções e também se alargou o leque de edições sobre o que se estava a passar no país. Editamos também livros infantis, embora sempre com uma vertente política", lembra Jacinta Ferreira ${ }^{47}$, que começou a trabalhar profissionalmente na editora no final de 1974. "Principalmente nos dois, três primeiros anos [após o 25 de Abril] houve um aumento de edições e de vendas, depois caiu e tivemos momentos de imensa dificuldade", lembra Jacinta.

Nessa nova etapa foram criadas as coleções Criar Poder Popular, Movimentos de Libertação, O que Faz Falta, Direito e Sociedade, Anátema, Novo Mundo Novo e Autobiografias Operárias.

Entre os títulos publicados no período 1974-78, ressaltava a preocupação com questões da nova realidade política, muitas vezes com obras que traziam propostas relacionadas a posições da esquerda não ortodoxa, conselhista e autogestionária.

Eis alguns títulos publicados nesse período: Democratizar a universidade:

\footnotetext{
${ }^{44}$ Entrevista com Jacinta Ferreira, Lousada, Portugal, 25/3/2011.

${ }^{45}$ Entrevista com Eduardo de Sousa, Lisboa, 13/1/2009.

${ }^{46}$ PIMENTEL, Irene Flunser. A Polícia Internacional de Defesa do Estado. Direcção-Geral-deSegurança (PIDE/DGS). História da Polícia Política do Estado Novo. 1945-1974. Dissertação de Doutoramento apresentada à Faculdade de Ciências Sociais e Humanas da Universidade Nova de Lisboa, 2007, p. 1006.

${ }^{47}$ Entrevista com Jacinta Ferreira, Lousada, Portugal, 25/3/2011. Todas as falas de Ferreira provêm desta entrevista.
} 
universidade para quê? Para quem?, de Boaventura de Sousa Santos (1975); O poder popular em Portugal, de M. Vieira e F. Oliveira (1976); AGFA-GEVAERT: retrato de uma multinacional, de Fernanda Barão (1977); Camponeses de Barcouço: não vamos morrer agarrados à enxada, de José A. Salvador (1977); As cooperativas depois de abril: uma força dos trabalhadores, de José Carlos Pereira Bastos (1977); Luta pela democracia nos Açores, de Manuel Barbosa (1978); O "Relatório das sevícias" e a legalidade democrática, organizado pelo Centro de Estudos Jurídicos (1977); As lutas dos moradores e a Constituição de 1976, de Luis Felipe Sabino, Saul Nunes, Amadeu Lopes Sabino (1977); Torre Bela: todos temos direito a ter uma vida, de Francis Pisanni (1978); A hierarquia militar e o Estado democrático: caso Rosa Coutinho, peças de um processo, coordenado por Luis de Azevedo (1978).

Rui Namorado destaca que o número de sócios da editora cresceu depois do fim da ditadura. "Talvez seja a Centelha a única entidade com alguma intenção política que tenha tido como membros-sócios Vasco Gonçalves, Melo Antunes e Otelo Saraiva de Carvalho", três das principais figuras do Portugal pós-25 de Abril, o que mostra a pluralidade que a editora representava, diz ele. Mas Namorado afirma que "Essa abrangência não teve efeitos, mas não sei a Centelha falhou ou se falharam outras coisas. Nesse aspecto foi um pouco diferente, porque muita gente foi fazer outras coisas. A Centelha depois do 25 de Abril em termos de ter uma intenção cívica frustrou um pouco", avalia.

Mas Jacinta Ferreira destaca que:

A Centelha teve uma influência muito grande ao nível da formação política. Depois do 25 de Abril houve imensa gente a comprar os livros, queriam saber o que era marxismo, leninismo, quem foi Che Guevara, quem foi Rosa Luxemburgo etc. Naqueles primeiros dois, três anos nós fazíamos imensas bancas, por exemplo, no $1^{\circ}$ de Maio, e vendíamos milhares de livros nesse dia. Havia uma ânsia de saber, e os livros da Centelha respondiam a uma parte desse desejo de informação. Então nesse momento [a Centelha] foi muito importante na formação política das pessoas. Nós disponibilizamos informação política.

Todavia, mesmo durante os dois anos após o 25 de Abril, período em que as atividades da editora foram mais fortes, a Centelha continuou se organizando como uma pequena editora, com não mais que três funcionários - ou pouco mais - que cuidavam da produção dos livros e da sua distribuição. As decisões eram tomadas em reuniões entre os funcionários, a direção e os colaboradores mais atuantes. Aí se decidia o que 
seria publicado, com base em pareceres que eram pedidos a outros colaboradores. $\mathrm{O}$ coordenador geral era Soveral Martins, e a partir de 1974 Francisco de Assis Pacheco e António Magalhães eram colaboradores constantes nesse trabalho. Durante muitos anos Orlando de Carvalho foi o presidente da assembleia geral, que reunia todos os sócios da cooperativa $^{48}$.

"A editora sempre funcionou muito à base do voluntariado. Fazíamos muitas bancas, feiras, $1^{\circ}$ de Maio, 25 de Abril, e eram sempre os sócios que faziam isso, era uma cooperativa. Nunca houve mesmo uma organização empresarial, nunca foi esse o lema da Centelha", ressalta Jacinta Ferreira. "A maior parte do trabalho era voluntário, do capista, que era o João Botelho, que tornou-se cineasta, aos tradutores, revisores", afirma ela.

A diminuição da demanda por obras políticas, a não profissionalização da editora e o fato de que muitos dos antigos colaboradores/sócios passaram a dedicar suas energias a outros projetos políticos parecem ter sido os fatores que levaram à diminuição das atividades da editora, o que resultou no fim de suas edições nos anos 1990, devido também à morte de Soveral Martins, que restara como o animador principal da editora.

Como lembra Eduardo Sousa, que atuou na editora a partir de 1976 e hoje é livreiro em Lisboa (Livraria Letra Livre), "a Centelha sempre viveu no vermelho, sempre teve dificuldades do ponto de vista financeiro, porque, como era um trabalho essencialmente amador e publicava muitos livros que não eram livros fáceis em termos de mercado... Vivia-se num equilíbrio precário" ${ }^{\text {49. }}$.

Outro colaborador da editora recorda que:

Durante anos, o Alfredo Soveral Martins bombardeou amigos e associados para a compra de acções de modo a manter a editora de pé. Mas os tempos tinham mudado. Apesar de se ter inflectido a linha editorial (colecções novas como a de títulos de música) continuava a faltar o capital mínimo que nos permitiria pagar dívidas antigas e recomeçar num patamar financeiro mais são. ${ }^{50}$

A Centelha foi uma das mais importantes e típicas editoras políticas de Portugal nos anos 1970. Criada por companheiros das lutas estudantis de Coimbra no final da década de 1960, foi sempre uma iniciativa claramente política, de intervenção na

\footnotetext{
${ }^{48}$ Entrevista com Jacinta Ferreira, Lousada, Portugal, 25/3/2011.

${ }^{49}$ Entrevista com Eduardo de Sousa, Lisboa, 13/1/2009.

${ }^{50}$ RIBEIRO, “Au bonheur des Dames no 22 ”, op. cit.
} 
realidade e de oposição à ditadura, sem ligações orgânicas com nenhum grupo, mas reunindo militantes e simpatizantes de várias organizações. Conseguiu manter-se sempre independente e com um perfil muito claro de esquerda não ortodoxa, o que se refletia também em sua opção pelo funcionamento como cooperativa, sempre em moldes semiamadores e autogestionários.

Se isso parece ter sido sempre um fator de instabilidade financeira para a editora, por outro lado fez dela uma das experiências editoriais de caráter político que conseguiu manter a "pureza" e a fidelidade aos princípios que estiveram na base de sua criação, e proporcionou, com todas as dificuldades imagináveis, a produção de cerca de 150 obras de caráter político entre 1968 e o começo dos anos 1980. No total, foram cerca de 200 títulos editados, incluindo as obras de poesia e teatro.

\subsection{Livraria Latitude}

Circunvulação, 2536, Areosa - Porto (Edições Latitude e Tipografia Latitude)

Rua Coelho Neto, 6 - Porto (Livraria Latitude)

Rua de Rebordãos, 407, Areosa - Porto (Edições Latitude)

Editores: A. Resende, António Abreu, Francisco Sardo.

Início das edições: 1970.

Distribuição: Livraria Latitude.

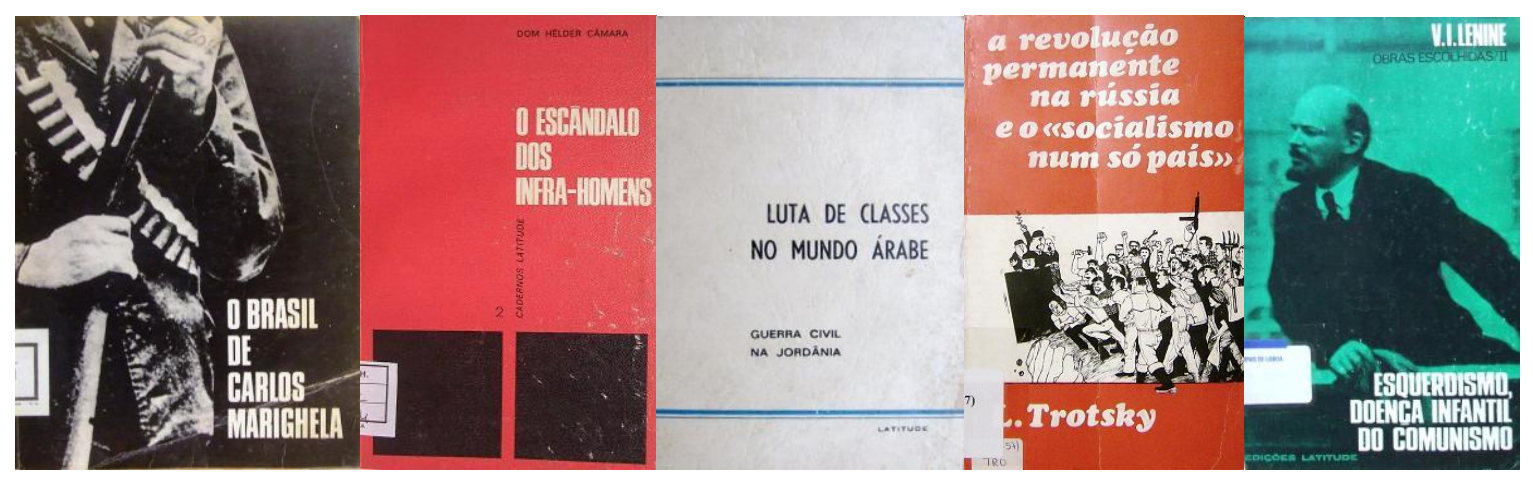

Trata-se de uma livraria e distribuidora de livros do Porto, que também atuou como editora entre 1970 e 1974. Sua linha editorial era eclética, indicando que a editora mantinha contatos tanto com grupos trotskistas e maoistas, como com setores dos católicos progressistas que faziam oposição à ditadura.

Este ecletismo manifestava-se no fato da Latitude ter editado, antes de 1974, obras de Marx, Trotsky, Mao Tsé-tung, Carlos Marighella, D. Hélder Câmara e José Viale Moutinho, além de um Guia prático de sexo, de autoria de Michel Mai-Tam e 
Michel Jossay.

De acordo com José Manuel Lopes Cordeiro, "a Latitude foi das primeiras editoras a publicar os tais livros 'fora do mercado', que se vendiam militantemente e, depois, por debaixo do balcão em algumas (muito poucas) livrarias",51.

Os livros de autoria de Leon Trotsky publicados pela Latitude foram três: $A$ revolução permanente na Rússia e o socialismo num só país (c1971, tradução e coordenação de João F. Viegas); Como fizemos a revolução (1971); e Natureza do Estado soviético (c1973, tradução de João F. Viegas).

A edição dessas obras decorria de contatos entre a Latitude e Francisco Sardo ${ }^{52}$, militante trotskista que viria a ser um dos fundadores da Liga Comunista Internacionalista (LCI) ${ }^{53}$. Manuel António Ribeiro Resende, também militante trotskista no Porto e fundador da LCI, recorda:

Lembro-me perfeitamente do livro A revolução permanente na Rússia $e$ o socialismo num só país, do Trotsky. Lembro-me de ver o Francisco Sardo trazer vários exemplares para uma reunião nossa [da LCI] e de se pôr a cheirar a lombada todo gozoso. Alguém do nosso entorno foi responsável por essa e outras publicações. ${ }^{54}$

Resende explica o fato de ele não conhecer a ligação entre Sardo e a Latitude como decorrência da situação repressiva da época: "Nessa altura a gente não podia muitas vezes revelar as coisas uns aos outros. Eu era amigo do Sardo, éramos militantes da LCI, mas ele também não me contava tudo". Resende ressalta que "esses livros foram importantes para nós, trotskistas" 55 .

As obras editadas pela Latitude e vinculadas a setores católicos progressistas parecem estar relacionadas à atuação de António Daniel Abreu, que era ligado a estes setores e tinha feito parte da Juventude Operária Católica (JOC) e do Gedoc (Grupo de Estudos e Documentação) ${ }^{56}$. Abreu foi o responsável pela edição de dois livros: $O$ Brasil de Carlos Marighela: na senda de Guevara, com seleção e coordenação literária de Milton Miranda (c1971); e O escândalo dos infra-homens (c1971), de Dom Hélder Câmara. Além desses, a Latitude editou ainda de Dom Hélder Câmara $O$ capitalismo contra a paz (c1971).

\footnotetext{
${ }^{51}$ Mensagem eletrônica de José Manuel Lopes Cordeiro enviada em 2/9/2012.

52 Mensagem eletrônica de João Barrote enviada em 28/6/2011.

${ }^{53}$ Sobre a LCI ver o item sobre as Edições Antídoto.

${ }^{54}$ Mensagem eletrônica de Manuel António Ribeiro Resende enviada em 30/8/2012.

${ }^{55}$ Idem.

${ }^{56}$ Entrevista com António Daniel Abreu, São Paulo, 23/8/2012. Sobre António Daniel Abreu ver os itens sobre as editoras Cadernos Para o Diálogo, Textos Marginais, Rés e Nova Crítica.
} 
Houve também a edição de duas obras de Mao Tsé-tung: Cinco artigos do presidente Mao Tsetung (s/d); e A propósito dos métodos de direcção e outros textos (1972), o que indica que a Latitude deveria ter também contatos com grupos maoistas. E foi publicado ainda um livro de Lenin: As questões nacional e colonial (s/d).

O jornalista e escritor português José Viale Moutinho teve também dois títulos publicados: O nosso amargo cancioneiro (1972), do qual foi coordenador, e Histórias do tempo da outra senhora (1974).

Esta linha eclética é assim explicada por Manuel Resende: "Nessa altura havia uma certa coexistência entre as várias correntes de extrema-esquerda e dos católicos progressistas, inclusive com os maoistas. Havia relações pessoais entre militantes de diferentes grupos, havia menos sectarismo" ${ }^{, 57}$.

Após o 25 de Abril, parece ter havido uma mudança na linha editorial da Latitude, que somente publicou, então, a coleção Obras Escolhidas de Lenine, que teve três volumes: O Estado e a revolução; Esquerdismo, doença infantil do comunismo; e As duas tácticas da social-democracia na revolução democrática, lançados em 1974.

Estes foram os últimos títulos editados pela Latitude.

Em boa parte dos livros editados aparece o nome de A. Resende como responsável pela edição. Inicialmente pareceria que A. Resende seria Manuel António Ribeiro Resende, mas de acordo com este último, não se tratava dele ${ }^{58}$. Não foi possível descobrir quem era essa pessoa, e se de fato ela existia ou se era apenas um nome "frio" usado para "legalizar" a edição, como às vezes era feito por algumas editoras nesse período, em função de perseguições por parte da polícia política.

Outro ponto importante a destacar é que provavelmente as edições feitas pela Livraria Latitude tivessem alguma relação com a Editorial Inova, de José da Cruz Santos, pois uma das coleções editadas, a Cadernos Latitude, tinha características gráficas muito parecidas com as da Inova e seu projeto gráfico era de autoria do mesmo artista responsável pelos livros daquela editora, Armando Alves.

Entre 1970 e 1974 a Latitude publicou cerca de 20 livros. A distribuição era feita pela própria Livraria Latitude. Mas certamente podemos afirmar que havia uma parte da distribuição que era militante, realizada por pessoas ligadas a setores dos católicos progressistas, dos trotskistas e dos maoistas cujas obras foram editadas pela Latitude.

\footnotetext{
${ }^{57}$ Mensagem eletrônica de Manuel António Ribeiro Resende em 30/8/2012.

${ }^{58}$ Idem.
} 
Por todas estas características, a Livraria Latitude parece ter sido, antes de 1974, uma espécie de "frente editorial" que publicava obras de católicos progressistas, trotskistas e maoistas, servindo, assim, de canal para a veiculação das ideias de grupos ligados a esses setores, e ao mesmo tempo obtendo um bom resultado comercial, pois, como já vimos pelos depoimentos de vários editores, este tipo de livro tinha boa vendagem nesse período.

Somente após o 25 de Abril é que parece ter havido uma definição política mais clara - e mais restritiva - da linha editorial, com a edição apenas de obras de Lenin. No entanto, a editora encerrou suas atividades neste mesmo ano, 1974.

Desse modo, a Latitude pode ser definida como uma editora política de esquerda, mas sem vinculação a um grupo político específico.

\subsection{Livraria Ler Editora}

Rua Almeida e Sousa, 24-C - Lisboa

Editor: Luís Alves Dias.

Início das edições: 1971.

Distribuição: Livraria Ler, Dinalivro.

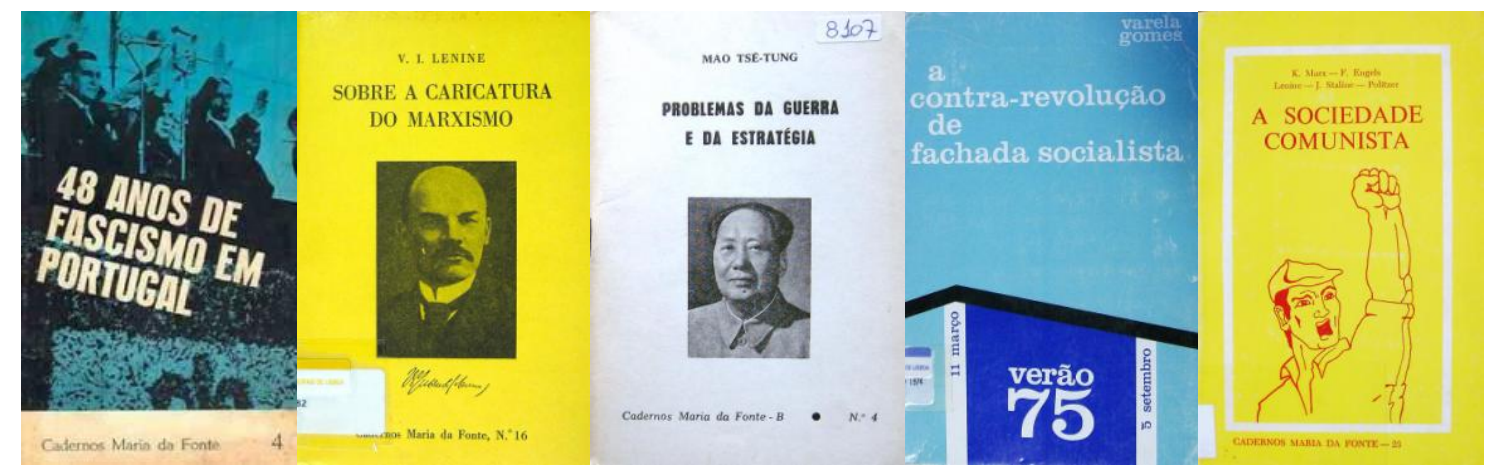

A Livraria Ler foi criada em fevereiro de 1970 por Luís Alves Dias. Ele iniciou sua vida de livreiro ainda adolescente na Livraria Aillaud \& Lello, na rua do Carmo, em Lisboa, onde trabalhou por 15 anos. Depois esteve por cinco anos na Livraria do Diário de Notícias, no Rossio, até ser convidado por Álvaro Gonçalves Pereira para trabalhar na abertura do Centro do Livro Brasileiro, onde ficou por sete anos ${ }^{59}$. Assim, era já um experiente profissional da área, com 38 anos de idade, quando abriu a sua livraria na rua

59 DAURO, Covas. "Ler com o Sr. Luís \#1". Blogue Todos os Livros, 11/1/2008. Disponível em: <http://todos-os-livros.blogspot.com/2008/01/ler-com-o-sr-lus-1.html>. Acesso em 10/05/2010. 
Almeida e Sousa, no bairro de Campo de Ourique, junto ao Jardim da Parada, em Lisboa.

Logo que abriu a livraria, surgiu a demanda em relação aos livros políticos, os "livros proibidos", como conta Luís Alves:

Quando vim para cá comecei a fazer distribuições de pessoas amigas, em geral autores proibidos como o Padre Felicidade Alves, o Raúl Rego... Entre as editoras contava-se a Raiz, de Tomar, que já faliu e que só editava livros proibidos ${ }^{60}$. Foi aí que começou a perseguição da PIDE. Sabiam que eu era o distribuidor da Raiz, que recebia livros brasileiros proibidos... ${ }^{61}$

A Livraria Ler somente começaria a editar livros com sua própria chancela em 1974, após o 25 de Abril, com a coleção Cadernos Maria da Fonte. No entanto, esta coleção havia começado em 1971, e inicialmente era coeditada pela Livraria Ler, juntamente com um dos funcionários da livraria, João Camacho. Camacho havia sido proprietário da Livraria Guernica, em Lisboa, era militante do MRPP e já havia editado, em 1971, o livro Divergências sobre alguns problemas importantes da política actual do partido, de Mao Tsé-tung. Este livro apareceu como "Edição do Tradutor”, que era o próprio Camacho. Depois dessa experiência, ele começou a editar por sua conta, em 1971, os Cadernos Maria da Fonte ${ }^{62}$. Foram lançados três títulos até 1972, sob a responsabilidade de Camacho: Sobre a repressão, de Victor Serge (1971); Sobre a emancipação da mulher, coletânea com textos de Marx, Engels, Lenin e Kollontai (1971); e Citações do presidente Mao Tsé-tung (1972).

Neste primeiro momento, a Livraria Ler assumiu a responsabilidade pela distribuição dos livros da coleção, mas não pela edição. Acredito que de fato Luís Alves tenha sido uma espécie de sócio nestas edições, ou seja, Camacho escolhia os títulos e editava os livros, e Alves comprava grande parte da edição e fazia a distribuição comercial dos livros. Podemos considerar que era um tipo de coedição entre João Camacho e a Livraria Ler.

Camacho conta como começaram os Cadernos Maria da Fonte:

Foi uma iniciativa minha, a escolha dos títulos era eu que fazia. Era

\footnotetext{
${ }^{60}$ Pelo que apurei, a Raiz não era uma editora, mas sim uma distribuidora. A editora dos livros distribuídos pela Raiz era a Nova Realidade, criada em 1966 por Carlos Loures, Manuel Simões e Júlio Estudante, em Tomar. Ver o item sobre esta editora Capítulo 9.

${ }^{61}$ DAURO, Covas. "Ler com o Sr. Luís \#2". Blogue Todos os Livros, 14/1/2008. Disponível em: $<$ http://todos-os-livros.blogspot.com/2008/01/ler-com-o-sr-lus-2.html>. Acesso em 10/05/2010.

${ }^{62}$ Entrevista com João Camacho, Lisboa, 3/3/2011.
} 
uma pequena editora. Todos estes três livros que lancei nos Cadernos Maria da Fonte tiveram problemas com a PIDE. [...] As tiragens eram de 10 mil exemplares, era muito fácil de vender. Apareciam os jovens na altura com apetência política, estudantes. Havia algumas livrarias em que se vendiam muitos livros proibidos, por exemplo, a Ler, a Barata, a Guernica (até fechar), a Livrelco, vendiam milhares de livros para os estudantes. Eu editei até o terceiro volume dos Cadernos. ${ }^{63}$

Ele conta ainda que a homenagem à heroína portuguesa deveu-se ao fato de a Livraria Ler, onde ele então trabalhava, estar situada ao lado do Jardim da Parada, uma praça onde há uma estátua de Maria da Fonte.

Luís Alves, por ser o distribuidor, foi chamado à PIDE três vezes por causa dos Cadernos, ou seja, a cada livro lançado havia sempre problemas com a polícia. Alves conta que não foi maltratado na PIDE, mas foi ameaçado:

Só me disseram que eu deixasse de editar livros deste género, senão viam-se obrigados a fechar-me a livraria. Mas não me bateram. É claro que me fizeram estar à espera uma data de tempo. Perdi lá dias inteiros. Era a filosofia deles. Mas ameaçaram-me e a livraria foi fechada mais do que uma vez para passarem vistoria aos livros. ${ }^{64}$

Como vemos, Alves era importunado pela PIDE tanto por distribuir/editar livros inconvenientes para o regime como por vender em sua loja obras desse mesmo teor. Ele lembra de um caso curioso que aconteceu com o livro Citações do presidente Mao Tsétung. A edição chinesa desse livro (em português) tivera a sua venda liberada por uma circular do governo de Marcelo Caetano. No entanto, a edição da obra nos Cadernos Maria da Fonte teve problemas com a polícia:

[...] quando o livro estava pronto [na gráfica] para entrega, apareceu lá uma brigada da PIDE, que apreendeu os livros, mas não os levou logo. Avisaram-me da tipografia e eu peguei na circular e fui à sede da PIDE, na [rua] António Maria Cardoso. Apresentei-me e apresentei o caso. Eles admitiram que tinham apreendido os livros e eu mostrei a circular da censura. Eles tiveram que dar o braço a torcer e dar ordem à tipografia para me entregar os livros. ${ }^{65}$

Camacho recorda que esse livro "praticamente esgotou assim que saiu". A tiragem teria sido de 10 mil exemplares. Camacho chegou a ser preso devido à edição desse livro ${ }^{66}$.

\footnotetext{
${ }^{63}$ Idem. Como vimos no item sobre as Edições Maria da Fonte, no Capítulo 5, no começo de 1974 Camacho criou esta editora e se afastou dos Cadernos Maria da Fonte.

${ }^{64}$ DAURO, C. "Ler com o Sr. Luís \#2", op. cit.

65 Ibidem.

${ }^{66}$ Entrevista com João Camacho, Lisboa, 3/3/2011.
} 
Provavelmente em função dos problemas com a polícia política, os Cadernos só foram retomados após o fim da ditadura. "O Luís Alves Dias me pediu autorização para continuar com eles", conta Camacho, que nessa altura já tinha a sua própria editora, a Nova Aurora $^{67}$ (ver item sobre esta editora no Capítulo 5). Assim, surgiu o quarto volume da coleção e se iniciou uma nova fase, sendo todos os títulos editados a partir de então de responsabilidade da Livraria Ler e de Luís Alves.

O primeiro livro dessa nova fase foi 48 anos de fascismo em Portugal, lançado em junho de 1974 e que vendeu cerca de 50 mil exemplares ${ }^{68}$. Daí em diante o ritmo de lançamentos foi intenso, totalizando, em 1974, 22 títulos. No ano seguinte este número caiu para dez títulos. A partir de 1976 a atuação editorial da Ler tornou-se apenas residual, com seis títulos publicados entre 1976 e 1981.

A coleção Cadernos Maria da Fonte concentrava a maior parte dos lançamentos. $\mathrm{O}$ autor que teve mais obras publicadas foi Lenin, com oito livros (além de um em coautoria). Na coleção foram editadas também três obras relacionadas ao Partido Africano da Independência da Guiné e Cabo Verde (PAIGC): Manual político, do PAIGC; Textos políticos de Amílcar Cabral, e Pelas regiões libertadas da Guiné (Bissau) / Missão Especial da ONU nas regiões libertadas.

Foram publicados na coleção autores como: Fernanda Agria (A greve); Nicolau Bukharin ( $A B C$ do comunismo); Arsénio Mota (Um país de pequenos burgueses); Ernesto Pastrana e Monica Threlfall (Pão, tecto e poder: o movimento popular de reivindicação habitacional no Chile, 1970-1973), Wilhelm Reich e Vera Schmidt (Psicanálise e educação), além do Resumo da história do Partido do Trabalho da Albânia. O último livro da coleção foi o Dicionário do militante operário, de Miguel Lemos (junho, 1975).

Havia outra coleção intitulada Cadernos Maria da Fonte B, que teve oito volumes, lançados em 1974 e 1975. Seis dessas obras eram de autoria de Mao Tsé-tung, uma do Partido Comunista Chinês e uma do líder albanês Enver Hoxha.

Além disso, foram lançados fora de coleção, em 1975, dois outros títulos nesta mesma linha: Obras escolhidas de Mao Tsetung, Tomo III e As questões do leninismo, de J. Stalin.

Nestas duas coleções aparece com frequência o nome de J. Bragança como

\footnotetext{
${ }^{67}$ Idem.

${ }^{68}$ DAURO, Covas. "Ler com o Sr. Luís \#3". Blogue Todos os Livros, 21/1/2008. Disponível em: <http://todos-os-livros.blogspot.com/2008/01/ler-com-o-sr-lus-3.html>. Acesso em 10/05/2010.
} 
responsável pela edição. Ao que tudo indica, tratava-se de um pseudônimo, talvez do próprio Luís Alves ${ }^{69}$. Isso era um resquício dos tempos da ditadura, quando era comum que editores de livros considerados subversivos usassem pseudônimos ou simplesmente inventassem um nome ao qual era atribuída a responsabilidade da edição. O último livro em que aparece J. Bragança como editor é A origem do cristianismo, de Jacó Abramovitch Lentsman (maio, 1976).

Depois de 1976 a Livraria Ler só voltou à edição em 1979, e de forma esporádica. Adotou então uma nova denominação: Ler, Editora. Continuavam a ser editados livros de caráter político, mas agora de autores portugueses e sobre a realidade do país. Foram cinco títulos: Textos de guerrilha, de Luiz Pacheco (1979); Tempo de resistência, de Varela Gomes (1980); Textos de guerrilha: $2^{a}$ série, de Luiz Pacheco (1981); O prof. Bento de Jesus Caraça: presença viva do seu pensamento e da exemplaridade da sua acção cultural e cívica, de António de Sequeira Zilhão (1981); e A contra-revolução de fachada socialista: 11 de março - Verão 75 - 5 de setembro, de Varela Gomes (1981). Este parece ter sido o último título editado pela Livraria Ler.

Apesar de predominarem, entre os títulos lançados pela Ler, os livros ligados a ideias de extrema esquerda, Luís Alves explica de modo simples o motivo pelo qual publicou estas obras: "Era o que se vendia naquela altura". Ele afirma:

Não tive envolvimento com nenhum partido, nem antes, nem depois do 25 de Abril. Só fiz parte das eleições do Humberto Delgado [em 1958]. [...] Eu nunca me filiei em nenhum partido, mas não houve nenhum ano em que não fosse votar. Sou democrata $100 \%$, mas como tinha uma casa comercial, não queria estar conotado com nenhum partido. $^{70}$

Apesar disso, Alves diz que "não há dúvida que eu fui conotado com o PCP a seguir ao 25 de Abril". Ele explica:

Quando se deu o 25 de Abril eu enchi as montras [vitrines] com os autos de apreensão. Fiz as contas e tinha mais de 400 contos em livros apreendidos, o que era muito dinheiro. Uma noite, ouvi umas pessoas a comentarem os autos: "Eu não te disse que o sr. Luís era comunista?". Fui conotado e editei várias coisas de tipos que eram da oposição. $^{71}$

Entre 1974 e 1981 a Livraria Ler editou 35 títulos (além dos três coeditados

\footnotetext{
${ }^{69}$ Essa hipótese foi corroborada por Luís Manuel Vaz Alves, filho de Luís Alves Dias, em conversa por telefone em 26 de setembro de 2012.

${ }^{70}$ DAURO, C. "Ler com o Sr. Luís \#3”, op. cit.

${ }^{71}$ Ibidem.
} 
antes de 1974), todos de caráter político, muitos deles conotados com ideias de extrema esquerda. Apesar disso, a editora não tinha, segundo seu proprietário, ligações com qualquer grupo político. Como vimos, Luís Alves considerava que ligar-se a um grupo ou partido político poderia prejudicar seus negócios.

A grande maioria dos títulos - 29 - foi editada em 1974 e 1975. Como lembra Alves: "A seguir ao 25 de Abril apareceu tudo o que estava proibido. Foi a altura em que se vendeu mais livros". Ele diz que esse período durou até princípios de 1977. Além desse fator, Alves explica que a sua opção por diminuir as edições após 1976, até a suspensão completa em fins de 1981, "teve a ver com o facto de eu preferir a actividade de livreiro à de editor. Uma editora consome muito tempo e eu prefiro estar no meio dos livros" $" 72$.

Assim, a Livraria Ler foi uma editora que publicou livros políticos - e somente livros políticos -, mas não era vinculada a qualquer grupo ou partido político. Tratavase de uma editora independente desses grupos, mas que certamente devia ter alguma relação com pessoas a eles vinculadas, o que explicaria os títulos escolhidos para serem editados, todos ligados ao pensamento de esquerda (e mesmo de extrema esquerda). Mas o objetivo principal de seu proprietário parecia ser o êxito comercial dos livros editados, tendo ele aproveitado o novo momento político do país após o 25 de Abril para incrementar esse objetivo com a edição de livros políticos. Dessa forma, soube também responder a uma demanda social que veio à tona com grande força a partir de abril de 1974.

A Livraria Ler continua em atividade até hoje, no mesmo endereço, apenas como livraria, tendo à frente Luís Manuel Vaz Alves, filho de Luís Alves Dias.

${ }^{72}$ Ibidem. 


\subsection{Cadernos Para o Diálogo}

\section{Porto}

Editor: António Daniel Abreu.

Início das edições: 1971.

Distribuição: Livraria Paisagem.

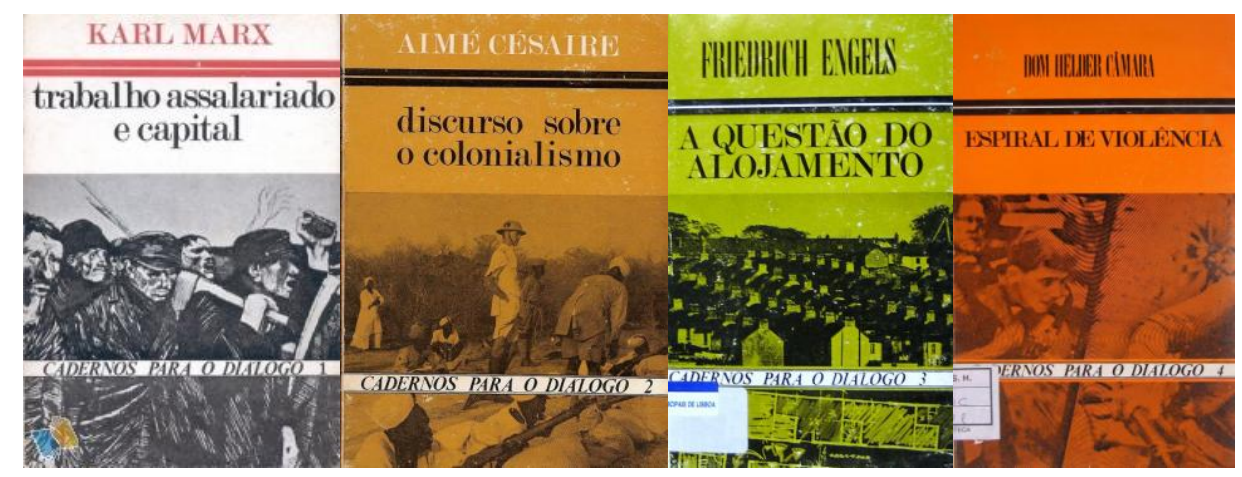

Editora criada em 1971 por António Daniel Abreu na cidade do Porto. Sua origem relaciona-se à atividade profissional de Abreu na Editora Paisagem (ver item sobre esta editora no Capítulo 11), onde ele trabalhava no setor de vendas.

Abreu tinha ligações com setores católicos progressistas, que faziam oposição à ditadura, e tinha feito parte da Juventude Operária Católica (JOC) e do Gedoc (Grupo de Estudos e Documentação). O nome da editora foi inspirado na revista espanhola Cuadernos para el Diálogo ${ }^{73}$, que circulou entre 1963 e 1978 e vinculava-se inicialmente ao pensamento democrata-cristão, “evoluindo para posições próximas à centro-esquerda, para terminar, em sua última fase, com um jornalismo de corte socialista" ${ }^{, 74}$. O mesmo grupo que editava a revista criou na Espanha, em 1965, uma editora com o mesmo nome ${ }^{75}$.

Depois que saiu da Paisagem, no começo da década de 1970, Abreu foi trabalhar na editora Inova, de José Cruz Santos, também no Porto. Lá ficou pouco tempo, pois decidiu começar a editar por conta própria. “Comecei a editar em 1971. Eu tinha 19 anos, então a minha mãe teve que me dar a emancipação, pois eu era menor de 21 anos", conta Abreu ${ }^{76}$, que desde 1986 vive no Brasil.

"O Abreu, do seu trabalho de vendas, percebeu que havia espaço para fazer

\footnotetext{
${ }^{73}$ Conforme lembrou João Barrote em mensagem eletrônica enviada em 28/6/2011.

${ }^{74}$ DAVARA TORREGA, Francisco Javier. "La aventura informativa de Cuadernos para el diálogo". Estudios sobre el Mensaje Periodístico, $\mathrm{n}^{\circ}$ 201, 2004, p. 201-220. Disponível em: $\langle$ http://revistas.ucm.es/index.php/ESMP/article/view/ESMP0404110201A/12595〉. Acesso em 26/10/2012.

${ }^{75}$ MORET, Tiempo de editores, op. cit., p. 296.

${ }^{76}$ Entrevista com António Daniel Abreu, São Paulo, 23/8/2012. Todas as demais falas de Abreu provêm desta entrevista.
} 
publicações de orientação oposta ao regime, que condiziam com os sentimentos dele de opositor da ditadura, e começou a fazê-las, com todo o atrevimento e ingenuidade", lembra João Barrote ${ }^{77}$, que trabalhou com Abreu na Editora Paisagem e depois colaborou com ele na editora Textos Marginais.

A primeira editora criada por António Daniel Abreu foi a Cadernos Para o Diálogo, que editou seis títulos em 1971. Entre os autores estavam Marx (Trabalho assalariado e capital), Engels (A questão do alojamento), D. Helder Câmara (Espiral de violência) e Aime Césaire (Discurso sobre o colonialismo). Este último livro, em particular, "era uma afronta para o regime, porque a palavra colonialismo tinha sido banida em Portugal", lembra Abreu. Os outros dois títulos publicados foram $O$ império Rockefeller e Comuna de Paris 1871, de Prosper Ollivier Lissagaray.

Tais lançamentos não passaram despercebidos pela polícia política. Abreu recorda que:

A Cadernos Para o Diálogo publicou livros, digamos, muito avançados, a polícia política, a PIDE/DGS, veio em cima de mim, apreendeu tudo, fizeram um processo, e eu tive que parar com aquilo porque não tinha mais condições. Qualquer livro que saísse eles vinham em cima de mim.

Um bom exemplo dessa perseguição foi a censura ao livro Discurso sobre o colonialismo, de Aime Césaire. O texto foi retirado da revista francesa Présence africaine, trazida clandestinamente para Portugal por membros do PCP. O livro começou a ser distribuído no dia 6 de dezembro de 1971 e dois dias depois já era de conhecimento da PIDE/DGS ${ }^{78}$. Abreu diz que "neste caso foram informadores infiltrados na gráfica que terão entregue uma cópia do livro directamente às autoridades quando este estava pronto para ser distribuído" ${ }^{79}$.

O relatório da DGS sobre o livro é curto e direto: "O autor é negro, comunista e foi em tempos deputado francês. Trata-se duma diatribe contra a civilização ocidental, numa pseudo defesa das civilizações negra, oriental e índia. Para proibir" ${ }^{\prime 80}$.

Para tentar escapar à perseguição e ao estigma que a Cadernos Para o Diálogo tinha criado junto à PIDE, Abreu resolveu encerrá-la e iniciar uma outra editora. "Foi

\footnotetext{
${ }^{77}$ Entrevista com João Barrote, freguesia de Arnoia, concelho de Celorico de Bastos, distrito de Braga, 22/6/2011.

${ }^{78}$ CÉSAR, Felipa. "Notas sobre o fac-símile da publicação Cadernos para o Diálogo 2". In: CÉSAIRE, Aimé. Discurso sobre o colonialismo. Edição fac-similar. Berlin: Bom Dia, 2012.

${ }^{79}$ Ibidem.

${ }^{80}$ Relatório 9253 da DGS sobre o livro Discurso sobre o colonialismo, datado de 11 de janeiro de 1972 , assinado por Simão Gonçalves. Reproduzido em CÉSAR, op. cit.
} 
quando eu comecei a Textos Marginais, com uma proposta diferente, mais aberta", diz Abreu.

Assim, a existência da Cadernos Para o Diálogo foi curta, cerca de um ano apenas, com seis títulos publicados, todos com padrão gráfico e editorial profissional e distribuídos pela Livraria Paisagem. A editora foi vítima das perseguições policiais e da censura da época, que acabaram por inviabilizar a sua continuidade. Dito de outra forma, a editora "[...] desapareceu somente por motivos coercitivos" $" 81$.

Abreu criou mais três editoras em Portugal - Textos Marginais, Rés e Nova Crítica -, sempre no Porto. Em 1986 mudou-se para São Paulo, onde vive desde então, também exercendo a profissão de editor, à frente da editora Landy.

\subsection{Textos Marginais}

Porto

Editor: António Daniel Abreu.

Início das edições: 1972.

Distribuidor: Dinalivros / Brasil: Martins Fontes.

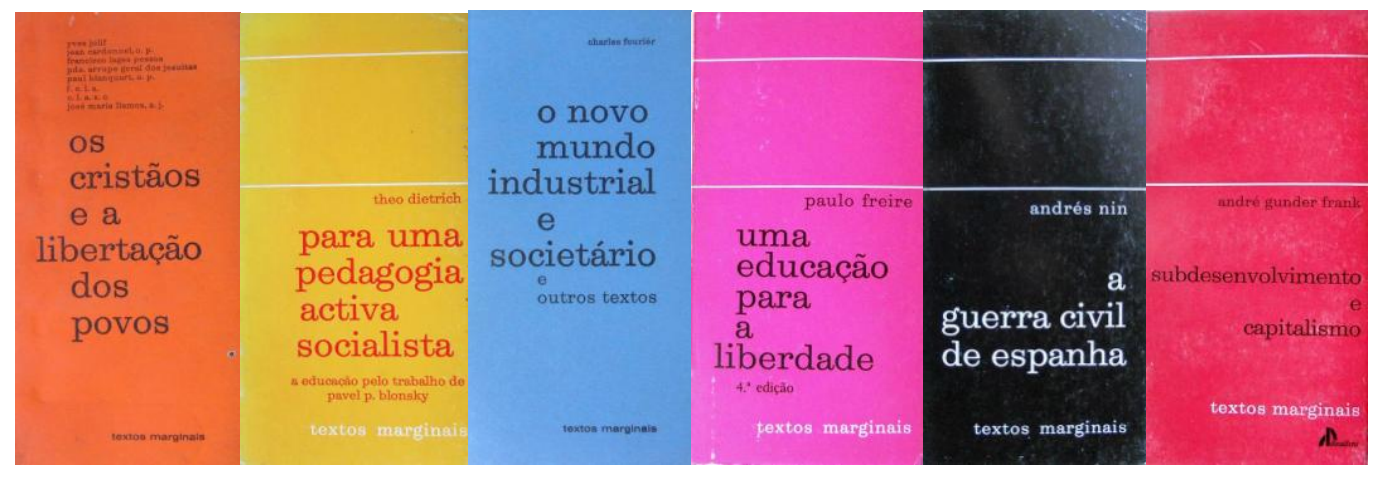

Editora criada por António Daniel Abreu na cidade do Porto, em 1972, para dar continuidade à sua atividade de editor. Abreu havia criado no ano anterior a editora Cadernos Para o Diálogo, que havia tido muitos problemas com a polícia política e a censura, devido aos títulos publicados.

A criação da Textos Marginais foi a forma encontrada por Abreu para tentar escapar a esta perseguição, já que qualquer título que viesse a ser publicado pela Cadernos Para o Diálogo estava fadado à censura e à apreensão. O nome da nova

\footnotetext{
${ }^{81}$ Tal afirmação aparece na contracapa do livro $O$ que é uma constituição política?, de Ferdinand Lassalle, que em 1976 inaugurou a nova série da coleção Cadernos Para o Diálogo, recriada por Abreu na editora Nova Crítica (ver item sobre esta editora no Capítulo 11).
} 
editora parece ter sido inspirado pela coleção Cuadernos Marginales, da Editorial Tusquets, de Barcelona, criada em $1969^{82}$.

Os livros editados pela Textos Marginais se caracterizavam pelo marcado caráter político e ideológico ligado ao pensamento transformador, de esquerda e marxista, mas não tocavam diretamente na questão colonial, que, na opinião de Abreu, era o ponto que mais incomodava o regime. Diz ele:

Antes do 25 de Abril havia uma "liberdade vigiada" pela polícia política. Os livros eram isentos de censura [prévia], mas eram apreendidos quando ultrapassavam as barreiras da "legalidade" imposta. Havia algumas coisas que eles não permitiam de jeito nenhum. Em relação aos clássicos, Marx, Engels, a perseguição não era tão grande, mas as coisas ligadas aos movimentos coloniais eles não perdoavam de jeito nenhum. ${ }^{83}$

Antes do 25 de Abril a Textos Marginais publicou livros como: O sistema irracional, de Paul Baran e Paul Sweezy (1972); A guerra civil de Espanha, de Andrés Nin (1972); Contribuição para a história do cristianismo primitivo, de Karl Marx e Friedrich Engels (1972); Os cristãos e a libertação dos povos, de Yves Jolif e outros (1972); Uma educação para a liberdade, de Paulo Freire (1972); Discurso sobre as artes e as ciências, de Jean-Jacques Rousseau (1972); O novo mundo industrial e societário e outros textos, de Charles Fourier (1973); e Império e imperialismo americano, Celso Furtado e outros (1973).

António Abreu recorda que:

Os livros da Textos Marginais eram um sucesso. Quando fiz o primeiro eu tinha um certo receio, porque a polícia vinha sempre em cima de mim, então eu comecei com 1.500 exemplares, que já saíam praticamente vendidos. Aí eu fui aumentando a tiragem até que chegou a 10 mil a tiragem inicial. E vendia tudo.

A partir do quinto ou do sexto livro editado, Abreu passou a contar com a assessoria de João Barrote, com quem havia trabalhado na Editora Paisagem, e que em 1973 criou as Publicações Escorpião/Textos Exemplares. Barrote fazia a supervisão das traduções e também indicava textos para edição. "Mas a grande maioria era eu mesmo que selecionava", afirma Abreu.

Os recursos investidos na editora eram de Abreu. "Na verdade o investimento era quase nulo, porque os livros já saíam quase todos vendidos”, diz ele.

\footnotetext{
${ }^{82}$ Conforme lembrou João Barrote em mensagem eletrônica enviada em 28/6/2011.

${ }^{83}$ Entrevista com António Daniel Abreu, São Paulo, 23/8/2012. Todas as demais declarações de Abreu provêm desta entrevista.
} 
Um dos maiores sucessos da editora foi o livro $O$ combate sexual da juventude, de Wilhelm Reich, publicado em 1972, que vendeu quase 30 mil exemplares. "Quando eu resolvi editar este livro todo mundo disse que eu estava louco, que eu seria preso, mas resolvi editar assim mesmo. Foi um sucesso, vendeu uns 20 mil, 30 mil exemplares. Eu tirei os primeiros 5 mil e vendeu tudo em 24 horas", lembra Abreu.

"Com a Textos Marginais os problemas com a censura e a PIDE/DGS foram poucos", diz. Ele lembra que teve problemas em 1972, quando uma nova Lei de Imprensa reforçou a exigência de registro na Secretaria de Estado da Comunicação Social para se poder editar. "Como eu não estava inscrito lá, eles fizeram um processo por conta do livro A medicina e a vida hospitalar na República Popular da China. Aí fiquei praticamente proibido de editar, meu nome não podia aparecer nos livros".

Em 1973 Abreu estava em idade militar e foi enviado para Angola, onde ficou 21 meses. "Com o meu histórico com a PIDE, fui pra lá com uma espécie de 'estatuto de revolucionário', que eu nunca tive de fato", lembra. Mas mesmo na África Abreu conseguiu dar continuidade às edições, inclusive realizando algumas revisões de textos que lhe eram enviados por correio.

Quando deu-se o 25 de Abril, Abreu estava em Angola, mas pouco tempo depois já havia retornado a Lisboa .

Depois do 25 de Abril os livros continuaram vendendo bem, conta Abreu. Um indicador desses bons resultados é o fato de três títulos da editora terem aparecido na secção "Os best-seller da quinzena" do jornal Expresso, em 1974 e 1975 . O livro $O$ combate sexual da juventude, de W. Reich, apareceu em $5^{\circ}$ lugar (24/5/1975), em $3^{\circ}$ (7/6/1975) e em $9^{\circ}$ (21/6/1975). Já a obra de Paulo Freire, Uma educação para a liberdade, foi mencionada em $10^{\circ}$ lugar em 25/1/1975. E A nossa arma é a greve, reunião de textos de Franz Mehring, Rosa Luxemburgo e Emile Vandervelde, surgiu em $7^{\circ}$ lugar em $21 / 6 / 1975^{84}$.

Outros títulos editados a partir de 1974 foram: Uma iniciação à economia, de Charles Rouge (1974); Teoria e história do capitalismo monopolista, de Harry Magdoff, Paul Baran e Paul Sweezy (1974); A aplicação da psicanálise à investigação histórica, de Wilhelm Reich (1974); Progresso social e liberdade, de Herbert Marcuse (1974); Viver em Moscovo, viver em Nova York, de K. S. Karol e Herman Schreiber (1975);

\footnotetext{
84 “Os best-seller da quinzena". Secção do jornal Expresso, 1974 e 1975. Hemeroteca Municipal de Lisboa.
} 
Inquérito operário e luta política, com textos de K. Marx e Mao Tsé-tung (1975); Socialismo, casamento e família: a doutrina socialista do casamento, de David Riazanov (1975); e As três fontes do marxismo: a obra histórica de Karl Marx, de Karl Kautsky (1975).

Mas os novos tempos trouxeram mudanças para o setor editorial:

As coisas mudaram radicalmente. Antes do 25 de Abril o livro saía com o rótulo de proibido, então havia todo um mercado paralelo, que se formou em função disso, as livrarias recebiam os livros que sabiam que seriam proibidos e já tinham uma forma de os vender, recebiam os livros e nem expunham, ficavam debaixo do balcão e havia os clientes certos que iam lá e compravam. Eram tiragens de 3 mil, 4 mil exemplares e vendia tudo. Normalmente uns $30 \%$ ou $40 \%$ da tiragem eram já destinados para a apreensão, a gente já contava com aquilo. Com o 25 de Abril surgiram dezenas de editoras, e naturalmente eu também perdi espaço, eu tive que me afastar de algumas coisas e mudar o rumo.

Abreu lembra, com ironia, que "Com o 25 de Abril todos se transformaram em revolucionários, até alguns que eram ligados ao antigo regime foram parar no Partido Comunista". Mas, depois de cerca de dois anos em que a agitação política foi intensa e vendeu-se livros políticos como nunca em Portugal - de abril de 1974 até o final de 1975 -, o mercado para este tipo de livro começou a diminuir. "Depois, já em 1976-78, começou a haver uma definição de mercado, porque o mercado era muito bagunçado. $\mathrm{O}$ mercado começou a ser muito mais seletivo, ficaram alguns, a Afrontamento, a Centelha, o resto caiu tudo", diz Abreu, que completa: "O interesse pelo livro político caiu muito. O interesse era motivado, em grande parte, pela repressão política”.

Já em 1975 Abreu partiu para uma nova empreitada, criando a editora Rés em sociedade com Reinaldo Carvalho (ver item sobre esta editora no Capítulo 11).

António Abreu avalia da seguinte forma a atuação das editoras políticas em Portugal no período que precede ao 25 de Abril e nos anos imediatamente seguintes ao fim da ditadura:

Acho que as editoras que publicaram livros políticos tiveram um papel importante na formação política, porque não existia formação política em Portugal devido ao longo período da ditadura. A maioria dessas pequenas editoras era ligada a algum movimento. Elas não tinham uma visão comercial, eram idealistas que faziam aqueles livros.

Todos os títulos editados pela Textos Marginais eram de autores estrangeiros, com exceção de uma única obra: Miséria de cinema, de António Faria, publicado em 
maio de 1974. Os livros tinham tratamento editorial e gráfico profissional, e a distribuição era feita pela Dinalivro.

A editora atuou até 1977, tendo publicado 28 títulos. O período de maior atuação foi entre 1972 e 1974, quando saíram 21 títulos. Em 1975 foram editados apenas quatro, em 1976 apenas um, e 1977 dois títulos. Os três últimos títulos já saíram em edições feitas pela Dinalivro, a quem Abreu havia vendido a Textos Marginais em fins de 1975.

Em alguns livros da Textos Marginais aparece o seguinte crédito: "Edição: Henrique A. Carneiro". Como esclareceram-me António Abreu, José de Sousa Ribeiro ${ }^{85}$, da editora Afrontamento, e João Barrote ${ }^{86}$, este senhor era um dos proprietários da Gráfica Firmeza, do Porto, onde foram impressos muitos livros de caráter político naqueles anos. $\mathrm{O}$ seu nome aparecia para cumprir a exigência legal de que houvesse um editor autorizado que fosse responsável pela publicação - e também para proteger os reais editores de possíveis problemas com a polícia política. Mas de fato o senhor Henrique A. Carneiro não era o editor daquelas obras, mas sim o tipógrafo responsável por sua impressão. A menção de seu nome como responsável pela edição ocorre em livros de muitas outras editoras do Porto (ver item sobre a Editora Textos Políticos, neste capítulo).

\subsection{Publicações Escorpião / Textos Exemplares}

Porto

Editor: João Barrote.

Início das edições: 1973.

Distribuição: Ulmeiro, Assírio \& Alvim, Dinalivro.

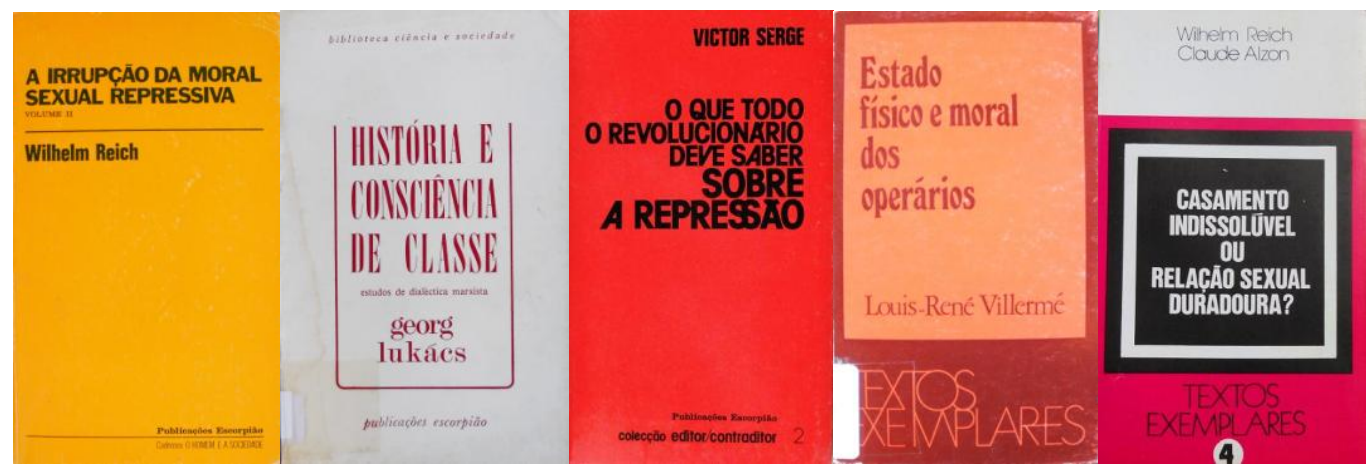

\footnotetext{
${ }^{85}$ Entrevista com José de Sousa Ribeiro, Porto, 24/3/2011.

${ }^{86}$ Entrevista com João Barrote, Arnoia, 22/6/2011.
} 
Editoras criadas por João Barrote em 1973, na cidade do Porto. Barrote havia iniciado sua trajetória como editor na Editora Paisagem (ver item sobre esta editora no Capítulo 11), tendo participado da nova etapa da editora Afrontamento que se iniciou no começo dos anos $1970^{87}$ e trabalhado com António Daniel Abreu na editora Textos Marginais, sempre no Porto ${ }^{88}$.

As Publicações Escorpião editaram seu primeiro título em março de 1973, tendo lançado mais seis títulos até o final daquele ano. A Textos Exemplares lançou seu primeiro livro em outubro de 1973, e o segundo em dezembro.

A Escorpião e a Textos Exemplares são iniciativas do mesmo editor - João Barrote -, quase simultâneas (ambas começam em 1973), mas são editoras diferentes. A Escorpião era um projeto mais estruturado de editora, com coleções definidas e títulos que respondiam a um anseio de informação que crescia muito naquele momento. Já a Textos Exemplares era, mais do que uma editora, "uma coleção de heterodoxia", nas palavras de Barrote:

$\mathrm{Na}$ Textos Exemplares havia um aspecto ideológico, a vontade de editar livros que eu acreditava relevantes do ponto de vista do pensamento. A Escorpião é uma coisa mais institucional, a grande diferença é essa, [era] uma editora que se queria uma grande editora. A aventura de publicar coisas como História e consciência de classe [de Lukacs] era uma ambição que não havia com a Textos Exemplares.

Mas ambas as editoras se beneficiavam, é certo, de uma dinâmica comum de funcionamento no que diz respeito à gestão, aos serviços editoriais (revisão, tradução, produção gráfica) e à distribuição.

Sempre de acordo com Barrote, "o nome Escorpião expressava a ideia de ser uma coisa que incomodasse, é um bicho que pica, é um 'pau na engrenagem', como diria o José Mario Branco", compositor português. E o nome Textos Exemplares se baseou nos Contos exemplares, livro de Sophia de Melo Breyner Andresen, o que parece exprimir a ideia de publicar textos realmente importantes e de valor literário.

Estas iniciativas de Barrote estão diretamente relacionadas às suas experiências anteriores. "Vi a experiência do António Abreu [com a editora Textos Maginais] e a relativa facilidade do ponto de vista econômico em fazer vingar a distribuição e, portanto, sustentar a atividade", lembra Barrote, era um caminho natural iniciar a sua

\footnotetext{
${ }^{87}$ Entrevista com José de Sousa Ribeiro, Porto, 24/3/2011.

${ }^{88}$ Grande parte das informações utilizadas neste item são oriundas da entrevista que realizei com João Barrote na freguesia de Arnoia, concelho de Celorico de Bastos, distrito de Braga, Portugal, em 22/6/2011. Todas as falas de Barrote que aqui aparecem provêm dessa entrevista.
} 
própria editora. Além disso, recorda ele, "eu tinha acabado de ler este texto A revolução da vida quotidiana [que seria o primeiro titulo publicado na coleção Textos Exemplares] que tinha me marcado muito e me motivado na ideia de tentar continuar na periferia do sistema”. Para Barrote:

Como editor eu não me comprometia diretamente com o sistema, era uma atividade de relativa liberdade, com a publicação de textos que eram socialmente úteis, o que pra mim é muito importante, estou aqui a fazer coisas que quero que sejam socialmente úteis. E sempre nas margens do sistema. [...] A partir do momento em que eu visualizei que havia a possibilidade de trabalho de uma forma autônoma, consistente do ponto de vista técnico, consistente do ponto de vista da qualidade de informação, e útil, para mim era óbvio que eu tinha que trilhar este caminho, porque resolvia duas questões ao mesmo tempo: a questão da minha própria subsistência, e a questão de exprimir, do ponto de vista ideológico, aquilo que eu acreditava.

Para iniciar as editoras, Barrote contou com recursos próprios e o crédito de algumas gráficas do Porto, como a Gráfica Firmeza, que o conheciam do trabalho na Paisagem, na Afrontamento e na Textos Marginais.

Tanto na Escorpião como na Textos Exemplares João Barrote era a peça-chave, o editor e o coordenador de todas as atividades, sempre contando com a participação de sua esposa, Amélia, e de alguns amigos. Mas era ele a mola-mestra. Isso também era válido do ponto de vista econômico, ou seja, o investimento e os riscos eram assumidos por ele.

Nos livros de ambas as editoras aparecem sempre nomes de outras pessoas como responsáveis pela edição. Isso era uma forma, muito usada na época, para despistar a polícia política, com explica Barrote:

Os nomes de editores que aparecem são nomes reais de pessoas que assumiam algum risco. Aparecer como editor, ou aparecer como tradutor, nem sempre sendo o tradutor, era um expediente para contornar a dificuldade... Se eu me matriculasse como editor no SNI [Secretariado Nacional da Informação, Cultura Popular e Turismo] eu estava automaticamente a ser controlado de uma forma mais apertada. Isto [não estar registrado] dava-me liberdade. Mas o editor dos livros era eu.

A Escorpião publicou as coleções O Homem e a Sociedade, Editor/Contraditor, Biblioteca Ciência e Sociedade, e Eros \& Política. Antes do 25 de Abril a editora lançou os seguintes títulos: Para uma crítica da economia política, com textos de Paul Sweezy e Karl Marx (1973); Sobre o conceito de consciência de classe, de Georg Lukacs e Adam Schaff (1973); As raízes da burocracia, de Isaac Deutscher (1973); Formações 
económicas pré-capitalistas, de Karl Marx (1973); Imperialismo: unidade ou rivalidade?, de Bob Rowthorn (1973); A re-produção das relações de produção, de Henri Lefebvre (1973); Crítica da medicina liberal, de Robert Silman/Comité d'Action Santé (1973); Guia breve da ideologia burguesa, de Robin Blackburn (fevereiro, 1974).

E a Textos Exemplares editou três títulos neste período: A reprodução da vida quotidiana, de Fredy Perlman (1973); Consequências sociais da maquinaria automatizada, com textos de Karl Marx e Rudi Supek (1973); e A lenda do grande inquisidor, de Feodor Dostoievsky (abril, 1974).

Nas duas editoras a distribuição foi inicialmente feita pela Ulmeiro - livraria e editora de José Antunes Ribeiro, de Lisboa, da qual falaremos no Capítulo 8. Depois, com o surgimento da editora Assírio \& Alvim, que era também distribuidora e da qual Ribeiro foi um dos fundadores, a distribuição passou a ser feita por esta empresa. Mas pouco tempo depois a Assírio \& Alvim começou a ter problemas financeiros e deixou de pagar os fornecedores. Foi quando a distribuição passou para a Dinalivro, que foi a responsável por este setor até o final das atividades das editoras.

Como lembra Barrote, o êxito das editoras foi grande, pois mesmo antes do 25 de Abril "os livros vendiam-se como pãozinho quente. A $1^{a}$ edição nunca era menor que 4 mil exemplares".

E depois do fim da ditadura as vendas continuaram muito bem, e até melhoraram. Isso é particularmente visível em relação aos livros da Escorpião, pois vários deles são mencionados na secção "Os best-seller da quinzena" do jornal Expresso, em 1974 e 1975, algumas vezes ocupando o primeiro lugar da lista. São os seguintes os livros que apareceram na lista do Expresso, todos da Escorpião ${ }^{89}$ : Divisão social do trabalho, ciência, técnica e modo de produção capitalista, vários autores $-6^{\circ}$ lugar (8/6/1974); Trabalho assalariado e capital / Salário, preço e lucro, de Karl Marx - $2^{\circ}$ lugar (22/6/1974); Miséria da filosofia, de Karl Marx - 5 lugar (14/9/1974) - $9^{\circ}$ lugar (25/1/1975) - $8^{\circ}$ lugar (15/2/1975) - 2o lugar (1/3/1975) - e $2^{\circ}$ lugar (15/3/1975); Psicologia de massas do fascismo, de W. Reich - $1^{\circ}$ lugar (1/11/1974) - 2o lugar (16/11/1974); A acumulação primitiva do capital, de Karl Marx - $8^{\circ}$ lugar (1/11/1974) $9^{\circ}$ lugar (3/5/1975); O que todo revolucionário deve saber sobre a repressão, de Victor Serge - $9^{\circ}$ lugar (30/11/1974); O sindicalismo I: teoria, organização, actividade, de

\footnotetext{
89 “Os best-seller da quinzena”. Secção do jornal Expresso, 1974 e 1975. Hemeroteca Municipal de
} Lisboa. 
Karl Marx e Friedrich Engels. Seleção, introdução e notas de Roger Dangeville $-1^{\circ}$ lugar (11/1/1975) - 2o lugar (25/1/1975); O sindicalismo II. , de Karl Marx e Friedrich Engels - $1^{\circ}$ lugar $(24 / 5 / 1975)-1^{\circ}$ lugar $(7 / 6 / 1975)-1^{\circ}$ lugar $(21 / 6 / 1975)-3^{\circ}$ lugar (19/7/1975) - $6^{\circ}$ lugar (2/8/1975); Introdução à economia política I, de Rosa Luxemburg - $10^{\circ}$ lugar (3/5/1975); A irrupção da moral sexual repressiva, de W. Reich - $8^{\circ}$ lugar (21/6/1975); O partido de classe I, de Karl Marx e Friedrich Engels - $8^{\circ}$ lugar $(2 / 8 / 1975)$.

Todos estes livros foram publicados pela Escorpião já depois do 25 de Abril. Já a Textos Exemplares editou sete livros após o fim da ditadura: Crítica dos programas socialistas de Gotha e Erfurt, de K. Marx e F. Engels (1974); Casamento indissolúvel ou relação sexual duradoura?, de W. Reich e Claude Alzon (1975); O que é a consciência de classe?, de W. Reich (1975); Pluralismo, totalitarismo e esquerda radical, de José Baptista (1975); Estado físico e moral dos operários, de Louis-René Villermé (1976); Controlo operário e socialismo, de Anton Pannekoek (1976); O elogio do socialismo, de Samir Amin e Paul M. Sweezy (1977).

O êxito das edições permitiu até que, durante certo período, os rendimentos da Escorpião ajudassem a financiar a editora Afrontamento. "Uma parte das edições era distribuída pela Afrontamento ficando todo o produto dessas vendas para a esta editora", revela Barrote.

Outro fator que ajudava nas boas vendas eram os preços baixos. A maior parte dos livros da Escorpião e da Textos Exemplares era formada de pequenos volumes, de menos de cem páginas e formato também pequeno $(10,5 \mathrm{~cm} \mathrm{X} 18 \mathrm{~cm})$. De acordo com Barrote, isso gerava economia nos custos de produção e

permitia ter preços, às vezes, para o mesmo volume de texto, $40 \%$, $50 \%$ mais barato que os concorrentes. Havia livros a custar 15 escudos, o que significaria hoje vender livros a dois ou três euros. E a margem bruta era superior a $100 \%$ para o editor, com pagamento a 30 dias, com direitos pagos, com traduções pagas a valores superiores aos do mercado. E a cada reedição os tradutores eram novamente remunerados. E isso tinha retorno, as pessoas faziam o seu trabalho e se sentiam retribuídas condignamente.

Essa filosofia estava na base do trabalho editorial de Barrote: "Que sentido haveria em fazer publicações como essas e depois funcionar como empresário capitalista strictu sensu? Era capitalista, é evidente, havia uma apropriação da minha parte, mas uma apropriação com uma distribuição que saía fora do sistema". Isso se 
refletia também na comercialização de parte dos livros:

Toda agremiação de esquerda que batesse à minha porta dizendo que queria livros da Escorpião pra vender, eu dizia: “A Escorpião só vende para um distribuidor. Então, vocês vão à tipografia, levantam os livros, deixam uma nota dizendo quantos livros pegaram. Têm é que vender os livros ao mesmo preço que a distribuidora. Se houver algum desconto, numa banca, seja lá onde for, se houver reclamação da distribuidora, vocês não pegam nem mais um livro". Se me perguntar quantos livros foram ou não foram [distribuídos dessa forma] eu não sei. Quando eu pegava a nota eu rasgava e jogava fora. Isso não é altruísmo, para mim era um comportamento absolutamente básico, elementar, de postura social. A mais-valia que eu tinha que administrar, que era fruto do trabalho de um grupo de pessoas que estava à minha volta, não era minha, eu era uma peça. A minha visão de vida, das relações, não é senão essa. Eu tinha dinheiro para pagar a mais-valia coletiva que vinha do trabalho coletivo. Eu era o pião, o pivô daquilo tudo, mas eu não fazia nada sem aquela gente. E isto assumido até as últimas consequências é assim, não é de outra maneira. Pagava o que as pessoas diziam que o trabalho valia. Porque o dinheiro era bastante. Em 1974 eu faturei da ordem de milhares de contos, era uma coisa...

Perguntado sobre o que mudou na sua atuação como editor com o 25 de Abril, Barrote responde de chofre: "Nada". Mas em seguida completa:

Quer dizer, passamos a editar sem receios, essa foi uma mudança. As vendas aumentaram, passamos a vender sem restrições, desse ponto de vista as coisas ficaram mais fáceis. Mas não me facilitou nada a qualidade do trabalho, as dificuldades com os tradutores etc. Houve até um cuidado maior em não publicar certas coisas que eram solicitadas, por exemplo, publicar textos marxistas-leninistas. Houve alguma pressão para isso, pessoas da [distribuidora] Dinalivro pediam isso, diziam, "você está a perder dinheiro".

Houve também, após o 25 de Abril, algumas rusgas com certos setores da esquerda, em função de alguns títulos publicados, que faziam críticas à União Soviética e aos seus aliados. "Houve alguns velhos conhecidos meus que chegaram a dizer: 'Depois, quando nós chegarmos ao poder, tu vais ver'. E eu dizia: 'Ó pá, então a PIDE não me assustava e são vocês agora que me vão assustar?'. Mas não publicar aquelas coisas seria uma traição à verdade".

A trajetória de João Barrote como editor foi abruptamente interrompida em 1979, quando ele teve um colapso que afetou gravemente sua saúde e teve que se afastar do trabalho editorial. Sem a sua presença, as edições não tiveram continuidade.

As Publicações Escorpião editaram pouco mais de 50 títulos, o último dos quais em 1978. A empresa esteve comercialmente ativa até o começo dos anos 1980. A Textos 
Exemplares fez a sua última edição em 1977, e no total publicou dez títulos.

Perguntado se acha que conseguiu atingir alguns dos propósitos a que se propôs como editor, inclusive aquele de atuar nas margens do sistema, ser um “editor/contraditor" (nome de uma das coleções da Escorpião) e cumprir um papel político, Barrote responde:

Acho que sim. Acho que essa intenção foi conseguida, realizada, com que repercussão ou impacto isso não é possível avaliar. $\mathrm{O}$ reconhecimento do trabalho em termos editoriais foi geral, e o reconhecimento da qualidade da informação veiculada é incontestável. Só posso pensar que valeu a pena, que consegui o que foi possível, os objetivos que eu tinha em vista, que eram intenções, não havia objetivos precisos.

E completa, referindo-se não só às editoras que dirigiu, mas ao conjunto de editoras de caráter político que atuou em Portugal naquele período: “O papel destas editoras foi real, mas limitado. Não se muda o mundo com livros. Os destinatários eram pessoas, muita gente terá se beneficiado disso, não tanto da literatura de caráter mais político, mas dos conteúdos sociológicos etc.”.

Atualmente, João Barrote e Amélia dedicam-se à agricultura orgânica (biológica) em Arnoia (concelho de Celorico de Basto, distrito de Braga). Ele tem planos de voltar a editar (e reeditar).

\subsection{Assírio \& Alvim}

R. Passos Manuel, 67-B, Lisboa

Editores: José Antunes Ribeiro, João Carlos Alvim, Assírio Bacelar, Mário Reis e Carlos Alberto Caeiro.

Início das edições: 1973.

Distribuição: Própria.

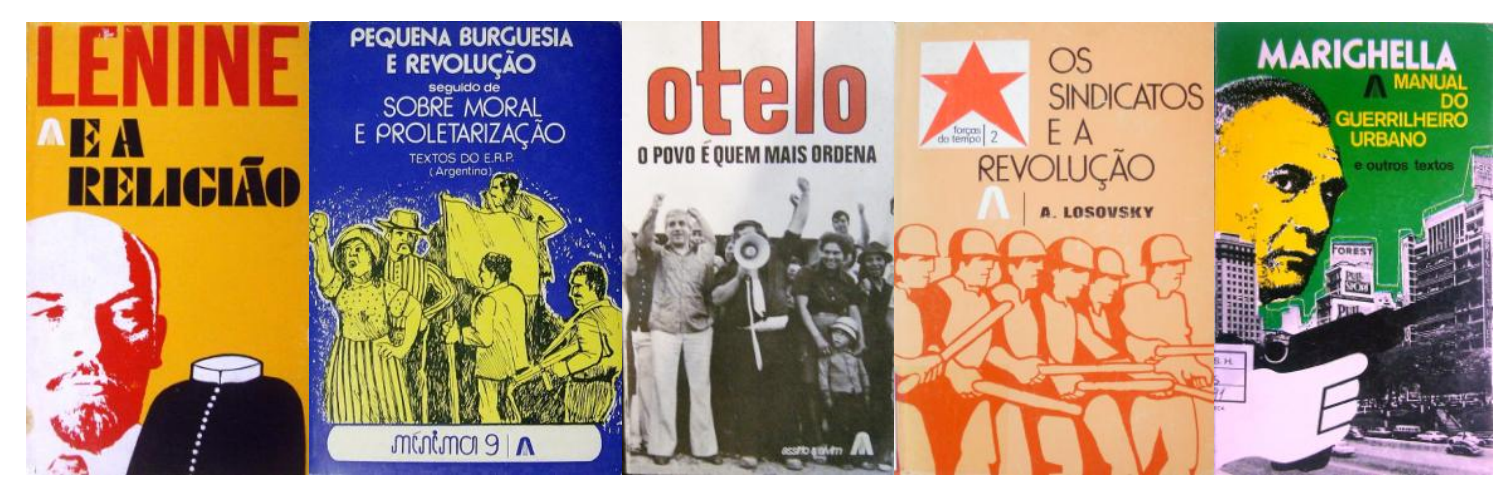

A Assírio\&Alvim surgiu da parceria entre José Antunes Ribeiro, que fora o criador da editora Ulmeiro (ver Capítulo 8), e João Carlos Alvim, que era à época 
jornalista e tinha 22 anos. Alvim desejava sair do jornalismo e, com recursos obtidos junto à sua mãe, procurou Ribeiro, da editora Ulmeiro, no começo de 1972, e lhe propôs tornar-se seu sócio na editora. Ribeiro contrapropôs que seria melhor criarem uma nova editora, em virtude dos problemas que a Ulmeiro enfrentava com a PIDE ${ }^{90}$. Juntaram-se a eles Mário Reis (que depois criaria a livraria Arco-Íris), Assírio Bacelar (que criaria a editora Vega) e Carlos Alberto Caeiro, este último o "sócio-capitalista invisível", de acordo com a definição de José Ribeiro ${ }^{91}$. Caieiro era funcionário público e entrou com fundos que possibilitaram que a editora tivesse desde o começo uma sede própria ${ }^{92}$. Foram estes cinco sócios que fundaram em novembro de 1972 a Assírio\&Alvim, que seria editora e distribuidora.

Como lembra João Carlos Alvim:

Nós éramos todos muito jovens, muito idealistas, com muito pouca prática em coisas essenciais, como a gestão, por exemplo, e o resultado foi que ao fim de um ano e pouco a Assírio\&Alvim estava tecnicamente falida. A editora entrou numa fase muito convulsionada e rapidamente se transformou numa cooperativa de trabalhadores. Havia muitos trabalhadores dentro. Ainda a Assírio\&Alvim não tinha publicado um único livro e já havia 22 pessoas a trabalhar lá. ${ }^{93}$

Ribeiro levou para a Assírio\&Alvim muitas das editoras que eram distribuídas pela Ulmeiro, particularmente editoras espanholas, o que permitiu que a nova casa começasse já com um bom patamar comercial.

Um dos primeiros livros editados, Portugal sem Salazar, lançado em outubro de 1973, foi proibido pela censura, sob a acusação de que a obra fazia a apologia "do desmembramento da mãe-pátria”, o que gerou um processo contra a editora ${ }^{94}$. O livro trazia uma entrevista com Manuel Lucena, e uma mesa-redonda com António Barreto, Eurico de Figueiredo, Medeiros Ferreira e Valentim Alexandre, figuras da oposição à ditadura que se encontravam naquele momento exiladas. $\mathrm{O}$ trabalho jornalístico do livro foi realizado por Mario Mesquita. O objetivo da obra era debater "as modificações operadas na conjuntura política portuguesa após a morte do antigo mestre de

\footnotetext{
${ }^{90}$ Entrevista com João Carlos Alvim, Lisboa, 16/2/2011; Entrevista com José Antunes Ribeiro, Lisboa, 2/2/2011.

${ }^{91}$ Entrevista com José Antunes Ribeiro, Lisboa, 2/2/2011.

${ }^{92}$ Conferência de José Antunes Ribeiro. Ciclo de Debates Livros que Tomam Partido. Lisboa, BibliotecaMuseu República e Resistência, 13/3/2011.

${ }^{93}$ Entrevista com João Carlos Alvim, Lisboa, 16/2/2011. Todas as falas de Alvim que aqui aparecem provêm dessa entrevista.

${ }^{94}$ Conferência de José Antunes Ribeiro, op. cit.
} 
Coimbra" ${ }^{95}$. Esse foi o caso mais grave de cerceamento às atividades da Assírio\&Alvim.

Antes do 25 de Abril foram editados os seguintes títulos políticos: Sexualidade e repressão, de Carlos Castilla del Pino; Linguagem e criação, de José Martins Garcia; $O$ que deve saber-se sobre a sexualidade, obra coletiva; Sade/Masoch, de Giles Deleuze; A China e as raízes da sinofobia ocidental, de Maria-Antonieta Macciocchi e outros; Carta ao general Franco, de Arrabal; e A revolta do grelo, de Vasco Pulido Valente.

No período inicial da editora, Ribeiro era uma espécie de diretor-geral, Alvim responsabilizava-se pela direção editorial, Assírio Bacelar pelo setor comercial. "Mas como éramos também um grupo de amigos, as fronteiras não eram tão rígidas como seria hoje numa empresa mais organizada. Na verdade havia um diálogo permanente", lembra Alvim.

Dentro do clima de agitação política vigente a partir do 25 de Abril - e também devido aos problemas econômicos que logo sobrevieram - a editora foi transformada em uma cooperativa gerida pelos seus trabalhadores.

Alvim salienta que o projeto da editora estava ligado a uma postura de oposição à ditadura, mas não ia muito além disso em sua origem:

Não havia ideias muito precisas, para falar com franqueza. A impressão que tenho é que nós queríamos divulgar livros que o regime não permitia facilmente que fossem divulgados por cá, e acho que as coisas não iam muito para além dessa ideia vaga. Depois foi a própria prática de todos os dias que acabou fazendo com que a editora se encaminhasse em alguns sentidos e não em outros.

Mas ele ressalta que o viés político teve importância para a criação da editora:

Havia seguramente um fundo político, que era mais presente em alguns de nós do que em outros. Era seguramente muito presente no Zé Ribeiro, desse ponto de vista de certa maneira ele liderou, porque ele de fato estava muito comprometido politicamente com movimentos à esquerda. No meu caso não era bem isso, eu queria fazer oposição ao regime mas não tinha ideias muito claras de como fazê-lo, e queria editar, basicamente era isso.

No período de funcionamento como cooperativa houve mudanças na sistemática de organização da editora, e as decisões sobre o que seria publicado passaram a ser definidas em assembleias dos cooperantes. "A linha editorial chegou a ser alvo de ple-

\footnotetext{
${ }^{95}$ MESQUITA, Mario. Portugal sem Salazar. Entrevistas de Mario Mesquita. Lisboa: Assírio\&Alvim, 1973 , p. 5.
} 
nário. As escolhas eram sempre assumidas coletivamente. Essa foi, ao mesmo tempo, a maior força e fraqueza da casa", recorda Alvim ${ }^{96}$. Essa forma de funcionamento durou até o começo dos anos 1980, quando a editora deixou de ser cooperativa e voltou a ser uma sociedade por cotas, como havia sido originalmente ${ }^{97}$.

João Carlos Alvim sintetiza o modo como funcionava a editora até o início dos anos 1980:

Nós tínhamos todos os tiques do amador e do pequeno editor. Aquele de nós que já não era amador, porque tinha práticas anteriores de edição, era o Zé Ribeiro, mas o Zé tinha estado sempre ligado a uma edição muito militante e muito artesanal, e portanto transpôs pra ali a mesma perspectiva, muito respeitável, mas era essa perspectiva limitada.

Os resultados comerciais da editora, de acordo com Alvim,

nunca foram na escala de best-sellers, vendíamos 2 mil ou 3 mil exemplares de cada título ao fim de meia dúzia de meses, o que hoje é muito bom, mas na altura não era tão bom assim. Aqueles fenômenos de vender 10 mil exemplares de um título não me recordo de ter acontecido por lá.

Aos poucos todos os sócios fundadores abandonaram a editora, a começar por Carlos Caeiro, que passou suas cotas para Ribeiro. Este, por sua vez, deixou editora no começo de 1975 - quando detinha a maioria das cotas da Assírio\&Alvim -, cansado dos constantes conflitos internos. João Carlos Alvim é o último dos fundadores a sair, em 1981, quando era um dos cooperados da editora.

Mesmo após a transformação em cooperativa a situação financeira continuou a ser "catastrófica", diz Alvim:

Não houve injeção de capital, ninguém tinha posto um tostão depois disso, tinha-se que sobreviver só com o que se vendia. $\mathrm{O}$ trabalho seguia pelo fato de todos nós, cooperantes, estarmos dispostos a trabalhar sem praticamente receber nada durante muito tempo. Eu lembro-me que durante anos, já depois de 1976, e até a minha saída de lá, chegava a sexta-feira - porque as pessoas estavam a receber a semana, não havia capacidade de pagar por mês - e se fazia uma espécie de reunião magna, via-se um pouco o que havia a receber dos vários postos de venda e havia alguns de nós que, como os cavaleiros da távola redonda, partiam em várias direções para ver se recebiam alguma coisa. Depois, ao fim do dia, juntava-se o que se havia

\footnotetext{
96 “Manuel Hermínio Monteiro (1952-2001) - Uma memória". Texto originalmente publicado por Felipa Melo em Visão, $\mathrm{n}^{\circ}$ 245, nov. 1997. Disponível em: <http://coracaoduplo.blogspot.com/2010/11/manuelherminio-monteiro-1952-2001-uma.html>. Acesso em jun. 2012.

${ }^{97}$ Entrevista com João Carlos Alvim, Lisboa, 16/2/2011.
} 
conseguido e distribuía-se para que as pessoas tivessem ao menos dinheiro no fim de semana. Isto evidentemente era insuportável. Para a maioria dos cooperantes aquela era a única fonte de renda.

Tal situação só se mantinha porque as pessoas envolvidas estavam profundamente engajadas no projeto da Assírio\&Alvim, o que, para João Carlos Alvim, tinha aspectos positivos e negativos:

As pessoas que acabaram por ficar lá nesta fase viveram aquilo como uma coisa que não era muito diferenciável de suas próprias vidas particulares. Foram frequentes os casos de paixão entre pessoas, como foram frequentes os casos de ódios e de zangas. Porque justamente aquilo não era uma coisa só profissional, era uma coisa em que as pessoas estavam muito por paixão. [...] E como as pessoas estavam muito envolvidas em termos pessoais, e até umas com as outras, quando as coisas se misturam dessa forma, evidentemente que há sempre conflitos.

Mas deve-se destacar que, mesmo nesse período, os livros editados pela Assírio\&Alvim tiveram um padrão gráfico e editorial altamente profissional. Apesar do grande número de sócios da cooperativa, o trabalho de revisão era feito todo por freelancers pagos por serviço e externos à editora ${ }^{98}$.

Apesar da Assírio\&Alvim ter se mantido independente de grupos políticos, houve ocasiões em que não escapou às conjunções dos anos quentes de 1974 e 1975. Por exemplo, de acordo com José Antunes Ribeiro, durante algum tempo a policopiadora da editora foi utilizada para imprimir comunicados da Intersindical $^{99}$, central sindical ligada ao PCP.

Outro exemplo interessante do reflexo das disputas políticas de setores da esquerda dentro da editora é o "Prefácio" do livro China, país capitalista ou socialista, organizado por Lucília Cardoso Salgado (novembro, 1975). O livro traz uma "Introdução", assinada por José P. Rebelo, em que se analisa a tomada do poder na China pelo Partido Comunista e a Revolução Cultural. Em seguida, são apresentados "textos de diversas origens sobre a luta de classes da República Popular da China" $" 100$. O prefácio (não assinado, mas supõe-se que seja da organizadora) diz em certo ponto:

$\mathrm{Na}$ verdade, nós não estamos de acordo com os pontos de vista defendidos nesses textos. Ainda que eles procedam de uma tentativa de análise crítica da política chinesa, tal crítica permanece no terreno

\footnotetext{
${ }^{98}$ Idem.

${ }^{99}$ Conferência de José Antunes Ribeiro, op. cit.

${ }^{100}$ Os textos são de autoria de A. Sofri (Lotta Continua), do Progressive Labor Party e dos Comitês Comunistas Revolucionários.
} 
dessa mesma política, dela não se conseguindo libertar. [...] No entanto, achamos importante a divulgação destes textos; não é na ignorância de outras ideias diferentes das "ideias justas" que se podem formar opiniões fundamentadas sobre a sociedade, que nos ajudem a lutar contra a exploração de que somos vítimas e a encontrar o modo de transformar o mundo. ${ }^{101}$

As principais coleções da editora na sua fase inicial foram Cadernos Peninsulares (dando continuidade à coleção iniciada na editora Ulmeiro), Mínima, Temas Internacionais, Forças do Tempo e Textos de Ciências Sociais, entre outras.

Eis alguns títulos, editados após o fim da ditadura, que mostram o ecletismo da Assírio\&Alvim: O problema colonial, de J. Pedro Capitão (1974); Lenine e a religião (1974); A queda do fascismo: Maio, 1974, de António Ferreira (1974); 100.000 relógios sem patrão (Processo LIP), de François-Henri de Virieu (1974); A corrupção do poder, de Peter Dale Scott e Frank Browing (1974); As três fontes do marxismo, de Karl Kautsky (1975); Cartas da prisão, de Rosa Luxemburgo (1975); A guerrilha do Che, de Régis Debray (1975); Manual do guerrilheiro urbano e outros textos, de Carlos Marighella (1975); Sobre a estratégia global da revolução brasileira, de José Crispim (1975); Tito e a revolução, de Marcel Veyrier (1976); O Congo de Lumumba: história de um assassinato político, de Adérito Lopes (1976); Os comunistas dos conselhos e a III Internacional, de Pannekoek, Lukacs, Bordiga e outros (1976); O marxismo e a questão nacional, de Stalin (1976); Deus e o Estado, de Bakunine (1976); Capitalismo e esquizofrenia. Dossier Anti-Édipo, de Deleuze, Guattari, Lyotard e outros (1976); A Frente Popular Antifascista em Portugal: o primeiro esboço da unidade antifascista, de Afonso Manta (1976); O povo é quem mais ordena, de Otelo Saraiva de Carvalho (1977); A Internacional Comunista, de Dominique Desanti (1977); Breve história do pensamento e das lutas sociais em Portugal, de Edgar Rodrigues (1977); Elementos para a história do movimento operário em Portugal, de Ramiro da Costa (1979).

Mas devemos lembrar que a Assírio\&Alvim desde o seu primeiro ano de atuação também editava poesia e obras de ficção, nunca tendo sido uma editora voltada exclusivamente para a política. Para Alvim, “olhando para trás, os livros editados pela Assírio\&Alvim em 1974 e 1975 eram na sua esmagadora maioria panfletários”. No começo da década de 1980, todavia, a editora já havia adquirido um cariz marcadamente literário, com a publicação de autores como Herberto Helder, Mario

101 "Prefácio". In: SALGADO, Lucília Cardoso (org.). China, país capitalista ou socialista. Lisboa: Assírio\&Alvim, 1975, p. 5-6. 
Cesariny, Ruy Belo e Ernesto de Mello e Castro ${ }^{102}$, até em função da diminuição das edições políticas como decorrência da normalização ocorrida no país.

A partir de 1983 a Assírio\&Alvim passou a ser dirigida por Manuel Hermínio Monteiro - que havia entrado na editora como vendedor ainda em 1974 -, caracterizando-se como editora literária, com ênfase na poesia ${ }^{103}$. "O Hermínio de certa forma sistematizou aquela linha literária que já havia sido iniciada, e eliminou aos poucos tudo aquilo que era político ou sociológico. Ele afunilou o campo de atuação, dando coerência ao projeto da editora", avalia Alvim. "Tiro-lhe o chapéu por ter conseguido afirmar a Assírio como um exemplo único de reconversão de sucesso" ${ }^{\text {"104, }}$, conclui.

Analisando-se os títulos publicados, podemos concluir que desde as suas origens a Assírio\&Alvim foi uma editora que pretendeu ir além da política, abordando outros temas e dando destaque à literatura. Durante o período de 1974 a 1977 houve um claro predomínio da edição política, que decai a partir de então, até praticamente deixar de existir na segunda metade dos anos 1980.

Entre 1973 e 1982, a editora publicou mais de 70 títulos de caráter político. A Assírio\&Alvim continua em atuação até os dias de hoje. A partir de 2012 passou a fazer parte do Grupo Porto Editora, um dos maiores grupos editoriais portugueses.

\subsection{N. A.* Orion}

Rua 2 à Rua Prof. Egas Moniz, Lt. 4 - Buraca - Amadora

Editor: Orlando Gonçalves.

Início das edições: 1973.

Distribuição: própria

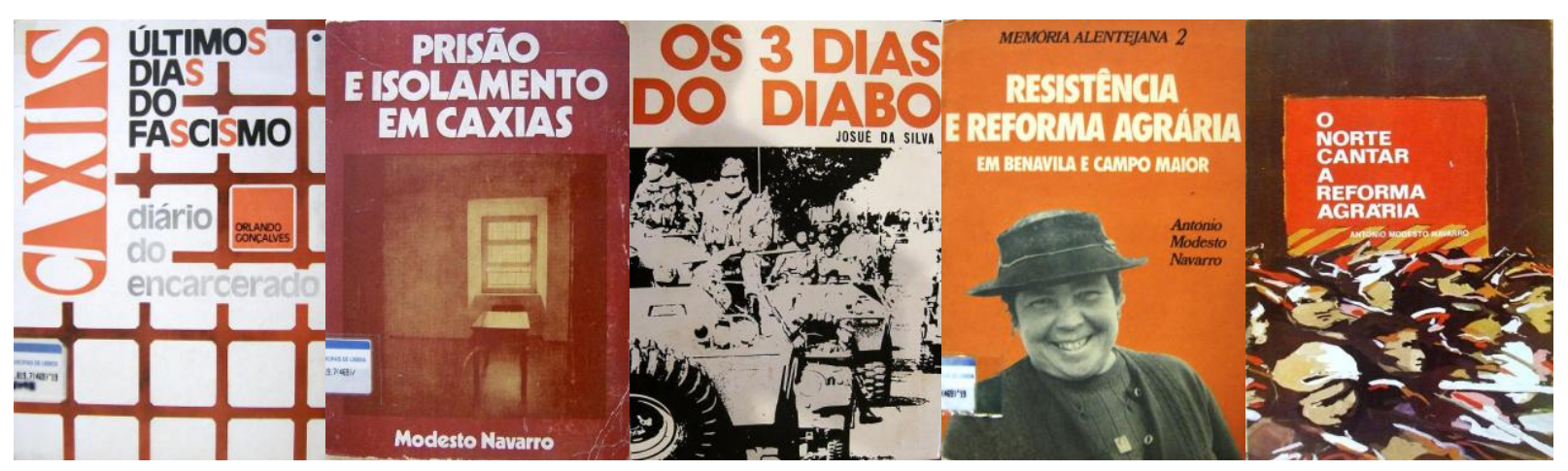

\footnotetext{
${ }^{102}$ Entrevista com João Carlos Alvim, Lisboa, 16/2/2011.

${ }^{103}$ Hermínio Monteiro. 1952-2001: Editor. Lisboa: Câmara Municipal de Lisboa, Comissão Municipal de Toponímia, 2005, p. 4.

104 “Manuel Hermínio Monteiro (1952-2001) - Uma memória”, op. cit.
} 
A Editora N. A.*Orion surgiu em 1973. Suas origens remontam a 1954, quando o jornalista Orlando Gonçalves criou a Editora Orion, juntamente com António Miguel Mendes, a qual manteve-se em atividade até o início da década de $1960^{105}$. Mas antes disso Gonçalves já havia tido outras duas experiências na área editorial, primeiro em 1950, quando foi um dos fundadores do Centro Bibliográfico, "uma editora que editou, entre outros, José Gomes Ferreira, Eugénio de Andrade, José Fernandes Fafe, Antunes da Silva, Orlando da Costa e Alexandre Cabral", de acordo com Orlando César, filho de Orlando Gonçalves ${ }^{106}$. E em 1951 lançou e dirigiu a Colecção Horizonte, com antologias de contos e novelas de diversos autores, que foi apreendida pela Polícia de Vigilância e Defesa do Estado (PVDE) ${ }^{107}$, antecessora da PIDE.

Em 1963 Gonçalves tornou-se proprietário e diretor do jornal Notícias da Amadora, função que ocupou até sua morte, em $1994^{108}$. Entre 1963 e 1973, a censura e a polícia política não autorizaram que o nome de Gonçalves constasse como diretor do jornal, por isso continuou a aparecer no cabeçalho da publicação o nome do antigo diretor, Domingos Janeiro, que era amigo de Orlando Gonçalves ${ }^{109}$. Orlando César explica porque isso acontecia:

A recusa da Censura baseava-se na informação da PIDE (registada nas fichas guardadas no Arquivo Nacional da Torre do Tombo) que dava Orlando Gonçalves como "adversário do Estado Novo" (1946) ou como "elemento de tendências comunistas, não dando garantias de cooperar na realização dos fins superiores do Estado" (1964). Orlando Gonçalves solicitou autorização para figurar como director pelo menos cinco vezes, tanto com Salazar como com Caetano, e foi sempre recusado. Todavia, era com Orlando Gonçalves que a Censura e a Secretaria de Estado da Informação e Turismo tratavam tudo o que respeitava ao jornal. ${ }^{110}$

Somente após o 25 de Abril o nome de Gonçalves pôde aparecer no cabeçalho do jornal como seu diretor ${ }^{111}$.

\footnotetext{
${ }^{105}$ Mensagem eletrônica de Orlando César enviada em 10/10/2012.

${ }^{106}$ Idem.

107 Idem.

108 "Notícias de Orlando Gonçalves". Blogue Liberdade e Cidadania. Disponível em: <http://www.noticiasdaamadora.com.pt/nad/texto.php?cod=orlandogoncalves $>$. Acesso em 30/9/2012.

${ }^{109}$ Mensagem eletrônica de Orlando César enviada em 1/11/2012.

${ }^{110}$ Idem.

${ }^{111}$ Orlando César detalha o que ocorreu antes disso: "Em 1973, Domingos Janeiro pediu que o seu nome fosse retirado do cabeçalho do jornal. Sem que tivesse obtido autorização, Orlando Gonçalves figurou como diretor durante 14 edições. Mas foi proibido, o que levou a indicar o nome de Sérgio Ribeiro para o cargo (em que figurou durante 11 edições). Também proibido, foi indicado e aceite o nome de Carlos Carvalhas. Este episódio levou a que, após o 25 de Abril, o nome dos três figurasse como direcção colectiva durante algumas edições". Mensagem eletrônica de Orlando César enviada em 1/11/2012.
} 
O jornal Notícias da Amadora destacou-se, a partir de 1963, como um dos portavozes da oposição democrática à ditadura, reunindo em sua redação e entre os colaboradores, muitos de seus simpatizantes. Entre estes, "são os activistas do PCP (particularmente dos sectores intelectuais e sindicalistas) que mais contribuem para a expansão do jornal". E fazem-no de duas formas: "como colaboradores e fontes de informação; e como angariadores de novos assinantes" ${ }^{\text {112 }}$. Orlando César destaca que:

O jornal empenha-se na divulgação das acções desenvolvidas pelos oposicionistas nas eleições legislativas de 1969 e 1973, no congresso [da oposição] de 1973, mas também da actividade dos deputados da ala liberal do regime (legislatura iniciada em 1969). Noticia de forma activa todas as acções de sindicalistas e as lutas laborais, desencadeadas a partir de 1970, com a criação da estrutura ilegal da Intersindical, constituída por um grupo de sindicatos, entre eles o dos jornalistas. $^{113}$

Assim, o jornal manteve ligações com amplos setores da oposição democrática, neles incluídos os comunistas, socialistas, católicos progressistas e ativistas sem partido antes do 25 de Abril. Com a queda de Marcelo Caetano, o jornal manteve ligações com o Movimento Democrático Português/Comissão Democrática Eleitoral (MDP-CDE) e, por via deste, ao $\mathrm{PCP}^{114}$, mas também com o PS e outros setores ${ }^{115}$.

Nos anos 1960-70 o jornal também fez a distribuição de livros da Edições Imbondeiro, de Angola, dirigida pelo escritor Garibaldino de Andrade ${ }^{116}$.

Em 1973, quando o Notícias da Amadora passou a ter uma tipografia própria, Gonçalves começou a editar livros sob a chancela N. A.*Orion - em que "N.A." eram as iniciais do nome do jornal. Esta iniciativa representou uma espécie de fusão das experiências editorias e jornalísticas de Gonçalves, sempre de modo coerente com seu posicionamento político de oposição. A Editora N. A.*Orion era, dessa forma, intimamente ligada ao jornal Notícias da Amadora, e até mesmo dependente deste.

No ano de criação da editora foi lançado apenas um título: Raízes da nossa força, com texto de Helena Neves e fotos de Alfredo Cunha. Textos e fotos uniam-se, no livro, para mostrar a verdadeira situação social do país, constituindo "um acto de

\footnotetext{
112 Mensagem eletrônica de Orlando César enviada em 19/10/2012.

${ }^{113}$ Idem.

114 "Por esta altura há 41 anos...". Boletim Holos, $\mathrm{n}^{\circ}$ 45, fevereiro de 2008. Disponível em: <http://www.gdctincm.org/pdf/holos/holos_45.pdf>. Acesso em 23/7/2011.

${ }_{115}$ Mensagem eletrônica de Orlando César enviada em 1/11/2012.

${ }^{116}$ Mensagem eletrônica de Orlando César enviada em 10/10/2012.
} 
denúncia" ${ }^{117}$. O livro foi apreendido pela PIDE/DGS ${ }^{118}$.

A tipografia, além de produzir o jornal e os livros da N. A.*Orion, executava também serviços para outros clientes, como sindicatos, outras editoras e edições de autor. "As buscas da polícia política à tipografia eram constantes, com algumas apreensões de material (livros)", lembra Orlando César. "Passou-se a utilizar estratégias para evitar apreensões. Por exemplo: levar o material impresso para outras casas e trazêlo depois em quantidades adequadas ao trabalho diário, que possibilitassem os acabamentos e entrega ao cliente (editora)", recorda $^{119}$.

Poucos dias antes do fim da ditadura, "as instalações da tipografia do jornal foram assaltadas pela Direcção-Geral de Segurança (DGS), que sucedeu à PIDE, e Orlando Gonçalves foi preso. A DGS tencionava encerrar a tipografia e o jornal, mas antes que isso acontecesse deu-se o 25 de Abril", continua Orlando César ${ }^{120}$.

Após o 25 de Abril, o Notícias da Amadora "perdeu quadros e a importância que tivera", pois "não tinha meios para competir" com os outros jornais de maior envergadura, "e perdeu parte significativa dos seus redactores e colaboradores" ${ }^{121}$. Pode-se dizer, de certa forma, que a vitória da revolução teve efeito paradoxal para o Notícias da Amadora, pois se por um lado representava o objetivo pela qual o jornal sempre lutara, por outro acabou por tirar-lhe muito da capacidade de intervenção que tinha. Como lembra Orlando César, após o fim da ditadura:

Orlando Gonçalves passou a exercer funções de presidente da Câmara Municipal [prefeito] de Oeiras, Carlos Carvalhas foi para o Ministério do Trabalho, Sérgio Ribeiro passou a exercer funções políticas também na área do trabalho, vários jornalistas entraram para redacções de jornais diários e rádios. ${ }^{122}$

A atuação da Editora N. A.*Orion poderia significar um contrapeso a esta situação, uma vez que foi após o 25 de Abril que a editora passou a ter maior atividade. Mas efetivamente isso não aconteceu, já que o número de títulos lançados pela N.A.*Orion foi sempre pequeno, em média apenas dois por ano.

Dos livros lançados ainda em 1974, dois traziam testemunhos sobre as prisões políticas do salazarismo: Caxias: últimos dias do fascismo (Diário do encarcerado), de

\footnotetext{
${ }^{117}$ Idem.

${ }^{118}$ Esta informação é apresentada em outros livros da editora publicados após o 25 de Abril.

${ }^{119}$ Mensagem eletrônica de Orlando César enviada em 19/10/2012.

${ }^{120}$ Idem.

${ }^{121}$ Idem

${ }^{122}$ Idem.
} 
Orlando Gonçalves (julho, 1974); e Prisão e isolamento em Caxias: uma breve experiência, de António Modesto Navarro (setembro, 1974).

Modesto Navarro, aliás, foi o autor com maior número de títulos publicados pela editora: seis obras.

Destaco a seguir outras obras de caráter político editadas. Em 1975 foi lançado o livro Mulheres de um tempo ainda presente, de Helena Neves, com crônicas escritas antes do 25 de Abril sobre a situação das mulheres durante a ditadura.

Em 1976 temos o livro Os três dias do diabo: narrativas, de Josué da Silva, que apresentaria a "primeira perspectiva de esquerda (em livro) sobre o 25 de Novembro", de acordo com o texto da contracapa do livro.

No ano de 1977 surge $O$ norte cantar a reforma agrária; poemas, de Modesto Navarro. Este mesmo autor publicou mais duas obras na coleção Memória Alentejana: Memória Alentejana: a vida no Alto Alentejo nas últimas décadas, a resistência e a reforma agrária (1977); e Resistência e reforma agrária: em Benavila e Campo Maior (1978). Esta coleção foi prevista como "uma série de três [volumes] dedicada ao levantamento da vida no Alentejo nas últimas décadas, ao conhecimento do que foi a Resistência ao fascismo e do que é a luta pela Reforma Agrária" ${ }^{123}$. No entanto, o terceiro volume não foi editado.

A N. A.*Orion publicou também obras de Maria Luísa Gonçalves e Carlos Pinhão. Entre 1973 e início dos anos 1980, editou cerca de 15 títulos. Ao que parece, encerrou suas atividades no começo da década de 1980.

Editora com poucas obras publicadas, a N. A.*Orion foi uma atividade subsidiária do jornal Notícias da Amadora, e parece nunca ter chegado a ganhar verdadeira autonomia como empreendimento editorial ou comercial. Como salienta Orlando César:

A actividade da N.A.*Orion era, de facto, complementar do jornal. Os livros eram impressos na tipografia, eram divulgados no jornal e adquiridos por leitores e assinantes. A maior aposta era então o jornal e não havia recursos financeiros e humanos nem liberdade para assegurar as duas frentes de forma autónoma. ${ }^{124}$

\footnotetext{
123 "Introdução". In: NAVARRO, António Modesto: Resistência e reforma agrária: em Benavila e Campo Maior. Amadora, N.A Orion, 1978, p. 5.

${ }^{124}$ Mensagem eletrônica de Orlando César enviada em 10/10/2012.
} 


\subsection{Edições Spartacus}

Apartado 4200 - Lisboa

Início das edições: 1974.

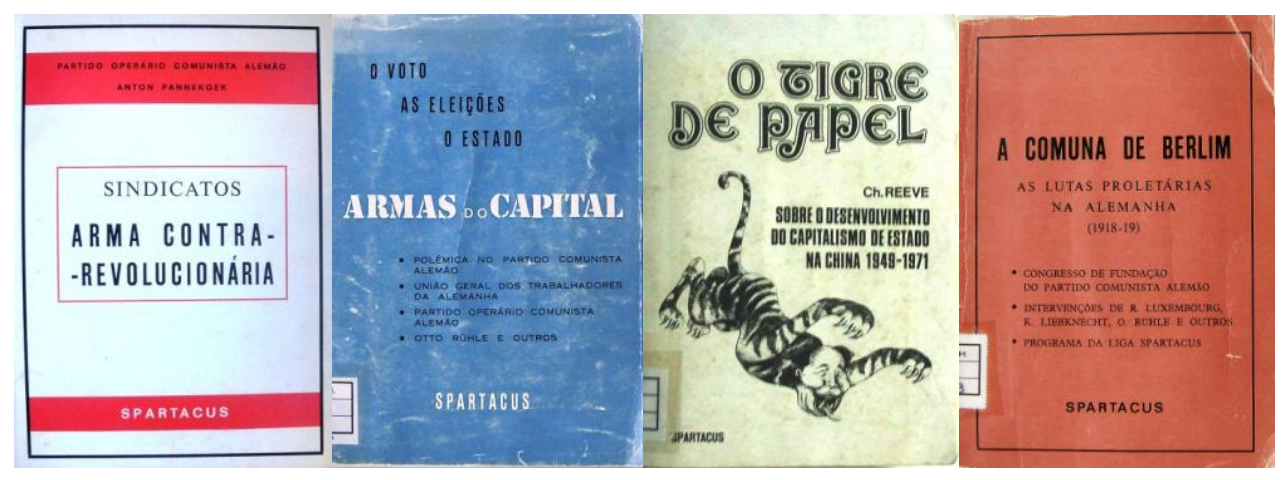

Editora surgida em 1974, e que teve entre seus animadores José Maria Carvalho Ferreira e António Caetano ${ }^{125}$. Ferreira, bem como Jorge Valadas, autor de um dos livros editados pela Spartacus (e que assinava com o pseudônimo Charles Reeve), participaram dos Cadernos de Circunstância, publicação surgida em 1967, na França. "De difícil catalogação ideológica, os Cadernos de Circunstância encontravam-se próximos das tendências autonomistas italianas que na altura floresciam e com quem mantiveram contactos"126.

Houve no mesmo período outra editora com o mesmo nome, possivelmente também ligada, em suas origens, ao grupo que inicialmente organizou a revista Spartacus no exterior, e vinculada à Organização Comunista Marxista-Leninista Portuguesa/OCMLP (ver item sobre a Editora Spartacus/OCMLP no Capítulo 5).

Entre os títulos publicados pelas Edições Spartacus predominam aqueles de crítica ao "socialismo real", inclusive ao chinês, e ao leninismo, numa linha que se poderia caracterizar como socialista/marxista-libertária, e também com ligações às ideias situacionistas. Assim, a editora acaba por distanciar-se dos vários grupos marxistas-leninistas e maoistas então existentes em Portugal.

Uma resenha do jornalista Júlio Henriques sobre o livro $O$ tigre de papel: sobre o desenvolvimento do capitalismo de Estado na China, 1949-1971, de Charles Reeve, lançado em abril de 1975, destaca esses aspectos:

Por entre as toneladas de ideologia do capitalismo de Estado postas a circular no Portugal post 25 de Abril, tanto pelos partidários da URSS como pelos da China e afins, o aparecimento de trabalhos críticos

\footnotetext{
${ }^{125}$ FREIRE, op. cit., p. 450-51.

${ }^{126}$ CARDINA, Margem de certa maneira, op. cit., p. 155; FREIRE, op. cit., p. 366-373.
} 
sobre a realidade da luta de classes naquelas sociedades não pode deixar de ser assinalado como algo de muito importante. [Este livro] é um contributo de assinalável importância para o conhecimento da sociedade real chinesa e, simultaneamente, para a desmistificação da ideologia veiculada pelos grupos maoistas portugueses, aqui e agora. $^{127}$

Os outros livros lançados pela Spartacus foram: Sindicatos: arma contrarevolucionária, de Anton Pannekoeck, Herman Gorter e Bergmann (1974); A Comuna de Berlim: as lutas proletárias na Alemanha, 1918-19 (1974); O voto, as eleições, o Estado: armas do capital (1975); Lenine e a revolução, de Anton Ciliga (1975); e A revolução social em Espanha, de Vernon Richards (1975).

Os livros das Edições Spartacus tinham um tratamento gráfico e editorial profissional. Não há informação, nos livros que consultei, sobre como era feita a distribuição comercial dos mesmos.

A Spartacus atuou de meados de 1974 até o final de 1975. Neste período localizei seis títulos publicados.

Anteriormente, nos anos 1920, houve também uma Editora Spartacus, fundada em 1924 por João Campos Lima (1877-1956), advogado e jornalista divulgador de ideias libertárias $^{128}$. Esta editora não tinha nenhuma relação com a Spartacus de 1974.

\subsection{Edições Espaço}

Braga

Editor: António Manuel Correia.

Início das edições: 1974.

Distribuição: O Século.

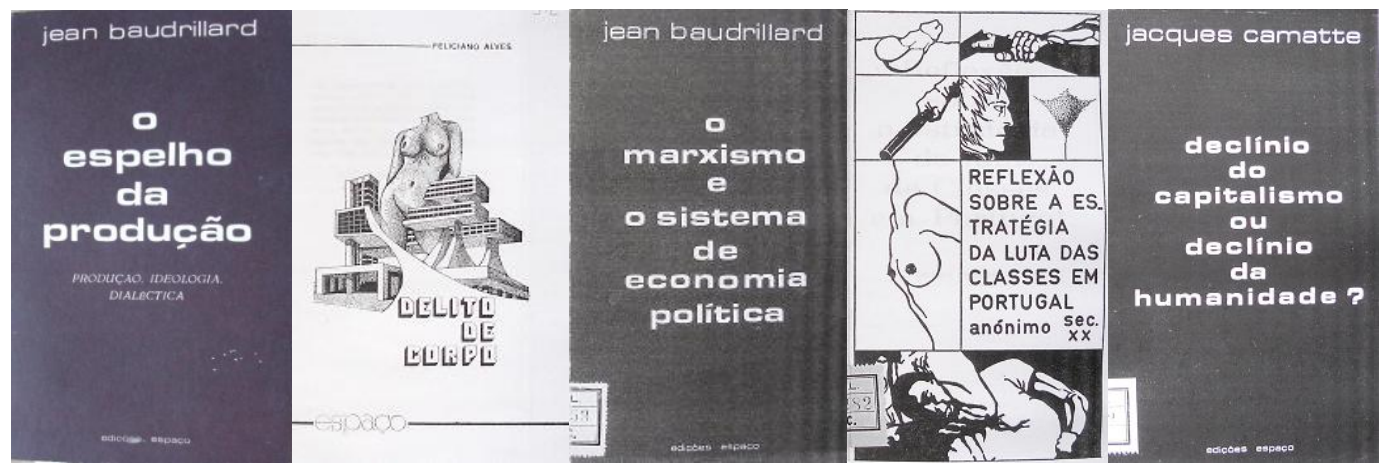

${ }^{127}$ HENRIQUES, Júlio. "O tigre de papel”. Expresso, Lisboa, 9/8/1975.

128 "Campos Lima" (Verbete). Site Almanaque Republicano. Disponível em: <http://arepublicano.blogspot.com/search/label/Campos\%20Lima)〉. Acesso em jul. 2012. 
Editora criada por António Manuel Correia na cidade de Braga, publicou seu primeiro título em 1974, já após o 25 de Abril, e parece ter encerrado suas atividades no começo dos anos 1980.

Publicou cerca de dez títulos, todos de caráter político e alinhados a um pensamento de esquerda libertário, questionador do marxismo, tanto o mais ortodoxo, do PCP, quanto o da chamada extrema esquerda e dos grupos maoistas.

Este ideário é perceptível já no primeiro título publicado pela Espaço, o livro Delito de corpo, de Feliciano Alves, em que o autor, com ironia, fazia críticas ao modo como alguns grupos de esquerda tratavam questões políticas e temas morais e comportamentais, como podemos ver neste trecho:

Consequência da cristalização de "linhas políticas injustas" e certamente alimentada por inconfessáveis "desvios revolucionários", a aplicação prática de toda esta loucura generalizada espanta os menos avisados. Que o digam o MRPP ou o Partido Comunista Português, constrangidos, numa época em que a Revolução se anuncia como qualquer coisa de francamente muito indecente, a manterem a "decência revolucionária" expulsando das suas fileiras alguns militantes ortodoxos, que "à uma" usavam nas suas reuniões políticas clandestinas tanto a cama como o quarto... [...] A existência na prática duma polícia de costumes interna, mostra-se como a única defesa possível destes "bondosos espíritos de esquerda" contra o ameaçador projecto revolucionário que lhes há-de transformar a pele em couro para calçado. Incitando aparentemente a desprezar a polícia, a prática vem demonstrando que estes grupos de ajuda filantrópica ao proletariado, desgraçada e eternamente por eles condenado à inconsciência - vide Que Fazer - Lenine - exortam na realidade a viver num mundo onde impera um policiamento asfixiante. ${ }^{129}$

Também o texto de contracapa do livro $O$ espelho da produção, de Jean Baudrillard, ajuda a entender o alcance das críticas e dos questionamentos que as Edições Espaço pretendem que seus livros divulguem:

Os conceitos de trabalho e produção estão adaptados à sociedade industrial em via de desenvolvimento? Que se entende por “organização pré-industrial”? Para tentar responder a estas questões, Jean Baudrillard examina a lição do marxismo que criou o modelo produtivista e engendrou o fetichismo do trabalho. É necessário quebrar, diz ele, o espelho da produção "onde se vem reflectir toda a metafísica ocidental" e arrancar a lógica marxista ao contexto restrito da economia política que a viu nascer. Não basta proclamar uma certa vitória do proletariado para poder pretender que a exigência de Marx,

${ }^{129}$ ALVES, Feliciano. Delito de corpo. Braga, Edições Espaço/Potlatch, 1974, p. 10. 
que era de transformar a vida, se torne realidade. ${ }^{130}$

Alguns dos títulos editados eram na verdade artigos que haviam sido publicados em revistas francesas, que o editor traduzia e transformava em pequenos livros. Este é o caso dos livros: Luta de classes na China (1975), traduzido da revista Vroutsch, série La Marge, 1973; O espelho da produção: produção, ideologia, dialéctica, de Jean Baudrillard (1976), traduzido da revista Utopie, $\mathrm{n}^{\circ}$ 5, de maio de 1972; Declínio do capitalismo ou declínio da humanidade?, de Jacques Camatte (1976), traduzido da revista Invariance, $\mathrm{n}^{\mathrm{o}} 3$, 1973; e O marxismo e o sistema da economia política, de Jean Baudrillard (1977), traduzido da revista Utopie, $\mathrm{n}^{\circ}$ 6, de fevereiro de 1973.

Outros livros publicados pela Espaço foram: Reflexão sobre a estratégia da luta de classes em Portugal, cuja autoria é atribuída a um “Anónimo do Século XX” (1976); 4 ensaios sobre a mulher, de C. Castilla del Pino (1977); Semiologia - poética epistemologia, de R. Jakobson (1978); e Roland Barthes: discurso-escrita, texto (1979).

As Edições Espaço caracterizaram-se pela coerência ideológica, que pode ser vista nos poucos títulos que editou. Sem ligações a um grupo político específico, a editora teve uma linha de publicações claramente política e que procurava promover o debate sobre questões teóricas do marxismo e a prática dos grupos de esquerda e de extrema esquerda em Portugal, a partir de textos provocativos e que buscavam apresentar ideias que fugiam aos enquadramentos comumente existentes nesses debates.

\subsection{Textos Políticos}

Porto.

Editor: Henrique A. Carneiro.

Início das edições: 1974.

Distribuição: Dinalivro.

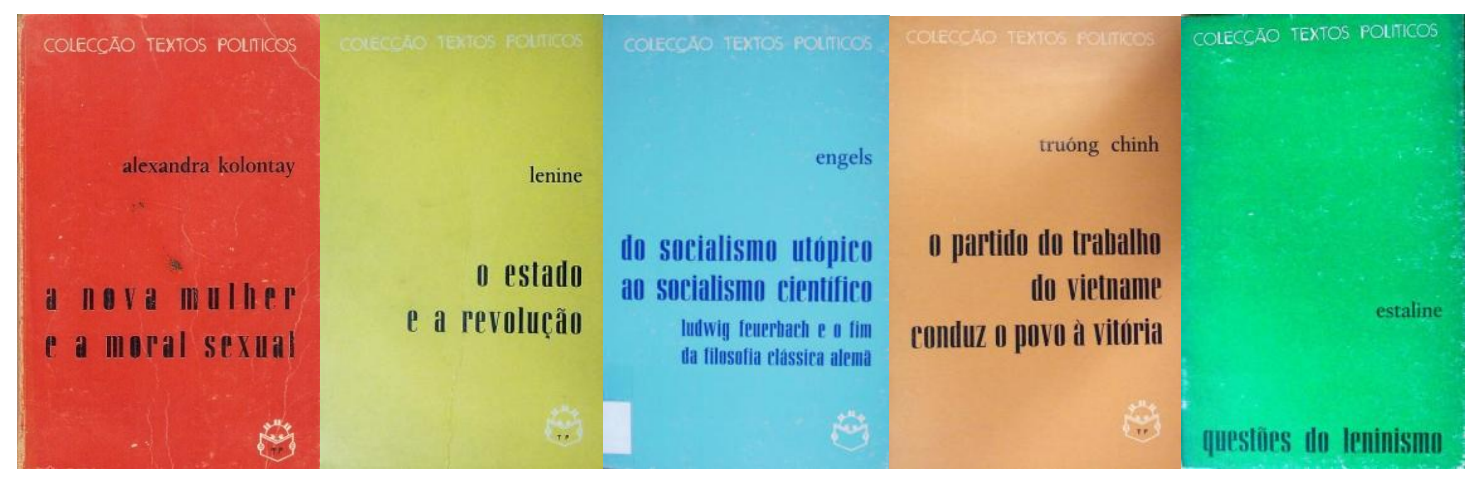

${ }^{130}$ Texto de contracapa do livro: BAUDRILLARD, Jean. O espelho da produção: produção, ideologia, dialéctica. Braga, Edições Espaço, 1976. 
Editora criada por Henrique A. Carneiro, um dos proprietários da Gráfica Firmeza, do Porto. A Gráfica Firmeza era uma pequena tipografia que, a partir do começo dos anos 1970, passou a imprimir boa parte dos livros políticos editados no Porto. Além de Carneiro, o outro sócio da gráfica era o Sr. Agostinho.

A Gráfica Firmeza teve importante papel na edição de livros de caráter político no Porto durante a ditadura ao conceder crédito a pequenos editores que publicavam esse tipo de obra. Além disso, Henrique A. Carneiro cedeu o seu nome, em inúmeros casos de edição de livros políticos, para cumprir a exigência legal de que houvesse um editor autorizado responsável pela publicação - e também para proteger os reais editores de possíveis problemas com a polícia política. Mas de fato, nesses casos, o senhor Carneiro não era o editor das obras, mas sim o tipógrafo responsável por sua impressão ${ }^{131}$.

António José Fonseca (proprietário das editoras Sementes e Estrela Vermelha, do Porto; ver Capítulo 5), lembra sobre Carneiro: “Tenho uma boa recordação dele. Como industrial aproveitou aquela época revolucionária para ganhar dinheiro. Considero que

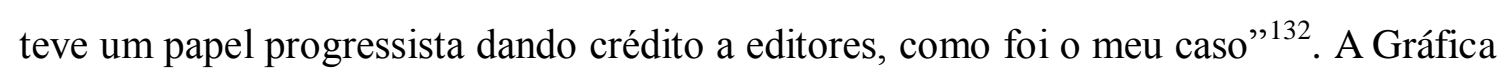
Firmeza também assegurou crédito, entre outros, para os editores António Daniel Abreu (Cadernos Para o Diálogo, Textos Marginais), João Barrote (Escorpião/Textos Exemplares) e para a editora Afrontamento.

De acordo com Fonseca, Carneiro "tinha uma ligação comercial muito forte com a Dinalivro" ${ }^{133}$, o que fez com que algumas das editoras que trabalhavam com a Gráfica Firmeza acabassem por estabelecer também uma relação comercial com essa distribuidora de livros.

A partir dessa experiência como gráfico, Carneiro resolveu ele mesmo editar alguns títulos políticos e aproveitar o grande interesse que havia, principalmente após o 25 de Abril, em relação a esse tipo de livro. Assim surgiu a editora Textos Políticos, que publicou seu primeiro livro em 1974. Era uma editora que publicava obras políticas mas que não tinha objetivos políticos ou ligações com grupos políticos.

A Textos Políticos editou principalmente obras dos principais pensadores marxistas: Marx, Engels, Lenin e Stalin.

\footnotetext{
${ }^{131}$ Entrevista com João Barrote, op. cit.; Entrevista com António Daniel Abreu, op. cit.; Entrevista com José de Sousa Ribeiro, op. cit.

${ }^{132}$ António José Fonseca lembra que a Textos Políticos teria sido criada "apenas com o objetivo de obter lucro". Mensagem eletrônica de António José Fonseca enviada em 9/9/2012.

${ }^{133}$ Idem.
} 
Os três últimos tiveram três obras editadas cada um. De Lenin saíram: $O$ Estado e a Revolução (1974), Como iludir o povo com os slogans de liberdade e igualdade (1975) e A revolução bolchevique (1975).

De Stalin: $O$ materialismo dialéctico e o materialismo histórico (1974), Princípios do leninismo (1974) e Questões do leninismo (1974).

De Engels: Do socialismo utópico ao socialismo científico (1975), Cartas sobre o materialismo histórico (1975) e Questão do alojamento (1975). E também o Manifesto do Partido Comunista (1976), em coautoria com Karl Marx. De Marx foi publicado Revolução e contra-revolução (1975).

De acordo com a secção "Os best-seller da quinzena" do jornal Expresso, alguns títulos editados pela Textos Políticos tiveram boas vendas e constaram da lista do jornal no ano de $1975^{134}$ : O Estado e a Revolução, de Lenin (5º lugar, 15/3/1975; $1^{\circ}$ lugar, $28 / 3 / 1975 ; 3^{\circ}$ lugar $3 / 5 / 1975 ; 3^{\circ}$ lugar, 24/5/1975; $2^{\circ}$ lugar, $7 / 6 / 1975 ; 10^{\circ}$ lugar, 21/6/1975; Leis fundamentais da economia, de Jean Baby (4º lugar, 15/3/1975; $2^{\circ}$ lugar, 28/3/1975); O materialismo dialéctico e o materialismo histórico, de Stalin (8 lugar, 28/3/1975); Fundamentos da dialéctica da história, de V. Podossetnik e A. G. Spirkin ( $8^{\circ}$ lugar, 7/6/1975); Revolução e contra-revolução, de Lenin (5º lugar, 19/7/1975).

Os livros editados tinham padrão editorial e gráfico profissional e a distribuição comercial era feita pela Dinalivro.

A editora atuou entre 1974 e 1976, período em que publicou 16 títulos.

\subsection{Serviços Sociais dos Trabalhadores da CGD (Caixa Geral de Depósitos) - Secção Cultural}

Rua Marechal Saldanha, 5 - r/c - Lisboa

Início das edições: 1974.

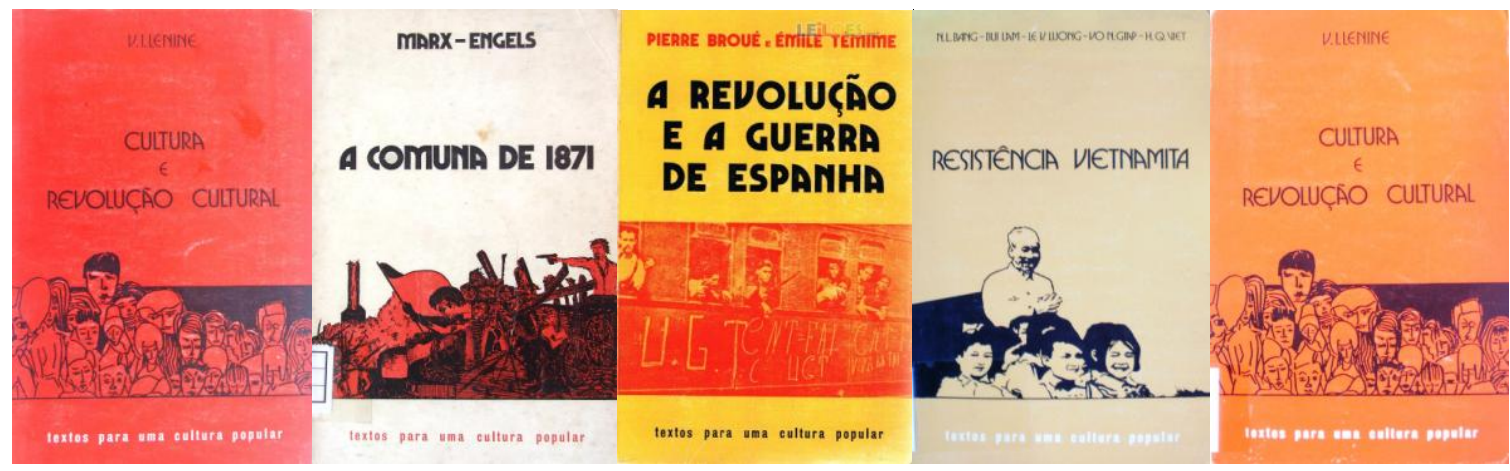

134 “Os best-seller da quinzena”. Secção do jornal Expresso, junho de 1974 a junho de 1975 . Hemeroteca Municipal de Lisboa. 
Os Serviços Sociais dos Trabalhadores da Caixa Geral de Depósitos constituem "uma instituição autónoma dos trabalhadores da Caixa, cujos órgãos sociais são directamente eleitos pelos funcionários", e são responsáveis por organizar "as mais diversas actividades de ocupação de tempos livres, lazer, cultura e desporto dos colaboradores do Grupo"135.

A Caixa Geral de Depósitos foi fundada a 10 de abril de 1876 e foi inicialmente administrada pela Junta do Crédito Público. Sua finalidade principal era a recolha de depósitos obrigatórios constituídos por imposição da lei ou dos tribunais.

Em 1896 a CGD tornou-se autônoma em relação à Junta de Crédito Público, e em 1969 a Caixa, "que até então era um serviço público, sujeito às mesmas regras dos serviços da administração direta do Estado, passa a ser definida fundamentalmente como uma empresa pública para o exercício de funções de crédito"136.

A atuação da Secção Cultural dos Serviços Sociais dos Trabalhadores da CGD no campo editorial parece ter ocorrido apenas entre 1974 e 1981, e está diretamente ligada ao fim da ditadura. Certamente o clima político propício à participação dos trabalhadores na política e na vida social como um todo motivou os funcionários da CGD a dinamizarem a ação dos seus Serviços Sociais, incluindo o início da atividade editorial por parte da sua Secção Cultural.

O primeiro livro editado foi $O$ quarto, peça teatral de Costa Ferreira (outubro, 1974), na coleção Repertório Para um Teatro Popular. A peça havia sido escrita em 1961, mas na ocasião foi proibida pela censura e não pôde ser encenada ${ }^{137}$. Reflexo do momento político que o país vivia, o autor anuncia, na apresentação da obra editada em 1974, que a peça não poderá também ser apresentada na democracia. Eis sua explicação:

Proibida pela censura, a peça não pôde ser representada durante o fascismo. E não poderá ser representada agora, porque o autor, profissional do teatro, entende que o espetáculo é um acontecimento social responsável, que tem a sua oportunidade histórica e o desespero

\footnotetext{
135 "Olhar pelos nossos". Disponível em: $<$ http://www.wehppsaude.pt/index.php?option=com_content\&view=article\&id=86:olhar-pelosnossos\&catid=28: we-do\&Itemid=34>. Acesso em 13/11/2012. Acesso em 13/11/2012.

136 "História da Caixa Geral de Depósitos". Disponível em: <https://www.cgd.pt/Corporativo/Historia/Pages/Historia.aspx>. Acesso em 13/11/2012.

137 “Combate em família”. Vida Mundial, Lisboa, no 1.837, 28 /11/1974, p. 7-8.
} 
negro desta peça é socialmente inoportuno depois de abril de $1974 .{ }^{138}$

Em 1975 e 1976 são feitas a maior parte das publicações da editora, com as coleções Cadernos Hipopótamos e Textos Para uma Cultura Popular. Nestas coleções surge uma pluralidade de posições políticas que espelham, ao que tudo indica, a diversidade política que havia entre os participantes dos Serviços Sociais dos Trabalhadores da CGD.

Assim, são editadas obras claramente ligadas ao pensamento socialista/comunista, como: Cultura e revolução cultural, coletânea de textos de Lenin (fevereiro, 1975); Resistência vietnamita, de N. L. Bang, Bui Lam, Vo N. Giap, H. Q. Viet (junho, 1975); e A Comuna de 1871, de Marx e Engels (abril, 1976).

Mas também é editado um livro vinculado ao pensamento trotskista: $A$ Revolução e a Guerra de Espanha, de Pierre Broué e Émile Témime (1976). Ao mesmo tempo, são editados em 1975 os livros Política externa do V governo provisório, organizado por Manuel Braga da Cruz (nesse momento ligado ao Movimento de Esquerda Socialista-MES), e Textos de política econômica, de Mário Murteira (católico progressista que veio a fundar a União da Esquerda para a Democracia SocialistaUEDS, uma cisão do Partido Socialista).

São publicadas ainda nestes anos as obras: Problemas da juventude, de Émile Copferman (1975); A encenação no teatro de amadores, de Manfred Wekwerth (1976); A construção da personagem, de Constantin Stanislavski (1977).

A editora publicou também as coleções Poesia, Textos Para uma Cultura Popular-Ficção e Girassol, de livros infantis. Entre 1974 e 1981 os Serviços Sociais dos Trabalhadores da CGD publicaram 15 títulos.

Os títulos políticos editados mostram uma linha eclética, não vinculada a uma corrente política específica, mas de viés de esquerda.

\footnotetext{
${ }^{138}$ FERREIRA, Costa. "Palavras do autor". In: O quarto. Lisboa: Serviços Sociais dos Trabalhadores da
} CGD, 1974. 


\subsection{DiAbril Cooperativa Editorial}

Rua Infantaria 16, 37A - Lisboa

Rua D. Estefânia, 177-6º-D - Lisboa (1975)

Editores: Serafim Ferreira e Orlando Neves.

Início das edições: 1975

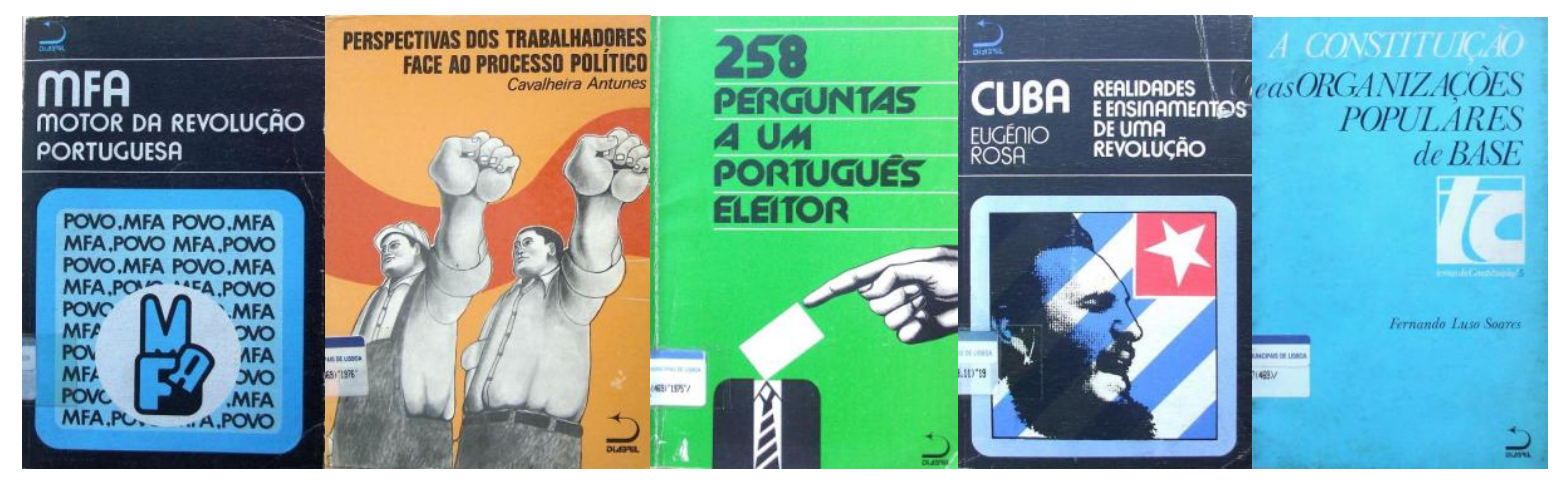

Editora criada em março de 1975 por Serafim Ferreira e Orlando Neves, editores e escritores atuantes no meio editorial português à época. Ambos haviam deixado pouco antes a direção literária da Portugália Editora, por discordâncias políticas e profissionais $^{139}$.

Como indica o nome da editora, o seu projeto ligava-se diretamente à realidade portuguesa surgida após o 25 de Abril e o fim da ditadura salazarista.

Serafim Ferreira havia começado sua vida editorial na editora Ulisseia, em 1962.

Em 1964 transferiu-se para a Portugália Editora. Depois da experiência da DiAbril, fundou a Editorial Fronteira. Entre 1978 e 1979 trabalhou na revista Notícias do Livro $^{140}$. Foi muito atuante também como tradutor.

Orlando Neves foi escritor, poeta, dramaturgo e tradutor. Antes da DiAbril, trabalhou como editor no Círculo de Leitores e na Portugália Editora. Colaborou nas secções culturais de muitos jornais portugueses. Faleceu em janeiro de $2005^{141}$.

O pintor Dorindo Carvalho era o responsável pelo setor de criação gráfica da editora.

De acordo com Serafim Ferreira, a ideia ao criar a DiAbril era ter uma editora "voltada para as realidades portuguesas e sobretudo interessada na divulgação de obras

\footnotetext{
${ }^{139}$ HORTA, Maria Teresa. "Conversa com Serafim Ferreira: A Diabril será uma editora de espírito verdadeiramente cooperativo". Flama, Lisboa, no 409, 7/3/1975, p. 60-61.

${ }^{140}$ FERREIRA, Serafim. Olhar de editor. Lisboa: Editorial Escritor, 1999.

141 "Orlando Neves: Uma vida muito multifacetada e quase sempre ligada à cultura". Texto publicado em 7/8/2010 no blogue "Montalvo e as ciências do Nosso Tempo". Disponível em:<http://montalvoeascinciasdonossotempo.blogspot.com/2010/08/orlando-neves-uma-vidamuito.html $>$. Acesso em out. 2011.
} 
que, nesta hora portuguesa, tragam ao público a informação honesta e responsável que ele merece ter e era impossível tê-la antes do 25 de Abril”. Assim, a editora teria uma linha "politicamente bem definida e progressista nos seus objetivos editoriais" e voltada para "uma sociedade que verdadeiramente procura consolidar-se no caminho da democracia" 142 .

$\mathrm{Na}$ mesma entrevista, Serafim Ferreira destaca que a editora foi criada como uma

espécie de "sociedade cooperativa", congregando em si diversos intelectuais e outras pessoas interessadas na actividade editorial, como Fernando Luso Soares, Noronha Feio, José Carlos de Vasconcelos, José Saramago, Artur Maurício, Casimiro de Brito, Eduardo Prado Coelho, Manuel Alberto Valente, Alina Vaz, Fernando Cabrita, Vasco, António Quelhas e outros [...] seremos uma editora de espírito verdadeiramente "cooperativo". 143

Todavia, a permanência de Serafim Ferreira na DiAbril foi muito breve, pois em meados de 1975 ele criou uma nova editora, a Fronteira, cujo primeiro livro foi lançado em agosto daquele mesmo ano ${ }^{144}$. É de se supor que algo muito grave tenha acontecido para Ferreira optar por criar uma nova editora menos de seis meses após o início das atividades da DiAbril.

Claramente engajada no processo revolucionário iniciado em Portugal em 1974, alinhada com o Movimento das Forças Armadas (MFA) e com os governos provisórios até meados de 1975, a DiAbril criou coleções voltadas para exprimir esta nova realidade e sua dinâmica: Teoria e Prática, Universidade do Povo, As Leis e a Revolução e Temas da Constituição.

Muitos dos livros editados nestas coleções se diferenciavam por trazerem textos de apresentação assinados pelos editores que explicitavam a sua posição política. É o caso, por exemplo, da "Nota dos Editores" que consta do livro Sabotagem económica. Dossier Banco Espírito Santo, editado em abril de 1975 e que mostra todo o entusiasmo decorrente dos acontecimentos de 11 de março de 1975, que levaram a uma viragem à esquerda no quadro político:

[...] a DiAbril orgulha-se de publicar este livro e contribuir assim para dar a conhecer [...] todo o processo de luta que os bancários do

\footnotetext{
${ }^{142}$ HORTA, “Conversa...”, op. cit.

143 Ibidem.

${ }^{144}$ Em seu livro de memórias Olhar de editor, Ferreira menciona de forma brevíssima a sua participação na DiAbril, e fala em “esquecer a aventura da DiAbril”. FERREIRA, op. cit., p. 121.
} 
BESCL [Banco Espítiro Santo e Comercial de Lisboa] se não cansaram de entabular desde o 25 de Abril até aos acontecimentos do 11 de março - ou seja, entre duas datas que são marcos realmente importantes na nossa arrancada para um futuro verdadeiramente livre, independente e democrático: a queda fulgurante do fascismo e a nacionalização da banca e dos seguros, feita de modo firme e decidido pelo Conselho Superior da Revolução. E está assim aberto o caminho (o nosso caminho) para o triunfo final da Revolução Portuguesa. ${ }^{145}$

Em uma resenha na revista semanal Flama sobre este mesmo livro, Maria Teresa Horta assinalava:

Agora, que mais do que nunca é urgente e indispensável a vigilância popular do nosso país, para defendermos uma revolução que é nossa, que é feita diariamente por todos os portugueses, este livro publicado pela DiAbril tem um significado especial, uma grande importância. ${ }^{146}$

Também no livro MFA, motor da revolução portuguesa, coordenado por Serafim Ferreira e lançado em julho de 1975, havia uma epígrafe que mostrava bem o engajamento da editora:

Este livro revela que os homens do MFA têm sabido conduzir a todos os níveis o nosso processo revolucionário no caminho de uma sociedade democrática rumo ao socialismo e é a homenagem a todos aqueles que, com extrema lucidez e coragem, têm sabido lançar as linhas fundamentais de uma verdadeira e original "PEDAGOGIA DA REVOLUÇÃO PORTUGUESA". 147

A coleção Universidade do Povo trazia, em todos os seus volumes, um texto, apresentado na contracapa dos livros, que deixava claro o papel de intervenção política e pedagógica que a editora pretendia cumprir:

Esclarecer é um dever cívico no tempo português de hoje. Reflectir sobre os problemas nacionais contemporâneos é uma obrigação de todos. Tomar posição é participar da vida comum. Universidade do Povo constituirá uma colecção de apoio para esclarecer, ajudar a reflectir e a optar. Só é autenticamente livre um povo que conhece e, conscientemente, escolhe. Universidade do Povo actuará como um estímulo à reflexão, dentro de uma perspectiva permanentemente actual. $^{148}$

A DiAbril realizou um importante trabalho político e editorial ao produzir livros

\footnotetext{
145 “Nota dos Editores". In: COMISSÃO de Delegados Sindicais do Banco Espírito Santo e Comercial de Lisboa. Sabotagem económica. Dossier Banco Espírito Santo. Lisboa: DiAbril, 1975, p. 12.

${ }^{146}$ HORTA, Maria Teresa. Resenha do livro Sabotagem Económica, da DiAbril. Flama, 30/05/1975, p. 6.

${ }^{147}$ FERREIRA Serafim (coord.). MFA, motor da revolução portuguesa. Lisboa: DiAbril, 1975, p. 6. Grifos do original.

${ }^{148}$ Texto publicado na contracapa do livro: PINTO, Álvaro Vieira. Os ricos não fazem greve. Porquê? Lisboa: DiAbril, 1975.
} 
que reuniram parte importante da documentação referente ao processo revolucionário português, além de editar obras de figuras de destaque naquele período e que, sem deixar os fatos esfriarem, publicaram na editora obras sobre aquela experiência. Tais livros constituem ainda hoje importante fonte de pesquisa sobre a época.

Eis alguns títulos que marcam esta linha da editora: Textos históricos da revolução, em três volumes coordenados por Orlando Neves (1975-76); MFA, motor da revolução portuguesa, coordenado por Serafim Ferreira (seleção de textos do Boletim 25 de Abril, do MFA, julho, 1975); Saneamento da função pública, de Artur Maurício e Castelo Branco Gonçalves (maio, 1975); Revolução necessária: crónica do $1^{o}$ ano da revolução de 25 de Abril, de José Gomes Ferreira (junho, 1975); Portugal: dois anos de revolução na economia, de Eugénio Rosa (dezembro, 1976); Luta pela reforma agrária, de António Lopes Cardoso (dezembro, 1976); Contrapoder e revolução, de Fernando Pereira Marques (janeiro, 1977).

Importante também foi a coleção Temas da Constituição, dirigida por Rui Pinheiro e Artur Maurício, que teve 19 volumes publicados em 1976 e 1977, entre os quais: A Constituição e o direito do trabalho, de Pedroso de Lima; Constituição e direito agrário, de Dimas de Lacerda; A Constituição e as organizações populares de base, de Fernando Luso Soares; A Constituição e a condição da mulher, de Lia Viegas Cantante; e A Constituição e as associações sindicais, de Carlos Barbeitos.

Outros títulos políticos a destacar foram: Introdução à política, de Fernando Luso Soares (1975); MFA e revolução socialista, de César Oliveira (1975); Hipóteses de Abril, de Eduardo Prado Coelho (1975); Que são as Ligas Camponesas, de Francisco Julião (1975); Cuba, realidades e ensinamentos de uma revolução, de Eugénio Rosa (1975); Resistência africana, antologia poética coordenada por Serafim Ferreira (1975); Legião Portuguesa: força repressiva do fascismo, de Josué da Silva (1975); Poemas para a revolução, de José Carlos Vasconcelos (1975); A ofensiva do capital e a luta pelo socialismo, de J. Cândido de Azevedo (1976); O sabor das trevas. Romance-alegoria dos tempos amargos, de José Gomes Ferreira (1976); Contrapoder e revolução, de Fernando Pereira Marques (1977).

Assim, a postura política da editora e os livros que ela editou tornam a DiAbril um dos mais interessantes casos de editoras da revolução, ou seja, editoras que surgiram, no Portugal pós-25 de Abril, com um claro propósito de atuação e intervenção política na realidade do país. No caso da DiAbril, parece não haver uma vinculação 
direta com nenhum partido político, mas é certo que as simpatias demonstradas pela editora pelos setores mais progressistas do MFA e dos governos provisórios até 25 de novembro de 1975, indicam alguma proximidade com setores do Partido Comunista Português.

A DiAbril atuou somente por três anos (1975-1977), período em que publicou cerca de 60 títulos de caráter político. Mas a editora publicou também livros infantis (coleção Diabrete) e as coleções Textos Pedagógicos, Clássicos da Aventura, Antologias, Cordel, Grandes Clássicos do Erotismo, Páginas Exemplares e Teatro DiAbril, totalizando mais de cem títulos editados nesse período. Foi anunciada ainda a coleção Biblioteca Sexológica.

\subsection{Editorial Fronteira}

Rua Elias Garcia, 328, $3^{\circ}$ Dto. - Amadora.

Editor: Serafim Ferreira.

Fundação: 1975.

Distribuição: Expresso.

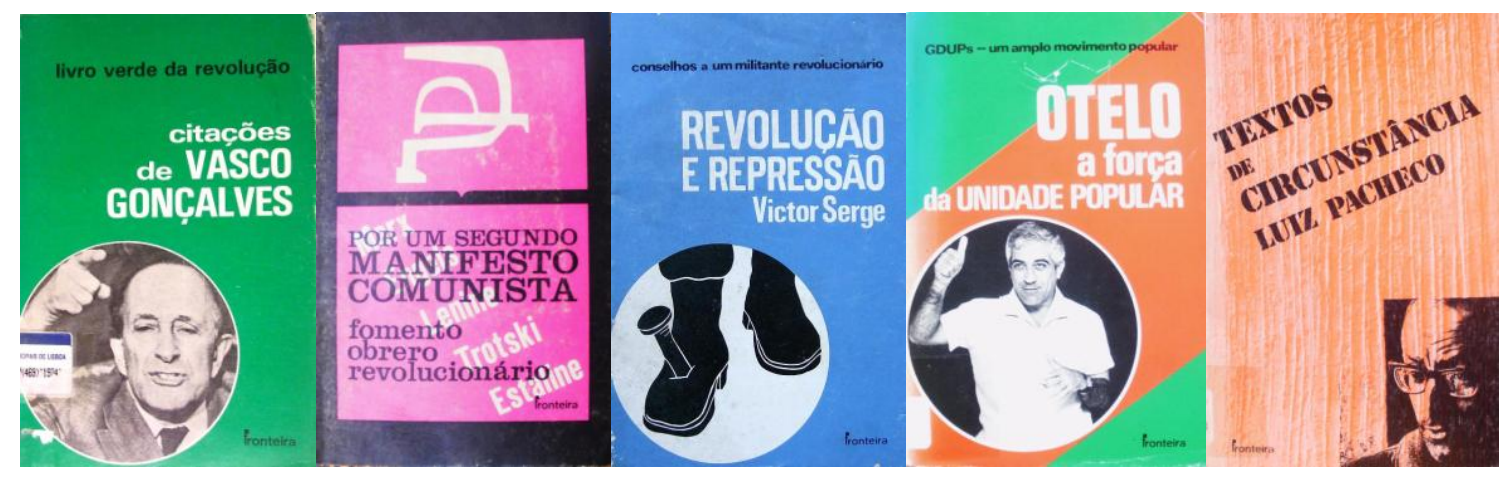

A Editora Fronteira ${ }^{149}$ foi criada em meados de 1975 por Serafim Ferreira, que poucos meses antes fundara a editora DiAbril junto com Orlando Neves, como vimos.

A Fronteira nasceu, portanto, pouco depois da participação de Ferreira na DiAbril, e foi também uma editora marcadamente engajada no processo revolucionário português. Porém, em relação à DiAbril, a Fronteira se alinha mais à esquerda no

149 A Liga de Acção e Unidade Revolucionária (LUAR) tinha um jornal que também se chamava Fronteira, e o grupo chegou a editar pelo menos um livro com o selo Fronteira: Apontamentos sobre a revolução, de Fernando Pereira Marques (1974). 
espectro político, o que fica claro com a edição de algumas obras, e em particular do livro Otelo, a força da unidade popular, coordenado por Serafim Ferreira (agosto, 1976), que reúne textos e documentos da campanha de Otelo Saraiva de Carvalho nas eleições presidenciais de 1976. Otelo foi candidato de um conjunto de organizações de esquerda radical.

De acordo com Ferreira, seu projeto ao criar a Fronteira era:

[...] editar na intenção de intervir no processo revolucionário e despertar a atenção dos leitores para as questões ideológicas. [...] avancei nessa linha editorial dentro dos valores que há muito defendia e, com as melhores intenções, desejava que os livros da Fronteira contribuíssem para se entender as razões do que andava no centro de todas as conversas, no emprego e nas ruas, nos lugares de convívio ou reuniões políticas, comícios e manifestações [...]. ${ }^{150}$

Os títulos editados efetivamente buscavam cumprir estes objetivos. O primeiro livro lançado pela editora tem um especial significado. Trata-se do Livro verde da revolução: Citações de Vasco Gonçalves, coordenado por Serafim Ferreira (agosto, 1975), que representa um inequívoco apoio ao primeiro-ministro Vasco Gonçalves, que exatamente nesse mês de agosto de 1975 deixou a chefia do V Governo constitucional, o que representou uma virada à direita nos rumos políticos do país - que foi consolidada com o 25 de Novembro.

$\mathrm{Na}$ contracapa do livro podemos ler o seguinte texto:

Personificando na figura de Vasco Gonçalves todo o exemplo combativo do próprio Movimento das Forças Armadas, gostaríamos que as Citações aqui reunidas servissem de reforço à unidade que é tão indispensável à vida política portuguesa para que se não percam de todo as inúmeras conquistas já obtidas. ${ }^{151}$

E no prefácio, assinado pelo editor, este não exita em afirmar que o livro visa a ser um interveniente na conjuntura política:

[...] este LIVRO VERDE DA REVOLUÇÃO deverá ser o guia na orientação de quem pretende acima de tudo a melhor e única alternativa que se depara no nosso caminho: estar sempre ao lado da Revolução para se poder travar o passo à Reação. [...] Que este livro seja entendido como símbolo desta nossa tão original Revolução, seja efetivamente a bandeira revolucionária a erguer nos momentos de entusiástica adesão coletiva em torno dos nossos reais e concretos

\footnotetext{
${ }^{150}$ FERREIRA, op. cit., p. 121-23.

151 Texto publicado na contracapa do livro: FERREIRA, Serafim (coord.). Livro verde da revolução. Citações de Vasco Gonçalves. Lisboa: Fronteira, 1975.
} 
problemas $[\ldots] .^{152}$

Até o final 1975 seriam ainda lançados alguns títulos com este mesmo viés político: Fazer a revolução, com textos de Fidel Castro e de Otelo Saraiva de Carvalho; Luta de morte ao imperialismo: construir o socialismo, com textos de Vasco Gonçalves, Che Guevara, Camilo Torres, Carlos Marighella, Ho Chi Minh e Santiago Carrillo; e A revolução é de todos. Rumo ao socialismo, coordenado por Serafim Ferreira.

Não é à toa que a jornalista Maria Teresa Horta afirmava que "doa a quem doer, neste momento [Serafim Ferreira] é um dos poucos 'editores' interessados em colaborar autenticamente com o processo revolucionário do nosso país" ${ }^{" 153}$.

O início das atividades da editora coincide, portanto, com um momento de viragem no quadro político português, que culminará com o fim do "processo revolucionário em curso" e a consequente normalização política imposta pelo golpe de 25 de novembro, seguida pela eleição de Ramalho Eanes para a presidência do país, em 1976. Assim, parece que a Editorial Fronteira foi criada com a intenção de atuar em uma conjuntura de grande agitação, em que os grupos de esquerda e de extrema esquerda apareciam com muita força, mas viu essa situação mudar significativamente pouco tempo depois do início de suas atividades, o que afetou diretamente os seus planos.

No prefácio, datado de julho de 1976, ao livro Otelo, a força da unidade popular, Serafim Ferreira ainda depositava esperanças nos Grupos Dinamizadores de Unidade Popular (GDUPs) como instrumentos que poderiam dar continuidade à revolução em Portugal:

A organização revolucionária dos GDUPs poderá ser de fato um passo decisivo num amplo movimento de esquerda ou frente revolucionária [...] que objetive e consolide, através de posições ideológicas mais corretas, as várias e diversificadas tendências defendidas e conhecidas pelos partidos da chamada "extrema esquerda". ${ }^{154}$

Mas, efetivamente, as apostas políticas feitas pela Fronteira foram derrotadas, e a atuação da editora viu-se fortemente afetada por esse novo quadro.

Ainda assim, a editora manteve uma produção razoável em 1976 e 1977 - cerca de dez títulos por ano -, e com a mesma linha política, até encerrar as atividades em 1978.

\footnotetext{
${ }^{152}$ FERREIRA, Serafim. "Prefácio". In: Livro verde da revolução, op. cit., p. 13-14.

${ }^{153}$ HORTA, Maria Teresa. Resenha do livro Fazer a revolução. Flama, Lisboa, 12/12/1975, p. 7.

${ }^{154}$ FERREIRA, Serafim. "Prefácio". In: Otelo, a força da unidade popular. Lisboa: Fronteira, 1976, p. 10. Grifos no original.
} 
A Fronteira publicou, entre outras, as seguintes obras: A burocracia nos estados operários, de Ernest Mandel (1975); Por um segundo Manifesto Comunista, do grupo Fomento Obrero Revolucionário (1975); A Comuna de Paris, com textos de Marx, Engels e Lenin (1975); URSS e países de leste: socialismo ou capitalismo?, de Fernand Charlier (1975); Revolução e movimento operário, de Paul Sweezy, Emmanuel Terray, Serge Depaquit e Jean-Pierre Vigier (1976); Um homem do povo na revolução, de Roger Vailland e Raymond Manevy (1976); Como fizemos a revolução em Outubro, de Trotsky (1976); A revolução russa de 1917 (Preparando a tomada do poder), de Lenin (1976); A revolução cubana e a construção do socialismo, de Che Guevara (1976); Revolução e repressão: conselhos a um militante revolucionário, de Victor Serge (1976); A formação dos intelectuais, de António Gramsci (1976); Revolução Russa e União Soviética: os primeiros anos do Estado Operário, de António Gramsci (1977); Revolução socialista e internacionalismo proletário: documentos sobre a luta política dos "spartaquistas" na Alemanha, de Rosa Luxemburg e Karl Liebkanecht (1977); Textos de circunstância/A PIDE nunca existiu, de Luiz Pacheco (1977); Escritos políticos, do Marquês de Sade (1977); México Insurrecto, de John Reed (1977).

Alguns desses títulos denotam uma aproximação a pensadores representativos de um marxismo heterodoxo, que ia além dos cânones do PCP, por exemplo.

Os últimos livros editados foram, em 1978, os dois volumes da coleção Poesia e Revolução: Maiakovski, de Viktor Sklovski; e O poeta descalço, de João Apolinário.

Entre 1975 e 1978 a Editorial Fronteira publicou cerca de 30 títulos, todos de inequívoco caráter político e de esquerda.

Em seu livro de memórias Serafim Ferreira recorda com certa decepção a experiência da Fronteira:

[...] a ideia de criar a Fronteira, no sonho de ser editor independente e de certa forma esquecer a aventura da DiAbril [...]. Mas, sem armas nem bagagens para lá do meu próprio trabalho, quase sem horário, alarguei os dias e as horas na realização de todos os projetos, sabendo à distância destes anos como a Fronteira teve algumas edições de interesse pelo interesse que as questões políticas ainda mereciam em meados de 1975 [...]. ${ }^{155}$

E lembra também que não faltaram amigos que o previnissem dizendo: "Não sei se esse será o melhor caminho. Olha que a revolução tem os dias contados e depressa

${ }^{155}$ FERREIRA, S. Olhar de editor, op. cit., p. 121-23. 
há-de murchar o interesse pela política" ${ }^{\text {156 }}$.

Ferreira faz também uma espécie de balanço de sua atuação na Fronteira, e, na verdade, de sua vida como editor:

[...] tenho consciência de que nessa barricada editorial em que me fechei pude prosseguir no papel de ser franco-atirador e agitador cultural [...]. Porque intervir sem alienar e publicar sem nunca mercadejar, tu sabes, meu caro amigo, como foi esse o sentido da minha ação como editor. Claro, depressa se impôs a necessidade de parar e, atado de pés e mãos e com o mercado em recessão, por serem outros os tempos que chegaram após novembro triste de tão má memória, suspendi a atividade por entre muitas dívidas acumuladas e montes de livros para vender a peso, as mãos vazias e a consciência de querer que a vida rumasse noutro sentido. ${ }^{157}$

A Editorial Fronteira, pelos motivos expostos, é um dos casos em que mais claramente se percebe a influência direta da conjuntura política sobre a atuação e os destinos de uma editora portuguesa no pós-25 de Abril. Criada com uma intenção militante de intervenção na realidade do país, viu seus planos prejudicados pela derrota dos setores do MFA ligados a Vasco Gonçalves e pelo fim do "processo revolucionário em curso".

${ }^{156}$ Ibidem.

${ }^{157}$ Ibidem. 
UNIVERSIDADE DE SÃo PAULO

Faculdade DE Filosofia, Letras E CiênCias Humanas

DEPARTAMENTO DE HISTÓRIA

PROGRAMa DE Pós-GRaduAÇÃo EM HistóRIA SOCIAL

FLAMARION MAUÉS PELÚCIO SILVA

\section{Livros que tomam partido: a edição política em Portugal, 1968-80}

VOL. 2

São Paulo

2013 


\section{FLAMARION MAUÉS PELÚCIO SILVA}

\section{Livros que tomam partido: a edição política em Portugal, 1968-80}

VOL. 2

Tese do Doutorado apresentada ao Programa de História Social do Departamento de História da Faculdade de Filosofia, Letras e

Ciências Humanas da Universidade de São Paulo, para a obtenção do título de doutor em História.

Orientador: Prof. Dr. Lincoln Secco.

São Paulo

2013 


\section{SUMÁRIO}

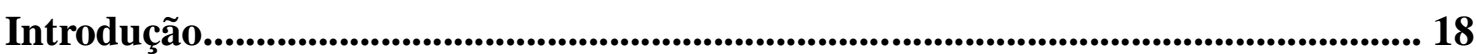

O universo da pesquisa: editoras que publicaram livros de caráter político em

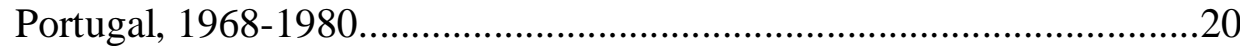

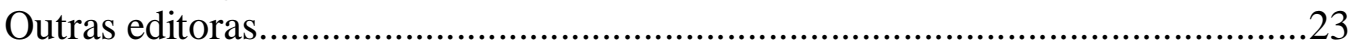

Exposição da investigação e dos seus resultados............................................24

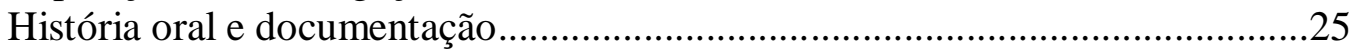

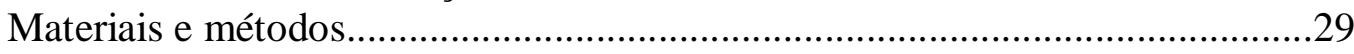

Um estrangeiro estudando a história contemporânea de Portugal.......................33

\section{$\underline{\text { Parte I - A edicão política em Portugal nos anos 1960-70 }}$}

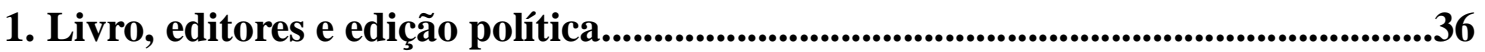

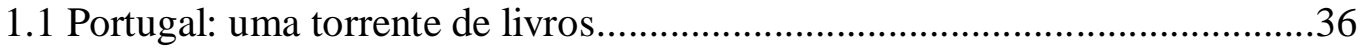

1.2 Portugal no final dos anos 1960 e o mercado editorial..................................42

1.3 Editoras de oposição e Editoras da revolução...............................................45

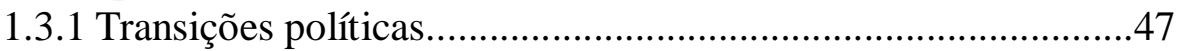

1.4 Livro e história editorial......................................................................49

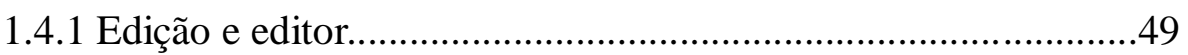

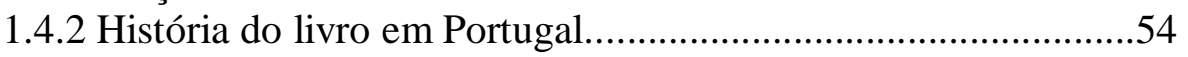

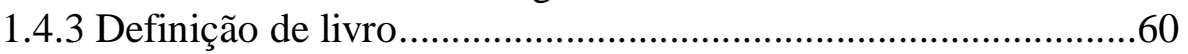

1.5 Difusão e edição política................................................................................63

1.5.1 Difusão e disseminação ampla.................................................63

1.5.2 A edição política e o livro político.............................................66

2. A edição política em Portugal antes e depois do 25 de Abril...................................74

2.1 Os livros de caráter político antes do 25 de Abril...........................................74

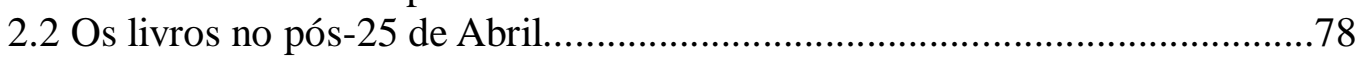

2.3 As editoras no pré e no pós-25 de Abril......................................................... 81

3. As editoras que publicaram livros de caráter político em Portugal, 1968-80......91

3.1 Quadro Sinóptico das editoras que publicaram livros de caráter político em

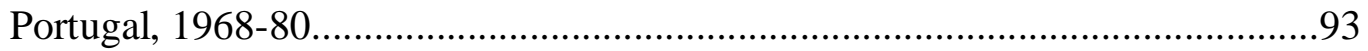

3.2 Síntese analítica do "Quadro Sinóptico"...................................................98

3.2.1 Lisboa e Porto concentraram a produção editorial......................98

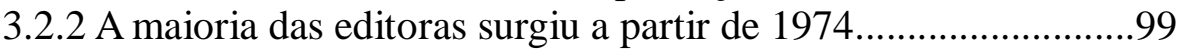

3.2.3 Quase três quartos das editoras tinham perfil político..............101

3.2.4 Mais da metade das editoras eram ligadas à esquerda..............101

3.2.5 Editoras ligadas a grupos maoistas formavam o maior conjunto;

PCP era o partido com maior número de editoras........................103

3.2.6 Editoras ligadas a grupos de esquerda.....................................104

3.2.7 Mais de metade das editoras era de pequeno porte..................105

$\underline{\text { Parte II - As editoras de caráter político em Portugal: história e atuacão }}$

4. Editoras políticas de esquerda - ligadas ao Partido Comunista Português

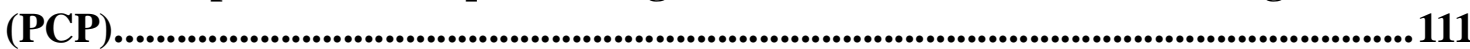

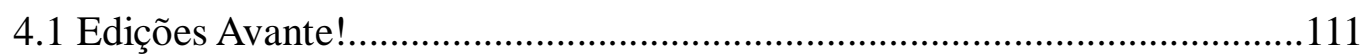

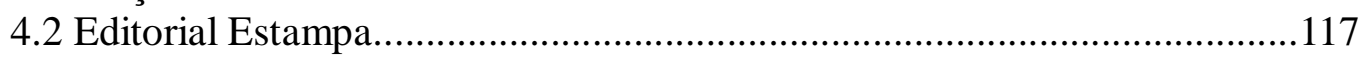




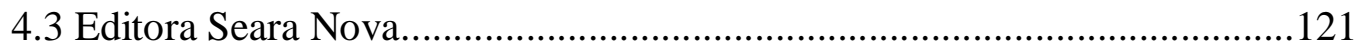

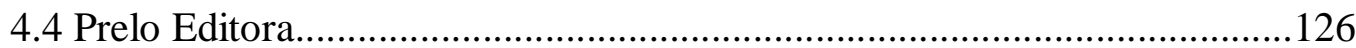

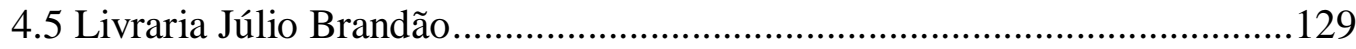

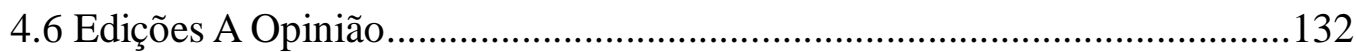

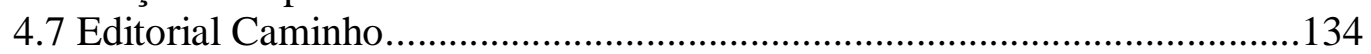

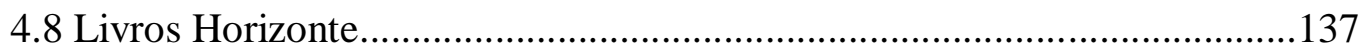

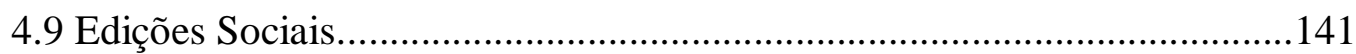

4.10 Manuel Rodrigues Xavier.....................................................................144

4.11 Novo Curso Editores.................................................................................... 145

5. Editoras políticas de esquerda - ligadas a grupos de extrema esquerda maoistas................................................................................................................................147

5.1 Partido Comunista de Portugal (marxista-leninista) - PCP(m-l)-Vilar / Comitê Marxista-Leninista Português (CMLP)....................................................148

5.1.1 Edições do Partido.......................................................................148

5.1.2 Edições Seara Vermelha..............................................................150

5.2. Partido Comunista de Portugal (marxista-leninista) - PCP(m-l)-Mendes/

Comité Marxista-Leninista Português (CMLP) ..................................................152

5.2.1 Edições Unidade Popular..........................................................152

5.2.2 Edições Militão Ribeiro............................................................153

5.2.3 Edições A Verdade....................................................................155

5.3 Organização Comunista Marxista-Leninista Portuguesa (OCMLP)............157

5.3.1 Edições O Grito do Povo.........................................................157

5.3.2 Edições Spartacus/OCMLP..........................................................159

5.4 Comité Marxista-Leninista de Portugal (CMLdeP)......................................161

5.4.1 Publicações O Proletário Vermelho/Editora Outubro................161

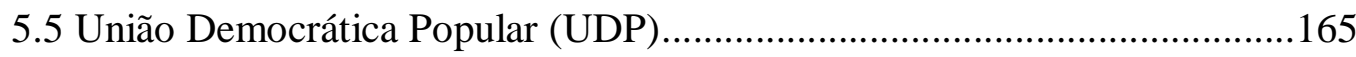

5.5.1 Edições Maria da Fonte...........................................................165

5.5.2 Edições Voz do Povo..................................................................169

5.5.3 Edições Povo e Cultura................................................................171

5.6 Organização para a Reconstrução do Partido Comunista (marxista-leninista)

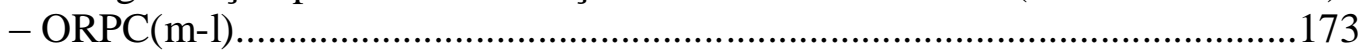

5.6.1 Edições A Causa Operária............................................................173

5.6.2 Revolução Proletária...............................................................175

5.7 Partido Comunista Português (Reconstruído)-PCP(R) / Partido Comunista

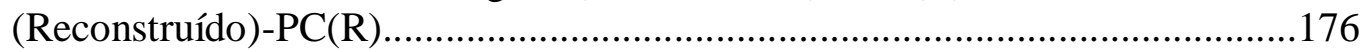

5.7.1 Edições Bandeira Vermelha.........................................................176

5.8 Movimento Reorganizativo do Partido do Proletariado (MRPP)/ Partido Comunista dos Trabalhadores Portugueses (PCTP)...........................................178

5.8.1 Vento de Leste.......................................................................178

5.8.2 Publicações Nova Aurora........................................................185

5.8.3 Editora Sementes.................................................................... 189

5.8.4 Edições Estrela Vermelha...........................................................194 
5.8.5 Germinal Editora e Distribuidora............................................195

5.8.6 Edições Bandeira Vermelha - PCTP/MRPP.............................198

5.8.7 Edições AAPA (Associação de Amizade Portugal-Albânia)...199

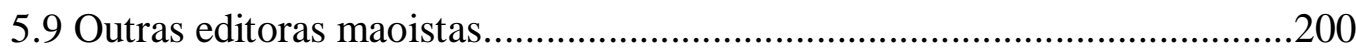

5.9.1 Edições do Povo...................................................................200

5.9.2 Edições Movimento Operário..................................................202

5.9.3 Pensamento e Acção............................................................203

5.9.4 Textos da Revolução.............................................................204

6. Editoras políticas de esquerda - ligadas a outros grupos (esquerda radical, trotskistas, anarquistas, Partido Socialista, outros)..................................................206

6.1 Editoras ligadas a grupos de esquerda radical e trotskistas.......................206

6.1.1 Edições Contra a Corrente (jornal Combate)...........................206

6.1.2 Edições Revolução (PRP/BR).................................................213

6.1.3 Editora 17 de Outubro (PRP/BR)...........................................215

6.1.4 SLEMES - Serviço de Livros e Edições do MES (Movimento de

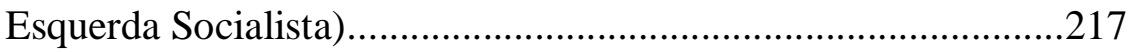

6.1.5 Edições Antídoto (LCI/PSR) ...............................................219

6.1.6 Editorial Divul (PRT) .....................................................221

6.2 Editoras ligadas ao pensamento anarquista..............................................223

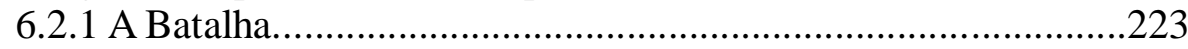

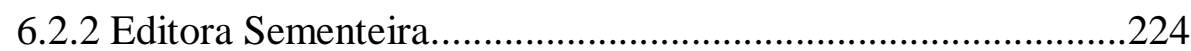

6.2.3 Cooperativa Cultural Editora Fomento Acrata........................22

6.2.4 Livraria Editora Sotavento..................................................228

6.3 Editoras ligadas ao Partido Socialista.......................................................229

6.3.1 Edições Portugal Socialista.................................................229

6.3.2 Perspectivas \& Realidades - p\&r.........................................230

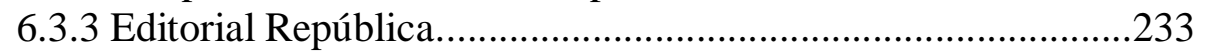

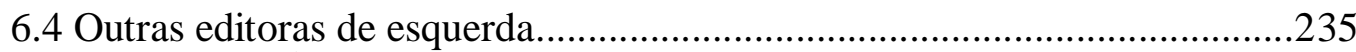

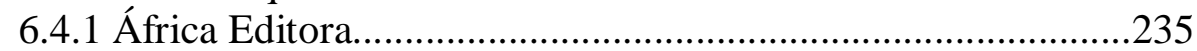

6.4.2 Portucalense Editora...........................................................236

6.4.3 AEPPA (Associação de Ex-Presos Políticos Antifascistas)......239

7. Editoras políticas de esquerda sem vinculação partidária.................................242

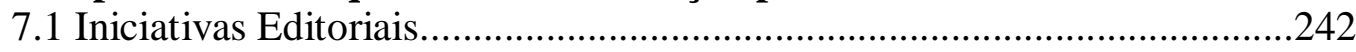

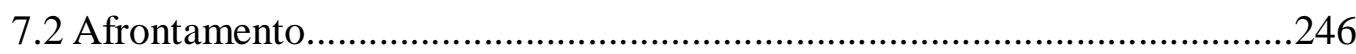

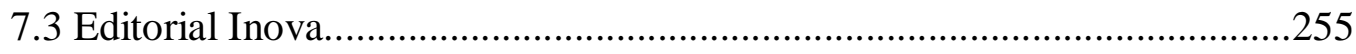

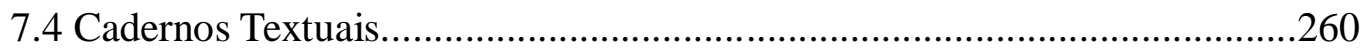

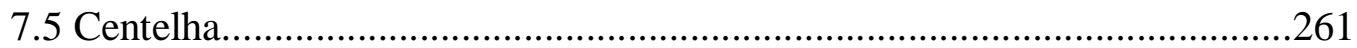

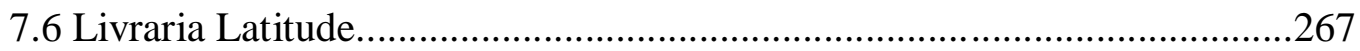

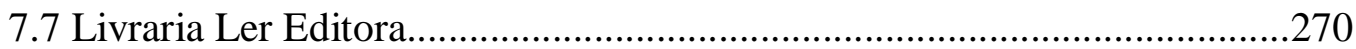

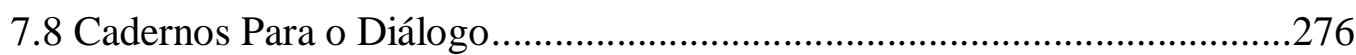

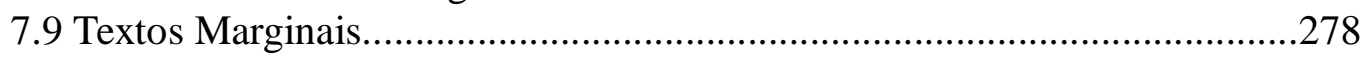

7.10 Publicações Escorpião/Textos Exemplares..............................................228

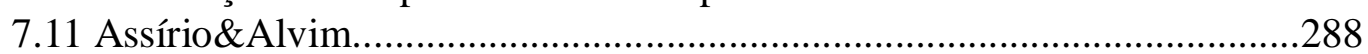

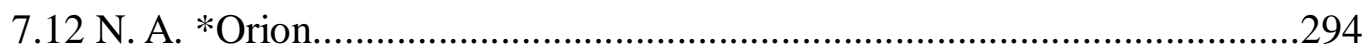




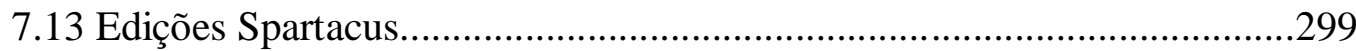

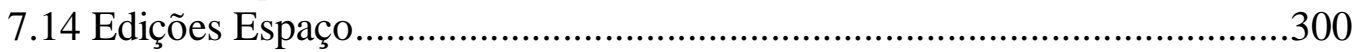

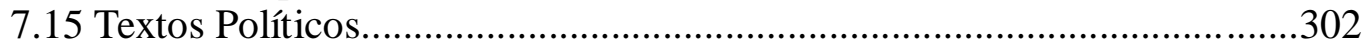

7.16 Serviços Sociais dos Trabalhadores CGD (Caixa Geral de Depósitos).....304

7.17 DiAbril Cooperativa Editorial....................................................................307

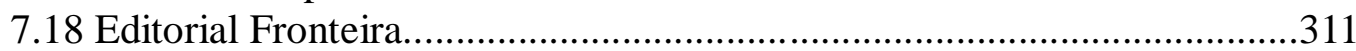

8. Editoras políticas ligadas à oposição católica/católicos progressistas..................316

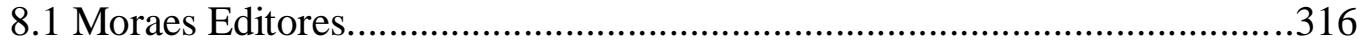

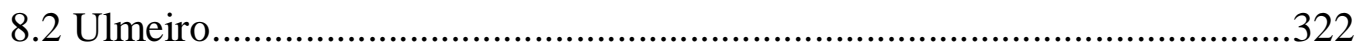

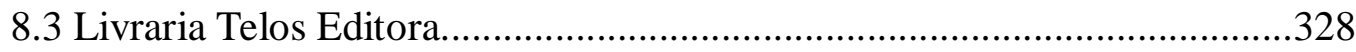

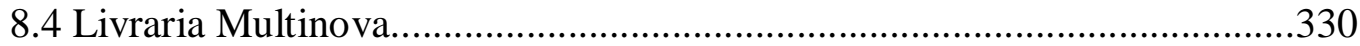

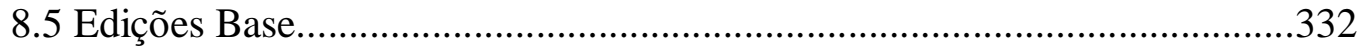

8.6 Edições CIDAC (Centro de Informação e Documentação Amílcar

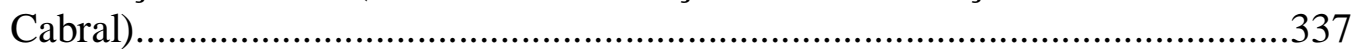

9. Editoras políticas sem vinculação a grupos políticos.............................................340

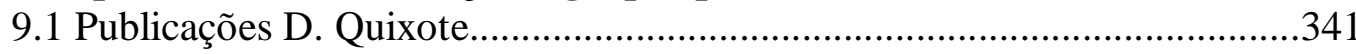

9.2 Edições Afrodite/ Edições Fernando Ribeiro de Mello................................347

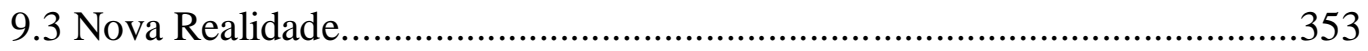

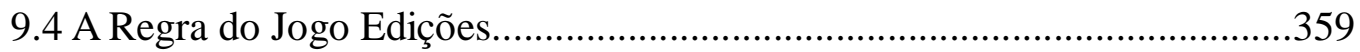

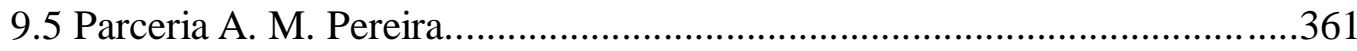

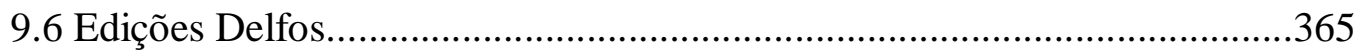

10. Editoras políticas de direita...................................................................................367

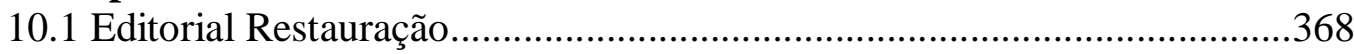

10.2 Sociedade Cooperativa Livreira Cidadela..............................................372

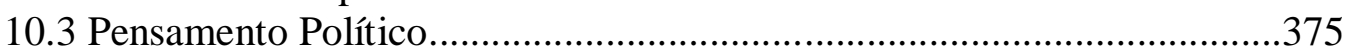

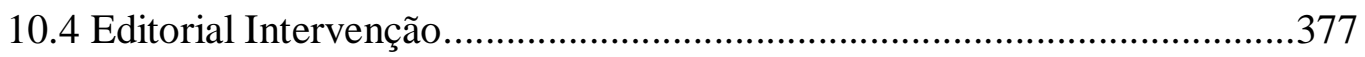

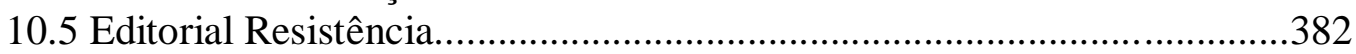

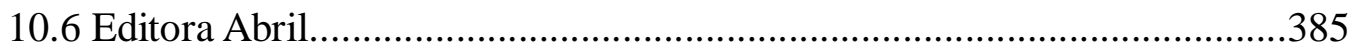

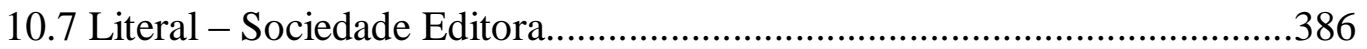

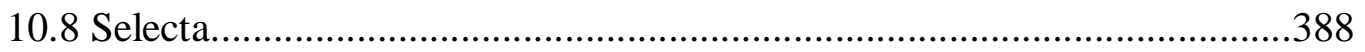

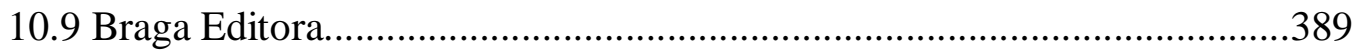

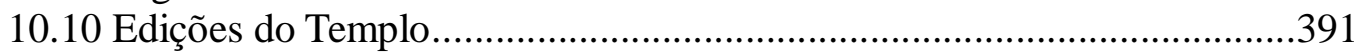

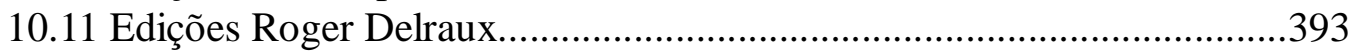

10.12 Edições FP (Fernando Pereira - Editor)...............................................394

10.13 Livraria Popular de Francisco Franco......................................................396

11. Algumas editoras que publicaram livros políticos, mas que não se

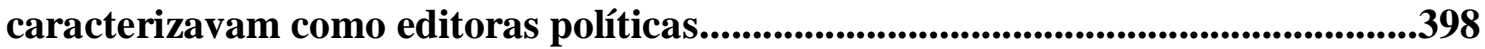

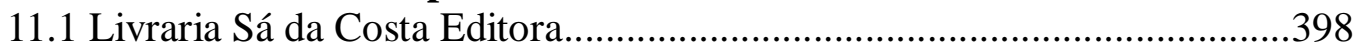

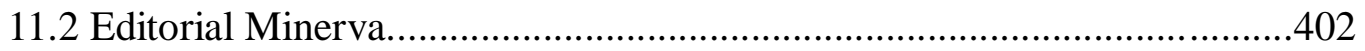

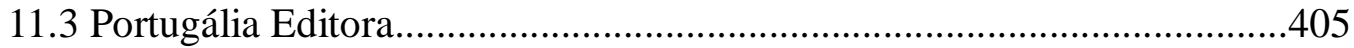

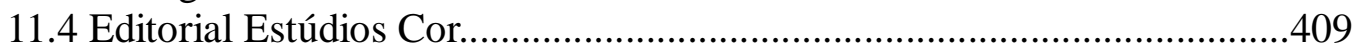

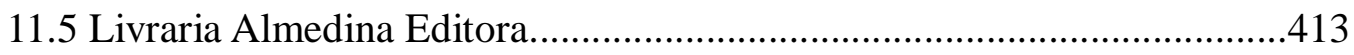

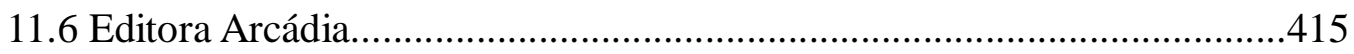

11.7 Paisagem Editora........................................................................4. 420

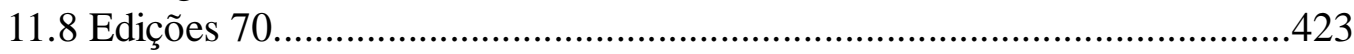

11.9 Liber - Editorial e Publicidade Portugal Brasil.......................................426 
11.10 Edições Rés

11.11 Editora Nova Crítica.

Parte III - A edicão política e seu papel nas lutas contra a ditadura 435-464

12. O papel da edição política em Portugal. .432

12.1 A edição política e a denúncia dos crimes da ditadura em Portugal (1968-80)

12.1.1 Livros de oposição antes do 25 de Abril

12.1.2 O pós-25 de Abril

12.1.3 Um breve balanço

12.2 A edição política no olhar do editor

Conclusões. .461

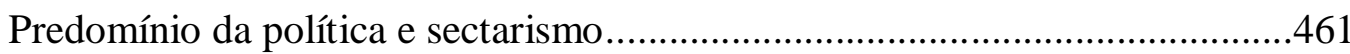

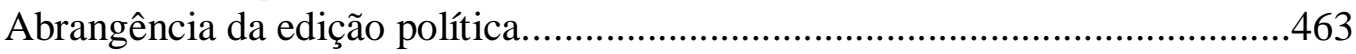

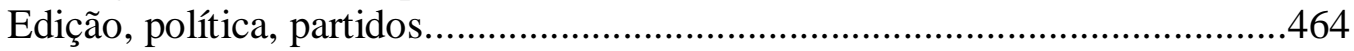

Agitação política, engajamento e estratégias editoriais....................................466

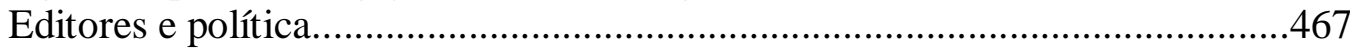

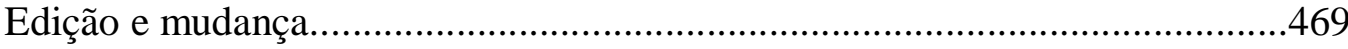

Bibliografia e fontes....................................................................................................471

Apêndice 1 - Lista das Editoras Políticas (100 editoras). .494

Apêndice 2 - Lista das Editoras Não Políticas (37 editoras) que publicaram livros políticos...... 496

Apêndice 3 - Lista de livros políticos publicados em Portugal entre 1968 e 1980 pelas 137 editoras incluídas neste trabalho.

Apêndice 4 - Lista de livros políticos publicados em Portugal entre 1968 e 1980 por outras 107 editoras não incluídas neste trabalho (publicaram menos de cinco títulos políticos no período) 


\section{EDITORAS POLÍTICAS LIGADAS À OPOSIÇÃO CATÓLICA/CATÓLICOS PROGRESSISTAS ${ }^{1}$}

Entre as seis editoras deste grupo, duas podem ser vinculadas à oposição católica (Moraes e Telos) e quatro aos grupos católicos progressistas (Ulmeiro, Multinova, Base e CIDAC). Ao mesmo tempo, Telos e Multinova se caracterizavam como editoras religiosas, ligadas ou muito próximas a estruturas institucionais da Igreja Católica, enquanto as outras quatro editoras tinham um caráter mais "leigo". Nestes casos, seus catálogos eram menos voltados para temas diretamente religiosos, e mais abertos a questões e debates mais amplos, em que o pensamento cristão aparecia como substrato das análises e propostas.

\subsection{Moraes Editores}

Rua da Assunção, 49-51, Lisboa/ Av. 5 de Outubro, 297 - $1^{\circ} \mathrm{Dt}^{\circ}$ - Lisboa (1969) / Av. Alm. Barroso, 6, 1505 - Rio de Janeiro (1969) / Rua do Século, 34, 2a - Lisboa (1974) Editores: António Alçada Baptista, Pedro Tamen, Carlos Miranda, Nelson de Matos. Início das edições: 1960.

Distribuição: Expresso, O Século.

Distribuidor no Brasil: Livraria Martins Fontes.

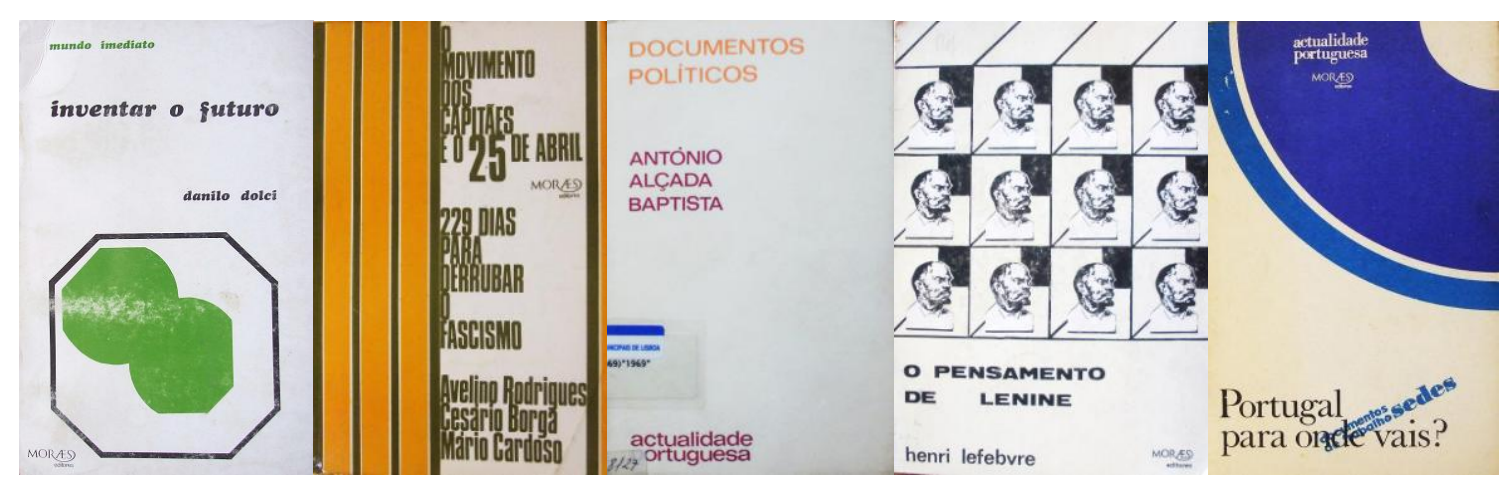

Editora cujas origens remontam à livraria e editora fundada em Lisboa em 1922 por João de Araújo Moraes, chamada Livraria Morais Editora. Mas é apenas em 1958,

\footnotetext{
${ }^{1}$ Adoto aqui a diferenciação entre "católicos progressistas" e "oposição católica" apresentada por João Miguel Almeida. Para ele, a oposição católica é composta por aqueles católicos que se destacaram por "terem entrado em ruptura com o regime e contestarem a relação deste com a Igreja Católica". Assim, é mais ampla que o grupo formado pelos "católicos progressistas", pois inclui também, além destes, os "católicos liberais, democratas-cristãos, católicos sociais e monárquicos de formação integralista". Para Almeida, os católicos progressistas foram a "presença dominante [...] na mobilização deste movimento oposicionista [católico] à ditadura portuguesa". ALMEIDA, João Miguel. A oposição católica ao Estado Novo (1958-1974). Lisboa: Edições Nelson de Matos, 2008, p. 17-18 e 20.
} 
quando é adquirida por António Alçada Baptista, que efetivamente entra no ramo da edição e adquire importância nacional. Pouco depois, Pedro Tamen torna-se sócio da editora $^{2}$.

Alçada Baptista era advogado e escritor, e fez parte do núcleo dos chamados católicos progressistas, "grupo de católicos que, a partir dos finais da década de cinquenta, entra em aberta contestação política ao Estado Novo"3, pondo em questão as relações entre a Igreja e o governo português ${ }^{4}$. Baptista e Tamen se propuseram a tornar a Livraria Morais Editora (nome da empresa na época) num "espaço de promoção e disseminação editorial em que o personalismo e o progressismo ligado ao pensamento cristão constituíssem o cerne das obras publicadas". Para ajudá-los, trouxeram da Editorial Aster Carlos Miranda, que assumiu a coordenação editorial da Morais e teve papel destacado na condução da editora ${ }^{5}$.

Durante a década de 1960 a editora tornou-se uma das mais importantes de Portugal na área do pensamento progressista e de oposição ao Estado Novo, tanto pelos livros publicados como pela revista O Tempo e o Modo, editada a partir de 1963.

Seus títulos buscavam "enfrentar a mentalidade dominante doutrinal e socialmente no seio das comunidades católicas portuguesas, nas quais se buscava introduzir um clima de discussão livre análogo ao que se vivia no resto da Europa católica". As áreas privilegiadas foram o ensaio, as ciências sociais e humanas, e os livros sobre religião, mas a literatura também tinha importância, com as coleções Círculo de Poesia e Círculo de Prosa, além da edição das obras de José Cardoso Pires ${ }^{6}$.

Nuno Medeiros define a postura política da Morais como de recusa dos "alicerces ideológicos do salazarismo e, simultaneamente, a ortodoxia de esquerda representada pelo PCP e a tradição jacobina de um republicanismo reviralhista"7.

O surgimento da revista $O$ Tempo e o Modo em 1963, com um perfil pluralista,

\footnotetext{
${ }^{2}$ MEDEIROS, Edição e editores, op. cit., p. 229.

${ }^{3}$ REZOLA, Maria Inácia. “Católicos progressistas”. Verbete. In: ROSAS, Fernando e BRITO, J. M. Brandão de (coords.). Dicionário de história do Estado Novo. Vol. I. Lisboa: Bertrand, 1996, p. 137-39.

${ }^{4}$ MATOS E LEMOS, Mário. Candidatos da Oposição à Assembleia Nacional do Estado Novo (19451973). Um Dicionário. Lisboa: Divisão de Edições da Assembleia da República/Texto Editores, 2009. Disponível em: <http://www.parlamento.pt/ArquivoDocumentacao/Documents/Candidatos_Oposicao.pdf $>$. Acesso em ago. 2011.

${ }^{5}$ MEDEIROS, op. cit., p. 230 e 233-34.

${ }^{6}$ Ibidem, p. 231-32.

${ }^{7}$ Ibidem, p. 232. "É designada de reviralhista a acção revolucionária levada a cabo por vários sectores do republicanismo radical, para derrubar, pela força das armas, a Ditadura Militar saída do 28 de Maio de 1926 e reconduzir o país à normalidade constitucional, restaurando a "República Democrática'". Cf. FARINHA, Luís. "Reviralhismo”. Verbete. In: ROSAS; BRITO, op. cit., Vol. II, p. 832-34.
} 
agrega em torno da editora intelectuais católicos críticos do salazarismo, setores da esquerda (tanto os próximos do PCP quanto os ligados aos socialistas) e grupos estudantis. "Em 1967-1968, a revista perde as raízes personalistas e católicas e vira ainda mais à esquerda, iluminada pelos fulgores do Maio de 1968" ${ }^{8}$. Em março de 1969, Alçada Baptista deixa a direção da revista, que é assumida por João Bérnard da Costa $^{9}$. Em precária situação financeira, a publicação deixa de ser editada pela Livraria Morais Editora. Em 1970, a revista é "tomada" pelos maoistas do MRPP, com a entrada de Arnaldo Matos e Amadeu Lopes Sabino no conselho de redação ${ }^{10}$, e vai perdendo sua importância, até deixar de existir, em $1977^{11}$.

A Moraes também editava a revista Concilium, dirigida por Helena Vaz da Silva.

Os livros da Morais e a revista O Tempo e o Modo foram sempre alvo de forte censura e de apreensões por parte da PIDE, e este foi também um dos motivos que levaram aos problemas econômicos que sempre fizeram parte da vida da editora ${ }^{12}$.

Do ponto de vista empresarial, o projeto da editora caracterizava-se, nesta etapa, por um "voluntarismo transformador", levado a cabo por uma pequena equipe, o que deságua em "uma torrente editorial desacompanhada de preocupações sistemáticas de distribuição e venda", resultando em insuperável insustentabilidade financeira. Tais consequências ressaltam o fato de que, "No caso da Livraria Morais Editora, dirigida por Alçada Baptista, a dimensão cultural prevalecia imperialmente no código genético da editora e nos objectivos que a sua acção tentou cumprir"13.

Assim, a editora é vendida em agosto de 1971 à Sociedade Financeira Portuguesa, e passa a denominar-se Livraria Moraes Editores ${ }^{14}$, restando a Alçada Baptista uma dívida que ele levará anos para saldar. Pedro Tamen permanece como administrador na Sociedade Financeira Portuguesa. Em maio de 1973, a editora passa às mãos do banqueiro Jorge de Brito, proprietário da editora e do jornal $O$ Século, que

\footnotetext{
${ }^{8}$ MEDEIROS, op. cit., p. 235-36.

9 PEREIRA, Nuno Teotônio. "O Tempo e o Modo". Verbete. In: BARRETO; MÓNICA, op, cit., Vol. IX, Suplemento P/Z, 1999, p. 509.

${ }^{10}$ MEDEIROS, op. cit., p. 236.

${ }^{11}$ Uma análise detalhada das coleções da Livraria Morais Editora e da revista $O$ Tempo e o Modo na década de 1960, sob o ponto de vista do seu diálogo com o pensamento cristão tradicional, pode ser vista em: ALMEIDA, op. cit., p. 112-22.

${ }^{12}$ Alguns casos de censura a livros são descritos nos anexos de: TAMEN, Isabel (org.). A aventura da Moraes. Lisboa: Centro Nacional de Cultura, 2006, p. 94-97.

${ }^{13}$ MEDEIROS, op. cit., p. 238-39.

14 TAMEN, op. cit., p. 92.
} 
unifica as atividades de distribuição e edição das empresas. "A partir de abril de 1974, a agitação social no interior das empresas do grupo d'O Século é permanente, com a comissão de trabalhadores a tomar conta dos seus destinos em 1975. [...] Em 1976, Nelson de Matos torna-se administrador da editorial, aí ficando até 1980"15. Desde 1974, portanto, as ligações da editora com os chamados católicos progressistas deixa de ser determinante para atuação da editora.

Desse modo, no que diz respeito ao período que interessa ao nosso estudo (1968 até finais dos anos 1970), a editora passa por dois momentos diferentes, o que implica, inclusive, na mudança de seu nome de Livraria Morais Editora para Moraes Editores no começo dos anos 1970.

Até a venda da editora para a Sociedade Financeira Portuguesa, a linha editorial mantém-se a mesma iniciada por Alçada Baptista em 1960, havendo, todavia, uma leve inflexão à esquerda no final dos anos 1960.

Nessa etapa, alguns dos títulos publicados foram: O personalismo, de Emmanuel Mounier (1960); Princípios de uma política humanista, de Jacques Maritain (1960); O reino da estupidez, de Jorge de Sena (1961); Crescimento económico e sistemas sociais, de Mário Murteira (1962); Socialismo vivo, de Jules Moch (1964); Razões da democracia, de Pietro Pavan (1965); Catolicismo de vanguarda: Textos e documentos do catolicismo francês, 1942-1962, de Jean-Marie Domenach e Robert de Montvalon (1965); As nações proletárias, de Pierre Moussa (1966); A empresa socialista na Jugoslávia, de Georges Lasserre (1966); Contra os tecnocratas, de Henri Lefebvre (1968); Crise da democracia, crise da civilização de Jean Lacroix (1968); 1917: história de uma revolução, de Jean-Paul Ollivier (1968); Os católicos e a esquerda, de Adrian Cunningham e outros (1968); O ofício de revolucionário, de Victor Serge (1968); O pensamento de Lénine, de Henri Lefebvre (1969); O fim da utopia, de Herbert Marcuse (1969); Maio 68: inventário de uma rebelião, de E. Morin, C. Lefort e J.-M. Coudray (1969); O marxismo como moral, de José Luis Aranguren (1969); Cristianismo e marxismo no mundo de hoje, de Paulus-Gesellschaft (1969); Sociologia e ideologia do desenvolvimento: estudos e ensaios, de Adérito Sedas Nunes (1969); Documentos políticos, de António Alçada Baptista (1970); Dez mulheres anticonformistas, de Julienne Travers (1970).

${ }^{15}$ MEDEIROS, op. cit., p. 240. 
Os quase dois anos sob a direção da Sociedade Financeira Portuguesa são marcados pelo fim definitivo da coleção de livros O Tempo e o Modo, cujos últimos títulos foram editados em 1969, e por uma aproximação com setores mais liberais do governo de Marcelo Caetano, o que se materializa em edições de obras coordenadas pela SEDES (Sociedade de Estudos para o Desenvolvimento Económico e Social/Associação para o Desenvolvimento Económico e Social), organização política criada em 1970, e na publicação de livros de figuras destacadas da chamada Ala Liberal. A Ala Liberal era um grupo de deputados eleito em 1969 nas listas da União Nacional, o partido governista, mas que se posicionou em favor de "um regime político de liberdade, em que seja possível discutir, controlar os actos do Governo e escolher os representantes da Nação", conforme sintetizou um dos seus membros, o médico Miller Guerra $^{16}$.

Neste curto período, destacam-se os seguintes títulos: Órgãos da soberania: a Assembleia Nacional - um debate, de A. Carlos Lima (1971); Uma tentativa de participação política, de Francisco Sá Carneiro (1971); Inverter as instituições, de Ivan Illich (1972); Debate sobre o programa de política económica e social, de Melo Antunes, Francisco S. Cabral, César Oliveira, L. Ferraz de Carvalho, J. Martins, João Cravinho e Eugénio Rosa (1972); A liberalização bloqueada, de Francisco Sá Carneiro (1972); Progresso na liberdade, de Miller Guerra (1972); Sedes: dossier 70/72, de Emilio Rui Vilar e A. Sousa Gomes (1973); Encontro de reflexão política, de Magalhães Mota, Oliveira Dias e José da Silva (1973); Emigração e despovoamento, de Joaquim Jorge Magalhães Mota, Oliveira Dias e José da Silva (1973); Uma perspectiva sobre Portugal, de Francisco Sarsfield Cabral (1973); Um socialismo possível, de François Miterrand (1973).

Apesar do papel dos católicos progressistas já ter diminuído nessa etapa da vida da editora, será a partir de 1974 que essa influência deixará definitivamente de ter peso em suas decisões.

A partir da compra da Moraes pelo grupo do jornal O Século (que tinha também uma editora de livros), em maio de 1973, parece haver uma redução no ritmo dos lançamentos. Tal redução em parte é decorrência do "clima de conflito com a comissão

\footnotetext{
${ }^{16}$ J. M. M. “Ala Liberal”. Verbete. In: ROSAS; BRITO, op. cit., Vol. I, p. 32. Ver também: FERNANDES, Tiago. “A Ala Liberal da Assembleia Nacional (1969-1973): um perfil sociológico”. Penélope, $\mathrm{n}^{\circ}$ 24, 2001, p. 35-64.
} 
de trabalhadores de $O$ Século", que ganha corpo entre abril de 1974 e julho de 1975, até o ponto em que a comissão toma o poder dentro das empresas, levando à demissão de Pedro Tamen, em agosto de $1975^{17}$. O momento seguinte será a intervenção estatal no jornal em fevereiro de 1975 e sua nacionalização em julho de $1976^{18}$.

A partir da intervenção estatal e da ação da comissão de trabalhadores da editora, o ritmo das edições é retomado. O clima, todavia, não era tranquilo. Nelson de Matos lembra que durante o "processo revolucionário em curso" (PREC) houve reuniões na editora em que algumas pessoas colocavam os revólveres em cima da mesa como "uma forma de pressão"19.

Entre 1974 e 1977 a editora publicou predominantemente obras ligadas ao pensamento de esquerda, por exemplo: O movimento dos capitães e o 25 de Abril: 229 dias para derrubar o fascismo, de Avelino Rodrigues, Cesário Borga e Mario Cardoso (1974); A armadilha da divida externa, de Cheryl Payer (1974); Introdução aos marxismos, de J. B. Fages (1974); Sobre o comunismo, de Sergio Ribeiro (abril, 1975), Imperialismo e teorias sociológicas do desenvolvimento, de Babakar Sine (1975); Canto do amor armado, de Thiago de Melo (1975); Angola: o longo caminho da liberdade, de Amadeu José de Freitas (1975); Comunistas e socialistas, a união é um combate, de Étienne Fajon (abril, 1976); O materialismo militante: questões fundamentais do marxismo, de G. Plakhanov (1976); Lénine, a arte e a revolução (3 volumes), de JeanMichel Palmier (1976), A crítica contra Lin Piao e Confúcio (julho, 1976); Portugal: os pontos nos ii, de Jacques Frémontier (1976); China, 25 anos, 25 séculos, de Francis Audray (1976); A terra a quem a trabalha, de Gerrard Winstanley (1976); O sistema político chinês no movimento de educação socialista, de Yves Viltard (1976); Política económica numa sociedade em transição, de Mário Murteira (1977); Cartas à GuinéBissau, de Paulo Freire (1977); Arte: produção e revolução proletária, de Boris Arvatov (1977); Sobre a ditadura do proletariado, de Etienne Balibar (1977); Ensaios de pósAbril, de Urbano Tavares Rodrigues (1977).

Em 1976 Nélson de Matos foi nomeado administrador por parte do Estado na Moraes Editores, representando o então Instituto das Participações do Estado $^{20}$. O perfil da editora e sua linha de publicações não mudam de forma substancial nesse período,

\footnotetext{
${ }^{17}$ TAMEN, op. cit., p. 92.

${ }^{18}$ ANDRADE, John. Dicionário do 25 de Abril. Lisboa: Nova Arrancada, 2002, p. 367-68.

19 "Revólveres e livros". Jornal de Letras, Lisboa, 25/5/1994, p. 18-19.

20 "Nota Biográfica" de Nélson de Matos. Disponível em: <http://www.edicoes-nelsondematos.com>.
} 
talvez porque seus editores ainda acreditassem, em meados de 1976, que atuavam em uma "sociedade que decididamente quer encaminhar-se para o socialismo", como afirmavam em texto de apresentação da editora ${ }^{21}$.

No período entre 1968 e 1980 a Livraria Morais Editora/Moraes Editores editou cerca de 80 obras de caráter político, a maior parte delas publicadas após a venda da editora por Alçada Baptista em 1971, o que significa dizer que as mudanças pelas quais a editora passou a partir de então não modificaram a sua vocação para a política. Mas transformaram o seu perfil político, o qual, principalmente a partir de 1975, passou a ser mais de esquerda, devido às mudanças na conjuntura política do país que levaram à mais forte participação da comissão de trabalhadores nas decisões da empresa e, em seguida, à intervenção estatal na editora.

Todavia, tal percurso não se mostrou viável a partir de certo momento, até mesmo em função do arrefecimento da agitação política e da perda de influência social dos setores de esquerda, levando a que a Moraes Editores encerrasse suas atividades em meados dos anos 1980.

\subsection{Ulmeiro}

Av. do Uruguai, 13-A - Lisboa

Editor: José Antunes Ribeiro.

Início das edições: 1970.

Distribuição: Própria.

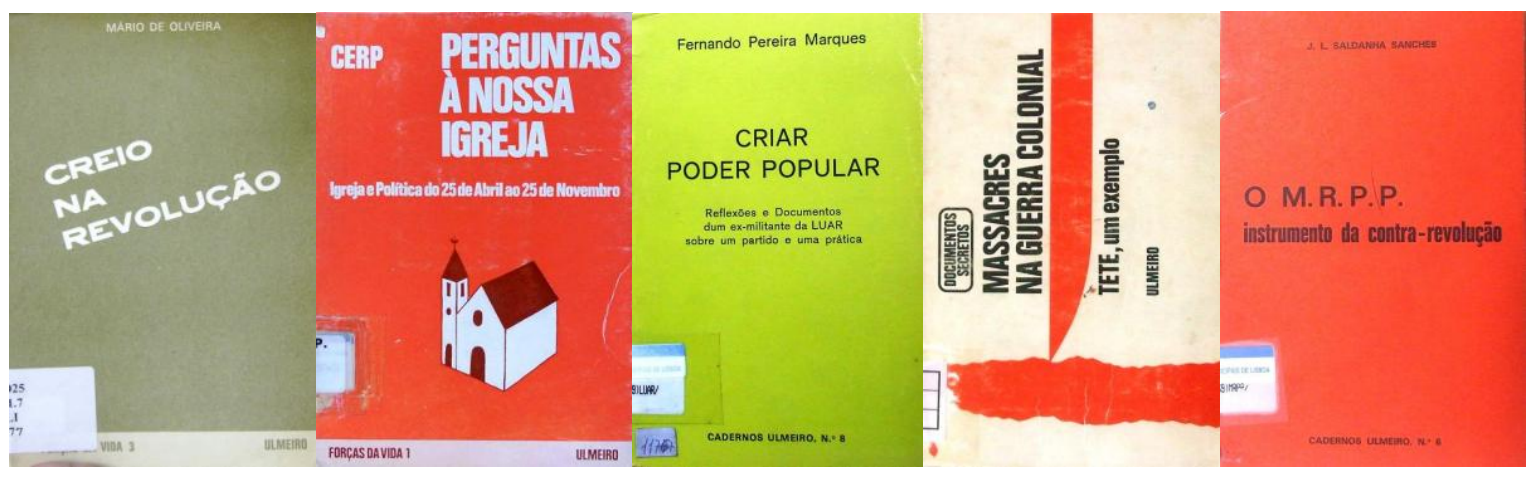

A Ulmeiro surgiu em 1969, como livraria e distribuidora, pelas mãos de José Antunes Ribeiro, juntamente com dois outros amigos - Maria Aurélia e Victor - no bairro de Benfica, em Lisboa. Em seguida, se juntaria a eles Lúcia Ribeiro, esposa de

${ }^{21}$ AA.VV. Editores portugueses na IV Bienal Internacional do Livro São Paulo: 14 a 22/agosto/1976. Lisboa: Associação Portuguesa dos Editores e Livreiros, 1976. 
José Ribeiro. A Ulmeiro foi distribuidora das editoras Centelha e Afrontamento, entre outras. Em 1970 entrou também no ramo da edição. Suas origens ligam-se ao movimento das cooperativas culturais criadas nos anos $1960^{22}$ e aos grupos de católicos progressistas.

José Ribeiro, que sempre foi o principal responsável pela linha editorial da Ulmeiro, esteve ligado a grupos católicos progressistas e foi colaborador, na década de 1960, da revista $O$ Tempo e o Modo. "Minha matriz política estava próxima dos católicos progressistas", diz ele ${ }^{23}$.

Ribeiro começou sua vida de livreiro com a criação da Livraria Obelisco, na Amadora, cidade vizinha a Lisboa, em fins dos anos 1960. Em seguida fez algumas publicações nas Edições Itau. Depois dessas experiências, Ribeiro foi para Lisboa, onde no final de 1969 criou a Ulmeiro, primeiro como livraria e distribuidora, e depois também como editora. Inicialmente o projeto era dar mais ênfase à distribuição, mediante o trabalho com as editoras Centelha, de Coimbra, e Afrontamento, do Porto, "que eram duas das editoras que mais publicavam obras de cariz político e de intervenção", diz Ribeiro ${ }^{24}$.

A livraria marcou época como um local de encontro e de debates de pessoas que se opunham à ditadura e chegou a ser uma das grandes livrarias de Lisboa:

Nessa época conturbada do Salazarismo, e antes do 25 de Abril de 1974, esta era uma livraria "marcadamente de contestação", segundo palavras da D. Lúcia Ribeiro. (...) A Livraria assumia um papel de núcleo de concentração dos intelectuais que queriam fazer ouvir as suas vozes contra o governo. "Há ali um período em que era só política, pronto. Aí foi o auge da política. A gente queria era saber alguma coisa de política" (...), e na Ulmeiro começaram a realizar-se sessões culturais de cariz político-informativo. ${ }^{25}$

A livraria caracterizou-se por atividades culturais com nomes que viriam a ter destaque nesse campo em Portugal:

A Ulmeiro com as suas acções de poesia e música... O primeiro local em Lisboa onde Mário Viegas declamou poesia, o refúgio onde Zeca Afonso encontrava guarida... por onde também passaram Carlos

\footnotetext{
${ }^{22}$ Entrevista com José Antunes Ribeiro, Lisboa, 2/2/2011.

${ }^{23}$ Idem.

${ }^{24}$ Idem.

${ }^{25}$ CARVALHO, Alexandra. "Livrarte/Ulmeiro... 40 anos a resistir". Blogue Mercado de Bem-Fica, 17/1/2009. Disponível em: <http://mercadodebemfica.blogspot.com/2009/01/livrarte-40-anosresistir.html>. Acesso em dez. 2010.
} 
Paredes, Rogério Paulo e Francisco Fanhais, entre tantos outros. ${ }^{26}$

Em 1970 saíram os primeiros livros: Isto anda tudo ligado, de Eduardo Guerra Carneiro, ao qual seguiu-se A poesia deve ser feita por todos, de Carlos Loures, ambos de poesia.

Depois vem o livro Histórias do cárcere, do espanhol Juan Gómez Casas. Apesar do título, o livro não tinha conotação política, mas assim não entendeu a PIDE, que apreendeu toda a edição de 2.500 exemplares, o que trouxe grave prejuízo econômico à Ulmeiro ${ }^{27}$.

Pelos livros que distribuía - políticos e de intervenção, com ideias opostas ao regime -, pelas atividades culturais que promovia e, depois, pelos livros que passou a editar, a Ulmeiro era um centro de produção e agitação política e cultural naqueles tempos. E sofreu as consequências disso, ou seja, a perseguição por parte da polícia política da época.

Desses tempos, Zé Ribeiro relembra como, em certo dia, quando a PIDE foi à Ulmeiro, quase fechou a Av. do Uruguai [onde se localizava a livraria/editora], numa espécie de operação quase de comandos. Porque, em determinada altura, as apreensões que eram feitas pela PIDE eram destinadas a inviabilizar o projecto da Ulmeiro e a sua actividade, porque como se diz "é preciso matar o bicho para acabar com a peçonha" 28 .

Esse foi um dos motivos que levou Ribeiro a "acalmar a parte da edição", mantendo a livraria e a distribuição, que também sofreu muitas perseguições por parte da polícia política. Pouco depois, em 1972, ele esteve na origem da editora Assírio\&Alvim - ao lado de João Carlos Alvim, Assírio Bacelar, Mário Reis e Carlos Caeiro -, direcionando para essa editora o seu trabalho como editor até o início de 1975 (ver o Capítulo 7). Isso levou a uma interrupção das edições por parte da Ulmeiro, que só retomou essa atividade em 1975. Entre 1972 e 1975 a Ulmeiro manteve-se basicamente como livraria e papelaria ${ }^{29}$.

A editora teve, portanto, duas fases: a primeira desde sua fundação até 1972, e a segunda a partir de 1975 e até meados dos anos 1980. Entre 1972 e 1975, José Ribeiro dedicou-se primordialmente à Assírio\&Alvim, que de certa forma foi para ele uma

\footnotetext{
${ }^{26}$ CARVALHO, Alexandra. "Gente de Benfica - V". Blogue Retalhos de Bem-Fica, 10/12/2010. Disponível em: <http://retalhosdebemfica.blogspot.com.br/2010/12/gente-de-benfica-v.html〉. Acesso em jan. 2011.

${ }_{27}^{27}$ Entrevista com José Antunes Ribeiro, Lisboa, 2/2/2011.

${ }^{28}$ CARVALHO, "Gente de Benfica - V', op.cit.

${ }^{29}$ Entrevista com José Antunes Ribeiro, Lisboa, 2/2/2011.
} 
alternativa para tentar escapar das pressões, apreensões e perseguições que a Ulmeiro estava sofrendo por parte da PIDE.

Na primeira fase a editora publicou apenas a coleção Cadernos Peninsulares, que teve cinco títulos, entre os quais aqueles mencionados anteriormente. Na segunda fase, mais prolífica e em que os títulos políticos predominaram, têm destaque as coleções Cadernos Ulmeiro, Biblioteca Ulmeiro, Documentos de Cuba, Obra Completa de Che Guevara, Terceiro Mundo e Revolução, e Forças da Vida, esta última de livros ligados a setores dos católicos progressistas. Nesta etapa, o período mais intenso é aquele que José Antunes Ribeiro chama de "a fase mais ativa do 25 de Abril", desde o fim da ditadura até 1977. De acordo com ele, nesse momento, assim como em toda a existência da editora, os títulos publicados eram definidos a partir de suas simpatias políticas pessoais na época, e não por arranjos ou injunções de grupos políticos. Na segunda metade da década de 1970, Ribeiro teve como sócio na Ulmeiro seu irmão mais velho.

Na fase iniciada em 1975, vale assinalar que a Ulmeiro editou várias obras sobre a realidade portuguesa pós-25 de Abril, algumas delas sobre questões polêmicas da conjuntura política da época, como $O M R P P$, instrumento da contra-revolução, de J. L. Saldanha Sanches (1975); Portugal, nem tudo está perdido: do Movimento dos Capitães ao 25 de Novembro, do Capitão Fernandes (abril, 1976); Massacres na guerra colonial (Tete, um exemplo), organizado por José Amaro (abril, 1976); Criar poder popular: reflexões e documentos dum ex-militante da LUAR sobre um partido e uma prática, de Fernando Pereira Marques (junho, 1976); Perguntas à nossa Igreja: Igreja e política do 25 de Abril ao 25 de Novembro, organizado pelo grupo Cristãos em Reflexão Permanente/CERP (1976); A ITT contra o 25 de Abril, de Oliveira Antunes (1976); MFA e luta de classes: subsídios para a compreensão do processo histórico português, de Ramiro Correia, Pedro Soldado e João Marujo (1977); MFA Dinamização cultural e acção cívica, de Ramiro Correia, Pedro Soldado e João Marujo (1977); Textos cristãos: 25 Abril - Novembro 25 (1977); e Creio na revolução, de Mário de Oliveira (1977).

Além disso, publicou obras sobre as lutas de libertação das ex-colônias africanas, obras sobre a revolução cubana, a libertação do Vietnã e clássicos do pensamento socialista. Destaque para as seguintes obras: A grande tarefa da revolução consiste em formar o homem novo, de Fidel Castro (1975); Sobre a ditadura do proletariado, com textos de Marx, Engels e Lenine (1975); Sobre o problema das cooperativas agrícolas, de Mao Tsé-tung (1975); Testamento do presidente Ho Chi 
Minh (1975); Textos Económicos, de Che Guevara (1975); Angola: documentos da independência (1976); A África deve unir-se, de Kwame Nkrumah (1977); Os condenados da terra, de Frantz Fanon (1976); Sobre democracia operária e outros textos, de António Gramsci (1976); Teoria da insurreição, de Emílio Lusso (1977); Problemas actuais do marxismo, de Henri Lefebvre (1977); Angola, do 25 de Abril ao 11 de Novembro, de Artur Queiroz (1978); A CIA contra Angola, de John Stockwell (1979).

No primeiro momento os resultados comerciais dessas edições foram muito positivos. Ribeiro recorda que:

Numa certa fase as tiragens eram de no mínimo 3 mil exemplares. Eu recordo-me que no caso do livro Massacres da guerra colonial [de 1976] vendemos rapidamente uma edição de 10 mil exemplares. $O$ livro do Saldanha Sanches sobre o MRPP [O MRPP, instrumento da contra-revolução] teve enorme repercussão e vendeu muito, com duas edições de 10 mil exemplares cada [a $1^{\text {a }}$ em 1975 e a $2^{\text {a }}$ em 1976]. ${ }^{30}$

Havia também eventos de lançamento de livros na Ulmeiro nessa época, com debates, apresentação de obras e noites de autógrafos, tanto de livros da própria editora como de outras casas publicadoras.

Esta etapa corresponde a uma estrutura mais profissionalizada da Ulmeiro, com pessoal de armazém, revisores, capistas etc., ou seja, um corpo maior de funcionários, o que acabou por gerar alguns problemas financeiros. Além disso, havia também partes do trabalho que eram feitas por free-lancers. Mas em todas as etapas da vida da editora foi sempre José Ribeiro que concentrou a maior parte das atividades de produção editorial, além de acompanhar as vendas e a parte administrativa.

Refletindo sobre essa questão, Ribeiro diz que:

O negócio do livro é contraditório porque era um negócio e ao mesmo tempo era militância, era debate de ideias, e a parte do negócio acaba sempre a condicionar [tudo]. Quando a gente cresce, ou tenta crescer, já não tem hipótese de fazer grande coisa, porque o peso da estrutura é tal que a certa altura temos a estrutura mas já não dá pra fazer grande trabalho. ${ }^{31}$

O livro Massacres na guerra colonial (Tete, um exemplo), organizado pelo jornalista José Amaro e lançado em abril de 1976, foi alvo de um processo movido pelo

\footnotetext{
${ }^{30}$ Entrevista com José Antunes Ribeiro, Lisboa, 2/2/2011.

${ }^{31}$ Idem.
} 
Estado Maior General das Forças Armadas e assinado pelo general Ramalho Eanes na sua qualidade de Chefe do Estado Maior do Exército. O livro reproduzia documentos militares oficiais sobre a ação das forças armadas portuguesas na guerra colonial em Moçambique. O general acusava o autor e o editor do livro de violar a Lei de Imprensa por "divulgar segredos militares essenciais à defesa nacional e de contribuir para minar a disciplina e a coesão no seio das forças armadas" ${ }^{32}$. José Antunes Ribeiro e José Amaro foram processados. O processo se arrastou por anos, até que ambos acabaram por ser anistiados pelo $5^{\text {a }}$ Tribunal Militar Territorial de Lisboa ${ }^{33}$.

O predomínio das edições políticas dura somente alguns anos, principalmente no período entre 1975 e 1977. Diz Ribeiro:

A parte propriamente de política pura e dura encerrou-se praticamente com a extinção do 25 de Abril. Quando a chamada democracia estabilizou eu acho que o apetite pelos livros políticos também arrefeceu, muito embora se tenha ainda publicado depois muita política de extrema direita. ${ }^{34}$

Nos anos 1980 as cotas da Ulmeiro foram dividas em três partes entre Ribeiro, Carlos Garcia e Natércia Oliveira. Seguiu-se uma tentativa de "tomada" da editora pelas Forças Populares 25 de Abril (FP-25), organização armada criada em abril de 1980 mas esta tentativa acabou por não ter êxito. Natércia Oliveira chegou a ser, inclusive, presa no âmbito do processo das FP-25, em meados dos anos 1980. Já Carlos Garcia manteve-se nesse período mais tempo em Moçambique, tendo em seguida se afastado da Ulmeiro. Mas a editora não foi atingida diretamente por este processo e continuou em atividade, pois efetivamente não tinha ligações com as FP- $25^{35}$.

Avaliando a atuação da Ulmeiro, José Ribeiro diz que valeu a pena. "A editora cumpriu um certo papel nos debates, além disso foi um grande aprendizado pessoal". Mas não esconde também alguma desilusão com a política:

Eu vinha com a ideia um pouco ingênua de que era possível um grande debate à esquerda, de que era possível editar coisas que servissem um pouco para toda a gente [dentro desse campo]. Quando houve o 25 de Abril nós pusemos na montra [vitrine] da livraria cartazes do PS, do PC e do MRPP, o que diz bem da ingenuidade. E eu venho a descobrir, numa aprendizagem pessoal, que a realidade não é

\footnotetext{
32 “Eanes processa jornalista por livro sobre massacres coloniais”. Página Um, Lisboa, 17/9/1976, n 56, p. 1.

${ }^{33}$ Entrevista com José Antunes Ribeiro. Lisboa, 2/2/2011.

34 Idem.

${ }^{35}$ Mensagem eletrônica de José Antunes Ribeiro enviada em 14/9/2012.
} 
nada daquilo que eu acho, não só as pessoas são inimigas ferozes, como dentro das organizações as pessoas se dividem em grupos e os grupos são igualmente inimigos. ${ }^{36}$

A editora atuou até o começo da década de 1990. Em todo o período de sua atuação editou cerca de 60 títulos de caráter político. Desde o começo dos anos 1980 passou a predominar e edição de obras de ficção, poesia e literatura. A livraria Ulmeiro passou a chamar-se Livrarte nos anos 1990, mas em 2012 retomou a antiga denominação, e continua a funcionar no mesmo endereço da Avenida do Uruguai, no bairro lisboeta de Benfica, agora como sebo (alfarrabista).

\subsection{Livraria Telos Editora}

Rua Santa Catarina, 521 - Porto

Início das edições: 1971.

Distribuição: Multinova.

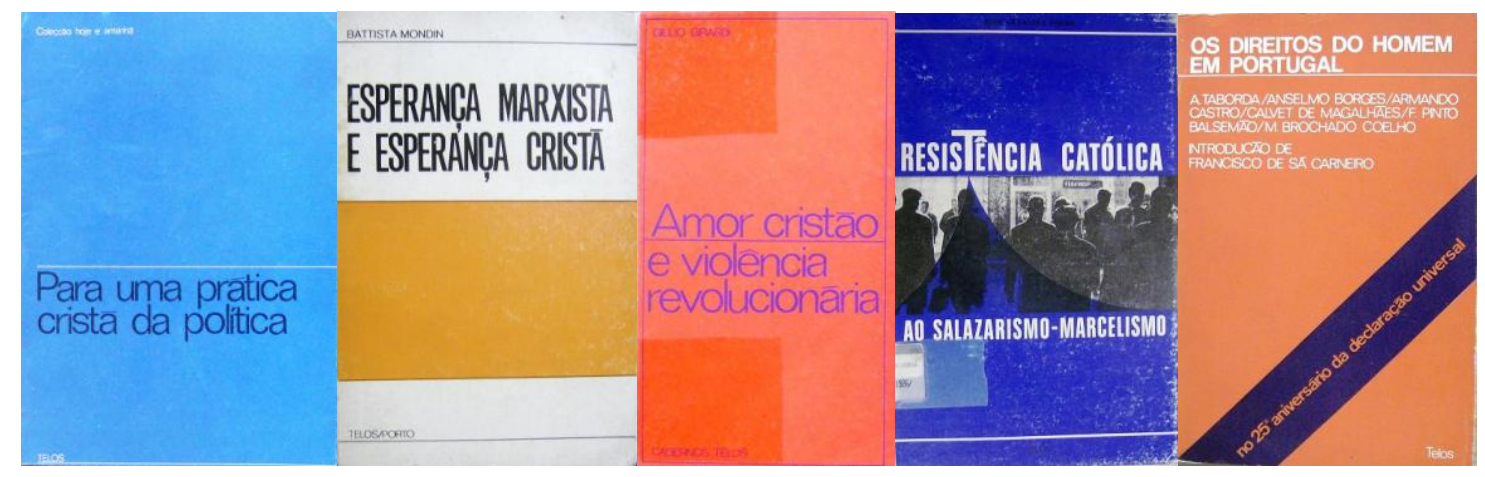

Editora ligada à Diocese do Porto, publicava o semanário Voz Portucalense, criado em janeiro de 1970 por D. António Ferreira Gomes, que retomara no ano anterior suas funções de bispo do Porto, após dez anos de exílio ao qual foi obrigado após ter enviado uma carta em 1958 a Salazar com críticas à situação política, social e religiosa da nação ${ }^{37}$.

Um dos fundadores da Telos foi o engenheiro portuense Joaquim Macedo Correia $^{38}$, que era membro da Ala Liberal da União Nacional. Correia havia sido membro da Acção Católica e da União Católica de Industriais e Dirigentes de

\footnotetext{
${ }^{36}$ Entrevista com José Antunes Ribeiro, Lisboa, 2/2/2011.

37 “D. António Ferreira Gomes”. In: Infopédia [Em linha]. Porto: Porto Editora, 2003-2012. Disponível em: <URL: http://www.infopedia.pt/\$d.-antonio-ferreira-gomes>. Acesso em jun. 2012.

38 "Instituto Cultural D. António Ferreira Gomes: instituição diocesana". Disponível em: <http://www.etc.pt/VP/ler_seccao2e936-2.html?diranter274*3\%7C2>. Acesso em jun. 2012.
} 
Trabalho ${ }^{39}$.

O primeiro livro da Telos foi Deus para que serve?, de Zacarias de Oliveira, publicado em 1971.

De 1972 até 1976, as principais obras editadas foram: Esperança marxista e esperança cristã, de Battista Mondin (1972); Marxismo/Cristianismo, de Castro Fernandes, F. Pereira de Moura, Jofre Nogueira e Sousa Marques (1972); A Igreja pósConciliar, de D. António Ferreira Gomes (1972); Evolução da teologia da guerra, de M. D. Chenu (1972); O que é ser cristão: apresentação essencial do cristianismo (1972); Paz da vitória ou paz da justiça?, de D. Antonio Ferreira Gomes (1973); Amor cristão e violência revolucionária, de Giulio Girardi (1973); Retrato de uma comunidade de base, de Domingos Barbé e Emmanuel Retumba (1973); Jesus Cristo é liberdade, de Ernest Kasemann (1973); Dimensões políticas da fé, de René Coste (1973); Portugal 73: ano político. Notas para o cidadão eleitor, de Diogo Duarte, Emílio Rui Vilar e Manuel Bidarra (1973); Liberdade e manipulação na sociedade e na igreja, de Karl Rahner (1974); Paz em Portugal pela reconciliação entre os portugueses, de D. António Ferreira Gomes (1975); Bater a penitência no peito dos outros?!, de D. António Ferreira Gomes (1975); Consciência cristã e opção política, de Manuel Alves Pardinhas (1975); Evangelho e libertação humana, de D. Helder Câmara (1975); Resistência católica ao salazarismo-marcelismo, de José Geraldes Freire (1976); Para uma leitura cristã da luta de classes, de Alfred Ancel (1976).

$\mathrm{Na}$ "Introdução" ao livro Os direitos do homem em Portugal: no $25^{\circ}$ aniversário da declaração universal, editado em fevereiro de 1974, Francisco Sá Carneiro expunha o pensamento de alguns setores católicos ligados à editora no que diz respeito à situação das liberdades em Portugal: "Este livro poderia intitular-se 'Réquiém português pela Declaração dos Direitos do Homem no seu $25^{\circ}$ aniversário'. Da sua leitura se vê que nenhum dos direitos analisados e enumerados na Declaração é efectivamente assegurado em Portugal" ${ }^{\text {40 }}$.

Já em 1975, outro texto introdutório a um livro da editora afirmava que "a nossa palavra sobre política [não deve ser] simulada, capciosa ou anódina, servindo para tudo. Deve ser orientadora, clara e dita com liberdade para permitir liberdade" ${ }^{, 41}$.

\footnotetext{
${ }^{39}$ FERNANDES, op. cit., p. 60.

${ }^{40}$ CARNEIRO, Francisco Sá. "Introdução". In: TABORDA, A. et al. Os direitos do homem em Portugal: no $25^{\circ}$ aniversário da declaração universal. Porto: Telos, 1974, p. 5.

41 “Introdução". In: PARDINHAS, Manuel Alves et al.Consciência cristã e opção política. Porto: Telos,
} 
De acordo com a página eletrônica da Fundação Voz Portucalense (que incorporou o acervo da editora), a atuação da Telos deu-se "captando, sinalizando e reflectindo os grandes temas da actualidade eclesial, teológica, económica, laboral, social e política" ${ }^{\prime 2}$.

A Telos Editora situava-se no campo da oposição católica ao regime do Estado Novo, representando o pensamento dominante na Diocese do Porto sob o comando de D. António Ferreira Gomes.

Em termos políticos estava mais ao centro do que os chamados católicos progressistas. Após o 25 de Abril, manteve a edição de obras que advogavam a participação política dos católicos na vida portuguesa.

As edições políticas tiveram maior destaque na editora entre 1972 e 1976, período em que foram editados cerca de 25 obras com essa característica. A partir desse ano passam a predominar as obras de cariz mais diretamente religioso.

\subsection{Livraria Multinova}

Av. S Joana Princesa, 12-E - Lisboa

Editor: Manuel Bidarra

Início das edições: 1973.

Distribuição: Própria.

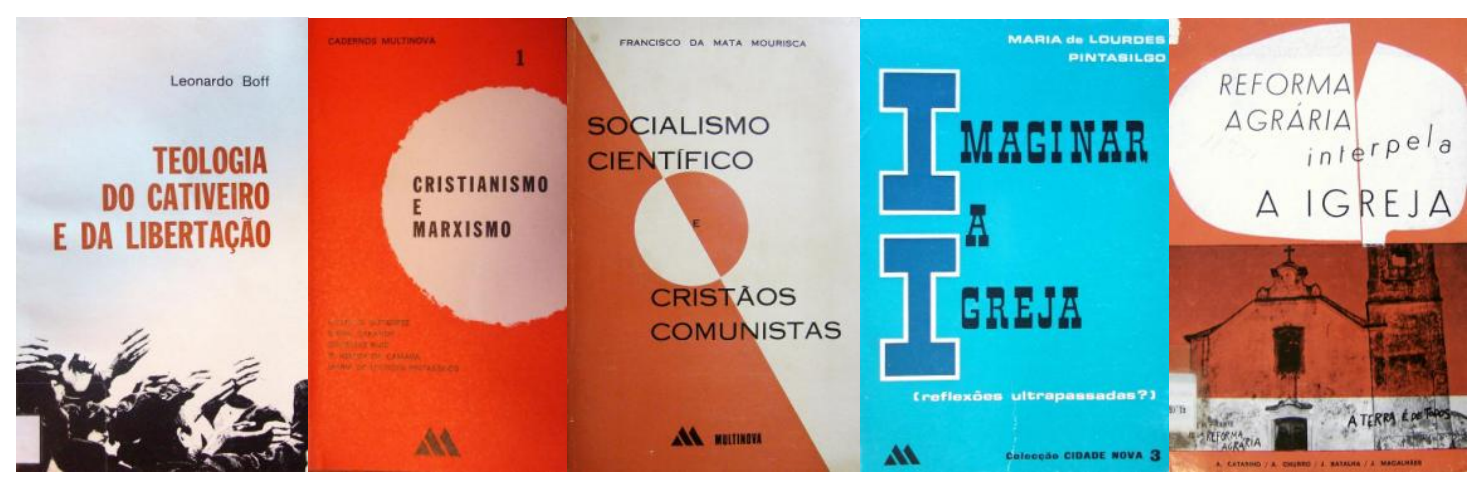

A Livraria Multinova foi fundada em maio de $1970^{43}$. Um de seus fundadores foi Manuel Bidarra, que havia sido militante da Juventude Operária Católica e, em 1959,

1975, p. 6.

42 "Fundação Voz Portucalense". Disponível em: http://netsearch.pt/livrariaportocristadeus>. Acesso em jun. 2012.

43 "Quem somos". Página eletrônica da Editora Multinova. Disponível em: $<$ http://www.multinova.pt/Homepage/Sobre-a-Multinova/Quemsomos/Content.aspx?tabid=2815\&code=pt $>$. Acesso em jun. 2012. 
fora um dos signatários da carta aberta dirigida a Salazar denunciando os métodos da PIDE. Foi também chefe de serviço de pessoal da Lisnave e diretor administrativo da Gaslimpo, além de ter sido um dos fundadores da cooperativa Pragma, em 1964, e da SEDES, em $1970^{44}$. No ramo editorial, havia criado, no começo dos anos 1960, a Livraria S. Pedro, Editora, junto com Manuel d'Oliveira Campos ${ }^{45}$.

De acordo com a página eletrônica da editora, Bidarra teria sito "a alma do projecto livreiro e cultural da Multinova" ${ }^{\text {. }}$. Bidarra faleceu em setembro de 2010.

O primeiro título da editora, lançado em 1973, já deixava clara a linha política da Multinova. Tratava-se do livro Os explorados e a teologia da libertação, de Gustavo Gutierrez, um dos principais pensadores da Teologia da Libertação.

Até 1980 predominaram nas edições da Multinova as obras de caráter político, em particular as obras ligadas ao pensamento cristão progressista e à Teologia da Libertação. Alguns dos títulos editados nesse período foram: Cristianismo e marxismo, de G. Gutierrez, R. Garaudy, G. Ruiz, D. Hélder Câmara e Maria de Lourdes Pintassilgo (1974); Fé e política, de Y. Jolif, G. Casalis e P. Blanquar, com apresentação de José Felicidade Alves (1974); O crucificado e a sua igreja, de Ernst Käseman (1974); Os cristãos e a esquerda, de Bartolomeu Valente, com comentários do padre Mário de Oliveira (1975); Uma leitura política do Evangelho, de Fernando Belo (1975); Evangelização, anúncio de liberdade, de José da Cruz Policarpo (1975); A graça libertadora no mundo, de Leonardo Boff (1976); Teologia do cativeiro e da libertação, de Leonardo Boff (1976); Revolução e libertação (Aspectos psicológicos e sociológicos da revolução), de Aires Gameiro e José Carlos Sousa (1976); Reforma agrária interpela a igreja, de Acácio Catarino, Alberto Churro, Joaquim Batalha e José Magalhães (1977); O materialismo e a ciência, de Mata Mourisca (1978); Repensar Portugal, de Manuel Antunes (1979); Socialismo científico e cristãos comunistas, de Francisco da Mata Mourisca (1979); O pensamento de Paulo Freire: uma revolução na educação, de Manuel Moura (1979); Imaginar a Igreja (Reflexões ultrapassadas?), de Maria de

${ }^{44}$ GOMES, João Gomes. "Manuel Bidarra - In Memoriam”. Observatório da Cultura, n. ${ }^{\circ}$ 14. Disponível em: <http://www.snpcultura.org/obs_14_manuel_bidarra.html>; LOPES, Joana. "Manuel Bidarra". Disponível em: <http://entreasbrumasdamemoria.blogspot.com.br/2010/09/manuel-bidarra.html>. Acesso em jun. 2012; ALMEIDA, João Miguel. "A morte de Manuel Bidarra". Disponível em: <http://avezdopeao.blogspot.com.br/2010/09/morte-de-manuel-bidarra.html>. Acesso em jun. 2012. ${ }^{45}$ GOMES, op. cit.

46 "Fundadores". Página eletrônica da Editora Multinova. Disponível em: $<$ http://www.multinova.pt/Homepage/Sobre-a-

Multinova/Fundadores/Content.aspx ?tabid=2816\&code=pt $>$. Acesso em jun. 2012. 
Lourdes Pintasilgo (1980); Uma luz nas trevas: a luta pelos direitos humanos na Rússia

- tal como eu os vi, de Victor Sparre, com prefácio de António Alçada Baptista (1980).

Como podemos ver, foram editadas obras de expoentes do catolicismo progressista, além de prefácios e comentários dos padres José Felicidade Alves e Mário de Oliveira, religiosos perseguidos pelo Estado Novo e que simbolizavam a oposição católica ao regime ditatorial.

A editora realizou coedições com a editora católica brasileira Vozes, também vinculada ao pensamento cristão progressista.

A Multinova representou um canal de manifestação de setores cujas origens ligam-se aos chamados católicos progressistas (ver item sobre a Editora Morais). A editora começou a publicar ainda sob o governo de Marcelo Caetano, mas a sua atuação desenvolveu-se efetivamente a partir do 25 de Abril, o que lhe permitiu apresentar de forma mais livre as obras sobre a Teologia da Libertação, proporcionando o debate sobre essa corrente de pensamento cristão em Portugal. A partir do começo dos anos 1980, essa linha de edições perdeu força e a editora voltou-se para temas religiosos menos polêmicos e para outros tipos de obras.

Entre 1973 e o início dos anos 1980 a editora publicou 20 títulos de caráter político. A editora ainda está em atuação e dedica-se, atualmente, também à edição de livros escolares.

\subsection{Edições Base}

Lisboa - R. S. Bento, 672 / Porto - R. Passos Manuel, 209 - $1^{\circ}$

Editor: Fernando Moreira de Abreu.

Início das edições: 1973.

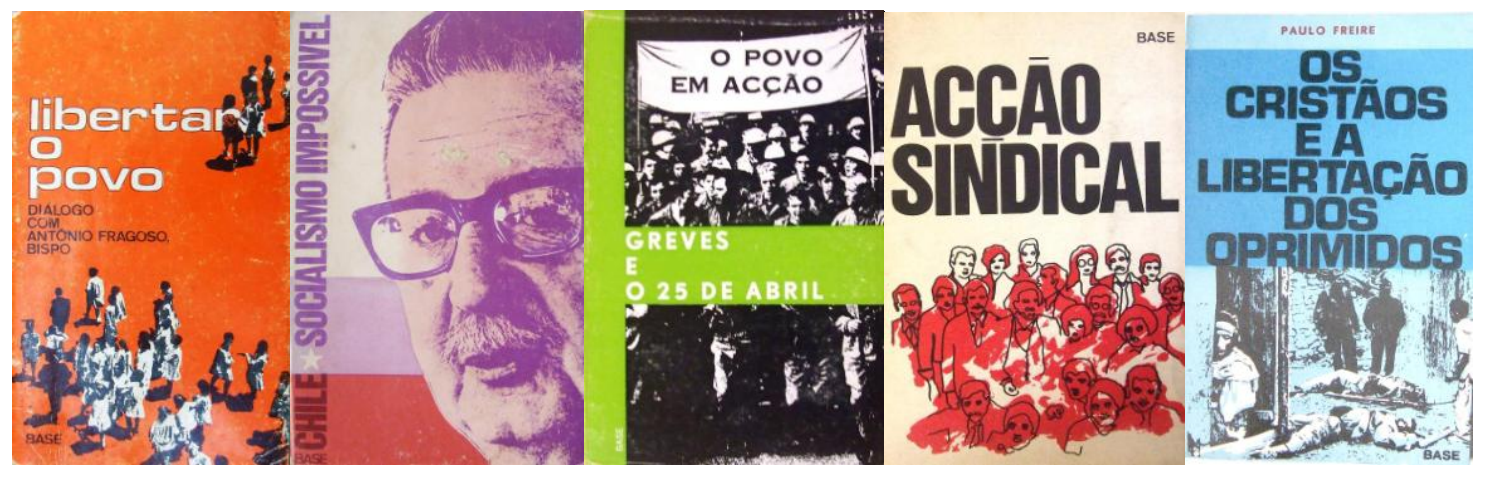

A editora surgiu a partir da ação de militantes católicos que atuavam no Centro de Cultura Operária (CCO), organização vinculada à Liga Operária Católica, e que 
visava a "formação de sindicalistas e animadores culturais católicos" " anos 1960 militantes do CCO criaram o grupo Base. Como recorda Fernando Abreu, dirigente do $\mathrm{CCO}$ à época:

Depois da constituição do $\mathrm{CCO}$, chegamos a um momento em que se conclui que a formação que se está a fazer no campo da actividade cultural, sindical e também política tem que ter uma estrutura política, e, portanto, a Base se constitui como um movimento clandestino, embrionário, na altura, em 1968, por aí. ${ }^{48}$

De acordo com Abreu, "As edições começaram ainda no CCO, com uns folhetos sobre questões económicas, sociais e políticas. Inicialmente, eu e a Maria Elisa Salreta éramos responsáveis pelas edições, era um trabalho militante" ${ }^{\natural 9}$. Eram os Cadernos de Cultura Operária, que começaram a ser editados em $1967^{50}$, juntamente com outros livretos $^{51}$. É a partir desse momento também que o CCO se define por uma linha de atuação contrária à “criação de sindicatos e partidos políticos confessionais, defendendo a unidade de acção com trabalhadores de diferentes opções religiosas e políticas" ${ }^{\text {"52 }}$.

A nova direção que assume o CCO em 1969 tem à frente Fernando Moreira de Abreu, um dos líderes do grupo Base, e dá uma nova dinâmica ao Centro, privilegiando "a formação de militantes comprometidos na transformação da sociedade portuguesa"

A primeira edição com o selo Base surgiu em agosto de 1973: Libertar o povo (Diálogo com António Fragoso, Bispo), coordenado por Maria da Conceição Moita. Antes do 25 de Abril houve ainda dois títulos lançados: E o sol é só um, coordenado por Elisa Salreta, e Chile: socialismo impossível, coordenado por Fernando Abreu, ambos editados em dezembro de 1973.

Em 30 de outubro de 1974, como decorrência das mudanças políticas geradas com o fim da ditadura, o CCO e o grupo Base autonomizam-se em relação à Liga Operária Católica e passam a se denominar Base-Frente Unitária de Trabalhadores ${ }^{54}$, tendo como projeto político uma sociedade socialista e autogestionária.

\footnotetext{
${ }^{47}$ ALMEIDA, op. cit., p. 137.

${ }^{48}$ Entrevista com Fernando Moreira de Abreu e Brandão Guedes, Lisboa, 15/2/2011.

${ }^{49}$ Idem.

${ }^{50}$ ABREU, Fernando. "As nossas origens a partir do Centro de Cultura Operária (CCO). In: Base-FUT: 30 anos. Lisboa: Base, 2004, p. 9.

${ }^{51}$ Encontrei referências aos seguintes títulos, além dos Cadernos de Cultura Operária, lançados pelo Centro de Cultura Operária antes do 25 de Abril: Realidades económicas e sociais (2 volumes); Desemprego; A criança no trabalho; A história do movimento sindical e da legislação sindical (1834/1926); Origens e história do movimento operário.

${ }^{52}$ ABREU, “As nossas origens...", p. 10.

${ }^{53}$ Ibidem, p. 10.

${ }^{54}$ Ibidem, p. 18-19.
} 
Os objetivos do grupo Base com a criação das Edições Base é assim expresso por seu coordenador, pouco depois do 25 de Abril:

A nossa intervenção, no campo editorial, em breve se estenderá a outros domínios da preparação sindical com o objectivo de contribuirmos para a formação de uma força operária militante consciente, decidida a reivindicar, a lutar e a assumir "de facto", em cada momento, em todas as situações e em qualquer sistema económico-político a orientação e organização das suas lutas. ${ }^{55}$

O resultado buscado com as obras editadas era revelar "aos trabalhadores portugueses ideias e experiências que sejam contributo para a edificação entre nós de um Movimento Sindical Revolucionário, Autónomo e Apartidário" ${ }^{, 56}$.

O público privilegiado pelos editores parecia ser aquele composto pelos militantes sindicais, mais do que os trabalhadores em geral, o que indica uma preocupação com a formação política de novas lideranças de trabalhadores dentro dos princípios da autonomia sindical. Isso fica claro na "Apresentação" do livro Sindicalismo e política:

A edição do presente livro [...] tem por objectivo contribuir para que um maior número de trabalhadores, sobretudo sindicalistas, possa, ampliando a sua formação sindical, informar-se e reflectir sobre as ideias e experiências acerca do modo como o sindicalismo se tem relacionado com a política, em geral, e com os partidos políticos, em particular, desde as suas origens até aos nossos dias. [...] a sua leitura contribuirá certamente para tornar mais evidente o que se esconde por detrás das manobras, manipulações e ingerências partidárias e governamentais no Movimento Sindical, ajudando, ainda, a "descobrir" ou a "re-descobrir" a via da Autonomia do Movimento Sindical Português. 57

De acordo com José Vieira, os títulos publicados pelas Edições Base estavam "quase todos ligados às problemáticas quotidianas dos trabalhadores desse tempo", entre as quais ele destaca: "sindicalismo, política, educação e ensino, alfabetização, socialismo, autogestão, novas formas de pensar a sociedade e a vida, e uma outra maneira de ser cristão comprometido na fé, a partir do testemunho" ${ }^{\text {" }}$.

Muitos dos livros editados continham textos produzidos pela própria Base-FUT, ou seja, não tinham um autor específico, mas reproduziam documentos e resoluções do

\footnotetext{
55 ABREU, Fernando. “Apresentação”. In: PIAZZI, Ugo. Acção sindical. Lisboa: Base, 1974, p. 7.

56 “O Autor”. In: VIEIRA, Alexandre. Subsídios para a história do movimento sindicalista em Portugal (1908 a 1919). Lisboa: Base, julho, 1977, p. 9.

57 “Apresentação". In: Sindicalismo e política. Lisboa: Base, 1979, p. 3.

${ }^{58}$ VIEIRA, José. “Edições Base”. In: Base-FUT: 30 anos. Lisboa: Base, 2004, p. 53.
} 
grupo.

Após o 25 de Abril e até o começo da década de 1980, os principais títulos publicados foram: Acção sindical, de Ugo Piazzi (1974); Autogestão (JugusláviaChecoslováquia), coordenado por Fernando Abreu (1974); Alfabetização: caminho para a liberdade (1975); Não ao ensino burguês, do Centro de Cultura Operária (1975); Autarquias locais (O que são?) (1976); Unidade sindical: a força dos trabalhadores (1976); Por um novo sindicalismo. Princípios e perspectivas sindicais da BASE-Frente Unitária de Trabalhadores (1976); Greves e o 25 de Abril, de José Pires (1976); Manual de alfabetização (Para quem quer aprender com o povo), do Centro de Cultura Operária (1977); Subsídios para a história do movimento sindicalista em Portugal (1908 a 1919), de Alexandre Vieira (1977); Os cristãos e a libertação dos oprimidos, de Paulo Freire (1978); Autogestão e sindicalismo, documento da Confederação Francesa Democrática do Trabalho (1978); Acção sindical frente às multinacionais, documento da Confederação Mundial do Trabalho (1978); Pelo socialismo autogestionário (1979); O Brasil dos trabalhadores, texto da Oposição Sindical do Brasil (1980); Empregadas domésticas, mulheres em luta: para a história do serviço doméstico em Portugal - das origens ao fascismo, de Olegário Paz (c1980); Trilateral: a "nova” face do capitalismo, de Fernando Abreu, José Fernandes Dias e Assembleia Permanente dos Direitos Humanos da Bolívia (1981); Movimento pela autogestão na Polónia, de Cláudio Araújo Nascimento (1983).

Uma das características dos livros editados pela Base é a presença, em quase todos eles, de textos introdutórios dos editores sobre a obra, contextualizando a sua publicação e expondo a posição da Base-FUT sobre o tema abordado, além de exporem os princípios e as bases programáticas do grupo.

Os livros editados tinham, em geral, tratamento gráfico e editorial de nível profissional, em que pese o trabalho realizado na editora ser quase todo voluntário. Da mesma forma, no campo da distribuição dos livros, a editora trabalhava com a rede livreira comercial mas buscava realizar também a distribuição por meio de militantes ${ }^{59}$. Em 1977-78, os responsáveis pela editora enfatizavam que "seria desejável que os militantes reforçassem a venda 'de mão em mão', que procurassem realizar maior número de 'bancas', que tentassem fazer exposições em Organizações Populares de

\footnotetext{
${ }^{59}$ Entrevista com Fernando Moreira de Abreu e Brandão Guedes, Lisboa, 15/2/2011.
} 
BASE, etc. $"$ "60.

Deve ser destacado que as publicações realizadas só foram possíveis porque a Base "possuía um conjunto de máquinas de imprimir (uma ofsete, uma gravadora, uma fotocopiadora laser, uma aparadora) que embora não tivessem a perfeição de empresas profissionais do ramo, possibilitava o trabalho com alguma qualidade" 61 .

Num dos primeiros livros editados após o 25 de Abril, Fernando Abreu enfatizava que a Base estava "empenhada na luta de classes": "É nossa convicção que só a acção operária revolucionária e violenta (não necessariamente sangrenta) levará a classe operária (os trabalhadores das fábricas e dos campos) ao poder”. E ressaltava que “a acção sindical deve ser livre da sujeição a partidos políticos e a programas partidários" ${ }^{\prime 62}$.

Em 1976, a Base-FUT definia-se

como sendo um Movimento político, autónomo, de trabalhadores, independente de todo e qualquer partido, defendendo a construção de uma sociedade socialista autogestionária, um movimento onde os trabalhadores discutem, reflectem as suas lutas diárias e descobrem a ideologia que as anima e do que delas decorre. ${ }^{63}$

E, no ano seguinte, a Edições Base definia-se como "uma editorial militante, não comercial, nem comercialista"64 e também como "uma editora revolucionária"65.

Até o fim das suas atividades, em 1999, foram editados 37 títulos. Sua ação editorial concentrou-se na década de 1970, quando foram lançados 27 títulos. Nos anos 1980 editou também a revista Autonomia Sindical.

As Edições Base representaram uma iniciativa de segmentos católicos progressistas que atuavam no setor sindical e que buscaram sempre uma atuação autônoma tanto em relação à hierarquia eclesiástica como aos partidos políticos, e que viam na edição de livros uma forma de dialogar com seus militantes e com setores próximos às causas que defendiam.

\footnotetext{
${ }^{60}$ EDIÇÕES BASE. "Relatório actividades 1977 e plano para 1978”. Documento policopiado, s/d. Grifo do original.

${ }^{61}$ VIEIRA, op. cit., p. 54.

${ }^{62}$ ABREU, Fernando. "Apresentação", op. cit., p. 6.

63 "Por um socialismo autogestionário". Página Um, Lisboa, 12/11/1976.

${ }^{64}$ EDIÇÕES BASE, op. cit.

${ }^{65}$ A Base-FUT e a Feira do Livro. Folheto distribuído na Feira do Livro de Lisboa, maio, 1977.
} 
8.6 Edições CIDAC (Centro de Informação e Documentação Amílcar Cabral) R. Pinheiro Chagas, 77, $2^{\circ}$ Esq. - Lisboa

Editor: Luís Moita.

Início das edições: 1974.
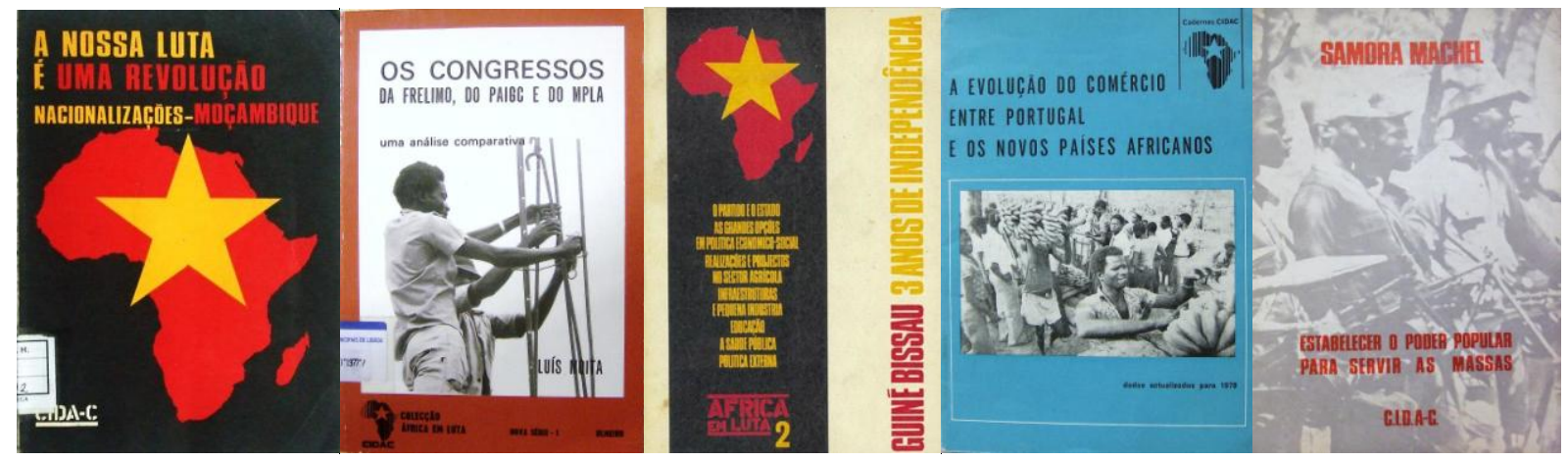

Editora do Centro de Informação e Documentação Anti-Colonial (CIDA-C), criado em maio de 1974 por militantes católicos progressistas engajados na luta contra a guerra nas colônias portuguesas da África. Alguns destes militantes haviam publicado anteriormente, de forma clandestina, o boletim Direito à Informação (editado entre 1963 e 1971) e o Boletim Anti-Colonial (BAC), este último publicado entre outubro de 1972 e fins de novembro de 1973, quando suas instalações foram descobertas pela polícia política, levando ao desmantelamento do grupo e à prisão de alguns de seus membros, que somente seriam libertados após o 25 de Abril. Seus militantes também participaram ativamente da Vigília na Capela do Rato, ocorrida em 31 de dezembro de 1971 e reprimida pelo regime ${ }^{66}$.

Após o 25 de Abril, Nuno Teotónio Pereira e Luis Moita, dois dos responsáveis pelo $B A C$ "pensaram o que fazer com o acervo de documentos que a PIDE tinha apreendido e arquivado na sua sede". Daí surgiu a ideia de organizar o Centro de Informação e Documentação Anti-Colonial (CIDA-C) ${ }^{67}$.

O centro foi posto de pé por Luís Moita - ex-padre, experiente militante católico progressista e um dos criadores do movimento Cristãos pelo Socialismo em Portugal - e mais quatro jovens militantes e/ou estudantes: Luísa Ivo, Luísa Teotónio Pereira, Carol Quina e Henrique Sanches. Este último logo se afastou do grupo por divergências políticas, em função de sua militância no MRPP (Movimento Reorganizativo do Partido

\footnotetext{
${ }^{66}$ MATIAS, Augusto. "Entre o BAC e o CIDAC". In: A cor das solidariedades: pela justiça e equidade nas relações internacionais. 30 anos do CIDAC. Lisboa/Porto: CIDAC/Afrontamento, 2004, p. 21-25.

${ }^{67}$ MATIAS, op. cit., p. 25.
} 
do Proletariado) ${ }^{68}$.

O objectivo do CIDA-C era "pressionar o novo poder para que reconhecesse o direito à autodeterminação e independência das colônias e fazê-lo utilizando a estratégia que o grupo do $B A C$ tinha afinado: a disponibilização de informação e a consequente iniciativa cívica" ${ }^{\prime 69}$.

Luís Moita ressalta que a gênese do CIDAC "é indissociável do apoio de certos grupos estrangeiros, onde se destacam os holandeses. Daí veio um incentivo à nossa iniciativa e uma contribuição financeira que se revelaria determinante". Alguns desses grupos foram o Comitê Angola, o grupo "X-Y", ambos da Holanda, o Comitê Contra a Fome e para o Desenvolvimento, da França, entre outros ${ }^{70}$.

As primeiras edições ocorreram em 1974, com a publicação de livros contendo os programas e estatutos do Partido Africano da Independência da Guiné e Cabo Verde (PAIGC), da Frente de Libertação de Moçambique (Frelimo) e do Movimento Popular de Libertação de Angola (MPLA).

Ainda em 1974 foram editados: Imagens da Guiné-Bissau, reportagem fotográfica de Koen Wessing, e Estabelecer o poder popular para servir as massas, de Samora Machel, líder da Frelimo.

Em 1976 surgiu a coleção África em Luta, com dois títulos: A nossa luta é uma revolução: nacionalizações-Moçambique, de Samora Machel e outros, e Guiné Bissau, 3 anos de independência, de Luísa Teotónio Pereira e Luís Moita.

Num dos livros dessa coleção está expresso pelos autores aquele que seria o estado de ânimo dos militantes do CIDAC:

Mais do que trabalho jornalístico, poderia falar-se de "reportagem política", no sentido em que é feita por militantes que ao longo da sua luta anticolonialista foram amadurecendo a percepção que tinham acerca da realidade de um povo ao qual estão ligados por um combate comum. [...] Escrever este livro é para nós um acto de internacionalismo militante. ${ }^{71}$

Em janeiro de 1977 o centro passou a denominar-se Centro de Informação e Documentação Amílcar Cabral (CIDAC), como forma de homenagem a um dos líderes

\footnotetext{
${ }^{68}$ PEREIRA, Luísa Teotónio. "Encruzilhada de solidariedades". In: A cor das solidariedades, op. cit., p. 28.

${ }^{69}$ Ibidem, p. 27-28.

${ }^{70}$ MOITA, Luís. "Na origem do CIDAC, uma certa "cultura política". In: In: A cor das solidariedades, op. cit., p. 55-56.

${ }_{71}^{7}$ PEREIRA, Luísa Teotónio; MOITA, Luis. Guiné Bissau, 3 anos de independência. Lisboa: CIDAC, 1979.
} 
da independência de Guiné e de Cabo Verde.

Somente em 1979 voltaram a ser lançados livros. Na coleção Cadernos CIDAC saíram: Contubel, uma cooperativa agrícola na Guiné- Bissau; Eritreia: a resistência dum povo; A roça Rio do Ouro: uma empresa agrícola nacionalizada em S. Tomé e Príncipe; e A evolução do comércio entre Portugal e os novos países africanos, todos publicados em 1979.

Os outros títulos lançados até o começo dos anos 1980 foram: Os congressos da Frelimo, do PAIGC e do MPLA: uma análise comparativa, de Luís Moita (1979, coedição com a editora Ulmeiro); A mulher e a revolução na Eritreia (1980); O não alinhamento: história e doutrina do movimento dos não alinhados, de Luís Moita (1982); e Viva a resistência do povo de Timor-Leste.

As edições do CIDAC se inseriam em uma série de atividades promovidas pelo centro, como palestras, cursos, exibição de filmes, debates etc. O CIDAC buscava ter uma atuação apartidária, apesar de dois de seus membros fundadores serem filiados ao MES (Movimento de Esquerda Socialista) ${ }^{72}$.

$\mathrm{Na}$ avaliação de Luís Moita, a atuação do CIDAC representou

um certo entendimento da acção política. Entendíamos aquele trabalho como militância política, como forma de luta por causas, e ali se misturavam a austeridade da tradição cristã que marcava o nosso passado com a ambição de uma sociedade nova, mais justa, que constituía o nosso ideal político. ${ }^{73}$

Entre 1974 e 1982 o CIDAC publicou 15 títulos. Os livros editados tinham padrão gráfico e comercial profissional. A distribuição era militante. Nesse período editou também o boletim África em Luta.

O CIDAC continua em atividade e desde fevereiro de 2004 mudou mais uma vez a sua denominação para Centro de Intervenção para o Desenvolvimento Amílcar $\mathrm{Cabral}^{74}$.

\footnotetext{
${ }^{72}$ PEREIRA, L. T., op. cit., p. 30.

${ }^{73}$ MOITA, L., op. cit., p 54.

74 “Quem somos”. Página eletrônica do CIDAC. Disponível em: 〈http://www.cidac.pt〉. Acesso em jul. 2012.
} 


\section{EDITORAS POLÍtiCAS SEM VINCULAÇÃO A GRUPOS POLÍTICOS}

Neste capítulo temos um grupo de editoras políticas com características um pouco diferentes das vistas nos capítulos anteriores. Isto porque são editoras que não estavam vinculadas a nenhum grupo político, mas para as quais a atuação política foi em algum momento um fator importante. Todavia, essa importância variou muito em grau e intensidade entre elas. Ao mesmo tempo, eram editoras que não podiam ser caracterizadas claramente como de direita ou de esquerda, se levarmos em conta a trajetória integral de cada uma delas.

Aqui apresentarei estudos sintéticos sobre seis dessas editoras: D. Quixote, Afrodite, Nova realidade e A Regra do Jogo, que eram editoras em que a atuação política de oposição e contestação foi o leitmotiv inicial; e Delfos e Parceria A. M. Pereira, editoras que em suas origens não tinham características políticas, mas que em períodos determinados publicaram obras políticas. Nestes casos, a atuação política representou apenas um momento delimitado na vida dessas editoras, mas um momento em que essa opção foi muito marcada, modificando as suas características editoriais.

Além dessas seis editoras, faziam parte desse grupo outras cinco: Presença, Expresso, Teorema, Terra Livre e Via Editora. Nelas predominavam as obras políticas, mas eram editoras que não tinham ligações com nenhum grupo ou partido. Os livros publicados por elas podem ser vistos no Apêndice A. 


\subsection{Publicações D. Quixote}

R. da Misericórdia, 117-2º - Lisboa (1968); R. Luciano Cordeiro, 119 - Lisboa (1970)

Editores: Snu Abecassis, Carlos Araújo, Nélson de Matos.

Fundação: 1965.

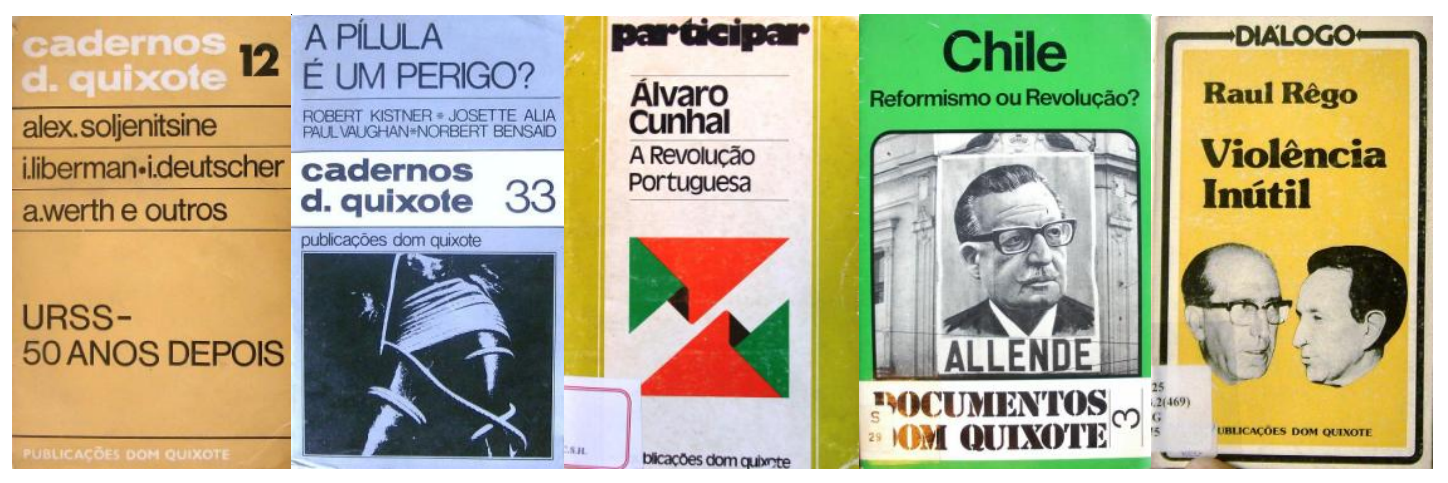

Editora fundada em $1^{\circ}$ de abril de 1965 pelos portugueses António Neves-Pedro e Vasco Abecassis, e pela dinamarquesa Snu Abecassis (cujo nome de batismo era Ebba Merete Seidenfaden). Vasco e Snu eram casados e tinham cerca de 25 anos de idade. Vasco era de uma família muito rica, que tinha negócios ligados à indústria farmacêutica em Portugal. Ele foi logo em seguida convocado para o serviço militar, e Neves-Pedro - que havia antes trabalhado nas Publicações Europa-América - somente permaneceu na sociedade até 1966, de modo que foi Snu Abecassis quem efetivamente tornou-se a responsável pela editora. A partir do segundo ano de existência da D. Quixote, Carlos Araújo - amigo de Neves-Pedro e que vinha da Europa-América tornou-se o diretor literário da editora, cargo que ocupou até abril de $1974^{1}$.

Snu e Araújo imprimiram um caráter dinâmico à editora, investindo em literatura, ensaios e debates. "Apostam no risco", como bem define Nuno Medeiros ${ }^{2}$, com autores e temas que se chocam, quase sempre, com o que era tolerado pelas autoridades de então, seja no campo político, seja no campo dos costumes. A vivência internacional de Snu, apesar de sua pouca idade, além de sua intenção de "dar a conhecer os caminhos da democracia" ${ }^{3}$ aos portugueses, certamente foram fatores importantes para a definição dessa linha de atuação.

A coleção Cadernos D. Quixote foi, a partir de 1967, a "marca registrada" da editora. "Foi a grande viragem na editora, por si próprios, e pelo arrastamento que fez.

\footnotetext{
${ }^{1}$ Página eletrônica das Publicações D. Quixote. Disponível em: <http://www.dquixote.pt/editora.html>; LEITE, op. cit., p. 198-99; MEDEIROS, Edição e editores, op. cit., p. 253.

${ }^{2}$ MEDEIROS, Edição e editores, op. cit., p. 253.

${ }^{3}$ BONNIER, Jytte. Snu. Lisboa: Quetzal, 2003, p. 63.
} 
Foi assim como enviar um 'destacamento' que vai fazer a exploração do terreno, e o grosso vem atrás", afirma Carlos Araújo ${ }^{4}$. Publicados em ritmo intenso - até o seu final, em 1972, a coleção chegou em 50 volumes -, esses cadernos traziam temas da atualidade, geralmente polêmicos e provocativos, tratados em textos jornalísticos e analíticos em sua maior parte traduzidos da imprensa internacional. O intervalo entre a edição de cada volume da coleção variava entre 30 dias e três meses. Umas das características da coleção é que ela incluía "vários livros inventados pelos seus editores", mediante a reunião de textos de origens diversas na imprensa estrangeira, "constituindo assim verdadeiros dossiers sobre cada tema".

Um acontecimento importante nos primeiros anos da D. Quixote, e que contribuiu para marcar o perfil inovador da editora, foi o lançamento, em 1966, da Autobiografia prematura, do poeta russo Ievgueni Ievtuchenko. "Ele funcionava como uma espécie de embaixador cultural da URSS, protegido pelo Krutschov. Já tinha estado em vários países da Europa Ocidental, e também em Cuba", lembra Araújo ${ }^{6}$. Em maio de 1967 o autor veio a Portugal e participou de sessões de autógrafos, visitou a cidade de Fátima e realizou uma sessão pública de declamação de poesia no Teatro Capitólio ${ }^{7}$. "Foi um êxito tremendo. [...] O espectáculo teve uma atmosfera muito 'electrificada', pois sabiase que havia umas dezenas de pides na assistência”, conta Araújo. "Ele [Ievtuchenko] era um showman no palco [...]. Tudo aquilo foi um imprevisto que veio reforçar a ideia, na opinião pública, que a $\mathrm{D}$. Quixote era uma nova editora, com uma grande pujança e atrevimento político", completa ${ }^{8}$.

Em 1968 a editora lançou outro livro de Ievtuchenko, Poemas, com tradução de Fernando Assis Pacheco e J. Seabra-Dinis.

A partir de 1970, os livros da coleção Cadernos D. Quixote passaram a trazer o seguinte texto na página de rosto:

Cadernos D. Quixote pretendem pôr à disposição do leitor português textos internacionais considerados relevantes para a compreensão de problemas que afectam o mundo dos nossos dias. Nem sempre estamos de acordo com as ideias expressas pelos autores. Todavia,

\footnotetext{
${ }^{4}$ PESSOA, Carlos; MOREIRA, José Guardado. "Carlos Araújo, um editor militante à conversa com Carlos Pessoa e José Guardado Moreira". Duas Margens. Cultura de Livros \& Libros. Ano 2, n 2, set. 2012, p. 8 15. Disponível em: <http://duasmargens.pt/>. Acesso em 20/10/2012.

${ }^{5}$ MEDEIROS, N. Edição e editores, op. cit., p. 255-56.

${ }^{6}$ PESSOA; MOREIRA, op. cit.

${ }^{7}$ MEDEIROS, N. Edição e editores, op. cit., p. 254.

${ }^{8}$ PESSOA; MOREIRA, op. cit.
} 
entendemos que elas exprimem diferentes maneiras de pensar, cujo conhecimento se torna indispensável para quem pretenda formar uma opinião.

Eis alguns títulos da coleção: Bolívia - um segundo Vietname? (1967); A revolta dos negros americanos (1967); O drama do Terceiro Mundo (1969); A revolta de maio em França (1968); Apartheid (1969); Black Power - Poder negro (1969); Itália entre direita e esquerda (1970); O Brasil na encruzilhada (1970); Hippies - Quem os conhece? (1970); A pílula é um perigo? (1971); Cuba e o socialismo (1971).

Entre os autores nela editados estão: James Bladwin, Paulo VI, Linus Pauling, Josué de Castro, Robert Kennedy, Jean Lacouture, A. Toynbee, H. Marcuse, Norman Mailer, Jean-Paul Sartre, Daniel Cohn-Bendit, Henri Lefebvre, A. Soljenitsine, I. Deutscher, Padre Felicidade Alves, D. Hélder Câmara, Camilo Torres, J. J. ServanSchreiber, G. D’Estaing, Bertrand Russell, Edgar Morin, Régis Debray, Fidel Castro, Mao Tsé-tung, Fernando Claudin e K. S. Karol.

A coleção Cadernos D. Quixote teve vários problemas com a PIDE e a censura. "Um dos Cadernos, o número seis, com o título $O$ drama do Terceiro Mundo foi, segundo [Carlos] Araújo, apreendido ainda antes da distribuição na livraria”. Snu Abecassis entrou em contato com as autoridades, argumentando que se tratava da tradução de uma publicação da Unesco. "A acção surtiu efeito sendo a edição devolvida integralmente passados poucos dias" ". Até o término da coleção, “[...] dos cinquenta volumes publicados, pelo menos oito foram alvo de apreensão ou proibição, estatuto eufemizado na expressão "fora do mercado"”,

A partir de 1972 surgiram os Novos Cadernos D. Quixote, com um projeto gráfico um pouco diferente do anterior, mas que dão continuidade à linha de publicações iniciada em 1967.

Em 1968 teve início a coleção Diálogo, que também buscava intervir nos debates políticos do momento. Tal intento era exposto na página de rosto dos volumes da coleção, que também assinalavam a sua proximidade com os Cadernos D. Quixote:

Diálogo é uma coleção de certo modo paralela aos CADERNOS DOM QUIXOTE. Nela se pretende apresentar textos controversos, susceptíveis de provocar no leitor não só a necessidade de se debruçar sobre assuntos que dizem respeito a todos nós, num mundo em rápida transformação, como também a necessidade de os discutir.

\footnotetext{
${ }^{9}$ LEITE, op. cit., p. 200.

${ }^{10}$ MEDEIROS, Edição e editores, op. cit., p. 257.
} 
A principal diferença é que esta coleção publicava predominantemente obras autorais, e menos coletâneas (que, todavia, também estão presentes na coleção). Eis alguns dos títulos publicados: A responsabilidade dos intelectuais, de Noam Chomsky (1968); Progresso, coexistência e liberdade intelectual, de Andrei Sakharov (1969); Um português em Cuba, de Alexandre Cabral (1969); Da liberdade de pensamento e de expressão, de John Stuart Mill (1969); Regressar para quê?, de Victor de Sá (1970); Pensar Portugal hoje, de João Martins Pereira (1971) e Violência inútil, de Raul Rêgo (1975).

É importante destacar que a D. Quixote também deu importância, desde a sua fundação, à literatura e à poesia. A coleção Cadernos de Poesia, por exemplo, publicou autores como Carlos Oliveira, Pablo Neruda, Alexandre O’Neill, Vinícius de Moraes, David Mourão-Ferreira, Ruy Belo e Sophia de Mello Breyner.

Outra coleção importante foi a Universidade Popular, que até fins de 1973 havia publicado cerca de 40 volumes. Nesse período, a editora tinha ainda as coleções Documentos Dom Quixote, Viragem, Cadernos de Literatura, Cadernos de Cinema, Estudos Portugueses e Vector.

Toda essa atividade fez da D. Quixote "uma editora marcante, nos anos 60 e 70, na busca de espaços de liberdade num ambiente de censura ditatorial", e que "não fugia a publicar autores de esquerda, pensadores marxistas, obras sobre a realidade nacional [...]. Nos meios estudantis [...] era uma das editoras com mais público", afirma Marcelo Rebelo de Sousa ${ }^{11}$.

Quando deu-se o 25 de Abril a D. Quixote já era uma das mais atuantes editoras do país, com uma postura marcadamente de oposição ao regime derrubado. No mesmo mês do golpe dos capitães, Carlos Araújo deixou a direção literária da editora para ser consultor da Editora Sá da Costa. Snu Abecassis passou a ter uma atuação pública de caráter mais político do que até então. "Snu começara a desempenhar o seu papel na nova vida de Portugal. Encontrava-se com políticos e outras figuras públicas e publicava livros em que se falava do futuro do país"12.

Nesse novo período, a editora manteve uma linha de livros políticos, com a continuação de coleções existentes e a criação de outras, como, por exemplo, a coleção Participar, em que foram publicadas obras de Mário Soares (Democratização e

\footnotetext{
${ }^{11}$ SOUSA, Marcelo Rebelo de. "Prefácio". In: BONNIER, op. cit., p. 9.

${ }^{12}$ BONNIER, op. cit., p. 77.
} 
descolonização: dez meses de Governo Provisório), Francisco Sá Carneiro (Por uma social-democracia portuguesa), Álvaro Cunhal (A revolução portuguesa), Jorge Campinos (A ditadura militar (1926-1933)), Eduardo Lourenço (O fascismo nunca existiu), Vasco Pulido Valente (O poder e o povo: a revolução de 1910) e Aníbal Cavaco Silva (A política económica do governo de Sá Carneiro) - o que aponta também a preocupação da editora em demonstrar o seu pluralismo e a sua independência face aos principais partidos políticos do país na conturbada conjuntura daquele momento.

Outros títulos políticos lançados entre 1974 e o final dos anos 1970 foram: As empresas multinacionais (1974); O 25 de Abril na imprensa estrangeira (1974); Sobre a democracia (1974); Peru - Exército, nação, revolução, de Juan Velasco Alvarado e outros (1974); CIA - a arte de desestabilizar governos (1975); Europa - um novo comunismo? (1975); Os militares e o poder na América Latina e na África (1975); EUA, URSS e o destino dos outros (1975); A via argelina: um modelo para Portugal? (1975); KGB, a CIA soviética (1975), todos estes na coleção Novos Cadernos D. Quixote.

Em outras coleções saíram: Franco e o franquismo, de Jacques Georgel (1974); O exército chinês: o "herdeiro" de Mao?, de Jean-Pierre Brulé (1975); O pensamento de Lenine, de György Lukács (1975); Os camponeses na luta de classes, de Bernard Lambert (1975); Mao Tsé-tung e a construção do socialismo, de Hu Chi-Hsi (1975); O projecto esperança, de Roger Garaudy (1976); Portugal: cinquenta anos de ditadura, de António de Figueiredo (1976); Não percas a rosa. Diário e algo mais (25 de Abril de 1974-20 de Dezembro de 1975), de Natália Correia (1978); Uma constituição para os anos 80: contributo para um projecto de revisão, de Francisco Sá Carneiro (1979); Capitalismo para principiantes, de Robert Lekachman e Boris van Loon (1982); Lénine para principiantes: de A a Z, de Richard Appignanesi e Oscar Zarate (1983).

A partir de meados dos anos 1970 começa a crescer a ênfase em outras áreas que não a política, nas quais a editora já atuava, como a literatura e as obras universitárias. Em 1976, a editora enfatizava que publicava "volumes de carácter cultural [...] além dos manuais, livros de debate, um número apreciável de volumes sobre actualidade, dicionários, literatura estrangeira e portuguesa, bem como poesia"13.

Snu era mais próxima, ideologicamente, de setores ligados ao PPD (Partido

\footnotetext{
${ }^{13}$ AA.VV., Editores Portugueses na IV Bienal Internacional do Livro São Paulo: 14 a 22/Agosto/1976. Lisboa: APEL, 1976.
} 
Popular Democrático), de centro-direita. A partir desses contatos acabou por ter início uma relação pessoal entre ela e Francisco Sá Carneiro, um dos líderes do partido, que em 1980 tornou-se primeiro-ministro de Portugal. Ambos faleceram em um acidente aéreo em 4 de outubro de 1980.

Após a morte de Snu Abecassis, as Publicações D. Quixote foram compradas por Nélson de Matos ${ }^{14}$. Entre 1999 e 2007, a Dom Quixote esteve ligada ao Grupo Planeta, da Espanha. E em dezembro de 2007, a editora foi adquirida pelo português Grupo Leya $^{15}$.

De sua fundação em 1965 até o início dos anos 1980, a D. Quixote foi uma das mais atuantes editoras políticas do país, tendo editado nesse período cerca de 200 títulos políticos, o que a coloca entre as quatro editoras que mais lançaram obras desse tipo no país, ao lado de Estampa, Avante! e Iniciativas Editoriais.

Assim, a D. Quixote foi uma das mais importantes e marcantes editoras de Portugal nesses anos, lugar que continuou a ocupar no campo da edição literária a partir da segunda metade da década de 1970. Antes do 25 de Abril, foi claramente uma editora de oposição, publicando dezenas de obras que traziam para o debate público temas e autores incômodos para o regime, desafiando o poder estabelecido na área da cultura, dos costumes e da política. Pluralista na escolha dos temas e dos autores editados, pode ser caracterizada como uma editora democrática, voltada para a promoção do debate e da polêmica, postura que certamente lhe deu relevo no ambiente autoritário que prevalecia em Portugal nesses anos.

Com o 25 de Abril a editora continuou atuando com grande destaque no campo editorial português, e ainda deu grande ênfase à edição política até o final dos anos 1970. Mas não resta dúvida de que o caráter político que marcava a sua atuação era um dos pontos fortes da editora, e tal caráter perdeu centralidade no catálogo da editora a partir de então. Diante das mudanças no país, a D. Quixote passou a direcionar com cada vez mais ênfase a sua atuação para a literatura e a universidade, áreas em que passou a ocupar também um lugar de liderança na indústria editorial nacional.

\footnotetext{
14 "Nota Biográfica". Disponível em: <http://www.edicoes-nelsondematos.com>. Acesso em 20/3/2011.

${ }^{15}$ Página eletrônica das Publicações D. Quixote. Disponível em: <http://www.dquixote.pt/editora.html>. Acesso em 12/4/2011.
} 


\subsection{Edições Afrodite/ Edições de Fernando Ribeiro de Mello}

\section{Lisboa}

Editor: Fernando Ribeiro de Mello.

Fundação: 1965.

Distribuição: Quadrante e Expresso - Bloco editorial de Distribuição.
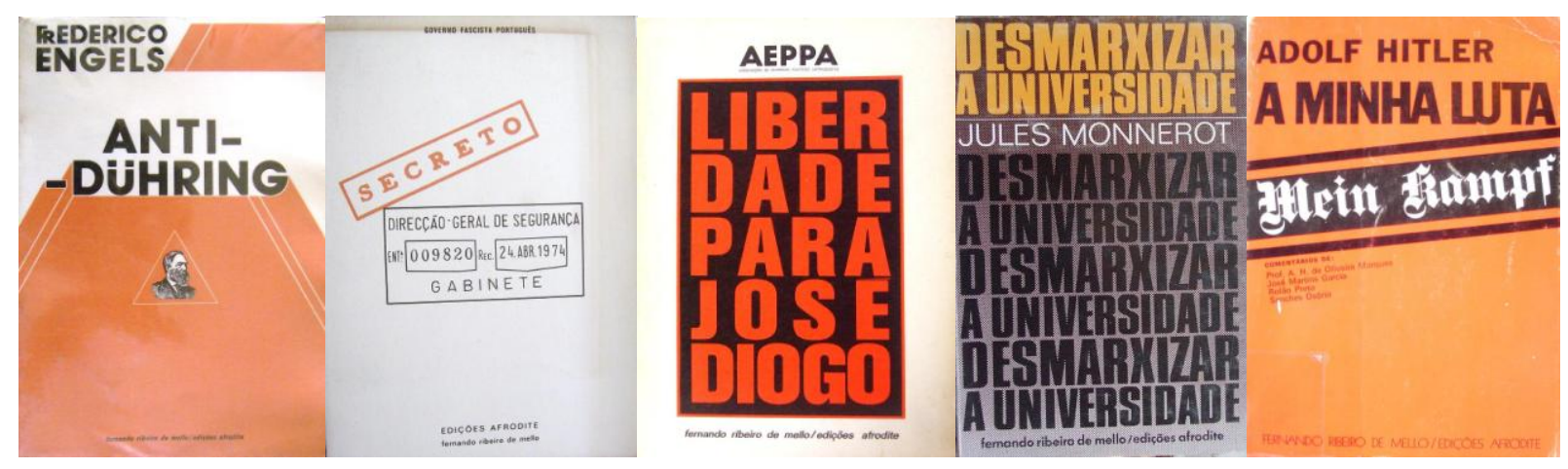

Editora criada em 1965 por Fernando Ribeiro de Mello, em Lisboa. Mello tinha na época 24 anos e havia vindo do Porto para Lisboa no começo da década de 1960. Ousado e inovador, ele seria o responsável por uma das casas editoras mais singulares de Portugal. Os primeiros títulos editados, de caráter erótico, tinham a clara intenção de chocar e causar polêmica, desafiando os estreitos limites morais impostos pela ditadura, marcando desde as origens o "espírito transgressor"

A escritora Ana Hatherly definia desse modo o editor quando de sua chegada a Lisboa:

Era pequenino, franzino, loiro, nervoso, libidinoso e excêntrico. Apesar de todo o seu dinamismo tinha algo de antiquado na sua aparência, um quê de século XIX, que aliás cultivava. Usava grandes bigodes retorcidos, barbicha e, em vez de gravata, uma lavallière. Fernando Ribeiro de Mello tinha poucos recursos financeiros mas um grande cabedal de imaginação e audácia que, mais tarde e durante um certo tempo, viriam a fazer dele um editor destacado neste país. ${ }^{17}$

É também Hatherly quem ressalta a importância da escritora Natália Correia na trajetória de Mello: "Natália Correia tornou-se mentora do audacioso jovem, influindo na programação das suas primeiras publicações, que surgiram com a chancela de Afrodite, Edições de Fernando Ribeiro de Mello" ${ }^{18}$.

O primeiro título publicado, na coleção que tinha o mesmo nome da editora, foi

${ }^{16}$ HATHERLY, Ana. "Prefácio". In: SACHER-MASOCH. A Vénus de Kazabaïka. Lisboa: Relógio d'Água Editores, 2. ${ }^{a}$ edição, 1994. Disponível em: <http://editoraafrodite.blogspot.com.br/2007/10/prefcio-2-edio-da-vnus.html>. Acesso em 5/3/2012.

${ }^{17}$ HATHERLY, op. cit.

${ }^{18}$ HATHERLY, op. cit. 
Kama Sutra: manual do erotismo hindú, em 1965. Esta coleção teve mais três lançamentos até 1966: Antologia de poesia portuguesa erótica e satírica: dos cancioneiros medievais à actualidade, com seleção, prefácio e notas de Natália Correia; A filosofia na alcova, do Marquês de Sade; e A Vénus de Kazabaika, de Leopold von Sacher-Masoch, com tradução de Anna Hatherly.

Dessa forma, Mello punha em prática a "tentativa de divulgar certo tipo de obras 'malditas' pela sacristia político-cultural em que os portugueses iam existindo e asfixiando" 19 . A repressão não se fez esperar: "Conforme eram lançadas, todas as edições desta coleção foram imediata e inquisitorialmente apreendidas pela Polícia Judiciária e pela PIDE-DGS e, duas delas, até acusadas, julgadas e condenadas pelo fogo fascista do Tribunal Plenário de Lisboa" ${ }^{\text {20 }}$.

As duas obras julgadas e condenadas foram a Antologia de poesia portuguesa erótica e satírica e A filosofia na alcova. No primeiro caso, "Tanto a coordenadora da edição [Natália Correia] como os colaboradores - Mário Cesariny, José Carlos Ary dos Santos, Ernesto Melo e Castro e Luiz Pacheco - foram processados por abuso de liberdade de imprensa" ${ }^{21}$. Já em relação à obra de Sade, foram processados o editor, o tradutor (António Manuel Calado Trindade), o ilustrador (João Rodrigues), o prefaciador (Luiz Pacheco), além de Herberto Hélder, apontado como "cúmplice"22.

A ousadia da Afrodite refletia-se também no aspecto gráfico de certos livros, que buscavam soluções de capa e de apresentação visual do texto que fugissem à obviedade.

As seguidas apreensões trouxeram consequências para o editor. "A perseguição a Fernando Ribeiro de Mello redobrou”, lembra Anna Hatherly, e ele, "não tendo já onde esconder os livros que tinha em armazém (Kama-Sutras, Sades, etc., que vendia às escondidas)", pediu à escritora que guardasse em sua casa alguns exemplares, o que Hatherly aceitou fazer, "empilhando no quarto da criada grande quantidade dessas obras que a polícia procurava",23.

Depois desse início marcante, porém preocupante do ponto de vista da

\footnotetext{
19 Texto de orelha (badana) da edição de O Supermacho, de Alfred Jarry (Lisboa: Afrodite, 1975). Blogue Afrodite. Disponível em: <http://editora-afrodite.blogspot.com/2006/07/fernando-ribeiro-de-melloedies_07.html>.Acesso em 5/3/2011.

${ }^{20}$ Idem.

${ }^{21}$ MEDEIROS, Edição e editor, op. cit., p. 246.

22 “O processo da edição da Filosofia na Alcova: arguidos, advogados, sentenças e testemunhas”. Blogue Afrodite. Disponível em: <http://editora-afrodite.blogspot.com.br/2007/03/o-processo-da-edio-dafilosofia-na.htm>. Acesso em 5/3/2011.

${ }^{23}$ HATHERLY, op. cit.
} 
continuidade da editora, a Afrodite resolveu mudar um pouco a linha de edições, evitando enfrentamentos tão diretos com a censura. Em 1968 surgiu a coleção de livros infantis Cabra-Cega, que foi a mais atuante até 1973. Foi criada também a coleção Antologias, com temas como o "conto abominável", o "humor português" e o "humor negro" 24 .

Mesmo quando editou obras políticas nessa etapa, na coleção Ensaio/Documento, optou por livros voltados para um público mais restrito e acadêmico, de modo a criar menos problemas com a repressão. Assim, publicou nesta coleção: Anti-Dühring, de F. Engels (1971); A sociedade do espetáculo, de Guy Debord (1972); e Teatro de vanguarda, de Fernando Luso Soares (1973).

Mas a principal investida da editora antes do 25 de Abril foi a coleção Clássicos, que entre 1970 e 1973 editou obras marcantes da cultura portuguesa e do ocultismo, sempre acompanhadas por estudos críticos: Arte de Furtar (Anônimo do Séc. XVII); Peregrinação, de Fernão Mendes Pinto; História trágico-marítima, de Bernardo Gomes de Brito; Grande livro de S. Cipriano ou tesouros do feiticeiro; Apocalipse do apóstolo João; e O manual dos inquisidores, de Nicolau Emérico.

A atuação de Fernando Ribeiro de Mello como editor também foi marcada por alguns momentos extravagantes, mas sempre voltados para divulgar a editora. Foi o caso, por exemplo, do evento de lançamento dos livros História trágico-marítima e Alice no país das maravilhas (de Lewis Carroll), realizado em 15 de dezembro de 1971... numa banheira. Anunciada como "O editor na banheira”, a conferência de imprensa do lançamento foi planejada para causar impacto, e efetivamente teve sucesso.

O Diário de Lisboa noticiou o fato em primeira página:

[...] dezenas de entendidos assistiram ontem à noite ao entremez "Um editor na banheira", representado por Fernando Ribeiro de Mello (Edições Afrodite) no seu rés-do-chão da Rua do Cabo [...] A cena passou-se ontem, à noite, como dizíamos, numa banheira. [...] "Ó pás, façam-me lá publicidade aos livros", atalhava Ribeiro de Mello para os jornalistas quase no fim da "cimeira" da banheira. Dois diabos ensonados misturavam-se com a assitência, enquanto duas beldades do conhecido editor (Palola e Eugénia) iam servindo e retirando o alvo bacio de louça. Num requinte de maladez publicitária Ribeiro de Mello pintara "slogans" editoriais sobre a cútis das raparigas. ${ }^{25}$

\footnotetext{
${ }^{24}$ Para conhecer mais detalhes de grande parte do catálogo da Afrodite e da atuação de Fernando Ribeiro de Mello, consultar o excelente blogue Afrodite, editado por Ricardo Jorge, um admirador da atuação de Mello como editor. Cf. <http://editora-afrodite.blogspot.com.br/>. Acesso em 5/3/2011.

25 "Um editor na banheira". Diário de Lisboa, 16/12/1971, p. 1-2. Disponível em:
} 
Com o 25 de Abril, Fernando Ribeiro de Mello foi um dos primeiros editores a aproveitar a liberdade gerada com o fim da ditadura, tendo lançado em maio de 1974, ou seja, no mês seguinte ao golpe dos capitães, o livro Secreto. Último relatório sobre a situação geral do país do ex-Ministério do Interior para a ex-PIDE/DGS, cuja autoria é atribuída ao "Governo Fascista Português". O livro é exatamente o que se anuncia no título: a reprodução daquele que seria o último relatório de rotina enviado pelo Ministério do Interior à DGS, e que deu entrada naquela repartição no dia 24 de abril de $1974^{26}$. Sua publicação visava mostrar como era organizada a repressão durante a ditadura e como ela estava incorporada ao modo de atuação rotineiro dos órgãos de governo.

A partir daí, a Afrodite publicou uma série de livros de caráter diretamente político, principalmente nas coleções Doutrina/Intervenção e Documentos. As obras editadas não seguem uma linha política única, mas prevalecem claramente os títulos de crítica e denúncia do comunismo, principalmente daquele vinculado à linha soviética.

Ainda assim, houve a edição de algumas obras cuja temática tinha afinidade com o pensamento de esquerda, como: Lugar de massacre, de José Martins Garcia, sobre o colonialismo (1975); Liberdade para José Diogo, coedição com a Associação de ExPresos Políticos Antifascistas-AEPPA (1975); e O pequeno livro vermelho do estudante, de Soren Hansen e Jesper Jensen (1977), sobre a juventude e as transformações nos costumes.

Mas prevalecem as obras questionadoras do ideário comunista, assim como algumas claramente ligadas ao pensamento de direita: Mein Kampf, de Adolf Hitler, com comentários de A. H. de Oliveira Marques, José Martins Garcia, Rolão Preto e Sanches Osório (1976); Uma nova doença mental na URSS: a OPOSIÇÃO, de Vladimir Boukovsky (1976); Revolucionários e querubins, de José Martins Garcia (1977); O socialismo: fenómeno mundial, de Igor Chafarevitch (1977); Marx contra Marx, de Marc Paillet (1977); Sexo. Espionagem: a exploração do sexo pelos serviços secretos soviéticos, de David Lewis (1977); Eu pertenci à KGB, de Aleksei Myagkov (1977); 26 anos na União Soviética. Notas do exílio do Chico da CUF, de Francisco Ferreira, $7^{\text {a }}$ ed. (1977); Blatnoï: a máfia, o crime, a marginalidade, na URSS, de Mikhail Diomine

<http://www.fmsoares.pt/aeb_online/visualizador.php?nome_da_pasta=06813.163.25844\&bd=IMPRENS A>. Acesso em 20/10/2012.

${ }^{26}$ MADUREIRA, Fernando. "Nota prévia ou o lápis vermelho". In: Secreto. Último relatório sobre a situação geral do país do ex-Ministério do Interior para a ex-PIDE/DGS, Lisboa: Afrodite, 1974. 
(1978); Os intelectuais e o poder soviético. Kontinent 1, com textos de Andrei Sakharov, Eugene Ionesco, Siniavski, Djilas, Aleksandr Soljenitsine (1978); Desmarxizar a universidade, de Jules Monnerot (1978); Os normalizados, de Christian Jelen (1978); Sociologia do comunismo, de Jules Monnerot (1978); e Nova direita, nova cultura: antologia crítica das ideias contemporâneas, de Alain de Benoist e notas de José Miguel Júdice (1981).

Ao comentar as razões que o levaram a editar, em 1976, o Mein Kampf - um dos títulos da Afrodite que mais polêmica causou no pós-25 de Abril e que teve tiragem de 10 mil exemplares -, Mello deixou clara a sua posição contrária ao comunismo soviético. Em entrevista a António Carmo Luís, o editor falou sobre a publicação da obra de Hitler:

FRM [Fernando Ribeiro de Mello] - Ainda era a mesma luta contra o poder. $\mathrm{O}$ meu mal foi querer provar, com alguns anos de antecedência, algumas coisas que toda a gente agora sabe: os regimes do Leste dividiam a sociedade em classes fortemente hierarquizadas, faziam uma censura feroz às ideias, à liberdade de criação, sob o ponto de vista económico eram uma aldrabice. Tentei dizer isto mas era cedo, quem lia livros preferia acreditar no que lhe convinha.

Pergunta - Seria preciso chegar ao Mein Kampf de Adolf Hitler? O que tinha ele a ver com os regimes de leste?

FRM - Tinha o seguinte: um discurso praticamente igual, assustadoramente igual. Igual porque discurso caucionador, em todos os regimes totalitários, da necessidade de fazer crer ao povo que a sua dureza é inspirada por princípios nobres e pela vontade de o proteger. Os extremos tocam-se.

$P$ - Mas em Portugal já tinha havido eleições democráticas, e a Afrodite insistia nessa cruzada...

FRM - Acha que a situação estava estabilizada? Que já não havia perigo? Lembre-se de que a União Soviética ainda praticava uma política de infiltração, e este canto era muito apetecível como pedra a tomar no xadrez universal. ${ }^{27}$

A Afrodite também editou nessa época livros que buscavam apresentar informações e análises sobre a realidade portuguesa no novo contexto pós-ditadura: Guia prático do trabalhador português, de Francisco Marcelo Curto (1974); Inquérito

\footnotetext{
${ }^{27}$ LUÍS, António Carmo. "Portugal em Sade, Sade em Portugal (história, histórias...) - adaptação de um capítulo do livro inédito Sete Encenações Falhadas de uma Batalha Campal”. In: PAULHAN, Jean. $O$ Marquês de Sade e a sua cúmplice; seguido de Portugal em Sade, Sade em Portugal. Lisboa: Hiena, 1992. Blogue Afrodite. Disponível em: <http://editora-afrodite.blogspot.com.br/2009/10/porqueedicao-do-mein-kampf.html>. Acesso em 5/3/2011.
} 
aos partidos políticos: esclarecer o eleitor, de Francisco Pereira Moura, António Borges Coelho, Avelino Rodrigues e outros (1975); O processo das virgens: aventuras, venturas e desventuras sexuais em Lisboa nos últimos anos do fascismo (1975); Dossier $2^{a}$ República, em dois volumes organizados por José-Pedro Gonçalves (1976 e 1977).

Além disso, a editora manteve a linha de publicações literárias, eróticas, de teatro, poesia etc.

A edição do livro $O$ processo das virgens gerou alguma polêmica. A obra reproduzia "peças de três processos judiciais instruídos pela Polícia Judiciária e julgados pelo Tribunal de Execução de Penas nos últimos anos do fascismo", processos estes resultantes do escândalo que ficou conhecido como "caso dos Ballets Rose" e envolvia figuras de destaque do salazarismo ${ }^{28}$.

Ocorre que a organizadora do volume, Marta Castro Alves, sob o pretexto de evitar o "sensacionalismo", optou por "apagar a identificação dos personagens" e alterar os "nomes dos intervenientes principais" no escândalo ${ }^{29}$, substituindo os nomes reais por fictícios. Tal decisão provocou forte crítica por parte da escritora e jornalista Maria Teresa Horta. Para ela a importância da obra seria justamente "desmascarar figuras que não só jamais chegaram a ser totalmente desmascaradas como hoje até já novamente há quem queira recuperá-las perante a opinião pública”. Pergunta a resenhista: “Quem se pretende, ainda, poupar neste país? E porquê? Porque esta escandalosa substituição de nomes?'. Segundo ela, as justificativas para esta opção:

Simplesmente não convencem ninguém. Desculpas de mau pagador. Quem quiser saber os nomes verdadeiros, que leia nas entrelinhas... Ora, estamos todos fartos de ler nas entrelinhas (foram 48 anos disso!), meus senhores! A hora é de dizer a verdade nas linhas todas, e bem claramente! Chega de favorecer capitalistas, fascistas, personagens coniventes com o antigo regime! [...] Não, Edições Afrodite, assim não! ${ }^{30}$.

Entre 1965 e 1978 a Afrodite publicou 40 obras de caráter político, incluindo-se aí aqueles primeiros títulos eróticos, que tanta dor de cabeça deram à censura de Salazar; ou seja, cerca de metade do total das obras publicadas pela editora eram políticas. A Afrodite manteve-se em atuação até o final dos anos 1980, mas já sob forte

\footnotetext{
${ }^{28}$ Texto de contracapa do livro O processo das virgens: aventuras, venturas e desventuras sexuais em Lisboa nos últimos anos do fascismo (Lisboa: Afrodite, 1975).

${ }^{29}$ ALVES, Marta Castro. "Nota prévia". In: O processo das virgens: aventuras, venturas e desventuras sexuais em Lisboa nos últimos anos do fascismo. Lisboa: Afrodite, 1975, p. 7-8.

${ }^{30}$ HORTA, Maria Teresa. "Livros”. Flama, Lisboa, no 1.471, 14/05/1976, p. 6.
} 
crise financeira. Com a morte de Mello, em 1991, a empresa não teve continuidade.

Personagem e personalidade polêmica e provocadora, além de editor muito competente, vale a pena dar a última palavra a Fernando Ribeiro de Mello, e ouvi-lo sobre a sua autoimagem como pessoa e como editor:

Sempre travei batalhas suicidas, sempre me atirei de cabeça pelas minhas verdades sem medir muito as consequências. Hesitar, seria pressupor uma frieza que eu não tenho, e mau será que um dia venha a tê-la. Editei o Sade quando era impossível editá-lo. O degelo marcelista permitiu alguns Sades sem risco, na Arcádia, na Estampa, creio que na Presença; e depois de não haver censura apareceram dois com linguagem crua, um na [editora] \&Etc e os volumes de $O s 120$ dias de Sodoma. Mas eu editei Sade contra Salazar, com todo o risco que era estar contra ele, editei-o para abalar a censura... ${ }^{31}$

\subsection{Nova Realidade}

Tomar

Editor: Carlos Loures, Manuel Simões, Júlio Estudante.

Fundação: 1966.

Distribuição: Raiz Representações, Lda. (Tomar)

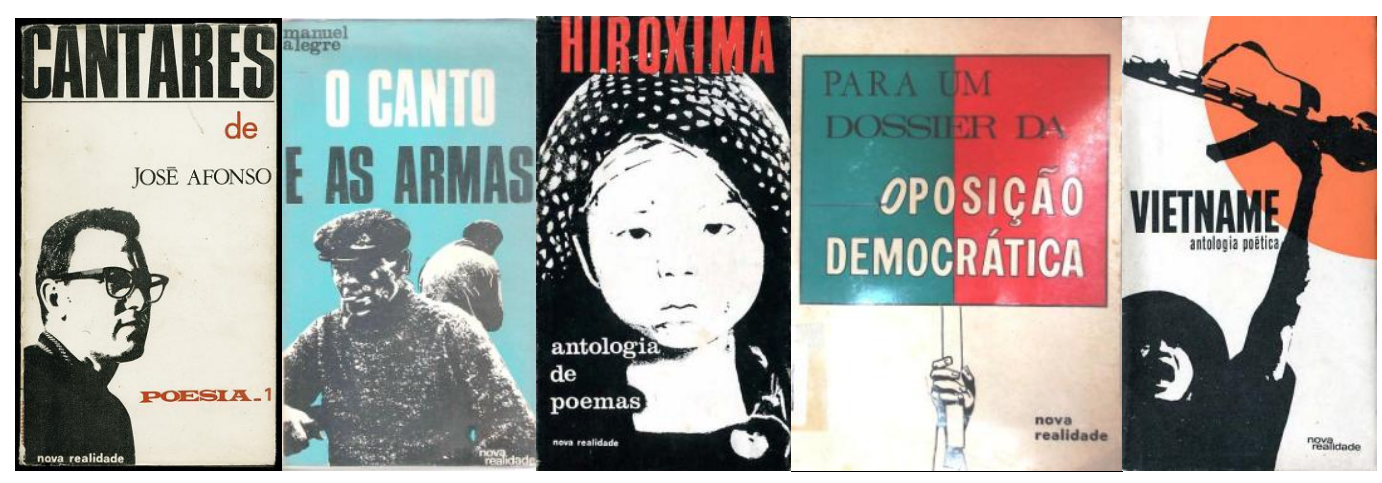

A Nova Realidade foi criada por três amigos, Carlos Loures, Manuel Simões e Júlio Estudante em 1966, na cidade de Tomar, distrito de Santarém. Nessa altura, Simões era funcionário do Banco de Portugal e aluno do curso de Filologia Românica na Faculdade de Letras de Coimbra, cidade onde residia. Carlos Loures era bibliotecário da Fundação Calouste Gulbenkian e Júlio Estudante era contabilista na Fábrica de Papel de Porto de Cavaleiros (Tomar). Ambos residiam em Tomar ${ }^{32}$.

Carlos Loures assim resume o projeto que levou à criação da editora:

\footnotetext{
${ }^{31}$ LUÍS, A. C., op. cit.

${ }^{32}$ Mensagem eletrônica de Manuel Simões, 3/10/2012.
} 
Por meados da década de 1960, [consideramos] a hipótese de criar uma editora outsider que publicasse obras de índole política. Obras merecedoras de publicação, mas que, por razões óbvias, as editoras comerciais não se arriscavam a publicar. Era um projecto que, por diversas, vezes tinha sido aventado pelo Júlio Estudante, pelo Manuel Simões e por mim. ${ }^{33}$

Manuel Simões aprofunda um pouco mais a concepção que deu origem ao projeto:

[...] nasceu como exigência de dar voz ao pulsar alternativo que se pressentia na intellighezia portuguesa que, por sua vez, já não se sentia representada pelo discurso literário do neo-realismo, mas sem que a alternância recaísse num pathos utópico, quer dizer, numa literatura de esperança abstrata. [...] De certo modo o grupo de "Nova Realidade" procurava reformular uma perspectiva crítico-histórica da obra artística [...]. ${ }^{34}$

Loures relembra também como foi a escolha do nome da editora:

Tema recorrente nas nossas conversas, julgo ter sido durante umas férias que passámos juntos em Buarcos, em agosto de 1966, que a ideia de concretizar o projecto ganhou forma. Lembro-me de estarmos num café, o Júlio, o Manuel e eu, a decidirmos qual o nome. Novo Rumo era uma das propostas, e tendo prevalecido a opção Nova Realidade, a Novo Rumo passou a constituir uma marca alternativa para conteúdos considerados à partida mais susceptíveis de ser censurados e apreendidos. ${ }^{35}$

Um dos apoios iniciais, e importantes, que o trio obteve para pôr em prática a ideia veio do poeta Joaquim Namorado. Loures lembra que no mesmo fim de semana em que decidiram o nome da editora foram à casa de Namorado, que apadrinhou a ideia e lhes forneceu uma cópia do arquivo de assinantes da revista Vértice. "Foi um importante contributo, pois permitia-nos vender uma boa parte da edição antes de a colocarmos no circuito de distribuição", diz Loures ${ }^{36}$.

Os três fundadores da editora não pertenciam a qualquer partido ou grupo político, mas eram militantes da oposição à ditadura ${ }^{37}$. As decisões sobre os títulos a serem editados eram tomadas de forma colegiada. Júlio Estudante assumiu as responsabilidades pelas funções administrativas da editora e pelo contato com as

\footnotetext{
${ }^{33}$ Mensagem eletrônica de Carlos Loures, 1/10/2012.

${ }^{34}$ SIMÕES, Manuel. "Hiroxima e Vietname: memória poética e consciência ética". Rivista di Studi Portoghesi e Brasiliani. Roma, Istituti Editoriali e Poligrafici Internazionali, III, 2001, p. 87.

${ }^{35}$ Mensagem eletrônica de Carlos Loures, 1/10/2012.

${ }^{36}$ Idem.

${ }^{37}$ Idem.
} 
$\operatorname{tipografias}^{38}$.

O primeiro livro saiu ainda em 1966, foi a obra Cantares, de José Afonso, “a primeira recolha de textos cantados por esse grande renovador da expressão musical portuguesa" 39 , que teve a coordenação de Manuel Simões e Rui Mendes. O livro perseguia o objetivo programático da editora de fazer interagir a consciência ética com a exigência estética ${ }^{40}$.

Simões recorda como surgiu este projeto:

A ideia de reunir em volume as canções de José Afonso nasceu no âmbito do grupo da pastelaria Sírius, da rua da Sofia, em Coimbra, onde chegavam ecos da colecção projetada em Tomar. Foi o Rui Mendes quem a lançou, com o ar de coisa espontânea, mas sentia-se que se tratava de um plano arquitectado e cultivado há algum tempo, à espera de concretização. Pedido o consenso ao autor, então a lecionar na Beira, em Moçambique, a quem se tinha mandado, para eventuais correcções, a transcrição dos textos gravados a que era possível ter acesso, a sua plena adesão ao projecto constituiu uma motivação ainda mais encorajadora, sobretudo pelo envio de materiais inéditos, só mais tarde revelados entre nós, o que significava uma sintonia de opiniões quanto à validade da proposta e quanto à autonomia poética dos textos. $^{41}$

O livro, lembra Simões, "foi vendido de mão em mão e enviado pelo correio a pessoas que julgávamos interessadas", e esgotou-se rapidamente, havendo a necessidade de ainda em 1966 ser lançada a segunda edição. Por se tratar de obra de um dos cantores mais claramente identificados com a oposição ao salazarismo, os editores tiveram que tomar certos cuidados: "Como Tomar é uma pequena cidade de província e porque havia a suspeita de que um carteiro era informador da PIDE, as encomendas postais foram expedidas de várias cidades próximas, para não alertar a polícia”, conta Simões ${ }^{42}$.

De acordo com Loures, "os livros susceptíveis de ser apreendidos, eram rodeados de cuidados especiais. Geralmente não eram expostos nas montras ou escaparates [vitrinas]. Eram, como se dizia na época, vendidos 'por baixo do balcão' a clientes especiais". Ele diz que "Havia um conjunto de livrarias espalhadas pelo país que absorvia grande parte da edição, como por exemplo a Divulgação, no Porto, a

\footnotetext{
${ }^{38}$ Mensagem eletrônica de Manuel Simões, 3/10/2012.

${ }^{39}$ SIMÕES, Manuel. "Memória breve de Cantares. Prefácio à $3^{\text {a }}$ edição". In: AFONSO, José. Cantares. Coimbra, Fora do Texto, $4^{\mathrm{a}}$ ed., 1995, p. 9.

${ }^{40}$ Mensagem eletrônica de Manuel Simões, 3/10/2012.

${ }^{41}$ SIMÕES, Manuel. "Memória breve de Cantares. Prefácio à $3^{\mathrm{a}}$ edição". In: AFONSO, José. Cantares. Coimbra, Fora do Texto, $4^{\text {a }}$ ed., 1995, p. 9.

${ }^{42}$ Mensagem eletrônica de Manuel Simões, 2/10/2012.
} 
Martins, de Leiria. Em Lisboa, era a Quadrante, a Barata e, a partir do fim da década, a Ler, do Luís Alves. E havia outras"

Em 1967 a editora lançou outra obra que marcou época: o livro $O$ canto $e$ as armas, do poeta Manuel Alegre. Simões relembra:

$\mathrm{O}$ autor estava exilado em Argel e era o speaker de uma rádio clandestina (Rádio Portugal Livre) que transmitia da Rádio Nacional de Argélia. Foi uma edição preparada com muito cuidado e com uma tiragem de 3 mil exemplares (enorme para a época) mas esgotada numa semana. Quando a PIDE interveio, o livro estava esgotado: fezse fila nas livrarias para conseguir um exemplar. Foi proibido, mas já não havia livros disponíveis. ${ }^{44}$

Nesse mesmo ano saiu Hiroxima, uma antologia poética que trazia também depoimentos de poetas portugueses sobre o ataque atômico em 1945 às cidades japonesas de Hiroxima e Nagasaki. O livro, coordenado por Loures e Simões, representava um claro ato político, como explicitam os organizadores no prefácio: "Numa altura [...] em que hiroximas se estendem da África à Ásia [...] o nosso silêncio responsabilizar-nos-ia perante o julgamento futuro das épocas de crise e sua explicação histórica" ${ }^{45}$. E ressaltam a participação ativa no projeto dos poetas reunidos na antologia, destacando que eles "transcendem a posição de passivos antologiados; muito ao contrário, pela sua aquiescência a figurarem na presente antologia, eles interferem e depõem ativamente neste julgamento implacável" ${ }^{46}$. Assim, dos 30 poetas que compõem a antologia, quase todos publicaram textos inéditos ${ }^{47}$.

Nesta mesma linha foi produzida, em 1970, outra obra, Vietname, também organizada por Loures e Simões, em que os poemas e os depoimentos de poetas portugueses sobre a agressão norte-americana àquele país serviam também "para condenar a guerra colonial portuguesa, em ato desde 1961", destaca Simões ${ }^{48}$. Segundo os organizadores, nesta obra "o poeta revive as tarefas de resistir [...]. E o seu verbo não esconde a acusação contra o gesto que envergonha a humanidade"49.

\footnotetext{
${ }^{43}$ Mensagem eletrônica de Carlos Loures, 1/10/2012.

${ }_{4}^{44}$ Mensagem eletrônica de Manuel Simões, 2/10/2012.

45 "LOURES, Carlos; SIMÕES, Manuel. "Prefácio". In: Hiroxima: depoimentos de poetas portugueses sobre o flagelo atómico, no $20^{\circ}$ aniversário da destruição de Hiroxima e Nagaságui. Tomar, Nova Realidade, 1967, p. 17; citado em SIMÕES, “Hiroxima e Vietname...”, op. cit., p. 88.

${ }^{46}$ Idem.

${ }^{47}$ Idem.

${ }^{48}$ Mensagem eletrônica de Manuel Simões, 2/10/2012.

49 "LOURES, Carlos; SIMÕES, Manuel. "Prefácio". In: Vietname: depoimentos de poetas portugueses sobre a agressão norte-americana ao Vietname. Tomar, Nova Realidade, 1970, p. 9; citado em SIMÕES, "Hiroxima e Vietname...", op. cit., p. 90. Este formato de antologia de poemas e depoimentos voltou a ser
} 
A Nova Realidade deu ênfase em seus lançamentos à poesia de tons políticos. Além das obras já mencionadas, publicou também na poesia: Os homens cantam a Nordeste, de António Cabral (1967); O comércio dos nervos, de Armando da Silva Carvalho (1968); Algumas palavras, de Eduardo Guerra Carneiro (1969); Crónica Breve, de Manuel Simões (1970); Poesia amordaçada: Cânticos a Pablo, de José Ferreira Monte (1970); e Meu canto terra, de Costa Mendes (1971).

"A insistência nos textos poéticos deve-se à preferência do público por este género, em detrimento da prosa”, explica Simões. "É que, através das metáforas, era possível fazer passar certas mensagens que, de outro modo, não passariam", $\operatorname{completa}^{50}$.

Em 1968 foi publicado o livro O realismo como categoria artística, de Stefan Morawski, um “ensaio de carácter teórico e que se ajustava à linha literária e ideológica da Nova Realidade" 51 .

Em 1969, já com um pequeno catálogo de alguns livros publicados, os proprietários da Nova Realidade, ao lado de outros sócios, decidiram criar, também em Tomar, a Raiz, "uma livraria que funcionava como plataforma logística das edições da Nova Realidade" 52 , e que também fazia a distribuição dos livros da editora. Carlos Loures ressalta que "A poucos quilómetros de Tomar, no Entroncamento [cidade da região], funcionava uma delegação da polícia política. A Raiz era visitada com frequência por brigadas da PIDE/DGS" ${ }^{\text {"53. }}$.

Em outubro desse ano surgiu outro importante livro da editora, que reforçou seu perfil de oposição: Para um dossier da oposição democrática, que teve organização, prefácio e notas de Serafim Ferreira e Arsénio Mota. Reunia textos da oposição democrática desde a criação do Movimento de Unidade Democrática Juvenil (MUD Juvenil) em 1946 e a campanha de Norton de Mattos em 1949, até a Plataforma de São Pedro de Muel, de junho de 1969.

Em 1971 Carlos Loures foi viver em Lisboa e deixou de fazer parte da direção da Nova Realidade ${ }^{54}$.

No ano seguinte, apareceu outro título de evidente teor político, o livro $A$

utilizado pela Nova Realidade em 1984, no livro Poemabril: antologia poética. Depoimentos de alguns "Capitães de Abril" e poemas de poetas portugueses no $10^{\circ}$ aniversário do 25 de Abril, também coordenado por Carlos Loures e Manuel Simões.

${ }^{50}$ Mensagem eletrônica de Manuel Simões, 2/10/2012.

${ }^{51}$ Idem.

${ }^{52}$ Mensagem eletrônica de Carlos Loures, 1/10/2012.

${ }^{53}$ Idem.

${ }^{54}$ Idem. 
literatura revisionista na União Soviética, coletânea de textos chineses traduzida e organizada por Mário Guerreiro. Este livro levou a processo, instaurado por ação da PIDE, contra os editores. "A PIDE interveio aqui, não tanto pelo conteúdo do livro mas para indagar sobre o tradutor, pseudônimo que lhes interessava descodificar", lembra Simões. Ele completa:

Como era alguém supostamente a viver em Paris e como não lhes importava muito a questão ideológica, que até lhes dava jeito porque contrária às posições do Partido Comunista Português, entregaram a causa à Polícia Judiciária com a acusação de que era uma publicação ilegal. A coisa seguiu os seus trâmites e acabou no Tribunal: fomos absolvidos, isto ainda antes de $1974 .^{55}$

Entre 1966 e 1976 a Nova realidade editou cerca de 20 títulos, todos comprometidos com ideias e posturas de oposição à ditadura. $\mathrm{O}$ período de maior atividade vai até 1972. Depois disso as edições apenas são retomadas em 1976 com dois lançamentos, mas de forma descontinuada. Nos anos 1980 há alguma atividade, porém pouca.

Simões destaca que "a Nova Realidade não foi uma editora propriamente dita porque nunca conseguiu o alvará necessário". Para ele tratou-se de "uma 'coleção', funcionando os textos como edição dos autores (ou dos tradutores ou dos organizadores - tinha que haver um responsável pela edição)". Só depois de 1974, diz ele, "estando já reduzida aos dois sócios, Júlio Estudante e eu, é que foi legalizada, tornando-se editora para todos os efeitos"

No entanto, considero que a Nova Realidade era sem dúvida uma editora desde a sua origem, e como tal se organizou. Assim, não estava submetida a nenhuma estrutura superior que a englobasse e seus editores eram os responsáveis - juntamente com os autores - pelos livros publicados. Da mesma forma, responsabilizavam-se pela distribuição dos mesmos, seja pela venda de mão em mão, pelo correio ou, num segundo momento, por meio da Livraria Raiz.

A destacar ainda que a Nova Realidade tinha também um "segundo selo", o Novo Rumo, como já explicado por Carlos Loures. Com este selo foram editadas duas obras: A voz e o sangue, de Carlos Loures (1967), que era um violento libelo contra a ditadura; e Guevara: antologia, organizado e traduzido por Adriano de Carvalho e João Bernardo (1967).

\footnotetext{
${ }_{55}^{55}$ Mensagem eletrônica de Manuel Simões, 2/10/2012.

${ }^{56}$ Idem.
} 
Loures recorda que "a primeira edição de $A$ voz $e$ o sangue esgotou-se rapidamente em 1967 e, já em 1968, parte da segunda edição foi apreendida tendo eu sido preso por quase sete meses" em função desse livro. Também o livro com textos de Che Guevara foi apreendido pela polícia política ${ }^{57}$.

A Nova Realidade foi certamente uma das primeiras editoras de intenção política a surgir na década de 1960, com um projeto estético, intelectual e político bem definido, e que conseguiu ter uma marcante atuação política, principalmente com edição de obras de poesia. Não deixa de ser curioso que a editora tenha surgido na pequena Tomar, que está situada quase a meio caminho entre Lisboa e Porto, as duas cidades que concentravam (e concentram) a produção editorial portuguesa.

A destacar também o fato de que a Nova Realidade manteve sempre total independência de grupos ou partidos políticos, sem nunca deixar de ser uma editora nitidamente política. Apesar de ter publicado relativamente poucos títulos (cerca de 20), constituiu sem dúvida uma das experiências editoriais independentes mais interessantes dos anos 1960 e 1970 em Portugal.

\subsection{A Regra do Jogo Edições}

Rua Sousa Martins, 5, 2 D, Lisboa 1; Rua Costa Cabral, 859-c/v - Porto

Editor: José Leal Loureiro

Fundação: 1973.

Distribuição: Afrontamento.

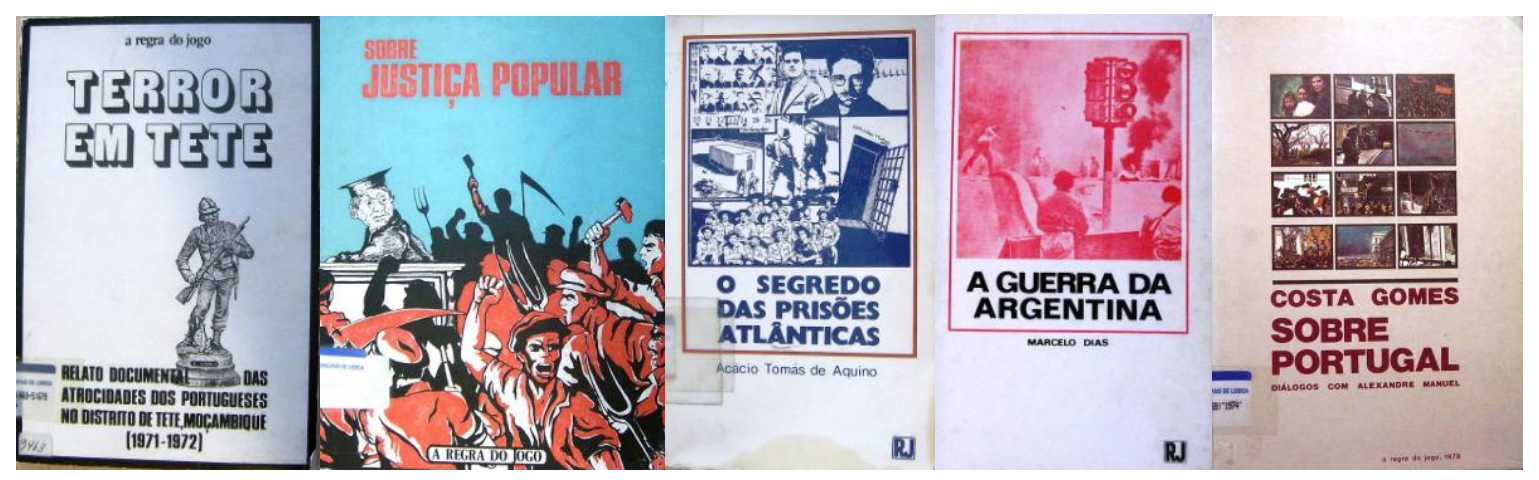

A editora A Regra do Jogo foi criada por José Leal Loureiro em 1973, ano em que lançou apenas um título de literatura infantil. Uma semana antes do 25 de Abril apareceu o segundo título, dessa vez de poesia ${ }^{58}$. Loureiro havia participado da

\footnotetext{
${ }^{57}$ Mensagem eletrônica de Carlos Loures, 1/10/2012.

${ }^{58}$ De acordo com afirmação do escritor Manuel António Pina. Ver: "Morreu o editor e livreiro José Leal Loureiro, "um homem muito inquieto"”. Agência Lusa, 27/12/2006. Disponível em:
} 
cooperativa Confronto e da editora Afrontamento a partir de 1966-67 ${ }^{59}$, no Porto, antes de fundar a sua editora. Ele faleceu em dezembro de 2006, quando estava à frente da Livraria Buchholz, em Lisboa.

Publicou livros de caráter político, mas a sua linha editorial foi marcada pela edição de poesia, ficção e obras acadêmicas, caracterizando-se por um certo ecletismo.

O escritor Manuel António Pina conta como foi escolhido o nome da editora:

O nome A Regra do Jogo foi escolhido por ele [Loureiro], por mim e por João Botelho, realizador de cinema. Vínhamos os três do cinema a dizer que tínhamos de criar uma editora para publicar os meus livros e escolhemos o nome do filme que tínhamos visto, A regra do jogo, de Jean Renoir. ${ }^{60}$

João Botelho tornou-se o capista da editora. Fernando Pereira Marques, dirigente da LUAR, trabalhava na editora ${ }^{61}$.

Os primeiros títulos políticos surgiram em outubro de 1974: Sobre justiça popular, que trazia um debate entre Michel Foucault e militantes maoistas sobre o tema; e Terror em Tete. Relato documental das atrocidades dos portugueses no distrito de Tete, Moçambique (1971-1972). Em 1975 e 1976 a produção da editora foi pequena, e nenhum título político foi editado. A partir de 1977 o ritmo de lançamentos cresceu significativamente, inclusive de obras de viés político.

Sem estar ligada a nenhum grupo político em particular, a editora publicou obras variadas sobre a realidade portuguesa contemporânea, como: Da reconquista da terra à reforma agrária: as ocupações de terras no Alentejo, de Vitor Matias Ferreira (1977); De repente Abril e outros escritos, de Sílvia Montarroyos (1977); Sobre Portugal: diálogos com Alexandre Manuel, de Costa Gomes (1979); e O processo de descolonização em Angola 1974-1976: ensaios de sociologia política, de FranzWilhelm Heimer (1980).

E editou também estudos e memórias sobre a história portuguesa do século XX: Relembrando e comentando (memórias de um operário corticeiro, 1914/1938), de José dos Reis Sequeira (1978); O 18 de Janeiro de 1934 e alguns antecedentes, com depoimentos de Acácio Tomaz de Aquino, Américo Martins, Custódio da Costa, José

<http://www.rtp.pt/noticias/index.php?article=159429\&tm=4\&layout=121\&visual=49>. Acesso em $30 / 9 / 2012$.

${ }^{59}$ COELHO, Mário Brochado. Confronto, memória de uma cooperativa cultural: Porto 1966-1972. Porto: Afrontamento, 2010, p. 41.

60 "Morreu o editor ...", op. cit.

${ }^{61}$ FREIRE, op. cit., p. 469. 
Francisco, Marcelino Mesquita e Emídio Santana (1978); O segredo das prisões Atlânticas, de Acácio Tomás Aquino (1978); A sociedade e a economia portuguesa nas origens do salazarismo (1917-26), de Fernando Medeiros (1978); Portugal na alvorada do século XX: forças sociais, poder político e crescimento económico de 1890-1914, de Manuel Villaverde Cabral (1979).

A Regra do Jogo tinha talvez como maior característica a sua independência política, e uma linha editorial generalista e eclética, em que havia também espaço para edições políticas, porém nunca partidarizadas.

De 1974 até o final dos anos 1970 a editora publicou cerca de 30 títulos políticos, o que representa por volta de um terço da sua produção. A editora manteve-se em atividade até meados dos anos 1980.

\subsection{Parceria A. M. Pereira}

Rua Augusta, 44-54 - Lisboa

Fundação: 1848.

Início das edições políticas: 1974.

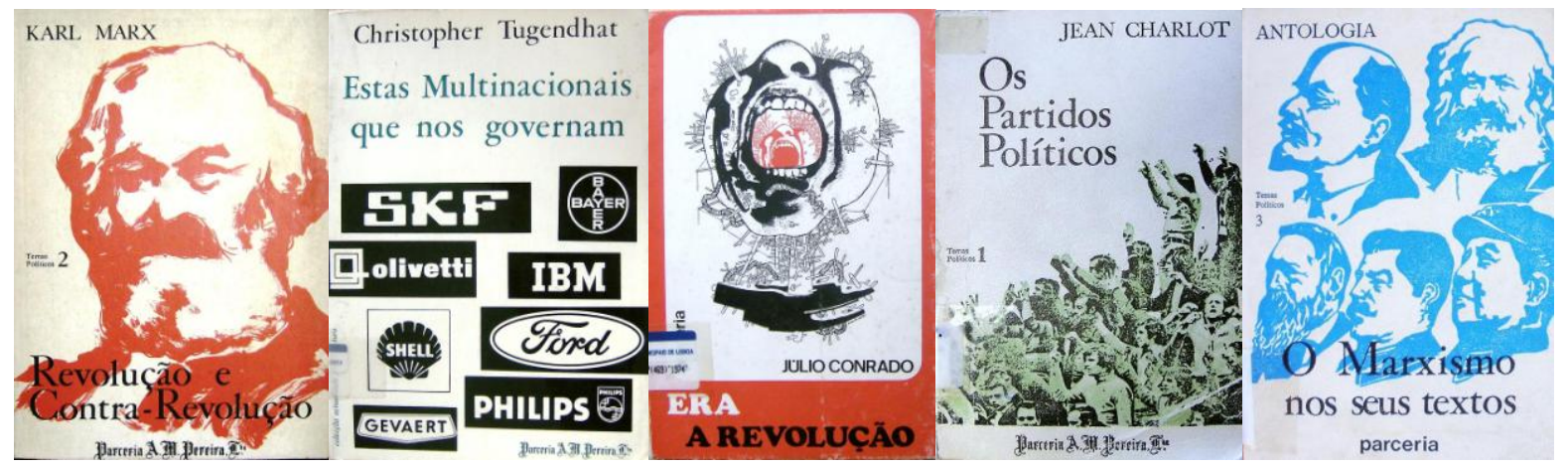

A Parceria A. M. Pereira foi uma das mais tradicionais editoras portuguesas, e esteve claramente vinculada ao regime salazarista durante décadas. Mas em 1975, em virtude de problemas econômicos e administrativos, e devido às transformações por que passava o país, viveu um período de autogestão em que editou alguns títulos de esquerda.

A livraria e editora de António Maria Pereira foi fundada em 1848, com a abertura da loja na rua Augusta, sendo assim "a mais antiga casa editora fundada, em Lisboa, por um editor português" ${ }^{\prime 2}$. Pereira começou a se destacar no panorama da

${ }^{62}$ BEJA, R. A edição em Portugal..., op. cit., p. 25. 
edição portuguesa quando tornou-se o primeiro editor lisboeta de Camilo Castelo Branco $^{63}$, autor de quem a editora lançou dezenas de títulos. O filho do fundador (que também se chamou António Maria Pereira, assim como o seu neto e o bisneto) assumiu os negócios na década de 1880. Sob sua direção a empresa passou a chamar-se Parceria A. M. Pereira e tornou-se uma das importantes livrarias e editoras do país ${ }^{64}$, editando, além de Camilo, Oliveira Martins, Eça de Queirós, Ramalho Ortigão e Teófilo Braga ${ }^{65}$.

Com a morte do segundo António Maria Pereira em 1898, quando seu filho (o terceiro António Maria Pereira) tinha apenas 3 anos, a empresa ficou até 1920 sob a direção de Henrique Monteiro, funcionário da empresa. A partir de então, a direção passou ao neto do fundador, ou seja, o terceiro António Maria Pereira. Em 1934, a editora publicou a obra Mensagem, de Fernando Pessoa, único livro do autor em língua portuguesa publicado enquanto ele ainda vivia ${ }^{66}$.

Esse período marcou um forte colaboracionismo da editora com Salazar e o Estado Novo. António Maria Pereira assumiu, em 1940, a presidência da primeira direção eleita do Grêmio Nacional dos Editores e Livreiros, cargo que ocupou até $1957^{67}$.

Após um período de grande atividade, no final dos anos 1940 (quando completou seu centenário) a empresa estava em processo pré-falimentar ${ }^{68}$. Nuno Medeiros considera que o posicionamento político de António Maria Pereira foi fator importante para que se chegasse a esta situação:

A sua simpatia pela figura de Salazar e a adesão incondicional aos princípios do presidente do Conselho constituem um elemento claro de travão, dissuadindo a livraria editora Parceria A. M. Pereira de um maior arrojo editorial e de uma incursão na publicação de um conjunto de autores que se começavam a afirmar. [...] As obras que edita [...] privilegiam claramente o campo ideológico e político identificado com o Estado Novo. [...] Concomitantemente, assistiu-se no mundo das ideias à generalização de um certo sentimento de repúdio do salazarismo por parte de intelectuais e escritores. A intelligentsia lusa

\footnotetext{
${ }^{63}$ MIGUEL, Telma. "Parceria". Revista Expresso, 16/2/2002, p. 72.

${ }^{64}$ DIAS, Débora. "Rotas de livreiros e seus Almanaques: intercâmbios luso-brasileiros nos circuitos do impresso". Anais do XXVI Simpósio Nacional de História, ANPUH, São Paulo, julho 2011, p. 11. Disponível em: http://www.snh2011.anpuh.org/resources/anais/14/1300656929_ARQUIVO_TrabalhoAnpuh2011.pdf. Acesso em 12/11/2012.

${ }^{65}$ MIGUEL, op. cit., p. 72-73.

${ }^{66}$ PEREIRA, Antónia Maria. Parceria A. M. Pereira: Crônica de uma dinastia livreira. Lisboa: Pandora, 1998, p. 170.

${ }_{67}^{67}$ MEDEIROS, Edição e editores, op. cit, p. 27 e 96.

${ }^{68}$ Ibidem, p. 147.
} 
não está, na sua maioria, com o regime [...]. Não está também, nessa medida, com António Maria Pereira, tido como próximo do regime. ${ }^{69}$

Já os filhos do terceiro António Maria Pereira ressaltam também suas limitações como gestor como um dos fatores que levaram à crise da empresa ${ }^{70}$.

A frágil situação econômica da editora motivou o envio de uma carta da esposa de António Maria Pereira a Salazar solicitando ajuda para a superação da crítica situação financeira $^{71}$, o que resultou na intervenção da Companhia Nacional Editora na empresa, "com as directivas de proceder ao saneamento financeiro da Parceria e à aquisição das quotas de familiares sócios. [...] A direcção da empresa nunca retorna ao antigo proprietário, que vem a morrer em 1972,

Somente após o 25 de Abril a Parceria A. M. Pereira viverá uma nova etapa, com a ocupação da empresa pelos trabalhadores em fevereiro de 1975. "A ocupação verificou-se a 17 de fevereiro, mas desde setembro [de 1974] que estamos praticamente em autogestão, pois a entidade patronal quase que não aparecia por cá [...]”, explicava a Comissão de Trabalhadores da Parceria A. M. Pereira em abril de $1975^{73}$. De acordo com a Comissão, “[...] à parte a publicação de alguns clássicos portugueses, teve esta editora sempre uma actividade editorial de cunho marcadamente reaccionário"74.

Para a Comissão de Trabalhadores, havia "incapacidade de gestão" por parte da direção,

agravando a situação dos trabalhadores através de uma gerência desastrosa, evitando aparecer na firma, fugindo a responsabilidades, mantendo fracas receitas devido a "stocks" não atualizados subtraindo-se inclusive a quaisquer investimentos que permitissem a continuidade normal das vendas, demonstrando um desinteresse absoluto pela casa. ${ }^{75}$

Já em 1974 a editora iniciou a coleção Temas Políticos - provavelmente em função do grande sucesso que o livro político passou a conhecer após o 25 de Abril e pelo fato de a autogestão de fato ter-se iniciado já em setembro desse ano, como vimos. Os primeiros volumes da coleção foram Os partidos políticos, de Jean Charlot; Revolução e contra-revolução, com textos de Karl Marx; e Fundamentos do leninismo,

\footnotetext{
${ }^{69}$ Ibidem, p. 145-46.

${ }^{70}$ MIGUEL, op. cit., p. 72-73; PEREIRA, op. cit , p. 151.

${ }^{71}$ MIGUEL, op. cit., p. 73.

72 MEDEIROS, Edição e editores, op. cit., p. 147.

73 "Parceria A. M. Pereira: ocupação de uma editora". Jornal Revolução, Lisboa, no 35, 10/4/1975, p. 10.

${ }^{74}$ HORTA, Maria Teresa. "Ecos literários". Expresso, Lisboa, no 116, 22/3/1975.

${ }^{75}$ Idem, ibidem.
} 
de Stalin. E também foi lançado o livro Estas multinacionais que nos governam, de Christopher Tugendhat (coleção Actualidade para o Futuro).

Após a ocupação da editora, a coleção Temas Políticos publicou mais cinco volumes, quatro deles com viés à esquerda: O marxismo nos seus textos, organizado por Serafim Ferreira (1975); O que disse “Che” Guevara, de António Melis (1975); Pensamento e acção de Lenine, de Valério Tonini (1976); e Os movimentos políticos árabes, de Paolo Minganti (1976).

Nessa etapa, para obterem recursos, os trabalhadores da empresa venderam o nome Parceria António Maria Pereira e a livraria adotou o nome de Livraria do $\operatorname{Arco}^{76}$. A autogestão ainda estava em vigor no começo de 1979, quando o livreiro Carlos Silva, membro da Comissão de Trabalhadores da editora, avaliava que "nada poderá mudar na empresa sem uma situação jurídica, definida”. De acordo com Silva, desde fevereiro de 1975 os trabalhadores estavam "sem uma solução que nos permita avançar com iniciativas mais práticas e objectivas". E completava:

Temos o problema do passivo que urge resolver, visto que estão envolvidas outras empresas fornecedoras, tais como tipografias, editoras, etc. É evidente que não cabe aos trabalhadores da Parceria a responsabilidade do passivo, mas de qualquer modo as entidades oficiais deveriam ter tratado há mais tempo do problema das empresas em autogestão. ${ }^{77}$

A edição de livros políticos de esquerda pela Parceria A. M. Pereira resultou de um momento excepcional e atípico na trajetória da empresa, que se iniciou após o 25 de Abril, quando os livros políticos passaram a ter uma procura acentuada, animou-se com o início da autogestão de fato na empresa (em setembro de 1974, de acordo com declaração da Comissão de Trabalhadores), e teve algum incremento após a ocupação da empresa pelos trabalhadores em fevereiro de 1975.

Mas, mesmo durante o período de autogestão, as edições políticas foram minoritárias entre as obras lançadas pela editora - 12 títulos entre cerca de 40 lançados entre 1974 e 1980. Continuaram a predominar de modo absoluto obras de caráter literário e generalista, com destaque para o sempre presente Camilo Castelo Branco.

Assim, os poucos livros políticos editados pela Parceria A. M. Pereira no período em foco são o resultado de um momento singular pelo qual passava o país e a empresa, e que pouco durou - os últimos títulos de caráter político foram lançados em 1977. Pelo

\footnotetext{
${ }^{76}$ PEREIRA, op. cit., p. 170.

77 "Entrevista com Carlos Silva". Notícias do Livro, n ${ }^{\circ}$, mar. 1979, p. 56-57.
} 
fato de a editora estar sob autogestão e ser dirigida desde o começo de 1975 pela sua Comissão de Trabalhadores, o viés de esquerda prevaleceu entre os livros políticos editados. No começo da década de 2000, a Parceria António Maria Pereira foi refundada por Antónia e António Maria Pereira, bisnetos do fundador da casa ${ }^{78}$.

\subsection{Edições Delfos}

Av. Luis Bivar, 7 - Lisboa

Início das edições: Anos 1960.

Editor: Humberto de Madureira.

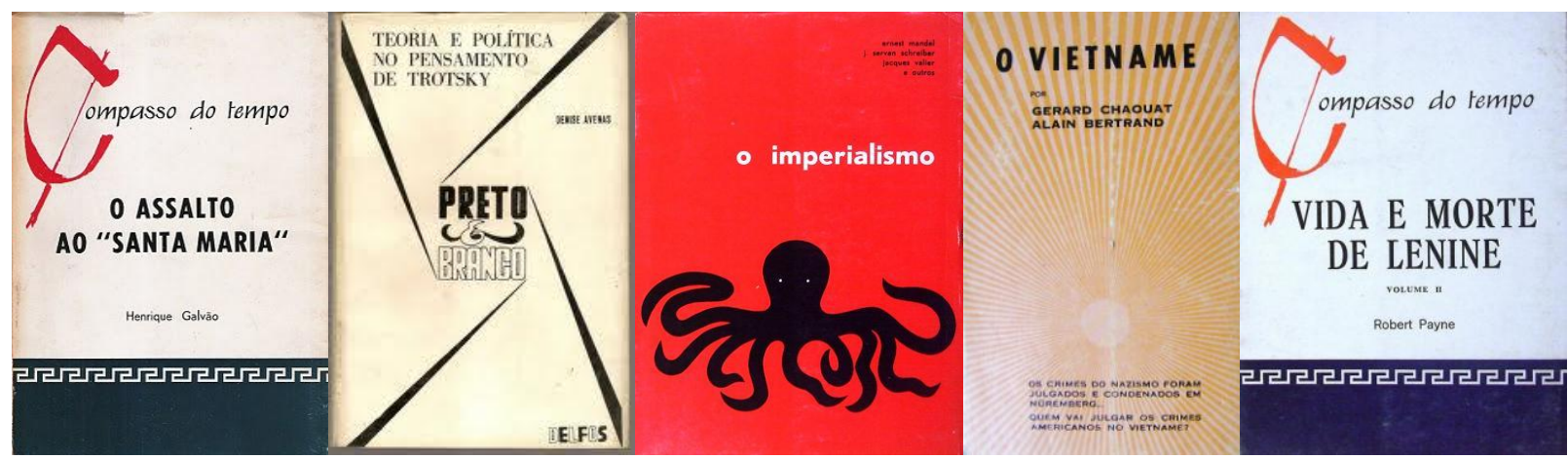

Foi uma atuante editora política desde 1968 até a segunda metade dos anos 1970. Antes de 1968 editava basicamente literatura estrangeira. A partir desse ano deu início às coleções Temas 2000 e Compasso do Tempo, ambas voltadas para a publicação de títulos políticos.

Na primeira foram editadas obras como: A revolta dos estudantes, de Maurice Caveing e Lucien Brunelle (1968); A África Austral de hegemonia branca, de Arnaud Durban (1970); Os cartazes de Paris: revolução de Maio de 1968 (1970); e O Partido Comunista (Sua definição), de Georges Marchais. 1972.

A coleção Compasso do Tempo foi a mais prolífica da editora, tendo publicado cerca de 30 títulos até 1977. Eis algumas das obras da coleção editadas antes de 1974: $O$ comunismo actual, de Waldeck Rochet (1968); O socialismo, de Guy Mallet (1968); Depois de Franco... O quê?, de Santiago Carrillo (1970); Vida e morte de Lenine, de Robert Payne (em dois volumes, 1972); Eleições presidenciais: subsídios para a história das candidaturas Norton de Matos (1949), Quintão Meireles (1952) e Humberto Delgado (1958) (1971); A mentira dos sindicatos, de Daniel Mothé (1973); O assalto ao "Santa Maria", de Henrique Galvão (1973); Eleições legislativas: subsídios para a história da vida portuguesa 1945-1973 (1973).

\footnotetext{
${ }^{78}$ MIGUEL, op. cit., p. 72.
} 
Ainda antes do 25 de Abril as coleções Toupeira, Perspectivas, Textos de Economia e Preto \& Branco também editaram obras políticas. Vários livros editados pela Delfos foram proibidos ou apreendidos pela polícia política ${ }^{79}$.

Após o fim da ditadura a Delfos continuou a editar livros políticos, dando sequência às coleções citadas. Entre as obras publicadas após o 25 de Abril, destacamse: Memórias, de Humberto Delgado (1974); Angola: no centro do furacão, de Basil Davidson (1974); A revolução cultural chinesa, de Henri Weber e outros (1974); O capital, de Karl Marx, em tradução de António Dias Gomes (1974); A revolução chilena (Um alerta ao Portugal de hoje), de Salvador Allende e J. Dominguez (1975); Revolução e contra revolução em Espanha, 1931-1936/1939, de Felix Morrow (1975); O M.R.P.P., de Judith Balso (1976).

A Delfos editou várias obras ligadas ao pensamento trotskista: Conceitos de moral, de Leon Trotsky (1969); Trotsky está vivo!, de Pierre Naville (1972); A revolução traída, de L. Trotsky (1973); Teoria e política no pensamento de Trotsky, de Denise Avenas (1973); Controle operário, antologia organizada por Ernest Mandel (1974); Vida e morte de Trotsky, de Pierre Frank e outros (1974); O imperialismo, de Ernest Mandel, J. Servan Schreiber, Jacques Valier e outros (1975); Tratado de economia marxista, de Ernest Mandel (1976); A curva do desenvolvimento capitalista, de Leon Trotsky e Christian Leucate (1978); Estados Unidos, país podre, de Ernest Mandel e Mary Joan Hiscox (1978).

Certamente isso indica que havia ligações da editora com militantes trotskistas ou com algum grupo trotskista ligado à Liga Comunista Internacionalista (LCI), grupo fundado em dezembro de 1973, que seguia a orientação política do Secretariado Unificado dirigido por Ernest Mandel e era participante da IV Internacional ${ }^{80}$.

No entanto, ao analisar a totalidade dos títulos publicados pela Delfos, ela não parece ser uma editora vinculada a um grupo trotskista, mas sim uma editora independente politicamente, sem vinculação a nenhum grupo específico, e que viu na edição de obras políticas um rentável filão editorial e comercial.

A Delfos encerrou suas atividades no final dos anos 1980.

\footnotetext{
${ }^{79}$ ALVIM, Maria Luísa. Livros portugueses proibidos no regime fascista: bibliografia. Braga, Faculdade de Letras da Universidade do Porto, 1992. Disponível em: <http://eprints.rclis.org/archive/00009450/01/livros_proibidos.pdf>. Acesso em 8/3/2008.

${ }^{80}$ Para mais detalhes sobre as origens da LCI ver o item sobre as Edições Antídoto, no Capítulo 6.
} 


\section{EDITORAS POLÍTICAS DE DIREITA}

As editoras de direita foram, em sua maior parte, criadas após o 25 de Abril (nove de treze), e mais particularmente a partir de 1976 - sete das treze editoras do grupo surgiram a partir desse ano.

Isso certamente se deve ao fato de que os setores de direita e de extrema direita tiveram grande dificuldade em responder ao novo quadro político criado com o fim do Estado Novo, já que boa parte deles tinha fortes vínculos com o antigo regime. O refluxo do processo revolucionário, principalmente após o golpe de 25 de novembro de 1975, parece ter sido o fator determinante para que esses setores voltassem a atuar de forma pública e legal, e uma dessas formas foi a edição política.

Este reaparecimento da direita e da extrema direita de modo aberto e por meio da publicação de obras com as suas posições sobre questões da conjuntura e da história recente de Portugal, gerava desconforto em setores democráticos e de esquerda, que viam nisso um ressurgimento do antigo regime. Zeferino Coelho, diretor da Editorial Caminho, afirmava, em abril de 1979: “Abundam nas livrarias as obras de caráter obscurantista que visam desviar a atenção das pessoas para falsos problemas, multiplicam-se obras de teor fascista ou fascizante, que apresentam de modo deturpado a realidade. Importa lutar contra esta situação [...]"1.

\footnotetext{
1 "Entrevista com Zeferino Coelho (Editorial Caminho)". Notícias do Livro, Lisboa, APEL, n 6, abril de 1979 , p. 35-36.
} 


\subsection{Editorial Restauração}

Travessa de São Pedro, 9, $2^{\circ}$ esq. - Lisboa

Editor: António da Cruz Rodrigues.

Início das edições: 1957.

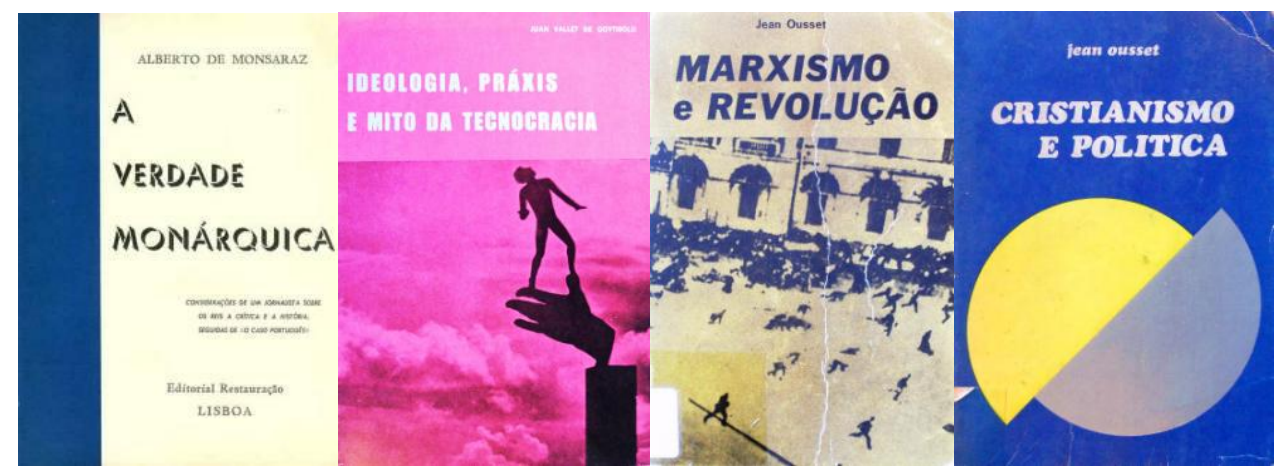

Editora ligada à organização Causa Monárquica, que defendia os valores da monarquia e sua restauração em Portugal, mas ao mesmo tempo tinha uma política de "colaboração aberta" com o Salazarismo e de apoio à política colonial do regime mesmo depois da "desilusão provocada pela recusa de Salazar em restaurar a monarquia, nos anos cinquenta",2.

A Causa Monárquica sofreu influência do Integralismo Lusitano, doutrina política que começara a ser veiculada a partir de 1914 pela revista Nação Portuguesa, de Coimbra, que advogava "o retorno a um sistema político monárquico tradicional e nacionalista, antiparlamentar, logo antirrepublicano, no qual o monarca assumiria papel de chefe de Estado, concentrando na sua pessoa as funções governativas" 3 .

A Restauração reeditou obras de dois dos principais pensadores do Integralismo Lusitano: Alberto de Monsaraz (A verdade monárquica, 1957) e António Sardinha (Ao princípio era o verbo, 1959; A epopeia da planície, 1960; e À sombra dos pórticos: novos ensaios, 1961).

Após um período em que seus esforços se concentraram no jornal O Debate importante periódico ligado à Causa Monárquica e que foi "um valioso acervo doutrinário", dirigido por Jacinto Ferreira ${ }^{4}$-, as edições são retomadas em 1969, ano da crise acadêmica de Coimbra, com o livro Cartas políticas, de Manuel Leal Freire,

\footnotetext{
${ }^{2}$ PINTO, Antonio Costa. "Integralismo Lusitano". Verbete. In: BARRETO, António e MÓNICA, Maria Filomena. Dicionário de História de Portugal. Porto: Figueirinhas, Vol. VIII, Suplemento F/O, 1999, p. 281.

3 “Integralismo Lusitano". In: Infopédia [Em linha]. Porto: Porto Editora, 2003-2012. Disponível em: <http://www.infopedia.pt/\$integralismo-lusitano>. Acesso em set. 2012.

${ }^{4}$ ANDRADE, John. Dicionário do 25 de Abril. Lisboa: Nova Arrancada, 2002, p. 72.
} 
“proprietário e director do jornal A Palavra, semanário 'ultranacionalista, monárquico e salazarista' que encerrou com a Revolução de Abril"5.

A retomada das edições pela Restauração parece relacionar-se com o surgimento de uma oposição de direita ao governo de Marcelo Caetano, principalmente em sua primeira fase "liberalizante". Esta oposição reunia setores muito diversos e que obedeciam a lógicas diferentes ${ }^{6}$. "Foi sob a experiência reformista do sucessor de Salazar que quer a direita radical, quer o neofascismo se demarcaram abertamente do poder político autoritário, procuraram chefes alternativos e apelaram mesmo a tentativas golpistas"?

De acordo com António Costa Pinto,

A extrema direita mais ou menos neofascista desenvolve-se em Portugal nos anos 60 com dois ou três catalisadores: o motor intelectual do neofascismo europeu, a derradeira batalha pela sobrevivência do império colonial português e a chegada ao poder de Marcello Caetano, com o seu ímpeto inicial de reforma do regime. [...] Ainda que sempre reduzidos às pequenas centenas [...] estes núcleos assumem-se então como um pequena "semi-oposição" à direita da ditadura e fazem da luta pela sobrevivência do "Império" a pedra de toque da sua ação política. ${ }^{8}$

Neste período a direção da editora estava sob a responsabilidade de António da Cruz Rodrigues, funcionário do Ministério das Corporações e Previdência Social até 1974, e militante ligado ao tradicionalismo católico de direita radical. Cruz Rodrigues participou da criação da revista Resistência em 1968 e do Círculo de Estudos Sociais Vector, em 1970. Foi membro da Comissão Consultiva do I Congresso dos Combatentes, realizado em junho de $1973^{9}$. Em 1974 participou também da fundação do Movimento Popular Português (MPP) e, em 1976, da Comissão Dinamizadora Nacional do Partido da Democracia Cristã (PDC) ${ }^{10}$.

\footnotetext{
${ }^{5}$ MANGAS, Francisco. "O trovador 'malcriado"'. Diário de Notícias, Lisboa, 8/8/2009. Disponível em: < http://www.dn.pt/gente/interior.aspx?content_id=1328986>.

${ }^{6}$ JÚDICE, José Miguel. "Oposição de direita a Marcelo Caetano". Verbete. In: BARRETO; MÓNICA, op. cit., Vol. 8, Suplemento F/O, 1999, p. 643-44.

${ }^{7}$ PINTO, António Costa. "Enfrentando o legado autoritário na transição para a democracia (1974-1976)". In: BRITO, J. M. Brandão de (coord.). O país em revolução. Lisboa: Editorial Notícias, 2001, p. 379.

${ }^{8}$ PINTO, António Costa. "Prefácio". In: MARCHI, Riccardo. Nação, Império, revolução: as direitas radicais portuguesas no fim do Estado Novo (1959-1974). Lisboa: Texto, 2009, p 13-14.

${ }^{9}$ Este Congresso visava defender um ideário nacionalista e conservador, que exaltava a "indivisibilidade" de Portugal pluricontinetal e multirracial e os "valores da Família, da Pátria, da Fé e do Trabalho". Cf. PINTO, Jaime Nogueira. "Congresso dos Combatentes" (verbete). In: BARRETO; MÓNICA, op. cit., Vol. 7, Suplemento A/E, 1999, p. 398.

${ }^{10}$ ANDRADE, op. cit., p. 341; para a informação sobre o I Congresso dos Combatentes: MARCHI, op. cit., p 374.
} 
Entre 1969 e agosto de 1974 a editora publicou apenas nove títulos, dos quais sete eram obras políticas de autores ligados à extrema direita ${ }^{11}$, como Manuel Ferreira Rosa (O projecto da reforma geral do ensino, 1971); António da Cruz Rodrigues (Antirazão, 1972); Jean Ousset (Marxismo e revolução, 1973; e Cristianismo e política, 1974); Jean Graviéres (As origens do progressismo cristão, 1973); e Juan Vallet de Goytisolo (Ideologia, práxis e mito da tecnocracia, 1974).

Os livros tinham tratamento gráfico e editorial profissional. Neles não havia informação de como era a feita a sua distribuição comercial.

Com o 25 de Abril, a editora sofreu o mesmo refluxo que atingiu todos os setores de direita e extrema direita no país, pois mesmo aqueles pequenos grupos que se colocavam na oposição ao regime deposto estavam mais próximos, do ponto de vista político e ideológico, do antigo regime do que dos vencedores do 25 de Abril. E muitos desses setores haviam sido apoiadores e sustentáculos do Estado Novo. Todos eles logo perceberam que os novos tempos não lhes seriam favoráveis.

O último livro editado pela Restauração, Cristianismo e política, de Jean Ousset (pseudônimo de Jean Marie Vaissière), em agosto de 1974, trazia uma introdução com algumas citações de autores cristãos que serviam para expressar o ânimo dos editores naquele momento:

Nestes tempos de anarquia social e intelectual, em que todos se consideram mestres e legisladores, é preciso lembrar energicamente que não se construirá a cidade em moldes diferentes dos de Deus, não se edificará a sociedade, se a Igreja não lhe põe os fundamentos nem lhe dirige os trabalhos [...]. ${ }^{12}$

E tal preocupação se completava com outra citação: "Não há tempo a perder. O tempo da reflexão e dos projetos passou: é a hora da ação. Estais preparados? As frentes opostas no domínio religioso e moral delimitam-se cada vez mais claramente: é a hora da prova"13.

Cruz Rodrigues afirma que em setembro de 1974 restavam apenas ele, Agnelo Galamba de Oliveira e José Francisco Rodrigues como acionistas e administradores da

\footnotetext{
${ }^{11}$ Os outros dois títulos eram: Coelhos (livro sobre criação de coelhos), de A. Jacinto Ferreira, editado em 1974; e $O$ que sabe sobre a droga: respostas às perguntas mais frequentes sobre o abuso da droga (documento do governo norte-americano sobre o assunto), 1973.

${ }^{12}$ Cardeal Pie, Oeuvres, T. VIII, p. 3 e 100, citado em: "Algumas citações à guisa de introdução". In: OUSSET, Jean. Cristianismo e política. Lisboa: Restauração, 1974, p. 2.

${ }^{13}$ Pio XII (7-IX-47), ibidem, p. 4.
} 
Editorial Restauração ${ }^{14}$. Naquele momento a iniciativa de maior repercussão da editora foi o lançamento do semanário Bandarra, do qual circularam apenas três números, entre 14 e 28 de setembro de 1974. Bandarra iria "distinguir-se pelos seus ataques ao processo descolonizador e em favor da manifestação da Maioria Silenciosa"15. O editor do jornal era Miguel Freitas da Costa e seu principal colaborador Manuel Maria Múrias ${ }^{16}$.

De acordo com o "Relatório do 28 de Setembro de 1974", editado pelo Movimento das Forças Armadas em 1975, o lançamento do jornal se inseria em uma "uma ofensiva orquestrada pela extrema direita", em que se destacavam alguns órgãos de imprensa, entre os quais o Bandarra ${ }^{17}$.

Com o fim das atividades da Editorial Restauração após a manifestação da “maioria silenciosa" em 28 de setembro de 1974, e a posterior renúncia do general Spínola à presidência da República, Cruz Rodrigues direcionou seus esforços na área da edição para a Editorial Resistência (ver mais adiante), que desde 1968 publicava a revista Resistência.

\footnotetext{
${ }^{14}$ RODRIGUES, António da Cruz. "As minhas memórias do Manuel Maria Múrias”. Blogue Aliança Nacional - Nação \& Liberdade, 24/10/2003. Disponível em: <http://nacionalismo-defuturo.blogspot.com.br/2003_10_19_nacionalismo-de-futuro_archive.html $>$. Segundo informação do "Relatório do 28 de Setembro de 1974", editado pelo Movimento das Forças Armadas em 1975, os acionistas da editora neste momento seriam Pedro Soares Martinez, Bernardo Mendes de Almeida (Conde de Caria) e Filipe de Bragança. Trechos do Relatório estão reproduzidos no blogue Papéis Velhos. Disponível em: <http://viriatos.blogspot.com.br/2003/11/papis-velhos.html>. Acesso em setembro de 2012.

${ }^{15}$ SANCHEZ CERVELLÓ, Joseph. Cronologia das organizações de direita (1973-1976). Centro de Documentação 25 de Abril, Universidade de Coimbra, 1994, mimeogr., p. 6.

${ }^{16}$ RODRIGUES, A. C, op. cit.

17 Trechos do Relatório estão reproduzidos no Blog Papéis Velhos. Disponível em: http://viriatos.blogspot.com.br/2003/11/papis-velhos.html. De acordo com a mesma fonte, o jornal fora financiado pelo Banco Espírito Santo \& Comercial de Lisboa, o qual "aceitou duas livranças de quatrocentos mil escudos, subscritas pelos administradores da editorial".
} 


\subsection{Sociedade Cooperativa Livreira Cidadela}

Rua Alexandre Herculano, 16 - Coimbra

Editor: José Miguel Júdice.

Início das edições: 1970.

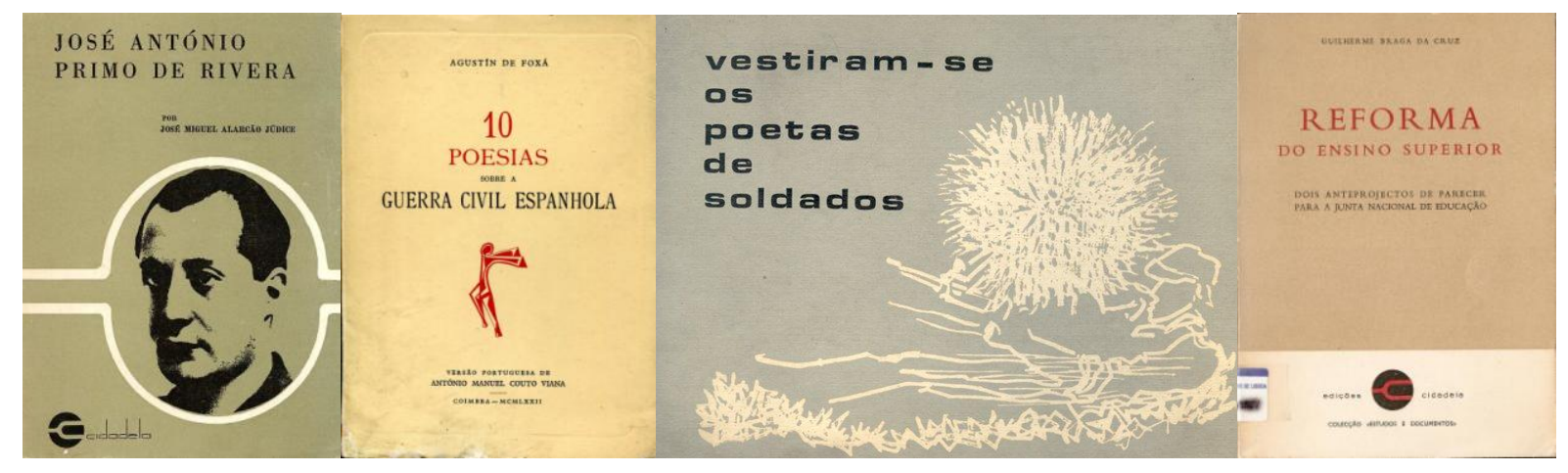

A Cooperativa Cidadela foi criada em novembro de 1970 por setores da extrema direita estudantil coimbrã ligados ao Secretariado Organizador da Acção e Coordenador dos Grupos de Estudo na Universidade de Coimbra, ao Orfeon Acadêmico da Universidade de Coimbra e à Oficina de Teatro da Universidade de Coimbra (OTUC). Em termos práticos, a ideia de criar a Cooperativa foi "do grupo nacionalrevolucionário da Faculdade de Direito, chefiado por José Miguel Júdice”, um dos líderes da extrema diretita naquela universidade ${ }^{18}$, e que depois do 25 de Abril integraria o Movimento Federalista Português/Partido do Progresso ${ }^{19}$.

De acordo com o historiador Riccardo Marchi, a ideia dos criadores da Cidadela era que ela fosse um ponto de confluência que completasse a rede por eles imaginada "como alternativa às estruturas controladas pelas esquerdas radicais" 20 .

Um fato interessante é que, embora no momento de criação da Cidadela estes setores da extrema direita já assumissem publicamente uma postura de oposição ao marcelismo, o projeto da cooperativa foi apresentado por José Miguel Júdice a Marcelo Caetano, e este aprovou a criação da Cidadela: “[...] ele aceita as garantias apresentadas pelos jovens militantes de Coimbra sobre a essência da sua oposição, feita com o intuito de purificar e não de destruir o regime",21.

Entre os objetivos da cooperativa estava a "edição ou venda de livros, revistas,

\footnotetext{
${ }^{18}$ MARCHI, Riccardo. “A direita radical na Universidade de Coimbra (1945-1974)”. Análise Social, vol. XLIII (3. $\left.{ }^{\circ}\right), 2008$, p. 571.

${ }^{19}$ SANCHEZ CERVELLÓ, J. Cronologia..., op. cit, p. 2.

${ }^{20}$ MARCHI, R. Império..., op. cit., p. 253.

${ }^{21}$ Ibidem.
} 
jornais e discos" ${ }^{22}$. O primeiro título foi lançado ainda em 1970. Trata-se de $O$ espírito $e$ a técnica: para uma reforma universitária, coletânea editada pelo Secretariado Organizador da Acção e Coordenador dos Grupos de Estudo na Universidade, com críticas e alternativas ao projeto de reforma universitária governamental.

Em 1971 surgiu o segundo título: O Ultramar e a revisão constitucional, de Francisco Lucas Pires, um dos líderes da extrema direita em Coimbra e nessa altura assistente da Faculdade de Direito.

Mas foi a partir de 1972, quando José Miguel Júdice assumiu a presidência da cooperativa, que as atividades culturais ganharam impulso, entre elas a edição de livros $^{23}$. Foram lançados dois títulos nesse ano: A antologia 10 poesias sobre a guerra civil espanhola, de Agustin de Foxá, e a coletânea de textos de José António Primo de Rivera, “cuja introdução de José Miguel Alarcão Júdice será um texto de referência para os nacionalistas revolucionários dos anos 70,24.

Em 1973 foram lançados cinco títulos: Vestiram-se os poetas de soldados: o canto da pátria em guerra, antologia de "poemas de diversos autores do nacionalismo revolucionário português" ${ }^{25}$, organizada e prefaciada por Rodrigo Emílio em homenagem aos combatentes da guerra no Ultramar e lançada no $1^{\circ}$ Congresso Nacional dos Combatentes ${ }^{26}$; A segunda cegueira, de Rodrigo Emílio; Manifesto de Portugal no qual se declara o modo que tem de se manter português, de Eduardo Freitas da Costa ( $3^{\text {a }}$ ed.); além de duas obras sobre questões ligadas à reforma universitária e ao ensino: Reforma do ensino superior: dois anteprojectos de parecer para a Junta Nacional de Educação, do ex-reitor da Universidade de Coimbra Guilherme Braga da Cruz; e Reforma do sistema educativo: um problema político, de Vítor Manuel Pires de Aguiar e Silva.

Estavam ainda previstos os lançamentos do livro Evolução na continuidade, de

\footnotetext{
${ }^{22}$ Ibidem, p. 255.

${ }^{23}$ Ibidem, p. 257.

${ }^{24}$ MARCHI, R. Império..., op. cit., p. 259. António José de Brito contesta essa afirmação: "Que a Introdução do Júdice à antologia sobre, ou melhor, de textos de José António Primo de Rivera fosse leitura de referência para os nacionalistas revolucionários (p. 259) é discutível. Alguns ficaram bastante escandalizados com ela. Na Cidadela, do Porto, o Júdice foi recebido com bastantes reticências exactamente por causa da mesma, que aliás despertou a discordância do Rodrigo Emílio". Ver o blogue

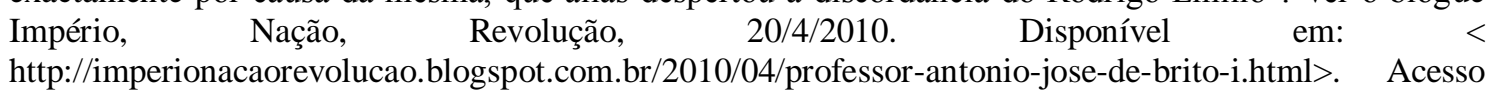
em setembro de 2012.

${ }^{25}$ MARCHI, R. Império..., op. cit., p. 258.

${ }_{26}$ Catálogo de Miguel de Carvalho. Disponível em: <http://www.livroantigo.com/site/temas.php?cod=12>. Acesso em set. 2012.
} 
Jaime Nogueira Pinto, e "antologias de Henry de Montherlant, Drieu La Rochelle, Vilfredo Pareto, Nobre França, Pierre Joseph Proudhon, Jorge Sorel"27.

Além dos títulos editados pela Cidadela, a cooperativa também proporcionava o acesso a toda uma série de publicações de direita:

A oferta bibliográfica da Cooperativa e as revistas existentes na sua hemeroteca evidenciam claramente as tendências políticas que a orientam: Brasillach, Bardeche, Huguenin, Ousset, Pound, SaintLoup, Von Salomon, Larteguy e Ortega y Gasset contam-se entre os autores que aí estavam representados, aos quais se juntavam as revistas Fuerza Nueva, Il Borghese, Il Secolo d'Italia (órgão do partido neofascista Movimento Sociale Italiano), Rivarol, entre outras. $^{28}$

As atividades da Cidadela, não só no campo editorial, mas também em outras áreas, como a realização de conferências, a transformaram, até o 25 de Abril, no "principal ponto de referência para a área nacional revolucionária de Coimbra", inserindo-se "na rede heterogênea da oposição de direita ao Governo de Marcello Caetano" 29 . Riccardo Marchi desta que:

Os seus militantes mais destacados são colaboradores constantes da revista Política, de Jaime Nogueira Pinto. Participam na fundação e na redacção dos estatutos de Programa - Associação de Estudos e Análise Social, presidida por Valle de Figueiredo e criada como contraponto à SEDES, da ala liberal. ${ }^{30}$

Com o 25 de Abril, a situação da Cidadela torna-se insustentável. Além de sua situação econômica ser crítica $^{31}$, a cooperativa era o símbolo maior da direita estundantil em Coimbra. Assim, a sua sede foi ocupada por grupos de esquerda no dia 27 de Abril, o mesmo ocorrendo com a sua delegação do Porto, pondo fim às atividades da cooperativa ${ }^{32}$.

Entre 1970 e 1973 a Cidadela publicou cerca de dez títulos. Não foi possível obter informações sobre a distribuição comercial dos livros, mas é de se supor que deveriam ser distribuídos pela própria cooperativa e por suas delegações.

\footnotetext{
${ }^{27}$ MARCHI, R. Império..., op. cit., p. 259.

${ }^{28}$ Ibidem, p. 571.

${ }^{29}$ Ibidem, p. 265.

${ }^{30}$ Ibidem, p. 573.

31 “[...] as informações da PIDE sobre a situação econômica da Cooperativa indicam uma grave crise" em fins de 1973. Ibidem, p. 265.

32 Ibidem, p. 266. Para uma versão desse episódio feita por apoiadores da Cidadela ver: "Ainda os dias da vergonha em Coimbra". Blogue Absonante, 30/4/2005. Disponível em: $<$ http://absonante.blogspot.com.br/2005/04/ainda-os-dias-da-vergonha-em-coimbra.html>. Acesso em set. 2012.
} 


\subsection{Pensamento Político}

Lisboa

Início das edições: 1971.

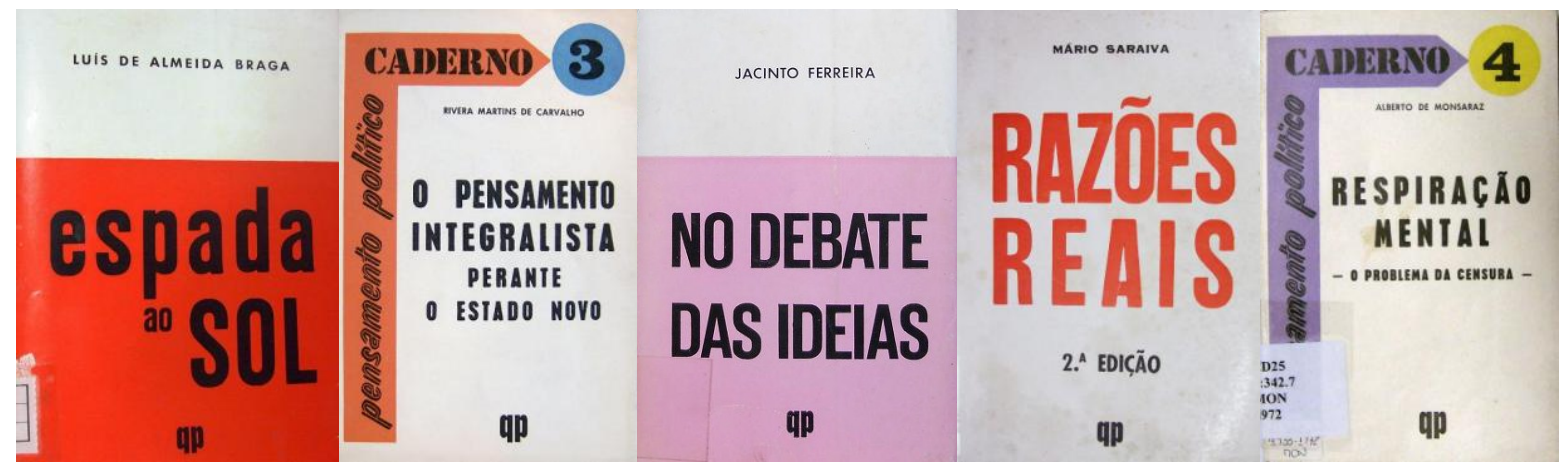

Editora ligada ao movimento monárquico integralista de final dos anos 1960, cujas figuras expoentes eram Rolão Preto ${ }^{33}$, Luís de Almeida Braga, Henrique Barrilaro Ruas e Mário Saraiva, entre outros. Sua filiação política remonta ao Integralismo Lusitano do começo do século XX, sendo seus membros representantes de diferentes gerações desse movimento, que se reuniram na Comissão Eleitoral Monárquica de 1969, no movimento Renovação Portuguesa, na Convergência Monárquica e na editora Pensamento Político ${ }^{34}$. Situava-se no campo da oposição monárquica e conservadora ao governo de Marcelo Caetano, ao mesmo tempo em que defendia a manutenção do "império" português e dos "territórios de Ultramar".

Publicou obras de destacados pensadores monarquistas, como Alberto de Monsaraz (Respiração mental: o problema da censura, 1972), António Sardinha (A aliança peninsular: antecedentes e possibilidades, 1972; e Ao ritmo da ampulheta, 1978), Luís de Almeida Braga (Espada ao Sol, 1969), Jacinto Ferreira (No debate das ideias, 1973), Mário Saraiva (Razões reais, 1970; A verdade e a mentira: algumas notas em resposta ao integralismo e a república de Carlos Ferrão, 1971; e As portas da cidade: critica e doutrina, 1976), Rivera Martins de Carvalho (O pensamento integralista perante o Estado Novo, 1971; e Diário político e outras páginas, 1972) e Henrique Barrilaro Ruas (A liberdade e o rei, 1971; e Os monárquicos e o Ultramar: à maneira de Livro Branco, em parceria com Marcus de Noronha da Costa, 1971).

\footnotetext{
33 "Rolão Preto". Verbete, Wikipédia. <http://pt.metapedia.org/wiki/Rol\%C3\%A3o_Preto>. Acesso em set. 2012.

34 QUINTAS, José Manuel. "Integralismo Lusitano - uma síntese". Disponível em: <http://www.angelfire.com/pq/unica/il_jmq_integralismo_lusitano_sintese.htm>. Acesso em set. 2012.
} 
O primeiro título editado surgiu em 1969, e o último em 1978. Neste período, foram publicadas 21 obras. Nos livros não consta informação sobre como era feita a distribuição comercial.

Até 1974 a editora não conseguiu ser formalmente criada, como se depreende desta nota publicada em alguns livros editados: "Por não se poderem concretizar, de momento, as condições necessárias ao início da nossa Editorial (em organização), vão sair os primeiros Cadernos como edições dos seus respectivos autores" ${ }^{\text {"35. }}$.

Isso talvez se devesse a motivos políticos, uma vez que, até o 25 de Abril, para a criação de uma editora era necessária autorização governamental, vinculada à aprovação política da PIDE/DGS dos nomes dos sócios proprietários. Como explica Nuno Medeiros, os decretos-leis n. ${ }^{\circ}$ 26.589, de 14/5/1936, e n. ${ }^{\circ} 33.015$, de 30/8/1943, estabeleciam "a idoneidade moral e financeira como critérios nucleares de autorização para a constituição de novas empresas devotadas à edição", de modo que "os diplomas referidos caucionavam uma profilaxia política, identificado como estava o carácter idóneo com o alinhamento com o regime ou com alguma garantia de inocuidade na actividade a prosseguir" ${ }^{\prime 36}$.

Como a editora Pensamento Político estava ligada a sectores da oposição monárquica, essa autorização pode não ter sido concedida por este motivo até o fim da ditadura.

Após abril de 1974 a atuação da editora diminuiu muito, de modo que entre 1974 e 1978 são lançados apenas seis títulos. Alguns dos responsáveis pela editora, como Rolão Preto e Henrique Barrilaro Ruas, participaram da criação do Partido Popular Monárquico (PPM), em maio de 1974.

\footnotetext{
${ }^{35}$ Esta nota foi publicada nos livros Marcuse ou o colapso de duas ideologias, de António Faria y Maia (1971); Diário político e outras páginas, de Rivera Martins de Carvalho (1972); e No debate das ideias, de Jacinto Ferreira (1973).

${ }^{36}$ MEDEIROS, Edição e editores, op. cit., p. 168.
} 


\subsection{Editorial Intervenção}

Braga - Lisboa

Editor: Paradela de Abreu.

Início das edições: 1974.

Distribuição: Centro do Livro Brasileiro, Casa do Livro Editora, Livraria Bertrand e O Século
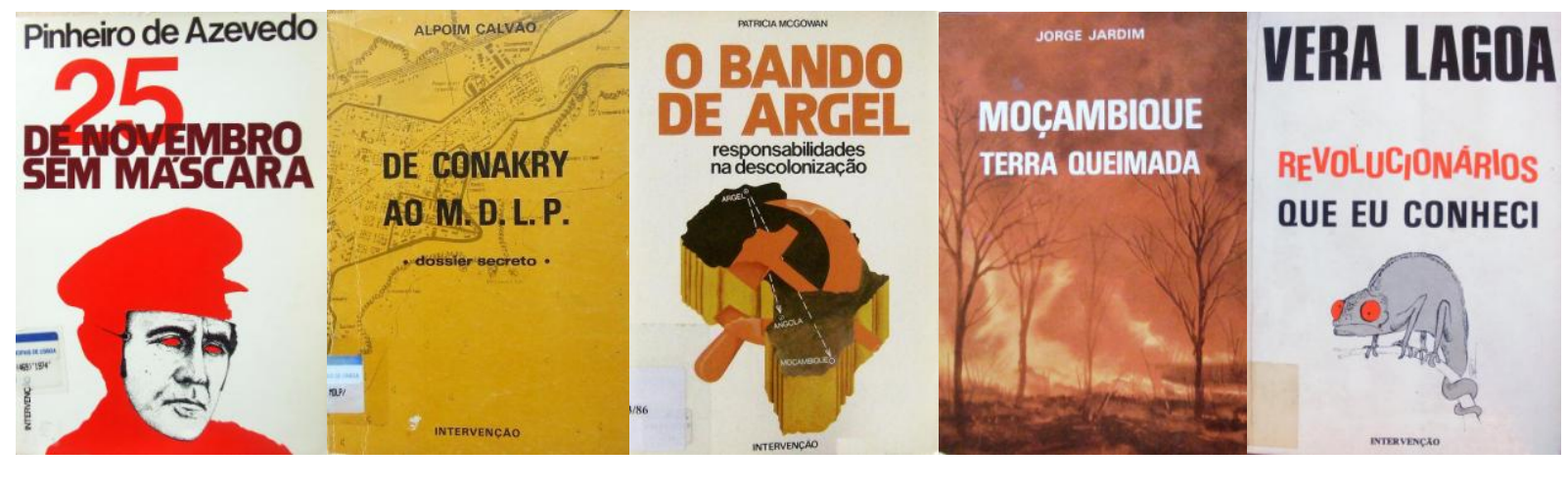

Editora criada em 1974 pelo jornalista e editor Waldemar Paradela de Abreu. Entre 1955 e 1958 Abreu trabalhou no jornal República. Em dezembro de 1960 criou a Editora Estampa, da qual se afastou em 1969. De 1972 a 1974 foi editor da Editora Arcádia, onde participou da publicação do livro Portugal e o futuro, do general António

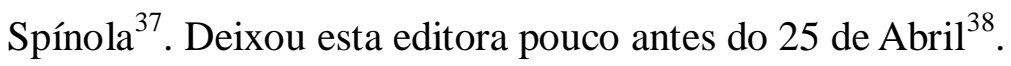

Em 1974 e 1975 foi chefe de redação do semanário Liberdade e diretor do jornal O Social Democrata, ambos ligados ao Partido Social Democrata Independente $(\mathrm{PSDI})^{39}$.

Profundamente anticomunista, Paradela de Abreu vinculou-se após o 25 de Abril a setores da extrema direita que foram derrotados no falhado golpe de 11 de março de 1975. No dia 12 de março o jornal Liberdade foi proibido e uma ordem de captura foi emitida contra o seu diretor, Luiz Arouca, e contra Paradela de Abreu ${ }^{40}$. A partir de então, o editor passou a viver na clandestinidade e tornou-se ainda mais ativo na militância ao lado da extrema direita. Juntamente com o major Sanches Osório e o engenheiro Jorge Jardim, concebeu e foi um dos principais operadores da Operação

\footnotetext{
37 "Na morte de Paradela de Abreu". Página eletrônica do Sindicato dos Jornalistas, 18/12/2003. Disponível em: <http://www.jornalistas.eu/?n=1656>, exceto para a informação sobre a Editora Estampa. ${ }^{38}$ MALTEZ, José Adelino. "16 de Março, 25 de Abril, 28 de Setembro, Marcelo, Spínola e Vasco Gonçalves”. Disponível em: <http://maltez.info/cosmopolis/anode1974/portugal74.htm>. Acesso em set. 2012.

${ }^{39}$ SANCHEZ CERVELLÓ, J. Cronologia..., op. cit, p. 8.

${ }^{40}$ ABREU, Paradela. Do 25 de Abril ao 25 de Novembro: memória do tempo perdido. Lisboa: Intervenção, 1983, p. 75.
} 
Maria da Fonte ${ }^{41}$, que mobilizou a Igreja e os setores mais conservadores do norte de Portugal para realizar uma série de ataques terroristas e intimidações aos comunistas e a outros grupos de esquerda entre julho e novembro de 1975, resultando no assalto, destruição e incêndio de dezenas de sedes dessas organizações naquela região do país ${ }^{42}$. Osório havia sido um dos “capitães de Abril” e criara em 1974 o Partido da Democracia Cristã (PDC), de extrema direita, que foi posto na ilegalidade após o golpe de 11 de março, e Jardim exercera várias funções no regime salazarista e fora enviado por Salazar a Moçambique para "missões especiais" 43. Apesar de haver algumas divergências entre os grupos, a Operação Maria da Fonte foi realizada de forma coordenada pelo Movimento Democrático de Libertação de Portugal (MDLP) e o Exército de Libertação de Portugal (ELP), organizações de extrema direita responsáveis por atentados a bomba em várias cidades de Portugal nesse período.

O primeiro livro da Intervenção foi editado em 1974, mas foi em 1975 que a vocação da editora de porta-voz de setores da extrema direita começou a ficar clara, com a edição do livro O equívoco do 25 de Abril, de Sanches Osório. Abreu assim explicou a edição da obra:

Era preciso denunciar a traição aos princípios formulados no dia $25 \mathrm{de}$ Abril de 1974 e organizar o povo para a guerra. Essa denúncia foi bem conseguida com o livro do major Sanches Osório O equívoco do 25 de Abril. Foi o primeiro passo destinado a preparar psicologicamente as pessoas para uma decisão que não era já a de lutar propriamente dentro de partidos - que nada podiam, como se verificou - contra o Partido Comunista [...]. ${ }^{44}$

Essa afirmação do editor mostra também que a editora visava, desde seus primórdios, ser um instrumento voltado para o embate político direto, neste caso, a Operação Maria da Fonte.

Este livro foi publicado primeiro na Espanha e no Brasil, e só depois disso em Portugal $^{45}$. Abreu afirmou na "Nota do editor" publicada nesta obra: “[...] sinto que este

\footnotetext{
${ }^{41}$ ABREU, Do 25 de Abril..., op. cit., p. 116.

${ }^{42}$ Para justificar os ataques e incêndios, Abreu chegou a escrever o seguinte: "Sendo o povo quem mais ordena, como é que esse mesmo povo poderia fazer sentir a sua vontade? Recordemos que, nessa altura, os órgãos de comunicação social estavam totalmente dominados pelos comunistas. [...] $\mathrm{O}$ instinto de defesa e a sabedoria ancestral imaginaram um processo áudio-visual de comunicação: o barulho das bombas e a visão dos incêndios. Quando o Norte ardeu, estava apenas a comunicar: as sedes do PCP foram apenas órgãos de comunicação social". ABREU, Paradela. "Nota do editor". In: BARRADAS, Fernando; AZEVEDO, Ercílio de. Os cravos na ferradura. Braga/Lisboa: Intervenção, 1976, p. 6.

${ }^{43}$ ANDRADE, op. cit., p. 355 e 195.

${ }^{44}$ ABREU, Do 25 de Abril..., op. cit., p. 101.

${ }^{45}$ Ibidem, p. 102.
} 
livro vai ajudar a derrubar o regime cunhalista-'rapazes da tropa",46.

Foi a partir de 1976, após o fim da Operação Maria da Fonte, que a Editora Intervenção começou uma intensa atividade editorial, que resultou em cerca de 40 títulos publicados até 1980.

Todas as obras editadas tinham evidente teor político e estavam claramente identificadas com o pensamento e as propostas da extrema direita portuguesa naquele momento. A Intervenção foi a editora de alguns dos expoentes desse setor político: Adriano Moreira, Alpoim Calvão, Jorge Jardim, Vera Lagoa, Franco Nogueira, Jaime Nogueira Pinto e o próprio Paradela de Abreu.

Grande parte dos títulos referia-se à questão da descolonização, com críticas e acusações à forma como tal processo havia sido realizado - para a extrema direita, tratava-se de uma "traição" ao país. Entre estas obras destacam-se: Angola: os vivos e os mortos, de Pompílio da Cruz (1976); De Conakry ao MDLP: dossier secreto, de Alpoim Calvão (1976); Moçambique, terra queimada, de Jorge Jardim (1976); África: vitória traída. Quatro generais escrevem, de J. da Luz Cunha, Kaúlza de Arriaga, Bethencourt Rodrigues e Silvino Silvério Marques (1977); O drama de Timor: relatório da O.N.U. sobre a descolonização, com comentários de Adriano Moreira (1977); e o Livro negro da descolonização, de Luis Aguiar (1977).

O livro De Conakry ao MDLP: dossier secreto, de Alpoim Calvão, foi resumido dessa forma em uma revista da época:

Trata-se de uma apologia dos "bons velhos tempos" da guerra colonial, onde se cantam com nostalgia os "feitos heroicos" que foram os massacres em África; as invasões aos países vizinhos; as destruições de cidades estrangeiras; os atentados a líderes e a chefes de Estado, aliados dos movimentos de libertação africanos. ${ }^{47}$

Destacam-se também obras dedicadas à causa anticomunista e aos desdobramentos do 25 de Abril, por exemplo: Os cravos na ferradura, de Fernando Barradas e Ercílio de Azevedo (1976); Acuso! Soares, Cunhal, Emídio Guerreiro, Lopes Cardoso na morte de Humberto Delgado, de Henrique Cerqueira (1976); Revolucionários que eu conheci, de Vera Lagoa (1977), Oposição=0,1\%. As eleições nos países de leste (1979); e 25 de Novembro sem máscara, de Pinheiro de Azevedo (1979).

\footnotetext{
${ }^{46}$ ABREU, Paradela. "Nota do editor". In: OSÓRIO, Sanches. O equívoco do 25 de Abril. Braga/Lisboa: Intervenção, 1975, p. 5.

47 “Calvão confessa 'tudo' e prepara-se para o regresso". Opção, Lisboa, n 10, 7/7/1976, p. 50.
} 
Outra linha importante e que mescla as características já expostas é a da edição dos cinco álbuns de cartuns de Augusto Cid sobre a política interna, entre os quais: Eanito el estático (1979) e O fim do PREC (1980).

Alguns livros editados parecem ter tido grande sucesso de vendas, a se acreditar nas palavras do editor. Por exemplo, o livro Moçambique, terra queimada, teria tido uma tiragem inicial de 50 mil exemplares em 1976 e teria sido um êxito ${ }^{48}$. O primeiro volume de Acuso! Soares, Cunhal... teria vendido 54 mil exemplares em 12 dias! ${ }^{49}$ Já o livro de Vera Lagoa, Revolucionários que eu conheci, teria tido os 10 mil exemplares da $1^{\text {a }}$ edição, lançada em novembro de 1977, "Esgotados em três semanas", e os 5 mil da $2^{\text {a }}$ edição - de dezembro de 1977 - "Esgotados em quinze dias"50.

Num balanço da atuação da editora feito no segundo semestre de 1979, Paradela de Abreu afirma que desde agosto de 1975, ou seja, desde o lançamento da primeira edição portuguesa do livro O equívoco do 25 de Abril, até julho de 1979 a editora publicara 34 títulos e vendera mais de 500 mil exemplares ${ }^{51}$.

Paradela de Abreu é um caso único - ao menos em Portugal - de editor que virou terrorista de extrema direita e, depois de liderar uma breve, mas intensa, campanha de terror político, voltou à edição. A sua editora Intervenção é claramente um instrumento de continuação de seu combate político por outros meios, caracterizando-se como uma editora militante e totalmente dedicada à defesa das ideias de extrema direita. O próprio Abreu fazia questão de declarar suas intenções como editor: "Se 'escrever é lutar', então editar será a forma de materializar essa luta. Se um escritor escreve uma 'bomba útil', o editor deve fazê-la explodir" ${ }^{\text {"52 }}$. E no seu caso isso não era mera figura de linguagem, já que ele participou, na Operação Maria da Fonte, de vários atos terroristas e apoiou os chamados "bombistas" do ELP e do MDLP.

No segundo semestre de 1979, ou seja, quase quatro anos após o golpe de 25 de Novembro de 1975 que "normalizou" a situação política, afastou definitivamente o PCP

\footnotetext{
48 ABREU, Paradela. "Nota do editor". In: JARDIM, Jorge. Rodésia: o escândalo das sanções. Lisboa/Braga, Intervenção, 1978, p. 7-8.

49 ABREU, Paradela. "Nota do editor". In: CERQUEIRA, Henrique. Acuso! Soares, Cunhal, Emídio Guerreiro, Lopes Cardoso na morte de Humberto Delgado: o crime, $2^{o}$ vol. Braga/Lisboa: Intervenção, 1977, p. 7.

${ }^{50}$ LAGOA, Vera. A cambada. Lisboa/Braga: Intervenção, 1978.

${ }^{51}$ ABREU, Paradela. “A razão do editor”. In: LEONE, Metzer (coord.). 13 boas razões para votar. Braga/Lisboa: Intervenção, 1979, p. 9.

${ }^{52}$ ABREU, "Nota do editor". In: OSÓRIO, op. cit., p. 5. Abreu faz menção nesta frase a um anúncio publicitário da Editora Arcádia publicado em novembro de 1974, que tinha como título: "Escrever é lutar. Editar também". Ver item sobre a Arcádia no Capítulo 11.
} 
do governo português e fez retroceder quase todas as conquistas mais avançadas do 25 de Abril, o editor Paradela de Abreu ainda definia a razão de ser da sua editora do seguinte modo: "A Intervenção tem sido, assim, uma editora exclusivamente política, vocacionada para o combate contra a 'gloriosa marcha' para a sovietização de Portugal" 53 . Neste mesmo texto, publicado como nota introdutória ao livro 13 boas razões para votar, Abreu não deixa dúvidas em relação aos fins visados por ele ao editar aquela obra: "É vital e absolutamente indispensável votar contra o PC e contra este PS: trata-se de um voto estratégico, inteligente, como quem faz um investimento a médio prazo com a certeza da rentabilidade" ${ }^{, 54}$.

O sentido militante da editora foi mais uma vez reafirmado por Abreu - sem perder a chance de dar um certo ar heroico a seus feitos - em seu livro de memórias, quando afirma: “O objetivo [da editora Intervenção] não era ganhar dinheiro mas editar o que eu próprio queria com o objectivo específico de esclarecimento ou de contrainformação política, mesmo que para isso tivesse de perder dinheiro - o que várias vezes aconteceu" $" 55$.

As edições da Intervenção praticamente cessaram em 1980, ano em que foram lançados cinco títulos ${ }^{56}$. No total, entre 1974 e 1980 a editora publicou cerca de 40 títulos, caracterizando-se como a mais atuante editora de extrema direita portuguesa nesse período.

Em 1987 Paradela de Abreu ainda criou a Editora Referendo, que existiu até 1991. Ele faleceu em dezembro de $2003^{57}$.

\footnotetext{
${ }^{53}$ ABREU, “A razão do editor”, op. cit., p. 10.

${ }^{54}$ Ibidem, p. 13.

55 ABREU, Do 25 de Abril..., op. cit., p. 142.

${ }^{56}$ Em 1983 foi editado ainda um último título, as memórias de Paradela Abreu, Do 25 de Abril ao 25 de Novembro: memória do tempo perdido, mas já como uma edição isolada.

57 “Na morte de Paradela de Abreu”..., op. cit.
} 


\subsection{Editorial Resistência}

Rua Nova de São Mamede, 27-2 ${ }^{\circ}$ Esq. - Lisboa

Editor: António da Cruz Rodrigues.

Início das edições: 1975.

Distribuição: própria.

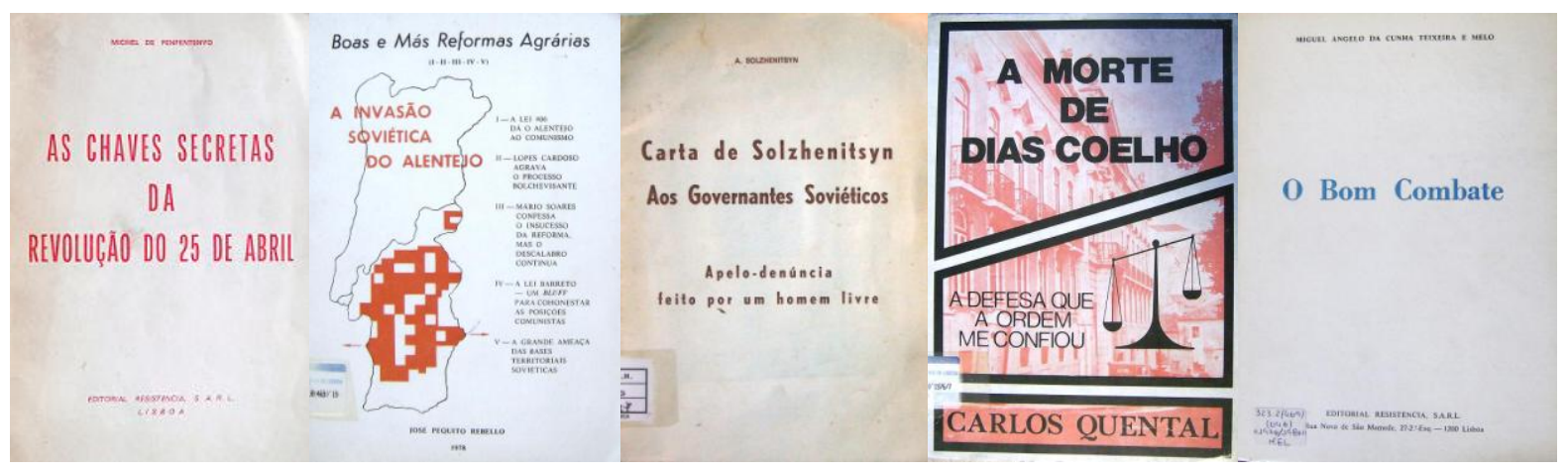

Editora criada inicialmente para editar a revista Resistência, que começou a circular em 1968. Eduardo Lourenço define a revista dessa maneira:

De inspiração integrista e ultranacionalista, o seu alvo de predilecção é menos um comunismo mítico e longínquo - embora pano de fundo permanente - que o progressismo caseiro, em particular o que começa a manifestar-se com relevo e intensidade nos meios culturais católicos, até então solidários do regime. [...] É uma revista-cruzada, destinada a mobilizar a autêntica e sólida direita portuguesa para os combates de fim de reino e ocaso de regime, que se adivinham perto. ${ }^{58}$

Lourenço a caracteriza ainda como "antiliberal, antidemocrática, anticomunista". Seus membros estarão entre os principais fundadores do Círculo de Estudos Sociais Vector, em 1970. "Num e noutro encontramos a fina flor da direita e da extrema-direita portuguesas, do passado, do presente e, sem dúvida, do futuro", afirma Lourenço ${ }^{59}$.

Seu editor (da revista e dos livros) é o mesmo António da Cruz Rodrigues, da Editorial Restauração, de quem já falamos.

A edição de livros por parte da Editorial Resistência começou apenas em 1975, depois que a Editorial Restauração saiu de cena, em consequência dos acontecimentos de 28 de setembro de 1974 e de seus desdobramentos. Como o grupo que dava sustentação a esta editora e à revista Resistência continuava em atividade - inclusive por meio do Círculo de Estudos Sociais Vector -, a necessidade de editar livros também

\footnotetext{
${ }^{58}$ LOURENÇO, Eduardo. "Fascismo e cultura no antigo regime". Análise Social, vol. XVIII (72-7374), $1982-3 .^{\circ}-4 .^{\circ}-5 .^{\circ}$, p. 1.435. Grifos no original.

${ }^{59}$ Ibidem, p. 1.436.
} 
permanecia como uma área de atuação a ser desenvolvida, mesmo nas condições adversas daquele momento para a direita. Por isso essa atividade passa a ser realizada pela Editorial Resistência.

O Vector e a revista Resistência tiveram grande participação na criação do Movimento Popular Português (MPP), em junho de $1974^{60}$. Cruz Rodrigues afirma que “A base logística [do MPP] era no andar da Editorial Resistência, na Rua Nova de São Mamede". O essencial da linha de pensamento e de ação do grupo pode ser resumido, de acordo com ele, neste trecho de seu manifesto: "Não se iluda. Comunismo é pior que Fascismo. Todos os países comunistas têm uma polícia igual a PIDE/DGS. Proíbem liberdade de expressão, direito à greve e partidos políticos divergentes" ${ }^{\text {61 }}$.

Uma das consequências do anticomunismo do MPP foi o rompimento com António Spínola, na época presidente da República. Isso pode parecer, à primeira vista, paradoxal, mas de acordo com Cruz Rodrigues, para o MPP Spínola era "o homem que todos considerávamos o principal responsável pelo êxito do assalto em curso ao poder por parte do PCP e, portanto, o principal responsável, pela consequente destruição de Portugal”. Em 27 de julho de 1974, quando Spínola fez o discurso em que reconhecia o direito das colônias à independência, a revista Resistência publicou um editorial em que atacava esta decisão ${ }^{62}$.

Após o 28 de Setembro, o MPP foi dissolvido e seus membros aderiram ao Partido da Democracia Cristã (PDC).

Como se depreende desses fatos, a Editorial Resistência foi claramente uma editora militante de extrema direita. Tal propósito, aliás, foi expresso em alguns textos publicitários da editora divulgados na revista Resistência. Um deles sugere que os leitores atuem "Animando o estudo, em equipa, dos textos doutrinários da revista ou outros afins". E completa: "Mas não esqueça as boas, embora simples, normas de funcionamento de grupos de estudo e ação doutrinal”. Sugere também que o leitor colecione a revista, pois "constituirá deste modo e progressivamente, mais e melhor, uma coleção de argumentos e informações a que em cada instante poderá recorrer, no

\footnotetext{
${ }^{60}$ SANCHEZ CERVELLÓ, Cronologia..., op. cit., p. 4.

${ }^{61}$ RODRIGUES, António da Cruz. "O Movimento Popular Português". Publicado no blogue Aliança Nacional. Disponível em: <http://porabrantes.blogs.sapo.pt/77538.html>. Acesso em set. 2012.

${ }^{62}$ RODRIGUES, “O Movimento...”, op. cit.
} 
combate como na tarefa igualmente indispensável de esclarecimento de todos os dias" ${ }^{\prime 63}$.

Entre os títulos publicados destacam-se aqueles sobre questões políticas da realidade portuguesa, como As chaves secretas da revolução do 25 de Abril, de Michel de Penfentenyo (1976); Quem era Salazar?, de António José de Brito e outros (1978); A morte de Dias Coelho: a defesa que a ordem me confiou, de Carlos Quental (1978); Boas e más reformas agrárias: a invasão soviética do Alentejo, de José Pequito Rebello (1978); Problemas actuais de educação: o futuro da educação ou a educação do futuro, de António da Cruz Rodrigues (1980).

Editou também obras de caráter mais doutrinário, como: Carta de Solzhenitsyn aos governantes soviéticos: apelo-denúncia feito por um homem livre, de Alexander Solzhenitsyn (1975); Liberdade-Autoridade, de Jean Ousset (1975); Conquista do mundo, de Marcel Clément (1975). Destacam-se ainda obras sobre a história de Portugal.

A Editorial Resistência possuía também uma livraria, e o seu intuito militante fica manifesto na intenção de transformar o local em ponto de reunião e de apoio para seus simpatizantes:

Visite as nossas novas instalações: Aí funcionam a nossa sede social... [...] Uma sala de reuniões, que pode utilizar... Um serviço de secretariado ao seu dispor (datilografia, policopiador, traduções, reservas de hotéis, etc.)... Consulta de uma centena de publicações periódicas que recebemos em permuta... ${ }^{64}$

Entre 1975 e 1981 a Editorial Resistência publicou 20 títulos. Os livros e a revista tinham tratamento gráfico e editorial profissional. A distribuição comercial era feita pela própria editora, que distribuía também livros de outros editores, inclusive estrangeiros.

Em 1995 Cruz Rodrigues voltou a atuar diretamente na área editorial com a criação da editora Nova Arrancada.

\footnotetext{
63 “'Como utilizar a Resistência...?”. Resistência, Lisboa, 15/11/1975, nº 114, p. 49.

64 “A nossa livraria”. Resistência, Lisboa, 15/9/1976, nº 134.
} 


\subsection{Editora Abril}

Editor: Martinho Simões.

Início das edições: 1976.

Distribuição: Centro do Livro Brasileiro.

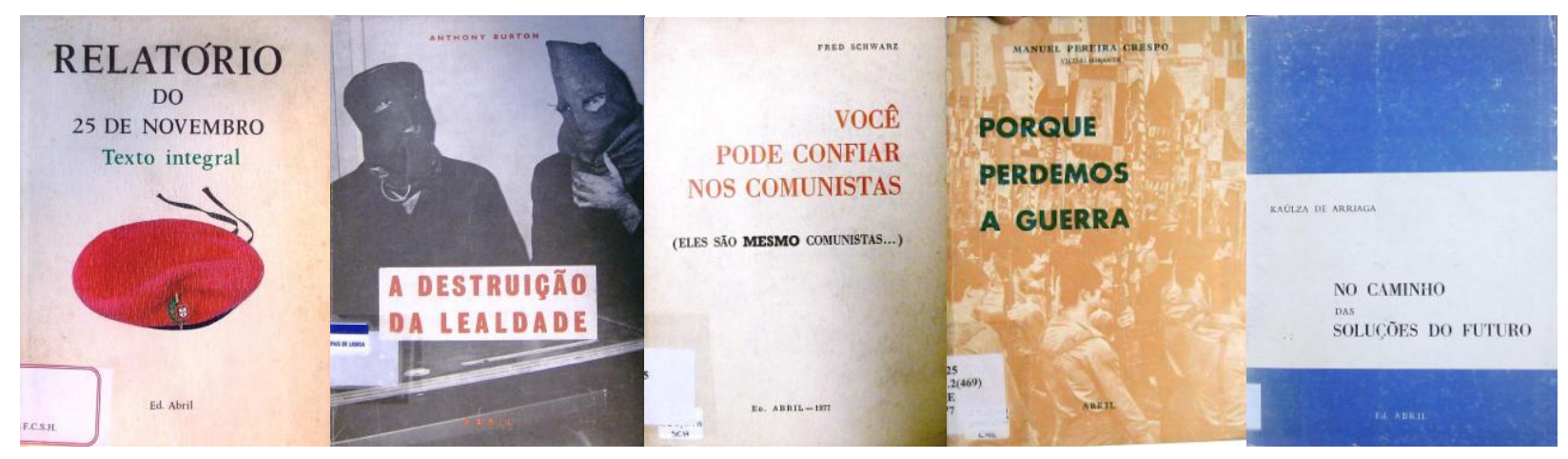

Editora criada pelo jornalista Martinho Simões em fins de 1976. Publicou obras críticas da descolonização dos territórios ocupados por Portugal até 1975 e obras anticomunistas, além de dois títulos de autoria do general Kaúlza de Arriaga, um dos expoentes dos setores ultraconservadores do Estado Novo.

O primeiro livro publicado pela Editora Abril foi o Relatório do 25 de Novembro de 1975: texto integral, em dezembro de 1976, organizado por Martinho Simões.

Sobre a descolonização, os títulos editados foram: Os "comandos" no eixo da revolução: crise permanente do PREC. Portugal, 1975-76, de Manuel Branco (1977); e Por que perdemos a guerra, de Manuel Pereira Crespo (1977).

Duas foram também as obras dedicadas à crítica ao comunismo: Você pode confiar nos comunistas (eles são mesmo comunistas...), de Fred Schwarz (1977); e $O$ urso à porta de trás: a ameaça soviética à linha vital do Ocidente em África, de Walter Walker (1978).

As obras de Kaúlza de Arriaga editadas foram: No caminho das soluções do futuro; e A proposta-MIRN: comunicação ao País em 28 de Junho de 1977, ambas publicadas em 1977. O general Arriaga havia passado à reserva em maio de 1974 por decisão da Junta de Salvação Nacional, e fora preso em 28 de setembro daquele ano por estar ligado à manifestação da "maioria silenciosa"65. Fundou, em julho de 1976 o Movimento Independente para a Reconstrução Nacional (MIRN), que visava "constituir uma frente única de centro-direita num quadro democrático", o que incluía promover a

\footnotetext{
${ }^{65}$ ANDRADE, op. cit., p. 30.
} 
união do Partido Popular Democrático (PPD) e do Centro Democrático Social (CDS ${ }^{66}$. Arriaga defendia a existência de "um Todo Português euro-afro-asiático" e acreditava que o 25 de Abril "destruiu Portugal multirracial e pluricontinental e [...] interrompeu o sentido secular da sua História, sem repensar o Espaço Lusíada e sem cuidar de uma nova dinâmica portuguesa",67.

Em 1979 o MIRN transformou-se em partido político com a denominação Movimento Independente para a Reconstrução Nacional/Partido da Direita Portuguesa, cujas atividades cessaram em1984 ${ }^{68}$.

Entre dezembro de 1976 e 1978 a Editora Abril publicou cerca de dez obras, todas editadas com padrão gráfico e editorial profissional. A distribuição comercial era feita pela distribuidora Centro do Livro Brasileiro.

Não há informação sobre o endereço da editora, nem mesmo da cidade em que ela estava sediada. A distribuidora Centro do Livro Brasileiro localizava-se em Lisboa, mas todos os livros foram impressos em gráficas de Coimbra. Já a "Nota do editor" de um livro editado em 1978 apresenta a informação de que foi redigida na cidade de Amadora, na região de Lisboa. Assim, não foi possível determinar a cidade onde estava localizada a editora.

\subsection{Literal - Sociedade Editora}

R. Conde Almeida Araújo, 42 r/c Esq. - Queluz

Início das edições: 1976.
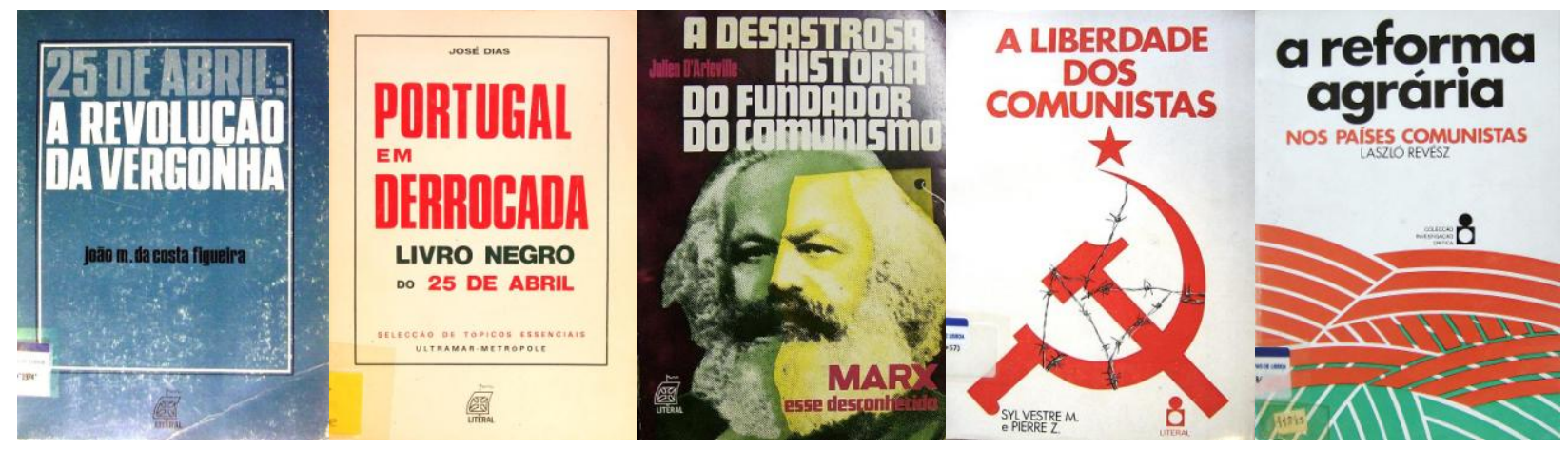

\footnotetext{
${ }^{66}$ Ibidem, p. 236.

${ }^{67}$ ARRIAGA, Kaúlza de. "Prefácio". In: No caminho das soluções do futuro. Coimbra: Ed. Abril, 1977, p. 16.

68 "Movimento Independente para a Reconstrução Nacional/Partido da Direita Portuguesa". Verbete, Wikipédia. Disponível em: <http://pt.wikipedia.org/wiki/MIRN>. Acesso em set. 2012.
} 
Editora ligada a sectores dos chamados "retornados", colonos portugueses dos antigos territórios coloniais na África e na Ásia, ou seus descendentes, muitos dos quais tiveram de abandonar aqueles territórios em função do processo de descolonização desencadeado pelo 25 de Abril.

A Editora Literal começou a publicar em 1976, e seus livros tratavam basicamente de dois temas: a crítica à descolonização e ao tratamento dado aos "retornados", e o combate ao comunismo. Em algumas obras editadas estes temas estavam imbricados.

Em função do posicionamento político que a Editora Literal assumiu em relação aos governos pós-25 de Abril na questão da descolonização, e de sua postura profundamente anticomunista, fica evidente que se trata de uma editora de direita.

Os nomes das duas principais coleções da editora deixam bem claro o seu posicionamento político: Coleção Para a História da Destruição de Portugal e Coleção Defesa do Ocidente.

Entre os vários títulos de crítica à descolonização e ao tratamento dado aos "retornados", destacamos: O pavoroso caso Timor, de Sá Pereira e Adulcino Silva (1976); Acusamos a descolonização (1976) - estes dois títulos traziam textos do jornal O Retornado e foram feitos em coedição com a Editora Selecta (ver item a seguir) -; 25 de Abril: a revolução da vergonha, de João M. da Costa Figueira (1977); Vida de refugiados, de Manuel Resende (1977); Tortura depois de Abril: relato duma jornalista detida em Caxias sem culpa formada, de Manuela Preto (1977); Portugal em derrocada: livro negro do 25 de Abril, de José Dias; Moçambique, a escalada do terror, de Inácio de Passos (1977); Aviltados e traídos: resposta a Costa Gomes, de Melo Machado (1977); Mflândia: cidade ocupada, de Martins Poças (1977); e Malandros: a evacuação aérea dos portugueses de Angola, de João dos Reis (1978).

$\mathrm{Na}$ linha das obras anticomunistas temos: A liberdade dos comunistas: polícia, prisões e campos soviéticos, de Sylvestre M. e Pierre Z. (1976); Marx, esse desconhecido: a desastrosa história do fundador do comunismo, de Julien d'Arleville; A liquidação da social-democracia na Europa de Leste, de László Revész (1977); e Livro negro: instruções secretas para a subversão da sociedade moderna, de Tito Kowalski (1977), entre outros.

Havia também uma coleção feita em coedição com a Editora Selecta. Era a coleção Investigação Crítica, e os dois títulos em coedição foram: A reforma agrária 
nos países comunistas (1977) e Exportação de revoluções (1977), ambos de autoria de Laszló Revész.

Os livros editados tinham padrão editorial e gráfico profissional. Não consta neles informação sobre como era feita a distribuição comercial.

Entre 1976 e 1978 a Literal editou cerca de 30 obras de caráter político.

\subsection{Selecta}

Rua Rodrigues Sampaio, 3-A, $5^{\circ}$ - Lisboa

Rua Marquês Sá da Bandeira, 14-1º (1978)

Início das edições: 1976.

Distribuição: EDP - Empresa Distribuidora de Publicações.

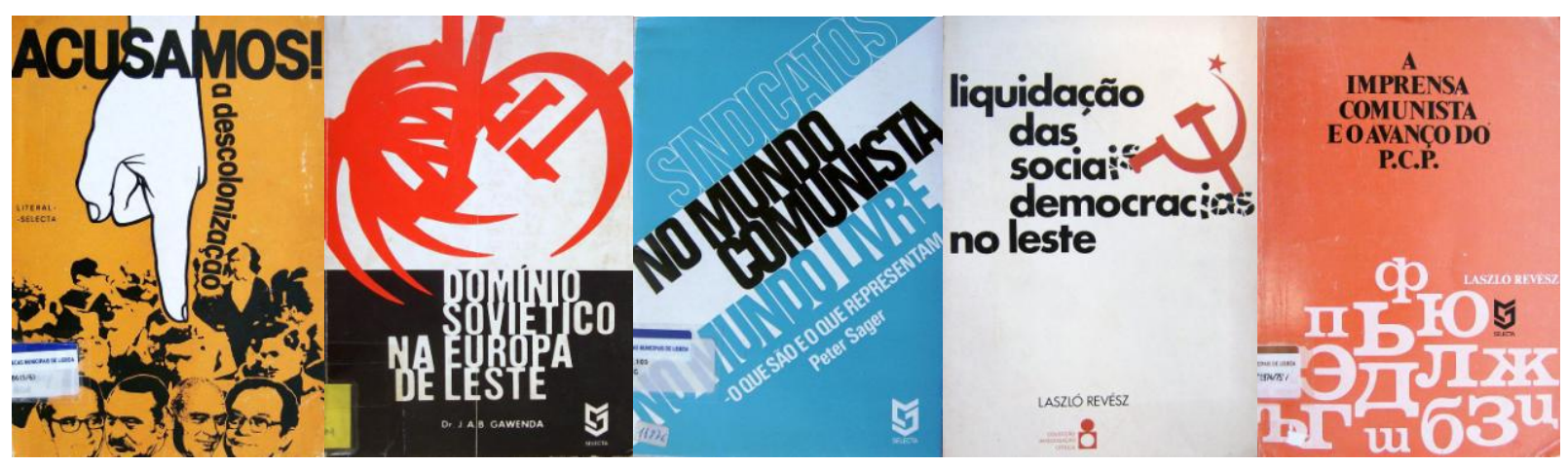

Editora dedicada principalmente à publicação de obras anticomunistas, em sua maior parte de autores estrangeiros.

As edições tiveram início em 1976 e duraram até meados de 1978. Algumas obras de cunho anticomunista editadas neste período foram: A imprensa comunista e o avanço do PCP, de Laszló Revesz (1976); Comandos da liberdade em Moscovo, de Michel Slavinsky (1977); Sindicatos no mundo comunista e no mundo livre: o que são e o que representam, de Peter Sager (1977); As ilhas da noite: um Goulag amarelo, de Robert Vidal (1977); A última chance de liberdade, de Jean Kiffer (1977); Testemunhos sobre o genocídio no Cambodja, compilado por Bernard Hamel e Soth Polin (1977); e Domínio soviético na Europa de Leste, de J. A. B. Gawenda (1978), entre outras.

A Selecta editou também algumas obras sobre o Portugal pós-25 de Abril, sempre de um ponto de vista de oposição aos novos rumos do país: $O$ pavoroso caso Timor, de Sá Pereira e Adulcino Silva (1976); Acusamos a descolonização (1976) - 
estes dois títulos traziam textos do jornal $O$ Retornado e foram feitos em coedição com a Editora Literal -; A bordo da revolução: ensaios de análise política 75/76 (1976), de Francisco Lucas Pires, que havia sido um dos líderes da extrema direita portuguesa e, quando este livro foi lançado, era candidato a deputado pelo CDS; Portugal 74-76: Ultramar-Metrópole: muitas promessas, tristes realidades, de J. Belard da Fonseca (1976); e Aos amigos, simpatizantes e militantes da Unita em Portugal, de Jonas Malheiro Savimbi (1978).

Como vimos no item anterior, a coleção Investigação Crítica era feita em coedição com a Editora Literal.

Os livros editados tinham padrão editorial e gráfico profissional. A distribuição comercial era feita pela EDP - Empresa Distribuidora de Publicações.

Entre 1976 e 1978 a Selecta publicou cerca de 20 obras de caráter político.

\subsection{Braga Editora}

Braga - Lisboa

Início das edições: 1977.

Distribuição: Livraria Bertrand

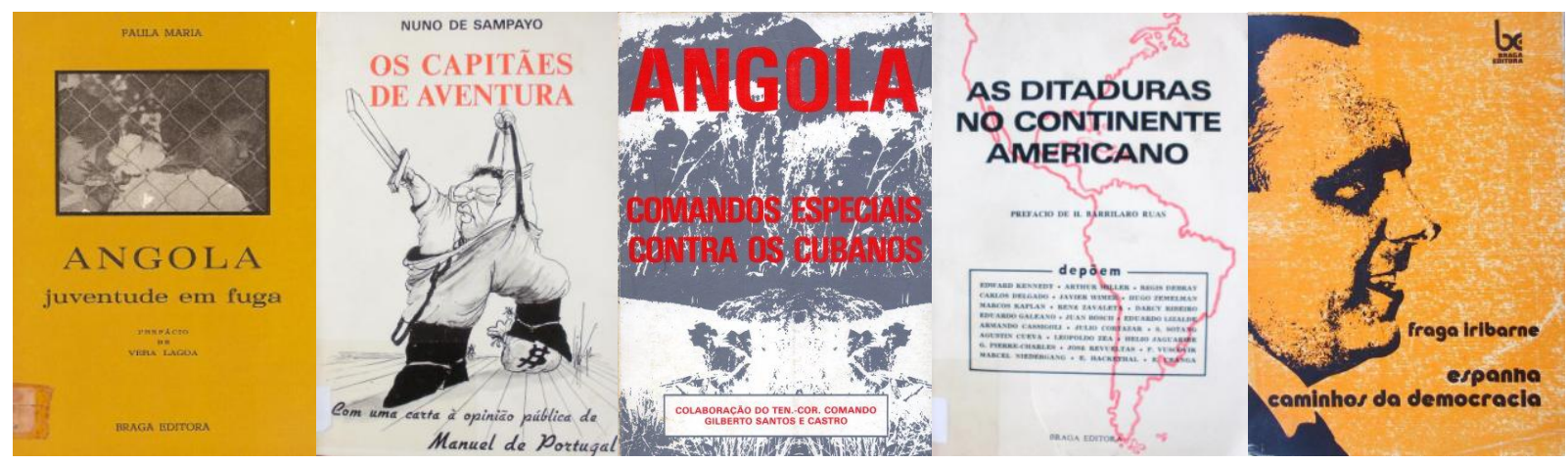

Editora ligada ao pensamento conservador, anticomunista e contrário à descolonização dos territórios africanos ocupados por Portugal até meados dos anos 1970.

Editou obras de autores ligados ao pensamento de direita, como Adriano Moreira (Tempo de vésperas, 1978) e Manuel Fraga Iribarne (Espanha: caminhos da democracia, 1977), além de ter um livro prefaciado pela conhecida jornalista (na época) 
Vera Lagoa ${ }^{69}$, expoente na imprensa do ideário de direita.

A questão da libertação das colônias foi abordada em duas obras sobre Angola (Angola, juventude em fuga, de Paula Maria, 1977; e Angola, comandos especiais contra os cubanos, de Pedro Silva, Francisco Esteves, Valdemar Moreira e Gilberto Santos e Castro, 1978) e em uma sobre Timor (Timor, quem é o culpado?, de António Manuel Cravo Cascais, 1977).

O combate às ideias comunistas surge nos livros Comunismo e maçonaria: forças secretas da guerra, de Tomé Vieira (prefácio de Mário Dias Ramos ${ }^{70}$, 1977) e Técnica soviética para a conquista do poder total: a experiência comunista no Chile, de vários autores (1978).

Destoa um pouco da linha seguida pela editora a publicação, em 1978, do livro As ditaduras no continente americano: Depoimentos, com prefácio de Henrique Barrilaro Ruas e organizado por José Luís Cuevas, Vlady e Morales Guerra Y Ortega. Esta obra, apesar do título, está centrada em debates sobre o fascismo e sobre a sua possível existência na América Latina, com textos de autores de variadas origens ideológicas, mas distantes do pensamento de direita, como Eduardo Galeano, Arthur Miller, Júlio Cortázar, Edward Kennedy, Hélio Jaguaribe, Emilio Uranga, Darcy Ribeiro, Leopoldo Zea, Pedro Vuskovic, Régis Debray e Susan Sontag.

No livro História da polícia em Portugal, de Mascarenhas Barreto, editado em 1979, temos uma amostra de como alguns autores publicados pela editora avaliavam a situação política portuguesa naquele momento. $\mathrm{O}$ autor afirma que em Portugal haveria um "[...] sistema de burocracia totalitarista que se apoderou do país, após o nefando mandarinato 'gonçalvista", e que aí teria se enraizado "um regime marxista - quer por arrebatamento do Poder, quer por infiltração nos quadros diretivos e administrativos da Nação [...]",71.

Os livros editados pela Braga Editora tinham padrão gráfico e editorial profissional, e a distribuição comercial era feita pela Livraria Bertrand.

A Braga Editora atuou entre 1977 e 1979, período em que publicou 11 obras.

\footnotetext{
${ }^{69}$ Trata-se do livro Angola, juventude em fuga, de Paula Maria, 1977.

${ }^{70}$ Dias Ramos também foi o autor da "Nota Introdutória" ao livro Espanha: caminhos da democracia, de Manuel Fraga Iribarne (1977).

${ }^{71}$ BARRETO, Mascarenhas. "Urgente". In: História da polícia em Portugal: polícia e sociedade. Braga/ Lisboa: Braga Editora, 1979, p. 9-10.
} 


\subsection{Edições do Templo}

Rua da Mãe d'Água, 13, 4 F - Lisboa

Editor: José Valle de Figueiredo

Início das edições: 1977.

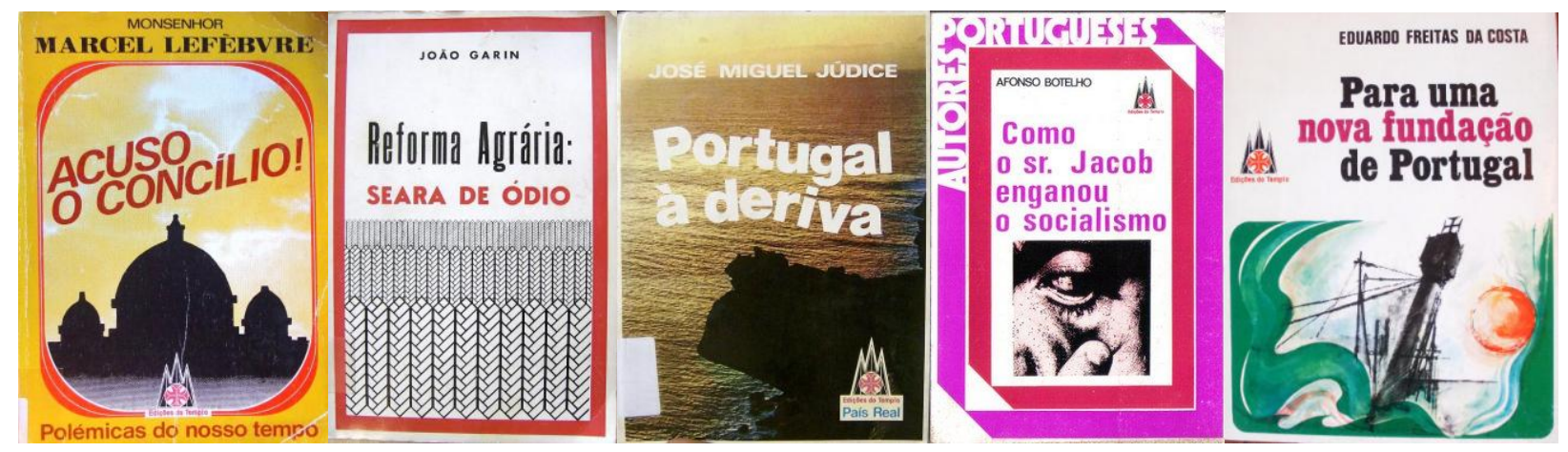

Editora criada por José Valle de Figueiredo, um dos líderes da extrema direita portuguesa, oriundo de setores estudantis da Universidade de Coimbra. Figueiredo fez parte nos anos 1960 do Movimento Jovem Portugal, “a mais importante organização neofascista activa em Lisboa, Porto e Coimbra entre 1961 e 1965"72. Foi também um dos fundadores, em fevereiro de 1962, do periódico estudantil Combate, iniciativa que contou com o apoio do regime salazarista ${ }^{73}$. Em 1970 Valle de Figueiredo foi para a tropa e serviu na Guiné. Em dezembro de 1972 participou da criação do Programa Associação de Estudos para o Progresso Nacional, "tentativa de criação de uma alternativa à Sedes, base dos economistas liberais e tecnocratas do Governo de Caetano" "74. Situava-se ao lado de sectores da direita salazarista que se colocavam na oposição a Marcelo Caetano.

Após o 25 de Abril, Figueiredo apoiou o projeto federalista de Spínola, juntando-se à facção que "fundará, nos meses seguintes, o Movimento Federalista Português/Partido do Progresso e integrará [após o 28 de Setembro], nos anos da clandestinidade em Espanha, a Comissão Política do Movimento Democrático de Libertação de Portugal (MDLP)"75.

\footnotetext{
${ }^{72}$ MARCHI, “A direita radical...”, op. cit., p. 559.

${ }^{73}$ De acordo com Riccardo Marchi: "Em 1962 o clima na Universidade favorecia uma iniciativa editorial desta natureza. $\mathrm{O}$ activismo crescente das esquerdas, que conduziria à eclosão da crise académica, preocupava as autoridades do regime, que, por isso, viram com bons olhos as iniciativas tomadas pelos movimentos de direita. $\mathrm{O}$ apoio do regime a esta iniciativa editorial é garantido através das ajudas económicas do governador civil de Coimbra, da isenção de censura prévia ao jornal e da colaboração editorial anónima do professor Miranda Barbosa com muitos artigos doutrinários". MARCHI, "A direita radical...", op. cit., p. 560.

${ }^{74}$ MARCHI, Império..., op. cit., p. 296 e 263.

${ }^{75}$ MARCHI, “A direita radical...", op. cit., p. 574.
} 
As Edições do Templo publicaram seus primeiros títulos em 1977, ou seja, já depois da experiência do MDLP e numa conjuntura em que os setores de extrema direita sentiam-se em grande medida traídos pelos desdobramentos do golpe de 25 de novembro de 1975.

Um dos primeiro livros publicados já trazia no texto da contracapa o ponto de vista visceralmente anticomunista da editora sobre o que se passara em Portugal desde o 25 de Abril:

O projecto da revolução de Abril, há muito gizado em Moscovo, foi delineado em Praga em 1964 com a cumplicidade de alguns militares portugueses entrados na Checoslováquia com documentos forjados pelos serviços de espionagem locais, liderados por Álvaro Cunhal e enquadrados por agentes soviéticos e checoslovacos. Depois de cumpridos, sob a capa de diversão da libertação do jugo fascista, os desígnios imperialistas de Moscovo, Álvaro Cunhal, acessorado [sic] por agentes comunistas internacionais, lança-se à execução do ponto de honra do seu partido a nível nacional: a Reforma Agrária. ${ }^{76}$

A Edições do Templo publicou alguns autores de referência do pensamento de extrema direita português, como Jaime Nogueira Pinto e António Marques Bessa (Introdução à política, 1977), Eduardo Freitas da Costa (Portugal urgente, 1978; Para uma nova fundação de Portugal, 1978) e José Miguel Júdice (Portugal à deriva, 1978).

Em 1978 reeditou as entrevistas de Salazar a António Ferro (editadas originalmente nos anos 1930), indicando uma clara intenção de recuperação e valorização da figura do ex-ditador.

Outros títulos com conteúdo político de direita foram: Reforma agrária: seara do ódio, de João Garin (1977); Orgulhosamente muitos..., de José Dias (1977); Portugal e agora?, de Silvino Silvério Marques (com prefácio de Adriano Moreira, 1978); e Acuso o Concílio, do Monsenhor Lefebvre (1978).

No entanto, as Edições do Templo não publicavam apenas obras políticas, havendo espaço para literatura e outros temas em coleções como Ensaístas Portugueses Modernos, Portugal Misterioso e Autores Portugueses, entre outras.

Ao que tudo indica as Edições do Templo atuaram apenas por três anos, entre 1977 e 1979, período em que publicou cerca de 30 títulos, dos quais metade eram obras políticas.

Os livros tinham padrão editorial e gráfico profissional. Não consta informação

\footnotetext{
${ }^{76}$ Contracapa do livro Reforma agrária: seara do ódio, de João Garin (Edições do Templo, 1977).
} 
sobre como era feita a sua distribuição comercial.

\subsection{Edições Roger Delraux}

Rua das Janelas Verdes, 32 - Lisboa

Editor: Gérard Leroux.

Início das edições: 1977.
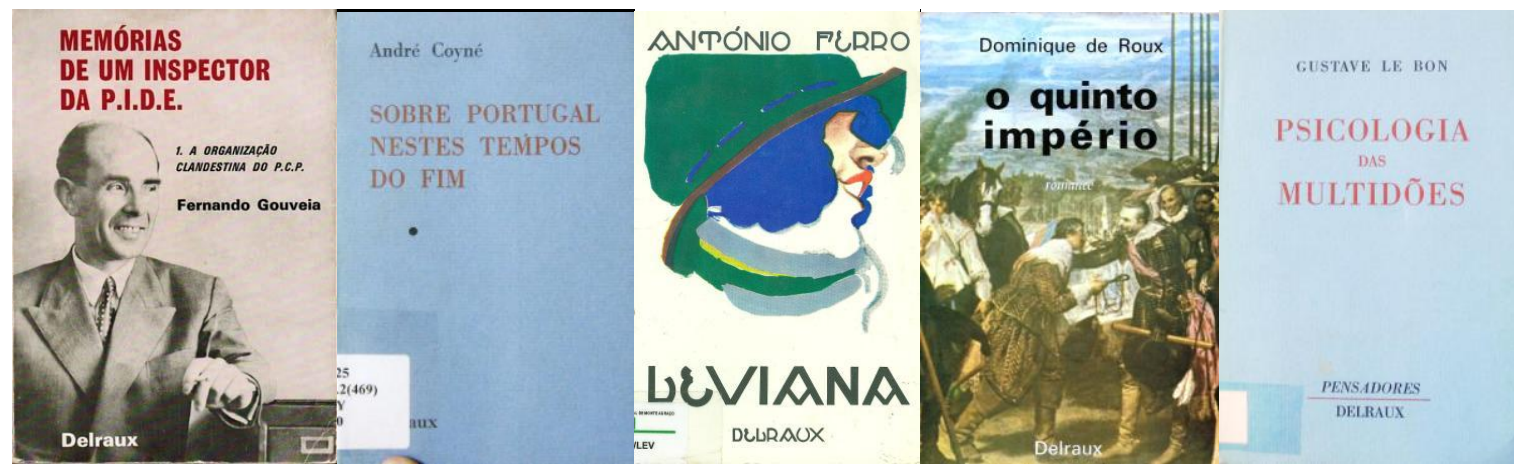

Editora criada pelo francês Gérard Leroux, que foi professor-assistente na Faculdade de Letras da Universidade de Lisboa ${ }^{77}$.

O nome Roger Delraux é um anagrama do nome do fundador da editora ${ }^{78}$. As Edições Roger Delraux parecem ser uma iniciativa individual de Leroux, sem vinculação direta a qualquer grupo ou associação, mas as obras que editou não deixam dúvidas de sua filiação ideológica ao pensamento de direita, tradicionalista e conservador. De acordo com Manuel Azinhal, Leroux teria afirmado: “a editora era só eu... depois quando perdi muito dinheiro tive que parar..."79.

As origens e ligações da editora parecem ser pouco conhecidas até mesmo em blogues ligados à extrema direita portuguesa, nos quais há poucas informações sobre ela.

Uma exceção é o blogue Sexo dos Anjos, de Manuel Azinhal. Todavia, o autor registrou que durante muito tempo as Edições Roger Delraux foram um mistério para ele. Isso apesar de, sempre de acordo com Azinhal, a editora ter tido durante alguns anos uma "atividade editorial importante". Ainda assim ele afirmava que durante muito tempo nada conhecia sobre a editora, por isso ficou

\footnotetext{
77 "Recuperação do Arquivo Histórico da Misericórdia de Alcobaça". Disponível em: <http://jeroalcoa.blogspot.com.br/2010_06_01_archive.html>. Acesso em set. 2012.

78 AZINHAL, Manuel. "Thomas Molnar". Blogue Sexos dos Anjos, 4/4/2002. Disponível em. <http://viriatos.blogspot.com.br/2004/04/thomas-molnar-ao-ler-no-nova-frente.html>. Acesso em set. 2012.

${ }^{79}$ Ibidem.
} 
sempre intrigado quanto à mesma, e seus responsáveis. E o certo é que ninguém era capaz de me dar informações mais precisas. [...] me intrigava o meu desconhecimento total, e o total desconhecimento dos meus conhecidos habituais, sobre quem na realidade estava por trás da editora. [...] Entretanto, tão misteriosamente como surgira, a editora cessou actividade. ${ }^{80}$

Azinhal depois descobriu que a editora fora criada por Leroux.

Entre os títulos editados quase todos se enquadram na classificação de obras ligadas ao pensamento de direita: O quinto império: romance de Dominique de Roux (1977); Não!: mas sim à Igreja Católica e Romana, do Monsenhor Lefebvre (1978); Teoria da indiferença, de António Ferro (1979); Memórias de um inspector da PIDE: 1. A organização clandestina do PCP, de Fernando Gouveia (1979); Sobre Portugal nestes tempos do fim, de André Coyné (1980); Nosografia de D. Sebastião, de Mário Saraiva (1980); Psicologia das multidões, de Gustave Le Bon (1980); A contra-revolução, de Thomas Molnar (1980).

Os livros publicados tinham tratamento gráfico e editorial profissional. Não há informação sobre como era feita a distribuição comercial.

Entre 1977 e 1980 a Roger Delraux publicou dez títulos. Em 2007 Leroux era o responsável pelo arquivo da Misericórdia de Alcobaça ${ }^{81}$.

\subsection{Edições FP (Fernando Pereira - Editor)}

Rua Pinheiro Chagas, 41 - cv 2 - Lisboa

Editor: Fernando Pereira.

Início das edições: 1978.

Distribuição: Própria.

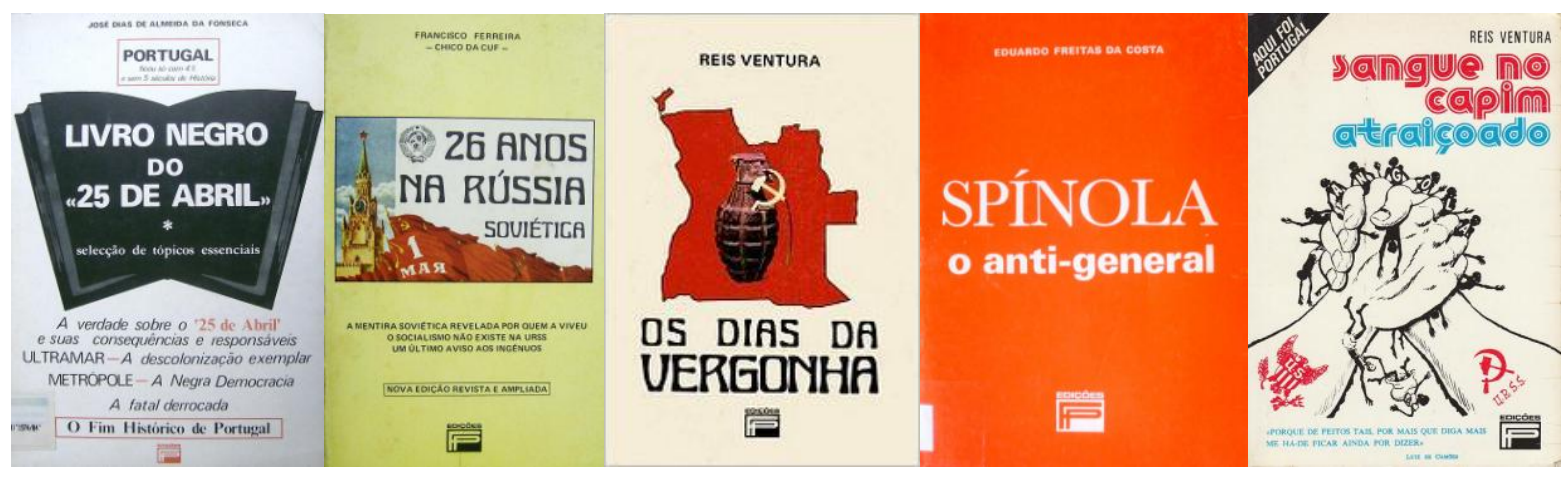

Editora criada na segunda metade dos anos 1970 sobre a qual não foi possível apurar informações mais detalhadas. Editou livros de caráter político ligados ao

\footnotetext{
${ }^{80}$ Ibidem.

81 “Recuperação...”, op. cit.
} 
pensamento de direita e conservador, de cunho claramente simpático a Salazar, ao salazarismo e à sua política colonial. Mas a maior parte dos títulos editados era composta de obras de ficção, além de algumas obras de caráter geral. Entre os autores que a editora publicou estão Eça de Queiroz, Mark Twain, Júlio Verne, Emilio Salgari, Oscar Wilde, William Shakespeare e Walter Scott, entre outros.

Fernando Pereira havia editado o jornal Europeu: Quinzenário Político, entre 1976 e 1980. As edições de livros parecem ter começado em 1978, e as obras políticas aparecem em 1979. Entre estas destacam-se Spínola, o anti-general, de Eduardo Freitas da Costa (1979); Últimas décadas de Portugal, de Américo Thomaz (1980); De Santo António a Oliveira Salazar, por Portugal, compilado por Miguel Taveira (1980); Sangue no capim atraiçoado, de Vasco Reis Ventura (1981); Salazar: o homem e a sua obra, de António Ferro (1982); Eu fui ao fim de Portugal: subsídios para o "dossier" do Timor português, de Rui Palma Carlos (1982); Quando os cravos murcham, de Barradas de Oliveira (1982).

Na primeira metade da década de 1980 a editora continuou a publicar obras com este mesmo viés, como, por exemplo, o Livro negro do "25 de abril". O fim histórico de Portugal, de José Dias de Almeida da Fonseca (1984); A década bastarda: Abril de 1974 a Abril de 1984. Dez anos de destruição revolucionária, de Mattos Gomes (1984); e ...Eles não sabem o que fazem! O comunismo e o socialismo matam mais gente do que o cancro, ajude-nos a combatê-lo, de Fernando Pereira (1984).

O pensamento de Fernando Pereira pode ser sintetizado neste trecho da sua "Nota do Editor" publicada na $8^{\mathrm{a}}$ edição do livro Sangue no capim atraiçoado, de Vasco Reis Ventura, editado em 1981, e que inaugurava uma coleção com o significativo nome Aqui foi Portugal!:

Quando os heróicos bravos da revolução reaccionária de 25 de Abril, data ímpar na História de Portugal, desmantelaram a Pátria, reduzindo-a ao que foi em 1263, no reinado de D. Afonso III, provaram que em 1974 era possível a existência de vários Migueis de Vasconcelos ${ }^{82}$. [...] Bastaram os anos de 1974 e 1975, os anos da vergonha, para destruir oito séculos de História, por obra e graça de um grupo de imbecis armados e a corja de políticos de pacotilha que os acompanhou, todos arvorados em progressistas, iluminados e mentalizados por caquéticos marxistas a soldo de Moscovo, onde nem

\footnotetext{
${ }^{82}$ Miguel de Vasconcelos era secretário de Estado português e defensor do domínio espanhol sobre Portugal quando ocorreu o movimento da Restauração, em $1^{\circ}$ de dezembro de 1640 . Considerado taridor, foi morto pelos defensores da Restauração.
} 
sequer faltou um autêntico louco!. ${ }^{83}$

A partir de novembro de 1981, Fernando Pereira passou a editar o jornal Novo Século - Quizenário Independente Nacionalista. No editorial do primeiro número do jornal, transparece uma certa simpatia pelo CDS (Centro Democrático e Social), como vemos neste trecho, em que há quase um apelo ao CDS para que se assuma como um partido de direita:

Tem o CDS todas as condições para se tornar o maior partido português, quando realmente escutar as bases e seguir o rumo certo. É erro grave afirmar-se centro, quanto é gravíssimo desconhecer as bases de sustentação. [...] É urgente e importante que [...] o CDS tome a imagem que as bases exigem. ${ }^{84}$

As Edições FP atuaram até a segunda metade dos anos 1980, sempre mantendo as suas duas linhas de edição, a de literatura e obras gerais, e a política, com viés de direita e conservador. Assim, caracterizou-se como uma editora de obras de caráter político, mas sem ser uma editora exclusivamente deste tipo de obras. Na verdade, a maior parte de suas edições era de literatura e obras gerais. Mas não resta dúvida que, pela coerência de sua linha de livros políticos, deve ser consignada como uma editora de direita, saudosa do salazarismo e do "império" português.

Entre 1979 e 1982 as Edições FP publicaram cerca de dez obras de caráter político, e cerca de 30 títulos de literatura e obras gerais.

\subsection{Livraria Popular de Francisco Franco}

Rua de Barros Queirós, 18 - Lisboa

Início das edições: década de 1890.
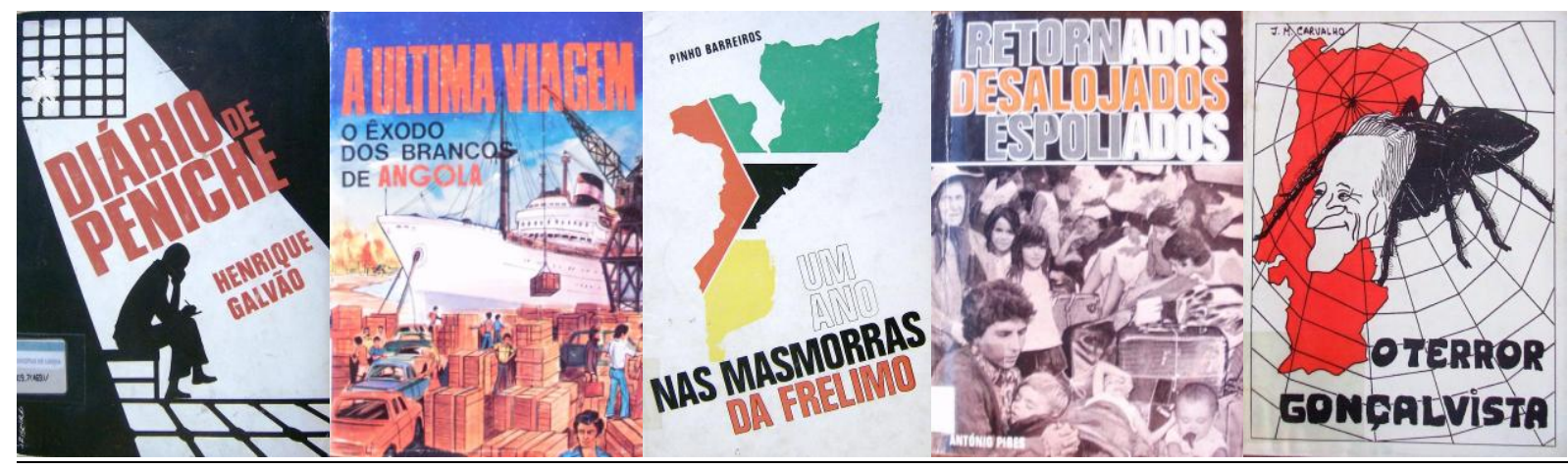

${ }^{83}$ PEREIRA, Fernando. "Nota do Editor". In: VENTURA, Vasco Reis. Sangue no capim atraiçoado. $8^{\mathrm{a}}$ edição. Lisboa: Edições FP, 1981. Disponível em: <http://www.macua.org/livros/sanguecapim.html>.

84 “Editorial”. Novo Século, no 1, 15/11/1981. Reproduzido em: PEREIRA, Fernando. ...Eles não sabem o que fazem! O comunismo e o socialismo matam mais gente do que o cancro, ajude-nos a combatê-lo. Lisboa: Edições FP, 1984, p. 8. 
Editora criada no final do século XIX em Lisboa. Caracterizou-se sempre pelo ecletismo, tendo publicados muitas obras escolares e de literatura, privilegiando o aspecto comercial do negócio editorial.

Após o 25 de Abril publicou alguns títulos mais diretamente políticos. Em 1974, reeditou obras de Henrique Galvão - um dos mais simbólicos opositores de Salazar e anticomunista ferrenho -, como Grades serradas e Diário de Peniche.

Em 1975 e 1976 passou a publicar algumas obras claramente vinculadas a posições políticas de direita. Dois desses livros eram romances de António Pires: $A$ última viagem: o êxodo dos brancos de Angola (1975); e Desalojados: a tragédia nacional dos "retornados”, portugueses expulsos de Angola (1976).

Outros dois títulos eram de autoria de J. M. Carvalho: O terror Gonçalvista; e Os cubanos e..., ambos publicados em 1976.

Em 1977 foi editada a obra Um ano nas masmorras da Frelimo, de Pinho Barreiros.

A edição dessas obras parece ter representado um momento atípico na história da editora, que nunca se caracterizou por editar obras de viés político. Mas, ao mesmo tempo, o conteúdo dos títulos acima mencionados indica que os proprietários da Livraria Popular de Francisco Franco deviam ter relações com pessoas ou grupos de direita.

A editora parece ter deixado de atuar na segunda metade dos anos 1980. 


\section{ALGUMAS EDITORAS QUE PUBLICARAM LIVROS POLÍTICOS, MAS QUE NÃ̃ SE CARACTERIZAVAM COMO EDITORAS POLÍTICAS}

Neste capítulo estão estudos sintéticos sobre editoras 11 das 37 editoras que publicaram pelo menos cinco títulos políticos no período do nosso estudo, mas que não se caracterizavam por serem editoras políticas, já que este tipo de livro não era o mais importante em seu catálogo e tampouco a sua produção estava vinculada a um engajamento político com alguma organização.

Das editoras deste grupo, 28 foram criadas antes de 1974, e apenas nove a partir desse ano. Isso reforça a ideia de que antes do 25 de Abril parte significativa da edição de obras políticas era feita por editoras não políticas, o que era decorrência da situação de ditadura que o país vivia, que tornava mais difícil e problemática a existência de editoras voltadas diretamente para temas políticos, mas não inviabilizava a edição de alguns livros desse tipo.

\subsection{Livraria Sá da Costa Editora}

Rua Garrett, 100-102, Lisboa

Editores: Augusto Sá da Costa, João Sá da Costa.

Fundação: 1913.

Distribuição: O Século.

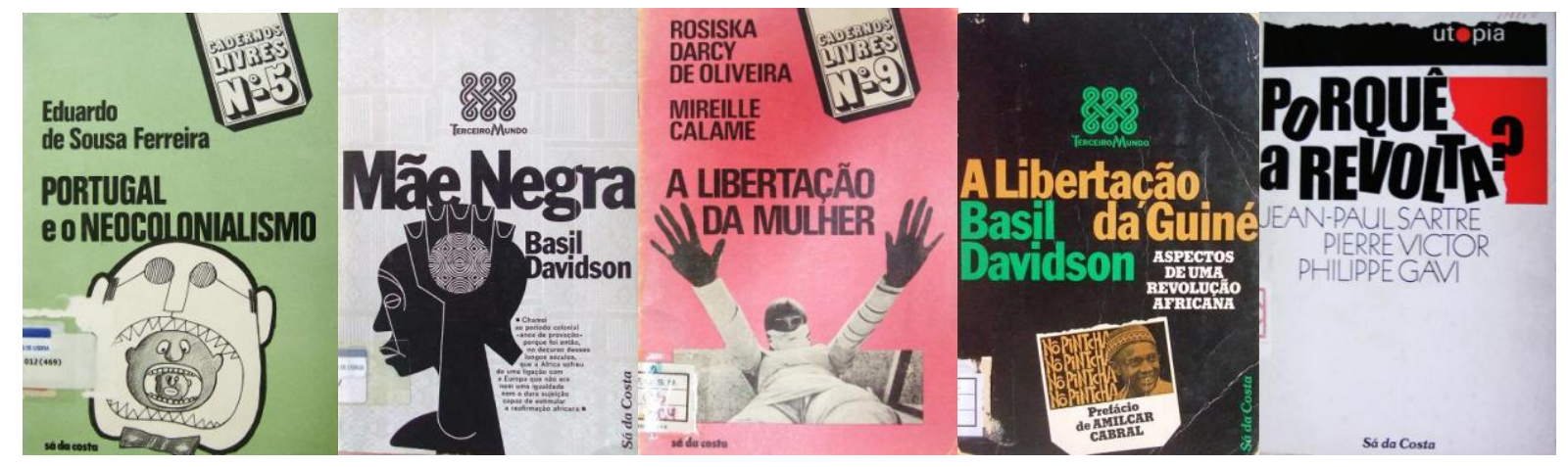

A Livraria Sá da Costa foi fundada em 1913, em Lisboa, por Augusto Sá da Costa, e em seus primeiros tempos atuou somente como livraria. Alguns anos depois iniciou a atividade editorial, com destaque para os livros escolares ${ }^{1}$. João Sá da Costa,

\footnotetext{
${ }^{1}$ AA.VV. Editores portugueses na III Bienal Internacional do Livro São Paulo: 15 a 23/Junho/1974.
} 
que era o responsável pela empresa nos 1970, identifica três fases na vida da livraria e editora: o primeiro que vai de 1913 a 1943, o segundo até cerca de 1970, e o terceiro a partir desse $a^{2}{ }^{2}$.

De acordo com João Sá Costa, “a primeira etapa corresponde ao início da sua atividade livreira e antiquária, a que se seguiu a atividade editora”, com destaque para a divulgação do livro português no exterior e a publicação de mais de meia centena de livros escolares. Em 1937 teve início a coleção Clássicos ${ }^{3}$.

O segundo período começa com a mudança da livraria, em 1943, para a rua Garrett, no Chiado. Na nova sede, a livraria passou a abrigar "uma das mais frequentadas tertúlias culturais da oposição democrática" durante o Estado Novo. Nesse momento, "A figura de referência da livraria foi Augusto M. Sá da Costa (n. 1913), matemático e professor universitário [que havia] sido afastado do ensino por razões políticas em 1946"4. A obrigatoriedade do livro único escolar, imposta pelo governo, afeta comercialmente a editora. Têm início as edições de obras de apoio universitário e, nos anos 1960, a publicação da enciclopédia Focus, dirigida por Vitorino Magalhães Godinho, Manuel Rocha e Celso Cunha 5 .

O início da década de 1970 marcaria, para João Sá Costa, uma “nova arrancada, perante uma situação crítica que o país atravessava”. Uma das iniciativas da editora nessa etapa foi a edição das obras completas de António Sérgio. Para Costa, "um editor também se define pelo seu empenhamento e intervenção na vida cultural do seu país, se está realmente interessado em cultura" ${ }^{\circ}$. O editor afirmava, em 1979, que foi somente após o 25 de Abril que "muitos de nós realizaram, pela primeira vez, o que era ser editor". E completava: "O que me importa é contribuir para o desenvolvimento do trabalho editorial de pedagogia social, digamos, se bem que hoje com maiores recursos de temática e expressão por termos reconquistado a liberdade" ${ }^{7}$.

E de fato as mudanças políticas decorrentes do 25 de Abril afetaram a linha editorial da Sá da Costa, que buscou adaptar-se aos novos tempos e abriu novas coleções que visavam responder ao crescimento da demanda por livros de temática política. Para isso trouxe, da Editora D. Quixote, Carlos Araújo para ser consultor

Lisboa: Império, 1974.

2 "Entrevista com João Sá da Costa". Notícias do Livro, Lisboa, APEL, no 4, fev. 1979, p. 9-13.

${ }^{3}$ Ibidem.

${ }^{4}$ LEITE, op. cit., p. 202.

5 "Entrevista com João Sá da Costa”, op. cit.

${ }^{6}$ Ibidem.

${ }^{7}$ Ibidem. 
editorial da casa, função que desempenhou até 1976. “A Sá da Costa era então uma livraria-editora de tipo familiar, especialista na edição de textos de literatura portuguesa clássica. Araújo, especialista em literatura inglesa, vai introduzir a literatura africana de expressão portuguesa" ${ }^{\sharp}$, principalmente com a coleção Vozes do Mundo. Os primeiros títulos desta coleção foram: Sagrada esperança, de Agostinho Neto (1974); Terra morta, de Castro Soromenho (1974); Poesia com armas, de Fernando Costa Andrade e prefácio de Mário Pinto de Andrade (1974); e Antologia temática de poesia africana, organizada por Mário de Andrade (1975).

Podemos ter uma ideia da importância do lançamento dessa coleção - e de seu significado político - a partir de uma resenha de Maria Teresa Horta sobre o primeiro volume publicado:

Não vou hoje fazer uma crítica, propriamente dita, ao livro que escolhi para falar esta semana: Sagrada esperança. Com ele venho antes dizer-vos a alegria de se poder, em Portugal, ler Agostinho Neto! [...] Analisá-la, [a poesia de Agostinho Neto] literariamente, penso que não será o que agora interessa fazer. Mas sim antes falar dela com o respeito político que lhe devemos; com a satisfação enorme pelo que significa a sua edição no nosso país. [...] Nestes poemas conta-nos ele de seus companheiros de sofrimento e luta. [...] Livro de espantosa humanidade [...], este. Livro que digo de paz. Livro que digo de liberdade. ${ }^{9}$

Agostinho Neto, líder do MPLA, se tornaria o primeiro presidente de Angola após a independência do país, em 11 de novembro de 1975.

A ação de Araújo também se fez sentir nas duas coleções que concentraram então as obras de caráter político lançadas pela Sá da Costa: Cadernos Livres e Terceiro Mundo.

A coleção Cadernos Livres guardava certa semelhança no desenho da capa com a coleção Novos Cadernos D. Quixote, lançada em 1972 pela Editora D. Quixote sob a coordenação de Carlos Araújo. A Cadernos Livres era definida, em um texto apresentado na contracapa de um de seus volumes, como tendo os seguintes objetivos: “Contribuir para o esclarecimento e formação política dos leitores, pondo-os em face dos problemas fulcrais do nosso tempo; contribuir para a nova cultura em Portugal sob o signo da defesa da liberdade e dos direitos dos povos" $" 10$.

\footnotetext{
${ }^{8}$ LEITE, op. cit., p. 202.

9 HORTA, Maria Teresa. "Resenha do livro Sagrada esperança", de Agostinho Neto. Flama, Lisboa, 3/1/1975, p. 6-7.

${ }^{10}$ Texto de contracapa do livro: ILLICH, Ivan. Energia e equidade. Lisboa: Sá da Costa, 1975.
} 
Na coleção Cadernos Livres, saíram obras como: A guerra do povo na GuinéBissau, de Mário de Andrade (1974); Democracia, de António Sérgio (1974); Sobre a situação em Cabo Verde, com um relatório do PAIGC (1974); Os camponeses africanos e a revolução, de Basil Davidson (1975); Portugal e o neocolonialismo, de Eduardo de Sousa Ferreira (1975); A decadência do corporativismo, de Eduardo de Sousa Ferreira (1975); A luta de classes em África, de Kwame Nkrumah (1976); Para a renovação da política nacional, de Vitorino Magalhães Godinho (1978), entre outras.

E na coleção Terceiro Mundo foram editados livros como: A libertação da Guiné: aspectos de uma revolução africana, de Basil Davidson, com prefácio de Amílcar Cabral (1975); Lutar por Moçambique, de Eduardo Mondlane (1976); O fim de uma era: o colonialismo português em África, de Eduardo de Sousa Ferreira (1977); A experiência chilena: reformismo ou revolução?, de Alain Labrousse (1978); A Igreja e a política no Brasil, de Márcio Moreira Alves (1978); Em defesa da revolução africana, de Frantz Fanon (1980); A crise do imperialismo, de Samir Amin, Alexandre Faire, Mahmoud Hussein e Gustave Massiah (1980); Angola sob o domínio português: mito e realidade, de Gerald J. Bender (1980); A pilhagem do Terceiro Mundo, de Pierre Jalée (1980).

Também outras coleções, como Nova Universidade, Descobrir Portugal e Utopia, publicaram obras políticas. A Sá da Costa editou também as obras completas de António Sérgio.

Uma resenha ao livro Porquê a revolta?, de Jean-Paul Sartre, Pierre Victor e Philippe Gavi, publicado em 1975 na coleção Utopia, mostra de certo modo o tipo de debate que os livros políticos podiam despertar:

Em suma: um livro discutível, suscitador de problemas, extremamente importante para os portugueses na hora que passa, pelo menos para os portugueses que procuram ideias revolucionárias que não sejam apenas as ideias revolucionárias do passado. Um diálogo que convida ao diálogo, que obriga o leitor a ser também dialogante, que convida o leitor até a opor-se-lhe. ${ }^{11}$

A Sá da Costa não se vinculava a nenhum grupo político, e as obras políticas editadas relacionavam-se, principalmente, com a temática da libertação das antigas colônias africanas e suas repercussões em Portugal, e com questões internacionais.

Há indicações de que "os ventos de abertura política e social oriundos do 25 de Abril cedo entraram em rota de colisão com o conservadorismo e imobilidade da

11 “Leitura". Vida Mundial, Lisboa, no 1.859, 1/05/1975, p. 5 e 6. 
estrutura empresarial da editora"12, o que teria levado à saída de Carlos Araújo em 1976. As coleções voltadas para temas políticos somente sobreviveram até a primeira metade dos anos 1980.

Em todo o período de sua atuação, mesmo nos anos entre 1974 e 1978, a Sá da Costa sempre se manteve como uma editora de literatura, de clássicos portugueses e estrangeiros, e de obras voltadas para o ensino. As obras políticas tiveram algum peso no catálogo da editora somente a partir do 25 de Abril e até o final da década de 1970, mas nunca foram de fato a marca característica da editora, que parece ter deixado de publicar no início dos anos 2000.

\subsection{Editorial Minerva}

Rua Luz Soriano, 31-33 - Lisboa

Editor: Manuel Rodrigues.

Fundação: 1927.

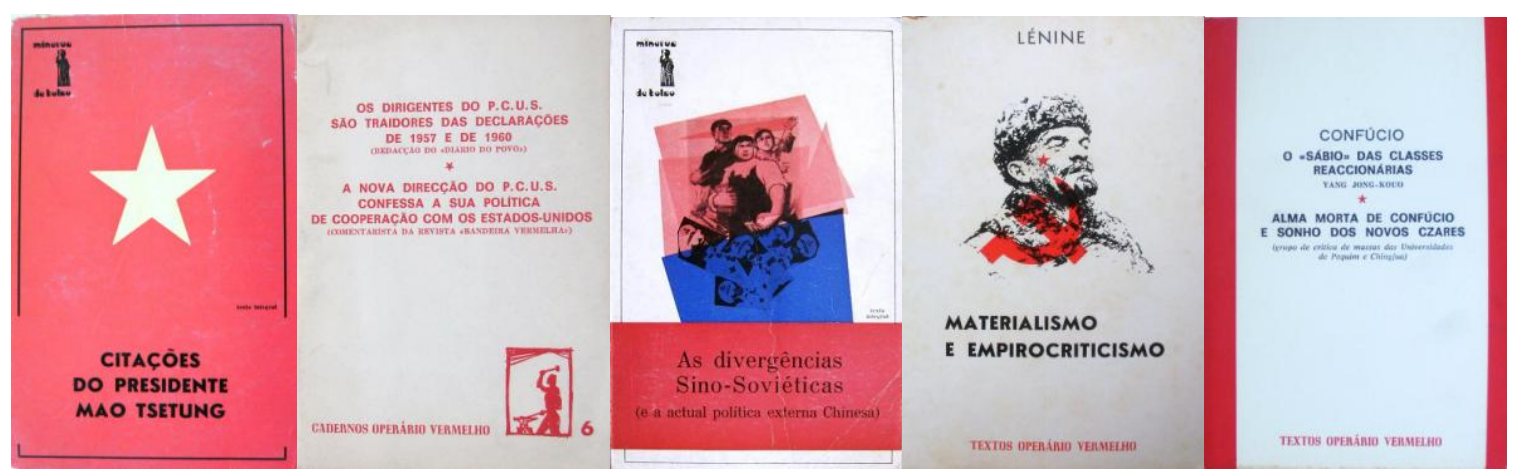

Editora fundada em 1927 por Manuel Rodrigues, em Lisboa. Rodrigues começou ainda jovem a sua atividade como editor, depois de ter trabalhado como tipógrafo. Serafim Ferreira define a Minerva como "uma modesta editora", criada por Rodrigues "no anseio de se colocar assim ao serviço de certas camadas mais populares, primeiro com folhetos e edições muito baratas, de que mais célebre ficou pelos tempos fora a do Borda d'Água [...] a par de livros de clássicos em traduções tantas vezes feitas à pressa e muito descuidadas" $" 13$.

Na página eletrônica da editora há uma definição da sua linha editorial que parece válida para toda a sua trajetória: "É uma editora generalista e publica todos os

\footnotetext{
${ }^{12}$ PESSOA; MOREIRA, op. cit.

${ }^{13}$ FERREIRA, Olhar de editor, op. cit., p. 102.
} 
géneros literários" $"$.

A Minerva tem como principal característica a edição de obras da literatura internacional, entre as quais as de renomados autores. Publicou também autores portugueses, porém em menor número.

Em sua longa história, certamente dois feitos destacam-se. Primeiro, a edição, desde 1929, do almanaque Borda d'Água, publicação anual de 24 páginas que tem o seguinte subtítulo: "Repertório útil a toda a gente". No almanaque podem ser consultadas informações e conselhos sobre o ano agrícola, as fases da lua, a previsão dos dias de tempo brusco ou calmaria, a lista dos dias de festas, romarias, feiras e mercados, além de provérbios e ditos da sabedoria popular. Em 2009 o Borda d'Água vendeu 330 mil exemplares ${ }^{15}$, utilizando um sistema de comercialização de mão em mão, por meio de vendedores de rua.

O segundo feito memorável se deu em 1947, com a publicação do primeiro romance do Prêmio Nobel José Saramago, Terra do pecado. Sobre a edição desse livro, o próprio Saramago escreveu uma nota à $6^{\mathrm{a}}$ edição da obra, em que narra as curiosas circunstâncias em que se deu a publicação - que mostram um pouco como atuava Manuel Rodrigues como editor:

Também não sabe explicar [ele, Saramago] por que foi que escolheu a Parceria António Maria Pereira quando, com notável atrevimento, sem padrinhos, sem empenhos, sem recomendações, se decidiu a procurar um editor para o seu livro. E ficará para sempre como um dos mistérios impenetráveis da sua vida haver-lhe escrito Manuel Rodrigues, da Editorial Minerva, dizendo ter recebido A Viúva na sua casa por intermédio da Livraria Pax, de Braga, e que passasse ele pela Rua Luz Soriano, que era onde estava a editora. Em momento nenhum ousou o autor perguntar a Manuel Rodrigues por que aparecia a tal Pax metida no caso, quando a verdade é que só tinha enviado o livro a António Maria Pereira. Achou que não era prudente pedir explicações à sorte e dispôs-se a ouvir as condições que o editor da Minerva tivesse para lhe propor. Em primeiro lugar, não haveria pagamento de direitos. Em segundo lugar, o título do livro, sem atractivo comercial, deveria ser substituído. Tão pouco habituado estava o nosso autor a andar com tostões de sobra no bolso e tão agradecido a Manuel Rodrigues pela aventura arriscada em que se ia meter, que não discutiu

14 "Um pouco da nossa história”. Página eletrônica da Editorial Minerva. Disponível em: $<$ http://www.editorialminerva.com/Contactos.html>. Acesso em 11/8/2012.

15 "Borda d'água". Blogue A Vida Portuguesa. Disponível em: $<$ http://www.avidaportuguesa.com/template.php?lng=pt\&sec=4\&sub=4\&hid=48>. Acesso em 15/11/2012; ALMEIDA, Marina. "Borda d'Água bateu recorde de vendas com 320 mil exemplares". Diário de Notícias, Lisboa, 8/5/2005. Disponível em: <http://www.dn.pt/inicio/interior.aspx?content_id=598542\&page=-1>. Acesso em 16/11/2012. 
os aspectos materiais de um contrato que nunca veio a passar de simples acordo verbal. Quanto ao rejeitado título, ainda conseguiu murmurar que iria tentar outro, mas o editor adiantou-se, que já o tinha, que não pensasse mais. O romance chamar-se-ia Terra do Pecado. ${ }^{16}$

Pouco antes do 25 de Abril a editora havia publicado duas obras políticas que fugiam um pouco às suas características: Vietname: a chacina de Mylai, de John Sack (1972); e Marcello e a Nação: ano de eleições de 1973, de Ângelo dos Santos (1973).

Em 1974, com o fim da ditadura, foram criadas duas coleções compostas apenas por títulos de caráter político: Cadernos Operário Vermelho e Textos Operário Vermelho. Os livros dessas coleções eram todos ligados ao pensamento de esquerda. Parte deles trazia obras relacionadas a grupos de extrema esquerda, inclusive com a publicação de documentos dos partidos comunistas da China e da Albânia, voltados para um público que não devia ser muito amplo. Os nomes das coleções também remetem à nomenclatura utilizada por grupos de extrema esquerda em Portugal, em especial grupos maoistas. Como vimos, havia também uma editora chamada O Proletário Vermelho, ligada ao Comitê Marxista-Leninista de Portugal (CMLdeP).

Cada uma das coleções publicou oito volumes, ou seja, 16 no total. Destes volumes, metade trazem obras de Lenin; quatro apresentam textos vinculados ao Partido Comunista da China, além de um de autoria de Mao Tsé-tung; dois são de autoria de Enver Hoxha, líder do Partido do Trabalho da Albânia. E dois volumes trazem obras de Friedrich Engels.

Além desses livros publicados nas duas coleções, foram editadas ainda as obras Citações do presidente Mao Tsetung, em junho de 1974, e As divergências sinosoviéticas (e a actual política externa chinesa), em novembro de 1974, ambos na coleção Minerva de Bolso.

Pelas características dos títulos publicados nas coleções Cadernos Operário Vermelho e Textos Operário Vermelho, é de se supor que houvesse, na sua definição, uma orientação oriunda de algum grupo político maoista que mantinha contatos com a Minerva.

Com o fim dessas coleções, já em 1976, a Editorial Minerva continuou com sua linha de livros generalista e voltada primordialmente para a literatura. Assim, a edição de obras de caráter político representou apenas uma opção momentânea para a Editorial Minerva, opção logo abandonada com a diminuição das vendas desse tipo de livro a

\footnotetext{
${ }^{16}$ SARAMAGO, José. “Aviso”. In: Terra do pecado. Lisboa: Caminho, 6ª ed., 1997.
} 
partir de 1976.

A editora continua em atuação até os dias de hoje.

\subsection{Portugália Editora}

Av. da Liberdade, 13, $3^{\circ}$ dto. - Lisboa.

Editores (no período 1968-1978): Agostinho Fernandes, José da Cruz Santos, Joaquim Soares da Costa, Serafim Ferreira, Orlando Neves.

Fundação: 1942.

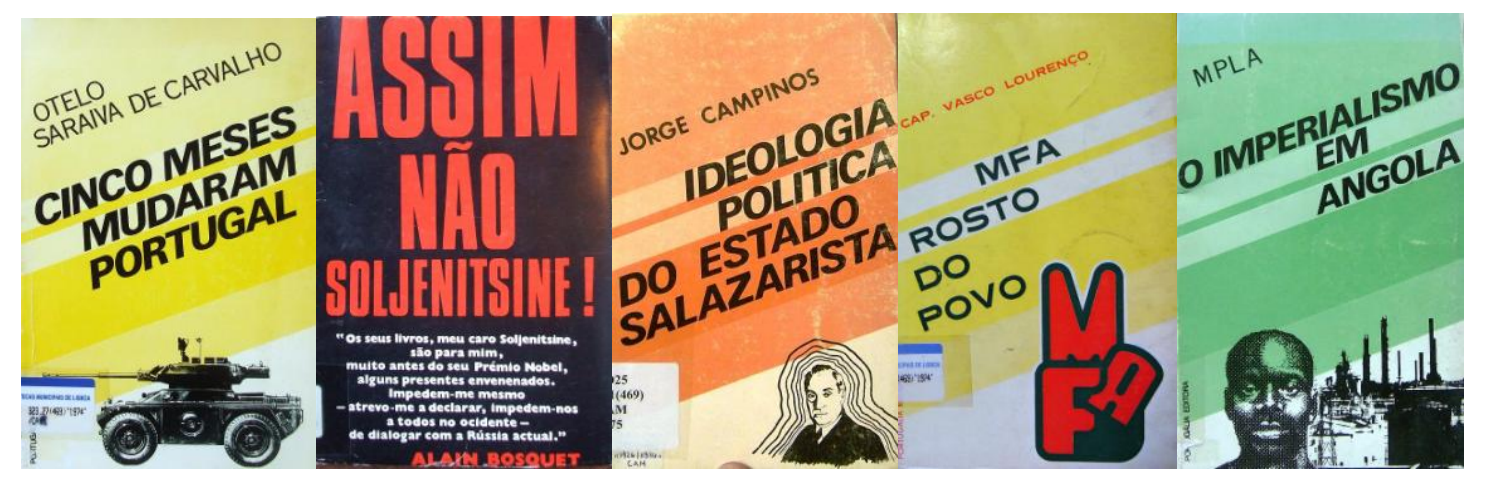

A Portugália Editora foi fundada em setembro de 1942 por Agostinho Fernandes (sócio capitalista), Raul Dias e Pedro de Andrade (sócios gerentes) ${ }^{17}$.

Agostinho Fernandes foi, até a sua morte, em 1972, o proprietário da editora e principal orientador de sua linha editorial, uma vez que decidia quais seriam os diretores literários da casa. Grande empresário da indústria pesqueira e conserveira portuguesa, era um mecenas das artes e das letras. Sua ação expandiu-se também para a área cinematográfica, com a criação, no mesmo ano de 1942, da Cinelândia. Foi um dos maiores colecionadores portugueses de obras de $\operatorname{arte}^{18}$.

O perfil político de Fernandes não deixa de apresentar uma certa dubiedade. José Tengarrinha o definia como "um homem abertamente oposto ao regime fascista", ainda que, ressaltava ele, "nunca o tivesse visto manifestar-se exuberantemente" a este respeito. Para Tengarrinha, "As obras de ficção publicadas [pela Portugália] são de autores nacionais e estrangeiros que, na maioria, não eram gratas ao regime"19. Já José da Cruz Santos, que trabalhou com Fernandes nos anos 1960 na Portugália - e que seria

17 “Contribuições e achegas para a história da Portugália Editora”. In: SANTOS, José da Cruz (coord.). Agostinho Fernandes: um industrial inovador, um coleccionador de arte, um homem de cultura. Lisboa: Portugália Editora Internacional, 2000, p. 213.

${ }^{18}$ MEDEIROS, Edição e editores, op. cit., p. 242.

${ }^{19}$ TENGARRINHA, José. "Em memória de Agostinho Fernandes". In: SANTOS, op. cit. 
"seu editor preferido", de acordo com Diniz Nazareth Fernandes ${ }^{20}$, neto de Agostinho -, o classifica como "um homem nitidamente de direita, com amizades no regime, mas que tinha uma grande abertura: basta ver que estavam na sua editora o Alves Redol ou o José Gomes Ferreira"21.

O primeiro diretor literário da casa foi João Gaspar Simões, que ocupou o cargo até 1946, período em que imprimiu um forte dinamismo à editora. A partir de meados dos anos 1950, Agostinho Fernandes passou a dedicar-se pessoalmente à editora, o que levou à retomada da atividade editorial da casa. Somente em 1956 um novo diretor literário foi nomeado: Jorge de Sena, que no entanto desempenhou esta função apenas por alguns meses. Na sequência, Augusto da Costa Dias assumiu o cargo e foi, até 1968, o editor de fato da Portugália ${ }^{22}$. Nesse arranjo, Fernandes era o publisher e Costa Dias o editor profissional, nos termos expostos no Capítulo 1.

Costa Dias, que era membro do Partido Comunista Português ${ }^{23}$, foi o responsável pela renovação da editora, reconfigurando-a e dando-lhe "a roupagem editorial que marcou os anos 60 da Portugália Editora". É ele quem, "sob a anuência compreensiva de Agostinho Fernandes, transforma a Portugália Editora, devolvendo-a a um fulgor análogo ao dos primeiros tempos" ${ }^{24}$. Esta foi a época áurea da editora, em que tornou-se referência cultural no país, graças à edição de autores portugueses e estrangeiros fundamentais. Entre os autores portugueses, destacavam-se Jaime Cortesão, José Régio, Carlos de Oliveira, Manuel da Fonseca, José Gomes Ferreira, José Rodrigues Miguéis, Vergílio Ferreira, Branquinho da Fonseca, João José Cochofel, Mário Dionísio, Sophia de Mello Breyner Andressen, Eugénio de Andrade, Ramos Rosa, Herberto Hélder, Casimiro de Brito e Fiama Hasse Pais Brandão, entre outros.

Também nas ciências humanas a editora se destacou, com a coleção Portugália, que "reuniu trabalhos de historiadores não alinhados com a história 'cristã' e patrioteira, dominante nas universidades portuguesas" ${ }^{25}$, como lembra António Borges Coelho. A coleção publicou autores como Armando de Castro, Oliveira Marques, José Tengarrinha, Joel Serrão, Victor de Sá, Alexandre Cabral, Augusto da Costa Dias,

\footnotetext{
${ }^{20}$ SANTOS, op. cit., p. 318.

${ }^{21}$ QUEIRÓS, Luís Miguel. “José da Cruz Santos, um inventor de livros”. Público, Lisboa, 01.04.2012. Disponível em: <http://www.publico.pt/Cultura/jose-da-cruz-santos-um-inventor-de-livros1540311?all=1>. Acesso em 21/4/2012.

22 “Contribuições e achegas...”, op. cit., p. 214; MEDEIROS, N. Edição e editores, op. cit., p. 243.

${ }^{23}$ TENGARRINHA, José. "Em memória...”, op. cit.

${ }^{24}$ MEDEIROS, Edição e editores, op. cit., p. 243-44.

${ }^{25}$ COELHO, António Borges. "Agostinho Fernandes". In: SANTOS, op. cit.
} 
Alberto Ferreira, Jorge de Sena, César Nogueira e Raul Esteves dos Santos.

Assim, merece destaque o fato de que muitos dos autores nacionais publicados pela Portugália alinhavam-se na oposição ao regime de Salazar.

Em 1963, José da Cruz Santos começou a trabalhar na Portugália, como editor, subordinado a Costa Dias. E em meados da década outro portuense, Joaquim Soares da Costa, também foi admitido, primeiro como redator de textos promocionais, e depois como diretor literário ${ }^{26}$. Também Serafim Ferreira ingressou na editora, em $1964^{27}$. Com a saída de Costa Dias da editora em 1968, Cruz Santos e Soares da Costa assumiram a direção editorial. Desde o ano anterior, Cruz Santos havia criado a sua própria editora a Inova - no Porto, e dividia seu tempo entre as duas casas.

A Portugália nesse momento "publicava em média dez livros por mês, tinha mais de mil títulos no catálogo, uma grande atividade, um prestígio e um nome firmados", lembra Soares da $\operatorname{Costa}^{28}$.

A editora passou por grandes mudanças em 1970, quando a empresa ficou sob administração dos herdeiros de Agostinho Fernandes, levando ao afastamento do próprio Fernandes, e de Cruz Santos e Soares da Costa ${ }^{29}$. Agostinho Fernandes faleceu em 1972.

No segundo semestre de 1974, Serafim Ferreira e Orlando Neves eram os responsáveis pela direção literária da Portugália. Ambos vinham da editora Círculo de Leitores $^{30}$. No ano seguinte eles criariam a editora DiAbril.

Ferreira e Neves criaram e coordenaram os Cadernos Portugália. De acordo com o clima da época, a iniciativa tinha um claro viés político, como fica evidente no texto que apresentava a coleção e que constava da contracapa de todos os seus volumes:

Divulgar informações exatas e dar ao povo português os fundamentos culturais que lhe permitam o exercício esclarecido dos seus direitos numa sociedade democrática - eis o objetivo dos CADERNOS PORTUGÁLIA. Para resolver os problemas do povo é preciso que o povo participe nas soluções - discutindo e debatendo, tomando conhecimento da sua força e revigorando a sua unidade. Um povo esclarecido é um povo forte, livre, unido e atento. CADERNOS PORTUGÁLIA pretendem ser um apoio nesta luta do Portugal de hoje.

\footnotetext{
26 "Entrevista com Joaquim Soares da Costa (Edições 70)". Notícias do Livro, Lisboa, APEL, o 3, jan. 1979, p. 14.

${ }^{27}$ FERREIRA, op. cit., p. 70.

28 "Entrevista com Joaquim Soares da Costa...”, op. cit., p. 14.

${ }^{29}$ Ibidem, p. 15; FERREIRA, op. cit., p. 71-72.

${ }^{30}$ HORTA, Maria Teresa. "Ecos literários". Expresso, Lisboa, 26/10/1974, p. 28.
} 
Os títulos publicados na coleção, todos em 1974 e 1975, foram: PIDE/DGS: um Estado dentro do Estado, de Fernando Luso Soares; O imperialismo em Angola, com textos do Movimento Popular de Libertação de Angola; $O$ que é o marxismo?, de Francisco dos Santos Costa; Crimes políticos e habeas corpus, de Artur Maurício; Desporto e política, de Noronha Feio; Cinco meses mudaram Portugal, de Otelo Saraiva de Carvalho; Ideologia e política do Estado salazarista, de Jorge Campinos; No regresso vinham todos: relato da companhia $n^{\circ} 2549$, de Vasco Lourenço; e MFA, rosto do povo; de Vasco Lourenço.

Em dezembro de 1974 Ferreira e Neves deixaram a editora por divergências políticas com os proprietários, que queriam que os Cadernos Portugália publicassem um livro de autoria do general Galvão de $\mathrm{Melo}^{31}$, um dos expoentes da direita militar. Serafim Ferreira e Orlando Neves, "por razões de coerência ideológica", não aceitaram essa imposição. "Foi essa a razão direta do conflito que nos opôs à decisão da gerência e justificou a nossa demissão", explicou Ferreira em $1975^{32}$.

$\mathrm{Na}$ mesma entrevista, Ferreira fazia uma dura avaliação da situação da Portugália no começo de 1975:

A Portugália está nas mãos de uma gerência quase "analfabeta", nada fadada para encarar em profundidade os problemas colocados pela existência e manutenção de uma editora e dos tentames que a devem ligar a uma sociedade que verdadeiramente procura consolidar-se no caminho da democracia - e daí a vaga de problemas que a todo momento entrevava a nossa atividade. Tendo sido uma editora com enorme prestígio na nossa vida cultural, a Portugália encontra-se hoje numa posição francamente caótica, com graves dificuldades econômicas, "destruindo" pelos saldos desordenados todo um passado editorial que outras pessoas, com todo o seu esforço, ajudaram a pôr de pé. [...] A culpa dessa atual situação só pode caber a uma gerência que não sabe (nem para isso tem capacidade) gerir nem orientar editorialmente uma casa com grandes tradições culturais. ${ }^{33}$

Os Cadernos Portugália parecem ter sido a única iniciativa de cunho diretamente político empreendida pela Portugália após o fim da ditadura.

Mas houve outros títulos políticos editados desde o final dos anos 1960: O poder americano e os novos mandarins, de Noam Chomsky (1969); Greves de ontem e de hoje, de Georges Lefranc (1970); Assim não, Soljenitsine!, de Alain Bosquet (1974); A

31 “Orlando Neves". Disponível em: 〈http://alfarrabio.di.uminho.pt/vercial/oneves.htm〉. Acesso em 20/6/2012. O livro de Galvão de Melo, intitulado MFA Movimento Revolucionário, acabou sendo lançado pela Portugália em 1975.

${ }^{32}$ HORTA, "Conversa com Serafim Ferreira", op. cit., p. 60-61.

${ }^{33}$ Ibidem. 
cruz e a espada em Moçambique, de Cesare Bertulli (1974); MFA Movimento Revolucionário, de Galvão de Melo (1975); Felizmente há luar!, de Luís de Sttau Monteiro (4 $4^{\mathrm{a}}$ ed., 1977).

Com a saída de Serafim Ferreira e Orlando Neves da editora, no final de 1974, a Portugália parece ter aprofundado um processo de decadência, que levou ao fim da editora no começo dos anos 1980. Na verdade, depois das mudanças ocorridas na editora em 1970, a empresa não conseguiu dar continuidade à sua trajetória anterior, que a havia transformado em uma das mais importantes editoras do país.

Entre 1968 e o começo dos anos 1980, a Portugália editou (ou reeditou) mais de 150 títulos. Destes, cerca de 20 eram obras de caráter político. Além disso, como vimos, vários dos autores da editora estavam ligados à oposição à ditadura. $\mathrm{O} 25$ de Abril não alterou significativamente a linha da editora, até porque nesse momento a Portugália já vivia uma situação de instabilidade e de reduzidas possibilidades de retomada de seu antigo papel no panorama editorial do país. E, se acreditarmos na avaliação de Serafim Ferreira, sua direção não se mostrou capacitada para enfrentar a nova situação que o país vivia após a queda da ditadura.

Em junho de 2008 a Portugália Editora foi relançada, sob a direção de Diniz Nazareth Fernandes, neto de Agostinho Fernandes. Na nova situação, a editora integrava um novo grupo editorial, que também incluiria a livraria Buchholz e a editora Sá da Costa, e tinha o patrocínio da Fundação Agostinho Fernandes ${ }^{34}$.

11.4 Editorial Estúdios Cor

Rua João Pereira Rosa, 20-A - Lisboa

Editores: Nataniel Costa, José Saramago, Natália Correia.

Fundação: 1949.

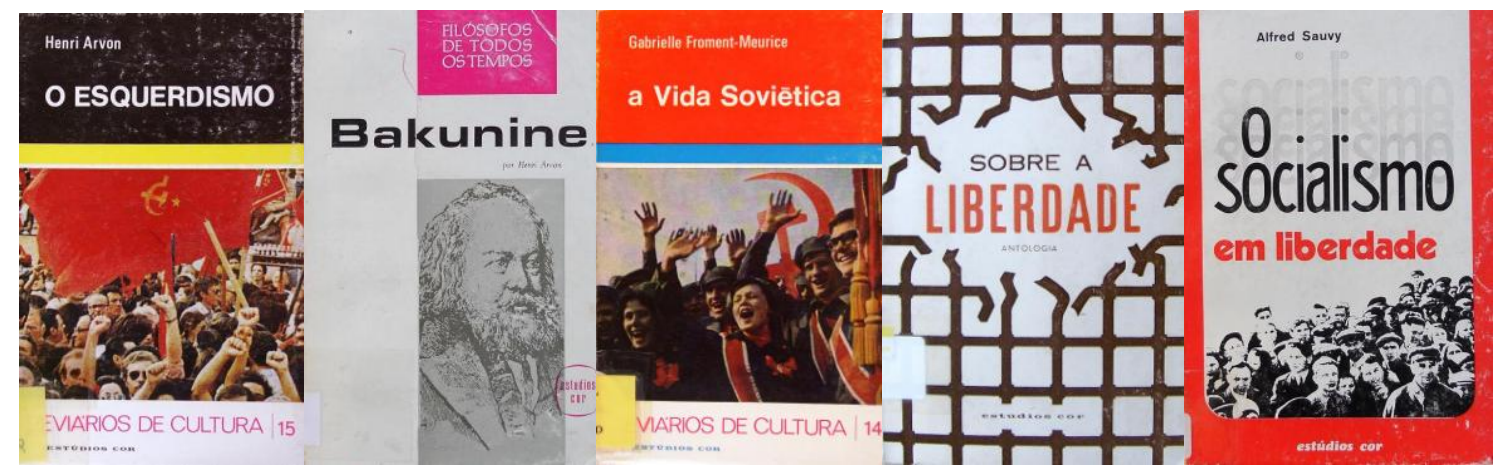

34 "Portugália Editora relançada terça-feira em novo grupo editorial". Expresso, Lisboa, 23/6/2008. Disponível em: <http://expresso.sapo.pt/livros-portugalia-editora-relancada-terca-feira-em-novo-grupoeditorial=f351286\#ixzz2CbwEGDOF $>$. Acesso em 10/11/2012. 
Fundada em 1949 por Fernando Canhão e Manuel Correia ${ }^{35}$, a Editorial Estúdios Cor começou editando a História da Arte, de Élie Faure, em fascículos. A partir de 1953, sob a direção literária de Nataniel Costa, iniciou uma trajetória que a levou a tornar-se uma conceituada editora de literatura e de livros de $\operatorname{arte}^{36}$.

Em 1955 José Saramago começou a colaborar no setor de produção da editora e em 1959 tornou-se diretor literário substituindo Costa, que encaminhou-se para a carreira diplomática. Saramago desempenhou esta função até o final de 1971, sendo substituído pela escritora Natália Correia. Correia ficou na editora até 1973. No ano seguinte Nataniel Costa era novamente diretor literário da Estúdios Cor $^{37}$.

Nos anos 1950 e 1960 a Estúdios Cor publicou mais de duas centenas de títulos, tornando-se uma importante editora no cenário português. Entre os autores que editou destacam-se Camilo José Cela, Graham Green, Máximo Gorki, François Mauriac, Thomas Mann, Stendhal, Colette, André Gide, Sinclair Lewis, Raul Brandão, José Rodrigues Miguéis, Alves Redol, Jorge de Sena, José Gomes Ferreira, Augusto Abelaira, Manuel da Fonseca, entre outros.

No início da década de 1970 "o capital da empresa se abriu a um novo grupo de acionistas ligados à banca e ao mundo empresarial - Moreira Rato, António Oliveira Pinto, Luís Arouca, Romeu de Melo e João Pires Lourenço" 38.

Serafim Ferreira considera que a editora "não voltou a ser a mesma depois da saída de José Saramago em finais de 1971",39. Ferreira reproduz uma carta que Saramago lhe enviou nessa ocasião que mostra que o futuro Prêmio Nobel saiu com certa mágoa da Estúdios Cor:

Já terá sabido que saio da editora. Hoje é o último dia que aqui estarei. São largos anos de trabalho que aqui me ficam, sem falar nos sacrifícios pessoais de toda a ordem. Aguentei esta casa de pé até ao momento conveniente... para os outros. É uma história algo suja que talvez ainda acabe por vir a público (se a tanto me forçarem) mas de que, em qualquer caso, lhe darei conta quando nos encontrarmos. ${ }^{40}$

Em abril de 1972, já sob a direção de Natália Correia, a Estúdios Cor publicou

\footnotetext{
${ }^{35}$ BEJA, Rui. A edição em Portugal, 1970-2010: percursos e perspectivas. Lisboa: APEL, 2012, p. 29.

${ }_{37}^{36}$ MEDEIROS, Edição e editores, op. cit., p. 166-67.

37 Ibidem; SARAMAGO, José. "Autobiografia". Disponível em: <http://www.controversia.com.br/index.php?act=textos\&id=6204>. Acesso em 15/11/2012; "Natália Correia". Disponível em: $<$ http://telepoesis.net/alletsator/wiki/index.php?title=Nat\%C3\%A1lia_Correia $>$. Acesso em 14/11/2012; AA.VV. Editores portugueses na III Bienal Internacional do Livro São Paulo: 15 a 23/Junho/1974. Lisboa: Império, 1974.

${ }^{38}$ BEJA, A edição em Portugal..., op. cit., p. 29-30.

${ }^{39}$ FERREIRA, op. cit., p. 105-106.

${ }^{40}$ Ibidem, p. 106.
} 
um dos livros que mais polêmica causou em Portugal antes do fim da ditadura: Novas Cartas Portuguesas, de Maria Isabel Barreno, Maria Teresa Horta e Maria Velho da Costa. Na obra, as três escritoras tratavam, em cartas, ensaios, poemas e fragmentos, da vida de mulheres "marcadas por condicionalismos de vária ordem, maltratadas, enclausuradas, dependentes, vítimas de amor ou paixão, casadas à força, enganadas, exploradas... e pacientes!" 41 . O livro foi considerado pelas autoridades como de "conteúdo insanavelmente pornográfico e atentatório da moral pública", o que levou a que a primeira edição fosse recolhida e destruída pela censura. Foi também instaurado um processo judicial contra as autoras e contra a editora ${ }^{42}$.

Maria Teresa Horta destaca o papel de Natália Correia na edição do livro: "Ninguém nos queria publicar o livro, mas a Natália Correia, que na altura era directora literária dos Estúdios Cor, disse que ou a editora publicava ou ela se demitia"43. Horta lembra também que a censura ao livro e a perseguição às autoras - que ficaram conhecidas como "as três Marias" - gerou "uma comovente onda de solidariedade":

Mandámos uma carta à Simone de Beauvoir e o que aconteceu depois foi inacreditável. "As Cartas" transformaram-se na primeira causa mundial feminina. A primeira e a última... Houve uma marcha de mulheres em Paris, mulheres invadiram a embaixada portuguesa na Holanda, e durante três anos houve sempre mulheres à frente da embaixada portuguesa em Washington, nos Estados Unidos. ${ }^{44}$

Foi somente graças ao 25 de Abril que o processo foi suspenso e as autoras e a editora viram o fim da perseguição de que eram vítimas. Em maio de 1974 o livro teve uma nova edição, mas dessa vez pela Editora Futura.

Desde fins dos anos 1960 a Estúdios Cor havia incrementado a edição de obras de caráter político, e ainda antes do 25 de Abril a editora havia publicado títulos como: O socialismo em liberdade, de Alfred Sauvy (1970); Lukacs ou a frente popular em literatura, organizado por Henri Arvon (1970); Bakunine ou a vida contra a ciência, organizado por Henri Arvon (1971); Sartre e a realidade humana, compilação de Colette Audry (1972); Garaudy e o marxismo do século XX, organizado por Serge

41 CASTILHO, Clara. "Mulheres de coragem - Novas Cartas Portuguesas". Blogue A Viagem dos Argonautas, 30/11/2011. Disponível em: <http://aviagemdosargonautas.net/2011/11/30/mulheres-decoragem-novas-cartas-portuguesas-por-clara-castilho/>. Acesso em 10/11/2012.

42 "História". Blogue Novas Cartas Portuguesas - 40 anos depois. Disponível em: <http://www.novascartasnovas.com/historia.html>. Acesso em 10/11/2012.

43 RIBEIRO, Ana Maria. "Quando íamos ser presas, aconteceu o 25 de Abril”. Correio da Manhã, 12/12/2010. Disponível em: < http://www.cmjornal.xl.pt/detalhe/noticias/lazer/cultura/maria-teresa-hortaquando-iamos-ser-presas-aconteceu-o-25-de-abril>. Acesso em 10/11/2012.

${ }^{44}$ Ibidem. 
Perottino (1972); Introdução à política, de Maurice Duverger (1972); A desobediência civil, de Henry David Thoreau (1972); A democracia na América, de Alexis de Tocqueville (1972); Sobre a liberdade, antologia organizada por Romeu de Melo (1973); O que é o materialismo dialéctico?, de O. Yakhot (1973); Os negros nos Estados Unidos, de Claude Fohlen (1973).

Após o fim da ditadura, aumentou a participação da política no catálogo da editora, acentuando-se o perfil de esquerda dos lançamentos, principalmente nas coleções Biblioteca Ciências Sociais e Breviários de Cultura. Na primeira foram editados: A resposta socialista ao desafio americano, de Ernest Mandel (1974); Da democracia socialista, de Roy Medvedev (1974); O capitalismo em causa, de Jacques Germain (1974); Marx, Freud e a crítica da vida quotidiana: para uma revolução cultural permanente, de Bruce Brown (1980). E na segunda: O conflito sino-soviético, de Jacques Lévesque (1974); O materialismo dialéctico, de Alexsander Georgievitch Spirkine e Ovshy Yakhot (1975); O materialismo histórico, de Spirkine e Yakhot (1975); A vida soviética, de Gabrielle Froment-Meurice (1976); O esquerdismo, de Henri Arvon (1977); O terrorismo político, de Paul Wilkinson (1978); e A social democracia na Europa do após guerra, de William E. Paterson e Ian Campbell (1980).

Mas deve-se destacar que a Revolução dos Cravos não alterou a característica principal da editora, ou seja, a literatura e a arte continuaram a ocupar os lugares principais entre os títulos publicados, de modo incontrastável. Dos cerca de 200 títulos editados entre 1968 e 1983, apenas cerca de 30 eram de caráter político.

A distribuição dos livros da Estúdios Cor era feita, nos anos 1970, pelo Bloco Editorial Expresso, empresa que fazia a divulgação e comercialização das obras de várias editoras progressistas, como Livros Horizonte, Estampa, Seara Nova, Prelo, Presença e Delfos, além da Arcádia.

A Estúdios Cor encerrou suas atividades nos anos 1980. Em toda a sua existência, a editora sempre se caracterizou por dar prioridade às obras literárias e de arte, tendo publicado, como vimos, importantes autores nacionais e estrangeiros. A edição de livros políticos teve um papel secundário no catálogo da editora. Após o 25 de Abril houve um pequeno aumento no número de obras desse tipo lançadas, que tinham também um viés mais à esquerda, mas nada que alterasse a predominância da literatura no seu catálogo.

Também não parece ter havido ligação da editora com um grupo ou partido 
político específico. Os livros políticos parecem, antes de tudo, responder à demanda sobre o tema, que era crescente a partir do final dos anos 1960.

\subsection{Livraria Almedina Editora}

Arco do Almedina, 15 - Coimbra

Editor: Joaquim Machado.

Fundação: 1955.

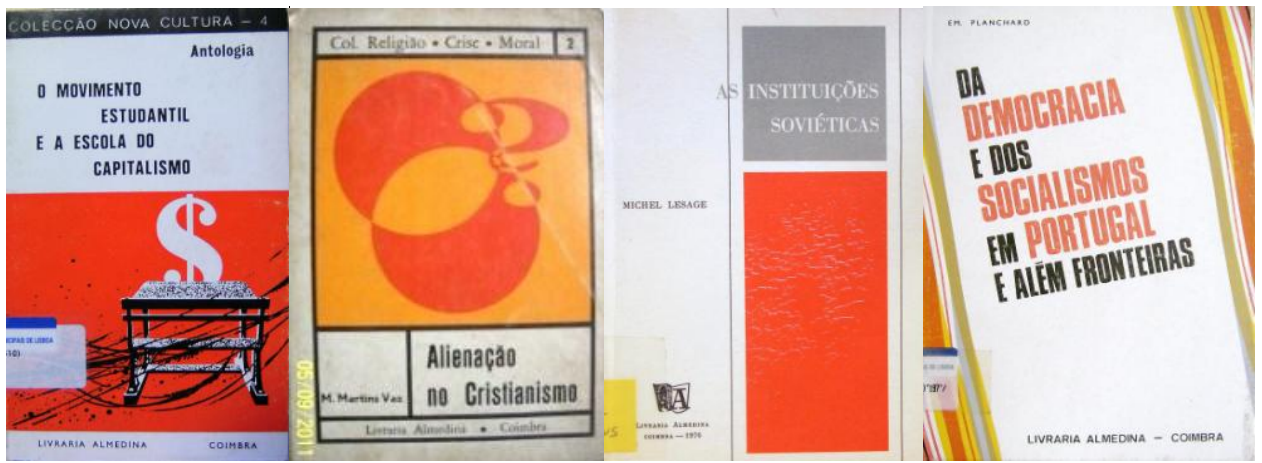

A Livraria Almedina foi fundada em 1955 por Joaquim Machado, em Coimbra. Machado tinha 31 anos quando abriu a sua própria livraria, mas desde os 15 anos de idade trabalhava no ramo, primeiro na Livraria Atlântida, onde ficou alguns anos, e depois na Livraria Coimbra Editora ${ }^{45}$. Essa experiência foi fundamental para o início da atividade editorial da Almedina: "[...] os anos passados ao balcão, em contato permanente com algumas das principais personalidades da Universidade de Coimbra, em breve [o] obrigariam a pensar numa atividade editorial orientada para os domínios do Direito e das Ciências do Homem"46.

Machado explica que a suas opções como livreiro e editor estão diretamente ligadas ao fato de atuar em Coimbra:

Ser-se livreiro em Coimbra significa estar em contato com uma clientela muito especial. Naturalmente que numa cidade pequena onde há milhares de clientes ligados à Universidade, resultam daí características de exigências diferentes de outras cidades, onde não há uma concentração tão grande de pessoas com cursos superiores ou a caminho disso [...]. Por este motivo as pessoas sabem o que querem, pois o livro na maioria dos casos é a sua "ferramenta". [...] Como editor sofro naturalmente a influência do grande contato que tenho

45 "Biografia do fundador". Página eletrônica do Grupo Almedina. Disponível em: $<$ http://www.grupoalmedina.net/?q=node/32>. Acesso em 22/11/2012.

${ }^{46}$ AA.VV. Editores portugueses na IV Bienal Internacional do Livro São Paulo: 14 a 22/Agosto/1976. Lisboa: Associação Portuguesa dos Editores e Livreiros, 1976. 
tido com este público. ${ }^{47}$

Joaquim Machado concluía da seguinte maneira a sua autodefinição como editor: "[...] eu sou pouco de projetos. Com a minha atividade editorial e livreira sou como dizem na minha terra: 'danço conforme a música'. Isto é, como editor, a partir do livreiro vou editando conforme as exigências do público que sirvo" ${ }^{\text {.48 }}$.

Assim, a editora especializou-se em obras universitárias, em especial na área do Direito.

Somente no final dos anos 1960 a editora "iniciou uma nova fase, com a publicação de obras de linguística, filologia, literatura e cultura portuguesas"49. É quando surgem as coleções Nova Cultura e Religião - Crise - Moral. Estas coleções são as únicas, durante a trajetória de mais de meio século da Almedina, em que foram editadas obras de caráter político.

O primeiro livro da coleção Nova Cultura foi o volume Igualdade radical para a mulher, que tratava de temas polêmicos e proibidos na época, problematizando questões como "o casamento, a virgindade, a pornografia, os concursos de beleza, a moda, o nudismo, a homossexualidade, a paz, o papel das mulheres perante a guerra colonial, a segregação sexual no desporto e o machismo" ${ }^{, 50}$. Estes temas eram abordados em textos produzidos pelo grupo "Quem Somos e o que Queremos", composto por "estudantes universitários de Coimbra, oriundos dos sectores católicos e que se haviam debruçado sobre estas questões pelo menos durante o ano lectivo de 1969/70",51. O livro foi proibido e apreendido pela polícia.

Outros títulos publicados pela coleção foram: A condição de estudante, de Catherine Valabrègue (1970); A crise do catolicismo, de José Luis L. Aranguren (1971); O movimento estudantil e a escola do capitalismo, antologia com textos de I. Illich, P. Freire, J. Golfin, L. Vandermeersch e M. Stirner (1972); e Banalidades de base, de Raoul Vaneigem (1972).

A coleção Religião - Crise - Moral, como o nome indica, era voltada para temas religiosos, mas sob um ponto de vista progressista, que defendia a livre participação dos cristãos na vida política da sociedade. Todos os títulos da coleção são de autores ligados ao pensamento cristão progressista: Chamados à liberdade, de Pierre Ganne (1971);

\footnotetext{
47 “Entrevista com Joaquim Machado". Notícias do Livro, Lisboa, APEL, nº 4, fev. 1979, p. 22-26.

${ }^{48}$ Ibidem.

${ }^{49}$ AA.VV. Editores portugueses..., op. cit.

${ }^{50}$ CARDINA, Margem de certa maneira, op. cit., p. 271-72.

${ }^{51}$ Ibidem.
} 
Alienação no cristianismo, de M. Martins Vaz (1971); Evangelho sem mitos, de Louis Evely (1971); A esperança que está em nós, de Pierre Ganne (1972); A esperança é política, de André Biéler, com prefácio de D. Hélder Câmara (1972); e Fé: força política, de Jean Cardonnel, Hervé Chaigne e Karl Levêque (1972).

Curiosamente, a edição de obras de cunho político pela Almedina deu-se apenas antes do 25 de Abril, e teve caráter claramente ocasional e residual na atuação da editora, talvez fruto de uma experiência de renovação e abertura de seu catálogo, que todavia não teve continuidade.

Assim, as mudanças que ocorreram no país com o fim da ditadura não parecem ter afetado a linha editorial da Almedina, que manteve-se fiel às edições universitárias, com ênfase para o Direito, mas também com força nas áreas de Medicina, Psicologia, Educação, Economia e ciências exatas ${ }^{52}$.

Joaquim Machado faleceu em outubro de 2005. A editora continua em atuação e hoje encabeça o Grupo Almedina, constituído ainda por Edições 70, Actual Editora, a chancela Minotauro, uma rede de 12 livrarias e a Almedina Brasil ${ }^{53}$.

\subsection{Editora Arcádia}

Campo de Santa Clara, 160-D, Lisboa / R. da Horta Seca, 15-3º - Lisboa (1975)

Editor: Paradela de Abreu, Nélson de Matos.

Fundação: 1957.

Distribuição: Expresso Bloco Editorial de Distribuição

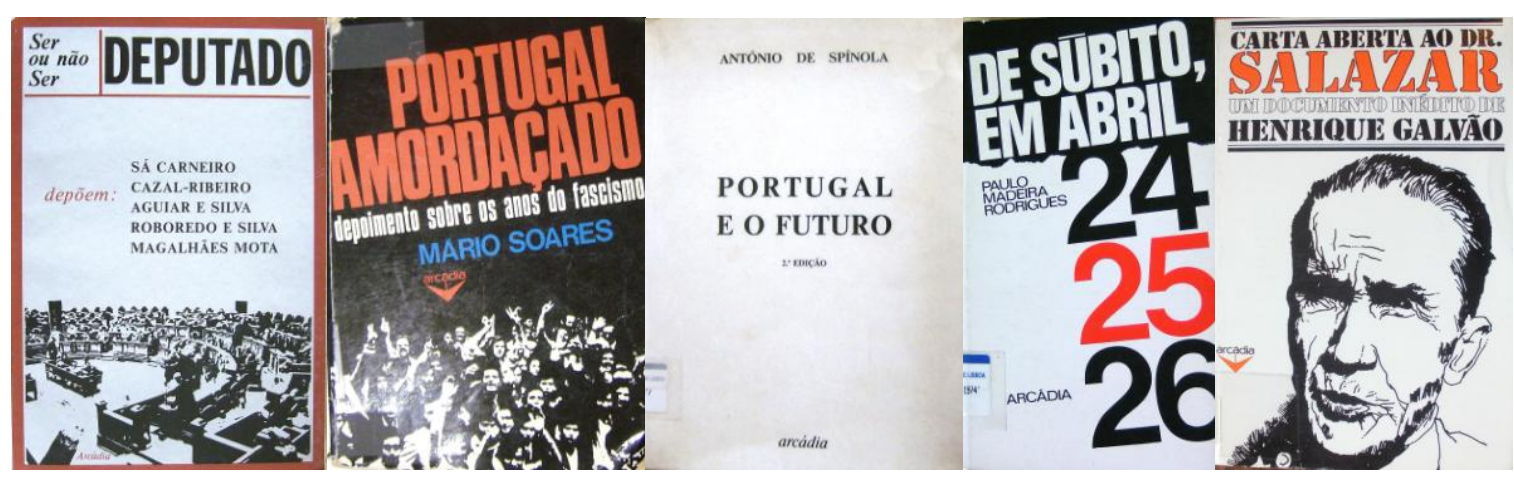

Editora criada em 1957 por António José da Guerra da Cruz Barreto ${ }^{54}$. Tratavase de uma editora de caráter comercial, com publicações principalmente na área de

\footnotetext{
52 "Grupo Almedina". Página eletrônica do Grupo Almedina. Disponível em: $<$ http://www.grupoalmedina.net/?q=node/4>. Acesso em 22/11/2012.

${ }^{53}$ Ibidem.

${ }^{54}$ BEJA, A edição em Portugal..., op. cit., p. 30-31.
} 
literatura, ciências humanas e história em quadrinhos (banda desenhada). Editou a coleção Clássicos Universais, que incluía as Obras Completas de Dostoievski (iniciada nos anos 1960) e as Obras Completas de Tolstoi $^{55}$ (início no começo da década de 1970). Em 1962 deu início à Biblioteca Arcádia de Bolso, com livros de bolso divididos em oito secções: "Arte e literatura", "Filosofia e psicologia", "História e geografia", "Ciências puras e aplicadas", "Ciências sociais", "Ficção", "Clássicos", "Documentos e estudos diversos" ${ }^{\$, 56}$. Esta coleção teve mais de 150 títulos.

A partir do começo dos anos 1970, os títulos de caráter político ganham importância no catálogo da editora. Nesse momento a editora pertencia a Carlos Manuel Beirão da Veiga e o diretor editorial, entre 1972 e 1974, era Paradela de Abreu $^{57}$ (ver item sobre a Editora Intervenção no Capítulo 10). Desde 1973 a escritora Natália Correia era a diretora cultural da editora ${ }^{58}$.

Talvez o ponto de inflexão na linha editorial da Arcádia tenha sido a publicação do livro Dinossauro excelentíssimo, de José Cardoso Pires, em 1972, uma fábula satírica "que retrata a vida de Salazar, a sua ditadura e o Portugal do Estado Novo num tom bastante irônico e amargurado" 59 . De acordo com o autor, parte da repercussão do livro se deveu ao fato de que "numa discussão na Assembleia Nacional sobre a liberdade de imprensa, um deputado ultrafascista, Casal Ribeiro, em discussão com Miller Guerra, quis demonstrar a existência de liberdade dando como exemplo a publicação de Dinossauro Excelentíssimo". A partir de então, o livro não poderia mais sofrer censura sem que isso causasse grande desgaste ao governo ${ }^{60}$.

Em 1973 teve início a coleção Ser ou Não Ser, coordenada por José Silva Pinto. Esta coleção publicou títulos que colocavam em discussão temas políticos polêmicos por meio de textos de políticos e intelectuais da oposição ou ligados ao regime. Foram quatro títulos publicados em 1973: Ser ou não ser deputado; Ser ou não ser por uma abertura a leste; Ser ou não ser pelo partido único; e Ser ou não ser pela Bolsa.

Entre os autores da coleção estavam: Sá Carneiro, Casal-Ribeiro, Roboredo e Silva, Magalhães Mota, Vergílio Ferreira, Raul Rêgo, Manuel Vinhas, Barradas de

\footnotetext{
${ }^{55}$ MEDEIROS, op. cit., p. 249.

${ }^{56}$ Ibidem.

${ }^{57}$ ABREU, Do 25 de Abril ao 25 de Novembro, op. cit., p. 33; "Na morte de Paradela de Abreu". Nota do Sindicato dos Jornalistas, disponível em: 〈http://www.jornalistas.eu/?n=1656>. Acesso em set. 2012.

${ }_{59}^{58}$ ABREU, op. cit., p. 30.

59 "Dinossauro excelentíssimo". Verbete da Wikipédia. Disponível em: <http://pt.wikipedia.org/wiki/Dinossauro_Excelent\%C3\%ADssimo)>. Acesso em set. 2012. ${ }^{60}$ Idem.
} 
Oliveira, Magalhães Godinho, Nogueira Pinto, Barrilaro Ruas, Pinto Balsemão e Maia Cadete, entre outros.

Em fins de 1973 a Arcádia foi vendida à Companhia de Seguros Império, empresa do grupo CUF (Companhia União Fabril) ${ }^{61}$, um dos maiores grupos econômicos portugueses. Nesse momento, de acordo com Paradela de Abreu, então diretor editorial da Arcádia, já estava contratato e em avançado estágio de produção o livro Portugal e o futuro, do general António Spínola ${ }^{62}$. Como já foi mencionado (ver Capítulo 1), este livro, cuja primeira edição foi lançada com grande sucesso dia 22 de fevereiro de 1974, teve importante papel político no fim da ditadura em Portugal e certamente foi também decisivo para que Spínola assumisse o cargo de presidente da República após o 25 de Abril.

Quinze dias após o lançamento do livro do general Spínola, em 7 de março, Paradela de Abreu foi demitido da Arcádia, num episódio em que não ficou claro se houve ou não motivações políticas ${ }^{63}$. Os novos proprietários nomearam Nélson de Matos, que havia antes trabalhado na Editora D. Quixote, para a direção da editora, cargo que ele ocupou até $1976^{64}$.

Já sob o novo comando, a Editora Arcádia se definia da seguinte forma em junho de 1974:

Três linhas de força caracterizam a ação editorial da ARCÁDIA: a difusão da melhor literatura estrangeira, clássica e moderna, a par da informação mais idônea sobre os temas da atualidade mundial; a preocupação de reunir um corpo de autores portugueses que documentem, pela sua alta qualidade, a importância crescente da literatura portuguesa; facultar o debate sobre os mais prementes problemas nacionais, dentro de um construtivo espírito de independência. ${ }^{65}$

A partir do 25 de Abril as edições de livros políticos alcançam novo patamar na Editora Arcádia, principalmente a partir de 1975, seja em função do fim da ditadura, seja pela dinâmica trazida pelo novo diretor editorial. Mas já em 1974 essa mudança se fez sentir com a edição de livros como De súbito, em Abril: 24, 25, 26, de Paulo

\footnotetext{
${ }^{61}$ ABREU, op. cit., p. 35.

${ }^{62}$ Ibidem, p. 25-52.

${ }^{63}$ O jornal oposicionista República, dirigido por Raul Rêgo, noticiou a demissão na primeira página, apontando "a ligação óbvia entre o despedimento e o papel de Paradela de Abreu na edição do livro". Cf. Centro de Documentação 25 de Abril - Arquivo Electrónico. Resumo dos jornais de 16 de março de 1974. Disponível em: <http://www1.ci.uc.pt/cd25a/wikka.php?wakka=marco16>.

64 "Nota Biográfica" de Nélson de Matos. Disponível em: <http://www.edicoes-nelsondematos.com>.

${ }^{65}$ AA.VV. Editores portugueses na III Bienal Internacional do Livro São Paulo: 15 a 23/Junho/1974. Lisboa: Império, 1974.
} 
Madeira Rodrigues (junho); Diário político: os políticos e o poder económico, de Raul Rêgo (agosto); Portugal amordaçado: depoimento sobre os anos do fascismo, de Mário Soares (outubro); e A funda. $5^{\circ}$ volume: o spinolismo, de Artur Portela Filho (outubro).

Esta linha de livros, apesar de não ser a majoritária em termos numéricos na editora, foi altamente valorizada pela Árcadia, como podemos ver em um anúncio publicitário publicado no jornal Expresso em $1^{\circ}$ de novembro de 1974. Este anúncio, que ocupava um quarto de página (tamanho standart), tinha como título: "Escrever é lutar. Editar também", slogan que passou a ser usado pela Arcádia também em outros anúncios. Trazendo na sua parte superior caricaturas de Mário Soares, Raul Rêgo e Artur Portela Filho, a peça publicitária era completada por um texto que deixava muito clara a importância que a editora atribuía ao seu próprio papel político:

Uma casa editora não é um luxo. Nem é, fundamentalmente, um negócio. É uma responsabilidade. Social. Cultural. Nacional. A Arcádia assume essa responsabilidade. Lançando Portugal amordaçado, de Mário Soares, a reconstituição de 30 anos de luta contra o fascismo. Lançando Diário político, de Raul Rego, o estudo da relação entre os políticos e o poder econômico. Lançando A funda, $5^{\circ}$ volume, de Artur Portela Filho, a análise de seis meses de spinolismo. E não só. Vamos lançar ficção, teatro, poesia, estudos, que são a nossa participação na atividade de crítica, de esclarecimento, de construção do novo homem português. Somos uma casa de cultura. Queremos ser a sua casa de cultura.

Em 1975 começou a ser editada a coleção Alternativas Socialistas, dirigida por Roger Garaudy, que publicou coletâneas de temas ligados ao debate sobre o socialismo. São lançados em 1975 os seguintes volumes: Socialismo e liberdade; Religião e socialismo; A recessão generalizada da economia capitalista internacional; e A luta de classes em Portugal, de Paul Sweezy. Em 1976 saem: Capitalismo ou socialismo, de Paul Sweezy e Leo Huberman; Respostas do socialismo à crise do capitalismo; Um outro marxismo: Antonio Gramsci, organizado por Pedro Cavalcanti e Paolo Piccone. E em 1977: Socialistas e comunistas: a origem da ruptura; e A alternativa italiana do $P C I$, ambos organizados por Pedro Cavalcanti.

Outros títulos importantes editados no campo político foram: Carta aberta ao Dr. Salazar (janeiro, 1975) e Da minha luta contra o salazarismo e o comunismo em Portugal (abril, 1976), ambos de Henrique Galvão, importante nome na luta contra o salazarismo.

A editora publicou também alguns autores clássicos do pensamento de esquerda: 
Lenin (As eleições para a Assembleia Constituinte e a ditadura do proletariado, 1975); Bakunin (Revolução social ou ditadura militar e Confissão, 1975); e Trotsky (Escritos sobre Espanha: a revolução espanhola - 1931-1939, organizado por J. Cabral Fernandes). E lançou também, em 1976, uma biografia de Lenin, de autoria de Maria Prilejaieva.

Nesse ano publicou ainda o livro Memórias do exílio. Brasil 1964/19??, com depoimentos de exilados brasileiros - e que foi vendido também no Brasil.

As coleções Biblioteca Arcádia, Biblioteca Arcádia de Bolso, Introdução à Política, Temas Portugueses (dirigida por Vitorino Magalhães Godinho), Encontro Especial e Documento/Ensaio também editaram obras políticas.

Entre 1972 e 1979 a Arcádia editou cerca de 60 abras de caráter político. É importante destacar que mesmo após 1974 a Arcádia nunca foi uma editora que publicasse predominantemente livros políticos, pois sempre prevaleceram as edições de obras literárias.

A troca da direção da editora, decorrente da mudança de proprietário, no começo de 1974, e o fim da ditadura, quase em seguida, parecem ser os dois fatores que se combinaram para que a edição de obras políticas ganhasse espaço na editora, mesmo que esta linha não tenha sido em nenhum momento a principal da Arcádia.

Juntava-se a experiência do novo diretor editorial, Nelson de Matos, que editara muitas obras de caráter político na Editora D. Quixote, com uma nova conjuntura política em que tais obras ganhavam espaço.

Como já vimos, as obras políticas se tornaram um campo editorial promissor e lucrativo a partir do 25 de Abril, quando os entraves da censura e das perseguições da polícia política a esse tipo de livro deixaram de existir, ao mesmo tempo em que crescia de modo exponencial o interesse por essas obras. E a experiência de Portugal e o futuro havia sido extremamente positiva para a Arcádia, seja comercialmente, seja do ponto de vista da imagem pública da editora. Para os novos proprietários - o poderoso grupo CUF -, a edição dessas obras era vista com bons olhos, uma vez que eram rentáveis naquele momento.

Dessa forma, a Arcádia é um bom exemplo de editora que publicou obras políticas, mas que não pode ser classificada como uma editora política, nos termos por mim definidos. Tal opção editorial vinculava-se, primordialmente, ao aproveitamento das oportunidades que a nova situação política portuguesa proporcionava, e não há um 
posicionamento político de seus proprietários. Certamente o perfil de Nelson de Matos também foi importante para que tais obras ganhassem importância no catálogo da editora.

A Arcádia, todavia, praticamente cessou as suas atividades na primeira metade dos anos 1980. Em 2010 ela foi reinaugurada como parte do grupo Babel ${ }^{66}$.

\subsection{Paisagem Editora}

Rua José Falcão, 188 - Porto

Editores: Carmo Ferreira, João Barrote e José Viale Moutinho.

Início das edições: 1970.

Distribuição: Própria.

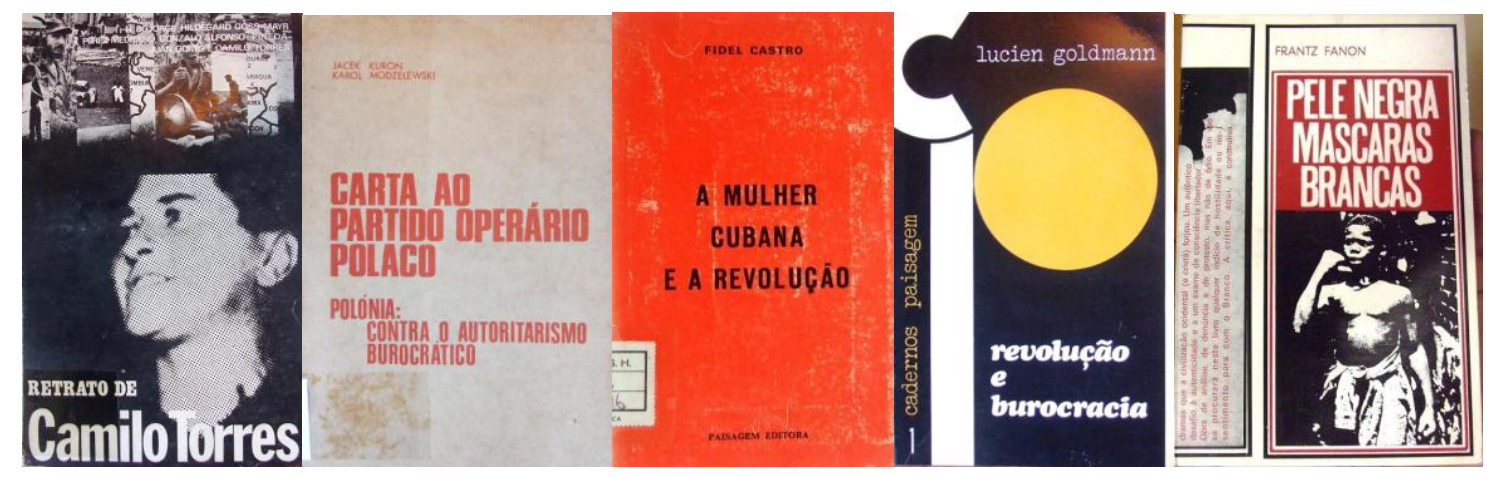

Editora criada pela Distribuidora Paisagem, do Porto, em 1970.

A Distribuidora Paisagem atuava com ênfase na área dos livros de sociologia e religiosos, e era a distribuidora, no Norte de Portugal, da Moraes Editora (ver Capítulo 8), que teve papel importante na abertura cultural e na informação de caráter religioso de orientação progressista nos anos 1960 no país.

O sócio-gerente da Paisagem, Carmo Ferreira - cuja esposa, Maria Amélia, era também sócia da empresa - resolveu em 1967 abrir uma livraria na cidade do Porto. Contratou então um jovem estudante da Escola Superior de Serviço Social, João Barrote, para dirigir a instalação da loja. Com os bons resultados da livraria, o passo seguinte foi começar a edição de livros, processo que se iniciou em 1969, também sob a direção de João Barrote. As primeiras edições surgiram em $1970^{67}$.

Barrote explica os termos em que começou o seu trabalho como editor na

\footnotetext{
${ }^{66}$ BEJA, op. cit., p. 31.

${ }^{67}$ Entrevista com João Barrote, freguesia de Arnoia, concelho de Celorico de Bastos, distrito de Braga, dia 22/6/2011.
} 
Paisagem: "Havia uma autonomia total [como editor], havia confiança pessoal da parte dos proprietários e creio que havia alguma afinidade em termos de pensamento social, de filosofia de vida entre nós". O que não quer dizer que não existissem restrições:

Havia uma restrição relacionada com o ambiente político, as coisas tinham que ser feitas com toda a discrição e cautela. Toda a gente sabia que livro com alguma implicação política era sujeito a apreensão. E não havia interesse nenhum da empresa em ter livros apreendidos. $^{68}$

Com estes cuidados, os primeiros títulos começaram a ser lançados. Eram livros de caráter político, ligados ao pensamento de esquerda, mas que se caracterizavam por não se relacionarem com o campo comunista ou mais próximo ao Partido Comunista Português. Alguns desses primeiros títulos vinculavam-se ao novo pensamento cristão progressista que começava a ter maior peso em Portugal. É o caso dos livros Construir a paz, do padre ganhador do Nobel da Paz Dominique Pire; de Retrato de Camilo Torres, de H. Bojorge; e de Evangelho e problemática social, de D. António Fragoso (bispo de Cratéus, no Brasil).

E havia também títulos com críticas ao comunismo soviético e a seus aliados, como são os casos dos livros Carta ao partido operário polaco, de Jacek Kuron e Karol Modzelewski, uma crítica ao "autoritarismo burocrático"; e Fidel 1959: antes e depois, de J. J. Nattiez.

Um dos colaboradores da editora nesta fase foi o historiador César Oliveira, que organizou alguns livros para a Paisagem ${ }^{69}$, entre os quais destacam-se Rosa Luxemburgo viva!, antologia de textos da autora polaco-alemã lançada em fevereiro de 1972; e O Estado, a democracia burguesa, a prática revolucionária e o anarquismo, antologia com textos de Bakunin, Kropotkin, Malatesta, Daniel Guérin e Engels (1972).

Ainda nesta primeira fase vale destacar a coleção Eros e Pessoa, que publicava títulos voltados para a educação sexual, tema pouco comum na época. Também importante foi a edição, em 1972, de Pele negra, máscaras brancas: um negro num mundo branco, do antilhano Frantz Fanon, autor do clássico Os condenados da terra.

Mas, como não podia deixar de acontecer naqueles anos, houve alguns problemas com a polícia política e a censura. Como lembra Barrote, em relação a certos títulos editados:

\footnotetext{
${ }^{68}$ Idem.

${ }^{69}$ OLIVEIRA, op. cit., p. 92-121.
} 
Alguns foram apreendidos, em menos de duas semanas a PIDE tinha apanhado a sua ração habitual, umas dezenas ou centenas de livros, mas havia milhares a circular, isso não impedia a circulação, havia uma circulação clandestina perfeitamente tranquila. Eu creio que havia uma tentativa de impedir a circulação de informação de caráter sociológico e político, mas isso não era tido como a ameaça principal ao regime, daí uma relativa moleza da atuação da polícia política. Eu só fui incomodado uma vez, posteriormente, por causa de um livro editado na Afrontamento, de autoria do José Capela, cujo título era Moçambique pelo seu povo [lançado em agosto de 1971]. ${ }^{70}$

De acordo com Barrote, sabia-se que poderia haver problemas com a PIDE, e isso "fazia parte do negócio também":

Do ponto de vista da empresa, havia uma certa intenção de contestação por parte das pessoas que a dirigiam, havia de algum modo uma consonância, um consenso em relação à necessidade e à utilidade social desse tipo de publicações, e os riscos eram prevenidos. E do ponto vista comercial foi compensador, sem dúvida nenhuma, não houve edição que não se esgotasse e de que não se fizesse reedições. $^{71}$

Mas, apesar dos bons resultados, em dois anos a empresa estava com dificuldades de pagamentos aos fornecedores e aos funcionários, provavelmente devido a má gestão. Isso levou à saída de Barrote, em função dos atrasos de salários. Barrote iria, em seguida, atuar em outras editoras na região do Porto, tendo sido um dos colaboradores da nova etapa da editora Afrontamento que se iniciou no começo dos anos 1970, colaborador da Textos Marginais (de António Daniel Abreu) e fundador das editoras Escorpião e Textos Exemplares (ver Capítulo 7).

Com a sua saída, houve um período de transição na Paisagem Editora e, em seguida, assumiu a direção editorial o jornalista e escritor José Viale Moutinho, provavelmente em 1973.

Nesta fase, principalmente a partir de 1975, há a edição de obras marcadamente políticas, certamente ainda sob o impulso do 25 de Abril. São publicados dois livros com discursos de Fidel Castro: CIA, imperialismo e crise económica e A mulher cubana e a revolução. E é lançada, também 1975, a coleção Cadernos Paisagem, que abre espaço para temas como os conselhos populares e a autogestão, com títulos como: Revolução e burocracia, de Lucien Goldman; O Estado, o plano e a república dos conselhos, de Jean Dru; Autogestão e dialéctica, de Maurice Montuclard; e Socialistas e

\footnotetext{
${ }^{70}$ Entrevista com João Barrote, op. cit.

${ }^{71}$ Idem.
} 
comunistas: informação e autogestão, de Rémi Hess, Yves Durrieu e Yvon Bourdet.

A distribuição dos livros era feita pela própria Livraria Paisagem, que, como vimos, era originalmente distribuidora, atividade que continuou a exercer.

A Paisagem ainda publicou títulos de caráter político até 1977. Entre 1970 e 1977 a editora publicou cerca de 35 títulos com estas características. Desde meados da década já predominava uma linha editorial mais eclética, com a publicação de coleções como Paisagem (literatura), Arte Poética (poesia), Construir (costumes), Técnica e Escolares Paisagem. A editora funcionou até 1988.

\subsection{Edições 70}

Av. Duque de Ávila, 69 r/c Esq. - Lisboa

Editor: Joaquim Soares da Costa, Carlos Araújo.

Fundação: 1970.

Distribuição: Livraria Quadrante, O Século, Diglivro.

Distribuidor no Brasil: Livraria Martins Fontes.
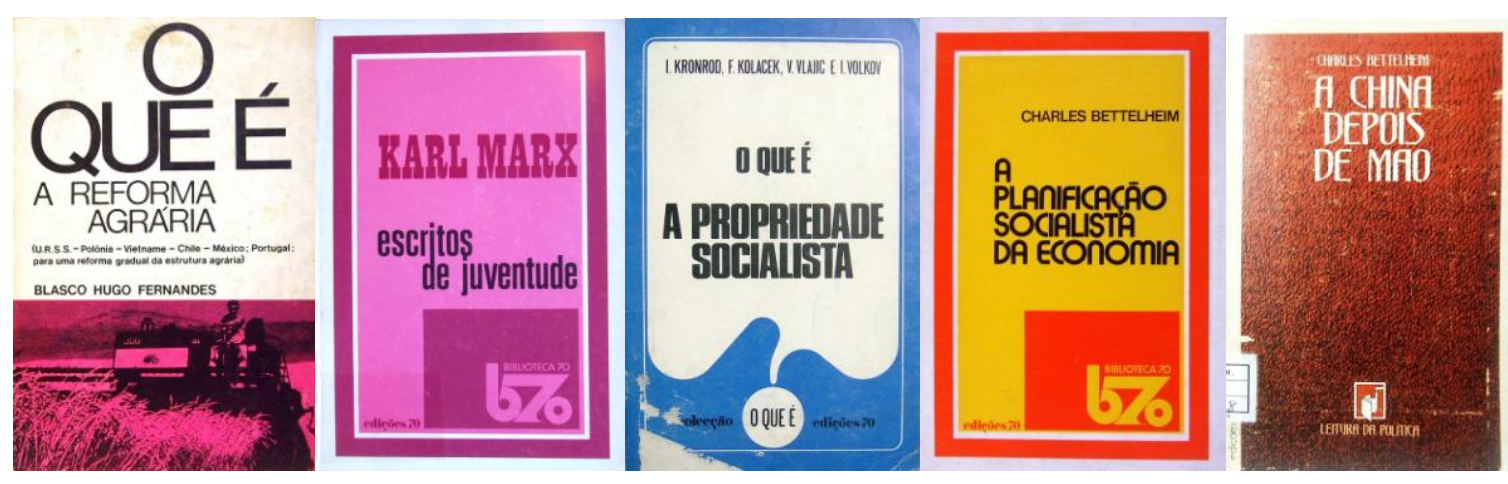

Editora fundada em fins de 1970 por Joaquim Soares da Costa, que havia sido gerente da filial da Livraria Divulgação em Lisboa, e havia sido também diretor literário da Portugália Editora na segunda metade dos anos $1960^{72}$.

A editora visava que as suas publicações fossem "o reflexo da decisão de apresentar propostas sérias de reflexão, necessariamente abertas ao confronto, à polémica até, numa perspectiva crítica rigorosa, mas sem exclusão de pontos de vista", expressando "uma concepção de cultura e informação sem dogmas nem fronteiras, num confronto sistemático com a realidade em processo" $"$.

\footnotetext{
72 "Entrevista com Joaquim Soares da Costa (Edições 70)”, op. cit., p. 14-15.

73 Texto publicado na última página do livro $O$ que é a reforma agrária, de Blasco Hugo Fernandes (Lisboa: Edições 70, maio, 1975).
} 
A primeira coleção lançada intitulava-se O Que É e "pretendia fornecer elementos de discussão e análise sobre problemas concretos da realidade sociopolítico e cultural portuguesa", de acordo com o editor Joaquim Soares da Costa ${ }^{74}$. O primeiro volume da coleção foi o livro $O$ que é a inflação (Porque sobem os preços), de Armando de Castro, publicado em outubro de 1970. O livro teve grande sucesso, como lembra Costa:

Foi de facto um livro importante no contexto social e político da época, que eu pedi ao Armando de Castro que escrevesse. A $1^{\text {a }}$ edição, de três mil exemplares, esgotou-se em cinco dias; a $2^{\mathrm{a}}$, de cinco mil, em três semanas. Ao todo fizeram-se quatro edições, com um total creio que de 18 mil exemplares. Foi um sucesso estimulante, e que deu durante anos a tônica da ação da editora. ${ }^{75}$

Os primeiros títulos da editora tiveram claro viés político. Além do citado $O$ que é a inflação, foram lançados: O que é o mercado comum (A integração e Portugal), de Sérgio Ribeiro (1971); O que é a reforma agrária, de Blasco Hugo Fernandes (1971); e Luuanda - estórias, de José Luandino Vieira (1972).

Este último título, como se sabe, recebera em 1965 o Grande Prémio da Novelística concedido pela Sociedade Portuguesa de Escritores (SPE). Na época o escritor angolano era prisioneiro político, e cumpria pena de 14 anos por "práticas terroristas" . Thal fato levou à extinção da SPE por despacho de maio daquele ano do ministro da Educação Nacional, pois a obra fora considerada "profundamente ofensiva ao sentimento nacional" ${ }^{\prime 77}$. Por isso, a edição de 1972 foi apreendida pela polícia política e editora multada em 30 mil escudos. A pedido do editor, foram testemunhas nesse processo os escritores Ferreira de Castro e Jorge de Sena, tendo este último afirmado que a obra desempenhava "papel primordial no desenvolvimento da literatura angolana de expressão portuguesa" ${ }^{, 78}$.

Mas foi com o 25 de Abril que, durante certo tempo, as edições políticas ganharam protagonismo no catálogo da editora. A coleção Biblioteca 70 editou quase 30 volumes, entre 1974 e 1976, de obras políticas, entre as quais se destacam quatro obras com textos de Karl Marx: O capital (Edição popular), 1974; Sociedade e mudanças

\footnotetext{
74 "Entrevista com Joaquim Soares da Costa...”, op. cit., p. 15.

${ }^{75}$ Idem.

${ }_{76}$ "Sinopse do livro Luaanda". Página eletrônica a Editora Almedina. Disponível em: <ttp://www.almedina.com.br/catalog/product_info.php?products_id=4425>. Acesso em 17/11/2012.

77 "Sociedade Portuguesa de Escritores" (verbete). In: BARRETO, António e MÓNICA, Maria Filomena (coords.). Dicionário de História de Portugal (Suplementos). Porto: Livraria Figueirinhas, 1999-2000, vol. 9, p. 464.

78 "Sinopse do livro Luaanda", op. cit.
} 
sociais (1974); Sobre a religião (1975); e Escritos da juventude (1975).

Na mesma coleção destacam-se ainda os seguintes títulos: A revolução russa, de François-Xavier Coquin (1974); Para compreender o pensamento de Karl Marx, de Henri Lefebvre (1974); A concepção marxista da história, de Helmut Fleischer (1975); Reforma e revolução, de André Gorz (1975); Crise da sociedade contemporânea, de R. Barthes, R. Dumont, A. Sauvy, A. Touraine, M. Duverger, O. Palme, E. Marie, R. Aron e M. Rocard (1975); A transição para o socialismo, de Charles Bettelheim e Paul Sweezy (1976); Classe operária e revolução, de Fréderique Bon e M-E. Burnier (1975); A planificação socialista da economia, de Charles Bettelheim (1975); Imperialismo e acumulação de capital, de Rosa Luxemburgo e Nikolai Burkharine (1976); Humanismo socialista, de E. Fromm, L. Goldmann, H. Marcuse, U. Cerroni, A. Schaff, K. Kosik, E. Bloch, R. Supek, T. Bottomore e outros (1976); e A questão comunista, de Enrico Berlinguer (1976).

Além destes títulos, a editora publicou também a coleção Os Caminhos da Liberdade, com livros como: Cuba: guerra revolucionária, de Ernesto Che Guevara (1975); A vida de Lenine, de Nina Gourfinkel (1976); e Tejas verdes: diário de um campo de concentração no Chile, de Hernán Valdés (1977).

As Edições 70 haviam também se tornado uma espécie de "editora oficial dos novos Países Africanos de Expressão Portuguesa",79, graças à edição de obras de José Luandino Vieira (como A vida verdadeira de Domingos Xavier, 1974; No antigamente, na vida, 1974; e Velhas estórias: contos, 1975) e às coleções Vozes de África e Autores Angolanos, dedicadas à literatura africana.

Em 1976, a editora fazia o seguinte balanço de suas atividades:

Nos seis anos que medeiam entre a fundação e o momento atual, o seu desenvolvimento tem-se processado a ritmo regular; em 1971 foram publicados quatro títulos, em 1972, seis, em 1973, dez, e em 1974 cerca de 20 títulos novos, além de várias reedições; em 1975 e parte de 1976 tem continuado a cumprir-se um programa de expansão refletido num volume de produção que ronda os 30 títulos novos, acompanhados de sucessivas reedições de outros. ${ }^{80}$

Em 1981 uma nova coleção foi lançada, chamada Leitura da Política, e seus dois primeiros títulos foram: O Estado em discussão, de Etienne Balibar, Nico Poulantzas e outros; e A China depois de Mao, de Charles Bettelheim.

\footnotetext{
${ }^{79}$ LEITE, op. cit., p. 202.

80 "Edições 70, Lda.". In: AA.VV. Editores portugueses na IV Bienal Internacional do Livro São Paulo: 14 a 22/Agosto/1976. Lisboa: Associação Portuguesa dos Editores e Livreiros, 1976.
} 
No entanto, deve-se destacar que a Edições 70 nunca foi uma editora predominantemente política. E também nunca esteve ligada a qualquer grupo ou partido político. As obras de ficção, acadêmicas e esotéricas tiveram desde o início predomínio em seu catálogo. Por exemplo, a coleção Signos editou obras de Eduardo Prado Coelho, Jorge de Sena, Roland Barthes, Julia Kristeva e Noam Chomsky. E a coleção Esfinge dedicava-se a obras sobre astrologia, ocultismo e vida extraterrestre.

Em 1977 Carlos Araújo - que havia trabalhado nas editoras D. Quixote e Sá da Costa, além de ter sido um dos fundadores da editora Teorema - foi contratado pela Edições 70. Ele ajudou a desenvolver as coleções existentes e criou outras, como Perspectivas do Homem (de antropologia), Vozes da América Latina (literatura), e O Lugar da História, além de iniciar a linha de história em quadrinhos (banda desenhada) para adultos da editora ${ }^{81}$.

Com atuação até hoje, a editora especializou-se em obras de ciências humanas e sociais. Em 2005 foi adquirida pelo Grupo Almedina.

\subsection{Líber - Editorial e Publicidade Portugal Brasil}

Duque de Ávila, 28-2 ${ }^{\circ}$ - Lisboa / Av. 5 de Outubro, 89, 8º esq. - Lisboa (1975) / Av. Álvares Cabral, 84, r/c Do - Lisboa (1978)

Início das edições: 1975.

Distribuição: Regimprensa.

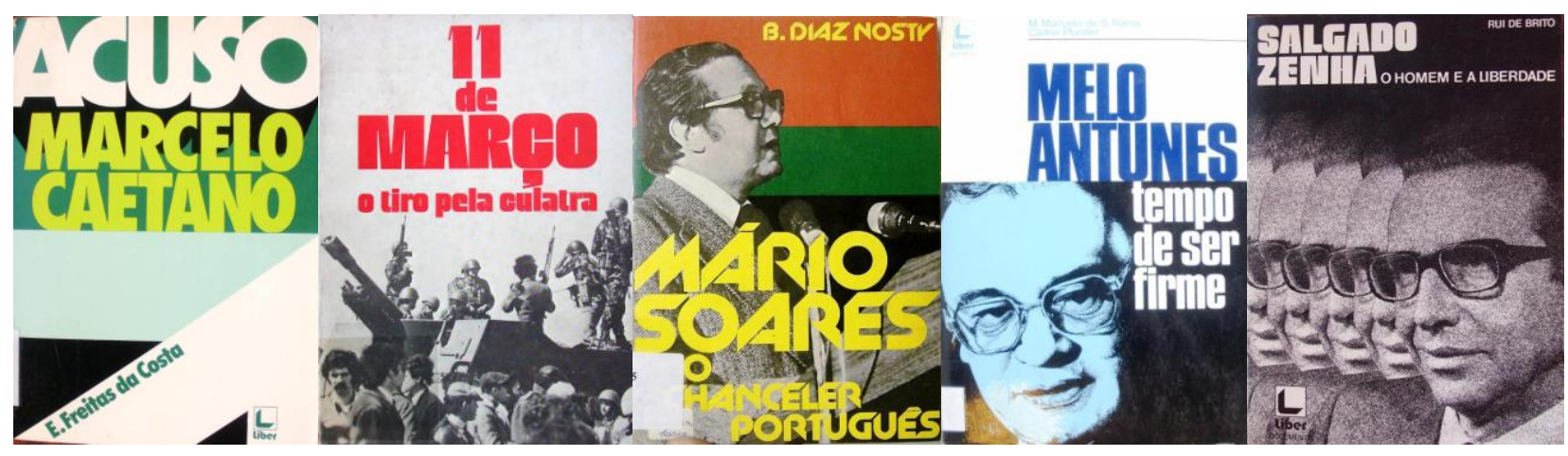

Editora que publicou entre 1975 e 1978 cerca de 30 obras de caráter político. O selo Líber surgiu em 1974 e voltava-se para obras políticas, algumas das quais simpáticas ao Partido Socialista - por exemplo, Mário Soares: um combatente do socialismo e Mário Soares, o chanceler português, ambas de B. Diaz Nosty e editadas

\footnotetext{
${ }^{81}$ PESSOA; MOREIRA, op. cit.
} 
em 1975; Salgado Zenha: o homem da liberdade, de Rui de Brito (maio, 1975), Melo Antunes: tempo de ser firme, de Maria Manuela Rama e Carlos Plantier (janeiro, 1976).

Nesse período editou obras sobre a resistência à ditadura em Portugal e sobre a realidade nacional pós-25 de Abril. Alguns dos títulos publicados foram: Humberto Delgado: assassinato de um herói, de Mariano Robles Romero-Robledo e José António Novaes (1974); "Dossier" Goa. Vassalo e Silva: a recusa de um sacrifício inútil, coordenado por Botelho da Silva (1975); 11 de Março: o tiro pela culatra, de Dinis de Abreu (1975); 1 ano da jovem democracia portuguesa: saúde, a ferida aberta, de João Alves da Costa (1975); Acuso Marcelo Caetano, de E. Freitas da Costa (1975); Eleições em Abril: diário de campanha, de Dinis de Abreu (1975); A sombra de Ho Chi Minh: a derrota norte-americana no Vietname, de J. N. Servent (1976); A Revolução Cubana na Íbero-América, de Rosendo Canto Hernández (1976); A comuna das Astúrias: 15 dias de poder proletário, de B. Diaz Nosty (1976); A funda, $7^{\circ}$ volume, de Artur Portela (1977); Figuras que Abril deu, de Rui de Brito (1977).

A Líber era uma editora profissional e com distribuição comercial feita pela Distribuidora Regimprensa. Até 1980 publicou cerca de uma centena de títulos, caracterizando-se como uma editora eclética, cuja maior parte das obras era de literatura infantil, histórias em quadrinhos (banda desenhada) e ficção estrangeira.

Existe também uma editora chamada Meribérica/Líber, que publica livros infantis e a coleção de livros de Asterix.

\subsection{Edições Rés}

Rua Lima Júnior, 64 - Porto

Editores: Reinaldo Carvalho e António Daniel Abreu.

Fundação: 1975.

Distribuidora: DIG.

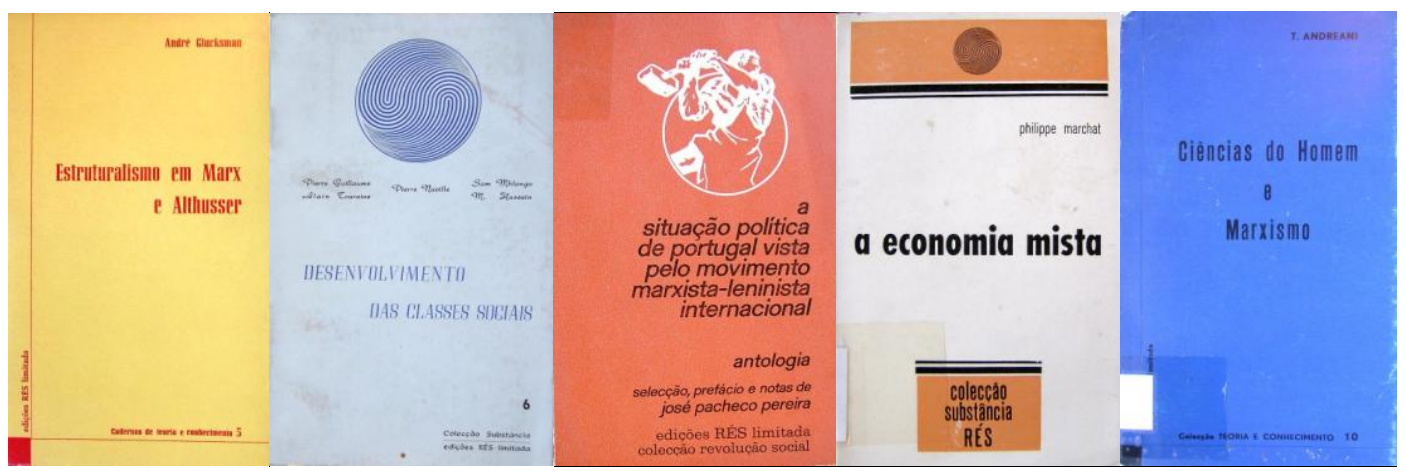


Editora criada em 1975 por Reinaldo Carvalho e António Daniel Abreu, no Porto. Carvalho era um empresário ligado ao Partido Socialista (PS), e Abreu era editor, e já havia criado as editoras Cadernos Para o Diálogo e Textos Marginais (ver Capítulo 7). Eles foram apresentados um ao outro por um amigo comum, Fernando Fernandes, da Livraria Leitura, "que era a livraria onde se reunia todo o pessoal de esquerda do Porto", como conta António Abreu ${ }^{82}$.

Carvalho queria abrir uma editora e procurava um sócio, e Abreu buscava novas formas de atuação no mercado editorial após o 25 de Abril. A ideia de ambos era criar uma grande editora. "A Rés não era nada voltada para a política, era uma empresa", lembra Abreu. Mas havia uma diferença importante entre os dois sócios, de acordo com Abreu: "O Reinaldo era um empresário mesmo, ele via aquilo como um negócio, e a minha visão era outra, sempre foi mais romântica”.

A editora acabou por ter um perfil mais acadêmico, voltando-se principalmente para as áreas de filosofia, educação e economia.

As edições de livros de caráter político se concentraram nos anos de 1975 e 1976, quando a Rés publicou autores como Marx (Economia nacional e economia política), Engels (Introdução à economia política), Bakunin (Conceito de liberdade), Proudhon (A nova sociedade) e André Glucksman (Estruturalismo em Marx e Althusser), além dos dois volumes da coleção Revolução Social, dirigida por José Pacheco Pereira: A situação política de Portugal vista pelo movimento marxistaleninista internacional e Sem independência nacional, um povo nada terá: textos e artigos de marxistas-leninistas sobre a luta pela independência, ambos compilados pelo diretor da coleção e editados em 1975.

Mas logo a editora assumiu seu caráter acadêmico e os livros de caráter mais claramente político perderam espaço em seu catálogo.

António Abreu também não ficou muito tempo como sócio da Rés, e cerca de um ano depois do início das atividades deixou a empresa para abrir uma nova editora, a Nova Crítica (ver item a seguir).

Um dos livros políticos editados em 1975 foi incluído na secção "Os best-seller da quinzena" do jornal Expresso. Trata-se da obra Partidos e pessoas, de Reinaldo Carvalho, que aparece em $4^{\circ}$ lugar na lista publicada em 7 de junho de $1975^{83}$.

\footnotetext{
${ }^{82}$ Entrevista com António Daniel Abreu, São Paulo, 23/8/2012. Todas as demais falas de Abreu provêm desta entrevista.

83 "Os best-seller da quinzena". Secção do jornal Expresso, 1975. Hemeroteca Municipal de Lisboa.
} 
As edições políticas da Rés parecem se dever mais ao momento político em que a editora foi criada, ou seja, o ano de 1975, quando a agitação política em Portugal decorrente do 25 de Abril ainda era intensa, do que a um projeto editorial que estivesse voltado para esse tipo de livro. O fato de Reinaldo Carvalho ser militante do PS, assim como a experiência de António Abreu como editor de obras políticas, foram também fatores que no primeiro momento levaram a Rés a voltar-se um pouco mais para essa área. Mas logo o perfil da editora se estabeleceu de modo mais claro, e a Rés definiu-se como uma editora de obras acadêmicas na área de ciências sociais e humanas, tendo publicado desde o seu surgimento mais de duas centenas de títulos.

Em 1975 e 1976 a Rés editou cerca de 20 títulos de caráter político.

A Rés ainda continua em atividade e desde 2011 está sob a direção de Joana Carvalho, filha de Reinaldo Carvalho, e de seu marido, João Nuno Marinho ${ }^{84}$.

\subsection{Editora Nova Crítica}

Rua Costa Cabral, 456, $3^{\mathrm{a}}$ - Porto

Livraria Nova Crítica - Pr. Mousinho de Albuquerque, 113 - Porto (1979)

Início das edições: 1975.

Editor: António Daniel Abreu.
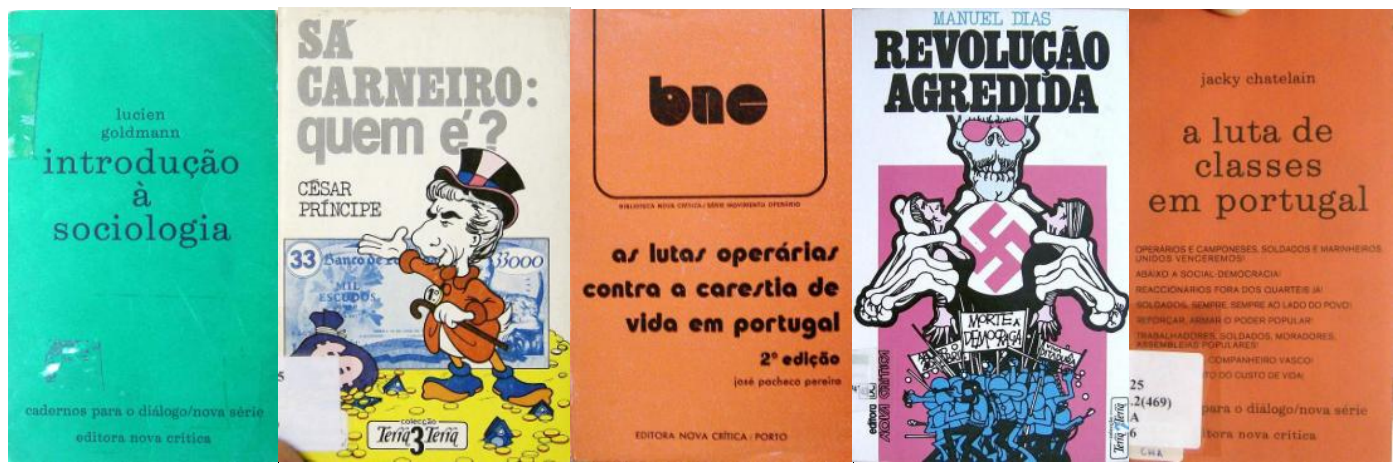

A Editora Nova Crítica foi criada em 1975 por António Daniel Abreu depois de sua saída da Edições Rés. Como vimos, Abreu havia também criado, anteriormente, as editoras Cadernos Para o Diálogo e Textos Marginais.

A Nova Crítica mantinha uma importante linha de obras políticas, com um perfil mais voltado para o público universitário, com as coleções Biblioteca Nova Crítica, Cadernos Para o Diálogo/Nova Série e Terra a Terra, mas a editora voltava-se também ${ }^{84}$ PEREIRA, Ana Isabel. "Da editora à livraria palco de eventos culturais". 05/05/2011. Disponível em:
http://praca.porto24.pt/2011/05/05/da-editora-a-livraria-palco-de-eventos-culturais/>. 
para outros temas, como folclore, contos populares e literatura, que eram acolhidos nas coleções Outras Terras Outras Gentes, Planetarium, Andanças, Sucessos e Guias.

Entre 1975 e 1980, a Nova Crítica publicou cerca de 20 obras de caráter político, entre as quais destacam-se: Para a história da Revolução Cultural chinesa: antologia de documentos fundamentais (1975); As lutas operárias contra a carestia de vida em Portugal: a greve geral de Novembro de 1918, de José Pereira Pacheco (1976); A luta de classes em Portugal, de Jacky Chatelain (1977); A mensagem de Paulo Freire: teoria e prática da libertação (1977); Realismo, arte de vanguarda e nova cultura, de Urbano Tavares Rodrigues (1978); Marx e Engels como historiadores da literatura, de Georges Lukacs (1979); Revolução agredida, de Manuel Dias (1979); Sá Carneiro: quem é?, de César Príncipe (1980).

A Nova Crítica tinha também uma livraria no Shopping Center Brasília, que havia sido inaugurado no Porto no final dos anos 1970. Foi a última editora que Abreu criou em Portugal, pois em 1986 ele mudou-se para o Brasil, onde continua atuando no setor editorial $^{85}$.

${ }^{85}$ Entrevista com António Daniel Abreu em São Paulo, 23/8/2012. 


\section{PARTE III}

A EDIÇÃO POLÍTICA E SEU PAPEL NAS LUTAS CONTRA A DITADURA 


\section{O PAPEL DA EDIÇÃO POLÍTICA EM PORTUGAL}

\subsection{A edição política e a denúncia dos crimes da ditadura em Portugal (1968-80)}

Alguns livros políticos editados em Portugal durante o período aqui estudado tiveram importante papel na oposição ao regime e na denúncia dos crimes, arbitrariedades e violências cometidos pela ditadura de Salazar e Caetano, contribuindo para que os portugueses tivessem uma ideia mais clara do legado que o longo período autoritário deixou ao país. A edição desses livros aconteceu mesmo durante a ditadura, apesar da censura, e cresceu após o 25 de Abril.

Apresento neste capítulo um levantamento parcial dos principais títulos editados entre 1968 e 1980 que se caracterizaram pela oposição ao Estado Novo e por denunciar as violências cometidas pela ditadura, de modo a que possamos ter uma noção mais concreta da participação das editoras e dos livros políticos na ação política real antes e depois do 25 de Abril. Buscarei entender o papel dessas editoras e desses livros na denúncia do autoritarismo e do seu legado e mostrar quais editoras publicaram tais obras, procurando compreender suas motivações políticas e ideológicas.

Para realizar este levantamento de títulos, a primeira questão a enfrentar é a necessidade de estabelecer certos critérios para a seleção e classificação dos livros que o comporiam. Tendo em conta que minha ideia é verificar aquelas obras que de modo mais evidente e direto se dispunham a manifestar posturas de oposição ao regime e a tornar pública a estrutura repressiva construída durante o período do Estado Novo, decidi incluir neste levantamento apenas as obras de caráter não-ficcional (reportagens, relatos, testemunhos, memórias, autobiografias, diários, ensaios, obras jurídicas etc.) que cumpram esse objetivo. Estão excluídas, portanto, obras de ficção - apesar de existirem também obras ficcionais que retratavam esta temática. Por terem pouca relevância no período em foco, estão excluídas também as obras de caráter marcadamente acadêmico, que surgem em maior quantidade, sobre o tema, a partir da década de 1980.

Outro critério utilizado é que os livros incluídos devem ter sido editados em Portugal. No caso de obras editadas antes do 25 de Abril, estão incluídas tanto obras que foram proibidas de circular ou parcialmente apreendidas ("fora de mercado") como aquelas que não o foram. 
Assim, classifiquei os livros que compõem este levantamento da seguinte forma:

- Livros com documentos da oposição democrática;

- Obras que descrevem a repressão durante o salazarismo;

- Memórias e relatos sobre a prisão política;

- Livros sobre a PIDE/DGS (Polícia Internacional e de Defesa do Estado / Direcção Geral de Segurança);

- Livros sobre a censura em geral;

- Documentos judiciais sobre a repressão (pré-25 de Abril)

Desse modo, não estão contemplados aqui os livros que tratam, em termos genéricos, da resistência ao fascismo. Tais obras somente foram incluídas quando traziam referências significativas à repressão política ou a movimentos de oposição.

No caso das obras editadas antes de 25 de Abril, há uma categoria de livros que é específica dos primeiros anos da década de 1970: trata-se da publicação de documentos judiciais sobre a repressão, ou seja, das peças que formavam esses processos, o que tornava difícil a sua censura pelo governo. Foi uma forma encontrada por setores oposicionistas para denunciar as arbitrariedades e violências do regime contra aqueles que de alguma forma o questionavam. Após a queda de Caetano, a edição desse tipo de obra praticamente deixou de existir, pois se tratava, de fato, de uma maneira de driblar a censura.

\subsubsection{Livros de oposição antes do 25 de Abril}

Foi considerável a quantidade de livros de oposição lançados entre 1968 e abril de 1974, inclusive aqueles sobre as arbitrariedades e a repressão do regime. Apesar da censura e do clima político opressivo - atenuado apenas por breve período durante a "primavera marcelista", que permitiu alguma ampliação dos debates políticos -, não foi sem importância a atuação de alguns editores, livreiros e autores para a edição e a circulação de obras dessa natureza, como veremos em seguida. Ainda que a lei estabelecesse a obrigatoriedade de censura prévia aos livros que tratassem de "assuntos de carácter político ou social", a verdade é que a grande maioria dos editores de livros

\footnotetext{
1 MOURA, Pereira F.; NEVES, Mario; FERNANDES, Rogério; ZENHA, Salgado. O estatuto da imprensa. Coleção Cadernos de Hoje. Lisboa: Prelo, 1968, p. 14-15. A base legal para a censura prévia
} 
não submetia suas obras previamente à censura, sujeitando-se ao risco de vê-las apreendidas após a edição, com as perdas econômicas que isso também implicava ${ }^{2}$.

Houve, portanto, iniciativas editoriais que tinham claramente o objetivo de denunciar a ditadura. É o caso da série de três livros de teor oposicionista intitulada "Documentos da Hora Presente", lançada em 1969, e composta pelos seguintes livros: Escritos políticos, de Mário Soares; Horizontes fechados: páginas de política, de Raul Rego; e Falar claro, de José Magalhães Godinho. Todos foram lançados como "Edição do Autor", mas parecem fazer parte de uma iniciativa conjunta e articulada, pois além de comporem uma coleção, tinham também o mesmo desenho gráfico, inclusive na capa. Além disso, a Editorial Inquérito, de Eduardo Salgueiro, sempre aparecia como "depositária" dos livros.

Também foram editados alguns livros que tratavam dos congressos e das campanhas da oposição para as "eleições" de 1969 e 1973, quase sempre reproduzindo os documentos elaborados pelos oposicionistas. É o caso dos seguintes livros:

- Para um dossier da oposição democrática. Organização, prefácio e notas de Serafim Ferreira e Arsénio Mota. Edição dos organizadores. Tomar: Nova Realidade, Outubro, 1969.

- As eleições de Outubro de 1969: documentação básica, coordenado por João Palma-Ferreira. Mem-Martins: Europa-América, 1969;

- II Congresso Republicano de Aveiro: Teses e documentos. Lisboa: Seara Nova, 1969.

- Documentos políticos, precedidos de uma Introdução onde se pretende contribuir para um diagnóstico da vida pública nacional, de António Alçada Baptista. Lisboa: Moraes, 1970;

- Dossier Candidatura, Leiria 1969, de Sérgio Ribeiro. Lisboa: Prelo, 1970;

- Eleições de 1969. Documentos eleitorais da Comissão Democrática do Porto. Seleção de Virgínia Moura. Porto, 1971. Distribuição: Editorial Inova

- Eleições presidenciais: subsídios para a história das candidaturas Norton de Matos (1949), Quintão Meireles (1952) e Humberto Delgado (1958). Lisboa: Delfos, 1971.

aos livros era o Decreto 22.469, de 11 de abril de 1933.

2 Depoimentos de José Antunes Ribeiro e Sérgio Ribeiro, editores da Ulmeiro e da Prelo, respectivamente, em 6 de março de 2012 no ciclo de debates "Livros que tomam partido", organizado por mim na Biblioteca-Museu República e Resistência, em Lisboa, com o apoio do Instituto de História Contempôranea da Universidade Nova de Lisboa. 
- Movimento Democrático do Distrito de Setúbal. Teses apresentadas ao III Congresso da Oposição Democrática, Aveiro, 4/8 de Abril de 1973. Edição da Comissão Distrital de Setúbal do III Congresso da Oposição Democrática. Setúbal, Julho, 1973;

- Intervenção política. Democratas de Braga, 1949-1970. Seleção e edição de Humberto Soeiro. Outubro, 1973. Distribuição: Editorial Inova.

- Ano de eleições, de José Magalhães Godinho. Lisboa: Editorial República, 1973.

- Congresso da Oposição Democrática: conclusões. Lisboa: Seara Nova, $1973 / 1974$.

- Teses $3^{o}$ Congresso da Oposição Democrática de Aveiro. Aveiro, 4 a 8 de Abril de 1973. Lisboa: Seara Nova, 1974.

Foram, portanto, 12 títulos que reproduziam documentos da oposição democrática, com diagnósticos e críticas sobre a situação do país e propostas de mudança nas políticas de governo.

Em novembro de 1968, a Editora Prelo, próxima ao PCP, publicou o livro $O$ estatuto da imprensa, que trazia um debate entre Francisco Pereira Moura, Mario Neves, Rogério Fernandes e Salgado Zenha sobre a Lei de Imprensa em Portugal e as limitações e constrangimentos que ela impunha à liberdade de edição e, portanto, de expressão. Com este mesmo intuito, dois outros livros foram publicados: Da liberdade de imprensa, de Alberto Arons de Carvalho e António Monteiro Cardoso (Lisboa: Meridiano, Junho, 1971) e A censura e as leis de imprensa, de Alberto Arons de Carvalho (Lisboa: Seara Nova, 1973).

Uma das linhas mais prolíficas de publicações oposicionistas antes do 25 de Abril foi a edição de documentos judiciais sobre a repressão. Estes livros em geral reproduziam as peças jurídicas que formavam esses processos: pedidos de habeas corpus, medidas de segurança, reprodução da legislação em vigor, autos de interrogatório, acórdãos de tribunais etc. Tratava-se, portanto, de documentos oficiais, o que tornava embaraçoso para o governo a sua censura. Foi, sem dúvida, um subterfúgio inteligente para dificultar a censura, apesar de boa parte desses livros terem sido postos "fora de mercado", ou seja, foram censurados da mesma forma. Todavia, a censura nem sempre significava, como vimos em outros capítulos, que o livro efetivamente deixava 
de circular.

Nessa linha, em janeiro de 1969, Salgado Zenha publicou Quatro causas: peças forenses (Lisboa: Liv. Morais), em que apresentava casos de defesa de perseguidos políticos.

Mas foi sem dúvida a coleção Bezerro D’Ouro, publicada pela Editora Afrontamento, do Porto, a responsável pelo aparecimento da maior parte das obras de denúncia de arbitrariedades baseadas na edição de processos judiciais. O nome da coleção parece ter sido inspirado em um pequeno texto de apresentação do livro que seria o primeiro da série (Em defesa de Joaquim Pinto de Andrade, de Mario Brochado Coelho $)^{3}$. No referido texto, Brochado Coelho diz:

“... os que se preocupam ou se deixam sensibilizar pelos problemas ligados à concepção do direito e sua relação com o poder poderão, ao examinar as peças dos autos ora publicadas, recriar algumas das suas formulações pessoais e até, porventura, encontrar fundamento para novas análises desse bezerro de ouro da sociedade de classes que é o direito". 4

Eis os livros que formam a coleção:

1 Em defesa de Joaquim Pinto de Andrade, de Mario Brochado Coelho (julho, 1971);

2 A prisão do doutor Domingos Arouca, de Salgado Zenha (novembro, 1972);

3 Estudantes de Coimbra no plenário: peças de um processo, de António Monteiro Taborda, Arnaldo Mesquita, Joaquim Loureiro, José Luís Nunes, Mario Brochado Coelho, Raul Castro e Rui Polónio de Sampaio (janeiro, 1973);

4 Uma farsa eleitoral: o caso do Sindicato dos Metalúrgicos de Aveiro. Peças de um processo, de José Afonso e Mário Brochado Coelho (fevereiro, 1973);

5 O caso da capela do Rato no Supremo Tribunal Administrativo, de Salgado Zenha, Francisco de Sousa Tavares, Jorge Sampaio, José Vasconcelos Abreu e José Vera Jardim (março, 1973);

6 O julgamento dos padres Macúti, de João Afonso dos Santos, Carlos Adrião Rodrigues, António Pereira Leite e Willem Gerard Pott (agosto, 1973);

7 O segundo julgamento do padre Mário, de Eloy Pinho, Fernanda Gomes, Helena Policarpo, Luís Humberto, José Gomes Bandeira, José Capela, Manuel António

\footnotetext{
${ }^{3}$ A primeira edição dessa obra saiu pela Afrontamento, como edição do autor, mas sem fazer parte da coleção - que ainda não existia. A $2^{a}$ edição já saiu como parte da coleção, sendo o seu primeiro volume.

${ }^{4}$ COELHO, Mario Brochado. Em defesa de Joaquim Pinto de Andrade. Porto: Afrontamento, 1971, p. 9.
} 
Pina e Santos Ribeiro (fevereiro, 1974);

8 Angolanos no Tarrafal: alguns casos de habeas corpus, de Fernando de Abranches-Ferrão, Francisco Salgado Zenha, Levy Baptista e Manuel João da Palma Carlos (janeiro, 1974);

9 Agarra que é estudante! Um caso de justiça repressiva, de Rui Polónio de Sampaio (fevereiro, 1974).

Como vemos, os livros abordavam temas centrais relacionados à ação repressiva da ditadura: a perseguição a expoentes da luta anticolonial, do movimento estudantil, da Igreja progressista e do sindicalismo, além de uma obra ligada à prisão política do Tarrafal.

Na mesma linha de edição de documentos judiciais sobre a repressão, cabe destacar o livro Subversão ou evangelho? O processo do pároco de Macieira da Lixa no Tribunal Plenário do Porto, de José da Silva (Porto: Editor Eloy A. Pinho, 1971), além de duas obras do advogado Raul Castro, do Porto: Estudantes do Porto no Tribunal de Polícia: duas alegações para o Tribunal da Relação do Porto (Porto: Edição do Autor, setembro, 1973) e Reunião ilegal ou acusação irreal? Alegação de recurso para o Tribunal da Relação do Porto no processo dos 90 estudantes do Tribunal de Polícia (Porto: Edição do Autor, março, 1974). Nestas duas últimas obras aparece a informação de que a sua distribuição era feita pela Editorial Inova, do Porto, de propriedade de José da Cruz Santos.

Obra de grande importância na denúncia do regime foi Presos políticos: documentos 1970-1971, publicada pela Comissão Nacional de Socorro aos Presos Políticos (CNSPP), com edição de Armando de Castro, Francisco Pereira de Moura e Luís Felipe Lindley Cintra (Porto: Afrontamento, março/abril, 1972). Este livro, em que já o título é uma denúncia, traz uma síntese do programa da CNSPP e reproduz os documentos referentes aos dois primeiros anos de ação da entidade, como circulares, cartas e telegramas.

Merecem ainda menção entre as obras que representaram uma manifestação de denúncia da ditadura antes do 25 de Abril, os seguintes títulos:

- Memórias de um resistente (Narrativa romanceada), de Alexandre Cabral. Porto: Inova, dezembro, 1970;

- O dilema da política portuguesa, de Sottomayor Cardia. Lisboa: Prelo, 1971; 
- Cela sem número, de Arnaldo Pinto. Porto: Edição do Autor, maio, 1972;

- Portugal sem Salazar, de Mario Mesquita. Lisboa: Assírio\&Alvim, outubro, 1973

- Direitos, liberdades e garantias individuais, de José Magalhães Godinho. Lisboa: Seara Nova, 1973;

- Carta aberta ao presidente do Conselho: análise de um regime, de José Magalhães Godinho. Coleção Cadernos República. Lisboa: Editorial República, outubro, 1973;

- "Continuidade": glosas ao discurso eleitoral do prof. Marcelo Caetano, de Raul Rego. Coleção Cadernos República. Lisboa: Editorial República, outubro, 1973.

O jornalista Martinho de Freitas, na sua já citada série de oito artigos no jornal Época sobre o "movimento editorial de intenção revolucionária" em Portugal, destacou também o que chamou de "textos para-revolucionários" de autores portugueses". Esse levantamento incluiu obras publicadas em 1971 e no primeiro semestre de 1972. Como já assinalado, o jornal Época era claramente identificado com a ditadura.

Muitos dos tais "textos para-revolucionários" listados por Freitas podem ser classificados como livros de denúncia dos crimes da ditadura, e alguns deles efetivamente são os mesmos que apresentei anteriormente. Mas o olhar de Freitas está focado em obras vinculadas de algum modo ao "socialismo científico" e que, segundo ele, "convergem no sentido de facilitar a acção revolucionária, minando as estruturas oponíveis ou postulando alinhamentos colaborantes" e agem "pela inculcação das perspectivas doutrinárias adoptadas [e] pelo esvaziamento e corrosão das estruturas que lhe são adversas" 6 .

De toda forma, alguns livros apresentados em seu levantamento complementam uma lista inicial de obras que na prática realizam a denúncia das arbitrariedades do regime. Mas, como já destaquei, Freitas busca questionar a "liberdade" que estas obras gozam, sutilmente postulando providências governamentais para pôr fím a este "abuso".

Eis alguns dos títulos "para-revolucionários" listados por Freitas:

- Evangelizar os pobres, de Mario de Oliveira. Porto: Figueirinhas, 1969.

\footnotetext{
5 FREITAS, Martinho de. "Textos para-revolucionários de autores de língua portuguesa editados em Portugal (1971)". Época, Lisboa, ano I, no 334, 7/1/1972.

6 FREITAS, Martinho de. "Análise dos textos para-revolucionários de autores de língua portuguesa editados em Portugal (1971)". Época, Lisboa, ano 2, n 426, 9/4/1972.
} 
- Ensino primário e ideologia, de Maria de Fátima Bivar. Lisboa: D. Quixote, 1971.

- Portugal e a Comuna de Paris, de Ana Maria Alves. Lisboa: Estampa, 1971.

- A Revolução Industrial em Portugal no século XIX, de Armando de Castro. Lisboa: D. Quixote, 1971.

- Sobre o capitalismo português, de A. J. Avelãs Nunes. Coimbra: Atlântida, 1971.

- Encontro. Alguns aspectos da religião tradicional discutidos pelo povo de Macieira da Lixa, coordenado por Mario Pais de Oliveira. Porto: Afrontamento, 1971.

- Imprensa: deformar ou informar?, de José Viale Moutinho. Porto: Paisagem, 1971.

- Pensar Portugal hoje, de João Martins Pereira. Lisboa: D. Quixote, 1971.

- A liberalização bloqueada, de Francisco de Sá Carneiro. Lisboa: Moraes, 1972.

- O reino flutuante, de Eduardo Prado Coelho. Lisboa: Edições 70, 1972.

- A condição da mulher portuguesa, de Sérgio Ribeiro e outros, com apresentação de Urbano Tavares Rodrigues. Lisboa: Estampa, 1972.

- Movimento Estudantil e política educacional, de Rui Namorado. Coimbra: Centelha, 1972.

Somados todos estes títulos, chegamos a quase meia centena de livros, editados de 1968 até abril de 1974, que podem ser considerados como de oposição à ditadura em Portugal. Vale lembrar que boa parte destes livros foram censurados ou parcialmente apreendidos - como se pode verificar ao consultar o levantamento realizado por José Brandão e publicado em seu artigo "Os livros e a censura em Portugal", de 20077. Mas se havia censura, também havia a luta contra a censura. Assim, editores, gráficos e livreiros criaram mecanismos e estratégias para produzir e fazer circular os livros políticos, ou que simplesmente eram perseguidos pela censura (como vimos no Capítulo 1). Tiragens subfaturadas, venda "por baixo do balcão", troca do nome do autor do livro (p.e., Vladimir Ulianov em vez de Lenin) eram algumas das táticas utilizadas para escapar à polícia.

Como lembra o livreiro António André, que trabalhou na Livraria Barata e na livraria 111, em Lisboa, sempre "havia o 'risco' da repressão policial-pidesca; o que se,

\footnotetext{
${ }^{7}$ Disponível em: <http://www.vidaslusofonas.pt/livros_e_censura.htm>.
} 
por um lado, muito atemorizava, por outro lado também acicatava. Era uma forma de resistência ao regime, uma forma de lutar contra o obscurantismo cultural imposto pelo poder de então"8.

Desse modo, e quase sempre com grandes riscos, dificuldades e perseguições, pode-se afirmar que ainda durante a ditadura foi possível, de modo limitado, a circulação de livros de oposição, de denúncia do autoritarismo, juntamente com livros sobre o pensamento de esquerda - marxistas e socialistas -, principalmente no final dos anos 1960 e início da década de 1970. Como nos disse o livreiro Silvério Amaro, antes do 25 de Abril a sua distribuidora de livros, a Dinalivro, fez circular dezenas de títulos políticos produzidos por editoras do Porto e de Lisboa ${ }^{9}$.

\subsubsection{O pós-25 de Abril}

Logo após o 25 de Abril começam a surgir os livros em que as denúncias dos crimes, arbitrariedades e violências cometidos pelo Estado Novo surgem de forma clara e sem subterfúgios - e já não mais submetidos à censura. Não são tantos quantos se poderia supor inicialmente, e isso talvez se possa explicar pelo fato de a preparação de um livro, sua edição e impressão demandar um certo tempo de produção, bem maior do que o tempo necessário para a publicação de jornais e revistas, por exemplo, que podiam suprir a necessidade desse tipo de informação com maior rapidez.

Surgem com destaque obras sobre a PIDE/DGS, livros que descrevem a repressão durante o salazarismo, além de livros de memórias e relatos sobre a prisão política. Sobre a PIDE/DGS temos as seguintes obras em 1974:

- Secreto. Último relatório do ex-Ministério do Interior para a ex-PIDE/DGS. Lisboa: Afrodite, maio, 1974;

- PIDE: a história da repressão, coordenado por Manuel Alexandre, Rogério Carapinha e Dias Neves. Fundão, Jornal do Fundão, junho, 1974;

- O último dia da Pide. 26 de Abril no Porto. Editado pelo Movimento Democrático do Porto, com prefácio de Raul Castro. Porto: outubro, 1974;

- PIDE/DGS: um Estado dentro do Estado, de Fernando Luso Soares. Lisboa: Portugália, novembro, 1974;

\footnotetext{
8 "Entrevista com António André (Livraria 111 - Lisboa)". Notícias do Livro, Lisboa, APEL, n 3, jan. 1979 , p. 25-26.

${ }^{9}$ Entrevista com Silvério Amaro, Lisboa, 21/3/2012.
} 
- Dossier PIDE: os horrores e crimes de uma “polícia”, cuja autoria é atribuída ao "Repórter Sombra”. Lisboa: Agência Portuguesa de Revistas, 1974.

Em 1975, localizei apenas três livros sobre o tema: Três tiros da PIDE: quem, porquê e como mataram Amílcar Cabral, de Oleg Ignatiev (Lisboa: Prelo, fevereiro, 1975); A defesa acusa: os comunistas portugueses perante a polícia e os tribunais fascistas, da Coleção "Resistência” (Lisboa: Avante!, abril, 1975. Tiragem: 15:500); e Dossier Pide-DGS (Alfragide, Acrópole, 1975), uma história em quadrinhos (banda desenhada) com texto de José Gabriel e ilustrações de Vítor e Carlos Guedes, que teve tiragem de 30 mil exemplares. Anunciada com o uma série, resumiu-se, no entanto, apenas a este volume.

E em 1976, houve apenas um título sobre o assunto: Elementos para a história da PIDE, editado pela Associação de Ex-Presos Políticos Antifascistas (AEPPA) e que faz parte da coleção "Para o Tribunal que Julgue a PIDE".

Em 1977 são quatro títulos, três dos quais editados pela AEPPA: Vigiados $e$ perseguidos (Documentos secretos da PIDE/DGS), de Nuno Vasco (Lisboa: Bertrand, Abril, 1977) ${ }^{10}$; A PIDE e as empresas, da coleção "Para o Tribunal que Julgue a PIDE" (Lisboa: AEPPA, fevereiro, 1977); Mais uma traição ao povo (Lisboa: AEPPA, 1977) e Os mortos reclamam justiça (Lisboa: AEPPA, 1977) ${ }^{11}$.

São, portanto, apenas 13 títulos dedicados especificamente à polícia política em quatro anos, o que talvez se explique, ao menos em parte, pelo fato de a imprensa ter publicado muitas informações sobre este tema no período e ter conseguido, por sua imediatez, atender melhor a maior parte do público interessado no assunto nesse momento.

De certa forma, a relativa escassez de obras especificamente sobre a polícia política também se explica por haver nesse período muitos lançamentos de obras sobre as prisões políticas, um tema que mescla-se ao anterior. Assim, temos em 1974 os seguintes títulos sobre prisões políticas durante o Estado Novo:

- Tarrafal, aldeia da morte: o diário da B5, de Manuel Francisco Rodrigues. Porto: Brasília Editora, julho, 1974;

10 Este livro contém em sua parte final a "Relação das indentidades dos directores de serviços, inspectores, inspectores-adjuntos, inspectores superiores, subinspectores, chefes de brigada, agentes de $1^{\mathrm{a}}$ e $2^{\text {a }}$ classes, motoristas e radiotelegrafistas ao serviço da PIDE/DGS em 25 de Abril de 1974”.

${ }^{11}$ Este livro traz a lista de todos os mortos pela polícia política portuguesa desde 1931 até 25 de abril de 1974. 
- Tarrafal, o pântano da morte, de Cândido de Oliveira. Lisboa: Editorial República, julho, $1974^{12}$;

- Caxias: últimos dias do fascismo (Diário do encarcerado), de Orlando Gonçalves. Amadora: N.A.*Orion, julho, 1974;

- Prisão e isolamento em Caxias: uma breve experiência, de António Modesto Navarro. Amadora: N.A.*Orion, setembro, 1974;

- Diário de Peniche, de Henrique Galvão. Lisboa: Livraria Popular de Francisco Franco, 1974;

- Fuga de Caxias no carro blindado do Salazar, de Antonio Alexandre Tereso.

Coleção "Episódios da Resistência Antifacista Contados por Quantos a Viveram”. Lisboa: Edições Sociais, 1974;

- Com a certeza de quem quer vencer, de Aida Paula. Coleção "Episódios da Resistência Antifacista Contados por Quantos a Viveram”. Lisboa: Edições Sociais, 1974;

- Nos cárceres do fascismo: notas, escritos, reflexões, de Carlos Almeida. Coimbra: Atlântida, dezembro, 1974.

Em 1975 o ritmo de edições sobre este tema é mantido:

- Presos políticos: documentos 1972-1974, pela Comissão Nacional de Socorro aos Presos Políticos. Lisboa: Iniciativas Editoriais, fevereiro, 1975;

- Cartas da prisão (1 Vida prisonal), de José Magro. Coleção Resistência, Lisboa: Avante!, maio, 1975. Tiragem: 10.000;

- Memórias de um prisioneiro do Tarrafal, de Correia Pires. Lisboa: Deagá, julho, 1975. Tiragem: 5.000;

- Tarrafal, campo da morte lenta, de Pedro Soares. Coleção Resistência, Lisboa: Avante!, setembro, 1975. Tiragem: $10.500^{13}$;

- Histórias da prisão, de Júlio Graça. Lisboa: Iniciativas Editoriais, 1975;

- Cartas da prisão, de Mario Pais de Oliveira. Coleção O Povo e a Igreja, Lisboa: Iniciativas Editoriais, 1975;

- A longa luta: preso, algemado e deportado, de A. Neves Anacleto. Lisboa: Edição do Autor, 1975.

\footnotetext{
${ }^{12}$ Este livro traz a lista dos 30 mortos no Tarrafal.

${ }^{13}$ Este livro havia sido publicado anteriormente de forma clandestina pela Avante!
} 
Em 1976 localizei apenas dois títulos: Recordações dos tempos difíceis, de Miguel Wager Russell (Coleção Resistência, Lisboa: Avante!, agosto, 1976. Tiragem: 5.500) e No Tarrafal, prisioneiro, de Joaquim Ribeiro (Coleção Depoimentos, Porto: A Opinião, setembro, 1976) ${ }^{14}$. E em 1977 e 1978, apenas um título em cada ano: Tortura na colónia de Moçambique, 1963-1974: depoimentos de presos políticos, da Coleção Libertação dos Povos das Colónias (Porto: Afrontamento, julho, 1977. Tiragem: 3.000); e Nas trevas da longa noite: da guerra de Espanha ao campo do Tarrafal, de Manuel Firmo (Mem-Martins, Europa-América, janeiro, 1978).

Nota-se, assim, que o número de títulos, 19 nos quatro anos em foco, é maior do que aquele de livros sobre a PIDE/DGS. No total, são 32 títulos de memórias e relatos sobre a prisão política e sobre a PIDE/DGS.

Localizei também quatro livros que analisam e historiam a ação da censura durante o Estado novo: O obscurantismo salazarista, de Joaquim Barradas de Carvalho (Coleção Argumentos, Lisboa: Seara Nova, 1974); O processo das três Marias: defesa de Maria Isabel Barreno, de Duarte Vidal (Lisboa: Futura, outubro, 1974); Visado pela censura: A imprensa - Figuras - Evocações da ditadura à democracia, de Norberto Lopes (Lisboa: Aster, 1975); e Os segredos da Censura, de César Príncipe (Lisboa: Caminho, 1979).

Existe ainda um conjunto de obras em que há referências significativas à repressão política. São livros que descrevem a repressão durante o salazarismo, mas sem terem como centro a repressão policial e prisional. Trata-se, na verdade, de uma gama variada de livros, num total de 25 títulos, que abordam diversos aspectos das arbitrariedades e violências da ditadura. Alguns apresentam depoimentos e biografias de pessoas que lutaram contra o regime, muitas das quais foram presas; outros títulos tratam do assassinato de opositores, de violências cometidas na guerra colonial, e há até um sobre a proibição do casamento às enfermeiras. Apresento a seguir a lista dessas obras:

1974

- A resistência em Portugal, de José Dias Coelho. Coleção Situações. Porto: Inova, junho, 1974;

\footnotetext{
${ }^{14}$ Este livro também traz a "Lista dos falecidos" no Tarrafal.
} 
- 48 anos de fascismo em Portugal. Lisboa: Livraria Ler, junho, 1974;

- Portugal amordaçado: depoimento sobre os anos do fascismo, de Mário Soares. Lisboa: Arcádia, outubro, 1974;

- O aniversário do m/P.B., de Hortênsia Silva. Coleção "Episódios da Resistência Antifacista Contados por Quantos a Viveram”. Lisboa: Edições Sociais, 1974;

- A revolta dos marinheiros, de João Borda. Coleção "Episódios da Resistência Antifacista Contados por Quantos a Viveram”. Lisboa: Edições Sociais, 1974;

- A morte no monte: Catarina Eufémia, de José Miguel Tarquini. Lisboa: Casa Portuguesa, 1974;

$\underline{1975}$

- Portugal oprimido: factos e nomes da ditadura salazarista, de Fernando Capitão Quiroga. Lisboa: O Século, fevereiro, 1975;

- Caminhos para uma revolução, de Jacinto Baptista. Lisboa: Bertrand, abril, 1975

- Mulheres portuguesas na resistência, de Rose Nery Nobre de Melo. Lisboa: Seara Nova, agosto, 1975. Tiragem: 5.200;

- Da resistência à revolução: 1963-1975, de Miguel Urbano Rodrigues. Coleção Caminhos da Revolução. Lisboa: Avante!, outubro, 1975. Tiragem: 5.500;

- Histórias da opressão 1. Depoimentos gravados, de António Norton. Porto: A Opinião, novembro, 1975;

- A liberdade tem um preço, Luís Calafate. Póvoa do Varzim: Edição do Autor, 1975

- Quatro anos de deportação, de Mário Castelhano. Lisboa: Seara Nova, 1975;

- Depoimento inacabado, de Vasco da Gama Fernandes. Lisboa: EuropaAmérica, 1975;

- A raiva de Salazar e da P.I.D.E. contra a unidade democrática representada por Humberto Delgado e outros episódios por mim vividos em 32 anos de luta antifascista, de António Horácio Simões de Abreu. Coleção "Episódios da Resistência Antifacista Contados por Quantos a Viveram”. Lisboa: Edições Sociais, 1975;

- A força ignorada das companheiras, de Gina de Freitas. Lisboa: Plátano, 1975;

- Palavras de combate, de Urbano Tavares Rodrigues. Lisboa: Seara Nova, 
1975

$\underline{1976}$

- Combates pela democracia, de José Manuel Tengarrinha. Lisboa: Seara Nova, 1976;

- Portugal - cinquenta anos de ditadura, de António de Figueiredo. Lisboa: Dom Quixote, 1976;

- Massacres na guerra colonial (Tete, um exemplo). Documentos secretos, de José Amaro (org.). Lisboa: Ulmeiro, abril, 1976;

1977

- Uma vida na revolução, de Francisco Miguel. Porto: A Opinião, fevereiro, 1977

- Sarmento Pimentel ou uma geração traída (Diálogos de Norberto Lopes com o autor das "Memórias do capitão”), de Norberto Lopes e Sarmento Pimentel. Prefácio de Vitorino Nemésio. $2^{\mathrm{a}}$ edição com documentos da luta contra a ditadura. Lisboa: Aster, 1977;

- O caso Delgado: autópsia da Operação Outono, de Manuel Garcia e Lourdes Maurício. Lisboa: Expresso, 1977;

- O caso Dias Coelho: alegações da assistente Maria Teresa Tengarrinha Dias Coelho no seu recurso para o Supremo Tribunal Militar, de Fernando Luso Soares. 1977. Fundão: Jornal do Fundão, 1977.

\subsubsection{Um breve balanço}

Não deixa de ser supreendente que entre 1968 e o começo de 1974 tenhamos localizado cerca de 50 títulos que podem ser considerados de oposição e de denúncia da ditadura editados em Portugal. Isso mostra que apesar das restrições, constrangimentos e violências contra a manifestação do pensamento oposicionista, este nunca deixou de procurar meios de se expressar. E que a edição de livros foi um dos canais para que este pensamento viesse a público. É importante lembrar que boa parte desses títulos foi censurada ou parcialmente apreendida, mas isso não impediu, em muitos casos, que estes livros circulassem, ainda que de modo restrito. 
Antes do 25 de Abril merecem destaque as edições de autor, as obras da editora Afrontamento, em particular a coleção Bezerro D’Ouro, as da Editorial República, da Estampa e da Prelo, além da atuação da Inova na distribuição de alguns títulos.

Após o fim da ditadura, não deixa de ser surpreendente que o levantamento tenha apontado apenas 61 títulos diretamente relacionados à denúncia dos mecanismos de repressão do Estado Novo. Acredito que este número cresceria razoavelmente se nesta lista fossem incluídas as obras de ficção, como romance, conto e poesia. Outro fator importante, como veremos em seguida, é a ausência de obras sobre esta temática publicadas por editoras ligadas a grupos de extrema esquerda.

No pós-25 de Abril destacam-se, entre as editoras que publicaram os livros aqui mencionados, a Avante! e a Edições Sociais, ligadas ao PCP. Ambas criaram coleções voltadas para a recuperação da memória da resistência à repressão: a coleção Resistência (Avante!) e a coleção "Episódios da Resistência Antifascista Contados por Quantos a Viveram" (Edições Sociais).

A ressaltar, ainda, o papel da editora Seara Nova, que tanto antes como depois do 25 de Abril publicou várias obras de denúncia da ditadura.

É interessante notar que todas estas editoras tinham vinculações políticas. A Afrontamento tinha ligações com setores oposicionistas ligados aos católicos progressistas e a outros segmentos da esquerda não-comunista; a Inova tinha afinidades com o Partido Comunista Português (PCP); A Editorial República era ligada ao jornal homônimo e vinculava-se a setores do Partido Socialista e da oposição liberal; a Avante! era a editora oficial do PCP; a Edições Sociais, a Estampa e a Prelo eram próximas a este partido, assim como a Seara Nova, principalmente a partir de 1974.

Chama atenção, ao mesmo tempo, a total ausência, no levantamento apresentado neste capítulo, de obras publicadas por editoras ligadas a grupos de extrema esquerda, o que merece uma análise mais cuidadosa. Tal ausência pode ser entendida no período anterior ao 25 de Abril, quando estes grupos estavam todos na mais severa clandestinidade. Todavia, alguns desses grupos, como vimos no Capítulo 5 e em parte do Capítulo 6, criaram editoras antes de 1974, mas o seu foco estava na edição de obras sobre o pensamento socialista e comunista, e nos debates doutrinários, políticos e ideológicos que se travavam nesse campo.

Todavia, após a queda da ditadura as dificuldades decorrentes da clandestinidade e da repressão deixaram de existir. Assim, ressalta o fato de grande parte da produção 
dessas editoras dedicar-se aos clássicos do socialismo e aos seus desenvolvimentos e polêmicas, principalmente às obras de combate político dos seus principais teóricos. Muitas vezes os temas relacionados a questões nacionais e da atualidade somente apareciam quando havia a publicação de documentos ou resoluções sobre a conjuntura de autoria dos grupos ou partidos políticos a que estas editoras estavam vinculadas.

Mas, de fato, podemos dizer que as editoras da extrema esquerda deram pouca atenção, seja antes ou depois do 25 de Abril, à publicação de livros que recuperassem a memória do período do fascismo em Portugal.

Nesse ponto, não resta dúvidas de que as editoras ligadas ao PCP e a grupos da oposição democrática valorizaram bem mais esta temática em suas edições.

\subsubsection{Algumas considerações preliminares}

Parece claro que a edição dos livros de oposição e de denúncia dos crimes, arbitrariedades e violências cometidos pela ditadura de Salazar e Caetano contribuiu, antes do 25 de Abril, para dar resposta à necessidade que os setores oposicionistas tinham de denunciar e combater a ditadura. E, posteriormente, foi um dos canais utilizados pelos vitoriosos do 25 de Abril para dar a conhecer a história do regime fascista, de sua máquina repressiva e dos crimes praticados; para mostrar como era estruturada e como funcionava a repressão, inclusive com a preocupação de não deixar que tal história fosse esquecida; e para reivindicar, em muitos casos, a punição dos culpados, dos torturadores, dos chefes e mandantes da repressão.

Tais obras cumpriram um papel importante na difusão das ideias oposicionistas e na questão da recuperação e do debate sobre os legados que o longo período do fascismo deixou para Portugal, pois parte importante desse legado está ligado aos traumas, perdas e violências resultantes do arbítrio vigente nesses anos. Possibilitar o conhecimento desses fatos, das memórias dos seus protagonistas e da história dos indivíduos e das organizações que lutaram contra o autoritarismo é fundamental para que este legado possa ser colocado como um tema importante para a sociedade portuguesa na atualidade. 


\subsection{A edição política no olhar do editor}

Depois desse amplo levantamento sobre a edição política - e, portanto, sobre as editoras e os livros políticos -, será importante verificar como alguns destes editores, que em larga medida estiveram por trás desse processo, avaliam a sua atuação e o papel da edição política em Portugal no período 1968-1980.

Tentarei neste item dar a palavra aos editores, de modo a permitir entrever como eles mesmos analisam e avaliam o seu papel, particularmente no que diz respeito à atuação política do livro e da edição.

Seguirei a linha cronólogica que venho tomando como parâmetro até aqui, dividindo estas avaliações em dois períodos: o pré-25 de Abril e o pós-ditadura.

Manuel Rodrigues de Oliveira, da Edições Cosmos - casa marcante na história editorial e intelectual portuguesa nos anos 1940 e 1950 - enquadra, de certa forma, a ação dos editores do país em termos mais abrangentes no período analisado:

Penso que falar de editores [...] entronca na mesma raiz que é a situação histórica e social deste nosso país. Ora, ser editor num país que é dos mais atrasados da Europa, que está em primeiro lugar no consumo da batata, no consumo do pão, mas em último lugar no consumo de proteínas, da carne e do peixe, que bebe menos leite do que vinho, que está em primeiro lugar na mortalidade infantil e no analfabetismo, ora, já vê, a posição do editor tem que estar entroncada a este mesmo nível. ${ }^{15}$

Se é certo que tal declaração reflete uma certa tendência de parte dos editores de sempre lamentar-se das condições culturais e econômicas de seu país, ela também nos dá um quadro da situação estruturalmente precária em que tinham que atuar os editores portugueses em boa parte do século XX. Devemos ter esse quadro em mente para avaliar o que os editores foram capazes de fazer nessa situação.

António Alçada Baptista, da Moraes Editores, cuja atividade como editor remonta ao começo dos anos 1960, recorda que "Antigamente, uma editora não era um negócio. Era uma maneira de contribuir, através da publicação das obras de escritores portugueses e estrangeiros, para uma vida cultural que estava parada e da qual as pessoas pareciam estar desinteressadas" ${ }^{\prime 16}$.

15 Entrevista com Manuel Rodrigues de Oliveira (Edições Cosmos). Cf. "Manter uma editora durante quarenta anos com a linha editorial da Cosmos é um acto de coragem de todos os dias". Notícias do Livro,

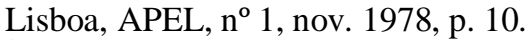

${ }^{16}$ BAPTISTA, António Alçada. "A Portugália Editora e Agostinho Fernandes". In: SANTOS, José da 
Este "antigamente" parece ter tido valência em Portugal até os anos 1980, ou seja, em todo o período aqui enfocado boa parte dos editores estava neste "antigamente". Ao menos no que diz respeito à forma como os editores viam a si mesmos. Não que a edição não fosse um negócio; era sim, ou melhor, era também um negócio, mas neste negócio prevalecia, em amplos setores, um ideal de diferenciação, de missão, de "nobreza" do ofício, que lidava com ideias, com arte, com beleza. E, para muitos, relacionava-se com o desejo de participação na vida cultural e política. Será somente nos anos 1980 que tais ideias deixarão de prevalecer entre a maior parte dos editores portugueses e os aspectos comerciais serão plenamente assumidos como o motor da edição.

Mas estamos aqui ainda no "antes" do 25 de Abril. Diz Joaquim Machado, da Livraria Almedina Editora:

Todos sabemos "o antes", mas compete a nós profissionais, saber contornar os obstáculos. Contornar obstáculos, para mim como para tantos outros colegas que fizeram o mesmo jogo, acabou, até, por ser estimulante. Momentos de "aperto" todos tivemos: aparecer a polícia com a relação dos livros para apreender, e termos de lhes dizer que os não tínhamos, quando estavam por baixo do balcão, era pelo menos incômodo. Enfim, "o antes" para mim e para tantos outros colegas, foi como que a época da lei seca nos EUA aonde havia sempre uma "garrafita" debaixo do balcão para os amigos. ${ }^{17}$

Além desse trabalho de venda dos livros proibidos, algumas livrarias (que muitas vezes eram também editoras) tiveram um papel importante na promoção de debates e pelo fato de tornarem-se locais de encontros e reuniões de gente ligada à oposição. A Livraria Ulmeiro, em Lisboa, foi a partir de 1969 um desses locais, tornando-se uma livraria "marcadamente de contestação", como lembra Lúcia Ribeiro, proprietária da Ulmeiro ao lado de José Antunes Ribeiro, seu marido. "Há ali um período em que era só política, pronto. Aí foi o auge da política. A gente queria era saber alguma coisa de política", diz Lúcia ${ }^{18}$. Isso se manifestava nas muitas sessões de música e poesia que foram realizadas no subsolo (cave) da livraria. "Eram atos de resistência cultural contra a ditadura. Claramente. Não era qualquer cantor que vinha cá, era gente das cantigas de intervenção, o Zeca Afonso, o Carlos Paredes e outros”,

Cruz (coord.). Agostinho Fernandes: um industrial inovador, um coleccionador de arte, um homem de cultura. Lisboa: Portugália Editora Internacional, 2000.

17 “Entrevista com Joaquim Machado". Notícias do Livro, Lisboa, APEL, n 4, fev. 1979, p. 22-26.

18 "Livrarte/Ulmeiro... 40 anos a resistir". Bloge Mercado de Bemfica. Disponível em: <http://mercadodebemfica.blogspot.com/2009/01/livrarte-40-anos-resistir.html>. Acesso em julho de 2010. 
lembra Antunes Ribeiro ${ }^{19}$.

António José Fonseca, das editoras Sementes e Estrela Vermelha, vinculadas ao MRPP, também destaca a força do imperativo político para muitos editores: "Na época só havia um objetivo: combater a ditadura fascista. Posteriormente [depois do 25 Abril], divulgar a ideologia comunista. Não se pode dissociar a atuação das editoras desse aspecto" 20 .

Brandão Guedes, das Edições Base, lembra o papel que o livro tinha numa situação de ditadura como se vivia em Portugal nos anos 1960:

Isso era uma ditadura. Atenção que o país, na década de 1960, em termos políticos, era uma pobreza muito grande. E levar um livro político, no bolso do casaco, a uma reunião, nem que fosse para beber um copo, era um ato político, era entendido por aquela pessoa e pelos outros como um ato político. ${ }^{21}$

Muitas pessoas, diz Brandão, se aproximaram de alguma rede política por meio do livro:

Então isso tinha esse papel, era uma forma de uma pessoa chegar a um rapaz de 17, 18 anos na altura, que tinha o espectro da guerra colonial à frente. Dava-lhe o livro: olha, toma lá e lê. O livro é uma forma de abrir uma porta, uma consciência. Para muita gente nova era um modo de iniciar uma relação. E depois ele passava o livro a outro, no liceu, na universidade. E aquilo era um ato corajoso, porque muitos desses livros eram proibidos. ${ }^{22}$

Para António Abreu, das editoras Cadernos Para o Diálogo e Textos Marginais, “Antes do 25 de Abril havia uma 'liberdade vigiada' pela polícia política". Os problemas surgiam quando se ultrapassavam estes limites. "Havia algumas coisas que eles não permitiam de jeito nenhum. Em relação aos clássicos, Marx, Engels, a perseguição não era tão grande, mas as coisas ligadas aos movimentos coloniais eles não perdoavam de jeito nenhum" 23 .

Para ele "as editoras que publicaram livros políticos tiveram um papel importante na formação política, porque não existia formação política em Portugal devido ao longo período da ditadura". Abreu afirma que "A maioria dessas pequenas editoras era ligada a algum movimento. Elas não tinham uma visão comercial, eram

\footnotetext{
${ }^{19}$ Entrevista com José Antunes Ribeiro, Lisboa, 2/2/2011.

${ }^{20}$ Mensagem eletrônica de António José Fonseca em 9/9/2012.

${ }^{21}$ Entrevista com Brandão Guedes e Fernando Abreu, Lisboa, 15/2/2011.

22 Idem.

${ }^{23}$ Entrevista com António Daniel Abreu, São Paulo, 23/8/2012.
} 
idealistas que faziam aqueles livros" ${ }^{24}$.

José Antunes Ribeiro, da Ulmeiro, explica um pouco as dificuldades que parte dos editores militantes tinha para lidar com a edição como negócio:

O negócio do livro era contraditório porque era um negócio e ao mesmo tempo era militância, era debate de ideias, e a parte do negócio acaba sempre a condicionar [tudo]. Quando a gente cresce, ou tenta crescer, já não tem hipótese de fazer grande coisa, porque o peso da estrutura é tal que a certa altura temos a estrutura mas já não dá pra fazer grande trabalho. ${ }^{25}$

José Sousa Ribeiro, da Afrontamento, ressalta o papel que a edição política teve na divulgação de informações:

Sobretudo antes do 25 de Abril, numa altura em que a informação estava completamente bloqueada em Portugal, a possibilidade de publicar coisas que não eram controladas era extremamente apelativa [atraente], era um desafio. E acho que desse ponto de vista levamos isso ao limite no contexto da situação fechada que havia. E isso deu o seu contributo para abrir algumas cabeças. A importância do nosso trabalho foi fazer com que certas coisas se tornassem públicas, que abandonassem a clandestinidade a que estariam reservadas. ${ }^{26}$

Sousa Ribeiro pondera: "Não quer dizer que isso tivesse uma importância desmesurada, não foi por isso que caiu o fascismo". Mas ele também não deixa de destacar a importância do trabalho dos editores: “[...] a verdade é que tudo conflui, o rio engrossa se houver muitos fios d'água a ajudar, e a Afrontamento foi um desses fios d'água. Nunca ninguém quis reivindicar mais do que isso",27.

João Carlos Alvim, da Assírio\&Alvim, segue uma linha semelhante:

Eu tenho uma noção muito modesta do trabalho da Assírio\&Alvim, acho que produzimos alguns livros que foram efetivamente importantes, da mesma forma como outras editoras que estavam em atuação na altura. Acho que pesamos um bocadinho, mas tenho muita dificuldade em fazer essa avaliação. Acho que não fomos de todo excepcionais. Fizemos algum trabalho, fomos mais um elo. ${ }^{28}$

João Camacho, da Nova Aurora, não hesita em afirmar que o livro "tem uma força política enorme, teve um enorme papel político antes e depois do 25 de Abril". Segundo ele, "Houve um movimento cultural muito grande da esquerda em Portugal, que começou nas livrarias e nos cineclubes, e depois com o nascimento das pequenas

\footnotetext{
${ }^{24}$ Idem.

${ }^{25}$ Entrevista com José Antunes Ribeiro, Lisboa, 2/2/2011.

${ }^{26}$ Entrevista com José Sousa Ribeiro, Porto, 24/3/2011.

27 Idem.

${ }^{28}$ Entrevista com João Carlos Alvim, Lisboa, 16/2/2011.
} 
editoras" 29.

João Sá Costa, da Editora Sá da Costa, considera que "um editor também se define pelo seu empenhamento e intervenção na vida cultural do seu país, se está realmente interessado em cultura" ${ }^{30}$. Por isso ele entendeu que era necessária, no início da década de 1970, uma "nova arrancada [da Sá da Costa], perante uma situação crítica que o país atravessava". Com isso ele buscava "contribuir para o desenvolvimento do trabalho editorial de pedagogia social"31. Sua concepção de "editor de cultura" representa, em suas palavras, "não ceder nada à incultura, nada ao oportunismo, nada à facilidade, nada à promoção ou venda com recurso a formas demagógicas ou deturpantes... É ter paixão, digamos assim, do pensamento autônomo e atuante" ${ }^{\text {32 }}$.

O tema da paixão pelo ofício aparece também em entrevista de Carlos Araújo, que se destacou inicialmente na editora D. Quixote, ainda nos anos 1960. Respondendo à questão “O que é para si um editor?", ele afirmou:

Tem de haver paixão pelo livro. Ser editor não se "transmite". Ou se tem, ou não se tem. Não há cursos que "façam" um editor. [...] A minha passagem pela D. Quixote foi uma grande aventura na minha vida, entre 1966 e 1974. Digamos até que foi um momento decisivo, de força incontrolável. Foi então e aí que fiquei dominado pela paixão de descobrir livros para publicar, de defender assim ideias contra ventos e marés. ${ }^{33}$

Foi este também o sentido da atuação de Fernando Ribeiro de Mello, da Afrodite, em sua própria avaliação: "Sempre travei batalhas suicidas, sempre me atirei de cabeça pelas minhas verdades sem medir muito as consequências", diz ele. "Editei o Sade quando era impossível editá-lo. [...] eu editei Sade contra Salazar, com todo o risco que era estar contra ele, editei-o para abalar a censura..."34.

João Barrote, da Escorpião/Textos Exemplares, viu na edição uma opção de vida que permitia conciliar participação social autônoma e uma forma de autossustento econômico:

Como editor eu não me comprometia diretamente com o sistema, era uma atividade de relativa liberdade, com a publicação de textos que

\footnotetext{
${ }^{29}$ Entrevista com João Camacho, Lisboa, 3/3/2011.

30 “Entrevista com João Sá da Costa”. Notícias do Livro, Lisboa, APEL, no 4, fev. 1979, p. 9-13.

31 Idem.

32 Idem.

33 PESSOA, Carlos; MOREIRA, José Guardado. "Carlos Araújo, um editor militante à conversa com Carlos Pessoa e José Guardado Moreira". Duas Margens. Cultura de Livros \& Libros. Ano 2, no 2, set. 2012, p. 8-15. Disponível em: <http://duasmargens.pt/>. Acesso em 20/10/2012.

${ }^{34}$ LUÍS, António Carmo, op. cit.
} 
eram socialmente úteis, o que pra mim é muito importante [...]. A partir do momento em que eu visualizei que havia a possibilidade de trabalho de uma forma autônoma, consistente do ponto de vista técnico, consistente do ponto de vista da qualidade de informação, e útil, para mim era óbvio que eu tinha que trilhar este caminho, porque resolvia duas questões ao mesmo tempo: a questão da minha própria subsistência, e a questão de exprimir, do ponto de vista ideológico, aquilo que eu acreditava. ${ }^{35}$

José da Cruz Santos, da Inova, considera que "está por fazer um estudo sobre o contributo dos editores para o desenvolvimento do país", principalmente durante a ditadura, quando, segundo ele, muitos livros “ajudaram a transformar o pensamento de muitos milhares" 36 .

Sérgio Ribeiro, da Prelo, considera que a sua editora "teve um papel mais importante antes do 25 de Abril". Para ele, "A Prelo foi uma vivência de 20 anos de tremenda importância". Ribeiro destaca o aspecto organizador que a edição propiciava:

A Prelo foi muito importante num determinado momento, não só por aquilo que editamos, mas também porque isso representava uma mobilização de gente a mexer, de trabalho coletivo, de apoio para a tomada de consciência das pessoas às quais chegávamos. Não só a Prelo mas outras editoras também. ${ }^{37}$

Podemos perceber que todos os editores citados destacam a importância do papel das editoras e dos livros políticos no período pré-25 de Abril, seja por sua participação no debate político, seja pela agitação e questionamento que promoviam no campo cultural.

Mesmo os que relativizam essa importância não deixam de reconhecer a sua existência. E se é certo que os editores não reivindicam para si um papel central na derrota da ditadura, não deixam de reivindicar um lugar de destaque na luta contra o Estado Novo, particularmente no campo dos debates políticos e culturais, em questões que eram sensíveis para o regime, como a política colonial, a "moral e os bons costumes" e a denúncia da opressão.

O 25 de Abril propiciou um novo quadro social e político em que as editoras passaram a atuar. Para aquelas que já existiam, a nova situação trazia também novos desafios. E para muitas que surgiram a partir de então, a política se colocava como o

\footnotetext{
${ }^{35}$ Entrevista com João Barrote na freguesia de Arnoia, concelho de Celorico de Bastos, distrito de Braga, Portugal, 22/6/2011.

36 ALMEIDA, Sérgio. "Uma vida tecida de livros". Jornal de Notícias, 05/02/2012. Disponível em: <http://www.jn.pt/blogs/babel/archive/2012/02/05/uma-vida-tecida-de-livros.aspx>. Acesso $\mathrm{em}$ 15/04/2012.

${ }^{37}$ Entrevista com Sérgio Ribeiro, Lisboa, 24/2/2011.
} 
centro de sua ação.

Sérgio Ribeiro expressa bem essa problemática, ao afirmar que "Nós, na Prelo, nos sentimos vitoriosos com o 25 de Abril, porque em alguma coisa contribuímos, e isso nos deu ânimo para continuar. [...] Depois do 25 de Abril a Prelo potencialmente tinha um papel a desempenhar mas que não chegou a fazê-lo". Isso se deu, de acordo com ele, porque "na sequência do processo histórico que estávamos vivendo a luta tomou outro aspecto, outros caminhos". Há alguma desilusão em sua conclusão: "Coisas que a Prelo fez e que na altura eu pensei que pudessem transformar-se em bons instrumentos e em boas armas de luta foram completamente ignoradas [...], foram ultrapassadas",38.

José Antunes Ribeiro manifesta outro tipo de desconforto político gerado pela nova situação de liberdade:

Eu vinha com a ideia um pouco ingênua de que era possível um grande debate à esquerda, de que era possível editar coisas que servissem um pouco para toda a gente. Quando houve o 25 de Abril nós pusemos na montra [vitrina] da livraria cartazes do PS, do PC e do MRPP, o que diz bem da ingenuidade. E eu venho a descobrir numa aprendizagem pessoal que a realidade não é nada daquilo que eu acho, não só as pessoas são inimigas ferozes, como dentro das organizações as pessoas se dividem em grupos e os grupos são igualmente inimigos. $^{39}$

Carlos da Veiga Ferreira, da Teorema, menciona a abrangência que a política ganhou no país:

Em abril de 1974 foi todo um país que despertou para a política. Aqueles anos da brasa foram de fato... E o mundo editorial passou por isso. Todo o mundo intelectual, na verdade. Foi um fenômeno transversal, toda a cultura foi abrangida pela invasão da política.

Em relação à Teorema, ele considera que "certos autores publicados foram fundamentais para a formação política de muita gente". E conclui: "É evidente que os livros por si sós não fazem nada, mas acho que o papel de intervenção da Teorema nesses anos de 1974 e 1975 foi muito importante" ${ }^{\text {40 }}$.

Natália Correia, escritora e diretora literária da Editora Arcádia, destacava em agosto de 1974 a preocupação com a pluralidade ideológica. Em resposta à questão de qual deveria ser "o verdadeiro papel de uma editora" em Portugal naquele momento, ela

\footnotetext{
${ }^{38}$ Idem.

${ }^{39}$ Entrevista com José Antunes Ribeiro, Lisboa, 2/2/2011.

${ }^{40}$ Entrevista com Carlos da Veiga Ferreira, Lisboa, 1/4/2011.
} 
afirmava:

Mais do que nunca desenvolver uma acção formativa não condicionada por postulados ideológicos que unilateralizem esse objectivo. O 25 de Abril veio enlouquecer o ponteiro da bússula das editoras que se lançam na corrida do livro político até agora proibido ou tendencioso. Esta generalização conduz a uma homegeneidade castradora de uma controvérsia desejável e salutar. Entendendo a cultura como uma polêmica em perpétuo curso (e não vejo outra forma de a entender) cabe à responsabilidade educativa das editoras pôr o leitor em contacto com diversas e mesmo antagônicas correntes ideológicas, promovendo uma pluralidade de pontos de reflexão sem a qual não existem opções fundamentadas e conscientes. Igualmente importante é reforçar a produção de carácter imaginativo e humanístico. ${ }^{41}$

Orlando Neves, poeta e diretor literário, à época, da Editora Portugália, mencionava o propósito de dar ênfase aos livros de informação e esclarecimento, ao ensaio e à poesia produzidos por autores portugueses. "Penso, pois, que o papel de uma editora será o de intervir no esclarecimento e na formação do público e nessa orientação considero (é capaz de ser discutível) a poesia fundamental", afirmava ele ${ }^{42}$.

O peso das mudanças políticas decorrentes do 25 de Abril aparece com clareza na declaração enviada pela Editorial Futura ao Expresso, em resposta à questão sobre quais eram os seus planos de edição para 1975. Eis a resposta enviada pela editora ao jornal:

O plano editorial da Futura para a época ora começada, teria forçosamente de ser alterado, após o 25 de Abril. Alterado em livros que estavam programados e cujo lançamento se atrasa por necessidade de introduzir os leitores portugueses a obras que antes não tinham acesso. Por outro lado o editor português pode efectivamente a partir de agora ser um EDITOR. A procura incessante que se tinha, de livros, que por "meias palavras" atingissem os objectivos pretendidos, contrapõe-se agora à decisão do editor perfeitamente clara daquilo que quer editar, porque o pode. Daí que se tenha também de dar tempo ao editor de fazer a sua aprendizagem, tal como parece estar a acontecer aos escritores portugueses. A aprendizagem do "reescrever" é acompanhada forçosamente pela aprendizagem do "reeditar". [...] Os editores têm que ter mais que qualquer outra pessoa uma definição política. Poderão pôr ou não a sua editora ao serviço de um partido. Nesta altura, parece à Futura que auxiliará mais os objectivos nacionais apresentando aos leitores interessados, a visão

\footnotetext{
41 "Natália Correia fala da sua posição, hoje". Flama, Lisboa, no 1382, ano XXXI, 30/8/1974, p. 61.
}

42 “Orlando Neves fala da sua posição hoje”. Flama, Lisboa, no 1390, ano XXXI, 25/10/1974, p. 61. 
experimentada de homens que desde sempre se dedicaram à luta pelas liberdades fundamentais. ${ }^{43}$

Parece não haver dúvida de que o livro político desempenhou um papel de destaque na nova conjuntura. Como lembra Jacinta Ferreira, da Centelha:

Depois do 25 de Abril houve imensa gente a comprar os livros, queriam saber o que era marxismo, leninismo, quem foi Che Guevara, quem foi Rosa Luxemburgo etc. Naqueles primeiros dois, três anos nós fazíamos imensas bancas, por exemplo, no $1^{\mathrm{o}}$ de Maio, e vendíamos milhares de livros nesse dia. Havia uma ânsia de saber, e os livros da Centelha respondiam a uma parte desse desejo de informação. Então nesse momento [a Centelha] foi muito importante na formação política das pessoas. Nós disponibilizamos informação política. $^{44^{3}}$

Mesmo uma editora como a Arcádia, que não se caracterizava como predominantemente política, usava um slogan, em 1974, que punha os embates políticos em primeiro plano: "Escrever é lutar. Editar também"45.

António Abreu menciona um novo elemento que o fim da ditadura potencializou: "Com o 25 de Abril surgiram dezenas de editoras, e naturalmente eu também perdi espaço, eu tive que me afastar de algumas coisas e mudar o rumo" ${ }^{\text {. }}$. Portanto, a concorrência aumentou com o surgimento de novas editoras voltadas para a política. E num segundo momento, lembra Abreu, o mercado para o livro político começou a diminuir. Após 1976, "O mercado começou a ser muito mais seletivo, ficaram alguns, a Afrontamento, a Centelha, o resto caiu tudo. $\mathrm{O}$ interesse pelo livro político caiu muito. O interesse era motivado, em grande parte, pela repressão política" 47 .

Rita Delgado, da Contra a Corrente, aponta na mesma direção, mas dá ênfase mais ao aspecto político do que ao mercadológico para o definhamento da edição política:

As primeiras edições tiveram maior circulação, as pessoas queriam perceber tudo, estavam abertas à novidade. Depois houve um certo cansaço da população, cansaço da atuação dos partidos, e começaram a assustar-se, a achar que era tudo igual, que nada dava saída, e que a

\footnotetext{
${ }^{43}$ HORTA, Maria Teresa. “O que vamos ler”. Expresso, Lisboa, 9/11/1974, p. IV.

${ }^{44}$ Entrevista com Jacinta Ferreira, concelho de Lousada, distrito do Porto, 25/3/2011.

${ }^{45}$ Anúncio publicitário da Editora Arcádia. Expresso, Lisboa, 1/11/1974.

${ }^{46}$ Entrevista com António Daniel Abreu, São Paulo, 23/8/2012.

${ }^{47}$ Idem.
} 
atuação dos partidos era perniciosa, e de fato as coisas foram morrendo muito depressa em Portugal. ${ }^{48}$

Isso também deve ter acontecido em função do caráter panfletário de grande parte dos títulos políticos então editados. Isso era de tal modo um fenômeno da época que, mesmo ao referir-se a uma editora que não era voltada apenas para a política, João Carlos Alvim considera, hoje, que, "olhando para trás, os livros editados pela Assírio\&Alvim em 1974 e 1975 eram na sua esmagadora maioria panfletários" ${ }^{\text {"49 }}$.

Uma parte significativa dessas novas editoras era ligada a grupos políticos eram editoras políticas militantes. Para estas editoras, a política estava no cerne de sua existência e a edição era vista como um instrumento político antes de qualquer outro aspecto. Não à toa, Serafim Ferreira, editor veterano que no pós-25 de Abril criou a DiAbril e a Fronteira, duas editoras não ligadas a partidos políticos mas fortemente engajadas nos embates do "processo revolucionário em curso", falava em sua atuação nesse período como uma "barricada editorial" que seu projeto com a Editorial Fronteira era “[...] editar na intenção de intervir no processo revolucionário e despertar a atenção dos leitores para as questões ideológicas" ${ }^{, 51}$. Ele definia-se como "franco-atirador e agitador cultural", que buscava, em sua ação como editor, "intervir sem alienar e publicar sem nunca mercadejar"

O caráter instrumental era claramente afirmado pela Avante!, editora oficial do PCP, em texto de um catálogo publicado em maio de $1976^{53}$. Nele se afirmava a missão da editora: "Exprimir a consciência do processo revolucionário, transmitir os conhecimentos fundamentais para uma acção verdadeiramente revolucionária". Essa ideia era complementada em outro catálogo com a seguinte afirmação: "O combate ideológico também se trava com livros" ${ }^{\text {. }}$.

Francisco Melo, da Avante!, considera que as "editoras progressistas tiveram um papel muito importante mesmo antes do 25 de Abril, mesmo entre os militares" que derrubaram o Estado Novo. E especificamente sobre a Avante!, ele afirma: "A editora teve, depois do 25 de Abril, importante papel na divulgação do partido, das suas posições, o que era a ideologia marxista-leninista". E destaca: "Também foi importante

\footnotetext{
${ }^{48}$ Entrevista com Rita Delgado, Lisboa, 12/2/2011.

${ }^{49}$ Entrevista com João Carlos Alvim, Lisboa, 16/2/2011.

${ }^{50}$ FERREIRA, Olhar de editor, op. cit., p. 122.

${ }^{51}$ Ibidem, p. 121-23.

${ }^{52}$ Ibidem.

${ }^{53}$ Catálogo das Edições Avante!, maio de 1976, por acosião das Feiras do Livro de Lisboa e do Porto.

54 “Saudando a Conferência do PCP”. Catálogo das Ediçõe Avante!, 1976.
} 
na formação, sobretudo na formação ideológica dos militantes, que era um dos primeiros objetivos, eles liam estes materiais avidamente" ${ }^{, 55}$.

As organizações de extrema esquerda, em particular as maoistas, foram responsáveis pela criação de mais de duas dezenas de editoras nesse período. Não era incomum, nos livros publicados por estas editoras, a inserção de textos introdutórios que mencionavam explicitamente o desejo de que aquele livro fosse "uma arma nas mãos de todos os camaradas", como na "Introdução" à obra Dez questões sobre a China, da Editora Vento de Leste $^{56}$, do MRPP.

De acordo com esta visão, os livros políticos deveriam ser uma espécie de guia orientador para os militantes e simpatizantes do partido, como fica expresso no texto de apresentação do livro A questão do poder na luta antifascista de libertação nacional do povo albanês, publicado em 1975 pela Editora A Causa Operária, ligada à ORPC(m-l):

[...] os marxistas-leninistas, os operários e demais trabalhadores de vanguarda, todos os simpatizantes do comunismo, devem estudar os textos que agora começamos a editar, discutindo-os com os seus camaradas e extraindo deles as lições que permitam fortalecer as nossas fileiras $[\ldots]^{57}$.

António José Fonseca, editor ligado ao MRPP, afirma que as editoras ligadas ao grupo "Contribuíram de forma significativa para reunir a intelectualidade progressista e para a divulgação dos ideais revolucionários e do marxismo-leninismo-maoismo que o MRPP defendia”. Tiveram, portanto, em sua avaliação, uma grande importância para o grupo. "Já para o país creio que tiveram um contributo modesto", conclui ele ${ }^{58}$.

Também editores ligados à extrema direita, como Paradela de Abreu, da Editora Intervenção, destacam o sentido instrumental de davam à edição política. Em seu livro de memórias, ele declara que pretendia "editar o que eu próprio queria com o objectivo específico de esclarecimento ou de contra-informação política [...]" $]^{, 59}$.

Mas o interesse pelas obras políticas durou relativamente pouco tempo após o fim da ditadura. José Antunes Ribeiro afirma que "A parte propriamente de política pura e dura encerrou-se praticamente com a extinção do 25 de Abril. Quando a chamada

\footnotetext{
${ }^{55}$ Entrevista com Francisco Melo, Lisboa, 1/2/2011.

56 “Introdução". In: Dez questões sobre a China. Lisboa: Vento de Leste, 1975.

57 Texto do editor publicado nas p. 7-8 de: OMARI, Luan. A questão do poder na luta antifascista de libertação nacional do povo albanês (Relatório). Lisboa: A Causa Operária, 1975.

${ }^{58}$ Mensagem eletrônica de António José Fonseca em 9/9/2012.

59 ABREU, Do 25 de Abril ao 25 de Novembro, op. cit., p. 142.
} 
democracia estabilizou eu acho que o apetite pelos livros políticos também arrefeceu"60.

De certa forma, o período que se inicia com o fim da ditadura parece ter aberto grandes expectativas para os editores mais engajados, mas também parece ter deixado para alguns uma certa sensação de decepção. Diante de possibilidades que se apresentavam como extremamente radicais e transformadoras, os resultados efetivamente obtidos podem ter representado uma derrota para alguns. Para as editoras de partido, foi um momento de atividade febril, em que a edição aparecia como um instrumento a mais para a revolução, para o acirramento da luta de classes e para a luta política em que estavam empenhadas.

Ao mesmo tempo, o interesse pelos temas políticos foi enorme após 48 anos de ditadura, assim como enorme foi a oferta de títulos, o que logo levou a um excesso de publicações. Estas, depois de um curto período em que foram avidamente consumidas, começaram a ver sua procura diminuir com a mesma rapidez com que antes haviam sido solicitadas.

Fortemente relacionado ao clima de agitação política que atravessava o país, o surto editorial político pós-25 de Abril foi da mesma forma enfraquecido pelo arrefecimento desse clima e pela normalização política que se consolidou a partir de 1976.

Um tema abordado por João Barrote chamou a atenção por ser pouco comum entre as avaliações que a maior parte dos editores de esquerda faz da atuação de suas editoras na época. Trata-se da forma de como as editoras de esquerda lidavam com assuntos relacionados à gestão econômica, aos pagamentos dos colaboradores e aos possíveis lucros auferidos com o negócio. Diz Barrote sobre a sua experiência:

A mais-valia que eu tinha que administrar, que era fruto do trabalho de um grupo de pessoas que estava à minha volta [na editora], não era minha, eu era uma peça. A minha visão de vida, das relações, não é senão essa. Eu tinha dinheiro pra pagar a mais-valia coletiva que vinha do trabalho coletivo. Eu era o pião, o pivô daquilo tudo, mas eu não fazia nada sem aquela gente. $E$ isto assumido até as últimas consequências é assim, não é de outra maneira. Pagava o que as pessoas diziam que o trabalho valia. ${ }^{61}$

João Carlos Alvim também abordou o tema, em artigo publicado em 1977. Em seu texto, ele sugere que nem sempre a prática dessas editoras era coerente com suas

\footnotetext{
${ }^{60}$ Entrevista com José Antunes Ribeiro, Lisboa, 2/2/2011.

${ }^{61}$ Entrevista com João Barrote na freguesia de Arnoia, concelho de Celorico de Bastos, distrito de Braga, Portugal, 22 de junho de 2011.
} 
posturas ideológicas: “[...] é necessário que as editoras que procuram, com um mínimo de consequência, respeitar um projecto cultural progressista devem tentar fazê-lo com uma transparência de meios muito grande”. Para Alvim, “[...] o que seria trágico é que a esquerda se limitasse a ser, a coberto de álibis mais ou menos simpáticos, a imagem desfocada dos vícios da direita" ${ }^{62}$. Isso poderia ocorrer porque existiria, entre outras questões, uma "ausência de critérios, por parte das editoras, no que diz respeito quer à remuneração do trabalho dos autores, quer ao seu próprio trabalho editorial". Alvim sugere então:

[...] o que pode e deve alterar-se é o facto de nenhuma delas [as editoras de esquerda] ter uma linha transparente de actuação no que concerne à gestão dos seus dinheiros (e isto passa por um tratamento igual de todos os autores, por um pagamento aos tradutores que valorize a profissão [...], por uma política de preços de capa unívoca e explicável [...]; o que pode e deve alterar-se é, enfim, o facto de, com mais ou menos idealismo e com mais ou menos disfarces, todas tratarem o livro como um simples produtor de mais-valia. ${ }^{63}$

Gostaria de terminar este item com uma nota positiva, pois acredito que a atuação dos editores políticos foi muito exitosa em Portugal - e esta é a avaliação que a maior parte dos editores faz também, com variações de intesidade e grau, é claro. É o que pensa também João Barrote, que julga, certamente como outros editores também o fazem, que a sua intenção de intervenção e participação política por meio da edição foi atingida:

Acho que essa intenção foi conseguida, realizada, com que repercussão ou impacto isso não é possível avaliar. [...] Só posso pensar que valeu a pena, que consegui o que foi possível, os objetivos que eu tinha em vista, que eram intenções, não havia objetivos precisos.

Para ele, "O papel destas editoras foi real, mas limitado". Afinal, diz, "Não se muda o mundo com livros. Os destinatários eram pessoas, muita gente terá se beneficiado disso $[\ldots]^{3,64}$.

\footnotetext{
${ }^{62}$ ALVIM, João Carlos. "Um equívoco chamado livro”. Seara Nova, Lisboa, nº 1584, out. 1977, p. 42.

${ }^{63}$ Ibidem, p. 42.

${ }^{64}$ Entrevista com João Barrote, freguesia de Arnoia, concelho de Celorico de Bastos, distrito de Braga, $22 / 6 / 2011$.
} 


\section{CONCLUSÕES}

\section{Predomínio da política e sectarismo}

O período analisado neste trabalho se caracteriza pela quebra de rotina e por certas inovações na sociedade e no campo político portugueses, com o crescimento da inquietação intelectual e política, que se manifesta em grande medida na ampliação da oposição ao regime e ao seu continuísmo, primeiramente, e num período de acentuadas lutas sociais, agitação e instabilidade política, um período pré-revolucionário, a partir do 25 de Abril.

O afastamento de Salazar da chefia do governo, os acenos de abertura de Marcelo Caetano, o incremento do ativismo estudantil e dos grupos de extrema esquerda, o movimento das cooperativas culturais, o crescimento de setores católicos oposicionistas, a atuação da Ala Liberal no parlamento, o descontentamento gerado pela guerra colonial nas forças armadas, a retomada de alguma organização sindical independente com o surgimento da Intersindical em 1970, são alguns dos fatores que caracterizam o período que vai de 1968 até abril de 1974.

A edição apresenta-se, neste contexto, como instrumento de intervenção política com forte potencial a ser explorado pelos setores que buscam opor-se e contestar a situação vigente. Isenta, na prática, da censura prévia, a edição de livros beneficiava-se desse fator se comparada à imprensa, além de contar com uma rede de distribuição bem estruturada e razoavelmente eficiente, como testemunham muitos livreiros e editores. Mas isso não quer dizer que os livros estivessem livres para serem produzidos e vendidos, ao contrário, estavam sujeitos a constantes perseguições, proibições e apreensões, que causavam prejuízos e sobressaltos à atividade editorial e livreira.

Todavia, no quadro de restrições gerais às manifestações oposicionistas, a edição representava uma opção viável de divulgação de ideias, proselitismo e doutrinação, inclusive no que diz respeito aos custos, que permitiam a realização de edições por pequenas editoras ou até mesmo por autores ou tradutores, como iniciativa individual.

É certo que antes de 1968 muitos editores já tinham uma clara atuação política de oposição ou de estímulo ao debate crítico, como foram os casos de Manuel Rodrigues de Oliveira e Bento de Jesus Caraça (Edições Cosmos), Francisco Lyon de 
Castro (Publicações Europa-América), Eduardo Salgueiro (Inquérito), Rogério Moura (Livros Horizonte), Câmara Reis (Seara Nova), para citar somente alguns dos mais destacados. Mas deve-se assinalar que até a segunda metade dos anos 1960 a atuação desses editores se dava sob limites muito estreitos e em moldes mais culturais do que políticos, em virtude dessas limitações. É a partir do final da década de 1960 que os editores começam efetivamente a arriscar a publicação de obras que afrontam mais diretamente a ditadura.

Estas considerações, e os dados aqui apresentados, mostram assim que o boom editorial político teve seu início em fins dos anos 1960 e alcançou seu auge após o 25 de Abril, nos anos de 1974 e 1975, e começou a declinar a partir de 1976, tendo chegado ao fim juntamente com a década de 1970.

Desse modo, o forte movimento de edição política que ocorre nos anos do "processo revolucionário em curso" (PREC) não nasce abruptamente, mas é fruto de um processo de maturação que vem de alguns anos antes. Todavia, é inegável que o 25 de Abril inaugura e proporciona um período de excepcional efervescência e agitação políticas. É a partir de então que surgem quase a metade $(48,5 \%)$ das editoras que publicaram livros políticos no período aqui analisado, ou seja, houve uma intensificação da edição política que deu ao fenômeno uma nova proporção e qualidade.

Certamente nunca houve tantas editoras políticas em atuação simultaneamente no país como nos anos de 1974 e 1975. Não é possível afirmar, estatisticamente, que a produção de livros políticos tenha superado neste período o conjunto das demais edições (não políticas), mas essa percepção faz parte do senso comum de muitos que viveram a época, assinalado em diversas matérias da imprensa de então, como vimos. Esta percepção, e a sua memória, caminham no sentido de afirmar uma prevalência dos livros políticos e das editoras políticas, naquele período, o que por si só torna este um momento especial na história editorial, cultural e política de Portugal.

Ao mesmo tempo, e em consequência, ocorre também, principalmente após o fim da ditadura, uma intensa partidarização da edição política, pois são muitos os partidos que criam suas próprias editoras ou que veem militantes seus criarem editoras que passam a atuar em consonância com o partido. Concretamente, esta partidarização significou a sectarização de boa parte das editoras ligadas a grupos políticos, que tinham esta característica - em particular alguns da extrema esquerda. 
Assim, se por um lado esse surto editorial político proporcionou um amplo debate e a ampliação das perspectivas políticas em discussão, por outro foi marcado por forte sectarismo, levando, muitas vezes, ao empobrecimento dos debates possíveis, limitados que eram pelas posturas pouco afeitas ao diálogo de alguns desses grupos e partidos. Isso se refletia na produção de suas editoras, que parecem, em grande medida, voltadas apenas para os seus próprios militantes, além de extremamente panfletárias.

Mas talvez devesse ser assim mesmo, ou seja, essa era a marca de alguns desses grupos, era a marca de um certo tipo de esquerda da época - e assim como boa parte dessa esquerda que não se reciclou e não ampliou as suas perspectivas perdeu significância política a partir dos anos 1980, a editoras a elas vinculadas também deixaram de existir. Mas ressalte-se que o sectarismo não era exclusividade da esquerda ou da extrema esquerda. A direita e a extrema direita não ficavam atrás, como vimos ao tratar das editoras que se vinculavam a estes setores.

Mas é preciso também destacar que havia muitas editoras políticas (de esquerda ou não) que não eram sectárias, e marcaram sua atuação pelo pluralismo das obras publicadas.

\section{Abrangência da edição política}

Boa parte das editoras políticas que atuavam antes de 1974 se caracterizava por editar livros que representavam manifestações de oposição à ditadura, seja no campo político, seja no campo da cultura e dos costumes.

Com o fim da ditadura, este deixa de ser o mote para a edição política, que passa a enfatizar as lutas políticas e sociais que se apresentam para a sociedade portuguesa nessa nova época. Isso passa pela recuperação da história recente de Portugal, trazendo à tona o que representou a ditadura em termos de repressão, violência e silenciamento, de atraso político, econômico e cultural, como vimos no Capítulo12.

O debate de ideias, de propostas, a discussão doutrinária e ideológica, as novas questões ligadas aos costumes, às liberdades individuais, passam a compor o leque de temas cobertos pelas editoras políticas, que torna-se mais amplo, mais dinâmico e mais contemporâneo. Se uma parte das editoras, em virtude de seu sectarismo, tinha o seu horizonte político e ideológico limitado pela ortodoxia, muitas outras conseguiram 
apresentar nas obras que publicaram as novas temáticas e os novos olhares que emergiram a partir do final dos anos 1960.

Como já expusemos, surgiram a partir de abril de 1974 algumas editoras da revolução, ou seja, editoras criadas como consequência direta do fim da ditadura e do processo de lutas políticas que então se iniciou, e que voltavam a sua atuação integralmente para este processo. Mas houve também outras tantas editoras políticas (de esquerda ou não, militantes ou não) que tiveram importante atuação nesses anos e que dirigiam sua ação editorial para além das disputas políticas mais imediatas. Desse modo, não devemos limitar o alcance temático do movimento editorial político pós-25 de Abril apenas a estas disputas políticas mais imediatas, pois isto significaria empobrecer a contribuição que o conjunto das editoras que publicaram livros políticos proporcionou ao país nos campos cultural e político.

\section{Edição, política, partidos}

As 40 editoras de esquerda criadas em 1974 e 1975 sem dúvida representaram, sob certo ponto de vista, a partidarização de um setor da edição, que pode ter sido vista também como uma invasão do ramo editorial por editoras em geral pouco profissionais, voltadas primordialmente para o uso instrumental do livro, gerando algum "desarranjo" e excesso de oferta no mercado. Isso transparece em algumas manifestações na imprensa da época, como no caso dessa nota de Maria Teresa Horta no Expresso, em novembro de 1974:

Tornamos a recomendar (nunca é demais!) cuidado quanto à compra e principalmente quanto à leitura e aceitação como honesta, de certa literatura dita "política", que agora tanto prolifera por aí, à venda em livrarias, papelarias e mesmo em bancadas ao ar livre e supermercados. Cuidado, pois nem tudo o que luz é ouro... ou seja: nem todos os "grandes" títulos querem dizer boas obras, correctas traduções, etc. Hesitem ante as edições "pirata". A "chancela" de um editor sempre vale alguma coisa, sempre é uma garantia de responsabilidade. ${ }^{1}$

Não fica claro quais são as editoras "pirata" que a jornalista menciona, mas parece certo que a chancela recomendada provém de editoras profissionais, e não daquelas meramente políticas ou de partidos.

\footnotetext{
${ }^{1}$ HORTA, Maria Teresa. “Ecos literários”. Expresso, Lisboa, 16/11/1974, p. III.
} 
Mas se é certo que muitas editoras de partido eram de fato semiamadoras ou pouco profissionais, isso não vale para todas elas. As editoras ligadas ao PCP, por exemplo, não se enquadravam nesse figurino, que se encaixa com mais precisão às editoras ligadas a grupos de extrema esquerda.

A discussão dos temas da conjuntura política foi uma das características marcantes da edição política a partir do 25 de Abril. Promover o amplo debate sobre as questões que mais afligiam a sociedade, intervir na realidade e influenciar os rumos do país eram metas de muitos editores.

Por isso, chama a atenção o fato de que algumas das editoras ligadas a grupos de extrema esquerda, em particular os maoistas, tenham publicado pouquíssimos títulos de autores portugueses. Parece que nestes casos, alguns desses grupos julgavam que as obras teóricas e históricas sobre o comunismo e o socialismo que elas editavam, principalmente dos autores mais representativos dessas correntes, como Marx, Engels, Lenin, Trotsky, Stalin, Mao Tsé-tung, Rosa Luxemburgo, Enver Hoxha e outros, supririam todas as necessidades de informação e formação política que seus simpatizantes e militantes buscavam nos livros - sendo os temas diretamente relacionados ao dia a dia do país supridos por seus jornais, já que a maior parte destes grupos possuía veículos periódicos, além de editoras de livros.

Algumas dessas editoras inseriam nos livros dos autores estrangeiros textos introdutórios de claro viés prescritivo, explicando como se devia ler aquela obra e como relacioná-la à realidade portuguesa que se vivia então. Estas editoras, por tais características, eram em geral fortemente panfletárias, emprestando aos livros que publicavam um aspecto instrumental muito saliente.

Aqui, mais uma vez as editoras vinculadas ao PCP em geral distinguiam-se das de extrema esquerda maoista, uma vez que davam importância em seus catálogos aos autores nacionais, além de publicarem muitos dos autores clássicos mencionados.

Neste quesito, vale destacar que as editoras políticas sem vinculação com grupos políticos e as editoras não políticas deram também espaço amplo para autores e temas nacionais, e tinham catálogos mais ecléticos, nos quais as obras políticas ocupavam em geral um espaço menos exclusivista. Foram também, via de regra, as editoras que tiveram vida mais longa e conseguiram sobreviver ao refluxo político e editorial que se iniciou em 1976. 
As editoras de direita, cuja atuação ganha peso a partir de 1976, repartiam seus lançamentos entre autores nacionais e estrangeiros. No primeiro caso, os temas privilegiados eram a denúncia do "abandono" das ex-colônias da África - e dos portugueses que lá viviam - e o perigo da "sovietização" de Portugal. No caso dos autores estrangeiros, as obras editadas eram no mais das vezes panfletos de propaganda anticomunista.

Como esperado, constatou-se um amplo predomínio de editoras políticas ligadas a grupos ou ao ideário de esquerda (50\%), enquanto apenas 9,6\% eram de direita. Este predomínio talvez possa ser visto não só como um sinal da forte atuação da esquerda no período, mas também como um indicador da importância que este setor político dava à área cultural, à divulgação e ao debate público de suas ideias, em contraposição aos setores de direita. Estes dados parecem indicar também uma maior capacidade dos setores de esquerda de responder ao novo quadro político surgido com o 25 de Abril, ao mesmo tempo em que espelham as dificuldades dos setores de direita de se articularem após a queda do fascismo, regime ao qual muitos deles estavam intimamente ligados.

Vitoriosa em 1974, a esquerda queria mostrar-se e expor suas propostas - após mais de quatro décadas de clandestinidade -, enquanto a direita recolhia-se, temerosa pelo que poderia acontecer. Não por acaso, as editoras de direita vêm à tona principalmente a partir de 1976, quando os setores mais radicais da esquerda são derrotados e o PREC chega ao fim.

\section{Agitação política, engajamento e estratégias editoriais}

Estas conclusões corroboram em grande medida as assertivas de Jean-Yves Mollier sobre o papel do impresso como arma no combate político, sua influência na formação de uma opinião pública em períodos de agitação política, potencializando mudanças sociais importantes. Em Portugal, parece se aplicar a sua ideia de que o impresso político - com destaque para o livro político - foi um dos fatores que colaboraram, após o 25 de Abril, "para fazer a política descer às ruas" ${ }^{2}$, suprindo uma enorme demanda por informação e formação política.

No caso das considerações de Julien Hage sobre editoras de extrema esquerda, algumas podem ser verificadas no grupo mais restrito das editoras políticas militantes

\footnotetext{
${ }^{2}$ MOLLIER, Jean-Yves. “Quando o impresso...”, op. cit., p. 263.
} 
aqui abordadas, como, por exemplo, a prevalência de uma produção mais diretamente política e pragmática em detrimento da literatura ${ }^{3}$, a sua ligação a setores de esquerda que buscavam se diferenciar, ou mesmo se opor, aos partidos comunistas e socialdemocratas tradicionais ${ }^{4}$, e a valorização de elementos paratextuais, como os prefácios e notas explicativas ${ }^{5}$.

Em relação a parte deste grupo de editoras políticas militantes, certamente se aplica também uma das características que François Valloton apontou na editora suíça La Cité, a saber, a ausência de um projeto editorial a longo prazo. O criador da La Cité, Nils Andersson, assim caracterizou a sua editora: "La Cité era um instrumento mais do que uma empresa para sustentar" ${ }^{\prime 6}$. Como conclui Valloton, esta escolha certamente limitou a envergadura da editora, mas foi fundamental para "a grande coerência de um

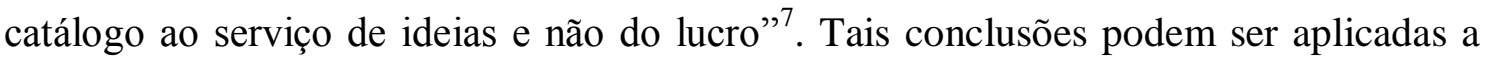
muitas das editoras militantes portuguesas.

Voltando às considerações de Julien Hage, vemos que algumas delas se aplicam ao conjunto mais amplo da edição política em Portugal. Assim, podemos apontar que as editoras políticas constituíram uma "tribuna das vanguardas intelectuais e estéticas de seu tempo", e assim contribuíram para uma renovada oferta editorial, com a valorização do documento político, dos textos teóricos, das obras de ciências sociais e militantes 9 .

Para a maior parte das editoras políticas portuguesas do período, parce ser válida a afirmação de Hage de que uma das bases de identidade destas editoras decorria da estreita relação entre suas estratégias editoriais e seus engajamentos militantes ${ }^{10}$.

\section{Editores e política}

Como vimos, alguns dos editores entrevistados - ou dos quais foi possível apurar a opinião por meio da imprensa e de outros documentos - consideram que suas editoras foram um dos fatores, entre outros, que contribuíram para o fim da ditadura.

\footnotetext{
${ }^{3}$ HAGE, Julien. "Collections politiques...", op. cit.

${ }^{4}$ HAGE, Julien. Feltrinelli, Maspero, Wagenbach, op. cit.

${ }^{5}$ HAGE, Julien. "Collections politiques...", op. cit.

${ }^{6}$ VALLOTON, op. cit., p. 21.

${ }^{7}$ Ibidem, p. 21-22.

${ }^{8}$ HAGE, Julien. Feltrinelli Maspero Wagenbach, op. cit.

${ }^{9}$ HAGE, Julien. "Collections politiques...", op. cit.

${ }^{10}$ Ibidem.
} 
Em certos casos, tal afirmação é feita com cuidadosas ponderações, que indicam a preocupação de não dar à edição política um papel primordial ou de primeiro plano neste processo, mas também sem nunca deixar de incluí-la nesse movimento.

Não parece haver uma auto-heroicização destes editores e do seu papel na luta contra o Estado Novo. Reivindicam o seu lugar nesta luta, não há dúvida, mas ao mesmo tempo parecem acreditar que nela se colocaram ao lado de outros tantos setores profissionais, políticos, sociais, econômicos que em algum momento estiveram na oposição à ditadura.

Estes editores estavam por trás do que Nuno Medeiros chamou de "bases tipográficas do descontentamento", tendo também destaque no balizamento dos moldes da sua circulação ${ }^{11}$. Assim, seu papel tem importância também por serem eles os responsáveis por dar uma forma concreta e circulável, comercializável, às ideias e propostas em debate, o que lhes dá um alcance social mais abrangente, possibilitando a ampla circulação dessas ideias.

Talvez a diferença fundamental do setor editorial, juntamente com a imprensa, em relação a outros setores socioprofissionais e políticos, é que pela natureza mesma de sua atividade, tal postura de oposição precisa ser pública para ter alguma eficácia, o que implica que tais atividades expõem-se mais às represálias do poder, resultando muitas vezes em constrangimentos não só políticos e policiais, mas também econômicos.

No pós-25 de Abril a situação modifica-se, e os editores em geral afirmaram seu papel no atendimento de uma ampla demanda por informação política que então surgiu, assumindo, novamente ao lado da imprensa, um papel até certo ponto pedagógico, já que é unânime a opinião de que as quatro décadas do Estado Novo haviam gerado um cidadão português pouco informado sobre política e sobre democracia. Este papel pedagógico, em muitas editoras políticas - em geral as partidárias -, confundia-se ou mesclava-se com a doutrinação em torno de seus princípios ideológicos.

Nesse período, é interessante pensar na ideia de "mobilização leitural"12, pois certamente parte dos editores políticos atuava para que os títulos que publicava tivessem um papel efetivo na realidade do país, um papel interveniente e mobilizador, o que era expresso na fórmula do livro como "arma" política, como instrumento de luta.

Mas tanto antes como depois do 25 de Abril, o certo é que os editores que publicaram obras políticas assumiram majoritariamente uma posição nas lutas políticas

\footnotetext{
${ }^{11}$ MEDEIROS, Edição e editores, op. cit., p. 205.

${ }^{12}$ Ibidem, p. 238.
} 
que se travavam em Portugal, e essa posição era em favor da liberdade de edição, contra a censura, pelo debate livre de ideias - contra a ditadura, enfim. Tal postura levava, no período do Estado Novo, e independentemente da posição ideológica de cada editor, a um confronto com o governo e com a polícia política. Já com o fim da ditadura, tais editores mantiveram sua postura em favor daquelas ideias e puderam colocá-las em prática com muito menos limitações. Em ambos os períodos, os editores políticos e suas casas editoriais foram sujeitos ativos na sociedade portuguesa, com papel de destaque nos debates então travados.

\section{Edição e mudança}

Um dos aspectos mais importantes de toda essa ampla difusão de livros políticos é que a história e a realidade mais recentes de Portugal começaram a vir a público e a ser conhecidas por amplas camadas da sociedade, de uma maneira totalmente diferente do que ocorria durante a ditadura. $\mathrm{E}$ isso certamente foi importante para ajudar a transformar o país.

Assim, as editoras de caráter político - e as obras por elas editadas - foram um destacado sujeito do processo político português, seja nos anos que antecederam ao 25 de Abril, seja no processo desencadeado a partir daquele momento.

A ligação entre edição e política nesse período foi tão forte que verificamos que a mesma conjuntura de intensificação das lutas sociais que gerou o substrato para o surgimento de muitas das editoras políticas foi também o fator que levou, quando do seu refluxo e do fim do período revolucionário, ao fechamento de muitas dessas editoras.

Como espero ter comprovado com esta investigação, os livros políticos tiveram grande produção e circulação no período 1968-1980, principalmente em 1974-1975, quando passou a ser possível obter mais informações sobre qual era a circulação e os resultados de vendas desses livros. Isso nos permite concluir, em consequência, que estas obras tiveram também ampla aceitação nesses anos. Apesar de não haver dados objetivos sobre a produção e a venda desses livros, parece não haver dúvidas de que efetivamente tanto uma como outra atingiram então níveis inéditos no país - níveis que não voltaram a se repetir.

O levantamento que realizei de cerca de 4.600 títulos políticos editados entre 1968 e 1980 (ver Apêndice 3) é um dado que parece confirmar esta conclusão, e 
referendar a ideia da ampla produção, circulação e repercussão que estas publicações tiveram naquele período.

Desse modo, estes editores colaboraram efetivamente para que ocorressem mudanças na sociedade portuguesa no período analisado, e foram de certa forma agentes dessas mudanças, ao proporcionar a circulação e difusão de ideias, promovendo o debate, levando informação ao público e propiciando elementos para a formação cultural e política dos cidadãos. 


\section{Bibliografia e fontes}

\section{Livros e artigos em livros}

A COR DAS SOLIDARIEDADES: pela justiça e equidade nas relações internacionais. 30 anos do CIDAC. Lisboa/Porto: CIDAC/Afrontamento, 2004.

ABREU, Paradela. Do 25 de Abril ao 25 de Novembro: memória do tempo perdido. Lisboa: Interveção, 1983.

ALMEIDA, João Miguel. A oposição católica ao Estado Novo (1958-1974). Lisboa: Edições Nelson de Matos, 2008.

ALVIM, Maria Luísa. Livros portugueses proibidos no regime fascista: bibliografia. Braga, Faculdade de Letras da Universidade do Porto, 1992. Disponível em: <http://eprints.rclis.org/archive/00009450/01/livros_proibidos.pdf>. Acesso em $8 / 3 / 2008$.

ANDRADE, John. Dicionário do 25 de Abril. Lisboa: Nova Arrancada, 2002.

ANSELMO, Artur. História da edição em Portugal. Das origens até 1530. Porto: Lello \& Irmão, 1991.

ANTUNES, António Lobo. "Homenagem a José Ribeiro". In: Livro de Crónicas. Lisboa: Dom Quixote, 2000.

AVILLEZ, Maria João. Do fundo da revolução. Lisboa/Porto: Público, 1994.

AZEVEDO, Cândido de. A censura de Salazar a Marcelo Caetano. Lisboa: Caminho, 1999.

AZEVEDO, Cândido de. Mutiladas e proibidas: para a história da censura literária em Portugal nos tempos do Estado Novo. Lisboa: Caminho, 1997.

BÁRCIA, Paulo e SILVA, António. Movimento de Esquerda Socialista: uma improvável aventura. Porto: Afrontamento, 2010.

BARRETO, António. “Mudança social em Portugal, 1960-2000”. In: PINTO, António Costa (coord.). Portugal contemporâneo. Lisboa: D. Quixote, 2005.

BARRETO, António e MÓNICA, Maria Filomena (coords.). Dicionário de História de Portugal (Suplementos). Porto: Livraria Figueirinhas, vols. VII-IX, 1999-2000.

BARROSO, José Manuel. Segredos de Abril. Lisboa: Editorial Notícias, 1995.

BEJA, Rui. À janela dos livros: memória de 30 anos de Círculo de Leitores. Lisboa: Círculo de Leitores, 2011.

BEJA, Rui. A edição em Portugal, 1970-2010: percursos e perspectivas. Lisboa: APEL, 2012.

BLOCH, Marc. "Para uma história comparada das sociedades europeias". In: História e historiadores. Lisboa: Teorema, 1998, p. 119-150.

BONNIER, Jytte. Snu. Lisboa: Quetzal, 2003.

BRITO, J. M. Brandão de (coord.). Do Marcelismo ao fim do Império. Lisboa: Editorial Notícias, 1999. 
BRASÃO, Inês et alli. Comunidades de leitura: cinco estudos de sociologia da cultura. Lisboa: Colibri, 2009.

BRITO, J. M. Brandão de (coord.). O País em Revolução. Lisboa: Editorial Notícias, 2001.

BURNAND, Léonard; CARRON, Damien; JEANNERET, Pierre. Livre et militantisme. La Cité Editeur, 1958-1967. Lausanne, Editions d'en bas, 2007.

CÁDIMA, Francisco Rui. “Os 'media' na revolução (1974-1976). In: ”BRITO, J. M. Brandão de (coord.). O País em Revolução. Lisboa: Editorial Notícias, 2001, p. 333.

CARDINA, Miguel. A esquerda radical. Coimbra, Angelus Novus, 2010.

CARDINA, Miguel. A tradição da contestação: Resistência estudantil em Coimbra no marcelismo. Coimbra: Angelus Novus, 2008.

CARDINA, Miguel. Margem de certa maneira: o maoísmo em Portugal (1964-1974). Lisboa: Tinta da China, 2011.

CARVALHO, Alberto Arons de. A censura à imprensa na época marcelista. Coimbra: Minerva, 1999.

CARVALHO, Alberto Arons de; CARDOSO, A. Monteiro. Da liberdade de imprensa. Lisboa: Meridiano, 1971.

CARVALHO, Joaquim Barradas de. O obscurantismo salazarista. Lisboa: Seara Nova, 1974.

CASTANHEIRA, José Pedro e GOMES, Adelino. Os dias loucos do PREC. Lisboa: Público-Expresso, 2006.

CASTRO, F. Lyon de. "Percurso de um editor". In: C. AZEVEDO, A censura de Salazar e Marcelo Caetano, op. cit., p. 526-544.

CÉSAR, Felipa. "Notas sobre o fac-símile da publicação Cadernos para o Diálogo 2". In: CÉSAIRE, Aimé. Discurso sobre o colonialismo. Edição fac-similar. Berlin: Bom Dia, 2012.

CÉU E SILVA, João. Uma longa viagem com José Saramago. Porto: Porto Editora, 2009.

CHARTIER, Roger. A ordem dos livros. Brasília, Editora da UnB, 1994.

CHARTIER, Roger (coord.). As utilizações do objecto impresso (séculos XV-XIX). Miraflores: Difel, 1998.

CHARTIER, Roger. Cultura escrita, literatura e história. Porto Alegre, Artmed, 2001.

CHARTIER, Roger e ROCHE, Daniel. “O livro: uma mudança de perspectiva”. In: LE GOFF, Jacques e NORA, Pierre (orgs.). História: novos objetos. Rio de Janeiro: Francisco Alves, 1976.

CHERESKY, Isidoro e CHONCHOL, Jacques (orgs.). Crise e transformação dos regimes autoritários. Campinas/ São Paulo: Ed. Unicamp/Ícone, 1986.

CHILCOTE, Ronald H. A revolução portuguesa de 25 de Abril de 1974: Bibliografia anotada sobre os antecedentes e evolução posterior. Vol. I. Coimbra: Centro de Documentação 25 de Abril, 1987. 
CHILCOTE, Ronald H. A revolução portuguesa de 25 de Abril de 1974: Bibliografia anotada sobre os antecedentes e evolução posterior. Vol. II. Coimbra: Centro de Documentação 25 de Abril, 1987.

COELHO, Mário Baptista (coord.). Portugal: o sistema político e constitucional (19741987). Lisboa: Instituto de Ciências Sociais, Universidade de Lisboa, 1989.

COELHO, Mário Brochado. Confronto, memória de uma cooperativa cultura: Porto, 1966-1972. Porto: Afrontamento, 2010.

COGGIOLA, Osvaldo. "A origem das crises portuguesa e espanhola da década de 70". In: COGGIOLA, Osvaldo (org.). Espanha e Portugal: O fim das ditaduras. São Paulo: Xamã, 1995, p. 35.

CORDEIRO, José Manuel Lopes. "Glossário dos anos do PREC... e de alguns mais". In: FREITAS, José Gualberto de Almeida. A guerra dos cartazes. Lembrabril, 2009, p. 105-133.

CORDEIRO, José Manuel Lopes. Verbetes "Extrema-Esquerda", "Maoísmo", "Movimento Reorganizativo do Partido do Proletariado (MRPP)", "Organização Comunista Marxista-Leninista Portuguesa (OCMLP)" e "Partido Comunista de Portugal (marxista-leninista) (PCP M-L)". In: BARRETO, António e MÓNICA, Maria Filomena (coords.). Dicionário de História de Portugal (Suplementos). Porto: Livraria Figueirinhas, vol.7, 8 e 9, 1999-2000.

CORREIA, Pedro Pezarat. Questionar abril. Lisboa: Caminho, 1994.

COSTA, Sara Figueiredo. Fernando Guedes: O decano dos editores portugueses. Lisboa: Booktailors, 2012.

CRUZEIRO, Maria Manuela. Vasco Gonçalves: um general na revolução. Lisboa: Editorial Notícias, 2002.

CUNHA, Carlos Alberto. "Partido Socialista". Verbete. In: BARRETO, António e MÓNICA, Maria Filomena. Dicionário de História de Portugal. Porto: Figueirinhas, Vol. IX, Suplemento P/Z, 1999, p. 30.

CUNHAL, Álvaro. “A Revolução dos Cravos: Abril de 1974 - Novembro de 1975”. In: COGGIOLA, Osvaldo (org.). Espanha e Portugal: O fim das ditaduras. São Paulo: Xamã, 1995, p. 139-152.

CUNHAL, Álvaro. A verdade e a mentira na Revolução de Abril (A contra-revolução confessa-se). Lisboa: Avante!, 1999.

CUNHAL, Álvaro. A Revolução Portuguesa: o passado e o futuro. Lisboa: Avante, 1994.

CURTO, Diogo Ramada. Cultura Escrita: Séculos XV a XVIII. Lisboa: Imprensa de Ciências Sociais, 2007.

CURTO, Diogo Ramada. “As gentes do livro". In: CURTO, Diogo Ramada; DOMINGOS, Manuela; FIGUEIREDO, Dulce; Gonçalves, PAULA (orgs.). As gentes do livro: Lisboa, Século XVIII. Lisboa: Biblioteca Nacional, 2007, 15-47.

CURTO, Diogo Ramada, ed. Estudos de Sociologia da Leitura em Portugal no Século XX. Lisboa: Fundação Calouste Gulbenkian, 2006.

DARNTON, Robert. “A importância de ser bibliográfico”. In: A questão dos livros. São Paulo: Cia. das Letras, 2010, p. 146-163. 
DARNTON, Robert. "O que é a história dos livros" revisitado. Trad. de Lilia G. M. Tavolaro. ArtCultura, v. 10, no 16, p. 153-167, jan.-jun. 2008.

DARNTON, Robert. "O que é a história dos livros". In: O beijo de Lamourette. São Paulo: Cia. das Letras, 1990, p. 112.

DARNTON, Robert. $O$ Iluminismo como negócio: história da publicação da Enciclopédia, 1775-1800. São Paulo: Cia. das Letras, 1996.

DARNTON, Robert. Os best-sellers proibidos da França revolucionária. São Paulo: Cia. das Letras, 1998.

DARNTON, Robert. Edição e sedição: o universo da literatura clandestina no século XVIII. São Paulo: Cia. das Letras, 1992.

DELGADO, Iva et alli (orgs.). De Pinochet a Timor Lorosae: impunidade e direito à memória. Lisboa: Edições Cosmos/Fundação Humberto Delgado, 2000.

DINIZ, Pedro de Sousa. A dramatização na imprensa do "PREC". Coimbra: MinervaCoimbra, 2003.

DIONÍSIO, Eduarda. “As práticas culturais”. In: REIS, António (coord.). Portugal 20 anos de democracia. Lisboa: Temas e Debates, 1996.

"DOSSIERS DE LUTA: UMA EXPLICAÇÃO NECESSÁRIA". In: Trabalhadores dos transportes Estefânia em luta contra o patrão. Lisboa, Contra a Corrente, 1976.

EISENSTEIN, Elizabeth L. A revolução da cultura impressa: os primórdios da Europa Moderna. São Paulo: Ática, 1998.

ESCARPIT, Robert. A revolução do livro. Rio de Janeiro: Ed. Fundação Getúlio Vargas/Instituto Nacional do Livro, 1976.

FARIA, Margarida Lima; CAMPOS, Ana Margarida. "Contextos sociais de edição e de leitura da Colecção Livros RTP-Verbo - Uma abordagem preliminar”. In: SERUYA, Teresa (org.). Estudos de tradução em Portugal: a colecção de livros RTP-Biblioteca Básica Verbo 1971-1972. Lisboa: Universidade Católica, 2005.

FARIA, Maria Isabel e PERICÃO, Maria da Graça. Dicionário do livro: da escrita ao livro eletrônico. São Paulo: Edusp, 2008.

FARINHA, Luís. "Reviralhismo". Verbete. In: ROSAS, Fernando; BRITO, J. M. Brandão de (coords.). Dicionário de história do Estado Novo. Vol. II. Lisboa: Bertrand, 1996, p. 832-34.

FERREIRA, José Medeiros. "Portugal em transe". In: MATTOSO, José (coord.). História de Portugal, v. VIII. Lisboa: Círculo de Leitores, 1993.

FERREIRA, Serafim. Olhar de editor. Lisboa: Escritor, 1999.

FIGUEIRA, João. Os jornais como actores políticos: o Diário de Notícias, Expresso e Jornal Novo no Verão Quente de 1975. Coimbra: MinervaCoimbra, 2007.

FREIRE, João. “A Batalha”. Verbete. In: BARRETO, António; MÓNICA, Maria Filomena (coords.). Dicionário de História de Portugal. Lisboa/Porto: Figueirinhas, Vol. VII, Suplemento A/E, 1999, p. 176.

FREIRE, João. Pessoa comum no seu tempo: memórias de um médio.burguês de Lisboa na segunda metade do século X. Porto: Afrontamento, 2007. 
FREITAS, Sônia Maria de. História oral: Possibilidades e procedimentos. São Paulo: Humanitas/Imesp, 2002.

FURTADO, José Afonso. O que é o livro. Lisboa: Difusão Cultural, 1995.

FURTADO, José Afonso. Os livros e as leituras: novas ecologias da informação. Lisboa: Livros e Leituras, 2000.

FURTADO, José Afonso. O papel e o Pixel. Coimbra: Ariadne, 2007.

GALIZA, Rui Daniel; PINA, João. Por teu livre pensamento: histórias de 25 ex-presos políticos. Lisboa: Assírio \& Alvim, 2007.

GUEDES, Fernando. Livreiros em Portugal e suas associações, desde o século XV até aos nossos dias. Lisboa: Verbo, 1993.

GUEDES, Fernando. O livro como tema. História, cultura, indústria. Lisboa: Verbo, 2001.

HABERMAS, Jürgen. L'Espace Public. Archéologie de la publicité comme dimension constitutive de la société bourgeoise. Paris: Peyot, 1978.

HALLEWELL, Lawrence. O livro no Brasil: sua história. São Paulo: Edusp, 2005.

HATHERLY, Ana. "Prefácio". In: SACHER-MASOCH. A Vénus de Kazabaïka. Lisboa: Relógio d'Água Editores, 2ª edição, 1994.

HENRIQUES, Júlio. “O tigre de papel”. Expresso, 9/8/1975.

HENRIQUES, Julio. "Um jornal diferente". In: RODRIGUES, Francisco Martins (coord.). O futuro era agora: o movimento popular do 25 de Abril. Lisboa: Dinossauro, p. 52-54.

HERMÍNIO MONTEIRO. 1952-2001: Editor. Lisboa: Câmara Municipal de Lisboa, Comissão Municipal de Toponímia, 2005.

ISIDRO, João. Proscritos à sobremesa: facturas de revoluções passadas com ementa de alhadas frescas. Lisboa: Hugin, 1997.

JALALI, Carlos. Partidos e democracia em Portugal (1974-2005). Lisboa: ICS, 2007.

JARA, José Manuel. A farsa dos pseudo-radicais em Portugal: estudo político e teórico sobre os grupos maoístas e trotskistas perante a revolução. Lisboa: Edições Sociais, 1974.

JARA, José Manuel. Maoísmo em Portugal: ideologia anarquista, contra-revolucionária e paródia burguesa do marxismo. Lisboa: Edições Sociais, 1975.

JEANNERET, Pierre. "Les engagements politiques des années 60 et l'expulsion de Nils Andersson". In: BURNAND, Léonard; CARRON, Damien; JEANNERET, Pierre. Livre et militantisme. La Cité Editeur, 1958-1967. Lausanne, Editions d'en bas, 2007, p. 124.

JÚDICE, José Miguel. "Oposição de direita a Marcelo Caetano". Verbete. In: BARRETO; MÓNICA, op. cit., Vol. 8, Suplemento F/O, 1999, p. 643-44.

KOSHIYAMA, Alice Mitika. Monteiro Lobato: intelectual, empresário, editor. São Paulo: T. A. Queiroz, 1982, p. 8.

LARSSON, Flora Manuela. "Alguns aspectos da actividade editorial portuguesa desde 1973 a 1976". In: COELHO, Jacinto do Prado et alii. Problemática da Leitura. Aspectos sociológicos e pedagógicos. Lisboa: Instituto Nacional de Investigação Científica, 1980. 
LEMUS LOPEZ, Encarnacion. "La transición ibérica. Ruptura frente a reforma en las democratizaciones de Portugal y España”. In: Relações Portugal - Espanha: Uma história paralela, um destino comum? Porto: CEPESE-Universidade do Porto/FRAH, 2002.

LINDIM, Isabel. Mulheres de armas. Carnaxide: Objectiva, 2012.

LISBOA, Irene. Inquérito ao Livro em Portugal. Vol. I, Editores e Livreiros. Lisboa: Seara Nova, 1944.

LISBOA, Irene. Inquérito ao Livro em Portugal. Vol. II, A Arte do Livro. Lisboa: Seara Nova, 1946.

LIVROS proibidos no Estado Novo. Catálogo da exposição realizada na Livraria Parlamentar, Assembléia da República, em abril de 2004. Lisboa: Divisão de Edições da Assembléia da República, 2005.

LOFF, Manuel; MEIRELES, M. da Conceição (coords.). Portugal: 30 Anos de Democracia (1974-2004). Porto: Editora da Universidade do Porto, 2006.

LOFF, Manuel. O nosso século é fascista! O mundo visto por Salazar e Franco. Porto: Campo das Letras, 2008.

LOPES, Moacir C. A situação do escritor e do livro no Brasil. Rio de Janeiro: Cátedra, 1978.

LOUÇÃ, Francisco; ROSAS, Fernando (orgs.). Ensaio geral: Passado e futuro do 25 de Abril. Lisboa: D. Quixote, 2004.

LUÍS, António Carmo. "Portugal em Sade, Sade em Portugal (história, histórias...) adaptação de um capítulo do livro inédito Sete Encenações Falhadas de uma Batalha Campal". In: PAULHAN, Jean. O Marquês de Sade e a sua cúmplice; seguido de Portugal em Sade, Sade em Portugal. Lisboa: Hiena, 1992. Blogue Afrodite. Disponível em: <http://editora-afrodite.blogspot.com.br/2009/10/porque-edicao-do-meinkampf.html>. Acesso em 5/3/2011.

MADEIRA, João (coord.); FARINHA, Luís; PIMENTEL, Irene Flunser. Vitímas de Salazar: Estado Novo e violência política. Lisboa: Esfera dos Livros, 2007.

MADEIRA, João. Os engenheiros de almas: o Partido Comunista e os intelectuais (dos anos trinta a inícios de sessenta). Lisboa: Estampa, 1996.

MALTEZ, José Adelino. Tradição e revolução: uma biografia do Portugal político do século XIX ao XXI. Vol. II (1910-2005). Lisboa: Tribuna da História, 2005.

MANUEL, Alexandre; CARAPINHA, Rogério e NEVES, Dias (coord.). PIDE: A história da repressão. Fundão, Editora Jornal do Fundão, 1974.

MARCHI, Riccardo. Nação, Império, revolução: as direitas radicais portuguesas no fim do Estado Novo (1959-1974). Lisboa: Texto, 2009.

MARTINS, Jorge Manuel. Profissões do livro: editores e gráficos, críticos e livreiros. Lisboa: Verbo, 2005.

MARTINS, Jorge Manuel. Marketing do livro: materiais para uma sociologia do editor português. Oeiras, Celta, 1999.

MASCARENHAS, João Mário; REIS, António. 25 de Abril. Lisboa: Biblioteca-Museu República e Resistência, 1998. 
MATEUS, Rui. Contos proibidos: memórias de um PS desconhecido. Lisboa: Dom Quixote, 1996.

MATOS E LEMOS, Mário. Candidatos da Oposição à Assembleia Nacional do Estado Novo (1945-1973). Um Dicionário. Lisboa: Divisão de Edições da Assembleia da República/Texto $\quad 2009 . \quad$ Dditores, 2 em: $<$ http://www.parlamento.pt/ArquivoDocumentacao/Documents/Candidatos_Oposicao.p df>

MAXWELL, Kenneth. "A derrubada do regime e as perspectivas de transição democrática em Portugal”. In: O'DONNEL, Guillermo; SCHMITTER, Philippe C; WHITEHEAD, Laurence (eds.). Transições do regime autoritário: Sul da Europa. São Paulo: Vértice, 1988, p. 160-199.

MAXWELL, Kenneth. O império derrotado: Revolução e democracia em Portugal. São Paulo: Cia. das Letras, 2006.

MEDEIROS, Nuno. "O universo editorial nos anos trinta e quarenta: a dinâmica do livro, entre persistência e mudança". In: PITA, António Pedro Pita; TRINDADE, Luís Trindade (coords.). Transformações estruturais do campo cultural português: 19001950. Coimbra: Centro de Estudos Interdisciplinares do Século XX da Universidade de Coimbra, 2009, p. 107-133.

MEDEIROS, Nuno. "Editores e livreiros: que papéis de mediação para o livro?”. In CURTO, D. R. (dir.). Estudos de Sociologia da Leitura em Portugal no Século XX. Lisboa: Fundação Calouste Gulbenkian, 2006, pp. 343-385.

MEDEIROS, Nuno. Edição e editores: o mundo do livro em Portugal, 1940-1970. Lisboa: ICS, 2010.

MEIHY, José Carlos Sebe. Manual de história oral. 4ª ed. São Paulo: Loyola, 2002.

MELO, Daniel. A leitura pública no Portugal contemporâneo (1926-1987). Lisboa: ICS, 2004.

MERCADANTE, Paulo. Portugal ano zero. Rio de Janeiro: Artenova, 1975.

MESQUITELA, Gonçalo. “Apresentação”. In: ZORRO, António Maria. Cuidado, Carl... Queluz: Literal, 1978.

MINISTÉRIO DA COMUNICAÇÃO SOCIAL. Portugal: Liberdade é também vontade. Lisboa: Ministério da Comunicação Social, 1975.

MOLLIER, Jean-Yves. Édition, presse et pouvoir en France au XX siècle. Paris: Fayard, 2008.

MOLLIER, Jean-Yves. "Quando o impresso se torna uma arma no combate político: a França do século XV ao século XX". In: DUTRA, Eliana Freitas; MOLLIER, J.Y. (Org.). Política, nação e edição. O lugar dos impressos na construção da vida política. Brasil, Europa e Américas nos séculos XVIII-XX. São Paulo: Annablume, v. 1, 2006, p. 259-274.

MORET, Xavier. Tiempo de editores: historia de la edición en España, 1939-1975. Barcelona: Destino, 2002.

MOURA, Pereira F.; NEVES, Mario; FERNANDES, Rogério; ZENHA, Salgado. $O$ estatuto da imprensa. Coleção Cadernos de Hoje. Lisboa: Prelo, 1968. 
NASCIMENTO, Ulpiano do. "Seara Nova". Verbete. In: BARRETO, António e MÓNICA, Maria Filomena. Dicionário de História de Portugal. Porto: Figueirinhas, Vol. IX, Suplemento P/Z, 1999, p. 407-10.

NERY, Sebastião. Portugal, um salto no escuro. Rio de Janeiro: Francisco Alves, 1975.

NORONHA, Ricardo. “'A banca ao serviço do povo': lutas sociais e nacionalizações durante a revolução portuguesa". In: VARELA, Raquel (org.). Revolução ou transição? História e memória da Revolução dos Cravos. Lisboa: Bertrand, 2012.

NUNES, João Arsénio. “Avante!”. Verbete. BARRETO, António e MÓNICA, Maria Filomena. Dicionário de História de Portugal. Porto: Figueirinhas, Vol. VII, Suplemento A/E, 1999, p. 151-53.

O 25 DE ABRIL NA IMPRENSA ESTRANGEIRA. Lisboa: Dom Quixote, 1974.

O’DONNEL, Guillermo; SCHMITTER, Philippe C. (eds.). Transições do regime autoritário: Primeiras conclusões. São Paulo: Vértice, 1988.

O'DONNEL, Guillermo; SCHMITTER, Philippe C.; WHITEHEAD, Laurence (eds.). Transições do regime autoritário: Sul da Europa. São Paulo: Vértice, 1988.

O fascismo em Portugal: Actas do Colóquio realizado na Faculdade de Letras de Lisboa em Março de 1980. Lisboa: A Regra do Jogo, 1982.

OLIVEIRA, César. Anos decisivos: Portugal 1962-1985, um testemunho. Lisboa: Presença, 1993.

PAÇO, António Simões do. Os anos de Salazar. Coleção em 30 volumes. Lisboa: Planeta DeAgostini, 2008.

PALACIOS CEREZALES, Diego. O poder caiu na rua. Lisboa: ICS, 2003.

PEREIRA, Antónia Maria. Parceria A. M. Pereira: Crônica de uma dinastia livreira. Lisboa: Pandora, 1998.

PEREIRA, José Pacheco. A sombra: estudo sobre a clandestinidade comunista. Lisboa: Gradiva, 1993.

PEREIRA, José Pacheco. O um dividiu-se em dois: origens e enquadramento internacional dos movimentos pró-chineses e albaneses nos países ocidentais e em Portugal (1960-65). Lisboa: Aletheia, 2008.

PEREIRA, José Pacheco. As armas de papel: publicações periódicas clandestinas e do exílio ligadas a movimentos radicais de esquerda cultural e política (1963-1974). Lisboa: Temas e Debates, 2013.

PEREIRA, Nuno Teotônio. "O Tempo e o Modo". Verbete. In: BARRETO, António e MÓNICA, Maria Filomena. Dicionário de História de Portugal. Porto: Figueirinhas, Vol. IX, Suplemento P/Z, 1999, p. 509.

PIMENTEL, Irene Flunser. A história da PIDE. Lisboa: Córculo de Leitores, 2007.

PIMENTEL, Irene Flunser. José Afonso: Fotobiografias século XX. Lisboa: Círculo de Leitores, 2009.

PINHEIRO, Maria Odete Manso (coord.). Antonio Carlos Manso Pinheiro: a homenagem. Lisboa: Estampa/APEL, 2007. 
PINTO, António Costa. "Enfrentando o legado autoritário na transição para a democracia (1974-1976). In: 'BRITO, J. M. Brandão de (coord.). O País em Revolução. Lisboa: Editorial Notícias, 2001, p. 379.

PINTO, António Costa (coord.). Portugal contemporâneo. Lisboa: D. Quixote, 2005.

PINTO, António Costa. "Saneamentos políticos e movimentos radicais de direita na transição para a democracia, 1974-1976". In: Portugal e a transição para a democracia (1974-1976). I Curso Livre de História Contemporânea, Lisboa, 23 a 28 de Novembro de 1998. Organizado pela Fundação Mário Soares e Instituto de História Contemporânea da Universidade Nova de Lisboa. Coord. Fernando Rosas, p. 29-48.

PINTO, Antonio Costa. "Integralismo Lusitano". Verbete. In: BARRETO, António e MÓNICA, Maria Filomena. Dicionário de História de Portugal. Porto: Figueirinhas, Vol. VIII, Suplemento F/O, 1999, p. 281.

PINTO, António Costa. O fim do império português. Lisboa: Livros Horizonte, 2001.

PINTO, Jaime Nogueira. "Congresso dos Combatentes". Verbete. In: BARRETO; MÓNICA, op. cit., Vol. 7, Suplemento A/E, 1999, p. 398.

PORTUGAL NA IMPRENSA ESTRANGEIRA: um ano depois. Lisboa: Dom Quixote, 1975.

PORTUGAL, UM ANO DE REVOLUÇÃO, 1974-1975. Catálogo da exposição. Lisboa: Associação Portugal-RDA, 1975.

RABY, Dawn Linda. A resistência antifascista em Portugal. Comunistas, democratas e militares em oposição a Salazar, 1941/1974. Lisboa: Edições Salamandra, 1990.

Janice Radway. Reading the Romance: women, patriarchy and popular literature. Chapel Hill: University of North Carolina Press, 1984.

REIMÃO, Sandra. Livros em revistas. São Paulo: Salesiana Dom Bosco, 1996.

REIMÃO, Sandra. Repressão e resistência: Censura a livros na ditadura militar. São Paulo: Edusp/ Fapesp, 2011.

REIS, António (dir.). Portugal Contemporâneo, vols. III a VI. Lisboa: Publicações Alfa, 1989.

REIS, António (coord.). Portugal 20 anos de democracia. Lisboa: Temas e Debates, 1996.

REIS, António. "O Partido Socialista e a defesa da democracia representativa pluralista". In: Portugal e a transição para a democracia (1974-1976). I Curso Livre de História Contemporânea, Lisboa, 23 a 28 de Novembro de 1998. Organizado pela Fundação Mário Soares e Instituto de História Contemporânea da Universidade Nova de Lisboa. Coord. Fernando Rosas, p. 49-61.

REIS, António. "Seara Nova" (verbete). In: ROSAS, Fernando; BRITO, J. M. Brandão de (coords.). Dicionário de história do Estado Novo. Vol. II. Lisboa: Bertrand, 1996.

REZOLA, Maria Inácia. 25 de Abril - Mitos de uma Revolução. Lisboa: Esfera dos Livros, 2007.

REZOLA, Maria Inácia. António de Spínola: Fotobiografias século XX. Lisboa: Círculo de Leitores, 2001. 
REZOLA, Maria Inácia. "Católicos progressistas". Verbete. In: ROSAS, Fernando e BRITO, J. M. Brandão de (coords.). Dicionário de história do Estado Novo. Vol. I. Lisboa: Bertrand, 1996, p. 137-39.

REZOLA, Maria Inácia. "Imprensa clandestina". Verbete. In: ROSAS, Fernando; BRITO, José Maria Brandão de (dir.). Dicionário de História do Estado Novo. V. I. Lisboa: Círculo de Leitores, 1996, p. 441-451.

REZOLA, Maria Inácia. Os militares na Revolução de Abril. Porto: Campo da Comunicação, 2006.

"Os Militares, o 25 de Abril e a transição para a Democracia". In: TEIXEIRA, Nuno Severiano (coord.). Os militares e a democracia. Lisboa: Colibri, 2007, p. 23-39.

RIBEIRO, Sergio. 50 anos de economia e militância. Lisboa: Avante!, 2008.

RODRIGUES, Avelino; BORGA, Cesário; CARDOSO, Mario. Portugal depois de Abril. Lisboa: Intervoz, 1976.

RODRIGUES, Francisco Martins. Abril traído. Lisboa: Dinossauro, 1999, p. 35.

RODRIGUES, Francisco Martins. O futuro era agora. Lisboa: Dinossauro, 1994,

ROSAS, Fernando. "Biografia". In: PINHEIRO, Maria Odete Manso (coord.). Antonio Carlos Manso Pinheiro: a homenagem. Lisboa: Estampa/APEL, 2007, p. 4-7.

ROSAS, Fernando (coord.). Portugal e o Estado Novo (1930-1960). Coleção Nova História de Portugal dirigida por Joel Serrão e A. H. De Oliveira Marques. Lisboa: Presença, 1992.

ROSAS, Fernando e BRITO, J. M. Brandão de (dirs.). Dicionário de História do Estado Novo, 2 vols. Lisboa: Círculo de Leitores, 1996.

ROSAS, Fernando. “O Estado Novo (1926-1974)". In: MATTOSO, José (dir.). História de Portugal, vol. VII. Lisboa Círculo de Leitores, 1994.

ROSAS, Fernando. "O Marcelismo e a crise final do Estado Novo". In: Portugal e a transição para a democracia (1974-1976). I Curso Livre de História Contemporânea, Lisboa, 23 a 28 de Novembro de 1998. Organizado pela Fundação Mário Soares e Instituto de História Contemporânea da Universidade Nova de Lisboa. Coord. Fernando Rosas, p. 9-27.

SÁ, Pinto de. Conquistadores de almas: memórias de uma militância e prisões políticas (1970-1976). Lisboa: Guerra e Paz, 2000.

SANCHES, J. L. Saldanha. O MRPP, instrumento da contra-revolução. Lisboa: Ulmeiro, 1975.

SÁNCHEZ CERVELLÓ, Josep. A revolução portuguesa e a sua influência na transição espanhola (1961-1976). Lisboa: Assírio e Alvim, 1993.

SANTOS, António Costa. Proibido! Lisboa: Guerra e Paz, 2007.

SANTOS, Boaventura de Sousa, CRUZEIRO, Maria Manuela e COIMBRA, Maria Natércia. O pulsar da Revolução cronologia da Revolução de 25 de Abril (1973-1976). Lisboa: Afrontamento, 1997.

SANTOS, Boaventura de Sousa. O Estado e a sociedade em Portugal (1974-1988). Porto: Afrontamento, 1990. 
SANTOS, José Alberto Loureiro dos. "Os militares na democratização de Portugal". In: TEIXEIRA, Nuno Severiano. Os militares e a democracia. Lisboa: Edições Colibri, 2007.

SANTOS, José da Cruz (coord.). Agostinho Fernandes: um industrial inovador, um coleccionador de arte, um homem de cultura. Lisboa: Portugália Editora Internacional, 2000.

SANTOS, Paula Borges. Igreja Católica, Estado e sociedade (1968-1975): o caso Rádio Renascença. Lisboa: ICS, 2005.

SCHIFFRIN, André. La edición sin editores. Barcelona, Destino, 2000.

SCHIFFRIN, André. O negócio dos livros: como as grandes corporações decidem o que você vai ler. Rio de Janeiro: Casa da Palavra, 2006.

SCHMITTER, Philippe C. "Introdução às transições sul-européias do regime autoritário: Itália, Grécia, Portugal e Espanha". In: O'DONNEL, Guillermo; SCHMITTER, Philippe C.; WHITEHEAD, Laurence (eds.). Transições do regime autoritário: Sul da Europa. São Paulo: Vértice, 1988, p. 19-20.

SECCO, Lincoln. A revolução dos Cravos e a crise do império colonial português. São Paulo: Alameda, 2004.

SERUYA, Teresa. Estudos de tradução em Portugal: a colecção de livros RTPBiblioteca Básica Verbo 1971-1972. Lisboa: Universidade Católica, 2005.

SERVIÇO DE INTERCÂMBIO Político e Cultural. Portugal, um guia para o processo. Lisboa: Slemes, 1976.

SILVA, António. Conversas (durante anos) com José Fernandes Fafe. Lisboa: Almedina, 2002.

SILVA, Josué. "Nota introdutória". In: Legião Portuguesa: força repressiva do fascismo. Lisboa: DiAbril, 1975, p. 7-8.

SILVA, Maria Beatriz Nizza da. "História da leitura luso-brasileira: balanços e perspectivas". In: ABREU, Márcia (Org.). Leitura, história e história da leitura. Campinas, Mercado de Letras, 2000.

SILVA, Mário Augusto Medeiros da. Escritores da guerrilha urbana: literatura de testemunho, ambivalência e transição política (1977-1984). São Paulo: Annablume, 2008.

SIMONIN, Anne. Les éditions de Minuit, 1942-1955. Le devoir d'insoumission. Paris, IMEC Éditions, 1994.

SOARES, Mario. Caminho difícil: do salazarismo ao caetanismo. Rio de Janeiro: Lidador, 1973.

"Sociedade Portuguesa de Escritores" (verbete). In: BARRETO, António e MÓNICA, Maria Filomena (coords.). Dicionário de História de Portugal (Suplementos). Porto: Livraria Figueirinhas, 1999-2000, vol. 9, p. 464.

SOUSA, Franco de. "Dedicatória ao povo português". In: BORDA, João. A revolta dos marinheiros. Coleção Episódios da Resistência Antifascista Contados por Quantos a Viveram, vol. 1. Lisboa: Edições Sociais, 1974.

SPÍNOLA, António. Portugal e o futuro. Lisboa: Arcádia, 1974. 
SPÍNOLA, António. Portugal e o futuro. Lisboa: Prefácio, 2003.

TAMEN, Isabel (org.). A aventura da Moraes. Lisboa: Centro Nacional de Cultura, 2006.

UNSELD, Siegfried. O autor e seu editor. Rio de Janeiro: Ed. Guanabara, 1986.

UNWIN, Stanley. O que é uma editora. São Paulo: Record, 1960.

VALLOTON, François. 'Edition et militantisme: le catalogue de 'La Cité: Editeur' (1958-1967)". In: BURNAND, Léonard; CARRON, Damien; JEANNERET, Pierre. Livre et militantisme. La Cité Editeur, 1958-1967. Lausanne, Editions d'en bas, 2007, p. 7-26.

VENTURA, António. Memórias da Resistência: Literatura autobiográfica da resistência ao Estado Novo. Lisboa: Câmara Municipal de Lisboa, 2001.

VENTURA, António. "O marxismo em Portugal no século XX". In: CALAFATE, Pedro (dir.). História do pensamento filosófico português. Lisboa: Caminho, vol. V, tomo 2, 2000, p. 195-220.

VIEIRA, José. "Edições Base”. In: Base-FUT: 30 anos. Lisboa: Base, 2004.

VILA-SANJUÁN, Sergio. Pasando página: autores y editores en la España democrática. Barcelona: Destino, 2003.

VINTE e cinco anos do 25 de Abril: da revolução ao 25 de Novembro - as mudanças. Vila Nova de Famalicão, Museu Bernardino Machado/Câmara Municipal de Vila Nova de Famalicão, 2000.

VALLOTON, François. 'Edition et militantisme: le catalogue de 'La Cité: Editeur' (1958-1967)". In: BURNAND, Léonard; CARRON, Damien; JEANNERET, Pierre. Livre et militantisme. La Cité Editeur, 1958-1967. Lausanne, Editions d'en bas, 2007.

\section{Artigos (em revistas, jornais e anais)}

350 TÍTULOS PARA A HISTÓRIA DO LIVRO E DA LEITURA EM PORTUGAL. Grupo Interdisciplinar do Livro e da Leitura. Universidade Nova de Lisboa. Cultura - Revista de História e Teoria das Ideias, Centro de História da Cultura-FCSH, Universidade Nova de Lisboa, II a série, vol. IX, 1997, p. 314-35. Volume temático sobre "O livro e a leitura", coordenado por João Luís Lisboa. Disponível em <http://www.fcsh.unl.pt/chc/pdfs/350TIT.pdf>. Acesso em 17/3/2008.

“A OPINIÃO”. Blogue Almocreve das Petas, 24 de Abril de 2004. Disponível em: <http://almocrevedaspetas.blogspot.com/2004_04_04_almocrevedaspetas_archive.htm> . Acesso em julho de 2010.

“Ainda o estranho caso do Proletário Vermelho". Expresso, no 93, 12/10/1974, p. 2.

“Alguns elementos históricos sobre o MRPP”. O Tempo e o Modo, no 117, Abril 1976, p. 17. Disponível on line no site da Fundaçao Mário Soares: $<$ http://www.fmsoares.pt/aeb_online/visualizador.php?bd=IMPRENSA\&nome_da_past $\mathrm{a}=08033.117 \&$ numero_da_pagina $=19>$.

ALMEIDA, Nuno Ramos de. "Reuni muitas vezes com um capuz enfiado na cabeça. Entrevista com José Pacheco Pereira". Jornal i, nº 673, 2/3 Julho 2011, p. 18-20. 
Disponível em: <http://www.ionline.pt/conteudo/134127-pacheco-pereira-reuni-muitasvezes-com-um-capuz-enfiado-na-cabeca>

ALMEIDA, Sérgio. "Zeferino Coelho, editor de sempre, destaca legado". Diário de Notícias, Lisboa, 19 jun. 2010.

ALVES, Jofre. "Jornais do PREC - 3, A Batalha". Blogue Abril de Novo em 15/5/2012. Disponível em: < http://abril-de-novo.blogspot.com.br/>. Acesso em junho de 2012.

ALVES, Jofre. "Manuel Quirós: uma vida temperada na luta". Blogue Abril de Novo, 25/10/2009. Disponível em: <http://abril-de-novo.blogspot.com/search/label/CMLP>. Acesso em junho de 2011.

ALVIM, João Carlos. "Um equívoco chamado livro". Seara Nova, Lisboa, no 1584, out. 1977, p. 42.

AMARAL, Celestino. "Caso PRP: a manobra político-policial...". Ponto, $\mathrm{n}^{\mathrm{o}} 8$, 24/121980, p. 4. Disponível em: <http://memoriando.net/prp/>.

ANN, Mary. “O desamor". Blogue MikeRomeoPapaPapa, 21/3/2009. Disponível em: <http://mikeromeopapapapa.blogspot.com/2009_03_01_archive.html>. Acesso em novembro de 2010.

ARCARY, Valério. "Quando o futuro era agora". Disponível em: <http://www.socialismo-o-

barbarie.org/europa/040627_revolucionportuguesa30aniversario.htm\#_ftn32>. Acesso em maio de 2011.

"As massas exigem a libertação do camarada Arnaldo de Matos e os militaristas respondem a tiro". Luta Popular, no 63, 14/6/1975, p. 6-7; Entrevista com João Camacho, Lisboa, 3/3/2011.

BARATA, Clara; QUEIRÓS, Luís Miguel. "Os livros da resistência: livrarias no regime fascista". Público, Porto, 11 Jun. 1994, sup. Leituras, p. 1-4. Disponível em: <http://quexting.di.fc.ul.pt/teste/publico94/ED940606.txt>.

“Bertrand (Plurali\$ta) edita Spínola e Wallraff”. Página Um, 21/10/1976, p. 12.

BOUJU, Marie-Cécile. "Les maisons d'édition du PCF, 1920-1956". Nouvelles FondationS, 3/2007 ( ${ }^{\circ}$ 7-8), p. 260-265. Disponível em: <www.cairn.info/revuenouvelles-fondations-2007-3-page-260.htm>. Acesso em maio de 2011.

BRAGANÇA, Aníbal. "Uma introdução à história editorial brasileira". Cultura Revista de História e Teoria das Ideias, Vol. XIV/2002, II ${ }^{\circ}$ Série, Livros e cultura escrita: Brasil, Portugal, Espanha. Coord. José Luiz Lisboa, Lisboa, Centro de História da Cultura, 2002, p. 57-83.

BRANDÃO, José. "Os livros e a censura em Portugal”. 2007. Disponível em: <http://www.vidaslusofonas.pt/livros_e_censura.htm>.

CARDINA, Miguel. "Guerra total à fera fascista. A AEPPA e a memória como combate". Texto apresentado no Colóquio Internacional Legados do Autoritarismo em Portugal em perspectiva comparada, realizado na Faculdade de Ciências Sociais e Humanas da Universidade Nova de Lisboa nos dias 23 e 24 de abril de 2012.

CARVALHO, Alexandra. "Livrarte/Ulmeiro... 40 anos a resistir". Blogue Mercado de Bem-Fica, 17/1/2009. Disponível em: <http://mercadodebemfica.blogspot.com/2009/01/livrarte-40-anos-resistir.html>. Acesso em dezembro de 2010. 
CARVALHO, Frederico. "Diógenes Arruda, construtor e homem de Partido". Bandeira Vermelha, no 307, 4/12/1981, p. 2.

"CLANDESTINOS". Público, 25 de abril de 1994. Disponível em: 〈quexting.di.fc.ul.pt/teste/publico94/ED940425.txt>.

CORDEIRO, José Manuel Lopes. "Radicalismo político e activismo estudantil nos últimos anos do fascismo (1969-1974)". Revista Vírus (on line), n ${ }^{\circ} 12$, abril/maio 2011, p. 31-37. Disponível em: < http://www.esquerda.net/virus/index.php?option=com_content\&task=view \&id=182\&Ite $\operatorname{mid}=26>$.

CORDEIRO, José Manuel Lopes. "As Origens do PCP no Porto" . Público, 11 Mar. 2001

Disponível em:

http://estudossobrecomunismo2.wordpress.com/2003/05/25/jose-manuel-lopescordeiro-origens-do-pcp-no-porto/>.

CORREIA, Helder Manuel Bento. Comité Marxista-Leninista Português: Breve história de uma organização política (1964-1975). Mimeogr., Portimão, 2000.

CURTO, Diogo Ramada. "A história do livro em Portugal: uma agenda em aberto". Leituras: Revista da Biblioteca Nacional, no 9-10, Outono-Primavera (2001--2002): 1361.

CRUZ, Rui Paulo da. "Os jornais progressistas do pós-25 de Abril”. Vida Mundial, Lisboa, $\mathrm{n}^{\circ}$ 1.835, 14/11/1974, p. 47.

DAURO, Covas. "Ler com o Sr. Luís". Entrevista com Luís Alves Dias. Blogue Todos os Livros, Janeiro/Fevereiro 2008. Disponível em: <http://todos-oslivros.blogspot.com/2008/01/ler-com-o-sr-lus-1.html>.

DAVARA TORREGA, Francisco Javier. "La aventura informativa de Cuadernos para el diálogo". Estudios sobre el Mensaje Periodístico, n ${ }^{\circ}$ 201, 2004, p. 201-220. Disponível em: <http://revistas.ucm.es/index.php/ESMP/article/view/ESMP0404110201A/12595>. Acesso em 26/10/2012.

DIAS, Débora. "Rotas de livreiros e seus Almanaques: intercâmbios luso-brasileiros nos circuitos do impresso". Anais do XXVI Simpósio Nacional de História, ANPUH, São Paulo, julho 2011, p. 11. Disponível em: http://www.snh2011.anpuh.org/resources/anais/14/1300656929_ARQUIVO_TrabalhoA npuh2011.pdf. Acesso em 12/11/2012.

"Entrevista com António André (Livraria 111 - Lisboa)". Notícias do Livro, Lisboa, APEL, n 3, jan. 1979, p. 25-26.

"Entrevista com Carlos Silva". Notícias do Livro, no 5, mar. 1979, p. 56-57.

“Entrevista com João Sá da Costa". Notícias do Livro, Lisboa, APEL, no 4, fev. 1979, p. 9-13.

"Entrevista com Joaquim Soares da Costa (Edições 70)". Notícias do Livro, Lisboa, APEL, ${ }^{\circ}$ 3, jan. 1979.

Entrevista com Manuel Rodrigues de Oliveira (Edições Cosmos). Cf. "Manter uma editora durante quarenta anos com a linha editorial da Cosmos é um acto de coragem de todos os dias". Notícias do Livro, Lisboa, APEL, n 1 , nov. 1978

Entrevista com Maria da Piedade e Pina Mendes, responsáveis pelo Departamento Editorial da Bertrand, Notícias do Livro, Lisboa, n 5 , mar. 1979, p. 8. 
"Entrevista com Zeferino Coelho (Editorial Caminho)". Notícias do Livro, Lisboa, APEL, no 6, abril de 1979, p. 35-36.

ESCARPIT, Robert. "O livro no Brasill". Cadernos de Jornalismo e Editoração, São Paulo, ECA-USP, n 1, p. 7-13, set. 1970.

FERNANDES, Tiago. “A Ala Liberal da Assembleia Nacional (1969-1973): um perfil sociológico". Penélope, no 24, 2001, p. 35-64.

FERREIRA, Marieta de Moraes. "Historia oral: una brújula para los desafios de la história". Historia, Antropologia y Fuentes Orales: escenarios migratorios. Barcelona, $\mathrm{n}^{\mathrm{o}} 28, \mathrm{p} .141-152,2002$.

FERREIRA, Marieta de Moraes. "História, tempo presente e história oral". Topoi, Rio de Janeiro, p. 314-332, dezembro 2002.

FERREIRA, Marieta de Moraes. "Entrevista". Revista Eletrônica História em Reflexão, Dourados, Universidade Federal da Grande Dourados, Vol. 2, nº 3, jan/jun 2008.

FERREIRA, Serafim. "Editor do mês. Entrevista com Zeferino Coelho (Editorial Caminho)". Notícias do Livro, Lisboa, no 6, abril 1979, p. 35-39.

FREITAS, Martinho de. "Análise dos textos para-revolucionários de autores de língua portuguesa editados em Portugal (1971)”. Época, Lisboa, ano 2, n 426, 9 abr. 1972.

FREITAS, Martinho de. "Características da edição dos textos revolucionários em Portugal (1971)". Época, Lisboa, ano 2, n 405, 19 mar. 1972; n 417, 31 mar. 1972; n ${ }^{\circ}$ 424, 7 abr. 1972.

FREITAS, Martinho de. "Contributo ao estudo da edição de textos revolucionários em Portugal (1971)". Época, Lisboa, ano I, no 299, 30 nov. 1971.

FREITAS, Martinho de. "Contributo ao estudo da edição de textos revolucionários em Portugal (1971)". Época, Lisboa, ano I, no 299, 30 nov. 1971.

FREITAS, Martinho de. "Segundo contributo ao estudo da edição de textos revolucionários em Portugal (1971)". Época, Lisboa, ano I, no 316, 19 dez. 1971.

FREITAS, Martinho de. "Terceiro contributo ao estudo da edição de textos revolucionários em Portugal (1971)”. Época, Lisboa, ano I, nº 331, 4 jan. 1972.

FREITAS, Martinho de. "Textos para-revolucionários de autores de língua portuguesa editados em Portugal (1971)". Época, Lisboa, ano I, no 334, 7 jan. 1972.

FREITAS, Martinho de. "Textos revolucionários e anexos editados em Portugal (1972 $1^{\text {o }}$ trimestre)". Época, Lisboa, ano 2, no 433, 16 abr. 1972.

FREITAS, Martinho de. "Textos revolucionários e anexos editados em Portugal (1972 $2^{\circ}$ trimestre)". Época, Lisboa, ano 2, no 438, 21 abr. 1972.

FREITAS, Martinho de. "Uma carta da Editorial Presença e a resposta de Martinho de Freitas". Época, Lisboa, ano 2, n 440, 23 abr. 1972.

HAGE, Julien. "Collections politiques et effets de sens: Littérature et politique dans les nouvelles maisons d'édition politique d'extrême gauche au cours des années 1960 et 1970". Cahiers du CRHQ (Centre de Recherche d'Histoire Quantitative), n 2, 2010. Disponível em: <http://www.crhq.cnrs.fr/cahiers/page-article.php?num=313\&ch=7>. Acesso em 17/10/2012. 
HAGE, Julien. "François Maspero, éditeur partisan". Contretemps, Paris, Les éditions Textuel, $\mathrm{n}^{\circ}$ 15, fev. 2006, p. 104. Disponível em: <http://www.contretemps.eu/sites/default/files/Contretemps\%2015.pdf>. Acesso em 24/10/2012.

HALPERN, Miriam. "Enorme interesse pelo marxismo". Vida Mundial, Lisboa, no 1.860, 8/05/1975, p. 29.

HENRIQUES, Eduardo. “A fusão LCI-PRT”. Disponível em: $<$ http://litci.org/especial/index.php/construcao/portugal/portugal-artigos/1806-a-fusaolci-prt>. Acesso em janeiro de 2012.

HORTA, Maria Teresa. "Conversa com Serafim Ferreira: A Diabril será uma editora de espírito verdadeiramente cooperativo". Flama, Lisboa, no 409, 7/3/1975, p. 60-61.

HORTA, Maria Teresa. “Ecos literários”. Expresso, Lisboa, no 127, 7/6/1975.

J. M. M. “Ala Liberal” (verbete). In: ROSAS, Fernando e BRITO, J. M. Brandão de (coords.). Dicionário de história do Estado Novo. Vol. I. Lisboa: Bertrand, 1996, p. 32.

LISBOA, João Luís. "Ao leytor". Cultura - Revista de História e Teoria das Ideias, Centro de História da Cultura-FCSH, Universidade Nova de Lisboa, II ${ }^{a}$ série, vol. IX, 1997, p. 12. Volume temático sobre "O livro e a leitura", coordenado por João Luís Lisboa.

LOURENÇO, Eduardo. "Fascismo e cultura no antigo regime". Análise Social, vol. XVIII (72-73-74), 1982-3. ${ }^{\circ}-4 .^{\circ}-5 .^{\circ}$.

“MAIS DE 100 MIL!”. Avante!, n 68, 17/7/1975. Reproduzido em O Militante, no 2 , série IV, jul. 1975.

MARCHI, Riccardo. "A direita radical na Universidade de Coimbra (1945-1974)". Análise Social, vol. XLIII (3. $\left.{ }^{\circ}\right), 2008$.

MARQUES, Vanda. "Vida dedicada aos livros". Diário de Notícias, Lisboa, 9 jun 2007. Disponível em: <http://dn.sapo.pt/inicio/interior.aspx?content_id=659043>. Acesso em abril de 2011.

MARTINS, Jorge Manuel. "Livreiro, motor da edição". $O B S$, Observatório das Actividades Culturais, $\mathrm{n}^{\mathrm{o}}$ 14, Nov. 2005.

MAUÉS, Eloísa Aragão. “A editora Alfa-Omega nos anos de chumbo: Entrevista com Fernando Mangarielo". Oralidades, São Paulo, Núcleo de História Oral da USP, $\mathrm{n}^{\circ} 2$, jul-dez, 2007, p. 155-171.

MAUÉS, Flamarion. "Livros contra a ditadura: A Editora Brasil Debates e a Dissidência do PCdoB". Revista Perseu: História, Memória e Política, $\mathrm{n}^{\circ}$ 2, São Paulo, Editora Fundação Perseu Abramo, set./dez. 2008, ISSN 1982-4289, p. 261-291. Disponível em: <http://www.fpabramo.org.br/uploads/P2A-FlamarionMaues.pdf>.

MAUÉS, Flamarion. "Um livro de oposição: Poemas do Povo da Noite, de Pedro Tierra". Espaço Acadêmico, $\mathrm{n}^{\circ}$ 48, revista eletrônica, Univ. Estadual de Maringá, disponível em: www.espacoacademico.com.br/048/48cmaues.htm

MAUÉS, Flamarion. “' 'Ter simplesmente este livro nas mãos é já um desafio’: Livros de oposição no regime militar, um estudo de caso". Em Questão, Revista da Faculdade de Biblioteconomia e Comunicação, v. 11, $\mathrm{n}^{\mathrm{o}}$ 2, jul.-dez. 2005, p. 259-279. Disponível em: <http://www6.ufrgs.br/emquestao/pdf_2005_v11_n2/3_tersimplesmente.pdf>. 
MAUÉS, Flamarion. "A tortura denunciada sem meias palavras: um livro expõe o aparelho repressivo da ditadura”. In: SANTOS, Cecília MacDowell; TELES, Edson Luís de Almeida e TELES, Janaina de Almeida (Orgs.). Desarquivando a Ditadura: memória e Justiça no Brasil. São Paulo: Hucitec, p. 110-134.

MAUÉS, Flamarion. "O momento oportuno: Kairós, uma editora de oposição". História, São Paulo, Faculdade de Ciências e Letras da Unesp, v. 25, n 2, p. 115-146, 2006. Disponível em: http://www.scielo.br/pdf/his/v25n2/05.pdf

MEDEIROS, Nuno. "Objecto dúctil: a emergência de uma sociologia histórica da edição". Tempo Social. Revista de Sociologia da USP. São Paulo, Departamento de Sociologia, Faculdade de Filosofia, Letras e Ciências Humanas, Universidade de São Paulo, vol. 22, no 2, nov. 2010, p. 241-261.

MEDEIROS, Nuno. "Acções prescritivas estratégicas: a edição como espaço social". Revista Crítica de Ciências Sociais, Coimbra, Centro de Estudos Sociais, $\mathrm{n}^{\circ}$ 85, junho 2009, p. 131-146.

MEDEIROS, Nuno. "Editores e Estado Novo: o lugar do Grémio Nacional dos Editores e Livreiros”. Análise Social, vol. XLIII (4. $\left.{ }^{\circ}\right), 2008$, p. 795-815.

MEDEIROS, Nuno. "Problematizar o objecto consagrado: definindo o livro como ideia e materialidade através da edição". Revista Portuguesa de História do Livro, n. ${ }^{\circ} 25$, 2010, p. 556.

MELO, Francisco. "As Edições Avante! e a história do PCP. Breve roteiro bibliográfico". $O$ Militante, $\mathrm{n}^{\circ}$ 253/254/255, 2001. Disponível em:<http://www.pcp.pt/publica/militant/253/p47.html>. Acesso em 9/3/2009.

MOLLIER, Jean-Yves. “A história do livro e da edição: um observatório privilegiado do mundo mental dos homens do século XVIII ao século XX". Vária História, Belo Horizonte, vol. 25, no 42, p. 521-537, jul/dez 2009.

M. R. "Prioridade ao tema político". Vida Mundial, Lisboa, no 1.834, 7 /11/1974, p. 4950 .

"Nota de leitura do romance $O$ general do exército morto (romance albanês de Ismail Kadaré)". O Tempo e o Modo, no 117, abril 1976, p. 23-25. Disponível on line no site da Fundação Mário Soares: $<$ http://www.fmsoares.pt/aeb_online/visualizador.php?bd=IMPRENSA\&nome_da_past $a=08033.117 \&$ numero_da_pagina $=25>$.

NUNES, de Maria Leonor. "Os três mosqueteiros - Irmãos Moura". Jornal de Letras, Lisboa, 12 jun 2002. Disponível em: <http://blogtailors.com/3258982.html>. Acesso em fevereiro de 2012.

“O estranho caso da livraria Outubro". Expresso, no 91, 28/9/1974, p. 2.

“O estranho caso do Proletário Vermelho". Expresso, n 92, 5/10/1974.

“OS BEST-SELLER DA QUINZENA”. Expresso, 1974 e 1975. Hemeroteca Municipal de Lisboa.

PALACIOS CEREZALES, Diego. "Um caso de violência: o 'Verão Quente' de 1975". Análise Social, Instituto de Ciências Sociais da Universidade de Lisboa, vol. XXXVII (165), 2003, p. 1127-1157.

"PARCERIA A. M. PEREIRA: ocupação de uma editora". Jornal Revolução, Lisboa, no 35, 10 Abr 1975, p. 10. 
PEREDA, Rosa Maria. "La fiebre del libro político". El País, 3/2/1977. Disponível em: <http://elpais.com/diario/1977/02/03/cultura/223772401_850215.html>. Acesso em 23/19/2012.

PEREIRA, José Pacheco. "Cadernos Vanguarda". Página eletrónica Ephemera, Biblioteca a arquivo de José Pacheco Pereira: 〈http://ephemerajpp.wordpress.com/2010/07/18/cadernos-vanguarda/>.

PESSOA, Carlos; MOREIRA, José Guardado. "Carlos Araújo, um editor militante à conversa com Carlos Pessoa e José Guardado Moreira". Duas Margens. Cultura de Livros \& Libros. Ano 2, $\mathrm{n}^{\mathrm{o}}$ 2, set. 2012, p. 8 15. Disponível em: $<$ http://duasmargens.pt/>. Acesso em 20/10/2012.

PORTELA, Manuel. "Essa estória da História Livro (1998, 2004)". Biblos, $2^{\mathrm{a}}$ série, Vol.III, 2005, p. 85-112. Disponível em <http://www1.ci.uc.pt/pessoal/mportela/arslonga/MPENSAIOS/essa_estoria_da_histori a.htm\#L4>. Acesso em 17/3/2008.

“QUATRO LIVRARIAS CDL”. Notícias do Livro, no 4, fevereiro, 1979, p. 34-38.

QUEIRÓS, Luís Miguel. "José da Cruz Santos, um inventor de livros”. Público, Lisboa, 1/4/2012. Disponível em: <http://www.publico.pt/Cultura/jose-da-cruz-santos-uminventor-de-livros-1540311?all=1>. Acesso em 15/04/2012.

QUINTAS, José Manuel. "Integralismo Lusitano - uma síntese”. Disponível em: <http://www.angelfire.com/pq/unica/il_jmq_integralismo_lusitano_sintese.htm>.

Acesso em setembro de 2012.

REIMÃO, Sandra. Fases do Ciclo Militar e censura a livros - Brasil, 1964-1978. Texto apresentado no XXVIII Congresso Brasileiro de Ciências da Comunicação - Intercom, 2005, disponível em http://sec.adaltech.com.br/intercom/2005/resumos/R0771-1.pdf.

REIMÃO, Sandra. "Livro e prisão: o caso Em câmara lenta, de Renato Tapajós". Em Questão, Porto Alegre, Revista da Faculdade de Biblioteconomia e Comunicação, Universidade Federal do Rio Grande do Sul, v. 15, nº 1, p. 99-108, jan./jun. 2009.

RESENHA do livro Indústria, ideologia e quotidiano (ensaio sobre o capitalismo em Portugal), de João Martins Pereira. Vida Mundial, Lisboa, no 1.829, 3 /10/1974, p. 6.

RIBEIRO, Ana Maria. "Quando íamos ser presas, aconteceu o 25 de Abril”. Correio da Manhã $12 / 12 / 2010$.

Disponível

em:

http://www.cmjornal.xl.pt/detalhe/noticias/lazer/cultura/maria-teresa-horta-quandoiamos-ser-presas-aconteceu-o-25-de-abril>. Acesso em 10/11/2012.

RIBEIRO, Sérgio. "A Prelo Editora 1". Blogue Som da Tinta. Disponível em: <http://som-da-tinta.blogspot.com.br/2008/07/prelo-editora-1.html>. Acesso em fevereiro de 2012.

RODRIGUES, António da Cruz. "O Movimento Popular Português". Publicado no blogue "Aliança Nacional". Disponível em: <http://porabrantes.blogs.sapo.pt/77538.html>. Acesso em setembro de 2012.

SANCHEZ CERVELLÓ, Joseph. Cronologia das organizações de direita (1973-1976). Centro de Documentação 25 de Abril, Universidade de Coimbra, 1994, mimeogr.

SCHRAPPE, Max. "O livro e a indústria gráfica". Revista do Livro. Rio de Janeiro, Biblioteca Nacional/Departamento Nacional do Livro, nº 44, ano 14, jan. 2002. 
"SEARA NOVA: ontem e hoje ao serviço da democracia" (1974). Seara Nova, no 1550, Dezembro de 1974, p. 2-3.

SILVA, Flamarion Maués Pelúcio. "Um livro de oposição: Poemas do Povo da Noite, de Pedro Tierra". Espaço Acadêmico, revista eletrônica, ano IV, no. 48, maio de 2005, disponível no endereço: www.espacoacademico.com.br/048/48cmaues.htm

SILVA, Helena Vaz da. 'Um grupo 'contra a corrente' abre uma livraria”. Expresso, Lisboa, 19/11/1975, p. 13.

SILVA, José Mário. "Fundador da Livros Horizonte, publicou mais de 2000 livros em 55 anos de actividade". Expresso, Lisboa, 24/11/2008. Disponível em: $<$ http://aeiou.expresso.pt/rogerio-mendes-de-moura-1925-2008=f461530>. Acesso em julho de 2011.

SILVA, Vicente Jorge. "Selecção - Livros políticos”. Expresso, Lisboa, no 113, 1/3/1975. SIMÕES, Cid. "A OPINIÃO - Uma voz democrática”. Blogue As Palavras são Armas, 11/2/2009. Disponível em: < http://aspalavrassaoarmas.blogspot.com/2009_02_01_archive.html>. Acesso em julho de 2010.

SIMÕES, Manuel. "Hiroxima e Vietname: memória poética e consciência ética". Rivista di Studi Portoghesi e Brasiliani. Roma, Istituti Editoriali e Poligrafici Internazionali, III, 2001, p. 87.

“SOBRE AGITAÇÃO E PROPAGANDA”, O Militante, no 18, série IV, dez. 1976.

“SOLIDARIEDADE com O Proletário Vermelho". Voz do Povo, no 9, 1/10/1974, p. 7.

TAMEN, Pedro. "Selecção crítica da semana”. Expresso, Lisboa, no 112, 22/2/1975.

“Um editor na banheira”. Diário de Lisboa, 16/12/1971, p. 1-2. Disponível em: $<$ http://www.fmsoares.pt/aeb_online/visualizador.php?nome_da_pasta=06813.163.2584 4\&bd=IMPRENSA>. Acesso em 20?10/2012.

\section{Teses e dissertações}

ABADIA, Danúbia Mendes. O jornal Combate e as lutas sociais autonomistas em portugal durante a revolução dos cravos (1974-1978). Dissertação de Mestrado em História, Universidade Federal de Goiás, Faculdade de História, Goiânia, 2010, p. 64.

BRAGANÇA, Aníbal. Eros pedagógico: a função editor e a função autor. São Paulo, tese de doutorado, Escola de Comunicações a Artes-ECA, Universidade de São Paulo, 2001.

BRUNO, Lúcia. Portugal: O “COMBATE” pela autonomia operária. Dissertação de Mestrado em Ciências Sociais, PUC-SP, 1983.

CARDINA, Miguel. Margem de certa maneira: o maoísmo em Portugal (1964-1974). Tese de Doutorado em História, Faculdade de Letras da Universidade de Coimbra, 2010.

GOMES, Carlos Manuel de Sousa Gomes. A edição e a revolução: o caso da revista Gaiola Aberta, José Vilhena. Mestrado em Edição de Texto, Universidade Nova de Lisboa, 2008. 
HAGE, Julien. Feltrinelli, Maspero, Wagenbach: une nouvelle génération d'éditeurs politiques d'extrême gauche en Europe Occidentale 1955-1982. Thèse de Histoire Contemporaine, Universite de Versailles Saint-Quentin-En-Yvelines Batiment D’Alembert, Decembre, 2010. Resumo disponível em: <http://www.uvsq. fr/feltrinellimaspero-wagenbach-une-nouvelle-generation-d-editeurs-politiques-d-extreme-gaucheen-europe-occidentale-1955-1982--96344.kjsp>. Acesso em 20/10/2012.

LEITE, Pedro Jorge de Oliveira Pereira. Mercadores de letras : rumos e estratégias dos editores e livreiros na divulgação cultural durante o Estado Novo: 1933-1974. Lisboa, Tese de mestrado em História Contemporânea apresentada à Faculdade de Letras da Universidade de Lisboa, 1998. Disponível em: $<$ http://barrigadefreira.blogspot.com/>

LOPES, Nuno André Proença Vaz Seabra. Panorama editorial: a indústria do livro em Portugal e os seus principais problemas. Mestrado em Linguística, Faculdade de Letras, Universidade de Lisboa, 2006.

MAUÉS, Eloísa Aragão. Em Câmara Lenta, de Renato Tapajós: A história do livro, experiência histórica da repressão e narrativa literária. Departamento de História da Faculdade de Filosofia, Letras e Ciências Humanas da Universidade de São Paulo (FFLCH-USP), 2008, dissertação de mestrado.

MAUÉS, Flamarion. Editoras de oposição no período da abertura (1974-1985): Negócio e política. Departamento de História da Faculdade de Filosofia, Letras e Ciências Humanas da Universidade de São Paulo (FFLCH-USP), 2006, dissertação de mestrado.

MEDEIROS, N. Edição e Editores Portugueses. Prescrições, Percursos e Dinâmicas (Décadas de 1940 a 1960). Dissertação de mestrado em Sociologia Histórica, Lisboa, Universidade Nova de Lisboa, policopiado, s. n., 2007.

PEREIRA, Luciana Lombardo Costa. A lista negra dos livros vermelhos: uma análise etnográfica dos livros apreendidos pela polícia política no Rio de Janeiro. Tese (Doutorado em Antropologia Social). Rio de Janeiro, tese de doutorado, Universidade Federal do Rio de Janeiro, Programa de Pós-Graduação em Antropologia Social, 2010.

PIMENTEL, Irene Flunser. A Polícia Internacional de Defesa do Estado. DirecçãoGeral-de-Segurança (PIDE/DGS). História da Polícia Política do Estado Novo. 19451974. Dissertação de Doutoramento apresentada à Faculdade de Ciências Sociais e Humanas da Universidade Nova de Lisboa, 2007, texto policopiado, p. 1006.

RODRIGUES, Maria Mazzarello e FERREIRA, Paulo Bernardo Vaz. Vega: Essai de bilan de dix ans d'experience editoriale au Bresil. La place de la petite entreprise dans lê marche du livre brésilien. Dissertação de mestrado apresentada em 1980 à Universidade Paris-Nord - XIII, Faculdade de Ciências da Expressão e da Comunicação - Departamento de Edição.

ROLLEMBERG, Marcello Chami. Um circo de letras: A Editora Brasiliense e as transformações sociais, culturais e políticas do Brasil nos anos 80. Dissertação de mestrado em Jornalismo, Escola de Comunicações e Artes da Universidade de São Paulo, 2005.

SALGADO, Gilberto Barbosa. O imaginário em movimento: crescimento e expansão da indústria editorial no Brasil (1960-1994). Dissertação de mestrado apresentada ao Instituto Universitário de Pesquisas do Rio de Janeiro. Rio de Janeiro, 1994. 
XAVIER, Andréa Lemos. A produção da coleção Primeiros Passos: um projeto político-cultural da editora Brasiliense (1979-1985). Dissertação de mestrado em História Cultural, PUC-RJ, 2003.

GALÚCIO, Andréa Lemos Xavier. Civilização Brasileira e Brasiliense: trajetórias editoriais, empresários e militância política. Niterói, tese de doutorado, Programa de Pós-Graduação em História Social da Universidade Federal Fluminense, 2009.

\section{Documentos}

AA.VV. Editores portugueses na III Bienal Internacional do Livro São Paulo: 15 a 23/Junho/1974. Lisboa: Império, 1974.

AA.VV. Editores portugueses na IV Bienal Internacional do Livro São Paulo: 14 a 22/Agosto/1976. Lisboa: Associação Portuguesa dos Editores e Livreiros, 1976.

ABNT NBR 6029. Informação e documentação - Livros e folhetos - Apresentação. Associação Brasileira de Normas Técnicas, 2006, p. 3. Disponível em: <http://www.ufpi.br/subsiteFiles/ppgaarq/arquivos/files/6029-LivroseFolhetos.pdf>. Acesso em 8/10/2012.

AUGSBURGER, Alberto E. El mercado del libro en América Latina. Unesco, 1981.

CAMACHO, José Antonio. Curso para editores. Texto apresentado no I Curso de Formación para Editores de América y de España. Sociedad Iberoamericana de Amigos del Libro y de la Edición/ Universidad Carlos III de Madrid, março de 2001, mimeogr.

CATÁLOGO DA EXPOSIÇÃO “AMBIENTES DE ABRIL”. 20 de abril a 28 de junho, $2001 . \quad$ Disponível em: <http://www.csarmento.uminho.pt/docs/sms/exposicoes/Cat\%C3\%A1logo25Abril.pdf>. Acesso em julho de 2010.

CATÁlOGO DAS EDITORAS Vento de Leste e Germinal, 1975. Pasta "Cultura". Dossiers Temáticos, Centro de Documentação 25 de Abril, Universidade de Coimbra.

"CIRCULAR: Sem um amplo trabalho cultural a revolução não é possível”, 1976. Pasta “Cultura”. Dossiers Temáticos, Centro de Documentação 25 de Abril, Universidade de Coimbra.

DELKÁDER, Jorge. La actividad editorial como actividad empresarial. Texto apresentado no I Curso de Formación para Editores de América y de España. Sociedad Iberoamericana de Amigos del Libro y de la Edición/ Universidad Carlos III de Madrid, março de 2001, mimeogr.

EARP, Fábio Sá e KORNIS, George. A economia do livro: A crise atual e uma proposta de política. Universidade Federal do Rio de Janeiro, Rio de Janeiro, Série Textos para Discussão, 2005. Disponível em www.ufrj.br.

EDIÇÕES BASE. "Relatório actividades 1977 e plano para 1978". Documento policopiado, s/d. Grifo do original.

GARCÍA, Clara Eugenia. El sector editorial. Texto apresentado na I Curso de Formación para Editores de América y de España. Sociedad Iberoamericana de Amigos del Libro y de la Edición/ Universidad Carlos III de Madrid, Departamento de Economia de la Empresa, março de 2001, mimeogr. 
GORINI, Ana Paulo Fontenelle e CASTELLO BRANCO, Carlos Eduardo. "Panorama do setor editorial brasileiro". Relato Setorial, BNDES, Rio de Janeiro, no 11, p. 3-26, mar. 2000. (http://www.bndes.gov.br/conhecimento/bnset/set1101.pdf). Acessado em $15 / 01 / 2004$.

"MANIFESTO DO COMBATE". Combate, Lisboa, no 1, 21/6/1974. Disponível em: <http://www.marxists.org/portugues/tematica/combate/01/manifesto.htm>. Acesso em dezembro de 2010.

PEREIRA, José Pacheco. "Censura - Relatório no 9274 (26 de janeiro De 1972) Relativo a 'Memórias de um Operário', de José Silva”. Blogue Estudos sobre o Comunismo, Biblioteca e arquivo de José Pacheco Pereira: < http://estudossobrecomunismo.wordpress.com/2012/03/19/censura-relatorio-no-927426-de-janeiro-de-1972-relativo-a-memorias-de-um-operario-de-jose-silva/>. Acesso em dezembro de 2009.

Relatório 9274 da DGS, de 19/10/1971 sobre o livro Memórias de um operário, de José Silva. Blogue Estudos sobre o Comunismo. Disponível em: $<$ http://estudossobrecomunismo.wordpress.com/2012/03/19/censura-relatorio-no-927426-de-janeiro-de-1972-relativo-a-memorias-de-um-operario-de-jose-silva/>. Acesso em julho de 2012.

SAAB, William George Lopes, GIMENEZ, Luiz Carlos Perez e RIBEIRO, Rodrigo Martins. "Cadeia de comercialização de livros: situação atual e propostas para desenvolvimento". Estudos Setoriais, BNDES, Rio de Janeiro, dez. 1999. (http://www.bndes.gov.br/conhecimento/relato/rel-livr.pdf). Acessado em 15/01/2004.

UMA POLÍTICA integrada do livro para um país em processo de desenvolvimento: preliminares para a definição de uma política nacional do livro. São Paulo/Rio de Janeiro, Câmara Brasileira do Livro/Sindicato Nacional dos Editores de Livros, 1976, vol. 1, p. 223.

UNESCO. Records of the General Conference. Thirteenth Session. Resolutions. United Nations Educational, Scientific and Cultural Organization. Paris, 1964, p. 144. Disponível em: <http://unesdoc.unesco.org/images/0011/001145/114581e.pdf>. Acesso em $9 / 10 / 2012$.

\section{Entrevistas}

Entrevista com Eduardo Sousa. 13 de Janeiro de 2009, Lisboa.

Entrevista com Francisco Melo. $1^{\circ}$ de Fevereiro de 2011, Lisboa.

Entrevista com José Antunes Ribeiro. 2 de Fevereiro de 2011, Lisboa.

Entrevista com Rita Delgado. 12 de Fevereiro de 2011, Lisboa.

Entrevista com Fernando Abreu e Brandão Guedes. 15 de Fevereiro de 2011, Lisboa.

Entrevista com João Carlos Alvim. 16 de Fevereiro de 2011, Lisboa.

Entrevista com Sérgio Ribeiro. 24 de Fevereiro de 2011, Lisboa.

Entrevista com António Monteiro Cardoso em 2 de março de 2011.

Entrevista com João Camacho, 3 de março de 2011, Lisboa.

Entrevista com José Sousa Ribeiro. 24 de Março de 2011, Porto. 
Entrevista com Jacinta Ferreira. 25 de Março de 2011, concelho de Lousada, distrito do Porto.

Entrevista com João Freire. Março de 2011.

Entrevista com Carlos da Veiga Ferreira. $1^{\circ}$ de Abril de 2011, Lisboa.

Entrevista com João Barrote. 22 de junho de 2011, freguesia de Arnoia, concelho de Celorico de Bastos, distrito de Braga.

Entrevistas por telefone e por email:

José Manuel Lopes Cordeiro.

António José Fonseca.

Luís Manuel Vaz Alves.

Carlos Loures.

Manuel Simões.

Manuel António Ribeiro Resende.

Maria Teresa Horta. 
Apêndice 1

Lista das Editoras Políticas (100 editoras)

\begin{tabular}{|c|c|c|}
\hline Editora & Início(1) & Títulos(2) \\
\hline
\end{tabular}

(1) Refere-se ao início da atividade de edição de livros.

(2) № aproximado de títulos políticos editados no período 1968-1980.

\begin{tabular}{|c|c|c|}
\hline 17 de Outubro & 1975 & 6 \\
\hline A Batalha (3) & 1975 & 6 \\
\hline A Causa Operária & 1975 & 11 \\
\hline A Opinião & 1975 & 15 \\
\hline A Regra do Jogo & 1973 & 30 \\
\hline A Verdade & $1974 / 75$ & 5 \\
\hline AAPA Ass. Amiz. Portugal-Albânia & 1976 & 5 \\
\hline Abril & 1976 & 8 \\
\hline Acrata & 1975 & 10 \\
\hline AEPPA & 1974 & 7 \\
\hline África Editora & 1974 & 15 \\
\hline Afrodite & 1965 & 40 \\
\hline Afrontamento & 1963 & 150 \\
\hline Antídoto & 1975 & 50 \\
\hline Assírio \& Alvim & 1973 & 75 \\
\hline Avante! (4) & 1974 & 210 \\
\hline Bandeira Vermelha /MRPP & 1975 & 8 \\
\hline Bandeira Vermelha /PCP $(\mathrm{R})$ & 1976 & 50 \\
\hline Base & 1973 & 35 \\
\hline Braga Editora & 1977 & 11 \\
\hline Cadernos para o Diálogo & 1971 & 6 \\
\hline Cadernos Textuais & 1969 & 6 \\
\hline Caminho & 1975 & 60 \\
\hline Centelha & 1971 & 150 \\
\hline CIDAC & 1974 & 15 \\
\hline Cidadela & 1970 & 10 \\
\hline Contra a Corrente & 1975 & 55 \\
\hline Delfos & Anos 1960 & 70 \\
\hline DiAbril & 1975 & 60 \\
\hline Dom Quixote & 1965 & 200 \\
\hline Edições FP (Fernando Pereira) & 1978 & 7 \\
\hline Edições do Partido & 1970 & 45 \\
\hline Edições do Povo & 1971 & 7 \\
\hline Edições do Templo & 1977 & 10 \\
\hline Edições Militão Ribeiro & 1975 & 6 \\
\hline Edições Roger Delraux & 1977 & 7 \\
\hline Edições Sociais & 1974 & 27 \\
\hline Editorial Divul & 1974 & 10 \\
\hline Escorpião/ Textos Exemplares & 1973 & 60 \\
\hline Espaço & 1974 & 7 \\
\hline Estampa & 1960 & 300 \\
\hline Estrela Vermelha & 1974 & 8 \\
\hline Expresso & 1974 & 8 \\
\hline Fronteira & 1975 & 34 \\
\hline Germinal & 1974 & 20 \\
\hline Horizonte & 1953 & 70 \\
\hline Iniciativas Editoriais & 1956 & 200 \\
\hline Inova & 1968 & 35 \\
\hline Intervenção & 1974 & 41 \\
\hline Latitude & $1970 / 1971$ & 16 \\
\hline
\end{tabular}




\begin{tabular}{|c|c|c|}
\hline Literal & 1976 & 27 \\
\hline Livraria Júlio Brandão & 1971 & 15 \\
\hline Livraria Ler Editora & 1971 & 41 \\
\hline Liv. Popular de Francisco Franco & Anos 1930 & 8 \\
\hline Manuel Xavier & 1971 & 20 \\
\hline Maria da Fonte & 1973 & 80 \\
\hline Moraes & 1956 & 95 \\
\hline Movimento Operário & 1974 & 4 \\
\hline Multinova & 1973 & 18 \\
\hline N. A. * Orion & 1973 & 13 \\
\hline Nova Aurora & 1974 & 35 \\
\hline Nova Realidade & 1966 & 8 \\
\hline Novo Curso & 1975 & 14 \\
\hline O Grito do Povo & 1973 & 36 \\
\hline O Proletário Vermelho & 1974 & 20 \\
\hline Parceria A. M. Pereira (5) & 1848 & 11 \\
\hline Pensamento e Acção & 1975 & 5 \\
\hline Pensamento Político & 1971 & 21 \\
\hline Perspectivas \& Realidades ( $\mathrm{p} \& \mathrm{r}$ ) & 1975 & 25 \\
\hline Portucalense & 1928 & 20 \\
\hline Portugal Socialista & 1973 & 15 \\
\hline Povo e Cultura & 1971 & 20 \\
\hline Prelo & 1960 & 140 \\
\hline Presença & 1962 & 75 \\
\hline República & 1973 & 12 \\
\hline Resistência & 1975 & 15 \\
\hline Restauração & 1969 & 7 \\
\hline Revolução & 1974 & 10 \\
\hline Revolução Proletária & 1975 & 3 \\
\hline Seara Nova & 1921 & 200 \\
\hline Seara Vermelha & 1974 & 45 \\
\hline Selecta & 1976 & 26 \\
\hline Sementeira & 1974 & 10 \\
\hline Sementes & 1974 & 20 \\
\hline Serv.Sociais Trabalhadores CGD & 1974 & 14 \\
\hline Slemes & 1975 & 20 \\
\hline Sotavento & 1979 & 4 \\
\hline Spartacus & 1974 & 6 \\
\hline Spartacus OCMLP & 1974 & 5 \\
\hline Telos & 1972 & 25 \\
\hline Teorema & 1974 & 15 \\
\hline Terra Livre & 1975 & 9 \\
\hline Textos Marginais & 1972 & 27 \\
\hline Textos Políticos & 1974 & 15 \\
\hline Textos da Revolução & 1974 & 12 \\
\hline Ulmeiro & 1970 & 60 \\
\hline Unidade Popular & 1974 & 4 \\
\hline Vento de Leste & 1974 & 70 \\
\hline Via Editora & 1976 & 20 \\
\hline Voz do Povo & 1974 & 5 \\
\hline Tota de Títulos & & 3722 \\
\hline
\end{tabular}

(3) Refundação do jornal A Batalha em 1974; fundação original em 1919.

(4) Início da atuação legal da editora.

(5) Consideramos apenas o período em que a editora esteve em autogestão e sua linha editorial modificou-se significativamente. 
Apêndice 2

Lista das Editoras Não Políticas (37 editoras) que publicaram livros políticos

\begin{tabular}{ll|l|}
\hline Editora & Início(1) & Títulos(2) \\
\cline { 2 - 2 }
\end{tabular}

(1) Refere-se ao início da atividade de edição de livros.

(2) № aproximado de títulos políticos editados no período 1968 1980 .

\begin{tabular}{|c|c|c|}
\hline Acrópole & 1954 & 14 \\
\hline Agência Portuguesa de Revistas & 1948 & 15 \\
\hline Alfaómega & 1975 & 6 \\
\hline Almedina & 1955 & 15 \\
\hline António Ramos & 1976 & 17 \\
\hline Arcádia & 1957 & 65 \\
\hline Armazém das Letras & 1977 & 7 \\
\hline Aster & Anos 1950 & 10 \\
\hline Ática & 1933 & 14 \\
\hline Atlântida & 1926 & 30 \\
\hline Bertrand & 1732 & 102 \\
\hline Brasília & Anos 1950 & 30 \\
\hline Centro do Livro Brasileiro & 1963 & 10 \\
\hline Círculo de Leitores & 1971 & 6 \\
\hline Edições 70 & 1970 & 51 \\
\hline Editorial Notícias & 1929 & 11 \\
\hline Estúdios Cor & 1949 & 30 \\
\hline Europa-América & 1945 & 75 \\
\hline Forja & 1975 & 15 \\
\hline Futura & 1971 & 20 \\
\hline Heptágono & 1975 & 8 \\
\hline Jornal do Fundão & 1959 & 9 \\
\hline Líber & 1975 & 32 \\
\hline Limiar & 1975 & 15 \\
\hline Liv. Al (Apostolado da Imprensa) & Anos 1920 & 6 \\
\hline Meridiano & 1964 & 10 \\
\hline Minerva & 1927 & 22 \\
\hline Nova Crítica & 1975 & 18 \\
\hline O Século & 1900 & 15 \\
\hline Paisagem & 1969 & 30 \\
\hline Plátano & 1972 & 6 \\
\hline Portugália & 1942 & 20 \\
\hline Rés & 1975 & 20 \\
\hline Sá da Costa & 1913 & 40 \\
\hline Socicultur & 1971 & 15 \\
\hline Ulisséia & 1946 & 15 \\
\hline Verbo & 1959 & 15 \\
\hline Tota de Títulos & & 839 \\
\hline
\end{tabular}




\title{
APÊNDICE 3
}

\section{Lista de livros políticos publicados em Portugal entre 1968 e 1980 pelas 137 editoras incluídas neste trabalho}

\begin{abstract}
Neste Apêndice estão listados todos os livros políticos editados em Portugal entre 1968 e 1980 pelas 137 editoras que compõem o universo analisado neste trabalho, ou seja, editoras que publicaram pelo menos cinco títulos políticos nesse período. Eles somam um total de cerca de 4.600 títulos. Os títulos estão separados por editoras, e estas aparecem em ordem alfabética.

A lista traz as as seguintes informações: Nome da Editora. Nome da coleção (quando houver). Título da obra. Autor. Mês da edição (quando houver), Ano da edição. Tiragem (quando houver).

Quando não constar o ano da edição isto significa que tal informação não aparece no próprio livro e que não foi possível apurar, por nenhuma outra fonte, qual seria essa data. Da mesma forma, quando aparecer a informação sobre a tiragem da obra é porque a mesma constava dos exemplares publicados. O local da edição é o mesmo da sede da editora.
\end{abstract}




\section{Editoras que publicaram livros políticos em Portugal no período 1968-1980 (cinco títulos ou mais)}

\section{7 de Outubro Editora (Barreiro)}

Sobre a aliança operário e camponesa: textos 1899-1921. Lenine. Fevereiro, 1975.

A nossa luta na Sierra Maestra: a Revolução Cubana por ele próprio. Ernesto Che Guevara. Abril, 1975. (2a ed. 1975)

A revolução russa. Rosa Luxemburg. Junho, 1975.

Revolução na revolução. Régis Debray. Setembro, 1975.

Dimensão internacional da revolução. Che Guevara. Março, 1976.

Biografia do Manifesto Comunista: a luta de classes e o processo histórico. Riazanof. Julho, 1976.

\section{A Batalha (Lisboa)}

Coleção Problemas actuais

1 Anarco-sindicalismo e autogestão. René Berthier. 1975.

2 A verdade sobre Cronstadt. Stepan Petritchenko. 1975.

3 Que sindicalismo? 1975. Tiragem: 3.000.

\section{Coleção Textos Doutrinários}

A doutrina anarquista ao alcance de todos. José Oitícica. Janeiro, 1976. Tiragem: 3.000.

\section{$\underline{\text { Sem Coleção }}$}

Porque sou anarquista. Rudolf Rocker. 1975.

Autogestão; Gestão operária; Gestão directa. Maurice Joyeux. 1975.

\section{Edições A Causa Operária (Lisboa)}

22 de Abril de 1974: 104 aniversário de Lenine. (Livreto artesanal dactilografado)

Informe apresentado na primeira conferência consultiva dos quadros do Partido Comunista da Albânia. Enver Hoxha. Agosto, 1975.

Por uma ampla frente anti-fascista e patriótica caminho para a república popular! (Documento do Comité Central da ORPC $[\mathrm{m}-\mathrm{l}])$. Setembro, 1975.
Acerca da luta anti-imperialista. Partido Comunista do Brasil. Dezembro, 1975.

Entrevista concedida ao Diário Popular pelos camaradas Francisco Martins e Frederico Carvalho em 7/8/1975. (Livreto artesanal datilografado)

O Partido Comunista e o parlamentarismo. Segundo Congresso da Internacional Comunista. 1975.

Um militante modelo e outros textos. Estaline, Dimitrov, Enver Hoxha. Agosto, 1975. ("Edição organizada pelo núcleo de simpatizantes da Causa Operária da Amadora”.)

Coleção Conferência Nacional de Estudos sobre a Luta Antifascista de Libertação Nacional do Povo Albanês

1 A questão do poder na luta antifascista de libertação nacional do povo albanês (Relatório). Luan Omari. 1975.

2 A luta antifascista de libertação nacional. Grande revolução popular conduzida pelo PC da Albânia (Relatório). Nexhmije Hoxha. 1975.

3 A união do povo albanês em torno do PC da Albânia na frente de libertação nacional (Relatório). Ndreçi Plasari. 1975.

\section{A Opinião (Lisboa)}

Coleção Edições A Opinião

1 Rumo à vitória: as tarefas do Partido na Revolução Democrática e Nacional. Álvaro Cunhal. Maio, 1975.

2 Assim foi temperado o aço. Nikolai Ostrovski. 1975.

3 Poemas. Francisco Miguel. 1976.

\section{Coleção Os Comunistas}

1 Bento Gonçalves. Maio, 1976.

2 Francisco Miguel. Uma vida na revolução. Fevereiro, 1977.

Coleção Histórias da opressão

1 Depoimentos gravados. Antonio Norton. Novembro, 1975. 
Coleção Economia

1 Nacionalizações e controlo da produção: trabalho colectivo de organização de economistas do Porto do Partido Comunista Português. Introdução de Armando Castro. Junho, 1975.

Coleção Depoimentos

2 No Tarrafal, prisioneiro. Joaquim Ribeiro. Setembro, 1976.

\section{Coleção A Terra}

1 A agricultura da Bulgária vista por um agricultor português. Fevereiro, 1976.

\section{Coleção Poesia}

1 Pedra a pedra. José Manuel Mendes. 1977.

2 Sementes à terra. Francisco Miguel. 1977.

\section{$\underline{\text { Sem coleção }}$}

Problemas urgentes da emigração portuguesa. 1975.

A guerra invisível. Vasili Ardamatski. 1978.

A canção política em Portugal: da resistência à revolução. José Jorge Letria. 1978.

\section{A Regra do Jogo (Porto/Lisboa)}

Sobre justiça popular. Michel Foulcault e militantes maoístas. Outubro, 1974.

Terror em Tete. Relato documental das atrocidades dos portugueses no distrito de Tete, Moçambique (1971-1972). Outubro, 1974.

Desemprego e capital. Bertrand Bellond. 1975.

Aborto/Contracepção. M.N.E.F. (Mutuell Nationale des Etudiants de France). Novembro, 1975. Tiragem: 3.000.

Da reconquista da terra à reforma agrária: as ocupações de terras no Alentejo. Vitor Matias Ferreira. Maio, 1977. Tiragem: 3.000 .

Integração capitalista e ruptura operária. Paul Mattick. 1977.

De repente Abril e outros escritos. Sílvia Montarroyos. 1977.

Sobre Portugal: diálogos com Alexandre Manuel. Costa Gomes. 1979.

O fascismo português numa perspectiva comparada. Manuel Vilaverde Cabral. 1982.

Para uma antropologia cultural da canção portuguesa na primeira fase da ditadura
(1926-1937). Manuel de Cadafaz de Matos. 1982.

O Congresso fascista em Montreux: 1934. João Medina. 1982. (Sep. Colóquio sobre o Fascismo em Portugal, Faculdade de Letras de Lisboa, Março de 1980)

\section{Coleção História}

A conquista portuguesa de Angola. David Birmingham. 1974.

Biblioteca de História - Dirigida por Alfredo Margarido

$1 O$ desenvolvimento do capitalismo em Portugal no século XIX. Manuel Villaverde Cabral. Junho, 1976. Tiragem: 3.000. (1977. $2^{\mathrm{a}}$ ed.)

2 A luta de classes em França na Primeira República, 1793-1795. Daniel Guérin. Maio, 1977. Tiragem: 5.000.

3 Ensaios sobre a Revolução Francesa. François Furet. 1978.

4 A sociedade e a economia portuguesa nas origens do salazarismo (1917-26). Fernando Medeiros. 1978.

5 Portugal na alvorada do século XX: forças sociais, poder político e crescimento económico de 1890-1914. Manuel Villaverde Cabral. 1979.

6 Decadência e queda da I República portuguesa. $1^{\circ}$ Vol. António José Telo. 1980.

7 O Marquês de Pombal e o vinho do Porto: dependência e subdesenvolvimento em Portugal no século XVIII. Susan Schneider. 1980.

Colonialismo e feudalismo: a questão dos prazos da coroa em Moçambique nos finais do século XIX. Giuseppe Papagno. Julho, 1980. Tiragem: 3.000 .

9 Exército e sociedade em Portugal: no declínio do antigo regime e advento do liberalismo. Fernando Pereira Marques. 1981.

10 A política portuguesa de emigração (18501930). Miriam Halpern Pereira. Abril, 1981. Tiragem: 3.000.

11 O fascismo em Portugal: actas do Colóquio realiz. na Fac. de Letras de Lisboa. Org. António Costa Pinto... [et al.]. 1982.

\section{Livros da Estrada}

O camponês russo durante e após a revolução. Ida Mett. Dezembro, 1975. Tiragem: 3.000.

Utopia Camponesa (dirigida por Manuel 
Villaverde Cabral)

1 A questão camponesa e o capitalismo. Kostas Vergopoulos/Samir Amin. 1978.

Viagem de теи irmão Alexis ao país da utopia camponesa. Ivan Kremniov (Chayanov) (No prelo)

\section{Cadernos de Filosofia}

1 Notas para o conceito de ideologia: teoria e prática. Fernando Belo. 1977.

\section{Livros RJ - Coleção de Bolso}

1 Documentos sobre a repressão e a luta dos operários na Polônia/1976. Comité de Defesa dos Operários. 1977.

2 A guerra da Argentina. Marcelo Dias. 1978.

3 Relembrando e comentando (memórias de um operário corticeiro, 1914/1938). José dos Reis Sequeira. 1978.

$4 \quad O \quad 18$ de Janeiro de 1934 e alguns antecedentes: depoimento colectivo. Acácio Tomaz de Aquino, Américo Martins, Custódio da Costa, José Francisco, Marcelino Mesquita e Emídio Santana.. Julho, 1978. Tiragem: 3.000.

5 O segredo das prisões Atlânticas. Acácio Tomás Aquino. 1978.

\section{Estudos}

Introdução à sociologia do trabalho. Pierre Rolle; trad. Ana Falcão Bastos, Luís Leitão. 1978.

\section{Textos de Antropologia}

1 Poder, sociedade, simbólico: ensaio de antropologia política. 1977.

\section{Materiais}

A guerra da mina: os mineiros da Panasqueira. Daniel Reis, Fernando Paulouro Neves. 1979.

\section{Economia e Socialismo}

Salários e lucros na Divisão Internacional do Trabalho. Ladislau Dowbor. 1982.

Coleção CEDEP (Centro de Estudos da Dependência)

1 O processo de descolonização em Angola 1974-1976: ensaios de sociologia política. Franz-Wilhelm Heimer. 1980. Tiragem: 3.000 .

\section{A Verdade (Lisboa)}

Coleção Os comunistas e a luta de classes

1 Documentos da III Conferência do Comité Marxista-Leninista Português (Abril 1975). Volume I. 1975.

2 Documentos da III Conferência do Comité Marxista-Leninista Português. Volume II. 1975.

\section{Coleção Educação comunista}

$1 O$ partido do trabalho da Albânia: sobre a vida e a edificação do partido. Outubro, 1975.

\section{$\underline{\text { Sem Coleção }}$}

Cada classe seu sindicato. Para a classe operária sindicatos verticais de classe (linha sindical do CMLP). 1975.

Lutemos contra os espiões e provocadores. Breve históra de alguns casos de provocação no PCP segundo o original de edições Avante!, Dezembro de 1952. s/d.

\section{AAPA - Associação de Amizade Portugal-} Albânia (Lisboa)

O ensino na Albânia. Abril, 1976.

Como se exerce o controle operário na Albânia. Gilbert Mury. Dezembro, 1976.

Constituição da República Popular Socialista da Albânia: Projecto. 1976.

A luta do povo albanês pela emancipação da mulher. 1976.

Albânia, saúde pública e medicina preventiva. Madeleine Stryn Béhar e Abraham Béhar. Dezembro, 1977. Tiragem: 2.000.

Habitação na Albânia. Mariano Roque Laia. 1978.

\section{Abril (Coimbra)}

Relatório do 25 de Novembro de 1975: texto integral. Dezembro, 1976.

Os "comandos" no eixo da revolução: crise permanente do PREC. Portugal, 1975-76. Manuel Branco. 1977.

Por que perdemos a guerra. Manuel Pereira Crespo. 1977.

Você pode confiar nos comunistas (eles são mesmo comunistas...). Fred Schwarz. 1977.

A proposta-MIRN: comunicação ao País em 28 de Junho de 1977. Kaúlza de Arriaga. 
Movimento Independente para a Reconstrução Nacional. 1977.

No caminho das soluções do futuro. Kaúlza de Arriaga. Março, 1977.

Segurança nacional forma adulta da defesa nacional. J. Baptista Comprido. 1978.

Coleção Sonda do Mundo

A destruição da lealdade: um estudo da ameaça da propaganda e da subversão contra as forças armadas do Ocidente. Anthony Burton. Novembro, 1978.

O urso à porta de trás: a ameaça soviética à linha vital do Ocidente em África. Walter Walker. 1978.

\section{Acrata (Lisboa)}

Solução anarquista para a questão social. Errico Malatesta. Setembro, 1975.

O que querem os anarquistas. E. Malatesta. s/d.

A moral anarquista. Pedro Kropotkine. s/d.

Anarchia, sua philosophia, seu ideal. Pedro Kropotkine. s/d.

$O$ rei e o anarquista. Liberta. s/d.

12 provas da inexistência de deus. Sebastião Faure. s/d.

Paralelo entre os sistemas económicos "ocidentais" e "soviético". S. Agourski. s/d.

Erros e contradições do marxismo. Varlan Tcherkesoff. s/d.

Entrevista com Lenine, de Nestor Magno. Marxismo leninista, de J. de B. I Marxismo, escola de ditadores, do Dr. Roberto das Neves. s/d.

$1^{\circ}$ de Maio de 1866. Greve pelas 8 horas. 11-111887 Forças ao alto e outros textos/ Para os mártires de Chicago. / Considerações, confusões e contradições./ "O Messias" alienado. 1979.

\section{Acrópole (Alfragide)}

Depoimento dum preso político. Regis Debray. $\mathrm{s} / \mathrm{d}$.

A revolução russa e o Estado Soviético: 19171921. Martin McCauley. 1975.

Martin Luther King, Jr. marcha para a liberdade. Robert Bleiweiss. 1974.

Dossier Pide-DGS. Banda Desenhada. Texto: José Gabriel, Ilustrações: Vítor e Carlos Guedes. 1975. Tiragem: 30.000.

A política da pornografia. Rousas J.
Rushdoony. 1975.

O programa do MFA e dos partidos políticos. 1975. ( $2^{\mathrm{a}}$ ed. 1977)

MDLP e ELP: o que são? Verdade sobre os dois movimentos clandestinos. Carlos Dugos. 1976

O materialismo dialéctico. Henri Lefebvre. 1977.

\section{Cultura Contemporánea}

Democracia e liberdade. Pref. Roger Garaudy. c1974.

\section{Coleção Política}

Eleições 75 (Primeiras eleições livres). $O$ Programa do MFA e dos partidos políticos. $2^{\mathrm{a}}$ ed. 1975.

\section{$\underline{\text { Biografia }}$}

3 Mao Tsé-Tung sem artifícios: o homem que alterou o rumo da história. Stuart Schram. 1976.

\section{Coleção Análise $\mathrm{n}^{\circ} 1$}

1 Revolução em perigo. Estudo sumário $e$ independente à III $^{a}$ República. Carlos Dugos. 1975.

2 Comunismo?: o povo é quem mais ordena. Dos incidentes no norte às medidas concretas. Carlos Dugos e Neves Ramos. 1975.

3 Descolonização portuguesa: o malogro de dois planos. Carlos Dugos. 1975.

\section{AEPPA (Associação de Ex-Presos Políticos Antifascistas) (Lisboa)}

Para o Tribunal que Julgue a PIDE

1 Elementos para a história da PIDE. 1976.

2 A PIDE e as empresas. Fevereiro, 1977.

Morte à PIDE

1 Mais uma traição ao povo: a fuga-libertação de Alcoentre. 1977.

$\underline{\text { Sem colecção }}$

Porque não se destroem os ficheiros da PIDE?. 1975.

Liberdade para José Diogo. Coedição com Afrodite. Maio, 1975. Tiragem: 6.200.

Os mortos reclamam justiça. Janeiro, 1977.

A política de genocídio contra os índios do 
Brasil. 1976.

\section{África Editora (Lisboa)}

Sem coleção

Massacres em Luanda. A. Bobela-Motta e Albertino Almeida. Movimento Democrático de Angola. Agosto, 1974.

E a raiva passa por cima, fica engrossar um silêncio. Ascêncio de Freitas. 1979.

\section{Coleção Dossier Angola}

1 Coringe e os três irmãos. Emílio Felipe. 1974.

2 S. Nicolau, Tarrafal angolano. Emílio Filipe. 1975.

3 Terra vermelha: estórias para a história da guerra colonial em Angola. Carlos Martins Pereira. 1978.

\section{Coleção Documentos de Hoje}

Angola: fim do mito dos mercenários. Raul Valdes Vivo. Dezembro, 1976. Tiragem: 7.500 .

\section{Coleção Tempo Africano}

1 Gentes do mato. Manuel Pedro Pacavira 1975.

2 As lágrimas e o vento (Romance). Manuel dos Santos Lima. 1975.

A pele do diabo: drama em III actos. Manuel Dos Santos Lima. 1977.

Não adianta chorar: contos coloniais. A. Bobela Mota; Pref. de Manuel Ferreira. 1977.

Voz de prisão. Manuel Ferreira. 1978.

\section{Coleção Cântico Geral}

1 Memória da longa resistência popular. Nito Alves. 1976.

Poesia do colonialismo. Carlos Espírito Santo. 1978.

20 canções do Zambeze. Carlos Monteiro dos Santos. 1980.

\section{Afrodite (Lisboa)}

\section{Coleção Afrodite}

Kama Sutra: manual do erotismo hindú, séc. V d.C. Vatsyayana; trad. Nuno Bacelar. 1965.

Antologia de poesia portuguesa erótica $e$ satírica: (dos cancioneiros medievais à actualidade). Selecção, prefácio e notas de Natália Correia.
A Vénus de Kazabaika. Leopold von Sacher Masoch; trad. de Anna Hatherly. 1966.

A filosofia na alcova. Marquis de Donatien Alphonse François de Sade; trad. Manuel João Gomes. 1966.

Cara lh amas: poemas eróticos e sarcásticos 1964/1975. E. M. de Melo e Castro. 1975.

\section{Ensaio/Documento}

1 Anti-Dühring. F. Engels. Novembro, 1971.

2 A sociedade do espetáculo. Guy Debord. 1972.

3 Teatro de vanguarda. Fernando Augusto de Freitas Mota Luso Soares. 1973.

\section{Doutrina / Intervenção}

Inquérito aos partidos políticos: esclarecer o eleitor. Francisco Pereira Moura, António Proença Varão, António Borges Coelho, Avelino Rodrigues, Daniel Sampaio, carlos Caldeira. 1975.

A metafísica do sexo. Julius Evola; trad. de Elisa Teixeira Pinto. 1976.

Mein Kampf. Adolf Hitler; comentários de A. H. de Oliveira Marques, José Martins Garcia, Rolão Preto e Sanches Osório. Novembro, 1976. Tiragem: 10.000.

Marx contra Marx. Marc Paillet; trad. Rafael Gomes Filipe. 1977.

$O$ socialismo: fenómeno mundial. Igor Chafarevitch. Outubro, 1977.

Sociologia do comunismo. Jules Monnerot. Março, 1978.

Nova direita, nova cultura: antologia crítica das ideias contemporâneas. Alain de Benoist; nota à edição portuguesa José Miguel Júdice; trad. Diogo Pacheco de Amorim. 1981.

Os normalizados. Christian Jelen. 1978.

\section{Coleção Documentos}

Secreto. Último relatório do ex-Ministério do Interior para a ex-PIDE/Direção-Geral de Segurança. Maio, 1974.

Liberdade para José Diogo. Coedição com AEPPA (Associação de Ex-Presos Políticos Antifascistas). Maio, 1975. Tiragem: 6.200.

$O$ processo das virgens: aventuras, venturas $e$ desventuras sexuais em Lisboa nos últimos anos do fascismo. $2^{\mathrm{a}}$ ed. Dezembro, 1975. Tiragem: 6.200.

Uma nova doença mental na URSS: a OPOSIÇÃO. Vladimir Boukovsky. Outubro, 1976. 
Dossier $2^{a}$ República, vol. I, 25/4/74 - 25/4/75. Organização, seleção e introdução de JoséPedro Gonçalves. Abril, 1976.

Dossier $2^{a}$ República, vol. II, 25/4/74 25/11/75. Organização, seleção e introdução de José-Pedro Gonçalves. Janeiro, 1977.

26 anos na União Soviética. Notas do exílio do Chico da CUF. Francisco Ferreira. $7^{\mathrm{a}}$ ed. Julho, 1977. Tiragem: 6.200.

A $3^{a}$ guerra mundial já começou. Jacques Bergier. Março, 1977.

Sexo. Espionagem. A exploração do sexo pelos serviços secretos soviéticos. David Lewis. Abril, 1977.

Direitos do homem: Declaração Universal dos Direitos do Homem: Convenção Europeia dos Direitos do Homem. Organização das Nações Unidas. 1977.

Os intelectuais e o poder soviético. Kontinent 1. Andrei Sakharov, Eugene Ionesco, Siniavski, Djilas, Aleksandr Soljenitsine. Abril, 1978.

Ditadura sem proletariado. Kontinent 2. Conquest, Grahan Greene, Maksimov, Nekrasov, Ota Filip, Soljenitsine. Abril, 1978.

A vida secreta de Adolf Hitler: do "dossier" mais bem guardado de Himmler... David Lewis; trad. Guilhermina Ramalho. 1978.

Eu pertenci à KGB. Aleksei Myagkov. Abril, 1977.

Autores

1 Textos malditos. Luiz Pacheco. 1977.

$2 O$ encoberto: teatro. Natália Correia. $2^{\mathrm{a}}$ ed. 1977.

O blatnoi: a mafia, o crime, a marginalidade, na URSS. Mikhail Diomine; trad. José Martins Garcia. 1978.

\section{Autores II}

Alecrim, alecrim aos molhos... José Martins Garcia. 1974.

Lugar de massacre. José Martins Garcia. 1975.

Revolucionários e querubins. José Martins Garcia. Janeiro, 1977. Tiragem: 3.500.

A fome. José Martins Garcia. 1977.

\section{Coleção Guias}

Guia prático do trabalhador português. Francisco Marcelo Curto. Abril, 1974.

O pequeno livro vermelho do estudante. Soren Hansen, Jesper Jensen; trad. H. Madeiros. 1977.
Desmarxizar a universidade. Jules Monnerot. Março, 1978.

$\underline{\text { Sem coleção }}$

A vida sexual de Robin Crusoé. Michel Gall. 1978 Cat CP-LE1932

Afrontamento (Porto)

Coleção de Antologias (Coordenação e edição de Pedro Francisco)

1 Ao encontro da pessoa. Emmanuel Mounier e Jean Lacroix. 1963.

2 O homem invisível. Pablo Neruda. 1964.

3 Do Integrismo ao Nacional Catolicismo: os católicos e as direitas. Louis Davallon, P. A. Liège, M Garrigou Lagrange, Louis Guinchard, Yves Congar. Junho, 1965.

4 O Plano Langevin-Wallon para a reforma do ensino. Junho, 1966.

5 Iniciação à teoria económica. Ernest Mandel. 1968. ( $2^{a}$ edição), s/d. ( $3^{a}$ ed. 1976)

\section{Coleção Bezerro D'Ouro}

1 Em defesa de Joaquim Pinto de Andrade. Mario Brochado Coelho. Julho, 1971 ( $2^{\mathrm{a}}$ ed. Agosto, 1971). (Fora de mercado)

2 A prisão do Dr. Domingos Arouca. Francisco Salgado Zenha. Novembro, 1972.

3 Estudantes de Coimbra no plenário: peças de um processo. António Monteiro Taborda, Arnaldo Mesquita, Joaquim Loureiro, José Luís Nunes, Mario Brochado Coelho, Raul Castro e Rui Polónio de Sampaio. Janeiro, 1973.

4 Uma farsa eleitoral: o caso do Sindicato dos Metalúrgicos de Aveiro. Peças de um processo. José Afonso e Mário Brochado Coelho. Fevereiro, 1973.

5 O caso da capela do Rato no Supremo Tribunal Administrativo. Salgado Zenha, Francisco de Sousa Tavares, Jorge Sampaio, José Vasconcelos Abreu e José Vera Jardim. Março, 1973. $2^{\mathrm{a}}$ ed.

6 O julgamento dos padres do Macúti. João Afonso dos Santos, Carlos Adrião Rodrigues, António Pereira Leite e Willem Gerard Pott. Agosto, 1973.

7 O segundo julgamento do padre Mário. Eloy Pinho, Fernanda Gomes, Helena Policarpo, Luís Humberto, José Gomes Bandeira, José Capela, Manuel António Pina e Santos Ribeiro. Fevereiro, 1974. ("O produto líquido da venda deste livro será deixado à 
disposição do padre Mário para os fins que achar convenientes.")

8 Angolanos no Tarrafal: alguns casos de habeas corpus. Fernando de AbranchesFerrão, Francisco Salgado Zenha, Levy Baptista e Manuel João da Palma Carlos. Janeiro, 1974.

9 Agarra que é estudante! Um caso de justiça repressiva. Rui Polónio de Sampaio. Fevereiro, 1974.

\section{Sem Coleção}

Encontro. Alguns aspectos da religião tradicional discutidos pelo povo de Macieira da Lixa. Coord. de Mario Pais de Oliveira. 1971.

Presos políticos: documentos 1970-1971. Comissão Nacional de Socorro aos Presos Políticos. Março/Abril, 1972.

Nós matamos o cão-tinhoso. Luís Bernardo Honwana. 1972.

Ocupação do Bairro do Bom Sucesso em Odivelas por 48 familias de barracas. Coord. José João Louro. Colaboração de Ana Barbosa, Francisco Silva Alves, José Azevedo, Margarida Sousa Lobo e Pedro Villas-Boas. 1972.

Chicote no templo: pedaços do Evangelho proclamados hoje e aqui. Mário de Oliveira. 1973.

Maria de Nazaré: um pequeno povo pobre reconhece-a como a companheira ideal no esforço a desenvolver para a libertação de todos. Coord. e ed. de Mário Pais de Oliveira. 1974.

Os grandes senhores. Ronaldo Lima Lins. 1975. Tiragem: 2.000.

Vidas novas. Luandino Vieira; desenhos José Rodrigues. 1975.

O que é o M. I. R. 1975.

Lutas urbanas e poder político. Manuel Castells. 1976.

O pós-socialismo. Alain Touraine. 1981. Tiragem: 2.800 .

A acumulação capitalista em Portugal: das origens da nacionalidade aos inícios do século XIX. António Fonseca Ferreira. Julho, 1977. Tiragem: 3.000.

A esquerda alemã (1918-1921): "doença infantil” ou revolução? Dezembro, 1975. Tiragem: 3.000 .

ITT - Imperialismo no Chile, o Dossier Anderson. Abril, 1973. (Esgotado)

Nascer de novo. Ensaio de catequese libertadora. Mário de Oliveira. Março,
1976.

A revolução bolchevique. $1^{\circ}$ vol. , 1917-1923. A. H. Carr. Janeiro, 1977.

A revolução bolchevique. $2^{\circ}$ vol. , 1917-1923. A. H. Carr. Maio, 1979. Tiragem: 2.500.

Sulcos do nosso querer comum: recortes de entrevistas concedidas durante o $V$ Governo Constitucional. Maria de Lourdes Pintasilgo. 1980. Tiragem: 7.000.

\section{Coleção Zero}

6 Subsídios para a história da CUF. Edit. José Soares Martins. 1974.

7 O socialismo e as igrejas: o comunismo dos primeiros cristãos. Rosa Luxemburgo. 1976.

\section{Coleção Textos}

1 Mas socialismo porquê? Albert Einstein. 1968. (Esgotado)

2 Vietnam. A oposição à guerra nos E. U. A. Programa da Frente Nacional de Libertação do Vietname do Sul. 1969. (Esgotado)

3 O socialismo crítico de hoje: Teses de "Il Manifesto". Agosto de 1971. (Fora de mercado)

4 A dominação inglesa em Portugal. Estudo de Armando de Castro com 3 textos do século XIX em antologia. Junho, 1972.

5 Pedagogia do oprimido. Paulo Freire. Novembro, 1972. (2 ${ }^{\mathrm{a}}$ ed. Janeiro, 1975)

6 As greves selvagens na Europa ocidental. Fevereiro, 1973.

7 Luta de classes e instituições burguesas: o debate sobre as eleições legislativas em Itália 1972. "Il Manifesto". Dezembro, 1973.

8 A raia da Portugal: a fronteira do subdesenvolvimento. Eduardo Borrenechea $\mathrm{e}$ António Pintado. Fevereiro, 1974.

9 A mulher do futuro. Maya Castro. Setembro, 1974.

\section{Coleção Afrontamento Bolso}

1 Portugal / Capitalismo e Estado Novo. Francisco Rafael e outros. Setembro, 1976. Tiragem: 3.000 .

2 A situação dos direitos humanos no Chile. Exposição de Andres Pascal Allende, secretário gerla do MIR, enviada às Nações Unidas. Outubro, 1976. Tiragem: 2.500.

3 Para uma visão crítica da economia galega. Ramón L. Suevos. 1976.

4 Psiquiatria e antipsiquiatria em debate. Cooper, Basaglia, Tomkiewicz e outros. 
1977.

5 A revolução da Maria da Fonte. Subsídios para a sua história e interpretação. Joaquim Palminha Silva. 1978.

6 Portugal: a revolução impossível? Phil Mailer. Agosto, 1978.

7 Escravatura. Conceitos. A empresa do saque. José Capela. 1975. $2^{\mathrm{a}}$ ed. revista, Outubro, 1978. Tiragem: 3.000.

8 A dominação inglesa em Portugal. Armando Castro. $2^{a}$ ed. 1979.

9 Cultura e revolução em Angola. Leonel Cosme. 1979.

10 Oliveira Martins e o socialismo (Ensaio de leitura crítica). Augusto Santos Silva. Setembro, 1979. Tiragem: 3.500. (Com o patrocínio da Secretaria de Estado da Cultura)

11 O inimigo oculto: ensaio sobre a luta de classes: manifesto anti-ecológico. João Bernardo. 1979. Tiragem: 2.500.

12 Diário no Alentejo. Jochen M. Bustorff. 1983.

Coleção Crítica e Sociedade

1 Prática epistemológica e ciências sociais. Manuel Castells, Emílio Ipola. 1975.

2 Debate sobre o Estado capitalista. Nicos Poulantzas e Ralph Miliband. Julho, 1975. Tiragem: 4.000.

4 A caminho de uma nova crise estrutural do sistema capitalista. Samir Amin. 1975. (2a ed. 1978)

5 Ideologias e práticas psiquiátricas. Manuela Fleming. 1976.

6 Uma sociologia alternativa: da sociologia como técnica do conformismo à sociologia crítica. Franco Ferrarotti; trad. António Esteves. 1976.

7 Mulheres, celeiros \& capitais. Claude Meillassoux. 1977.

8 Marxismo e crítica literária. Terry Eagleton. 1978.

9 Temas de História em livros escolares. Maria Carlos Radich. 1979.

\section{Coleção Movimento Operário Português}

1 Da Casa Sindical ao Forte de Sacavém: notas de um sindicalista preso no último movimento operário. Frutuoso Firmino. Introdução de César Oliveira. Novembro, 1971. (Fora de mercado)

2 O congresso sindicalista de 1911. Seleção, prefácio e notas de César Oliveira.
Novembro, 1971. (Fora de mercado)

3 O operariado e a República democrática 1910-1914. César Oliveira. Abril, 1972.

4 O movimento operário em Portugal. Campos Lima. Maio, 1972.

$5 O$ sindicalismo em Portugal. Manuel Joaquim de Sousa. Maio, 1972. (4 ${ }^{\mathrm{a}}$ ed. Setembro, 1974)

6 A criação da União Operária Nacional: problemas e alternativas do Congresso operário de Tomar de 1914. Vol. 6. César Oliveira. Fevereiro, 1973.

7 O socialismo em Portugal, 1850-1900. César Oliveira. Maio, 1973.

8 Os trabalhadores e o Lock-out em Vieira de Leiria. José Gomes Bandeira e Luis Humberto. Julho, 1974.

9 Para a história do movimento comunista em Portugal. João G. P. Quintela. 1976.

Coleção Luta de classes

1 Classe, polítical política de classes. Colectivo. Junho, 1974.

2 Indústria, ideologia e quotidiano (ensaio sobre o capitalismo em Portugal). João Martins Pereira. Julho, 1974.

3 Para uma teoria do modo de produção comunista. João Bernardo. Fevereiro, 1975.

4 Cadernos de circunstâncias 67/70. Reedição de uma publicação clandestina colectiva. Junho, 1975.

5 A emancipação dos trabalhadores é obra dos próprios trabalhadores. Manuel Rodrigues. Julho, 1975.

6 Capitalismo privado ou capitalismo de Estado não é escolha! Editoriais e textos do jornal Combate. Julho, 1975.

7 O 25 de Abril e as lutas sociais nas empresas. Maria de Lourdes Lima dos Santos, Marinús Pires de Lima e Vítor Matias Ferreira. $1^{\circ}$ vol. Julho, 1976.

8 Contribuição para uma alternativa popular à crise da economia em Portugal: textos de apoio da candidatura à presidência da república de Otelo Saraiva de Carvalho (1976). Novembro, 1976.

$10 O 25$ de Abril e as lutas sociais nas empresas. Maria de Lourdes Lima dos Santos, Marinús Pires de Lima e Vítor Matias Ferreira. $3^{\circ}$ vol. Fevereiro, 1977Tiragem: 3.000 .

Portugal 1975 - Os campos. Fernando Oliveira Baptista. Abril, 1978. Abril, 1978. Tiragem: 3.000 . 
Coleção Saco de Lacraus

1 A oposição operária 1920-21. Alexandra Kollontai. Janeiro, 1973. ( $2^{a}$ edição março de 1977, tiragem 3.000)

2 Cronstadt 1921, último soviete livre. Ida Mett. Abril, 1974.

4 A situação da classe trabalhadora em Inglaterra. F. Engels. Maio, 1975.

5 Os bolcheviques e o controle operário. Maurice Brinton. 1975.

7 Operários e capital. Mario Tronti. 1976.

8 Marxismo e filosofia. Karl Korsch. 1977.

9 A cozinheira e o devorador de homens: ensaio sobre o Estado, o marxismo e os campos de concentração. Andre Glucksmann. Setembro, 1978. Tiragem: 3 mil.

11 A sociedade burocrática 1: as relações de produção na Rússia. Março, 1979. Tiragem: 2.500 .

\section{Coleção As Armas e os Varões}

1 Moçambique pelo seu povo. Seleção, prefácio e notas de José Capela. Agosto, 1971. $2^{\mathrm{a}}$ ed. Junho, 1974.

20 vinho para o preto: Notas e textos sobre a exportação do vinho para África. José Capela. Outubro, 1973.

3 Escravatura. A empresa a saque. $O$ abolicionismo (1810-1875). José Capela. 1974.

4 Povos de Moçambique: história e cultura. A. Rita Ferreira. 1975.

5 A burguesia mercantil do Porto e as colónias (1834-1900). José Capela. 1975.

6 o imposto de palhota e a introdução do modo de produção capitalista nas colónias: as ideias coloniais de Marcelo Caetano; legislação do trabalho nas colónias nos anos 60. José Capela. Maio, 1977.

7 Relações raciais no império colonial português 1415-1825. C. R. Boxer. 1977.

9 A tradição de resistência em Moçambique: $o$ vale do Zambeze, 1850-1921. Allen F. Isaacman; colab. Barbara Isaacman. 1979.

\section{Coleção Libertação dos Povos das Colónias}

1 História da Guiné e das ilhas de Cabo Verde. PAIGC. Junho, 1974.

2 História de Moçambique. Frelimo. Junho, 1974. (1971)

3 Textos políticos. Amílcar Cabral. Julho, 1974. $\mathrm{Na}$ p. 4 consta: "Reedição de uma publicação clandestina impressa a offset e editada pelo grupo responsável do Boletim
Anti-Colnial - BAC."

4 A luta continua. Samora Machel. 1974.

5 Wiriyamu. Adrian Hastings. Outubro, 1974.

6 Mensagem ao povo de Moçambique por ocasião da tomada de posse do governo de transição em 20 de Setembro de 1974. Samora Machel. Outubro, 1974.

8 História de Angola. Centro de Estudos Angolanos (Grupo de Trabalho e Etnologia) do MPLA. 1975.

9 Mobutu, chefe supremo. Jules Chomé. 1975.

10 Antologia da poesia pré-angolana 19481974. Compil. e anot. Pires Laranjeira. 1976.

11 Tortura na colónia de Moçambique, 19631974: depoimentos de presos políticos. Julho, 1977. Tiragem: 3.000.

\section{Coleção Arquivo}

1 Colonialismo e lutas de libertação (7 cadernos sobre a guerra colonial). Setembro, 1974.

\section{Coleção Cultura e Libertação}

1 Frente cultural. A. Jacinto Rodrigues. 1976.

\section{Coleção Cidade em Questão}

2 Urbanizar e construir para quem?: a propósito do plano de Chelas. Fernando Gonçalves. 1972.

Urbanismo e revolução. A. Jacinto Rodrigues. Julho, 1975.

4 Movimentos sociais urbanos e intervenção política: a intervenção do SAAL. Vítor Matias Ferreira. 1975.

6 O alojamento social sob o fascismo. Marielle Christine Gros. 1982.

\section{Coleção Viver é Preciso}

1 Alimentos, saúde e agricultura (crítica da agricultura dominante). Claude Aubert. Outubro, 1974

2 Perpectiva ecológica da agricultura: China, Estados Unidos, Terceiro Mundo. René Duchet, Robert Rodale, J. L. Messé. Abril, 1975.

3 O átomo e a história (o terror atômico, de Hiroshima às centrais nucleares). Pierre Pizon. 1975.

4 Ecologia: a cruzada humanista à critica do capitalismo. Antologia Organizada e Apresentada por Vítor Matias Ferreira. 1976. Tiragem: 2.500 .

6 Nós, a loucura e a antipsiquiatria. Ernesto 
Bono. 1976.

9 Sobre o antagonismo cidade-campo: manifesto por um renascimento rural. Compil. de A. Faria. 1977.

Capitalismo e modo de vida. Andre Granou. Agosto, 1975.

Coleção Biblioteca das Ciências Humanas

1 Marx crítico de Marx: livro primeiro. João Bernardo. 1977.

Coleção Cadernos de Ecologia e Sociedade

5 Tecnologia de aldeia, tecnologia do futuro. Compil. José Carlos Marques. 1977.

Coleção Regimes, Instituiç̃ões e Sistemas Económicos

1 A natureza da U. R. S. S.: antologia. Compil. e trad. Artur J. Castro Neves, António Vasconcelos. 1977.

Biblioteca das Ciências do Homem

A sociedade contra o Estado: investigações de antropologia política. Pierre Clastres. 1979. Antropologia; 1.

Passagens da antiguidade ao feudalismo. Perry Anderson. História; 1. 1980.

\section{Agência Portuguesa de Revistas (Lisboa)}

As mentiras de Marcello Caetano: resposta a um falso depoimento. Coronel Antonino Cruz e Vitoriano Rosa. 1974.

A revolução da democracia cristã. Rafael Caldera. 1974.

Estes doentes que nos governam. Pierre Accoce, Pierre Rentchnick. 1977.

Português sem Portugal. Artur Agostinho. 1977.

Dossier PIDE: os horrores e crimes de uma "polícia". Pelo "Repórter Sombra". 1974.

As revoluções rebentam de madrugada. Henrique de Sousa e Melo. 1974.

11 de Março: autópsia de um golpe. Jorge Feio, Fernanda Leitão e Carlos Pina. 1975.

Governo Soares: o exame de S. Bento. Agosto, 1976.

General mas não muito... Romance inspirado nos acontecimentos de 25 de Novembro (antes e depois). Henrique de Sousa e Melo. Janeiro, 1976. Tiragem: 4.500.

O fracasso de um processo: a reforma agrária no Alentejo. Vacas de Carvalho. 1977. "Edição do autor. Distribuído por: Agência
Portuguesa de Revistas".

A Comuna de Lisboa. Henrique de Sousa e Melo. 1977.

Jonas Savimbi: o homem do projeto angolano. Texto integral da histórica entrevista recentemente concedida ao jornalista do “Tempo” João Rosa. 1979.

Angola, a resistência em busca de uma nova nação. Jonas Savimbi. 1979.

O desafio de Savimbi. João Rosa. 1980.

Cadernos de Divulgação

MRPP: o que é? Jorge Feio, Fernanda Leitão e Carlos Pina. 1975.

\section{Alfaómega (Lisboa)}

Biblioteca Rosacruz

2 A doutrina secreta dos rosacruzes. Karl von Eckartshausen.

3 A Maçonaria e o Catolicismo. Max Heindel. Março, 1979. (Tradução cedida pelo Centro Rosacruciano de Lisboa)

Política do Século XX

1 Diálogos com Sá Carneiro. João Rosa. Junho, 1978.

2 Contraviolência: napalm, Pudding e outros textos. Ulrike Meinhof. Dezembro, 1978.

Coleção Autores

1 Homems e cães: contos. A. Vicente Campinas, Urbano Tavares Rodrigues. 1979.

2 Fronteira de Abril: contos e outros textos. Modesto Navarro. 1979.

3 Uma quarta de pão e quatro azeitonas. Franco de Sousa.

$\underline{\text { Ribalta }}$

1 Achada grande do Tarrafal: peça em quatro quadros e um epílogo. Franco de Sousa. 1979.

\section{Almedina (Coimbra)}

Nova Cultura

1 Igualdade radical para a mulher. Vários. 1970. (Retirado do mercado e esgotado)

2 A condição de estudante. Catherine Valabrègue. 1970.

3 A crise do catolicismo. José Luis L. Aranguren. 1971. 
$4 O$ movimento estudantil e a escola do capitalismo. Antologia. Centro C. Campano, Bolaff-Flores-Ingrai-Ruffolo-Russo, I. Illich, P. Freire, J. Golfin, L. Vandermeersch, M. Stirner. 1972.

5 Banalidades de base. Raoul Vaneigem. 1972.

6 Introdução à política. 2 volumes. Norberto Cunha e Marinho Magina. 1975.

Coleção Religião - Crise - Moral

1 Chamados à liberdade. Pierre Ganne; trad. Maria Adelaide de Castro Ramos. 1971.

2 Alienação no cristianismo. M. Martins Vaz. 1971.

3 Evangelho sem mitos. Louis Evely; trad. Maria Adelaide de Castro Ramos. 1971.

4 A esperança que está em nós. Pierre Ganne; trad. Manuel Arruda.1972.

5 A esperança é política. André Biéler; préf. de Hélder Câmara; trad. de Manuel Arruda. 1972.

6 Fé: força política. Jean Cardonnel; Hervé Chaigne; Karl Levêque. Trad. Manuel Arruda. 1972.

\section{Coleção Almedina}

23 O direito soviético. Jacques Bellon.

29 Instituições soviéticas. Michel Lesage. 1977.

$\underline{\text { Sem coleção }}$

Introdução à política: textos. Norberto Cunha $\mathrm{e}$ Marinho Magina. 2 volumes. 1975/1976.

Da democracia e dos socialismos em Portugal e além fronteiras. E. M. Planchard. 1977.

Argumentos para uma terceira via: nem comunismo soviético nem capitalismo. Ota Sik. 1978.

Democracia e utopia: reflexões. A. Barbosa de Melo. 1980.

\section{Antídoto (Lisboa)}

Documentos Antídoto

$1 O 25$ de Abril e a revolução socialista em Portugal e colónias. Ernest Mandel. Abril, 1975. Tiragem: 5.000 .

2 A agonia do franquismo e as tarefas da revolução espanhola. Resolução do Secretariado Unificado da IV Internacional.

Fora de coleção

A resposta operária à inflação, desemprego e imigração. E. Mandel, P. Bailey, L. Maitan e S. A. Udry. 1975.

A resposta socialista à austeridade. Textos da I Conferência Operária e Sindical da LCI. Janeiro, 1977.

A revolução portuguesa numa encruzilhada: Teses aprovadas no $3^{\circ}$ Congresso (extraordinário) da Liga Comunista Internacionalista, organização simpatizante da IV ${ }^{\mathrm{a}}$ Internacional. Janeiro, 1976.

Construir a Liga para construir o partido. Tese do IV Congresso da LCI. 1977.

Os SUV em luta.

Da comuna a maio de 68: Escritos políticos. Ernest Mandel. 1979.

Obras de Leon Trotsky

1 A revolução desfigurada: a falsificação estalinista da História. L. Trotsky. Janeiro, 1977.

2 A revolução traída. Leon Trotsky. Fevereiro de 1977.

3 A revolução permanente. L. Trotsky. 1977.

4 Programa de transição para a revolução socialista. 1978.

5 Questões do modo de vida. Léon Trotsky: a época do militarismo cultural e as suas tarefas. 1979.

6 A Internacional Comunista depois de Lenine.

7 As lições de outubro.

8 Como fizemos a revolução. 1979.

9 Balanço e perspectivas. 1978.

\section{Biblioteca Comunista}

1 Espanha abandonada: como Estaline abriu as portas a Franco. M. Casanova. Janeiro, 1977.

2 A China antes e depois de Mao. E. Mandel, Rousset, Rossi, Wu e Lew. Março, 1977.

3 A luta pela democracia socialista na União Soviética. E. Mandel. Maio, 1977.

4 A Quarta Internacional. Pierre Frank.

5 A actualidade de Rosa Luxemburgo. Norman Geras. 1978.

6 Introdução ao marxismo. Ernest Mandel. Fevereiro, 1976. $2^{\mathrm{a}}$ ed. Fevereiro, 1978.

7 Crítica Eurocomunismo. Ernest Mandel. Junho, 1978.

8 Acerca da natureza da URSS. Mandel, Bensaid, Weber.

9 Dialéctica e revolução. Michael Lowy.

11 Os estudantes, os intelectuais e a luta de classes. Ernest Mandel; trad. de Serafim 
Ferreira. Junho, 1979.

\section{Clássicos Antídoto}

1 A questão parlamentar e a Internacional Comunista. Zinoviev, Lenine, Trotsky, Bukharine e Bordiga. 1975.

2 A revolução permanente na Rússia. L. Trotsky. Abril, 1977.

3 O materialismo histórico. Franz Mehring.

4 Problemas da guerra civil. L. Trotsky. 1977.

5 O papel do indivíduo na história. Plekhanov.

6 Introdução à filosofia da praxis. A. Gramsci; trad. Serafim Ferreira. Março, 1979. ( $2^{\mathrm{a}}$ ed. Julho, 1979).

7 A moral deles e a nossa. L. Trotsky. 1979.

8 O Estado burguês e a revolução. Rosa Luxemburgo.

\section{Coleção Documentos}

1 África do Sul: história de uma crise. René Lefort. Junho, 1978.

\section{Coleção Argumentos}

1 Sobre o fascismo. E. Mandel. Abril, 1976.

2 Lenine e a imprensa revolucionária (Nome: Lenine; profissão: jornalista). Madeleine Worontzoff. Junho, 1977.

3 Teoria marxista do Estado. E. Mandel. 1977.

4 Do Compromisso histórico ao eurocomunismo. Enrico Berlinguer. Novembro, 1977.

5 Aborto e contracepção, um direito, uma escolha. Jacqueline Heinen, jane Snads, Mathilde Zimmerman.

6 Economia e política no pensamento de Trotsky. Denise Avenas.

\section{Coleção Economia e socialismo}

1 Sobre o imperialismo. Jacques Valier. 1977.

2 O capitalismo em crise. E. Mandel.

\section{Coleção Marxismo Vivo}

1 A teoria leninista da organização. E. Mandel. 1975.

\section{Modo de Vida}

1 O combate sexual da juventude. W. Reich. $2^{\mathrm{a}}$ ed. Fevereiro, 1978.

2 Ser mulher na URSS e países de leste. Tamara Volkova e D. Bor. Maio, 1978.

3 Mulheres, capitalismo e movimento operário.
Jacqueline Heinen, Antoine Artous, Alain Brossat.

4 Ecologia e luta de classes. J. P. Dèleage, Enzensberger.

5 Condição de mulher. Juliet Mitchell.

6 Conferências sobre a libertação das mulheres. Alexandra Kollontai.

Coleção Universidade

1 Iniciação à teoria económica marxista. E. Mandel.

2 Reich perante Marx e Freud. J. M. Brohn, Helmut Dahmer, Paul Frappier. 1978.

3 Guia para a leitura do Capital. Colectivo da Universidade de Berlim.

4 O que é a dialéctica? J. M. Brohn.

5 História das relações internacionais. Ekkehart Krippendorff. Fevereiro, 1979.

6 Pensamento e linguagem. Lev Semenovich Vygotsky. 1979.

\section{António Ramos (Lisboa)}

Coleção Arquivos de Sempre

A Itália de Berlinguer. Patrick Meney. Maio, 1977.

Um processo “comum” na URSS: o Dr. Stern perante os seus juízes. Março. 1977.

A queda final: a decomposição da esfera soviética. Emmanuel Todd. Outubro, 1977.

Linha geral. José Rabaça.

Um comunismo diferente? Annie Kriegel. 1978.

$O$ pelicano e a seara: integralistas e seareiros juntos na revista Homens Livres. João Medina. 1978.

Homens e temas

Política e autobiografia. Situações X. Jean-Paul Sartre; trad. de Pedro Tamen. Março, 1977.

Linhas quebradas. José Rabaça, Raúl Rêgo; pref. David Mourão Ferreira. 1977.

Retratos de alguns portugueses. Manuel Mendes. Março, 1977.

Quem são os dissidentes? David Cooper; trad. Pedro Tamen. 1978.

O homem precário e a literatura. André Malraux. 1978.

Afonso Lopes Vieira, Anarquista. Introdução e notas de João Medina. 1980.

Ciência e Cultura

História da sexualidade. Michel Foucault; trad. 
Pedro Támen. 1977.

$\underline{\text { Sem coleção }}$

Soares responde a Artur Portela. Novembro, 1980.

O Presidente da República e a democracia e outras crónicas: publicadas no Diário de Notícias de Agosto 1978 a Junho 1980. José Rabaça. Setembro, 1980.

\section{Arcádia (Lisboa)}

Socialismo científico: do Manifesto do Partido Comunista ao novo Estado industrial. G. Bourgin e P. Rimbert. Janeiro, 1972.

Dinossauro excelentíssimo. José Cardoso Pires. 1972.

Socialismo científico. Georges Bourgiw, Pierre Rimbert. 1972.

Os Congressos do Povo da Guiné: um novo caminho? Manuel Belchior. 1973.

Ensaio sobre a liberdade. John Stuart Mill. 1973.

A funda. $5^{\circ}$ volume: o spinolismo. Artur Portela Filho. Novembro, 1974.

Portugal e o futuro: análise da conjuntura nacional. António Sebastião Ribeiro de Spínola. Fevereiro, 1974. (2 a ed. Março, 1974)

Portugal amordaçado: depoimento sobre os anos do fascismo. Mário Soares. Outubro, 1974.

O suicídio das democracias. Claude Julien. Abril, 1974.

Diário político. Os políticos e o poder económico. Raul Rego. Agosto, 1974.

De súbito, em Abril: 24, 25, 26. Paulo Madeira Rodrigues. Junho, 1974.

A funda. $6^{\mathrm{o}}$ volume. Artur Portela Filho. Novembro, 1975. Tiragem: 5.000.

Trostsky e a segunda guerra mundial. Compil. Daniel Guérin. 1975.

Confissão. Mikhail Bakunine. Março, 1975. Tiragem: 3.000.

Pequeno manual de inflação: como se provoca inflação, como defender-se da inflação, como lucrar com a inflação. René Berger. Março, 1975.

Relatório sobre a tortura. Amnesty International. Junho, 1975. Tiragem: 5.000.

Memórias do exílio. Brasil 1964/19??. 1. De muitos caminhos. Novembro, 1976. Tiragem: 5.000.
O regresso do conde de Abranhos. Artur Portela Filho.

Lenine: a história da sua vida. Maria Prilejaieva. 1976.

Da minha luta contra o salazarismo $e \quad o$ comunismo em Portugal. Henrique Galvão. Abril, 1976. Tiragem: 5.000.

Coleção Ser ou não ser - Coordenação de José Silva Pinto

1 Ser ou não ser deputado. Sá Carneiro, CazalRibeiro, Aguiar e Silva, Roboredo e Silva, Magalhães Mota. 1973.

2 Ser ou não ser por uma abertura a leste. Vergílio Ferreira, Raul Rêgo, Manuel Vinhas, Barradas de Oliveira, Francisco Granadeiro. Julho, 1973.

3 Ser ou não ser pelo partido único. Magalhães Godinho, Nogueira Pinto, Barrilaro Ruas, Coelho da Silva, Victor Wengorovius e Pinto Balsemão. Introdução e coordenação de António Valdemar. Setembro, 1973.

4 Ser ou não ser pela bolsa. Maia Cadete, Vicente Marques, João Forjaz e Oliveira Santos. Outubro, 1973.

Ser ou não ser pelo amor livre. Pref. Maria Teresa Horta. 1975.

Alternativas socialistas - Coleção dirigida por Roger Garaudy

1 Socialismo e liberdade. 1975.

2 Religião e socialismo. Março, 1975.

3 A recessão generalizada da economia capitalista internacional. 1975.

4 A luta de classes em Portugal. Paul Sweezy. Dezembro, 1975. Número especial.

5 Capitalismo ou socialismo. Paul Sweezy e Leo Huberman. 1976.

5/6 Respostas do socialismo à crise do capitalismo. Vários. Abril, 1976. Tiragem: 3.000 .

7 Um outro marxismo: Antonio Gramsci. Org. Pedro Cavalcanti e Paolo Piccone. Outubro, 1976. Tiragem: 3.000. A partir deste volume a coleção não é mais dirigida por Roger Garaudy, mas sim por Pedro Cavalcanti.

8 Socialistas e comunistas: a origem da ruptura. Antologia organizada e anotada por Pedro Cavalcanti. 1977.

9 A alternativa italiana do P.C.I. introdução, notas e antologia de Pedro Cavalcanti. 1977.

$\underline{\text { Ensaio }}$

$O$ reino original: crônicas de um Portugal 
maltratado (1977-1980). Romeu de Melo. Julho, 1983. Tiragem: 2.000 .

\section{Biblioteca Arcádia}

Estado de sítio. Costa Gavras e Franco Solinas; trad. Orlando Vitorino e Almeida Gonçalves. Dezembro, 1974.

Repensar Portugal. Mário Baptista. Junho, 1975. Tiragem: 3.000.

Entrevista com a história. Oriana Fallaci. 1975.

África árabe, áfrica negra. Arnold Joseph Toynbee. 1975.

A teologia em processo face à crítica marxista. Louis Boisset. 1975.

Carta aberta ao Dr. Salazar. Henrique Galvão. Janeiro, 1975.

Questões sobre a revolução. Alain Krivine. 1975.

\section{Biblioteca Arcádia de Bolso}

138 A China Popular. Jacques Guillermaz. Julho, 1971.

169 Nacionalizar que grupos, porquê, como? Marc Dupuis. Julho, 1975. Tiragem: 3.000.

Revolução social ou ditadura militar. Mikhail Aleksandro Vítch Bakunin. 1975.

Racismo, opressão dos povos. Vinício de Sousa. 1975.

A exploração da mulher. Michele Noel. 1975.

As eleições para a Assembleia Constituinte e a ditadura do proletariado. Lenine. 1975.

Liberdade, igualdade, sexualidade. Michel Meignant. 1975.

Teoria da guerrilha. Carl Schmitt. 1975.

Introdução à Política

As organizações internacionais. Pierre Gerbert. $2^{\mathrm{a}}$ ed. Janeiro, 1977. Tiragem: 5.000. ( $1^{\mathrm{a}} \mathrm{ed}$. Novembro, 1967)

Temas Portugueses - dirigida por Vitorino Magalhães

1 Estrutura da antiga sociedade portuguesa. $2^{\mathrm{a}}$ e $3^{\mathrm{a}}$ ed. Vitorino Magalhães. ( $1^{\mathrm{a}}$ ed. 1971)

2 Os militares e o poder. Eduardo Lourenço. Novembro, 1975. Tiragem: 3.000.

3 Angola: da escravatura ao trabalho livre. Subsídios para a história demográfica do século XVI até a independência. António Carreira. 1977.

4 Para a história dos seguros em Portugal: notas e documentos. A. H. De Oliveira Marques. Maio, 1977. Tiragem: 2.000.
Encontro Especial

11 A queda de Paris. Ilia Ehrenburg. 1970.

12 Companheiros de armas. Konstantin Simonov. 1970.

13 A segunda Morte de Ramón Mercader. Jorge Semprun. 1970.

Dossier Zero

1 A conferência do terror. Compil. e pref. Afonso Cautela. 1973.

Testemunho directo

$1 O$ golpe israelita no Uganda: os 53 minutos de Entebbe. Salomon Lewinsky... [et al.]. 1976.

\section{Documento/Ensaio}

O sonho e a história: dois séculos de América. Claude julien. 1976.

As mulheres de Moçambique. Michéle Manceaux. 1976.

Escritos sobre Espanha: a revolução espanhola (1931-1939). Leon Trotski. Fevereiro, 1976. Tiragem: 3.000. Seleção e revisão de textos: J. Cabral Fernandes.

O fim dos ricos. Alfred Sauvy.

A igreja e os movimentos revolucionários. Vietname, América Latina, Colónias portuguesas. François Hontart, André Rousseau. Junho, 1976. Tiragem: 3.000.

A autogestão, uma utopia? Albert Garand. 1977.

Divórcio: liberalismo ou liberdade? Monique e Roland Weyl;pref., introd. de J. A. Barreiros. 1977.

Desenvolvimento e socialismos. René Dumont, Marcel Mazoyer. 1977.

A terceira via: a teoria marxista-leninista e a sociedade industrial moderna. Ota Sik. 1978.

\section{Cadernos Arcádia}

Centrais nucleares e meio ambiente. Isabel Torres. 1977.

Cinema

Cinema e censura em Portugal: 1926-1974. Lauro António. 1978.

\section{A Obra e o Homem}

António Sérgio: a obra e o homem. Montezuma de Carvalho. 1979. 


\section{Armazém das Letras (Lisboa)}

A revolução num regimento: a Polícia Militar em 1975. Autores: Militares do Regimento de Polícia Militar e Helena Domingos, José Serras Gago e Luís Salgado de Matos. 1977. Tiragem: 5.000.

A transição socialista: o debate soviético e o caso português. Bukharine e Preobrajensky. 1977. Tiragem: 3.000 .

Textos de política: textos para "introdução à política”. José Serras Gago, Luis Salgado de Matos e João B. Serra. 1977. (2 ed. 1977)

A política na escola. C. E. C.. 1978.

O outro lado do texto: textos de português. Eduarda Dionísio, Margarida Carneiro da Silva, Helena Domingos. 1978.

Os moradores à conquista da cidade: comissões de moradores e lutas urbanas em Setúbal, 1974-1976. Chip Dows, Fernando Nunes, Helena Gonçalves, Isabel Seabra. 1978. Tiragem: 2.500 .

Retrato dum amigo enquanto falo. Eduarda Dionísio. 1979.

\section{Assírio \& Alvim (Lisboa)}

\section{Sem Coleção}

Jardins de Guerra. Casimiro de Brito. $2^{\mathrm{a}}$ ed. Junho, 1974.

$A B C$ do anarquismo. Edgar Rodrigues. Setembro, 1976.

Canções de Sérgio Godinho. Anot. e coment. de Arnaldo Saraiva. 1977.

O povo é quem mais ordena. Otelo Saraiva de Carvalho. Janeiro, 1977.

$O$ povo em armas. Buenaventura Durruti e o anarquismo espanhol. Abel Paz. 2 volumes. Trad. Júlio Carrapato. s/d. (1977).

Textos e canções. José Afonso; organiz. e notas J. H. Santos Barros. 1983.

\section{Cadernos Peninsulares - Série Ensaio}

1 Sexualidade e repressão. Carlos Castilla del Pino. 1973.

2 Linguagem e criação. José Martins Garcia. 1973.

3 o que deve saber-se sobre a sexualidade. Colectivo, seguido de um texto de Tony Duvert. 1973.

4 Sade/Masoch. Giles Deleuze. 1973.

5 O problema colonial. J. Pedro Capitão. 1974.
6 Luta continua (Lotta continua). Outubro, 1974.

7 Nas origens do comunismo francês. Annie Kriegel. 1975.

8 Antologia sobre o materialismo dialéctico. Marx, Engels, Lenine, Mao Tsé-Tung. Junho, 1975.

9 Sobre a estratégia global da revolução brasileira. José Crispim. 1975.

$10 O$ desenvolvimento do capitalismo em Portugal. Ramiro da Costa. 1975.

11 Dois povos ibéricos: Portugal e a Catalunha. Félix Cucurull. 1975.

12 A III Internacional e o fascismo. Dimitrov. Agosto, 1975.

13 Os comunistas dos conselhos e a III Internacional. Pannekoek, Lukacs, Gorter, Bordiga, Silvia Pankhurst e outros. 1976.

14 O que é a consciência de classe. W. Reich.

15 Revolução e contra-revolução na Alemanha. Karl Marx. 1976.

16 O marxismo e a questão nacional. Staline. Junho, 1976.

17 O anarquismo hoje. Jean Barrué, seguido de A reacção da Alemanha, Miguel Bakunine. Agosto, 1976.

18 História do movimento macknovista: a insurreição dos camponeses da Ucrânia. Pedro Archinov. 1976.

19 Deus e o Estado. Bakunine. 1976.

20 Capitalismo e esquizofrenia. Dossier AntiÉdipo. Deleuze, Guattari, Lyotard e outros. 1976.

\section{Cadernos Peninsulares / Série Resposta}

1 A China e as raízes da sinofobia ocidental. Maria-Antonieta Macciocchi, Charles Bettelheim, Philipe Solers, Rossana Rossanda e outros. Abril, 1973.

2 Carta ao general Franco. Arrabal. 1973.

Cadernos Peninsulares / Ensaio especial

1 A Internacional Comunista. Dominique Desanti; trad. de Luísa Lemos. 1977.

4 Elementos para a história do movimento operário em Portugal. $1^{\circ}$ volume 1820-1929. Ramiro da Costa. Outubro, 1979.

5 Elementos para a história do movimento operário em Portugal. $2^{\circ}$ volume 1930-1975. Ramiro da Costa. Novembro, 1979.

21 Breve história do pensamento e das lutas sociais em Portugal. Edgar Rodrigues. 1977. 
Cadernos Peninsulares / Nova série/ Ensaio

Manual do guerrilheiro urbano e outros textos. Carlos Marighella. Março, 1975. Tiragem: 5.000 .

Lenine e a religião. Colectivo. Outubro, 1974.

Reviver Lenine. J. Staline e N. Kroupskaia. Junho, 1974.

A queda do fascismo: Maio, 1974. António Ferreira. Julho, 1974.

Da greve selvagem à autogestão generalizada. Ratgeb. 1974.

100.000 relógios sem patrão (Processo LIP). François-Henri de Virieu. Novembro, 1974.

$16 O$ vinte cinco de Abril nunca existiu. Baar. Fevereiro, 1977.

\section{Coleção Mínima}

2 Portugal sem Salazar. Entrevistas de Mario Mesquita. Outubro, 1973.

3 A revolta do grelo. Vasco Pulido Valente. 1973.

4 A corrupção do poder. Peter Dale Scott e Frank Browing. Dezembro, 1974.

5 As três fontes do marxismo. Karl Kautsky. Abril, 1975.

6 Aspectos fundamentais da economia chinesa. Them Chi. Junho, 1975.

7 Cartas da prisão. Rosa Luxemburgo. Setembro, 1975.

8 Princípios e métodos de acção revolucionária. Le Duan. 1976.

9 Pequena burguesia e revolução, seguido de Sobre moral e proletarização. Textos do ERP/PRT (Argentina). Julho, 1976.

Temas Internacionais

1 A guerrilha do Che. Régis Debray. 1975.

2 Os árabes hoje. Mahmoud Hussein. Março, 1975.

3 China, país capitalista ou socialista. Organização e textos e tradução de Lucília Cardoso Salgado. Novembro, 1975.

4 O heróico povo da Coreia. Colectivo. 1975.

5 Tito e a revolução. Marcel Veyrier; trad. Machado da Graça. Setembro, 1976.

5 O Congo de Lumumba: história de um assassinato político. Adérito Lopes. 1976.

Forças do Tempo (dirigida por L. H. Afonso Manta)

118 de Janeiro de 1934. L. H. Afonso Manta. 1975.
2 Os sindicatos e a revolução. A. Losovsky. 1975.

3 A Frente Popular Antifascista em Portugal: o primeiro esboço da unidade antifascista. Afonso Manta. Agosto, 1976.

4 1977/78 Sindicalismo em Portugal: perspectivas futuras/pacto social. Vários. 1977.

Dicionários Populares

1 Dicionário popular de política. José Maria Coloma. Junho, 1974.

2 Dicionário popular de economia. Abirov. 1975.

Textos de Ciências Sociais

10 A objectividade nas ciências sociais. Gunnar Myrdal. Agosto, 1976.

\section{Aster (Lisboa)}

Documentos do Nosso Tempo (Direcãa e coordenação de Henrique Barrilaro Ruas)

A revolução das flores: do 25 de Abril ao Governo Provisório. 1974.

A revolução das flores: o governo de Palma Carlos. s/d.

A revolução das flores: o governo de Vasco Gonçalves até ao acordo de Lusaka. s/d.

\section{Universidade Nova}

Sociedade e civilização russas no século XIX. Constantin de Grunwald. 1976.

Do conhecimento histórico. H.-I. Marrou; trad. Rui Belo. 1976.

Mao Tsé-Tung: a revolução absoluta. Alain Bouc; trad. de Maria de Lourdes Saraiva. 1977. BMRR $32 \mathrm{MAO} / \mathrm{BOU}$

Divórcio em Portugal. Virgílio Lopes. 1978.

\section{$\underline{\text { Perspectivas }}$}

1 Textos da China de Mao:o que dizem e como se expressam os poetas e escritores da China de mao. Rosanna Pilone. Agosto, 1975.

Ensaios e Documentos

Ensino sobre as liberdades. Raymond Aron.

Dossier do nacional socialismo. Walther Hofer.

Escândalo da justiça. D. Francisco da Mata Mourisca.

Política dum bispo? D. Francisco da Mata Mourisca, Bispo de Carmona e S. Salvador. 
Março, 1977.

Grandes Biografias

Trotsky. Victor Serge; trad. Mascarenhas Barreto, Ruy M. Sabiah. 1977.

Sarmento Pimentel ou uma geração traída (Diálogos de Norberto Lopes com o autor das "Memórias do capitão"). Norberto Lopes e Sarmento Pimentel. Prefácio de Vitorino Nenésio. $2^{\text {a }}$ edição com documentos da luta contra a ditadura. 1977.

Visado pela censura: A imprensa, figuras, evocações da ditadura à democracia. Norberto Lopes. 1975.

Introdução à política: a problemática da comunidade internacional. António José Fernandes. 1977.

Mons. Escrivá de Balaguer, Apontamentos sobre a vida do Fundador do Opus Dei. Salvador Bernal. Coedição Edições Prumo/Editorial Aster. 1978.

\section{Ática (Lisboa)}

As crises e os homens. Franco Nogueira. Agosto, 1971.

Informar ou depender. Francisco C. P. Balsemão. Junho, 1971.

Diário. Che Guevara. 1974.

Discursos políticos. Domingos Arouca. 1974.

O modelo político peruano de Velasco a Morales. Neiva Moreira. Fevereiro, 1976.

$O$ arquipélago de sangue: as atrocidades cometidas pelo Ocidente em nome da democracia e da liberdade. Noam Chomsky, E. Herman. Dezembro, 1975.

Ao serviço de Portugal. António de Spínola. Novembro, 1976. Coedição com Bertrand.

Salazar em França. João Medina. Março, 1977.

A mãe. Bertolt Brecht. Janeiro, 1978.

\section{Série Conhecer}

Conhecer Mao. Philippe Devillers. Dezembro, 1975.

Conhecer Nietzsche. Christophe Baroni. 1977.

Conhecer Marx. H. B. Acton. 1977.

Conhecer Lenine. Marcel Liebman.

Conhecer Freud. D. Stafford-Clark.

\section{Atlântida (Coimbra)}

Nos cárceres do fascismo: notas, escritos, reflexões. Carlos de Almeida. Dezembro, 1974.

A urbanização fascista e os trabalhadores. Carlos de Almeida. 1974.

Mais os cravos que as armas. Manuel Pinto. 1975.

Meu canto de hoje. Manoel Pereira. 1975.

As Nações Unidas, a O.I.T. e a liberdade sindical. 1975.

Baldios: legislação actualizada. 1976.

Em nome da vida não à bomba de neutrões. 1977.

Abril desencantado e outros poemas. Luz Videira. 1977.

Salazar. Vol. I: A mocidade e os princípios (1889-1928). Franco Nogueira. 1977.

Salazar. Vol. II: Os tempos áureos (19281936). Franco Nogueira. 1977.

Salazar. Vol. III: As grandes crises (19361945). Franco Nogueira. Junho, 1978.

Salazar. Vol. IV: O ataque (1945-1958). Franco Nogueira. 1980.

O Ultramar, a nação e o 25 de Abril. Silva Cunha. Julho, 1977.

Pequenos Estudos e Documentos

1 Direito à greve. Afonso Rodrigues Queiró. Julho, 1974.

2 Do direito à colonização ao dever de descolonização. Afonso Rodrigues Queiró. Julho, 1974.

3 O pensamento democrático como princípio estruturador na vida dos povos europeus. Gerhard Leibholz. Agosto, 1974.

4 Ultramar: direito à independência? Afonso Rodrigues Queiró. Agosto, 1974.

5 Os direitos e deveres naturais do homem e as funções do Estado segundo a "Pacem in Terris”. José da Silva. $2^{\mathrm{a}}$ ed. Outubro, 1974.

6 Uma constituição democrática: hoje-como? Afonso Rodrigues Queiró. 1980.

\section{$\underline{\text { Textos Vértice }}$}

1 Sociedade educação e reforma. Rui Climaco. 1971.

2 Sobre o capitalismo português. Armando Castro, A. J. Avelãs Nunes, Joaquim Gomes, V. Tribuna Moreira. 1971.

3 A ilha está cheia de vozes: novela; Três histórias plausíveis: contos. João Medina. 
1971.

4 Do capitalismo e do socialismo. A. J. Avelãs Nunes. 1972.

5 O homeme arrastado. Sidónio Muralha.

6 Capitalismo monopolista de Estado. 1972.

7 Os direitos do homem no Direito Civil. Orlando Carvalho.

8 Caminhos do teatro na actualidade. Mário Vilaça. 1974.

9 As ditaduras: o regime revolucionário. Basílio Teles. Janeiro, 1975.

10 O "reino da estupidez" e a reforma pombalina. Luís Guilherme Mendonça de Albuquerque. 1975.

11 O desenvolvimento e a paz. Março, 1977.

12 A conferência de Helsínquia. 1977.

13 Ponto de vista. Egídio Namorado. 1977.

\section{Avante! (Lisboa)}

Fora de coleção

Programa do Partido Comunista Português: aprovado pelo VI Congresso em 1965. $3^{\mathrm{a}} \mathrm{ed}$. Maio, 1974 ( $1^{\mathrm{a}}$ ed. 1965; $2^{\mathrm{a}}$ ed. 1970).

Estatutos do PCP. 1974.

Abril, Abril. Textos de escritores comunistas (DORL). Junho, 1975. Tiragem: 6.000.

Desenhos da prisão. Álvaro Cunhal. 1975.

Escrita e combate: textos de escritores comunistas. Junho, 1976. Tiragem: 3.500.

28 de Setembro: a conspiração da "Maioria Silenciosa”. Partido Comunista Português. Abril, 1975. Tiragem: 20.000.

No caminho da democracia e da paz.

Do capitalismo ao socialismo.

Conferência nacional unitária de trabalhadores.

Junta a tua à nossa voz.

Pela reforma agrária, a terra a quem a trabalha.

$O$ partido e as classes trabalhadoras moçambicanas na edificação da democracia popular: relatório do Comité Central ao III Congresso da FRELIMO. Samora Moisés Machel. Abril, 1978. Tiragem: 3.500.

Livro negro do MAP. 1977.

Poder local no Portugal de Abril: intervenções de Álvaro Cunhal e Carlos Costa. Documento Síntese. Manifesto. Novembro, 1981. Tiragem: 3.000 .

Avante com Abril: relatório da actividade do Comité Central ao IX Congresso do PCP. Álvaro Cunhal. Junho, 1979. Tiragem:
30.000 .

Angola: a tentativa de golpe de Estado de 27 de Maio de 77. Informação do Bureau Político do MPLA. Agosto, 1975. Tiragem: 5.200.

ABC do marxismo-leninismo. Série A: A sociedade e o Estado

1 Como o homem se tornou homem. 1976.

2 Desenvolvimento do homem e da sociedade (Da comunidade primitiva ao fim do feudalismo).

3 A origem do capitalismo: a revolução industrial em Inglaterra. Marianne Roth. 1976.

4 Liberdade, igualdade, fraternidade: a grande Revolução Francesa de 1789 e as suas repercussões. 1976.

5 Precursores do socialismo moderno: socialimo utópico. 1976.

6 A doutrina marxista das classes e da luta de classes. 1976.

7 O Outubro vermelho de 1917. Trad. de álvaro Pina. 1976.

8 A doutrina marxista das classes e da luta de classes (II). Marianne Roth; trad. de Álvaro Pina. 1976.

9 Origens e partes constitutivas do marxismo. Marianne Roth; trad. e adapt. de Álvaro Pina. 1976.

10 Friedrich Engels. Marianne Roth; trad. de Álvaro Pina. 1976.

11 A comuna de Paris (1871). Trad. Álvaro Pina. 1977.

12 O que o Marxismo ensina sobre o Estado. 1977.

13 Karl Marx. 1977.

14 A resistência antifascista na Alemanha: 1933-1939. 1977.

15 O socialismo e o comunismo científicos. 1978.

ABC do marxismo-leninismo. Série B: A imagem moderna do mundo

1 O problema fundamental da filosofia. 1976.

2 A história: acaso ou lei? 1976.

3 A concepção marxista do conhecimento. Marianne Roth. 1979.

4 Introdução à dialéctica marxista. 1976.

Elementos fundamentais do comunismo científico

1 Curso básico do comunismo científico. Vol. I. Dir. V. G. Afanassiev. 1976. 
2 Curso básico do comunismo científico. Vol. II. Dir. V. G. Afanassiev. 1976.

3 Curso básico do comunismo científico. Vol. III. Dir. V. G. Afanassiev. 1976.

4 Curso básico do comunismo científico. Vol. IV. Dir. V. G. Afanassiev. 1976.

5 O leninismo e a passagem do capitalismo ao socialismo. Vol. I. Konstantine Karódov. 1976.

6 O leninismo e a passagem do capitalismo ao socialismo. Vol. II. Konstantine Karódov. 1976.

7 O leninismo e a passagem do capitalismo ao socialismo. Vol. III. Konstantine Karódov. 1976.

8 Curso elementar de economia política. Vol. I. Lev. Leontiev. 1977.

9 Curso elementar de economia política. Vol. II. Lev. Leontiev. 1977.

10 Classe operária, partido e política de alianças. Dieter Klemm, Kurt Schneider, Gisela Pawula. 1977.

11 A via para o socialismo. Konstantine Zaródov. 1977.

12 O movimento comunista internacional: ensaio de estratégia e táctica. Vol. I. Sob a direcção de V. Zagládine.

13 O movimento comunista internacional: ensaio de estratégia e táctica. Vol. II. Sob a direcção de V. Zagládine.

14 Curso de materialismo dialéctico e histórico. Vol. I. Boguslavski, Karpuchine, Rakitov, Tchertikhine e Ezrine. Junho, 1978. Tiragem: 3.500 .

15 Curso de materialismo dialéctico e histórico. Vol. II. Boguslavski, Karpuchine, Rakitov, Tchertikhine e Ezrine. Junho, 1978. Tiragem: 3.500 .

17 Curso de economia política. Vol. I. Dir. Glenis Ann Kozlov. 1981.

18 Curso de economia política. Vol. II. Dir. Glenis Ann Kozlov. 1981.

\section{Coleção Leniniana}

1 A questão agrária. Lénine. Dezembro, 1975. Tiragem: 7.500.

2 Socialismo utópico e comunismo científico. Lénine.

3 Sobre os sindicatos. Lénine.

Para a Crítica da Ideologia Burguesa

10 anticomunismo, arma da reacção. Vladimir Mchvenieradze. 1975.

2 Socialismo: democracia e liberdade. G.
Chakhnazarov. Fevereiro, 1976. Tiragem: 5.500 .

3 O marxismo-leninismo e a luta contra o anticomunismo. P. Demitchev...[et al.]. 1977.

4 História e política: a historiografia americana sobre a sociedade soviética. B. I. Marúchkine. 1978.

6 A vanguarda revolucionária: a teoria leninista do Partido e os desvios de direita e de esquerda. M. I. Basmanov, B. M. Leibzon. 1979.

Caminhos da Revolução

1 Da resistência à revolução: 1963-1975. Miguel Urbano Rodrigues. Outubro, 1975. Tiragem: 5.500 .

2 Relatório do Comité Central: discursos de encerramento. $1^{o}$ Congresso do Partido Comunista de Cuba. Fidel Castro Ruz. Março, 1976. Tiragem: 10.000.

3 Caminho da vitória. Luís Corvalán.

4 Lenine e a Revolução de Outubro. Albert Rhys Williams. 1977.

5 Dez dias que abalaram o mundo. John Reed; nota introd. de V. I. Lénine; pref. de N. K. Krupskaia. 1977.

6 A revolução latino-americana: antologia de textos. Rodney Arismendi. 1977.

7 Da tempestade nasceram: relatos da revolução de Outubro. Anatoli Lunatcharski... [et al.]. 1979.

José Marti e a revolução cubana. Alexandre Cabral. 1976.

Problemas Politicos do Movimento Comunista e Operário Internacional

1 Comunistas e sociais-democratas. V. Vasin, S. Gribanov e I. Undasinov. Junho, 1975. Tiragem: 20.500.

2 Socialistas e comunistas: é possível a cooperação? Ernest Henri. Dezembro, 1975. Tiragem: 7.500 .

3 O ultra-esquerdismo, cavalo de Tróia do Imperalismo. 1976.

4 Relatório do Comité Central do PCUS. L. Brejnev.

5 O Partido Comunista Búlgaro e a edificação da sociedade socialista desenvolvida. Todor Jivkov. 1976.

6 A internacional comunista. Instituto de Marxismo-Leninismo anexo ao Comité Central do PCUS. Agosto, 1976. Tiragem: 7.500

9 Documentos do Partido Comunista 
Brasileiro: 1960-1975. 1976.

10 Na via de Ho Chi Minh: relatório político do C. C. ao IV Congresso, Dezembro de 1976. Le Duan. Maio, 1977. Tiragem: 5.000.

11 A revolução chilena: relatório ao Plenário de Agosto de 1977 do Comité Central do Partido Comunista do Chile. Luis Corvalán. 1978.

12 Os mil dias da revolução chilena: dirigentes do PCP sobre as lições dos acontecimentos do Chile. 1979.

\section{Coleção Dossier}

1 Dossier terrorismo. Junho, 1977. Tiragem: 3.500 .

2 Dossier eleições: em que sentido se desloca o eleitorado português? Setembro, 1977. Tiragem: 5.500.

3 "Dossier" anticomunismo. 1978.

4 "Dossier Carlucci-CIA". Recolha e redacção Ruben de Carvalho. 1978.

525 de Abril: resposta ITT. Coletivo. Setembro, 1978. Tiragem: 3.500.

6 "Dossier" Humberto Delgado: o crime premeditado. 1979.

7 Dossier Nato. Setembro, 1979. Tiragem: 3.500 .

8 "Dossier" comunicação social. João Paulo Guerra. 1981.

\section{Coleção Série Banda Desenhada}

1 Pela madrugada.

225 de Abril. Ernesto Neves. Abril, 1975. Tiragem: 50.000 .

Coleção Problemas da Paz e do Socialismo

1 A superioridade moral dos comunistas. Álvaro Cunhal. (2ºd.). Maio, 1975.

2 A força invencível do movimento comunista. Álvaro Cunhal. ( $2^{\circ}$ ed.). Maio, 1975. Tiragem: 20.500.

3 Internacionalismo proletário. Uma política e uma concepção do mundo. Álvaro Cunhal. ( $2^{\circ}$ ed.). Maio, 1975. Tiragem: 20.500.

4 Algumas experiências de 50 anos de luta do PCP. Álvaro Cunhal. 1975.

5 A consolidação da vitória, lei da revolução. $\mathrm{L}$ Angstrom. 1975.

6 Contribuição para a história da ideia de ditadura do proletariado. V. Venetsanopoulos, V. Guliev, S. Zawadski e J. Schmirgeld. 1975.

7 A força principal do processo revolucionário actual. Gyula Kallai. 1975.

8 A situação mundial e o processo revolucionário. Boris Ponomariov. Julho, 1975. Tiragem: 20.500.

9 Ensinamentos e perspectivas da revolução (Primeira carta do Chile). Vol. I. Rene Castillo. 1975.

10 Ensinamentos e perspectivas da revolução (Primeira carta do Chile). Vol. II. Rene Castillo. 1975.

11 O grande Outubro e a questão da frente única. Konstantin Zaradov. 1975.

12 O leninismo e a consolidação da vitória da revolução. Konstantin Zaradov. 1975.

13 Partido, revolução e edificação socialista. Lars Henderson. 1975.

14 As formas de luta pelo poder. A. Rodriguez. 1975.

15 Vitalidade e actualidade do MarxismoLeninismo. Konstantin Zarodov, Ib Norlund. 1975.

Documentos para a História do Partido Comunista Português

1 Relatório da actividade do Comité Central ao VI Congresso do Partido Comunista Português. Álvaro Cunhal. Fevereiro, 1975.

2 Documentos do Comité Central do Partido Comunista Português (1965). 1975.

3 O РCP e a luta sindical (1935-1973). Julho, 1975. Tiragem: 10.500.

4 A questão do Estado, questão central de cada revolução. Álvaro Cunhal. Fevereiro, 1977. Tiragem: 20.000.

6 As greves de 8 e 9 de maio de 1944. Setembro, 1979. Tiragem: 3.500 .

Documentos Políticos do Partido Comunista Português

1 Programa e Estatutos do PCP, aprovados no VI Congresso, em 1965.

20 radicalismo pequeno-bueguês de fachada socialista. Álvaro Cunhal. $4^{\text {a }}$ ed. revista, Julho, 1975. Tiragem: 5.000. (" $\mathrm{a}^{\mathrm{a}} \mathrm{e} 2^{\mathrm{a}}$ edições, 1971; 3ª edição, Agosto, 1974").

3 Discursos políticos I (Abril/Julho de 1974). Álvaro Cunhal. Outubro, 1974. ( $2^{\mathrm{a}}$ ed. Fevereiro, 1975)

4 A situação política e as tarefas do partido no momento actual. Álvaro Cunhal.

5 Programa e Estatutos do PCP, aprovados no VII Congresso (Extraordinário), 20/10/74. Outubro, 1974; $2^{\mathrm{a}}$ ed. Fevereiro, 1975.

6 Discursos políticos II (Agosto/Dezembro de 
1974). Álvaro Cunhal. Fevereiro, 1975.

7 Comunicados do Comité Central do PCP. Abril/Dezembro de 1974. Fevereiro, 1975.

8 Discursos políticos III (Dezembro, 1974/Marçao, 1975). Álvaro Cunhal. Maio, 1975. Tiragem: 10.500.

9 Discursos políticos (IV). Álvaro Cunhal.

10 Documentos do Comité Central do PCP. $2^{\circ}$ vol. (Janeiro/Junho de 1975). Fevereiro, 1976. Tiragem: 3.500.

11 A crise político-militar. Discursos políticos (V). Álvaro Cunhal. Março, 1976. Tiragem: 5.500 .

12 Documentos do Comité Central do PCP. $3^{\circ}$ vol. (Julho/Dezembro de 1975). Fevereiro, 1976. Tiragem: 3.500.

13 Pela democracia, pelo socialismo: textos da clandestinidade e discursos 1974/76. Octávio Floriano Rodrigues Pato. Junho, 1976. Tiragem: 5.200.

14 Do 25 de Novembro às eleições para a Assembleia da República. Discursos políticos (VI). Álvaro Cunhal. 1976.

15 Estatutos do PCP (aprovados no VIII Congresso realizado em Novembro de 1976).

16 As eleições para a Assembleia da República. Discursos políticos (VII). Álvaro Cunhal.

17 Uma política ao serviço do povo. Discursos políticos (VIII). Álvaro Cunhal.

18 Entre duas eleições. Discursos políticos (IX). Álvaro Cunhal.

19 Em defesa das conquistas da revolução. Discursos políticos $(X)$. Álvaro Cunhal. 1978.

20 Programa e Estatutos do Partido Comunista Português, aprovados no VII Congresso (Extraordinário) e no VIII Congresso do PCP. Novembro, 1979.

22-23 Crises e queda dos governos PS. Álvaro Cunhal. 1980.

Desporto, direito do povo: Encontro Nacional das Organizações do P. C. P. sobre Cultura Física e Desporto. 1979.

Documentos Políticos do Partido Comunista Português/Série Especial

1 VII Congresso do PCP.

2 VII Congresso do PCP (edição especial).

$32^{\circ}$ Encontro Nacional da União da Juventude Comunista (7 Março 1976). Abril, 1976. Tiragem: 5.500 .

4 Conferência Nacional do PCP: as eleições para a Assembleia Legislativa. Abril, 1976. Tiragem: 3.500 .
5 Alargar a unidade para reforçar o movimento estudantil (Intervenções e documentos do Encontro de Delegados da UEC, 6 de Junho de 1976). Julho, 1976. Tiragem: 3.500.

6 A revolução portuguesa. O passado e o futuro. Relatório aprovado pelo CC do PCP para o VIII Congresso. Álvaro Cunhal. Novembro, 1976. Tiragem: 30.000

7 VIII Congresso do PCP.

$81^{\circ}$ Congresso da UJC.

9 A juventude pelo direito ao trabalho.

10 A escola e a vida no caminho de Abril. UEC $1^{\circ}$ Congresso, 21/22-Janeiro. Maio, 1978. Tiragem: 2.500 .

17 Uma política de saúde para o Portugal de Abril. Encontro Nacional de Saúde do PCP. 1980.

20 Programa e estatutos do partido comunista português. 1979.

Intervenções e documentos. VII Congresso Extraordinário do Partido Comunista Português. 1974.

Cadernos de Iniciação ao Marxismo Leninismo

$1 O$ socialismo e o comunismo científicos (Gênese e princípios). Leonid Minaev.

2 As vias de passagem ao socialismo $(O$ socialismo e a ditadura do proletariado). A. Butenko. Março, 1975. Tiragem: 25.400.

3 O que é o comunismo? Perguntas e respostas. Março, 1975. Tiragem: 50.400.

4 A democracia popular, uma nova forma de Estado socialista. Nédiu Nédev.

5 Introdução ao marxismo. Emile Burns. 1975.

6 Lénine e os camponeses. P. Luniakov, A. Gontcharov. 1975.

7 Rudimentos de materialismo. Vassili Podossetnik, Alexandr Spirkine. Julho, 1975. Tiragem: 20.500.

8 Os primeiros passos do poder soviético. Vitali Diatchenko. 1975.

9 Os sindicatos soviéticos. Vassili Prokhorov. 1975.

10 Karl Marx: pequena biografia. Euguénia Stepanova. 1976.

11 Lenine: sobre o Estado e a Democracia. Alexandre Spirkine. 1976.

12 As cooperativas de produção na edificação do socialismo na URSS. Grigori Kuznetsov. 1976.

13 A politica económica dos sovietes nos primeiros anos da revolução. Ilia Berkhine. 1976.

14 V. J. Lénine: pequena biografia. G. 
Obitchkine... [et al.]; pref. Rodney Arismendi. 1976.

15 Gueargui Dimitrov: páginas de uma vida heróica. 1976.

$16 O$ aprofundamento da crise geral do capitalismo. Albert Norden. 1976.

17 A questão fundamental da filosofia. Alfred Kosing. 1977.

$18 O$ triunfo do socialismo na U.R.S.S. Ilia Berkhine. 1977.

19 Friedrich Engels: pequena biografia. Evgénija Stepánova. 1977.

20 O controlo popular na sociedade socialista. Victor Turovtsev. 1978.

21 A formação das democracias populares da Europa. Emil Borsi. 1981.

22 A formação da URSS: expressão da política nacional leninista. A. V. Likholat. Novembro, 1982. Tiragem: 5.000.

\section{Coleção Resistência}

1 Até amanhã, camaradas. Manuel Tiago.

2 Cartas da prisão (1 Vida prisonal). José Magro. Maio, 1975. Tiragem: 10.000.

3 A defesa acusa: os comunistas portugueses perante a polícia e os tribunais fascistas. Abril, 1975. Tiragem: 15:500.

4 Tarrafal, campo da morte lenta. Pedro Soares. $2^{\mathrm{a}}$ ed. Setembro, 1975. Tiragem: 10.500.

5 Testamento sob a forca. Julius Fucik.

6 Cinco dias, cinco noites. Manuel Tiago. Novembro, 1975. Tiragem: 20.500.

7 Recordações dos tempos difíceis. Miguel Wager Russell. Agosto, 1976. Tiragem: 5.500 .

8 Os mesu sete filhos. Renato Nicolai/ Alcide Cervi. Abril, 1977. Tiragem: 5.000.

9 Os dias da nossa vida. Mariana Sereni. Março, 1978. Tiragem: 3.000.

10 Um dia e uma noite. Jean Sanitas.

11 Torre cinzenta (Poemas da prisão). José Magro.

12 Sem tréguas. Giovanni Pesce.

13 Escrito na cela: testemunho e narrativa. Fernando Miguel Bernardes. Outubro, 1982. Tiragem: 4.000 .

\section{Biblioteca do Marxismo-Leninismo}

1 Trabalho assalariado e capital. K. Marx. Janeiro, 1975.

2 A doença infantil do comunismo: o "radicalismo de esquerda". V. I. Lénine.

3 O imperialismo, fase superior do capitalismo.

\section{I. Lénine.}

4 Do socialismo utópico ao socialismo cinetífico. F. Engels.

5 Manifesto do Partido Comunista. K. Marx e F. Engels. Julho, 1975. Tiragem: 50.000.

6 O socialismo científico. K. Marx, F. Engels, V. I. Lénine.

7 Duas tácticas da social-democracia na revolução democrática. V. I. Lénine.

8 Que fazer? V. I. Lénine. 1978.

9 Um passo em frente, dois passos atrás. V. I. Lénine.

10 Teses de abril. V. I. Lénine.

11 Princípios básicos do comunismo. Friedrich Engels. Março, 1978. Tiragem: 6.000.

12 O Estado e a revolução. V. I. Lénine. 1978.

13 Sobre o direito das nações à autodeterminação. V. I. Lénine. Abril, 1978. Tiragem: 3.500 .

14 A catástrofe que nos ameaça e como combatê-la. V. I. Lénine. 1978.

15 A revolução proletária e o renegado Kautsky. V. I. Lénine. 1979.

17 Revolução e contra-revolução na Alemanha. Friedrich Engels; trad. José Barata-Moura. 1981.

18 As lutas de classes em França. Karl Marx. 1982.

19 O 18 de brumário de Louis Bonaparte. Karl Marx. 1982.

\section{Cadernos do PCP}

1 A derrota da conspiração reaccionária (Setembro de 1974).

2 Por que lutam os comunistas.

3 Un même combat - Um mesmo combate PCF-PCP.

4 Com a UEC nas escolas a reacção não passará. Janeiro, 1975.

5 Comunistas e católicos.

6 A palavra do PCP.

7 O PCP e a luta pela reforma agrária. Junho, 1975. Tiragem: 10.400 .

8 O PCB e a juventude.

9 Com o PCP para a Unidade Popular rumo ao socialismo.

10 Por uma Constituição revolucionária.

11 Sindicatos e acção sindical. Albano Lima. Novembro, 1976. Tiragem: 5.000.

$\underline{\text { Rumo ao Socialismo }}$

1 Movimento sindical e unidade no processo 
revolucionário português. Albano Lima. Julho, 1975. Tiragem: 20.500.

2 A banca ao serviço do povo (Conclusões do Encontro dos Trabalhadores Bancários promovido pelo Partido Comunista Português). Agosto, 1975. Tiragem: 10.500.

\section{Reforma Agrária}

1 Contribuição para o estudo da questão agrária. Vol. I. Álvaro Cunhal. Setembro, 1976. iragem: 10.500.

2 Contribuição para o estudo da questão agrária. Vol. II. Álvaro Cunhal. Setembro, 1976. iragem: 10.500 .

3 A agricultura nos países socialistas da Europa. Jean Flavien e André Lajoinie. Maio, 1977. Tiragem: 5.500.

\section{O PCP na Assembleia da República}

Em defesa da reforma agrária: 4 dias de debate na Assembleia da República, 18/21 de julho de 1977. Setembro, 1977. Tiragem: 10.000.

\section{Portugal e o Mercado Comum}

Não ao Mercado Comum: intervenção de Álvaro Cunhal. Conclusões Gerais. Julho, 1980. Tiragem: 3.000 .

\section{Pequena Biblioteca Lenine}

1 Partido proletário de novo tipo (A importância mundial do bolchevismo). V. I. Lénine. Fevereiro, 1975.

2 Karl Marx e o desenvolvimento histórico do marxismo. V. I. Lénine.

3 Democracia socialista. V. I. Lénine.

4 A Comuna de Paris. V. I. Lénine. Agosto, 1975. Tiragem: 10.500

5 Sobre a origem dos sovietes.

Obras de Soeiro Pereira Gomes

1 Refúgio perdido e outros contos. Fevereiro, 1975.

2 Engrenagem.

3 Esteiros.

\section{Bandeira Vermelha - PCTP/MRPP (Lisboa)}

A revolução tem de avançar a todo o vapor. Arnaldo de Matos. 1975.

Apelo à esquerda. Arnaldo Matos. 1975. ("Edição do Aparelho Técnico Central da FEM-L.”)
A situação política actual e as nossas tarefas: informe à conferência de Jales. Arnaldo Matos. 1975.

O camarada Mao. Arnaldo Matos. Setembro, 1976.

As nossas tarefas. Documentos do I Plenum do I Comité Central do PCTP/MRPP. Janeiro, 1977.

20 questões na edificação do partido. Texto do camarada Arnaldo Matos sobre a organização Regional do Norte.

Estatutos do PCTP/MRPP, precedido do Programa geral do Partido.

Manifesto sindical.

\section{Bandeira Vermelha - PCP(R)/PC(R) (Lisboa)}

$\underline{\text { Sem Coleção }}$

Kruchov de joelhos diante de Tito (13 de Setembro de 1963). Enver Hoxha.

Os partidos revisionistas, partidos tipicamente burgueses. Fiqret Shehu.

Actualidade das ideias de Lénine. J. Amazonas e M. Grabois.

Declaração conjunta de cinco partidos marxistas-leninistas da Europa.

A crise do revisionismo moderno italiano. Enver Hoxha.

Carta do partido e do governo da Albânia ao partido e ao governo da China.

A política belicista chinesa e a visita de Hua Kuo-Feng aos Balcãs. Enver Hoxha.

Albânia socialista no mundo actual. Relatório ao $9^{\circ}$ congresso do PTA.

Resoluções da $6^{a}$ reunião pleneária (ampliada) do Comité Central do Partido Comunista Portugues (Reconstruído). s/d.

I Congresso do Partido Comunista Português (Reconstruído). (Dezembro 1975). 1976.

Resoluções: reunião plenária ampliada do Comité Central. Partido Comunista (Reconstruído). 1976.

Relatório sobre a actividade do Comité Central do Partido do Trabalho da Albânia: apresentado ao VII Congresso do PTA a 1 de Novembro de 1976. Enver Hoxha. 1976.

Cinquenta e cinco anos de luta dos comunistas portugueses. 1976.

Relatório sobre as directivas do VII Congresso do Partido relativas ao $6^{\circ}$ plano quinquenal (1976-1980) de desenvolvimento económico e cultural da República Popular da Albânia: apresentado ao VII Congresso do P.T.A. a 4 de Novembro de 1976. Mehmet Shehu. 
1977.

A imprensa comunista (princípios e experência). 1977.

A luta contra o fascismo. Relatório e discursos ao VII Congresso da Internacional Comunista. Dimitrov. Outubro, 1977. Tiragem: 2.500 .

No caminho do 25 de Abril do povo, da democracia popular e do socialismo (Resolução Política) e Estatutos do Partido Comunista Português (Reconstruído). Aprovados no II Congresso. Março, 1977.

Resolução política e Estatutos do Partido Comunista Português (Reconstruído). Aprovados no II Congresso. Março, 1977.

Resoluções do Comitê Central do Partido Comunista Português (Reconstruído) do I ao II Congresso. Abril, 1977.

Conquistemos o 25 de Abril do povo. Documento político da $10^{\mathrm{a}}$ Reunião Plenária do Comité Central aprovado no II Congresso do PCP(R) - Lisboa, Março de 1977.

Um ano de edificação do partido. Documento da $10^{a}$ Reunião Plenária do Comité Central sobre a edificação do partido aprovado pelo II Congresso do PCP(R). Março, 1977.

A vida de José Staline. Instituto Marx-EngelsLenine. 1978.

Levar à vitória a linha táctica do II Congresso, derrotar o oportunismo de diretita $e$ a capitulação. Resoçução da $8^{\mathrm{a}}$ reunião plenária do Comité Central do PCP(R), julho de 1978. 1979.

Com Stáline: recordações. Enver Hoxha. 1980. ("Por ocasião do centenário do nascimento do grande maxvista-leninista José Stáline.”)

Relatório de actividade do Comité Central do Partido do Trabalho da Albânia: apresentado ao 80 Congresso do PTA em 1 de Novembro 1981. Enver Hoxha. 1983.

$O$ proletariado e a revolução em Portugal. Informes e resoluções do $4^{\circ}$ Congresso do PC(R). Março, 1983.

Sobre certas questões fundamentais da política revolucionária do PTA para o desenvolvimento da luta de classes. Nexhmije Hoxha.

A revolução, problema candente que exige solução. Ramiz Alia.

Os partidos comunistas, dirigentes do movimento revolucionário. Agim Popa.

O agravamento da crise geral do capitalismo. Hekuran Mara.

Temas actuais. $25^{\circ}$ aniversário da morte de José Staline. J. Stáline.
A grande revolução socialista de outubro (revista ilustrada).

O $1^{o}$ aniversário da reconstrução do partido (revista ilustrada).

Comício de encerramento do $2^{o}$ congresso (revista ilustrada).

Aprender com Diógenes Arruda.

Luta de princípios desenvolvida pelo PTA contra os revisionistas soviéticos. Enver Hoxha (1961).

Por um movimento sindical revolucionário.

Análise Crítica

A guerra nacional revolucionária do povo espanhol contra o fascismo, 1936-1939. Setembro, 1976.

Cadernos Comunistas

1 O partido. Lenine, Staline. 1976.

\section{Coleção Obras}

19 A luta do Partido do Trabalho da Albânia contra o revisionismo kruchoviano. Enver Hoxha. 1976.

\section{Política Revolucionária}

A resistência armada do Araguaia. Partido Comunista do Brasil. 1978. Tiragem: 3.500.

Biblioteca do Marxismo-Leninismo

Obras escolhidas. Enver Hoxha. Tomo 2, Vol. 1. 1978. Tiragem: 3.000 .

O imperialismo e a revolução. Enver Hoxha. 1979.

Em Defesa dos Princípios

A teoria dos "três mundos" opõe-se frontalmente ao marxismo-leninismo.

Luta nos Campos e Reforma Agrária

Sobre a reforma agrária. Teses da I.C., Mao Tsetung, Kim Il Sung. Novembro, 1976.

Elementos para a História do Partido e do Movimento Operário em Portugal

1 Bento Gonçalves dirigente proletário. s/d.

Coleção $3^{\circ}$ Congresso do Partido Comunista Português (Reconstruído)

Crítica do $3^{\circ}$ Congresso ao Comité Central e autocrítica do Comité Central. Junho, 1979. 
$O$ aprofundameno da luta contra o revisionismo, necessidade do momento presente. Junho, 1979.

O $P C P(R)$ na luta para derrotar a ofensiva reaccionária e alcançar uma viragem na situação nacional. Junho, 1979.

\section{Base (Lisboa)}

Sem Coleção

Libertar o povo (Diálogo com António Fragoso, Bispo). Coord. Maria da Conceição Moita. Agosto, 1973.

Chile: socialismo impossível. Coord. e edição Fernando Abreu. 1973. (2 $2^{\mathrm{a}}$ ed., 1974).

E o sol é só um. Coord. Maria Elisa Salreta. 1973.

Acção sindical. Ugo Piazzi. 1974.

Autogestão (Juguslávia-Checoslováquia). Coord. Fernando Abreu. 1974.

Zapa: histórias para acordar. Adapt. de José Pires. 1974.

Alfabetização: caminho para a liberdade. Introdução de Manuel Canaveira. 1975.

Autarquias locais (O que são?). 1976.

Por um novo sindicalismo. Princípios $e$ perspectivas sindicais da BASE-Frente Unitária de Trabalhadores. s/d. (1976)

Manual de alfabetização (Para quem quer aprender com o povo). Centro de Cultura Operária (CCO). Janeiro, 1977.

Subsídios para a história do movimento sindicalista em Portugal (1908 a 1919). Alexandre Vieira. Julho, 1977.

Os cristãos e a libertação dos oprimidos. Paulo Freire. 1978.

Autogestão e sindicalismo. Confederação Francesa Democrática do Trabalho. 1978.

Zapa: histórias para acordar (A escola na luta de classes). Virgínia Pereira; adapt. e desenhos Mário Poças. 1978.

Diálogos com Roger Garaudy: o projecto do futuro. Trad. Maria Fernanda Branco. 1979.

O Brasil dos trabalhadores. Oposição Sindical do Brasil. Trad. Maria José Maya. 1980.

Trilateral: a "nova" face do capitalismo. Fernando Abreu, José Fernandes Dias e Assembleia Permanente dos Direitos Humanos da Bolívia. Trad. Brandão Guedes e Fernando Abreu. 1981.

O rei Lambãol As pulgas e a preguiça: teatro para crianças e jovens. José Vaz. 1983.

Movimento pela autogestão na Polónia. Cláudio Araújo Nascimento. 1983.
O povo em Acção

Greves e o 25 de Abril. José Pires. 1976.

Não ao ensino burguês. Centro de Cultura Operária (CCO). Maio, 1975.

\section{Controlo Operário}

Carta da Organização Socialista das Empresas na Argélia. Fevereiro, 1977.

\section{$\underline{\text { Movimento Operário }}$}

Empregadas domésticas, mulheres em luta: para a história do serviço doméstico em Portugal - das origens ao fascismo. Olegário Paz. c. 1980. Tiragem: 2.000.

Imperialismo e Colonialismo

2 Vietnam. François Houtart. Janeiro, 1976.

$\underline{\text { Textos Sindicais }}$

Sindicalismo e política. 1979.

Unidade sindical: a força dos trabalhadores. Outubro, 1976.

\section{Sociedade Nova}

Acção sindical frente às multinacionais. Confederação Mundial do Trabalho. 1978.

Pelo socialismo autogestionário. Base-FUT. 1979.

Autonomia Sindical: revista de informação e documentação. $N^{o}$ 3, Março/Maio 1981; n 4, Novembro 1981/Janeiro 1982.

Bertrand (Lisboa)

Morrer em Madrid. Frédéric Rossif e Madeleine Chapsal. Junho, 1975.

A burla do 28 de setembro. António Maria Pereira. Abril, 1976.

O pensamento de Che Guevara. Michael Lowy. Abril, 1976.

O racismo. François de Fontette.

Os insubmissos. Urbano Tavares Rodrigues. $6^{\mathrm{a}}$ ed. 1976.

Ao serviço de Portugal. António de Spínola. Coedição Ática. 1976.

Bar Don Juan. Antônio Callado. 1976.

Zero. Ignácio de Loyloa Brandão. 1976.

Alvorada em Abril. Otelo Saraiva de Carvalho. Novembro, 1977. 
Coleção Ciências Sociais e Humanas - Política

O socialismo, a transição e o caso português. João Martins Pereira. Dezembro, 1976.

Tratado de economia marxista. Vol. 1. Ernest Mandel. Janeiro, 1978.

Realidade e Denúncia

Vigiados e perseguidos (Documentos secretos da PIDE/DGS). Nuno Vasco. Abril, 1977.

Autores Portugueses

Imitação da felicidade. Urbano Tavares Rodrigues. $2^{\mathrm{a}}$ ed.

\section{Portugal 1900}

O 28 de maio e o fim do liberalismo. Vol. I. José António Saraiva e Júlio Henriques.

A ditadura militar e o advento do salazarismo. José António Saraiva e Júlio Henriques.

Portugal e a escalada do fascismo na Europa. José António Saraiva e Júlio Henriques.

O lento envelhecimento do Estado Novo. José António Saraiva e Júlio Henriques.

Salazar, Caetano e o futuro do Estado Corporativo. José António Saraiva e Júlio Henriques.

Da falência do marcelismo ao regresso de Salazar. José António Saraiva e Júlio Henriques.

O fim de um tempo. José António Saraiva e Júlio Henriques.

Surgindo vem ao longe a nova aurora: para a história do diário sindicalista A Batalha (1919-1927). Jacinto Baptista. 1977.

Salazar e os fascistas: salazarismo e nacionalsindicalismo: a história dum conflito 19321935. João Medina. Janeiro, 1979.

A desgraça da República na ponta das baionetas: as forças armadas do 28 de maio. José Freire Antunes. Julho, 1978.

Documentos de Todos os Tempos

A revolução imediata: da segunda revolução americana à segunda revolução mundial. Jean-François Revel. 1970.

Caminhos para uma revolução. Jacinto Baptista. Abril, 1975.

Morrer em Portugal. Mário Ventura. 1975.

A tentação totalitária. Jean-François Revel. 1976.

Liberdade para Portugal. Com a colaboração de Mário Soares, Willy Brandt e Bruno
Kreisky. Outubro, 1976.

Vida e morte do Chile popular. Diário sociológico/Julho-Setembro de 1973). Alain Tourraine. Abril, 1977.

Terras velhas semeadas de novo. Uma realidade portuguesa: os trabalhadores nas cooperativas. Antunes da Silva. Junho, 1976.

A descoberta de uma conspiração: a acçãoSpínola. Günter Wallraff, Hella Schlumberger. Novembro, 1976.

Trotsky. Gérardo Rosenthal.

Escritos do exílio. Mário Soares. 1975.

Em prol da verdade. Como e porquê de um crime político: a morte de Delgado. Valério Ochetto. 1978.

Portugal Europa face ao mercado comum. J. Cândido de Azevedo. Maio, 1978.

Abril nos quartéis de Novembro. Avelino Rodrigues, Cesário Borga e Mário Cardoso. Maio, 1979.

Informação Política

1 As atitudes políticas. Alain Lancelot.

2 O marxismo. Henri Lefebvre. Trad. J. Guinsburg. Outubro, 1974.

3 O capitalismo. François Perroux.

4 O socialismo reformista. Georges Lefranc.

5 As Internacionais Operárias. Annie Kriegel. Dezembro, 1974.

6 Sociologia das revoluções. André Decouflé.

8 Do Estado Novo à Segunda República (Crónica política de um tempo português). José António Saraiva. 1974.

Portugal - Cristianismo e revolução socialista. César Oliveira e Fernando Belo. 1975.

o 25 de Abril visto da História. José António Saraiva e Vicente Jorge Silva. Novembro, 1976.

Coleção Universidade

A opção. Pierre Mendès France. 1976.

\section{Braga (Braga-Lisboa)}

Angola, juventude em fuga. Paula Maria. Prefácio de Vera Lagoa. Maio, 1977.

Timor - quem é o culpado? António Manuel Cravo Cascais. 1977.

Espanha: caminhos da democracia. Manuel Fraga Iribarne. Nota Introdutória de Mário Dias Ramos. Junho, 1977. 
Comunismo e maçonaria: forças secretas da guerra. Prefácio de Mário Dias Ramos. Tomé Vieira. 1977.

Angola, comandos especiais contra os cubanos. Pedro Silva, Francisco Esteves e Valdemar Moreira. Colaboração do ten.-cor. Comando Gilberto Santos e Castro. 1978.

Os capitães de aventura: com uma carta à opinião pública de Manuel de Portugal. Nuno Sampayo. 1978.

Tempo de vésperas. Adriano Moreira. 1978.

Técnica soviética para a conquista do poder total: a experiência comunista no Chile. 1978.

As ditaduras no continente americano: Depoimentos. Pref. de Henrique Barrilaro Ruas; org. de José Luís Cuevas, Vlady e Morales Guerra Y Ortega. 1978.

História da polícia em Portugal: polícia e sociedade. Mascarenhas Barreto. 1979.

Um certo gosto a tamarindo: estórias de Angola. Fernando Amaro Monteiro. 1979.

\section{Brasília (Porto)}

Tarrafal, aldeia da morte: o diário da B5. Manuel Francisco Rodrigues. Julho, 1974.

Socialismo em liberdade. Manuel Francisco Rodrigues. Abril, 1975.

Posições Frontais: entrevistas políticas. Manuel Dias. Abril, 1975.

Obras Completas de Josué de Castro

Geopolítica da fome. $2^{\mathrm{a}}$ edição revista e muito aumentada. Setembro, 1974.

O livro negro da fome.

$O$ ciclo do caranguejo (romance).

Geografia da fome. $2^{\mathrm{a}}$ ed. Outubro, 1975.

Ensaios de geografia humana.

Ensaios de biologia social.

\section{Estudos Sociais e Filosóficos}

1 Crimes de guerra no Vietname. Bertrand Russell. s/d.

2 Porque não sou cristão. Bertrand Russell. 1970.

3 O abuso da força. Theodore Draper.

$4 O$ problema chinês. Roger Garaudy. (Em apêndice: Textos essenciais de Mao Tsétung).

5 Cristãos e marxistas: diálogo com Garaudy. G. Cottier, o.p. 1968.
6 Quatro ismos em foco: comunismo, fascismo, capitalismo, socialismo. William Ebenstein. Maio, 1974.

9 Socialismo e cibernética. Ilia B. Novik; pref. Armando Castro. 1970.

10 As revisões da constituição política de 1933. Francisco Sá Carneiro. 1971.

12 Os manuscritos económicos-filosóficos. Karl Marx; trad. e notas por César de Oliveira. 1971.

\section{Dossier Leitura}

1 A crise francesa de maio: propostas para uma acção. Pierre Mendès France. s/d.

2 Introdução ao pensamento de Herbert Marcuse: com uma entrevista feita por l'Express e uma antologia das obras de Marcuse. Milton Miranda. 1969.

9-10 Horizontes fechados: páginas de política. Raul Rego. 1970.

12 Os direitos do escritor. Alexandre Soljenitsin.

16 A comuna de Paris e os socialistas portugueses. Introdução, selecção de textos e notas por César de Oliveira.

Vietname: da resistência à vitória. Nguyen Giap.

O fenômeno universal da fome. Alan Toblem.

Acuso... Jean-Paul Sartre.

Os católicos holandeses e a evolução da igreja. Bispo de Bréda e outros. (Fora de mercado)

Oração fúnebre para Ernesto Che Guevara. Fidel Castro. (Fora de mercado)

\section{Cadernos Para o Diálogo (Porto)}

1 Trabalho assalariado e capital. Karl Marx. 1971.

2 Discurso sobre o colonialismo. Aime Césaire. 1971.

3 A questão do alojamento. Friedrich Engels. 1971.

4 Espiral de violência. D. Helder Câmara. 1971. Trad. M. Ferreira.

5 O império Rockefeller. Trad. António Guerreiro. 1971.

6 Comuna de Paris 1871. Prosper Ollivier Lissagaray; trad. João Mendonça. 1971.

\section{Cadernos Textuais (Porto)}

O Estado e a revolução. Lenine. 1969. 
Leis fundamentais da economia socialista. Jean Baby. 1970.

Origens e evolução das divergências. Mao Tsétung. 1970.

Entre o imperialismo e a revolução. Leon Trotsky. 1973.

Paz para os povos: por uma paz justa $e$ democrática pela segurança dos povos $e$ pela cooperação Internacional / $O$ assassinato de Amílcar Cabral. 1973. Contém: o texto "Paz para os Povos", discurso de Leonid Brejnev pronunciado no Congresso Mundial das Forças da Paz, Moscovo, 26 Out. 1973

Teoria do Estado de todo o povo: URSS. J.-G. Collignon. s/d.

Série A Memória Subversiva (coord. Júlio $\underline{\text { Henriques) }}$

Propriedade e capital: o marxismo dos gagos. Amadeo Bordiga. 1974.

Capitalismo e comunismo. Leninismo e ultraesquerda. Jean Barrot.

Sindicatos e revolução social. B. Péret, G. Muñis.

\section{Caminho (Lisboa)}

$\underline{\text { Sem coleção }}$

Capitão de médio curso. Baptista-Bastos.

Cadernos poder local. 1979.

Eleições para as autarquias locais: legislação actualizada e anotada. 1979.

Tarrafal: testemunhos. Coord. Franco de Sousa. Fevereiro, 1978. Tiragem: 4.000.

A reforma agrária acusa. Comissão Promotora do Tribunal Cívico sobre a Reforma Agrária. Fevereiro, 1980. Tiragem: 3.000.

A revolução portuguesa e a educação. António Teodoro. 1978.

Os dias cantados. José Jorge Letria; pref. José Carlos Ary dos Santos. 1978.

O Chile de Allende: visto por dentro. Edward Boorstein. 1978.

Lisboa: cidade, Abril. A. Silva Graça... [et al.]; colab. Arminda Silva... [et al.]. 1979.

Fraudes e irregularidades nas eleições 79. Luís Sá, Ana Filipe. 1980.

Watergate Sá Carneiro: história de uma fraude. O Diário. Setembro, 1980. Tiragem: 30.000.

Coleção Temas Políticos e Sociais

Revolução e vida. Miguel Urbano Rodrigues.
Fevereiro, 1977. Tiragem: 3.500.

A política e as palavras. Álvaro Mateus. Julho, 1977. Tiragem: 5.500.

A reforma agrária em perigo. Eugénio Rosa. Agosto, 1977. Tiragem: 5.500.

Portugueses na URSS. Entrevistas de Gina de Freitas. 1977.

Ideologia e prática. José Barata Moura.

O assassínio do general Humberto Delgado: a armadilha política. Pedro Ramos de Almeida. Fevereiro, 1978. Tiragem: 3.500.

Inflação e crise monetária: publicado sob a égide do Comité Económico e Social da Federação Sindical Mundial (FSM). Philippe Zarifian. 1978.

Que futuro para os Açores? A. Borges Coutinho, A. Soares de Melo, Carlos Enes, José Bettencourt, Victor Ávila. 1978.

Sessenta anos de luta pela paz. António Avelãs Nunes. 1978.

História Económica de Portugal - I. Armando Castro.

O sistema colonial português em África: meados do século XX. Armando Castro. 1978.

Vietname, pátria reencontrada. Nguyen Khac Vien. 1978.

O julgamento da rede bombista. Josué da Silva. Agosto, 1978. Tiragem: 3.500.

\section{Coleção Nosso Mundo}

1 África do Sul: um só caminho. Joe Slovo. Janeiro, 1979. Tiragem: 3.000.

2 A política da luta armada: libertação nacional nas colónias africanas de Portugal. Basil Davidson. Janeiro, 1979. Tiragem: 3.000 .

3 Progresso: história breve de uma ideia. Vasco de Magalhães Vilhena. 1979.

4 Catapulta para a liberdade: como sobrevivem os vietnamitas. Wilfred Burchett. 1979.

5 Os segredos da censura. César Príncipe. $3^{\mathrm{a}}$ ed. Maio, 1994 ( $1^{\mathrm{a}}$ ed. 1979). Tiragem: 2.000.

URSS reportagem a seis vozes. Mário Castrim... [et al.]. 1980.

7 Política monetária da teoria á realidade. José Martins Barata. 1979.

8 A questão do Vietname. Pedro Ramos de Almeida. 1979.

10 RDA, ida e volta. Pedro Alvim, Alice Nicolau. 1979.

12 Estados Unidos da América, que direitos humanos? Luís Eugénio Ferreira. 1980. 
13 Constituição e revisão constitucional. Vital Moreira. 1980.

15 A revolução sul-africana: documentos fundamentais do Congresso Nacional Africano (A.N.C.). 1980.

\section{Coleção Letras}

Soeiro Pereira Gomes e o futuro do realismo em Portugal. Álvaro Pina.

A ascensão dos generais. Rodolfo Konder.

Matai-vos uns aos outros. Jorge Reis.

Prática da escrita em tempo de revolução. Casimiro de Brito.

Tu, liberdade! Antologia de ficções em prosa. José Gomes Ferreira; org. e pref. Casimiro de Brito. 1977.

\section{Coleção Banda Desenhada}

A direita de cara à banda (desenhada). José Paulo Simões.

\section{O Campo da Palavra}

1 Círculo aberto. António Ramos Rosa. 1979.

2 A noite. José Saramago. 1979.

3 Nós e os outros. Faure da Rosa. 1979.

4 Canto civil. Orlando da Costa. 1979.

6 O poeta perguntador. Armindo Rodrigues; antologia organizada e apresentada por José Saramago. 1979.

7 A caça às rolas: novela. Filipe Leandro Martins. 1979.

8 Abecê da negação. Urbano Tavares Rodrigues. 1980.

9 Levantado do chão: romance. José Saramago. 1980.

10 Lisboa e outros sapatos. José Carlos González. 1980.

11 A malta da Rua dos Plátanos. Garcia Barreto. 1980.

\section{Uma Terra sem Amos}

1 Os pedaços de madeira de Deus. Sembéne Ousmane. 1979.

2 A última mulher e o próximo combate. Manuel Cofiño. 1979.

3 Primavera em Budapeste. Ferenc Karinthy. 1979.

4 O velho preto e a medalha. Ferdinand Oyono; trad. José Saramago. 1979.

5 Assim foi temperado a aço. Nikolai Ostrovski. 1979.

6 Governadores do orvalho. Jacques Roumain; trad. José Saramago. 1979.

7 A luz que rompe das trevas. Alex la Guma. 1979.

8 Os plátanos de Barcelona. Victor Mora; trad. Manuel de Seabra. 1979.

9 A jovem guarda. Alexandre Fadéiev. 1980.

10 Nosso sangue. Jesús Lara. 1980.

11 Insurreição. Liam O'Flaherty. 1980.

12 Não chores, menino. Ngugi Wa Thiong'o. 1979.

13 Sob o jugo. Ivan Vazov. 1980.

\section{Centelha (Coimbra)}

Coleção Textos - Nosso Tempo

1 Greve de massas e sindicatos. Rosa Luxemburgo. 1970.

2 A questão dos sindicatos. Lenine. 1971.

3 A guerra civil em França. Marx. 1971.

$4 O$ imperialismo, estádio supremo do capitalismo. Lenine. Tradução de Soveral Martins. Maio, 1971.

5 Sobre literatura e arte (1908-1942). Tradução de Rui Santos. Edição do Tradudor. Mao Tse-Tung e Lenine. 1971. (Não saiu com selo da Centelha, apenas como Textos Nosso Tempo)

6 A revolução proletária e o renegado Kautsky. Lenine. Junho, 1971. Julho 1974.

7 Crítica do Programa de Gotha. Marx. 1971.

8 A luta de classes em França - 1848-1850. Karl Marx. Julho, 1971. ( $2^{\text {a }}$ ed. 1975)

9 K. Marx, F. Engels, as três fontes. Lenine.

10 O 18 Brumário de L. Bonaparte. Marx. Novembro, 1971.

11 A Internacional, a Comuna, questões de problemática marxista. Marx, Engels.

12 Um passo em frente, dois passos atrás. Lenine.

13 O Anti-Kautsky (Terrorismo e comunismo). Trotsky. 1972.

14 A catástrofe iminente e os meios de a conjurar. Lenine. 1972. Maio, 1974.

15 Como iludir o povo. Lenine. $3^{\mathrm{a}}$ ed. Fevereiro, 1974.

16 As lições de outubro. Trotsky. 1975.

17 Manifesto do Partido Comunista. Trad. Soveral Martins. Marx e Engels. Maio, 1974.

$18 O$ esquerdismo, doença infantil do comunismo. Lenine.

19 A questão camponesa em França e na 
Alemanha. Friedrich Engels. Julho, 1974.

20 ABC do comunismo. Vol. 1. Boukharine e Préobrajenski. 1974.

22 Análise das classes na sociedade chinesa. Mao Tsé-tung.

23 As tarefas das Uniões da Juventude. Lenine.

24 Cartas de longe. Lenine.

25 Do Estado. Lenine. 1975.

26 Em defesa do marxismo. Lenine.

27 Relatório da delegação siberiana. L. Trotsky. Março, 1976.

28 A nossa revolução. Lenine. Abril, 1976.

Coleção Estudos - Nosso Tempo (ou Actualidade Nacional/Estudos)

1 Movimento Estudantil e política educacional. Rui Namorado. 1972.

2 Educação e política. Rui Namorado. Março, 1973. Texto no final do livro informa que a Centelha é agora editora, e não só distribuidora, como até então.

3 Capitalismo e concorrência. J. Teixeira Martins. Dezembro, 1973.

4 Sobre o Ultramar: fascismo e guerra colonia. Aníbal Almeida. 1974.

5 Democratizar a universidade: universidade para quê? Para quem? Boaventura de Sousa Santos. 1975.

6 Formação do movimento operário português: lição de síntese em concurso para professor da Faculdade de Letras do Porto em 7 de abril de 1978. Victor de Sá. Maio, 1978.

7 Acerca da doutrina militar para Portugal e as suas forças armadas. Vasco Gonçalvista. Setembro, 1979.

8 O renovamento de Marx e outros estudos. Vital Moreira. 1979.

\section{Coleção Temas - Nosso Tempo}

1 Centralismo democrático. Lenine, Rosa Luxemburgo e outros. 1971. (fora de mercado).

2 Os Panteras Negras. Org. de Maria João Delgado e Marcelo Correia Ribeiro, com textos de Eldridge Cleaver, Huey Newton e outros. 1971.

3 Elementos de teoria económica.

4 Socialismo no Chile? Salvador Allende, MIR, Pedro Vuskovic, Rossana Rossanda e outros. Seleção, introdução e tradução de Rui Namorado. "Edição do autor da tradução". Julho, 1972. "Distribuído por Centela Promoção do Livro, SARL".
5 O dilema chileno. Teitelbaum... [et al.]; selecção, nota introd. e trad. Rui Namorado. 1972.

6 Perú: camponeses e generais. Ricardo G. Acosta... [et al.; selec., trad. Rui Namorado. 1972.

7 China, revolução na educação. Seleção e tradução de Fátima Monteiro. $3^{\mathrm{a}}$ ed. Julho, 1974.

8 Cooperativismo e socialismo. Trad. Rui Namorado. 1973.

9 A Irlanda colonizada. 1973.

10 Argentina: compreender o peronismo. A. Carriego, Livioo Maitan, Conrad Detrez ERP, Montoneros, FAR. Seleção e estudo introdutório de Manuel Bastos. Junho, 1973.

11 Cartas da China. Anna Louise Strong. Setembro, 1973.

14 Como a imprensa americana distorceu a imagem do Chile. Maria Teresa Moraes. 1975.

15 Cuba: revolução no ensino. Michael Huteau, Jacques Lautrey. 1976.

16 Duas estratégias no processo chileno. Ruy Mauro Marini, José Reis. 1976.

17 Chile, economia de livre expressão. André Gunder Frank. 1976.

18 O modo de produção e as formações sociais: a concepção materialista da história. Oskar Lange. 1976.

19 A exploração capitalista: iniciação ao marxismo. Pierre Jalée. 1977.

20 Cultura e revolução: o Congresso Cultural de Havana. 1977.

21 Últimos escritos. Pier Paolo Pasolini. 1977.

23 Cooperativas: socialismo ou regressão? 1977.

24 Pedagogia: educação ou condicionamento? A. Clausse ...[et al.]. 1977.

A formação do pensamento económico de Marx. Ernest Mandel. 1978.

Coleção Perspectiva Jurídica

1 A teoria geral do Direito e o marxismo. Pasukanis. 1972.

2 Direito e luta de classes. Stücka. Setembro, 1973.

3 A ordem jurídica do capitalismo. Vital Moreira. 1973. ( $3^{\mathrm{a}}$ ed. 1978)

4 O Direito captado pela fotografia. Bernard Edelman. 1976.

5 Sobre a extenção do direito e a supressão dos juristas. Ramon Capella. 
Coleção Criar Poder Popular

1 Conselhos operários. Anton Pannekoek, L Magri, V Gerratana, M. Salvadori. 1975.

$2 O$ poder popular em Portugal. M. Vieira e F. Oliveira. Março, 1976.

3 O movimento dos conselhos operários na Alemanha, 1918-1921. H. Canne Meijer. Maio, 1976.

4 Conselhos operários e revolução. Max Adler. 1976.

5 Comunistas de conselhos. Paul Mattick, Roland Lewin, René Furth. Setembro, 1976. Tiragem: 3.000.

6 Democracia operária: partido, sindicatos e conselhos. Gramsci.

7 Luta de classes na Polónia: da greve às organizações de fábrica. Novembro, 1976. Tiragem: 3.500 .

8 As tarefas dos Conselhos Operários. Anton Pannekoek.

9 Cinturas industriais: uma experiência de poder popular no Chile. Angélica Silva, Patrícia Santa Lúcia. 1977.

10 A luta operária. Anton Pannekoek. 1977.

11 A contra-revolução burocrática. Karl Korsh, Anton Pannekoek e outros. 1978.

Movimentos de Libertação

1 Eu vivi a resistência palestina. Roger Coudroy. 1976.

$2 O$ problema palestiniano. Samir Amin e Yasser Arafat. 1976.

3 Angola: fim do mito dos mercenários. Raul Valdes Vivo. Outubro, 1976. Tiragem: 3.500.

5 Guerra do povo no Sahara Ocidental: a Frente Polisário. Carlos Benigno da Cruz. 1977.

\section{O que faz falta}

1 AGFA-GEVAERT: retrato de uma multinacional. Fernanda Barão. 1977.

2 Camponeses de Barcouço: não vamos morrer agarrados à enxada. José A. Salvador. Março, 1977.

3 As cooperativas depois de abril: uma força dos trabalhadores. José Carlos Pereira Bastos. Junho, 1977. Tiragem: 5.000.

4 Rui Gomes e a justiça militar. Nuno Crato. Dezembro, 1977.

5 Torre Bela: todos temos direito a ter uma vida. Francis Pisanni. 1978.

6 Luta pela democracia nos Açores. Manuel
Barbosa. Junho, 1978.

Direito e Sociedade

1 Actividade jurídica dos sindicatos. J. S. Dvornikov. 1974.

2 Direito sindical e função pública em França. Jorge Leite e G. B. 1974.

3 A participação dos trabalhadores na gestão das empresas na Polónia. Zbigniew Salwa. Novembro, 1974.

4 O direito na América Latina, conteúdo e ensino. Jorge Witker. 1975.

5 Experiências de justiça popular no Chile. Diversos.

6 Os tribunais de camaradas na Hungria. Gyorgy Gellet. 1975.

7 As ideias de Lenine acerca do direito soviético e da legalidade socialista. S. N. Bratous. 1976.

8 Justiça popular na China. Shao-Chuan-Leng. Setembro, 1976. Tiragem: 3.000.

9 A advocacia na República Popular da China. Sha Tchouang-Leng. 1976.

10 Justiça nos Estados Unidos: clínicas jurídicas. Colectivo de advogados - direitos dos pobres. 1976.

$11 O$ "Relatório das sevícias" e a legalidade democrática. Centro de Estudos Jurídicos. 1977.

12 A justiça e o advogado. Vários. 1977.

13 As lutas dos Moradores e a Constituição de 1976. Luis Felipe Sabino, Saul Nunes, Amadeu Lopes Sabino. Julho, 1977. Tiragem: 3.500 .

14 A hierarquia militar e o Estado democrático: caso Rosa Coutinho, peças de um processo. Luis de Azevedo (coord.). Abril, 1978.

\section{Coleção Ficção}

Guerrilheiro é terra móvel: estórias.Virgilio Alberto Vieira. 1977.

\section{Coleção Teatro - Nosso Tempo}

2 Operação Branca de Neve ou a direita não perdoa. Alfredo Nery Paiva.

3 Fábula: era uma vez. Alfredo Nery Paiva.

4 Fábulas sobre a revolução portuguesa. Richard Demarcy e Teresa Motta.

5 A linha e o nó. António Cabral.

6 Técnicas latino americanas de teatro popular. Augusto Boal. 1977.

$\underline{\text { Autobiografias operárias }}$ 
1 A história da minha vida. Parte 1, "O marçano". Virgilio Santos.

2 Perder a esperança porquê? Um operário fala do seu tempo. Manuel Monteiro. Janeiro, 1982.

Coleção "Fora de Coleção"

1 Portugal é demasiado pequeno (1974-1976). A. Lopes Sabino.

2 "O socialismo, a transição e o caso português", de J. M. Pereira: Um exemplo típico do idealismo académico. Ronaldo G. Fonseca. Setembro, 1977. Tiragem: 2.500.

Anátema (coord. Manuel de Sousa)

1 Da ecologia à autonomia. Cornelius Castoriadis, Daniel Cohn-Bendit. 1981.

2 Uma campanha de salubridade ou A crítica da ideologia do conformismo. Júlio Carrapato. Fevereiro, 1984. Tiragem: 2.000.

3 Comunicado urgente contra o desperdício. Comuna Anti-Nacionalista Zamoreana.

Novo Mundo Novo

1 Revolução Cubana: uma interpretação. Vania Bambirra.

2 Cambão: ligas camponesas. Francisco Julião. 1975.

3 Imperialismo e empresas multinacionais. Theotônio dos Santos. Dezembro, 1975.

5 Dialéctica da dependência. Ruy Mauro Marini. 1976.

\section{Centro do Livro Brasileiro (Lisboa)}

Trincadelas “revolucionárias". José Augusto de Vasconcellos e Sá. 1977.

Revolução e contra-revolução. Leon Trosky; trad. de Mário Pedrosa. 1968.

Missão em Portugal. Álvaro Lins. 1974.

O desafio democrático. Georges Marchais. 1974

A revolução sexual. Wilhelm Reich. 1975.

Reforma, revisionismo e oportunismo. Rosa Luxemburg; trad. de Lívio Xavier. 1975.

Tratado de materialismo histórico. $\mathrm{N}$. Bukharin. 1976.

O Deserto é fértil. Helder Câmara. 1976.

História do socialismo e das lutas sociais: da antiguidade aos tempos modernos. Max Beer. 1976.

Fundamentos de economia política. P.
Nikitin. 1976.

Crise 77-78: o acordo malogrado PS-PSD: alternativas e debates: programa do I Governo. Coord. Victor Silva Lopes. 1978.

CIDAC (Centro de Informação e Documentação Amílcar Cabral) (Lisboa)

Edição ainda como CIDA-C - Centro de Informação e Documentação Anti-Colonial

Partido Africano da Independência da Guiné e Cabo Verde: programa e estatutos do P.A.I.G.C. 1974.

Programa político e estatutos da Frente de Libertação de Moçambique (FRELIMO). 1974.

Programa político e estatutos do Movimento Popular de Libertação de Angola (MPLA). 1974.

Imagens da Guiné-Bissau. Uma reportagem fotográfica de Koen Wessing. 1974.

Estabelecer o poder popular para servir as massas. Samora Machel. 1974.

\section{Coleção África em Luta}

1 A nossa luta é uma revolução: nacionalizações-Moçambique. Samora Machel e outros. Maio, 1976.

2 Guiné Bissau, 3 anos de independência. Luísa Teotónio Pereira e Luís Moita. 1976.

Edições como CIDAC (Centro de Informação e Documentação Amílcar Cabral

\section{Cadernos CIDAC}

1 Contubel, uma cooperativa agrícola na Guiné- Bissau. 1979.

2 Eritreia: a resistência dum povo. 1979.

3 A roça Rio do Ouro: uma empresa agrícola nacionalizada em S. Tomé e Príncipe. 1979.

4 A evolução do comércio entre Portugal e os novos países africanos. 1979.

\section{África em Luta - Nova Série}

1 Os congressos da Frelimo, do PAIGC e do MPLA: uma análise comparativa. Luís Moita. Coedição com Ulmeiro. Fevereiro, 1979. Tiragem: 3.500 .

Sem coleção

A mulher e a revolução na Eritreia. 1980.

$O$ não alinhamento: história e doutrina do movimento dos não alinhados. Luís Moita. 1982. 
Viva a resistência do povo de Timor-Leste.

\section{Cidadela (Coimbra)}

O espírito e a técnica: para uma reforma universitária. Secretariado Organizador da Acção e Coordenador dos Grupos de Estudo na Universidade. 1970. Mimeografado.

o Ultramar e a revisão constitucional. Francisco Lucas Pires. 1971.

10 poesias sobre a guerra civil espanhola. Agustin de Foxá Torroba; trad. António Manuel Couto Viana. 1972.

A segunda cegueira. Rodrigo Emílio. 1973.

Reforma do sistema educativo: um problema político. Vítor Manuel Pires de Aguiar e Silva. Fevereiro, 1973.

Manifesto de Portugal no qual se declara o modo que tem de se manter português. Eduardo Freitas da Costa. $3^{\mathrm{a}}$ ed. 1973.

Vestiram-se os poetas de soldados. Compil. e pref. de Rodrigo Emílio. 1973.

$\underline{\text { Antologias cidadela }}$

1 José António Primo de Rivera. Introd. José Miguel Alarcão Júdice. 1972.

\section{Estudos e documentos}

Reforma do ensino superior: dois anteprojectos de parecer para a Junta Nacional de Educação. Guilherme Braga da Cruz. 1973

\section{Círculo de Leitores (Lisboa)}

Bastardos do Sol. Urbano Tavares Rodrigues. Julho, 1974.

O marxismo. Henri Lefebvre. 1974.

O capitalismo. François Perroux. 1974.

As atitudes políticas. Alain Lancelot. 1975.

$O$ socialismo reformista. Georges Lefranc. 1975.

A ciência política actual. Marcel Prélot. 1975.

O socialismo. G. Bouguin e P. Rimbert. 1975.

A propaganda política. Charles Domenach. 1975.

Os estudantes e o esquerdismo. Claude Prévost.

Sobre a democracia e outros estudos. Aldous Huxley. 1975.

História social do trabalho. Pierre Jacquard. 1975.

Quando a China despertar. Alain Peyrefitte. 1975.
Iniciação ao Sindicalismo. Lucien Rioux. Agosto, 1975.

\section{Contra a Corrente (Lisboa)}

A crise económica actual na esfera do capitalismo americano. João Bernardo. 23 de Abril de 1975; $2^{\text {a }}$ ed. 1975 a 8 de Junho de 1975. Tiragem: 1.500.

A crise económica actual na esfera do capitalismo americano/Suplemento (atualização de dados estatísticos). João Bernardo. Tiragem: 1.000. ("Edições Contra a Corrente no 1 / supl.”). 8 de Junho de 1975.

Um ano, um mês e um dia depois: para onde vai o 25 de Abril? (Economia e política da classe dominante). João Bernardo. 26 de Maio, 1975. Tiragem: $1.000 ; 2^{\mathrm{a}}$ ed. $12 \mathrm{de}$ Outubro, 1975. Tiragem: 1.000. ("Edições Contra a Corrente n ${ }^{\circ}$ ")

Crise da sociedade portuguesa: "descolonização" e "independência nacional”. Charles Reeve e J. CarvalhoFerreira. Setembro de 1975. Impresso na Gráfica 2000 em autogestão.

Portugal: a questão da organização revolucionária: uma posição de trabalhadores emigrantes. 1975. Escrito por um grupo de trabalhadores nascidos em Portugal mas a trabalhar em França.

Novo movimento: questões sobre a prática revolucionária. Henri Simon. Porto, 1975. A partir de "Nouveau Mouvement", traduzido por A. Ricardo.

Sobre a situação actual (banda desenhada). Francisco Silva. Porto. Fevereiro, 1976. Tiragem: 3.000.

Lutas sociais na China. João Berrnardo, 21 de Junho de 1976.

o que somos e o que queremos. Solidarity/Londres. Traduzido e publicado em 1976.

Contribuição para a percepção da cultura (política) em Portugal. Artur J. Castro Neves. Lisboa, 1976. Tiragem: 1.500.

Notas sobre a desvalorização do escudo. João Bernardo. 1977.

De camuflado no peito e na cabeça. José Luís Farinha. Maio, 1978.

Reforma agrária no Couço. Entrevistas realizadas em julho e outubro de 1976 e publicadas em 1978.

Para a revolta no Poço Verde. António Bito. Dezembro, 1978. (Retrato de um bairro integrado no processo SAAL, criado em 
agosto de 1974 e extinto em novembro de 1976.)

Tortura e repressão na social-democracia: Irlanda e Alemanha. Março, 1978.

Teses sobre o bolchevismo. ICC (International Council Correspondence), vol. I, $\mathrm{n}^{\mathrm{o}}$ 3, Dezembro de 1934. Este texto foi preparado colectivamente pelo Grupo de Comunistas Internacionais da Holanda (o rascunho foi redigido por Helmut Wagner). 1978.

A greve do calçado; Alicante 1977: no tempo em que os revolucionários tinham razão. Autor: Trabajadores por la autonomia Proletaria y la Revolución Social. Fevereiro, 1979. ("Impressão em oficinas próprias"; edição original espanhola)

Movimento urbanos e comissões de moradores: Portugal 1974-76. L. Leitão, A. Dias, J. Manuel, L. Dianoux. Março, 1980. (edição original francesa)

Por uma acção revolucionária em situação de refluxo. Colectivo do Combate e da Contra a Corrente, Dezembro de 1980.

Polónia 1980-81: solidariedade domesticada. Charles Reeve. Junho, 1981.

A flor no bico de um pássaro. M. Graciette Gaspar. 1982 (?).

Luta nos portos: Roterdão 79, Barcelona 80-81. s/d.

Sindicalismo e acção directa. Manuel Joaquim de Sousa. Prefácio de Emídio Santana. s/d. ("Edições Contra a Corrente no 2"; Edição em gráfica, com capa a cores.)

Trotsky e a ditadura do proletariado. H. Smith. s/d. Este texto foi publicado pela revista americana International Council Correspondence, vol. $3, \mathrm{n}^{\circ} 4$ de Abril de 1937.

Apelo do grupo "Verdade Operária" ao proletariado revolucionário (Rússia, 1923). s/d. Tradução de "Documentos de la revolucion mundial. 1 Democracia de trabajadores o dictadura de partido", Frits Kool y Erwin Oberlander, Edita Zero, 1971, Madrid, p. 244-252.

Sobre a organização dos trabalhadores. A. Pannekoek. s/d. Tradução de "General remarks on the question of organization" publicado com o pseudónimo de J. Harper na revista Americana Living Marxism, IV, Novembro de 1938.

O Comecon e a crise económica mundial. A crise do capitalismo nos países de leste. s/d. Foi traduzido da publicação francesa Jeune Taupe, Paris, e editada na Gráfica 2000 em autogestão.
Debate com "Minus". Grupo libertário de Hong Kong. s/d.

Dossiers de Luta do jornal Combate

1 Trabalhadores dos transportes Estefânia em luta contra o patrão. 1976.

2 Dossiers de Luta 1977: Balanço de um ano de lutas. 1978.

$\underline{\text { Do Quotidiano }}$

1 Condicionamento autoritário, repressão sexual e o irracional em política. M. Brinton (Solidarity/Londres). $2^{\circ}$ Semestre de 1975.

\section{Edições em inglês}

Manifesto of Combate. 1975.

Portugal, economy and policy of the dominant class. One year, one month and one day after: where is the 25th April going? João Bernardo, Janeiro de 1976. Tradução para inglês de Economia e política da classe dominante: um ano, um mês e um dia depois - para onde vai o 25 de Abril?. Contêm ainda um apêndice com a tradução para inglês de um extracto de A crise económica actual na esfera do capitalismo americano, também de João Bernardo, publicado em 23 de Abril de 1975.

After the 25th. November. 1976.

Crisis historical forms of their appearance and recuperation. João Bernardo. Janeiro, 1976.

Portugal: 5 years on. Dezembro, 1980. (Versão em inglês de Por uma acção revolucionária em situação de refluxo)

\section{Delfos (Lisboa)}

Temas 2000

1 A revolta dos estudantes. 1968.

3 Carta ao papa (sobre a pílula). Tradução de Mário Delgado. 1969.

4 Conceitos de moral. Leon Trotsky. 1969.

5 A África Austral de hegemonia branca. Arnaud Durban. 1970.

9 A fabricação de Fátima. Prosper Alfaric. 1971.

12 O Partido Comunista (Sua definição). Georges Marchais. 1972.

Estudo e ensaio

6 Teilhard de Chardin. Ernest Kahane. 1969.

8 Cartas, discussões, diálogos. Galileu Galilei. 1970. 
Livro Aberto

1 O combate sexual da juventude. Wilhelm Reich. 1972.

\section{Compasso do Tempo}

10 comunismo actual. Waldeck Rochet.

2 Adeus à velha igreja. James Kavanaugh. 1970.

3 Dez dias que abalaram o mundo. John Reed. $10^{\mathrm{a}}$ ed. 1975.

4 Depois de Franco... O quê? Santiago Carrillo. 1970.

5 O socialismo. Guy Mallet. 1968.

61789 ano um da liberdade. Albert Soboul. 1971.

7 Vida e morte de Lenine. 2 Vols. Robert Payne. 1972.

8 Eleições presidenciais: subsídios para a história das candidaturas Norton de Matos (1949), Quintão Meireles (1952) e Humberto Delgado (1958). 1971.

9 Deus para o homem de hoje. Jacques Duquesne.

10 Trotsky está vivo! Pierre Naville. 1972.

11 O financeiro Vaticano. Corrado Pellenberg. 1973.

12 A liberdade. Harold Laski. 1973.

13 A mentira dos sindicatos. Daniel Mothé. Junho, 1973.

$14 O$ assalto ao "Santa Maria". Henrique Galvão. 1973.

15 Eleições legislativas: subsídios para a história da vida portuguesa 1945-1973. 1973.

16 Contos sobre Lenine. Vários. Janeiro, 1974.

17 Controle operário. Antologia organizada por Ernest Mandel. 1974.

18 Memórias. Humberto Delgado. 1974.

19 Vida e morte de Trotsky. Pierre Frank e outros. 1974

20 Angola: no centro do furacão. Basil Davidson. Novembro, 1974

21 A revolução chilena (Um alerta ao Portugal de hoje). Salvador Allende, J. Dominguez. Maio, 1975.

22 A mulher no marxismo. Alexandra Kollontai. 1975.

23 Revolução e contra revolução em Espanha, 1931-1936/1939. Felix Morrow. Novembro, 1975.

24 Ano um da Revolução Russa. Victor Serge. Dezembro, 1975.
25 Sindicatos de ontem e de hoje. Goetz Briefs. Abril, 1976.

26 Palavras que abalaram o mundo. JeanJacques Marie.

27 O M.R.P.P. Judith Balso. c. 1976.

28 Fé na humanidade. Jacques Duclos. 1977.

O capital. Karl Marx. 1974.

A revolução cultural chinesa. Henri Weber e outros.

$O$ imperialismo. Ernest Mandel, J. Servan Schreiber, Jacques Valier e outros. Outubro, 1975.

Tratado de economia marxista. Ernest Mandel. 1976.

O totalitarismo. Paul T. Mason. 1977.

A curva do desenvolvimento capitalista. Léon Trotsky, Christian Leucate. 1978.

Estados Unidos, país podre. Ernest Mandel, Mary Joan Hiscox. 1978.

Toupeira

1 A revolução traída. L. Trotsky. 1973.

4 As quatro internacionais. George Novack, Dave Frankel, Fred Feldman. 1974.

\section{Perspectivas}

2 A Jugoslávia. C. Samary. 1973.

3 O Vietname: comentários aos arquivos do Pentágono. Gerard Chaquat e Alain Bertrand. Março, 1973.

Preto \& Branco (ou Argumentos)

10 Estado. Lenine/ Teoria marxista do Estado. Ernest Mandel. $2^{\mathrm{a}}$ ed. Fevereiro, 1975.

2 Sexualidade e repressão. Thomas Münzer. 1972.

3 Balanço e perspectivas.

4 Teoria e política no pensamento de Trotsky. Denise Avenas. 1973.

5 Lenine. Georg Lukacs. 1973.

6 Marxismo e "Populorum Progressio". Tomás Malagón. 1976.

7 À gente nova. Kropotkine. 1974.

8 Um mundo para todos os homens.

9 De quem é a empresa.

10 Estado e revolução. Lenine. 1975.

11 A conquista do pão. Kropotkine. Novembro, 1975. 
Textos de Economia

1 Capitalismo contemporâneo. Jacques Dubois, Christian Merlin, Jacques Valier. 1972.

2 Capitalismo ou socialismo? U.R.S.S. e países de leste. Fernand Charlier. 1972.

3 Inflação capitalista. 1973.

4 A construção do capitalismo na URSS (19151928). Véga Gangart. Maio, 1973.

5 A crise do dólar. Jacques Valier, Fompeyre, Ernest Mandel. Fevereiro, 1974.

\section{DiAbril (Lisboa)}

\section{Coleção Teoria e Prática}

1 Introdução à política. Fernando Luso Soares. Março, 1975. (2 $2^{\text {a }}$ ed. Junho, 1975; $5^{\text {a }}$ ed. 1976)

2 MFA e revolução socialista. César Oliveira. Março, 1975 (2 ed. Abril, 1975).

3 Em luta: gerra civil de Espanha. Dolores Ibarruri. Junho, 1975. Tiragem: 5.100.

4 Textos históricos da revolução. Coord. Orlando Neves. 1975. (2 ${ }^{\mathrm{a}}$ ed. 1976).

5 MFA, motor da revolução portuguesa. Coord. Serafim Ferreira. Julho, 1975. Tiragem: 3.100 .

6 Hipóteses de Abril. Eduardo Prado Coelho. 1975.

7 Que são as Ligas Camponesas. Seguido de Até quarta, Isabel! Francisco Julião. Outubro, 1975. Tiragem: 3.000.

8 A revolução em ruptura: textos históricos da revolução II. Coord. Orlando Neves. s/d.

9 Cuba, realidades e ensinamentos de uma revolução. Eugénio Rosa. Dezembro, 1975.

10 Actas Tupamaras: uma experiência de guerrilha urbana no Uruguai. 1976.

11 A comunidade internacional. Fernando Luso Soares. 1976.

12 E agora que fazer? Textos históricos da revolução III. Coord. Orlando Neves. 1976.

13 A Revolução Russa e a imprensa portuguesa da época. César Oliveira. Maio, 1976.

14 Chile / Setembro. Marcelo Dias. 1976.

15 Portugal: dois anos de revolução na economia. Eugénio Rosa. Dezembro, 1976.

16 A ofensiva do capital e a luta pelo socialismo. J. Cândido de Azevedo. 1976.

17 Contrapoder e revolução. Fernando Pereira Marques. Janeiro, 1977.

18 Luta pela reforma agrária. António Lopes Cardoso. Dezembro, 1976.

19 O desporto como prática filosófica. Manuel
Sérgio. Setembro, 1977.

Coleção Universidade do Povo

1258 perguntas a um português eleitor. Coord. António Quelhas, Artur Maurício, Fernando Luso Soares, Orlando Neves e Serafim Ferreira. Março, 1975.

2 Resistência africana. Antologia poética. Coord. Serafim Ferreira. Março, 1975.

3 Sabotagem económica. Dossier Banco Espírito Santo. Trabalho coletivo de delegados sindicais do banco Espírito Santo e Comercial de Lisboa. Abril, 1975.

4 Os ricos não fazem greve. Porquê? Álvaro Vieira Pinto. 1975.

5 Legião Portuguesa: força repressiva do fascismo. Josué da Silva. Maio, 1975.

6 O catolicismo é cristão? Padre Aloísio Guerra. 1975.

7 Poemas para a revolução. José Carlos Vasconcelos. 1975.

8 O Alentejo na reforma agrária: a viragem decisiva. Afonso Cautela. Julho, 1975.

9 Política da habitação. Henrique Oliveira e Sá.

10 Desporto para a liberdade: ou um ensaio para vários discursos sobre a maravilhosa experiência do caniço, com a esperança que dela algo de útil venha a resultar para os meninos do meu país. Noronha Feio. 1976.

\section{Colecão As Leis e a Revolução}

1 Saneamento da função pública. Artur Maurício e Castelo Branco Gonçalves. Maio, 1975.

$\underline{\text { Álbuns }}$

Desenhos políticos. Vasco. 1975.

\section{Obras de José Gomes Ferreira}

Revolução necessária: crónica do $1^{o}$ ano da revolução de 25 de Abril de 1974 segundo os documentos publicados na época pelo autor. José Gomes Ferreira. Junho, 1975. (2 ${ }^{\mathrm{a}}$ ed. 1977)

Gaveta de nuvens. José Gomes Ferreira. Fevereiro, 1975.

As aventuras de João Sem Medo. José Gomes Ferreira. $4^{\text {a }}$ ed. Junho, 1975.

O sabor das trevas. Romance-alegoria dos tempos amargos. José Gomes Ferreira. Novembro, 1976.

Intervenção sonâmbula: crónica do segundo ano da revolução de 25 de Abril de 1974 
através de documentos publicados pelo autor nesse período. José Gomes Ferreira. 1977.

\section{Coleção Extra}

1 Ceausescu. Giancarlo Elia Valori; pref. ed. port. Carlos Fabião; pref. ed. francesa Alain Poher. 1975.

2 Recordações da casa dos mortos: variações constituínticas sobre um tema de Dostoievski. Carlos Coutinho. Março, 1976.

3 Perspectivas dos trabalhadores face ao processo político: poder popular, cultura popular. Cavalheira Antunes. Março, 1976.

4 Experiência de liberdade: antologia de textos publicados no suplemento "Artes e Letras" do Diário de Notícias de Maio a Novembro de 1975. Pref. e notas de E. M. Melo e Castro. 1976.

6 Reino velho com emenda. António Borges Coelho. 1976.

8 Que socialismo?, que Europa? 1976.

Coleção Temas da Constituição - Dirigida por $\underline{\text { Rui Pinheiro e Artur Maurício }}$

1 A Constituição e processo penal. Rui Pinheiro e Artur Maurício. 1976.

2 A Constituição e o direito do trabalho. Pedroso de Lima. 1976.

3 A Constituição: alguns conceitos fundamentais. Luís Carvalho Oliveira. Outubro, 1976.

4 Constituição e direito agrário. Dimas de Lacerda.

5 A Constituição e as organizações populares de base. Fernando Luso Soares. Março, 1977.

6 A Constituição e a condição da mulher. Lia Viegas Cantante. 1977.

7 A Constituição e a defesa dos administrados. Guilherme da Fonseca. 1977.

8 A Constituição e a liberdade de imprensa. José Carlos de Vasconcelos.

8 A Constituição e o direito sucessório. Sérgio de Sousa. 1977.

9 A Constituição e os tribunais. Narciso da Cunha Rodrigues. 1977.

10 A Constituição e a organização económica do Estado. Vital Moreira.

11 A Constituição e o direito de família. Pereira Coelho.

12 A Constituição e as associações sindicais. Carlos Barbeitos.

13 A Constituição e o direito fiscal. Macaísta Malheiros.
15 A Constituição e o plano. José Campelo.

16 A Constituição e o direito de habitação. Eliseu Figueira. Abril, 1977.

17 A Constituição e as relações internacionais. Villaverde Cabral.

18 A Constituição e o direito de propriedade. Orlando de Carvalho.

19 A Constituição e o poder local. Luís Catarino.

\section{Coleção Ciência e Ideologia}

1 Para uma teoria da história de Althusser a Marx I. João Esteves da Silva.

2 Filosofias da história: declínio ou crise? Hélène Védrine. 1976.

3 Para uma teoria da história de Althusser a Marx II. João esteves da Silva. Junho, 1976.

\section{Quixote (Lisboa)}

Trotsky e o trotskismo. Jean-Jacques Marie. Maio, 1972.

Marx. Com uma antologia de textos de Marx. Henri Lefebvre. Julho, 1974.

\section{Coleção Cadernos D. Quixote}

$1 O$ conflito israelo-árabe. Bernard Féron, Georges Chaffard e outros. 1967.

2 Bolívia - um segundo Vietname? 1967. (Fora de mercado)

3 A revolta dos negros americanos. James Bladwin, Andrew Kopkind e Tom Hayden.

4 Grécia 67. 1968. (Fora de mercado)

5 Guerra ou paz? Paulo VI, Linus Pauling, René Maheu e outros.

6 O drama do Terceiro Mundo. Josué de Castro, René Dumont e outros. 1969.

7 Que futuro para o Vietname? Pham Van Dong, Robert Kennedy, Jean Lacouture. 1968.

8 Checoslováquia na hora da democratização. Dubcek, Vaculik, Michel Tatu e outros.

9 Biafra. Ojukwu, Gowon, A. Toynbee e outros. 1968.

10 EUA - ano de eleições. Marcuse, Mailer, Salinger e outros.

11 A revolta de maio em França. Jean-Paul Sartre, Daniel Cohn-Bendit, Henri Lefebvre. Novembro, 1968.

12 URSS - 50 anos depois. Alex Soljenitsine, I. Deutscher, A. Werth, I. Liberman e outros. (Fora de mercado) Janeiro, 1969.

13 A crise da igreja. Pa. Felicidade Alves, D. 
Hélder Câmara, Camilo Torres, Jean-Marie Domenach. (Fora de mercado)

14 O desafio americano. J. J. Servan-Schreiber, G. D'Estaing e outros. 1969.

15 China, hoje. Edgar Snow e outros. Março, 1969.

16 Médio Oriente - Solução impossível? 1969.

17 Apartheid. 1969.

18 Black Power-Poder negro. 1969.

19 As crises monetárias. 1969.

20 Lua - Sim ou não? Bertrand Russell e outros. Novembro, 1969.

21 De Adenauer a Willy Brandt.

22 A Rodésia e a independência. 1970.

23 Japão outro gigante. 1970.

24 Uma nova Espanha. 1970.

25 Itália entre direita e esquerda. 1970.

26 O Brasil na encruzilhada. 1970.

27 Droga - Inferno ou paraíso? 1971.

28 Igreja velha, Igreja nova. 1970.

29 Hippies - Quem os conhece? Edgar Morin e outros. Outubro, 1970.

30 Suécia-Mito ou realidade? 1970.

31 Bolívia, depois de Guevara. Régis Debray, Jean-Pierre Bernard, A. Moravia, Eduardo Haro Tecglen. Dezembro, 1970.

32 Cuba e o socialismo. Fidel Castro, René Dumont, Lee Lockwood e A. Birou. Janeiro, 1971.

33 A pílula é um perigo? Robert Kistner e outros. Fevereiro, 1971.

35 E depois do Laos? 1971.

38 Inglaterra-trabalhista, conservadores ou europeus. Anthony Sampson. 1971.

39 F.B.I. - Abuso de autoridade. Frank Donner, Arthur R. Miller, Olivier Todd. 1971.

42 Quem tem medo da China? Mao tsé-tung e outros. Abril, 1971.

44 E depois de Franco? Ricard Soler, Fernando Claudin, Juan Ruiz. 1972.

45 Grécia, ano quinto. Amalia Fleming, Yorgos Mangakis, R. Someritis. 1972.

46 A Jugoslávia de Tito. Anton Vratusa...[Et Al.]. 1972.

47 Polónia, um novo rumo? K. S. Karol, Victor Zorza, Tamara Deutscher. 1972.

48 A outra Alemanha. Heinz Klunker. 1972.

50 Albânia, o país das águias. Enver Hodja, Maurice Duverger, Maria Adele Teodori. 1972.

Novos Cadernos D. Quixote
1 América, Nixon, etc. 1972

2 Máfia $=$ Cosa Nostra?

3 Europa e Mercado Comum - sonhos, realidades e mitos. 1973.

4 Argentina - peronismo sem Perón?

5 Ecologia contra poluição.

6 Emigração - problema multinacional.

7 A sociedade de consumo. 1973.

8 Ainda há índios?

9 Espionagem política - Watergate, etc. 1973.

10 As "guerras" do petróleo.

11 Velhice e morte. 1973.

12 Psiquiatria e antipsiquiatria. 1973.

13 Delinquência - mal sem remédio? 1973.

14 Países ricos e países pobres. 1974.

15 As empresas multinacionais. 1974.

16 A crise de energia. 1974.

17 Automóvel - paraíso perdido!

18 Comer-perigo de morte? 1974.

19 Inflação - mal universal! Galbraith, Samuelson, Pen. Julho, 1974.

20 O 25 de Abril na imprensa estrangeira.

21 O negócio das armas.

22 Sobre a democracia. 1974.

23 Peru - Exército, nação, revolução. Juan Velasco Alvarado e outros. Dezembro, 1974.

24 CIA - a arte de desestabilizar governos. Janeiro, 1975.

25 Europa - um novo comunismo? Fevereiro, 1975.

261975 - A crise.

27 Os militares e o poder na América Latina e na África. 1975.

28 EUA, URSS e o destino dos outros. 1975.

29 Os anarquistas e a autogestão. Extraído da revista Autogestion et Socialisme. Junho, 1975. Tiragem: 4.200.

30 Portugal na imprensa estrangeira - um ano depois. 1975.

31 Pi-Lin, Pi-Kong, a campanha contra Confúncio e Lin Piao.

32 A via argelina: um modelo para Portugal? Outubro, 1975.

$33 K G B$ a CIA soviética. Colab. Frederick Barghoord,...[Et Al.]. 1975.

Documentos Dom Quixote

1 Camboja. Junho, 1970.

2 Irlanda(s) - católicos contra protestantes? Julho, 1970. 
3 Chile - reformismo ou revolução? Novembro, 1970.

4 Canadá - com ou sem Quebeque. Janeiro, 1971.

Coleção Diálogo

1 A responsabilidade dos intelectuais. Noam Chomsky. 1968.

2 América Latina. Miguel Angel Asturias.

3 Progresso, coexistência e liberdade intelectual. Andrei Sakharov. 1969.

4 Juventude e contestaçao. Sartre, Marcuse, Moravia, Faure. Abril, 1969.

5 Educação sexual. A Berge, A. S. Neill, A. S. Makarenko e B. Spock. 1970.

6 Um português em Cuba. Alexandre Cabral. 1969. (Fora de mercado)

7 Da liberdade de pensamento e de expressão. John Stuart Mill. $2^{\text {a }}$ ed. Maio, 1976 (1 ${ }^{\text {a }}$ ed. Novembro, 1969)

8 A arrogância do poder. William Fulbright. 1970.

9 Regressar para quê? Victor de Sá. 1970.

10 Ocidente e Oriente - Diálogo ou agressão? Georges Fradier. Julho, 1970.

12 Pensar Portugal hoje. João Martins Pereira. 1971.

13 Cultura asfixiante. Jean Dubuffet. 1971.

$15 O$ direito à preguiça. Paul Lafargue.

17 A revolução cultural na Universidade de Pequim. Victor Nee. 1969.

19 Violência inútil. Raul Rêgo. Abril, 1975.

\section{Os Homens e a História}

1 A partilha da África. Henri Brunschwig. 1972.

2 Trotsky e o trotskismo. Jean-Jacques Marie. 1972.

3 Quando Hitler atacou a leste. Piérre Rondiére. 1972.

4 A revolução russa de 1917. Marc Ferro. Trad. Ruy Belo. Setembro, 1972 (2 ${ }^{\mathrm{a}}$ ed. Março, 1975).

5 Os conquistadores da América. Ruggiero Romano. 1972.

6 Auschwitz: anatomia dum campo de concentração. Léon Poliakov. 1973.

7 A longa revolução. Edgar Snow. 1973.

8 A verdadeira guerra do ópio. Michel Lamberti e Catherine Lamour. Maio, 1973.

9 Franco e o franquismo. Jacques Georgel. 1974.

10 O exército chinês: o "herdeiro" de Mao?
Jean-Pierre Brulé. Setembro, 1975.

11 A minha vida. Golda Meir. 1976.

Viragem

1 Escuta, Zé Ninguém. Wilhelm Reich. 1972.

2 A alternativa: modificar o mundo e a vida. Roger Garaudy. 1972.

3 Libertar o futuro. Ivan Illich. 1970.

$4 \mathrm{O}$ racismo ao vivo. Margaret Mead e James Baldwin. 1973.

5 Política sexual. Kate Millett. 1970.

7 As origens do esquerdismo. Richard Gombin. Novembro, 1972.

8 Ajuda ou recolonização. Tibor Mende. 1974.

9 Marx depois de Marx. Pierre e Monique Favre. 2a ed. Outubro, 1974.

10 O pensamento de Lenine. György Lukács. Março, 1975.

11 Os camponeses na luta de classes. Bernard Lambert. 1975.

12 Mao Tsé-tung e a construção do socialismo. Textos coordenados e apresentados por $\mathrm{Hu}$ Chi-Hsi. 1975.

13 Palavra homem. Roger Garaudy. 3ª ed. 1976.

14 O meu país é o mundo. Andrei D. Sakharov. $2^{\mathrm{a}}$ ed. 1975.

15 O projecto esperança. Roger Garaudy. $2^{\mathrm{a}} \mathrm{ed}$. 1976.

16 Psicologia de massas do fascismo. Wilhelm Reich. 1976.

17 Para um diálogo das civilizações. Roger Garaudy. 1977.

18 A psicologia da incompetência dos militares. Norman F. Dixon. 1977.

19 A função do orgasmo. Wilhelm Reich. 1978.

20 Os mestres pensadores. André Glucksmann. 1978.

\section{Coleção Participar}

1 Democratização e descolonização: dez meses de Governo Provisório. Mário Soares. Março, 1975.

2 Por uma social-democracia portuguesa. Francisco Sá Carneiro. Março, 1976. Tiragem: 5.200.

3 A revolução portuguesa. Álvaro Cunhal. Abril, 1975. Tiragem: 5.200.

4 O general Sousa Dias e as revoltas contra a ditadura (1926-1931). A. H. de Oliveira Marques.

5 A Maçonaria portuguesa e o Estado Novo. A. $\mathrm{H}$. de Oliveira Marques. 
6 A ditadura militar (1926-1933). Jorge Campinos.

7 Portugal: cinquenta anos de ditadura. António de Figueiredo. Trad. J. M. Martins e Maria Manuela Palmerim. Março, 1976.

8 O fascismo nunca existiu. Eduardo Lourenço.

9 O poder e o povo: a revolução de 1910. Vasco Pulido Valente. Dezembro, 1976.

10 O labirinto da saudade. Eduardo Lourenço.

11 Não percas a rosa. Diário e algo mais (25 de Abril de 1974-20 de Dezembro de 1975). Natália Correia. Novembro, 1978.

12 Uma constituição para os anos 80: contributo para um projecto de revisão. Francisco Sá Carneiro. 2a ed. Janeiro, 1979. ( $1^{\mathrm{a}}$ ed. Janeiro, 1979)

13 O complexo Marx. Eduardo Lourenço.

14 Pensar portugal hoje. José Martins Pereira.

15 Direitos do homem. António Maria Pereira. Junho, 1979.

16 Social-democracia e doutrina social da igreja. António José Fernandes.

17 O império com pés de barro. José Freire Antunes.

18 O pensamento de Sá Carneiro em política externa. António Maria Pereira.

19 A política económica do governo de Sá Carneiro. Aníbal Cavaco Silva. Março, 1982.

\section{Coleção Documentário}

1 A África começa mal. René Dumont.

2 O dilema do homem branco. Boyd Orr e David Lubbock.

3 El Medhi bem Barka, meu irmão. Abdelkader bem Barka.

4 Crise em preto e branco. Charles E. Silberman.

5 Os assassinos de Kennedy. Richard $\mathrm{H}$. Popkin.

6 Um americano em Hanói. Harrison H. Salisbury.

7 Na órbita da China. Harrison H. Salisbury.

8 O impacte português sobre a civilização japonesa. Armando Martins Janeira.

9 A minha alma não está à venda. Bernardette Devlin.

10 Os tupamaros: a guerrilha urbana no Uruguai. Alain Labrousse. Novembro, 1971.

11 A China ontem e hoje (2 volumes). Edgar Snow.

12 O complexo militar-industrial americano. Claude Moisy.
Enciclopédia do Mundo Atual (EDMA)

A psicanálise. 1976.

As multinacionais. 1976.

Estudos Portugueses

Para onde vai a economia portuguesa? Francisco Pereira Moura. Outubro, 1969.

Desenvolvimento económico ou estagnação? Armando Castro. Fevereiro, 1970.

A revolução de setembro de 1836 . Victor de Sá.

5 Ensino primário e ideologia. Maria de Fátima Bivar. 1971.

\section{Universidade Moderna}

1 Introdução à política. Jean-Pierre Lassale.

2 Os testes mentais. Pierre Pichot.

3 Moderna teoria económica. Jan Pen.

4 A mitologia. Edith Hamilton.

5 Economia da URSS. Pierre George. Março, 1970.

6 A economia dos EUA. Pierre George. Março, 1970.

7 Maomé e Carlos Magno. Henri Pirenne.

8 As origens do fascismo. Robert Paris. $2^{\mathrm{a}}$ ed. Junho, 1974. ( $1^{\text {a }}$ ed. Maio de 1970)

9 Introdução à pedagogia. Jean Giraud.

10 Anarquistas e anarquismo. James Joll.

13 A revolução industrial em Portugal no século XIX. Armando Castro. Fevereiro, 1971.

14 Dialéctica e sociologia. Georges Gurvitch.

15 Teoria e política do desenvolvimento económico. Celso Furtado.

16 Caminhos para a Europa. Erik Seidenfaden.

17 Do feudalismo ao capitalismo. Paul Sweezy, Maurice Dobb, H. K. Takahashi, R. Hilton e C. Hill.

18 Curso de linguística geral. Ferdinand Saussure.

20 O fim da história. Henri Lefebvre.

21 Os grandes economistas. Robert Heilbroner.

22 A civilização de 1995. Jean Fourastié.

23 A economia da China. Jan Deleyne.

26 A economia da África. Andrew M. Kamark.

57 O capitalismo. Alain Cotta. Novembro, 1977.

\section{Poesia Século XX}

Poemas políticos. Hans Magnus Enzensberger. 1975. 
Vector

5 A grande viragem do socialismo. Roger Garaudy. Maio, 1970.

Para uma contracultura. Theodore Roszak.

Para Principiantes

5 Capitalismo para principiantes. Robert Lekachman, Boris van Loon. Outubro, 1982.

8 Lénine para principiantes: de A a Z. Richard Appignanesi, Oscar Zarate. Janeiro, 1983.

\section{Edições 70 (Lisboa)}

$O$ reino flutuante: exercícios sobre a razão e o discurso. Eduardo Prado Coelho. 1972.

Luuanda-estórias. José Luandino Vieira. 1972.

A vida verdadeira de Domingos Xavier. José Luandino Vieira. Setembro, 1974.

Linguística, sociedade e política. A. Schaff, S. Latouche, Rossi-Landi, A. Ponzio; H-P. Jeudy. 1975.

Os grã-capitães. Jorge de Sena. 1976.

\section{Coleção O que é}

10 que é a inflação (Porque sobrem os preços). Armando de Castro. Outubro, 1970.

20 que é o mercado comum (A integração e Portugal). Sérgio Ribeiro. 1971.

3 O que é a reforma agrária (URSS - Polónia Vietname - Chile - México; Portugal: para uma reforma gradual da estrutura agrária). Blasco Hugo Fernandes. Dezembro, 1974. $\left(1^{\circ}\right.$ ed. Novembro, 1971. ( $3^{\text {a }}$ ed. em Maio de 1975).

4 O que é um computador: cultura e mito, máquina e inteligência, cálculo, cibernética e informática. Jorge Branco. 1972.

5 O que é a propriedade socialista. L. Kronrod, F. Kolacek, V Vlajic e I. Volkov. 1975. (2a ed. Abril, 1975).

6 O que é autogestão. Daniel Chauvey. 1975.

\section{Coleção Biblioteca 70}

1 A economia portuguesa do século XX (19001925). Armando Castro. 1973. (3 $3^{a}$ ed. Abril, 1979).

2 Diversidade genética e igualdade humana. Theodozius Dobzhansky. 1974.

3 Antropologia: ciências das sociedades primitivas? Maurice Godelier, Serge Tornay, Jean Copans e Catherine Backès-Clément. 1974.

5 O capital (Edição popular). Karl Marx. 1974.
6 Meios de informação e violência. Mary Burnet. 1974.

7 Pedagogia e pedagogias. Marie-Claire Lepape. 1975.

8 Sociedade e mudanças sociais. Karl Marx. Novembro, 1974.

9 A revolução russa. François-Xavier Coquin. 1974.

10 Para compreender o pesamento de Karl Marx.Henri Lefebvre. 1974.

11 A concepção marxista da história. Helmut Fleischer. 1975.

12 A sociedade de consumo. Jean Baudrillard. 1975.

13 Sobre a religião. Karl Marx F. Engels. s/d.

14 A entrada da vida. Georges Lapassade.

15 Reforma e revolução. André Gorz. 1975.

16 Crise da sociedade contemporânea. $\mathrm{R}$. Barthes, R. Dumont, A. Sauvy, A. Touraine, M. Duverger, O. Palme, E. Marie, R. Aron e M. Rocard. 1975.

17 A transição para o socialismo. Charles Bettelheim e Paul Sweezy. 1976.

18 Classe operária e revolução. Fréderique Bon e M-E. Burnier. 1975.

19 A planificação socialista da economia. Charles Bettelheim. Junho, 1975.

20 Escritos da juventude. Karl Marx. Novembro, 1975.

21 O fascismo. Org. Mirella Bartolotti. 1975.

22 Estruturas e reformas agrárias. Michel Gutelman. Dezembro, 1975.

23 Imperialismo e acumulação de capital. Rosa Luxemburgo e Nikolai Burkharine. 1976.

24 Sociologia e negritude. Maria Carrilho. 1976.

25 Humanismo socialista. E. Fromm, L. Goldmann, H. Marcuse, U. Cerroni, A. Schaff, K. Kosik, E. Bloch, R. Supek, T. Bottomore e outros. 1976.

26 A alergia do trabalho. Jean Rousselet. 1976.

27 A questão comunista. Enrico Berlinguer. Setembro, 1976

28 Desenvolvimento económico e países subdesenvolvidos, seguido de A panificação socialista. Maurice Dobb.

Os Caminhos da Liberdade

1 Cuba: guerra revolucionária. Ernesto Che Guevara. Setembro, 1975.

2 A vida de Lenine. Nina Gourfinkel. 1976.

4 Tejas verdes: diário de um campo de concentração no Chile. Hernán Valdés; trad. 
de Fernando Batinga. 1977.

Leitura da Política

1 O Estado em discussão. Etienne Balibar, Nico Poulantzas e outros. 1981.

2 A China depois de Mao. Charles Bettelheim. Maio, 1981.

Estudos - Autores Angolanos

1 Feiras e presídios (Esboço e interpretação materialista da colonização de Angola). Eugénio Ferreira.

2 Angola, estrutura económica e classes sociais: os últimos anos do colonialismo português em Angola. Henrique Guerra. 4 ed. Dezembro, 1979.

\section{Edições FP (Fernando Pereira - Editor) (Lisboa)}

O colapso da democracia. Robert Moss. Março, 1979.

26 anos na Rússia Soviética. A mentira soviética revelada por quem a viveu. $O$ socialismo não existe na URSS. Um último aviso aos ingénuos. Francisco Ferreira (Chico da $C U F)$. Nova edição revista e ampliada. s/d.

Spínola, o anti-general. Eduardo Freitas da Costa. 1979.

Fogo cruzado: lembrança do sofrimento anónimo sem cuidar das ciladas que o futuro tecia: história de miséria e grandeza. Nuno Mira Vaz; pref. pelo Diogo Neto. 1980.

De Santo António a Oliveira Salazar, por Portugal: pérolas para porcos. [compil. de] Miguel Taveira. 1980.

Últimas décadas de Portugal. Américo Thomaz. 1980.

Salazar: o homem e a sua obra. António Ferro. 1982.

Eu fui ao fim de Portugal: subsídios para o "dossier" do Timor português. Rui Palma Carlos. 1982.

Quando os cravos murcham. Barradas de Oliveira. 1982.

Fátima e a grande conspiração. Deirdre Manifold. 1982.

\section{Coleção Aqui foi Portugal!}

Sangue no capim atraiçoado. Vasco Reis Ventura. 1981.

\section{Edições do Partido (Lisboa)}

1 Programa político do Partido Comunista de Portugal (marxista-leninista). $2^{\text {a }}$ ed. 1974 ( $1^{\mathrm{a}}$ ed. 1971).

2 Estatutos do Partido Comunista de Portugal (marxista-leninista).

3 Informe sobre a atividade da Comissão Central do Comité Marxista-Leninista Portugês. Apresentado ao $V$ Congresso (reconstitutivo) do Partido Comunista de Portugal (marxista-leninista). 1971.

4 Informe sobre as emendas ao Projecto de Programa.

5 Informe sobre as emendas ao Projecto de Estatutos.

6 Informe sobre a atividade da União dos Estudantes Comunistas (marxista-leninista). 1971.

7 Informe sobre o movimento comunista na Europa.

8 Manifesto do V Congresso.

9 Luta pacífica e luta armada no nosso movimento. $2^{\text {a }}$ ed. 1970.

10 A expulsão dum membro do $C C$ do $P$ “' $C$ ”' $P$.

$11 O$ abandono da aliança operário-camponesa - Expressão do abandono da revolução.

12 Luta de classes ou "Unidade de todos os portugueses honrados"?

13 A propósito do socialismo burocrático $e$ autoritário.

14 A unidade em 1944-1949: uma experiência actual.

15 Combater o chauvinismo imperialista é a base duma efectiva solidariedade com os povos das colónias.

16 Isolar a aniquilar os "sindicatos" fascistas.

17 Tracemos uma linha de demarcação extremamente clara entre marxistasleninistas e revisionistas - Documento de crítica ao castrismo.

18 Só o trabalho comunista pode conduzir à reconstrução do partido.

$19 \mathrm{Na}$ vanguarda do oportunismo e da trapalhice - Guia prático para melhor compreender a brochura dos "vanguardistas".

20 Acerca do afundamento do partido revisionista e das suas tábuas de salvação.

21 Lutemos contra os espiões e provocadores Breve história de alguns casos de provocação no PCP. ( $1^{\mathrm{a}}$ ed. $1952 ; 2^{\mathrm{a}}$ ed. 1971)

22 Sobre o partido revolucionário do proletariado de tipo novo. V. I. Lenin. 
23 Por onde começar? Seguido de Os objectivos imediatos do nosso movimento. V. I. Lenin.

24 Revisionismo em nova embalagem - A burguesia radical do jornal "O Comunista" faz concorrência ao revisionismo de Cunhal.

25 Resposta à manobra provocatória da EDE.

26 A propósito duma provocação do grupo " $A$ Vanguarda".

27 Proposta sobre a linha geral do movimento comunista internacional. Documento do PCC.

28 Origem e evolução das divergências entre a direcção do PCUS e nós. Documento do $P C C$.

29 É a Juguslávia um país socialista? Documento do PCC.

30 Apologistas do neo-colonialismo. Documento do PCC.

31 Duas linhas diferentes no problema da guerra e da paz. Documento do PCC.

32 Coexistência pacífica - Duas linhas diametralmente opostas. Documento do PCC.

36 Stalin, o amigo do povo chinês, seguido de A amizade mais profunda. Mao Tsetung.

40 A simbiose da PIDE com o anarcosindicalismo. 1973.

41 Os "desbravadores em rodagem" da EDE"MRPP" / O "poder duplo" - uma aberração trotskista perfilada pelo “MRPP”. 1973.

45 Resoluções da $3^{\circ}$ Conferência do PCP $(m-l)$.

46 As questões fundamentais do partido no presente. Informe do Secretariado do CC. $3^{a}$ Conferência do PCP (m-l). Vilar. Março (?), 1974.

47 Eliminemos os aspectos negativos do nosso trabalho. Informe do Secretariado do CC. $3^{a}$ Conferência do PCP (m-l). Sá. Março (?), 1974.

\section{Edições do Povo (Porto)}

\section{Coleção Edições do Povo}

1 Sobre a luta contra o revisionismo. Lenine. 1971. Edição de Henrique A. Carneiro. Tradução de A. Pereira. (2 $2^{\mathrm{a}}$ ed. Julho, 1974.)

2 Sobre a guerra prolongada e Problemas da guerra e da estratégia. Mao Tsé-tung. Outubro, 1971. Tradução e edição: A. Pereira.

3 Problemas estratégicos da guerra revolucionária na China e da guerra de guerrilhas contra o Japão. Mao Tsé-tung.
1972.

4 Três anos de execução do plano quinquenal: a situação económica da Rússia e a crise mundial do capitalismo: 1930. José Staline. Agosto, 1974. Edição de Henrique A. Carneiro.

5 Sobre a justa solução das contradições no seio do povo. Mao Tsé-tung. Setembro, 1974. Edição de F. Dinis.

6 Estudemos a teoria marxista-leninista em estreita ligação com a prática revolucionária. Enver Hoxha. Tradução e edição de F. Dinis. Setembro, 1974.

\section{Edições Militão Ribeiro}

Elementos para a história do movimento operário e do Partido Comunista em Portugal. Francisco Martins Rodrigues. Janeiro, 1975.

Os revisionistas continuam especulando com a via pacífica chilena para afastar os povos da revolução. Comentário da Rádio Tirana.

A participação dos revisionistas nos governos burgueses. Comentário da Rádio Tirana.

A fachada democrática e a realidade portuguesa. Comentário da Rádio Tirana.

$O$ revisionismo é o reflexo da influência burguesa sobre o movimento operário. Lenine.

Os princípios do partido em matéria de organização. Extraído da História do PC(b) da URSS.

\section{Edições do Templo (Lisboa)}

Sem coleção

Orgulhosamente muitos... José Dias. 1977.

Introdução à política. António Marques Bessa, Jaime Nogueira Pinto. 1977.

Acuso o Concílio. Monsenhor Lefebvre. 1978.

Salazar. António Ferro; pref. de Oliveira Salazar. 1978.

$A$ arte de continuar português: ensaios e textos polémicos. António Quadros. 1978.

Coleção País Real

Reforma agrária: seara do ódio. João Garin. 1977.

Portugal e agora? Silvino Silvério Marques. 1978.

Portugal à deriva. José Miguel Alarcão Júdice. 1978.

Portugal urgente. Eduardo Freitas da Costa. 
1978.

Para uma nova fundação de Portugal. Eduardo Freitas da Costa. 1978.

Coleção Os Destinos do Ocidente

Os novos primários. Jean-Marie Benoist; trad. de Artur Anselmo. 1978.

\section{Coleção Livro Urgente}

A cabeça: mecanismos e história breve. Hugo de Castro (Jorge de Morais). 1978.

\section{Coleção Autores Portugueses}

A intriga. Afonso Botelho. 2a ed. 1978.

Encruzilhada(s). Maria Manuela Couto Viana. 1979.

Como o sr. Jacob enganou o socialismo. Afonso Botelho. Novembro, 1978.

\section{Coleção Campo Livre}

6 Estrangeirados: um conceito a rever. Jorge Borges de Macedo. 1979.

$8 O$ que é a geopolítica. Alain de Benoist; tradução de Maria Júlia Beirão de Brito. 1978.

9 Ensaio sobre o fim da nossa Idade. António Marques Bessa. 1978.

\section{Edições Roger Delraux (Lisboa)}

$O$ quinto império: romance. Dominique de Roux; trad. Maria Bragança. 1977.

Não! mas sim à Igreja Católica e Romana. Monsenhor Lefebvre; entrevistas com José Hanu. 1978.

Arte de ser português. Teixeira de Pascoais. 1978.

Teoria da indiferença. António Ferro; prefácio de António Ferro. $3^{\mathrm{a}}$ ed. 1979.

Leviana: Novela em fragmentos com um estudo crítico do autor. António Ferro. 1979.

Memórias de um inspector da PIDE. 1. A organização clandestina do PCP. Fernando Gouveia. Janeiro, 1979. Tiragem: 5.000.

Sobre Portugal nestes tempos do fim. André Coyné. Setembro, 1980. Tiragem: 2.000.

Nosografia de D. Sebastião: revisão de um processo clínico. Mário Saraiva. Lisboa: Roger Delraux, 1980.

Coleção Pensadores (dirigida por Gérard Leroux)
Psicologia das multidões. Gustave Le Bon. Setembro, 1980. Tiragem: 3.000.

A contra-revolução. Thomas Molnar. 1980.

Edições Sociais (Lisboa)

História do mundo. A. Z. Manfred. 1977.

Origens e evolução do movimento de capitães: subsídios para uma melhor compreensão. Dinis de Almeida. 2 $2^{\mathrm{a}}$ tiragem. Março, 1977.

Ascensão, apogeu e queda do M.F.A. Diniz de Almeida. Vol. I. 1979. (O segundo volume foi publicado como Edição do Autor).

História da África Contemporânea: da segunda guerra mundial aos nossos dias. Marianne Cornevin. 1979.

\section{Coleção Para Compreender}

A economia capitalista: funcionamento $e$ evolução, contradições e crises. Bernard Marx; trad. H. L. M. s/d.

Álbuns Políticos

1 Retratos de Lenine. Coleção de postais com fotos de Lenine. s/d.

Episódios da Resistência Antifacista Contados por Quantos a Viveram - Dirigida por Franco de Sousa

1 A revolta dos marinheiros. João Borda. 1974.

$2 O$ aniversário do $m / P . B$. Hortência Silva. 1974.

3 Fuga de Caxias no carro blindado do Salazar. Antonio Alexandre Tereso. 1974.

4 Com a certeza de quem quer vencer. Ainda Paula. c1974.

5 Luta de corticeiros. Domingos Fernandes de Carvalho. 1974

6 A raiva de Salazar e da P.I.D.E. contra a unidade democrática representada por Humberto Delgado e outros episódios por mim vividos em 32 anos de luta antifascista. António Horácio Simões de Abreu. 1975.

7 El Paseo - Memórias de um preso político português, na Cadeia de Cárceres, durante a Guerra Civil de Espanha. Manuel Guedes e Franco de Sousa. 1974.

\section{Dossier Revolução}

Elementos para a compreensão do 25 de novembro. Capitão Duran Clemente. Janeiro, 1976. 
Textos de Intervenção

1 A farsa dos pseudo-radicais em Portugal: estudo político e teórico sobre os grupos maoístas e trotskistas perante a revolução. José Manuel Jara. Maio, 1974.

2 Sobre a participação dos trabalhadores na empresa: estudo para reflexão sobre um tema que toma espaço na vida social portuguesa. Sergio Ribeiro. Agosto, 1974.

3 A luta económica dos trabalhadores: estudo das formas da luta económica e da força política que é preciso para vencer. Sérgio Ribeiro (texto, arranjos e adaptações). 1974.

4 Anarquistas de ontem e de hoje. Jacques Duclos; trad. Franco de Sousa. 1974.

5 O marxismo e os caminhos do futuro. Waldeck Rochet. 1975.

6 A opção socialista e a democracia nacional: perspectivas que oferece a opção socialista. Nodari Simonia. Maio, 1975. Tiragem: 5.500 .

7 Maoísmo em Portugal: ideologia anarquista contra-revolucionária e paródia burguesa do marxismo. José Manuel Jara. Julho, 1975. Tiragem: 5.500.

$8 O$ sindicalismo mundial: o Estado de orientação socialista e a democracia. Sérgio Ribeiro. 1975.

9 A história falsificada ao serviço do Maoísmo. F. Burlatski...[et al.]. 1975.

10 O maoísmo contra a cultura. B. Bulatov. 1975.

O Leninismo Hoje

1 Lénine e as forças armadas soviéticas. 1975.

Combatentes do Povo

1 Amílcar Cabral. Anatoli Nikanorov. 1975.

\section{Editorial Divul (Lisboa)}

\section{Coleção Revolução Permanente}

1 A Revolução Chinesa e Indochinesa. Nahuel Moreno e outros. 1975.

20 marxismo e o desenvolvimento na natureza e na sociedade. George Novack. 1974.

Teses de Abril e cartas sobre táctica. Lenine. 1974.

Constituinte e revolução socialista. Lenine (com textos de Trotsky em apêndice). 1975.

Lógica marxista e ciências modernas. Nahuel Moreno. s/d. (Publicação: Argentina: Partido Socialista dos Trabalhadores, 1973)
$O$ debate entre os marxistas-revolucionários sobre a revolução angolana. Secretariado Unificado da Quarta Internacional. Junho/Julho, 1976.

Para compreender Mao e a China popular. Introd. Jaime Gonçalves. Outubro, 1976.

$O$ desenvolvimento desigual e combinado na Rússia: três concepções da Revolução. Leon Trotsky. 1976.

$\underline{\text { Sem coleção }}$

A comuna de Paris - 1871. F. Engels, V. I. Lénine, L. Trotsky. Agosto,

1974

Editorial Notícias (Lisboa)

Coleção Sinal dos Tempos

1 A agonia do franquismo. Andoni Ugarana Larrun.

2 Ângela Davis fala. 1975.

3 Filho do povo. Maurice Thorez. Abril, 1976.

4 A Europa acabou-se. José Alain Fralon.

5 Jimmy Carter ou a irresistível ascenção. Louis Wiznitzer. Abril, 1977.

6 Os jovens marginais: família, trabalho, violência, sexualidade, droga. Gilbert Mury, Vincent de Gaulejac; trad. Serafim Ferreira. 1980.

o 25 de Abril: uma síntese, uma perspectiva. Mário Matos e Lemos. 1986.

Ciência Aberta

1 Ecologia e política. Michel Bosquet. 1976.

6 Capitalismo socialidade participação. Amintore Fanfani. 1982.

7 As grandes questões do nosso tempo. Edgar Morin. 1981.

História do Homem

2 Textos II: Economia. Do homem alienado à sociedade comunista. A luta de classes. Karl Marx; escolh., anot. por Jean Kanapa. Setembro, 1978.

3 Textos. Karl Marx; escolh., anot. por Jean Kanapa. 1978.

Biblioteca de Conhecimentos Básicos

10 O que é ecologia? Dominique Simonet. 
Publicações Escorpião / Textos Exemplares (Porto)

Coleção O Homem e a Sociedade

1 Para uma crítica da economia política. Paul Sweezy, Karl Marx. Março, 1973.

2 Sobre o conceito de consciência de classe. Georg Lukacs, Adam Schaff. Maio, 1973.

3 As raízes da burocracia. Isaac Deutscher. Setembro, 1973.

4 Formações económicas pré-capitalistas. Karl Marx. 1973.

5 Imperialismo: unidade ou rivalidade? Bob Rowthorn. 1973.

6 A re-produção das relações de produção. Henri Lefebvre. Novembro, 1973.

7 Crítica da medicina liberal. Robert Silman/Comité d'Action Santé. 1973.

8 Guia breve da ideologia burguesa. Robin Blackburn. Fevereiro, 1974.

9 A crise internacional do capitalismo. André Granou. Abril, 1974.

10 Divisão social do trabalho, ciência, técnica e modo de produção capitalista. Stephen Maglin, Dominique Pignon e Jean Querzola, Emma Rothschild, André Gorz, Karl Marx. Maio, 1974.

11 Trabalho assalariado e capital. Salário, preço e lucro. Karl Marx. Maio, 1974. $2^{\mathrm{a}} \mathrm{ed}$. 1975.

12 A acumulação primitiva do capital. Karl Marx. 2a ed. Setembro, 1974.

13 A irrupção da moral sexual repressiva. Vol. 1. W. Reich. 1974.

14 Sobre a China. Karl Marx, F. Engels. Novembro, 1974.

15 Elementos para uma pedagogia antiautoritária. Conselho Central dos Jardins de Infância Socialistas de Berlim, Vera Schmidt, W. Reich. 1975.

16 O capital, volume I, livro I (Edição condensada). F. Engels. 1975.

17 Introdução à economia política I. Rosa Luxemburg. $2^{\mathrm{a}}$ ed. Março, 1976. Tiragem: 3.500. $\left(1^{\mathrm{a}}\right.$ ed. 1975$)$

18 A irrupção da moral sexual repressiva. Vol. 2. W. Reich. Maio, 1975. Tiragem: 4.550.

19 Do conceito de alienação ao conceito de mais-valia. Martin Nicolaus.

Da revolução burguesa à revolução proletária. Otto Rühle. Julho, 1975. Tiragem: 4.550.

23 Introdução à economia política III. Rosa Luxemburg. Dezembro, 1975. (2 ${ }^{\mathrm{a}}$ ed. 1976)

24 A dimensão mundial da luta de classes. Samir Amin. Dezembro, 1975.
25 Teoria das classes sociais. Nicos Poulantzas. Maio, 1976.

26 Memória a respeito dos escravos e tráfico da escravatura entre a costa d'África $e$ o Brasil: apresentada à Real Academia das Ciências de Lisboa 1973. Luís António de Oliveira Mendes; pref. de José Capela. Abril, 1977. Tiragem: 4.500.

27 Habitação, cidade, capitalismo: teorias $e$ ideologia urbanística. Fernando Ramón. 1977.

Coleção Editor/Contraditor

1 O papel da violência na história. Friedrich Engels. 1974.

20 que todo revolucionário deve saber sobre a repressão. Victor Serge. Novembro, 1974.

3 Reforma social ou revolução? Rosa Luxemburg. Janeiro, 1975.

4 A questão de Estaline. Lucio Colletti. Dezembro, 1975.

5 Os sindicatos na construção do socialismo. Teses ao X Congresso do PCR (b). Chliapnikov, Lenine, Trotsky. Abril, 1976.

6 Psicopatologia e sociologia da vida sexual 1. Wilhelm Reich. Junho, 1977. Tiragem: 4.500 .

8 Teoria da acumulação capitalista. Mário Cogoy, Paul M. Sweezy. Novembro, 1977.

Biblioteca Ciência e Sociedade

1 Psicologia de massas do fascismo. Wilhelm Reich. 1974.

2 Miséria da filosofia. Karl Marx. 1974.

3 Instituições militares e sociedade de classes. Karl Liebnecht.

$4 \mathrm{O}$ sindicalismo I: teoria, organização, actividade. Karl Marx, Friedrich Engels. Seleção, introdução e notas de Roger Dangeville. Novembro, 1974.

5 O sindicalismo II: conteúdo e significado das reivindicações. Seleção, introdução e notas de Roger Dangeville. Abril, 1975.

6 Imperialismo e economia mundial. Nikolai Bujarin. A PUBLICAR.

7 Lenine e a filosofia. Anton Pannekoek. A PUBLICAR.

8 O partido de classe I: teoria, actividade. Karl Marx, Fr. Engels (seleção e notas de Roger Dangeville). Junho, 1975.

9 O partido de classe II: problemas de organização. Karl Marx, Friedrich Engels (seleção e notas de Roger Dangeville). Outubro, 1975. 
10 Pedagogia socialista. Theo Dietrich. A PUBLICAR.

11 História e consciência de classe: estudos de dialética marxista. Georg Lukács. Dezembro, 1978.

12 Capítulo inédito d'O Capital: resultados do processo de produção imediato. Karl Marx. 1975.

13 O partido de classe III. Karl Marx, Fr. Engels (seleção e notas de Roger Dangeville). A PUBLICAR.

14 Acumulação do capital. Rosa Luxemburg. A PUBLICAR.

15 Divisão social do trabalho e modo de produção capitalista. André Gorz, Karl Marx, Stephen Maglin, Dominique Pignon, Jean Querzola, Marco Maccio, "Il Manifesto", Antonio Lettieri. Seleção e apresentação de André Gorz. Dezembro, 1976.

Eros \& política

2 Revolução sexual na União Soviética 19171944. Trad. Rogério Lima, João Dias. 1976.

3 As comunas: alternativa à família. Josep Maria Carandell. Setembro, 1976. Tiragem: 3.000 .

5 Contra a repressão sexual. Jean-Marie Brohm... [et al.]. 1977.

\section{Sem Coleção}

O corpo da criança: manual para pais $e$ educadores. Editor geral Ruth Midgley. 1978.

\section{Textos Exemplares - Livros publicados:}

1 A reprodução da vida quotidiana. Fredy Perlman. Outubro, 1973. Edição: José M. C. Sousa Ribeiro.

2 Consequências sociais da maquinaria automatizada. Karl Marx, Rudi Supek. Dezembro, 1973. Edição: José M. C. Sousa Ribeiro.

3 A lenda do grande inquisidor. Feodor Dostoievsky. Abril, 1974.

4 Casamento indissolúvel ou relação sexual duradoura? W. Reich, Cl. Alzon. $2^{\mathrm{a}}$ ed. 1975.

5 Crítica dos programas socialistas de Gotha e Erfurt. K. Marx, F. Engels. Julho,

1974. Edição: José M. C. Sousa Ribeiro.

60 que é a consciência de classe? W. Reich. Junho, 1975. Edição: J. M. Amaral.

7 Estado físico e moral dos operários. Louis-
René Villermé. Maio, 1976. Tiragem: 3.500.

8 Pluralismo, totalitarismo e esquerda radical. José Baptista. Julho, 1975. Tiragem: 4550. Edição: J. M. Amaral.

9 Controlo operário e socialismo. Anton Pannekoek. Março, 1976. Edição: J. M. Amaral.

10 O elogio do socialismo. Samir Amin, Paul M. Sweezy. Maio, 1977. Tiragem: 3.000.

\section{Espaço (Braga)}

Delito de corpo. Feliciano Alves. 1974. Potlatch/Edições Espaço.

Luta de classes na China. 1975. Potlatch/Edições Espaço.

O espelho da produção: produção, ideologia, dialéctica. Jean Baudrillard. 1976.

Reflexão sobre a estratégia da luta de classes em Portugal. Anónimo do Século XX. 1976.

Declínio do capitalismo ou declínio da humanidade? Jacques Camatte. Setembro, 1976.

O marxismo e o sistema da economia politica. Jean Baudrillard. Janeiro, 1977.

4 ensaios sobre a mulher. Carlos Castilla del Pino. Fevereiro, 1977. Tiragem: 2.000.

Semiologia - poética - epistemologia. Roman Jakobson. Janeiro, 1978.

Roland Barthes: discurso-escrita, texto. 1979.

\section{Estampa (Lisboa)}

Biblioteca do Socialismo Científico

$1 O$ esquerdismo, doença infantil do comunismo. V. I. Lénine. Dezembro, 1974. ( $2^{\mathrm{a}}$ ed. 1977)

2 Teses de Abril. V. I. Lénine. 1974. 2a ed. 1975.

3 Sobre o papel da mulher na sociedade. V. I. Lénine. 1974; $2^{\mathrm{a}}$ ed. 1975.

4 Acerca das questões do leninismo. Estáline. Janeiro, 1975.

5 Textos filosóficos. Karl Marx. 1975.

6 Textos económicos. Karl Marx. Janeiro, 1975.

7 O problema da habitação. Friedrich Engels. 1975.

8 O que é o marxismo? Vladimir Ilitch Ulianov (Lénine). Fevereiro, 1973. $6^{a}$ ed. Fevereiro, 1975; $8^{\mathrm{a}}$ ed. 1978.

9 Luta sindical e luta política. V. I. Lénine. Fevereiro, 1975.

10 Que fazer? V. I. Lénine. 
11Ludwig Feuerbach e o fim da filosofia alemã e outros textos filosóficos. Marx e Engels.

12 Do socialismo utópico ao socialismo científico. F. Engels. 1971. $5^{\mathrm{a}}$ ed. 1976; $6^{\mathrm{a}}$ ed. 1978.

13 Princípios do comunismo e outros textos. Marx e Engels. 1975.

14 O papel da violência na história. F. Engels. 1975.

15 A sociedade comunista. Marx, Engels e Lénine. 1975.

16 Acerca do partido. Marx, Engels e Lénine. 1975.

17 A cultura e a revolução cultural. V. I. Lénine. Maio, 1975. Tiragem: 5.200.

18 Sobre a juventude. Marx, Engels e Lénine. V. I. Lénine. 1975.

19 A moral dos comunistas. Marx, Engels, Lénine e outros. 1975.

20 As tarefas da revolução. V. I. Lénine. Julho, 1975. Tiragem: 5.200. ( $2^{\mathrm{a}}$ ed. 1978)

$21 O$ estado e a revolução: a doutrina marxista do estado e as tarefas do proletariado na revolução. V. I. Lénine. 1975.

22 O revolucionarismo pequeno-burguês. V. I. Lénine. 1975.

23 A revolução proletária e o renegado Kautsky. V. I. Lénine. 1975.

24 O imperialismo, fase final do capitalismo. V. I. Lénine. 1975.

25 O marxismo e a insurreição. V. I. Lénine. Julho, 1975. Tiragem: 5.200.

26 Sobre a imprensa e a literatura. V. I. Lénine. 1975.

27 Quem são os "Amigos do Povo" e como lutam contra os sociais-democratas. V. I. Lénine. Julho, 1975. Tiragem: 5.200.

28 Pela revolução democrática e nacional. Álvaro Cunhal. 1975.

29 Manifesto do Partido Comunista. Marx e Engels. 1975.

30 A questão militar e o trabalho político nas forças armadas. V. I. Lénine. 1975.

31 As duas tácticas da social-democracia na revolução democrática. V. I. Lénine. 1975.

32 A transformação socialista da agricultura. V. I. Lénine. 1975.

33 Fundamentos do leninismo. Estáline. 1975.

34 A catástrofe iminente e os meios de a combater. V. I. Lénine. 1975.

35 Sobre o materialismo dialéctico e histórico. Estáline. 1975; 2 ${ }^{\mathrm{a}}$ ed. 1978.

36 Feuerbach: a oposição entre as concepções materialista e idealista. Marx e Engels. 1975.

37 Sobre o direito dasd nações disporem de si próprias. V. I. Lénine. 1975.

38 O salário, o preço e o lucro. Karl Marx. 1975.

39 Um passo em frente dois à retaguarda. V. I. Lénine. Novembro, 1975. Tiragem: 5.200.

40 Sobre o internacionalismo proletário e o nacionalismo burguês. 1975.

41 Sobre a coexistência pacífica. Lenine. 1975.

42 As lutas de classes em França. Karl Marx. 1975.

43 Crítica dos programas de Gotha e de Erfurt. Karl Marx, Friedrich Engels. 1975.

44 O 18 de Brumário de Luís Bonaparte. Karl Marx. 1976.

45 Revolução e contra-revolução na Alemanha. Friedrich Engels. 1976.

46 Sobre a revolução democrática burguesa. Lenine. 1976.

47 O controle operário e a nacionalização da indústria. Lenine. 1976.

48 As questões fundamentais do marxismo. Jorge Plékhanov. 1976.

49 Sobre os princípios de organização do partido do proletariado. Lenine. 1976.

50 Miséria da filosofia. Karl Marx. 1978.

51 A guerra civil em França. Karl Marx. 1976.

52 O trabalho do partido entre as massas. V. I. Lénine. 1975

53 Sobre o verbalismo pseudo-revolucionário. V. I. Lenine. 1976.

54 A acumulação primitiva. Karl Marx. 1977.

55 Textos escolhidos. Rosa Luxemburg. 1977.

$56 O$ direito à preguiça e outros textos. Paul Lafargue. Agosto, 1977. Tiragem: 3.200.

57 Sobre a aliança da classe operária e do campesinato. V. I. Lenine. 1977.

58 Sobre o humanismo na sociedade comunista. Marx, Engels e Lénine. 1977.

59 Sobre os conceitos de democracia e de ditadura. V. I. Lénine. 1977.

61 A sociedade futura. August Bebel. 1978.

62 Sobre a liberdade e a democracia em regime socialista. Marx, Engels, Lénine. 1978.

63 Cartas sobre táctica. V. I. Lénine. 1978.

\section{Coleção Teoria}

1 Lenine e a filosofia. Louis Althusser. Maio, 1970. (2a ed. 1974)

2 Materialismo histórico e história das 
civilizações. A. Pelletier e J. J. Goblot. 1970: $2^{\mathrm{a}}$ ed. 1975.

3 A génese do socialismo científico. Émile Bottigelli. 1971; $3^{\text {a }}$ ed. 1974.

4 Para uma teoria da produção literária. Pierre Macherey. 1971.

5 Materialismo e empirocriticismo. Vladimir Ilitch Ulianov. 1971; $2^{\mathrm{a}}$ ed. 1975.

6 Do socialismo utópico ao socialismo científico. F. Engels. $3^{\mathrm{a}}$ ed. 1974.

7 Sobre literatura e arte. Marx, Engels. 1971; 1974. $3^{\text {a }}$ ed. 1975.

8 Contribuição para a crítica da economia política. Karl Marx. 1971. $5^{\text {a }}$ ed. Dezembro, 1977. Tiragem: 3.000.

9 Sobre a história das ciências. Michel Pécheux Fichant. 1971, 2ª ed. 1977.

10 Reflexos condicionados, inibição e outros textos. I. P. Pavlov.

$11 O$ materialismo histórico no estudo do direito. Georges Sarotte. 1972; $2^{\mathrm{a}}$ ed. 1975.

12 O que é o marxismo. Vladimir Ilitch Ulianov. 1973.

13 Sobre o conceito de modelo. Alain Badiou.

14 Os materialistas da Antiguidade. Paul Nizan. 1972; $2^{\mathrm{a}}$ ed. 1977.

15 Cinema e ideologia. Jean-Patrick Lebel.

16 Ensaios sobre a história do materialismo: D'Holbach, Helvetius, Marx. G. Plékhanov. $2^{\mathrm{a}}$ ed. 1979.

17 Sobre of feudalismo. C.E.R.M. 1973, 1976. $3^{\text {a }}$ ed. 1978.

18 Esboço para uma história do gosto. Galvano Della Volpe.

19 História e verdade. Adam Schaff.

20 Os primeiros filósofos. George Thomson.

21 Obras escolhidas. Vol. 1. António Gramsci. Junho, 1974.

22 Obras escolhidas. Vol. 2. António Gramsci. Julho, 1974.

23 Crítica da ideologia contemporánea. Galvano Della Volpe. 1974.

24 Os primeiros filósofos II. George Tomson.

25 Crítica das concepções filosóficas de Mao Tsé-tung. M. Altaiski e V. Gueórguiev. 1975.

26 Textos escolhidos. Ho Chi Minh. 1975.

27 As lutas de classes em Portugal nos fins da Idade Média. Álvaro Cunhal. Junho, 1975. Tiragem: 10.200 .

28 Análises marxistas da alienação. Lucien Sève. 1975.

29 Para uma crítica marxista da teoria psicanalítica. C. B-Clément, P. Bruno e L.
Sève. 1975

30 O imperialismo hoje. Gus Hall. 1975.

31 As artes plásticas e a política na URSS. Lunatcharsky.

32 Temas militares. F. Engels. 1976.

33 História marxista, história em construção. Pierre Vilar. 1975.

34 Ensino sobre o desenvolvimento da cancepção monista da história. Jorge Plékhanov. $2^{\mathrm{a}}$ ed. 1976.

35 Socialismo e democracia: resposta aos oportunistas. Boris Topornine e Eduard Matchuiski. 1976.

36 Ética proletária e social-democracia: contribuições para a definição dos fundamentos da aliança das classes médias e do proletariado. Michel Clouscard. 1977.

37 Contra o trotskismo. V. I. Lenine. 1977.

38 Lineamentos da história do pensamento científico. Alberto Trebeschi. 1977.

$39 O$ ano mil. Heni Focillon.

40 Ideologia e táctica da social-democracia contemporânea. Janusz W. Golebiowski. 1977.

43 Sobre o colonialismo. Karl Marx, Friedrich Engels. 1978.

45 A sociedade civil burguesa. G. W. F. Hegel; trad. José Saramago. 1979.

47 A transformação da filosofia; seguido de Marx e Lénine perante Hegel. Louis Althusser. 1981.

\section{Coleção Polémica}

1 A guerra do Vietnam. Jorge Santos... [et al.]. 1968.

4 O problema racial nos E.U.A. visto por portugueses. Apres. de Urbano Tavares Rodrigues. 1968.

\section{Coleção Polémica (Nova Série)}

1 A Lei de Imprensa e os jornalistas. 1971.

2 Portugal e a Comuna de Paris. Ana Maria Alves. 1971.

3 A condição da mulher portuguesa. Sergio Ribeiro e outros. Apres. Urbano Tavares Rodrigues. Março, 1972.

4 A leitura e a crítica. Nelson de Matos.

5 O mercado comum: a integração e Portugal. Sergio Ribeiro. $2^{\mathrm{a}}$ ed. Março, 1973. ( $3^{\mathrm{a}}$ ed. 1976; $4^{\mathrm{a}}$ ed. 1978)

6 A origem da $1^{a}$ Internacional em Lisboa. Carlos da Fonseca. Maio, 1973. ( $2^{\mathrm{a}}$ ed. 1976). 
7 Vietname. $O$ Acordo de Paris sobre a Indochina. 1973

8 Sociedades e grupos em Portugal. Maria Belmira Martins. $2^{\mathrm{a}}$ reimp. Março, 1975 (1 ${ }^{\mathrm{a}}$ ed. Outubro, 1973)

9 Comecon. Sergio Ribeiro. 1974.

10 A emigração portuguesa em França. J.A. Pires de Lima. 1974.

11 Para um "dossier" Gulbenkian. Mário Vieira de Carvalho. Novembro, 1974.

12 Política de emergência económica nacional. Júlio da Silva Martins. 1975.

13 Eleições para a Constituinte em processo revolucionário. Vasco Corregedor da Fonseca. Julho, 1975. Tiragem: 5.200.

14 Integração e ruptura operária: capitalismo, associacionismo, socialismo - 1836-1875. Carlos da Fonseca. Novembro, 1975. Tiragem: 5.200.

15 As multinacionais em Portugal. Maria Belmira Martins. Fevereiro, 1976. Tiragem: 5.200 .

16 A música e a luta ideológica. Mário Vieira de Carvalho. Março, 1976. Tiragem: 3.200.

17 BBC versus Portugal: a história de um despedimento político. António Cartaxo, Jorge Ribeiro. 1977.

18 Portugal e a escravatura em áfrica: cronologia do séc. $X V$ ao séc. $X X$. Pedro Ramos de Almeida. 1978.

21 A "nova ordem económica" face a uma política de desenvolvimento internacional. Jorge Pereira de Almeida. 1978.

\section{Clássicos de Bolso}

Reforma ou revolução? Rosa Luxemburg. 1970.

Antologia filosófica. Marx - Engels. 1971. (2 ed. Outubro, 1974. Tiragem: 5.000).

O que é a propriedade. Pierre Joseph Proudhon. 1971; $2^{\mathrm{a}}$ ed. 1975.

Escritos políticos; Simão Bolivar: vida e obra. Simão Bolivar. Compil e introd. de Graciela Sociano. 1977.

\section{Cadernos de Política Internacional}

1 Chile: a etapa necessária. A. Villaverde Cabral, José Garibaldi. Dezembro, 1971.

2 Paquistão. Albano Lima. 1971.

3 Israel. Albano Lima. 1972.

\section{Cadernos Políticos}

1 Anticomunismo e coexistência entre países socialistas e capitalistas. A. Boutenko e outros. Outubro, 1974.

2 O ABC da política. Outubro, 1974.

3 O socialismo científico. Marx, Engels, Lenine. Novembro, 1974; $2^{\mathrm{a}}$ ed. 1975.

4 Contra o revisionismo. M. A. Dynnik. 1974.

5 Os trabalhadores e o capitalismo monopolista do Estado. L. Tarassov, K. Ianov. Dezembro, 1974.

6 Principios do materialismo histórico. Aleksander Spirkine, O. Yakhot.1974.

8 Racismo e imperialismo. Piotr Chastitko. 1974; $2^{\text {a }}$ ed. 1975.

9 Os trotskistas e a juventude. Mikhail Basmanov. 1974.

10 Os comunistas e a social-democracia. V. Vassine, S. Gribanov, I. Undassynov. 1975.

11 Princípios do materialismo dialéctico. A. Spirkine, O. Yakhot. 1975; $2^{\mathrm{a}}$ ed. 1976.

12 Controle operário sobre a produção. Vladimir Alekseevich Vinogradov. 1975.

13 Intelectualidade e individualismo. 1975.

14 A classe operária irá desaparecer? N. Gaouzner. Fevereiro, 1975.

$15 O$ Partido Comunista na sociedade socialista. Gueorgui Chakhnazarov. 1975.

16 História da luta contra o trotskismo: 19031927. Sergei Sergeevitch Dmitriev e Isevolod Viacheslavovich Ivanov. 1975.

17 A fraude Sakarov-Soljenitsine. Gus Hall. 1975.

18 A aliança entre os monopólios e a "clique" militar. Alexandre Deikine. 1975.

19 China: a política económica ao serviço da hegemonico. V. Viatski. 1975.

20 Independência económica e sector público. A. Levkovski. 1975.

21 Doutrina dos "países pobres e paises ricos". Konstantin Petrovitch Ivanov. 1975.

22 Problemas da luta pela unidade do movimento comunista. Aleksandr Sóbolev. 1975.

23 O mercado socialista mundial. V. Shastitko. 1975.

24 Problemas da luta ideológica contemporânea. A. Iakovlev e outros. 1975.

25 O sistema eleitoral soviético. Vital Latov. 1975.

27 Sobre a coexistência pacífica entre os estados dos dois sistemas. Dmitri Tomachevski. 1975.

28 Sobre a "convergência" dos sistemas socialista e capitalista. Lev Abramovich Leontyev. 1975. 
29 Organizações económicas internacionais da comunidade socialista. V. Morozov. 1975.

30 O capitalismo e as consequências sociais da revolução técnica-científica. Nikolai Dmitrievich Gauzner. 1975.

31 Jorge Dimitrov sobre a frente única. Ilia Kiuliovski. Junho, 1975. Tiragem: 5.200.

32 Os kolkhozes cooperativas agrícolas soviéticas. N. Mymrikov. 1975.

33 A economia socialista. Léonide Abalkine. 1975.

34 A emulação socialista. Semião Guershberg. 1975.

36 A Europa-cooperação ou divisão? Vsevolod Kniajinski. 1975.

38 As vantagens da divisão internacional socialista do trabalho. A. Chaparov e Ivan Fomich Motorin. 1975.

40 Lénine: vida e obra. V. Zévine, Georgii Nazarovich Golikou. 1975.

41 A democracia burguesa: teoria e prática. A. Michine. 1975.

43 A aldeia soviética, ontem e hoje. Aleksei Emilianov. 1975.

45 Os comunistas hoje: questões da teoria e da prática do movimento comunista contemporâneo. Boris Leibzon. 1976.

47 O revisionismo de direita. V. Granov. 1976.

48 O leninismo e a revolução cultural. A. Arnoldov. 1976.

49 O nacionalismo, ideologia e política. S. Agaiev, Y. Oganisian. 1976.

50 Como superar o atraso económico. Latif Maksudov. 1976.

52 Organização da indústria e construção na $U$. R. S. S. A. Omarov. 1976.

53 A nacionalização socialista via ao progresso: os primeiros passos do poder dos sovietes para transformar a propriedade privada dos meios de produção em propriedade social. V. Gauriline. 1976.

54 O liberalismo americano: mitos e realidades. A. Valyuzhenich. 1977.

55 A revolução cultural vista de perto. Alexei Jelokhovtse. 1977.

56 A opção africana: orientação socialista do desenvolvimento dos estados africanos. Gleb Staruchenko. 1977.

57 O neomilitarismo. Boris Piaditchev. 1977.

58 Sobre o comunismo científico: questões teóricas e práticas. Boris Datsiuk. 1977.

59 Princípios básicos da organização da agrícultura soviética. V. Abramov. 1978.

60 No labirinto da democracia ocidental. 1978.
$62 O$ ensino na U. R. S. S.: estrutura economia. V. Zhamin. 1978.

63 A República Popular da China e os problemas de fronteiras. 1977.

Cadernos do Povo

Arrendamento rural. Blasco Hugo Fernandes. 1974.

$\underline{\text { Praxis }}$

1 O socialismo sueco. Jacques Arnault. 1970.

2 Colômbia: luta de guerrilhas. Jacobo Arenas. 1971.

3 O mito americano. Eric Gaument. 1971.

$4 O$ trotskismo. Léo Figuères. Abril, 1971.

5 Marxismo e Alemanha Federal: a revolução fetiche. Hans G. Helms. 1971.

6 Há uma esquerda nos E.U.A.? Marcel Rocques. 1971.

7 O que é a C.I.A.? Alain Guerin. 1971.

8 Lénine e a III Internacional. Vladimir Illitch Ulianov. 1971.

9 Sindicatos e luta de classes. Henri Krasucki. $1971 ; 3^{\text {a }}$ ed. 1974.

10 A nacionalização da indústria. Vladimir Vinogradov. 1971.

12 Que fazer? Vladimir Ilitch Ulianov. $2^{\mathrm{a}}$ ed. $1973 ; 5^{\mathrm{a}}$ ed. 1975.

13 Capitalismo, ontem e hoje. Maurice Dobb. 1972.

21 História da propriedade. Jean-Philippe Lévy. 1973.

23 As mulheres assalariadas. 1974.

24 A cooperação, ajuda ou neocolonialismo? Yves Fuchs. 1974

25 A República Democrática Alemã. M. Tailleur, J. Tailleur, B. Di Crescenzo. 1974.

$26 \mathrm{Um}$ ano de fascismo no Chile. Setembro, 1974.

27 Watergate: série negra para a Casa Branca. Claude Kroes. 1974.

28 Presença de Lenine. Georges Cogniot. 1975.

31 Os intelectuais e as lutas de classe. Antoine Casanova, Claude Prévost, Joe Metzger. 1976.

32 Teoria de desideologização: ilusões e realidades. L. Moskvichov. 1976.

35 NEP - política económica de transição para $o$ socialismo. Academia de Ciências da URSS. Abril, 1977. Tiragem: 3.200.

36 A Espanha entre o franquismo $e$ a democracia. Jean Rony. 1977. 
37 Experiências de direcção da indústria na URSS. S. Kamenister. 1977.

38 Os soviéticos: classes e sociedade na U.R. S. $S .1^{\circ}$ v.: Resumo de História Social da U. R. S. S. Francis Cohen. 1977.

39 Os soviéticos: classes e sociedade na $U . R$. S. $S .2^{\circ}$ v.: As classes sociais do socialismo desenvolvido. Francis Cohen. 1977.

40 Os soviéticos: classes e sociedade na U.R. S. $S .3^{\circ}$ v.: Evoluções sociais e democracia. Francis Cohen. 1977.

41 Liberdade, liberdades. Pierre Juquin. 1977.

42 O $22^{\circ}$ Congresso. Louis Althusser. 1978.

43 A função social da linguagem fascista. Lutz Winckler. 1978.

44 A revolução de Outubro e os intelectuais. S. Fedyukine. 1978.

45 A função política da contra-informação imperialista. Albert Norden. 1978.

46 História dos Estados Unidos de 1918 a 1975. N. Sivachyov, E. Yazkov. 1978.

47 A subida de Hitler ao poder: a ditadura e a imprensa. Alfred Grosser; trad. Mário Cesariny. 1979.

49 Marxismo e revolução sexual. Alexandra Kollontai. 1981.

52 A história dos Estados Unidos e o problema negro. R. Ivanov. 1976.

$\underline{\text { Clave }}$

3 As classes sociais. Pierre Laroque. 1967.

4 Capitalismo, ontem e hoje. Maurice Dobb. Outubro, 1967.

7 Os fascismos na história. Henri Lemaitre. Março, 1968.

\section{Biblioteca Estampa}

2 Dicionário filosófico. Ed. lit. M. M. Rosental, P. F. Iudin. 5 vol. 1972.

3 História das ideologias: o capitalismo. Direção de V. S. Pokrovski. 1972. $2^{\mathrm{a}}$ ed. 1973. Abril, 1973. $4^{\mathrm{a}}$ ed. 1977.

4 Manual de economia política. 5 Volumes. K. V. Ostrovitianov, L. A. Leontiev, I. D. Lantiev, L. M. Gatovski, I. I. Kuzminov e V. N. Starovski. 4 ed. Maio, 1976. Tiragem: 4.000. ( $1^{\mathrm{a}}$ ed. Outubro, 1972)

7 A origem do homem. Mikhail Fedorovic Nesturkh. 1972. $2^{\mathrm{a}}$ ed. 1975.

8 A vida sexual da mulher. Pierre Vellay. 1973.

$10 O$ pensamento político. $2^{\circ}$ v.: A decadência grega. Os romanos. Cristianismo e Idade Média. $3^{\circ}$ v.: Os modernos: técnica e utopia, o jusnaturalismo. $4^{\mathrm{o}}$ v.: Superação do jusnaturalismo. $\mathrm{O}$ tradicionalismo. $5^{\mathrm{o}}$ v.: Liberalismo, o socialismo utópico e o socialismo científico. Umberto Cerroni. 7 volumes. 1974, 1975.

12 História da Antiguidade. V. Diakov e S. Kovalev. 3 volumes. 1976.

13 Teoria marxista da educação. Bogdan Suchodolski. 3 volumes. 1976.

14 Introdução ao materialismo dialéctico. II $O$ materialismo histórico. Maurice Corforth. Outubro, 1976. Tiragem: 3.200.

16 O comunismo científico. P. Fédosséev e outros. 1977.

\section{Biblioteca de Economia Contemporânea}

1 Para compreender as crises monetárias. Jacques Kahn. $2^{\text {a }}$ ed. 1973; $3^{\text {a }}$ ed. 1977.

2 A economia mundial capitalista. 2 vol. A fase do monopólio. Christian Palloix. 1975.

3 A economia mundial de iniciativa privada: a fase de monopólio. Christian Palloix. 1975.

4 A troca desigual I. Arghiri Emmanuel. 1976.

5 A troca desigual II. Arghiri Emmanuel. 1976.

6 Os monopólios: ensaio sobre o capital financeiro e a acumulação capitalista. JeanPierre Delilez. 1974; 2a ed. 1976.

7 As firmas multinacionais e o processo de internacionalização. Christian Palloix. Abril, 1974.

8 Crise de energia ou crise política? Bernard di Crescenzo. 1974.

9 A organização científica do trabalho. José M. Vegara.

10 O Império da alta finança I: génese do capitalismo monopolista de Estado nos E.U.A. Vítor Perlo. 1976.

11 O Império da alta finança II. Vítor Perlo.

12 O Império da alta finança III. Vítor Perlo.

13 O modo de produção socialista: ensaio teórico. Maurice Décaillot. 1975.

$14 O$ pensamento económico moderno. Vincenzo Vitello. 1975.

15 As pequenas e médias empresas: a hora da escolha. Jean Chatain, Roger Gaudon, Gny Pelachaud. 1976.

16 O socialismo e a riqueza. E. Lazutkine; trad. José Saramago. Junho, 1976. Tiragem: 3.000 .

17 Desenvolvimento económico e planificação a longo prazo. N. Fedorenko... [et al.]. 1977.

18 Mobilidade do trabalho e acumulação do capital. Jean-Paul de Gaudemar. 1977. 
20 A economia política do capitalismo. G. Tchernikov... [et al.]. 1978.

21 Estudos sobre o capitalismo monopolista de Estado: sua crise e solução. Paul Boccara. 1978.

22 Planificação da economia socialista. L. Berri. 1979.

24 O ciclo económico: novos fenómenos no desenvolvimento económico do capitalismo. S. Menchikov. 1980.

Teses

1 A economia mundial de iniciativa privada. $1^{o}$ v.: A fase de concorrência. Christian Palloix. 1972.

2 A economia mundial de iniciativa privada. $2^{\circ}$ v.: A fase do monopólio. Christian Palloix. 1972.

7 A troca desigual. Arghiri Emmanuel. 1973.

9 Neofascismo e ideologia do desejo. Michel Clouscard. 1974

11 Modo de produção e formação económicosocial. Emilio Sereni e outros. 1974.

15 A universidade necessária. Darcy Ribeiro. 1975.

\section{Biblioteca Básica de Cultura}

3 A sociedade primitiva. V. Diakov, S. Kovalev. 1972.

4 História económica dos Estados Unidos. 1973.

12 Panorama da geografia económica mundial. Vol. 1. C. Spidtchenko. 1974.

13 Panorama da geografia económica mundial. Vol. 2. C. Spidtchenko. 1974.

16 As causas da Primeira Guerra Mundial. Jean Jaurés, Potemkine e outros. 1977.

19 O pensamento económico da burguesia no século XX. Karataev e outros. 1974.

$20 O$ que é a vida. Aleksandr Ivanovich Oparine. 1974.

21 As revoluções de 1848: França, Inglaterra, Alemanha, e Império Austro-Húngaro. Anatoli Efimov, Galkine, Zubok. 1974.

22 As revoluções burguesas: Inglaterra e França. Georgij Andreevich Efimov, Galkine, Zubok. 1974; $2^{\mathrm{a}}$ ed. 1977.

\section{Novas Direcções}

10 Memória. Álvaro Guerra. 1971.

11 Setembro de 1971. Alonso Féria. 1971.

28 Histórias para burgueses. Alonso Ibarrola. 1976.
33 O conto búlgaro contemporâneo. Compil. Comissão Nacional Búlgara para a Unesco. 1977.

34 Porque morreu Eanes. Álvaro Lapa. 1978.

36 A fábrica. Antunes da Silva. 1979.

Imprensa Universitária

2 Formas de exploração do trabalho e relações sociais na Antiguidade Clássica. 1978.

3 História do colonialismo português em África: cronologia. $1^{\mathrm{o}}$ v.: Séc. XV, XVI, XVII e XVIII. Pedro Ramos de Almeida. 1978.

4 História do colonialismo português em África: cronologia. $2^{\circ}$ v.: Séc. XIX. Pedro Ramos de Almeida. 1979.

5 História do colonialismo português em África: cronologia. $3^{\circ}$ v.: Séc. XX. Pedro Ramos de Almeida. 1979.

6 O mundo contemporâneo: 1945-1975. Marcel Pacaut, Paul M. Bouju. 1979.

9 A acumulação mundial: 1492-1789. André Gunder Frank. 1979.

\section{Obras Escolhidas}

1 A unidade popular na luta pelo socialismo. Todor Jivkov. Pref. álvaro Cunhal; trad. José Saramago. 1976.

2 Uma política de unidade ao serviço da paz. Todor Jivkov. 1977.

3 O Partido Comunista na sociedade socialista. Todor Jivkov; trad. José Saramago. 1979.

4 Trabalho e economia, progresso e bem-estar. Todor Jivkov; trad. José Saramago. 1980.

A unidade popular na luta pelo socialismo. Todor Jivkov; trad. José Saramago. 1976.

\section{Biblioteca de Ciências Humanas}

6 A crise da social-democracia. Rosa Luxemburg. $2^{\mathrm{a}}$ ed. 1975.

\section{Mundo Socialista}

História da Checoslováquia socialista: de Gottwald a Husák. 1978.

1 República Democrática Alemã: a construção do socialismo. 1975.

2 Hungria: das origens ao socialismo. András Székely e Tibor Huszár. Maio, 1975. Tiragem: 5.200.

3 Bulgária: trinta anos de revolução socialista. 1975.

4 U. R. S. S. a caminho da sociedade comunista. 1975. Agosto, 1975. Tiragem: 5.200. 
5 A Roménia contemporânea. 1975.

6 Cuba, o socialismo de A a Z. A. Carrel e Georges Fomnial. 1975.

7 A agricultura búlgara na etapa actual. Ivan Pramov; trad. José Saramago. 1976.

8 U. R. S. S.: a agricultura, a indústria, o bemestar. 1976.

9 Como se vive na R. D. A. Andreas Hell. 1976.

10 Polónia: sistema político e desenvolvimento socialista. Michael Sadowski. 1976.

11 República Socialista da Checoslováquia. Zdener Madar. 1976.

12 U.R.R.S.: a ciência, a instrução a cultura. 1976.

13 Roménia: a economia socialista. Constin Murgescu. 1976.

14 República Popular da Mongólia: da libertação nacional à democracia socialista. Jacques Legrand. 1977.

15 A República Popular Democrática da Coreia. Seguido de textos escolhidos de Kim Il Sung, com um prefácio de Etiénne Fajon. J. Suret-Canale, J. E. Vidal. Abril, 1977. Tiragem: 3.200.

16 R.D.A. - 100 perguntas, 100 respostas. 1977.

17 A economia da Polónia contemporânea. Pawel Bozik. 1977.

18 A Bulgária - perguntas e respostas. Petre Bakardjiev. 1978.

\section{$\underline{\text { Sem coleção }}$}

Z. Vassilís Vassilíkos. 1971.

Ensaio sobre a história do materialismo. Coment. Georgij Valentinovitch Plékhanov. 1973.

Problemas da industrialização dos países em vias de desenvolvimento. Manuela Barreto. 1975.

Literatura e luta de classes - Soeiro Pereira Gomes. Augusto da Costa Dias. 1975.

Obras escolhidas. Georgi Dimitrov. 1976.

História da Segunda Guerra Mundial na Frente Leste. Instituto do Marxismo-Leninismo. 1978.

Ao que isto chegou: feira portuguesa de opinião. 1978.

O eurocomunismo. J. Kanapa e outros. 1981.

\section{Estrela Vermelha (Porto)}

Coleção Cadernos

1 Discurso de Tem Siao-Pim, chefe da Delagação da República Popular da China, na sessão extraordinária na Assembleia Geral da ONU (10 de Abril de 1974). Tem Siao-Pim. Agosto, 1974.

2 Sobre a ditadura democrática popular. Mao Tsé-tung.

3 Os ensinamentos da Insurreição de Moscovo: Agosto de 1906; O programa militar da Revolução Proletária: Setembro de 1916. 1974.

\section{Cadernos de Teoria Política}

1 URSS-China: o revisionismo e o marxismoleninismo.PCUS, PCC. Novembro, 1974.

2 Imperialismo e social-imperialismo. Renmin Ribao, Hongqi, Mao Tse-Tung, Che Kiun, Jiefangjun Bao. Janeiro, 1975.

3 O pseudo comunismo de Kruchev. Renmin Ribao, Hongqi, Ramiz Alia, Mao Tsé-tung. Janeiro, 1975.

4-5 O partido do trabalho da Albânia em luta contra o revisionismo moderno: discursos $e$ artigos. Enver Hoxha, Zeri i Popullit. 1975.

\section{Coleção China - Albânia}

125 anos de lutas e vitórias na via do socialismo. Enver Hoxha.

\section{Estúdios Cor (Lisboa)}

Novas Cartas Portuguesas. Maria Isabel Barreno, Maria Teresa Horta e Maria Velho da Costa. Abril, 1972.

Ideias e factos na actividade industrial portuguesa: Coletânea dos artigos publicados em "O Primeiro de Janeiro" de 1972. Ferreira do Amaral. Março, 1972.

A desobediência civil. Henry David Thoreau. 1972.

Sobre a liberdade: antologia. Compil. e pref. Romeu de Melo. Janeiro, 1973.

\section{Biblioteca Ciências Sociais}

1 A resposta socialista ao desafio americano. Ernest Mandel. Novembro, 1974.

2 O que é o materialismo dialéctico? O. Yakhot. 1973.

3 Da democracia socialista. Roy Medvedev. Maio, 1974.

4 O capitalismo em causa. Jacques Germain. 1974.

Marx, Freud e a critica da vida quotidiana: para uma revolução cultural permanente. Bruce Brown. Abril, 1980. 
Ideias e formas

1 Introdução à política. Maurice Duverger. 1972.

8 A crise do homem. Karl Bednarik. 1971.

13 A democracia na América. Alexis de Tocqueville. Julho, 1972.

Breviários de Cultura

2 Os negros nos Estados Unidos. Claude Fohlen. 1973.

3 As políticas agrárias. Rolande Gadille. Abril, 1974.

6 História das relações sexuais. André MoraliDaninos. 1974.

7 O conflito sino-soviético. Jacques Lévesque; trad. Leonor Martinho Simões. Outubro, 1974.

$8 O$ materialismo dialéctico. Alexsander Georgievitch Spirkine e Ovshy Yakhot. Janeiro, 1975.

$9 O$ materialismo histórico. Aleksander Georgievitch Spirkine e Ovshy Yakhot. Janeiro, 1975.

10 História da filosofia e das ciências humanas. Roger Mucchielli. 1974.

14 A vida soviética. Gabrielle Froment-Meurice. Março, 1976.

$15 O$ esquerdismo. Henri Arvon; trad. Celeste Andrade. Junho, 1977.

16 A cultura política. Dennis Kavanagh. Março, 1977.

$17 O$ terrorismo político. Paul Wilkinson. Novembro, 1978.

18 A social democracia na Europa do após guerra. William E. Paterson e Ian Campbell. Maio, 1980.

Filósofos de todos os tempos

2 Lukacs ou a frente popular em literatura. Compil. Henri Arvon. Trad. António Borges Coelho. Outubro, 1970.

3 Bakunine ou a vida contra a ciência. Apresentação, escolha de textos e bibliografia por Henri Arvon. Janeiro, 1971.

5 Marcuse ou a busca de um universo transprometeico. Apresentação, biografia e bibliografia por André Nicolas; trad. Franco de Sousa. 1970.

6 Sartre e a realidade humana. Compil. Colette Audry. 1972.

7 Garaudy e o marxismo do século XX. Apresentação, selecção de textos, biografia, bibliografia de Serge Perottino. 1972.

O mundo em que vivemos

Um mundo possível. Tibor Mende. Julho, 1965.

12 O socialismo em liberdade. Alfred Sauvy; trad. de António Reis. Dezembro, 1970.

13 História secreta da guerra de Israel. Michel Bar-Zohar. 1970.

\section{Biblioteca do Ano 2000}

5 Depois do petróleo, o dilúvio: ecologia e dialéctica da crise. Afonso Cautela. Março, 1974.

\section{Europa-América (Mem-Martins)}

As eleições de Outubro de 1969. Documentação básica. Coord. João Palma-Ferreira. 1969.

O socialismo: do renascimento aos nossos dias. Claude Willard. 1973.

Cultura e dimensões políticas. Theodorakis. 1975.

A Liga de Paris e a ditadura militar - 19271928. Org. e notas de A. H. de Oliveira Marques. 1976.

O futuro será o socialismo democrático. Mário Saores. 1979.

\section{Biblioteca do Homem e da Mulher}

Aborto: crime ou libertação? Jean Toulat. 1974.

Livros de Bolso

131 Os dez dias que abalaram o mundo. John Reed. Maio, 1976.

Coleção Saber

O sindicalismo no mundo. Georges Lefranc. 1974.

Estudos e Documentos

40 China, de Confúncio a Mao Tsé-Tung. A. dos Santos Matias. 1968.

44 Vietname: Nas duas margens do inferno. Michèle Ray. 1968.

46 Mao Tsé-Tung. Stuart Achram. (Fora de mercado)

47 Situações I. Jean-Paul Sartre. 1968.

48 Situações II. Jean-Paul Sartre. 1968.

49 Ho Chi Minh. Jean Lacouture.

51 A vida e os homens. Ilya Ehrenbourg.

52 História da bomba atómica. Leandro 
Castellani e Luciano Gigante. 1969.

53 América em fogo. James Hepburn.

55 Lisboa, uma cidade em transformação. Keil do Amaral. 1969.

57 O livro negro da ditadura grega. Junho, 1970.

58 A revolução cultural chinesa. Alberto Moravia. Julho, 1970.

64 Socialismo africano. Eduardo dos Santos. Abril, 1971.

67 Situações III. Jean-Paul Sartre. 1971.

69 Situações IV. Jean-Paul Sartre.

75 Os cinco comunismos. Gilles Martinet. 1972.

82 A unidade da oposição à ditadura (19281931). História de Portugal Contemporâneo - Documentos, vol. 1. Direcção de A. H. de Oliveira Marques. Agosto, 1973.

90 A intervenção americana no Chile. Armando Uribe. 1974.

93 O que eu sei de Soljenitsine. Pierre Daix. Dezembro, 1974.

94 Diário de um resistente. Mikis Theodorakis. 1974.

96 As democracias populares (Vol. I - A era de Estaline). François Fejto. 1975.

97 As democracias populares (Vol. II - Depois de Estaline). François Fejto. 1975.

98 A empresa na União Soviética. Erik Egnell e Michel Peissik. 1975.

99 Amanhã, a Espanha: colóquios com Régis Debray e Max Gallo. Santiago Carrillo. Janeiro, 1975.

100 Liberdade e ordem social. Texto integral das conferências e debates dos XXII Encontros Internacionais de Genebra. Marcuse, Raymond Aron e outros. 1975.

101 ITT, o Estado soberano: uma história secreta. Anthony Sampson. Maio, 1975.

104 China, outro modo de viver. Wilfred Burchett. 1975.

105 Depoimento inacabado. Memórias. Vasco da Gama Fernandes. Maio, 1975.

108 Operação "Ogro": como e porquê executamos Carrero Blanco. Julen Aguirre. Julho, 1975.

109 História da repressão sexual. Jos Van Hussel. 1975.

113 Situações VII. Jean-Paul Sartre.

137 Tito: documentos, discursos, mensagens. Outubro, 1977

138 Nas trevas da longa noite: da guerra de Espanha ao campo do Tarrafal. Manuel Firmo. Janeiro, 1978.
154 História do movimento operário e das ideias socialistas em Portugal. I Cronologia. Carlos da Fonseca. c. 1979.

157 História do movimento operário e das ideias socialistas em Portugal. II - Os primeiros congressos operários, 1865-1894. Carlos da Fonseca. s/d.

168 História do movimento operário e das ideias socialistas em Portugal. IV-Greves e agitações operárias, $1^{a}$ parte. Carlos da Fonseca. s/d.

171 O segredo do 25 de Novembro. José Freire Antunes; pref. Vasco Graça Moura. 1980.

184 Memória da reforma agrária. António Barreto. $1^{\circ}$ vol. de A Reforma Agrária, série dirigida por António Barreto. s/d.

186 Conflitos sociais nos campos do sul de Portugal. José Pacheco Pereira. $2^{\circ}$ vol. de A Reforma Agrária, série dirigida por António Barreto. s/d.

187 O direito da terra. Maria José Nogueira Pinto. $3^{\circ}$ vol. de A Reforma Agrária, série dirigida por António Barreto. s/d.

204 Diário da reforma agrária. Teresa Almada. $4^{\text {o }}$ vol. de A Reforma Agrária, série dirigida por António Barreto. s/d.

205 Revolução e instituições: a extinção dos Grémios da Lavoura alentejanos. Manuel de Lucena. $5^{\circ}$ vol. de A Reforma Agrária, série dirigida por António Barreto. s/d.

211 Geografia da reforma agrária. Maria João Costa Macedo. $6^{\circ}$ vol. de A Reforma Agrária, série dirigida por António Barreto. s/d.

225 Anatomia de uma revolução: a reforma agrária em Portugal, 1974-1976. António Barreto. $7^{\circ}$ vol. de A Reforma Agrária, série dirigida por António Barreto. s/d.

Obras de António José Saraiva

3 Maio e a crise da civilização burguesa. Julho, 1970. Tiragem: 5.000 .

\section{Expresso (Lisboa)}

Economia. Mesas redondas Expresso. Antonio Poppe Lopes Cardoso e outros. Janeiro, 1974.

A resistência: subsídios para o estudo da crise político-militar do verão quente de 1975. José Gomes Mota. Julho, 1976.

Relatos da clandestinidade: o PCP visto por dentro. J. A. Silva Marques. Dezembro, 1976.

O caso Delgado: autópsia da Operação 
Outono. Manuel Garcia, Lourdes Maurício. 1977.

O estado da revolução: a Constituição de 1976. Manuel de Lucena. 1978.

O Grupo Estado: análise e listagem completa das sociedades do sector público empresarial. M. Belmira Martins e J. Chaves Rosa. Abril, 1979.

Humberto Delgado: o homem e três épocas. Victor Dimas. Dezembro, 1977.

\section{Forja (Lisboa)}

Seara de vento. Manuel da Fonseca. $3^{\text {a }}$ ed. 1975.

Poemas completos. Manuel da Fonseca. 1975.

Cerromaior. Manuel da Fonseca. 1976.

O fogo e as cinzas. Manuel da Fonseca. 1978.

Aldeia nova. Contos. Manuel da Fonseca. $6^{\text {a }}$ ed. 1978.

Cabeça de porco. Viale Moutinho. 1976.

Memórias de um pequeno camponês. Xosé Neira Vilas. 1977.

Á sombra das palavras. Torres Caeiro. 1977.

A farsa da Europa. Claude Bourdet. 1978.

\section{Cadernos Forja}

1 Chile, autores e réus. Fernando Dil. 1975.

2 Ser jornalista é tomar partido. Mário de Oliveira. Novembro, 1975.

3 O Terceiro Mundo em números. Pierre Jallée. Fevereiro, 1976.

$\underline{\text { Teatro }}$

1 Para um teatro pobre. Jerzy Grotowski. Agosto, 1975.

2 O Living Theatre. Pierre Biner. 1976.

3 Leitura de Brecht. Bernard Dort. Março, 1980. Tiragem: 4.000. ("Edição patrocinada pela Secretaria de Estado da Cultura").

\section{Fronteira (Amadora)}

\section{Coleção Revolução}

1 Livro verde da revolução. Citações de Vasco Gonçalves. Coord. Serafim Ferreira. s/d. Agosto, 1975.

2 Fazer a revolução. Fidel Castro e Otelo Saraiva de Carvalho. 1975.

3 Luta de morte ao imperialismo: construir o socialismo. Che Guevara, Camilo Torres, Carlos Marighella, Ho Chi Minh, Santiago Carrillo, Vasco Gonçalves. 1975.

4 A revolução é de todos. Rumo ao socialismo.
Coord. Serafim Ferreira. Dezembro, 1975. Tiragem: 3.100.

5 Um homem do povo na revolução. Roger Vailland e Raymond Manevy. Fevereiro, 1976. Tiragem: 3.100.

6 Como fizemos a revolução em Outubro. Leão Trotski; trad. Serafim Ferreira. 1976.

7 A revolução russa de 1917 (Preparando a tomada do poder). Lenine. Trad. Serafim Ferreira. Julho, 1976. Tiragem: 3.100.

8 Otelo a força da unidade popular. GDUPs, um amplo movimento popular (as eleições presidenciais de 1976). Coordenação: Serafim Ferreira. Agosto, 1976. Tiragem: 4.100 .

9 A revolução cubana e a contrução do socialismo. Che Guevara; trad. de Serafim Ferreira. 1976.

10 Revolução e repressão: conselhos a um militante revolucionário. Victor Serge; trad. Serafim Ferreira. Outubro, 1976. Tiragem: 3.100 .

11 Revolução Russa e União Soviética: os primeiros anos do Estado Operário. António Gramsci; trad. Serafim Ferreira. 1977.

12 Revolução socialista e internacionalismo proletário: documentos sobre a luta política dos "spartaquistas" na Alemanha. Rosa Luxemburg, Karl Liebkanecht; trad. Serafim Ferreira. 1977.

Prática Política

1 A burocracia nos estados operários. E. Germain (Ernest Mandel). 1975. Agosto, 1975. Tiragem: 3.100.

2 Por um segundo Manifesto Comunista. Fomento Obrero Revolucionário. Setembro, 1975. Tiragem: 3.100. Tradução de Serafim Ferreira.

3 A Comuna de Paris. Marx, Engels, Lenine. 1975.

4 URSS e países de leste: socialismo ou capitalismo? Fernand Charlier. Novembro, 1975. Tiragem: 3.100.

5 Revolução e movimento operário. Paul Sweezy, Emmanuel Terray, Serge Depaquit, Jean-Pierre Vigier. 1976.

6 O socialismo antes de Marx. Serafim Ferreira. 1976.

7 A formação dos intelectuais. António Gramsci. Tradução de Serafim Ferreira. Maio, 1976. Tiragem: 3.100.

8 A teoria e a moral marxista. A. F. Shiskhine.

9 O socialismo e a luta política. Georgij Valentinovitch Plékhanov; trad. Serafim 
Ferreira. 1976.

10 A luta pelo poder: os tempos de 1917. Léon Trotski; trad. de Serafim Ferreira. 1977.

Direito à Cultura

1 Literatura e revolução. Leon Trotski (2 volumes). 1976.

2 Sociologia do capitalismo. Karl Marx. Fevereiro, 1977. Tiragem: 3.100.

3 Revolução e cultura proletária. Victor Serge. 1977.

4 Revolução e reformismo, seguido de A greve geral. Rosa Luxemburg; trad. de Vera Veloso. Abril, 1977.

5 Textos de circunstância seguido de A PIDE nunca existiu. Luís Pacheco. Maio, 1977.

6 Escritos políticos. Marquês de Sade. Tradução Serafim Ferreira. Novembro, 1977.

\section{Coleção Clássicos da Revolução}

1 México Insurrecto. John Reed. Trad. Serafim Ferreira. Julho, 1977. Tiragem: 3.100.

20 espião. Máximo Gorki. Tradução Serafim Ferreira. Outubro, 1977.

$\underline{\text { Poesia e Revolução }}$

1 Maiakovski. Viktor Sklovski. Janeiro, 1978. Tiragem: 2.600 .

2 O poeta descalço. João Apolinário. 1978.

\section{Futura (Lisboa)}

Canto cubano da revolução. Seleção e notas de Manuel Seabra. Dezembro, 1975.

Poemas. Mao Tse-Tung; trad., pref. e notas de Manuel de Seabra. $2^{\mathrm{a}}$ ed. 1974 (1 ${ }^{\mathrm{a}}$ ed. 1972).

Antologia da poesia Soviética. Compil., trad., anot. Manuel de Seabra. Dezembro, 1973.

Antologia da novíssima poesia norteamericana. Compil., trad. e pref. Manuel de Seabra. 1973.

Ir à guerra (romance). Modesto Navarro. 1974.

Barões de fina flor. Modesto Navarro. 1974.

As opiniões que o D. L. teve. José Saramago. Coedição com Seara Nova. 1974.

Novas cartas portuguesas. Maria Isabel Barreno, Maria Teresa Horta, Maria Velho da Costa. Maio, 1974.

Reconhece-se homossexual? W. J. Sengers. 1974.

Poesia da revolução cubana. Anot., compil. e trad. Manuel de Seabra e Joaquim Horta.
1975.

Tratado da tirania. Vittorio Amadeo Alfieri. 1975.

Contos populares chineses. Vol. 6. 1975.

O ano de 1993. José Saramago.

A pedagogia socialista. Bogdan Suchodolski. 1976.

O comunismo europeu: o mito do eurocomunismo. Enzo Bettiza. Maio, 1979.

$\underline{\text { Panfleto }}$

1 O processo das três Marias: defesa de Maria Isabel Barreno. Duarte Vidal. Outubro, 1974.

2 A Espanha após o franquismo. Santiago Carrillo. Janeiro, 1975.

Futuramundi

3 A batalha do meio-ambiente. Jacques Vermier. 1973.

8 O Mercado Comum contra a Europa. Bernard Jaumont, Daniel Lenégre e Michel Rocard. Dezembro, 1974.

\section{Música e Combate}

Memória do canto livre em Portugal. Viale Moutinho. 1975.

Meridianos Futura (Depoimentos, pontos de vista, biografias, aventuras vividas)

Como roubar bancos sem violências. Roderic Knowles. 1974.

Nas prisões dos coronéis. Jean Starakis. Março, 1975.

Samizdat 1: Vozes da oposição soviética. Compilação de George Saunders. 1975.

Samizdat 2: Vozes da oposição soviética. Compilação de George Saunders. Julho, 1976.

Coleção Política

O que é a política. Julien Freud. 1974.

Democracia. Carl Cohen. 1975.

Política Futura

4 Perguntas ao estado socialista. Michel Rocard. Março, 1975.

Mulheres em Luta

Aborto, direito ao nosso corpo. Célia Metrass, Helena de Sá Medeiros, Maria Teresa Horta. 1975. 
vermelha. Chaquiapam. 1976.

\section{Germinal (Lisboa)}

Fora de Coleção

Análise das classes da sociedade chinesa. Mao Tsé-Tung. Novembro, 1974.

Sobre a eliminação das concepções erradas no seio do partido. Mao Tsé-Tung. Novembro, 1974.

Arranquemos à burguesia o véu púdico de "liberdade-igualdade-fraternidade". Dezembro, 1974.

Maior preocupação com a vida das massas e maior atenção aos métodos de trabalho. Mao Tsé-Tung. Novembro, 1974.

Sobre a prática. Mao Tsé-Tung. 1974.

Ser atacado pelo inimigo não é uma coisa má, mas sim uma coisa boa. Mao Tsé-Tung. 1975.

Uma faísca pode incendiar toda a pradaria. Mao Tsé-Tung. Fevereiro, 1975.

Levantemos alto a grande bandeira vermelha do pensamento de Mao Tsé-Tung e participemos activamente na grande revolução cultural socialista. 1975.

Perguntas e respostas sobre a ditadura do proletariado. 1976.

\section{Textos Revolução Democrática Popular}

1 Aos pobres do campo. Lenine. Outubro, 1974. ( $2^{\mathrm{a}}$ ed. Junho, 1975. Tiragem: 5.000)

2 A libertação da mulher albanesa. Enver Hoxha. Março, 1975.

3 Colonialismo e neo-colonialismo. Milo Paskal. 1975.

4 Problemas estratégicos da guerra revolucionária na China. Mao Tsé Tung. 1975.

5 Sobre o problema da cooperação agrícola. Mao Tse-Tung. Julho, 1975. Tiragem: 7.500.

6 A concepção materialista da história. Plékhanov. Julho, 1975. Tiragem: 5.000.

7 A China sem inflação. Ki Ti, Shia Wei, Wang Sing. Agosto, 1975. Tiragem: 5.000.

9 A frente única contra o fascismo e a guerra. Georgi Dimitrov. 1976.

Escola Nova

$1 O$ ensino na Albânia. Enver Hoxha. Maio, 1976. Tiragem, 3.000.

\section{Coleção Lu Sin}

1 A tomada da montanha do tigrel A lanterna

\section{Heptágono (Lisboa)}

Guia jurídico do trabalhador. 1976.

Guia jurídico do trabalhador. 1977.

Guia jurídico do trabalhador. 1978/79.

Guia jurídico da mulher. 1979.

Constituição da Républica Portuguesa: revista e anotada. Anot. de Albertino Antunes, Amadeu Lopes Sabino, Norberto Severino. 1982.

\section{Coleção Análise}

1 Portugal República socialista? Albertino Antunes, Alexandre Manuel, António Amorim e Mário Bacalhau. Setembro, 1975.

Eanes, a solução? Inquérito à situação política. Mário Bacalhau. 1979.

Capitães de Abril. Alexandre Pais e Ribeiro da Silva. 1974.

Polónia, um povo em luta. Jean-Marie Charpentier, Henri Israel; colab. Cesário Borga e José Pedro Castanheira. 1982.

Guia jurídico do morador. Amadeu Lopes Sabino e outros. 1978.

\section{Biblioteca Jurídica}

1 Greve e lock-out na história e na lei. José Revez. 1980.

2 Democracia na empresa: com comentário à Lei das Comissões de Trabalhadores, Lei 46-79 de 12 Setembro. Francisco Marcelo Curto. 1980.

\section{Horizonte (Lisboa)}

URSS 1970. Apontamentos e reflexões de viagem. Henrique de Barros. 1971.

Rumo de Portugal. A Europa ou o Atlântico? Joaquim Barradas de Carvalho. 1974.

As eleições de 25 de Abril: geografia e imagem dos partidos. Jorge Gaspar, Nuno Vitorino. Fevereiro, 1976. Tiragem: 5.200.

As eleições legislativas: algumas perspectivas regionais. Maria Emília Arroz e outros. 1977.

Coleção Horizonte - Direção de Joel Serrão

2 O socialismo e o futuro da península. Vitorino Magalhães Godinho. $3^{\mathrm{a}}$ ed. ampliada, Março, 1970. ( $1^{\text {a }}$ ed. Julho, 1969; $2^{\text {a }}$ ed. 
Setembro, 1969)

4 Do sebastianismo ao socialismo em Portugal. Joel Serrão. $3^{\text {a }}$ ed. 1973.

5 Portugal na balança da Europa: do que tem sido e do que era lhe convém ser na nova ordem de coisas do mundo civilizado. Almeida Garrett; introd. Joel Serrão. 1970.

7 Cooperação agrícola. Henrique de Barros. $3^{\text {a }}$ ed. Dezembro, 1979. (1 ${ }^{\text {a }}$ ed. Janeiro, 1970; $2^{\mathrm{a}}$ ed. Fevereiro, 1978)

11 A situação universitária portuguesa. Adérito de Oliveira Sedas Nunes. 1971.

12 A emigração portuguesa. Joel Serrão. 1971. ( $3^{a}$ ed. 1977)

24 Massa e classe. François Perroux.

27 Uma educação burguesa. Vasco Pulido Valente. 1974.

33 Testemunhos sobre a emigração portuguesa. Antologia. Joel Serrão e outros. 1976.

34 O carácter social da Revolução de 1383. Joel Serrão. 1976.

39 Política e economia: Portugal nos sec. XIX e $X X$. Miriam Halpern Pereira. Novembro, 1979.

40 Problemas de acumulação capitalista em Portugal. José Ribeiro Júnior. 1980.

\section{Coleção Movimento}

1 Introdução às ciências sociais. Pierre Jaccard. 1974.

2 História social do trabalho das origens até aos nossos dias. $1^{\circ}$ vol. Pierre Jaccard. 1974.

3 História social do trabalho das origens até aos nossos dias. $2^{\circ}$ vol. Pierre Jaccard. 1974.

4 O Terceiro Mundo e a luta pela independência económica. N. Simonia. 1975.

13 Problemas fundamentais da integração capitalista. M. Maximova.

14 Dialéctica das vanguardas. E. M. de Melo e Castro. 1976.

15 Socialismo, democracia, ideologia. D. Kérinov e E. Tchénharine. Outubro, 1976.

16 Estética da canção política: alguns problemas. José Barata Moura.

17 Repensar Portugal: reflexões sobre o colonialismo e a descolonização. Victor de Sá. 1977.

21 Uma introdução à economia política. Pierre Salama e Jacques Valier. 1978.

22 A nova lei da reforma agrária. Antonio Lopes Cardoso. Janeiro, 1977.

A questão do Estado na revolução portuguesa: do 25 de Abril de 1974 ao golpe de Tancos.
Ronaldo Guedes da Fonseca. 1983.

23 Palestinianos: os novos judeus. Helena Salem. 1978.

27 A ideologia, os ideólogos e a política: sociologia do conhecimento, ideologia $e$ pensamento político. Daniel de Sousa. Agosto, 1978.

29 Sobre o valor: elementos para uma crítica. Pierre Salama. 1980.

\section{Formação Cooperativa}

1 Como constituir uma cooperativa. Instituto António Sérgio do Sector Cooperativo. 1978.

2 As cooperativas na legislação fiscal. José carlos Gomes Santos. Maio, 1978.

3 O sector cooperativo: ensaio sobre o lugar do homem nas instituições cooperativas $e$ destas na economia. $2^{\circ}$ ed. Outubro, 1980 ( $1^{\circ}$ ed. Março, 1979).

4 Cooperação e cooperadores. J. Dias Agudo. Abril, 1980.

5 Cooperativas de consumo. J. Dias Agudo. 1980.

\section{Coleção Horizonte Universitário}

1 A formação da ciência económica. Henri Denis.

2 Ensaio sobre o desenvolvimento da concepção monista da história. Plekhanov.

4 História geral do socialismo. Vol. I. Direção de Jacques Droz.

5 História geral do socialismo. Vol. II. Direção de Jacques Droz.

6 História geral do socialismo. Vol. III. Direção de Jacques Droz.

7 Posições (1964-1975): Freud e Lacan a filosofia como arma de revolução. Louis Althusser. 1977.

8 Do Portugal do antigo regime ao Portugal oitocentista. $2^{\mathrm{a}}$ ed. Albert Silbert.

9 Da indústria portuguesa do antigo regime ao capitalismo. Antologia. Joel Serrão e Gabriela Martins. Junho, 1978.

16 Marxismo e teoria da personalidade. Lucien Séve. Vol. 1. 1979.

17 Marxismo e teoria da personalidade. Lucien Séve. Vol. 2. 1979.

18 Marxismo e teoria da personalidade. Lucien Séve. Vol. 3. 1979.

19 Liberalismo, socialismo, republicanismo: antologia de pensamento político português. Seleção, introdução e notas de Joel Serrão. 1979. 
Doutrinadores cooperativistas portugueses: subsídios para o estudo do sector cooperativo português. Fernando Ferreira da Costa. Novembro, 1978.

Biblioteca do Educador Profissional

Os professores e a reforma do ensino. Rui Grácio. Novembro, 1973.

29 Educação, acto político. Agostinho dos Reis Monteiro. 1976.

32 A escola na sociedade de classes: o professor primário e o insucesso escolar. Ana Benavente. 1976.

47 Educação popular e processo de consciencialização. Júlio Barreiro. 1978.

\section{Obras Completas de Jaime Cortesão}

1 Os factores democráticos na formação de Portugal. Jaime Cortesão; pref. Vitorino Magalhães Godinho. 1974. ( $3^{\mathrm{a}}$ ed. 1978)

\section{Obras de Victor de Sá}

2 A crise do liberalismo e as primeiras manifestações das ideias socialistas em Portugal (1820-1852). Victor de Sá. 1978.

Coleção Horizonte de Poesia

5 Coração em armas. José Jorge Letria. 1977.

\section{Coleção Dialéctica}

1 Igualitarismo agrário e socialismo utópico na transição do feudalismo para o capitalismo em França no século XVIII. Hernâni A. Resende. 1979.

2 Práxis: a categoria materialista de prática social. organização e selecção de Vasco de Magalhães Vilhena. Vol. 1. 1980.

3 Práxis: a categoria materialista de prática social. organização e selecção de Vasco de Magalhães Vilhena. Vol. 2. 1980.

5 Raízes teóricas da formação doutrinal de Marx e Engels (1842-1846). Compil. Vasco de Magalhães Vilhena. 1981.

Coleção Educação - Estudos e documentos

4 Educação popular em Portugal 1974-1976. Alberto Melo, Ana Benavente. 1979.

\section{Obras de Alexandre Cabral}

6 Memórias de um resistente: narrativa romanceada. Alexandre Cabral. 1980.
Coleção Horizonte jurídico

3 A participação popular na administração da justiça. Sindicato dos Magistrados do Ministério Público. 1982.

\section{Iniciativas Editoriais (Lisboa)}

Dicionário de História de Portugal. Dir. por Joel Serrão. 1963-1971.

Histórias da prisão. Júlio Graça. Março, 1975.

Presos políticos: documentos 1972-1974. Comissão Nacional de Socorro aos Presos Políticos. Fevereiro, 1975.

\section{Coleção Século XX/XXI}

O problema do Terceiro Mundo. Enrique Ruiz Garcia. 1970.

Um proletariado explorador? Charles Bettelheim, Arghiri Emmanuel, Henry Denis, André Granou, Guy Dhuquoïs e Christian Paloix. 1971.

Estado de direito e sociedade democrática. Elias Diaz. 1972.

O livro do rearmamento. Enrique Ruiz Garcia. Maio, 1972.

Inquérito à informação. Manuel Vásquez Montalbán. 1972

A leste, uma sociedade mais justa? Maria José Bandeira. 1973.

A experiência chilena. Entrevistas a dirigentes chilenos feitas por José Fernandes Fafe. 1973.

As classes sociais. $2^{\mathrm{a}}$ ed. Georges Gurvitch. 1973. (2 a ed. 1978)

A traição de Salazar: uma análise dos primeiros anos do fascismo português. Cansado Gonçalves. Outubro, 1974.

O que é ecologia? Michel Cuisin. 1974. (5 $5^{\mathrm{a}} \mathrm{ed}$. 1978)

A socialização da medicina. Compil., anot., pref. Luís Motoso. 1974.

Ler Gramsci. Dominique Grisoni e Robert Maggiori. 1974.

Iniciação ao sindicalismo. Lucien Rioux. Setembro, 1974.

O Capital: conceitos fundamentais. Marta Harnecker. 1975.

A revolução peruana. Juan Velasco Alvarado. Janeiro, 1975.

Reflexão sobre a formação dos homens. José Fernandes Fafe. 1975.

Origens da estratégia frentista. Estaline, Thorez, Togliatti, Manuilsky e Dimitroff. 
1975.

Crise de energia e modo de produção. Louis Puiseux. 1975.

Marx e a pedagogia moderna. Mario Alighiero Manacorda. 1975.

Pequena antologia do anarquismo. Stirner, Bakounine, Kropotkine. 1975.

Portugal correcto e aumentado. Manuel de Lucena. 1975.

O compromisso histórico. Berlinguer, Bufalmi, Cecchi. 1975.

Revolução e perspectiva do direito. Monique Weyl, Roland Weyl. 1975.

A educação em Cuba. Trad. A. Cardoso. 1975.

Balanço da colonização portuguesa. Banha de Andrade... [et al.]. 1975.

Escritos políticos. Ho Chi Minh. 1975.

A grande polémica (I): a revolução permanente de L. Trotsky, G. Procatti, G. Zinoviev, N. Boukharine. 1975.

A grande polémica (II): o socialismo num só país. J. Estaline, G. Procatti, G. Zinoviev, E. Carr. 1975.

Informação de classe. V. I. Lenine. Junho, 1975.

$O$ anticolonialismo europeu. A. Vieira, Karl Marx e outros. 1975.

Episódios da guerra revolucionária. $1^{\circ}$ vol. Che Guevara. Julho, 1975.

Episódios da guerra revolucionária. $2^{\circ}$ vol. Che Guevara. Julho, 1975.

A fome no mundo: onde o imperialismo contempla a sua obra. Ennio Galante, Giuseppe Vitale, Franco Graziosi, Laura Chiti e outros. Julho, 1975.

O combate do presidente Allende. Jorge Timossi. 1975.

Os comités de defesa da revolução. 1975.

Revolução socialista e independência nacional. César Oliveira. Setembro, 1975.

Teoria e prática da empresa multinacional. Paul Sweezy, Harry Magdoff e outros. 1975.

Para ler o Pato Donald. Ariel Dorfman e Armand Mattelard. 1975.

A consciência da mulher, o mundo do homem. Sheila Rowbotham. 1975.

O processo do Leipzig. Jorge Dimitrov. 1975.

Estruturas de dependência. Eduardo Sousa Ferreira. 1975.

Lenine e a questão colonial. Carlos Rafael Rodriguez. 1975.

Acusação ao imperialismo. Pedro Vuskovic. 1975.

Estratégia do terror. Ettore Biocca. 1975.
Os soldados socialistas de Portugal. Márcio Moreira Alves. Dezembro, 1975.

Cartas a Kugelman. Karl Marx. 1975.

Capitalismo periférico e comércio internacional. Samir Amin.

Subdesenvolvimento e revolução. Ruy Mauro Marini. Novembro, 1975.

Armar as massas revolucionárias. Vo Nguyen Giap. Dezembro, 1975.

Sr. Vogt (2 vol.). Karl Marx. 1976.

Teoria e prática da guerrilha. Robert Taber. Junho, 1976. Tiragem: 2.000.

O capitalismo, a família e a vida privada. Eli Zaretsky. 1976.

História da Revolução Russa (3 vol.). Marcel Liebman. 1976.

Os estalinistas (I). Dominique Desanti. Agosto, 1976.

A divisão capitalista do trabalho. A. Gorz, Panzieri e outros. 1976.

Pequena história da economia. Jürgen Kuczynski. Outubro, 1975.

Mulheres, resistência e revolução. Sheila Rowbotham. 1976.

Democracia e revolução. George Novack. 1976.

Educação em revolução. Fidel Castro. 1976.

Breve história do socialismo. vol. 1 (3 vol.). George Lichtheim. Outubro, 1976. Tiragem: 2.000 .

Os trabalhadores contra o capitalismo: curso de economia. Cultura e liberdade. Dezembro, 1976.

O desafio socialista. (2 vol.). Stuart Holland.

A economia política do imperialismo. D. W. Nabudere. 1976

A independência da nação. François Perroux. 1976.

Capitalismo e teoria. Michel Kidron. 1976.

A estrutura agrária portuguesa transformada? A. Bandarra e Nelly Jazra. Dezembro, 1976.

O leninismo sob Lenine: a conquista do poder. Marcel Liebman. 1976.

Crítica do capitalismo quotidiano. Michel Bosquet. 1976.

Origens e formas da emigração. Eduardo Sousa Ferreira. 1976.

Poder militar e socialismo em Portugal. Pierre Naville. 1976.

A crise da revolução: para uma análise do concreto da revolução portuguesa. Eduardo Lourenço, Eduardo Prado Coelho e César Oliveira. Janeiro, 1976.

Uma passagem pela China. J. K. Gallbraith. 
1976.

Cuba: democracia ou ditadura? Marta Harnecker. 1976.

O homem e a cultura. F. Engels, C. Geertz, Z. Bauman e outros. 1976.

Geografia económica marxista. Heinz Bleckert. 1976.

Dossier Palestina. Sami Hadawi. 1976.

Os exércitos na revolução (I). John Ellis.

Sobre o contrato social. Louis Althusser. 1976.

A teia das multinacionais (I). Armand Mattelart. Abril, 1976.

A teia das multinacionais (II). Armand Mattelart. Abril, 1976.

Problemas da transição para o socialismo. Marta Harnecker, P. Vuskovic, P. Sweezy e outros. 1976

Da I República ao Estado Novo. A. Viana Martins.

Raízes históricas do não alinhamento. Edvard Kardlj. Maio, 1976.

Por uma revolução diferente. E. Block, J. Habermas, L. Tadich e outros. 1976.

A contra-revolução científica. Georges Waysand. 1976.

A alternativa da esquerda italiana: o valor estratégico do governo das esquerdas. PDUP / II Manifesto. Junho, 1976.

Lenine, os camponeses e Taylor. Robert Linhart. 1977.

O socialismo e a Europa mediterrânica. Andreas Papandreu; entrev. Enrica Lucarelli. 1977.

Acumulação, dependência e subdesenvolvimento: compreender o subdesenvolvimento para lhe pôr termo. André Gunder Frank. Março, 1977.

Colonos, camponeses e multinacionais. Giovanni Arrighi. 1977.

Elementos de autocrítica. Louis Althusser. Janeiro, 1977. Tiragem: 2.000.

Plano e autogestão. Christian Pierre e Lucien Praire. 1977.

A geografia serve, antes de mais, para fazer a guerra. Yves Lacoste. 1977.

Teoria e prática da reacção. José Carlos Mariátegui. 1977.

Meios de comunicação de massa, ideologias e movimento revolucionário (II). Armand Mattelart. Março, 1977. Tiragem: 2.000.

116 Os marxistas e a política. Vol. 1: Das metamorfoses da revolução: 1843-1917. François Chatelet, Jean-Marie Vincent, Evelyne Pisier-Kouchner. 1977.
117 Os marxistas e a política. Vol. 2. François Chatelet, Jean-Marie Vincent, Evelyne Pisier-Kouchner. 1977.

118 Os marxistas e a política. Vol. 3. François Chatelet, Jean-Marie Vincent, Evelyne Pisier-Kouchner. 1977.

119 A relação homem-mulher na civilização burguesa. Umberto Cerroni. 1977.

120 O marxismo e o crime. Frank Pearce. 1977.

121 A ideologia. Michel Vadé. 1977.

123 O desenvolvimento da economia na China Popular. T. J. Hughes, D. E. T. Luard. 1977.

126 Para compreender a história: visão da história, da Grécia ao marxismo. George Novack. 1977.

127 O socialismo hoje e amanhã. Gilles Martinet. 1977.

128 As duas mortes de Mao Tse-Tung. Hua Lin, Cheng Ying-Hsiang, Claude Cadart. 1977.

Georges Sorel e a revolução do século $X X$. Michel Charzat. 1977.

Os socialistas perante os patrões. François Mitterrand... [et al.]. 1977.

130 A questão rodesiana. Centro de Estudos Africanos da Universidade de Maputo. 1978.

133 A América de Carter. Enrique Ruiz Garcia. 1978.

135 A estratégia do petróleo: o petróleo e o poder político. Enrique Ruiz Garcia. 1978.

136 A lógica em Marx. André Doz... [et al.]; ed. lit. de Jacques d'Hondt. 1978.

137 A aplicação da lei. Nicolas Herpin. 1978.

138 Marxismo e ciências sociais. Martin Shaw. 1978.

139 Quem é o inimigo? Vol. 1: Anatomia do colonialismo. Aquino de Bragança, Immanuel Wallerstein; pref. Melo Antunes. 1978.

140 Quem é o inimigo? Vol. 2: Os movimentos de libertação nacional. Aquino de Bragança, Immanuel Wallerstein; pref. Melo Antunes. 1978.

141 Quem é o inimigo? Vol. 3: A estratégia da libertação. Aquino de Bragança, Immanuel Wallerstein; pref. Melo Antunes. 1978.

142 O infiltrado. Robert Linhart. 1978.

A herança política de Franco. José Amodia. 1978.

A situação da mulher na sociedade portuguesa actual: os preconceitos e a luta pela emancipação. Abílio José Salgado. 1978.

As muletas do capital: critério de nacionalização. Anicet Le Pors. 1978.

Socialismo e democracia. Luciano Gruppi. 
1978.

Pontos de Vista

$1 O$ presidencialismo português. Sidónio Pais, Oliveira Salazar e Marcello Caetano. Selecção e notas de José-Pedro Gonçalves. s/d.

2 Cuba é estalinista? Heberto Padilla, Fidel Castro, Vargas Llosa, Charles Bettelheim, etc. 1971 .

3 Portugal pode viver sem as colónias? Respondem alguns dos melhores economistas portugueses. António Guterres, Augusto Mateus, Eduardo Mesquita Abreu, Ramos da Costa, Gilberto Lindim Ramos, João Martins Pereira, Joaquim Aguiar, Manuel Belo, Manuela Silva, Ulpiano F. Nascimento. Julho, 1974. (2 ${ }^{\mathrm{a}}$ ed. Setembro, 1974)

4 Sobre os sindicatos. Lenine. Agosto, 1974; $2^{\mathrm{a}}$ ed. Novembro, 1974.

5 Sobre o sindicalismo. Marx e Engels. Outubro, 1974.

6 A política dos Estados Unidos em relação à áfrica. Immanuel Wallerstein. 1974.

7 O pensamento político de Salvador Allende. Novembro, 1974.

8 A natureza de classe do 25 de Abril. Depoimentos de Eduardo Ferro Rodrigues, Fernando Piteira Santos e Mário Murteira. Novembro, 1974.

9 Antologia breve. Che Guevara.

1055 dias de uma experiência democrática. Mário Murteira. Janeiro, 1975.

11 A política económica do Governo Provisório. Eugénio Rosa, Francisco Camões e Maia Cadete. Janeiro, 1975.

12 O socialismo e o homem em Cuba. Che Guevara. 1975.

13 Sobre o poder local. Fidel Castro. 1975.

14 Portugal 75: dependência externa e vias de desenvolvimento. João Martins Pereira. Abril, 1975.

15 Kissinger e a Cia. Hernando Pacheco. 1975.

16 A batalha do Panamá. Gen. Omar Torrijos. 1975.

17 Concepção do partido proletário. A. Gramsci. Junho, 1975.

19 A Liga dos Comunistas (1847). Julho, 1975.

20 A juventude e a revolução. Lenine. 1975.

22 O não alinhamento jugoslavo. J. Tito.

23 A crise do capitalismo. Samir Amin. 1975.

26 A crise económica mundial e o Terceiro Mundo. André Gunder Frank. Janeiro, 1976.
29 Aprender as lições do passado para construir o futuro. Jaime Gazmuri. Março, 1976.

Sobre a revolução cultural. Lenine.

Pontos de Vista - Ciência e sociedade

1 Ciência e capitalismo. Alberto Gianquinto. 1975.

Coleção Publicações do Centro de Estudos da Dependência - CEDEP

1 A áfrica Austral em Perspectiva 1. Descolonização e neocolonialismo. 1976.

2 Leituras do imperialismo hoje. Márcio M. Alves. 1977.

3 A áfrica Austral em Perspectiva 2. "A África do Sul e as ex-colónias portuguesas”. Organização e prefácio de Eduardo Sousa Ferreira. Fevereiro, 1977.

4 O poder europeu 1: a emigração portuguesa e o seu contexto internacional. Org., pref. Eduardo de Sousa Ferreira. 1977

5 Empresas multinacionais e internacionalização do capital. 1977.

6 Economia política do desenvolvimento.

7 O negócio da fome. Susan George. Janeiro, 1978.

8 Processo de produção e crise do capitalismo. Christian Palloix. 1978.

Cadernos Políticos de Educação Popular Marta Harnecker e Gabriela Uribe

1 Explorados e exploradores. Junho, 1974.

2 Exploração capitalista. 1974. (3 ${ }^{\mathrm{a}}$ ed. 1978).

3 Monopólios e miséria. $2^{\mathrm{a}}$ ed. Março, 1975. (4 ed. 1978)

4 Luta de classes: as classes sociais em Portugal. $3^{\mathrm{a}}$ ed. 1978.

5 Imperialismo e dependência. Maio, 1975.

6 Capitalismo e socialismo. Março, 1976. Tiragem: 30.000 ( $2^{\mathrm{a}}$ ed. 1978)

7 Socialismo e economia. 1976.

$\underline{\text { Real Imaginário - Em busca das dimensões do }}$ humano

10 massacre. Faure da Rosa.

2 A engrenagem: variações sobre um tema de Sartre. Teatro de José Fernandes Fafe.

3 Operários falam: o trabalho e a vida. Recolha de textos por Júlio Graça. Setembro, 1973.

4 Quero entender o mundo. Keil do Amaral. 1974. 
5 As provocações policiais. Bernard Thomas.

6 Diário de um louco. Lu Sun; trad. Maria da Graça Morais Sarmento. 1976.

7 O céu é a nossa frente. Dinh Thi Nguyen; trad. Maria da Graça Lima Gomes. 1975.

9 A alma do homem sob o socialismo. Oscar Wilde. 1975.

13 Autobiografia de uma mulher emancipada. Alexandra Kollontai. 1976.

Zapata, terra e liberdade. Enrique Ruiz Garcia. Julho, 1976.

Tata-mai-lau: Timor contra o Japão 1941-1945. Francisco Garcia de Brito. 1977.

Moçambique: memórias de uma revolução. John Paul. 1977.

Vinte anos com Togliatti. Mario Spallone. 1978.

\section{O Povo e a Igreja}

Cartas da prisão. Mário Pais de Oliveira. Março, 1975.

Os marxistas e Jesus. Iring Fetscher, Milan Machovec e outros. Fevereiro, 1976.

\section{$\underline{\text { Sinal dos Tempos }}$}

1 A agonia do franquismo. Andoni Larrum Ugarana. 1975.

\section{Portugal Contemporâneo}

Polémica socialista. Compil. e pref. António Barreto, José Medeiros Ferreira. 1975.

Independência para o socialismo. António Barreto. 1975.

\section{Coleção Memória}

$A$ arte de governar. Luiz XIV.

O tribuno do povo. Gago Babeuf. 1977.

O heroi. Baltasar Gracian. 1977.

Como fazer a guerra. Napoleão Bonaparte. Abril, 1976.

13 Cartas de Portugal para Engels e Marx. Recolha, pref., not. César de Oliveira. 1978.

\section{Inova (Porto)}

Presença de Abel Salazar. Vários Autores. 1969.

A Mãe. Máximo Gorki. 1970.

Uma questão sindical (O processo dos metalúrgicos de Lisboa). Seleção, prefácio e edição Francisco Marcelo Curto e Victor Wengorovius. 1970.
Eleições de 1969: documentos eleitorais da Comissão Democrática do Porto. Seleção, prefácio e edição de Virgínia Moura. 1971.

Poemas (1941-1971). Sidónio Muralha. 1971.

Intervenção política: textos integrais. Selec. e ed. Humberto Soeiro; documentos coligidos Eduardo Ribeiro... [et al.]. 1973.

Duas teses antifascistas. Raúl Castro. 1974.

Agricultura e reforma agrária em Portugal: 1974. António Bica. 1975.

\section{Biblioteca Universitária Inova}

20 Progressismo na Europa desde 1789. David Caute; trad. Sérgio Lopes, José Leal de Loureiro. 1968.

3 A economia dos países subdesenvolvidos. Jagdish Bhagwati; trad. por Armando Castro. 1968.

Os Trabalhos e os Dias

2 Lenine (Seguido de Cartas e Documentos). Máximo Gorki. 1971.

Duas Horas de Leitura

Contos soviéticos. Trad. e compil. Egito Gonçalves. 1973.

As Palavras e as Coisas / Secção Documentos Atuais

1 Dossier do conflito israelo-árabe. Pref. de Jean Paul Sartre. 1969.

2 A resistência palestiniana. Gérard Chaliand. 1972.

As Palavras e as Coisas / Secção Filosofia e $\underline{\text { Religião }}$

1Frátria. Diálogo com os católicos (ou talvez. não). Mário Sacramento. Março, 1970.

3 A primavera de Garaudy. Roger Garaudy. 1971.

5 Vaticano II e evolução da Igreja. Antoine Casanova; tradução de Franciso de Melo. 1972.

16 Revolução sexual segundo Reich e Kinsey. Daniel Guérin. 1975.

O marxismo e o problema do homem. C. I. Gulian. Setembro, 1975.

Matamorfoses

6 Memórias de um resistente (Narrativa romanceada). Alexandre Cabral. Dezembro, 1970. 


\section{Situações}

1 Convite para a URSS. Óscar Lopes. $2^{\mathrm{a}}$ ed. s/d.

2 Em defesa do pensamento científico (Um incidente / Os condicionamentos do ensino superior). Armando de Castro. Novembro, 1973.

3 Palavras necessárias: a vida proletária em Portugal de 1872 a 1927. Bento Gonçalves. Edição de Virgínia Moura. $2^{\mathrm{a}}$ ed. Fevereiro, 1973.

4 A resistência em Portugal. José Dias Coelho. Junho, 1974. (2 ${ }^{\mathrm{a}}$ ed. Agosto, 1974)

5 O que é o comunismo? Georges Cogniot. Setembro, 1974.

6 Pequeno dicionário do marxismo. Pierre Masset. Outubro, 1974.

7 Agonia e morte de Lenine. Máximo Gorki e Gerard Walter. Trad. Egito Gonçalves. 1974.

Civilização Portuguesa

4 Ensaios sobre cultura e história. Armando Castro. 1969.

15 Estudos de história sócio-económica de Portugal. Armando Castro. Novembro, 1972.

19 Materiais para a história da questão agrária em Portugal, sec. XIX e XX. Seleção, prefácio e notas de Villaverde Cabral. Setembro, 1974.

\section{Coleção Ofício de Viver}

1 O espião que veio de Israel. Ben Dan. 1969.

5 Sorge, o espião que veio de Moscovo. S. Goliakov e V. Ponizovsky. (Retirado do mercado). 1969.

7 Regresso à suástica? Lord Russell of Liverpool.

8 A palma da mão (Sumário dos dias inquietos). Urbano Tavares Rodrigues.

10 Comandos palestinianos contra Israel. Jacques Mansour Vergès. 1970.

11 Exército de sombras (A luta herócia da Resistência Francesa). Joseph Kessel. 1970.

15 A guerrilha em França (1940-1944). Charles Tillon. s/d.

16 A aventura boliviana. Che Guevara. 1972.

17 Deserto com vozes. Urbano Tavares Rodrigues. 1972.

19 OS 1, Serviços Secretos Soviéticos contra Hitler. Vitor Alexandrov. 1973.

20 Memórias do capitão. João Sarmento Pimentel. $2^{\mathrm{a}}$ ed. Agosto, 1974.
As Mãos e os Frutos

10 Antologia. Pablo Neruda. 1973.

O homem esse desconhecido

14 Os conflitos sexuais da mulher. Héléne Michel Wolfromm. 1975.

$\underline{\text { Retrato em movimento }}$

1 Companheiro Vasco. Setembro, 1977.

\section{Intervenção (Braga-Lisboa)}

Como se faz um fascista: Por que razão os jovens de hoje poderão ser os fascistas de amanhã? Giulio Castelli. 1974.

Votem em mim! Uma sátira hilariante às eleições. W. C. Fields. 1975.

O equívoco do 25 de Abril. Sanches Osório. Agosto, 1975.

Os cravos na ferradura. Fernando Barradas e Ercílio de Azevedo. $4^{\mathrm{a}}$ ed. 1976.

Angola: os vivos e os mortos. Pompílio da Cruz. 1976.

De Conakry ao MDLP: dossier secreto. Alpoim Calvão. 1976.

Moçambique, terra queimada. Jorge Jardim. 1976.

Acuso! Soares, Cunhal, Emídio Guerreiro, Lopes Cardoso na morte de Humberto Delgado. Henrique Cerqueira. Outubro, 1976.

Acuso! Soares, Cunhal, Emídio Guerreiro, Lopes Cardoso na morte de Humberto Delgado: o crime. $2^{\circ}$ vol. Henrique Cerqueira. Fevereiro, 1977.

África: vitória traída. Quatro generais escrevem. J. da Luz Cunha, Kaúlza de Arriaga, Bethencourt Rodrigues e Silvino Silvério Marques. Abril, 1977.

O novíssimo príncipe: análise da revolução. Adriano Moreira. 1977; $3^{\text {a }}$ ed. 1978.

O drama de Timor: relatório da O.N.U. sobre a descolonização. Organização das Nações Unidas; compil. Adriano Moreira. Fevereiro, 1977.

A comédia do poder. Françoise Giroud. 1977.

Revolucionários que eu conheci. Vera Lagoa. 1977.

Livro negro da descolonização. Luis Aguiar. 1977.

A nação abandonada e Nação peregrina em terra alheia. Adriano Moreira. 1977. 
Rodésia: o escândalo das sanções. Jorge Jardim. 1978.

Julgamento dos responsáveis. A chamada “descolonização”. Luiz Aguiar. 1978.

A luta de Moçambique: 1970-1973. Kaúlza de Arriaga. 1978.

O vira-casacas. Fernando Vizcaino Casas. Setembro, 1978.

... e ao terceiro ano ressuscitou! Vizcaino Casas. 1978.

Meninas... à sala! Fernando Vizcaino Casas. s/d.

A cambada: crónicas da liberdade adaptadas $e$ baseadas nos artigos da autora publicados em "O Diabo" - $1^{a}$ fase, "O Sol", "O Pais" e "O Diabo" - $2^{a}$ fase. Vera Lagoa. $2^{\mathrm{a}}$ ed. 1978.

Oposição=0,1\%. As eleições nos países de leste. 1979.

25 de Novembro sem máscara. Pinheiro de Azevedo. 1979.

Diálogos interditos: a política externa portuguesa e a guerra de África. Vol. 1. Franco Nogueira. 1979.

O burro d'oiro. Nuno de Sampayo. 1979.

Dicionário político do ocidente. António Marques Bessa. 1979.

Caso "Angoche": mais um crime impune. Metzner Leone. 1979.

Eanito el estático. Augusto Cid. 1979.

O Superman. Augusto Cid. 1979.

O país das maravilhas. Vasco Pulido Valente. 1979.

O comunismo será solúvel em álcool? Antoine \& Philippe Meyer. 1979.

PREC II: de Junho de 1977 a Novembro de 1978. Augusto Cid. 1979.

O bando de Argel: responsabilidades na descolonização. Patrícia McGowan. 1979.

O último Tarzan. Augusto Cid. 1980.

A queda da India Portuguesa: crónica da invasão e do cativeiro. Carlos A. de Morais. 1980.

Eanes nunca mais! Vera Lagoa. 1980.

O fim do PREC. Augusto Cid. 1980.

Portugal no ano 2000. Coord. Jaime Nogueira Pinto. 1980.

Do 25 de Abril ao 25 de Novembro: memória do tempo perdido. Paradela de Abreu. C1983. (Há nota dizendo que "um grupo de amigos" (miliatres) se cotizou para pagar a produção do livro.)
Coleção Contra a Abstenção

13 boas razões para votar. António Lopes Ribeiro...[et al.]; coord. do jornalista Metzer Leone. 1979.

\section{Jornal de Fundão (Fundão)}

Vale a pena ser deputado? Sá Carneiro, Miller Guerra e Oliveira Dias. Dezembro, 1973.

Partidos políticos: ponto por ponto. Coord. Rogério Carapinha, António Vinagre e Joaquim Couto. Agosto, 1974.

Pide: a historia da repressão. Compil. Alexandre Manuel, Rogério Carapinha, Dias Neves. Junho, 1974.

Os dez dias que abalaram o mundo. John Reed. 1974.

Por onde vai Portugal? Almeida Martins, Cáceres Monteiro e João Vaz. Março, 1975.

Revolução industrial e aceleração da história. Antologia organizada por Joel Serräo, Gabriela Martins. Março, 1977.

O ajuste de contas. Nuno Teixeira Neves. 1974.

A Constituição política de 1976.

\section{Latitude (Porto)}

O Brasil de Carlos Marighela: na senda de Guevara. Selecção e coord. literária de Milton Miranda. Edição do tradutor (A. Abreu). s/d. 1971.

A revolução permanente na Rússia e o socialismo num só país. L. Trotsky. s/d. 1971. Tradução e coordenação de João F. Viegas.

Natureza do Estado soviético. Leon Trotsky. s/d. 1973. Edição do Tradutor (João F. Viegas).

Histórias do tempo da outra senhora. José Viale Moutinho. 1974.

Guia prático de sexo. Michel Mai-Tam e Michel Jossay.

\section{Cadernos Latitude}

1 Salário, preço e lucro. Karl Marx. 1971. Edição do Tradutor (J. Carlos Ramires)

2 O escândalo dos infra-homens. D. Hélder Câmara. c1971. Edição A. Resende.

3 Como fizemos a revolução. Leon Trotsky. 1971.

4 A propósito dos métodos de direcção e outros textos. Mao Tsé-tung. 1972.

5 O capitalismo contra a paz. Dom Hélder Câmara. c1971. Edição de A. Resende. 
Composto e impresso na tipografia Latitude.

Textos Latitude

1 Cinco artigos do presidente Mao Tsetung. s/d. Trad. M. Fernandes. Edição do tradutor.

2 Luta de classes no mundo árabe. Guerra civil na Jordânia. s/d. 1970. Edição de A. Resende. Composto e impresso na tipografia Latitude.

3 As questões nacional e colonial. Lenine. s/d. Edição e tradução de J. Moura. Composto e impresso na tipografia Latitude.

\section{Novo Norte}

$1 O$ nosso amargo cancioneiro. Pref. e coord. José Viale Moutinho. 1972.

\section{Obras Escolhidas de Lenine}

1 O Estado e a revolução. V. I. Ulianov; trad. de J. Ferreira. 1974

2 Esquerdismo, doença infantil do Comunismo. V. I. Lenine; trad. J. Ferreira. 1974.

3 As duas tácticas da social-democracia na revolução-democrática. V. I. Ulianov; trad. de Ferreira de Brito. s/d.

\section{Líber (Lisboa)}

Humberto Delgado: assassinato de um herói. Mariano Robles Romero-Robledo e José António Novaes. 1974.

Mário Soares: um combatente do socialismo. B. Dias Nosty. 1975.

"Dossier" Goa. Vassalo e Silva: a recusa de um sacrifício inútil. Coord. Botelho da Silva. 1975.

11 de Março: o tiro pela culatra. Dinis de Abreu (ccord.). 1975. Tiragem: 10.000.

Bilhetes saloios do templário. Fernanda Leitão. Novembro, 1975. Tiragem: 10.000 .

Cuba, verso e reverso: os Estados Unidos e a revolução castrista. Rosendo Canto Hernández. 1975.

Fraude nos tribunais eclesiásticos. António Aradillas. Março, 1975. Tiragem: 10 mil.

1 ano da jovem democracia portuguesa: saúde a ferida aberta. João Alves da Costa. Abril, 1975. Tiragem: 10.000 .

Salgado Zenha: o homem da liberdade. Rui de Brito. Maio, 1975. Tiragem: 10.000.

Dias de fome e de angústia. Neel Doff. 1975

Acuso Marcelo Caetano. E. Freitas da Costa. Novembro, 1975. Tiragem: 5.000.
Mário Soares, o chanceler português. B. Diaz Nosty. 1975.

Eleições em Abril: diário de campanha. Dinis de Abreu. Maio, 1975. Tiragem: 5.000.

Crónicas do reino. Rui de Brito. Julho, 1975. Tiragem: 5.000.

Watergate: as gravações do presidente. Pelos jornalistas do Washigton Post. $1^{\circ}$ vol. 1975.

Watergate: as gravações do presidente. Pelos jornalistas do Washigton Post. $2^{\circ}$ vol. Março, 1975. Tiragem: 5.000 .

A queda de um presidente. Pelos jornalistas do Washigton Post. $3^{\circ}$ vol. Março, 1975. Tiragem: 5.000.

A sombra de Ho Chi Minh: a derrota norteamericana no Vietname. J. N. Servent. 1976.

A Revolução Cubana na Íbero América. Rosendo Canto Hernández. 1976.

A funda. $7^{\mathrm{o}}$ volume. Artur Portela. Outubro, 1977. Tiragem: 5.000.

Melo Antunes: tempo de ser firme. Maria Manuela Rama e Carlos Plantier. Janeiro, 1976. Tiragem: 10.000 .

Manual de filosofia burguesa: textos acessíveis para reflexão apartidária. Rui de Brito. 1976.

A comuna das Astúrias: 15 dias de poder proletário. B. Diaz Nosty. 1976.

Paz e violência: a hipocrisia do Ocidente. Alexandre Soljenitsyne. 1976.

Figuras que Abril deu. Rui de Brito. 1977.

Viagem no interior do Partido Comunista. André Harris, Alain Sédouy. Março, 1978. Tiragem: 3.500 .

\section{Liber Documento}

Anatomia das palavras. Vasco Gonçalves. Rui de Brito. Fevereiro, 1976. Tiragem: 5.000.

\section{Cadernos de Economia e Ciências Sociais}

Planificação e gestão ao nível do ramo industrial na Europa de Leste. Revue de 1'Est.

Participação e conflitos nas relações de trabalho no universo socialista. Revue de 1'Est. 1975.

A agricultura, base do desenvolvimento em Cuba. David Barkin. 1976.

Chile: livro negro. Hans-Werner Bartsch, Martha Buschmann, Gerhard Stuby e Erich Wulff (eds.). Março, 1976. Tiragem: 5.500. 


\section{Limiar (Porto)}

Problemas e Soluções

1 Monopólios e política antimonopolista no Portugal de hoje. Carlos Pimenta. Abril, 1975.

2 A repressão fascista em Espanha. Org. e tradução: Egito Gonçalves e Luiz Francisco Rebello. Abril, 1975.

3 Urbanismo: uma prática social e política. A. Jacinto Rodrigues. 1976.

4 A educação democrática em perigo: o bloqueio político do MEIC. Raul Gomes. 1977.

$\underline{\text { Literaturas soviéticas }}$

1 Tchapaev. Dimitri Anreievitch Furmanov. 1975.

\section{A Base da História}

1 A aventura boliviana. Che Guevara, Fidel Castro e outros. 1975.

\section{Os Olhos e a Memória}

1 Poemas a Guevara. Sel. e trad. Egito Gonçalves. Janeiro, 1975.

4 Monangola: a jovem poesia angolana. Compil Virgílio Alberto Vieira. 1976.

7 Poemas de resistência chilena. Compil. e trad. de Egito Gonçalves. 1977.

9 Novos poetas russos. Selecção de Tatiana Kúzovleva; trad. e sel. de Manuel de Seabra. 1978.

18 Quatro poetas revolucionários búlgaros. Botev e outros; selecção, trad. e notas Egito Gonçalves. 1982.

\section{Obras de Armando Castro}

1 A evolução económica de Portugal dos séculos XII a XV. Armando Castro. 1975.

2 Teoria do conhecimento científico. Vol. 1. Armando Castro. 1975.

3 A revolução industrial em Portugal no século XIX. Armando Castro. 1976.

4 Teoria do conhecimento científico. Vol. 2. Armando Castro.

5 Estudos de História socio-económica de Portugal. Armando de Castro. $2^{\mathrm{a}}$ ed. Janeiro, 1980.

\section{Literal (Queluz)}

Para a História da Destruição de Portugal
Cravos para Cristina. Sá Pereira. 1976.

O pavoroso caso Timor: Jornal "O Retornado" denuncia ao mundo. Sá Pereira, Adulcino Silva. 1976. Coedição com Selecta.

Acusamos a descolonização: colectânea de cartas do Jornal "O Retornado". 1976. Coedição com Selecta.

25 de Abril: a revolução da vergonha. João M. da Costa Figueira. 1977.

Os Lusíadas no verso e na carne. Jorge de Villalva. 1977.

Angola em chamas... Compil. Sá Pereira. Maio, 1977. Tiragem: 3.200.

Portugal: procura-se. Reis Ventura. 1977.

Vida de refugiados. Manuel Resende. Fevereiro, 1977. Tiragem: 5.000.

Tortura depois de Abril: relato duma jornalista detida em Caxias sem culpa formada. Manuela Preto. 1977.

Eu fui ao fim de Portugal. Rui Palma Carlos. s/d.

Defesa do Ocidente

A liberdade dos comunistas: polícia, prisões $e$ campos soviéticos. Sylvestre M. e Pierre Z. Outubro, 1976.

África do Sul: impressões de uma viagem. Julio Cola Alberich. 1977.

Marx, esse desconhecido: a desastrosa história do fundador do comunismo. Julien d'Arleville. s/d.

A liquidação da social-democracia na Europa de Leste. László Revész. 1977.

Livro negro: instruções secretas para a subversão da sociedade moderna. Tito Kowalski. 1977.

O que Marx não disse. Armando Plebe. 1977.

$\underline{\text { Sem Coleção }}$

Portugal em derrocada: livro negro do 25 de Abril. Selecção de tópicos essenciais, Ultramar-Metrópole. José Dias. s/d.

A independência de Cabinda. Anônimo. 1977.

Moçambique, a escalada do terror. Inácio de Passos. 1977.

Aviltados e traídos: resposta a Costa Gomes. Melo Machado. 1977.

Mflândia: cidade ocupada. Martins Poças. 1977.

Pedradas a sorrir: o outro Abril-epigramas políticos (1974-1977). João Patrício. 1977

A economia portuguesa após o 25 de Abril. M. Teixeira de Melo. 1978. 
Angola, cinco séculos de cristianismo. Manuel Nunes Gabriel. 1978.

Malandros: a evacuação aérea dos portugueses de Angola. João dos Reis. 1978.

Longos Dias. Francisco do Cazal-Ribeiro. 1978.

Cuidado, Carl... António Maria Zorro. 1978.

Investigação Crítica

A reforma agrária nos países comunistas. Laszló Revész. 1977. Coedição com a Editora Selecta.

Exportação de revoluções. Laszló Revész. 1977. Coedição com a Editora Selecta.

\section{Livraria A.I. (Livraria Apostolado da Imprensa) (Lisboa)}

Coleção Ideologia e Fé

1 Socialismos: textos cristãos. Roque Cabral. 1974.

$2 O$ homem: antropologia cristã, antropologia marxista. Émile Rideau. 1974

3 Lutas de classes e sociedade. E. Pousset. Dezembro, 1974.

4 Cristãos socialistas? "Cristãos pelo socialismo”. 1. Opções e teses. Bartolomeo Sorge. 1975.

5 Política à luz da Fé. Roger Heckel e André Manaranche; trad. de António de Castro. 1975.

Princípios fundamentais do marxismoleninismo: unidade e luta dos contrários; passagem da quantidade à qualidade; negação da negação. Baldomero Ortoneda. 1980.

\section{Livraria Júlio Brandão (Vila Nova de Famalicão)}

Cadernos Vanguarda

1 Da prática: de onde vêm as ideias justas. Mao Tse Tung. 1971.

2 Cartas (Sobre o materialismo histórico). Tradução e edição: José Pacheco Pereira. F. Engels. Agosto, 1971. (Fora de mercado)

$3 O$ leninismo e a libertação dos povos oprimidos e outros textos. Tradução e edição Álvaro Machado. Ho Chi Minh. s/d. (Fora de mercado)

$4 O$ revisionismo contemporâneo: significado $e$ funções. Alfred Kosing. Dezembro, 1971. (Fora de mercado). Edição do tradutor.
5 Materialismo dialéctico, materialismo histórico. J. Estaline. 1972. (Fora de mercado)

6 O sionismo e o imperialismo. David Burstein. Abril, 1972. (Tradução de Álvaro Machado; edição do tradutor)

$\underline{\text { Temas Sociais }}$

1 Memórias de um operário. Vol. I. José Silva. Responsável pela edição: Manuel Duarte. 1971.

2 Memórias de um operário. (Após o 28 de Maio e oposição democrática). Vol. II. José Silva. Responsável pela edição: Manuel Duarte. 1971.

3 Questões sobre o movimento operário português e a Revolução Russa de 1917. José Pacheco Pereira. 1975. (Fora de mercado)

História e Filosofia

Questões do leninismo. J. Estaline. 1972. (Fora de mercado)

Princípios do leninismo. J. Estaline. 1972.

\section{Coleção Economia}

Parte dos salários no rendimento nacional. José Gomes e Manuel Ribeiro. Abril, 1972.

Coleção Ensino e pedagogia

1 A política de mão-de-obra barata do Ministério da Educação Nacional. Agostinho Lopes. 1971.

2 Os livros escolares. Costa Carvalho.

3 História do Movimento Associativo dos Professores do Ensino Secundário - 1891 a 1932. Bento Gomes. Janeiro, 1973.

\section{Livraria Ler Editora (Lisboa)}

Coleção Cadernos Maria da Fonte

1 Sobre a repressão. Victor Serge. Trad. João Camacho. 1971.

2 Sobre a emancipação da mulher. Marx, Engels, Lenine e Kollontai. Coordenação de João Camacho. 1971.

3 Citações do presidente Mao Tsé-tung. Março, 1972. Coordenação de João Camacho.

448 anos de fascismo em Portugal. Org. Carme D. Carvalhas. Junho, 1974.

5 A greve. Fernanda Agria. Junho, 1974.

6 Manual político. Partido Africano da Independência da Guiné e Cabo Verde. 
Junho, 1974. ( $1^{\mathrm{a}}$ ed. 1972, PAIGC, Coordenador: António Alves)

7 Textos políticos de Amílcar Cabral. Agosto, 1974. Tiragem: 5.000.

8 Pelas regiões libertadas Guiné (Bissau). Missão Especial da ONU nas regiões libertadas. António Alves (responsável). Setembro, 1974. Tiragem: 5.000.

9 Teses e resoluções do II Congresso da Internacional Comunista. Trad. J. Luciano. Outubro, 1974.

$10 A B C$ do comunismo. Nicolau Bukharin. 1974.

11 III Congresso da Internacional Comunista: Teses sobre a estrutura, os métodos e a acção dos partidos comunistas. Outubro, 1974.

$12 O$ direito das nações disporem de si próprias. Lenine. Outubro, 1974. Tiragem: 5.000 .

13 Resumo da história do Partido do Trabalho da Albânia. Outubro, 1974.

14 Sobre a religião. V. I. Lenine.

15 As teses de Abril. Lenine. Novembro, 1974.

16 Sobre a caricatura do marxismo. V. I. Lenine. Novembro, 1974.

17 Para caracterizar o romantismo económico. Lenine. 1974.

18 Do Estado, poder soviético e outros discursos. Lenine. 1974.

19 Um país de pequenos burgueses. Arsénio Mota. Janeiro, 1975.

20 Pão, tecto e poder: o movimento popular de reivindicação habitacional no Chile (19701973). Ernesto Pastrana e Monica Threlfall. Janeiro, 1975. Tiragem: 5.000.

21 Discursos pronunciados no I, II e III Congressos da Internacional Comunista. V. I. Lenine. Janeiro, 1975. Tiragem: 5.000.

22 Psicanálise e educação. Wilhelm Reich, Vera Schmidt. 1975.

23 A sociedade comunista. K. Marx, F. Engels, Lenine, J. Staline, Politzer. Maio, 1975.

24 A falência da II Internacional. Lenine. 1975.

25 Dicionário do militante operário. Miguel Lemos. Junho, 1975.

\section{Coleção Cadernos Maria da Fonte - B}

1 Sobre a eliminação das concepções erradas no seio do partido. Mao Tsé-Tung. 1974.

2 Sobre a táctica na luta contra o imperialismo japonês. Mao Tsé-Tung; trad. L. M. Vaz Alves. 1974.

3 Intervenções nos colóquios de Ien-An sobre literatura e arte. Mao-Tse-Tung; trad. L. M. Vaz Alves. 1974

4 Problemas da guerra e da estratégia. Mao Tsé-tung. Dezembro, 1974.

5 A nova direcção do P.C.U.S. confessa a sua política de cooperação soviética-norteamericana. Trad. L. M. Vaz Alves. 1974

6 A luta ideológica e a educação do homem novo. Enver Hoxha; trad. de L. M. Vaz Alves. 1974.

7 Sobre o governo de coalizão. Mao Tsé-Tung. Janeiro, 1975.

8 A propósito dos metodos de direcção: organizemo-nos. Mao Tsé-Tung; trad. de L. M. Vaz Alves. 1975.

Sem coleção

Obras escolhidas de Mao Tsetung. Tomo III. Novembro, 1975.

As questões do leninismo. I Vol. J. Staline. Julho, 1975.

A origem do cristianismo. Jacó Abramovitch Lentsman. Maio, 1976.

Textos de guerrilha. Luiz Pacheco; pref. de José João Louro. 1979.

Tempo de resistência. Varela Gomes. Outubro, 1980. Tiragem: 3.500 .

Textos de guerrilha: $2^{a}$ série. Luiz Pacheco; Poema Prefacial de José Correia Tavares; Carta Posfácio de Paulo Eduardo Pacheco. Julho, 1981.

O prof. Bento de Jesus Caraça: presença viva do seu pensamento e da exemplaridade da sua acção cultural e cívica. António de Sequeira Zilhão. 1981. Tiragem: 1.500.

A contra-revolução de fachada socialista: 11 de março - Verão 75 - 5 de setembro. Varela Gomes. Dezembro, 1981.

\section{Livraria Popular de Francisco Franco (Lisboa)}

Grades serradas. Henrique Galvão. 1974.

Diário de Peniche. Henrique Galvão. 1974.

Desalojados: a tragédia nacional dos "retornados", portugueses expulsos de Angola. Romance. António Pires. 1976.

A ultima viagem: o êxodo dos brancos de Angola: romance. António Pires. 1975.

Um ano nas masmorras da Frelimo. Pinho Barreiros. 1977.

Os cubanos e... J. M. Carvalho. 1976.

O terror Gonçalvista. J. M. Carvalho. 1976. 
Como torturavam as SS. J. Bogatsvo. 1979.

\section{Manuel Rodrigues Xavier (Amadora)}

\section{Colecção 70}

1 Revolução e contra-revolução. Karl Marx. Setembro, 1971.

2 Literatura, filosofia e realismo. Máximo Gorki e A. Zdanov.

3 O papel do indivíduo na história. Jorge Plakanov. 1971.

4 Escritos filosóficos e políticos. Marquês de Sade; trad. de Serafim Ferreira. 1971.

5 A formação dos intelectuais. António Gramsci. 1972.

8 Teoria da moral. A. F. Shiskhin; trad. Serafim Ferreira. 1972.

\section{Colecção 74}

1 Revolução e contra-revolução. Karl Marx.

2 Literatura, filosofia e realismo. Máximo Gorki e A. Zdanov.

3 O papel do indivíduo na história. Jorge Plakanov.

4 Escritos filosóficos. Marquês de Sade.

5 A formação dos intelectuais. António Gramsci.

6 Questões de política. Stalin.

8 Teoria da moral. A. F. Shiskhin.

10 O anticomunismo de hoje. W Mader e outros. 1974.

$11 O$ Comunismo científico $e$ seus falsificadores. P. N. Fedoseyev. Novembro, 1974. Tiragem: 3.000 .

12 O método na economia política. Karl Marx. 1974.

13 A concepção marxista sobre escola $e$ educação. Gaspar Jorge Garcia Galló. 1975.

$14 O$ capitalismo contemporáneo: novas realidades e contradições. $\mathrm{N}$. Inozemtsev. Abril, 1975. Tiragem: 3.000.

\section{Maria da Fonte (Lisboa)}

Coleção Textos Marte. Dirigida por Manuel Quirós.

Arte e ciência da guerra. Clausewitz. Novembro, 1973. (2 ${ }^{\mathrm{a}}$ ed. Julho, 1976)

\section{Textos Confronto}

1 Um mundo melhor. Jean Baby. Janeiro, 1974.

\section{Coleção Estudos}

1 A metade do céu: movimento de emancipação da mulher, na China. Claudia Broyelle. $3^{\text {a }}$ ed. Agosto, 1975 ( $1^{\text {a }}$ ed. 1974)

2 Castro/Debray contra o marxismo-leninismo. Antoine Petil. Dezembro, 1974.

3 A transformação socialista da economia nacional na China. Siné Mau Kiao, Sou Sing e Lin Tsé-li. Setembro, 1975.

4 A inteligência no poder. Um mundo novo: a China. Michelle Loi. Fevereiro, 1976.

5 A Revolução Cultural e a organização industrial na China. Charles Bettelheim. Julho, 1976. Tiragem: 3.000 .

Coleção Textos Maria da Fonte - Série A (dirigida por Manuel Quirós e Rui Viegas)

1 Trotsky e o trotskismo. Vários. Outubro, 1973. ( $2^{\mathrm{a}}$ ed. Maio, 1975. Tiragem: 3.000)

2 Marx e os sindicatos: antologia de Marx e Engels sobre o sindicalismo. A. Lesovski. $4^{\mathrm{a}}$ ed. Outubro, 1974.

3 Mao Tsé-tung e a política do partido. Mao Tsé-tung. Maio, 1974. (2 ${ }^{\mathrm{a}}$ ed. Julho, 1975. Tiragem: 5.000)

$4 O$ PTA e a luta contra o revisionismo. Enver Hoxha, Ramiz Alia e Nexhmile Hoxha. 1974.

5 Dimitrov e a luta sindical. George Dimitrov. 1974.

6 Lenine: a vida de um revolucionário. E Yaroslavski.

7 Combater o revisionismo: uma tarefa revolucionária. Enver Hoxha. Janeiro, 1975.

8 Sobre a guerra e a paz. Lenine. Março, 1975.

9 Os sindicatos da classe operária. Lenine. Junho, 1975.

10 As classes, a economia e a Frente Única. Mao Tsé-tung. 1975.

11 Os sindicatos da classe operária (II). Lenine. s/d.

12 A organização comunista. Lenine. 1975.

13 A estratégia e a táctica dos comunistas. J. Staline. 1976.

14 O método e o estilo de trabalho leninistas. Enver Hoxha. 1976.

15 O PTA e a luta de libertação nacional. Enver Hoxha. 1976.

16 Uma linha de luta e de vitória contra o revisionismo krutchevista. Enver Hoxha, Ramiz Alia. 1976.

17 O "esquerdismo", doença infantil do 
comunismo. Lenine.

18 Que fazer? Lenine. Outubro, 1976.

19 Lenine. Staline. 1977.

20 Conhecimento de base do partido: Xangai 1974. Partido Comunista Chinês. Julho, 1977.

21 Teoria e prática da revolução: crítica à teoria dos três mundos. Enver Hoxha. 1978.

\section{Coleção Documentos}

1 Sobre o trabalho de propaganda. Um congresso histórico. Mao Tsé-tung, Chou En-lai e Wang Hong-wen. Março, 1974.

2 A linha política revolucionária do Partido Comunista do Brasil (M-L). Agosto, 1974.

3 Proclamação Programa dos comunistas (bolcheviques) revolucionários soviéticos. Outubro, 1974.

4 Guerra popular: caminho da luta armada no Brasil. Partido Comunista do Brasil. 1974.

5 Programa e estatutos da Internacional Comunista. Maio, 1975.

6 Sobre a experiência da guerra de libertação nacional e o desenvolvimento do Exército de Libertação Nacional da Albânia. Mehemet Sheou. Junho, 1975. Tiragem: 5.000.

7 Temperado no fogo da luta: resumo breve da história do Exército de Libertação Nacional do Povo Albanês (1941-1944). Lefter Kasneci. 1975.

8 Primeiro Congresso do Partido Comunista (ML) da Bélgica.

9 Informe das actividades do CC do PTA. E. Hoxha.

10 História do Partido dos Trabalhadores do Vietname. Novembro, 1975. Tiragem: 3.500.

1150 anos de luta - Partido Comunista do Brasil (ML). 1975.

12 Teoria da construção económica do socialismo. Kim Il Sung. Janeiro, 1976.

13 Escritos I (1920-1954). Ho Chi Minh. Fevereiro, 1975.

14 Escritos II (1954-1969). Ho Chi Minh. 1976.

15 Primeiro Congresso do Partido Comunista de Espanha (ML): informe do Comité Central (I Parte). Março, 1976.

16 Dos presos políticos brasileiros. 1976.

17 II parte do Informe do CC ao I Congresso do Partido Comunista da Espanha (ML).

18 Relatório sobre o V Plano Quinquenal (1971-1975), apresentado ao VI Congresso do Partido do Trabalho da Albânia. Mehmet Shehu.
19 Os quatro primeiros congressos da Internacional Comunista. Vol. 1. 1976.

20 História da revolução de agosto. Setembro, 1976.

21 Política e revolucionarização do partido. Partido Comunista do Brasil. Janeiro, 1977.

22 Três anos de luta contra o fascismo em Espanha (1935-1938). Vol. I. José Diaz. 1977.

23 Três anos de luta contra o fascismo em Espanha (1935-1938). Vol. II. José Diaz. 1977.

24 Três anos de luta contra o fascismo em Espanha (1935-1938). Vol. III. José Diaz. 1977.

25 Posições do Comité Central da Organização dos Marxistas-Leninistas da Grécia. 1978.

26 Discurso pronunciado por Teng Siao-Ping na sessão extraordinária da Assembleia Geral da ONU: 10 de Abril de 1974. 1978.

27 Antologia de crítica a Teng Siao-Ping: artigos seleccionados da revista chinesa Pékin Information. 1978.

28 Antologia de textos de crítica ao bando dos quatro (extraídos da revista chinesa Pékin Information).

Coleção Libertação Nacional - Dirigida por Manuel Quirós

1 Quem é o inimigo? Qual o nosso objectivo? Agostinho Neto. 1974. $1^{\text {a }}$ edição esgotada.

2 Manual político do PAIGC. $1^{\mathrm{a}}$ edição esgotada. 1974.

3 Textos e documentos do MPLA sobre a revolução angolana. Vários. Setembro, 1974.

4 A Frelimo e a revolução em Moçambique. Mondlane, Machel. Fevereiro, 1975.

\section{Coleção Luta Operária}

1 Contra o Governo Provisório. José Staline. Fevereiro, 1975.

2 Relatório sobre a situação internacional. A. Jdanov. 1975.

3 Os comunistas e as eleições. V. I. Lenine. Abril, 1975.

4 Os ensinamentos do Processo de Moscovo 1936.

Textos Manuel Quirós

1 Para a reconstrução do Partido Comunista Marxista Leninista. Manuel Quirós. Novembro, 1975. 
2 A luta contra o subjectivismo no seio do Partido Comunista Chinês-Mao Tsé-tung.

Cultura Popular

1 A filosofia e a arte ao seviço da revolução. $\mathrm{Lu}$ Sin, Michelle Loi, Afredo Uçi, Tcheu KienJen, Jdanov. Julho, 1975.

2 Os tambores da chuva. Ismael Kadaré. 1976.

3 Memo Kovaçi. Dritero Agolli. 1977.

4 A criança-do-inverno. Li Xintian. 1977.

5 A torrente de ferro. Alexandre Serafimovitch. 1977.

8 Sol sobre o rio Sangkan. Ting Ling. 1977. ("Extraído da colecção Romances do Povo, da Editorial Vitória, Ltda., 1956.”)

9 A felicidade. Piotr Pavlenko. 1977.

\section{Nova China}

1 As comunas populares. Charles Bettelheim. Edição conjunta com a Associação (Unificada) de Amizade Portugal-China. Março, 1976.

2 Ensaios filosóficos escolhidos dos operários, camponeses e soldados. Coedição com Associação (Unificada) de Amizade Portugal-China. Julho, 1977.

\section{Sem coleção}

Entre 2 mundos: memórias. Anna Louise Strong (Escrito 1934), 2 volumes. 1978.

\section{Meridiano (Lisboa)}

Da liberdade de imprensa. Alberto Arons de Carvalho e António Monteiro Cardoso. Junho, 1971.

Profissão exilado. Manuel Vinhas. Maio, 1976.

A agricultura alentejana sem solução? José Miguel de Matos Fernandes Franco de Sousa. 1973.

A revolução, floresta de enganos? Fernando de Lemos. Março, 1976.

A dialéctica do sexo. Shulamith Firestone. 1977.

Economia financeira internacional: moeda. Raymond Bertrand. 1978.

\section{Divergência}

O 25 de Novembro. Charles Reeve. Agosto, 1976. (Na página de rosto, o título que aparece é outro, diferente da capa: "Portugal: a concepção golpista da revolução social".)

\section{Cultura Livre}

1 A mulher libertada? Pierrete Sartin. Julho, 1976. Tiragem: 3.000.

4 O fascismo na Europa. Coord. de S. J. Woolf. Julho, 1978. Tiragem: 3.000.

\section{O Homem e o Tempo}

5 O anarquismo: história das ideias e dos movimentos libertários. George Woodcock. Agosto, 1971.

10 O marxismo-leninismo: um compêndio da sua história e teoria. Jean Roux. Outubro, 1973.

\section{Marginália}

2 Hei-de cuspir-vos na campa. Boris Vian. 1977.

\section{Minerva (Lisboa)}

Cadernos Operário Vermelho

1 As massas edificam o socialismo, o partido fálas ganhar consciência. Enver Hoxha. 1974.

2 Sobre a caricatura do marxismo $e$ o "economismo imperialista". Lenine. s/d.

3 O imperialismo e a cisão do socialismo / Aventureirismo revolucionário. Lenine. 1975.

4 Comunicação acerca da posição do proletariado perante a democracia pequenoburguesa / Economia e política na época da ditadura do proletariado. Lenine. 1975.

5 Acerca do infantilismo esquerdista e do espírito pequeno-burguês. Lenine. 1975.

6 Os dirigentes do Partido Comunista da União Soviética são traidores das declarações de 1957 e 1960 / A nova direcção do Partido Comunista da União Soviética confessa a sua política de cooperação com os Estados Unidos. 1975. (PCC)

7 Socialismo pequeno-burguês e socialismo proletário: acerca dos compromissos: acerca da cooperação. Lenine. 1975.

8 Para a revolucionarização ulterior da nossa escola. Enver Hoxha. A revolucionarização do ensino superior na Albânia. Jorgji Sota. 1975.

Textos Operário Vermelho

Materialismo e empirocriticismo. Lénine. Abril, 1975.

Circular do Comité Central do Partido 
Comunista da China / Um grande documento histórico / Decisão do Comité Central do Partido Comunista da China sobre a grande revolução cultural proletária / A propósito da tríplice união revolucionária. Vários. Maio, 1975. (PCC)

Karl Marx / Vicissitudes históricas da doutrina de Karl Marx / O leninismo e o revisionimo contemporáneo / O pseudocomunismo de Kruchtchev e as lições históricas que dá ao mundo. Karl Marx, Lenine. Agosto, 1975. (PCC)

Confúcio, o "sábio" das classes reaccionárias. Yang Jong-Kouo / Alma morta de Confúcio e sonho dos novos czares. Grupo de crítica de massas das universidades de Pequim e Chingjua. Julho, 1975. (PCC)

Os cadernos sobre a dialéctica de Hegel. Lenine. 1975.

Anti-Dühring. Precedido de uma nota biográfica de Lénine sobre Engels. Vol. 1. Friedrich Engels. Novembro, 1975.

Anti-Dühring. Vol. 2. Friedrich Engels. Março, 1976.

Sobre a prática / Sobre a contradição / Contra o liberalismo / A orientação do movimento da juventude / Recrutar em grande número os intelectuais / Sobre a democracia nova / O regime constitucional de democracia nova. Mao Tsé-Tung. $2^{\text {a }}$ ed. Fevereiro, 1976. Tiragem: 3.000.

\section{Minerva de Bolso}

4 Vietname: a chacina de Mylai. John Sack. Fevereiro, 1972.

10 Voragem. Máximo Gorki. 1972.

11 Um socialista insociável. Bernard Shaw. 1972.

33 Citações do presidente Mao Tsetung. Junho, 1974. $3^{\mathrm{a}}$ ed. Maio 1975.

36 As divergências sino-soviéticas (e a actual política externa chinesa). Novembro, 1974.

$\underline{\text { Sem coleção }}$

Marcello e a Nação: ano de eleições de 1973. Ângelo dos Santos. 1973.

A negritude e a luta pelas independências na África Portuguesa. Eduardo dos Santos. 1975.

O que é a Maçonaria. Jorge Ramos. 1975.

Da vida e da obra de Teixeira Gomes. Joaquim António Nunes. 1976.

As flores de Abril: que Novembro endoou. Romance. Daniel Galhardo. 1979.

\section{Moraes (Lisboa)}

Inquérito ao marxismo. Pierre Fougeyrollas. Trad. Rogério Fernandes. 1961.

A escola dos ditadores. Ignazio Silone. 1966.

O movimento dos capitães e o 25 de Abril: 229 dias para derrubar o fascismo. Avelino Rodrigues, Cesario Borga e Mario Cardoso. Novembro, 1974.

Angola: o longo caminho da liberdade. Amadeu José de Freitas. 1975.

Portugal, transição para o socialismo ou capitalismo dependente. Celso Ferreira.

Comunistas e socialistas, a união é um combate. Étienne Fajon. Abril, 1976.

Ensaios de pós-Abril. Urbano Tavares Rodrigues. 1977.

\section{Círculo de Poesia}

69 Canto do amor armado. Thiago de Melo. 1975.

\section{Coleção O Tempo e o Modo}

$1 O$ personalismo. Emmanuel Mounier; trad. João Bénard da Costa. 1960.

4-5 Princípios de uma política humanista. Jacques Maritain. 1960.

8 Introdução ao pensamento de Teilhard de Chardin. Claude Tresmontant; trad. Nuno de Bragança. 1961.

10-11 Medicina e sociedade. Miller Guerra. 1961.

12 O reino da estupidez. Jorge de Sena. 1961.

13-14 Economia e sociedade. François Perroux. 1962.

17 A pessoa e o bem comum. Jacques Maritain. 1962.

18-19 Crescimento económico e sistemas sociais. Mário Murteira. 1962.

20-21 Introdução aos existencialismo. Emmanuel Mounier; trad. de João Bénard da Costa. 1963.

24-25 Socialismo vivo. Jules Moch. 1964.

28 Os estudantes. Pierre Gaudez. Trad. Vasco Pulido Valente. 1965. (Fora de mercado)

29-30 Economia e sociedade em África. Alfredo de Sousa. 1965.

Razões da democracia. Pietro Pavan. 1965.

Ensaios. Miller Guerra. 1965.

34 A empresa socialista na Jugoslávia. Georges Lasserre. 1966. 
37 Crise da democracia, crise da civilização. Jean Lacroix. 1968.

39 Os católicos e a esquerda. Adrian Cunningham e outros. 1968.

Maio 68: inventário de uma rebelião. E. Morin, Cl. Lefort e J.-M. Coudray. 1969.

O marxismo como moral. José Luis Aranguren. 1969.

O fim da utopia. Herbert Marcuse. 1969.

Racismo e luta de classes. James Boggs. 1969.

\section{A Marca do Tempo}

O ofício de revolucionário. Victor Serge. 1968

1917: história de uma revolução. Jean-Paul Ollivier. 1968.

$\underline{\text { Temas e Problemas }}$

Catolicismo de vanguarda: Textos e documentos do catolicismo francês: 1942-1962. JeanMarie Domenach, Robert de Montvalon; pref. António Alçada Baptista. 1965.

As nações proletárias. Pierre Moussa. 1966.

A economia do século XX. François Perroux. 1967.

O erotismo. Georges Bataille. 1968.

Contra os tecnocratas: acabar com a ficção cinetífica. Henri Lefebvre.1968.

A determinação do salário na indústria: ensaio metodológico. Mário Murteira. 1968.

O pensamento de Lénine. Henri Lefebvre. 1969. ( $2^{\mathrm{a}}$ ed. Maio, 1975 . Tiragem: 1.500).

Cristianismo e marxismo no mundo de hoje. Paulus-Gesellschaft. 1969.

15 Sociologia e ideologia do desenvolvimento: estudos e ensaios. Adérito Sedas Nunes. 1969.

Dez mulheres anticonformistas. Julienne Travers. 1970.

Os futuros possíveis. Lucien Gérardin. 1971.

A revolta das mulheres. Jean Mauduit. 1972.

A armadilha da dívida externa: o Fundo Monetário Internacional $e \quad o$ desenvolvimento da dependência. Cheryl Payer. Tiragem: 3.000. 1974.

Introdução aos marxismos. J. B. Fages. Agosto, 1974.

Uma aldeia da China popular. Jan Myrdal. 1975.

Imperialismo e teorias sociológicas do desenvolvimento. Babakar Sine. 1975.

Portugal: os pontos nos ii. Jacques Frémontier. Outubro, 1976. Tiragem: 3.000.
A esquerda armada no Brasil. Antonio Caso. 1976.

A sociedade concentracionária. Claude Boudet. 1976.

Literatura, política e ideologia. Claude Prévost. 1976.

O serviço militar ao serviço de quem? Daniel Pennac. 1976.

China, 25 anos, 25 séculos. Francis Audray. 1976.

O materialismo militante: questões fundamentais do marxismo. G. Plakhanov. 1976.

A terra a quem a trabalha. Gerrard Winstanley. 1976.

Lénine, a arte e a revolução. 3 volumes. JeanMichel Palmier. 1976.

O sistema político chinês no movimento de educação socialista. Yves Viltard. 1976.

Política económica numa sociedade em transição. Mário Murteira. Fevereiro, 1977. Tiragem: 4.000 .

O imperialismo e o fascismo no cinema. Eduardo Geada. 1977.

Cartas à Guiné-Bissau: registos de uma experiência em processo. Paulo Freire. 1977.

O ministro dos negócios estrangeiros: estudo de direito internacional público e de dirieto constitucional comparado. Jorge Campinos. Agosto, 1977. Tiragem: 3.000.

O sistema de organização e gestão socialista: análise crítica das teorias capitalistas de gestão. Vol. 1. Germain Gvichiani. Janeiro, 1977. Tiragem: 3.000 .

O sistema de organização e gestão socialista: análise crítica das teorias capitalistas de gestão. Vol. 2. Germain Gvichiani. Fevereiro, 1977. Tiragem: 3.000.

Arte: produção e revolução proletária. Boris Arvatov. 1977.

Sobre a ditadura do proletariado. Etienne Balibar. 1977.

\section{Actualidade Portuguesa}

Política nacional e relações internacionais. José Pedro Pinto Leite. 1970.

As universidades tradicionais e a sociedade moderna. Miller Guerra. 1970.

Documentos políticos. António Alçada Baptista. 1970.

Algumas reflexões sobre a situação da indústria em Portugal. Domingos Manuel Megre. 1970.

Órgãos da soberania: a Assembleia Nacional - 
um debate. A. Carlos Lima. 1971.

Uma tentativa de participação política. Francisco Sá Carneiro. 1971.

Debate sobre o programa de política económica e social. Melo Antunes, Francisco S. cabral, César Oliveira, L. Ferraz de Carvaloh, J. Martisn, João cravinho e Eugénio Rosa. Maio, 1972. Tiragem: 3.000.A liberalização bloqueada. Francisco Sá Carneiro. 1972.

Progresso na liberdade. Miller Guerra. 1972.

Sedes: dossier 70/72. Emilio Rui Vilar e A. Sousa Gomes. 1973.

Encontro de reflexão política. Magalhães Mota, Oliveira Dias e José da Silva. 1973.

Emigração e despovoamento. Documento de trabalho Sedes. Joaquim Jorge Magalhães Mota, Tomás Duarte da Câmara Oliveira Dias, José da Silva. 1973.

Portugal, para onde vais? Documento de trabalho Sedes. Janeiro, 1974.

Para uma política de saúde. Documento de trabalho Sedes. 1974.

Para uma renovação do desporto nacional. Manuel Sérgio. 1975.

16 S. Tomé e Príncipe: do colonialismo à independência. Introdução e coordenação de Carlos Benigno da Cruz. 1975.

A guerra social em Portugal. Jorge Semprun. 1976.

Mundo Imediato

Violência e consciência. H. Fronsac, M. Clément e P.-R. Rágamey. 1962.

$O$ pentagonismo, substituto do imperialismo. Juan Bosch. 1970.

Marcuse: contestação, filosofia e utopia. J.-M. Domenach, A. Clair e F. Chirpaz. 1970.

Portugal, anos 70. Mário Murteira. 1970.

Inventar o futuro. Danilo Dolci. 1971.

Inverter as instituições. Ivan Illich. 1972.

Um socialismo possível. François Miterrand. Maio, 1973.

Oito pecados mortais da civilização. Konrad Lorenz. 1974.

Revolução ou reforma? Uma confrontação. Herbert Marcuse e Karl Popper. 1974.

Sobre o comunismo. Sergio Ribeiro. Abril, 1975. Tiragem: 5.000 .

Malraux e sartre falam de... Abril, 1976. Tiragem: 3.000 .

A crítica contra Lin Piao e Confúcio. Julho, 1976. Tiragem: 3.000 .

Do capitalismo ao socialismo: necessidade $e$ prática do controlo operário da produção. Alberto Carreira. 1976.

Liberdade, liberdades: reflexões da comissão para uma carta das liberdades. Coord. Robert Badinter; pref. François Mitterrand. 1976.

Os novos feminismos: interrogação para os cristãos? Maria de Lourdes Pintasilgo. 1981.

1984: A esquerda face ao totalitarismo. José Pacheco Pereira e João Carlos Espada. 1984. Tiragem: 3.000 .

Estudos para o Desenvolvimento

1 Comunidade rural ao norte do Tejo. Moisés Espírito Santo. 1980.

2 Rendimento e riqueza desiguais. Manuela Silva e Anabela Santos. 1980.

3 Seminário internacional sobre desenvolvimento económico português num contexto internacional de mudança. Colectivo. 1981.

4 Comportamento religioso da população portuguesa. Luís de França. 1981.

5 Seminário sobre politica educacional num contexto de crise e transformação social. Colectivo. 1981.

6 Norte-Sul: assegurar a sobrevivência. Relatório da Comissão Internacional presidida por Willy Brandt, com prefácio de Mário Soares. Novembro, 1981. Tiragem: 2.000 .

7 Perspectivas da emigração portuguesa para a CEE 1980-1990. H. M. Stahl e outros. 1982.

Análise das disparidades salariais no pós 25 de Abril. Maria Lúcia Leitão, Vera Freitas. Coedição com Instituto de Estudos para o Desenvolvimento. Julho, 1982. Tiragem: 2.000 .

Hoje \& Amanhã

Uma perspectiva sobre Portugal. Francisco Sarsfield Cabral. 1973.

Situação da educação em Portugal. Rogério Fernandes. 1973.

A agricultura portuguesa. José Carvalho Cardoso. Junho, 1973.

O problema do desenvolvimento português. Mário Murteira. 1974.

A economia portuguesa em números. Eugénio Rosa. Julho, 1975. Tiragem: 5.000.

\section{Movimento Operário (Lisboa)}

1 O homem, o capital mais precioso / Para uma 
formação bolchevique. J. Staline. Novembro, 1975.

2 XXII Congresso do $P$ " $C$ ” $F$ (Um congresso social-democrata dos revisionistas franceses) / XXV Congresso do $P$ " $C$ "' US (O congresso dos revisionistas soviéticos, congresso da demagogia e da expansão social-imperialistas). Editoriais do "Zeri i Populit”. Tradução de C. Dionel. 1976.

Obras Escolhidas de Enver Hoxha

Obras escolhidas. Vol. I. Enver Hoxha. Instituto de Estudos Marxistas-Leninistas junto ao Comité Central do Partido do Trabalho da Albânia. Novembro 1941-Novembro 1944. Tradução de C. Dionel. ("Publicadas por decisão do Comité Central do Partido do Trabalho da Albânia"). Maio, 1976.

Obras escolhidas. Vol. II. Enver Hoxha. Instituto de Estudos Marxistas-Leninistas junto ao Comité Central do Partido do Trabalho da Albânia. Janeiro 1945-Outubro 1948. Tradução de C. Dionel. ("Publicadas por decisão do Comité Central do Partido do Trabalho da Albânia”). Abril, 1977.

\section{Multinova (Lisboa)}

\section{Cadernos Multinova}

1 Cristianismo e marxismo. G. Gutierrez, R. Garaudy, G. Ruiz, D. Hélder Câmara, Maria de Lourdes Pintassilgo. Julho, 1974.

2 Fé e política. Y. Jolif, G. Casalis e P. Blanquar. Apres. José Felicidade Alves. Julho, 1974.

3 O crucificado e a sua igreja. Ernst Käseman. 1974.

4 Os explorados e a teologia da libertação. Gustavo Gutierrez. 1973.

5 Os cristãos e a esquerda. Bartolomeu Valente. Coment. de P. Mário de Oliveira. 1975.

\section{Cidade Nova}

1 Revolução e libertação (Aspectos psicológicos $e$ sociológicos da revolução). Aires Gameiro, José Carlos Sousa. Junho, 1976. Tiragem: 2.000.

2 Repensar Portugal. Manuel Antunes. 1979.

3 Imaginar a Igreja (Reflexões ultrapassadas?). Maria de Lourdes Pintasilgo. 1980.

$\underline{\text { Sem coleção }}$

Uma leitura política do Evangelho. Fernando Belo. 1975.

Evangelização, anúncio de liberdade. José da
Cruz Policarpo. 1975.

Cristãos pelo socialismo. Vários ( $1^{\circ}$ Encontro). 1975.

A graça libertadora no mundo. Leonardo Boff. Coedição Vozes/Multinova. 1976.

Teologia do cativeiro e da libertação. Leonardo Boff. Janeiro, 1976.

Reforma agrária interpela a igreja. Acácio Catarino, Alberto Churro, Joaquim Batalha, José Magalhães. Maio, 1977. Tiragem: 1.000 .

Horizontes de libertação: linhas fundamentais da teologia da libertação em Leonardo Boff. Miguel Sapata Ramalho. Dezembro, 1978. Tiragem: 3.000 .

O materialismo e a ciência. Mata Mourisca. 1978. Coedição com Ed. Vozes (Brasil).

Socialismo científico e cristãos comunistas. Francisco da Mata Mourisca. Outubro, 1979.

O pensamento de Paulo Freire: uma revolução na educação. Manuel Moura. 1979.

Uma luz nas trevas: a luta pelos direitos humanos na Rússia - tal como eu os vi. Victor Sparre; pref. da ed. port. de António Alçada Baptista; trad. Manuel Bidarra, Maria Teresa Cardoso, 1980.

\section{N. A.* Orion (Amadora)}

Raízes da nossa força. Helena Neves. Fotos de Alfredo Cunha. 1973. (Apreendido pela PIDE/DGS)

Caxias: últimos dias do fascismo (Diário do encarcerado). Orlando Gonçalves. Julho, 1974. ( $2^{\mathrm{a}}$ edição revista e aumentada, $8^{\circ}$ milhar, Março, 1977.)

Prisão e isolamento em Caxias: uma breve experiência. António Modesto Navarro. Setembro, 1974.

Tempos livres. Depoimentos de jovens de todo o país, coligidos por Orlando César. 1974.

Mulheres de um tempo ainda presente. Helena Neves. 1975.

País de enquanto. Modesto Navarro. 1975.

Retornar. Modesto Navarro. 1976.

Os três dias do diabo: narrativas. Josué da Silva. Setembro, 1976.

$O$ norte cantar a reforma agrária; poemas. António Modesto Navarro. Março, 1977. Tiragem: 3.000.

Razão de recordar. Maria Luísa Antunes. 1978.

Este mundo dos homens. Orlando Gonçalves. $2^{\mathrm{a}}$ edição. 1979

Fantasia lispoeta. Carlos Pinhão. 1981. 
Memória Alentejana

1 Memória Alentejana: a vida no Alto Alentejo nas últimas décadas, a resistência e a reforma agrária. António Modesto Navarro. Agosto, 1977. Tiragem: 3.000.

2 Resistência e reforma agrária: em Benavila e Campo Maior. António Modesto Navarro. Janeiro, 1978. Tiragem: 3.000.

\section{Nova Aurora (Lisboa)}

Cultura Popular

1 No trabalho sanitário materializemos o princípio de que a revolução liberta o povo. Samora M. Machel. Junho, 1974. (Esgotado e reeditado na coleção $\mathrm{O}$ Povo Moçambicano em Armas, $n^{\circ} 3$ )

2 Discurso de Tchiao Cuan-hua, chefe da delegação da República Popular da China, na $28^{a}$ sessão da Assembleia Geral da ONU. Julho, 1974.

3 Sobre a Emancipação da Mulher: situação da mulher na sociedade burguesa (a mulher na revolução). K. Marx; F. Engels e V. I. Lenine. 1975. $3^{\mathrm{a}}$ ed. Fevereiro, 1975. (4 $\mathrm{ed}$. Janeiro, 1976).

$4 O$ materialismo dialético e o materialismo histórico. J Estaline. Setembro, 1974. $2^{\mathrm{a}}$ ed. Junho, 1975; $3^{\text {a }}$ ed. Janeiro, 1976.

5 Fazer da escola uma base para o povo tomar o poder. Samora Machel. Outubro, 1974. (Esgotado e reeditado na coleção O Povo Moçambicano em Armas. No 7).

6 Sobre a juventude. V. I. Lenine, Mao Tsétung, Enver Hoxha. Outubro, 1974.

7 A poderosa corrente contra o hegemonismo, o colonialismo e o imperialismo progride irresistivelmente. Dezembro, 1974.

8 A propósito das greves. V. I. Lenine. Dezembro, 1974.

9 A classe operária e a sua missão histórica mundial. Fato Çami. Fevereiro, 1975.

10 Os sindicatos reformistas e revisionistas ao serviço da burguesia. Filip Kota. Maio, 1975.

11 Sobre a ditadura do proletariado. K. Marx, F. Engels, V. I. Lenine. Julho, 1975.

12 Sobre o Estado. V. I. Lenine. Agosto, 1975.

13 O imperialismo e todos os reaccionários são tigres de papel. Mao Tsé-tung. Outubro, 1975.

$\underline{\text { O Povo Moçambicano em Armas }}$
1 Estabelecer o poder popular para servir as massas. Samora M. Machel. Setembro, 1974.

2 Produzir é aprender. Aprender para produzir e lutar melhor. Samora M. Machel. Novembro, 1974.

3 No trabalho sanitário materializamos o princípio de que a revolução liberta o povo. Samora M. Machel. $2^{a}$ ed. Novembro, 1974.

4 Educar o homem para vencer a guerra, criar uma sociedade nova e desenvolver a pátria. Samora Machel (a publicar).

5 A libertação da mulher é uma necessidade da revolução, garantia da sua continuidade, condição da seu triunfo. Samora Machel (a publicar).

6 Impermeabilizemo-nos contra as manobras subversivas do inimigo, intensificando a ofensiva ideolológica e organizacional no seio dos combatentes e massas. Samora Machel. Junho, 1975.

7 Fazer da escola uma base para o povo tomar o poder. Samora Machel. $2^{\text {a }}$ ed. Julho, 1975.

Coleção Ribeiro dos Santos

1 Citações do presidente Mao Tsé-tung. Janeiro, 1975.

2 Sobre o movimento de rectificação. Mao Tsétung. Setembro, 1974.

3 O homem, o capital mais precioso, seguido de Para uma formação bolchevique. J. Estaline. Novembro, 1975.

4 Cinco ensaios filosóficos. Mao Tsé-tung. Julho, 1976.

\section{Obras de Estaline}

1 Problemas económicos do socialismo na URSS, seguido do Discurso pronunciado no XIX Congresso do PCUS. J. Estaline. Fevereiro, 1975. Tiragem: 5.200.

\section{Textos do Partido Comunista da China}

1 Circular do Comité Central do Partido Comunista da China sobre a Grande Revolução Cultural Proletária, seguido de Um grande documento histórico. Abril, 1975.

2 Decisão do Comité Central do Partido Comunista da China sobre a Grande Revolução Cultural Proletária. Abril, 1975. Tiragem: 5.000.

Textos de Amílcar Cabral

1 Guiné- Bissau: nação africana forjada na 
luta. Amílcar Cabral. Agosto, 1974.

2 P.A.I.G.C., unidade e luta. Amílcar Cabral. Novembro, 1974.

3 Escritos (1920-1969), $1^{o}$ volume. Ho Chi Minh.

\section{Literatura Nova}

1 Poesia de combate. Patriotas moçambicanos, combatentes da Frelimo. Agosto, 1974.

2 Famintos (Romance do povo caboverdiano sob o domínio colonialista). Luís Romano. Março, 1975. ("Escrito na década de 1940, transportado clandestinamente para a África, publicado no Brasil em 1962 e interditado pela Censura.")

3 Caboverdeamadamente - Construção - Meu amor (poemas de luta). Osvaldo Osório. Outubro, 1975

Histórias Ilustradas

1 Contra a escravidão, pela liberdade. MPLA. Setembro, 1974.

$\underline{\text { Posters editados }}$

1 Glória a Amílcar Cabral.

Sem coleção

Manifesto do Partido Comunista. Marx e Engels. 1976.

\section{Nova Crítica (Porto)}

Biblioteca Nova Crítica / Ciências Humanas

1 Para a história da Revolução Cultural chinesa: antologia de documentos fundamentais. Dezembro, 1975. Tiragem: 3.000. Edição: Henrique A. Carneiro.

2 As lutas operárias contra a carestia de vida em Portugal: a greve geral de Novembro de 1918. José Pereira Pacheco. 2a ed. 1976. Editor: Henrique A. Carneiro.

3 Por uma escola nova. Alberto Silva.

5 As superestruturas ideologicas na concepção materialista da história. Vol. 1. F. Jakubowiski.

6 As superestruturas ideologicas na concepção materialista da história. Vol. 2. F. Jakubowiski.

7 Psicanálise e revolução. Jean-Marie Brohn.

8 A mensagem de Paulo Freire: teoria e prática da libertação. Textos de Paulo Freire selecionados pelo INODEP. 1977.

9 Realismo, arte de vanguarda e nova cultura.
Urbano Tavares Rodrigues. $2^{\mathrm{a}}$ ed. corrigida e aumentada. 1978.

11 Sobre o pensamento de Ivan Illich. Herbert Gintis, Vicente Navarro. Março, 1979. Tiragem: 3.250.

12 Marx e Engels como historiadores da literatura. Georges Lukacs. 1979.

Biblioteca Nova Crítica / Série Psicologica e Pedagogica

3 Por uma escola nova: a educação das massas. Alberto Silva. 1976.

Cadernos para o Diálogo/ Nova serie

$1 O$ que é uma constituição política? Ferdinand Lassalle. 1976. Edição: Henrique A. Carneiro.

2 A luta de classes em Portugal. Jacky Chatelain. 1977.

3 Introdução à sociologia. Lucien Goldmann. 1977.

\section{Terra a Terra}

1 Igreja, quem a confessa? Manuel Dias. Fevereiro, 1979. Tiragem: 3.250.

2 Revolução agredida. Manuel Dias. Novembro, 1979. Tiragem: 3.250.

3 Sá Carneiro: quem é? César Príncipe. 1980.

\section{Novo Curso (Amadora)}

Os fundamentos da filosofia marxista-leninista. Dir. lit. de F. V. Konstantinov. 1975.

Manual de economia política. N. D. Kolesov. $1^{\circ}$ vol. $2^{\mathrm{a}}$ ed. Setembro, 1977. Tiragem: 3.000.

Classes, estratos e poder. Wlodzimierz Wesolowski. 7 de Novembro de 1977 (" $60^{\circ}$ aniversário da Grande Revolução Socialista de Outubro"). Tiragem: 3.000.

História da filosofia. Iovchuk, Oizerman e Shchipanov. $1^{\text {o }}$ vol. Setembro, 1981. Tiragem: 3.000 .

\section{Ciências Económicas e Sociais}

2 Economia política do subdesenvolvimento. Tamás Szentes. 1979.

Manual de marxismo-leninismo. Otto V. Kuusinen e outros. Setembro, 1975. Tiragem: 4.000.

Dialéctica do processo revolucionário. I. Krassine. Fevereiro, 1978. Tiragem: 3.000.

Ciências sociais na U. R. S. S. Trad. João Alves Falcato. 1976. 
Introdução à psicologia social marxista. Hans Hiebsch e Manfred Vorwerg. 1980.

Teoria geral marxista-leninista do Estado e do Direito. N. G. Alexandrov e outros e outros. 1978.

Manual de materialismo dialéctico e histórico. S. M. Kovalhov e outros. 1980.

\section{Colecção 74}

15 Teoria das "relações humanas", instrumento ideológico dos monopólios. N. Bogomolova. Setembro, 1976. Tiragem: 3.000.

16 Fundamentos teóricos da História. L. Hosak e outros. 1976.

\section{Biblioteca Juvenil}

$O$ mundo ante os olhos do materialista. A. Pozner. Dezembro, 1980. Tiragem: 6.000.

A ciência do desenvolvimento: introdução à dialéctica. S. Stoliarov. 1981.

\section{Nova Realidade (Tomar)}

Cantares. José Afonso. 1966. (2ª ed., 1966)

Os homens cantam a Nordeste: poemas. António Cabral. 1967.

Hiroxima: depoimentos de poetas portugueses sobre o flagelo atómico, no $20^{\circ}$ aniversário da destruição de Hiroxima e Nagaságui. Coord. Carlos Loures e Manuel Simões. 1967.

O canto e as armas. Manuel Alegre. 1967. $1^{\text {a }}$ ed.

$O$ realismo como categoria artística. Stefan Morawski. 1968.

O comércio dos nervos: poemas. Armando da Silva Carvalho. 1968.

Engrenagens do ensino. Santos Simões. 1968.

Perspectivas 1. Coletânea de ensaios coordenada por Arsénio Mota. Esgotado.

Perspectivas 2. Henry George, G. B. Shaw, José Luis L. Aranguren, Carlos Gurméndez, Alberto Moravia, Jules Guesde. Selecção, tradução, prefácio e notas de Arsénio Mota. Janeiro, 1969.

Para um dossier da oposição democrática. Org., pref. e notas Serafim Ferreira e Arsénio Mota. Edição dos organizadores. Outubro, 1969.

Algumas palavras: poemas. Eduardo Guerra Carneiro. 1969.

Crónica Breve. Manuel Simões. 1970.

O ministério do amor: farsa em dois actos antes que seja tarde: peças em um acto. Carlos
Loures. 1970.

Poesia Amordaçada: Cânticos a Pablo. José Ferreira Monte. 1970.

Vietname: depoimentos de poetas portugueses sobre a agressão norte-americana ao Vietname. Coord. Carlos Loures e Manuel Simões. 1970.

Meu canto terra. Costa Mendes. 1971.

Adeus até ao meu regresso: emigração $e$ imperialismo. Vittorio Franceschi. 1976.

Crónica segunda: poemas. Manuel Simões. 1976.

Poemabril: antologia poética. Depoimentos de alguns "Capitães de Abril" e poemas de poetas portugueses no $10^{\circ}$ aniversário do 25 de Abril. Coord. e nota prévia de Carlos Loures e Manuel Simões. 1984. ( $2^{\mathrm{a}}$ ed. Coimbra, Fora do Texto, 1994.)

Coleção Nova Realidade de Bolso

1 Cantar de novo: poemas. José Afonso. 1971.

2 Sexualidade e feminilidade. B. Muldworf; trad. de Arnaldo Tereso. 1971.

3 Povoação, vende-se. Andrés Lizarraga; trad. Arsénio Mota. 1971.

4 A literatura revisionista na União Soviética. Tradução e compilação de Mário Guerreiro. Maio, 1972.

\section{O Grito do Povo (Porto-Lisboa)}

Textos Marxistas

$1 O$ papel do trabalho na transformação do macaco em homem. F. Engels.

2 A nossa estratégia da guerrilha. N. Van Tiem.

3 Socialismo e religião. Lenine.

4 Manifesto do Partido Comunista. Marx e Engels.

5 As três origens, as três partes que constituem o marxismo. Lenine. 1975.

6 Democracia burguesa e ditadura do proletariado. Lenine.

7 Em armas contra a burguesia. Lenine.

8 Os obejctivos dos destacamento do Exército Revolucionário. Lenine.

Plataforma da Internacional Comunista (1 ${ }^{o}$ Congresso da Internacional - 1919).

10 Crítica e autocrítica / Contra o liberalismo / A eliminação das concepções erradas no seio do partido. Gaston Monnosseau, Mao Tsétung.

11 Carta a um camarada. Lenine. 1975.

12 Sobre o partido. Lenine, Estaline. 
13 Sobre o Estado. Lenine, Estaline.

14 Materialismo dialéctico e materialismo histórico. Estaline.

15 Propostas sobre a linha geral do Movimento Comunista Internacional (Carta em 25 pontos do PC da China, 1963).

$16 O X$ Congresso do Partido Comunista Chinês.

17 As massas constroem o socialismo, o partido torna-as conscientes. Enver Hoxha.

Sobre certos problemas actuais da luta contra o revisionismo moderno. Fiqret Shehu. 1975.

19 Lenine e a construção do Partido Bolchevique. W. S. Mitskévitch Kapsoukas. 1975.

20 Por uma formação bolchevique. Staline.

Textos de Sindicalismo Revolucionário

1 A táctica de greve na época actual (Resolução da Conferência de Strasburgo da Internacional Sindical Vermelha). 1975.

\section{Linha Política}

$1^{a}$ Conferência Sindical da Organização Comunista Marxista-Leninista Portuguesa.

\section{O Nosso Partido}

1 A célula. ("Publicado pelo Comité Regional de Lisboa do PCP em 1932").

História

História do Partido Bolchevique. 1974.

Sem coleção

A exploração capitalista.

Princípios do comunismo.

Livros editados após a reconstituição da OCMLP em Outubro de 1976

A ditadura fascista na URSS.

Boletim $n^{o} 1-O$ pensamento Mao Tsé-Tung orienta sempre a nossa marcha em frente.

Boletim $n^{\circ} 2$ - O esmagamento do "Bando dos Quatro".

Boletim $n^{o} 4$ - Os crimes do "Bando dos Quatro" na sabotagem da revolução e da produção.

Boletim $n^{o} 5-O$ canto de sereia dos novos czares não enganará os povos africanos / $O$ social-imperialismo soviético é o inimigo mais perigoso da Terceiro Mundo.

Boletim $n^{o} 6-A$ tese dos três mundos é uma análise leninista da situação mundial. Jacques Jurquet.

Curso básico de marxismo-leninismo (Estágio de admissão à OCMLP - 12 fascículos).

Resolução sobre a célula. Aprovada na $1^{a}$ sessão plenária do CC eleito na $3^{a}$ Conferência Nacional da OCMLP (de reorganização).

Bento Gonçalves.

Coleção Independência nacional

1 O social-imperialismo soviético, inimigo mais perigoso dos povos de todo o mundo: os novos czares apertam o cerco à Europa Ocidental. 1977.

O Proletário Vermelho/Editora Outubro (Lisboa)

Obras 1. Mao Tsé-Tung. Dezembro, 1974. (Editado com a encadernação clássica do "Livro vermelho das citações do presodente Mao").

Obras 2. Mao Tsé-Tung. Fevereiro, 1975. (Editado com a encadernação clássica do "Livro vermelho das citações do presodente Mao").

\section{Série Lu-Sun}

1 A estrela vermelha. Li Sin-tien. Agosto, 1976. Tiragem: 3.000 .

2 Resistir ao ocupante. Wanda Wassilewska. (Prémio Staline - 1943)

3 O ritmo. Vito Koçi. 1976.

Cadernos O Proletário Vermelho

1 Fazer inquéritos à realidade: sem investigação não há direito à palavra! Junho, 1975. Tiragem: 3.000.

2 O que é o social-fascismo. Vários. Maio, 1976. Tiragem: 3.000.

3 O que é a ditadura do proletariado. 1976.

$4 O$ que é a vida quotidiana na China. Vários autores. Maio, 1976. Tiragem: 3.000.

$5 O$ que é o método dialéctico marxista. Georges Politzer. Maio, 1976. Tiragem: 3.000 .

60 que é o materialismo filosófico marxista. Georges Politzer. Janeiro, 1977. Tiragem: 3.000 .

7 O que é o materialismo histórico. Georges Politzer. Janeiro, 1977. Tiragem: 3.000.

8 O que é o materialismo histórico do Estado e 
da nação. Georges Politzer.

9 O que são as comunas populares.

10 O que é o problema de Angola.

Coleção Documentos

1 Trabalho assalariado e capital. Karl Marx. Agosto, 1976. Tiragem: 3.000.

\section{Cadernos Horizonte Vermelho}

1 Aliança contra-revolucionária (dos revisionistas e "socialistas" contra os povos). Omer Hashorva.

2 Não se pergunta a um escravo se quer ser livre. Jacques Jurquet.

3 Linhas gerais da economia chinesa. Tchem Chi. s/d. Tiragem: 2.000 .

4 A luta entre as duas linhas é a característica principal do movimento democrático internacional da juventude e dos estudantes! Asim Bedalli.

5 Aspectos gerais da cultura na China. Tse Bian.

6 A Albânia abandona o Pacto de Varsóvia. Em apêndice: Constituição actual da República Popular Socialista da Albânia. Mehemet Shehu. Outubro, 1976. Tiragem: 2.000.

\section{O Século (Lisboa)}

Cadernos do Século (coord. Afonso Cautela)

$1 O$ mundo contra a fome. Addeke H. Boerma e outros. Março, 1970.

3 o suicídio da humanidade: ano europeu de proteção à natureza.

5 O império do dólar. 1970.

6 Oito escritores frente à política.

7 Liberdade e alienação no pensamento contemporâneo.

9 Juventude e relações humanas. Igor Kon e outros. Fevereiro, 1971.

10 A China e o Ocidente. Josué de Castro e outros. Maio, 1971.

$\underline{\text { Sem coleção }}$

Portugal livre. 20 fotógrafos contam a Revolução dos Cravos. 1974.

Portugal oprimido: factos e nomes da ditadura salazarista. Capitão Fernando Queiroga. Fevereiro, 1975.

Radiografia militar. Manuel Barão da Cunha. 1975.

Portugal e as comunidades europeias.
Alexandre Cordeiro. 1977.

Alentejo: dos princípios à chamada "reforma agrária”. José Hipólito Raposo. 1978.

\section{Paisagem (Porto)}

Temas Actuais

1 Carta ao partido operário polaco. Polónia: contra o autoritarismo burocrático. Jacek Kuron, Karol Modzelewski. Edição: Manuel do Amaral. 1971.

2 Imprensa: deformar ou informar? José Viale Moutinho. 1971.

\section{Coleção Mutações}

1 Fidel 1959: antes e depois. J. J. Nattiez. Edição do tradutor. Agosto, 1970.

2 Construir a paz. Dominique Pire; colab. de Charles Dricot; préf. de Robert Oppenheimer. 1970.

3 Retrato de Camilo Torres. H. Bojorge e outros. 1970.

4 Evangelho e problemática social. D. António Fragoso (bispo de Cratéus, Brasil). s/d.

5 Pele negra máscaras brancas: um negro num mundo branco. Frantz Fanon. $1972\left(2^{\mathrm{a}}\right.$ ed 1975, saiu como $\mathrm{n}^{\circ} 8$ da coleção Mutações).

6 Gamal Abd-El-Nasser. J. Daumal e M. Leroy.

7 Deus toma partido. Jean Cardonnel; Trad. António Alberto Gonçalves. 1971.

8 Rosa Luxemburgo viva! Antologia. Coord. e prefácio de César Oliveira. Edição do coordenador. Fevereiro, 1972.

9 Christãos novos e christãos velhos em Portugal. A. N. Ribeiro Sanches; pref. Raul Rêgo. 1973.

10 Introdução ao nacionalismo galego. José Viale Moutinho. 1973.

Fora de coleção

CIA, imperialismo e crise económica: discursos. Fidel Castro. Março, 1975.

A mulher cubana e a revolução. Fidel Castro. Abril, 1975.

O governo revolucionário. Pedro Kropotkine. Maio, 1975. Tiragem: 3.000.

\section{Coleção T}

2 Aquele que diz sim, de Brecht; Guernica, de Arrabal; O ser sepulto, de António Rebordão Navarro.

4 O herói. António Cabral. 
Cadernos Paisagem

1 Revolução e burocracia. Lucien Goldman. Junho, 1975. Tiragem: 3.000.

$2 O$ Estado, o plano e a república dos conselhos. Jean Dru. Junho, 1975. Tiragem: 4.000 .

3 Autogestão e dialéctica. Maurice Montuclard. Junho, 1975. Tiragem: 3.000.

4 Socialistas e comunistas: informação $e$ autogestão. Rémi Hess, Yves Durrieu, Yvon Bourdet. 1975.

\section{Vozes Livres}

1 José Afonso, textos e canções. Viale Moutinho (coord.). Março, 1975.

2 Bob Dylan. Jesús Ordovás. 1973.

3 O mundo da música pop. Rolf-Ulrich Kaiser. 1973.

4 Joan Manuel Serrat. Manuel Vázquez Montalbán. 1973.

$5 O$ nosso amargo cancioneiro. $2^{\mathrm{a}}$ ed. revista e actualizada. José Viale Moutinho. Dezembro, 1973.

6 A arte de amar. José Jorge Letria.

\section{$\underline{\text { Temas }}$}

1 A construção do socialismo na União Soviética; seguido do "Testamento político" e outros textos de Lenine. Evgueni Varga. 1970. $2^{\text {a }}$ ed. Janeiro, 1974.

2 O Estado, a democracia burguesa, a prática revolucionária e o anarquismo. Antologia. Bakunine, Kropotkine, Malatesta, Daniel Guérin, Engels. Tradução e selecção de César Oliveira. 1972. (2 ${ }^{\mathrm{a}}$ ed. Março, 1975)

3 Explicar o socialismo. A. do Carmo Reis. Janeiro, 1977.

\section{Eros e Pessoa}

1 Educação sexual para os mais jovens: rapazes e raparigas dos 10 aos 12 anos. Grant Noble. 1972.

2 Educação sexual para os adolescentes: rapazes e raparigas dos 13 aos 15 anos. Grant Noble. 1972.

3 Prática sexual e controlo dos nascimentos. Jean Dalsace e Raoul Palmer. 1971.

4 Dicionário de informação sexual. Paul Bertrand, Victor Lapie, J. C. Pellé. 1976

Ciências do Homem

1 Sociologia. Jean Duvignaud. 1971.

\section{Parceria A. M. Pereira (Lisboa)}

Temas Políticos

1 Os partidos políticos. Jean Charlot. 1974.

2 Revolução e contra-revolução. Karl Marx. Trad. Serafim Ferreira. Setembro, 1974.

3 O marxismo nos seus textos. Serafim Ferreira. Outubro, 1975.

4 Fundamentos do leninismo. Staline. 1974.

5 O que disse "Che" Guevara. António Melis. 1975.

6 Pensamento e aç̧ão de Lenine. Valério Tonini. Abril, 1976.

7 Os movimentos políticos árabes. Paolo Minganti. 1976.

8 Pensamento político de João XXIII. Sosio Pezzella. 1977.

\section{Actualidade para o Futuro}

2 Estas multinacionais que nos governam. Christopher Tugendhat. Julho, 1974.

\section{O Mundo e o Homem}

4 Quando a China despertar.. o mundo tremerá... Alain Peyrefitte. $3^{\mathrm{a}}$ ed. Outubro, 1976. $\left(1^{\text {a }}\right.$ ed. Setembro, 1975; $2^{\text {a }}$ ed. Dezembro, 1975)

\section{Sem Coleção}

A felicidade antes de Abril . Romance. Júlio Conrado. Setembro, 1976.

Era a revolução. Novela. Júlio Conrado. Outubro, 1977.

\section{Plátano (Lisboa)}

\section{Coleção Combates}

1 A força ignorada das companheiras. Gina de Freitas. Julho, 1975.

2 Testemunho de um médico. Álvaro Soares de Pinho. 1976.

3 Milagre no Brasil. Augusto Boal. 1976.

Coleção Teatro Vivo

A $10^{a}$ turista. Mendes de Carvalho. $2^{\mathrm{a}}$ ed. 1974.

A noite de 28 de setembro. Richard Demarcy.

Introdução à política: as constituições portuguesas e os pactos MFA - partidos. António José Fernandes. 1977. 


\section{Pensamento e Acção (Lisboa)}

Últimos escritos, 1950-1953: O marxismo e os problemas da linguística; Problemas económicos do socialismo na URSS; Cartas a Mao Tsétung; Intervenção no XIX Congresso do PCUS. J. Stáline. Abril, 1975.

\section{Coleção Documentos}

1 Paz ou violência? e outros textos. Partido do Trabalho do Vietnam. Março, 1975.

2 Trotskismo ou leninismo?; Trotski e o trotskismo: colectânea. J. Stáline. 1975.

3 O trabalho dos bolcheviques no exército antes da Revolução de Outubro. E. Yarolavsky. Março, 1977.

\section{Homem Novo}

1 Albânia: como construímos o socialismo (perguntas e respostas). Harilla Papajorgji. Junho, 1976.

\section{Pensamento Político (Lisboa)}

\section{Cadernos do Pensamento Político}

1 A verdade e a mentira: algumas notas em resposta ao integralismo e a república de Carlos Ferrão. Mário Saraiva. 1971.

2 Marcuse ou o colapso de duas ideologias. António Faria e Maya. 1971.

3 O pensamento integralista perante o Estado Novo. Rivera Martins de Carvalho. 1971.

4 Respiração mental: o problema da censura. Alberto de Monsaraz. $2^{\mathrm{a}}$ ed. 1972.

5 Carta aos muçulmanos de Moçambique independente. Fernando Amaro Monteiro. 1975.

\section{Biblioteca do Pensamento Político}

Espada ao Sol. Luís de Almeida Braga. 1969.

Razões reais. Mário Saraiva. $2^{\mathrm{a}}$ ed. 1970.

D. Manuel II e João Franco. Rodrigues Cavalheiro. $2^{\mathrm{a}}$ ed. 1970.

Trincheira de combate. Manoel de Bettencourt e Galvão. 1970.

Estratégia estrutural portuguesa. Silvino Silvério Marques. 1970.

Os monárquicos e o Ultramar: à maneira de Livro Branco. Henrique Barrilaro Ruas e Marcus de Noronha da Costa (orgs.). 1971.

A liberdade e o rei. Henrique José Barrilaro
Fernandes Ruas. 1971

Diário político e outras páginas. Rivera Martins de Carvalho. Março, 1972.

A aliança peninsular: antecedentes $e$ possibilidades. António Sardinha. 1972.

No debate das ideias. Jacinto Ferreira. 1973.

Para uma sociologia da monarquia portuguesa. A. Crespo de Carvalho. 1973.

Portugal e a Africa no mundo de hoje. Otão de Habsburgo. 1974.

António Sardinha e o iberismo: acusação contestada. Pref. Manoel de Bettencourt e Galvão 1974.

A teoria das Cortes Gerais. António Maria de Sousa Sardinha. 2a ed. 1975.

As portas da cidade: critica e doutrina. Mário Saraiva. 1976.

Ao ritmo da ampulheta. António Sardinha. 2a ed. 1978.

\section{Perspectivas \& Realidades (Lisboa)}

O triunfo dos porcos. George Orwell. 1976.

A Suíça acima de qualquer suspeita. Jean Ziegler. Setembro, 1976.

Por uma política de concórdia e grandeza nacional: do 25 de Abril ao 25 de Novembro. Francisco Salgado Zenha. Abril, 1976.

O Alentejo saqueado. Jorge Morais. Maio, 1976.

Em defesa da democracia. Alfredo de Sousa e Eurico Ferreira. Março, 1976.

A URSS vista pela sua própria imprensa. Chico da CUF (Francisco Ferreira). Março, 1976.

A Europa connosco: dois discursos na cimeira socialista do Porto. Mário Soares. Março, 1976.

Reflexões sobre a China ou as atribulações de um ocidental no Ocidente. Álvaro Guerra. Outubro, 1976.

Se eles me matarem. Jiri Pelikan. 1976.

Mário Soares: o homem e o político. Isabel SOARES (coord.); Vítor Cunha RÊGO (pref.). 1976.

Da Guerra. Carl Von CLAUSEWITZ. 1976.

Os Wombles. Elisabeth Beresford; il. Barry Leith. 1976.

Técnica do golpe de estado. Curzio Malaparte. 1976.

Cultura, política, informação: um ano de luta contra os totalitarismos. José Martins Garcia. 1976.

Crise e clarificação. Mário Soares. Dezembro, 
1977.

Memórias de Barry Lyndon do reino da Irlanda. W. M. Thackeray. 1977.

Textos de afirmação e de combate do movimento surrealista mundial. Mário Cesariny. 1977.

Pássaro paradípsico. Manuel Lourenço; il. de Mário Cesariny. 1979.

História da social-democracia alemã. Joseph Rovan. Dezembro, 1979.

A emigração como força civilizadora. Eça de Queiroz; pref. de Raul Rego. 1979.

A revolta da Madeira: Açores e Guiné 4 de Abril a 2 de Maio de 1931. Org. João Soares. 1979.

Uma revolução falhada: os métodos de Boris Ponomariov na Europa. Gioacchino Santanché; pref. Raúl Rego. Junho, 1980.

Os dois velhos soldados. Texto e il. de Rui Perdigão. 1980.

Memórias. Raul Brandão. 1980.

A Realidade da Autogestão em Portugal. Comissão Coordenadora das Empresas em Autogestão; Diogo Duarte; Luís Ferreira; Nelson Trindade; Vasco Corregedor da Fonseca. 1981.

Esperanças de Abril: críticas, sátiras, discursos $e$ depoimentos. António Coimbra Martins. Março, 1981.

História: $7^{\circ}$ ano de escolaridade. Maria Teresa Ferreira, Miguel Rodrigues. 1982.

Os filhos da droga. Christiane F. 1982.

Antologia da imprensa operária portuguesa, 1837-1936. Recolha, prefácio e notas de César Oliveira. Coedição com UGT (União Geral de Trabalhadores). Março, 1984.

\section{Teoria Política}

A Evolução do Sistema Corporativo Português: o Salazarismo. Vol. I. Manuel de Lucena. 1976.

A Evolução do Sistema Corporativo Português: o Marcelismo. Vol. II. Manuel de Lucena. 1976.

A guerra civil mundial. Jacqueline Grapin, JeanBernard Pinatel. 1977.

\section{Coleção Textos}

Social-democracia. 1976.

\section{Coleção Construção da Sociedade Socialista}

1 Cooperativas de construção e habitação. Guenter V. Rupprecht. 1975.

2 As cooperativas de consumo e os países em vias de desenvolvimento. Harald Kerbs.

3 A caminho da igualdade. Alva Myrdal. 1976. Fevereiro, 1976.

4 As cooperativas agrícolas. R. H. Gretton. Setembro, 1976.

Escritos e Biografias

Portugal, que revolução? diálogo com Dominique Pouchin. Mário Soares. 1976.

Memórias de infância e de miséria. Guselle Amalrik. 1977.

Coleção Águia

1 A fera solitária e o ditador. Geoffrey Household. 1977.

2 Recompensa para um desertor. Michael Underwood. 1977.

\section{Tempos Livres}

1 A casa das mil lanternas. Victoria Holt. 1977.

\section{Coleção Direito}

O presidencialismo do Estado Novo. Jorge Campinos. 1978.

Estudos sobre temas de direito do trabalho. José Acácio Lourenço; pref. A. Monteiro Fernandes. 1979.

Relações colectivas de trabalho. Emílio Ricon Peres. 1979.

\section{Portucalense (Porto)}

Política internacional. Adriano Moreira. 1970.

A contra-revolução africana. Ivan M. Sicard 1970.

\section{Coleção A}

1 Marx: Crítica do Programa de Gotha. Engels: Crítica do Programa de Erfurt. Lenine: Marxismo e revisionismo. 1971.

2 A construção do socialismo na China. Bettelheim, Charrière, Marchisio. Julho, 1971.

3 Poder político e classes sociais do estado capitalista. Vol. I. Nicos Poulantzas. 1971.

4 Poder político e classes sociais do estado capitalista. Vol. II. Nicos Poulantzas. Novembro, 1971.

5 Lumpen-burguesia: lumpen-desenvolvimento. André Gunder Frank. Dezembro, 1971.

6 A era do imperalismo: a economia da política externa norte-americana. Harry Magdoff. 
Fevereiro, 1972.

7 A questão agrária. Vol. I. Karl Kautsky. Abril, 1972.

8 A questão agrária. Vol. II. Karl Kautsky. Maio, 1972.

9 Fascismo e ditadura: a III internacional face ao fascismo. Vol. I. Nicos Poulantzas. Julho, 1972.

10 Fascismo e ditadura: a III internacional face ao fascismo. Vol. II. Nicos Poulantzas. Agosto, 1972.

Textos de Apoio

1 China e URSS: dois "modelos" de industrialização. Charles Bettelheim, Marco Macciò. 2 ${ }^{\mathrm{a}}$ ed. Outubro, 1971. (Fora de mercado)

2 As lutas operárias contra a carestia de vida em Portugal: a greve geral de novembro de 1918. José Pacheco Pereira. Agosto, 1971. (Fora de mercado)

3 Sociedades de transição: luta de classes e ideologia proletária. Paul Sweezy, Charles Bettelheim. Setembro, 1971. (Fora de mercado)

4 Setembro 1970: a quinta tentativa de cerco e de liquidação da resistência palestiniana. Frente Popular Democrática para a Libertação da Palestina ( FPDLP). Novembro, 1971.

5 Sobre a teoria da ideologia: a política de Althusser. Jacques Rancière. Dezembro, 1971. (Fora de mercado)

6 Os bakuninistas em acção: o levantamento em Espanha no verão de 1873. F. Engels. Janeiro, 1972. (Fora de mercado)

7 Vietnam 1969. Vo Nguyen Giap. Janeiro, 1972. (Fora de mercado)

\section{Terceira Colecção}

1 Paris livre 1871. Jacques Rougerie. 1971.

2 O teatro popular porquê? Emile Copfermann; Maria Elena Curado e Melo. 1971.

3 Os muros do asilo. Roger Gentis. 1972. (Fora de mercado)

\section{Portugal Socialista (Lisboa)}

\section{Textos "Portugal Socialista"}

Construir uma nova vida. Destruir o sistema. Por um Partido Socialista forte e combativo. Agosto, 1973. (Impresso em Roma)

Declaração de princípios e programa do Partido Socialista. Setembro, 1973.
Socialismo, sim, ditadura, não! Relatório aprovado pelo I Congresso do PS na legalidade. 1975. Tiragem: 100.000.

$\underline{\text { Sem coleção }}$

Vencer a crise salvar a revolução. 1975.

O P.S. na constituinte missão cumprida. Araújo Dantas. 1976.

O Portugal Socialista na clandestinidade: 1967/1977: 10 anos de luta. 1977.

Política económica de transição: uma proposta do Partido Socialista. s/d.

Cem anos de esperança. Coordenação Isabel Soares. Novembro, 1979.

PS, fronteira da liberdade: da queda do Gonçalvismo às eleições intercalares 19751979. Mário Soares; pref., selec. e coord. de textos de Alfredo Barroso. 1979.

Estatutos / Partido Socialista. Aprovados no $4^{\circ}$ Congresso Nacional, Lisboa-81. 1981.

\section{Cadernos António Sérgio}

1 O marxismo e a revolução portuguesa. António Reis. Fevereiro, 1979. Tiragem: 3.000 .

\section{Cadernos Portugal Socialista}

Forças armadas e democracia. Sottomayor Cardia, Jaime Gama, Manuel Alegre e António Reis. 1976.

Gabinete de Estudos do Partido Socialista $\underline{\text { Série Estudos } 1}$

1 Os socialistas na Assembleia da República. Vol. 1. Colectânea comentada da legislação aprovada na Assembleia da República, 1976/1977.

2 Os socialistas na Assembleia da República. Vol. 2. Colectânea comentada da legislação aprovada na Assembleia da República, 1976/1977.

Textos do PS

$1-1^{o}$ Encontro dos Trabalhadores Socialistas da Função Pública.

2 - II Congresso do Partido Socialista: relatório do Secretario-Geral e Moções.

3 Encontros Socialistas de Autarquias Locais. Conclusões dos V, VI e VII Encontros.

4 Dez anos para mudar Portugal: proposta PS para os anos 80. Aprovado no III Congresso do Partido Socialista. Prefácio de Mário Soares. Março, 1979. 


\section{Portugália (Lisboa)}

$O$ poder americano $e$ os novos mandarins. Noam Chomsky; trad. António Guimarães. 1969.

Greves de ontem e de hoje. Georges Lefranc. 1970.

Assim não, Soljenitsine! Alain Bosquet; trad. de Searfim Ferreira. 1974.

MFA Movimento Revolucionário. General Galvão de Melo. 1975.

Cadernos Portugália (Dirigida por Orlando Neves e Serafim Ferreira)

1 PIDE/DGS: um Estado dentro do Estado. Fernando Luso Soares. 1974.

20 imperialismo em Angola. MPLA. 1974.

3 O que é o marxismo? Francisco dos Santos Costa. s/d.

4 Crimes politicos e habeas corpus. Artur Maurício. s/d.

5 Desporto e política. Noronha Feio.

6 Cinco meses mudaram Portugal. Otelo Saraiva de Carvalho. Janeiro, 1975.

7 Ideologia e política do Estado salazarista. Prof. Jorge Campinos. Janeiro, 1975.

8 No regresso vinham todos: relato da companhia $n^{o}$ 2549. Capitão Vasco Lourenço. s/d.

9 MFA. Rosto do povo. Capitão Vasco Lourenço. 1975.

Problemas

1 Estudos sobre teatro. Bertolt Brecht; trad. Fiama Hasse Pais Brandão. 1976.

24 Estruturalismo: antologia de textos teóricos. Selecção e introd. de Eduardo Prado Coelho; trad. Maria Eduarda Reis Colares, António Ramos Rosa, Eduardo Prado Coelho. 1978.

\section{Contemporânea}

34 Felizmente há luar! Luís de Sttau Monteiro. 4a ed. 1977.

126 Os negócios do senhor Júlio César. Bertolt Brecht. 1976

131 Todos os homens são irmãos. Mahatma Gandhi. 1976.

132 A cruz e a espada em Moçambique. Cesare Bertulli. 1974.

133 A CIA e o culto da espionagem. Victor Marchetti, John D. Marks. 1975.

\section{Povo e Cultura (Baixa da Banheira)}

Coleção Biblioteca Povo e Cultura

1 Acerca da contradição. Mao Tsé-tung. $2^{\mathrm{a}}$ ed. Julho, 1974.

$2 O$ trabalho político de massas. V. I. Ulianov (Lenine). Março, 1972. Edição do Tradutor. $2^{\mathrm{a}}$ ed. Julho, 1974.

3 Sobre a democracia nova. Mao Tsé-tung. $3^{\circ}$ ed. 1972.

4 A educação ideológica dos quadros e das massas. Enver Hoxha. Tradução e biografia: Manuel Quirós. Julho, 1974. (2 $2^{\mathrm{a}}$ ed. Outubro, 1974).

5 Anarquismo ou socialismo. J. Staline (a sair).

6 A teoria económica de Marx. K. Marx (a sair).

Coleção A Longa Marcha

História do Partido Comunista (Bolchevique) da U.R.S.S. 1975.

Cadernos Vermelhos

1 Conquista ou abandono dos sindicatos? A. Losovski. Julho, 1974.

2 Carta em 25 pontos do Partido Comunista da China ao Partido Comunista da URSS. Proposta sobre a linha geral do movimento comunista internacional. Julho, 1974.

3 Estratégia e táctica de greves. A. Losovski.

4 Ditadura da burguesia ou ditadura do proletariado? Lenine. Julho, 1974.

5 Estaline, o bolchevique. Bruce Franklin.

6 Os comunistas e o apartidarismo. 1975.

Cadernos Povo e Cultura - Série A: O Socialismo e a Vida

1 A libertação da mulher. Vários.

Combate

Evocar Lenine. A propósito do $7^{\circ}$ Congresso do Partido Comunista Português. Carlos Consiglieri. Maio, 1974.

2 Sobre a revolução proletária e a ditadura do proletariado. Citações de Lenine. Julho, 1975. Tiragem: 7.500.

3 A batalha da classe operária nos países revisionistas. Enver Hoxha.

Povo e Cultura - Poesia

Poemas de Natal. Álvaro Feijó e outros. Antologia; pref. de Felicidade Alves; 
Compil. Manuel Miranda. 1971.

Cadernos Povo e Cultura B, Zona das tempestades

1 Palestina um povo em armas. Trad. H. César Opz, A. Manso. 1977.

Sem coleção

O pátio da cobrança das rendas: a arte revolucionária na China, esculturas em barro.

O trabalho do partido entre as massas. Lenine ; trad. Manuel Miranda. $2^{\mathrm{a}}$ ed. 1974.

\section{Presença (Lisboa)}

A economia política do socialismo. Vol. 1. Bronislaw Minc. Fevereiro, 1977. Tiragem: 3.500 .

A economia política do socialismo. Vol. 2. Bronislaw Minc. Junho, 1977. Tiragem: 3.500 .

A economia política do socialismo. Vol. 3. Bronislaw Minc. Fevereiro, 1981.

\section{Questões}

1 Carta a uma professora, pelos rapazes da escola de Barbiana. 1967.

2 O budismo Zen. Alan W. Watts. 1972.

3 Uma experiência na América Latina. Salvador Allende.

4 A psiquiatria em questão. Ronald D. Laing. 1972.

5 As utilizações da cultura: aspectos da vida da classe trabalhadora com especiais referências a publicações e divertimentos. Vol. 1. Richard Hoggart. 1973.

6 Para uma escola do povo: guia prático para a organização material, técnica e pedagógica da escola popular. Céléstin Freinet. 1969.

7 A educação pelo trabalho I. Céléstin Freinet.

8 A educação pelo trabalho II. Céléstin Freinet.

9 História da revolução cultural chinesa. Jean Daubier. Vol. 1. Julho, 1974.

10 História da revolução cultural chinesa. Jean Daubier. Vol. 2. Julho, 1974.

11 A história me absolverá. Fidel Castro Ruz. 1974.

13 A crise das ditaduras: Portugal, Grécia, Espanha. Nicos Poulantzas. Outubro, 1975. Tiragem: 4.000 .

14 Ensaio de psicologia sensível: aquisição de técnicas construtivas de vida. Célestin
Freinet. 1976.

15 Gramática da vida. David Cooper. 1977.

16 O "eurocomunismo" e o Estado. Santiago Carrillo. Coedição com Martins Fontes. Março, 1978.

18 As utilizações da cultura: aspectos da vida da classe trabalhadora com especiais referências a publicações e divertimentos. Vol. 2. Richard Hoggart. 1975.

Biblioteca de Ciências Humanas

Dialéctica e ciências humanas I. Lucien Goldmann. 1972.

2 Materialismo dialético e psicanálise. Wilhem Reich. 1971.

3 Sobre o trabalho teórico. Louis Althusser. 1978.

5 Teoria do romance. Georg Lukács. 1971.

6 A crise da social-democracia. Rosa Luxemburg. 1971.

9 Proudhon e Marx I. Georges Gurvitch. 1971.

10 Textos filosóficos. Marx e Engels. $4^{\mathrm{a}} \mathrm{ed}$ Maio, 1974. ( $1^{\mathrm{a}}$ ed. 1971)

11 Materialismo dialéctico e sociologia. Henri Lebebvre. 1971.

12 Proudhon e Marx II: uma confrontação. Georges Gurvitch. 1971.

13 Crítica da filosofia do direito de Hegel. Karl Marx. 1971.

17 Da revolução à arte, da arte à revolução. Sérgei Michailovitch Eisenstein. 1972.

18 O estado na sociedade capitalista: uma análise do sistema de poder no ocidente. Ralph Miliband. 1969.

34 Reflexões sobre a história. Plekhanov. s/d.

37 Ideologia e aparelhos ideológicos do Estado. Louis Althusser. Outubro, 1974. Coedição com Livraria Martins Fontes, Brasil.

39 Escritores, intelectuais, professores e outros ensaios. Roland Barthes. 1975.

42 Conceitos elementares do materialismo histórico II. Marta Harnecker; apresentação por Louis Althusser. 1975.

44 As lições da revolução. Lénine. 1975.

45/46 Cinco estudos do materialismo histórico. Étienne Balibar. 1975.

47 As guerras camponesas na Alemanha. Friedrich Engels. 1975.

59/60 Combates pela história. Lucien Febvre. 1977.

Análise Social (AS)

1 Capitalismo, tecnologia e dependência em 
Portugal. José Manuel Rolo. Coedição com Gabinete de Investigações Sociais. Outubro, 1977. Tiragem: 3.000 .

2 Situação do operariado nas vésperas da implantação da República. Manuel Villaverde Cabral.

5 Educação e sociedade no Portugal de Salazar. Maria Filomena Mónica.

7 Desenvolvimento, subdesenvolvimento e o modelo português. Mário Murteira. Coedição com Gabinete de Investigações Sociais. Abril, 1979. Tiragem: 3.000.

Síntese

$1 O$ meio divino. Teilhard de Chardin.

20 existencialismo é um humanismo. Jean-Paul Sartre. Da fenomenologia a Sartre. Vergílio Ferreira. 1978.

3 A origem da família, da propriedade privada e do Estado: trabalho relacionado com as investigações de L. H. Morgan. Friedrich Engels. 1971.

8 A sociedade primitiva. Lewis H. Morgan. 1973.

13/14 O pensamento europeu no século XVIII: de Montesquieu a Lessing. Paul Hazard. 1974.

16 A ideologia alemã. Karl Marx, Friedrich Engels. 1974

17 A Sagrada Família ou crítica da crítica crítica contra Bruno Bauer e Consortes. Karl Marx, Friedrich Engels. 1976.

18 Dialéctica da natureza. Friedrich Engels. 1974.

19 Karl Marx. Franz Mehring. 1974.

22 A situação da classe trabalhadora na Inglaterra. Friedrich Engels. 1975.

\section{Biblioteca Universal Presença}

3 Causas sociais da Revolução Insdustrial. Nino Salamone. 1980.

\section{$\underline{\text { Perspectivas }}$}

20 Marcuse polémico. Erich Fromm, Herbert Marcuse, Karl Miller. 1969.

21 Teatro e vanguarda. Selec. e trad. Luz Cary. 1970.

22 Psicanálise e sociedade. Wilhelm Reich. Erich Fromm. Herbert Marcuse. J. A. Caruso. Edmund Bergler. Géza Roheim. 1970.

23 Situação actual da mulher. Selecção de textos e trad. de Luz Cary, Joaquim José Moura Ramos. 1970.
24 Sociologia e ideologia. F. Konstantinov e outros. 1970.

25 Cultura e Sociedade. T. W. Aderno, Herbert Marcuse, Max Horkheimer. 1970.

26 A história me absolverá. Fidel Castro. 1970.

28 Ideólogos e ideologias da nova esquerda. Bernd Oelgart. 1970.

29 Ensino: reforma ou revolução? Trad., pref. e compil. Arlindo Mota e Isabel Figueiredo Mota. 1971.

Biblioteca de Textos Universitários

36 Proudhon e Marx. Georges Gurvitch. Coedição com Martins Fontes (Brasil). $2^{\mathrm{a}}$ ed. 1980.

\section{Prelo (Lisboa)}

Nosso Lenine. Boris Polevoi e Nikolai Zhukov. Maio, 1975.

Perspectivas de libertação no nordeste transmontano. António Modesto Navarro. 1975.

O desporto e as estruturas sociais. José Esteves.

Os "capitães-generais" e os "capitãespolíticos" (Reflexões e objecções). Luís Ataíde Banazol. Junho, 1976. Tiragem: 5.200 .

\section{Coleção Documentos}

1 O papel do teatro na sociedade contemporânea. Vários.

2 Estes massacres que nos vêm do Vietnam (My Lay). Alice Nicolau. Junho, 1970.

3 A história me absolverá. Fidel Castro.

4 Chile: povo, governo, poder. Documentos. Vários. Setembro, 1971.

5 Pablo Neruda: Prémio Nobel de Literatura1971. Vários.

6 Problemas filosóficos. Oizerman, Sève, Gedoe.

7 Governo popular. Vários. Abril, 1972.

8 Problemas ideológicos contemporâneos. Bruno Frei, M. Sandros, K. Zaradov, Ibnorlund.

9 A China e as raízes da "sinofilia" ocidental. Antoine Casanova, Jacques Bonis. Agosto, 1972.

10 Problemas do socialismo não marxista moderno. Sommer, Dansoko, Kaufman e outros. Fevereiro, 1973.

11 Na pátria do socialismo. Alexandre Babo. Abril, 1973. 
12 Os estudantes e o esquerdismo. Claude Prévost. 1973.

13 O problema feminino e a questão social. Coord. Helena Neves.

14 Do conflito à coexistência. Allain van Lombeeck.

15 Discursos de Fidel Castro. Fidel Castro. $4^{\mathrm{a}}$ ed. 1975.

16 Ocupação sem limites: História breve da reacção popular contra os abusos da autoridade praticados na serra de Talhada do Vouga. Armando Pereira da Silva. 1973. Tiragem: 2.500 .

17 A concepção das "superpotências". Pierre Maes.

18 Os trabaladores na empresa. Armando Castro, Francisco Pereira de Moura, Francisco Marcelo Curto, Jorge Sampaio, Marco Pinto e Sérgio Ribeiro. Junho, 1974.

19 A origem do Movimento das Forças Armadas. Tenente Coronel Luís Ataíde Banazol. Julho, 1974.

20 O exército ao serviço de quem? Trabalho publicado na Nouvelle Revue Internationale. Agosto, 1974.

21 Guiné-Bissau: três vezes vinte e cinco. Tenente-coronel Luís Ataíde Banazol.

22 Os capitães: análise crítica da sua formação. Tenente-coronel Luís Ataíde Banazol. Novembro, 1974.

23 Peru: dois mil dias de revolução. Vários.

24 A tarde dos generais. Tenente-coronel Luís Ataíde Banazol.

25 O imperialismo, o internacionalismo $e$ o desespero da burguesia. Fidel Castro e L. Brejnev.

26 De como o golpe militar pode começar um processo revolucionário ou a história de Portugal que NÓS escrevemos HOJE. Sérgio Ribeiro. Junho, 1975. Tiragem: 2.500.

27 Pela a união dos comunistas brasileiros. Vários.

28 Moçambique, vítima do colonialismo. Ernesto Stepham.

29 Angola: na hora dramática da descolonização. Fernando Barciela Santos.

30 Formação do PCB - 1922/1928. Astrojildo Pereira. Março, 1976. Tiragem: 2.700.

Das árvores mortas à reforma agrária; reportagem. Modesto Navarro. Abril, 1976. Tiragem: 3.200 .

$\underline{\text { Biblioteca Popular }}$

1 Dossier Candidatura - Leiria 1969. Sérgio
Ribeiro. Abril, 1970.

2 Portugal através de alguns números. Blasco Hugo Fernandes. ( $3^{\mathrm{a}}$ ed.)

3 Sobre/de Lenine.

4 Censo: quantos/como somos? Sérgio Ribeiro.

5 O dilema da política portuguesa. Sottomayor Cardia. Maio, 1971.

6 Pequeno Dicionário de Economia. $1^{\circ}$ volume. Coord. Sérgio Ribeiro. Junho, 1974. ( $3^{\mathrm{a}}$ ed. Julho, 1975). Tiragem: 3.000.

7 Problemas monetários. G.T.B.

8 O labirinto monetário. Henri Claude e outros.

9 Lei de Imprensa - Liberdade de Imprensa. José Carlos Vasconcelos.

10 Comentários ao dia-a-dia internacional. Alberto Villaverde Cabral.

11 Problemas agrários portugueses: estruturas, tecnologias, política agrícola, reforma estrutural. Blasco Hugo Fernandes. Setembro, 1973.

12 Princípios elementares de filosofia. Georges Politzar.

13 Três eleições. Sérgio Ribeiro.

$14 O$ homem, as suas necessidades $e \quad o$ socialismo. B. Motchalov.

15 Lenine, a filosofia e a cultura. Guy Besse, Jacques Milhau e Michel Simon. Dezembro, 1974.

16 Sindicatos e trabalhadores imigrados. Léon Gani. Abril, 1975. Tiragem: 5.200.

17 Os marxistas e a religião. Michel Verret.

18 Pequeno Dicionário de Economia. $2^{\circ}$ volume. Coord. Sérgio Ribeiro. Novembro, 1974.

19 A revolução das revoluções: a propósito da história da Revolução Soviética. Jean Elleinstein. Março, 1975.

20 Pequeno Dicionário de Economia. $3^{\circ}$ volume. Coord. Sérgio Ribeiro. Fevereiro, 1975.

21 O Papel da mulher na solução do problema feminino nos países socialistas. Vários. 1975.

22 O subdesenvolvimento e o caminho para o desenvolvimento. Humberto Pérez. Junho, 1975. Tiragem: 3.200.

23 Os fundamentos da psicologia. Georges Politzer.

24 Socialismo e capitalismo: perspectivas económicas. Boris Surganov. Agosto, 1975. Tiragem: 3.700 .

31 Pequeno Dicionário de Economia. $4^{\circ}$ volume. Coord. Sérgio Ribeiro. Março, 1976. Tiragem: 5.200. 
Cadernos de Hoje

1 Raízes da expansão portuguesa. António Borges Coelho. $2^{\mathrm{a}}$ ed.

2 Leituras históricas: as origens da república. Flausino Torres.

3 Ensino: sector em crise. Rogério Fernandes.

4 História contemporânea do povo português I. Flausino Torres. $2^{\mathrm{a}}$ ed.

5 Revelando a velha África. Basil Davidson.

6 O Estatuto da Imprensa. Vários.

7 A legislação eleitoral e sua crítica. José de Magalhães Godinho.

8 A mulher na sociedade contemporânea. Colóquios na A. A. da Faculdade de Direito de Lisboa.

9 História contemporânea do povo português II. Flausino Torres.

10 Capitalismo e emigração em Portugal. Carlos Almeida e António Barreto. $2^{\mathrm{a}}$ ed. Agosto, 1974.

11 História contemporânea do povo português III. Flausino Torres.

12 Ordem dos Advogados: advogacia. José de Magalhães Godinho.

13 Comunas ou concelhos. António Borges Coelho.

14 Socilogia e ideologia. Michel Dior.

Política Económica/Economia Política Estudos

1 Para uma ciência da libertação da mulher. Isabel Larguia e John Dumolin. $2^{\mathrm{a}}$ ed. Janeiro, 1975.

4 As mulheres na sociedade em questão. Francette Lazard e outros. 1973.

5 Sobre a habitação. Sérgio Ribeiro. 1973.

Biblioteca de Economia - Direção de Sérgio $\underline{\text { Ribeiro }}$

1 A empresa: célula base da actividade económica. O. Lange, $\mathrm{H}$. Claude e outros.

2 Agricultura, reforma agrária $e$ desenvolvimento económico (seminário por correspondência). Josué de Castro, Ben Barka e outros. Outubro, 1967 (2 ${ }^{\mathrm{a}}$ ed. Fevereiro, 1977).

3 Rendimento e promoção humana: objetivos da política de pessoal nas empresas. Joaquim Marçal da Maia Antunes.

4 Cuba, socialismo e desenvolvimento. René Dumont. (Retirado do mercado)
5 De maio a maio. F. Lazard, Launay, Brière e outros. (Retirado do mercado)

6 Para uma reforma agrária em Portugal. Blasco Fernandes. Outubro, 1969.

7 A Europa e o mundo na década de 70. Mário Baptista.

8 A desvalorização da moeda. A. H. Leal dos Santos. (Esgotado). Novembro, 1970.

9 A economia nas sociedades modernas. Oskar Lange. Abril, 1971. ( $2^{\mathrm{a}}$ ed. Julho, 1975. Tiragem: 3.000.)

10 A agricultura socializada em Cuba. Michel Gutelman. Julho, 1975.

11 A planificação económica: seus fins $e$ realização prática. A. Efimov e A. Anchishkin. Janeiro, 1972. (Fora de mercado)

12 Empresas. Jean-Claude Poitou e outros.

13 Estruturas agrárias em Portugal continental. Vol. I. Júlio Martins.

14 As teoria económicas dominantes e o pensamento tecnocrático. M. Rivière.

15 Com os camponeses: para uma agricultura moderna. Louis Perceval. 1973.

16 A União popular e o domínio da economia. P. Herzog.

17 Política económica e planificação em regime capitalista. P. Herzog.

18 Estruturas agrárias em Portugal continental. 2 vol. Júlio Martins.

19 Trabalho coletivo e trabalho produtivo na evolução do pensamento marxista. Vol. 1. Jacques Nagels. Julho, 1975. Tiragem: 3.200 .

20 O neocolonialismo e os seus métodos. V. Vakhruchev. Agosto, 1975.

21 Estudo marxista sobre a contabilidade nacional. J. C. Delaunay.

22 A economia política marxista e a realidade africana. Y. Popov.

23 A integração socialista. M. Senin.

24 Noções de economia política. Lev Leontiev.

25 Textos económicos (de teoria, reflexão, intervenção). Sérgio Ribeiro.

26 De Keynes à síntese neo-clássica: uma análise crítica. Irina Osdchaya. Janeiro, 1977. Tiragem: 3.200.

$O$ (quase) diário duma desvalorização. Sérgio Ribeiro. 1968.

Política Económica/Economia Política Caderno

1 Fim de década, começo de quê? 
2 Começo de quê, viragem para onde? Março, 1970.

Coleção Para todos - Série A: Mas... Afinal?!... (Direção de Sérgio Ribeiro)

União Soviética: liberdades e direitos. Outubro, 1974.

Os sistemas políticos, os povos e a paz. 1974.

$O$ desporto: quando e onde um necessidade $e$ um direito. 1974.

Pequenas e médias empresas. 1974.

A religião: crítica e autocrítica. 1974.

A economia: lucros ou satisfação das necessidades? (I). 1974.

A nação... o que é... e quem é pela nação? 1974.

A economia: lucros ou satisfação das necessidades? (II). 1974.

A doutrina social da igreja: esmola para homens a mais? 1974.

Sobre (e a propósito) da Unicidade Sindical. Janeiro, 1975.

Eleições e propriedade nos países socialistas. Fevereiro, 1975.

Comunistas e cristãos, face a face e face à crise. 1975.

A juventude da República Democrática Alemã. 1975.

A criação artística e os judeus na União das Repúblicas Socialistas Soviéticas. 1975.

O que é o modo de produção. 1975.

O que é o subdesenvolvimento. 1975.

A dominação do homem e a sexualidade na condição feminina. 1975

A criança: o Homem de (qual?) amanhã. 1975.

O Homem no Mundo

Do Monte Sinai à ilha de Vénus. N Kazantzaki.

Borobudor. Roger Vailland.

Lenine. Roger Garaudy.

As histórias dramáticas da emigração. Waldemar Monteiro.

Revolução, meu amor. Maria Antónia Palla.

A presença negra na América Latina. Luciano Castro.

Barcelona, cidade na Catalunha. António A. Sales.

Emigrados e ofendidos. Manuel Geraldo.

Heroínas da resistência. Coord. Silvia Soares. 1973.

Emigração e crise no nordeste transmontano. Modesto Navarro.
O Esquadrão da Morte. Aderito Lopes.

Um português em Cuba. Alexandre Cabral.

Três tiros da PIDE: quem, porquê e como mataram Amílcar Cabral. Oleg Ygnatiev. Fevereiro, 1975.

\section{República (Lisboa)}

Cadernos República

1 A estrutura agrária portuguesa; problema ainda sem solução à vista. Henrique de Barros. 1972.

2 Relações Igreja-Estado. Entrevista com o Bispo do Porto. Raul Rêgo, João Gomes. Junho, 1973.

3 Emigração: fatalidade irremediável? Francisco de Sales Ramos da Costa. Setembro, 1973.

4 Carta aberta ao presidente do Conselho: análise de um regime. José Magalhães Godinho. Outubro, 1973.

5 "Continuidade": glosas ao discurso eleitoral do prof. Marcelo Caetano. Raul Rego. 1973.

6 Um rumo para a educação. Vitorino Magalhães Godinho. 1974.

7 Do III congresso de Aveiro à última campanha eleitoral. Vasco da Gama Fernandes. 1974.

8 Citações. Américo de Deus Rodrigues Tomás; compil. Abílio Belo Marques, Orlando Leonardo. 1975.

9 "Depoimento" ou libelo: reflexões sobre o livro de memórias de Marcelo Caetano. Raul Rêgo. 1975.

\section{Coleção Documentos}

Ano de eleições. José Magalhães Godinho. 1973.

Tarrafal, o pântano da morte. Cândido de Oliveira. 1974

La rose au poing: para um novo modelo do socialismo. François Mitterrand; pref. Mário Soares. 1975.

\section{Rés (Porto)}

Coleção Revolução social (dirigida por José Pacheco Pereira)

1 A situação política de Portugal vista pelo movimento marxista-leninista internacional: antologia. Selec., pref. e notas José Pacheco Pereira. Setembro, 1975.

2 Sem independência nacional, um povo nada terá: textos e artigos de marxista-leninistas 
sobre a luta pela independência. Compil., anot. e pref. José Pacheco Pereira. Dezembro, 1975. Tiragem: 3.100.

\section{Coleção Substância}

2 A moeda em Marx: teoria marxista da moeda. Suzanne de Brunhoff. 1975.

3 Conceito de liberdade. Bakunine. 1975.

4 Introdução à economia política. Engels.

6 Desenvolvimento das classes sociais. Pierre Guillaume, Alain Touraine, Pierre Naville, Sam Mhlongi, M Hussein. Abril, 1976.

7 Formas políticas, económicas e sociais de exploração. F. Hinkelammert, C. Meillassoux, J. P. Olivier e S. C. Kolm. Março, 1976.

10 A nova sociedade. Proudhon.

17 A economia mista. Philippe Marchat; trad. de Alfredo de Barros. Janeiro, 1977.

\section{Coleção Teoria e Conhecimento}

1 Nietzsche, Freud e Marx / Theatrum Philosoficum. Michel Foucault. 1975.

2 Partidos e pessoas. Reinaldo de Carvalho. Maio, 1975.

3 Dicionário de marxismo. André Barjonet. Maio, 1975.

5 Estruturalismo em Marx e Althusser. André Glucksman. Junho, 1975. Tiragem: 3.100.

6 A planificação e os polos de desenvolvimento. François Perroux. 1975.

8 Consequências da evolução do homem. Friedrich Engels... [et al.]. Novembro, 1975.

9 Economia nacional e economia política. Marx e Engels.

10 Ciências do homem e marxismo. T. Andreani. 1976.

11 A origem do homem. Ernest Heinrich Haeckel. 1976.

\section{Espiral}

A gestão das empresas nacionalizadas. Claude Berthomieu. 1977.

\section{Restauração (Lisboa)}

Cartas políticas. Manuel Leal Freire. 1969.

O projecto da reforma geral do ensino. Manuel Ferreira Rosa. 1971.

Anti-razão. António da Cruz Rodrigues. $2^{\mathrm{a}}$ ed. 1972.

Marxismo e revolução. Jean Ousset (pseudônimo de Jean Marie Vaissière). 1973.

As origens do progressismo cristão. Jean Graviéres. 1973.

Ideologia, práxis e mito da tecnocracia. Juan Vallet de Goytisofo. Trad. Ruivo Serpa. Abril, 1974.

Cristianismo e política. Jean Ousset (pseudônimo de Jean Marie Vaissière). Trad. Ruivo Serpa. Agosto, 1974.

\section{Revolução (Lisboa)}

Coleção Documentos do Partido

Brigadas Revolucionárias. Dossier. Novembro, 1974.

Documentos do Partido Revolucionário do Proletariado-Brigadas Revolucionárias, 1971-1974. 1975. [Este livro aborda os primeiros anos do partido desde a sua fundação até ao período de clandestinidade de antes do 25 de Abril de 1974. http://prpbr.no.sapo.pt/livros3.htm]

E agora? O proletariado na hora das grandes opções. Abril, 1976. [Este livro foca o período revolucionário em curso de 1975 e 76]

Revolução e contra revolução. O PRP responde por si. Documentos do 25 de Abril ao 25 de Novembro. 1977.

\section{Sem Coleção}

Do Estado. Lenine. Setembro/Outubro, 1974.

Conselhos Revolucionários. Projecto PovoMFA. 1975.

O partido e a organização autônoma: uma só solução revolução socialista. 1974.

Do desemprego para a socialização: uma luta política a travar. c. 1974.

Pela ditadura do proletariado, pela revolução socialista. 1975.

Manifesto. Contra a guerra cilvil, a insurreição armada. Novembro, 1975. Tiragem: 50.000.

A insurreição operária do 18 de Janeiro.

\section{Revolução Proletária (Lisboa)}

\section{Coleção Revolução Proletária}

1 O PCE $(\mathrm{ml})$ no VI Congresso do PTA: discurso pronunciado pelo responsável da delegação do CC do PCE (ml) no VI Congresso do PTA. Julho, 1975. Tradução: A. J. M. A.

2 O processo da revolução democrática popular em Moçambique. Samora Moisés Machel. 
1975. Tradução: A. J. M. A.

325 de Setembro dia da revolução moçambicana. Frelimo. Novembro, 1975. Responsável: A. J. M. A.

\section{Resistência (Lisboa)}

Carta de Solzhenitsyn aos governantes soviéticos: apelo-denúncia feito por um homem livre. Alexander Isaievitch Solzhenitsyn. Fevereiro, 1975.

Liberdade-Autoridade. Jean Ousset (Jean Marie Vaissière). 1975.

Conquista do mundo. Marcel Clément. 1975.

As chaves secretas da revolução do 25 de Abril. Michel de Penfentenyo. Janeiro, 1976.

Leonardo Coimbra: acto de encontro. Amândio César. 1976.

Quem era Salazar? António José de Brito e outros. 1978.

A morte de Dias Coelho: a defesa que a ordem me confiou. Carlos Quental. Março, 1978. Tiragem: 5.000.

Boas e más reformas agrárias (I - II- III - IVV): a invasão soviética do Alentejo. José Pequito Rebello. 1978.

As condições da esperança. Jorge Borges de Macedo. 1978.

As falsas ideias claras em economia agrária. José Pequito Rebelo. 1979.

Europa, meus amores. António da Cruz Rodrigues. 1979.

A formação do pessoal. Manuel Damásio. 1979.

A diplomacia portuguesa nos seculos XVII e XVIII. Eduardo Brazão. 1980.

Problemas actuais de educação: o futuro da educação ou a educação do futuro. António da Cruz Rodrigues. 1980.

A dez anos da morte de José Régio: testemunhos. Orlando Taipa,...[et al.]. 1980.

Armadas portuguesas de meados do século XIV a meados do século XVI: alimentação $e$ abastecimento. José de Vasconcellos e Menezes. 1980.

A política económica do Marquês de Pombal: apontamento ensaístico. António de Sousa Lara. 1981.

$O$ bom combate. Miguel Ângelo da Cunha Teixeira e Melo. Outubro, 1981. Tiragem: 2.000 .

Temas económico-sociais: o trabalho e a sociedade, propriedade e participação, Portugal e a integração económica europeia. Miguel Ángelo da Cunha Teixeira e Melo. 1981.

Boticas e boticários de além mar: armadas portuguesas de meados do século $X V$ ao $3^{\circ}$ quartel do século XVI. José de Vasconcellos e Menezes. 1981.

\section{Sá da Costa (Lisboa)}

Cadernos Livres

1 A guerra do povo na Guiné-Bissau. Mário de Andrade. 1974.

2 Democracia. António Sérgio. 1974.

3 Sobre a situação em Cabo Verde. Relatório do PAIGC. 1974.

4 Os camponeses africanos e a revolução. Basil Davidson. 1975.

5 Portugal e o neocolonialismo. Eduardo de Sousa Ferreira. 1975.

6 Educação política e conscientização. Paulo Freire. 1975.

7 Energia e equidade. Ivan Illich. 1975. Tiragem: 3.000.

8 A decadência do corporativismo. Eduardo de Sousa Ferreira. 1975. Tiragem: 3.000.

9 A libertação da mulher. Rosiska Darcy de Oliveira e Mireille Calame. 1976. Tiragem: 3.000 .

10 A luta de classes em África. Kwame Nkrumah. 1976.

11 Ivan Illich e Paulo Freire: a opressão da pedagogia, a pedagogia dos oprimidos. Rosiska Darcy de Oliveira e Pierre Dominicé. 1977. Tiragem: 3.000.

12 A energia nuclear. Jaime da Costa Oliveira.

13 Para a renovação da política nacional. Vitorino Magalhães Godinho. 1978. Tiragem: 4.000 .

14 Guiné-Bissau: reinventar a educação. Rosiska e Miguel Darcy de Oliveira. 1978.

15 Discurso sobre o colonialismo. Aimé Césaire. 1978. Tiragem: 3.000.

16 A ordem social do futuro. H. Caeiro Pereira. 1978.

\section{$\underline{\text { Terceiro Mundo }}$}

1 A libertação da Guiné: aspectos de uma revolução africana. Basil Davidson; prefácio de Amílcar Cabral. Junho, 1975. Tiragem: 3.000 .

2 Lutar por Moçambique. Eduardo Mondlane. $2^{\mathrm{a}}$ ed. 1976. Tiragem: 5.000 .

3 O fim de uma era: o colonialismo português em áfrica. Eduardo de Sousa Ferreira. 1977. 
Tiragem: 3.000 .

4 A experiência chilena: reformismo ou revolução? Alain Labrousse. 1978.

5 Mãe negra: África - os anos de provação. Basil Davidson. 1978. Tiragem: 4.000.

6 A Igreja e a política no Brasil. Márcio Moreira Alves. 1978.

7 Em defesa da revolução africana. Frantz Fanon. 1980.

8 Breve história de África. Roland Oliver, J. D. Fage. 1980.

9 Que é o desenvolvimento. Yves Benot. 1980.

10 A crise do imperialismo.Samir Aimn, Alexandre Faire, Mahmoud Hussein, Gustave Massiah. 1980.

11 Angola sob o domínio português: mito $e$ realidade. Gerald J. Bender. 1980.

12 A pilhagem do Terceiro Mundo. Pierre Jalée. 1980.

13 O imperialismo em 1970. Pierre Jalée. 1981.

14 Ideologias das independências africanas. Yves Benot. 1981.

15 Da China. Maria Antoniettta Macciocchi.

16 Neocolonialismo, último estágio do imperialismo. Kwame Nkrumah.

$\underline{\text { Utopia }}$

Utopia ou morte! René Dumont. 1975.

Porquê a revolta? Jean-Paul Sartre, Pierre Victor e Philippe Gavi. 1975.

Vozes do Mundo

1 Sagrada esperança. Agostinho Neto. 1974.

3 Terra morta. Castro Soromenho. 1975.

4 Poesia com armas: poemas. Fernando Costa Andrade; pref. Mário Pinto de Andrade. 1974

5 Antologia temática de poesia africana. 1: $\mathrm{Na}$ noite grávida de punhais. Mário de Andrade. 1975.

Nós os do Makulusu. Luandino Vieira. 1974.

Angola Angolê Angolema. Arlindo Barbeiros.

Antologia de poesia açoriana: do século XVIII a 1975. Selecção, pref. e notas de Pedro da Silveira. 1977.

\section{Clássicos Sá da Costa. Nova Série}

Democracia: diálogos de doutrina democrática; alocução aos socialistas; cartas do terceiro homem. António Sérgio; edição crítica orientada por Castelo Branco Chaves. 2a ed. 1974.
Ensaios. António Sérgio; edição orientada por Castelo Branco Chaves, Vitorino Magalhães Godinho, Rui Grácio e Joel Serrão; organizada por Idalina Sá da Costa e Augusto Abelaira. 1974.

\section{Descobrir Portugal}

Ricos e pobres no Alentejo: uma sociedade rural portuguesa. José Cutileiro. 1977.

Cristianismo e revolução. Joaquim Alves Correia; sel. de textos e coord. de Anselmo Borges. 1977.

\section{Nova Universidade}

3 A economia política, uma ciência social. M. H. Dowidar; trad. de António Neves Pedro. 1978.

$\underline{\text { Sem coleção }}$

Antologia dos economistas portugueses (Século XVII). António Sérgio. 1974.

Pequeno manual de filosofia. V. de Magalhães Vilhena. 1975. (Esteve proibido pela censura por muitos anos)

Breve interpretação da história de Portugal . António Sérgio. 4a ed. 1975.

Ensaios II: sobre a história de Portugal. Vitorino Magalhães Godinho. 2a ed. correcta e ampl. 1978.

Origens do colonialismo português moderno: 1822-1891. Valentim Alexandre. 1979.

\section{Seara Nova (Lisboa)}

\section{Sem coleção}

Cancioneiro da esperança.Antologia organizada por Maria Teresa Horta e José Carlos Ary dos Santos. 1971.

A revisão do contrato colectivo de trabalho dos metalúrgicos. 1974.

Palavras de combate. Urbano Augusto Tavares Rodrigues. 1975.

Mulheres portuguesas na resistência. Rose Nery Nobre de Melo. Agosto, 1975. Tiragem: 5.200 .

No reino de Caliban I: antologia panorâmica da poesia africana de expressão portuguesa: Cabo Verde, Guiné-Bissau. Organização, selecção, prefácio e notas de Manuel Ferreira. 1976

No reino de Caliban II: antologia panorâmica da poesia africana de expressão portuguesa: Angola, São Tomé e Principe. Organização, selecção, prefácio e notas de Manuel 
Ferreira. 1976.

O capital monopolista conspira assim! Análise e divulgação de documentos inéditos. Comissão Coordenadora Intercomissões de Trabalhadores do Grupo CUF. 1977.

Discursos, conferências, entrevistas. Vasco Gonçalves. 1977.

Os pobres. Raul Brandão. 1978.

Coleção Edições do Cinquentenário

Seara Nova: antologia. Compil. e pref. Mário Sotomaior Cardia. 1972.

Obra política de Raul Proença. Raul Proença. Introd. Câmara Reys. 4 Vols. Edições comemorativas do cinquentenário 1921/1971. 1972.

Antologia

Pela reforma da República 1921-1926. Organização, prefácio e notas de Sottomayor Cardia. 1972.

\section{Coleção Nova Realidade}

1 Viagem à R.D.A. Blasco Hugo Fernandes. 1975.

\section{Coleção Congressos}

II Congresso Republicano de Aveiro: Teses e documentos. 1969.

Congresso da Oposição Democrática: conclusões. 1973.

Teses. $3^{\circ}$ Congresso da Oposição Democrática de Aveiro, Aveiro, 4 a 8 de Abril de 1973. 1974.

\section{Factos e Documentos}

5 O movimento operário britânico. A. L.Morton e George Tate. Junho, 1968.

6 Novamente a Coreia? Wilfred Burchett. Abril, 1969.

7 Palestina: liberdade ou morte. Ania Francos. 1970.

8 Para onde vai a Alemanhã? Heinz Abosch. 1970.

9 A segunda guerra da Indochina. Wilfred G. Burchett ; trad. Augusto Abelaira. 1971.

\section{Cadernos Seara Nova}

De Bandung a Nova Delhi. Josué de Castro. 1968.

Introdução ao teatro cubano. Rine Leal e Rogério Paulo. 1971.
Cadernos Seara Nova / Economia \& Finanças

$O$ orçamento, a "política" e a "economia". Sérgio Ribeiro. Fevereiro, 1969.

Proposta de lei de meios para 1969. Sérgio Ribeiro.

A política económica portuguesa: diálogo entre dois economistas. F. Pereira de Moura, Sérgio Ribeiro. 1969.

A estratégia do desenvolvimento. Josué de Castro. 1971.

Cadernos Seara Nova / Política

Os direitos do homem (Documentos da ONU). Introdução de Mario Sottomayor Cardia. Dezembro, 1968.

Quatro semanas em outubro: reflexões políticas. Alberto Ferreira. Abril, 1970.

Sobre o humanismo na sociedade comunista. Marx, Engels, Lenine. Maio, 1977.

Cadernos Seara Nova / Série Movimento das $\underline{\text { Ideias }}$

Nossa América. Salvador Bueno, Roberto F. Retamar. 1973.

Cadernos Seara Nova / Actualidade Nacional

As cooperativas em questão: para a história da decreto-lei 520/71. Organização, prefácio e notas de Lino de Carvalho e Gorjão Duarte. Novembro, 1972.

A banca, o "Estado social" e a expansão dos lucros. Francisco Pereira de Moura. Outubro, 1973.

A evolução da economia portuguesa. Armando de Castro e Gilberto Lindim Ramos. Maio, 1973.

Por uma democracia anticapitalista. Mario Sottomayor Cardia. Julho, 1973.

A inflação e os trabalhadores. Armando Castro, Caiano Pereira e Francisco Pereira de Moura. Fevereiro, 1973. (Esgotado)

Fortaleza. António Borges Coelho. 1974.

Assimetrias de crescimento e dependência externa. Miriam Halpern Pereira. 1974.

Sobre o direito de reunião: condenação $e$ absolvição dos democratas de Braga. 1974.

Os trabalhadores e o custo de vida. Eugénio Rosa. Abril, 1974.

As opiniões que o DL teve. José Saramago. Coedição com Futura. Janeiro, 1974.

Vinte e um dias de luta. Urbano Tavares Rodrigues. Maio, 1975. 
Cantos da revolução. José Jorge Letria. Maio, 1975. Tiragem: 10.200 .

Herdeiros e continuidores do anarquismo. Pedro Soares. Março, 1975. Tiragem: 10.200.

Os apontamentos. José Saramago. Janeiro, 1976. Tiragem: 4.200.

Registos do outono quente. Urbano Tavares Rodrigues. 1976.

Sobre as qualificações escolares e profissionais dos trabalhadores portugueses. António Teodoro. 1977.

A adesão ao Mercado Comum: fatalidade ou opção? Sérgio Ribeiro. 1977.

A economia portuguesa em debate. Eugénio Rosa, Mário Murteira, Sérgio Ribeiro. 1977.

Cadernos Seara Nova / Actividade Nacional

Uma etapa da revolução. Urbano Tavares Rodrigues. Outubro, 1975. Tiragem: 4.200.

\section{Cadernos Seara Nova / De Leste a Oeste}

Viagem à União Soviética e outras páginas. Urbano Tavares Rodrigues. $2^{\mathrm{a}}$ ed. Dezembro, 1973.

Porque se revoltam os estudantes? As origens dos movimentos estudantis nos países de capitalismo avançado. Fernando Correia. Novembro, 1973.

África: colonialismo e socialismo. Edgar de Valles. 1974.

Sobre as sociedades multinacionais. CGT CUT. 1975.

As grandes manobras dos monopólios petrolíferos. Léonide Madvedko. 1975.

Cuba e Argélia: caminhos do Terceiro Mundo. Novembro, 1975. Tiragem: 4.200.

Mercado comum - Comecon. Sérgio Ribeiro. 1975.

A ciência e a revolução socialista de outubro. José Gaspar Teixeira. 1975.

Problemas da cultura em Cuba. 1975. Dezembro, 1975. Tiragem: 4.200.

Sobre a nacionalização da banca. V. I. Lénine. Abril, 1975. Tiragem: 7.200.

Sobre a liberdade e a democracia em regime socialista. Marx, Engels, Lenine. Novembro, 1976. Tiragem: 3.200.

O Capital de Marx sempre actual. Porquê? V. Vygodski. 1976.

No labirinto da democracia ocidental. Vários autores. 1976.

O capitalismo contemporâneo e os intelectuais. S. Nadel. 1976.
Cadernos Seara Nova / Actividade Internacional

A nova face da ditadura brasileira. Miguel Arraes. Novembro, 1974.

Argumentos

2 Perspectivas de paz. J. D. Bernal. 1968.

3 Os materialistas franceses de 1570 a 1800. Roland Desné. 1969.

4 Portugal na Europa do seu tempo (História socioeconómica medieval comparada). Armando Castro. 1970.

5 As ideias políticas e sociais de Alexandre Herculano. $2^{\mathrm{a}}$ ed. corrig. E aument. Joaquim Barradas de Carvalho. 1971.

6 Sobre o antimarxismo contestatário ou as infelicidades de um jdanovista ofuscado pelo neocapitalismo. Sottomayor Cardia. Dezembro, 1972.

7 Educação, igualdade e socialismo: teoria e prática da diferenciação social em países socialistas. Janina Markiewicz-Lagneau. 1973.

8 Pensamento e acção. Paul Langevin. 1974.

9 Sindicatos e socialismo. Henri Krasucki. Maio, 1974.

$10 O$ obscurantismo salazarista. Joaquim Barradas de Carvalho. Novembro, 1974.

11 O homem dominado. Albert Memmi. 1975.

12 Charrua em campo de pedras (Perfil da vida $e$ obra de Alves Redol). José Manuel Mendes.

13 António Gramsci. Palmiro Togliatti. 1976.

14 Lições sobre o fascismo. Palmiro Togliatti. 1975.

15 Suor e alegria: os trabalhadores em Cuba. Márcio Moreira Alves. Julho, 1975. Tiragem: 3.200.

16 o 25 de Abril e o problema da independência nacional. António Borges Coelho. Agosto, 1975. Tiragem: 5.200.

17 Comités de Defesa da Revolução em Cuba. 1975.

18 Contra o dogmatismo e o sectarismo do movimento operário. V. I. Lénine. Janeiro, 1976. Tiragem: 4.200.

19 Lénine e o partido bolchevique. Humberto M. da Cruz. 1976.

20 A técnica do golpe de estado contrarevolucionário. Marcos Domic. 1976.

21 Desporto e democracia. Manuel Sérgio. 1976.

22 Cartas sobre a revolução portuguesa. Louis 
Althusser e Luiz Francisco Rebello. Abril, 1976. Tiragem: 5.200.

23 Princípios da política do PCF. Julho, 1976. Tiragem: 5.200.

24 O socialismo para a França. Georges Marchais. 1976

25 Escritos da prisão. Marcelino Camacho. Setembro, 1976. Tiragem: 4.200.

26 Combate por um teatro de combate. Luiz Francisco Rebello. Março, 1977. Tiragem: 3.200 .

27 A formação dos quadros. V. I. Lenin. 1977.

28 O conceito comunista de moral. Karl Marx, Friedrich Engels, Lenine. 1977.

29 A contra-revolução silenciosa. Janos Berecz ; trad. de Adelino dos Santos Rodrigues. 1977.

30 Lukács e a crítica da filosofia burguesa. J. Paulo Netto. 1978.

Coleção Seara Nova/ Biblioteca de Estudos sobre a Sociedade e a Cultura Portuguesas

3 Estudos de economia teórica e aplicada. Armando Castro. 1968.

4 Crítica a alguns aspectos do Plano de Fomento. Álvaro Neto. 1969.

5 A crise do liberalismo e as primeiras manifestações das ideias socialistas em Portugal (1820-1852). Victor de Sá. Dezembro, 1969.

6 Histórias à margem de um século de história. F. Keil do Amaral. 1970.

7 Para a história do sindicalismo em Portugal. Alexandre Vieira. Dezembro, 1970.

8 Episódios dramáticos da Inquisição portuguesa. Vol. 1: Homens de letras e de ciência por ela condenados. António Baião. 1972.

9 Episódios dramáticos da Inquisição portuguesa. Vol. 2: Homens de letras e de ciência por ela condenados. António Baião. 1972.

10 Episódios dramáticos da Inquisição portuguesa. Vária. António Baião. 1972.

11 Os crimes da Monarquia. Compil., anot. e pref. Alexandre Cabral. 1973.

12 Eça político. João Medina. 1974.

13 Para a história do sindicalismo em Portugal. $2^{\mathrm{a}}$ ed. Alexandre Vieira. Abril, 1974.

14 O operariado e a República Democrática (1919-1914). César Oliveira. 1974.

18 O primeiro congresso do Partido Comunista Português. César Oliveira. 1975.

19 Quatro anos de deportação. Mário
Castelhano. 1975

20 A revolução de 1383: tentativa de caracterização. António Borges Coelho. 1975.

21 Diário da guerra civil (1826-1832). Vol. I. Recolha, notas e prefácio de José Tengarrinha. Sá da Bandeira. Setembro, 1975. Tiragem: 3.200.

22 Diário da guerra civil (1826-1832). Vol. I. Recolha, notas e prefácio de José Tengarrinha. Sá da Bandeira. Setembro, 1975.

23 Escritos (1927-1930). Bento Gonçalves. 1976.

24 Subsídios para a história do movimento sindical rural no Alto Alentejo (1910-1914). António Ventura. Dezembro, 1976. Tiragem: 3.200 .

25 Os sindicatos operários e a república burguesa (1910-1926). David de Carvalho. Março, 1977. Tiragem: 3.000.

26 O sindicalismo do funcionalismo público na I República. Beatriz Ruivo e Eugénio Leitão. Junho, 1977.

27 Emílio Costa e o sindicalismo: da formação libertária à casa sindical. Seleção, introdução e notas de António Ventura e Alberto Pedroso. Janeiro, 1978.

Coleção Que país?

1 Investimentos estrangeiros em Portugal (alguns aspectos). Luis Salgado de Matos. Fevereiro, 1973.

2 Direitos, liberdades e garantias individuais. José Magalhães Godinho. 1973.

3 A censura e as leis de imprensa. Alberto Arons de Carvalho. 1973.

4 Para onde vai a economia portuguesa? Francisco Pereira de Moura. $4^{\mathrm{a}}$ ed. 1973.

5 Da filosofia no liceu. José Trindade Santos.1974.

6 Causas que foram casos. José Magalhães Godinho. 1974.

7 Problemas actuais da economia portuguesa: Os monopólios e o 25 de Abril. Eugénio Rosa. Dezembro, 1974.

8 Como fazer controlo da produção. Carlos Pimenta. 1976.

9 Combates pela democracia. José Tengarrinha. 1976.

10 O projecto burguês do governo socialista. Francisco Pereira de Moura. 1977.

11 O fracasso da política de direita: 16 meses de governo PS. Eugénio Rosa. Fevereiro, 
1978. Tiragem: 5.200.

12 Reforma agrária: contributo para a sua história. Blasco Hugo Fernandes. Agosto, 1978. Tiragem: 3.200 .

Obras Escolhidas de Amílcar Cabral (Texto coordenados por Mário de Andrade)

A arma da teoria: unidade e luta. Vol.I. $2^{\mathrm{a}}$ ed. Fevereiro, 1978. Tiragem: 3.000.

A prática revolucionária: unidade e luta. Vol. II. Novembro, 1977. Tiragem: 5.200.

Documentos Vivos da História de Portugal

1 Manifesto dos emigrados da Revolução Republicana de 31 de janeiro de 1891. 1974.

2 Sindicatos: tarefas de ontem e de hoje. Textos de 1926-1927. Seleção e prefácio de Canais Rocha. Outubro, 1974.

3 A evolução anarquista em Portugal. J. M. Gonçalves Viana. Abril, 1975. Tiragem: 4.200 .

4 Em marcha! Notas e comentários sobre a greve do funcionalismo público em 1920. Nogueira de Brito. Agosto, 1976. Tiragem: 4.000 .

5 O sindicalismo no Alentejo: a "tournée" de propaganda de 1912. António Vieira. Julho, 1977. Tiragem: 4.200.

\section{Coleção De Leste a Oeste}

1 A actor em viagem (Cuba 1970/1972). Rogério Paulo. Novembro, 1972.

2 A segurança e a cooperação europeias. 1973. (Fora de mercado)

3 Programa comum do governo. Partido Comunista Francês, Partido Socialista Francês. 1973.

4 Os Estados Unidos em movimento. Compilação de Roger Kempf. 1973.

5 A minha guerra com a CIA (A luta do Camboja pela sobrevivência). Norodom Sihanouk. Julho, 1975. (1 ${ }^{\mathrm{a}}$ ed. 1973)

6 A ciência, a paz e a segurança mundial. Federação Mundial dos Trabalhadores Científicos. 1973.

7 Autogestão à prova. Milojko Drulovic. 1973.

8 Duas ou três coisas sobre a União Soviética. Martine Monod. 1974.

9 Alguns princípios do partido. Amílcar Cabral. Setembro, 1974.

10 A guerra em Angola. Mário de Andrade e Marc Ollivier. Setembro, 1974.

11 Análise de alguns tipos de resistência.
Amílcar Cabral. 1974. $2^{\circ}$ ed. Março, 1975.

12 O despertar da revolução brasileira. Márcio Moreira Alves. Janeiro, 1975.

13 O socialismo vai bem. Michel Jouet. Abril, 1975. Tiragem: 6.350 .

14 Sete palmos de terra e um caixão. Josué de Castro. 1975

15 Como a Europa subdesenvolveu a África. Walter Rodney. 1975.

16 Portugal depois da Revolução dos Capitães. Wilfred Burchett. Julho, 1975. Tiragem: 20.200.

17 Portugal antes e depois do 25 de novembro. Wilfred Burchett. Abril, 1976. Tiragem: 5.200 .

18 A derrota americana no Vietnam: gafanhotos contra elefantes. Wilfred Burchett 1977.

19 A crise do Apartheid. Edgar Valles. 1977.

19 A contra-revolução húngara. Janos Berecz. 1977.

22 Espanha - estado multinacional. Dolores Ibarruri. 1978.

Aspectos do colonialismo português. Eduardo de Sousa Ferreira. 1974.

Africa Austral: o passado e o futuro. Eduardo de Sousa Ferreira ; pref. Basil Davidson. 1977.

Estudo dos obstáculos ao desenvolvimento do Terceiro Mundo: perspectivas de desenvolvimento. Maria Isabel de Sousa Melo. 1977.

A agonia do fascismo espanhol. Xesus Cambre Mariño. 1977.

Coleção Leste a Oeste / Nova Série

Redescoberta da França. Urbano Tavares Rodrigues. 1973.

Coleção Universidade Livre

2 Marx/Engels. Jean Bruhat. 1973.

3 O Modo de Produção Asiático. CERM. 1974.

4 Camponeses, sans-cullotes e jacobinos. Albert Soboul. 1974.

5 Condicções actuais do humanismo. Hector Agosti.

6 Escritos políticos. Vol. I. Antonio Gramsci. 1976.

7 Sobre as sociedades pré-capitalistas. Vol. I. Maurice Godelier.

8 Sobre as sociedades pré-capitalistas. Marx, Engels, Lenine. Vol. II. 1976.

9 Estrutura e dialéctica da personalidade. Alberto L. Merani. 1976.

10 O O capitalismo monopolista do Estado: 
tratado marxista de economia politica. Paul Boccara. Vol. I. Paul Boccara. 1976.

11 O capitalismo monopolista de Estado. Vol. II. Paul Boccara.

12 O capitalismo monopolista de Estado. Vol. III. Paul Boccara.

13 O capitalismo monopolista de Estado. Vol. IV. Paul Boccara.

14 Escritos políticos. Vol. II. Antonio Gramsci. 1977.

15 Economia política do capitalismo. Vol. I. Humberto Pérez González. 1977.

16 Economia política do capitalismo. Vol. II. Humberto Pérez González. 1977.

17 Sobre "O Capital” de Marx. F. Engels. 1977.

18 Escritos políticos. Vol. III. Antonio Gramsci. 1977.

19 Escritos políticos. Vol. IV. Antonio Gramsci. Abril, 1978. Tiragem: 3.200.

$\underline{\text { Temas actuais }}$

1 Português, trabalhador, doente mental. Maria de Fátima Bivar Velho da Costa. 1976.

2 Mandei-lhe uma boça. Olga Gonçalves. 1977.

3 A mulher, a família e a lei. Laura Lopes. 1977.

4 A crítica das armas. Regis Debray. 1977.

Para uma nova ordem económica internacional. Simpósio Internacional de Argel-1975. Prefácio de Mário Ruivo. Dezembro, 1977.

Biblioteca Socialista Portuguesa

1 A associação. José Cipriano da Costa Godolfim. 1974.

2 A Rússia dos sovietes. J. Carlos Rates ; pref. César Oliveira. 1976.

Educação e Ensino

1 Ensino primário e ideologia. Maria de Fátima Bivar. 1975.

2 A educação em Cuba. trad. Natividade Correia. 1975.

4 O ensino na República Democrática Alemã. G. Bouvard, P. Pellenq. 1976.

6-7 Sobre a educação. V. I. Lenine ; compil. Jesualdo ; trad. de Eduardo Saló. 1977.

8 Desporto e desenvolvimento humano. Y. Adam e outros; pref. Arnaldo Pereira. 1977.

9 A instrução pública na URSS. N. Kuzine, M. Kondakov, P. Zimine, M. Kolmakova, V. Lubovski, G. Berezina e A. Foteeva. 1977.

10 Formação do pessoal da alfabetização funcional: guia prático. Unesco. 1977.
11 Problemas da educação escolar soviética. Anton Makárenko. 1978.

12 Problemas actuais na democratização dos ensinos secundário e superior. A. Le Gall e outros. 1978.

Ecologia e sociedade

1 Uns comem os figos... 1975.

2 Marxismo e meio ambiente. Guy Biolat. 1977.

3 Como vamos sobreviver. The Ecologist... [et al.]. 1977.

\section{Seara Vermelha (Lisboa)}

$\underline{\text { Sem Coleção }}$

Sobre a propaganda. Mao Zedong. 1977.

Textos escolhidos. Mao Zedong.

Sobre as dez grandes relações. Mao Zedong.

Sobre a organização. Mao Zedong.

Notas sobre temas contemporâneos: a China.

Os submarinos de Cunhal no PS; seguido de Os cabeças de gis do social imperalismo russo. Júlio Dias. 1977.

Dois anos a contracorrente: informe apresentado ao VII Congresso do Partido Comunista de Portugal (M-L). Heduíno Gomes (Vilar). 1977.

Cadernos de Estudos e Debates

2 Como escolhi o leninismo. Ho Chi Minh.

Pequena Biblioteca Operária

$1 O$ que foi o XX Congresso PCUS?

2 Princípios do comunismo. F. Engels.

3 Manifesto do Partido Comunista. Marx e Engels. 1975.

Clássicos Marxistas

1 Os princípios do leninismo. Stalin.

2 Trotskismo ou leninismo? Stalin.

3 A revolução de Outubro e a tática dos comunistas russos. I. Stalin.

4 A amizade mais profunda. Mao Zedong.

5 Cinco ensaios filosóficos. Mao Zedong. 1975. Tiregem: 3.000 .

$\underline{\text { Teoria e Ensaio }}$

Marxismo-leninismo contra revisionismo em Portugal (I).

História do Partido Comunista (Bolchevique) 
da URSS. 1974.

Leninismo ou social-imperialismo? Pelas redações do Renmin Ribao, da revista Hongqi e do Jiefangjun Bao. $2^{\text {a }}$ ed. 1974.

Proclamação-Programa dos comunistas (Bolcheviques) revolucionários soviéticos. 1974.

As tarefas das secções da Internacional Comunista na política municipal.

Sobre a Edificação do Partido. José Gregório.

Sobre a associação e o movimento do operariado vidreiro. José Gregório. 1975.

Programa e Estatutos do Partido Comunista de Portugal (Marxista-Leninista): aprovados no VI Congresso. 1975. Tiragem: 5.000.

Informe apresentado ao VI Congresso do Partido Comunista (Marxista-Leninista). E. Vilar.

Ciências e Técnicas

1 China: um esboço geográfico.

Ilustrações e Documentos

"Unidade Popular" Clandestina: Números 1 a 19. Março de 1969 a Abril de 1974. 1974.

\section{Literatura}

1 A estrela vermelha. Li Sitian.

2 Numa comuna popular. Zhu Li e Tian Shieyun.

\section{Sementeira (Lisboa)}

Páginas do meu caderno: poesia. Artur Modesto. 1978.

Solidariedade com os trabalhadores alentejanos! 1978.

Maio 68: textos e cronologia. 1979.

O despertar operário em Portugal, 1834-1911. Edgar Rodrigues. Agosto, 1980. Tiragem: 1.500 .

Os anarquistas e os sindicatos: Portugal, 19111922. Edgar Rodrigues. Janeiro, 1981. Tiragem: 1.500 .

A resistência anarco-sindicalista à ditadura: Portugal 1922-1939. Edgar Rodrigues. Dezembro, 1981. Tiragem: 1.500.

A oposição libertária em Portugal (1939-1974). Edgar Rodrigues. 1982.

Episódios da minha vida familiar e de militante confederal. José Francisco. 1982.

Dois exemplos de autogestão na Espanha revolucionária, 1936-1939. Gaston Leval. Suplemento ao no 4 de A Ideia. Abril, 1976.

Federalismo; A Associação dos Irmãos Internacionais. Bakunine. Suplemento ao $\mathrm{n}^{\circ}$ 5 de A Ideia. Julho, 1976.

\section{Sementes (Porto)}

Coleção Sementes

1 Manifesto do Partido Comunista. MarxEngels. Junho, 1974. ( $3^{\text {a }}$ ed. esgotada)

2 China: a luta contra o revisionismo. Agosto, 1974.

3 A nossa política económica. Mao Tsétung.

4 Sobre a literatura, a filosofia e a música. A. Jdanov. 1975.

5 Lenine. Estaline.

6 A revolução em Espanha. Karl Marx, Friedrich Engels. 1976

7 Marxismo e questões de linguística. Estaline. 1975.

825 anos de lutas e vitórias na via do socialismo. Enver Hoxha.

9 O general do exército morto. Ismail Kadaré. 1976.

10 A democracia popular. Dimitrov. Dezembro, 1975.

11 O controlo operário. Enver Hoxha. 1976.

12 A guerra popular. N. Giap. Janeiro, 1976.

13 A escola para todos. Naim Frashëri. Fevereiro, 1976.

16 Como enganar o povo. Lenine. 1976.

Foice e Martelo

1 Os problemas económicos do socialismo na URSS. Estaline.

2 A luta de guerrilhas. Marx, Engels, Lénine, Estaline. 1975.

4 O sistema de trabalho assalariado. F. Engels. Fevereiro, 1976.

\section{Selecta (Lisboa)}

A imprensa comunista e o avanço do P.C.P. Laszló Revesz. 1976.

O pavoroso caso Timor: Jornal "O Retornado" denuncia ao mundo. Sá Pereira, Adulcino Silva. Coedição com a Editora Literal. Outubro, 1976. Tiragem: 10.000.

A bordo da revolução: ensaios de análise política 75/76. Francisco Lucas Pires. 1976. Tiragem: 5.000 . 
Acusamos a descolonização: colectânea de cartas do Jornal "O Retornado". Coedição com a Editora Literal. Novembro, 1976.

Portugal 74-76: Ultramar-Metrópole: muitas promessas, tristes realidades: balanço de 2 anos com 6 governos. J. Belard da Fonseca. Maio, 1976.

Um ABC de termos políticos modernos. Compil. Lewis Barton. 1976.

Comandos da liberdade em Moscovo. Michel Slavinsky. 1977.

O caso Lefebvre. Roland Gaucher. 1977.

Reaccionarismo de Esquerda: Socialismo Democrático ou sociedade livre. Compil. R.C.D.S. 1977.

Sindicatos no mundo comunista e no mundo livre: o que são e o que representam. Peter Sager. 1977.

A última chance de liberdade. Jean Kiffer. 1977.

Testemunhos sobre o genocídio no Cambodja. Compil. Bernard Hamel, Soth Polin; trad. Carlos Gaspena. 1977.

As ilhas da noite: um Goulag amarelo. Robert Vidal. 1977.

Os últimos dias do fascismo na Europa. Jacques de Lunay. Maio, 1978.

Cartas de Jonas Savimbi. Aos amigos, simpatizantes e militantes da Unita em Portugal. Maio, 1978.

O massacre dos alienados: dos teóricos nazis aos médicos SS. Ives Ternon, Socrate Helman; trad. Armando da Silva. 1978.

Domínio soviético na Europa de Leste. J. A. B. Gawenda; trad. Carlos Rabaçal; pref. M. P. Airey Neave. Janeiro, 1978.

Aos amigos, simpatizantes e militantes da Unita em Portugal. Jonas Malheiro Savimbi. 1978.

O centrismo democrático e o totalitarismo. Peter Sager; trad. Ana Maria de Melo Torres.

\section{Investigação Crítica}

A liquidação da social-democracia na Europa de Leste. László Revész. 1977.

A reforma agrária nos países comunistas. Laszló Revész. Coedição com a Editora Literal. 1977.

Exportação de revoluções. Laszló Revész. Coedição com a Editora Literal. 1977.

Serviços Sociais dos Trabalhadores da C. G. D. (Lisboa)

Coleção Repertório Para um Teatro Popular
1 O quarto. Costa Ferreira. Outubro, 1974.

Cadernos Hipopótamos

1 Política externa do $V$ governo provisório. Introd. e compil. Manuel Braga da Cruz. 1975.

2 Textos de política econômica. Mário Murteira. 1975.

3 A encenação no teatro de amadores. Manfred Wekwerth; trad. Mendes de Carvalho. 1976.

Coleção Textos Para uma Cultura Popular

1 Cultura e revolução cultural. V. I. Lenine. Fevereiro, 1975.

2 Resistência vietnamita. N. L. Bang, Bui Lam, Vo N. Giap, H. Q. Viet. Junho, 1975. Tiragem: 5.000.

3 Problemas da juventude. Émile Copferman. 1975.

4 A Comuna de 1871. Marx e Engels. Abril, 1976. Tiragem: 4.000.

5 A Revolução e a Guerra de Espanha. Pierre Broué, Émile Témime; trad. de Mendes de Carvalho, Carmen Ferreira Alves. 1976.

6 A construção da personagem. Constantin Stanislavski. 1977.

Coleção Textos Para uma Cultura Popular Ficção

1 Uma família e duas repúblicas. António Eduardo da Costa Ferreira. 1976.

Coleção Poesia

1 Ecos do silêncio: poesia. Carlos Madeira. 1981.

2 Neves de Agosto. Luís Canceira. 1981.

Coleção Girassol

O peixinho preto. Samad Behranghi; adapt. livre Arsénio Mota; il. Camilo, Branca. 1976.

Sonhos na gaiola: versos para crianças. Manuel Maria; trad. Arsénio Mota, António Cabral. 1977.

Slemes - Serviço de Livros e Edições do MES (Lisboa)

Cadernos Slemes

1 Poder popular: um projeto político? D. Oliveira e M. Vieira. Setembro, 1975.

2 o processo da revolução democrática popular em Moçambique. Samora Machel. Outubro, 
1975.

3 Crise, programa e nova oposição. Lúcio Magri. Março, 1976.

4 A questão do imperialismo em V. I. Lénine e Rosa Luxemburgo. Christian Palloix. Abril, 1976.

5 Luta de classes em Portugal. Paul M. Sweezy. Abril, 1976.

6 Perspectivas sobre a Comuna e a $1^{a}$ Internacional em Portugal. Jacinto Rodrigues. Junho, 1976.

7 Notas sobre a questão da téctica. Raul Vilela. (No prelo)

\section{A Arma da Crítica}

1 A origem do revisionismo: sobre a questão de Estaline. 1976.

História do Movimento Comunista Internacional

Manifestos, teses e resoluções dos quatro primeiros Congressos da Internacional Comunista (1919-1923). Vol. I. 1976.

Cadernos do MES

1 Controlo operário / Poder popular. Janeiro, 1976.

2 A luta de classes à escala mundial (do Relatório da CPN do MES ao II Congresso Nacional - II parte). Março, 1976.

3 Frente de luta nas forças armadas. 1976.

425 de Abril 1974 / 25 de Novembro 1975 - 19 meses de luta. Junho, 1976.

5 Unir a classe operária e o povo contra a exploração e a repressão (Conclusões da $1^{a}$ Conferência de Trabalhadores Fabris da Região de Lisboa, promovida pelo MES). Outubro, 1976.

\section{Sem Coleção}

Poemas. António Machado. 1976.

Portugal: Um guia para o processo. Serviço de Intercâmbio Político e Cultural. Agosto, 1976.

Antes morrer de pé do que toda a vida de joelhos. António Albino Machado.

Pelo sonho não vamos lá. Martinho Marques.

\section{Socicultur (Lisboa)}

Meio Ambiente e Ideologia. Tomás Maldonado; trad. de António Luís Moreira. 1971.
Portugal Hoje

O Portugal de Otelo: a revolução no labirinto. Jean Pierre Faye. Novembro, 1977.

\section{Coleção Ágora}

1 O suicídio nuclear português. Afonso Cautela.

2 O risco nuclear. Jean Rossell.

4 Utopias realizáveis. Yona Friedman. 1978.

5 Como se transferem milhões para a Suíça: o dinheiro secreto e os bancos suíços. J. M. Laya. c. 1978.

\section{Pedagogia e Práxis}

1 Piaget na prática pedagógica. Hilda Santos.

\section{Fermento}

1 A filosofia do trabalho. Henri Arvon.

2 As teorias das ciências humanas. Julien Freund.

3 Autogestão ou ditadura do proletariado. JeanLuc Dallemagne.

\section{Coleção Sobreviver}

2 A invasão farmacêutica. J.-P. Dupuy e Karsenty.

3 Ecologia e luta de classes em Portugal: reportagens. Afonso Cautela. Fevereiro, 1977. Tiragem: 3.200 .

4 Do crescimento económico ao desenvolvimento humano. Jacques Robin.

\section{Sotavento (Faro)}

O ladrão. Georges Darien; trad., notas e pref. de Júlio Carrapato. 1979.

Documento/Depoimentos

Relatório secreto de Nikita Kruchtchev ao XX Congresso do Partido Comunista da União Soviética (texto integral): autópsia do stalinismo. Notas de A. Rossi (Tasca), exsecretário da Internacional Comunista; trad. Júlio Carrapato. 1981.

\section{A Toupeira da História}

1 Diálogo entre Marx e Bakunine. Maurice Cranston; trad. e notas de Júlio Carrapato. Junho, 1979. Tiragem: 2.000.

2 O absurdo da política. Textos de crítica da democracia. Paraf-Javal / Albert Libertad. Tradução e prefácio de Júlio Carrapato. 
Novembro, 1979. Tiragem: 2.000 .

3 Do anarquismo. Nicolas Walter. Tradução e notas de Júlio Carrapato. Dezembro, 1981. Tiragem: 1.500 .

4 Comunismo e Burocracia. Luciano Pellicani. Trad. Do italiano por Irineu Cortes. 1982.

\section{Spartacus (Lisboa)}

Sindicatos: arma contra-revolucionária. Partido Operário Comunista Alemão. Anton Pannekoeck, Herman Gorter e Bergmann. Tradução E. S. Outubro, 1974.

A Comuna de Berlim: as lutas proletárias na alemanha (1918-19). Vários.autores. Dezembro, 1974.

$O$ voto, as eleições, o Estado: armas do capital. Vários. Janeiro, 1975.

O tigre de papel: sobre o desenvolvimento do capitalismo de Estado na China, 1949-1971. Charles Reeve [Jorge Valadas]. Abril, 1975. Tiragem: 3.000 .

Lenine e a revolução. Anton Ciliga. 1975.

A revolução social em Espanha. Vernon Richards. 1975.

\section{Spartacus/OCMLP (Lisboa)}

O Povo em Luta

1 O viaduto. Jan Talpe. Dezembro, 1974.

2 Fazer da escola uma base para o povo tomar o poder. Samora Machel. Janeiro, 1975.

\section{Cultura Nova}

1 Contos vietnamitas.

\section{$\underline{\text { Sem Coleção }}$}

A comuna de Paris, 1871. História aos quadradinhos. Outubro, 1975.

Unir a maioria, para derrotar a minoria: a linha revolucionária da política externa chinesa. Jack A. Smith.

\section{Telos (Porto)}

Os direitos do homem em Portugal: no $25^{\circ}$ aniversário da declaração universal. A. Taborda e outros. Compil., Pref. Francisco se Sá Carneiro. Fevereiro, 1974.

Resistência católica ao salazarismomarcelismo. José Geraldes Freire. Julho, 1976.

\section{Teologia e Sociedade}

1 Jesus Cristo é liberdade. Ernest Kasemann. 1973.

2 Dimensões políticas da fé. René Coste. 1973.

4 Liberdade e manipulação na sociedade e na igreja. Karl Rahner; trad. Anselmo Borges. Porto. 1974

6 Para uma leitura cristã da luta de classes. Alfred Ancel. Novembro, 1976. Tiragem: 2.000 .

Hoje e Amanhã

1 Portugal 73: ano político. Notas para o cidadão eleitor. Diogo Duarte, Emílio Rui Vilar, Manuel Bidarra de Almeida. Fevereiro, 1973.

2 Para uma prática cristã da política. Documento do Episcopado francês. Fevereiro, 1973.

\section{Caderno Telos}

1 A Igreja pós-Conciliar. D. António Ferreira Gomes. 1972.

20 que é ser cristão: apresentação essencial do cristianismo. 1972.

3 Evolução da teologia da guerra. M. D. Chenu. 1972.

4 Paz da vitória ou paz da justiça? Antonio Ferreira Gomes, bispo do Porto. Janeiro, 1973.

6 Amor cristão e violência revolucionária. Giulio Girardi; trad. Anselmo Borges. Junho, 1973.

A igreja e a comunidade política. 1973.

11 Bater a penitência no peito dos outros?! D. António Ferreira Gomes, Bispo Do Porto. 1975.

12-13 Consciência cristã e opção política. Manuel Alves Pardinhas e outros. 1975.

14 Evangelho e libertação humana. D. Helder Pessoa Câmara . 1975.

\section{$\underline{\mathrm{Re} / \mathrm{Ver}}$}

2 Deus para que serve? Zacarias de Oliveira. 1971.

3 Esperança marxista e esperança cristã. Battista Mondin. Junho, 1972.

4 Retrato de uma comunidade de base. Domingos Barbé e Emmanuel Retumba. Fevereiro, 1973.

Paz em Portugal pela reconciliação entre os portugueses. António Ferreira Gomes, Bispo 
do Porto. 1975.

Mesa Redonda

1 Marxismo/Cristianismo. Castro Fernandes, Francisco Pereira de Moura, Jofre do Amaral Nogueira e Sousa Marques. 1972.

4 Os direitos culturais como direitos do homem. Unesco. 1973.

\section{Teorema (Lisboa)}

$\underline{\text { Lobo Mau }}$

1 Para uma antipolítica da saúde. Jean Carpentier. (Esgotado) Fevereiro, 1974.

2 Educação sem escola? Ivan D. Illich. 1974.

3 Racismo e fascismo. Wilhelm Reich. Julho, 1974.

4 Exigir o impossível. Herbert Marcuse. Junho, 1974.

5 A religião do capital. Paul Lafarge. Maio, 1975.

6 A verdadeira história do Tio Sam. Ezequiel Martinez Estrada e Siné. Maio, 1975.

7 Chile, a desnacionalização. Marta Harnecker. Junho, 1975. Tiragem: 5.000.

8 Discurso sobre o filho-da-puta. Alberto Pimenta. 1977.

As paredes em liberdade. Agosto, 1974. (Recolha de fotografias sobre as paredes com pichagens de carácter político e social logo após o 25 de Abril.)

O direito à preguiça. Paul Lafargue. 1977.

Universidade Paralela

1 Ler o capitalismo: sobre o capitalismo mundial e sua crise. Michel Beaud, Bertrand Bellon e Patrick François. Julho, 1977. Tiragem: 3.200.

Teorema Universidade

1 Poética. Tzvetan Todorov. 1977.

2 Marxismo e poesia. George Thomson. 1977.

$\underline{\text { Sem coleção }}$

Manifesto comunista. Karl Marx, F. Engels, Ro Marcenaro. Banda desenhada. 1976.

\section{Terra Livre (Lisboa)}

Coleção Problemas Quotidianos

Portugal: agricultura e problemas humanos.
Gonçalo Santa Rita. 1979. Janeiro, 1979. Tiragem: 20.000.

Portugal Ontem, Portugal Hoje

Memórias políticas I. José Relvas. Tiragem: 20.000 .

Memórias políticas II. José Relvas.

História Imediata

Portugal reencontrado. 1975.

25 de Novembro. Breve panorama gráfico e noticioso duma crise. $2^{\mathrm{a}}$ ed. Março, 1976. Tiragem: 5.000 .

Cidade Livre

Origem e actualidade do civismo. Afonso Botelho. 1979. Tiragem: 20.000.

\section{$\underline{\text { Sem Coleção }}$}

Mocidade Portuguesa: breve história de uma organização salazarista. Lopes Arriaga. 1976.

Esta é a ditosa pátria minha amada. Jacinto Ramos Luz Franco.

\section{Textos da Revolução (Porto)}

1 Relatório ao $6^{\circ}$ Congresso do Partido do Trabalho da Albânia. Enver Hoxha. Agosto, 1974.

2 A libertação da mulher é uma necesidade da revolução, garantia da sua continuidade, condição do seu triunfo. Samora Machel. 1974.

3 A Revolução de Outubro e a táctica dos comunistas russos. Estaline. Outubro, 1974.

4 Princípios do comunismo. F. Engels. Setembro, 1974.

5 Aos pobres do campo. Lenine.

6 A medicina na China. A. Macciochi. Dezembro, 1974.

7 Perguntas e respostas. José Estaline. 1975.

8 Como funcionam os sovietes. John Reed. 1975.

9 Sobre alguns aspectos do problema da mulher albanesa. Enver Hoxha e R. Alia. 1975.

10 As ideias e a obra de Lenine são imortais. Lenine, José Estaline, Zeri i Popullit. 1975.

11 Democracia e ditadura em socialismo. Agim Popa. 1975

120 anarquismo e o trotskismo, teorias contrarevolucionárias. Partido do Trabalho da 
Albânia. 1975.

\section{Textos Marginais (Porto)}

1 O sistema irracional. Paul Baran e Paul Sweezy. Março, 1972.

2 A guerra civil de Espanha. Andrés Nin. Março, 1972. (Fevereiro, 1975)

3 O combate sexual da juventude. Wilhelm Reich.1972.

4 Contribuição para a história do cristianismo primitivo. Karl Marx, Friedrich Engels. Abril, 1972. (3 ${ }^{\mathrm{a}}$ ed. Fevereiro, 1975).

5 Os cristãos e a libertação dos povos. Yves Jolif, CLASC e FCLA, Jean Cardonnel O. P., Francisco Lage Pessoa, padre Arrupe, Paul Blanquart O. P., José Maria Llanos S. J. Maio, 1972. (Volume editado por F. Osório)

6 Discurso sobre as artes e as ciências. JeanJacques Rousseau. 1972.

7 A medicina e a vida hospitalar na República Popular da China: testemunhos sobre a República Popular da China. Dr. J. S. Horn e outros. 1972. $3^{\text {a }}$ ed. Janeiro, 1975.

8 Uma educação para a liberdade. Paulo Freire. 1972. $4^{\text {a }}$ ed. Agosto, 1974.

9 A função do orgasmo em Wilhelm Reich, seguido de $O$ sexo vermelho. Constantin Sinelnikoff. Abril, 1975.

10 O novo mundo industrial e societário $e$ outros textos. Charles Fourier. Junho, 1973.

11 Revolução científica e técnica $e$ transformações sociais. Radovan Richta. 1973.

12 Império e imperialismo americano. Celso Furtado e outros. Setembro, 1973.

13 Uma iniciação à economia. Charles Rouge. $2^{\mathrm{a}}$ ed. Maio, 1974. $3^{\mathrm{a}}$ ed. 1976.

14 Ideologias e elites contemporáneas. Mauro Fotia.

15 Teoria e história do capitalismo monopolista. Harry Magdoff, Paul Baran e Paul Sweezy. 1974. $2^{\text {a }}$ ed. 1976.

16 Viver em Moscovo, viver em Nova York. K. S. Karol, Herman Schreiber. 1975.

17 Miséria de cinema. António Faria. Maio, 1974.

18 Inquérito operário e luta política. K. Marx, Mao Tsé-tung. 1975.

19 A aplicação da psicanálise à investigação histórica. Wilhelm Reich. 1974.

20 Para uma pedagogia activa socialista: a educação pelo trabalho de Pavel P. Blonsky. Theo Dietrich. Setembro, 1974.
21 Progresso social e liberdade. Herbert Marcuse. 1974.

22 Socialismo, casamento e família: a doutrina socialista do casamento. David Riazanov. Janeiro, 1975.

23 Economia política do imperialismo. Paul Sweezy, Richard Wolf, Theotónio dos Santos, Harry Magdoff. Março, 1975.

24 A nossa arma é a greve: a experiência belga de Greve Geral. Franz Mehring, Rosa Luxemburgo, Emile Vandervelde. Maio, 1975.

25 As três fontes do marxismo: a obra histórica de Karl Marx. Karl Kautsky. Julho, 1975.

26 Karl Marx: biografia breve seguida de uma exposição do marxismo. Vladimir I. Lenine. Março, 1976. Tiragem: 3.000. (Dinalivro)

27 Subdesenvolvimento e capitalismo. André Gunder Frank. Fevereiro, 1977. Tiragem: 3.000. (Dinalivro).

28 A formação da consciência socialista. Paul M. Sweezy, Socialist Revolution. Março, 1977. Tiragem: 3.000. (Dinalivro).

\section{Textos Políticos (Porto)}

1 O Estado e a Revolução. Lenine.

2 O materialismo dialéctico e o materialismo histórico. Estaline. Setembro, 1974.

3 Princípios do leninismo. Estaline.

4 Leis fundamentais da economia. Jean Baby. 1974.

5 Questões do leninismo. Estaline. Dezembro, 1974.

6 Do socialismo utópico ao socialismo científico (Ludwig Feuerbach e o fim da filosofia clássica alemã). Engels. Fevereiro, 1975.

7 Cartas sobre o materialismo histórico. Friedrich Engels. 1975.

8 Manifesto do Partido Comunista. Karl Marx e Friedrich Engels. 1976.

9 A nova mulher e a moral sexual. Alexandra Kolantay. 1975.

10 Como iludir o povo com os slogans de liberdade e igualdade. Lenine. 1975.

11 Fundamentos da dialéctica da história. V. Podossetnik, Aleksander Georgievich Spirkin; trad. A. C. Reis. 1975.

12 O partido do trabalho do Vietname conduz o povo à vitória. Truóng Chinh. 1976.

13 Revolução e contra-revolução. Karl Marx. 1975. 
14 Questão do alojamento. Friedrich Engels. 1975.

15-16 A revolução bolchevique. Lenine; trad. Maria Teresa. 1975.

17 A questão judaica. Karl Marx. 1976.

\section{Ulisséia (Lisboa)}

Vietname: os escritores tomam partido. Cecil Woolf, John Bagguley. Abril, 1968.

Armas da guerrilha. Jean-Louis Brau. s/d.

Crónicas e cartas de Manuel de Portugal. Março, 1976.

\section{Biblioteca Ulisseia do Conhecimento Actual}

O socialismo a partir de Marx. Robert KilroySilk. 1975.

\section{A História que Vivemos}

1 Os últimos dias de Estaline. Georges Bortoli.

2 A história secreta da base dps Açores. R. E. Vintras.

4 Os contestatários na União Soviética. Vladimir Gedilaghine. Novembro, 1975.

\section{Alternativas e Experiências}

1 O Chile, o socialismo e a igreja. François Francou.

2 Democracia francesa. Giscard d'Estaing.

3 China: a revolta dos camponeses (18401949). Jean Chesneaux. s/d.

4 O novo totalitarismo. Roland Huntford.

5 A Espanha na encruzilhada. Ricardo Paseyro. s/d.

Corpos de Elite

A Legião Estrangeira. Erwan Bergot. 1973.

\section{Ulmeiro (Lisboa)}

\section{Cadernos Peninsulares}

1 Isto anda tudo ligado, com poemas de Eduardo Guerra Carneiro. 1970.

2 A poesia deve ser feita por todos, de Carlos Loures. 1970.

3 Causas de decadência dos povos peninsulares. Antero de Quental. 1970.

4 Histórias do cárcere: contos. Juan Gómez Casas; trad. José Rolim. 1970.

5 O teatro, a crítica e a sociedade. Adolfo Gutkin. 1971.
Fora de coleção

Massacres na guerra colonial (Tete, um exemplo). Documentos secretos. José Amaro (org.). Abril, 1976.

A África deve unir-se. Kwame Nkrumah. 1977.

Cidade/Campo (Cadernos da Habitação ao Território). № 1 - Fev./78

\section{Cadernos Ulmeiro}

1 A grande tarefa da revolução consiste em formar o homem novo. Fidel Castro. Junho, 1975. Tiragem: 5.000.

2 A Revolução Russa. Rosa Luxemburgo. 1975.

3 Os camponeses cubanos e a revolução. Departamento de orientação revolucionária do CC do PC Cuba. Junho, 1975. Tiragem: 5.000 .

4 Sobre a ditadura do proletariado. Marx, Engels e Lenine. 1975. $2^{\mathrm{a}}$ ed. 1977.

5 Sobre o problema das cooperativas agrícolas. Mao Tse Tung. Novembro, 1975. Tiragem: 5.000 .

6 O MRPP, instrumento da contra-revolução. J. L. Saldanha Sanches. 1975. $2^{\mathrm{a}}$ ed. Fevereiro, 1976. Tiragem: 10.000. $\left(1^{\mathrm{a}}\right.$ ed. Em Dezembro de 1975; Tiragem: 10.000.)

7 Testamento do presidente Ho Chi Minh. 1975.

8 Criar poder popular: reflexões e documentos dum ex-militante da LUAR sobre um partido e uma prática. Fernando Pereira Marques. Junho, 1976.

9 A classe trabalhadora deve conquistar $e$ exercer o poder na frente da ciência e da cultura: discurso... por ocasião do $1^{\circ}$ de Maio de 1976. Samora Machel; pref. de Ramiro Correia; ed. de José Fortunato. 1977.

10 A questão judaica. Karl Marx. $1^{\mathrm{a}}$ ed. agosto, 1976. Tiragem: 3.000. ( $2^{\mathrm{a}}$ ed. Junho, 1978. Tiragem: 3.000.)

11 Angola: documentos da independência. 1976.

12 Crítica da economia nacional. K. Marx. 1976.

13 A ITT contra o 25 de Abril. Oliveira Antunes. Dezembro, 1976.

\section{Cadernos Ulmeiro - Série Dois}

1 As mistificações da "autenticidade" africana. N. Tutashinda. Janeiro, 1978. Tiragem: 3.000 .

$\underline{\text { Imperialismo Americano - Inimigo } \mathrm{n}^{\circ} 1 \mathrm{dos}}$ $\underline{\text { Povos }}$ 
1 Textos de Kim Il Sung.

\section{Documentos de Cuba}

1 Primeira e Segunda Declaração de Havana; Declaração de Santiago do Chile; Lei das Nacionalizações; Lei da Reforma Urbana; Lei da Função Bancária; Lei da Reforma Agrária. Compil. José Fortunato. 1975.

2 Orgãos de poder popular em Cuba: documentos sobre a experiência de Matanzas. Junho, 1976.

\section{Obra Completa de Che Guevara}

1 Textos políticos (Ao Primeiro Congresso Latino-Americano da juventude. Cuba, execepção histórica ou vanguarda na luta anticolonialista? O que deve ser um jovem comunista. $\mathrm{O}$ que é um guerrilheiro. Discurso de Argel. O socialismo e o homem em Cuba. Mensagem à Tricintinental).

2 Textos Económicos. Outubro, 1975. Tiragem: 5.000 .

Terceiro Mundo e Revolução

1 Guerra do povo, exército do povo. V. N. Giap. 1975.

2 Colonialismo e alienação: contribuição para a teoria política de Frantz Fanon. Renate Zahar. 1976.

3 Os condenados da terra. Frantz Fanon. 1976.

$4 O$ armamento das massas revolucionárias, edificação do exército do povo. Vo Nguyen Giap. Novembro, 1976.

\section{$\underline{\text { Biblioteca Ulmeiro }}$}

1 Portugal, nem tudo está perdido: do Movimento dos Capitães ao 25 de Novembro. Capitão Fernandes. Abril, 1976.

2 MFA e luta de classes: subsídios para a compreensão do processo histórico português. Ramiro Correia, Pedro Soldado e João Marujo. 1977.

3 MFA Dinamização cultural e acção cívica. Ramiro Correia, Pedro Soldado e João Marujo. Tiragem: 5.000. 1977.

4 Sobre democracia operária e outros textos. António Gramsci. Setembro, 1976.

5 Sobre Brecht. Mário Sério. 1976.

6 História da China - 1840/1949. 1977.

7 Teoria da insurreição. Emílio Lusso. 1977.

8 O imperialismo e o desenvolvimento desigual. Samir Amim. 1977.

10 Problemas actuais do marxismo. Henri
Lefebvre. Setembro, 1977. Tiragem: 3.200.

12 O sidonismo e o movimento operário: luta de classes em Portugal, 1917-1919. António José Telo. 1977.

13 Angola, do 25 de Abril ao 11 de Novembro. A via agreste da liberdade. Artur Queiroz. Julho, 1978.

14 A CIA contra Angola. John Stockwell. 1979.

16 Alvorada em Abril. Otelo Saraiva de Carvalho. Abril, 1984. $3^{\mathrm{a}}$ ed. $\left(1^{\mathrm{a}}\right.$ na Ulmeiro). Tiragem: 2.200.

\section{Forças da Vida}

1 Perguntas à nossa igreja: Igreja e política do 25 de Abril ao 25 de Novembro: cronologias / C. E. R. P. (Cristãos em Reflexão Permanente). 1976.

2 Textos cristãos: 25 Abril - Novembro 25. Dezembro, 1977.

3 Creio na revolução. Mário de Oliveira. Dezembro, 1977.

4 A Igreja e o tempo. D. Manuel Vieira Pinto (Bispo de Nampula, Moçambique). Abril, 1979.

\section{África em Luta - Nova Série}

1 Os congressos da Frelimo, do PAIGC e do MPLA: uma análise comparativa. Luís Moita. Coedição com CIDAC. Fevereiro, 1979. Tiragem: 3.500 .

\section{Teatro Ulmeiro}

1 Ah Q: tragédia chinesa baseada em Lu Sun. Bernard Chartreux, Jean Jourdheuil. 1976.

2 Fanshen. Adapt. David Hare. 1976.

\section{Para Ler / Para Fazer (livros infantis)}

Era uma vez uma ilha... onde as crianças construiram a escola nova. Ilust. Roerto Ravazzi. 1975.

\section{Coleção Viver}

1 Crescimento zero. Luís Racionero. s/d.

2 Manifesto sobre política energética: por um debate nacional sobre a opção nuclear. Vários autores. Janeiro, 1978. Tiragem: 3.000 .

\section{Unidade Popular (Lisboa)}

1 Proposta sobre a linha geral do movimento comunista internacional. Partido Comunista da China. 1974. 
2 Luta pacífica e luta armada no nosso movimento. Francisco Martins Rodrigues. $3^{\text {a }}$ ed. Outubro, 1974.

Reforcemos a combatividade dos comunistas e de todos os antifascistas frente à PIDE / Se fores preso camarada... Duas linhas diferentes sobre a posição frente à PIDE. s/d.

A revolução democrático-popular, parte integrante da revolução socialista. A propósito da etapa da revolução. [Texto publicado no $\mathrm{n}^{\mathrm{o}} 24$ do jornal "Unidade Popular", órgão do Partido Comunista de Portugal (marxista-leninista)]. s/d.

\section{Vento de Leste (Lisboa)}

\section{Sem Coleção}

Glória eterna à memória do grande dirigente e grande educador o Presidente Mao TséTung! Setembro, 1976.

A catástrofe iminente e os meios de a conjurar. V. I. Lenine. 1976.

Documentos do XI Congresso do Partido Comunista da China (Agosto de 1977). 1977.

Lenine em Outubro. 1976.

Obras Escolhidas (1949-1957). Mao Tsé Tung. $5^{\circ}$ volume. 1977.

\section{Cadernos Vento Leste}

1 Sobre o Estado e as eleições. K. Marx, F. Engels. Neste livro aparece: "Editora responsável: O Tempo e o Modo, SARL". Janeiro, 1975.

2 Sobre as greves e os sindicatos. V. I. Lenine. Março, 1975.

3 Viva o partido! Lenine. 1975.

4 Sobre o Estado e as eleições. Lenine. 1975.

5 Viva o $1^{o}$ de Maio. Lenine, Estaline. Março, 1975.

6 Guerra do povo à guerra imperialista. Lenine. 1975.

7 Aliança operária-camponesa. Lenine. 1975.

8 Sobre o projecto de Constituição da U. R. S.S. Estaline. Agosto, 1975.

9 A imprensa operária. Lenine. 1975.

10 O exército ao serviço de quem? Fevereiro, 1976. Tiragem: 3.000 .

11 "Nada é impossivel no universo, desde que se ouse escalar a montanha" (Balanço 1975). 1976.

Sobre os quadros. Georgi Dimitrov. 1976.
Obras Completas de Estaline

1 Estaline: obras. Vol.1: 1901-1907. 1975.

Amizade Portugal-China

1 Constituição da República Popular da China. Março, 1975.

2 Dez questões sobre a China. Maio, 1975. Tiragem: 5.000.

3 Ensaios filosóficos escolhidos de operários, camponeses e soldados. Julho, 1975. Tiragem: 5.000.

4 A revolução cultural nas fábricas chinesas. Outubro, 1975. Tiragem: 3.000.

5 A Revolução Cultural nos campos chineses. Novembro, 1975.

6 A mulher na nova China. 1976.

\section{Amizade Portugal-Albânia}

125 anos de lutas e de vitórias na construção do socialismo. Enver Hoxha. 1975. (Editora responsável: O Tempo e o Modo, S.A.R.L.)

\section{Movimento Comunista Internacional}

1 História do Partido do Trabalho da Albânia I (1928-1941). Instituto de Estudos MarxistasLeninistas. "Publicação da responsabilidade da Sociedade Anônima O Tempo e o Modo, SARL". Novembro, 1974.

2 História do Partido do Trabalho da Albânia II (1941-1948). Janeiro, 1975.

3 História do Partido do Trabalho da Albânia III (1948-1960). Abril, 1975. Tiragem: 5.000 .

4 História do Partido do Trabalho da Albânia IV.

5 História do Partido Comunista (bolchevique) da URSS. Vol. I (1883-março 1917). "Editora responsável: O Tempo e o Modo, SARL". 1975. (A 2 $2^{\mathrm{a}}$ edição não trás a identificação como Vol. I, e no subtítulo a data é 1883-1937). Tiragem: 3.000. 1975.

6 História do Partido Comunista (bolchevique) da URSS. Vol. II.

7 Duas linhas antagónicas no movimento sindical mundial. Filip Kota. 1975.

8 Diversos aspectos da degenerescência $e$ desintegração nos países e partidos dominados pelos revisionistas.

9 Os 50 anos do Partido Comunista da China: 1921-1971. (Editora responsável: O Tempo e o Modo, SARL). Dezembro, 1974. Tiragem: 10.000 . 
10 História do Partido do Trabalho da Coreia. Por ocasião do XX aniversário da fundação do Partido do Trabalho da Coreia. Kim Il Sung. Junho, 1975.

11 Viva a Comuna de Paris! 1975.

12 Sobre a edificação e a vida do partido. Textos do PTA. Vol. I. Janeiro, 1976. Tiragem: 3.000.

13 Cuba, um mito que se apaga: da revolução anti-imperialista a peão do social.imperialismo. 1976.

Cadernos Martins Soares

1 Chile: uma lição para os revolucionários de todo o mundo.

2 Guia de agitação e propaganda. 1975.

3 Viva a vitória da ditadura do proletariado. Em comemoração do centenário da Comuna de Paris.

4 "Uma grande desordem sob os céus!". Fevereiro, 1975.

5 O social-imperialismo e a guerra. Redacção do "Diário do Povo" e da revista "Bandeira Vermalha". Abril, 1975. Tiragem: 5.000.

6 Os revisionistas soviéticos restauram o capitalismo na URSS. 1975.

7 A actual crise. 1975.

8 O social-imperialismo revisionista soviético. 1975.

9 Viva a revolução cultural proletária: crítica a Confúcio e a Lin Piao. 1975.

11 O Estado e as eleições. José Estaline. 1976.

\section{Coleção Clássicos}

1 Sobre o partido da classe operária. Estaline. 1974. ("Este livro é a $2^{\mathrm{a}}$ edição revista e aumentada do primeiro livro publicado por esta editora." Setembro, 1975.)

2 Cartas de longe e Teses de Abril. V. I. Lenine. 1974.

3 Anarquismo ou socialismo? José Estaline. 1974.

4 Teses sobre a democracia burguesa e ditadura do proletariado. V. I. Lenine. Dezembro, 1974. (Editora responsável: O Tempo e o Modo, S.A.R.L.)

5 Escritos militares. Lenine.

6 o perigo de direita, o desvio de direita. Estaline. Julho, 1975.

7 Sobre a literatura e a arte. Mao Tsé-tung. 1975.

8 O 18 brumário de Luís Bonaparte. Karl Marx. 1975.
9 Fábrica e controlo operário. Lenine. Setembro, 1975. Tiragem: 5.000 .

10 A organização. Lenine. 1975.

11 Escritos militares. Marx/ Engels. 1975.

12 Marxismo ou revisionismo. Lenine.

Arte e Cultura Novas

1 Histórias de Ye Sinan. Ho Yi. 1974.

2 Lutar é aúnica coisa que nos resta. 1975.

312 de Outubro vermelho. Teatro. Junho, 1975.

4 Contos Laocianos. 1975. Setembro, 1975. (Este livro é editado em colaboração com o jornal Yenan.")

6 Com o presidente Mao. Tchen Tchang.Feng. Janeiro, 1976. ("Este livro é editado em colaboração com o jornal Yenan.")

Quadros heróicos do povo em luta. Teatro. Júlio Vilarinho. Janeiro, 1977.

Histórias de Ye Siuan.

\section{Cultura Democrática e Popular}

Nós povo: poesia. Leonel Santos. 1976.

Clássicos do Povo

1 História do Partido Comunista (Bolchevique) da URSS.

2 Manifesto do Partido Comunista. Karl Marx, Engels.

3 Do socialismo utópico ao socialismo científico. Friedrich Engels.

4 O que é o marxismo? Lenine. Maio, 1977.

Obras de Maiakovski

1 Eu próprio / Poesia 1912-1916. Maiakovski. 1979.

\section{Coleção Linha Geral}

1 Sobre a linha geral para o movimento comunista internacional. 1979.

\section{Verbo (Lisboa)}

História breve das constituições portuguesas. Marcelo Caetano. 2a ed. 1968.

Pelo futuro de Portugal. Marcello Caetano. 1969.

Os descobrimentos portugueses. Damião Peres. 1970.

Mandato indeclinável. Marcello Caetano. 1970.

Renovação na continuidade. Marcello Caetano. 1971. 
Cárcere invisível. Francisco Costa. 1972.

As grandes opções. Marcello Caetano. 1973.

O 25 de Abril e o ultramar: três entrevistas e alguns documentos. Marcello Caetano. 1976.

Minhas memórias de Salazar. Marcello Caetano. 1977.

PREC - Processo revolucionário eventualmente chocante: de 16 de Março de 1974 a 10 de Junho de 1977. Augusto Cid. 1977.

Constituições portuguesas; quinta edição, segundo a edição revista e actualizada pelo autor com análise da Constituição de 1976. Marcello Caetano. Outubro, 1981.

O pensamento político de Sá Carneiro e outros estudos. José Miguel Júdice. 1982

\section{Via Editora (Lisboa)}

Coleção Biblioteca

1 Psicologia e materialismo dialéctico. JeanFrançois Le Ny. 1976.

20 discurso do poder de Estado (Diário). José Amaro. Março, 1978.

3 Terrorismo ou revolução, de Raoul Vaneigem, seguido de Pela revolução, de Ernest Coeurderoy. 1978.

\section{Prática Teórica}

1 Teoria económica e economia política. Trotsky, Lenine e outros.

2 África: ensino e revolução. Ahmed Sèkou Touré. 1977

\section{Vias de Facto}

1 Por uma tecnologia libertadora. Murray Bookchin. 1976.

\section{Enciclopédia Universitária}

3 Paul Goodman e a reconquista do presente. Bernard Vicent. 1978.

6 As origens intelectuais do Leninismo. Alain Besançon. 1979.
Autores de Expressão Portuguesa

Vida e morte de João Cabafume. Gabriel Mariano. 1976.

Coleção Economia

1 A economia da revolução. Ahmed Sékou Touré. 1977.

2 A política económica da burguesia. Jean-Luc Dallemagne. 1977.

3 Ensaios sobre a teoria do valor em Marx. Vol. I. I. Rubin. 1977.

4 O neocapitalismo : uma política económica do capitalismo contemporâneo. Guy Quaden. 1978.

Livros de Algibeira. Política

2 Carta aos militantes comunistas espanhóis : sonho e mentira do eurocomunismo. Arrabal. 1979.

$\underline{\text { Literatura de Combate }}$

1 Horizonte aberto. Sukre D'Sal. 197?.

Fora de coleção

A longa marcha da revolução. Ernest Mandel. 1979.

Porcos com asas. Rocco e Antónia. 1980.

\section{Voz do Povo (Lisboa)}

Revolução Popular. Edição completa, 1964-65. Setembro, 1974.

O que é a UDP? A situação política, programa, estatutos. União Democrática Popular. 1975.

A missão histórica mundial da classe operária. Foto Çami. 1975.

Controlo operário. s/d. (c. 1975)

A União Democrática Popular na Assembleia Constituinte : declaração de voto... 1976. 


\section{APÊNDICE 4}

\section{Lista de livros políticos publicados em Portugal entre 1968 e 1980 por outras 107 editoras não incluídas neste trabalho (publicaram menos de cinco títulos políticos no período)}

Neste Apêndice estão listadas as 107 editoras que localizei em meu levantamento que publicaram até quatro títulos políticos no período entre 1968 e 1980. Estas editoras não são objeto de análise nesta tese. A lista apresenta apenas as obras políticas publicadas por essas editoras.

As editoras aparecem em ordem alfabética.

A lista traz as as seguintes informações: Nome da Editora. Nome da coleção (quando houver). Título da obra. Autor. Mês da edição (quando houver), Ano da edição. Tiragem (quando houver).

Quando não constar o ano da edição isto significa que tal informação não aparece no próprio livro e que não foi possível apurar, por nenhuma outra fonte, qual seria essa data. Da mesma forma, quando aparecer a informação sobre a tiragem da obra é porque a mesma constava dos exemplares publicados. O local da edição é o mesmo da sede da editora. 


\section{Editoras que publicaram livros políticos em Portugal no período 1968-1980 (menos de cinco títulos)}

\author{
Académica (Lisboa) \\ Trotsky ou Mao? A crise (revolução) francesa \\ de Maio-Junho. Mario Matos e Lemos. \\ Prefácio de Pedro Cabrita. Julho, 1968. \\ O espantalho da política. Pedro Cabrita. 1968.
}

\section{Colecção Espaço Actual}

1 Revolução permanente: a crise francesa de Maio-Junho de 1968. Pedro Cabrita e Martins da Cruz. 1968.

ADFA - Associação dos Deficientes das Forças Armadas

Trinta facadas de raiva. Capitão Calvinho. $2^{\text {a }}$ ed. 1976.

Amigos do Livro, Editores (Lisboa)

Capitães de Abril. Alexandre Pais e Ribeiro da Silva. 2 volumes. s/d.

António dos Reis / Intervoz (Lisboa)

Eanes, porquê o poder? Paulino Gomes. 1976.

Portugal depois de Abril. Avelino Rodrigues, Casário Borga e Mário Cardoso.

Obviamente demito-o: retrato de Delgado nas palavras dos companheiros de luta. Manuel Beça Múrias. s/d.

Área - Sociedade de Comunicação Visual (Lisboa)

Até na prisão fui roubado! Artur Agostinho. Abril, 1976. Tiragem: 20.000.

Arte na Luta

O viaduto. Jan Talfe. 1975.

8 de Março Dia Internacional da Mulher. s.d.

\section{Associação de Amizade Portugal-Cuba}

A revolução cubana e o ódio do imperialismo: intervenção na Sessão de Solidariedade para com o Povo Cubano realizada...em 27 de Maio de 1980. Alexandre Cabral. 1980.

\section{Bazar Gomes Freire (Lisboa)}

Como se vive na URSS? Adriano Vaz Velho. Março, 1975.

\section{Cadernos da Prática}

Inquérito operário e luta política. Tradução, seleção, prefácio e edição de Amadeu Lopes Sabino e Sebastião Lima Rego. 1971.

\section{Cadernos de Hoje (Lisboa)}

Notas para uma análise da Revolução Russa. J. Barrot. Maio, 1972.

\section{Cadernos do Século}

O mundo contra a fome.

O império do dólar.

Oito escritores frente à política.

Liberdade e alienação no pensamento contemporâneo.

\section{Cadernos Marxistas (Lisboa)}

Ensaio para uma revolução. 25 Abril 10 anos de lições. Francisco Louçã. s/d.

\section{Cadernos Populares}

Democracia burguesa e ditadura do proletariado. Lenine. s/d.

Cadernos Renovação - Associação Nacional de Estudos Políticos e Sociais (Lisboa)

Pensar na revolução. Afonso Oliveira. 1978.

\section{Casa Viva}

25 de Abril. Afonso Praça, Albertino Antunes, Cesário Borga e outros.

Guerrilha no deserto. Manuel Batoréo. 1978.

Artistas de Moçambique

1 Transformei-me em tartaruga para resistir. Inácio Matsinhe. 1975.

Centro de Estudos Político-Económicos CEPE (Lisboa)

Comentários à política económica do VIII governo-AD. João Costa Figueira. 1983.

\section{Coimbra Editora (Coimbra)}

Entre duas tiranias. Mário Braga. 


\section{Colecção Coimbra Editora}

36 O pensamento político e social de Karl Marx. Shlomo Avineri. Agosto, 1978.

\section{Cooperativa Editora História Crítica}

A Acção Escolar Vanguarda (1933/1936): a juventude nacionalista nos promórdios do Estado Novo. António Costa Pinto e Nuno Afonso Ribeiro. 1980.

\section{Copsa - Cooperativa Editorial Perspectivas Sociais Autónomas (Porto)}

\section{Cadernos Livres}

10 apartidarismo e o valor social do trabalho. Manuel Rodrigues. 1976.

2 As gentes e as coisas... Ana Correia, Henrique Monteiro. 1976.

3 O Conselho Municipal do Porto: balanço de uma experiência. A. Botelho, M. Pinheiro. 1977.

4 Temas da revolução. Manuel Rodrigues. 1977.

\section{Cosmos (Lisboa)}

António Sérgio, "o idealismo crítico e a crise da ideologia burguesa”. Vasco Magalhães Vilhena. $2^{\mathrm{a}}$ ed. 1975.

A educação num Portugal em mudança. Vitorino Magalhães Godinho. 1975.

\section{Cronos Publicações (Lisboa)}

Memórias de um polícia português. António Augusto Afonso. Abril, 1973.

\section{Dêagá (Lisboa)}

Unicidade: minicomícios no grande comício. Pedro Alvim. Fotos de José Tavares e Jose Teixeira. Outubro, 1975. Tiragem: 5.000.

Memórias de um prisioneiro do Tarrafal. Correia Pires. Julho, 1975. Tiragem: 5.000.

Pedro e Luísa: morrer antes do fim. Nuno Gomes dos Santos e José Tavares. Prefácio de Álvaro Cunhal. Junho, 1975. Tiragem: 5.000 .

Portugal ano um da Revolução. Texto: Josué da Silva; fotos: José Tavares, Álvaro Tavares e José Teixeira. Julho, 1975. Tiragem: 15.000.

\section{Decibel (Lisboa)}

11 de março. Março 1975. Tiragem: 40.000.

Primeiras eleições livres. Maio, 1975. Tiragem:
País Realidade / "Cadernos" Decibel

Portugal a democracia difícil. Alfredo Barroso. Maio, 1975. Tiragem: 6.500.

\section{DIG Livros (Lisboa)}

Sócio-psicanálise da revolução portuguesa. Manoel Lourenço Forte. Março, 1982. Tiragem: 3.200.

\section{Dinalivro (Lisboa)}

$1 O$ sindicato na empresa. Hubert Lesire Ogrel. Maio, 1976. Tiragem: 3.000 .

4 Poder político e classes sociais do estado capitalista. Nicos Poulantzas. 1977.

5 Prefácio a nova economia política. Celso Furtado. 1976.

Edição EL (Esquerda Laboral) - Editorial Esquerda Democrática

Para a história do PS. Textos da Esquerda Laboral. Prefácio e seleção de Francisco Marcelo Curto. Tiragem: 2.000.

\section{Edição Somuna}

Memórias de um ano de revolução: itinerário de um jornalista na luta por um jornal. Nuno Rocha. Junho, 1975. Tiragem: 5.000.

\section{Edições 18 de Setembro}

Lenine Propagandista. s/d.

\section{Edições A Comuna (Lisboa)}

$O$ assalto à COPAM: ascensão e queda dos patrões cunhalistas. Ana Barbosa. 1978.

\section{Edições Alavanca}

História da Intersindical. Vol. I. Setembro, 1978. Tiragem: 10.000

Se o pacote 2 for aplicado... Confederação Geral dos Trabalhadores Portugueses Intersindical Nacional. $2^{\text {a }}$ ed. Setembro, 1977.

\section{Edições Armasilde}

Coleção Arquivo da História

1 A tortura no mundo. Vários. Janeiro, 1978.

\section{Coleção Kiri}

Jonas Savimbi: um desafio à ditadura 
comunista em Angola. Marcos Vinícius e Maria João Saldanha. Outubro, 1977. Tiragem: 1.500 .

\section{Edições Azinhaga (Lisboa)}

No mundo dos PPDês. Fernanda Mestrinho e Rui Ochoa. Tiragem: 2.000.

\section{Edições Bairro (Lisboa)}

Colecção Reflexão Política

1 A minha carreira e os meus combates: uma análise sobre o movimento sindical. Andre Bergeron. 1977.

2 Os palestinianos do silêncio. Clara Halter. 1977.

\section{Colecção Mundos Ocultos}

1 O nazismo, sociedade secreta. Werner Gerson. 1976. Tiragem: 3.000 .

2 Origens da máfia. Andrew Williams.

\section{Edições Branco e Negro (Lisboa)}

O depoimento de Américo Thomaz. José Vilhena. 1975.

Vera Lagoa meteu a pata na poça. José Vilhena. 1979.

A grande gaita. Tomo I. J. Vilhena. 1973.

\section{Edições Comité 28 de Novembro (Lisboa)}

A nossa vitória é apenas questão de tempo: comunicado do Comité Permanente do C. C. da Fretilin de 14-9-77, aquando da traição de Xavier do Amaral. 1978. Texto em português e em tétum (dialecto timorense).

\section{Edições Flecha}

Angola, independência envenenada. Georges Lecoff. 1977.

\section{Edições Folha Comunista}

Os fatores objectivos e subjectivos na revolução. Foto Çami.

\section{Edições Fronteira (LUAR)}

Apontamentos sobre a revolução. Fernando Pereira Marques. Agosto, 1974.

\section{Edições Itau}

A explosão demográfica e a fome no mundo. Josué de Castro. 1968.

Estatutos do homem. Tiago de Melo. 1970.
A fome. Michel Cépéde, Hugues Gounelle. 1973.

Portugal à mesa: entre a fome e a abundância. Júlio Roberto. 2a ed. 1977.

Edições Luta Estudantil - Comissões Estudantis de Unidade Revolucionária

A resistência anti-fascista (1926-1940): relatório de José Gregório sobre os acontecimentos de 18 de Janeiro de 1934. Janeiro, 1975.

\section{Edições M.B. (Viseu)}

Acuso e... recuso a canga. Após o Abril dos rubros cravos: apontamentos para a história de uma revolução. Afonso da Costa Robeiro (Paulo Nazaré). Abril, 1976.

\section{Edições Macroplan (Lisboa)}

Impasse. Francisco Sá Carneiro. $3^{\mathrm{a}}$ ed. Abril, 1978. ( $1^{a}$ ed. Abril, 1978, $2^{\text {a }}$ ed. ampliada, Abril, 1978)

\section{Edições Na Revolução (Lisboa)}

O Capital, de Marx em banda desenhada. Carlos Barradas, Orlando Neves e Pedro Rodrigues.

O Alentejo na reforma agrária. Álbum fotográfico. Sérgio Guimarães.

Eanes um presidente no curso da constituição. Carlos Pinto Santos, Orlando Neves. 1978.

\section{Edições O Comunista}

A evolução proletária e a ditadura do proletariado (excertos). José Estaline. s/d (c. 1977)

\section{Edições O Jornal (Lisboa)}

Angola, um país de vida ou morte. Cadernos $\mathrm{O}$ Jornal.

Cartoons, 1969-1975. João Abel Manta; prefácio de José Cardoso Pires. 1975.

Eleições 76: o futuro em causa. 1976.

Caricaturas portuguesas dos anos de Salazar. João Abel Manta. 1978.

\section{Edições O Operário Marítimo}

Sobre a emancipação da mulher. 1975.

\section{Edições O Professor (Porto)}

2 Perspectiva do ensino em Portugal. António Pedro. Maio, 1976. Tiragem: 3.000. 
3 Educação: luta de ontem, luta de hoje. Jofre Amaral Nogueira, Óscar Lopes, Armando de Castro e outros. Junho, 1976. Tiragem: 3.000 .

4 Cuba: por uma escola nova. Fidel Castro e Elio D. Henriquez.

6 Escolas do magistério e contra-reforma. Cabral Pinto. Maio, 1977. Tiragem: 3.500.

\section{EDOC - Edições Operário-Cristãs (Lisboa)}

Horizonte Aberto

Em diálogo: pastoral operária. Bispo do Porto, Pe. Chenu. 1979.

\section{$\underline{\text { Reflexão }}$}

1 Os pobres e a libertação dos homens. A. Rebré. 1978.

3 A mensagem libertadora de Jesus Cristo. A. Rebré. 1979.

\section{Edições Paulistas (Apelação, Loures)}

\section{Coleção Grito da Liberdade}

1 Sakharov e a luta pelos direitos do homem na Rússia. André Martin. Novembro, 1976.

2 Bukovski o contestatário.

3 Os cristãos na Rússia.

4 Os campos de trabalho na Rússia. Abraão Chifrine 1978.

\section{Edições Pelagus (Lisboa)}

Cartas da revolução. António Augusto Sales. Março, 1978. Tiragem: 2.000.

\section{Edições Rolim (Lisboa)}

Coleção Figuras Políticas - dirigida por Loy Rolim

Continuar Portugal: discursos e outros escritos. Galvão de Melo. s/d.

Willy Brandt e a Alemanha de hoje. Henri Ménuder. Julho, 1978.

Um argelino chamado Boumediène. Ania Francos e J. P. Séréni.

\section{Edições Saber Porquê}

Tomás, por ele mesmo.

\section{Edições Viriato (Lisboa)}

A lei de reforma agrária na China. 1976.

Carta a Otelo Saraiva de Carvalho. Agosto 1975.

\section{Ediguia (Amadora)}

Setembro 28: a negra madrugada. Vida e morte de um atentado à democracia. Amadeu José de Freitas e Flamarion Cruz.

Campanha eleitoral na TV 1976: textos integrais das intervenções de todos os partidos. 1976.

\section{Editora Infinito (Lisboa)}

O MFA no banco dos réus. Quem foi julgado: Sanches Osório ou Vasco Lourenço? Sanches Osório e Henrique de Sousa e Melo. 1976. Tiragem: 10.000 .

O mito do saneamento e a contra-revolução silenciosa. Francisco dos Reis Sapim.1977.

\section{Editora Nosso Tempo}

Hon Dat. Autor: Anh Duc. 1975.

\section{Editorial 18 de Janeiro}

Otelo. António Tavares Teles. Novembro, 1976. Tiragem: 5.000.

As sevícias dum relatório. Outubro, 1977. Tiragem: 5.000.

\section{Editorial Aqui}

Tudo sobre Intersindical e Carta Aberta. Coord. de António Serzedelo. 1977.

\section{Editorial Formação}

Angola, a guerra e o crime. Valdemiro de Sousa. Abril, 1976. Tiragem: 5.000.

$O$ homem perante o homem. Valdemiro de Sousa. 1976.

\section{Editorial Gleba}

Vasco Gonçalves: perfil de um homem. Fernando Luso Soares. 1979.

A oposição em Espanha. Loy Rolim. 1977.

\section{Editorial Império (Lisboa)}

$O$ inferno vermelho: coisas vistas. Guido Moinés. 1936.

\section{Editorial Minotauro (Lisboa)}

Peças em um acto: a Guerra Santa / A estátua. Luís Stau Monteiro. 1966.

Profissão exilado. Manuel Vinhas.

A questão académica de 1907. Natália Correia; pref. de Mário Braga. 
Colecção O Livro do Dia

O Vietname entre a paz e a guerra. Jean Lacouture. Dezembro, 1965.

\section{Editorial Pórtico (Lisboa)}

Carta aberta à direita. Jean-François Revel.

\section{Editorial Propaganda}

O pequeno livro negro: pensamentos de Adolf Hitler. 1976.

Protocolos dos sábios de Sião. 1976.

\section{Editorial Signum (Lisboa)}

\section{Coleção Documentos}

1 Os novos processos de Moscovo: o caso Guinzburg-Galanskov. Compil. JeanJacques Marie e Carol Head. Dezembro, 1970.

Coleção Autores contemporâneos

1 Memória destruída. Rogério de Freitas. 1970

\section{Coleção Biblioteca das Ideias}

2 Alienação e sociedade industrial. François Perroux. 1970.

\section{Editorial Vouga (Aveiro)}

25 de Abril: Liberdade e esperança. Augusto Vieira. Maio, 1974.

\section{Editus (Lisboa)}

Xeque mate sem cobertura. Monstruário da ditadura. Vítor Ribeiro, Zé Dalmeida. 1975.

25 de Novembro: anatomia de um golpe. L Pereira Gil. Março, 1976. Tiragem: 10.000.

Constituição da República portuguesa 1976 (anotada). Victor Silva Lopes. $3^{\mathrm{a}}$ ed. Maio, 1976. Tiragem: 5.000 .

Cenas parlamentares: humor, agitação $e$ ataques na Constituinte. Victor Silva Lopes. 1976.

\section{Frase, Cooperativa Editora (Lisboa)}

Andrade da Silva: legítima defesa dum capitão de Abril. Manuel Geraldo. s/d.

Ramiro Correia: soldado de Abril. Eduardo Miragaia, Joaquim Vieira, Manuel Vieira. c1977.

\section{Gabinete Alpeca - Edições (Almada)}

Colecção Marxismo

1 Trabalho assalariado e capital. Karl Marx. $2^{\mathrm{a}}$ ed., s/d.

2 Salário, preço e lucro. Karl Marx. s/d.

3 O sistema de trabalho assalariado. Friedrich Engels. s/d.

4 Manifesto do Partido Comunista (1847). Karl Marx e Friedrich Engels. Coordenação e tradução de Alfredo Camacho. s/d.

\section{Génese (Lisboa)}

Colecção Cadernos Critério

1 A democracia socialista, um mundo novo e um novo Portugal. Vitorino Magalhães Godinho. Abril, 1976.

2 Situação africana e consciência nacional. Eduardo Lourenço. Agosto, 1976.

3 Um país, um projeto: caminhos e atalhos da via socialista portuguesa. Grupo. S. L. Outubro, 1976.

\section{Sem Coleção}

Estampas revolucionárias. 1974.

\section{Grupo Autónomo do Partido Socialista - GAPS}

Greve geral 18 de janeiro 1934. 1974.

\section{Guimarães \& C C $^{\text {a }}$ Eitores (Lisboa)}

Sociologia e Política

A nova fase do socialismo. João de Meneses. Agosto, 1975. Tiragem: 2.500.

A introdução do marxismo em Portugal (18591930). Alfredo Margarido. Agosto, 1975. Tiragem: 2.500 .

\section{Imprelivro (Lisboa)}

A conjuntura nacional e a minha posição perante o momento político português. Kaúlza de Arriaga. Maio, 1976.

\section{Inquérito (Lisboa)}

Documentos da Hora Presente

1 Escritos políticos. Mário Soares.

2 Horizontes fechados: páginas de política. Raul Rego. Edição do Autor. 1969.

3 Falar claro. José Magalhães Godinho. Edição do Autor. 1969.

\section{Livraria e Editora Pax (Braga)}

Quando Timor foi notícia: memórias. Cacilda dos Santos Oliveira Liberato. Outubro, 1972.

A economia portuguesa: dois anos com Marx. 
António M. Bessa. Junho, 1976. Tiragem: 3.000 .

\section{Livraria Figueirinhas (Porto)}

Evangelizar os pobres. Mario de Oliveira. $3^{\mathrm{a}}$ ed.

Revisão da Constituição política. Discursos dos deputados subscritores do projecto. Sá Carneiro. Julho, 1971.

\section{Livraria Internacional Lda. (Porto)}

O Partido Socialista e o processo revolucionário. João Cília. Abril, 1976.

\section{Livraria Sampedro Editora (Lisboa)}

Colecção Factos e Documentos

Dossier Coimbra - 1969: A crise de Coimbra vista por observadores estranhos aos acontecimentos. $2^{\mathrm{a}}$ Edição. António da Cruz Rodrigues, José Maria Marques, Joaquim Maria Marques. 1969.

\section{Coleção Futuro-Hoje}

Reforma universitária e política acadêmica. José Valle de Figueiredo. Dezembro, 1972.

\section{Livraria Sólivros - Editora}

Entrevistas. Galvão de Melo. Abril, 1976. Tiragem: 15.000.

\section{Livros E(co)logiar a Terra (Camarate)}

Sentir esse retrato de Portugal ainda ocupado. Manuel Cadafaz de Matos. Março, 1975.

\section{Luta Comunista}

\section{Colecção Cadernos Militantes}

1 Acerca das greves. Lenine. Setembro, 1975.

2 O movimento revolucionário actual $e$ o trotskismo. Agim Popa. 1975. 8 pp.

\section{Margem (Lisboa)}

Oito meses nas prisões do Portugal democrático (1974-75). Pedro Manuel de Oliveira Reis. Dezembro, 1976.

\section{Melgaço \\ Angola e o general Norton de Matos (Subsídios para a história e para uma biografia). António Durães. Maio, 1976. Tiragem: 500.}

\section{Mil Dias (Lisboa)}

Da resistência à libertação: comemorações do
$3 o$ aniversário do 25 de Abril de 1974. Sérgio Guimarães; fot. Abel Fonseca e outros. 1977.

Mil dias - diário de uma revolução: de 25 de Abril de 1974 a 30 de Setembro de 1974. $1^{\circ}$ vol. Dir. Orlando Neves com a colab. Carlos Pinto dos Santos... [et. al.]. Janeiro, 1978. Tiragem: 5.000.

O 25 de Abril visto pelas crianças. Abril, 1978. Tiragem: 5.000 .

As paredes na Revolução: graffiti. 1978.

\section{Mondar (Lisboa)}

Imperialismo e dependência. Salvador Allende, Olivier Todd, Fernando H. Cardoso. Fevereiro, 1974. ("Apreendido antes do 25 de Abril.")

Política e linguística sobre a resistência. Noam Chomsky. Janeiro, 1974. ("Apreendido antes do 25 de Abril.")

Cia. Siné. 1974.

Retrato do colonizado, precedido do retrato do colonizador. Prefácio de Jean-Paul Sartre. Albert Memmi. Julho, 1974.

\section{Movimento Democrático das Mulheres Portuguesas}

Salvador Allende e o processo da contrarevolução fascista no Chile. 1974.

\section{Movimento Popular Cooperativista}

Cooperativismo popular. Textos de K. Marx, Rosa Luxemburgo e Lenine. s/d.

\section{Mundo Novo}

A Bolívia e as lutas de guerrilhas na América Latina A prisão de Régis Debray e a morte de Che Guevara. Trad. e compil. Araújo Lopes. 1972.

Vida política e morte de Humberto Delgado: revelações novas sobre a sua morte no VII capítulo desta $3^{a}$ ed. do "Reinado de reinações reinadias...”. 1967.

\section{Novo Mundo}

\section{Cadernos Novo Mundo / Série "Informação"}

1 Vietnam, uma guerra de paciência. 1971.

2 O fascismo em Itália? O socialismo no Chile? 1971.

Documentos Políticos

1 A crise de confiança: ideias, poder e violência na América. Arthur M. Schlesinger Jr.. 1969. 


\section{Novo Tempo}

Duas tácticas. V. I. Lenine. Trad. João Lobo. 1971.

Do socialismo utópico ao socialismo científico. Ludwig Feurbach e o fim da filosofia clássica alemã. Engels. Trad. João Lobo. 1974.

\section{O Emigrante (Lisboa)}

O Povo Quer Saber

Cartilha política do povo. José Pires, Paulo da Trindade Ferreira, Maria Helena de Sá Dias e Vitor Melícias Lopes. Junho, 1974.

Portugal novo: movimentos e partidos políticos. Rafael Prata, Carlos Santos Ferreira, Vitor Melícias Lopes. Agosto, 1974.

Angola! Angola! Testemunho sobre o problema colonial. José Pires. Outubro, 1975.

\section{O Malho}

A estratégia actual do neocolonialismo. Maï Volkov. Agosto, 1977. Tiragem: 3.000.

\section{Palas Editores (Lisboa)}

Espanha, 1936-1939. Pietro Nenni. 1975.

\section{Praça do Livro (Lisboa)}

Humberto Delgado: 70 cartas inéditas: a luta contra o Fascismo no exílio. Manuel Sertório. Junho, 1978.

\section{Prometeu (Porto)}

O fim histórico de Portugal. Amorim de Carvalho. 1976.

\section{Publicações Forum}

História de um atentado: o atentado a Salazar. Emídio Santana. Maio, 1976.

\section{Publicações Limite/Editorial Terceiro Mundo}

Textos Latino-americanos

1 Proposta socialista para o Chile. Carlos Altamirano. Set., 1977. Tiragem: 3.000.

\section{Colecção Terceira Poesia}

$1 O$ cântico do habitante: precedido de duas gestas. Osvaldo Osório. Novembro, 1977. Tiragem: 1.150 .

\section{Publitur}

Cadernos de Divulgação

1 Alguns problemas político-constitucionais. Moura Dinis. 1975.

2 O que é o socialismo. Moura Diniz. 1975.

\section{Representações Literárias ASA (Lisboa)}

Colecção Documentos Políticos

15 meses no governo ao serviço da descolonização. António de Almeida Santos. Novembro, 1975.

\section{RPA Publicações (Lisboa)}

A revolução social e a sua interpretação anarquista. José Correia Pires. Outubro, 1975. Dist. Agência Portuguesa de Revistas.

Scire

País sem rumo: contributo para a história de uma revolução. António de Spínola. 1978.

Soapli - Sociedade de Estudos e Publicações

Partidos e movimentos políticos em Portugal. Abril, 1975.

\section{Sociedade de Publicações Economia e} Finanças (Lisboa)

Portugal, os anos do fim. Jaime Nogueira Pinto. 1976.

Democracia ou ditadura: arriscar o Líbano para evitar o Chile e fugir à Albânia. António Palha. Junho, 1977. Tiragem: 3.000.

\section{Socorro Vermelho Português}

Defesa no Tribunal Plenário (Maio de 1970. Francisco Martins Rodrigues. 1970.

\section{Textos Anti-Capitalistas}

1 Os deveres da juventude comunista. Lenine. Trad. A. Gil. Dezembro, 1974.

2 A religião dos capitalistas. Lafargue. Trad. A. Gil.

\section{Torres \& Abreu}

Saneamento nacional. Adriano Moreira. Junho, 1976.

\section{Vozes na Luta - Cooperativa de Acção Cultural (Lisboa) \\ Cantos de luta. Grupo de acção cultura "Vozes na luta". $3^{\mathrm{a}}$ ed. 1976.}

